\title{
"EL USO DE LA PIEL ANIMAL COMO SOPORTE PARA OBRA GRÁFICA ORIGINAL"
}

(TOMO PRIMERO)

Autor: Óscar Juan Martínez García Directora: Dra. Blanca Rosa Pastor Cubillo 

A mis padres, por supuesto... 

Muchas son las personas que han colaborado desinteresadamente en que esta investigación llegara a buen puerto, por lo que citarlas una a una sería prolijo y excesivamente largo. Sin embargo, no podemos dejar pasar la ocasión de agradecer encarecidamente la ayuda prestada por Miguel Francés y María Ángeles Herrero de calzados Moore, la eterna disponibilidad de Pepe Poveda a la hora de proporcionar pieles y cueros de todo pelaje y condición, la colaboración inicial de Ramiro Herrero y Paco Alcocel, y, por supuesto, la labor de la directora de esta tesis, Blanca Rosa Pastor, gracias a quién, este trabajo ha podido ver finalmente la luz. 

I. CONSIDERACIONES GENERALES 13

I.1. ESTRUCTURA Y COMPOSICIÓN 15

I.1.1. Epidermis $\quad 16$

I.1.2. Dermis 19

I.1.3. Tejido subcutáneo 21

I.1.4. Composición 22

I.1.4.a. Agua 22

I.1.4.b. Proteínas 24

I.1.4.c. Minerales 25

I.1.4.d. Grasas 26

I.1.4.e. Nitrógeno 26

I.2. IMPERFECCIONES Y DEFECTOS 27

I.2.1. Factores Genéticos 28

I.2.2. Factores fisiológicos 29

I.2.3. Factores higiénico sanitarios 31

I.2.4. Factores de manejo y explotación 34

I.3 CUEROS Y PERGAMINOS

I.3.1. El cuero

I.3.1.a. Antecedentes históricos del curtido 37

I.3.1.b. Síntesis del proceso de curtido 44

I.3.1.c. Despiece de los cueros 54

I.3.2. El pergamino 58

I.3.2.a. La fabricación del pergamino 61

II. LA PIEL EN LA HISTORIA DEL ARTE $\quad 71$

II.1. ARTE SOBRE PIEL 75

II.1.1. Página de beato mozárabe 77

II.1.2. Sala de los reyes de la Alambra 85

II.1.3.Dibujos renacentistas sobre vitela 88

II.1.4. Andrea del Castagno: David 91

II.1.5. Alberto Durero: Carraca muerta 94

II.1.6. Hans Holbein: William Roper 100 
II.1.7. Rembrandt: Las tres cruces 105

II.1.8. Keith Haring: Sin título 112

II.2. ARTE EN PIEL 115

II.2.1. Encuadernación mudéjar 117

II.2.2. Estuche litúrgico o crismera 126

II.2.3. Caballero 131

II.2.4. Revestimiento mural de guadamacil 135

II.2.5. Joan de Joanes: Rodrigo de Boria 142

III.EXPERIMENTACÍON Y MATERIALES 151

III.1. EL CUERO: SELECCIÓN DE PIELES 153

III.1.1. Cueros caprinos 157

III.1.2. Cueros porcinos 159

III.1.3. Cueros ovinos 163

III.1.4. Cueros vacunos 164

III.2. MANIPULADO PREVIO DE LAS PIELES 168

IV. ANÁLISIS Y CATALOGACIÓN 173

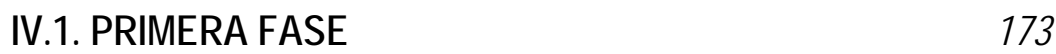

IV.1.1 Grabado xilográfico $\quad 187$

IV.1.1.a. Tinta negra 187

IV.1.1.b. Tinta blanca 196

IV.1.1.c. Tinta azul traslúcido 206

IV.1.1.d. Tinta azul opaco 216

IV.1.2. Grabado calcográfico 221

IV.1.2.a. Tinta negra 223

IV.1.2.b. Tinta blanca 232

IV.1.2.c. Tinta azul traslúcido 243 
IV.1.2.d. Tinta azul opaco 249

IV.1.3. Reflexiones parciales 256

IV.1.3.a. Estampas xilográficas 260

IV.1.3.b. Estampas calcográficas 269

IV.2. SEGUNDA FASE 281

IV.2.1. Punta seca 286

VI.2.1.a. Análisis de los resultados 289

VI.2.1.b. Reflexiones parciales 296

IV.2.2. Estezado 299

VI.2.2.a. Análisis de los resultados 305

VI.2.2.b. Reflexiones parciales $\quad 310$

IV.2.3. Transferencia $\quad 315$

IV.2.3.a. Análisis de los resultados $\quad 319$

IV.2.3.b. Reflexiones parciales 327

V.PROPUESTA PLÁSTICA PERSONAL 331

V.1. ANOTACIONES PREVIAS 331

V.2. DEFINICIÓN Y OBJETIVOS ESPECÍFICOS 345

V.3. METODOLOGÍA Y PROCESO 348

V.3.1. Concepción de la obra $\quad 350$

V.3.2. Planificación técnica 358

V.3.3. Resolución 363 
V.4. SELECCIÓN DE OBRAS

V.4.1. Xilografía y calcografía 369

V.4.2. Xilografía y transferencia 387

V.4.3. Calcografía y transferencia 405

V.4.4. Estezado $\quad 425$

CONCLUSIONES 435

REFERENCIAS BIBLIOGRÁFICAS 443 


\section{INTRODUCCIÓN}

A lo largo de la historia, las pieles y cueros han sido empleados dentro de innumerables actividades tanto sociales como culturales, alcanzando en algunos momentos niveles de utilización realmente masivos. Su descubrimiento nos remonta hasta la prehistoria y los albores de la humanidad, y desde entonces los cueros han servido como elementos de protección contra la climatología, como materia prima para utensilios de todo tipo y condición, como armaduras defensivas y formando parte de armas ofensivas, como receptores de toda clase de escrituras y por tanto vehículo de infinidad de conocimientos culturales y religiosos, y también como soporte para diferentes técnicas plásticas y por consiguiente como parte constitutiva de lo que conocemos como el mundo del arte. En todos y cada uno de los campos anteriormente citados, tras momentos en los cuales los 
derivados de las pieles animales gozaron de una posición de predominio, sobrevino una decadencia en su empleo provocada por la irrupción de nuevos materiales que vinieron a sustituirlos. Ocurrió en el mundo de la vestimenta con la aparición de los tejidos manufacturados, en el ámbito de la guerra con el descubrimiento y desarrollo de materiales más resistentes, con la irrupción imparable del papel como soporte de escritorio, e incluso en un campo tan exclusivo como el de las decoraciones murales los guadamaciles fueron desbancados por los papeles japoneses.

Sin embargo, dentro de lo que estrictamente podemos considerar como arte desde una tradición academicista (pintura, dibujo, grabado, escultura...las bellas artes al fin y al cabo), el papel reservado a los cueros, pieles y pergaminos casi nunca dejó de ser marginal, abandonando su posición secundaria como soportes en escasísimas ocasiones. Será precisamente en este último campo, y más concretamente dentro del mundo del grabado, en el cual se centrará nuestro trabajo, intentando revalorizar la utilización de los cueros como soportes alternativos para las técnicas de la estampa con objeto de lograr obras originales mediante la fusión de ambos elementos.

¿De dónde surge el interés por tratar de encontrar posibles alternativas al papel a partir de estos materiales? ¿Cuándo aparece la idea de establecer este tema como centro de una investigación doctoral? Hemos de remontarnos al año 2001 dentro del programa de cursos de doctorado del Departamento de Dibujo de la Facultad de 
Bellas Artes de San Carlos de Valencia, y más concretamente al curso impartido por la doctora Blanca Rosa Pastor Cubillo titulado Grabado en relieve y libro artístico. Como trabajo de culminación de dicho curso se realizaron tres ejemplares de libro de artista en los cuales el cuero tenía un papel fundamental como soporte de las imágenes, estampadas en aquel caso concreto a partir de planchas xilográficas y matrices de técnicas aditivas. Ante la necesidad de elegir un tema de estudio para realizar el proyecto de investigación inmediatamente posterior, y gracias a los buenos resultados obtenidos estampando sobre cuero, se decidió enfocar dicho trabajo investigador hacia la experimentación sistemática de las posibilidades plásticas de las técnicas de grabado unidas a los soportes de piel. Fruto de ese proceso fue el trabajo de investigación titulado Estudio y catalogación de diferentes tipos de pieles según su respuesta a la impresión de grabado, germen a partir del cual ha tomado forma y contenido la actual tesis doctoral.

Aquel proyecto de investigación se centraba en un estudio pormenorizado de la respuesta de los cueros ante distintos tipos de técnicas de estampación, sin atender demasiado a los aspectos teóricos e historiográficos de la utilización de la piel a lo largo del desarrollo artístico y cultural de la civilización occidental, ausencia que quedará subsanada en el presente estudio. En este nuevo y, obviamente, más amplio trabajo no sólo basaremos nuestra investigación práctica en la catalogación sistemática de diferentes tipos de cueros unidos a distintas técnicas de grabado, sino que trataremos 
de realizar una propuesta de obra personal en la cual el cuero sea el soporte fundamental de dichas estampaciones. ${ }^{1}$

Esta tesis doctoral poseerá por tanto objetivos más amplios, pudiendo diferenciar entre un propósito general y otros accesorios. E objetivo global es demostrar la viabilidad del empleo del cuero como soporte para la estampa desde un punto de vista amplio.

Entre los objetivos específicos podemos distinguir los de carácter puramente teórico y los eminentemente prácticos. En los objetivos teóricos figurarán el conocimiento de la naturaleza del cuero y sus características propias como paso inicial para una compresión de sus posibilidades como soporte para la estampa, así como el análisis de los precedentes del empleo de dichos cueros dentro del campo de las artes. Por lo que respecta a los objetivos prácticos, éstos estarán a su vez divididos en dos grandes líneas. Por

\footnotetext{
${ }^{1}$ Será este material, de naturaleza flexible y gran variedad de tonalidades y acabados, el que empleemos como soporte para los trabajos con las técnicas del grabado, y no tanto el otro soporte sobre el cual versará parte del análisis teórico de la primera parte de la tesis, el pergamino. Como veremos más adelante el pergamino proviene a su vez de los pellejos y pieles animales, pero no es una piel curtida sino trabajada a partir de una serie de procedimientos diferentes. No emplearemos el pergamino como soporte principal para la obra gráfica original, pero nos parece de gran interés el estudio historiográfico de las diferentes manifestaciones culturales y artísticas en las cuales el pergamino ha jugado un rol de trascendencia. Por lo tanto, durante una buena parte de la tesis se analizarán los distintos empleos a los que ha sido sometido la charta pergamena, cuya estrecha relación casi fraternal con el cuero (no en vano provienen de una misma madre) nos hace decidirnos por otorgarle un papel protagonista en la investigación historiográfica que desarrollaremos a continuación.
} 
un lado ampliar la catalogación ya realizada en el citado trabajo de investigación, añadiendo nuevos tipos de pieles así como técnicas y procedimientos diferentes, con lo que se logrará trazar un panorama lo suficientemente extenso como para lograr el último de los objetivos del presente estudio, el cual versará alrededor de la propuesta de una obra plástica personal que tenga al cuero como soporte y emplee las técnicas del mundo de la estampa que se han analizado con anterioridad.

Nuestra investigación estará por tanto dividida en dos grandes bloques perfectamente acotados y que responden a la posibilidad de acercamiento al tema desde dos. Así, en primer lugar trataremos de analizar algunos de los fenómenos más significativos relacionados con el amplio mundo de los cueros y pieles, intentando en todo momento no perder de vista el objetivo central del estudio, el cual está obviamente relacionado con el trabajo práctico. Para ello desarrollaremos una serie de capítulos eminentemente teóricos organizados a partir de un esquema piramidal ascendente que comenzará con conceptos de marcada amplitud para ir progresivamente ascendiendo y acotando cada vez más el tema de análisis en sucesivos capítulos, hasta alcanzar los aspectos eminentemente artísticos sobre los cuales se colocará nuestra aportación práctica a modo de piramidion que culminará el esquema propuesto. La investigación colocada por debajo de dicha cúspide estará basada en conceptos mayoritariamente teóricos, constituyendo el primer gran bloque de nuestra tesis y actuando como los cimientos 
sobre los cuales elevar la segunda de las partes del trabajo, la práctica y el trabajo de taller que permitirán aplicar los conceptos teóricos a la creación artística.

En esta última el método de acercamiento al tema central del estudio cambiará su enfoque teórico para ser sustituido por el trabajo y la actuación directa sobre los materiales seleccionados, comenzando con una amplia experimentación de las distintas posibilidades que la combinación de cueros y técnicas gráficas permita, hasta proponer, y realizar como culminación a la tesis, una obra gráfica original a partir de la utilización y empleo de los cueros y pieles como soporte.

Como apéndice a este volumen se añade una recopilación de las fichas técnicas realizadas a lo largo del proceso de catalogación de los cueros, fichas que se encuentran clasificadas dependiendo de la técnica empleada en cada caso concreto. Su organización no ha seguido un modelo previo, sino que ha sido el trabajo de taller el que ha sugerido las diferentes posibilidades de resolución de las mismas, existiendo por tanto diferencias entre las dedicadas a las técnicas calcográficas y xilográficas, y las destinadas a recoger la información derivada del trabajo con la transferencia, el estezado y la punta seca. Junto a estas fichas se incluye a su vez una serie de tablas estadísticas que recogen la totalidad de los datos analizados a la hora de realizar las consideraciones parciales a cada uno de los procedimientos. 


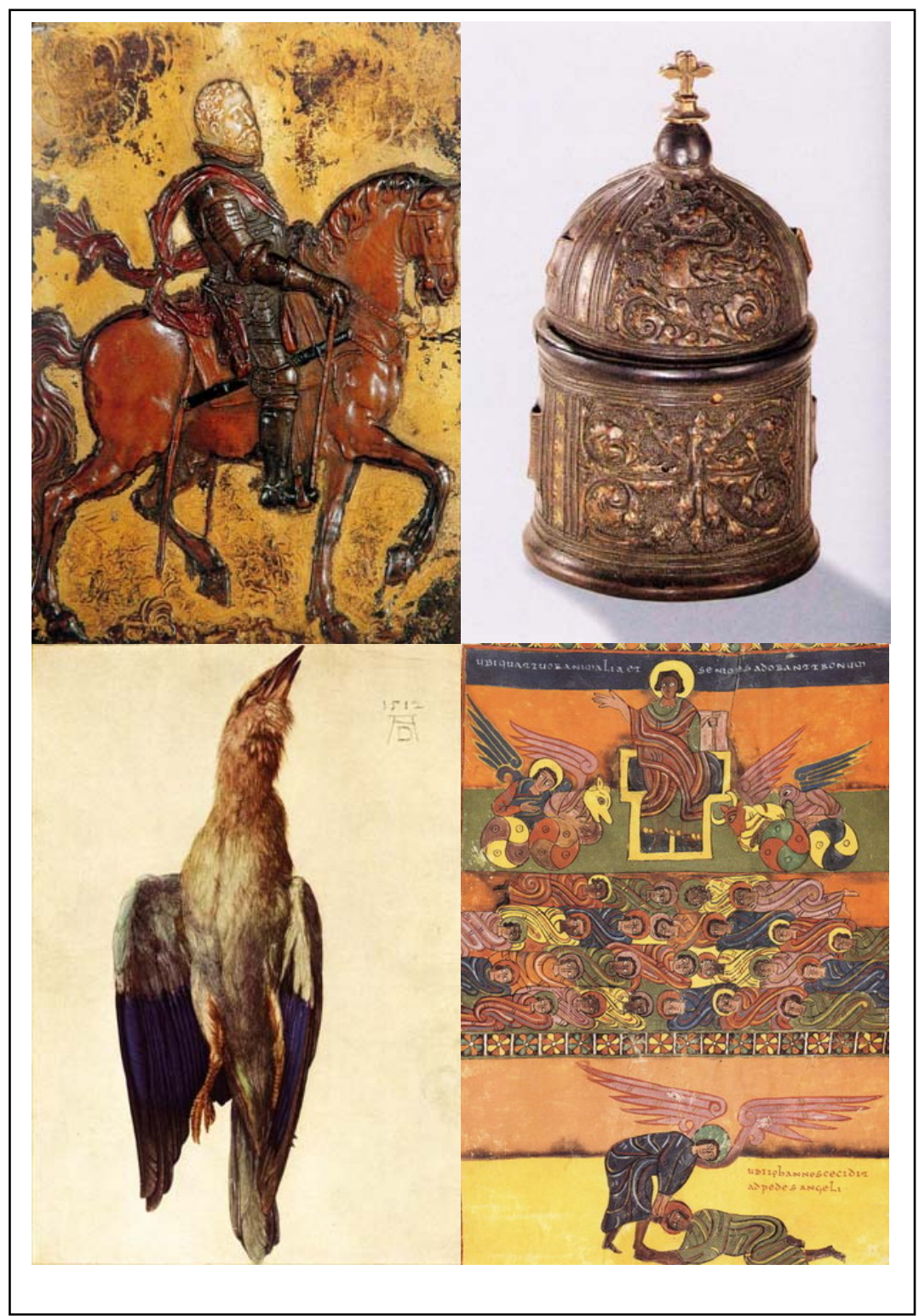





\section{CONSIDERACIONES GENERALES}

En el intento de ofrecer una primera definición de la piel nos remitiremos a uno de los diccionarios más usados dentro de la lengua castellana, el de Maria Moliner. Según el Diccionario de uso del español 2la palabra piel proviene y deriva de la latina pellis y posee tres acepciones principales, las cuales se mantienen casi invariables en todas las lenguas romances. La primera de ellas define la piel como la "capa de tejido resistente y flexible que recubre el cuerpo de los animales"; la segunda afirma que la piel es "esta capa separada del cuerpo de los animales" mientras que la última de las definiciones la describe como "la misma capa despojada de pelo y generalmente curtida, empleada como material". Sin embargo existen muchas otras palabras de nuestra lengua que definen la materia de la que trata este

${ }^{2}$ DICCIONARIO (2000), p. 1073-1074. 
trabajo, entre ellas cuero, la más común, pelleja o pellejo, así como infinidad de vocablos locales que se refieren a la piel curtida. En los párrafos siguientes nos referiremos a la piel de los mamíferos, entre los cuales se encuentra el ser humano, dejando las pieles de los reptiles, los peces y otros animales para un posible estudio futuro.

Desde el punto de vista anatómico la piel es un tegumento externo que recubre todo el cuerpo de los animales, extendiéndose hacia el interior del mismo a través de los orificios naturales, las membranas mucosas y los tubos digestivo, respiratorio y urogenital. Dentro de sus múltiples funciones destacan las de actuar como regulador de la temperatura del cuerpo, almacenar sustancias grasas, proteger al organismo de la posible entrada de todo tipo de bacterias 0 microorganismos perjudiciales, así como albergar órganos sensoriales y gran número de glándulas secretoras y excretoras. A su vez posee anexos córneos tales como uñas y cuernos, los cuales se comportan como órganos de aprehensión y defensa. ${ }^{3}$

Las pieles pueden poseer, como veremos a continuación, muy distintas características que dependen de la edad del animal, de la especie e incluso de las diferentes condiciones de crianza y alimentación a las que haya sido sometido. Estos factores influirán en el color y el grosor de las pieles, pero también en su respuesta al proceso de curtido y sus futuras calidades una vez convertida en cuero. La flexibilidad, la resistencia 0 los posibles defectos

${ }^{3}$ LACERCA, A. M. (1976), p. 41. 
superficiales que pueda presentar, dependerán de una amplia gama de condicionantes que hacen casi imposible encontrar dos pieles totalmente idénticas. Es más, incluso en una misma pieza de piel proveniente de un único animal, las características del cuero variarán dependiendo de la zona que escojamos para trabajar.

\section{I.1. ESTRUCTURA Y COMPOSICIÓN}

La piel está formada por tres capas perfectamente diferenciadas y con características propias. No todas serán válidas ni aprovechables a la hora de conseguir el cuero deseado tras el proceso de curtido, pero es conveniente realizar un breve análisis de todas ellas con objeto de comprender mejor la naturaleza del tejido que nos ocupa. Estas tres capas, epidermis, dermis y tejido subcutáneo, como vemos en la fig. 1, variarán de grosor y características según el tipo de animal, la raza o la parte del cuerpo del ejemplar, aunque se pueden establecer unas consideraciones generales para cada una de ellas. 


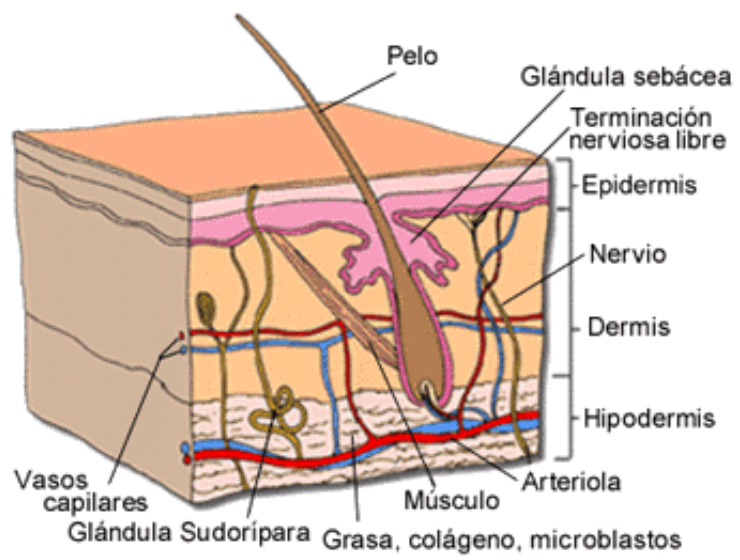

Fig 1: Esquema de la piel.

\section{I.1.1. Epidermis}

Se trata de la capa más externa de las que conforman la piel, así como la más delgada de las tres. Tan sólo representa un 1\% del grosor total de la piel en bruto ${ }^{4}$, aunque a su vez se encuentra estratificada y dividida en otras capas. Las más importantes son, desde el interior del cuerpo hacia fuera, la capa de Malpighi o basal, la capa granular y la capa córnea. Sin embargo, y como se observa en la fig. 2, podemos diferenciar una gran variedad de tejidos diferentes que forman este recubrimiento externo de la piel.

\footnotetext{
${ }^{4}$ QUÍMICA (1985), p. 4.
} 


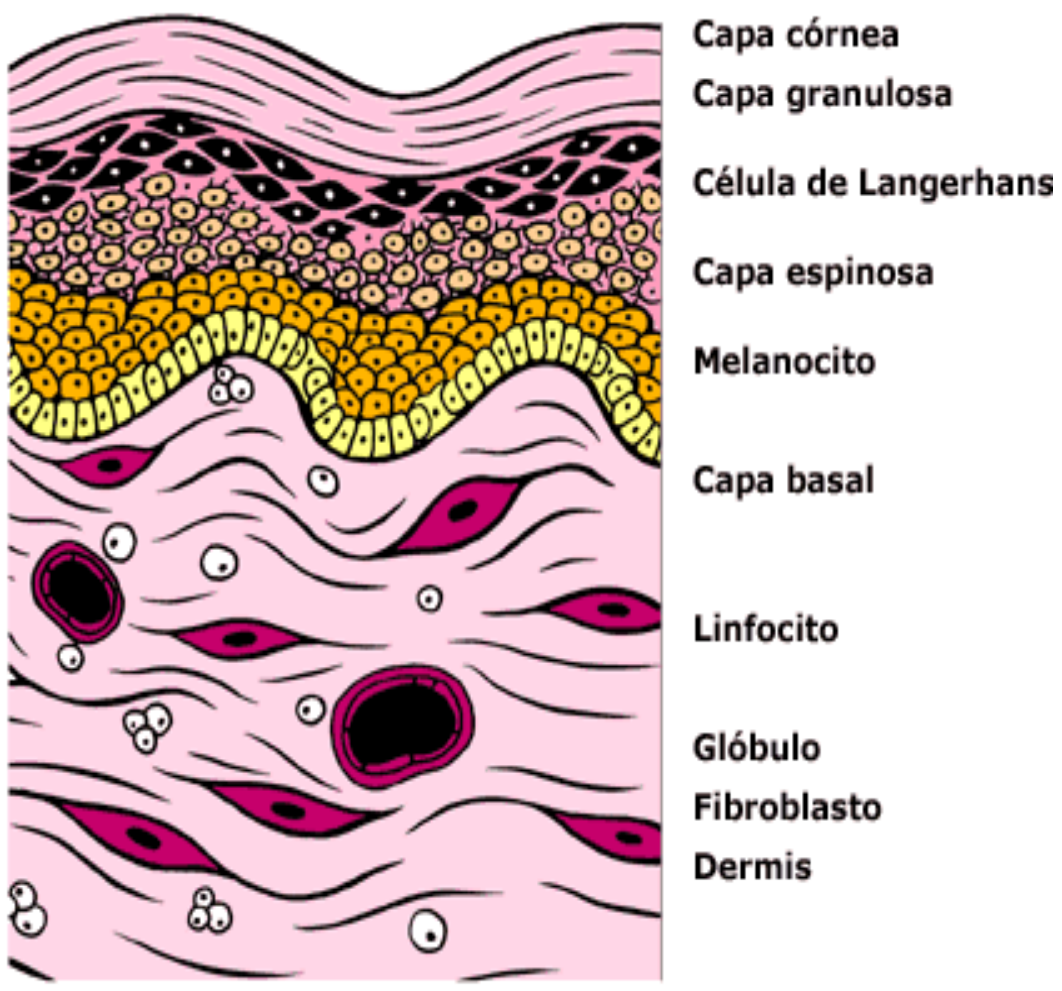

Fig. 2: Corte de la piel.

Está constituida en su mayor parte por dos tipos de células: los queratinocitos y los melanocitos 5 . Los primeros, los queratinocitos, forman una barrera exterior o estrato córneo, la cual funciona como una auténtica barrera contra agentes externos. Estos queratinocitos tienen una vida media de 27 días, tras los cuales son sustituidos por un nuevo sustrato de células, y en su citoplasma son capaces de

${ }^{5}$ LACERCA, A. M. (1976), p. 52. 
acumular queratina, sustancia que permite crear la citada barrera protectora. Esta queratina es perjudicial para el cuero, debido a su dureza y rigidez, por lo que es eliminada mediante la acción de los taninos en el proceso de curtido. ${ }^{6}$ Las otras células que forman la epidermis, los melanocitos, son aquellas en las cuales se acumula la melanina, sustancia de color entre pardo oscuro y negro que produce los distintos tonos de piel que podemos encontrar, no sólo en el ser humano, sino en toda clase de mamíferos.

La epidermis posee una serie de componentes, los cuales influirán de manera decisiva en la formación y calidad del cuero, que se pueden agrupar en tres grandes grupos:

PELO: Se trata del elemento de mayor importancia desde el punto de vista del curtidor, ya que define de manera clara las características de la piel curtida. Por lo general en casi todos los animales se encuentra un pelo por cada folículo piloso, aunque en ciertas especies, como los gatos, los perros y sobre todo los cerdos, podemos encontrar tres pelos por cada folículo piloso. Este dato aparece como importantísimo para poder distinguir una piel porcina, de cerdo, de cualquier otro tipo de cuero de los generalmente usados.

\footnotetext{
${ }^{6}$ Véase apartado I.3.1.b., p. 44-53.
} 
GLANDULAS SEBÁCEAS: Pequeñas bolsas que sirven para acumular materias grasas y así poder lubricar el pelo o la capa córnea de la epidermis, la más externa de las tres que forman el tejido estudiado.

GLANDULAS SUDORÍPARAS: Segregan, almacenan y eliminan el sudor con objeto de poder regular la temperatura del organismo, como ya hemos visto una de las funciones principales de la piel.

\section{I.1.2. Dermis}

También llamada corium o piel verdadera, está situada bajo la epidermis y separada de ésta por la membrana hialina. Esta membrana de separación entre dermis y epidermis es transparente y ondulada, y forma una superficie pulida que dará lugar, tras el curtido, a la flor del cuero, que tiene una importancia capital en la apariencia y calidad del propio cuero. ${ }^{7}$ El espesor de la dermis constituye el $84 \%$ del total de la piel en bruto ${ }^{8}$ y se trata de la parte aprovechable de la misma para la producción y obtención del cuero.

${ }^{7}$ QUÍMICA (1985), p. 9.

${ }^{8}$ QUÍMICA (1985), p. 10. 


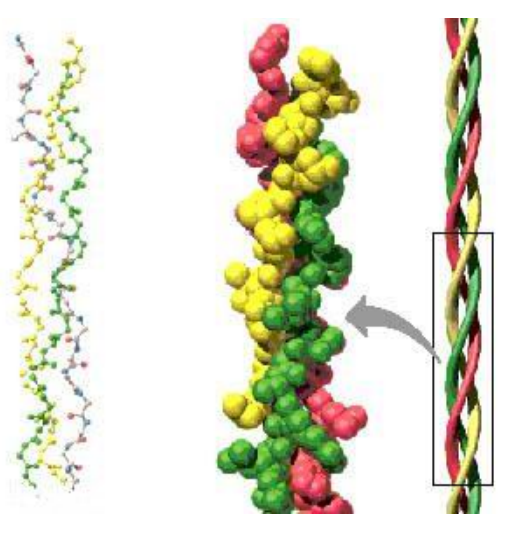

Fig. 3: Fibras de colágeno.

A su vez la dermis está formada por otras dos capas 0 estratos fundamentales, uno externo, la capa o zona papilar, y uno interno, la zona reticular. ${ }^{9}$ La primera, la zona papilar, es también llamada "capa flor" y está formada por diferentes elementos como glándulas, folículos pilosos y fibras de colágeno (fig. 3). Se extiende desde la membrana hialina hasta la base de los folículos pilosos y condiciona el aspecto del cuero y su acabado desde un punto de vista estético en su lado flor. Entre sus funciones también se encuentra la de actuar como regulador térmico del organismo. La segunda de las capas, la zona reticular, está formada en su mayor parte por fibras de colágeno reticuladas, y entra en contacto con el tejido subcutáneo inferior, con un grosor mucho mayor que el de la zona papilar anteriormente descrita. ${ }^{10}$ En la imagen de la fig. 4 vemos un corte transversal de la piel, con la capa superior de la epidermis y el resto prácticamente ocupado por los tejidos pertenecientes a la dermis. En esta última podemos incluso diferenciar las dos capas citadas anteriormente, la

\footnotetext{
${ }^{9}$ QUÍMICA (1985), p. 10-11.

${ }^{10} \mathrm{Si}$ la zona papilar posee un espesor de aproximadamente el $15 \%$ del total de la piel, esta capa reticular tiene, por su lado, un grosor del 85\% restante.
} 
zona papilar, la más cercana a la epidermis, y la reticular bajo ella y con un grosor mucho mayor.

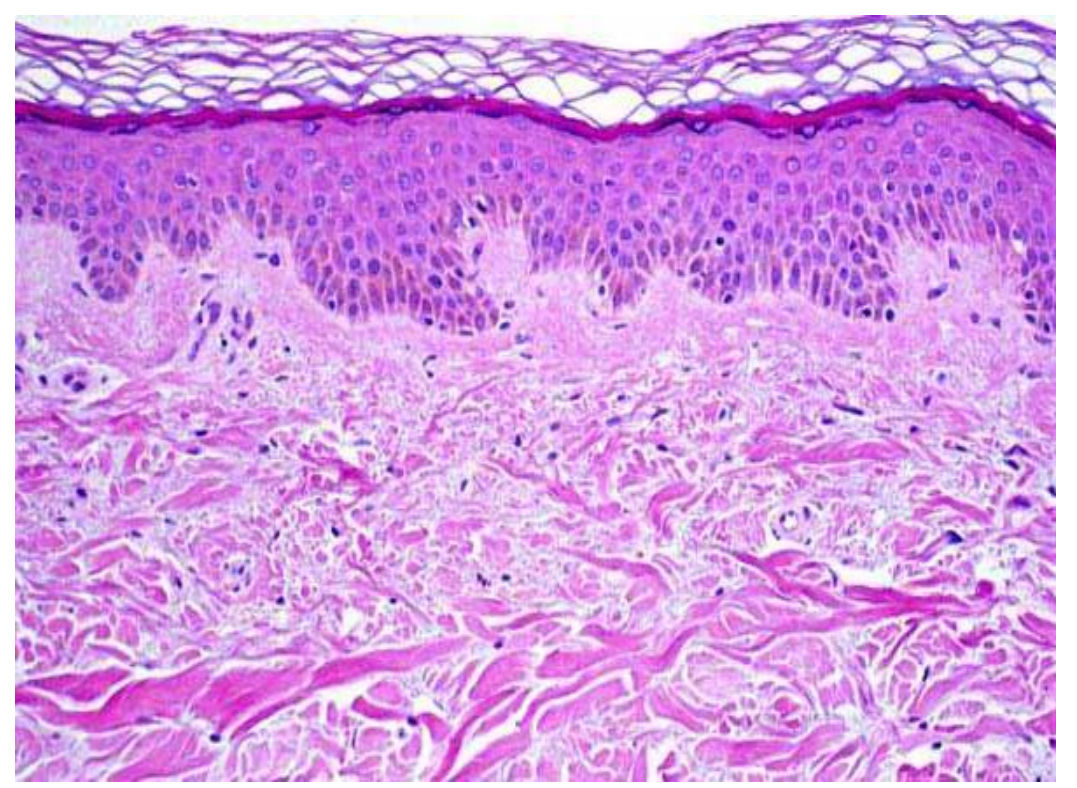

Fig. 4: Corte transversal de la piel donde se aprecian las diferentes capas que la conforman.

\section{I.1.3. Tejido subcutáneo}

También conocido como carne o hipodermis, sería la porción del cuerpo del animal que queda adherida a la piel tras el proceso de desollado. Está formado por vasos sanguíneos, tejidos adiposos y conjuntivos. Forma el $15 \%$ del grosor total de la piel en bruto, ${ }^{11}$ actuando como una especie de cojín para las dos capas anteriores. Sin

${ }^{11}$ QUÍMICA (1985), p. 15. 
embargo su interés para la industria del cuero es nulo, ya que debe ser retirado rápidamente durante el curtido mediante la operación denominada descarnado.12

\section{I.1.4. Composición}

Tras la breve explicación de las diferentes capas que estructuran la piel, analizaremos a continuación su composición, dado que está formada por una serie de sustancias entre las que destacan por su importancia las siguientes: agua, proteínas, minerales, grasas y nitrógeno. ${ }^{13}$

\section{I.1.4.a. Agua}

Se trata del componente mayoritario de todas las pieles animales, como también ocurre con la mayoría de tejidos orgánicos. La proporción de agua en una piel varia en relación a valores tales como el grosor o el tipo de animal del cual provenga el cuero, así como la raza, la edad, la alimentación o los métodos de cría. Por tanto, para pieles de un grosor elevado la cantidad de agua será menor que para pieles más finas, las cuales tendrán una mayor proporción de agua en

\footnotetext{
${ }^{12}$ Véase el apartado I.3.1.b. referente al curtido, p. 44-53.

${ }^{13}$ Para todo lo referente a la composición de las pieles véase: LACERCA, A. M. (1976).
} 
su composición. También la zona del cuerpo de un mismo animal incide en el porcentaje de agua dentro del tejido estudiado. De tal modo para una piel vacuna, las zonas del bajo vientre son más finas y tienen un mayor porcentaje acuoso, mientras que en la zona del cuello, la grupa o el lomo, la proporción de agua será mucho menor por efecto del mayor grosor del tejido.

En lo que respecta a la diferencia en el porcentaje de agua con relación al tipo de animal se pueden establecer una serie de equivalencias, las cuales quedan reflejadas en la fig. 5.14

\begin{tabular}{|ll|}
\hline & \\
Vacunos & $69-79 \%$ \\
Potros & $77-79 \%$ \\
Becerros & $79-83 \%$ \\
Cabras & $80-82 \%$ \\
Ovejas & $85-88 \%$ \\
& \\
Fig. 5: Tabla de equivalencias con respecto al \\
porcentaje de agua.
\end{tabular}

\footnotetext{
${ }^{14}$ Según Schroeder y Paessher, citados por LACERCA, A. M. (1976), p. 73.
} 
Estos datos inciden de nuevo en el hecho mencionado respecto a la influencia del grosor de los cueros en el porcentaje de agua. Así, en el caso de las pieles vacunas o equinas hay menor porcentaje de agua en su composición, mientras que en pieles mucho más finas como son las de cabra y oveja, las cifras ascienden hasta alcanzar casi un $90 \%$ del total del tejido.

\section{I.1.4.b. Proteínas}

Junto con el agua, las proteínas son los principales componentes de las pieles, y condicionarán las características y naturaleza del tejido. Podemos distinguir dos grupos fundamentales de proteínas en la composición de la piel: las fibrosas o escleroproteínas y las globulares.

Las fibrosas están a su vez divididas en tres grupos principales:

- Colágeno, el cual forma el tejido conjuntivo que encontramos dentro de los diferentes estratos o capas en los que se separa el tejido piel. 15

\footnotetext{
${ }^{15}$ De este colágeno es de donde se extraerá la gelatina, material muy importante dentro de la producción y aprovechamiento de las pieles.
} 
- Queratina, proteína de gran dureza y rigidez que se puede localizar en el tejido epitelial así como en las faneras . ${ }^{16}$

- Elastina, también encargada de formar tejidos conjuntivos aunque en este caso de naturaleza elástica.

Entre las globulares destacan las albúminas, la globulina, las prolaminas, las histonas y las protaminas. Cada una de ellas posee una cualidad concreta y precisa, conformando en sus múltiples combinaciones las diferentes naturalezas de los sucesivos estratos de la piel. Sin embargo, su estudio escapa a los límites y objetivos de este análisis, entrando ya dentro del campo de la biología, la química o la bioquímica.

\section{I.1.4.c. Minerales}

Se trata de componentes que encontramos en ínfimas cantidades dentro de la piel animal, lo que no indica que su misión sea de poca importancia. A pesar de ello su análisis no aporta demasiado interés al estudio de los cueros y pieles desde el ángulo de este trabajo.

\footnotetext{
${ }^{16}$ Por faneras se entienden las uñas, el pelo o las pezuñas.
} 


\section{I.1.4.d. Grasas}

El porcentaje de grasas dentro de la composición de la piel varía de manera extraordinaria en relación al tipo de alimentación al que haya sido sometido el animal. Así, en ejemplares criados y alimentados de manera natural, la proporción de grasas es muy escasa, aproximadamente el 0'5\%, mientras que, en animales criados y cebados con concentrados alimenticios como suele ser el caso de los cerdos, esta proporción se eleva hasta casi el 50\%. Las zonas de mayor concentración de grasas son las del lomo, mientras que no están tan presentes en otras áreas del cuerpo de los animales.

\section{I.1.4.e. Nitrógeno}

Es un elemento presente en la composición de las pieles que, a pesar de su escasa proporción, se muestra de gran importancia dentro del proceso de curtido. En efecto, durante esta serie de operaciones dirigidas a transformar la piel animal en cuero imputrescible, es necesario conocer los índices de nitrógeno aproximado de las pieles, con el fin de calcular las cantidades y la naturaleza de los curtientes y taninos a emplear. 


\section{I.2. IMPERFECCIONES Y DEFECTOS}

La piel es un material orgánico que está expuesto a múltiples manipulaciones e inconvenientes que repercuten en su calidad final. Desde el momento del nacimiento del animal, pasando por todo su desarrollo y su muerte, las intervenciones inmediatamente posteriores al sacrificio, o todo el proceso de curtido hasta llegar a obtener una piel dispuesta para ser utilizada, los factores que determinan la calidad de este cuero son numerosos y muy variados. A continuación intentaremos analizar los más importantes, con objeto de poder conocer mejor las características del material con el cual vamos a trabajar en un futuro.

Dentro de la industria del curtido existen una serie de datos en los que se basa un análisis cualitativo de los cueros. ${ }^{17}$ Entre ellos destaca la integridad de la pieza (el aprovechamiento más o menos válido de toda la extensión de la piel); el grosor, la flexibilidad, la elasticidad o la resistencia (factores que dependerán, como veremos a continuación, de la raza, del cruce, de la edad, del estado de salud del animal, del peso o de la alimentación); la coloración del cuero (el ideal sería un blanco uniforme con objeto de aceptar de manera óptima

\footnotetext{
${ }^{17}$ PIELES (1994), p. 21.
} 
cualquier tipo de tinte o pigmentación); el tamaño (depende del animal del cual provenga la piel y su finalidad), o incluso el tipo de lana (sólo en aquellas pieles que mantengan el pelo después del proceso de curtido).

Todos estos campos de análisis están a su vez determinados por una serie de factores de los cuales depende que una piel reúna las características adecuadas para un correcto manejo y aprovechamiento en la industria y en la artesanía. Nos referimos a los aspectos genéticos, fisiológicos, higiénico-sanitarios y de explotación.

\section{I.2.1. Factores Genéticos}

Por factores genéticos entenderemos sobre todo los propios de la raza del animal. Ésta es fundamental a la hora de modificar la naturaleza del cuero obtenido, pues varía el método y el resultado en función de uno u otro ejemplar de diferente raza. Así, según Peyron18 sería la raza del animal el factor que más influiría en la naturaleza de la piel. A la vez que determina la calidad del cuero, la raza influirá, como es lógico, en el precio y la valoración económica de los pellejos, pudiendo llegar a duplicar su coste.

${ }^{18}$ PIELES (1994), p. 22. 
Dentro de este grupo también podemos incluir la rila o rilao, arrugas o depresiones profundas en la piel que suelen afectar normalmente a la zona del cuello y las costillas de los animales. Posee un carácter hereditario, por lo que la única manera de evitarla es utilizar sementales que no posean tal defecto con objeto de limitar la incidencia de la enfermedad, la cual devalúa tremendamente las pieles inutilizándolas en gran parte de su superficie.

\section{I.2.2. Factores fisiológicos}

Los factores fisiológicos también son de suma importancia para reconocer las características de un cuero, y dentro de este grupo podemos incluir un gran número de consideraciones tales como la edad, el sexo, el medioambiente o el número de partos de un animal hembra.

Con respecto a la edad, la piel de animales jóvenes siempre será de mayor calidad que la de ejemplares viejos, los cuales pueden presentar arrugas, endurecimientos o marcas derivadas de alguna enfermedad o traumatismo.

En lo que respecta al sexo, los cueros de animales hembra suelen ser más finos que aquellos provenientes de ejemplares 
machos, por lo que según la finalidad para la que se desee utilizar la piel, se deberá elegir entre una u otra opción.

El clima y la temperatura también determinarán la naturaleza de la piel y así, un animal criado a la intemperie ofrecerá un cuero de estructura mucho más compacta que los criados a cubierto o en climas templados, los cuales darán cueros más finos y menos compactos. A su vez la piel de animales salvajes o semisalvajes será siempre de mayor calidad que la de aquellos crecidos en cautividad, mientras que estos últimos ofrecerán mayores inconvenientes para ofrecer un cuero en condiciones ideales para su manufactura.

Sin embargo e independientemente de todo lo citado anteriormente, otro de los factores de mayor incidencia para conseguir pieles de calidad es la alimentación de los animales. De aquellos ejemplares alimentados mediante raciones equilibradas, continuadas y periódicas se recogerán cueros de excelente nivel. Estas raciones serán todavía más efectivas si contienen un alto porcentaje de proteínas, en particular de aminoácidos sulfurados como la cistina y la metionina. ${ }^{19}$ Por otro lado, los animales alimentados de manera intensiva y con un alto porcentaje de grasas, darán cueros "hinchados", repletos de lípidos y muy poco valorados por la industria debido a su escasa utilidad real. Si estos ejemplares han recibido una alimentación deficiente y pobre ofrecerán pieles frágiles que pueden llegar a sufrir roturas durante el proceso de curtido.

${ }^{19}$ PIELES (1994), p. 24. 


\section{I.2.3. Factores higiénico sanitarios}

La aparición de enfermedades como sarnas, tiñas, garrapatas, viruelas o linfoadenitis, provoca serios desperfectos en las pieles, devaluando enormemente su coste y su validez como material.

La sarna (fig. 6) es una de las dolencias parasitarias que en mayor medida afecta a la calidad de los pellejos. Aparece en forma de manchas más o menos extensas, ataca a la flor del cuero, acartona la piel e impide una correcta y eficiente

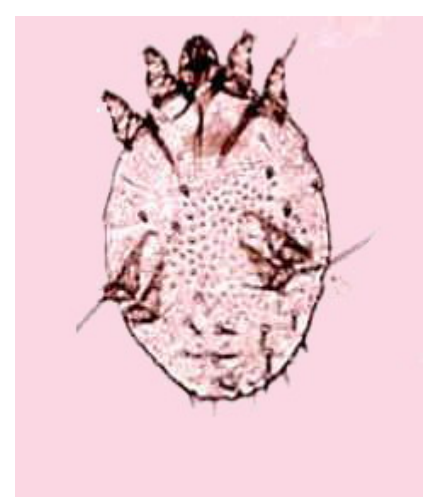

Fig. 6: Sarna. pigmentación y fijación del tinte. A lo largo de la historia ha ocasionado importantes pérdidas a la industria peletera, siendo uno de los problemas más serios a los que los peleteros se han debido enfrentar durante siglos. ${ }^{20}$

${ }^{20}$ PIELES (1994), p. 36. 
Las garrapatas (fig. 7) son otro de los factores de deterioro de los cueros, aunque suelen atacar con mayor dureza a los animales provenientes de explotaciones basadas en el pastoreo. Provocan perforaciones circulares con los bordes endurecidos, causan lesiones parecidas a cráteres e inutilizan las pieles.

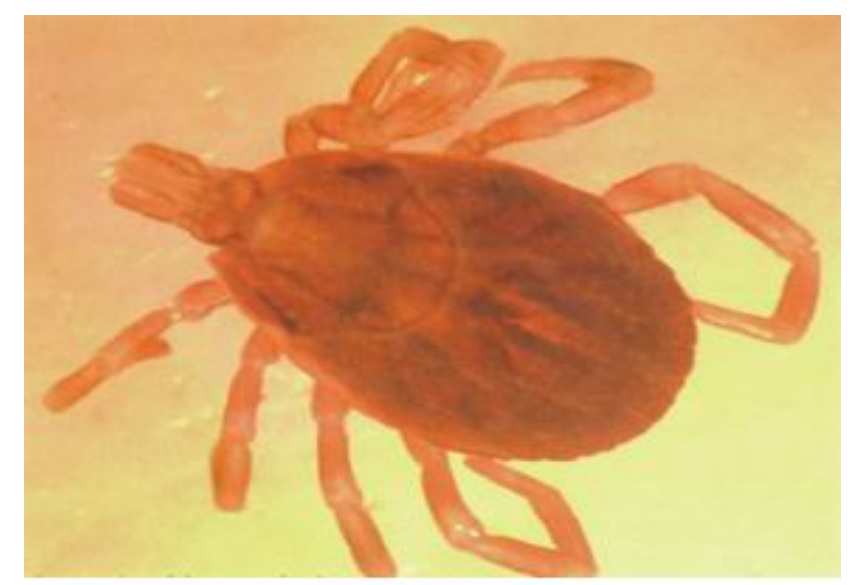

Fig. 7: Garrapata.

Mencionaremos en esta selección de enfermedades más frecuentes que dañan la piel, dolencias muy contagiosas como la linfoadenitis (fig. 8). Esta afección daña casi por completo las pieles y crea grandes nódulos y cicatrices en la zona de la cabeza, el cuello y la espalda de los animales, aunque puede llegar a extenderse en ocasiones y casos de extrema gravedad. Su incidencia es muy elevada en ejemplares adultos estabulados, disminuyendo de forma radical al salir a pastar al aire libre. El agente causal es el Corynebacterium 
pseudotuberculosis, el cual es muy resistente pues se mantiene vivo durante mucho tiempo en carne, heces, pus y suelo. ${ }^{21}$

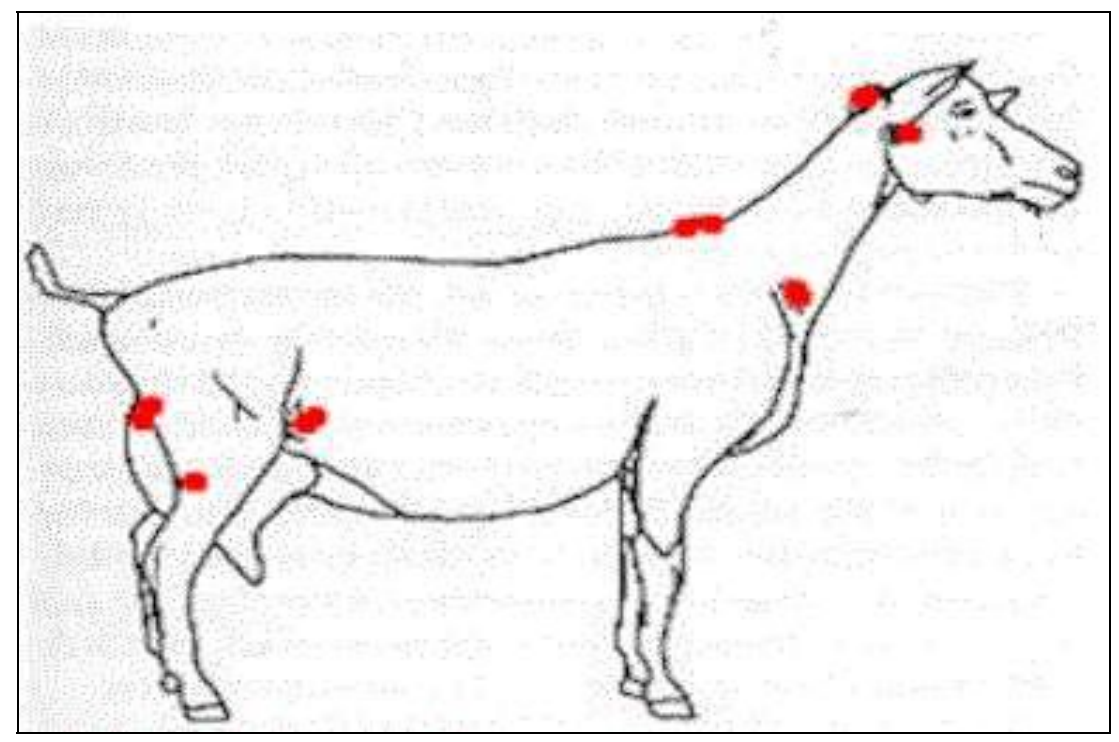

Fig. 8: Zonas de mayor incidencia de la linfoadenitis.

La viruela es otra enfermedad que ataca de manera extrema a la piel, inutilizándola casi en su totalidad. Felizmente está prácticamente erradicada en numerosos países, por lo que el riesgo de que la padezca algún animal disminuye claramente.

${ }^{21}$ CAPRA. La linfoadenitis caseosa. [en línea]. [consulta 13 mayo 2004]. Disponible en [http://capra.iespana.es/capra/linfoadenitis/linfoadenitis.htm] 


\section{I.2.4. Factores de manejo y explotación}

Dentro de este grupo podemos incluir todas las operaciones violentas que puede sufrir la piel de un animal, tanto antes como después del desuello. Entre ellas podemos destacar las vacunaciones y las quemaduras por marcaje, acciones durante las cuales la piel puede sufrir importantes daños que serán heredados por el cuero extraído de dicho animal. Durante el proceso de esquilado también pueden producirse heridas y cortes que dañen la piel, por lo cual se aconseja dejar entre 5 y 6 semanas tras el esquilado y hasta el sacrificio del animal. De este modo se consigue una perfecta cicatrización de las heridas y se evitan en gran medida los daños sobre el futuro cuero.

La pincha es quizá el factor de mayor incidencia en la devaluación de la calidad de una piel. En España conocemos por pincha a las heridas o abcesos producidos en el cuerpo de un animal por efecto de las espigas, semillas o restos vegetales que el ejemplar pueda encontrar durante su vida. En nuestro país provoca cuantiosas pérdidas y puede llegar a ser la responsable de una devaluación de hasta el $90 \%$ en el precio de los cueros. ${ }^{22}$

${ }^{22}$ PIELES (1994), p. 38-39. 
Durante el proceso de desuello pueden aparecer nuevos y numerosos inconvenientes. Como veremos más adelante, para un correcto desuello deben confluir una serie de factores: la salud de los ejemplares, ya que si la piel posee desperfectos por la acción de parásitos es más fácil dañarla; la edad, pues es mucho más fácil desollar animales jóvenes; el sexo, ya que los ejemplares hembra serán de mejor desuello que los machos; 0 incluso el sistema de explotación, con los animales criados al aire libre como los mejores para ser desollados y no los criados en establos, mucho más difíciles de desollar. En el delicado proceso de extraer la piel se pueden producir cortes al abusar del uso del cuchillo, así como desgarros como consecuencia de una excesiva tracción. Pueden aparecer también las denominadas "pieles espeletilladas", aquellas que sufren daños durante el desuello pero que no aparecen ni se hacen patentes hasta el curtido, pudiendo entonces llegar a provocar perforaciones en los cueros, los cuales quedan entonces muy dañados y deteriorados.

También durante el proceso de conservación y curtido pueden existir problemas que incidan en la calidad final de las pieles. Así, en el salado, en el almacenamiento, remojo, descarnado 0 acabado, se debe ser lo más cuidadoso posible para evitar cualquier tipo de perjuicio sobre la superficie del pellejo.

Como hemos podido comprobar tras esta breve reseña de los factores negativos que pueden influir en la devaluación de la calidad de una piel, un cuero en perfectas condiciones es un material 
I. Consideraciones generales

extraordinario que ha superado una serie de procesos y dificultades que hacen de él un elemento de gran resistencia y fiabilidad y un soporte muy interesante, susceptible de ser empleado dentro de múltiples campo, entre los cuales se incluye el grabado y la estampación. 


\section{I.3. CUEROS Y PERGAMINOS}

\section{I.3.1. El cuero}

\section{I.3.1.a. Antecedentes históricos del curtido}

Como es sabido, mediante el curtido se consigue convertir el pellejo del animal en un material de gran duración, flexibilidad y resistencia, ya que no en vano la piel curtida es imputrescible, ésto es, inmune a las bacterias y microorganismos que podrían provocar su destrucción. Las diferentes fases que constituyen la operación destinada a curtir la piel han evolucionado desde los inicios de dicha actividad, aunque todavía permanece intacto el elemento fundamental que provoca la conversión de la piel en cuero: la acción de los taninos. Sin embargo, los orígenes históricos, o mejor dicho, prehistóricos de la actividad del curtido, no están ligados a las citadas sustancias de origen vegetal, a los taninos. En efecto, antes que la utilización de los curtientes vegetales se generalizase, otros medios y procedimientos de tratamiento de las pieles fueron empleados por los hombres primitivos. Entre ellos podemos destacar el curado por salazón, gracias a la acción de la sal; el curado por secado, por efecto de la exposición de 
los pellejos al aire; 0 el curado por ahumado, mediante el uso del humo proveniente de fuegos o fogatas. ${ }^{23}$ Con el descubrimiento del proceso básico de curtido a partir del empleo de los taninos, la concepción de la piel sufrió un cambio radical dado que los cueros conseguidos tras dicho procedimiento ganaban en resistencia y ductilidad, convirtiéndose en un material de enormes posibilidades prácticas.

Los taninos empleados en tiempos remotos eran, en su mayor parte, de origen vegetal, siendo sustancias ácidas y astringentes cuya fermentación provoca la caída del pelo de los pellejos y una eliminación de la queratina presente en la piel, curtiéndola y convirtiéndola en cuero. ${ }^{24}$ Desde la aparición del curtido vegetal con taninos durante el periodo prehistórico el procedimiento básico no sufrió excesivos cambios, por lo que la evolución del proceso se centró en un perfeccionamiento de las técnicas empleadas tanto en la extracción de las sustancias curtientes como en los diferentes pasos de los que constaba la conversión de un pellejo en cuero curtido. Uno de los campos en los que la evolución fue constante, el de las técnicas de pigmentación y coloración de los cueros, usó tanto pigmentos vegetales como minerales. Entre los primeros tenemos el rojo proveniente de las flores de la fucsia y el amarillo de la corteza de la

\footnotetext{
${ }^{23}$ Este último podría ser el más antiguo según investigaciones recientes, y todavía hoy es practicado por los mongoles, los chinos, lo inuit o esquimales, o los indios americanos weymantachies. Véase: TOUSSANT-SAMAT, M. (1994), p. 315.

${ }^{24}$ La procedencia y extracción de los taninos, así como otras cuestiones de índole técnica, serán analizadas con mayor profundidad en el apartado I.3.1.b., p. 44-53.
} 
granada, llamada no sin motivo fruta del cuero en Irán, mientras que algunos de los pigmentos minerales más usados fueron la malaquita y la azurita, para el verde y el azul respectivamente. ${ }^{25}$

Durante toda la Antigüedad y la Edad Media el proceso de curtido fue perfeccionándose de manera patente, empleando todo un

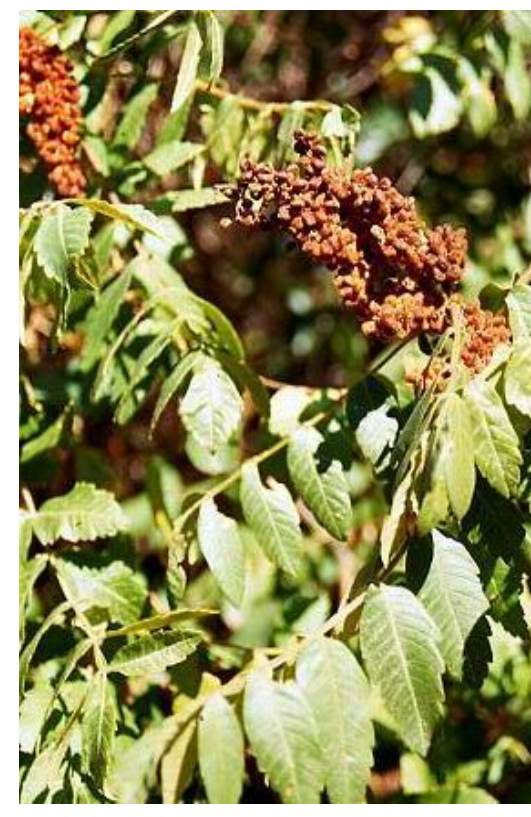

Fig. 9: Planta de zumaque. abanico de procedimientos que denotan una continua evolución hacia técnicas mucho más desarrolladas. ${ }^{26} \mathrm{~A}$ medida que avanzamos en el tiempo el número de sustancias de las cuales se extraen los taninos se amplia ostensiblemente, y comienzan a utilizarse de manera generalizada las cortezas de pino y de granado, las bellotas, la acacia o el zumaque (fig. 9), convirtiéndose este último en uno de los productos más

${ }^{25}$ TOUSSANT-SAMAT, M. (1994), p. 417.

${ }^{26}$ Gracias a pinturas y relieves funerarios egipcios, sabemos con total certeza que se sometía a las pieles a inmersiones en líquidos diversos y a procesos de secado y ablandado mediante el uso de cuchillas de madera y metal, configurando un mecanismo cada vez más complejo. También los hebreos perfeccionaron los procesos de curtido al comenzar a utilizar la corteza de roble, de altísimo porcentaje en taninos, empleo que se mantiene en la actualidad y que podemos encontrar citado en el Talmud. Véase: LACERCA, A. M. (1976), p. 27. 
importantes de la industria del cuero, ${ }^{27}$ la cual alcanzó un grado de perfeccionamiento tal que, hasta finales de la Edad Media, no sufrió excesivas modificaciones, continuando prácticamente estancada en unos modos antiquísimos. Fue entonces, en el paso del Medioevo al Renacimiento, cuando se descubrieron las propiedades curtientes del alumbre, sulfato doble de aluminio y potasio, lo que provocó una revolución en los mecanismos del curtido, así como una floreciente industria alrededor de su compraventa. El comercio del alumbre llegó a ser una de las bases de enormes fortunas como la de los Medici florentinos, y el curtido mediante esta sustancia fue el más eficiente y usado en ciertas zonas de Europa hasta finales del XIX, cuando fue sustituido por la introducción del curtido al cromo. ${ }^{28}$

Es durante el siglo XVIII cuando esta situación de inmovilismo y estancamiento cambia radicalmente; la llegada de la llustración marca un antes y un después, no sólo dentro del ámbito de nuestro estudio, sino también en la concepción global del mundo de la época. Asistimos a los primeros intentos considerables de investigar científicamente los procesos de curtido con el fin de lograr su modernización, y es en Francia, cuna del movimiento ilustrado, donde se dan los primeros avances en una técnica y unos procedimientos que habían permanecido anclados en el pasado durante siglos.

\footnotetext{
${ }^{27}$ Los cordobanes hispanos eran célebres por su curtido con zumaque, el cual les otorgaba unas cualidades especiales y muy apreciadas. Véase apartado II.2.2., p. 126.

${ }^{28}$ TOUSSANT-SAMAT, M. (1994), p. 318.
} 
Colbert, ministro de Luis XIV, el Rey Sol, comenzó a investigar científicamente los métodos y las sustancias empleadas para el proceso de curtido, para lo que tuvo que enfrentarse al inmovilismo que defendían los gremios de curtidores y zurradores, quienes querían seguir basándose en la tradición oral y el mero empirismo. Tras sus investigaciones, Colbert encargó a Des Billetes la escritura del primer tratado de la historia acerca de las técnicas del arte de la piel, el cual apareció en 1708 bajo el título de La tannerie et la preparation des cuirs (El curtido y la preparación de los cueros), trabajo al que siguieron otros, entre los que destacó el tratado de Lalande, de 1764, L'art du tanneur (El arte del curtidor). ${ }^{29}$

Es en el paso del siglo XVIII al XIX, concretamente en 1805, cuando encontramos uno de los primeros tratados acerca del arte de curtir en nuestro país. Precisamente así titula Don Cayetano Miguélez su obra Arte de curtir o instrucción general de curtidos, publicada por la Imprenta Real en 1805. En el prólogo de dicho texto Miguélez hace un resumen de los objetivos que le impulsaron a escribir su tratado, en el cual describe muchos y variados métodos de curtido que se venían usando en países vecinos, intentando adaptarlos a la geografía española:

\footnotetext{
${ }^{29}$ ROMERA, E. El comercio de la piel en España en el siglo XVIII [en línea]. [consulta 23 marzo 2006]. Disponible en [http://www.cueronet.com/historia5.htm]
} 
"Los extranjeros, por el contrario, han escrito mucho sobre él [el arte de curtir], principalmente después que la Química ha prestado á los hombres los medios de indagar los obscuros misterios de la naturaleza, penetrando sus mas ocultos senos, sorprendiéndola (digámoslo así) en sus mismas operaciones. Pero los extranjeros han escrito para ilustrar á sus compatriotas; por esta razon se han ceñido en sus instrucciones á la situacion del país, á la clase de sus producciones naturales, á la calidad y virtud de estas, al clima, á las aguas; y nadie ignora quan diversos suelen ser todos estos objetos aun en un mismo suelo, y quan distintos con relacion á otro suelo y clima diferentes. De aquí es que á excepción de aquellos principios generales que son comunes á este arte en todos los suelos y climas, ninguna otra noción puede sacar un español de sus sabias y útiles producciones; y de aquí tambien la necesidad de publicar una pequeña obra, que adaptando estos mismos principios, señale, describa y analice las producciones naturales de nuestro suelo, y las aplique por principios sólidos, y por un órden tan metódico como claro, á las diferentes operaciones de este arte." 30

En este volumen vemos un reflejo en nuestro país del interés latente en toda Europa, e incluso en América, por modernizar y progresar en el estudio de los procesos de curtido, el cual no es sino síntoma del clima general de desarrollo intelectual, científico e

\footnotetext{
${ }^{30}$ Fragmento extraído de la introducción del texto en el cual se ha conservado la ortografía original del tratado MIGUÉLEZ, C. (1805).
} 
industrial en el que se ve envuelta la sociedad del siglo XIX. Es dentro de este periodo de incesantes cambios cuando las artes de la piel conocen una serie de avances que provocan una vertiginosa evolución. El hallazgo de nuevos extractos curtientes supone un avance extraordinario dentro del proceso de curtido de las pieles, y así aparecen el curtido al aluminio y al cromo, gracias a las patentes de Cavalin y Knapp. A la vez que se descubren estos productos se investiga en la creación de sustitutos artificiales de las sustancias que se venían utilizando desde antaño para el curtido, con lo que surgen taninos artificiales creados por síntesis química, los primeros de los cuales fueron patentados y producidos por Schiff en el año 1871. Como vemos la industria de la piel se incorpora perfectamente a la progresiva evolución industrial, tecnológica y científica de la segunda mitad del siglo XIX. ${ }^{31}$

Para finalizar este escueto repaso histórico, diremos que en el siglo XX las tenerías e industrias de la piel sufren el lógico cambio que supone la progresiva e imparable modernización técnica. El elemento humano desaparece casi por completo para ser sustituido por máquinas de todo tipo que realizan su trabajo de forma mecánica y programada previamente. En otro orden de cosas, la aparición de innumerables materiales sintéticos asociados a la industria textil y del calzado, provoca una lógica caída del uso masivo de la piel animal y

\footnotetext{
${ }^{31}$ ROMERA, E. Las grandes revoluciones técnicas y la utilización industrial de la piel [en línea]. [consulta 23 marzo 2006]. Disponible en [http://www.cueronet.com/historia6.htm]
} 
del cuero. Sin embargo, ésta nunca ha dejado de estar presente en la vida cotidiana, ya sea forrando un sillón, bajo la forma de unos zapatos, un bolso o en el cinturón que usamos cada día. Se nos presenta por tanto como uno de los materiales más antiguos y utilizados a lo largo de los siglos, pero a la vez como un material versátil y flexible que es capaz de adaptarse a cualquier cambio 0 revolución social.

\section{I.3.1.b. Síntesis del proceso de curtido}

El análisis pormenorizado de las diferentes fases que componen el proceso de curtido excede sobremanera los límites de este estudio, por lo que, en las líneas que siguen, ofreceremos una visión general sin entrar en una descripción exhaustiva. Como se ha indicado previamente, los procedimientos de curtido de las pieles han sufrido una patente evolución y perfeccionamiento a lo largo de la historia, lo que provoca que actualmente existan múltiples variedades de curtido y posibilidades de manipulación de los pellejos hasta convertirlos en cuero. Ante la imposibilidad de hacer referencia a todas estas variantes, nos hemos decantado por proponer un esquema tipo de los procesos curtientes, indicando donde sea preciso las posibles variaciones, pero tratando de otorgar una breve visión panorámica de los diferentes pasos que conforman el procedimiento. Es también 
evidente que dejaremos de lado los detalles de índole fisicoquímica y científica, fundamentales dentro del curtido pero que en nuestro caso no harían otra cosa sino entorpecer una comprensión del conjunto de operaciones a analizar. ${ }^{32}$

El primer paso del curtido es el desollado (fig. 10) en el cual se procede a separar la piel del cuerpo sin vida del animal escogido,

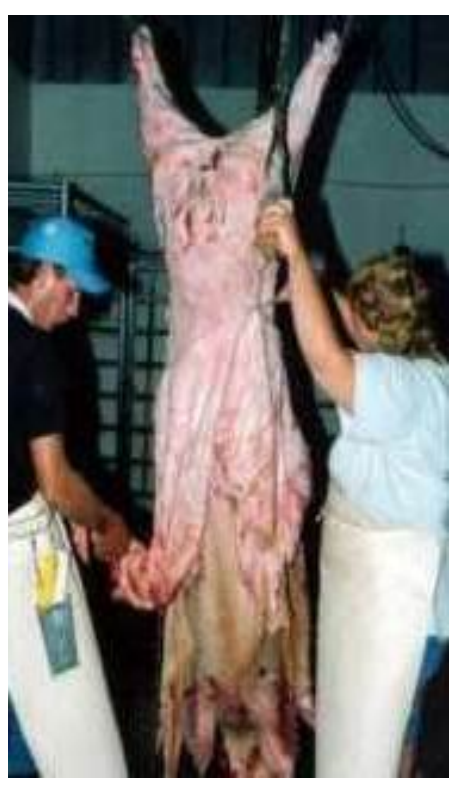

Fig. 10: Proceso de desollado. operación que debe realizarse con el máximo cuidado para evitar en lo posible la aparición de defectos y obtener así un pellejo lo más uniforme posible. Una vez obtenida la piel se debe eliminar cualquier resto del tejido carnoso que haya podido quedar adherido al lado carne del pellejo. Éste incluye vasos sanguíneos, capas de grasa y tejidos conjuntivos que no son de utilidad alguna en lo que a la obtención de cueros se refiere, y pueden incluso provocar la aparición de infecciones en la piel. Para evitarlo se lavan las pieles eliminando la suciedad, el estiércol, los restos de carne, sangre o linfa,

${ }^{32}$ Para una visión pormenorizada de los aspectos fisicoquímicos del curtido, así como un análisis de las diferentes posibilidades de la moderna industria del cuero, véase: QUÍMICA (1985). 
dejando los pellejos lo más limpios que se pueda. Posteriormente se recorta la piel y se quitan las partes inservibles como aquellas cercanas a las patas, la cabeza o las del bajo vientre, eliminándose también el vergajo, la cola, las ubres, la bolsa testicular, las orejas, el hocico y el morro, zonas todas susceptibles de convertirse en focos de infección. Obtendremos así una superficie lo más homogénea posible y lista para continuar el proceso iniciado.

Una vez tenemos el pellejo limpio comienzan los pasos referentes al proceso de conservación, operación fundamental dentro del curtido ya que permitirá minimizar el riesgo de aparición de posibles infecciones. Es en el periodo post mortem y tras el desuello cuando los ataques bacterianos son más frecuentes, siendo en algunos casos incluso inevitables, lo que hace imprescindible su conservación, la cual detiene, o al menos reduce al máximo, el proceso natural de degradación de la piel, manteniéndola en buenas condiciones hasta iniciar la elaboración de los cueros propiamente dicha. ${ }^{33}$ Existen varios métodos para la conservación de los pellejos, desde los empleados ya por los curtidores primitivos hasta modernas operaciones basadas en la acción de productos químicos. Sin entrar a

\footnotetext{
${ }^{33}$ Las propias enzimas de la piel provocan una reacción de autólisis o muerte celular que, según sea la temperatura, la humedad y el tiempo, puede llegar a ser más o menos grave y dañino para la piel. Al mismo tiempo comienza la acción de las bacterias, condicionada sobre todo por los tres factores antes apuntados, lo que conlleva que en las zonas cálidas y húmedas las bacterias produzcan daños irreparables en un lapso de tiempo muy corto. Por su lado, en áreas frías el tiempo transcurrido hasta que la acción bacteriana es irreparable es mucho más amplio, permitiendo trabajar con mayor tranquilidad.
} 
analizar en profundidad ninguno de ellos, podemos citar el secado, el salado y el pickelado. Tanto el secado como el salado (fig. 11) están basados en el concepto de la deshidratación de los pellejos, disminuyendo el nivel de humedad de las pieles y dificultando por ende la aparición de la flora bacteriana y los microorganismos, los cuales necesitan un cierto nivel de humedad para su desarrollo. Dependiendo de las condiciones climáticas, de consideraciones económicas como el precio de la sal, o del tipo de piel a conservar, se podrá elegir uno u otro procedimiento, aunque actualmente sea el pickelado, junto a otros procesos químicos, uno de los más empleados. El pickelado combina elementos de los dos anteriores, aunque sometidos a las modernizaciones y evoluciones que un negocio como el de las curtidurías requiere. Consiste básicamente en tratar las pieles con una solución de sal común y ácido sulfúrico, la conocida como solución de pickel, la cual impedirá la aparición de ataques bacterianos u hongos, consiguiéndose una conservación idónea. ${ }^{34}$

Finalizada la conservación entramos en lo que Lacerca denomina fabricación de la piel, fase en la cual se convertirán los pellejos en verde en cueros curtidos listos para su uso industrial. El primer paso de esta nueva etapa es el remojo, destinado a rehidratar

\footnotetext{
${ }^{34}$ Esta solución debe contener un $12-15 \%$ de $\mathrm{NaCl}$ y un $1,5-2 \%$ de $\mathrm{H}_{2} \mathrm{SO}_{4}$, obtenida mediante la mezcla de 100 litros de $\mathrm{H}_{2} \mathrm{O}, 10$ kilos de ClNa y 1 kilo de $\mathrm{H}_{2} \mathrm{SO}_{4}$. Véase: QUíMICA (1985), p. 189 y siguientes.
} 
de nuevo las pieles y devolverlas a un estado de ductilidad necesario para los procesos inmediatamente posteriores. ${ }^{35}$

Cuando la piel ha recuperado su flexibilidad original se puede proceder a realizar el apelambrado y el descarnado. En el primero de ellos el objetivo es eliminar el pelo y la lana que pudieran existir en el lado flor de la piel, así como las capas de tejido inútiles para la obtención del cuero curtido. ${ }^{36}$ Es en este momento preciso cuando se

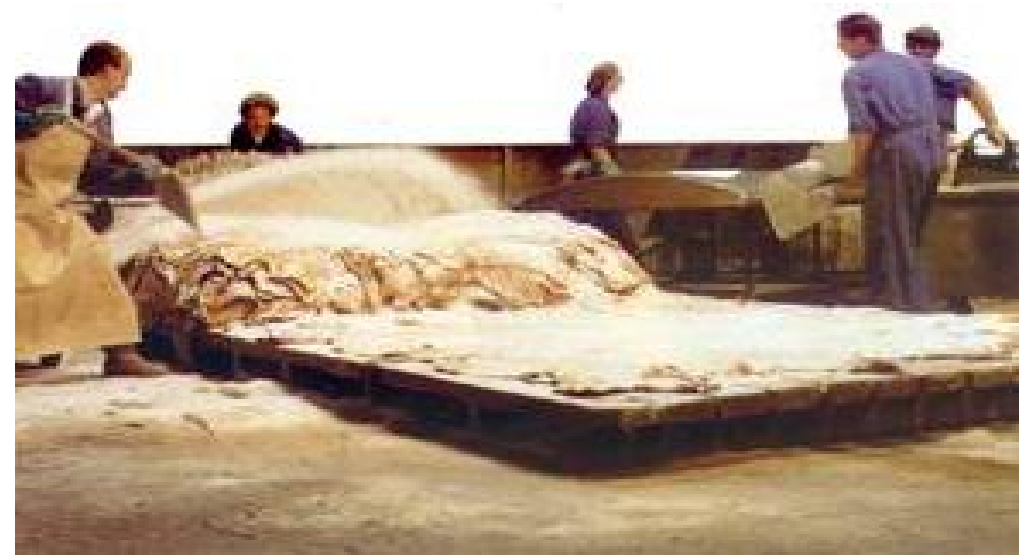

Fig. 11: Formación de las pilas para el salado.

suprime la epidermis, mientras que en el descarnado será la hipodermis, o tejido adiposo subcutáneo, la capa eliminada dada su

\footnotetext{
${ }^{35}$ En algunos lugares a esta operación del remojo se le conoce con la denominación de reverdecido.

${ }^{36}$ De los tres estratos que conforman la piel, epidermis, dermis e hipodermis, tan sólo el central, la dermis o corium, es válido para el curtido y el que configurará el producto definitivo.
} 
inutilidad dentro de la obtención de los cueros. ${ }^{37}$ Con la eliminación de estos tejidos inútiles en este preciso momento del proceso, se consigue que los productos curtientes que en pasos sucesivos actuarán sobre la piel, penetren de manera idónea en la dermis convirtiéndola en cuero.

Descarnadas y apelambradas las pieles, y tras el breve paso del desencalado, mediante el que se elimina la cal existente en el interior de los pellejos después de las operaciones inmediatamente precedentes, se puede proceder a la etapa central de todo el proceso: el curtido. Será éste el paso fundamental para determinar la calidad, naturaleza y características del futuro cuero, teniendo un papel determinante en el resultado definitivo del proceso la elección de uno u otro tipo de sustancias curtientes, las cuales son definidas por Lacerca como aquellas que, al ser absorbidas por las pieles de los animales, convierten a éstas en cuero. ${ }^{38}$

Merece la pena establecer una división general entre los dos grandes tipos de curtientes: los de origen vegetal o taninos, y los provenientes de síntesis química a partir de sustancias minerales. Si bien los primeros ya vimos que han sido los curtientes más empleados

\footnotetext{
${ }^{37}$ Tanto el apelambrado como el descarnado pueden realizarse a mano o con maquinaria apropiada para tal fin. Dentro del descarnado debemos mencionar la opción del dividido de la piel, no siempre necesaria aunque muy útil si la ocasión lo permite. Mediante el dividido se pueden obtener dos pieles de un mismo pellejo, siempre que éste posea un grosor suficiente como para ser partido en dos longitudinalmente. Una de las pieles obtenidas conservará la flor del cuero en ella, mientras que la otra actuará como descarne.

${ }^{38}$ LACERCA, A. M. (1976), p. 83.
} 
durante milenios, en la actualidad la gran parte de la industria del cuero se ha decantado por la utilización de curtientes minerales, y más concretamente por la modalidad del curtido al cromo, la cual predomina desde su descubrimiento. ${ }^{39}$

Aparte de la posibilidad de escoger entre sustancias curtientes vegetales o minerales, a lo largo de la historia se han empleado otros procedimientos para hacer entrar en contacto de manera eficaz y efectiva las soluciones curtientes

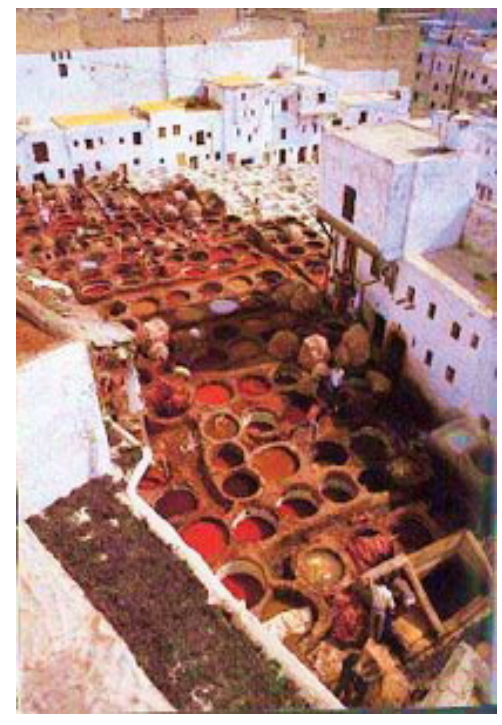

Fig. 12: Curtido en fosas. con las pieles. Desde el curtido en fosas, el más antiguo conocido y casi totalmente extinguido si exceptuamos algunas zonas del Magreb (fig. 12), al curtido acelerado combinando piletas y fulones 0 el curtido veloz, las posibilidades son innumerables, aunque todas tienen como objetivo conseguir una piel curtida en el menor tiempo posible y con la mayor calidad.

\footnotetext{
${ }^{39}$ El proceso que emplea las sales de cromo como producto curtiente fue descubierto en 1858 por Knap y desde entonces se convirtió en el más empleado, a pesar de que también se han utilizado sales de aluminio o zirconio, así como tratamientos mediante sílice o polifosfatos, Véase: QUÍMICA (1985), p. 318 y siguientes.
} 
Una vez acabado el curtido, los cueros poseen una coloración blanca que casi nunca se conserva. Muy al contrario, desde tiempos inmemoriales la operación del teñido de las pieles ha sido fundamental dado que condiciona la apariencia cromática final del cuero. La gama de colores que puede adoptar una piel es prácticamente inabarcable, y si bien antiguamente los curtidores se veían obligados a emplear sustancias colorantes naturales, tras el descubrimiento de los colorantes y pigmentos de síntesis, el teñido de los cueros ha sufrido un auge extraordinario. Cualquier tonalidad puede ser conseguida, teniendo como objetivo en esta fase, no sólo la coloración del cuero, sino también la fijación de los pigmentos para no ser eliminados tras un simple lavado. ${ }^{40}$

Curtida y teñida la piel, tan sólo falta una serie de operaciones destinadas a devolver a los cueros las propiedades que, a lo largo de las fases anteriores, pueden haber perdido. Nos referimos al engrasado, acondicionado y ablandado, procesos por los que se otorga a las pieles tacto superficial agradable, flexibilidad, resistencia, permeabilidad al aire e impermeabilidad al agua, entre muchas otras características. Como paso final del curtido aparecen las numerosísimas posibilidades asociadas al acabado, grupo de operaciones que pueden modificar sustancialmente cuestiones tales como el tacto del cuero, su aspecto, la presencia de afelpado, su

\footnotetext{
${ }^{40}$ Los métodos de teñido son numerosísimos y de muy distinto tipo, destacando entre otros los teñidos en bombo, en máquina de sectores, en molineta, en tina, a cepillo o a pistola.
} 
textura superficial o la aparición de brillos y reflejos. La evolución de los procedimientos de acabado es realmente imparable y constante, surgiendo continuamente nuevas soluciones técnicas basadas en los últimos avances tecnológicos que vienen a sustituir a las ya existentes.

El cuero definitivo es el resultado de esta larga serie de operaciones fisicoquímicas que tan sólo hemos esbozado someramente; un material con enorme resistencia a la putrefacción pese a provenir de organismos vivos; un material duradero a la vez que flexible; un material empleado durante milenios en las más variadas parcelas de la vida humana y que en este trabajo pretendemos aplicar a un campo, no totalmente inédito pero sí realmente tangencial y secundario, aunque no por ello menos apasionante. 
ESQUEMA BÁSICO DEL PROCESO DE CURTIDO

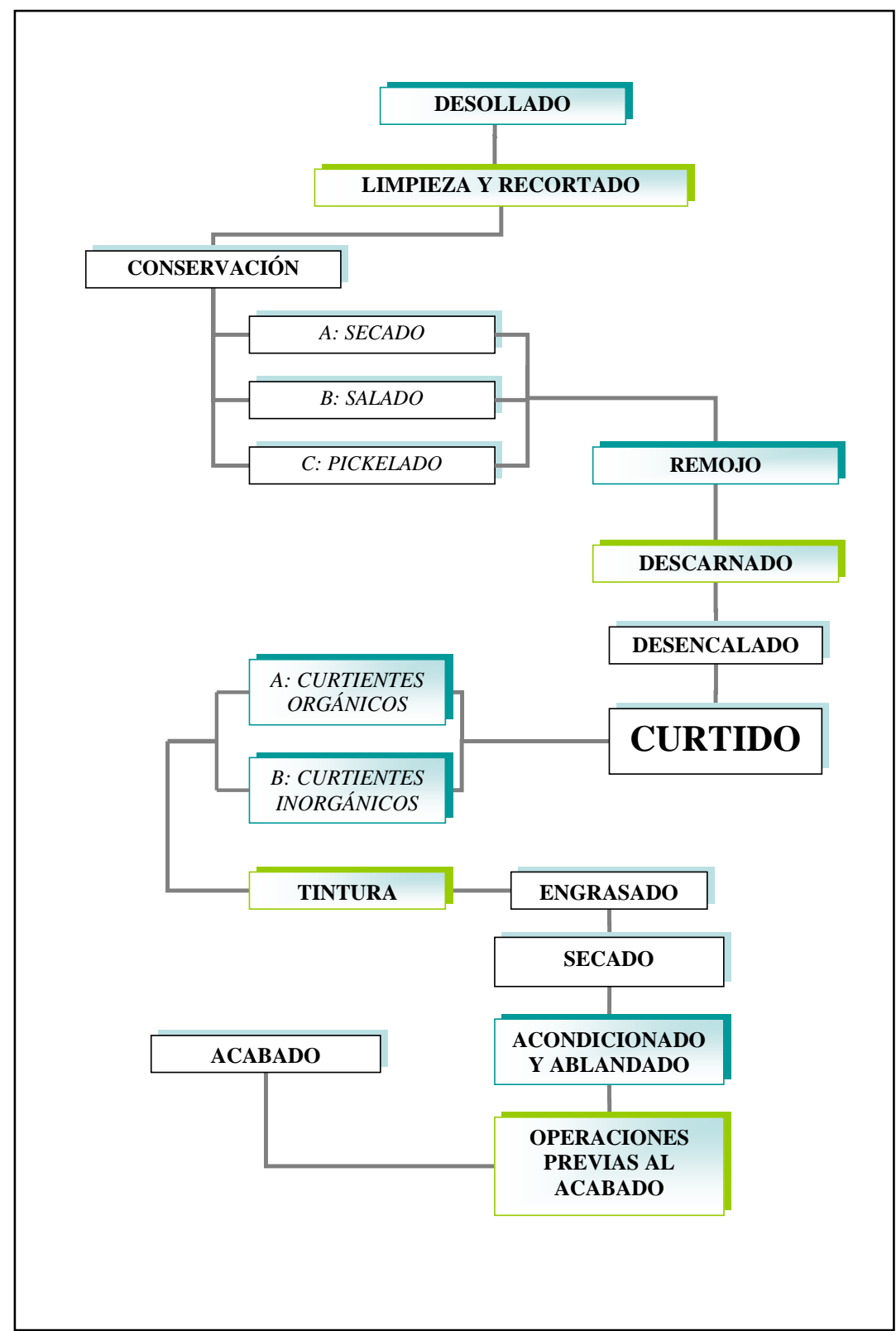




\section{I.3.1.c. Despiece de los cueros}

En este breve apartado veremos las diferentes zonas en las cuales se dividen y clasifican los cueros una vez curtidos. En una primera división podemos distinguir las zonas que quedan reflejadas en la fig. 13. Una clasificación más específica enumera

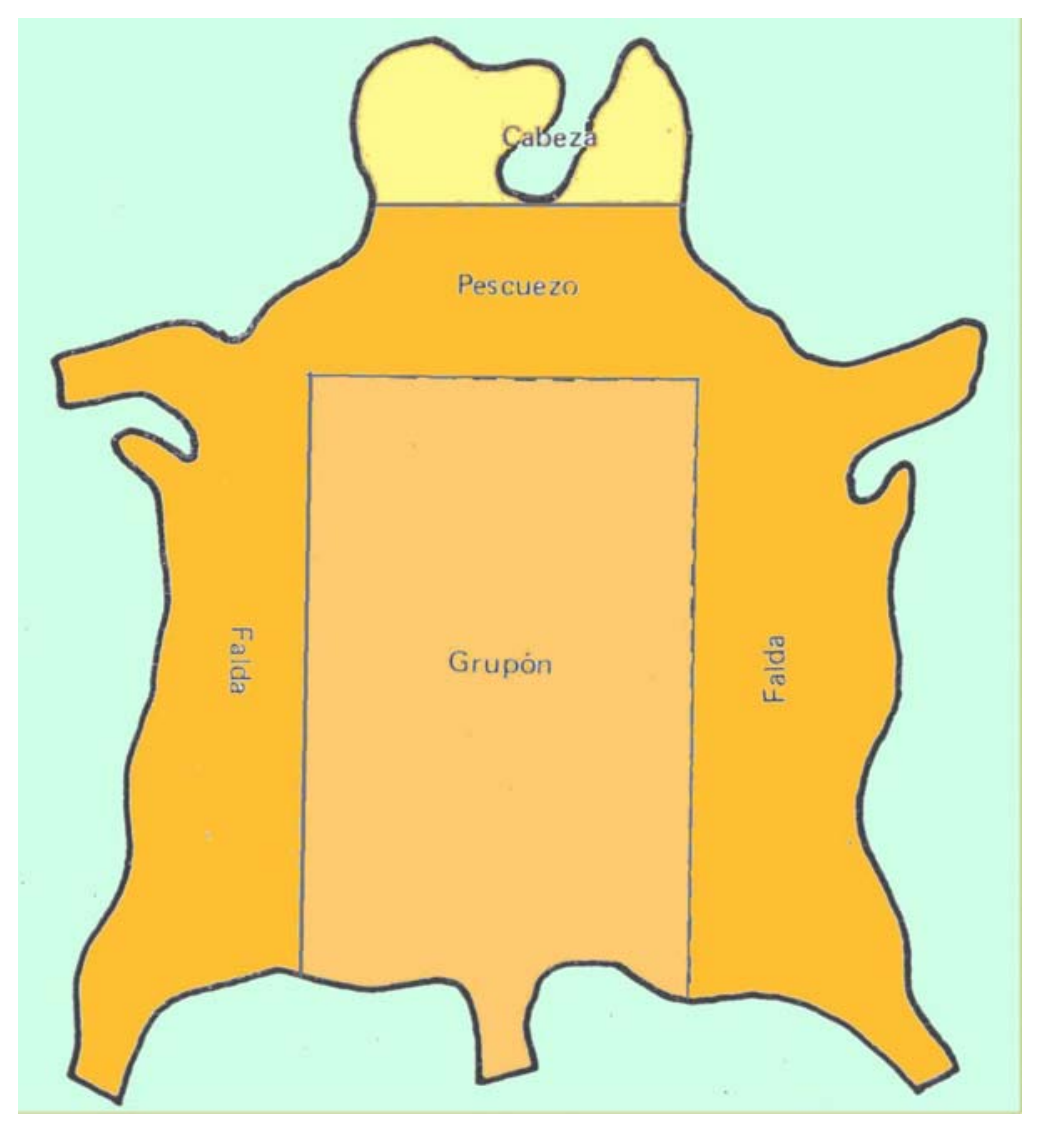

Fig. 13: Esquema general de despiece de una piel. 
diferentes áreas con características propias, las cuales pueden verse a su vez en la fig. 14.41

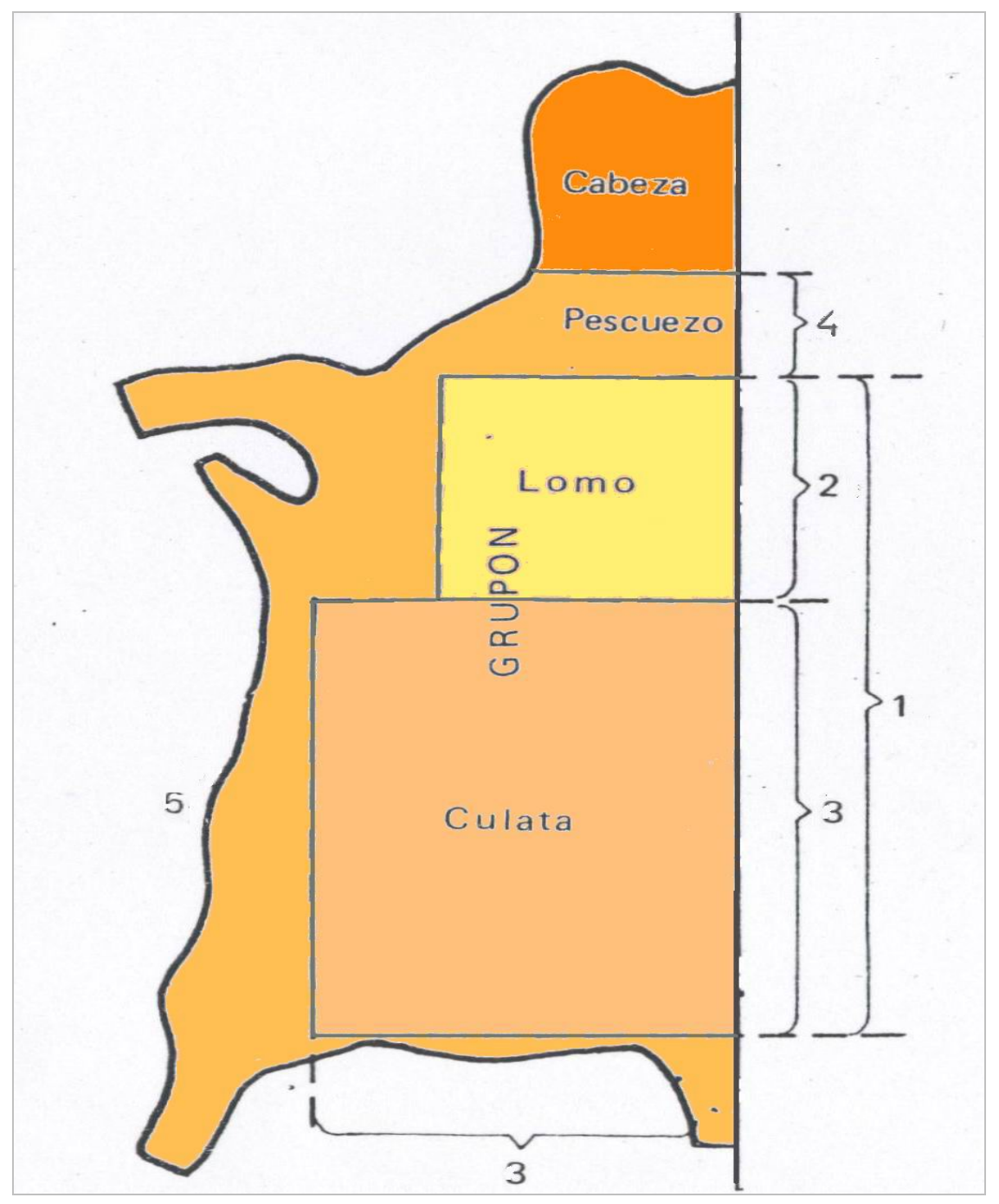

Figura 14. Diferentes zonas de despiece de una piel animal tipo.

\footnotetext{
${ }^{41}$ Para todo lo referente al despiece véase: QUÍMICA (1985), p. 1-3.
} 
En la imagen de esta última fig. 14 podemos distinguir las siguientes zonas:

GRUPÓN: Ocupa la región dorsal y lumbar del animal (1). Se trata de la zona más homogénea, más compacta y de mejor calidad de toda la piel. Es por tanto la más valiosa y apreciada y supone un peso del $46 \%$ con respecto al total del cuero. Está dividida en dos partes: por un lado el lomo (2) y por otro la culata (3), ambos con similares características de calidad y homogeneidad. Esta zona de los cueros es la idónea para realizar estampaciones sobre ella, debido a su homogeneidad y regularidad, tanto superficial como en lo que respecta al grosor.

CUELLO O PESCUEZO: Esta zona de la piel (4) ofrece irregularidades de grosor y consistencia, ya que es donde se manifiestan de manera más evidente las profundas arrugas tan comunes en algunos animales adultos (las rilas). Su peso es del $26 \%$ del total del cuero y puede ser aprovechada en nuestro trabajo de estampación siempre que provenga de animales jóvenes que no presenten rila, la cual podría provocar irregularidades en las imágenes. La pieza formada por el crupón y el cuello, tras haber eliminado las faldas, se conoce dentro de la industria del cuero como dosset. 
FALDAS: Las faldas (5) son las zonas que cubren el vientre y las patas del animal, con el $28 \%$ del peso total de la piel. Posee enormes irregularidades y diferencias de espesor, flexibilidad y densidad del cuero, por lo que no ofrece demasiadas ventajas y suele ser eliminada de los procesos de manufactura del cuero. Tampoco en un proceso de estampación homogénea será de utilidad, aunque esto siempre queda a expensas de los efectos buscados por el artista grabador. 


\section{I.3.2. El pergamino}

"-Como le digo, era un trozo de pergamino, y no de papel. El pergamino es de una materia duradera, casi indestructible. Rara vez se consignan sobre uno cuestiones de poca monta, ya que se adapta mucho peor que el papel a las simples necesidades del dibujo 0 de la escritura. $"$ "42

La invención o descubrimiento del pergamino está teñida de tintes legendarios. Según Plinio, fue el rey Eumenes II de Pérgamo (197-158 a.C.) quién inventó dicho material en la citada ciudad de Asia Menor donde se encontraba la célebre Biblioteca de Pérgamo fundada por el rey Atalo I, pero que bajo el reinado de Eumenes alcanzó su máximo esplendor. ${ }^{43}$ Hasta entonces el material comúnmente usado

\footnotetext{
${ }^{42}$ ALLAN POE, E. (2003), p. 13.

${ }^{43}$ Para todo lo relacionado con la historia y evolución del pergamino véase: DE HAMEL, C. (1999) y DAHL, S. (1985).
} 
como soporte para la escritura había sido el papiro, proveniente en su mayor parte de Egipto, soporte de origen vegetal que continuó usándose hasta los siglos centrales de la Edad Media (fig. 15), a pesar de ser rápidamente desbancado por el pergamino. Según Plinio, Eumenes se vio obligado a recurrir a este nuevo material hasta entonces desconocido tras un bloqueo comercial que impidió que el papiro egipcio llegara a las costas de Jonia. Ante la necesidad de contar con un soporte para el buen funcionamiento de la biblioteca y de otros asuntos de la ciudad, Eumenes dio con la solución al utilizar pellejos de animales como material de escritorio.

El empleo de pieles de animales no era sin embargo totalmente novedoso, y parece ser que los egipcios, los israelitas, los asirios e incluso los mismos griegos, ya habían hecho intentos con el mismo material. Los griegos incluso poseían un término para referirse a este elemento: diptherai, pero no fue sino en Pérgamo cuando comenzaron a producirse a gran escala hasta originarse la llamada durante siglos charta pergamena. Nuestro término pergamino (del latín pergamenum) proviene por tanto de esta ciudad de Asia Menor, siendo sinónimo de otros como vitela (del latín vitellus), como queda patente en las palabras de William Horman a comienzos del siglo XVI: "[...] eso sobre lo que escribimos: está hecho de pieles de animales; a veces se llaman pergaminos y a veces vitela."44

\footnotetext{
${ }^{44}$ Citado por DE HAMEL, C. (1999), p. 8.
} 


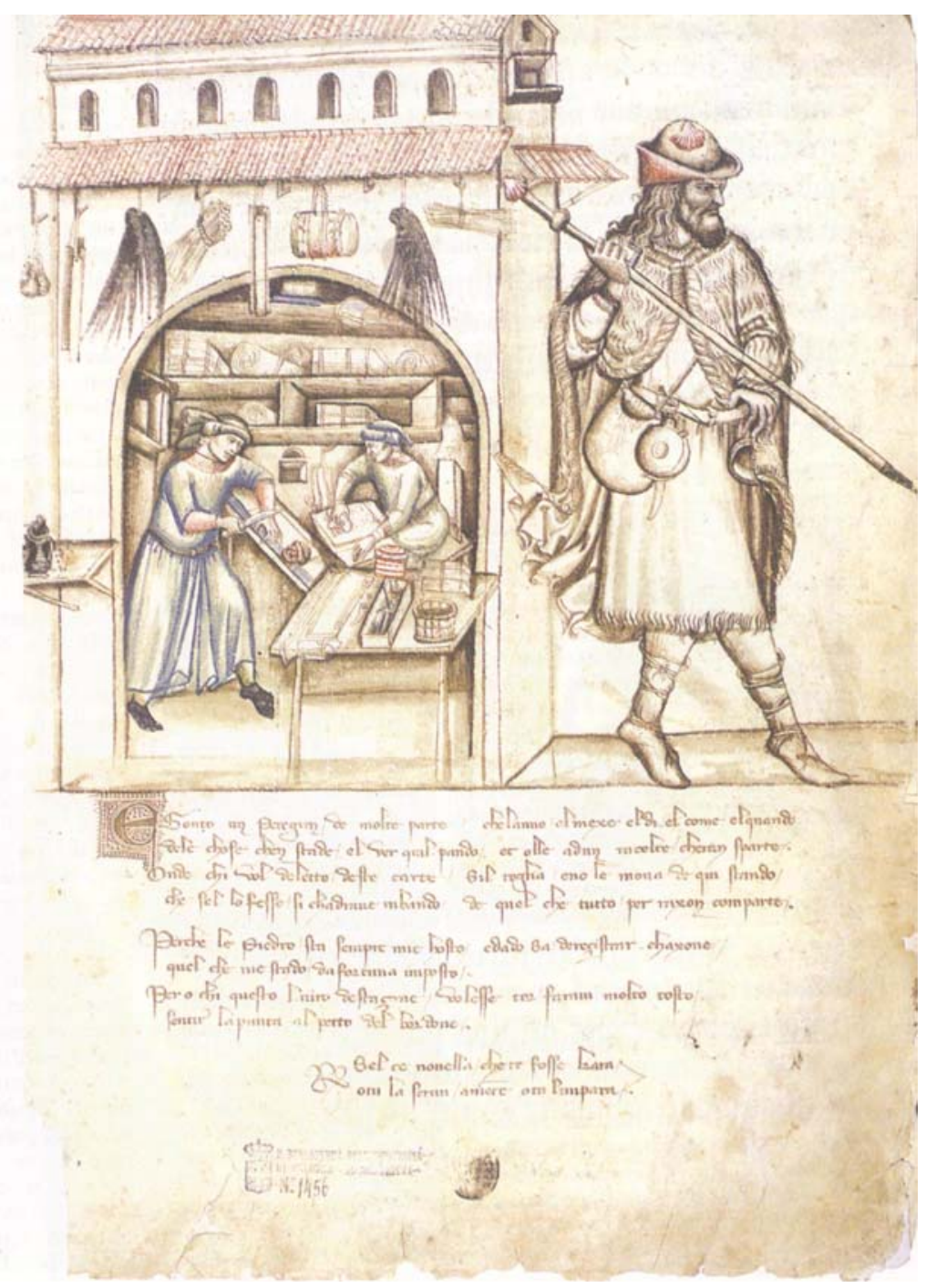

Fig. 15: Taller medieval de pergaminos tal y como aparece en una ilustración de una crónica italiana del siglo XV. 


\section{I.3.2.a. Fabricación de los pergaminos}

"- ¿No se hace el pergamino de las pieles de los corderos?

- Oh, señor, y también de pieles de vacas."45

Desde antiguo la técnica del procedimiento de preparación de los pergaminos no ha sufrido excesivos cambios (fig. 16). No debemos olvidar que un pergamino no es una piel curtida, sino que se trata de cueros secados en los cuales apenas han incidido ni actuado sustancias químicas si exceptuamos la cal. Antiguamente se empleaban para su fabricación pieles de cordero, ternero o cabra, aunque en Italia y en otras zonas se sabe del uso de pieles de ciervo, cerdo, liebre 0 incluso ardilla. ${ }^{46} \mathrm{El}$ proceso de fabricación de los pergaminos requiere de una serie de pasos que analizaremos a continuación.

${ }^{45}$ SHAKESPEARE, Hamlet, acto 5, escena 1, verso 110.

${ }^{46}$ DAHL, S. (1985), p. 31. 
En primer lugar debe escogerse una piel de excelente calidad, ya que de ello dependerán las características definitivas del pergamino obtenido al finalizar el proceso. También se debe tener en cuenta en

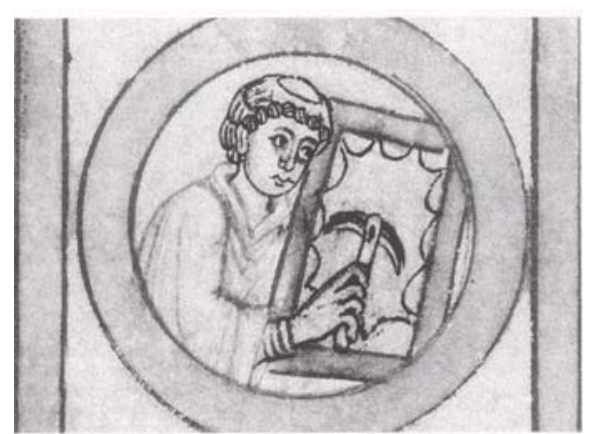

Fig. 16: Pergaminero medieval según una ilustración alemana del siglo XII.

este punto inicial el color

del pelo o la lana del animal elegido, ya que a pelo y lana blancos, el pergamino será de igual tonalidad, mientras que para tener superficies algo más coloreadas, serán las pieles de pelo oscuro las que debamos elegir. Una vez que ya se ha decidido el pellejo de cuero que usaremos, se procede a lavarlo en agua corriente y a bajas temperaturas. El tiempo destinado a esta operación previa de lavado difiere, aunque siempre debía quedar la piel lo suficientemente limpia como para poder continuar con los siguientes pasos del proceso. ${ }^{47}$

Cuando el pellejo ya está limpio se efectúa la eliminación del pelo, para lo cual previamente se deben remojar las pieles en un baño de agua y cal. Esta solución actúa sobre el folículo piloso debilitándolo y facilitando su posterior eliminación de manera parecida al proceso de

\footnotetext{
${ }^{47}$ Según algunos historiadores, el tiempo a emplear para este lavado debía ser de una noche y un día. Véase: DE HAMEL, C. (1999), p. 8.
} 
apelambrado del curtido tradicional de los cueros. ${ }^{48}$ De nuevo tenemos diferentes periodos de tiempo para este remojo de agua y cal, pudiendo variar entre 3 y 10 días.

Tras el baño de agua alcalina se sacan las pieles de las tinas 0 fosas donde han permanecido y se colocan sobre unas planchas de madera. Las pieles quedan tensadas y estiradas sobre dichas superficies con el lado flor, el del pelo, hacia fuera. Así el pergaminero puede eliminar el pelo y la lana que queda en este lado de los cueros; usa para ello una herramienta especial, que no es otra cosa que una cuchilla larga, curvada y con asas o agarraderas de madera en los extremos para facilitar su empleo. De este modo el artesano puede desprender el pelo con gran facilidad y sin apenas esfuerzo, y obtiene una superficie rosada donde el pelo era blanco y, donde el pelo era algo más pardo, una tonalidad descolorida de esta gama.

Finalizada la eliminación del pelo por el lado flor del cuero, se procede a dar la vuelta a la piel para, con la misma herramienta, quitar cualquier posible resto de carne o tejido adiposo que pudiera permanecer en el lado interno de la piel. Una vez ésta se encuentra totalmente limpia y exenta de residuos de pelo o carne, se vuelve a introducir en agua clara durante varios días para eliminar de manera integral cualquier rastro de cal que pudiera quedar en su interior. Acabado este remojo se procede a secar las pieles, para lo que se usan potentes y resistentes bastidores de madera en los cuales se

\footnotetext{
${ }^{48}$ Véase apartado I.3.1.b., p. 48.
} 
tensan las pieles, pudiendo ser tanto rectangulares como circulares Los pellejos nunca deben ser clavados a los marcos de madera, sino sujetados mediante cuerdas, tiras de cuero o clavijas presentes en los bastidores. Por efecto de la enorme tensión a la que son sometidas las pieles a lo largo de estas operaciones de tensado y secado, pueden producirse con gran frecuencia roturas en los cueros, que toman la

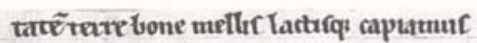

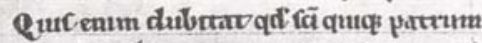
soeatronibs nof uutert a gettos ftosit confirment atip hoctertur granplat? fo cuolummubs fur p m que nob ad memoziam farpta welnquerutre do

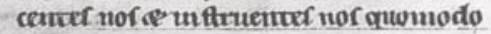
ad uetitum mumucar pouttarac dums. condinn ftr: equoin agonit tolezanda. cetha muna:'P ugnanto ğp not. * noc smata.tpor entinor bis benor adscranptie Qui dearté cossp pín for ca fก̃.

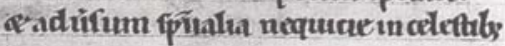

Fig. 17: Pergamino del siglo XII con rotura, procedente de la abadía inglesa de Winchombre (Gloucesterhire) forma de orificios ovalados y a veces se intentan coser para subsanar el daño. A pesar de todo no eran pocas las ocasiones en las cuales muchos monasterios pobres $\mathrm{y}$ carentes de elevados recursos económicos, usaban incluso estos pergaminos defectuosos adaptando el texto a las irregularidades de la superficie (fig. 17).

Cuando los futuros pergaminos están perfectamente tensados dentro de sus respectivos bastidores, se procede a la operación más delicada de todo el proceso. En ella, y mediante el empleo de la herramienta más característica del pergaminero, el lunellum, se raspan 
ambos lados de la piel para eliminar material sobrante y conseguir un soporte extremadamente fino y a la vez resistente. (fig. 18) Este cuchillo con forma de media luna se usa con extremo cuidado para no

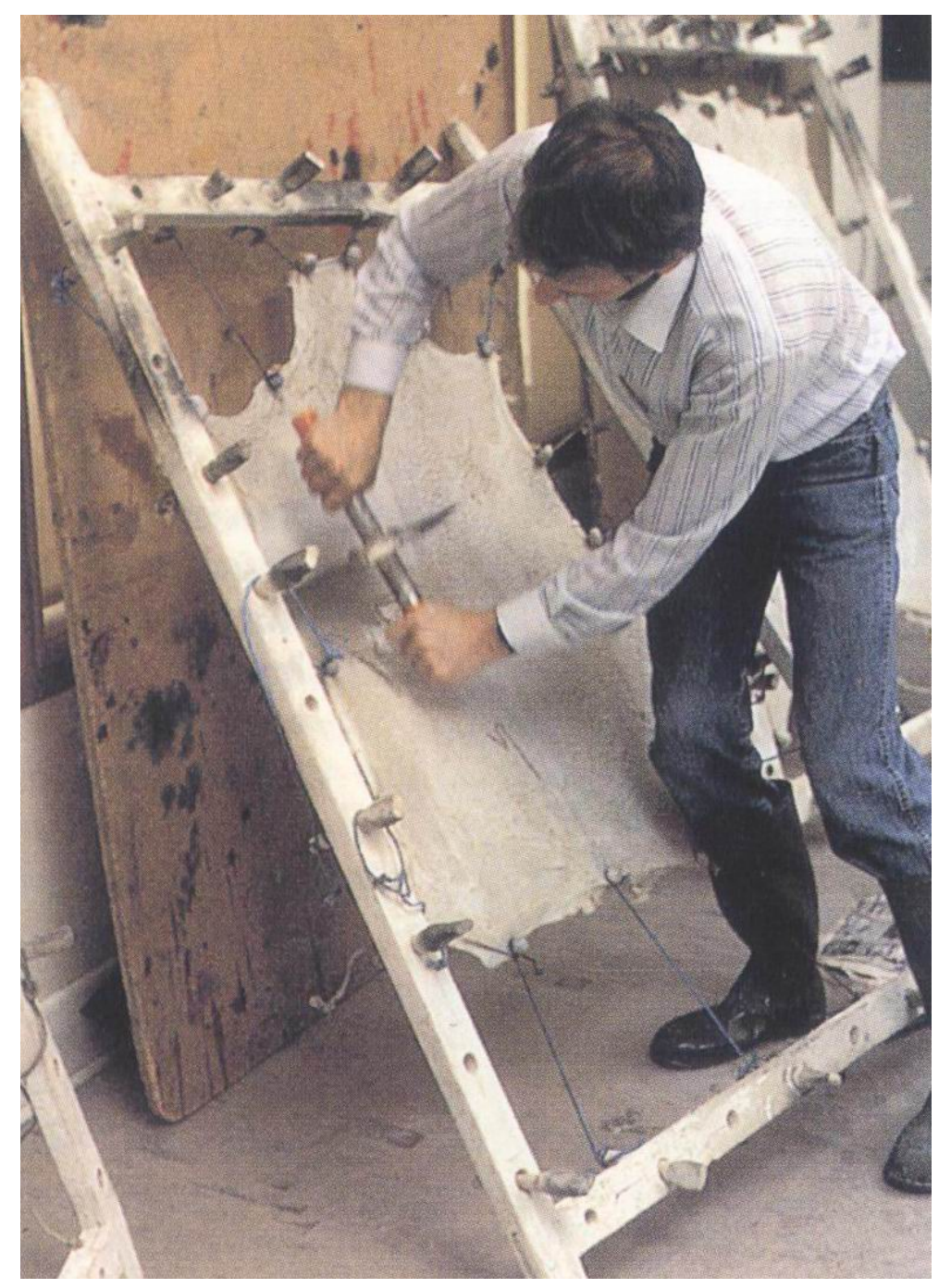

Fig. 18: Artesano trabaiando un pergamino. 
producir daños irreparables sobre la superficie del pergamino, insistiendo algo más sobre el lado carne o interno de la piel. A medida que se actúa con la cuchilla sobre el pellejo, se aprietan cada vez más las clavijas con el fin de que la tensión nunca decaiga y pueda alcanzarse un grosor adecuado. Incluso cuando la piel ya se ha dejado secar al sol (siempre dentro de los bastidores), se continúa con el comentado proceso de raspado sobre la superficie tensa como si de un tambor se tratara. 49

El raspado continuará dependiendo del grosor que se desee alcanzar para el pergamino definitivo, obteniéndose finuras que asemejan el papel de seda dada su extrema sutilidad. Como operación definitiva de esta fase fundamental del raspado se debía actuar finalmente sobre el lado flor para eliminar un cierto brillo satinado que solía aparecer, el cual dificultaba una correcta escritura sobre dicho soporte. Según De Hamel éste era el pergamino que se adquiría al percamenarius (fig. 19), no totalmente apto para su uso ya que le faltaba recibir una última preparación de yeso y un pulimentado final con ante o piedra pómez. ${ }^{50}$

\footnotetext{
${ }^{49}$ A lo largo de toda esta fase de raspado se produce una gran cantidad de desechos orgánicos (las virutas de la piel raspada) que pueden aprovecharse para la fabricación de importantes cantidades de colas orgánicas de diferentes usos.

${ }^{50}$ DE HAMEL, C. (1999), p. 14-15.
} 


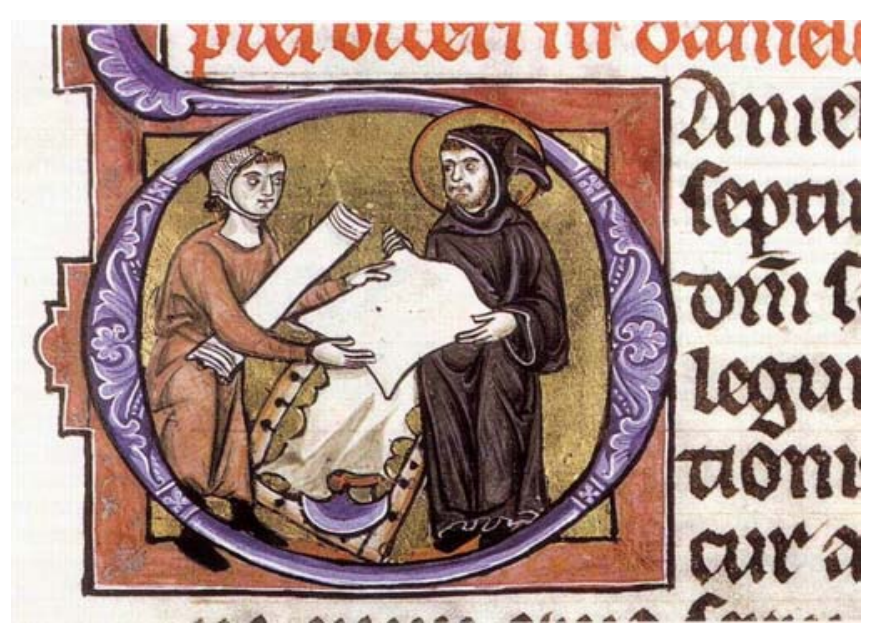

Fig. 19. Comercio medieval de pergaminos representado dentro de una inicial de un manuscrito francés del siglo XIII.

Una vez finalizado el proceso, el material obtenido es de una tremenda calidad y ofrecía una serie de ventajas muy significativas frente a otros soportes como el papiro, por lo que se prefería emplear en los documentos y textos importantes. Así mismo, era mucho más fácil de conseguir ya que sólo dependía de la existencia de los animales adecuados, mientras que el papiro tan sólo podía fabricarse en zonas muy concretas como el valle del Nilo o la ciudad de Siracusa, en la costa oriental de la isla de Sicilia. También el hecho de que puedan utilizarse ambas caras del material fue una tremenda ventaja frente al papiro, el cual tan sólo era útil para la creación de libros en forma de rollo, y no tanto para conformar un libro de páginas tal y como hoy lo conocemos. Otro de los factores que se sumaron a la lista de 
ventajas con las cuales partía el pergamino fue la posibilidad de realizar correcciones sobre su superficie mediante el raspado. De esta manera aparecieron los conocidos palimpsestos, manuscritos medievales en los cuales es posible rastrear los diferentes textos, correcciones y arrepentimientos de los sucesivos usos dados a un solo pergamino a lo largo de los años e incluso de los siglos.

Las dos caras del material obtenido poseían diferentes características que permiten distinguirlas incluso actualmente después de varios siglos. El lado flor, en el cual había estado el pelo, ofrece un aspecto y una textura algo más granulosa y suele ser más oscuro, cremoso o amarillento si es de oveja, o gris en el caso de proceder de una piel de cabra. Si analizamos con una lupa o lente de aumento la superficie del pergamino podremos apreciar los orificios de los citados pelos, hecho que casi nunca sucede en el lado carne. Por su parte éste ofrece un acabado más blanco, lo que provoca una sensación de contraste muy evidente al hojear un códice medieval realizado en pergamino. No posee un acabado tan granulado como el anterior, aunque pueden llegar a apreciarse las venas del animal en el caso de que la hoja sea de extrema delgadez o en un pergamino que no haya sido correctamente limpiado y todavía posea restos de tejido adiposo.

Al analizar las características y fabricación de los pergaminos existe un tema recurrente que suele aparecer con cierta frecuencia; hablamos de la existencia del pergamino uterino, aquel obtenido a partir de animales nonatos o fetos. Según las más antiguas tradiciones 
los pergaminos obtenidos de este tipo de animales eran los de mejor calidad y mayor finura, por efecto de las pieles todavía no expuestas a las inclemencias del mundo fuera del útero o matriz. Este término se ha empleado varias veces a lo largo de la historia para hacer referencia a las biblias francesas del XIII, aunque parece ser que no es totalmente exacto. En efecto, resulta más bien improbable, por no decir imposible, que un número tan elevado de vacas, cabras u otros animales hembra encintos, abortaran con el objeto de conseguir una pequeña cantidad de pieles de los fetos que portan en su interior. El riesgo de perder una gran cantidad de animales haría de dicho pergamino uterino un material de precio casi inaccesible, lo que hace pensar que, si bien habría veces en las cuales se usaban fetos para conseguir pergaminos de altísima calidad, no todos los que así se denominaban provenían de los comentados animales nonatos. Parece por tanto que la expresión viene a referir un tipo de pergamino de extrema finura y delgadez, así como de una naturaleza de similar calidad a los verdaderos pergaminos uterinos. ${ }^{51}$

A pesar de no proceder de animales nonatos, el precio de los pergaminos era elevadísimo. Si el material era de la más alta calidad su coste podía llegar a ser casi prohibitivo para un gran número de clientes. De Hamel cita un ejemplo muy clarificador al respecto. Se refiere al lujoso Misal Litlyngton de la abadía de Westminster, volumen realizado entre los años 1383 y 1384, para cuya fabricación se pagaron 4 libras, 6 chelines y 8 peniques en concepto de pergamino.

\footnotetext{
${ }^{51}$ Para mayor información ver: DE HAMEL, C. (1999), p. 13.
} 
I. Consideraciones generales

Esta partida económica para obtener 13 docenas de pieles del mejor pergamino de ternera, el llamado percamenti vitulini, fue la segunda más cara de todo el códice, tan sólo superada por la pagada para adquirir el oro necesario para iluminar el misal, lo que demuestra el altísimo precio de este soporte. 


\section{LA PIEL EN LA HISTORIA DEL ARTE}

El empleo de la piel animal y sus derivados como soporte 0 material dentro de la historia del Arte no es ni mucho menos una novedad. Tanto el cuero como el pergamino son conocidos desde hace siglos, y han sido utilizados para todo tipo de fines industriales, bélicos, artesanales y artísticos. Nos centraremos aquí obviamente en estos últimos, aunque tan sólo podremos ofrecer un breve panorama general que resalte las manifestaciones cuya importancia consideramos lo suficientemente relevante como para ser recogidas en este estudio. Organizaremos las manifestaciones artísticas en dos grandes grupos, dependiendo del papel que la piel animal haya jugado en cada una de ellas, y de tal modo distinguiremos entre Arte sobre 
piel, que emplea prioritariamente el pergamino, y Arte en piel, en el cual se utiliza sobre todo el cuero.

El primero de los grupos hará referencia a aquellas muestras en las cuales la piel animal actúa como mero soporte para la obra artística, obras en las que las distintas técnicas artísticas se funden y fusionan con el pergamino y, en menor medida con el cuero, para conformar piezas de indudable valor. Tendremos de tal modo ejemplos de pinturas, dibujos y grabados realizados, no sobre los soportes tradicionales para cada uno de los procedimientos plásticos, sino utilizando la piel animal. Óleos, acuarelas, gouaches y tintas chinas, dibujos a pluma y a pastel, aguafuertes y puntas secas; de todas estas posibilidades del mundo del dibujo, la pintura y el grabado, podremos encontrar ejemplos en los cuales los artistas decidieran, por diversos motivos, utilizar la piel animal como material sobre el cual realizar sus creaciones. Como vemos, no nos encontramos en este grupo ninguna técnica exclusiva o diferente a las que podemos emplear sobre cualquier otro tipo de soporte, si exceptuamos el caso de la miniatura sobre pergamino. Los artistas cuyas obras analizaremos brevemente en las siguientes líneas decidieron escoger el pergamino y el cuero como soportes heterodoxos y alejados de lo habitual dentro de sus respectivos campos de producción artística, aplicaron sobre ellos las técnicas que dominaban, pero cambiaron el papel, la tabla o el lienzo por el pergamino y el cuero, produciendo to que hemos decidido denominar como Arte sobre piel. 
Por su lado, refiriéndonos a la segunda de las manifestaciones artísticas en las cuales la piel animal ha desempeñado un papel de relevancia, el Arte en la piel, ¿cuál es la diferencia respecto del grupo anterior? Si en el primer apartado estudiaremos aquellas piezas en la que la piel animal posee un papel de soporte receptor de la imagen, en esta ocasión nos referiremos a las obras en las cuales los cueros y pieles son parte constituyente y sustancial de la naturaleza intrínseca de la pieza artística. No nos referimos en este caso por tanto a una pintura al óleo sobre cuero o un grabado al aguafuerte sobre pergamino, sino que por el contrario, analizaremos objetos en los que la piel animal posee un papel primario dentro de la concepción de la obra. Para comprender de manera totalmente clara y diáfana la diferencia establecida entre estos dos grupos, podemos recurrir a un símil de gran simplicidad, pero no por ello menos efectivo.

Tomemos un material como el mármol. Como es sabido existen obras, no excesivamente numerosas por otro lado, en las cuales el mármol ha servido como soporte para diversas técnicas pictóricas. Así, en un óleo sobre mármol este último posee un papel secundario en la naturaleza y características de la obra artística, actuando como receptor de la imagen pintada sobre él. ${ }^{52}$ Sin embargo, en el caso de una escultura realizada a partir de un bloque de mármol, el papel de éste cambia sustancialmente: ya no es un mero soporte,

\footnotetext{
${ }^{52}$ Es obvio que la naturaleza del soporte condiciona de manera clara y evidente el resultado de la obra, pero una vez superados los posibles condicionantes técnicos, es la imagen representada la que se impone por encima de los materiales sobre la que está reflejada.
} 
II. La piel en la historia del Arte.

sino que la naturaleza última de la pieza esta íntimamente relacionada con las características del material. Éste le sirve, no ya como receptáculo de una imagen determinada, sino como componente fundamental de la expresión artística.

De igual modo, en este segundo grupo englobaremos aquellas manifestaciones plásticas en las que la piel animal no es tan sólo un soporte para representaciones figurativas 0 abstractas, sino que se convierte en componente primario de dichos objetos artísticos. Por eso denominamos a estas obras, no ya como Arte sobre piel, sino como Arte en piel. 


\section{II.1. ARTE SOBRE PIEL}

Las ocasiones en las que un artista ha decidido emplear la piel animal como soporte para sus obras son muy numerosas, pero pese a ello representan un porcentaje mínimo dentro de toda la producción artística de la historia del Arte. De tal modo, a pesar de que existen multitud de dibujos realizados sobre pergamino, éstos representan una ínfima parte de todos los dibujos que se han realizado sobre papel a lo largo de siglos, y lo mismo ocurre con la pintura en cualquiera de sus variantes técnicas, ya sea el óleo, el temple, la acuarela o el gouache. Si excepcionales son las ocasiones en las que los artistas empleaban los cueros y pergaminos como soportes dibujísticos y pictóricos, todavía son más extraños y difíciles de encontrar los ejemplos de grabados realizados sobre piel. En este punto destaca sobremanera la figura excepcional de Rembrandt, a quien dedicaremos un capítulo específico en el que analizar el empleo del pergamino como soporte para algunos de sus más conocidos grabados al aguafuerte y a la punta seca.

De las innumerables obras que podríamos estudiar, hemos preferido seleccionar aquellas que consideramos más interesantes para realizar un amplio panorama de las diferentes posibilidades que el empleo de la piel animal ha sugerido a artistas de todo tipo y condición, 
desde las miniaturas altomedievales mozárabes hasta los trabajos sobre cuero de Keith Haring, pasando por las acuarelas de Durero o los aguafuertes sobre vitela de Rembrandt. Serán ocho obras, ocho paradas o estaciones, excepciones dentro del dominio abrumador de los soportes tradicionales dentro de cada campo artístico, rarezas y anomalías que demuestran el carácter inquieto, experimentador y revolucionario de algunos de los más grandes artistas de toda la historia del Arte. Ocho episodios, cada uno con sus características propias, que nos servirán para contextualizar el empleo de la piel animal como soporte artístico al mismo tiempo que plantean la diversidad de posibilidades de actuación susceptibles de ser retomadas, convenientemente actualizadas, en el proceso de creación de la propuesta de obra gráfica personal sobre piel animal, propuesta que culminará la presente tesis. 


\section{II.1.1. Página de beato mozárabe}

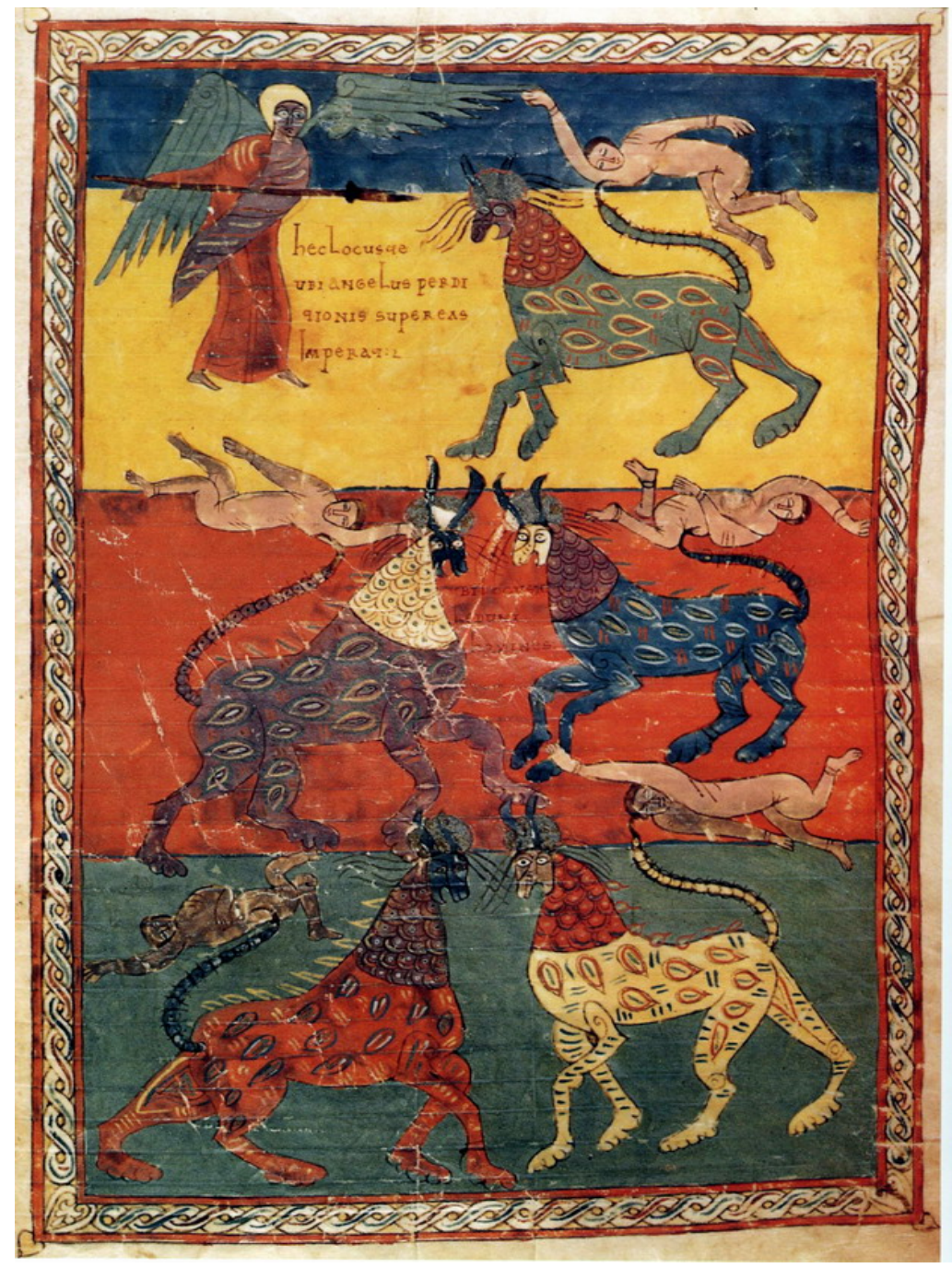

Fig. 20: La plaga de locust. Beato de Valladolid, miniatura sobre pergamino, s. X. Biblioteca Universitaria de Valladolid, fol.120. 
"En el mundo cristiano medieval el libro no era simplemente un objeto de uso; tenía, en sí mismo, un valor simbólico como testimonio de la salvación, un valor simbólico apenas inferior al de la cruz." 53

Nuestra primera parada tiene como escenario la miniatura medieval, capítulo fundamental del arte de la Edad Media europea en cuya creación tuvo una importancia capital el empleo del pergamino 0 vitela. Si en el resto de las manifestaciones que analizaremos la elección de la piel animal era tan sólo una de las opciones a las que se enfrentaban los diferentes artistas, no ocurre lo mismo en el caso de las miniaturas, entre las que se encuentran las imágenes mozárabes hispanas de finales del primer milenio de nuestra era. Holbein, Durero o Rembrandt eligieron utilizar el pergamino en lugar del mucho más habitual papel, pero los iluminadores de los reinos cristianos de la Península Ibérica tan sólo conocían el pergamino y no tuvieron otra elección a la hora de realizar sus imágenes. Sin embargo, la importancia de este tipo de manifestaciones artísticas nos hace decantarnos por dedicarles al menos un breve comentario, en el cual trataremos de centrar los aspectos técnicos de la iluminación de pergaminos que utilizaron.

Sin entrar a analizar de manera minuciosa la historia del libro, no debemos olvidar que la invención del pergamino fue definitiva para la evolución del rollo al códice. El antiguo rollo de papiro, incómodo de

${ }^{53}$ PACHT, O. (1987), p. 10. 
leer y difícil de conservar y consultar fue progresivamente desplazado por el códice de páginas de vitela. ${ }^{54}$ Durante siglos y hasta la irrupción del papel desde oriente, el pergamino fue el soporte único sobre el que se escribieron, dibujaron y pintaron todas las obras literarias, religiosas, científicas y artísticas de la Edad Media, e incluso cuando el papel se encontraba ya totalmente instalado dentro de la cultura occidental, en muchas ocasiones se siguió prefiriendo el pergamino como soporte para numerosos volúmenes. ${ }^{55}$

Las miniaturas medievales ${ }^{56}$ tan sólo suponen alrededor de un $5 \%$ de las páginas de todos los volúmenes producidos entre los siglos V y XV, y solían encontrarse por lo general en los ejemplares más lujosos y caros, destinados al público selecto de la más alta nobleza y la jerarquía eclesiástica. ${ }^{57}$ Ante la imposibilidad de realizar un recorrido por las diversas muestras del arte miniado medieval, y considerando el hecho de que en este trabajo estamos interesados en analizar el papel del soporte de pergamino, el cual fue común a la inmensa mayoría de las manifestaciones plásticas de los iluminadores y miniaturistas medievales, hemos escogido una página concreta sobre la cual vertebraremos las diversas anotaciones. Ante la disyuntiva de elegir una única imagen que pudiera condensar, en la medida de lo posible, las características del empleo del pergamino como soporte

\footnotetext{
${ }^{54}$ DAHL, S. (1985), p. 32.

${ }^{55}$ ALEXANDER, J. (1992), p. 35.

${ }^{56}$ Del latín minium (minio), pigmento de color rojizo muy empleado en la policromía de las ilustraciones.

${ }^{57}$ WEINSTEIN, K. (1998), p. 12.
} 
para la miniatura, hemos seleccionado una muestra de la producción artística del mozárabe español de la Alta Edad Media, una página del conocido como Beato de Valladolid (fig. 20)58. Sin duda nos encontramos ante uno de los episodios más importantes del arte medieval español, y no en vano estudiosos como Yarza han afirmado que pocas veces el arte hispano consiguió realizar productos artísticos $\tan$ personales y ricos. ${ }^{59}$

No es nuestro cometido entrar a analizar en estas líneas cuestiones relativas a factores estilísticos, escuelas regionales, iconografías o valores simbólicos y místicos de las imágenes realizadas en los comentarios de Beato al texto del Apocalipsis, pero sí que trataremos de profundizar acerca de la técnica empleada para realizar dichas imágenes, entre las que ocupa un lugar destacado la escogida como ilustración de este apartado. Desde el punto de vista técnico, poseemos dos fuentes principales para conocer el proceso de realización de las miniaturas, el cual no variaba sustancialmente dentro del solar europeo (fig. 21). Por un lado conservamos algunos manuales de la época, entre los que destacan el Mappae Clavicula (s.X), el De diversis artibus (s. XII) o el De arte iluminandi (s. XIV). ${ }^{60}$ Por otro lado, son los manuscritos inacabados que todavía se conservan en

\footnotetext{
${ }^{58}$ Para todo lo referente a la miniatura de los beatos mozárabes hispanos pueden consultarse, entre otros muchos: DOMÍNGUEZ BORDONA, J. (1962); MENTRE M. (1996); YARZA, J. (1985) y WILLIAMS, J. (1987).

${ }^{59}$ YARZA, J. (1985), p. 108.

${ }^{60}$ KRAMER, CH. (2000), p. 37.
} 
numerosas bibliotecas, los que nos ofrecen datos fundamentales acerca del modo de actuación de los artistas iluminadores.

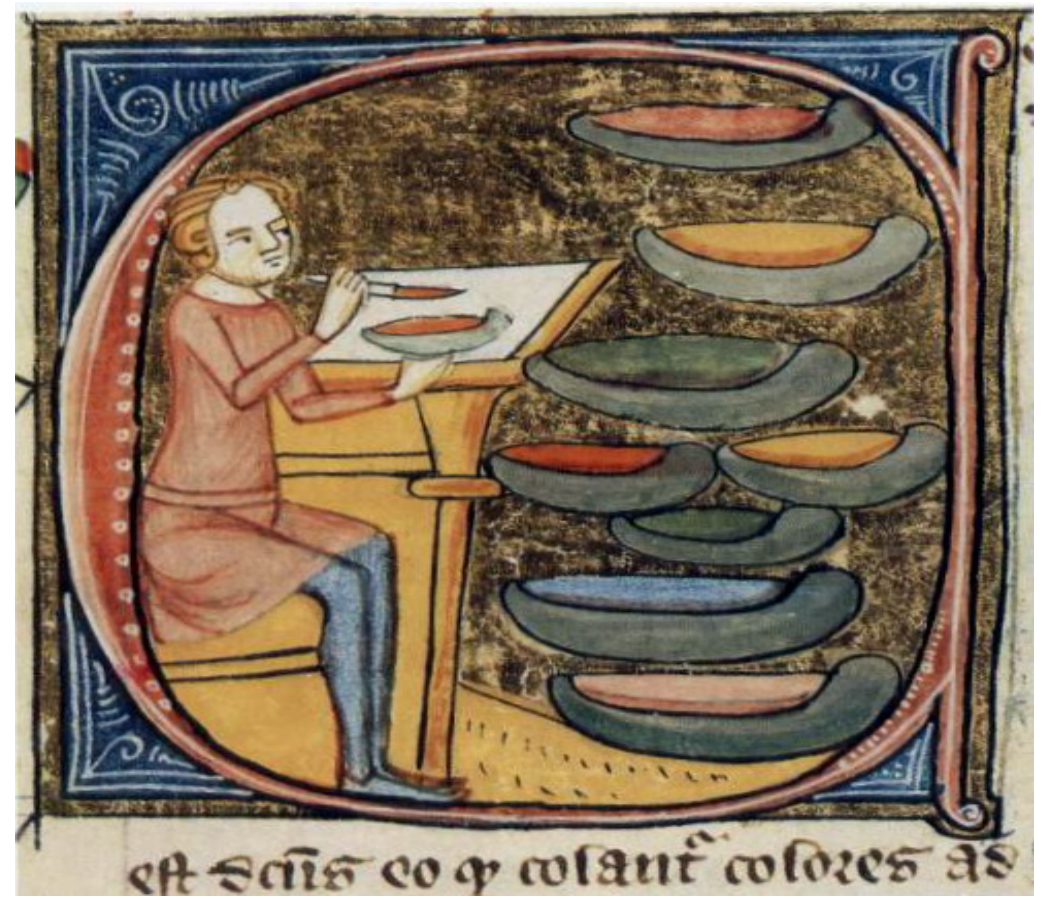

Fig. 21: Inicial decorada medieval donde se aprecia el trabajo de un miniaturista mezclando colores. Manuscrito inglés de hacia 1350.

En base a estas fuentes sabemos que los pergaminos solían ser lustrosos y grasos, lo que hacía necesario una cierta preparación previa al comienzo del trabajo con objeto de convertir dicha superficie en un soporte más absorbente. Existen varias recetas para desengrasar los pergaminos y permitir un correcto asentamiento de la pintura, pero uno de los procedimientos más comunes era frotar la piel 
con piedra pómez por ambas caras, consiguiendo de tal modo una superficie algo más rugosa. 61

El manuscrito napolitano De arte iluminandi (s. XIV) ofrece una lista de los pigmentos más comunes empleados por los miniaturistas medievales, siendo muchos de ellos de origen mineral y en menor medida vegetales o animales. Destacan el negro (proveniente del carbón), el blanco (extraído de la cerusita), el amarillo (cuyo origen podía darse en el ámbar o el azafrán), el azul (proveniente del lapislázuli o el cobalto), el rojo (el célebre minio u óxido de plomo, aunque también podía ser mercurio o madera de brasileo), el verde (malaquita o clorofila) o el rosa (que podía extraerse de la uva). A todo este catálogo de pigmentos se le unían distintos aglutinantes, destacando colas de pescado, clara de huevo, miel, ajo, goma arábiga 0 resina, en diferentes combinaciones y recetas dependiendo de la zona geográfica y de las coordenadas cronológicas de cada artista concreto. 62

En el caso de los beatos mozárabes españoles, los aglutinantes más empleados fueron la miel y el huevo, apareciendo en algunos casos concretos el uso de cera, la cual dotaba a las imágenes de un acabado característico. ${ }^{63}$ Por lo que respecta a los pigmentos, dominaron los colores cálidos, los naranjas, amarillos y rojos, dispuestos en amplias zonas de colores planos y de gran intensidad. El

${ }^{61}$ MALTESE, C. (2001), p. 306.

${ }^{62}$ KRAMER, C. (2000), p. 39-39.

${ }^{63}$ MENTRE, M. (1996), p. 45. 
proceso de elaboración de las miniaturas es bien conocido gracias a los citados tratados y sobre todo a las ilustraciones inacabadas que han llegado hasta nosotros. Parece seguir los dictados de san Isidoro de Sevilla, quién advertía que debía primero realizarse los contornos lineales de los objetos y figuras, para más tarde rellenar de color las zonas delimitadas. ${ }^{64}$ Los colores utilizados eran muy líquidos, lo que unido a la escasa capacidad de absorción del pergamino provocaba que existiera el peligro de que los tonos se mezclaran, por lo que para evitar tales inconvenientes se debía dejar secar completamente cada capa de pintura, lo que ralentizaba el proceso. En muchas zonas se llegaban a aplicar varias capas sucesivas de color con objeto de conseguir tonalidades intensas como las que aparecen en la página correspondiente a La plaga de locust del Beato de Valladolid de la fig. 20.65

Como hemos comprobado en esta primera etapa del recorrido que realizaremos a través de diversas obras de arte que poseen a la piel animal como soporte, el pergamino no fue una opción deliberadamente escogida sino una imposición de la realidad cultural de los artistas medievales. Como tal soporte, hemos visto el modo en el cual condicionó el proceso de elaboración de las imágenes y la elección de los aglutinantes, pero su papel en la configuración final de la obra no deja de ser secundario. Es cierto que el hecho de tener que trabajar a partir de capas sucesivas de pintura provoca que las

\footnotetext{
64 "Et nunc pictores prius umbras quasdam et lineas futurae imaginis ducunt, deinde coloribus complent”. Citado por MEINTRE, M. (1996), p. 45.

${ }^{65}$ MALTESE, C. (2001), p. 308.
} 
imágenes resultantes posean colores opacos, sin veladuras ni transparencias, y sí con amplias zonas de colores planos como en la imagen presentada. ${ }^{66}$ Sin embargo, una vez superados estos factores, la pintura tapa, oculta y esconde el soporte que la recibe. En muchas ocasiones lo que vemos son capas y capas de pigmentos y aglutinantes, que no nos dejan ver el material subyacente, el cual se convierte en un nuevo vehículo para la transmisión de la imagen representada sobre él, pero sin intervenir definitivamente en la configuración de esta última.

\footnotetext{
${ }^{66}$ No debemos olvidar por otro lado, que en el caso que nos ocupa, el del arte altomedieval, el estilo pictórico general se encontraba dominado por ese tipo de manchas planas de colores intensos. Por tanto, las especiales características del pergamino no modificaron el estilo pictórico, dado que sobre otros materiales como la tabla o el muro, el proceder de los imagineros medievales era muy similar.
} 


\section{II.1.2. Sala de los reyes de la Alhambra}

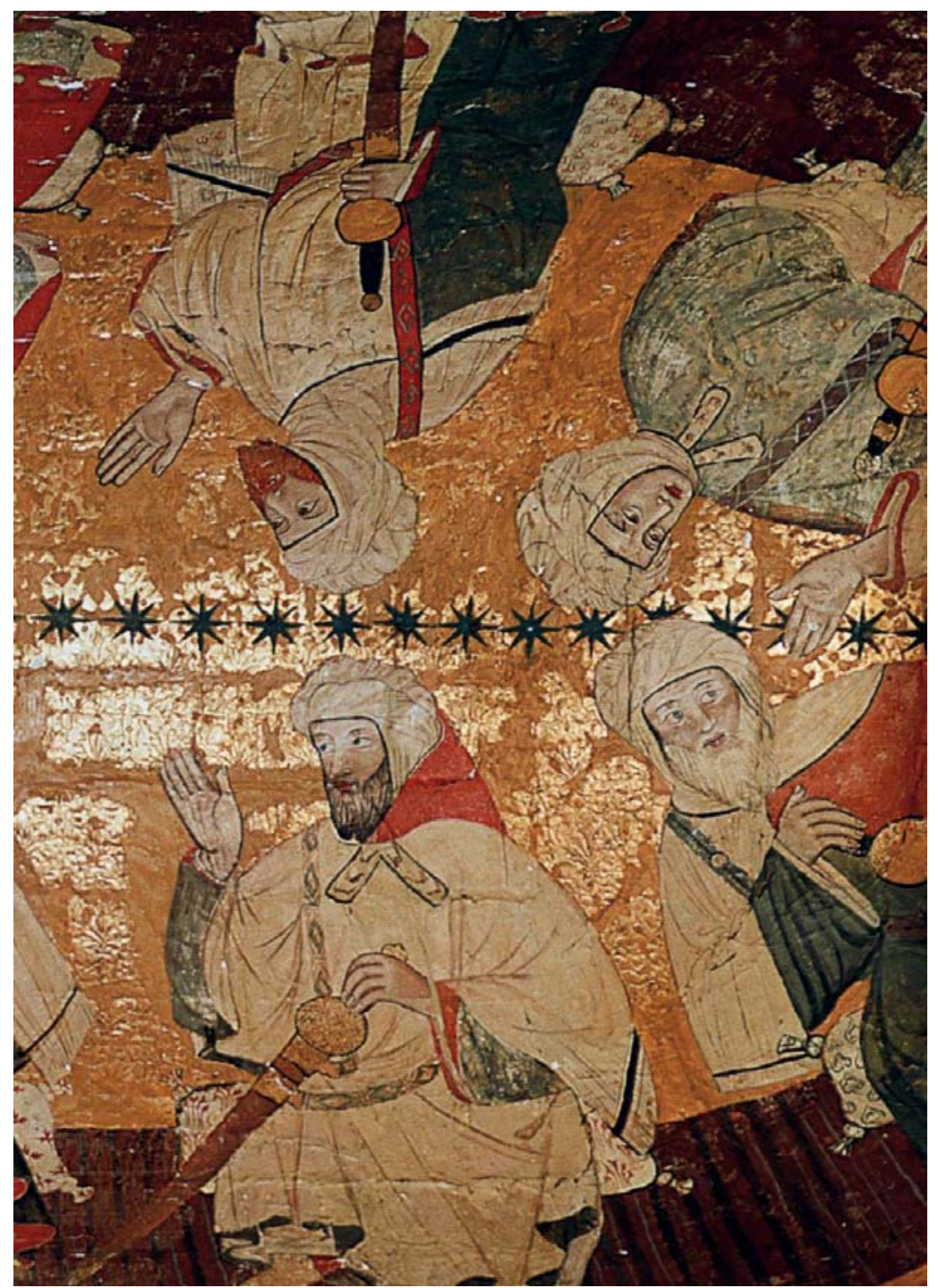

Fig. 22: Detalle de las pinturas anónimasde la bóveda de la Sala de los Reyes de la Alhambra. Temple sobre imprimación de yeso y cuero, siglo XIV. 
En la zona oriental del Patio de los Leones de la Alhambra de Granada se encuentra la conocida como Sala de los Reyes, en realidad una serie de estancias intercomunicadas con varias alcobas independientes. Es en los techos de estas pequeñas habitaciones donde se localizan unas célebres muestras de la pintura de la corte del sultán nazarí Muhamad V (1354-1391), pinturas que casi todos los estudiosos consideran obra de artistas cristianos cercanos al estilo de la Escuela de Avignon. ${ }^{67}$ La iconografía de las más importantes de ellas, las de la alcoba central, todavía no ha sido totalmente aclarada, pudiendo tratarse de una reunión de dignatarios islámicos 0 de sultanes nazaríes, pero en nuestro estudio no nos centraremos en analizar este tipo de cuestiones, ya que es la técnica utilizada la que las hace aparecer en este apartado concreto. ${ }^{68}$

En la práctica totalidad de textos y estudios estas obras aparecen reseñadas como pintura sobre cuero, lo que unido a sus fondos dorados podría llevar a la confusión de considerarlas muestras relacionadas con el campo de los cueros artísticos 0 guadamaciles. ${ }^{69}$ Nada más lejos de la realidad; se trata en realidad de unas pinturas al temple y barnizadas con cera, con la particularidad de que entre la película pictórica y las badanas de carnero llegan a existir hasta cinco capas de imprimación al yeso. Las pieles ovinas se encuentran fijadas

\footnotetext{
${ }^{67}$ BARRUCAND, M.; BEDNORZ, A. (1992), p. 196.

${ }^{68}$ Las pinturas se encuentran en un buen estado de conservación tras una reciente intervención destinada a restaurarlas, pudiendo ser apreciadas en el lugar original para el que fueron destinadas en el siglo XIV.

${ }^{69}$ Véase cap. II.2.2., p. 126.
} 
sobre el armazón lígneo de la cubierta y atirantadas gracias a la acción de pequeñas clavijas de bambú. ${ }^{70}$

De tal modo, y a pesar de lo que pueda parecer a partir de las informaciones otorgadas por los estudios superficiales acerca de las pinturas, nos encontramos ante una nueva ocultación total del soporte de cuero. Este encubrimiento es todavía más acusado que en el ejemplo referido a las miniaturas medievales, dado que, si en aquél la pintura se aplicaba directamente sobre la superficie orgánica de la piel animal, en éste el cuero tan sólo sirve de receptáculo para una gruesa imprimación sobre la que se deposita la película pictórica. Situación totalmente opuesta al ideal que perseguiremos durante la fase práctica de esta investigación, la cual deberá culminar en piezas en las cuales la piel animal posea un papel protagonista y no meramente secundario como es en este caso.

${ }^{70}$ BERMÚDEZ LÓPEZ, J. (2001), p. 290. 


\section{II.1.3.Dibujos renacentistas sobre vitela}
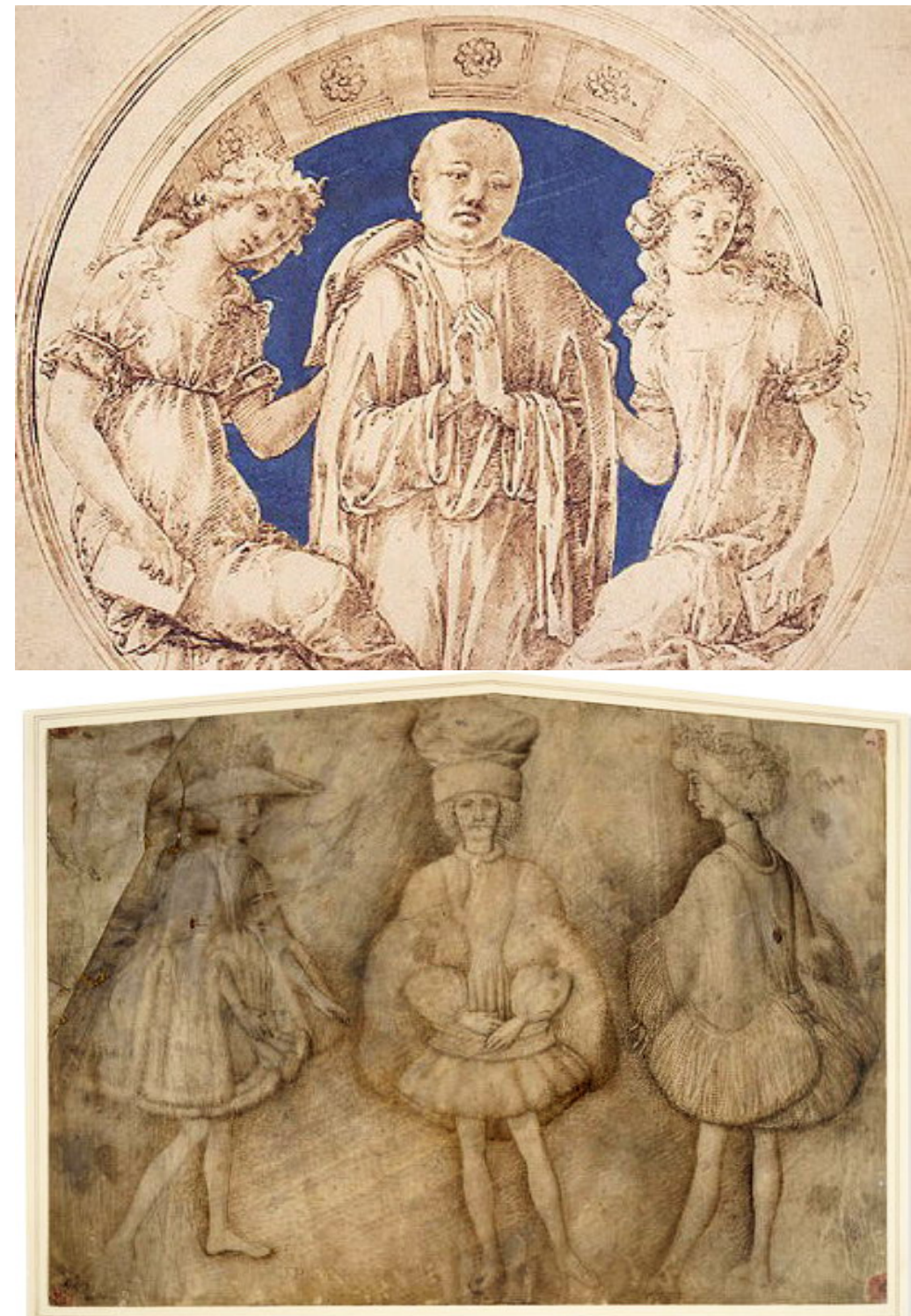

Fig. 23: De arriba abajo: Francesco di Giorgio Martini: Diseño para monumento mural, (hacia 1490); Pisanello: Tres figuras de pie, (hacia 1440). Ambos sobre pergamino. 
En el tránsito entre el s. XIV y el XV, cuando el Renacimiento italiano se encuentra en su periodo de formación, numerosos artistas realizaron dibujos, apuntes y bocetos sobre pergamino. Muchos de ellos se encontraban todavía imbuidos e influidos por la estética medievalizante inmediatamente anterior, lo que ha valido a algunos historiadores para explicar el empleo de este material de reminiscencias medievales. ${ }^{71}$ El uso del papel era ya absolutamente común no sólo como material de escritorio, sino también como soporte para las obras dibujísticas que tanta importancia alcanzaron durante el periodo. Gentile da Fabriano, Giovannino de Grassi, Francesco di Giorgio Martini, Pisanello (fig. 23), Jacobo Bellini o Sandro Boticelli (fig. 24) entre muchos otros, ofrecen ejemplos de este empleo del pergamino, con una técnica que se distancia de manera considerable de los usos de la piel animal analizados anteriormente. Ya no tratan de ocultar la superficie del soporte bajo capas de pintura o imprimaciones, sino que los sutiles trazos de la punta de plata, la pluma o la tinta pueblan la piel animal sin por ello cubrirla. La naturaleza del soporte se hace evidente dentro de la obra gracias a su tonalidad y color, a su textura y tacto, por lo que nos encontramos ante una opción personal del artista, quien decide no emplear el papel, de uso más común y ya indudablemente más barato, sino el pergamino. ${ }^{72}$ Pese a no contar con testimonios fidedignos, creemos que esta elección no podía estar

\footnotetext{
${ }^{71}$ PIGNATTI, T. (1981), p. 88.

${ }^{72}$ El precio de los pergaminos fue subiendo progresivamente a la vez que se hacía más difícil conseguir hojas de buena calidad. Con el papel ocurrió un fenómeno totalmente opuesto: de ser un artículo de lujo durante los siglos XI y XII, pasó a ser de uso común gracias a una expansión imparable. Véase ASUNCIÓN PASTOR, J. (2001).
} 
únicamente basada en el comentado cariz medievalizante del pergamino, y sí más bien en consideraciones plásticas relacionadas con la especial naturaleza de este tipo de soporte. Los condicionantes especiales e individuales que llevaron a cada artista concreto a decantarse por este material concreto son en casi todos los casos desconocidos, y en todo caso vale la pena hacer especial mención de la singularidad que el soporte otorga al trazo gráfico y a la calidad visual de las imágenes. Así pues nos encontramos ante una muestra de Arte sobre piel muy cercana a la consideración de Arte en piel, no tanto por la acción como por los resultados visuales.

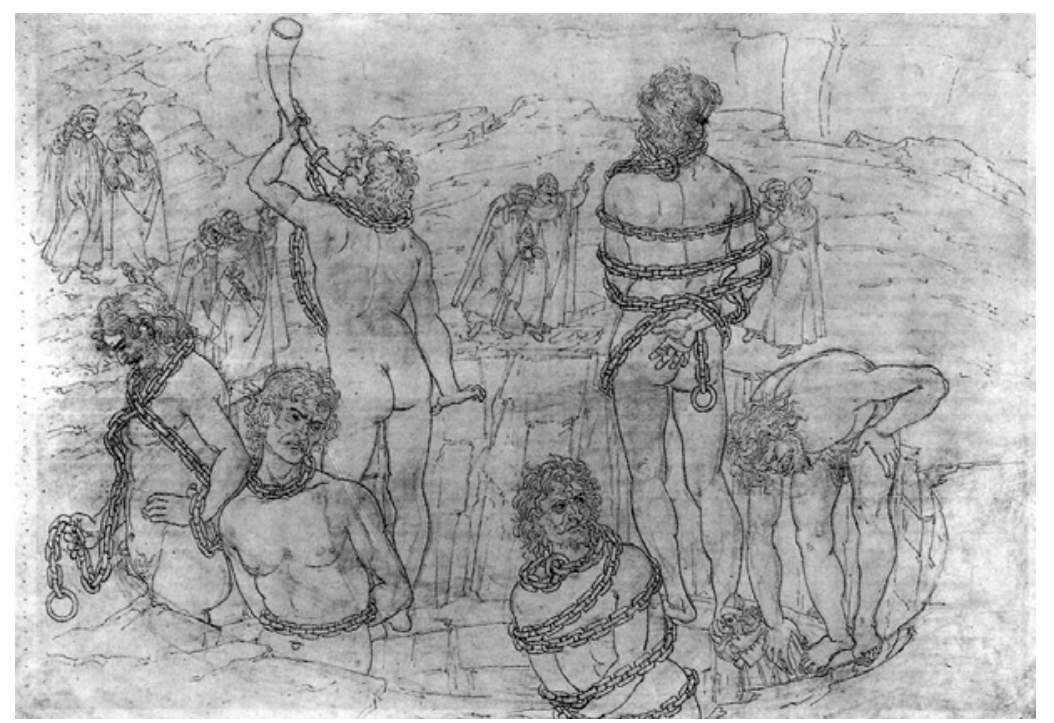

Fig. 24: Sandro Botticelli: Inferno, Canto XXXI, (hacia 1480-1500), punta de plata, pluma y tinta sobre pergamino. 


\section{II.1.4. Andrea del Castagno: David}

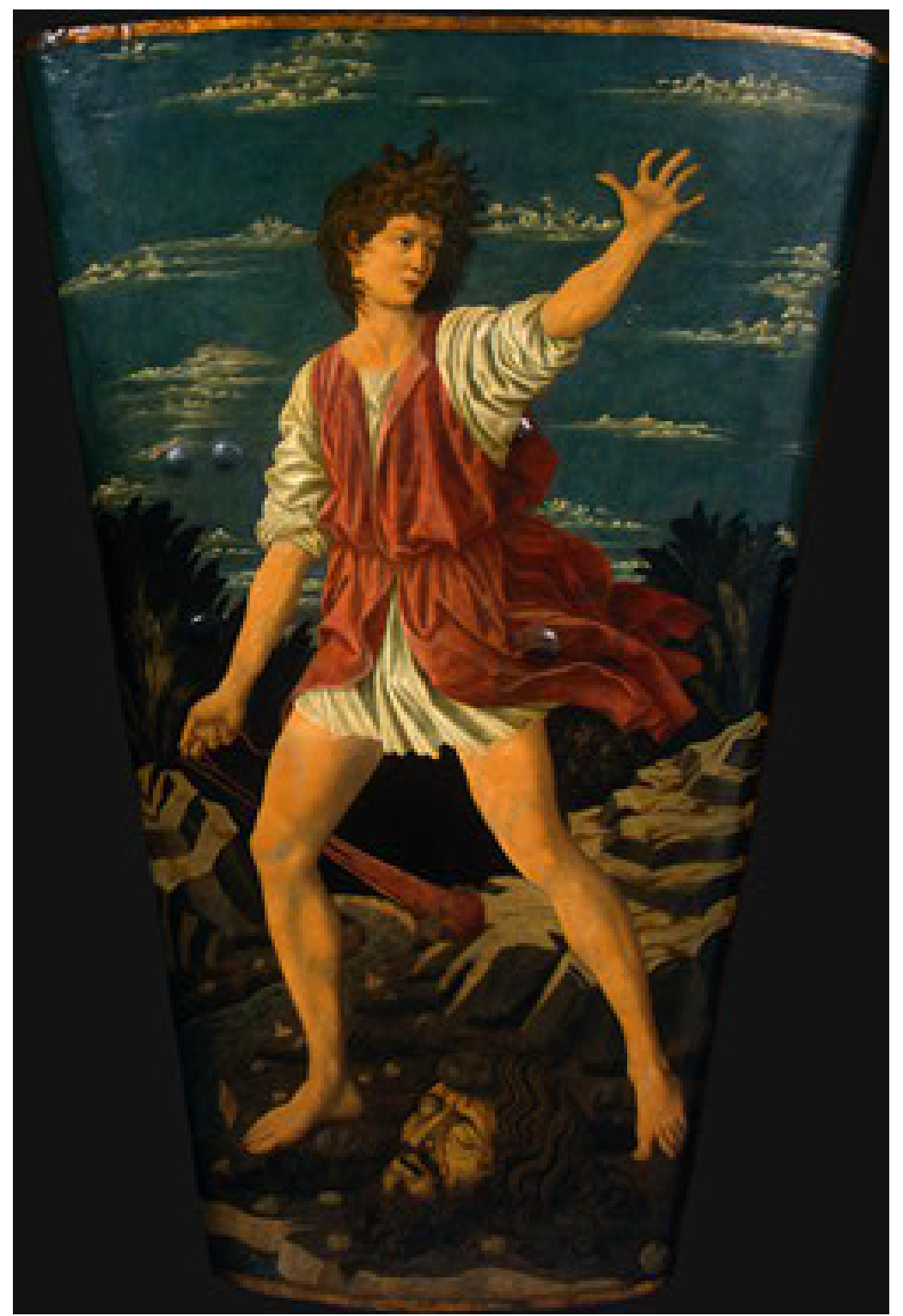

Fig. 25: Andrea del Castagno: David, (hacia 1449), pintura sobre cuero, National Gallery of Washington 
Si bien los ejemplos de pintura sobre pergamino son relativamente numerosos a lo largo del s. XV, los casos en los cuales un artista de la talla de Andrea del Castagno (1421-1457) decide realizar una obra sobre cuero son realmente excepcionales, de ahí que optemos por detener nuestro estudio en este caso concreto con el fin de analizarlo más detalladamente. Sin olvidar piezas como la Cabeza de Cristo (fig. 26) de Petrus Christus (Metropolitan Museum de Nueva York), el San Francisco del taller

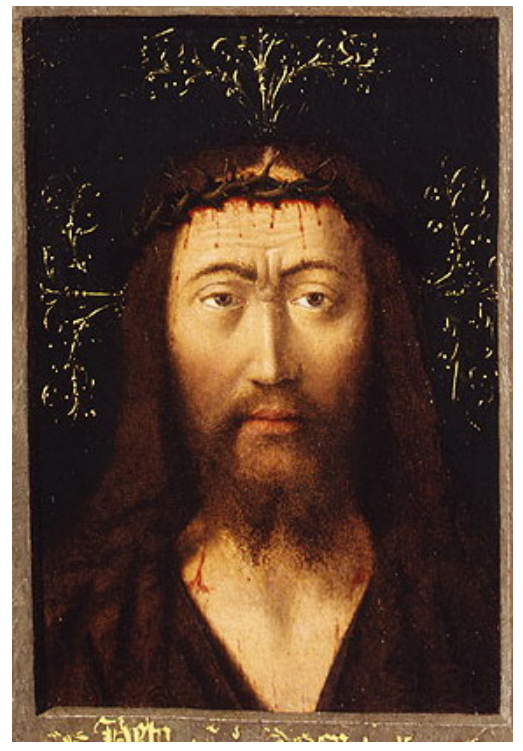

Fig. 26: Petrus Christus: Ecce Homo, (hacia 1445), óleo sobre pergamino. de Jan Van Eyck (Philadelphia Museum of Art), o la Virgen $y$ Niño de Gertgen ot Sint Jant (Pinacoteca Am-brosiana de Milán), ${ }^{73}$ repre-sentativas del estilo nórdico que podríamos relacionar con la miniatura bajomedieval por su minuciosidad y su detallismo, nos inclinamos por estudiar el potente y monumental David de Andrea del Castagno.

Esta obra ha sido pintada sobre un escudo de madera forrado enteramente de cuero, material que se adapta perfectamente a la superficie curva del arma defensiva en este caso convertida en elemento decorativo de claras

${ }^{73}$ AINSWORTH, M. W. (1994), p. 86-91. 
reminiscencias heráldicas. ${ }^{74}$ En esta muestra singular del arte pictórico renacentista, podemos comprobar como, de nuevo, un artista decide emplear un material que por aquel entonces no era excesivamente común como soporte pictórico. ¿Fue obligado por el comitente de la obra? ¿Era tan sólo una pieza de una larga serie de escudos todos ellos forrados de cuero? ¿Fue decisión exclusivamente individual del pintor el emplear este tipo de soporte? Son preguntas que nos hacemos ante una obra de tales características, si bien su respuesta no deja de tener un interés tangencial y secundario para nuestra investigación. Lo realmente interesante es la evidencia de que la película pictórica cubre totalmente la superficie del cuero, el cual no posee ningún tipo de relieve ni gofrado claramente visible, lo que la convierte en ejemplo de lo que venimos denominando Arte sobre piel y sin llegar a configurarse en una muestra de Arte en piel, ya que no existe una participación activa del cuero en el acabado definitivo de la obra si exceptuamos su rol como soporte de la película pictórica que representa al David vencedor.

\footnotetext{
${ }^{74}$ Pese a haber sido previamente atribuido a Antonio del Pollaiuolo por parte de J. P. Richter, finalmente Berenson lo adjudica al pintor nacido en Castagno, fechándolo a mediados del s. XV. Véase BERTI, L. (1967), p.35.
} 


\section{Il.1.5. Alberto Durero: Carraca muerta}

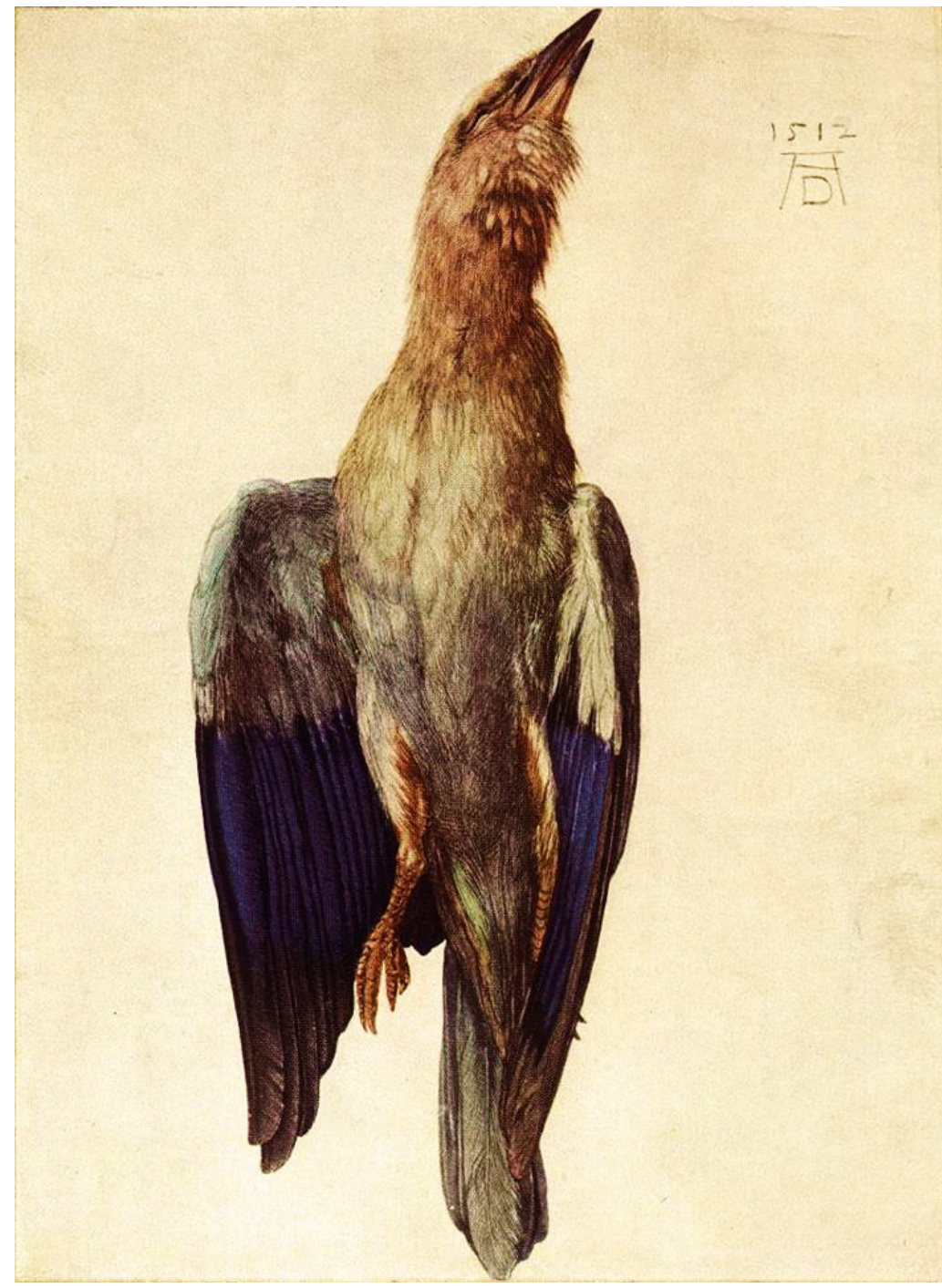

Fig. 27: Alberto Durero: Carraca muerta, (hacia 1500-1512) aguadas y albayalde sobre pergamino, Albertina, Viena. 
El genial artista que supuso el vínculo entre la tradición medieval y la renovación renacentista en el Norte de Europa, Alberto Durero (1471-1528), también dibujó algunos de sus más célebres estudios del natural sobre pergamino. Fechado por algunos en 1500, el fabuloso análisis de la anatomía de un ave de la fig. 27, es tan sólo uno de los muchos apuntes similares que Durero realizó a lo largo de su vida, y formó pareja con el conocido como Ala de carraca muerta, de la misma cronología y realizado también sobre pergamino (fig. 30). Ambas están realizadas mediante aguadas de colores con la ayuda de toques de pigmentos opacos en las zonas de mayor detalle, aplicados tanto a pincel como a pluma y realces de albayalde. La maestría de Durero en la captación de la naturaleza alcanza en estas obras sus más altas cotas, tan sólo comparables a las logradas en sus dos estudios más celebres Liebre (1502) y Hierbas (1503), ambos sobre cartulina (fig. 28).

El empleo del
pergamino como soporte
para sus pinturas no era algo
excepcional para Durero, y
ya en una obra tan temprana
como su Autorretrato a los 22
años de 1493 (fig. 29),
podemos encontrar una

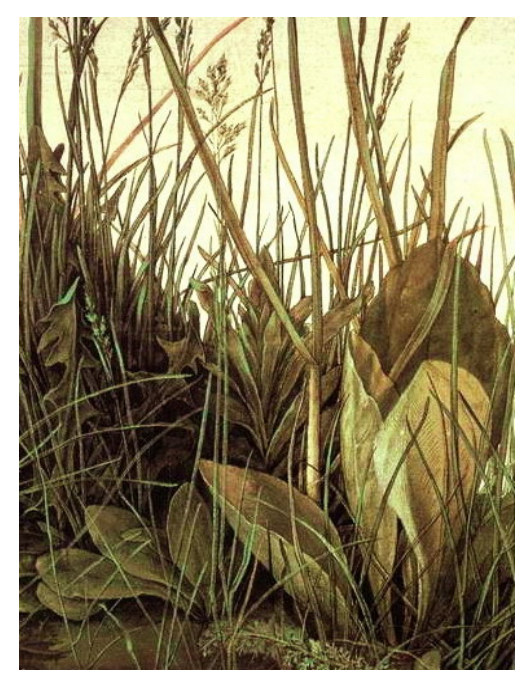

Fig. 28: Alberto Durero: Hierbas (detalle), (hacia 1503), aguadas sobre cartulina, Albertina, Viena. 
primera utilización de dicho soporte. ${ }^{75}$ Durero fue más remiso a elegir el pergamino como soporte para sus dibujos o sus grabados, pero no así en algunas de sus acuarelas más famosas como la que nos ocupa.

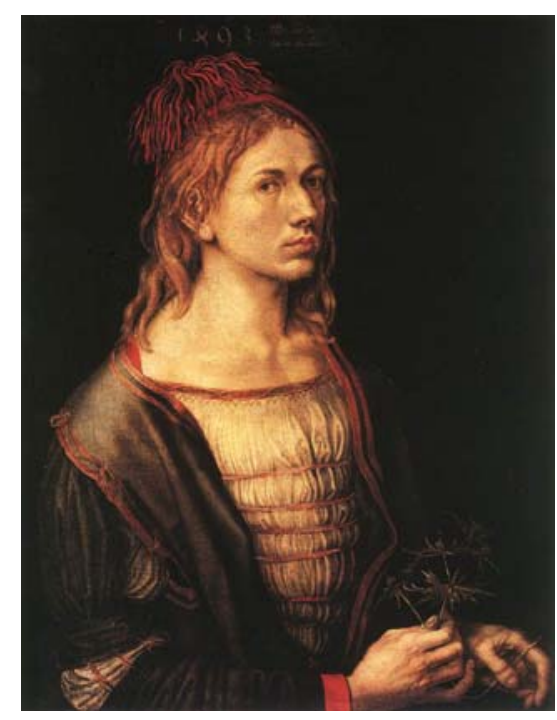

Fig. 29: Alberto Durero: Autorretrato a los 22 años, (1493), óleo sobre pergamino, Museo del Louvre, Paris.

Sin embargo, no existen estudios acerca del porqué de esta elección concreta y las posibles motivaciones estéticas 0 artísticas que movieron al artista alemán a decidirse por este tipo concreto de soportes orgánicos. ${ }^{76}$ Es cierto que podría encuadrarse este interés dentro de las inquietudes artísticas del pintor, quien, como es sabido, se interesó en grado sumo por técnicas de preparación de papeles provenientes de Italia. Así, tenemos la conocida como Pasión verde (1504) sobre papeles coloreados con dicho color, o los celebres estudios para el Retablo Heller (1508) sobre los mismos soportes. Debido a su interés por

\footnotetext{
${ }^{75}$ Actualmente dicha pintura se encuentra transferida a lino, pero originalmente estuvo realizada sobre un trozo de pergamino o vitela. ${ }^{76}$ En una obra de referencia como el texto de Panofsky, Vida y arte de Alberto Durero, no se hacen apenas alusiones a la utilización del artista de estos soportes. Véase PANOFSKY, E. (1982).
} 
trabajar sobre papeles coloreados como los que había conocido en su último viaje a tierras transalpinas, y ante la imposibilidad de encontrarlos en su patria, en 1507 hizo que en su taller se prepararan papeles con unos fondos verdosos sobre los que poder trabajar con tinta negra y albayalde. ${ }^{77}$

Es dentro de este afán por experimentar sobre materiales y soportes alternativos al común papel blanco donde podemos enmarcar la utilización de pergaminos para algunas de sus acuarelas de temas naturales, empleo que sería continuado por una legión de seguidores e imitadores. Entre éstos destaca Hans Hoffmann (1550-1591), pintor de cámara en la corte del emperador Rodolfo II en Praga, monarca que llegó a promover la creación de un taller de imitadores y copistas de Durero. Fue tal la actividad de esos talleres, que durante siglos se han atribuido a Durero infinidad de estudios del natural como el célebre Ramillete de violetas, ${ }^{78}$ cuya atribución parece haber sido definitivamente aclarada tras la exposición celebrada en la Albertina de Viena en $1985 .{ }^{79}$ Resulta curioso comprobar como en muchos casos las copias, imitaciones y obras de esta legión de seguidores están igualmente resueltas sobre pergaminos, como si fuera imposible separar las imágenes creadas por Durero del soporte elegido para ellas.

\footnotetext{
${ }^{77}$ MATILLA, J. M. ed. (2005), p. 244.

${ }^{78}$ MATILLA, J. M. ed. (2005), p. 132-135.

${ }^{79}$ En textos de mediados del s. XX todavía aparece como atribuida a Durero. Véase PÉREZ DOLZ, F.; GUTIÉRREZ MARÍN, M. (1943), p. 16.
} 
Los propios seguidores del artista de Nuremberg fueron conscientes de la importancia que la elección del pergamino debía tener para el pintor alemán, pese a que los motivos exactos de ésta no hayan quedado por el momento esclarecidos totalmente. Llama la atención, sin embargo, el hecho de que la gran mayoría de los apuntes realizados sobre pergamino estén dedicados a reflejar animales y en menor medida vegetales, mientras que cuando Durero se dedicaba a captar arquitecturas 0 vistas urbanas, objetos 0 paisajes, vestidos 0 armaduras, se decantara en casi todas las ocasiones por usar papel como soporte ${ }^{80}$ ¿Existe alguna motivación especial detrás de estos hechos o es pura y simple coincidencia? ¿Es posible que haya una relación que se nos escapa entre el soporte y la imagen representada, entre el pergamino y los animales y plantas reflejados por Durero? Lo que es cierto es que en obras como Ala de carraca muerta, las formas orgánicas de la extremidad animal parecen dialogar con las texturas de la superficie del pergamino, sobre el cual todavía son visibles para un ojo atento los rastros de los antiguos pelos y las venas que surcaban la piel. Da la sensación de que ha decidido elegir un soporte de reminiscencias, no ya medievales, sino orgánicas y naturales como base para sus estudios zoológicos y vegetales, descartando el mucho más manufacturado papel. De haber sido así, estaríamos ante una obra en la cual la piel animal no actúa como mero receptor y soporte de la imagen, sino que contribuye a la creación y conformación de la obra de arte como si se tratase del soporte idóneo para representar

\footnotetext{
${ }^{80}$ Véanse sus vistas de Innsbruck (1494-1495) o su serie acerca de las vestimentas típicas de las mujeres de Nuremberg (1500-1501).
} 
II. La piel en la historia del Arte.

seres afines a su naturaleza, tanto por la intención del artista como por la consecución de resultados.

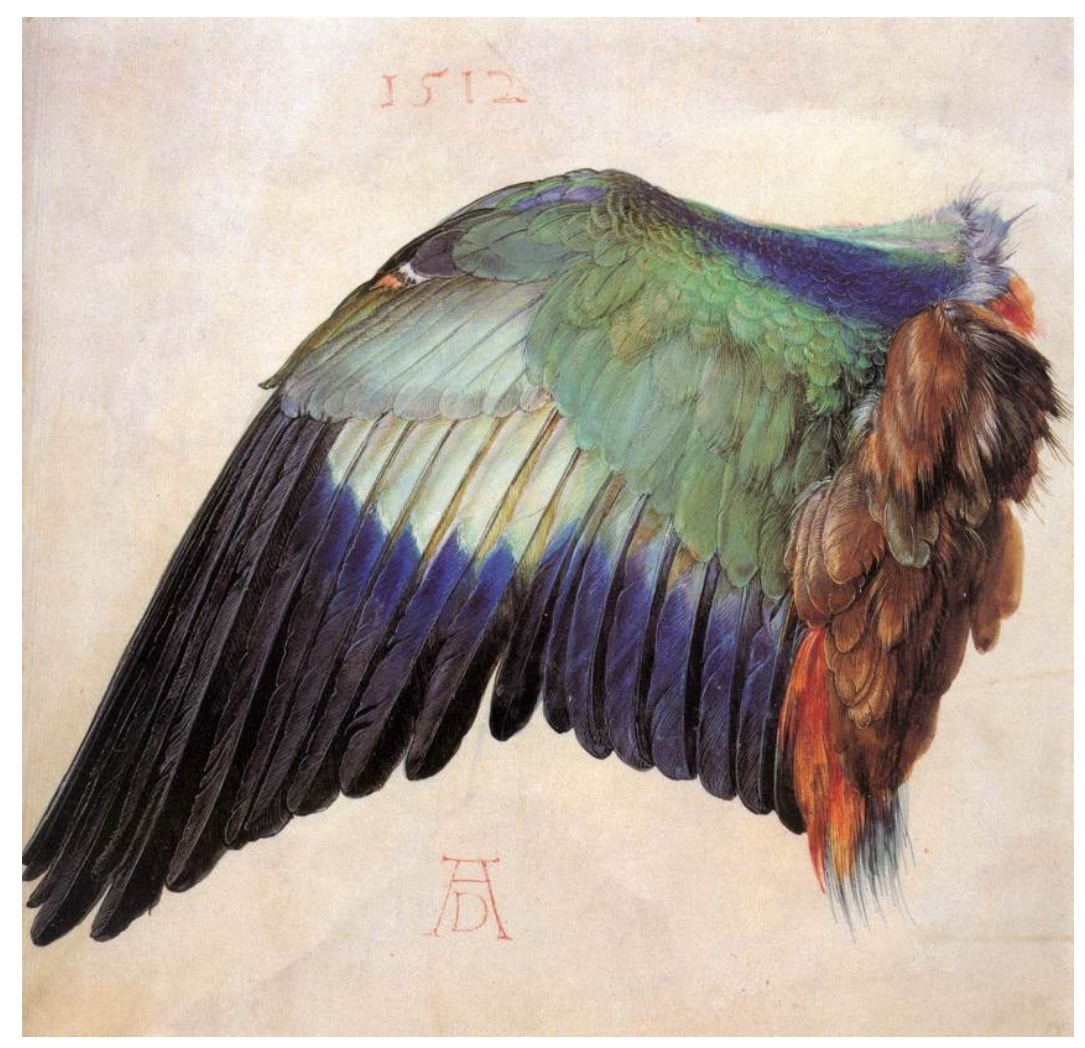

Fig. 30: Alberto Durero: Ala de carraca muerta, (hacia 1500-1512), aguadas de colores, pigmentos opacos y albayalde sobre pergamino, Albertina, Viena. 


\section{II.1.6. Hans Holbein: William Roper}

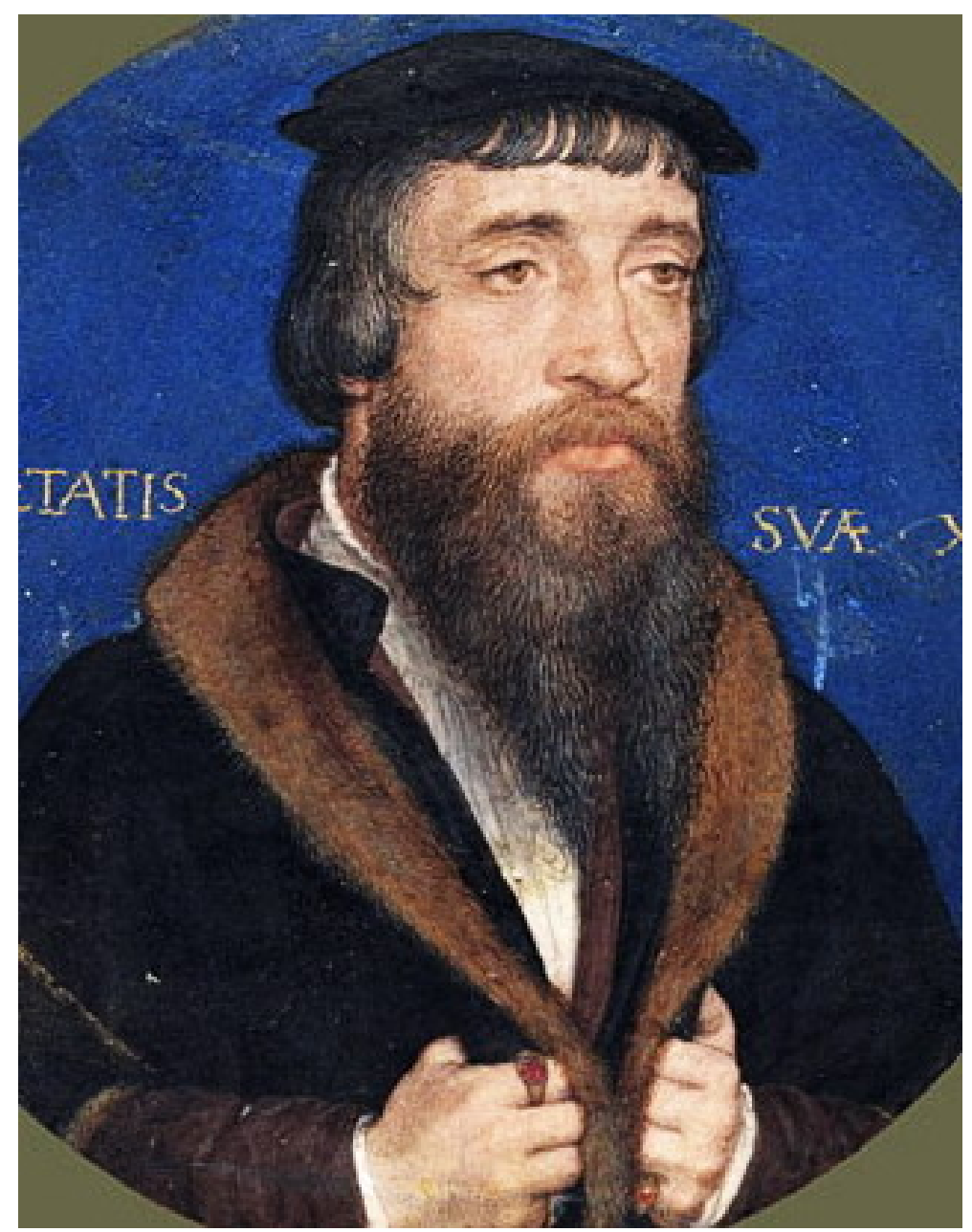

Fig. 31: Hans Holbein: William Roper (hacia 1535), miniatura sobre pergamino, Metropolitan Museum, Nueva York. 
Uno de los últimos episodios de la historia del Arte en los que la piel animal recuperó un papel preponderante como soporte fue el de la miniatura británica durante los siglos XVI y XVII. Los retratos en miniatura surgieron en los años iniciales del s. XVI al fundirse dos disciplinas diferentes: la iluminación de libros y el arte de la medalla, y fueron mayoritariamente Francia e Inglaterra los que impulsaron esta práctica retratística inicialmente exclusiva de los estratos sociales más elevados. ${ }^{81}$ Desde el principio, los soportes más comunes fueron pequeños trozos de vitela o pergamino, normalmente pegados con almidón a cartones, maderas finas o incluso naipes. Sin embargo, también se emplearon otros materiales como cobre o madera y, a partir del s. XVIII, con la irrupción del marfil, el pergamino cayó en desuso hasta desaparecer. ${ }^{82}$

La figura de Hans Holbein (1497-1543) fue fundamental para revitalizar y dotar de prestigio a un género que solía considerarse menor como es el de la miniatura. El que fue considerado en vida como el mejor retratista de Europa, debió aprender la técnica de la pintura de pequeños retratos sobre pergamino del pintor Lucas Horenbout (1490/5 -1544), pintor de corte desde 1526 e hijo de Gerald Horenbout de Gant, iluminador de libros. ${ }^{83}$ De dibujo y trazo increíblemente seguro y firme, algunos de los retratos en los que

\footnotetext{
${ }^{81}$ HIDALGO OGAYAR, J. (1994), p. 9.

${ }^{82}$ La introducción del marfil va unida a la figura de Rosalía Carriera (16751757), retratista veneciana que tuvo considerable influencia sobre los miniaturistas franceses. Véase: HIDALGO OGAYAR, J. (1994), p. 9-10. ${ }^{83}$ GANZ, P. (1950), p. 258 y s.
} 
demuestra un mayor dominio en lo que a la captación de la fisionomía humana se refiere, están hechos sobre pergamino, como el de William Roper (fig. 31) de $41 \mathrm{~cm}$. De diámetro. Parece evidente que el empleo de este material como soporte poseía influencias medievalizantes, pero la técnica empleada por autores como Holbein está muy lejos de los amplios campos de colores planos e intensos de los beatos mozárabes. (fig. 32).

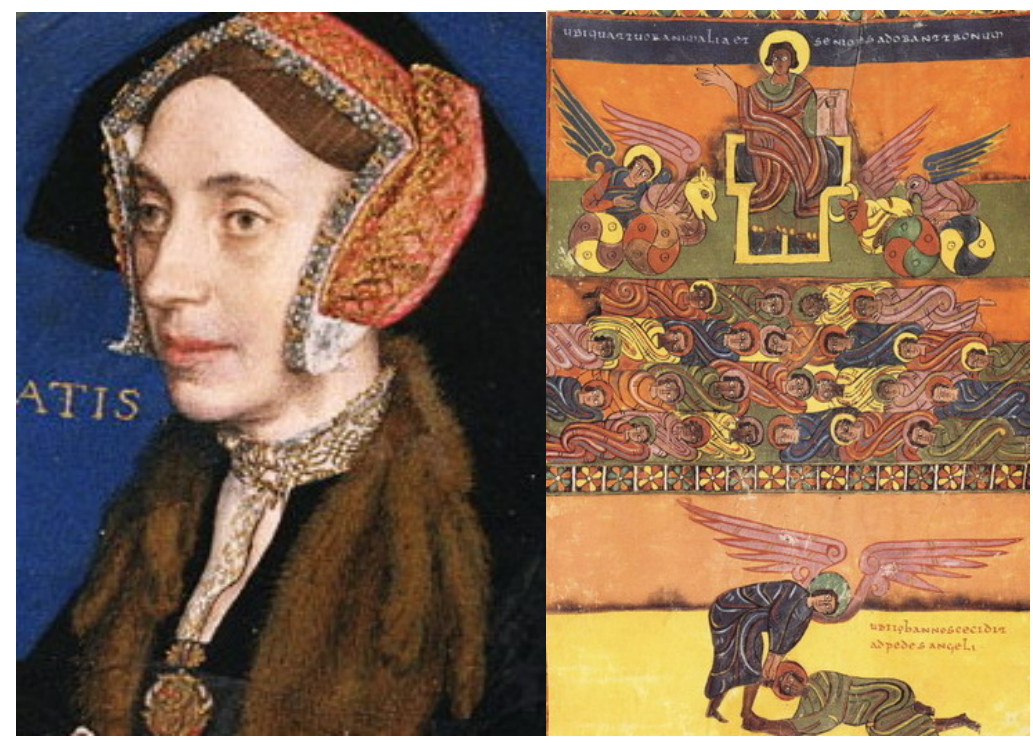

Fig. 32: De izquierda a derecha: Hans Holbein: Margaret More (hacia 1550), miniatura sobre pergamino; Anónimo: Beato de Nueva York, Adoración, miniatura sobre pergamino.

En estos retratos británicos vemos un dominio absoluto de las gradaciones tonales, las sombras que crean volúmenes y las sutilezas cromáticas; ya no estamos ante obras medievales sino ante auténticas obras maestras del retrato renacentista pese a las reminiscencias 
medievales relacionadas con el material. ${ }^{84}$ Los retratos en miniatura atribuidos a Holbein están llevados a cabo mediante la técnica de la acuarela directamente sobre la superficie del pergamino, consiguiendo zonas de gran transparencia en los colores, unidas a otras en las que, gracias a la superposición de capas, se han alcanzado tonalidades mucho más intensas. Como vemos, el proceso técnico es muy similar al de las iluminaciones medievales, pero si volvemos a la fig. 32, podremos ver como los resultados plásticos son absolutamente diferentes. Se demuestra de tal modo, que el pergamino se presenta como un soporte de gran versatilidad dado que sobre él pueden conseguirse imágenes de muy distinta naturaleza, sin que el material escogido condicione y coarte en exceso la creatividad del artista que se enfrenta a él.

¿Por qué, durante prácticamente dos siglos, se prefirió el pergamino frente al papel como soporte para estas acuarelas? Es difícil creer que hasta el s. XVIII fuera la reminiscencia medieval la que hubiera provocado esta particular elección, y más bien parece ser una cuestión meramente práctica y relacionada con las especiales características de la vitela, mucho más resistente que el papel y virtualmente imputrescible en condiciones estables de temperatura y humedad. Los miniaturistas británicos continuaron empleando el pergamino hasta que apareció en escena otro material que superaba las prestaciones de éste en cuanto a duración, resistencia,

\footnotetext{
${ }^{84}$ En muchas ocasiones aparecen letras u ornamentos dorados, elementos que denotan un origen íntimamente relacionado con el arte de la iluminación de manuscritos. Véase: GANZ, P. (1950), p. 258.
} 
transparencia y brillo de los colores: el marfil. ${ }^{85}$ En esta sustitución del pergamino por el marfil tenemos un episodio más de la historia de la piel animal, en la que ésta se ha visto desplazada de un campo en el que había predominado como soporte fundamental durante un largo periodo de tiempo. Si a finales de la Edad Media el papel vino a sustituir al pergamino como material de escritorio, y en los siglos XVIII y XIX los papeles pintados harán desaparecer los guadamaciles, en este caso es el marfil el que ocupará el lugar del pergamino, el cual quedará relegado al ostracismo y verá restringido cada vez más su ámbito de influencia.

\footnotetext{
${ }^{85}$ Tras Holbein, se desarrolló una auténtica corte de miniaturistas británicos, algunos de los cuales alcanzaron renombre y fama. Destacaron Nicholas Hilliard (1547-1618), Peter Oliver, John Hoskins (+1664) o Samuel Cooper (1609-1672), entre muchos otros. Véase: LUNA, J. J. (1990), p. 62.
} 


\section{II.1.7. Rembrandt: Las tres cruces}

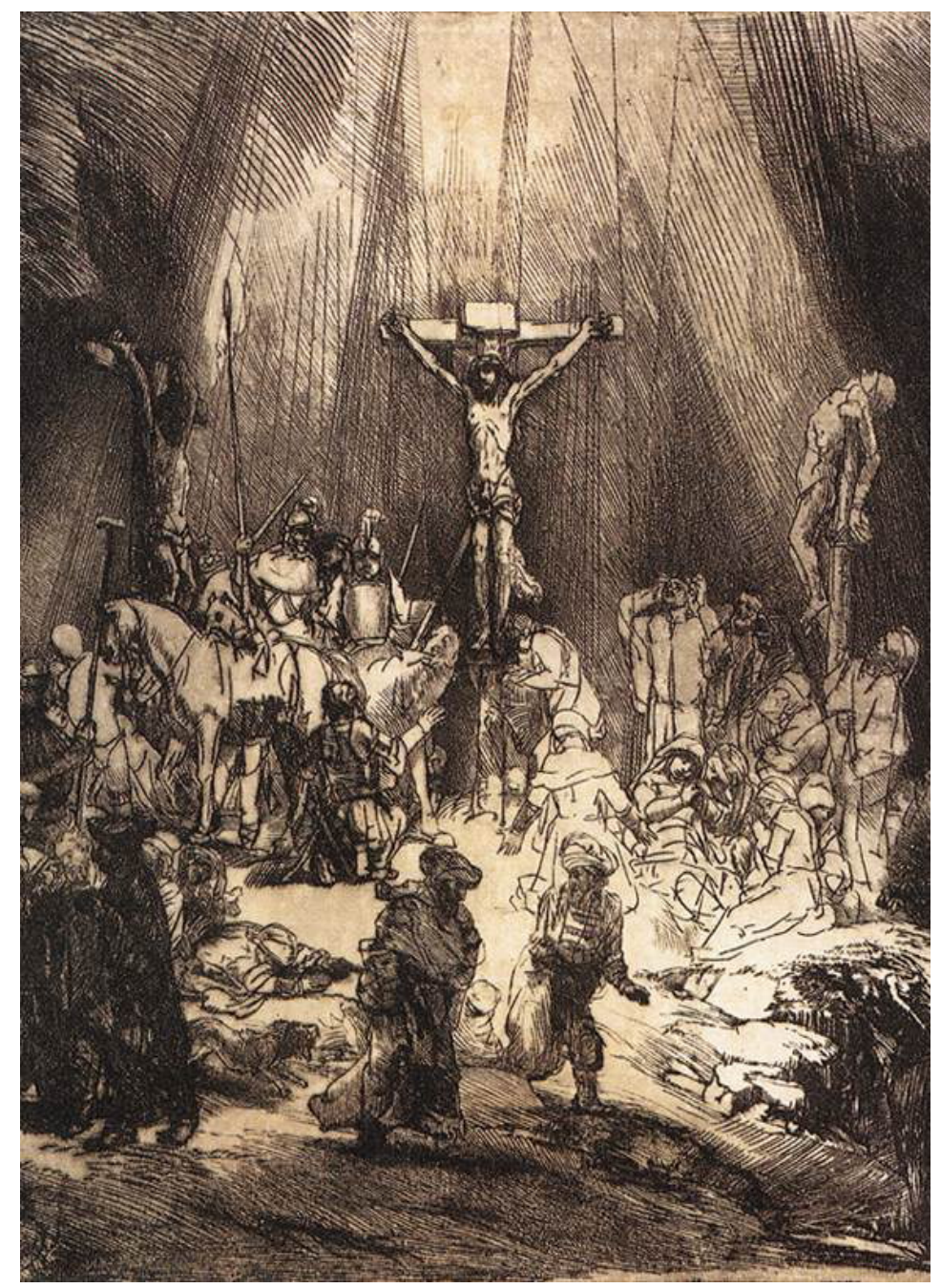

Fig. 33: Rembrandt van Rijn: Las tres cruces (1653), punta seca y buril sobre vitela, primer estado. 
El caso de Rembradt Van Rijn (1600-1669) es absolutamente excepcional dentro del recorrido que venimos haciendo, y por ende de toda la historia del Arte, dado que casi por vez primera vemos unida la técnica del grabado con los soportes derivados de la piel animal. Auténtico revolucionario del grabado, llevó el aguafuerte y la punta seca hasta cotas insospechadas hasta ese momento, pese a que muchos piensen que fue autodidacta en lo que se refiere al grabado indirecto sobre cobre. Comenzó a realizar aguafuertes alrededor del año 1628, con su anciana madre como modelo, pero fue a partir de 1640 cuando, totalmente seguro de su arte como grabador, inició sus experimentaciones con todo tipo de soportes. Será al final de este proceso de investigación plástica, ya durante la década de 1650 , cuando Rembrandt aborde estampaciones sobre vitela como la que nos ocupa, demostrando un afán innovador difícilmente comparable con cualquiera de sus coetáneos.

La técnica del grabado de Rembrandt ha sido estudiada en profundidad, desde las distintas mordidas que efectuaba en la plancha hasta la combinación de diferentes procedimientos 0 la exacta composición del ácido empleado. ${ }^{86}$ De igual modo, se han establecido distintas etapas dentro de la producción de grabados de Rembrandt dependiendo del soporte empleado mayoritariamente en cada una de ellas. Así, hasta 1640 y dentro del periodo de formación de su estilo, empleó papel europeo blanco, ya fuera éste francés $u$ holandés,

\footnotetext{
${ }^{86}$ Parece ser que usó un mordiente conocido como "ácido holandés”, formado por 1 litro de $\mathrm{H}_{2} \mathrm{O}, 125$ cc de $\mathrm{HCl}, 25$ gr. de $\mathrm{KClO}_{3}$ y 25 gr. de NaCl. Véase: REMBRANDT/1998, p. 21.
} 
situación que cambió a lo largo de la década de 1640-1650, dado que comienza a interesarse de manera evidente por los recursos pictóricos de sus procedimientos gráficos. ${ }^{87}$ Este interés le llevará a ampliar su gama de soportes hasta abarcar papeles orientales de gran belleza provenientes de India o Japón, los cuales le aportan nuevos resultados plásticos para sus estampas.88 También en esta etapa entra en contacto de manera cada vez más frecuente con un papel gris grueso y marcadamente verjurado, así como con el papel para envolver conocido en la época con los nombres de oatmeal, cardoes o cartrigepaper, usando ambos como soporte para gran número de sus grabados. ${ }^{89}$

Es en los primeros años de la década de los 50 , cuando el pintor decide experimentar de manera continua con los soportes de vitela y pergamino, lo cual puede considerarse como la culminación de un proceso de investigación técnica que había comenzado mucho tiempo atrás y había incluido, no sólo innumerables tipos de papel, sino incluso materiales como la seda (fig.34). ${ }^{90}$

\footnotetext{
${ }^{87}$ Para un análisis en profundidad de la técnica gráfica de Rembrandt véase la tesis doctoral inédita: CANO PÉREZ, V. (1987).

${ }^{88}$ El papel japón llegaba a Holanda proveniente de Nagasaki a través del puerto de Java, gracias a la Ducht East India Company.

${ }^{89}$ REMBRANDT/1998, p. 24.

${ }^{90}$ Ya de 1636 se conservan pruebas sobre seda, con el conocido ejemplo de un grabado titulado Autorretrato con Saskia como muestra. Véase:

LAMBERT, S. (2001), p. 18.
} 


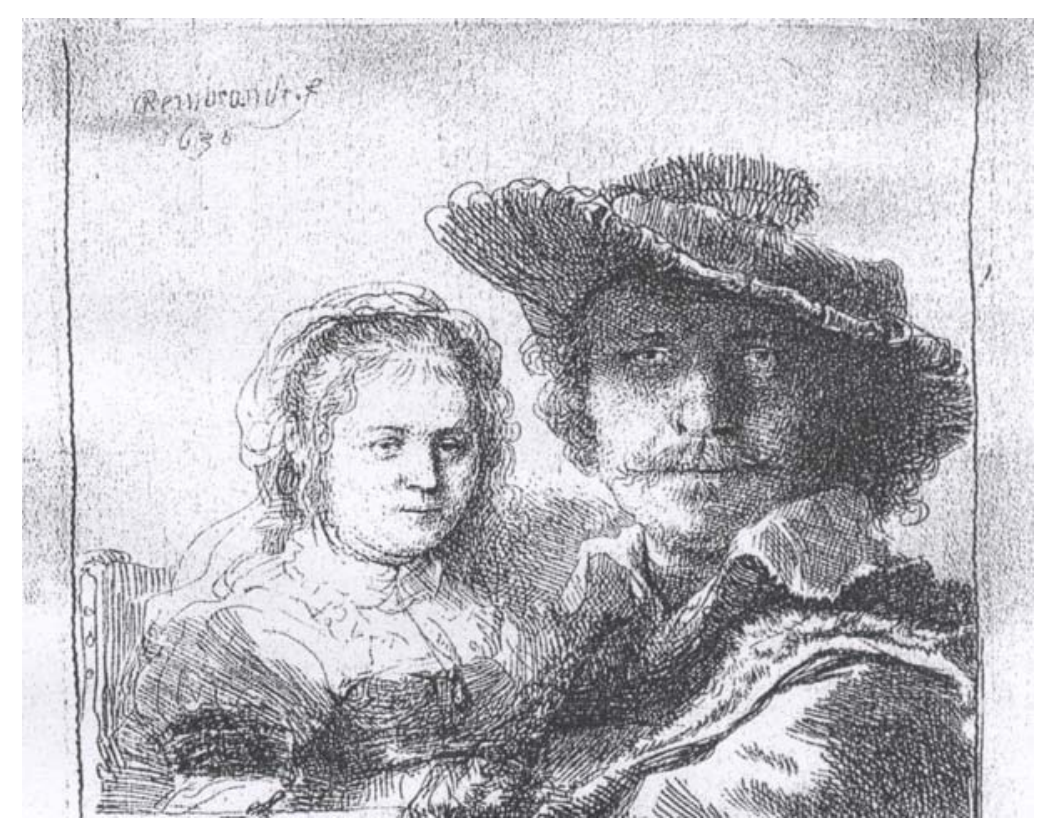

Fig. 34: Rembrandt van Rijn: Autorretrato con Saskia (detalle), grabado sobre seda.

La imagen seleccionada es buena prueba de este afán investigador dado que corresponde, no al estado definitivo de un grabado, sino a la primera prueba de estado de una de sus estampas más conocidas. Resulta cuando menos curioso comprobar como Rembrandt realizaba pruebas de estado en materiales tan caros como eran por aquel entonces el pergamino de vitela, lo cual puede responder a, como mínimo, dos motivaciones diferentes. 0 bien existían ya coleccionistas ávidos de su obra dispuestos a pagar elevadas sumas de dinero incluso por este tipo de pruebas de estado, o bien el espíritu investigador y experimentador de Rembrandt llegaba 
hasta el extremo de realizar incesantes pruebas con todo tipo de soportes y materiales diferentes sin reparar en el coste. ${ }^{91}$

Sea como fuere, nos encontramos ante una muestra del empleo totalmente consciente del pergamino como soporte susceptible de modificar la apariencia de una obra grabada, dado que si se comparan estampas del mismo estado realizadas cada una sobre papel y sobre pergamino, se comprobará como el resultado dista mucho de ser idéntico. Rembrandt sabía de las especiales características de los papeles orientales, y probó a producir estampas sobre vitela para descubrir las posibilidades plásticas que este soporte le otorgaba. Estamos por tanto ante la posición totalmente opuesta a la del iluminador altomedieval de beatos mozárabes: si aquél no poseía otra opción que realizar sus imágenes sobre pergaminos, el artista holandés, a diferencia de la práctica totalidad de sus contemporáneos, decide trabajar sobre dicho material con objeto de descubrir nuevas vías para su arte.

La superficie algo pulida del pergamino respondía de manera diferente ante la tinta de las planchas de Rembrandt, y si los papeles la absorbían en gran cantidad, sobre la vitela la tinta tendía a permanecer sobre la superficie del soporte. Esto da a las estampas sobre pergamino un acabado de enorme calidez una vez que la tinta ha

\footnotetext{
${ }^{91}$ En 14 de las 19 estampas de este primer estado de la plancha, Rembrandt empleó la vitela como soporte. Entonces, 12 hojas de vitela tenían el precio equivalente a una resma de 500 hojas de papel. Véase: REMBRANDT (2000), p. 297.
} 
secado, como puede comprobarse si se compara la imagen correspondiente al célebre grabado de Las tres cruces, con una prueba del mismo estado sobre papel (fig. 35).

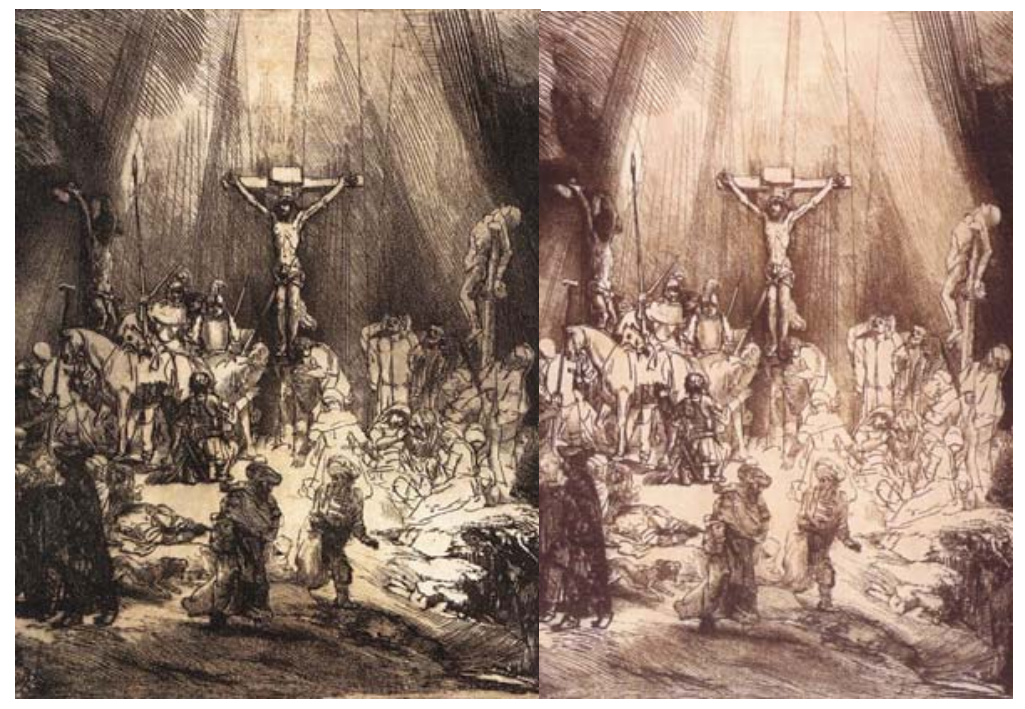

Fig. 35: A la izquierda, detalle del grabado Las tres cruces, estampado sobre vitela. A la derecha, el mismo estado de la plancha, estampado sobre papel.

El interés de Rembrandt por experimentar sobre soportes alternativos a los tradicionales es más que evidente, y no sólo en el campo del grabado que venimos analizando, dado que se conocen algunos dibujos del holandés realizados también sobre pergamino. ${ }^{92}$ Se trata de un artista plenamente consciente de sus posibilidades y

\footnotetext{
${ }^{92}$ Destacan entre otros: Retrato de Saskia (1663), punta de plata sobre pergamino tratado, de 185x105 mm, y Retrato de un caballero (1634), tiza roja y negra, pluma y pincel en bistre sobre pergamino, de 373x272 mm. Véase: HAAK, B. (1980), p. 21.
} 
ansioso por abrir nuevos caminos gracias a la experimentación con nuevos materiales, dentro de los cuales debemos incluir el pergamino. A diferencia de Durero, de quién no quedan absolutamente claras las motivaciones que le impulsaban en ciertos momentos a decantarse por el pergamino, la postura de Rembrandt es clara y meridiana. ${ }^{93}$ Para él, el soporte de sus grabados no es un simple receptáculo de la imagen estampada sino que interviene en el acabado, la apariencia y la naturaleza última de la obra. Se trata de Arte sobre piel, pero ésta alcanza una importancia extraordinaria como elemento conformador de la pieza artística; se trata de Arte sobre piel, pero ésta no queda oculta bajo capas y capas de pintura hasta casi desaparecer por completo, sino que su textura, su calidez y su tacto parecen poder percibirse entre las líneas de los grabados.

\footnotetext{
${ }^{93}$ La utilización del pergamino no se reduce a esta estampa concreta, sino que puede rastrearse en otros grabados como Huida a Egipto (hacia 1653), El entierro de Cristo (hacia 1654), San Francisco rezando bajo un árbol (1657) o Retrato de Jan Lutma orfebre (1656).
} 


\section{II.1.8. Keith Haring: Sin título}

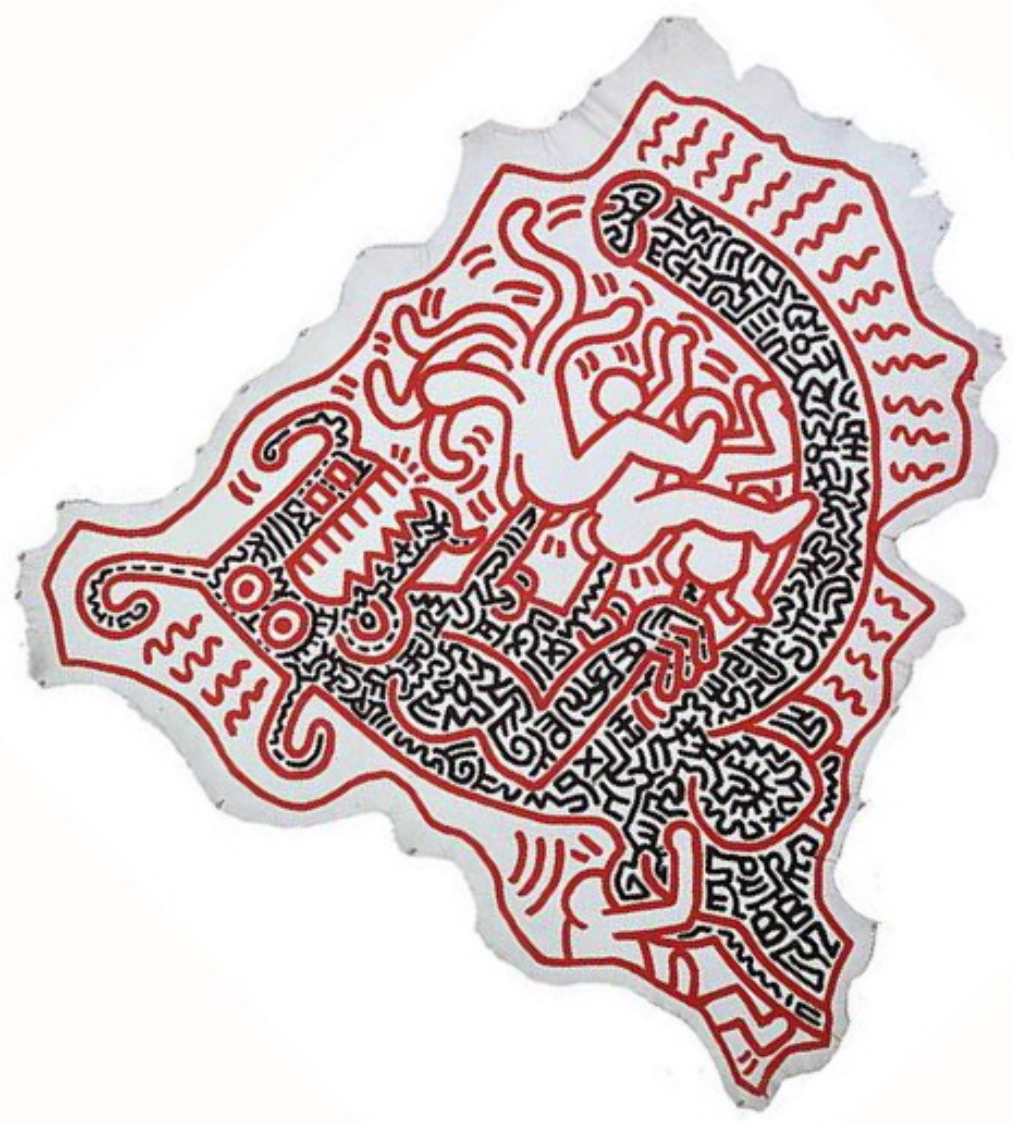

Fig. 36: Keith Haring: Sin título (1984), acrílico sobre cuero. 
La última parada de este recorrido nos lleva al s. XX y a la obra de uno de los artistas más célebres de su generación, el norteamericano Keith Haring (1958-1990), quién inundó todo tipo de soportes con sus dibujos lineales y esquemáticos de trazos gruesos y sencillos. Haring pintó murales, diseñó ropa, hizo grafitis en el metro, decoró los cuerpos de bailarines y bailarinas y realizó esculturas públicas, empleó un gran número de materiales como soporte para sus pinturas y dibujos, desde todo tipo de metales, pasando por diversos derivados plásticos, papeles, pizarras, carteles 0 la propia piel humana. Entre su ingente obra podemos encontrar piezas como este Sin título (1984) de la fig. 36, directamente realizado sobre un pellejo de cuero a partir del uso de pinturas acrílicas. Lo que para otros artistas podría suponer una rareza, para este creador, en muchos sentidos iconoclasta e inconformista, es tan sólo una consecuencia lógica de su praxis artística personal.

La piel animal escogida por Haring no sólo sirve como soporte para su pintura de connotaciones evidentemente sexuales, sino que condiciona toda la obra con su contorno absolutamente irregular y heterogéneo. La forma de la obra se adapta al soporte y ya no al contrario como había sucedido durante siglos, cuando eran los soportes, fueran del tipo que fuesen, los que se recortaban, ensamblaban, pegaban o partían para poder acoplarse de manera lo más perfecta posible a la imagen que el artista deseaba realizar sobre ellos. Aquí observamos como la forma orgánica irregular de un pellejo 
de cuero, ${ }^{94}$ provoca que los personajes antropozoomórficos de Haring deban adaptarse a sus contornos, cobrando éstos una importancia inusitada en la creación de la obra. Cualquier otra pieza de cuero habría dado lugar a un trabajo totalmente diferente, por lo que el cuero es a la vez soporte y parte constituyente, en tanto que su forma original, sin recortes o modificaciones, constituye el marco donde se engloban los trazos del pintor. Sin duda, nos encontramos muy lejos de las otras pinturas sobre cuero que hemos analizando previamente, tanto las de la sala de los Reyes de la Alhambra de Granada, como la del escudo forrado en piel del pintor italiano Andrea del Castagno: lo que en aquéllas era ocultamiento del material que servía como soporte, en ésta es afirmación extrema de las cualidades físicas de la piel animal. Si en aquéllas las capas de pintura cubrían totalmente la superficie del cuero, en ésta es el tono de la piel el que determina el color de fondo de la obra. Si en aquéllas los pellejos se adaptaban a unas formas determinadas previamente diseñadas, ya fuera la bóveda 0 el escudo, en ésta es la pintura la que se adapta a la forma arbitraria del cuero. El proceso de emancipación del cuero dentro de los elementos que configuran estas tres obras de arte es evidente, alcanzando en esta última un grado de madurez y autonomía digno de reseñar.

\footnotetext{
${ }^{94}$ Por sus dimensiones $(117 \times 210 \mathrm{~cm}$.) debe tratarse de un cuero vacuno.
} 


\section{II.2. ARTE EN PIEL}

Si en el apartado precedente hemos hecho un breve recorrido por algunas obras en las que la piel animal jugaba el papel de soporte, en éste veremos manifestaciones en las cuales los cueros ya no tienen un rol de receptores de las imágenes colocados sobre ellos, sino que son parte indisoluble de las piezas a las que dan forma. Nos enfrentaremos al análisis de técnicas y procedimientos exclusivos del mundo del cuero y la piel animal, aunque en ocasiones puedan intervenir procesos relacionados con el ámbito de la pintura. Durante siglos, las piezas y objetos de los que ofreceremos una muestra escogida han sido calificados como artesanía, denominación que podría denotar un cierto cariz despectivo si lo comparamos con las relativas a las Bellas Artes. Sin embargo, en este estudio consideramos que algunas de las obras que estudiaremos deben ser tenidas en la misma estima que otro tipo de manifestaciones históricamente mejor consideradas $y$, de igual manera que defendemos una revisión de dichos procedimientos, abogamos por una justa valoración de los cueros y pieles como materiales de primera fila a la hora de configurar determinados objetos artísticos de muy diversa índole. De modo similar a como hicimos en los apartados anteriores, escogeremos una serie de piezas que nos servirán como hilo 
conductor para realizar las oportunas reflexiones acerca de los distintos episodios en los que los cueros han tenido un papel protagonista en la creación de piezas artísticas.

Antes de entrar a valorar las distintas etapas en que hemos dividido este trayecto, debemos indicar que, en este apartado del Arte en piel, el pergamino deja de tener un papel protagonista para ceder toda la importancia a los cueros. Si ya hemos visto como ambos derivados de la piel animal han sido empleados como soportes para todo tipo de procedimientos dibujísticos y pictóricos, en este punto será el cuero el que se posicione como el material ideal. Son sus cualidades y características propias las que le permiten convertirse en materia prima a partir de la cual crear y fabricar infinidad de objetos con un claro carácter estético, a pesar de la evidente utilidad de muchos de ellos. Su ductilidad, la posibilidad de adquirir innumerables tonalidades gracias a los procesos de tintado, su resistencia y flexibilidad, lo convierten en un material perfecto, ya no sólo como soporte para otras técnicas artísticas, sino como base para la realización de obras que, modificando su naturaleza, logran alcanzar altas cotas de plasticidad. 


\section{II.2.1. Encuadernación mudéjar}

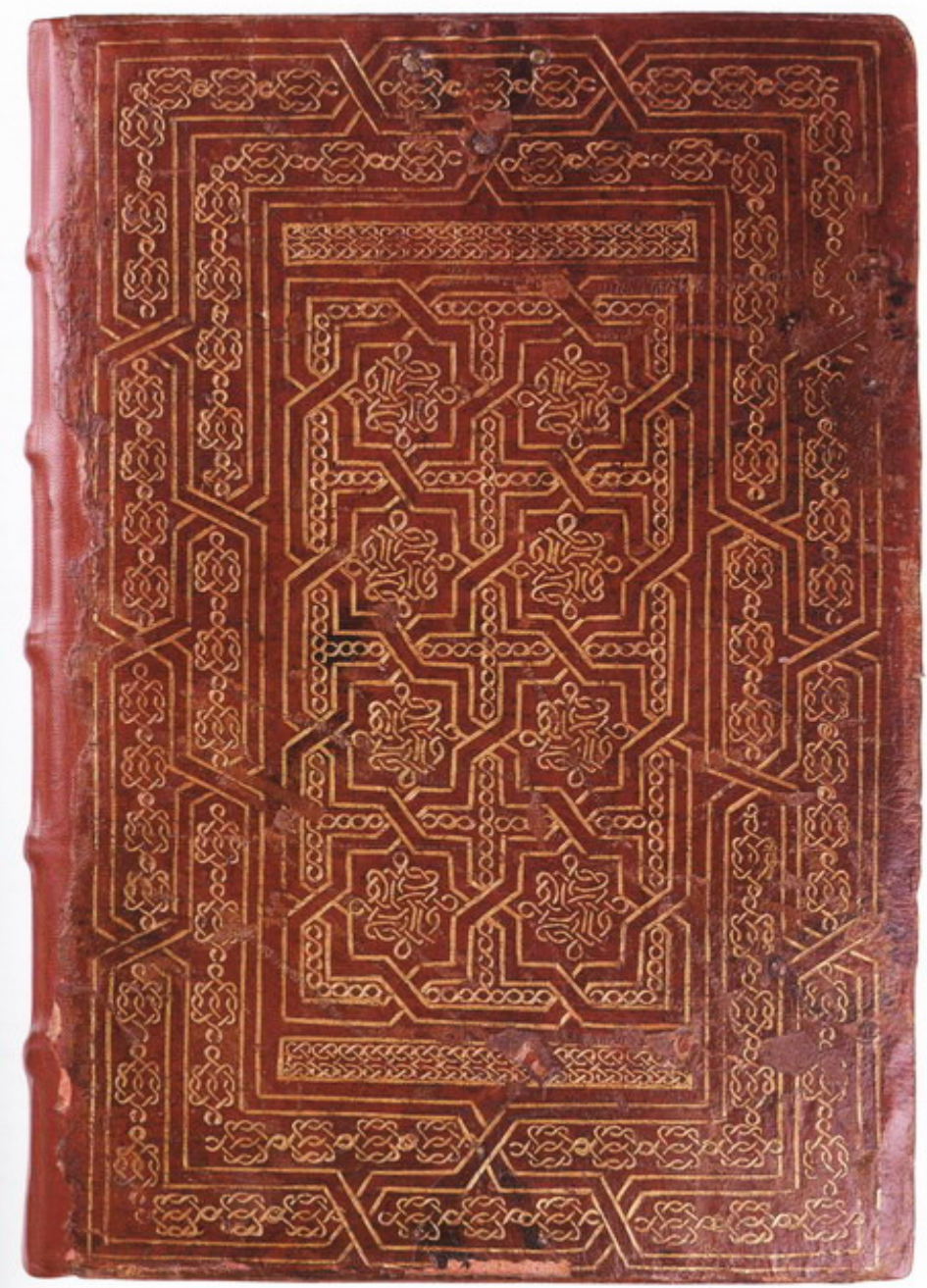

Fig. 37: Dionisius Halicarnasi, Originum sive antiquitatum

Romanorum (1482), encuadernación en piel roja, tafilete rojo gofrado y dorado. 
"Las encuadernaciones son las ropas con las que un libro se viste para elegir su lector"95

Si hay un ámbito en el que el empleo del cuero haya jugado un papel protagonista desde hace siglos, ése es el de la encuadernación de libros y volúmenes. Obviamente se trata de un campo de enorme extensión que no corresponde a esta investigación, pero no podemos dejar de hacer referencia a algunas manifestaciones de estos procedimientos artísticos que tienen al cuero como indudable actor principal. ${ }^{96}$ La piel animal fue el material escogido desde el primer momento en que se decide crear un objeto cuyo fin específico sea el de proteger las páginas de un libro, pese a que las primeras encuadernaciones que conocemos fueran ideadas para preservar los antiguos rollos de papiro y estuvieran realizadas en pergamino. ${ }^{97}$

Con la evolución del libro y el paso del rollo al códice a lo largo de la Baja Antigüedad, la morfología de las encuadernaciones cambió sustancialmente, pero no así el material empleado, que seguía siendo el derivado de la piel animal, ya fuera el pergamino para volúmenes no demasiado lujosos, o los cueros, decorados o no, para libros de más

\footnotetext{
${ }^{95}$ MANDIGORRA LLAVATA, M. L. (2003), p. 192.

${ }^{96}$ Existen numerosos textos donde encontrar abundante información acerca de la evolución, desarrollo y técnicas propias de la encuadernación en piel. Podemos destacar: LÓPEZ SERRANO, M. (1972); BERMEJO MARTÍN, J. B. coor. (1998) y BONET CORREA, A. coor. (1987).

${ }^{97}$ DAHL, S. (1985), p.32 y s.
} 
alto nivel. ${ }^{98}$ Ya desde el principio podemos rastrear muestras de decoración sobre los cueros que protegen los libros, con la particularidad de que esta ornamentación no está basada en una película pictórica superpuesta a la piel, sino que se logra a partir de procedimientos que cambian la naturaleza superficial del cuero.

Es en este punto donde establecemos la diferencia entre las manifestaciones artísticas descritas en el apartado precedente, que hemos denominado Arte sobre piel, y las que analizamos en estas líneas, definidas por su parte como Arte en piel. El cuero de las encuadernaciones, como más tarde el de los cordobanes y los guadamaciles, no es un soporte para una imagen, sino que las representaciones están trabajadas en dicha piel, de igual modo que el mármol de un relieve no es un mero receptor de las figuras que lo pueblan, sino el material del que están hechas esas mismas figuras. Así, en este apartado recordaremos someramente algunas de las técnicas y procedimientos mediante los que, desde hace siglos, se decoran y ornamentan las pieles y cueros, técnicas que son exclusivas del material que nos ocupa, constituyendo un capítulo aparte dentro de la historia del Arte. Estos procedimientos pueden a veces combinarse con métodos pictóricos o incluso escultóricos, sin que por ello vean

\footnotetext{
${ }^{98}$ Apenas si se conservan restos de las primitivas encuadernaciones, $\mathrm{y}$ debemos esperar hasta los siglos VII y VIII para encontrar restos de cubiertas coptas realizadas en cuero. Estas encuadernaciones presentan ya muestras de decoración sobre la superficie de la piel, con técnicas que, sin duda, los egipcios coptos heredaron de pueblos anteriores de los que, desgraciadamente, no han quedado restos tangibles. Véase: DAHL, S. (1985), p. 32 y ss.
} 
desvirtuada su naturaleza particular basada en el empleo de los cueros como materia prima de las formas artísticas. ${ }^{99}$

La imagen de la fig. 37, una cubierta del s. XVI en estilo mudéjar, demuestra un dominio exquisito de las más importantes técnicas que los artistas del cuero vienen empleando desde la baja Antigüedad. 100 Aun a riesgo de cometer una excesiva simplificación, y dado que no es el objetivo primordial de este estudio el análisis de dichos procedimientos, las agruparemos en tres grandes bloques: las que actúan sobre la piel creando relieves en frío; las que provocan esos relieves gracias al uso de calor; y las que no crean relieves pero doran los cueros.

La primera de las técnicas, una de las más antiguas, es conocida como estezado, y tiene como objetivo crear una serie de relieves, surcos, hendiduras y diferencias de textura sobre la superficie de la piel. ${ }^{101}$ Para tal fin se sirve de pequeñas planchas de hierro con

\footnotetext{
${ }^{99}$ No es nuestra intención hacer un repaso de las diferentes técnicas que han posibilitado todo tipo de encuadernaciones, aunque sí nos referiremos a las que consideramos más importantes, tratando de analizar en qué medida modifican las características propias de los cueros y qué posibilidades reales existen de poder aplicarlas en la formulación del bloque práctico desarrollado a partir del apartado III, el cual se inicia en la p. 151.

${ }^{100}$ Para un análisis más exhaustivo de este tipo de encuadernaciones hispanas pueden consultarse: ALVARO ZAMORA, M. J. (2003); LÓPEZ SERRANO, M. (1972); MANDIGORRA LLAVATA, M. L. (2003) y NIETO ALCAIDE, V. (1987).

${ }^{10 i}$ La terminología relativa a estos procedimientos no se encuentra tipificada de manera estricta y pueden existir confusiones. En nuestro caso hemos tratado de seguir la propuesta por BERMEJO MARTÍN (1998) y LÓPEZ SERRANO (1972).
} 
formas diversas, las cuales se aplican sobre el cuero, ya sea mediante golpes o presión, logrando que la piel adopte la forma deseada gracias a su conocida ductilidad y flexibilidad. Para aumentar la intensidad de los relieves, a la vez que disminuir la dificultad del proceso, se suele humedecer la piel, lo que aumenta su flexibilidad y permite un mejor resultado. La facilidad de esta técnica la hizo ser empleada durante siglos en la decoración de los cueros, aunque casi siempre se intentaba combinar con otras para realzar los resultados obtenidos.

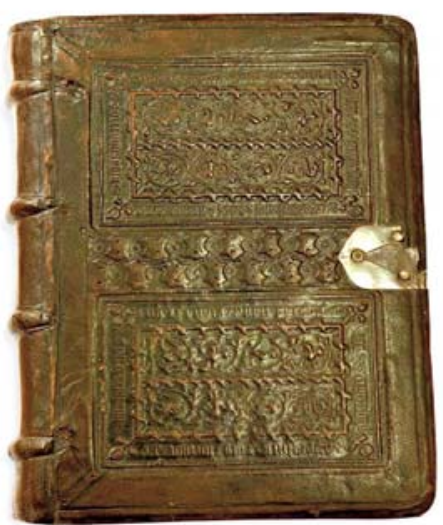

Fig. 38: Libro de regla de santa Clara (s. XV), encuadernación en cuero repujado, $12 \times 15 \mathrm{~cm}$.
Una variedad de este procedimiento es el repujado, también realizado sobre pieles húmedas sin la intervención del calor, y muy similar a la técnica del mismo nombre sobre planchas metálicas. Al igual que al trabajar el metal, con el cuero se debe proceder oprimiendo el lado carne interno de la piel con diferentes herramientas como punzones o cuchillos, logrando así que las figuras deseadas sobresalgan en el lado flor. El resultado alcanzado es una superficie lisa, dura y muy brillante, la cual puede incluso llegar a confundirse con la madera tallada y barnizada, aunque debemos indicar que este procedimiento no fue tan empleado en el mundo de la encuadernación como más tarde lo será dentro del campo 
de los cordobanes, pese a que existan ejemplos notables como el de la fig. 38.

Un paso más se logra al emplear el procedimiento del gofrado, también ampliamente utilizado para las encuadernaciones, el cual se diferencia del anterior en la participación del calor como elemento fijador del relieve. El humedecido de la piel sigue siendo necesario en muchos casos pero el proceso es menos complicado dado que se trabaja a partir de grandes matrices metálicas previamente compuestas y diseñadas, que facilitan la labor del artesano. ${ }^{102}$ Una vez calentadas las planchas al fuego y alcanzada la temperatura necesaria se presionan los troqueles metálicos contra el lado flor del cuero, quedando las formas marcadas en relieve sobre la piel, a la vez que aparece un ligero oscurecimiento por efecto del calor sobre la materia orgánica del cuero. ${ }^{103}$ Como vemos, con el gofrado no sólo se producen relieves y cambios de grosor en el material, sino que incluso se modifica su tono por efecto de la temperatura, modificación tonal que no debemos confundir con la provocada por una película pictórica ajena al cuero: en este caso es el cuero el que modifica su naturaleza intrínseca. Las imágenes y figuras no se encuentran en este caso sobre el cuero, como ocurría con todas las obras analizadas en apartado II.1., sino integradas en el cuero, y una vez que han sido creadas es absolutamente imposible separarlas del material que les ha dado forma.

\footnotetext{
102 BERMEJO MARTÍN, J. B. dir. (1998), p. 137.

${ }^{103}$ LÓPEZ SERRANO, M. (1972), p. 34 y s.
} 
El último de los procedimientos es el que incluye los procesos de dorado, que permiten decorar los cueros mediante finas capas de pan de oro que los dotan de una apariencia suntuosa. La variedad de posibles métodos diferentes es amplísima, ${ }^{104}$ por lo que en este punto concreto tan sólo nos limitaremos a analizar el papel estético del dorado en la configuración de las encuadernaciones. ${ }^{105}$ De orígenes confusos, era necesaria una gran pericia manual para llegar a dominar la técnica, dado lo delicado del trabajo con pan de oro y su combinación con el gofrado con calor. En efecto, el dorado puede considerarse como un perfeccionamiento de la técnica de gofrado, ya que son los hierros o ruedas aplicadas en caliente los que permiten fijar la fina lámina de oro a la superficie del cuero, a la vez que crean el consabido relieve. Por tanto, no se trata tan sólo de una película de pan de oro depositada sobre el cuero, sino que gracias a los hierros candentes y a los relieves conseguidos con ellos, el dorado y el cuero se funden en un todo homogéneo. (fig. 39)

\footnotetext{
${ }^{104}$ En dichos procesos solía intervenir la clara de huevo, el vinagre y el aceite de almendras dulces a modo de aglutinante. Véase: LÓPEZ SERRANO, M. (1972), p. 62.

${ }^{105}$ En el apartado II.2.4. (p. 135-141) dedicado a los guadamaciles, trataremos de manera más pormenorizada la técnica del dorado propia de dichas manifestaciones artísticas.
} 


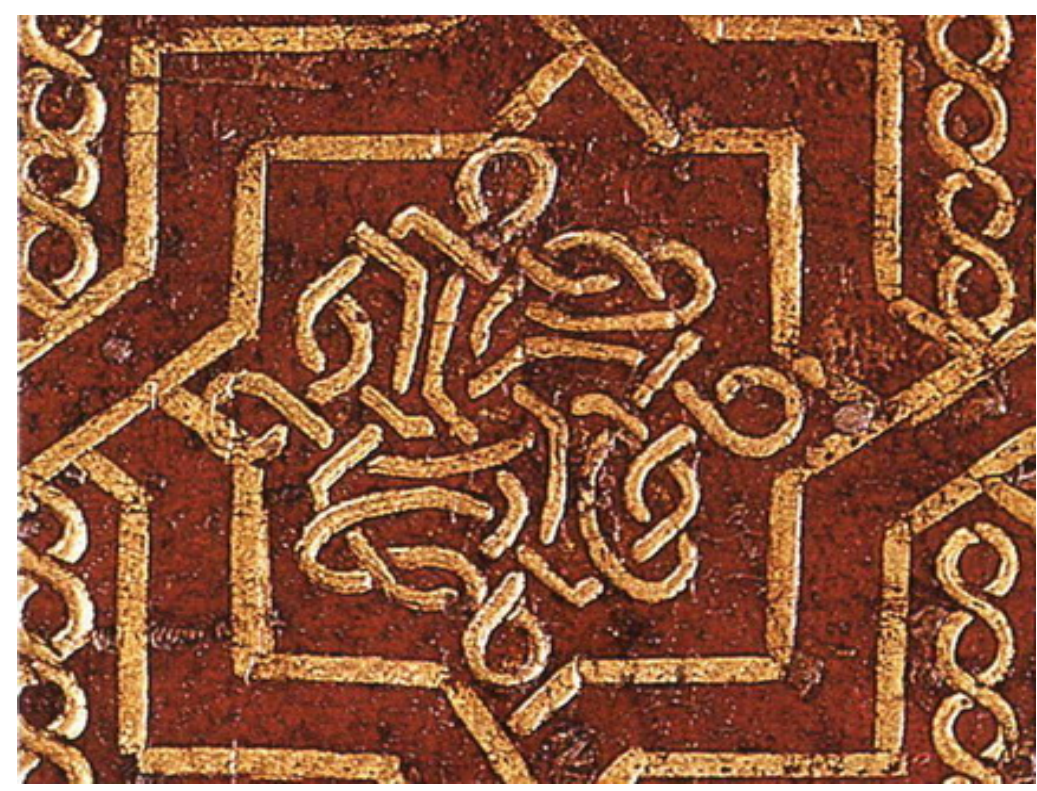

Fig. 39: Detalle de la fig.37, p. 117.

En la encuadernación mostrada para ilustrar este apartado podemos ver como la utilización de las diferentes técnicas que venimos detallando dan como resultado una muestra de enorme sensibilidad formal y plástica. La composición, perfectamente estudiada, se configura mediante una serie de elementos que se combinan de manera eficiente para dar a luz a un objeto que, pese a su evidente utilidad y funcionalidad, posee un claro valor estético. La superficie del cuero se ve alterada por los relieves y los dorados, dando forma a una composición abstracta y geométrica dominada por el espejo central con ocho estrellas de ocho puntas cada una, decoradas con motivos de sogueados formados por un hierro con un ovillo de entrelazos. La textura del cuero no sólo está presente en la 
encuadernación, sino que es el elemento que la dota de una naturaleza específica y diferenciada. En gran parte de las piezas mostradas en el apartado anterior, la piel animal era un elemento secundario, y pese a las especiales condiciones que presentaba como soporte las imágenes vertidas sobre ella podían haber sido igualmente válidas sobre otros materiales. ¿Acaso habríamos percibido alguna diferencia, si el David de Andrea del Castagno hubiera estado realizado sobre madera? ¿Cambiaría sustancialmente la pintura de la Sala de los Reyes de la Alhambra de haber estado pintada directamente sobre la madera de la bóveda? Desde un punto de vista técnico es evidente que podrían producirse cambios de diversa naturaleza, pero si nos centramos en un análisis estético, las diferencias habrían sido prácticamente imperceptibles. No ocurre lo mismo en el caso que ahora nos ocupa, ya que lo que convierte a esta encuadernación mudéjar en lo que realmente es, lo que constituye su esencia, es estar realizada con un cuero gofrado y dorado; de ahí que la consideremos Arte en piel. 


\section{II.2.2. Estuche litúrgico o crismera}

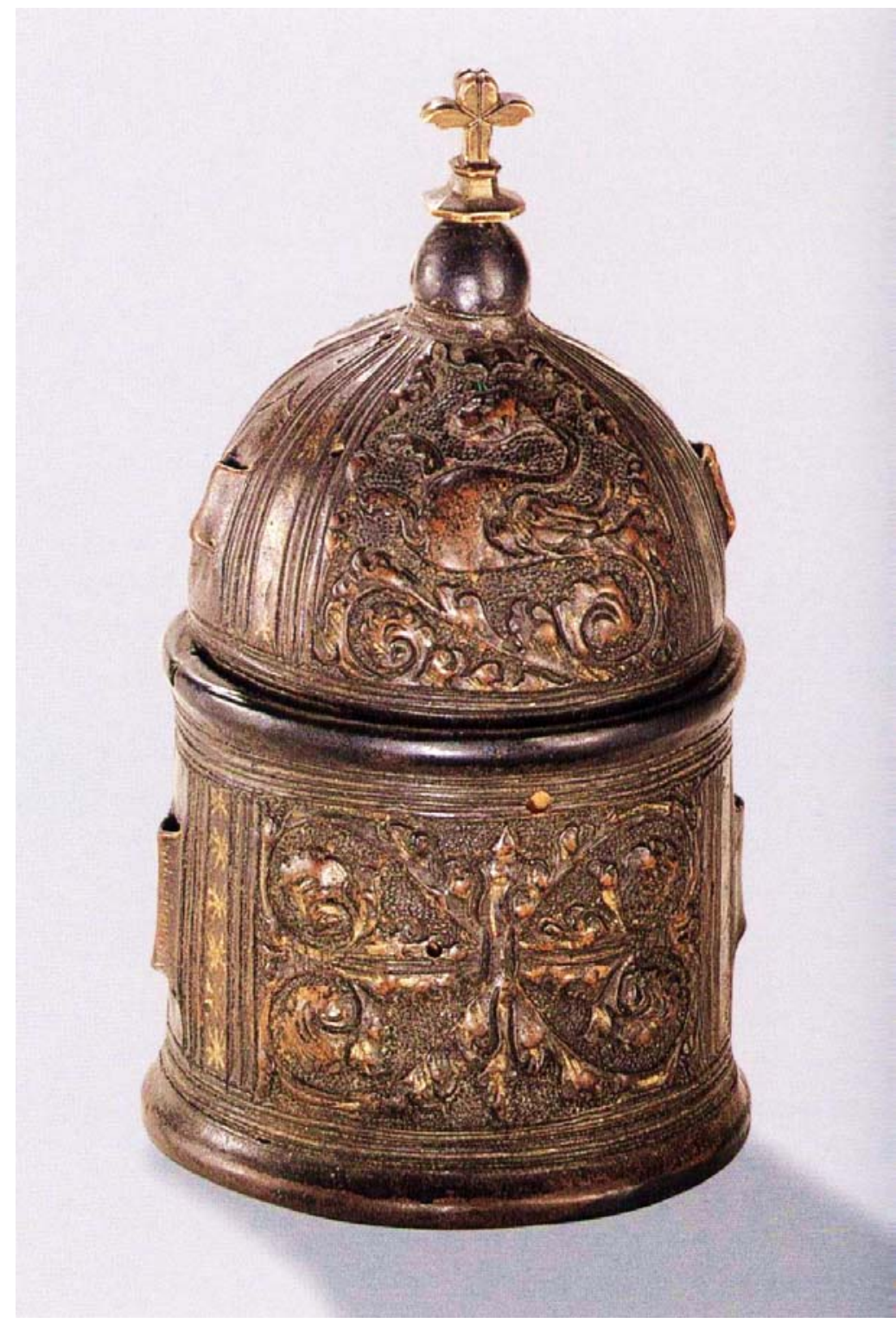

Fig. 40: Estuche litúrgico o crismera (siglo XVI), cordobán repujado y ferreteado, madera, procedente de los Países Bajos o Italia. 
Esta pieza nos introduce en uno de los capítulos más importantes dentro de la historia del uso de las pieles y del cuero en el mundo del Arte, episodio que corresponde al de los cordobanes y guadamaciles de origen claramente hispano. ${ }^{106}$ Pese a las confusiones que a veces aparecen entre estos dos términos, su diferenciación no presenta mayores problemas ya que, sin entrar a valorar con qué tipo de pieles se realizan cada uno, es en la distinta importancia que los factores puramente ornamentales poseen en cada uno de ellos donde reside su diferencia. Así, los cordobanes poseen un carácter más utilitario pese a estar profusamente decorados en la gran mayoría de las ocasiones, mientras que los guadamaciles, no en vano conocidos como cueros artísticos, tienen una finalidad casi exclusivamente ornamental y decorativa. ${ }^{107}$

Al hablar de cordobán nos referimos a la piel curtida que proviene exclusivamente de la cabra o del macho cabrio, excluyendo la posibilidad de trabajar con cueros derivados de otras especies animales. ${ }^{108}$ Las pieles debían ser de excelente calidad, factor que quedaba estipulado en las numerosas reglamentaciones y ordenanzas

\footnotetext{
${ }^{106}$ El término usado tradicionalmente para referirse a los cueros artísticos ha sido guadamecí o guadamecil. Sin embargo, basándonos en los estudios etimológicos de Elena Pazzi, elegimos emplear el término guadamacil, más similar al catalán guadamaçí. Véase: PAZZI, E (1990).

${ }^{107}$ SOLER I COLOMER, A. (1998), p. 33.

${ }^{108}$ Es posible que la elección de la piel de cabra, aparte de consideraciones meramente técnicas, tuviera algún tipo de connotación religiosa dirigida a evitar conflictos y problemas. Así, los musulmanes evitaban manipular pieles de cerdo, y los judíos cueros de vacuno.
} 
gremiales que todavía se conservan, ${ }^{109}$ pero el secreto de los cordobanes hispanos era su curtido con zumaque. El zumaque, como ya se ha apuntado anteriormente, 110 es una planta que, utilizada como producto curtiente, dota a los cueros de una calidad muy superior a otros taninos vegetales como pueden ser la corteza de pino o encina. Esta técnica de curtido fue introducida en España por los musulmanes, convirtiéndose Córdoba en el centro de producción más importante, y llegando a denominarse todas las pieles curtidas mediante este procedimiento como cordobanes, a pesar de que no estuvieran realizados en la antigua capital del califato andalusí.

Pese a que los cueros cordobanes fueron empleados con multitud de finalidades prácticas, ${ }^{111}$ en la mayoría de las ocasiones fueron decorados y ornamentados con diferentes técnicas, algunas de las cuales ya han sido comentadas dentro del apartado dedicado a la encuadernación. Los métodos para ornamentarlos son variados, dependiendo de la funcionalidad de la pieza a confeccionar el que se escogiera uno u otro. Desde el bordado con hilos de oro, plata, seda o

\footnotetext{
${ }^{109}$ Para un análisis de estos textos normativos, puede consultarse FERRANDIS TORRES, J. (1955).

${ }^{110}$ Véase capítulo I.3.1.a., p. 37.

${ }^{111}$ Los cordobanes fueron usados para la confección de arquetas, cajas, baúles, cofrecillos, sillas, sillones, cojines, sillas de montar, guantes, armas o zapatos, siempre de gran calidad. Como ejemplo, los zapatos más caros y exclusivos de toda Europa durante la Edad Media eran los confeccionados con cueros de Córdoba, y su manufactura llegó a designar un tipo específico de zapateros en ciertos países, como los cordewanier en los Países Bajos, o los cordwainer en Inglaterra.
} 
cáñamo, ${ }^{112}$ hasta el gofrado y el dorado, los cueros admitían todo un abanico de posibles manipulaciones destinadas a cambiar su superficie y su apariencia (fig 41). Sin embargo, es el repujado la más espectacular de las posibilidades de decoración de un cuero cordobán, dado que, aprovechando la flexibilidad de la piel, se podían conseguir volúmenes y relieves de extraordinaria plasticidad y fuerza estética.

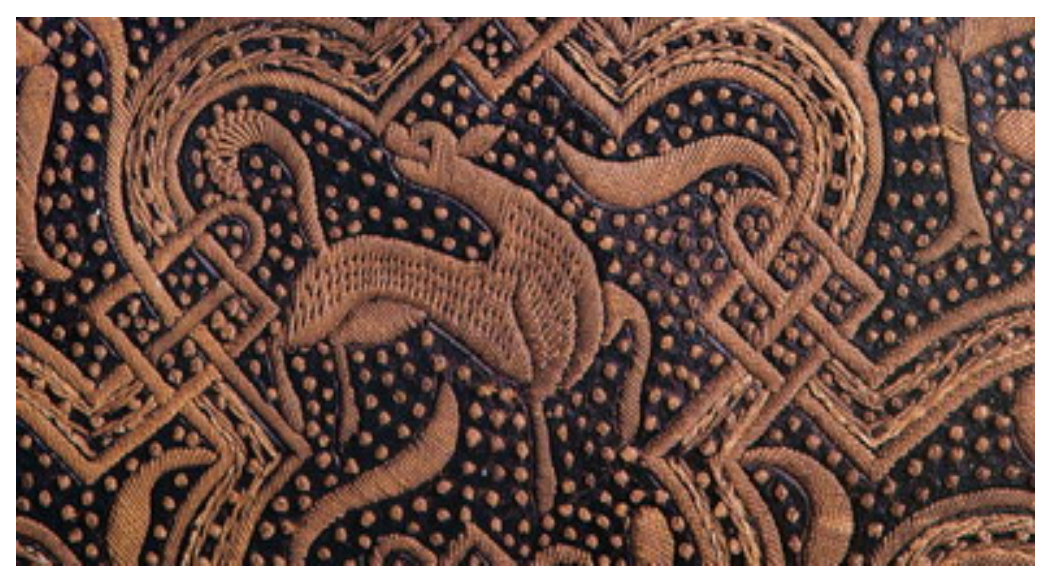

Fig. 41: Detalle de una petaca de cuero bordada con hilo de magüey (s. XVIII), Hispanoamérica.

La pieza escogida como ilustración de este apartado (fig. 40) muestra un perfecto dominio de estas técnicas, en especial del repujado, el cual ha permitido la creación de la decoración que puebla la práctica totalidad del estuche. Ésta se configura a partir de unos

\footnotetext{
${ }^{112}$ Es posible que ésta fuera la técnica más antigua destinada a enriquecer los cordobanes, dado que las pieles son tratadas como si se tratase de un tejido cualquiera sobre el que se desea bordar una imagen. Véase: AGUILÓ, M. P. (1998), p. 17-31.
} 
motivos vegetales de hojas de acanto en la parte inferior, mientras que en la tapa se repiten esos mismos motivos, pero acompañados de dos animales: un grifo y una paloma. ${ }^{113}$ Sin detenernos demasiado en el programa iconográfico, lo que es evidente es la importancia del material en lo que a la conformación de la pieza se refiere. Las formas decorativas no están pintadas sobre el cuero, como ocurre en muchas ocasiones, sino que surgen de la piel gracias a la acción de los hierros; no son ornamentaciones bidimensionales, sino que las hojas de acanto, el grifo y la paloma, adquieren corporeidad y avanzan, aunque todavía de manera tímida, hacia la tridimensionalidad. De no haber sido por las especiales características del cuero, por su flexibilidad y ductilidad, este resultado hubiera sido prácticamente imposible.

\footnotetext{
${ }^{113}$ Estos animales tienen una evidente significación simbólica doctrinal y litúrgica, con el grifo representando al mal, dada su naturaleza híbrida, y la paloma el bien. Véase: MADRID/1998, p. 77.
} 


\section{II.2.3. Caballero}

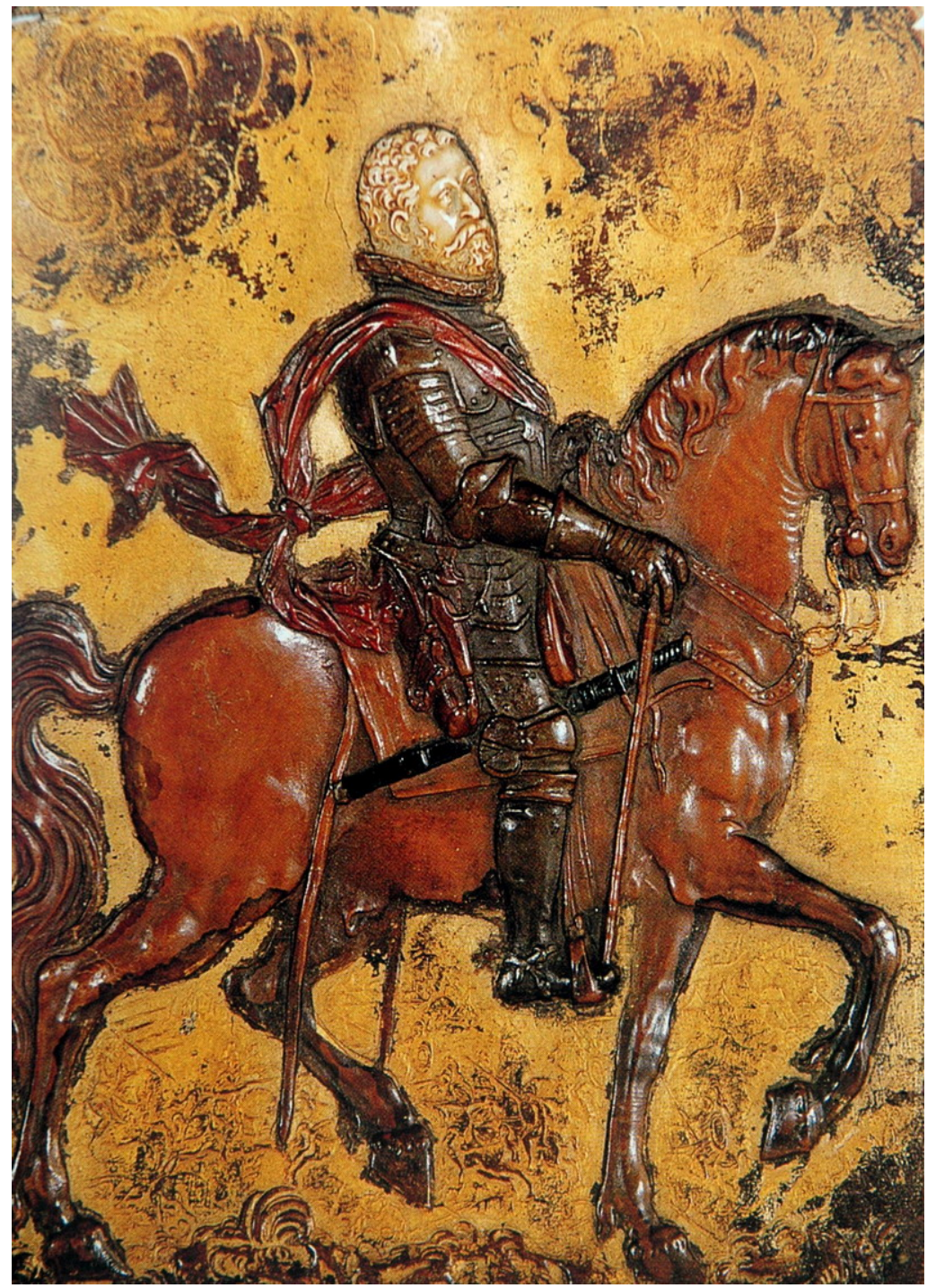

Fig. 42: Caballero (finales del s. XVI), piel moldeada, repujada, policromada, dorada y marfil, Centroeuropa. 
A medio camino entre el cordobán y el guadamacil, y mucho más cercano a lo que podríamos considerar como un relieve escultórico, se encuentra esta extraordinaria pieza centroeuropea de la fig. 42. Su finalidad es puramente estética, ya que, por su pequeño tamaño $(16 \times 12$ ' $5 \mathrm{~cm}$.) parece más bien el retrato ecuestre de un importante personaje cuya identificación no ha podido ser concretada por el momento. Nos encontramos ante un auténtico compendio de técnicas decorativas, dado que el cuero que sirve como material para el relieve ha sido modelado, repujado, policromado y dorado, hasta alcanzar la apariencia suntuosa que muestra la pieza. Para aproximarse todavía más al ámbito del relieve escultórico, el autor anónimo decidió incrustar una porción de marfil con objeto de resolver la zona de la cabeza del jinete con detalles más definidos, lo que hace inclinarse a los investigadores por considerar al relieve como un retrato individualizado. ${ }^{114}$ Sin entrar a analizar cuestiones iconográficas que resultan de menor importancia en este estudio, es patente que esta obra es una muestra excepcional de lo que hemos querido denominar Arte en piel. En ninguna otra pieza de las seleccionadas en este apartado será de mayor validez el símil previamente establecido con el mármol, ${ }^{115}$ dado que el cuero se presenta como el material a partir del cual se han logrado los volúmenes y relieves. La única diferencia técnica, excepción hecha de las cualidades intrínsecas de cada material, es que si al tallar un relieve en mármol se elimina material mediante un procedimiento sustractivo, en el caso del cuero éste se

\footnotetext{
${ }^{114}$ MADRID/1998, p. 77.

${ }^{115}$ Véase capítulo II., p. 73.
} 
mantiene, aunque modificando su superficie y volumen. Al realizar este relieve, el artista no debió eliminar ninguna porción de la piel que le servía de material inicial, sino que gracias a las técnicas propias del mundo del cuero pudo modelar la piel animal hasta alcanzar las formas tridimensionales deseadas.

De tal modo, usando el cuero como si de arcilla se tratara, el autor anónimo pudo conseguir la forma del caballo, su cola agitada, los más mínimos detalles de la armadura del caballero, el bastón de mando y las riendas de la montura, el pañuelo que se mueve por el movimiento del caballo y la golilla que cubre el cuello del personaje protagonista. Una vez logrado el relieve, decidió policromar el cuero para diferenciar todavía más las diferentes partes de la imagen, de manera similar a como los artistas medievales pintaban las innumerables figuras que poblaban las portadas de las catedrales románicas y góticas. Mantuvo el color original del cuero en el cuerpo del equino, oscureciendo algo el tono en la armadura, pintando de negro la espada y de rojo la banda que cruza el pecho del caballero. Por último, doró el fondo con vistas a dotar de suntuosidad la pieza e incluyó la cabeza de marfil, probablemente tallada por otro artista más ducho en el arte del retrato, completando la obra que hoy contemplamos.

Parece difícil poder encontrar un ejemplo en el que el cuero haya desempeñado un papel tan distinto al de mero soporte para una imagen; parece difícil poder encontrar una pieza que contraste de 
II. La piel en la historia del Arte.

manera tan evidente con obras como el David de Andrea de Castagno: lo que allí es receptáculo invisible para la pintura, aquí es materia fundamental perfectamente visible y de enorme importancia para la configuración de la obra; parece difícil poder encontrar una obra que se ajuste mejor a lo que entendemos, dentro de los límites de este trabajo, como Arte en piel. 


\section{II.2.4. Revestimiento mural de guadamacil}

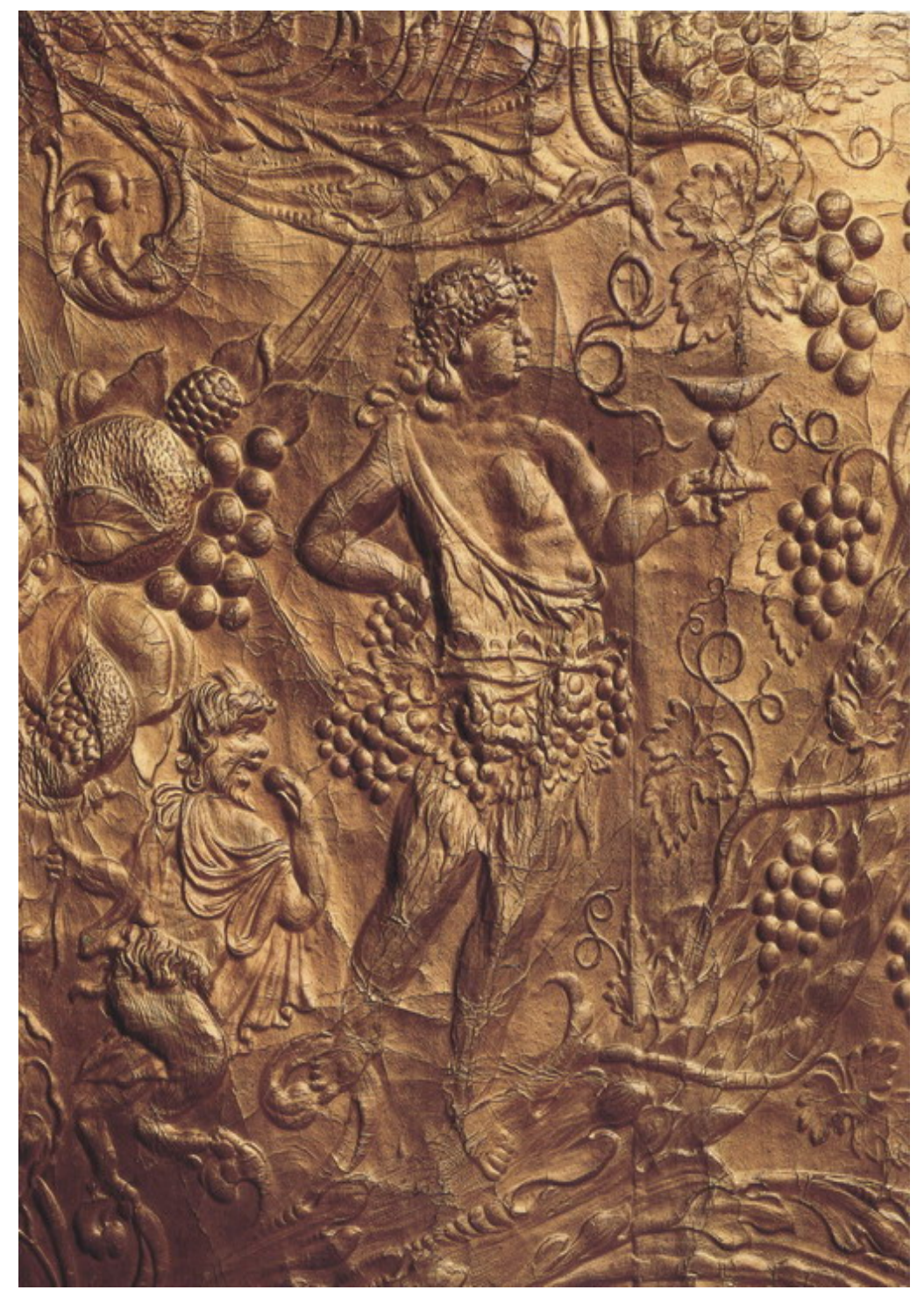

Fig. 43: Fragmento de revestimiento mural de guadamacil (s. XVIII), piel plateada, corlada y moldeada, Gran Bretaña. 


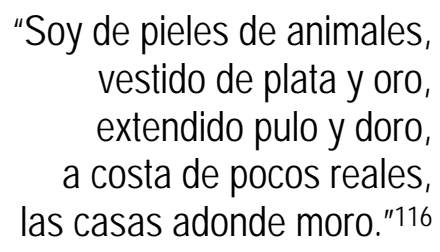

Con esta pieza abordamos el amplio campo de los guadamaciles o cueros artísticos, de enorme importancia dentro de las muestras de obras artísticas en las que el cuero ha tenido un papel preponderante. A diferencia de los cordobanes, es su carácter estético, suntuario y casi exclusivamente decorativo lo que los dota de validez en muchas ocasiones. ${ }^{117}$ En contraposición al cordobán, cuyo empleo dentro de un amplio abanico de objetos diferentes lo dotaba de una finalidad claramente funcional, el guadamacil se concentra en un número muy concreto de aplicaciones específicas, con una fuerte presencia de lo puramente ornamental. Uno de los usos más comunes era precisamente el recubrimiento mural de interiores (fig. 44), pero también podía encontrarse en tapizados de lujo y dentro del ámbito religioso, como parte constituyente de retablos, frontales, casullas 0 retratos. ${ }^{118}$

\footnotetext{
${ }^{116}$ PÉREZ DE HERRERA, Proverbios morales, emblema XXXV, 1608. Citado por: MADURELL MARIMÓN, J. M. (1973), p. 88.

${ }^{117}$ SOLER I COLOMER, A. (1998), p. 33.

${ }^{118}$ Véase apartado II.2.5., p. 142.
} 


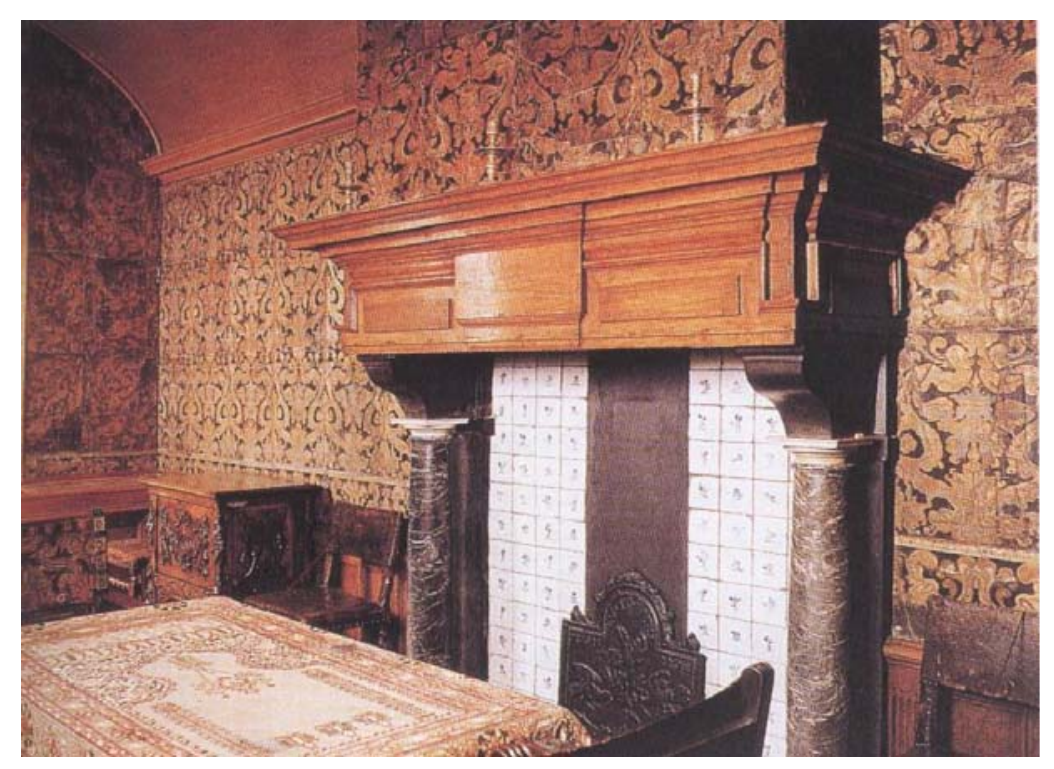

Fig. 44: Ejemplo de revestimiento mural a partir del uso de guadamaciles (1640), Museo de Lakenhal, Leyden

Los guadamaciles ${ }^{119}$ se fabricaban en su mayoría a partir de pieles de cordero, que al contrario de lo sucedido con los cordobanes, sufren una serie de procedimientos tras el curtido que cambian su apariencia hasta convertirlas en un material suntuoso y de extraordinaria riqueza visual. El proceso de manipulación de un cuero hasta convertirlo en guadamacil es perfectamente conocido y se encuentra ampliamente documentado, incluso con textos

\footnotetext{
${ }^{119}$ La técnica del guadamacil tuvo su origen en el norte de África, pasando de allí al sur de la península Ibérica durante el dominio musulmán. Fue en España donde alcanzó un desarrollo espectacular, y desde este territorio se extendió al resto de Europa y a América, logrando un auge tremendo en numerosos campos hasta que, en los siglos XVIII y XIX, la aparición de nuevos materiales más económicos, provocó su abandono. Véase: AGUILÓ ALONSO, M. P. (1987).
} 
contemporáneos a su época de esplendor. De manera resumida, se puede decir que la técnica constaba de tres pasos fundamentales, al margen de las posibles variaciones existentes entre diversas zonas geográficas y a la lógica evolución que sufrió el proceso a lo largo de los siglos. ${ }^{120}$

- Curtido: la piel de cordero, nunca de oveja dada su inferior calidad, debía ser curtida de la mejor manera posible ya que de ello dependía la calidad del guadamacil. Tan sólo con las mejores pieles se realizaban los guadamaciles, dado el coste económico del proceso.

- Plateado: a pesar de la apariencia dorada de la gran mayoría de los guadamaciles, el metal empleado era casi siempre la plata, dado su menor precio. De tal modo, y según explica Fioravanti, se debía aplicar una capa de plata en hoja sobre la piel previamente recubierta de cola. ${ }^{121}$ Una vez seca la plata, se bruñía hasta conseguir la intensidad de brillo deseada, para lo cual eran muy útiles las piedras de hematites 0 sanguinarias.

- Corlado: bruñida la plata, se aplicaba la corladura, el barniz especial destinado a cambiar la apariencia del metal argénteo y

\footnotetext{
${ }^{120}$ Una explicación pormenorizada del proceso se encuentra en el texto de LEONARDO FIORAVANTI (1517-1588), Specchio Universale (Venecia, 1564), cuyos fragmentos más significativos son citados por FERRANDIS TORRES, J. (1955), p. 13 y s.

${ }^{121}$ Esta cola podía ser de naturalezas diversas, aunque era muy empleada la derivada de los desechos de la fabricación del pergamino. Véase apartado I.3.2.a., p. 61.
} 
convertirlo en dorado. ${ }^{122}$ Se provocaba así un brillo dorado sobre la plata, y barnizando unas zonas de piel y conservando la plata bruñida en otras, el artista guadamacilero era capaz de crear extraordinarios efectos de brillo y cromatismo.

Llegados a este punto, los cueros podían ser trabajados con cualquiera de las técnicas que hemos detallado anteriormente, desde el bordado o el estezado, pasando por el repujado, el gofrado y el policromado con procedimientos pictóricos tales como el óleo (fig. 45). Durante los siglos XV y XVI, los guadamaciles fueron relativamente planos y bidimensionales, sin excesivos relieves ni repujados si exceptuamos pequeñas áreas, pero a partir del s. XVII y sobre todo durante el s. XVIII (fig. 43) los cueros artísticos poseen cada vez mayor volumetría. ${ }^{123}$ Es dentro de esta evolución hacia un relieve cada vez mayor donde podemos enmarcar la pieza seleccionada para iniciar este apartado, la cual ofrece un acabado de extraordinaria plasticidad gracias a los acusados relieves que configuran los diferentes elementos de esta escena dionisiaca. Si en otros muchos guadamaciles tanto españoles como europeos, el empleo de la policromía fue algo muy usual, en este caso nos encontramos ante una

${ }^{122}$ Este barniz de brillo amarillento posee diferente composición según el artista o el gremio concreto que lo fabricaba, aunque Fioravanti lo fija en una fórmula compuesta por cuatro partes de aceite de lino, dos de goma de pino y una de aloe camalín. Véase: FERRANDIS TORRES, J. (1955), p. 13 y s.

${ }^{123} \mathrm{El}$ invento del holandés Jacob de Swart en 1628, para repujar cueros de forma mecánica a partir de moldes de madera, fue auténticamente revolucionario. Supuso un avance imparable hacia la consecución de acusados relieves, abaratando los costes y permitiendo satisfacer una enorme demanda de cueros para paramentos murales. Véase: SOLER I COLOMER, A. (1998), p. 36-37. 
pieza que basa toda su potencia estética en los brillos de la plata corlada y en las sombras provocadas por los relieves del cuero.

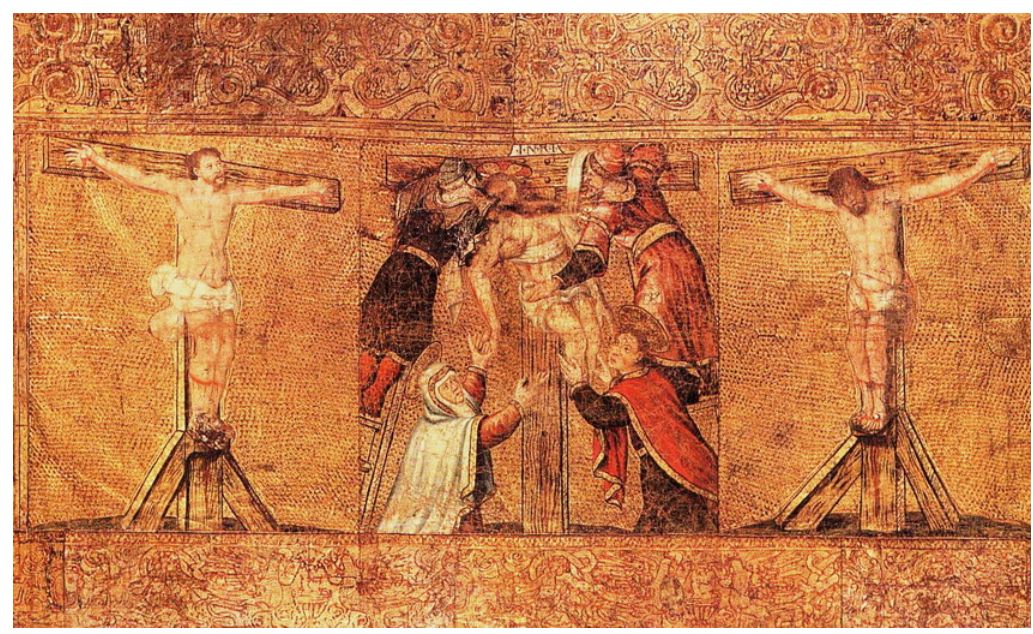

Fig. 45: Frontal de altar de guadamacil, Descendimiento de la cruz y los dos ladrones (s. XVI) España.

Pese a no llegar a los extremos de volumetría que alcanzaba la pieza anterior, este fragmento demuestra un dominio más que notable de las posibilidades que ofrece un material como el cuero. ${ }^{124} \mathrm{~A}$ diferencia de otras muestras analizadas, la superficie se encuentra totalmente cubierta por la capa de plata corlada, no pudiendo apreciarse la textura característica de la piel animal. Sin embargo, pese a que podría parecer que estamos ante un caso similar al de la pintura sobre cuero de Andrea del Castagno o del salón nazarí de la

\footnotetext{
${ }^{124}$ Nótese que, si la obra Caballero (fig. 42, p. 131) era una pequeña placa de apenas 16 x 12'5 cm, en este caso nos encontramos ante un revestimiento mural destinado a recubrir varios metros cuadrados de muro interior.
} 
Alhambra, ${ }^{125}$ calificados como Arte sobre piel dado que el cuero queda oculto bajo una capa ajena al mismo, las diferencias son más que evidentes. Mientras que en aquéllas el cuero mantenía una superficie totalmente lisa que no afectaba a la película pictórica depositada sobre él, en el fragmento de revestimiento mural de la fig. 44, el cuero ha cambiado su naturaleza superficial tras haber sido recubierto de la capa de plata fina, lo cual incide de manera directa en la aparición de las figuras y objetos. En aquellas era la pintura la que creaba las imágenes, y si hubiésemos eliminado la película pictórica el cuero habría quedado huérfano de éstas. Por el contrario, en este caso la capa de plata corlada no es la creadora de las figuras de la escena báquica, sino que simplemente recubre a un material, el cuero, que ya posee en sí mismo los relieves que conforman la imagen. La diferente naturaleza de estas capas, de pintura en unas ocasiones y de plata dorada en otro, hace que, en el primer caso, estemos ante Arte sobre piel, mientras que en este último no podamos evitar afirmar que el fragmento de guadamacil escogido se nos muestra como un claro ejemplo de obra artística en piel.

${ }^{125}$ Véase fig. 24 y fig. 22 respectivamente (p. 91 y 85). 


\section{II.2.5. Joan de Joanes: Rodrigo de Boria}

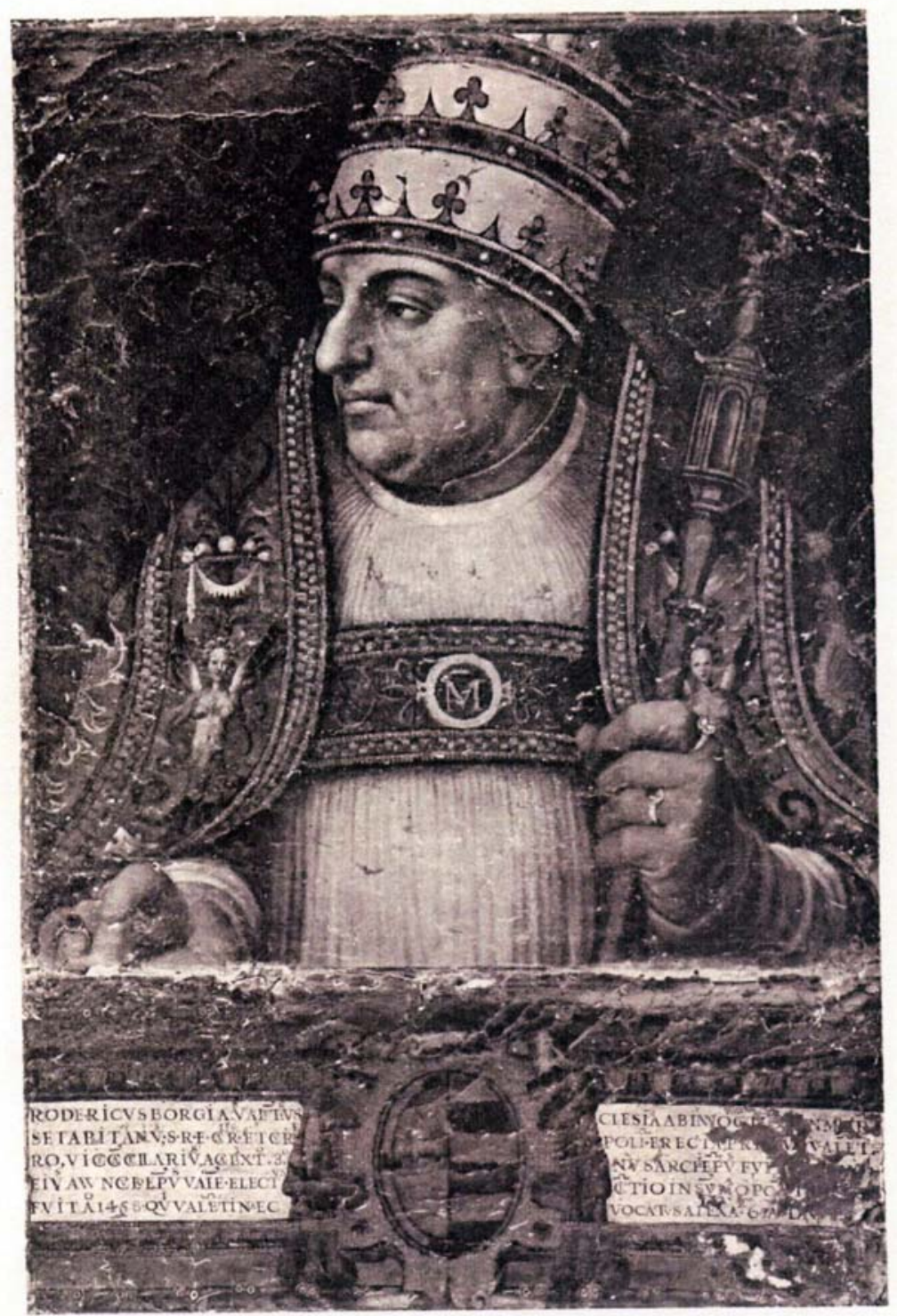

Fig. 46: Joan de Joanes: Rodrigo de Borja (1568), óleo sobre guadamacil, Sala Capitular nueva de la catedral de Valencia. 
En la Sala Capitular nueva de la catedral de Valencia, obra del arquitecto academicista Joaquín Tomás y Sanz, ${ }^{126}$ se conserva un extraordinario conjunto de retratos de los prelados valencianos. Se trata del episcopologio más antiguo de España tras el de la catedral de Toledo, ${ }^{127}$ con las efigies de todos los obispos y arzobispos valentinos desde la conquista de la ciudad por Jaime I hasta nuestros días. Sin embargo, su importancia no reside tan sólo en esta mera cuestión cronológica, que no deja de ser relevante en todo caso, sino en el hecho de que los primeros 28 retratos hasta el correspondiente a san Juan de Ribera, estén realizados sobre cueros dorados, sobre guadamaciles. ${ }^{128}$ En ningún otro lugar de España se conserva una serie de retratos sobre cuero tan extensa, lo que la convierte en un conjunto excepcional que, sin embargo y en contra de lo que cabría esperar, no ha recibido la suficiente atención por parte de los investigadores. En el resto de nuestra geografía apenas si conservamos muestras aisladas de la colaboración entre los guadamacileros y los pintores, con ejemplos tales como la serie de santos del Museo Episcopal de Vic (fig. 47), la Virgen de la Antigua de la colección sevillana Sánchez Dalp, ${ }^{129} 0$ el fabuloso retablo de San Miguel, proveniente del monasterio de Santa Clara de Ávila y hoy

\footnotetext{
${ }^{126}$ VILAPLANA ZURITA, D. (1997), p. 39.

${ }^{127}$ OÑATE OJEDA, J. A. (1995), p. 31.

${ }^{128}$ Nótese el hecho de que un cabildo catedralicio como el de Valencia, a la hora de encargar una serie de retratos de tanta importancia como el que nos ocupa, se decante por elegir un soporte como el de los guadamaciles. Una elección como ésta nos indica hasta qué punto eran apreciados los cueros artísticos en la época.

${ }^{129}$ AGUILÓ ALONSO, M. P. (1998), p. 26.
} 
II. La piel en la historia del Arte.

conservado en el Museo Nacional de Artes Decorativas. ${ }^{130}$ Pero ninguna de estas obras alcanza la importancia de esta serie de retratos valencianos, lo que no ha sido óbice para que permanezcan, todavía hoy, en un olvido poco comprensible.

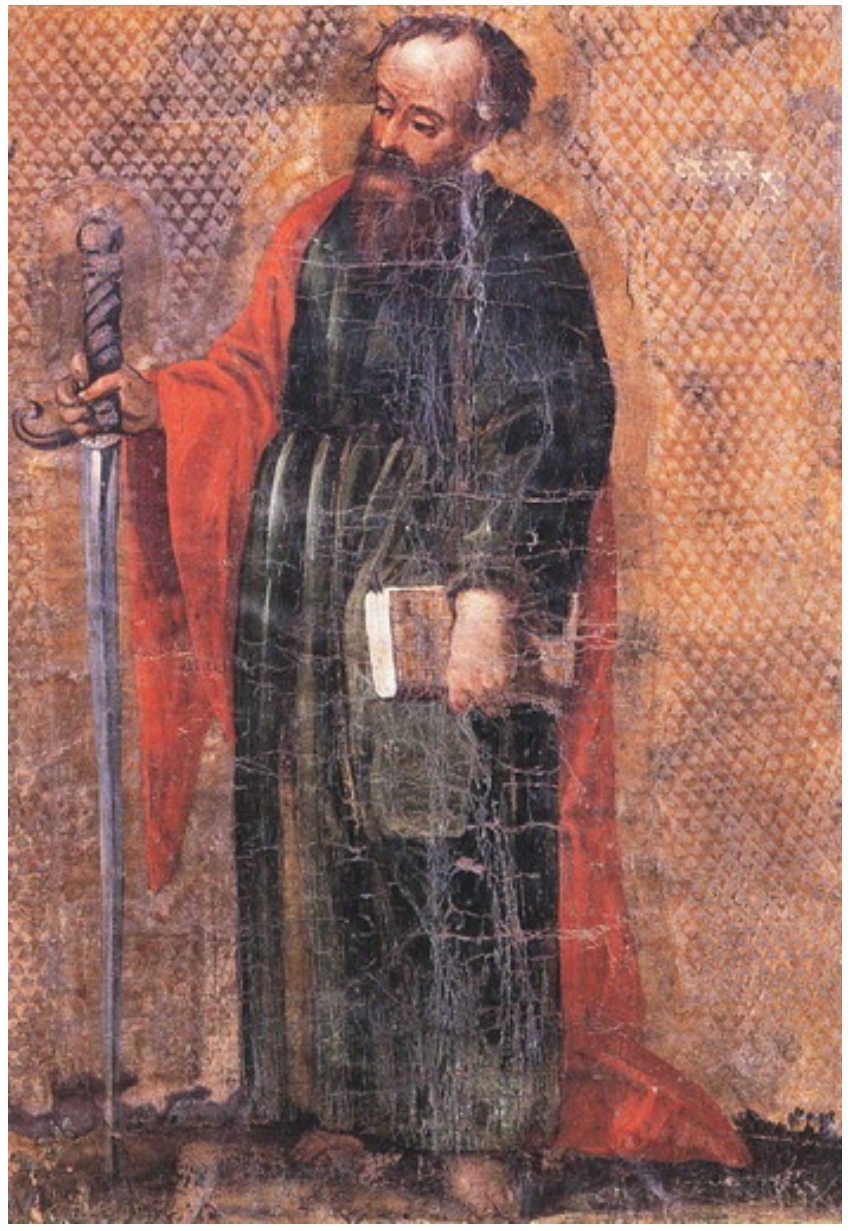

Fig. 47: San Pablo (siglo XVI), pintura sobre guadamacil, Museu de l'Art de la Pell de Vic.

${ }^{130}$ FERRANDIS TORRES, J. (1955), p. 43. 
Si la excepcionalidad de su técnica no fuera suficiente aval para otorgarles un interés evidente, a este factor se le une el hecho de que el grupo de retratos está estrechamente relacionado con la figura de uno de los más universales pintores valencianos: Joan de Joanes (c. 1523-1579). Todos los estudios que tangencialmente han tratado el conjunto de pinturas sobre guadamaciles coinciden en atribuirlo al círculo artístico de Joanes, ya sea a su propio taller o al de su hijo Vicente Joanes (c. 1555-1623). Sin embargo, es en la atribución concreta de las obras donde surgen las mayores contradicciones, lagunas y posibles imprecisiones, no existiendo todavía hoy una certeza total y absoluta acerca de quién pintó todos y cada uno de los retratos sobre cuero que adornan los muros de esta Sala Capitular mencionada. ${ }^{131}$

En nuestro caso, más que atenernos a cuestiones historiográficas, lo que nos interesa es comprobar como, en esta serie de obras, el cuero trabajado hasta convertirse en guadamacil ha servido a la vez de soporte para una pintura, y de parte constituyente de la misma. En efecto, la capa pictórica no cubre en su totalidad al cuero, sino que el trabajo del guadamacil es perfectamente visible en ciertas zonas del retrato, entre otras en las del vestido decorado con motivos renacentistas de grutescos. De tal modo, no estamos ante una

\footnotetext{
${ }^{131}$ El retrato escogido, el del que sería el primer arzobispo de Valencia y papa Alejandro VI, es uno de los pocos que, casi con total unanimidad, se atribuyen a la mano de Joanes (CASTELL MAIQUES, V. (1978);

VALENCIA/1980).
} 
pintura que cubra de manera radical el soporte de cuero que la cobija, sino que deja ver la labor del guadamacilero, la cual dialoga con la imagen pintada para configurar el conjunto de la obra. ${ }^{132}$ De nuevo debemos resaltar las diferencias existentes entre esta obra concreta (fig. 46) y pinturas ya analizadas como el David de del Castagno (fig. 25), dado que el papel asumido por la piel animal es muy distinto en cada uno de los casos. Si bien no llega a los extremos ya advertidos al referirnos a piezas como Caballero (fig. 42) y el Revestimiento mural de guadamacil (fig. 43), el uso del cuero en el retrato de Rodrigo Borgia supone un paso más si lo comparamos con el escudo pintado de Andrea del Castagno. Lo que en la obra del italiano era un simple soporte que quedaba totalmente oculto a la vista y que tan sólo puede percibirse tras un análisis pormenorizado de la pieza, en la obra de la catedral de Valencia es parte fundamental de la imagen, y sin su presencia el retrato ofrecería una apariencia totalmente diferente a la que todavía hoy en día apreciamos. ${ }^{133}$

Así, podemos decir que este retrato de Rodrigo Borgia se nos presenta como una muestra híbrida entre lo que hemos venido

\footnotetext{
${ }^{132} \mathrm{El}$ guadamacilero encargado de realizar los cueros artísticos sobre los que Joanes realizó sus pinturas fue Arcís Sancho de Stella. Véase: SANCHÍS SIVERA, J. (1909), p. 235.

133 Pese a que el nombre y la labor del guadamacilero han permanecido en una casi total oscuridad durante siglos, creemos de justicia resaltar su rol en la creación de esta serie de retratos, dado que su trabajo es parte constituyente y fundamental de las obras. No sólo el pintor debe ser considerado como autor de la pieza en cuestión, sino que también el guadamacilero debería ser citado a la hora de referirse a estos retratos concretos, más aún conociendo su nombre a través de documentos de archivo de la época.
} 
denominando Arte sobre piel y Arte en piel, dado que ofrece características propias de ambos. Por un lado podría incluirse dentro del Arte sobre piel ya que en ciertas zonas de la pieza, el cuero sirve tan sólo como soporte para la capa pictórica que representa al primer arzobispo de Valencia, sobre todo las manos y el rostro. Sin embargo, si nos detenemos en las áreas ya comentadas en las que es el cuero guadamacil el que configura las imágenes y los motivos decorativos de la vestidura religiosa, se podría considerar una muestra de las mismas características que piezas ya comentadas del Arte en piel.134

Si tomamos esta serie de retratos como ejemplos híbridos de ambas categorías artísticas, podemos afirmar que nuestro objetivo dentro de la propuesta personal que culminará esta tesis será aproximarnos a la concepción del medio que proponen estas piezas. Salvando las evidentes distancias de estilo, nuestra obra plástica personal intentará configurarse en piezas que puedan ser calificadas, indistintamente, como obras sobre y en piel; piezas que tratarán de fundir ambos campos, proponiendo un lenguaje que pueda dialogar con el cuero de dos maneras diferentes: como soporte para las imágenes realizadas sobre él, y como parte constituyente de las obras creadas en él.

\footnotetext{
${ }^{134}$ Véanse los apartados II.2.3. y II.2.4., p. 131 y 135 respectivamente.
} 



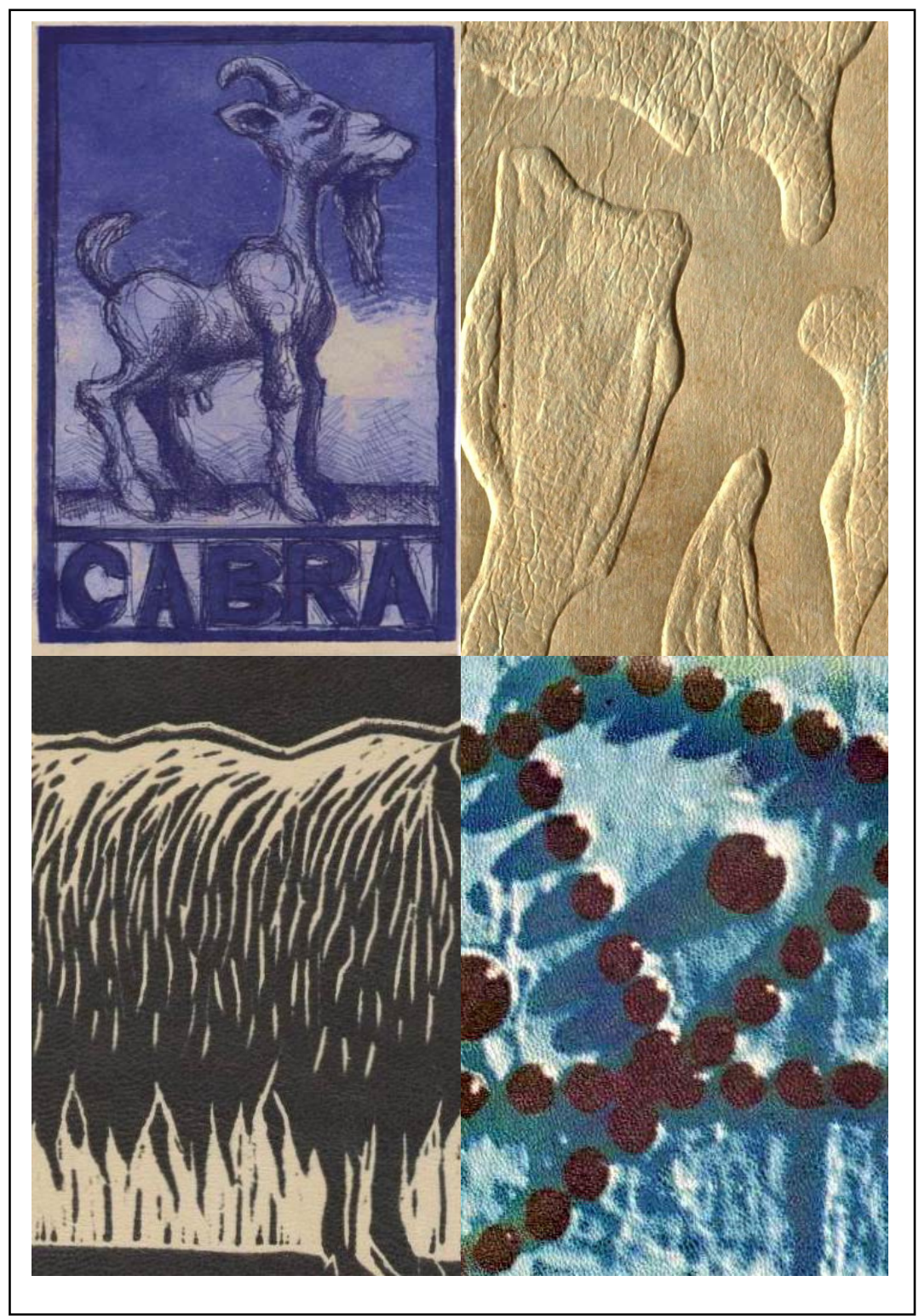





\section{EXPERIMENTACIÓN Y MATERIALES}

El objetivo específico de esta segunda parte del trabajo será descubrir nuevas fórmulas en el empleo del cuero como soporte para obras realizadas mediante técnicas de grabado y estampación. Como veremos, esta fase tendrá un esquema piramidal de trabajo similar al propuesto en la parte teórica de la tesis; un esquema que partirá del estudio generalizado de las posibilidades que ofrecen la gran cantidad y variedad de soportes de piel unidos a los procedimientos gráficos, para ir acotando su campo de acción hasta lograr la elección de un número limitado de cueros y técnicas con el cual realizar el trabajo plástico personal. Sin embargo, antes de adentrarnos en esta etapa de la investigación se hace necesario analizar las características específicas de los soportes de cuero que utilizaremos durante el 
trabajo de taller. En el primer capítulo ya vimos algunos datos acerca de las pieles desde un punto de vista general sin prestar atención a la naturaleza del cuero ya curtido, por lo que ahora detallaremos de manera mucho más precisa las cualidades y posibilidades que ofrecen los cueros escogidos para esta investigación.

Tenemos por tanto dos grupos de elementos que analizaremos y fusionaremos para conformar nuestra obra personal: por un lado el conocimiento de los cueros, y por otro las técnicas de grabado y demás procedimientos relacionados con la estampación, aunque no específicamente considerados como de dicho campo. El planteamiento que seguiremos durante esta fase de trabajo de taller tendrá dos grandes etapas:

- Análisis sistemático y catalogación de estampas realizadas sobre una serie de cueros de distinta naturaleza, con técnicas tradicionales del grabado, así como mediante los procedimientos del estezado y de la transferencia.

- Realización de obra personal, como culminación a todo lo anteriormente expuesto, donde se aplicarán todos los conocimientos y experiencias adquiridas. 


\section{III.1. EL CUERO: SELECCIÓN DE PIELES}

Al hablar del cuero como soporte no debemos pensar en un único material con características similares y naturaleza parecida, sino en una enorme variedad de soportes diferentes que conforman un abanico de posibilidades aparentemente imposible de abarcar. Al igual que dentro de las Bellas Artes podemos encontrar infinidad de tipos diferentes de papel con variaciones en cuanto a color, gramaje, textura, acabado, ductilidad, resistencia a la presión o al tacto, en la industria de las pieles las variables en lo que a fabricación del cuero se refiere son casi innumerables. Ya vimos al estudiar el proceso de curtido que las posibilidades de un campo como el del acabado eran tremendas, pudiendo dotar a un cuero de características totalmente diferentes de otro similar, tan sólo atendiendo a las operaciones de dicho proceso. Así, podemos encontrar cueros de diferentes animales que poseerán naturalezas distintas dependiendo de la especie escogida; pieles de tantos colores como podamos imaginar; pellejos curtidos mediante procedimientos especiales que los dotan de acabados que imitan las pieles de cualquier tipo de reptil; cueros con reflejos irisados, dorados y metálicos; diferentes grados de brillo; acabados de tacto ceroso o áspero; afelpados de extrema sutilidad y superficies totalmente pulidas de tremenda frialdad... En definitiva una gama de posibilidades tan variada que se hace forzosamente 
necesaria una acotación de los soportes escogidos para que el trabajo del investigador pueda desarrollarse con garantías de éxito.

Esta elección responde a una serie de criterios establecidos previamente que creemos son lo más objetivos posible dentro del intento de utilizar los cueros como soporte para realizar grabados y estampaciones con una intención artística concreta. Estos criterios de selección pueden resumirse en los siguientes puntos:

- Empleo de cueros provenientes de animales y especies más comunes dentro de la industria del cuero española. Pese a que actualmente y gracias a la importación es posible encontrar prácticamente cualquier tipo de cuero, hemos preferido obviar aquellos derivados de la explotación de animales exóticos, ya sean mamíferos, reptiles o especies acuáticas. Por tanto la gama de cueros escogidos para realizar el trabajo investigador se ciñe a las pieles de ganado caprino, porcino, ovino y vacuno, cuyas características analizaremos algo más adelante.

- Elección de acabados poco agresivos y lo más neutros que sea posible, renunciando a cueros que presenten excesivos brillos o encerados, texturas artificiales, dorados, lacados, acabados metálicos y, por supuesto, demasiado pelo en su lado flor. ¿Por qué decidimos eliminar todas estas posibilidades que la piel nos ofrece? Consideramos necesario 
comenzar el estudio a partir de una gama reducida de cueros, los cuales presenten las características propias de las pieles curtidas sin excesivos aditamentos industriales que pudieran alterar su respuesta a nuestra acción. De tal modo los cueros que escogeremos para el trabajo de taller tendrán las siguientes cualidades:

- Sin brillos acusados.

- Con una textura lo más uniforme posible dentro de las características propias de cada especie animal.

- Sin acabados que puedan interferir de manera evidente en la relación entre imagen estampada y soporte piel.

- Uso de cueros coloreados dentro de una gama cromática que podríamos denominar básica. El color de una piel curtida virgen y sin colorear se encuentra muy cercano al blanco, pero es muy difícil encontrar dicho tipo de cueros dentro del mercado ya que los procesos de tintura se encuentran incorporados a casi todos los procedimientos de curtido. En la industria del cuero podemos encontrar pieles de prácticamente la totalidad de los tonos que podamos imaginar; hay pieles verdes, azules, rojas y amarillas, jaspeadas y de varios tonos unidos, violetas, naranjas, negras, grises y muchas otras. Sin embargo, existe una gama de tonos que desde siglos ha sido relacionada de manera casi inmediata con el cuero y cualquier tipo de objeto manufacturado a partir 
de él: la gama de los tonos marrones, ocres, arenas, pardos y sienas. Será por tanto dentro de estos colores donde podremos encontrar los cueros escogidos para nuestra investigación, dejando de lado otro tipo de pieles con colores más llamativos 0 , cuando menos, no tan relacionados con lo que podemos entender como el color natural del cuero y la piel curtida.

Una vez explicados los criterios de selección de los cueros con los cuales procederemos a realizar nuestra investigación práctica, podemos pasar a comentar de manera breve las características que diferencian a cada una de las pieles curtidas en relación con el animal del cual proceden. Estas tipologías son validas para el resto del trabajo de taller, detallando de manera más precisa alguna de ellas cuando sea oportuno a lo largo del análisis de los resultados obtenidos durante dicho proceso. En los puntos siguientes hemos intentado resumir en unas pocas líneas las características de cada tipo de cuero, sin entrar en excesivos detalles ni distinciones demasiado precisas dentro de cada uno de los apartados, pero haciendo hincapié en las diferencias entre las distintas especies animales y los cueros que de ellas provienen en función del interés artístico que nos mueve. 


\section{III.1.1. Cueros caprinos}

El primer tipo de cuero que incluimos en nuestro análisis es el proveniente del ganado caprino, (fig. 48) por lo general uno de los más finos que se pueden encontrar. ${ }^{135}$ Su delgadez y forma han hecho que a lo largo de los siglos las pieles de cabra hayan sido empleadas en la manufactura de los calzados más lujosos y delicados, los guantes más refinados y las mejores encuadernaciones. De los animales más jóvenes se extraen las mejores pieles y las de mayor valor, y su textura superficial en el lado flor es muy delicada y de gran finura, en contraste con la del cerdo, en la cual son mucho más visibles los orificios creados por los folículos capilares. Debido a esta superficie tan pulida y alisada, la piel de ganado caprino registra con gran perfección hasta el mínimo detalle presente en la matriz de grabado, ya sean finas líneas de aguafuerte como sutiles gradaciones tonales de las aguatintas. Por lo que respecta al lado carne, a la superficie interna, presentará casi siempre el habitual afelpado típico, aunque no tan acusado y rugoso como en otros tipos de pieles, encontrándonos un afelpado muy sutil que permite obtener imágenes y estampas muy interesantes.

\footnotetext{
${ }^{135}$ Es un cuero algo más sutil y fino que el que encontraremos al estudiar las pieles ovinas y porcinas y mucho más delgado que el derivado de las vacas o terneras.
} 


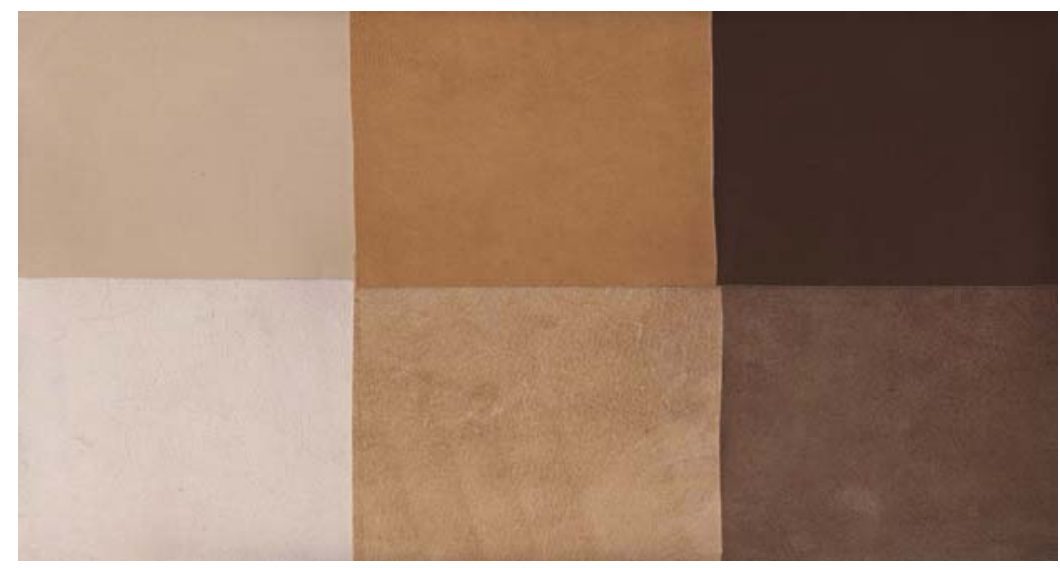

Fig. 48: Cueros de cabra. De izquierda a derecha y de arriba abajo: claro flor, medio flor, oscuro flor, claro carne, medio carne y oscuro carne.

En general las pieles de cabra no muestran excesivas diferencias con respecto a la zona del animal de la cual procedan. En las piezas que podemos obtener en los comercios especializados, el grosor es bastante uniforme en todas las zonas, sin presentar los tremendos cambios de grosor y calibre que encontraremos en la piel de cerdo. En lo que respecta a la textura superficial, ésta se muestra también por lo general con gran regularidad a lo largo y ancho de la pieza, ya sea en el lado flor como en el carne, aunque nunca debemos descartar que algún cuero determinado posea ciertas irregularidades superficiales. Por último indicaremos que estas pieles, como consecuencia de los usos que se les suelen dar, vienen acabadas de una manera muy satinada e incluso brillante por su lado flor, lo que será determinante para la estampación, pues sobre superficies muy satinadas y acabados muy lustrosos se debe tener un especial cuidado y atención a la hora de elegir la presión del tórculo. Como se 
verá a lo largo del estudio, estas superficies son muy delicadas y fácilmente afectables por un eventual exceso de presión en la estampación.

\section{III.1.2. Cueros porcinos}

La piel de cerdo es porosa pero fuerte y suave y se trata de un cuero que una vez curtido, y tras superar los procesos de industrialización, se convierte en un material muy duradero. Sus características están muy relacionadas con los hábitos de vida que haya llevado el animal del cual proceden, y así, un cerdo doméstico no ofrece la misma piel que si se tratara de un ejemplar criado de manera salvaje. Un elemento que configura y caracteriza a los cueros de cerdo es el pelo. El pelo de cerdo es bastante rígido y su bulbo capilar está instalado muy cerca de la superficie interna del lado carne, lo que ofrece unas pieles muy porosas y con abundantes orificios. Esta piel es en la que son más patentes estos orificios capilares, dotando a su superficie de una acusada textura muy peculiar e inconfundible. 


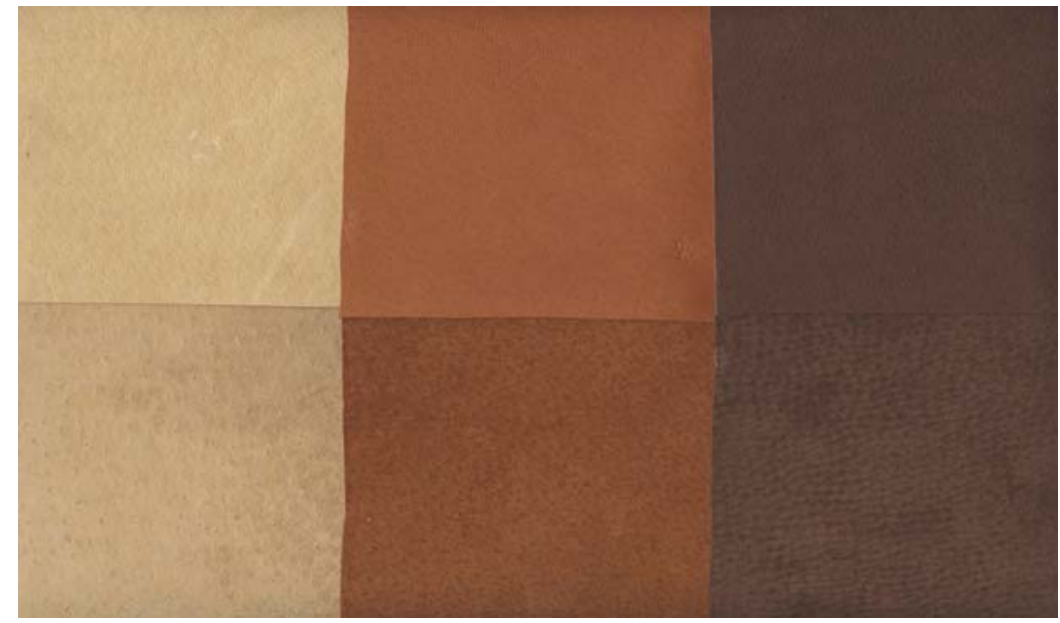

Fig. 49: Cueros de cerdo. De izquierda a derecha y de arriba abajo: claro flor, medio flor, oscuro flor, claro carne, medio carne y oscuro carne.

Por tanto el cuero porcino se presenta como la piel de mayor textura de las cuatro estudiadas, así como de un grosor medio entre las pieles de cabra y de vaca. Su textura es mucho más patente y evidente en el lado flor, aunque en el lado carne también pueden apreciarse rastros de los citados folículos pilosos (fig. 50), y puede ser modificada y exagerada mediante procedimientos empleados durante el proceso de estampación. ${ }^{136}$ En caso de que la pieza tuviera un afelpado demasiado acusado podría interferir en algunos factores de la estampa como pudieran ser la nitidez de las líneas o la intensidad de los grises, obteniéndose por tanto una imagen poco satisfactoria.

\footnotetext{
${ }^{136}$ Al estampar, según la cantidad de tinta empleada y la intensidad de la presión ejercida con el tórculo, esta textura puede verse exagerada hasta hacerse muy evidente. Véase capítulo IV.1., p. 173.
} 


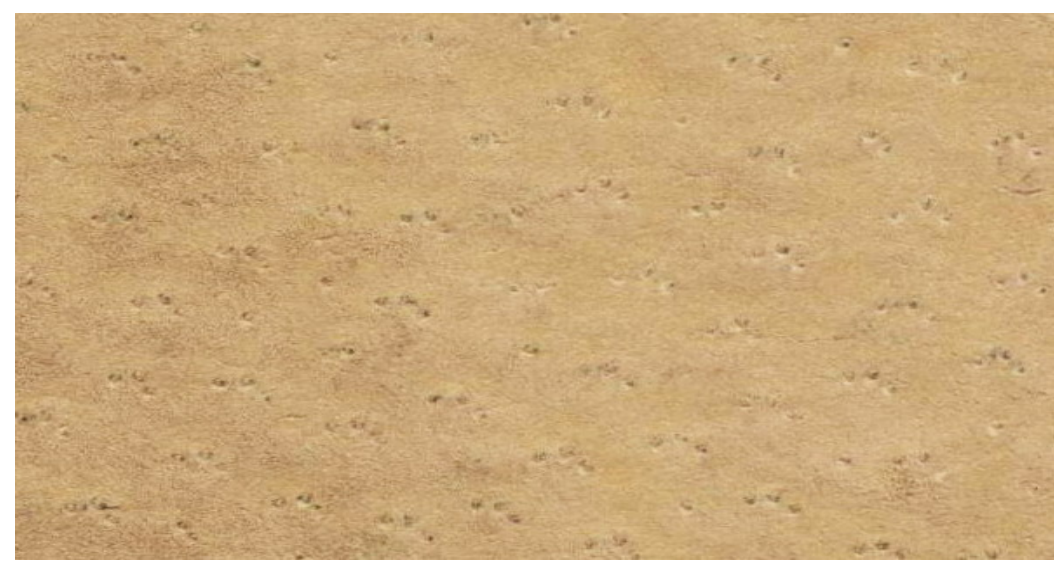

Fig. 50: Lado carne de un cuero porcino donde se aprecian los orificios de los folículos pilosos agrupados de tres en tres.

Por otro lado las pieles de cerdo son aquellas en las que las diferencias entre las distintas zonas de la pieza son más evidentes y patentes. Al contrario que en otros tipos de cueros tales como los vacunos, en éstos podemos encontrar numerosas diferencias entre las diversas áreas, y así, es fácil observar variaciones de elasticidad, grosor o textura en casi todas las piezas que podamos encontrar en el mercado. En efecto, según nos vamos acercando a los bordes de un cuero porcino comienzan a ser evidentes los cambios en sus propiedades, con variaciones muy evidentes en cuanto a grosor y elasticidad. De este modo las zonas más externas serán mucho más elásticas y flexibles que aquellas centrales, mientras que el grosor disminuye sobremanera según nos alejemos de la línea del espinazo del animal hasta llegar a ser mínimo y convertirse la piel en un material 
casi traslúcido en los bordes de la pieza. Como es lógico estas variaciones pueden suponer un claro contratiempo a la hora de estampar, sobre todo en formatos de grandes dimensiones en los cuales necesitemos usar zonas externas de una pieza porcina, por lo que tendremos que prestar especial atención a la naturaleza de la pieza sobre la cual procedemos a realizar nuestro trabajo. En definitiva, las zonas más estables y con mejor calidad son las centrales, y serán éstas las que debemos elegir cuando abordemos un trabajo plástico con la piel de cerdo como soporte.

Hemos de señalar por último que hemos escogido un tipo concreto de cuero porcino para todas las estampas, el conocido como forro de cerdo, que es una modalidad de piel llamada así por su utilización dentro de la industria zapatera para forrar el interior de los zapatos. Esta piel presenta unas características muy favorables para la estampación, con un acabado casi mate, poco satinado superficial y una apariencia bastante natural. Se nos muestra por tanto como una de las superficies más convenientes para la estampación, ya sea xilográfica como calcográfica, además de que su bajo coste en el mercado la haga todavía más atractiva para ser utilizada como soporte. 


\section{III.1.3. Cueros ovinos}

La tercera de las variedades de cuero incluidas en el estudio ofrece particularidades que la diferencian del resto de las pieles escogidas (fig. 51); es algo más gruesa que la de cabra y de similares condiciones que la procedente de los cerdos, aunque no aparecen de manera tan evidente los orificios de los folículos pilosos como en esta

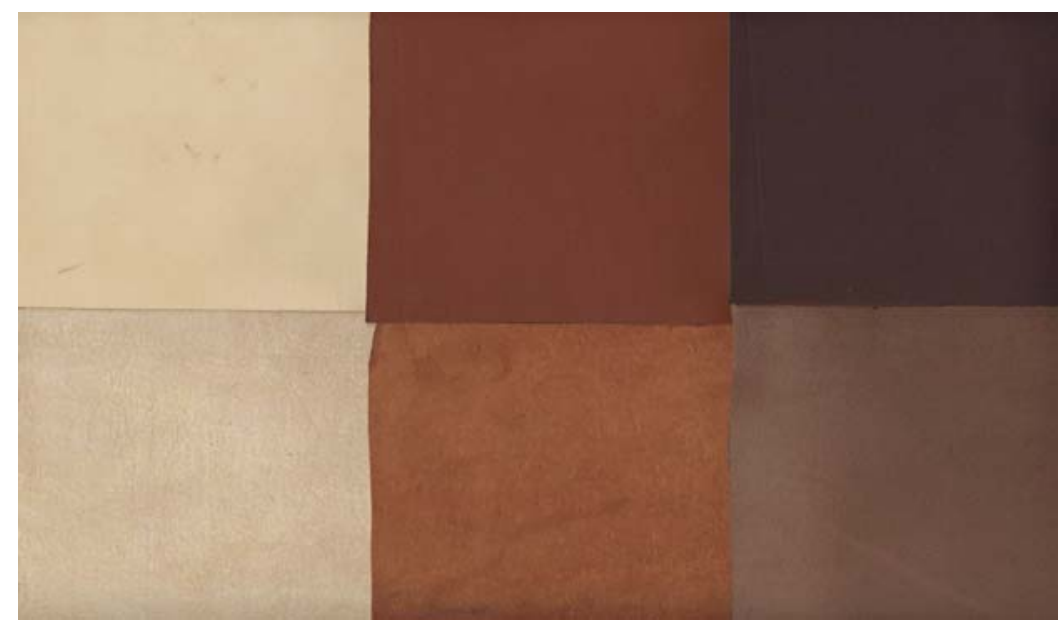

Fig. 51: Cueros de cordero. De izquierda a derecha y de arriba abajo: claro flor, medio flor, oscuro flor, claro carne, medio carne y oscuro carne.

última. Las mejores pieles de ganado ovino se obtienen de los animales cuya lana no es apreciada por el mercado y, por supuesto, de los ejemplares jóvenes que todavía presenten un perfecto estado de salud. Son cueros muy empleados para confeccionar guantes, zapatos 
o bolsos, aunque casi siempre de inferior calidad que los manufacturados a partir de pieles de cabra.

Desde un punto de vista práctico los cueros de ganado ovino suelen ser relativamente finos y de gran flexibilidad y capacidad de dilatación, cualidades éstas a tener muy en cuenta durante los procesos de estampación en relación a la acción de la presión del tórculo sobre el soporte piel. Como en el resto de los casos las áreas más estables y aprovechables para nuestra investigación serán aquellas cercanas al espinazo del animal, donde el cuero ofrece una estructura de mayor solidez y homogeneidad.

\section{III.1.4. Cueros vacunos}

Se trata de una de las pieles más usadas dentro de la industria de la confección, ya sea para manufactura de calzado como de otro tipo de objetos, y tanto las piezas en verde, ${ }^{137}$ como las conservadas, son de las materias más usadas por artesanos e industriales de todo el mundo. Los cueros de vacas y vaquillones (fig. 52) están formados por un tejido fibroso y muy elástico que los hace ideales para la confección de elementos de grano fino y de gran delicadeza, aunque conviene hacer una distinción entre las pieles provenientes de animales macho y

${ }^{137}$ Denominación empleada para las pieles sin curtir. 
hembra. Los primeros son cueros de mayor espesor y un grano algo más grueso que los provenientes de animales hembra, aunque su calidad sigue siendo muy elevada. Generalmente se escogen las pieles de animales jóvenes, las cuales ofrecen un mejor resultado que aquellas de ejemplares viejos, con falta de elasticidad y excesiva

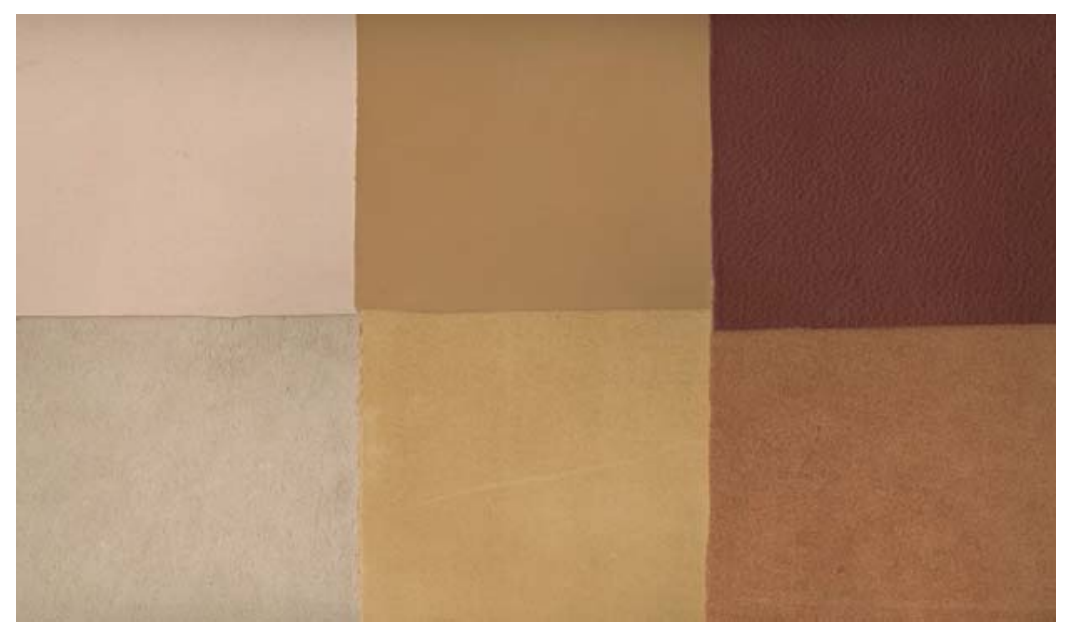

Fig. 52: Cueros de vaca. De izquierda a derecha y de arriba abajo: claro flor, medio flor, oscuro flor, claro carne, medio carne y oscuro carne.

rigidez en muchas ocasiones. Por otro lado también se prefieren los cueros de animales que hayan sido criados en el campo frente a aquellos que hayan crecido dentro de un establo, ya que los primeros serán de mucha mejor calidad.

La piel de vacuno es, con mucha diferencia, la de mayor grosor y calibre de las cuatro escogidas, pudiendo llegar a doblar a la de cabra en espesor, a la vez que es sustancialmente más gruesa que 
la de cerdo y la de cordero, por lo que se deben tomar especiales precauciones para estampar sobre ella. En efecto, un mínimo exceso de presión provocará defectos evidentes en la superficie de la estampa, sobre todo si nos referimos al lado flor, mientras que sobre el lado carne el margen de maniobra es algo mayor y permite trabajar con más tranquilidad. Por lo que respecta a la textura superficial del cuero vacuno, las diferencias entre el lado flor y la carne son muy patentes y marcadas. (fig. 53) En el primero la textura suele ser de una gran finura y sutileza, pareciéndose a veces a la observada sobre las pieles de cabra, por lo que permitirá la estampación de motivos de gran precisión y nitidez. Sin embargo, esta norma generalizada no es completamente válida para todos los casos ya que podemos encontrar pieles con la flor corregida, como ocurre con el cuero de tono oscuro escogido para este estudio.138 Por su parte el lado carne puede

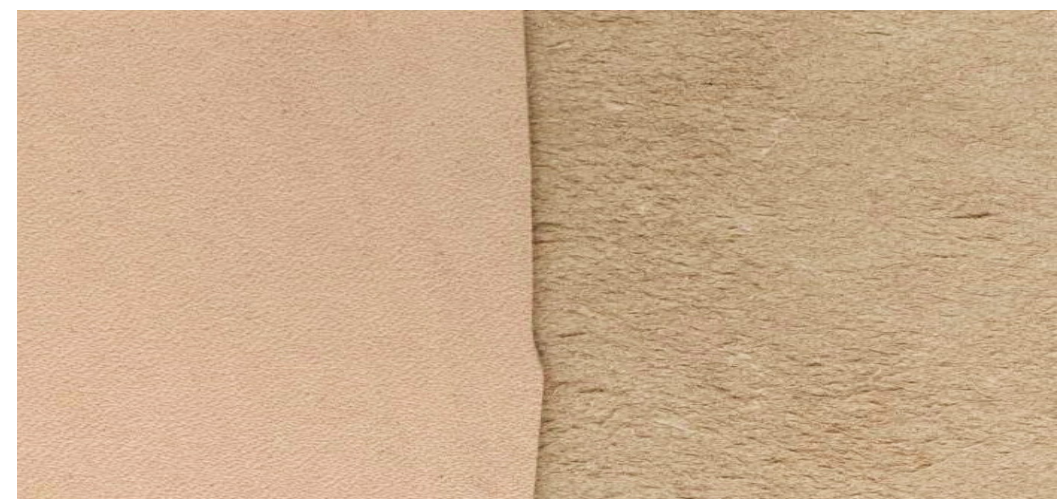

Fig. 53: Diferencia de textura entre el lado flor, izquierda, y el carne, derecha.

\footnotetext{
${ }^{138}$ Como veremos en el capítulo IV, la superficie del lado flor de la piel oscura de vaca ofrece un acabado rugoso que puede afectar a la nitidez de los grafismos estampados sobre ella.
} 
presentar unos acabados de muy variada naturaleza, desde un afelpado muy ligero (como si de la piel de un melocotón se tratara) hasta texturas tremendamente rugosas y llenas de pelos. Dependiendo del tipo de acabado que encontremos en el lado carne la superficie será más o menos adecuada para distintos tipos de estampas, variables éstas que estudiaremos con mayor detenimiento a lo largo del presente trabajo de investigación.

Por último queda indicar que las pieles de vaca son de una gran regularidad y homogeneidad en sus diferentes zonas, por lo que no será fácil encontrar cambios y variaciones tan bruscos y patentes como los apreciados con gran asiduidad sobre la superficie de los cueros de cerdo, de tal modo que el grosor y la flexibilidad de la piel vacuna se mantienen casi invariables a lo largo y ancho de la superficie de la pieza, lo que unido a las grandes dimensiones de dichas pieles nos permite realizar trabajos de tamaño más que considerable. 


\section{2. MANIPULADO PREVIO DE LAS PIELES}

Antes de entrar en el análisis concreto de la experimentación práctica, ofrecemos unas breves indicaciones de carácter general para un correcto manejo de los cueros, con el fin de evitar pequeños problemas que pudieran aparecer. Estas observaciones están centradas básicamente en el corte de los pellejos y su transformación en los soportes que usaremos en la estampación. Lo más normal es que partamos de un pellejo entero y no sólo de una porción seleccionada de la piel, por lo que se debe elegir la zona a emplear para la estampación eliminando las zonas inútiles del cuero. Dependiendo de la naturaleza del trabajo a realizar escogeremos una u otra parte de la piel, sin olvidar que prácticamente su totalidad es susceptible de ser empleada como soporte para la impresión de grabados, como puede apreciarse en la fig. 54 . Como se vio más arriba139 el pellejo está dividido en varias zonas de características diferentes que habrán de tenerse en cuenta al seleccionar la porción deseada y cortarla con la dimensión elegida.

${ }^{139}$ Véase apartado I.3.1.c., 54. 


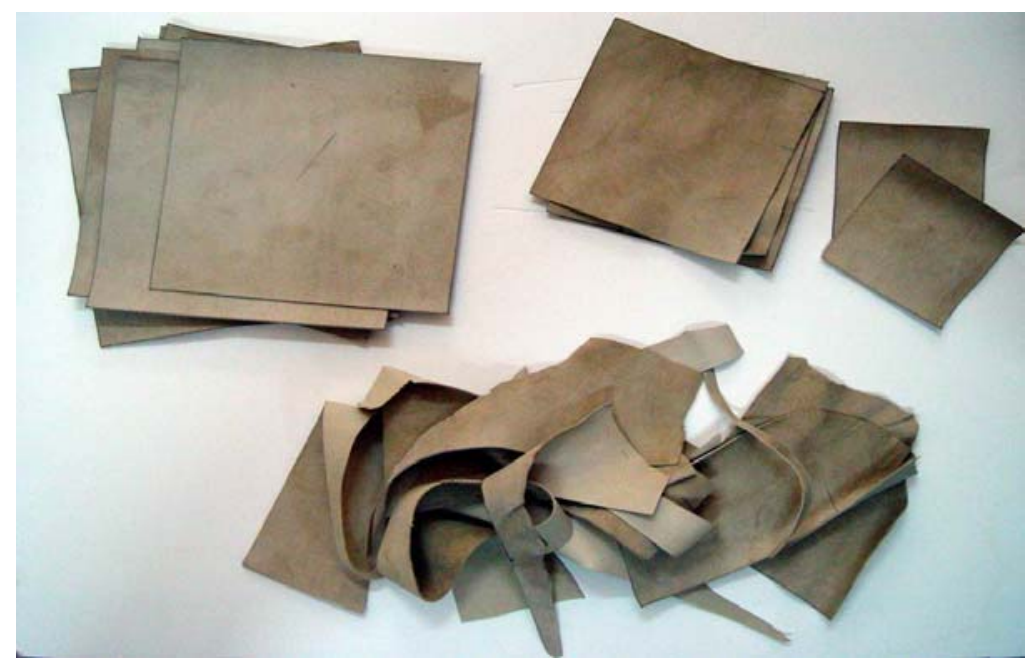

Fig. 54. Despiece de un cuero de cabra.

Pese a lo aparentemente sencillo de este proceso, el cortado de las pieles presenta unos condicionantes característicos que hacen necesarias unas breves observaciones al respecto. En primer lugar nos referiremos a la herramienta de corte, fundamental para un resultado satisfactorio de la operación; no es en absoluto conveniente decantarse por las tijeras, sobre todo en lo que se refiere a cortes en línea recta, por lo que una opción mucho mejor es una buena cuchilla muy afilada, ya sea un bisturí, un cutter o cualquier herramienta de similares características, con la cual obtendremos un corte mucho más limpio y sin irregularidades. La naturaleza flexible de la piel condiciona su corte, siendo más fácil dividir los cueros de cierta rigidez, como los 
vacunos, que otros de patente flexibilidad como los de cordero o los de las zonas periféricas de cualquier pellejo. ${ }^{140}$

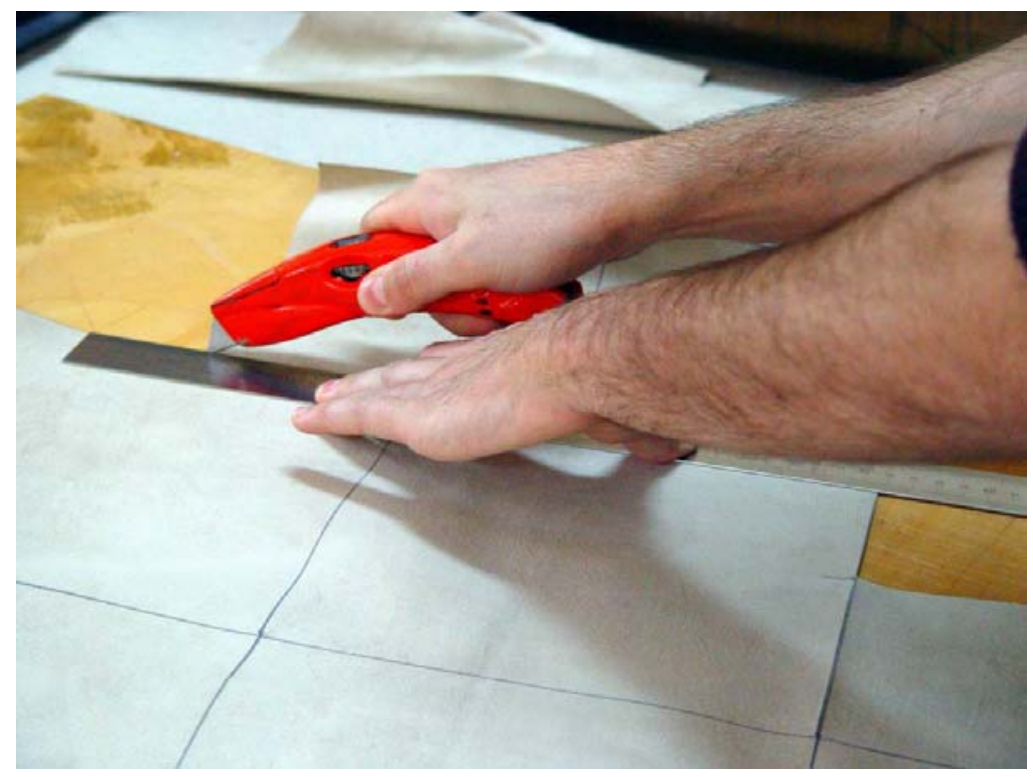

Fig. 55. Proceso de corte de un cuero.

Como superficie de corte, las que mejor resultado ofrecen son las rígidas y algo duras como una tabla de madera, un trozo de PVC o incluso una plancha de metal (fig. 55). En caso de cortar las pieles sobre un material blando, las posibilidades de obtener un corte irregular e impreciso se multiplican. Por último hacer una pequeña referencia al lado de la piel elegido como soporte de trabajo y al corte previo; es conveniente marcar y cortar por el lado contrario al escogido para trabajar independientemente de cual sea éste. De este modo

${ }^{140} \mathrm{El}$ pescuezo y las faldas. Véase apartado I.3.1.c., p. 54. 
III. Experimentación y materiales

protegemos la superficie de trabajo definitiva de posibles manchas, restos de las líneas de corte y cualquier otro tipo de problema que pueda surgir durante el proceso de división de los cueros. 
III. Experimentación y materiales 


\section{ANÁLISIS Y CATALOGACIÓN}

\section{IV.1. PRIMERA FASE}

Una vez vistas las características fundamentales de los cuatro tipos diferentes de cueros que utilizaremos a lo largo de nuestra investigación, podemos pasar a plantear la primera de las actuaciones que emprenderemos con los soportes piel. Se trata de la continuación y ampliación del trabajo iniciado dentro del proyecto de investigación citado en la introducción de esta tesis, proyecto en el cual se analizaron y catalogaron sistemáticamente un gran número de estampas conseguidas mediante la consideración de distintos factores. La herramienta auxiliar de trabajo de esta fase práctica serán las fichas de trabajo, ${ }^{141}$ fichas en las que están reflejadas las características distintivas de las estampas realizadas, y que permiten reunir, al

${ }^{141}$ La estructura y contenido de estas fichas han sido definidos por el autor en base a la experiencia vivida, la cual ha permitido sistematizar los resultados en la forma que más abajo se detallará con mayor precisión. 
finalizar el proceso, toda la información necesaria para redactar las reflexiones parciales. Antes de pasar a comentar los campos y conceptos que se han tenido en cuenta para la catalogación y estudio de las fichas de estampación, deberemos explicar cual ha sido el proceso de trabajo seguido para alcanzar los resultados que expondremos más abajo.

Con el objetivo de lograr el mayor número de alternativas posibles y así disponer la cantidad de información que nos permita exponer unas conclusiones válidas, se combinan diferentes aspectos relativos a los tipos de pieles, su color, las técnicas de grabado o las tintas. Los diferentes conceptos que se relacionarán, referentes a la definición del soporte y al proceso de estampación, pueden quedar resumidos en la fig. 56 .

Alternando todos estos factores se logra un total de 192 estampas diferentes que forman la fuente de información de la cual extraeremos las reflexiones de este bloque práctico. Como se observa en la tabla, existen diferentes variables, algunas ya conocidas, como los cuatro tipos diferentes de piel, y otras que aparecen en este momento por vez primera, lo que hace necesaria una explicación de su porqué en esta relación. 


\section{FACTORES COMBINADOS EN EL PROCESO DE ESTAMPACIÓN:}

PIELES Y CUEROS:

- Cabra

- Cerdo

- Cordero

- Vaca

TONO DE LOS CUEROS:

- Claro

- Medio

- Oscuro

SUPERFICIE DE ESTAMPACIÓN:

- Lado flor

- Lado carne

TÉCNICAS DE GRABADO:

- Grabado xilográfico

- Grabado calcográfico

TIPO Y COLOR DE LA TINTA:

- Negro

- Blanco

- Azul traslúcido

- Azul opaco

Fig. 56 
Se puede ver que empleamos tres tonos de intensidad diferentes para cada tipo de cuero, todos ellos dentro de la gama cromática de los marrones y pardos anteriormente citada. Con ello tratamos de observar diferentes condiciones de respuesta a la impresión dependiendo de la intensidad del tono del soporte piel, con lo que se logran interesantes soluciones plásticas.

En lo que respecta a las dos superficies de cada cuero, es obvio que la naturaleza de los lados flor y carne de una piel difiere sobremanera, por lo que es forzoso experimentar sobre ambas caras con objeto de lograr un conocimiento más profundo de la respuesta de los soportes de cuero. Ya es sabido que el lado flor de los cueros ofrece una superficie más lisa, pulida e incluso brillante, mientras que por su parte el lado carne presenta el conocido afelpado, más o menos acusado según el tipo de cuero escogido. Hasta aquí llegan las variables referidas al soporte piel (tipo de animal, intensidad de tono y superficie) por lo que los dos últimos conceptos están relacionados con los sistemas de grabado y estampación.

De las numerosas técnicas que actualmente podemos encontrar dentro del mundo del grabado hemos decidido acotar la investigación a las dos más usuales, antiguas y tradicionales: la xilografía y la calcografía, englobando en esta última el aguafuerte y el 
aguatinta. ${ }^{142}$ Las respuestas sobre un soporte piel de otros procedimientos derivados de la calcografía, creemos que pueden ser deducidas del estudio de los resultados alcanzados a través del análisis de las técnicas del aguafuerte y el aguatinta, sin que por ello estas técnicas vayan a quedar apartadas de los siguientes bloques de investigación práctica, como se verá en el ultimo apartado práctico referente a la obra personal. Un capítulo aparte merece la punta seca, la cual tiene un papel de tremenda importancia en la formulación de la obra personal y goza de un análisis específico en el segundo bloque práctico.

En relación a la elección de tintas escogidas, el criterio ha sido tratar de ofrecer la mayor cantidad de información posible al posible estampador sobre soporte de piel. La elección de la tinta negra143 es tan obvia que se hace casi superflua una explicación de su aparición en este trabajo, mientras que el empleo de tinta blanca144 viene dado por el interés que puede suponer el conocimiento de los resultados obtenidos a partir del uso de tintas cubrientes, en cuya composición puede intervenir ésta, de tal modo que se toma la tinta blanca como patrón a partir del cual se pueden analizar los resultados deseados

\footnotetext{
${ }^{142}$ Para las estampas xilográficas se utilizan matrices de madera de media densidad o DM, mientras que para las imágenes calcográficas se emplean planchas de zinc trabajadas según los procedimientos clásicos de las técnicas escogidas.

${ }^{143}$ La tinta negra utilizada en esta investigación corresponde a la marca comercial Lorilleaux.

${ }^{144}$ En el caso del color blanco empleamos el llamado Blanco cubriente, de Charbonell.
} 
aplicando las variaciones necesarias en función del tipo de tinta que se emplee.

Es el interés en experimentar con estampas de color, el motivo fundamental de la inclusión en esta lista de las dos últimas tintas utilizadas, a las que hemos denominado de un modo convencional como azul traslúcido y azul opaco. ${ }^{145}$ De entre los innumerables tonos que podríamos haber elegido nos hemos inclinado por los tonos azules debido al interesante contraste que se produce entre su frialdad y la calidez de los tonos escogidos para los soportes de cuero. La diferenciación entre azul translúcido y opaco (en realidad el mismo tono de azul variando su intensidad mediante la inclusión en la mezcla de preparación traslucida) nos permite resultados de enorme interés como se verá más adelante, en especial mediante la fusión de las tonalidades de los soportes piel con los azules traslúcidos y los tonos resultantes.

Una vez realizada esta breve exposición de las razones que han motivado los límites, la acotación, los materiales y las técnicas del primer bloque práctico, debemos entrar a analizar brevemente los campos de estudio a los que atenderemos en cada una de las estampas, así como las organización y exposición de los resultados

\footnotetext{
${ }^{145}$ En lo que respecta al azul transparente la composición de la tinta viene dada por un 90\% de preparación translúcida Isis Lorilleaux, un 9\% de Azul Oriente de Charbonell y un 1\% de Sepia Simphonie de Lorilleaux, mientras que el azul opaco es una mezcla de un $90 \%$ de Azul Oriente de Charbonell y un $10 \%$ de Sepia Simphonie, ambos de la marca Lorilleaux.
} 
individuales en las fichas de estampación. Como vemos en la fig. 57, cada una de las fichas está compuesta por elementos relacionados visualmente con la exposición de los resultados, campos que nos permiten catalogar fácilmente las imágenes realizadas dentro de esta primera etapa de experimentación práctica. ${ }^{146}$

Una gran parte de la ficha la ocupa la reproducción de la imagen estampada sobre el soporte piel, imagen que trata de relacionar inmediatamente la estampa con el tipo de animal del cual proviene el cuero. Es obvio que en esta primera fase práctica no se pretende que las imágenes posean un carácter de obra artística personal, sino que el máximo interés es conseguir una rápida asociación de ideas gracias a una estampa sencilla, directa y de fácil comprensión. Pese a su sencillez manifiesta se ha intentado crear una serie de grabados que permitan extraer las conclusiones y los objetivos previamente fijados para este bloque. Incluso en la elección de los motivos y en su modo de realización, estas imágenes están relacionadas con el lenguaje gráfico previsto para la obra personal que realizaremos al final del presente trabajo. Las reflexiones extraídas de esta experimentación práctica son válidas también en relación con el estilo personal y las características gráficas particulares, factores ambos que se reflejarán en las imágenes que conformarán el conjunto de la obra personal.

\footnotetext{
${ }^{146}$ Las fichas de la segunda etapa del trabajo de taller, tendrán una sistematización diferente que será convenientemente explicada llegado el momento.
} 


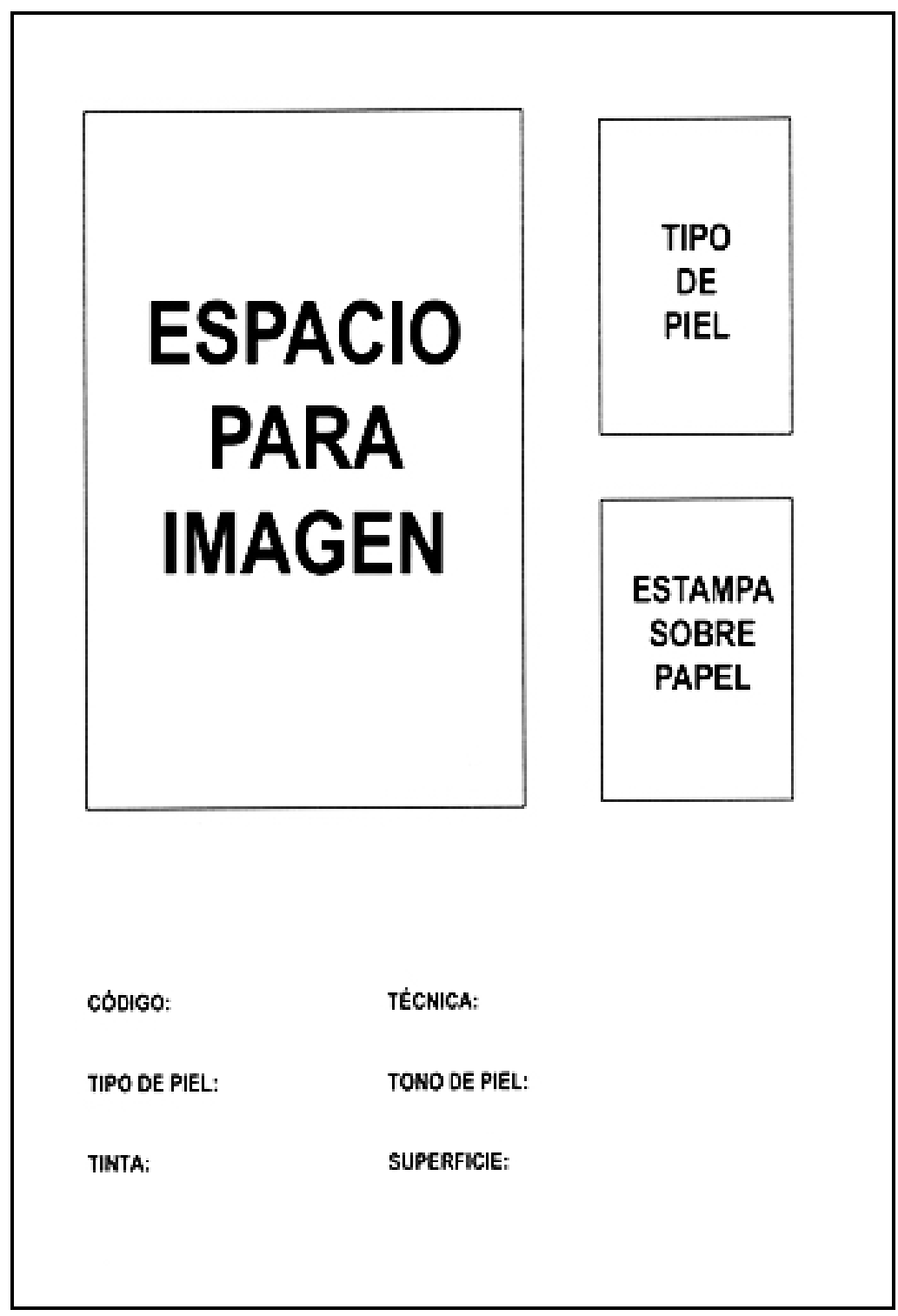

Fig. 57: Esquema genérico de las fichas de análisis. 
A la derecha de la imagen completa podemos encontrar dos pequeños recuadros en los que vienen indicados una muestra del cuero empleado y un detalle de la imagen estampada, no ya sobre el soporte piel, sino sobre un soporte blanco de papel. ¿Qué objetivo persigue la colocación de esta información junto a la estampación definitiva? Se intenta, mediante esta disposición, hacer ver los posibles cambios de color, tono, definición o contraste por los que puede verse afectada una imagen grabada al ser estampada sobre un soporte piel dependiendo de las características propias y la naturaleza del mismo. Si en ocasiones tales como en las estampaciones mediante tinta negra los cambios son difícilmente apreciables, en los casos de las imágenes realizadas usando tintas translúcidas los resultados son muy interesantes e incluso sorprendentes.

En la ficha también vienen reflejados una serie de datos que sirven para identificar la estampa en relación a los cinco factores que hemos comentado: piel, tono de piel, lado o superficie, técnica y tinta. A su vez, aparece un código formado por las primeras letras del animal del que proviene el cuero y un número, código que facilita la localización de la estampa a lo largo del desarrollo del análisis. Por último, la ficha de estampación se completa con el análisis pormenorizado de una serie de conceptos previamente establecidos y que permiten un conocimiento profundo de los resultados obtenidos en cada una de las estampas que componen esta fase práctica. Estos conceptos están divididos y organizados en cinco apartados: calidad, mancha o aguatinta, grafismo o aguafuerte, contraste y brillo. 
El primero de ellos, la calidad, reseña una valoración global del nivel de la estampa a partir de la suma de los factores tanto positivos como negativos de los otros cuatro campos, sirviendo por tanto como resumen de estos últimos. Caso de existir algún tipo de información que no esté relacionada con los cuatro campos específicos de análisis, será en éste donde se recogerá, tratando de dar al lector toda la información pertinente y relativa a la estampa concreta. En esta primera parte de la ficha se incluye una valoración cualitativa de cada una de las estampas analizadas, otorgándoles una calificación que puede variar entre muy buena, buena, mediocre, mala y muy mala. Los criterios seguidos para alcanzar estas valoraciones poseen una patente carga de subjetividad, ya que se encuentran íntimamente relacionados con los intereses particulares del autor en lo que se refiere a la posterior realización de la obra personal. De tal modo, y como resumen general de los criterios convencionales prefijados, se valoran positivamente aquellas estampas que presenten las siguientes características:

- Notable nitidez de registro en lo que a los grafismos se refiere.

- Homogeneidad en la mancha, sin cambios de tonalidad que no se encuentren reflejados en la plancha matriz.

- Nivel de intensidad de contraste elevado.

- Ausencia de brillos excesivos que puedan resultar molestos a la correcta visión de la estampa. 
A partir de estos criterios se otorgan las calificaciones comentadas, las cuales sirven, en el apartado de las conclusiones parciales, como herramienta de estudio y análisis de los resultados obtenidos durante todo el trabajo experimentador. Gracias a esta sistematización por calidades se podrán realizar tablas y gráficos estadísticos de enorme utilidad a la hora de plantear las consideraciones pertinentes, las cuales se apoyarán en dichos datos para establecer sus correspondientes conclusiones.

El siguiente epígrafe está relacionado con las características de la estampa en sus zonas de mayor extensión de tinta, y así, en las fichas relativas a los grabados xilográficos hemos dado en denominarlo mancha, mientras que en aquellas imágenes calcográficas el análisis de estos conceptos se encuentra bajo el epígrafe aguatinta. ${ }^{147}$ En este apartado se analiza la respuesta de amplias zonas de tinta al contacto con la superficie de los soportes de cuero, tanto en las uniformes zonas de las estampas xilográficas, como en los dos tonos que presentan las imágenes calcográficas en lo que al aguatinta se refiere.

El apartado inmediatamente posterior de la ficha estudia los trazos lineales, tanto xilográficos como calcográficos, sobre la

\footnotetext{
${ }^{147}$ Esta diferenciación viene provocada por el deseo de mantener la denominación de aguatinta al referirnos a las áreas de tonos calcográficos, diferente al empleado para indicar las zonas de mayor extensión de tinta de las imágenes xilográficas. En lo referente al análisis de las líneas ocurre algo similar: se conserva el término aguafuerte para las fichas calcográficas mientras que en las xilográficas se opta por denominarlas grafismos.
} 
superficie del cuero y sus posibles variables. A nuestro entender es absolutamente necesario centrarnos en un análisis concreto y pormenorizado de la respuesta de dichos grafismos, imprescindibles para un correcto estudio de las posibilidades del grabado sobre superficies como las pieles animales. Pueden aparecer inconvenientes relacionados con la falta de nitidez 0 con posibles deformaciones ante presiones excesivas, problemas de asentamiento de la tinta y otras zonas en las cuales los grafismos más sutiles desaparezcan, todo lo cual queda convenientemente reseñado en el apartado correspondiente de la ficha técnica que venimos introduciendo.

Los dos últimos aspectos incluidos en la ficha de estampación hacen referencia al contraste y al brillo; el primero de ellos condicionado por la intensidad de la tinta, del soporte y su relación tonal, y el segundo relacionado de manera íntima con la naturaleza del soporte y su acabado superficial. Pese a que puedan parecer conceptos no tan importantes como los anteriores, en muchas ocasiones el buen resultado de una estampa dependerá de la intensidad de uno y otro, por lo que su análisis se hace imprescindible para un estudio pormenorizado de las posibilidades de las estampas sobre cuero. Indicar en este punto que los criterios de valoración de estos factores son totalmente convencionales y dependen de unos intereses previos relacionados con la plástica personal del autor y la aplicación de los resultados obtenidos en la fase de realización de la obra personal. Se valoran como positivos aquellos ejemplos en los que el brillo no es excesivo y permita una visión lo más correcta de la 
imagen, lo que no quiere decir que una estampa que presente un acusado brillo no pueda ser perfectamente válida para cualquier otra persona interesada en dichos efectos plásticos. Algo similar ocurre en lo que respecta al contraste: se tiende a valorar de manera más positiva las estampas en las cuales el contraste sea bastante intenso, mientras que aquellas en las que éste resulta más sutil no tienen una calificación tan alta.

A partir del análisis, puesta en común y configuración de todos estos factores detallados en cada una de las fichas se alcanzan las conclusiones parciales que determinan la actuación de los capítulos siguientes. Llegados a este punto debemos explicar la organización, disposición y metodología de los capítulos y apartados que aparecen a continuación con el fin de dejar claras las bases y los conceptos seguidos para tal exposición.

Si bien el título de la presente tesis se organiza alrededor de los cueros y pieles, en el análisis de las consideraciones parciales de este primer bloque práctico el concepto que sirve como eje sobre el cual gire la explicación de las estampas obtenidas es el de las técnicas de grabado elegidas. De tal modo, en lugar de proponer a continuación una serie de apartados referidos a los distintos tipos de pieles y su respuesta con relación a los procedimientos gráficos, organizamos los capítulos en función de las dos técnicas, xilografía y calcografía, comparando los resultados obtenidos con los diferentes cueros. Creemos que así conseguiremos establecer unos resultados de mayor 
utilidad para el estampador interesado en experimentar dentro del campo de los soportes piel, ya que su trabajo estará condicionado en la gran mayoría de los casos por las técnicas con las cuales sienta mayor afinidad, y no tanto por un tipo concreto de cuero o piel. Es más lógico a nuestro parecer que un estampador, ante la serie de obras que desee realizar ya sean xilográficas o calcográficas, esté interesado en buscar qué tipo de pieles o cueros pueden ser los más adecuados para su objetivo. La técnica, por tanto, condiciona al soporte y no el soporte a la técnica, tal y como veremos en los capítulos que siguen.

Pasamos por tanto a exponer y analizar los resultados del estudio de la combinación de los soportes de piel con los procedimientos de grabado y estampación, comenzando, aunque tan sólo sea por una cuestión de antigüedad cronológica dentro de la historia del arte, por el grabado xilográfico para continuar con el análisis de las estampas calcográficas. 


\section{IV.1.1. Grabado xilográfico}

\section{IV.1.1.a. Tinta negra}

A continuación analizamos la respuesta de las tintas negras dentro de las estampas xilográficas dependiendo de los campos de estudio acotados previamente (mancha, grafismo, contraste y brillo) agrupando los dos últimos en un solo apartado por la brevedad que en ocasiones ofrecen algunos de ellos.

\section{- Mancha}

Por lo general los resultados obtenidos con la tinta negra son realmente satisfactorios y positivos, con algunas excepciones que comentamos a continuación. La potencia visual y plástica de las amplias áreas de tinta negra permiten estampas de alta calidad. En lo que respecta a las pieles de cabra el nivel de calidad del estampado es muy elevado a excepción de la imagen CA-005148 en la cual

\footnotetext{
${ }^{148}$ Los códigos escogidos para referirnos a las diferentes estampas están compuestos por las dos primeras letras del nombre del animal del cual provienen, más tres dígitos que indican su referencia concreta. Así, las imágenes de los cueros caprinos se localizan con las siglas CA seguidas del número correspondiente (001, 002, 003, etc).
} 
aparecen diferencias notables en el asentamiento de la tinta sobre la superficie del cuero. En dicha estampa la relación de una capa de tinta negra junto con un cuero muy satinado en su lado flor, provoca la aparición de problemas de asentamiento y secado de la tinta que estropean la imagen.

Ya vimos que los cueros de cerdo ofrecen características especiales debido a la conocida textura superficial que presentan, con una marcada presencia de los folículos pilosos; esta textura es muy

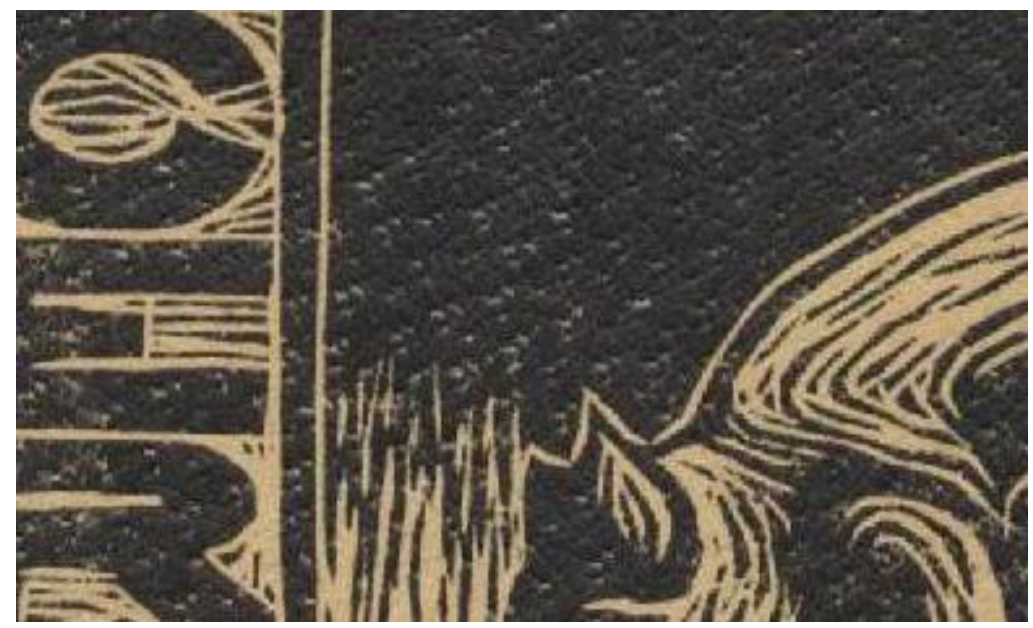

Fig. 58: Ejemplo de estampación con poca presión.

evidente por el lado flor de los cueros pero en algunos casos puede ser visible incluso en el interior de las pieles, en el lado. En estampas realizadas sobre estos soportes, CE-001 a CE-006, nos aparece por tanto esta textura, la cual podemos tratar de acentuar 0 mitigar mediante ciertas acciones. En efecto, si estampamos con presión 
escasa, la tinta no logra penetrar hasta el interior de los orificios de los folículos pilosos, lo que nos permite lograr una interesante textura orgánica, como puede verse en la fig. 58. Por el contrario si la presión es algo mayor conseguimos una mancha uniforme y homogénea que, sin embargo, no logra eliminar por completo el granulado de la superficie del cuero. Hemos de resaltar que, en ambos casos, la calidad de las estampaciones con tinta negras sobre este cuero es altísima, con manchas homogéneas y regulares que permiten obtener imágenes de elevada plasticidad.

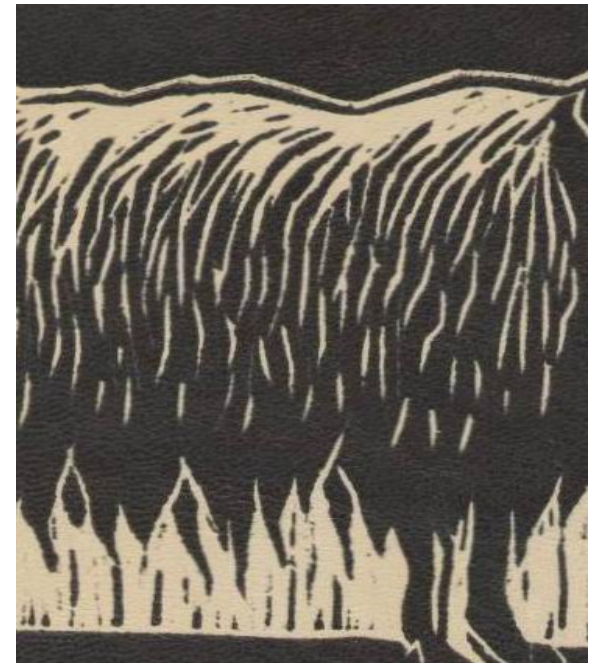

Fig. 59: Estampa CO-001

Los cueros de cordero ofrecen resultados excelentes en la estampación con tinta negra, con la única excepción de la imagen CO-005. Tanto sobre el lado flor como sobre la superficie interna de las pieles, la calidad de la mancha obtenida es altísima, con gran homogeneidad y regularidad. En las imágenes CO-001 y CO-003, ambas sobre el lado flor, la tinta negra provoca una ligera acentuación de la textura propia del cuero lográndose interesantes efectos plásticos, como puede verse en la fig. 59. En las pieles escogidas para 
nuestro trabajo no encontramos texturas excesivamente acentuadas en sus lados carne, por lo que las estampas obtenidas no se ven alteradas por el afelpado del cuero. Tan sólo en el ejemplo CO-005 podemos encontrar inconvenientes relacionados con el contraste, los cuales serán analizados más adelante en el apartado correspondiente.

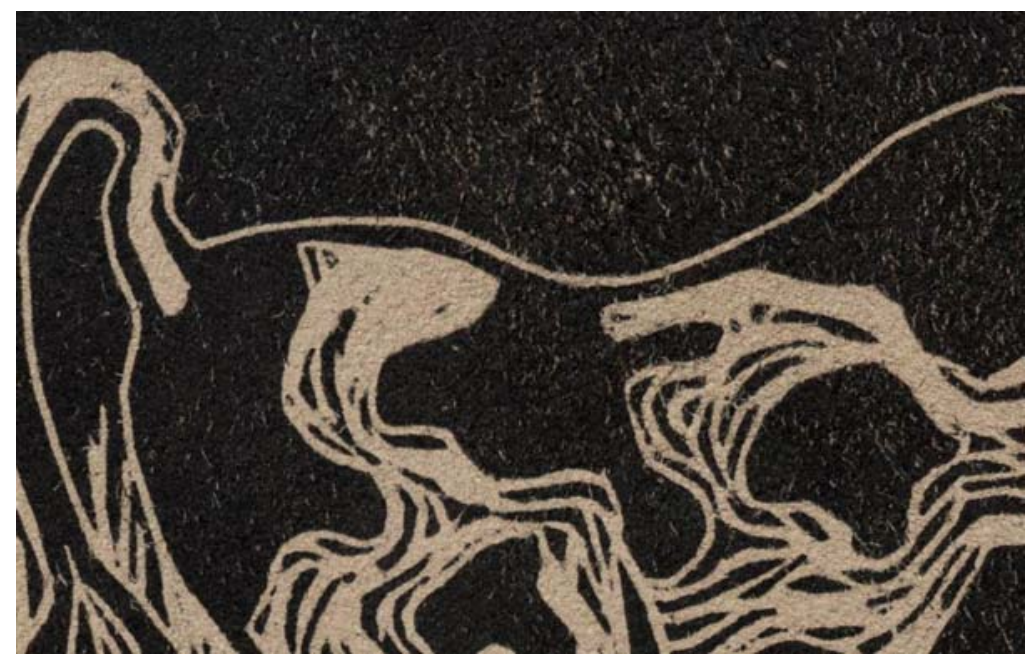

Fig. 60: Detalle de la estampa VA-002 donde se aprecia el afelpado de la superficie del lado carne del cuero.

Por lo que respecta a las pieles de vaca los resultados también son bastante positivos en general, debiendo prestar atención a ciertas estampas en particular. En cueros como el usado en la imagen VA-002 (fig. 60), con un lado carne que ofrece un afelpado de gran rugosidad y textura, éste condiciona la apariencia definitiva de las áreas de tinta negra. De nuevo, y al igual que anteriormente al referirnos a la textura presente en la superficie del cuero porcino, la 
presión del tórculo nos permite debilitar 0 acentuar dicho efecto si es que así lo deseamos.

\section{- Grafismos}

Al igual que en lo comentado previamente con respecto a la mancha, los grafismos xilográficos estampados en negro ofrecen unos resultados bastante satisfactorios y positivos, con las salvedades que reflejaremos en las siguientes líneas. En los cueros de cabra aparecen ligeras diferencias dependiendo de la superficie escogida como soporte para nuestra imagen, ya sea el lado flor o el lado carne. El hecho de que, incluso aquellos de menor calidad, ofrezcan un acabado bastante satinado en su lado flor provoca ciertos inconvenientes al estampar sobre esa superficie. Así, vemos que en las imágenes CA-001, CA-003 y CA-005, se debe cuidar de manera minuciosa la presión aplicada con el tórculo, ya que ante un mínimo exceso las líneas y grafismos se deforman irremediablemente dificultando su apreciación, mientras que con una presión justa este problema desaparece por completo, obteniendo un registro perfecto. Este tipo de inconvenientes no se observan en las estampaciones sobre el lado carne, el cual presenta un ligero afelpado que permite absorber de manera mucho más eficiente un eventual exceso de presión ejercido con el tórculo. 
Los cueros de cerdo se comportan de manera excelente en lo que respecta a los grafismos xilográficos dado que las pieles escogidas para nuestro estudio no presentan un satinado excesivo en su lado flor. Tan sólo en la estampa CE-005 y debido al ligero acabado brillante del cuero se debe prestar una mayor atención a la presión de estampación, mientras que en los otros casos las deformaciones del registro tan sólo aparecen con un tremendo exceso de presión.

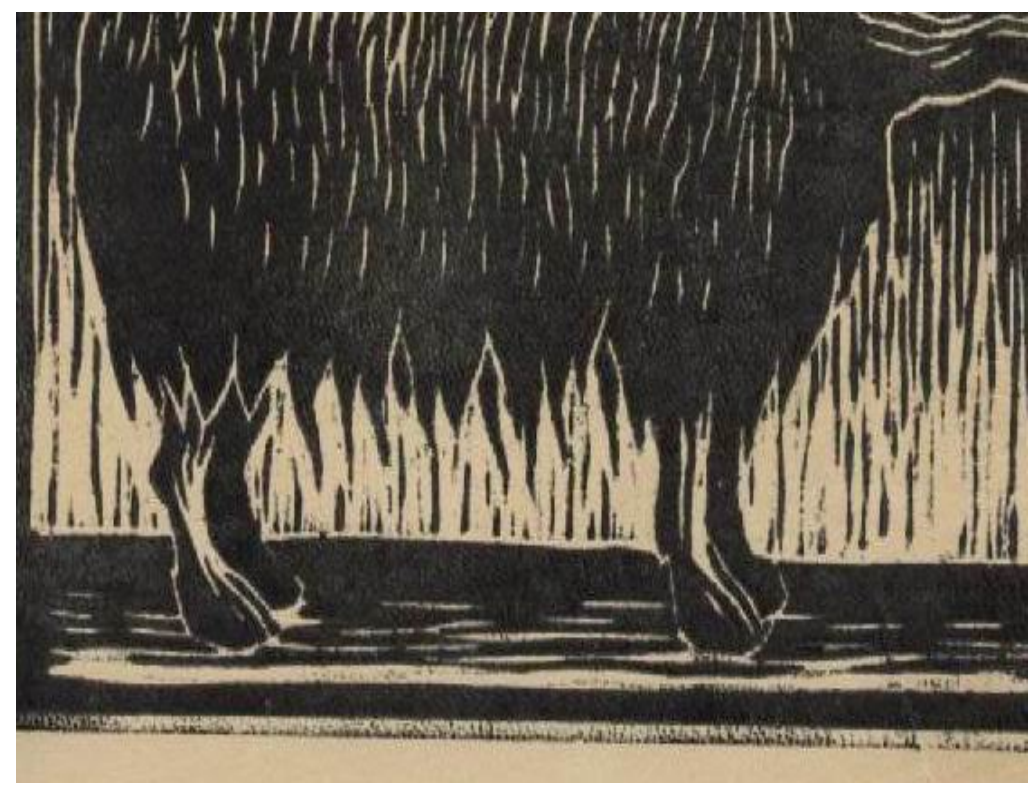

Fig. 61: Detalle del exceso de presión en la zona inferior de la imagen.

Los cueros ovinos se presentan como soportes ideales para registrar los grafismos xilográficos, no apareciendo apenas inconvenientes ni problemas, ni sobre el lado flor ni sobre la superficie 
ligeramente afelpada del lado carne. Debido a la gran flexibilidad de los cueros, también es necesario prestar una especial atención a los niveles de presión durante el estampado. Ante un mínimo exceso de la misma los seños y grafismos aparecen desvirtuados y deformados estropeando la imagen (fig. 61), pero si controlamos este factor el resultado es a todas luces excelente.

Las estampas sobre las pieles vacunas escogidas ofrecen los inconvenientes derivados de estampar sobre las superficies muy satinadas del lado flor y sobre las texturas de afelpado excesivo, en algunas ocasiones, del lado carne. En el primer caso vemos las imágenes VA-001 y VA-003, en las que la solución a los posibles problemas de definición de los registros viene condicionada, al igual que en los casos anteriores, por la modificación de los niveles de presión durante la estampación. Se debe tener en cuenta el mayor grosor de los cueros vacunos, que llega a ser hasta el doble que los caprinos en algunos casos, el cual obliga a unos niveles de presión diferentes de los del resto de los cueros si no queremos que aparezcan defectos como el reflejado en la fig. 62. En ésta, podemos apreciar, en la zona inferior de la imagen, como se ha producido una estampación defectuosa del seño xilográfico que entorpece una correcta percepción de los contornos de los grafismos. 


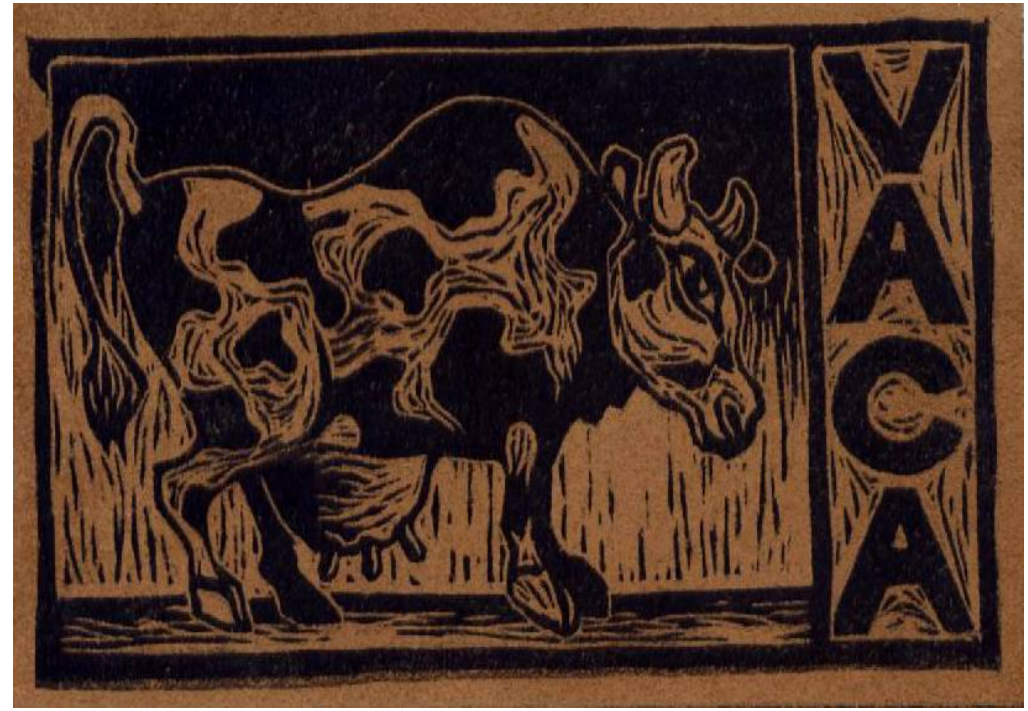

Fig. 62: Ejemplo de excesiva presión en la estampación.

En lo que respecta al lado carne de las pieles que presentan un acusado afelpado, éste incide en la definición de los contornos de los grafismos xilográficos, pudiendo lograr una mayor nitidez a partir de un exceso de presión controlado que permita disminuir la acción perturbadora de la superficie del cuero. En caso de no lograrlo, y si lo que se desea es lograr un registro xilográfico de extrema nitidez, es aconsejable cambiar de soporte y elegir un cuero con características diferentes, dado que la naturaleza de este tipo de soportes no permite alcanzar acabados de gran nitidez y limpieza. 


\section{- Contraste y brillo}

Podemos afirmar que en la totalidad de las estampas realizadas, el análisis del contraste muestra que el tono negro no cambia de intensidad de manera relevante a lo largo de toda la serie de estampas, al contrario de lo que ocurre al emplear otro tipo de tintas, por lo que el contraste depende casi exclusivamente del tono del soporte: a mayor oscuridad de la piel, menor contraste, y viceversa.

Podemos citar como ejemplo de contraste mínimo la estampa C0-035, cuyo detalle vemos en la fig. 63, la cual está realizada sobre un cuero tan oscuro que llega a ser difícil apreciar los contornos de la figura. Sin embargo, lo normal es que la tinta negra cree al menos un

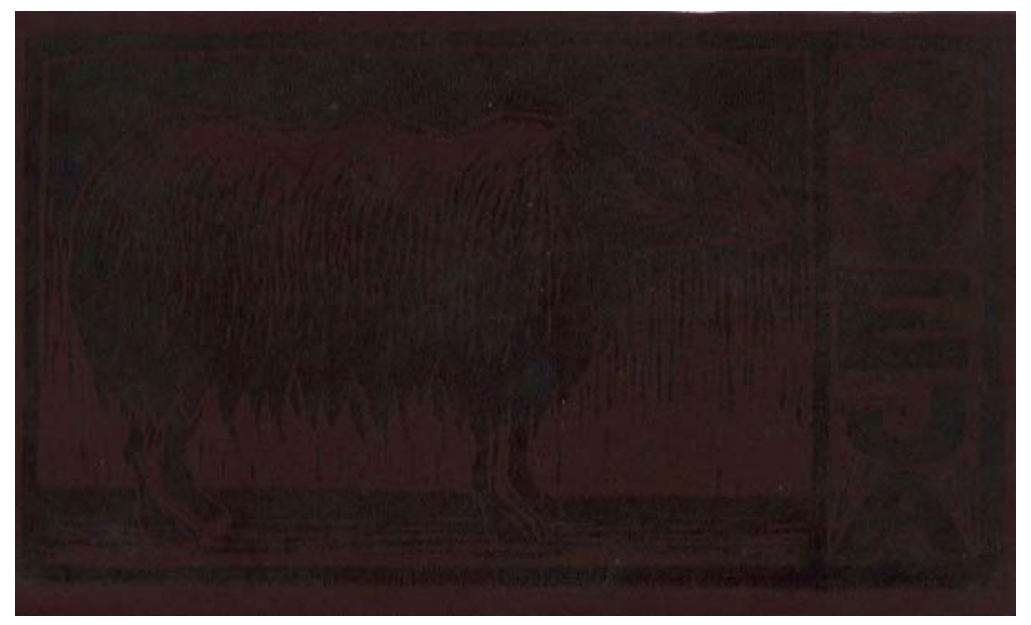

Fig. 63: Estampa CO-035, de casi nulo contraste. 
nivel contraste lo suficientemente elevado como para poder percibir la naturaleza de la imagen estampada

\section{IV.1.1.b. Tinta blanca}

Las consideraciones apuntadas previamente el referirnos al análisis de la tinta negra cambian de manera radical al trabajar con la tinta blanca, con tremendas variaciones de calidad dependiendo de las características del soporte y la naturaleza de la piel. Vemos una gran cantidad de inconvenientes que hacen de esta tinta una difícil opción a la hora de abordar estampas xilográficas sobre soportes piel.

\section{- Mancha}

Las diferencias entre los resultados obtenidos al estampar sobre el lado flor y el lado carne son muy acusadas, algo que no ocurría con las imágenes logradas a partir del empleo de tinta negra, dada la mayor capacidad cubriente de esta última en comparación con el blanco que analizamos en este apartado. 
En los cueros de cabra ya podemos apreciar esta distinción tan marcada, con una calidad general de las estampas que nunca llega a alcanzar los niveles que veremos con otras tintas. Así, en las imágenes sobre lado flor ligeramente satinado, la tinta blanca presenta un defecto en las zonas en las cuales se concentra en mayor cantidad,

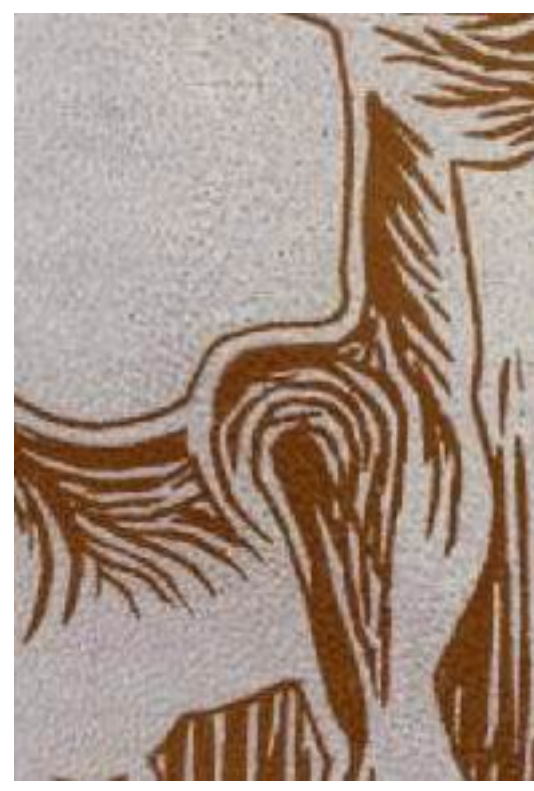

Fig. 64: Detalle de la estampa CA009 en el cual se aprecian los grumos de la tinta.

defecto que denominaremos

grumosidad 149 y el cual se producirá en todos aquellos cueros satinados (fig. 64). Este hecho se une a que la tinta blanca, al contrario que la negra, nunca logra alcanzar una intensidad lo suficientemente densa como para cubrir perfectamente la superficie de la piel, por lo que las zonas estampadas ofrecen un acabado heterogéneo y por momentos muy irregular.

\footnotetext{
${ }^{149}$ Con este término nos referimos a la textura irregular que aparece en la película de tinta depositada sobre la superficie del cuero. La tinta no se asienta de manera homogénea, sino que lo hace formando pequeños grumos que pueden llegar a ser enormemente incómodos para apreciar correctamente las imágenes.
} 
En el lado carne también podemos percibir el defecto que se repite sobre cualquier superficie de parecidas características independientemente de la naturaleza de la piel. El

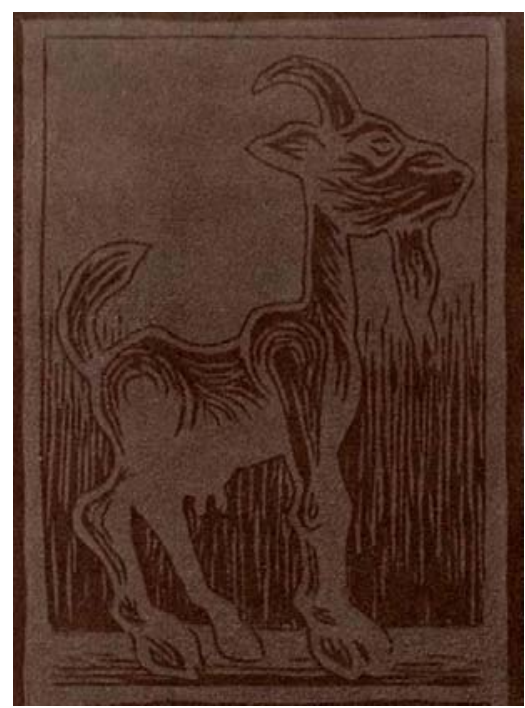

Fig. 65: Imagen CA-012 en la cual se aprecia el tono marrón claro en el que se transforma la tinta blanca al contacto con el afelpado. afelpado actúa de una manera inesperada sobre la tinta blanca, lográndose imágenes que necesitan de un minucioso estudio y análisis. Al estampar las planchas sobre los soportes de piel, éstos recogen casi la totalidad de la tinta presente en las matrices, por lo que sería lógico que las imágenes ofrecieran una gran intensidad de blancos, y sin embargo, nada más lejos de la realidad, ya que las estampas apenas ofrecen unas débiles manchas de un tono muy alejado del blanco que deberíamos obtener. Logramos unas manchas de un gris sucio que muchas veces son incapaces de contrastar con el tono del fondo, como se aprecia claramente en las estampas CA-008 y CA-012 (fig. 65), muestras de que la tinta blanca, al contacto con una superficie afelpada, pierde gran parte de su intensidad y fuerza, consiguiéndose manchas de muy poca calidad. 
Las pieles de cerdo son las únicas que escapan a estas generalidades, no ya en las estampas realizadas sobre el lado carne, que repiten los defectos citados, sino en las imágenes sobre el lado flor. El acabado poco satinado de estos cueros hace que la tinta blanca asiente de manera suficientemente correcta para evitar casi por completo la aparición del efecto de grumosidad tan molesto y que sí se

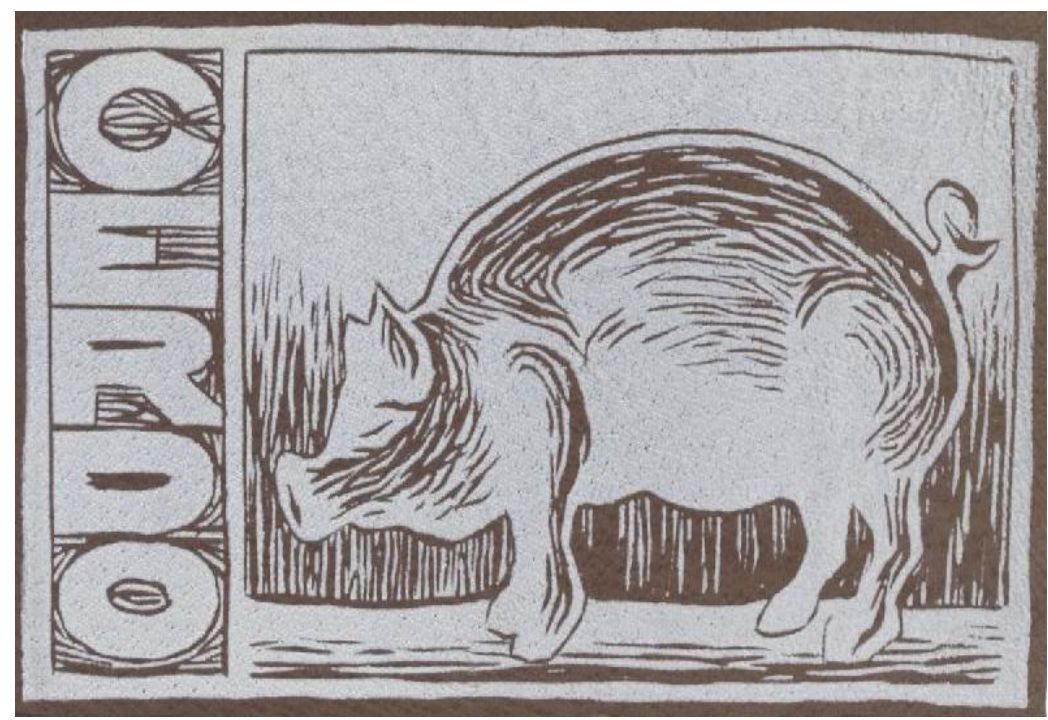

Fig. 66: Estampa CE-011, de buen resultado con la tinta blanca

da en el resto de estampaciones. Un ejemplo perfecto puede ser la estampa CE-011, con un registro muy correcto de la tinta blanca sobre el cuero (fig. 66). 
El resultado y calidad de la mancha blanca sobre los cueros ovinos viene determinado en todos los casos por la superficie escogida, ya sea del lado flor o del carne, de tal modo que las tres estampas recogidas sobre el primer lado, tal como vemos en las CO007, CO-009 y CO-011, presentan aceptables niveles de calidad en el registro de grandes áreas de tinta blanca, e incluso en las dos últimas imágenes estamos ante algunas de las mejores logradas mediante

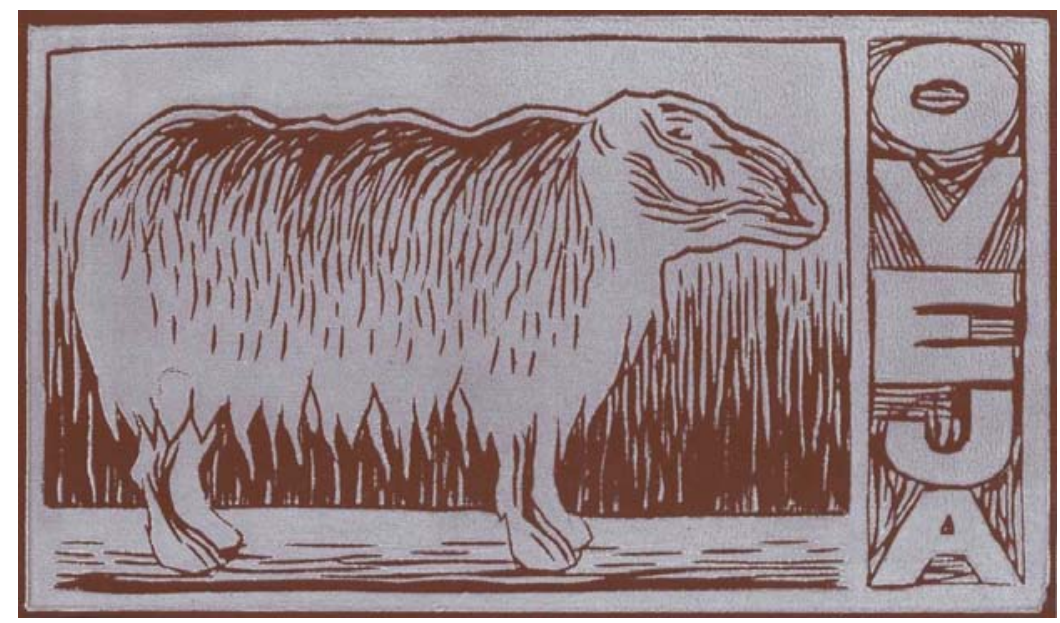

Fig. 67: CO-009, uno de los mejores ejemplos con tinta blanca.

empleo de blanco, con ausencia de defectos y texturas desagradables en la película de tinta para configurar zonas homogéneas y regulares (fig. 67).

Por el contrario, la superficie afelpada del lado carne es incapaz de recoger y registrar de manera aceptable la carga de tinta 
blanca presente en la plancha xilográfica, obteniéndose manchas sucias, texturas desagradables y tonos débiles e irregulares. Concretamente la imagen CO-008 (fig. 68) es, junto a la estampa con piel de vaca VA-008, una de las de peor calidad de todo el trabajo, siendo casi imposible distinguir las zonas entintadas de aquéllas en las

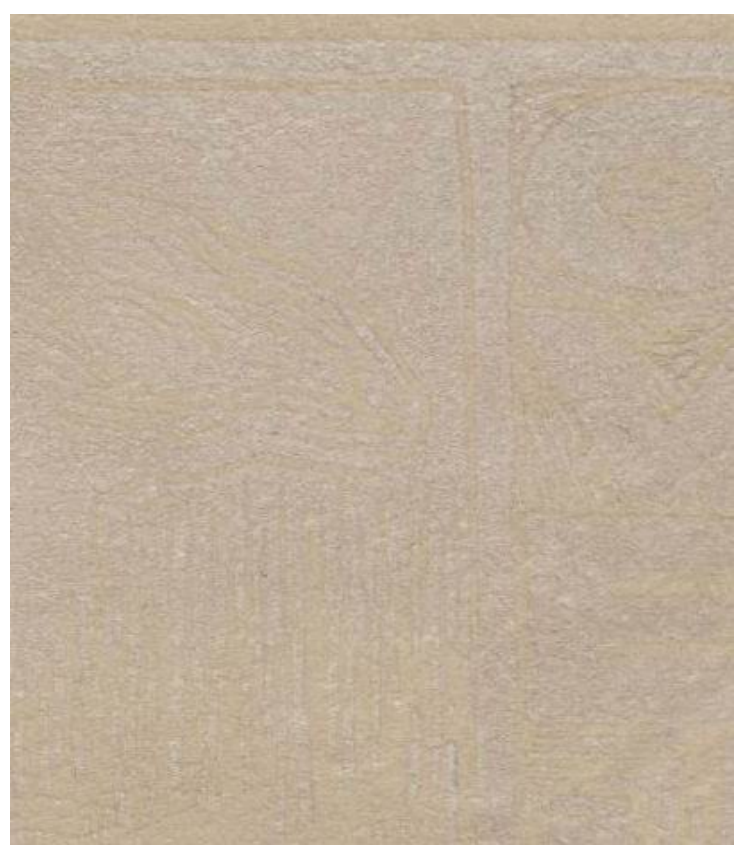

Fig. 68: Detalle del ejemplo CO-008

que la superficie del cuero permanece virgen, sin duda provocado por el excesivo afelpado de su textura, el cual absorbe la tinta impidiendo que ofrezca un resultado positivo y válido.

Por ultimo los cueros vacunos no ofrecen excesivas novedades a lo ya comentado con anterioridad; el grado de 
grumosidad depende de lo satinado del acabado de la cara flor de la piel, con casos en los que es apenas visible, como en la VA-007, y otros donde aparece en toda su intensidad (VA-009).

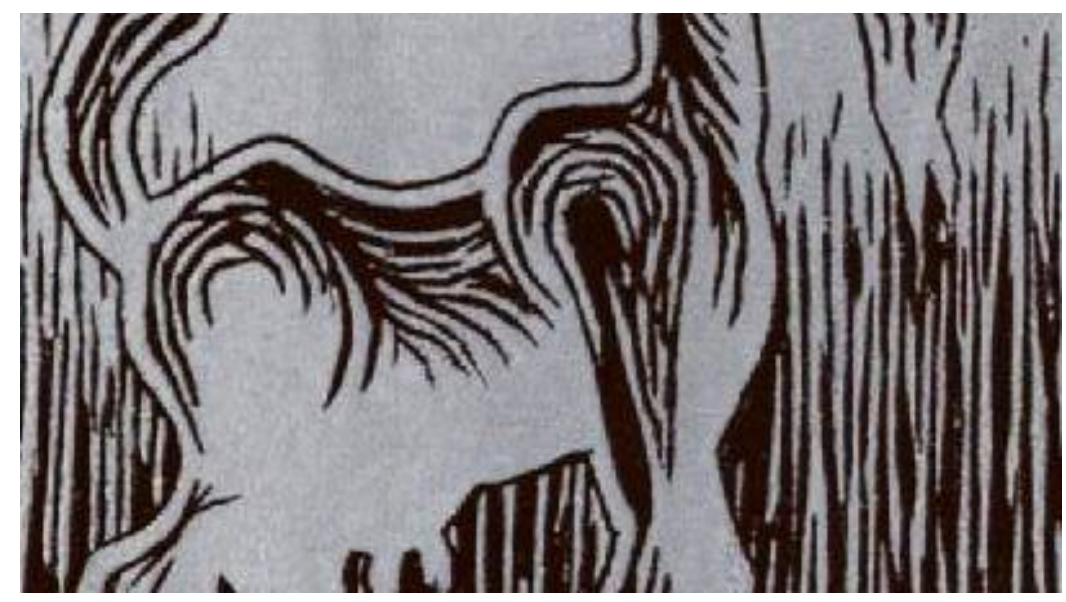

Fig. 69: Detalle de los grafismos de la imagen CA-011.

\section{- Grafismos}

El registro de los grafismos xilográficos repite punto por punto los inconvenientes reflejados en el apartado anterior referente a la mancha, con mínimas diferencias que detallaremos a continuación. Los efectos de grumosidad son menos visibles, no porque no aparezcan, sino porque al ser mucho menor la superficie cubierta de tinta blanca se hace más difícil su apreciación. En lo que respecta a los defectos de nitidez por una excesiva presión, este problema no afecta 
con la misma intensidad que en las tintas negras, debido a las densidad y peso de las tintas blancas, que le permiten asentar de manera algo más correcta sobre la superficie de la piel. Ejemplos de grafismos de más que aceptable nivel pueden ser los recogidos en las imágenes CA-011 (fig. 69), CE-009 y CO-009 entre otros, cuyos resultados ofrecen una gran nitidez y definición, sin problemas de deformaciones siempre que trabajemos con la presión correcta. Si al analizar la mancha sobre el lado carne de los cueros veíamos las dificultades de obtener resultados aceptables, con los grafismos ocurre exactamente lo mismo, incluso acentuándose todavía más los problemas. En efecto, en algunos casos concretos y extremos, véase CA-008, CO-008 o VA-008 (fig. 70), los grafismos y líneas xilográficas llegan a perderse por efecto del excesivo afelpado de la superficie del soporte, impidiendo una correcta visión y apreciación de las estampas.

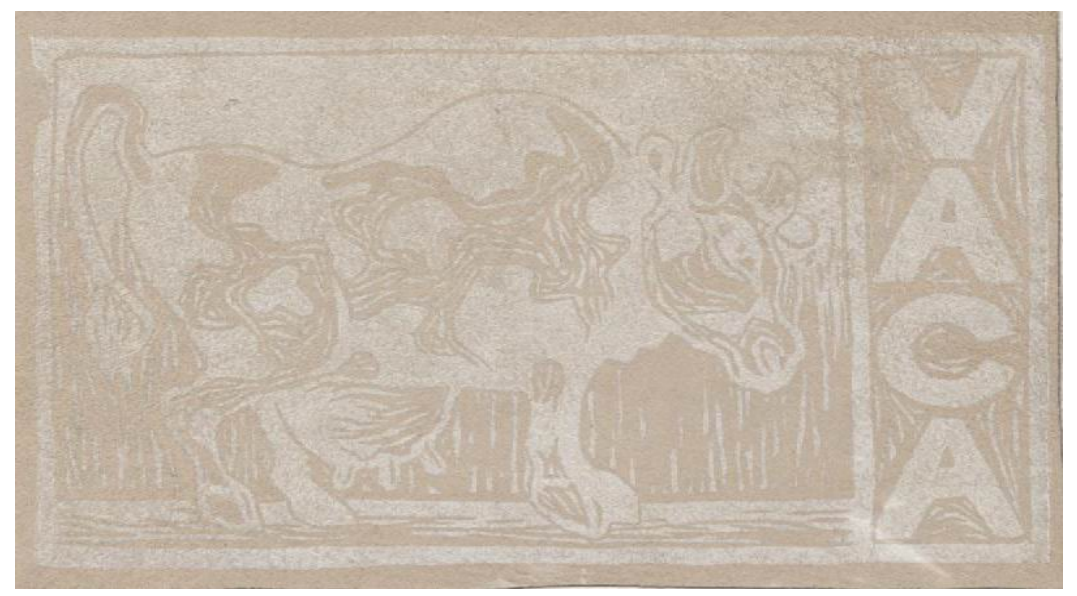

Fig. 70: Estampa VA-008. 


\section{- Contraste y brillo}

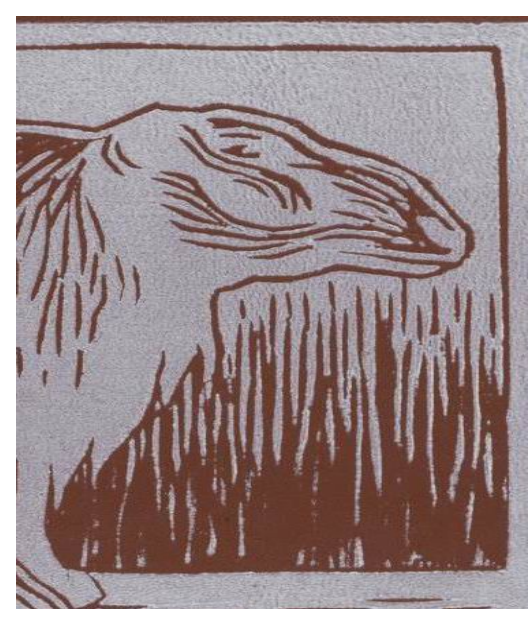

Fig. 71: Detalle de la imagen CO009.
Analizando

las

peculiaridades del contraste aparecido en estas estampas debemos hacer referencia, de nuevo, a las características propias de la tinta blanca. Al hablar de las imágenes estampadas en negro vimos con toda razón que dicha tinta apenas registra cambios de intensidad, sin embargo, tal afirmación no es válida para la tinta blanca, ya que ésta sufre importantes variaciones dependiendo de la superficie sobre la cual se estampe. Es necesario remarcar que jamás alcanza la intensidad que sería deseable y que, a pesar de su denominación como blanco cubriente, no logra resultados satisfactorios en el lado flor. Por tanto si el tono de blanco no es lo suficientemente intenso, el contraste tampoco lo será en la mayoría de las estampas, exceptuando tan sólo aquellas realizadas sobre un soporte muy oscuro, como sucede en los casos CA-011, CE-011, CO009 (fig. 71) o VA-011, y ni siquiera en éstas es totalmente correcto y válido. En lo que respecta al lado carne los resultados son todavía 
peores, con ausencia casi absoluta de contraste en algunos ejemplos como los VA-008, CO-008 y muy especialmente el CA-008 (fig. 72), lo que provoca una pérdida casi total de la imagen.

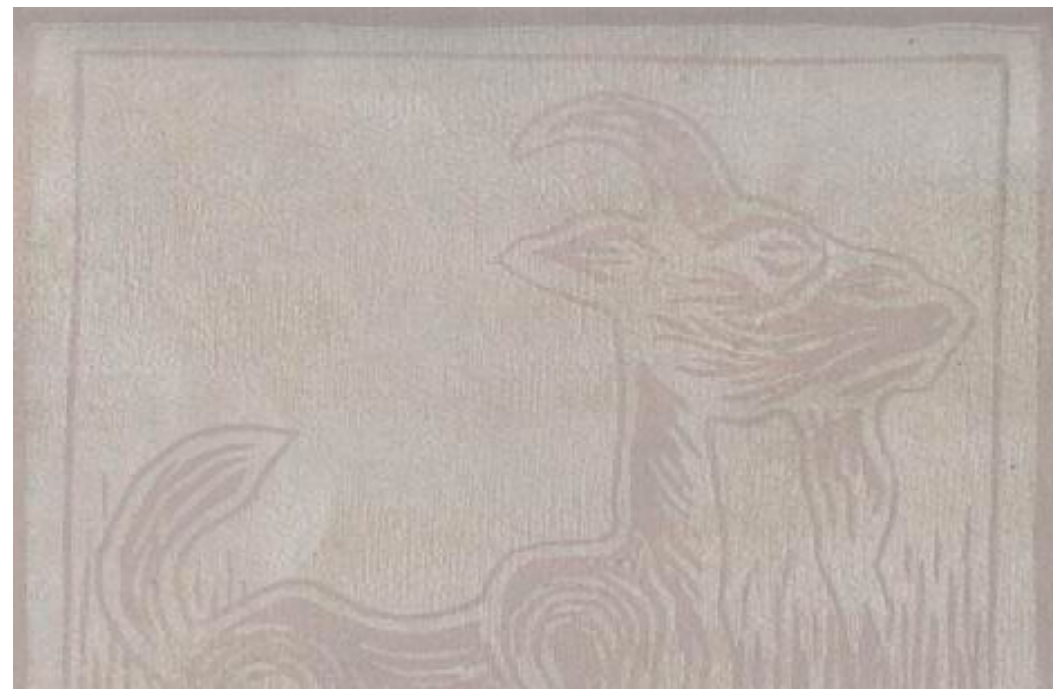

Fig. 72: Detalle de la estampa CA-008.

En efecto, con la tinta blanca sobre el lado carne de los cueros se produce un fenómeno ciertamente extraño; la imagen estampada nunca alcanza una intensidad de tono lo suficientemente elevada como para poder provocar la aparición de un contraste potente, pero no es por ausencia de tinta sobre la superficie del cuero por lo que se produce este defecto. Al estampar la piel recoge la práctica totalidad de la tinta presente en la plancha xilográfica, la cual queda casi absolutamente limpia, pero la misma piel absorbe tal cantidad de tinta 
blanca gracias a su acabado afelpado que impide la creación de una película visible en superficie.

Por último al hablar de brillo y de tintas blancas todo se reduce a una cuestión muy simple y sencilla: usando tinta blanca no aparecen nunca brillos sobre la superficie de la piel. La naturaleza intrínseca de la tinta blanca es mate, por lo que ni siquiera al estampar sobre superficies muy satinadas nos encontraremos con brillos intensos. En su lugar, existen numerosos ejemplos en los cuales la tinta blanca elimina el brillo que pudiera tener el cuero, quedando éste sólo en las zonas libres de tinta tal como se aprecia en los ejemplos CE-011 o VA011, por citar tan sólo dos de ellos.

\section{IV.1.1.c. Tinta azul translúcido}

Como vemos a continuación, el empleo de tintas translúcidas permite conseguir unos resultados de enorme interés tanto estético como técnico, abriendo un interesante campo de actuación a partir de las técnicas xilográficas asociadas a soportes piel. Las características y naturaleza propias de estas tintas provocan que su interacción con el cuero sea quizá la más estrecha y la que ofrece mayores alternativas. 
- Mancha

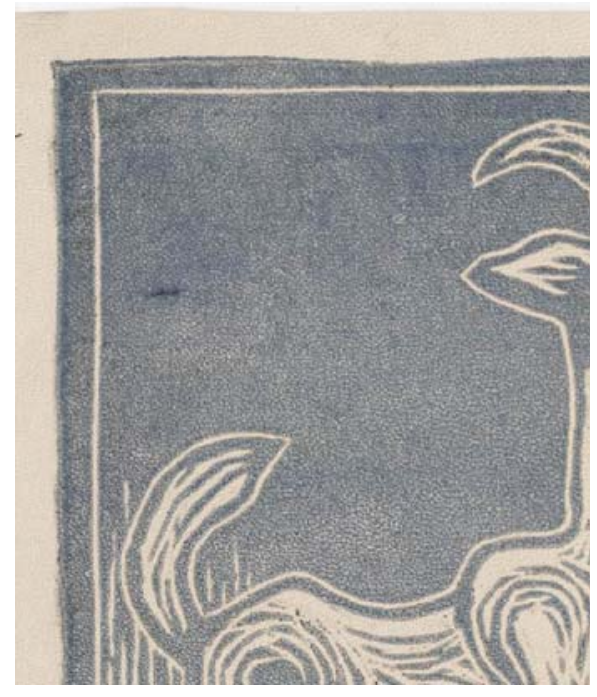

Fig. 73: Detalle de la imagen CA-013 en el cual se aprecia el defecto de la piel.
Las imágenes logradas a partir del uso de la tinta azul translúcido ofrecen un nivel de calidad bastante bueno, con ejemplos de manchas y áreas entintadas de excelentes resultados. Ya en las estampas sobre las pieles de cabra podemos apreciar algunas de las características que se

repiten a lo largo del resto de los grabados, las cuales pueden resumirse en un patente cambio dependiendo de la superficie escogida al estampar, ya sea sobre el lado flor o sobre el lado carne, algo parecido a lo ocurrido con la tinta blanca aunque con tipologías diferentes.

Sobre el lado flor, los ejemplos realizados en cueros caprinos presentan ya las tres características generales que se encuentran en los otros tipos de pieles. 
- La primera viene determinada por la naturaleza traslúcida de la tinta empleada, la cual se verá incapaz en muchas ocasiones de cubrir los posibles defectos o imperfecciones que aparezcan en la superficie del soporte, llegando incluso a hacerlos más patentes y visibles en algunas ocasiones, como refleja la fig. 73.

- La segunda está relacionada con la grumosidad ya mencionada al tratar las tintas blancas. De tal modo, si usamos un exceso de tinta en la estampación y ésta se realiza sobre una superficie satinada en exceso, obtenemos de nuevo esta desventaja.

- La tercera característica aparecida es común a ambos lados de la piel y a todos los tipos de cueros; la mezcla por transparencia. 150 Con este nombre queremos denominar uno de los fenómenos más interesantes que se producen al emplear los cueros como soporte para estampas xilográficas, consistente en el cambio acaecido en el tono de la tinta al entrar en contacto con la superficie de la piel. Sucede algo similar a lo ocurrido cuando se superponen diferentes capas de colores pintando a la acuarela, los cuales se van mezclando por transparencia, aunque en el caso que nos ocupa los resultados son a veces todavía más sorprendentes.

Este cambio del tono de la tinta, que se produce en ambas caras del cuero, tiene una incidencia mucho mayor en las estampas

\footnotetext{
${ }^{150}$ Este fenómeno se produce al estampar sobre cualquier soporte coloreado, ya que se trata de una característica intrínseca de la tinta y no tanto del soporte.
} 
sobre la superficie afelpada del lado carne de la piel. Si en las superficies algo más satinadas de la flor de los diferentes cueros el cambio producido en la tinta es ya visible, en las superficies internas de las pieles el afelpado característico provoca no sólo una modificación tonal sino a su vez un oscurecimiento muy patente de la tinta original hasta convertirla en otra tonalidad totalmente diferente. La fig. 74 presenta, de izquierda a derecha, la estampación sobre el lado carne, el lado flor y sobre papel, pudiendo comprobar visualmente como el tono de la tinta sufre este proceso de cambio cromático.

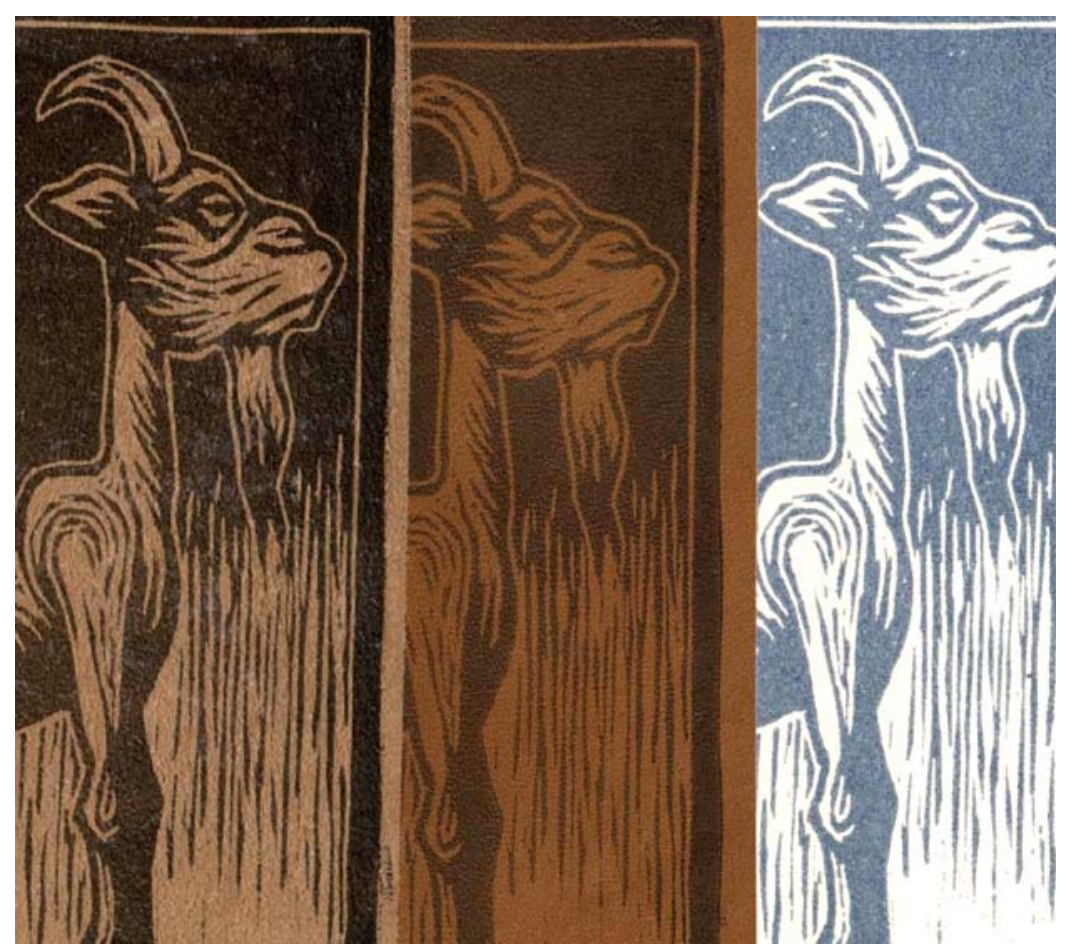

Fig. 74: Mezcla por transparencia: carne-flor-papel. 


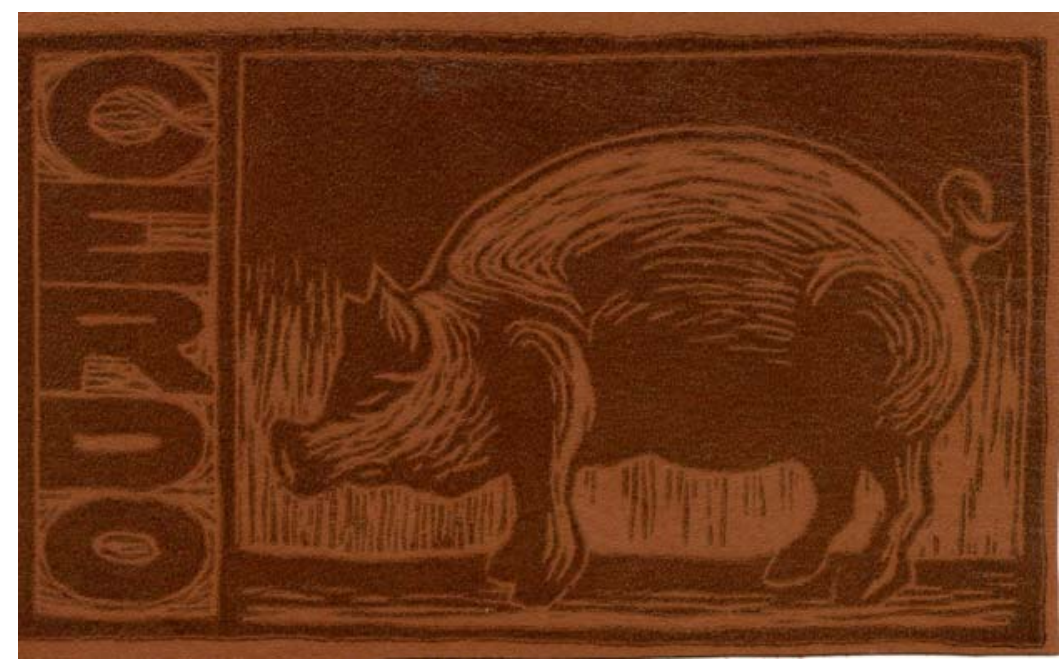

Fig. 75: Imagen CE-015 realizada con tinta azul traslúcido.

En estampas como las CA-016, CA-018, CE-015, C0-016 y VA-018, los cambios son evidentes, pudiendo establecer la regla de que, a mayor y más acusado afelpado de un cuero, mayor será el oscurecimiento de la tinta. A su vez señalamos el hecho de que, en muchas ocasiones, los tonos y colores obtenidos a partir de esta mezcla por transparencia poseen unas cualidades excepcionales; en las imágenes VA-018 y CE-015 (fig. 75), vemos que serían muy difíciles de conseguir si no fuera mediante el empleo y utilización de este tipo de tintas traslúcidas, lo que las convierte en un elemento de gran interés dentro de nuestro estudio. Un ejemplo ideal de este fenómeno de cambio cromático de la tinta lo tenemos en la mencionada estampa CO-016, en la cual la tinta azul se ha convertido en un tono marrón cálido totalmente diferente. El color obtenido se 
integra de manera perfecta con el tono del soporte cuero dada la naturaleza traslúcida de la tinta, que acentúa la textura propia de la piel si es que la hubiera, y logra un efecto plástico muy atractivo.

\section{- Grafismos}

Analizando el grafismo de las imágenes podríamos repetir casi todas las apreciaciones precedentes, ya que se vuelven a dar con mayor o menor intensidad dependiendo de los casos. Sin embargo, sí podemos añadir alguna particularidad más referida obviamente a los contornos de los grafismos presentes en las estampas. Como ya ocurriera con las tintas blancas en las estampas realizadas sobre superficies muy satinadas, aparece la conocida textura a grumos, la cual se hace muy patente en los contornos de la imagen ya que la tinta transparente no asienta bien y muchas veces las líneas pierden nitidez, a lo que ayuda también la gran transparencia del tono empleado en la estampación. 
Estos contornos algo difusos son visibles sobre todo en cueros de cabra y vaca, los cuales suelen presentar acabados más brillantes y satinados en algunos casos y podemos estudiarlos en los ejemplos CA-013 y VA-015 (fig. 76). Sin embargo, debemos indicar que estas anomalías son mínimas y que no suelen incidir demasiado en la calidad y el resultado final de las estampas.

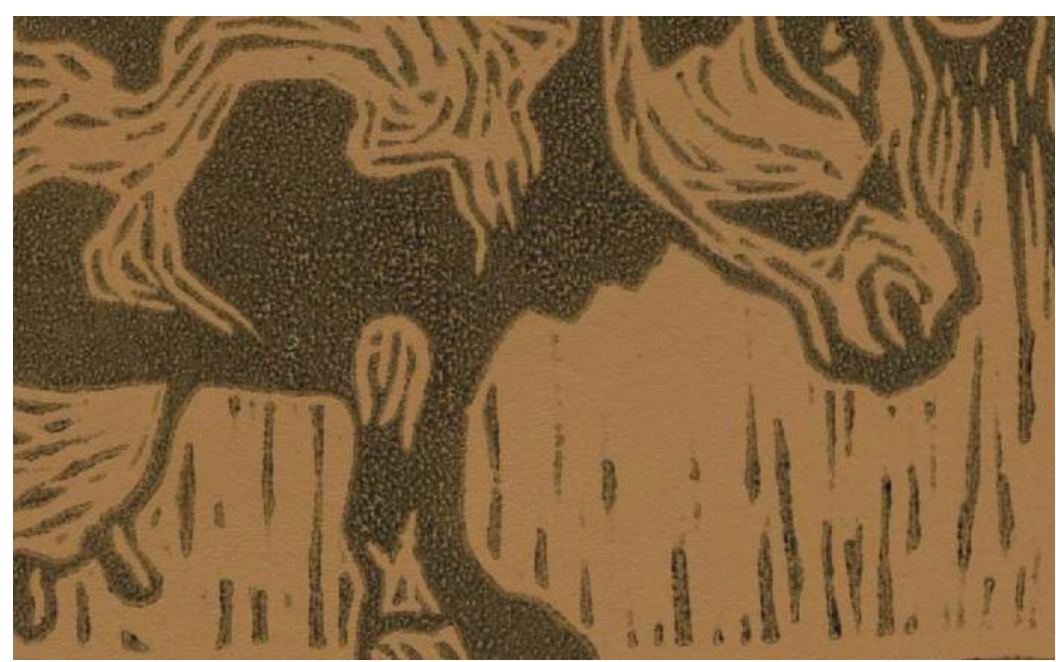

Fig. 76: Detalle de la estampa VA-015, en el cual se aprecian las irregularidades del registro de ciertos grafismos.

Por su parte en el lado carne estos defectos son casi inapreciables ya que la tinta se oscurece al contacto con la superficie afelpada e impide la aparición de estas texturas. Por último, indicaremos que las irregularidades de los contornos pueden estar provocadas a veces por un exceso de presión, por lo que si 
estampamos con la presión mínima necesaria, algo que deberíamos hacer siempre, sus efectos pueden minimizarse al máximo.

\section{- Contraste y brillo}

Al analizar el contraste existente en las estampas realizadas con esta tinta debemos tener muy en cuenta dos de los fenómenos anteriormente comentados: la mezcla por transparencia y el oscurecimiento al contacto con una superficie afelpada. Ambos efectos son de capital importancia con vistas a analizar la intensidad del contraste presente en las imágenes ya que producen notables cambios en los efectos de la tinta y por consiguiente en su relación tonal con el soporte. Por tanto, podemos enunciar una norma general: siempre que los tonos del lado flor y del lado carne sean similares, el afelpado del segundo provocará que el contraste sea más intenso en este último. En efecto, en las estampas sobre el lado flor tan sólo actúa la mezcla por transparencia, mientras que sobre el lado carne a ésta se le une el oscurecimiento de la tinta, de tal modo que la intensidad de la tinta aumenta mucho más, convirtiéndose en un tono mucho más oscuro y provocando un contraste más potente y pronunciado, lo cual se evidencia siempre que los tonos de ambos lados del cuero sean similares en intensidad. 
Este fenómeno es muy patente y fácilmente apreciable si comparamos estampas gemelas ${ }^{151}$ como las CA-015 y CA-016 o las CE-015 y CE-016, entre muchas otras. (fig. 77) En ellas vemos claramente como la tinta azul transparente se ha transformado en dos colores totalmente distintos y con diferentes intensidades, siendo siempre más oscuro el obtenido al estampar sobre el lado carne. A pesar de todo lo comentado, es obvio que en el contraste continúa

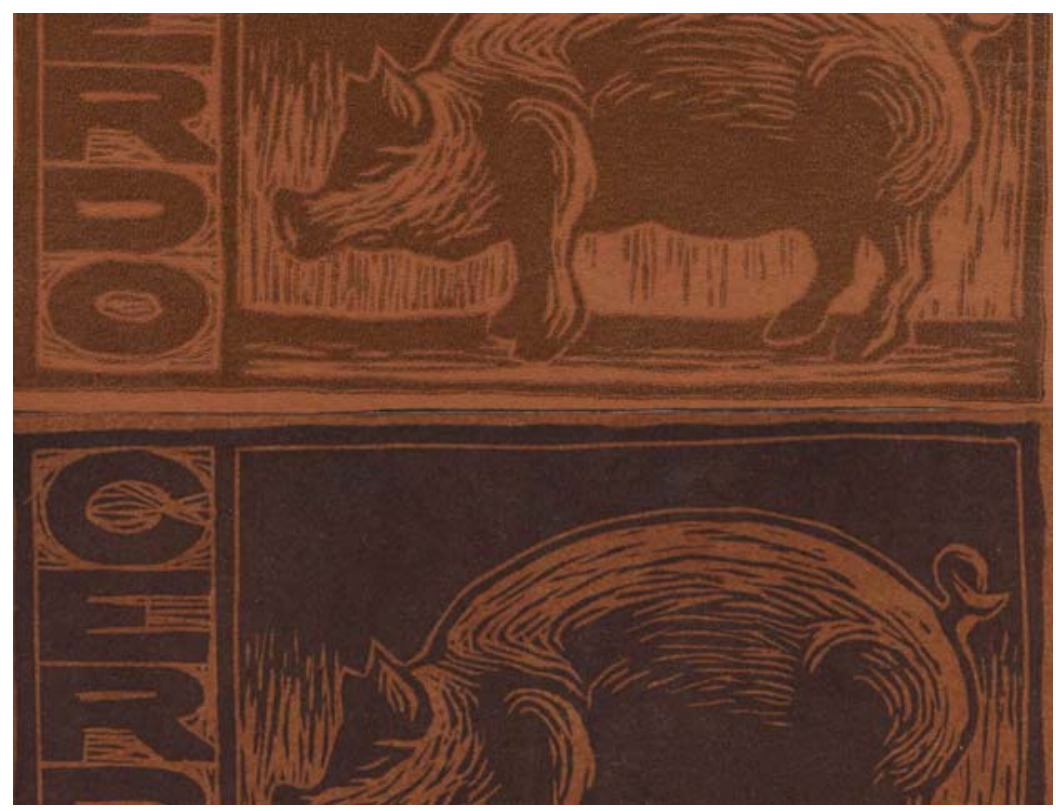

Fig. 77: Estampas CE-015 y CE-016, ambas realizadas con azul traslúcido.

\footnotetext{
${ }^{151}$ Con este adjetivo nos referimos a partir de este momento a aquellas estampas realizadas con los mismos factores de estampación, ya sea tipo de piel, tono de la misma, técnica y tinta, pero cambiando el lado del cuero, es decir, una estará realizada sobre el lado flor y la segunda sobre el lado carne de la misma piel.
} 
influyendo sobremanera el tono del soporte-piel, por lo que a cueros más oscuros les corresponden contrastes más débiles y viceversa.

Por último, al analizar el brillo vemos que se comporta de manera muy similar a como ya vimos en relación con la tinta negra. En las imágenes estampadas sobre el lado flor, con superficies normalmente muy satinadas, aparece un patente brillo, mientras que sobre el lado carne, con sus típicas superficies afelpadas, éste desaparece por completo. Se repite así el esquema ya estudiado para con la tinta negra, en el que la intensidad del brillo en las imágenes sobre el lado flor depende de lo satinado del acabado de dicha superficie.

En general casi todas las pieles de cabra y algunas de vacuno y cordero son las que suelen presentar acabados más satinados, por lo que ofrecen una superficie ideal para la aparición de intensos reflejos en las zonas entintadas. Por su parte en la piel porcina, en el forro de cerdo, estos brillos son mucho más débiles ya que su acabado no ofrece un grado tan alto de satinado. En lo que respecta al lado carne, no aparece ningún tipo de brillo intenso, como es lógico si tratamos de una superficie afelpada, la cual absorbe todos y cada uno de los reflejos. 


\section{IV.1.1.d. Tinta azul opaco}

Analizamos ahora los resultados obtenidos a partir del uso de tintas opacas, en este caso el tono de azul cuyas características ya han sido detalladas en la nota 145. Esta tinta ofrece estampas totalmente diferentes a las realizadas con tinta blanca o azul traslúcido, mientras que por otro lado la dicción de las imágenes resultantes es similar a las analizadas respecto al empleo del color negro.

\section{- Mancha}

La tinta azul empleada se presenta óptima para conseguir potentes, homogéneas y regulares zonas entintadas sobre la superficie del cuero escogido. La calidad de la mancha alcanza niveles altísimos en la práctica totalidad de los ejemplos propuestos, y tan sólo aparecen inconvenientes relacionados con algunas superficies de naturaleza algo particular, como pueden ser la VA-020 y la VA-024, ambas con un marcado afelpado en su lado carne, cuya textura, al igual que en otros casos analizados, puede llegar a interferir en una correcta estampación y homogeneidad de las zonas entintadas.

Un fenómeno a comentar en este punto es el efecto producido sobre la apreciación del tono de la tinta según sea su color y la 
intensidad del tono del cuero utilizado como soporte. Es evidente que un azul oscuro como el empleado en la experimentación no es percibido igual sobre un soporte totalmente blanco que sobre otro más intenso, y dicho efecto es perfectamente apreciable en las estampas de este trabajo. Sin embargo, a este hecho, el cual es independiente de la naturaleza del soporte pudiendo ocurrir exactamente igual al estampar sobre un papel, se le une la aparición de un factor relacionado con la mezcla por transparencia. De tal modo, y pese a estar empleando una tinta a la cual no le hemos incorporado preparación traslúcida, la naturaleza oleosa propia de las tintas de grabado hace que cierto efecto de transparencia se produzca siempre. Por supuesto, no será tan acusado como en el caso de las estampas realizadas con tinta azul translúcido, pero aun siendo mucho más sutil merece la pena comentarlo. Así, al igual que en los ejemplos citados, la tinta cambia ligeramente de tono al relacionarse con el color del soporte piel, efecto que es todavía más evidente en las estampas realizadas sobre el lado carne de los cueros dado el oscurecimiento del tono de la tinta al contacto con la superficie afelpada típica de dichas pieles, de manera parecida a lo ocurrido al analizar ejemplos de tinta translúcida, aunque en un grado no tan acusado. Podemos comprobarlo comparando imágenes como la VA-019 y la VA-020; es evidente que en la estampación sobre el lado carne la tinta azul, pese a su opacidad, sufre un marcado oscurecimiento con respecto de la otra (fig. 78). 


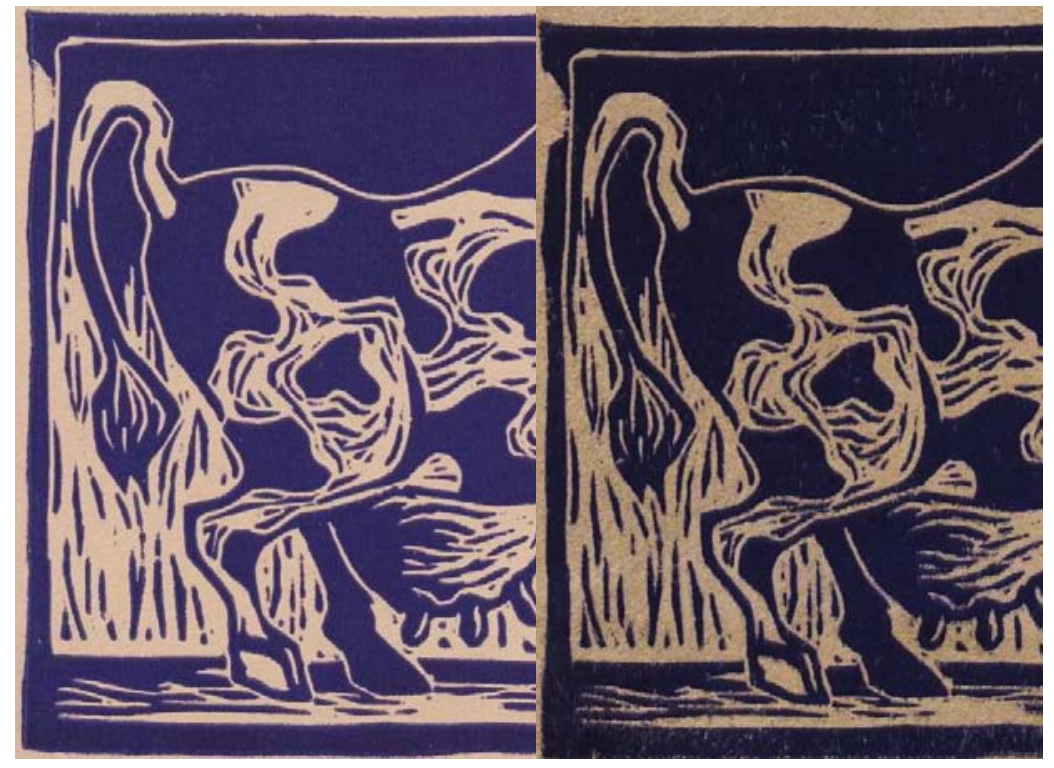

Fig. 78: Detalle de las estampas VA-019 y VA-020, en el que se aprecia el oscurecimiento de la tinta al contacto con el afelpado del lado carne.

\section{- Grafismos}

La naturaleza de la tinta azul utilizada permite que el nivel de registro de los grafismos xilográficos obtenidos sea bastante satisfactorio. Siempre que la presión sea la correcta y no aparezcan texturas excesivamente agresivas en los cueros, sobre todo en lo que respecta a los lados carne, los grafismos xilográficos se estampan de manera correcta, y cuando la superficie del lado carne de la piel ofrezca un afelpado sutil y no demasiado acusado, los resultados serán mejores que sobre la misma piel por su lado flor. Ejemplos de 


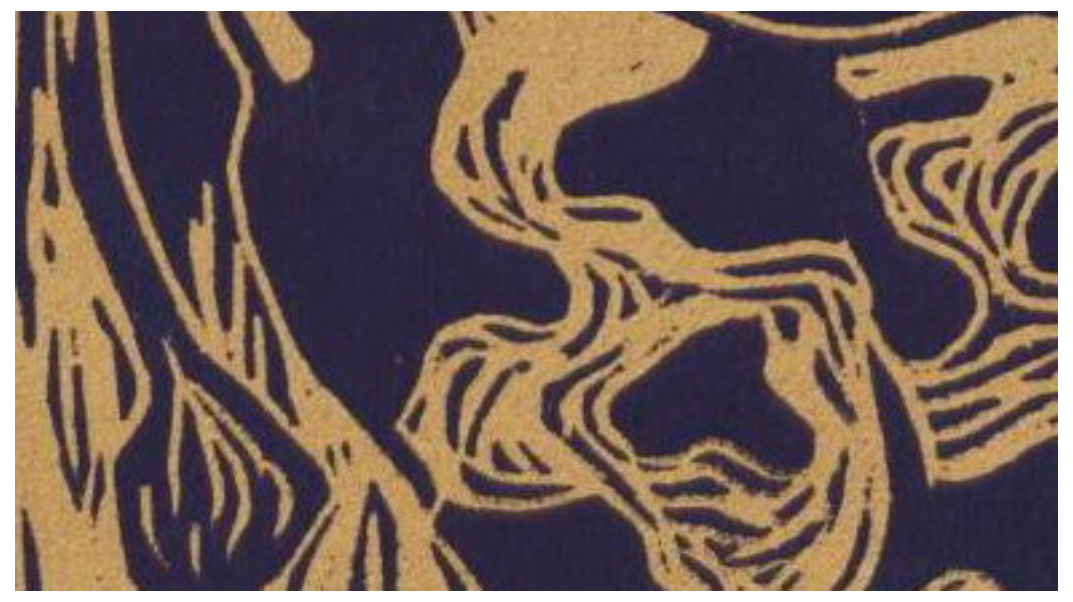

Fig. 79: Detalle de la estampa VA-022.

este hecho podemos encontrarlos en las estampas CO-022, VA-022 (fig. 79), CA-020 y CE-022 por citar sólo algunos de ellos. En éstos los contornos de los grafismos presentan una definición perfecta e incluso un leve exceso de presión no afecta de manera tan evidente al seño como en los lados flor de los cueros, generalmente más satinados. En definitiva estamos ante una tinta que ofrece resultados muy satisfactorios y de gran calidad en general, como vemos al analizar las estadísticas generales de todas las estampas en el apartado de consideraciones parciales de este bloque práctico. 
- Contraste y brillo

Al referirnos al contraste debemos reincidir y retomar el fenómeno del oscurecimiento de los tonos de la tinta en contacto con la superficie del cuero. El nivel de intensidad del contraste depende, de nuevo, de la relación tonal entre la tinta y el color del soporte piel, y por tanto el contraste sigue fundamentalmente las normas ya establecidas con la tinta negra.

En lo que respecta al brillo se cumple, como es obvio, la norma de la desaparición de cualquier tipo de reflejo en los casos estampados sobre superficies afelpadas como las de los lados carne de los cueros. Por el contrario en las superficies algo más satinadas de su lado flor, aparecen brillos y reflejos en las zonas cubiertas por la tinta, aunque nunca llegan a alcanzar los niveles de intensidad que aparecen en los ejemplos que emplean tinta negra para su realización y estampación. Los brillos son por tanto más sutiles y se integran mejor con el soporte piel, logrando imágenes muy atractivas plástica y estéticamente. 


\section{IV.1.2. Grabado calcográfico}

La elección de las técnicas más representativas del mundo del grabado calcográfico, el aguafuerte y la aguatinta, viene determinada, no sólo por la importancia de ambos procedimientos, sino también por un interés particular en las características de las imágenes con ellas conseguidas, interés que está íntimamente relacionado con la propuesta de obra personal que más tarde abordaremos. Es evidente que mediante el empleo de ambos procedimientos se puede alcanzar un análisis bastante correcto de la respuesta de las imágenes calcográficas sobre las pieles animales, tanto en lo que a grafismos se refiere como en lo relativo a amplias zonas de grises y tonos medios.

Con objeto de lograr una mayor cantidad de información se ha decidido proponer en las imágenes dos intensidades diferentes tanto de grafismo como de tono del aguatinta, algo que obviamente era del todo imposible al trabajar con planchas xilográficas. De tal modo se pueden distinguir en las estampas dos tipos distintos de línea, una más sutil colocada bajo el cuerpo del animal representado, y otra mucho más potente y gruesa que conforma el resto de la estampa. Lo mismo ocurre con los tonos del aguatinta, ya que en el fondo de la imagen aparece un tono medio, mientras que en el marco y en la zona reservada al nombre de la especie animal se ha empleado una 
intensidad mucho mayor hasta alcanzar un tono bastante oscuro. Con esta variedad de intensidades (fig. 80), que no hemos querido que fuera excesiva para no dificultar el análisis de los resultados, se pretende ofrecer una mayor y mejor información que sirva como base para las consideraciones parciales de este bloque práctico.

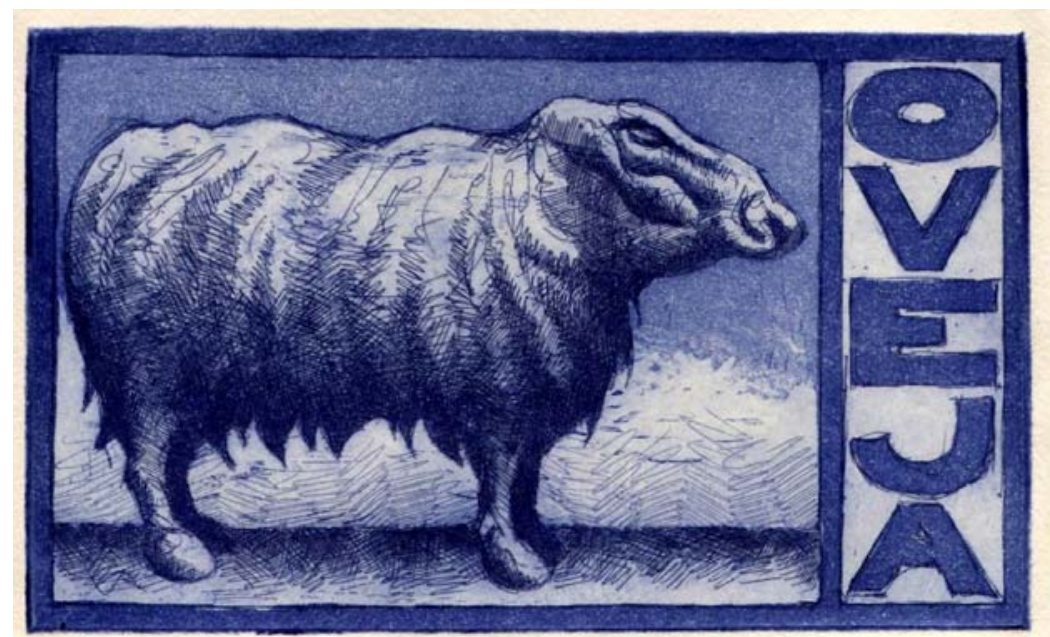

Fig. 80: Imagen calcográfica sobre papel en la cual se pueden apreciar las diferentes intensidades, tanto de grafismos como de zonas de aguatinta. 


\section{IV.1.2.a. Tinta negra}

Al igual que durante el apartado referente a la xilografía comenzamos nuestro análisis refiriéndonos a los resultados obtenidos a partir del empleo de tinta negra sobre los cueros escogidos.

\section{- Aguatinta}

Iniciamos el estudio de las aguatintas estampadas sobre el lado flor de los cueros empleados, y en primer lugar vemos que los resultados obtenidos son de gran calidad en casi todos los casos, así como que los mayores problemas observados no están relacionados con cuestiones meramente técnicas del aguatinta sino con el contraste y el brillo. En general, debido a la sutileza del grano del aguatinta, estas zonas se verán muy afectadas por las posibles irregularidades superficiales 0 incluso por las propias texturas de los cueros. Como es sabido las zonas de mancha de esta técnica están formadas por minúsculos puntos que recogen la tinta para crear visualmente la ilusión de una zona contínua de gris, siendo por tanto el registro más sutil de los que estudiaremos a lo largo de este análisis. Dado que se trata del registro más delicado también será el más sensible a posibles desarreglos superficiales de los cueros y a las texturas causadas por su naturaleza específica. 
A pesar de estas consideraciones en casi la totalidad de las impresiones los resultados son muy satisfactorios incluso en aquellas pieles con tonalidad muy oscura que impide una correcta apreciación de los grises. En especial los ejemplos más positivos son aquellos estampados sobre superficies bastante lisas y algo satinadas como suelen ser los lados flor de los cueros de cabra, cordero y algunos de vacuno, ya que se consigue una altísima calidad de registro en ambos tonos de grises. Así lo vemos en las estampas CA-025 (fig. 81), CO-

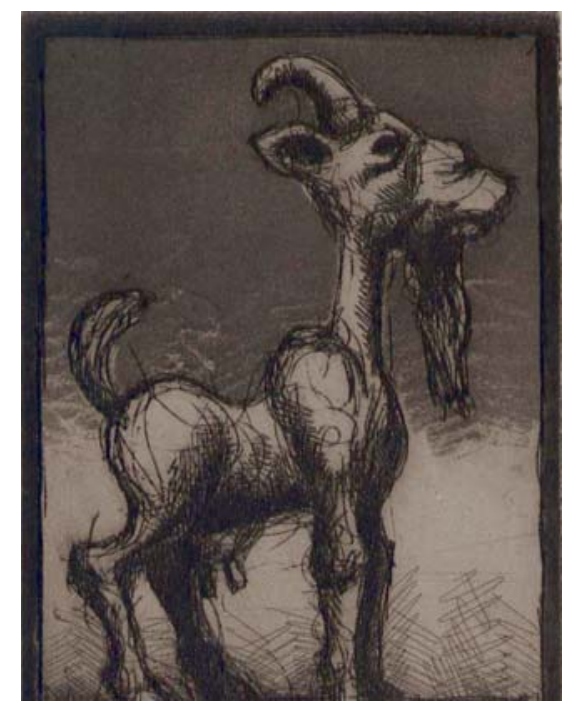

Fig. 81: Detalle de la imagen CA-025
027, VA-025 o VA-027, en las cuales la nitidez del aguatinta es casi perfecta, así como la relación de intensidad tonal entre ellos. Por el contrario, las pieles de cerdo, debido a su típica textura, no se ofrecen como soportes tan idóneos en su lado flor para este tipo de estampas, aunque si la textura superficial no es demasiado acusada el resultado será bastante satisfactorio. 
En lo que se refiere al análisis de estas zonas de mancha sobre el lado carne de los cueros, debemos recordar el oscurecimiento de las tintas al contacto con una superficie afelpada, fenómeno que ya había sido profusamente analizado al hablar de las estampaciones xilográficas con azul traslúcido, Sin embargo, al estudiar las imágenes calcográficas, con mucha menos cantidad de tinta e impresa con una textura de graneado, este oscurecimiento sí que es claramente visible sobre todo en las manchas más débiles y de menor intensidad tonal. En efecto, en estas zonas se aprecia un patente proceso de subida de los tonos originales del aguatinta, como puede observarse en el ejemplo CA-028, siendo este proceso tanto más pronunciado a medida que el afelpado del lado carne se vuelve más acusado. Una estampa que nos demuestra claramente este fenómeno es la VA-030, en la que el tono general del aguatinta se ha intensificado hasta hacer confundir ambos tipos de grises, los más débiles y los más intensos, provocando la aparición de una imagen algo confusa y oscura. Por tanto, cuanto mayor sea el afelpado de una piel este proceso de oscurecimiento general de la estampa es también más acusado y provoca a su vez un acercamiento de los tonos del aguatinta hasta llegar a perderse las diferencias entre los tonos. Por el contrario, y como era de esperar, en cueros como los de forro de cerdo, algunos cueros caprinos y ciertas pieles de cordero en los que el afelpado es muy sutil y ligero, este fenómeno de oscurecimiento es mucho menos visible y no aparece con tanta intensidad. Si comparamos estampas como la CA-025 con sus parejas en el lado flor 0 con las imágenes originales sobre papel lo apreciaremos fácilmente (fig. 82). 


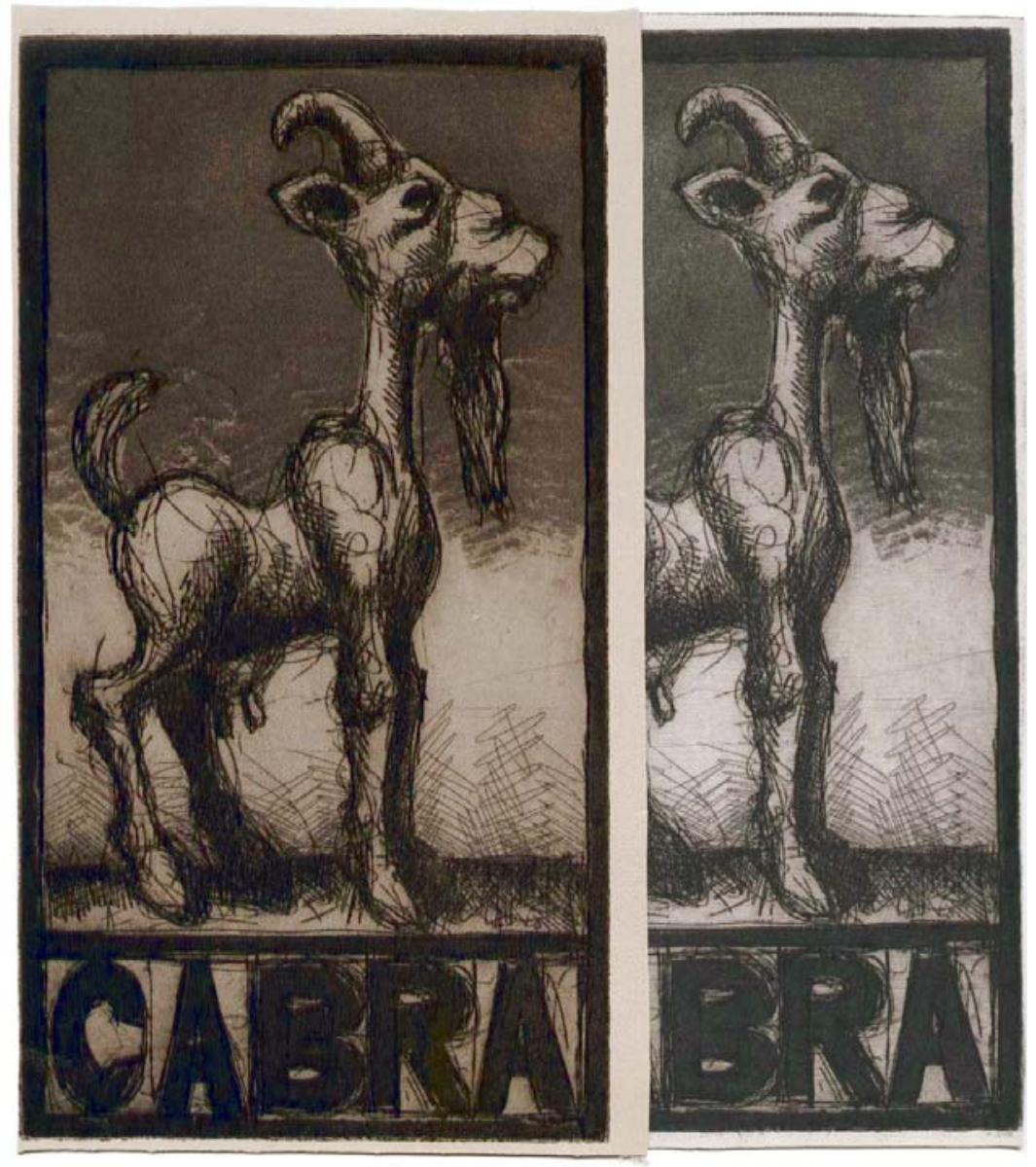

Fig. 82: Estampas CA-025 y CA-026 en las que se ve como el proceso de oscurecimiento en el lado carne es mucho menos intenso que en otros ejemplos. 


\section{- Aguafuerte}

El análisis de los resultados obtenidos en el registro de los grafismos de aguafuerte no presenta tantas particularidades como el relativo a las aguatintas. Como es sabido el registro lineal del aguafuerte es mucho más potente ${ }^{152}$ que la sutil aguatinta y, por consiguiente, es susceptible de superar de manera más satisfactoria los inconvenientes derivados de la textura superficial de los cueros empleados. Al igual que en las zonas solucionadas mediante aguatinta se ofrecen dos tipos de líneas diferentes, unas más sutiles y delicadas y otras de mayor grosor y potencia visual. Las primeras se sitúan en una zona determinada sobre la línea del horizonte de las diferentes estampas, mientras que el segundo tipo será el encargado de dar forma al resto de la imagen, teniendo por tanto un papel preponderante dentro de la estampa. Al igual que con el caso de las aguatintas, analizamos por separado ambos tipos de línea para tratar de buscar diferencias apreciables y conseguir aportar la mayor cantidad posible de información.

Al comenzar a analizar los resultados obtenidos por el aguafuerte sobre el lado flor de los cueros escogidos nos damos cuenta de que aquellos trazos lineales estampados sobre la casi totalidad de las pieles escogidas con un cierto grado de satinado, se

${ }^{152}$ En las líneas formadas por el aguafuerte la tinta se concentra de manera mucho más intensa que en la sutil superficie del graneado del aguatinta. 
registran de modo casi perfecto y sin apenas inconvenientes. Así lo podemos ver en ejemplos como el CA-025, con un registro perfecto en

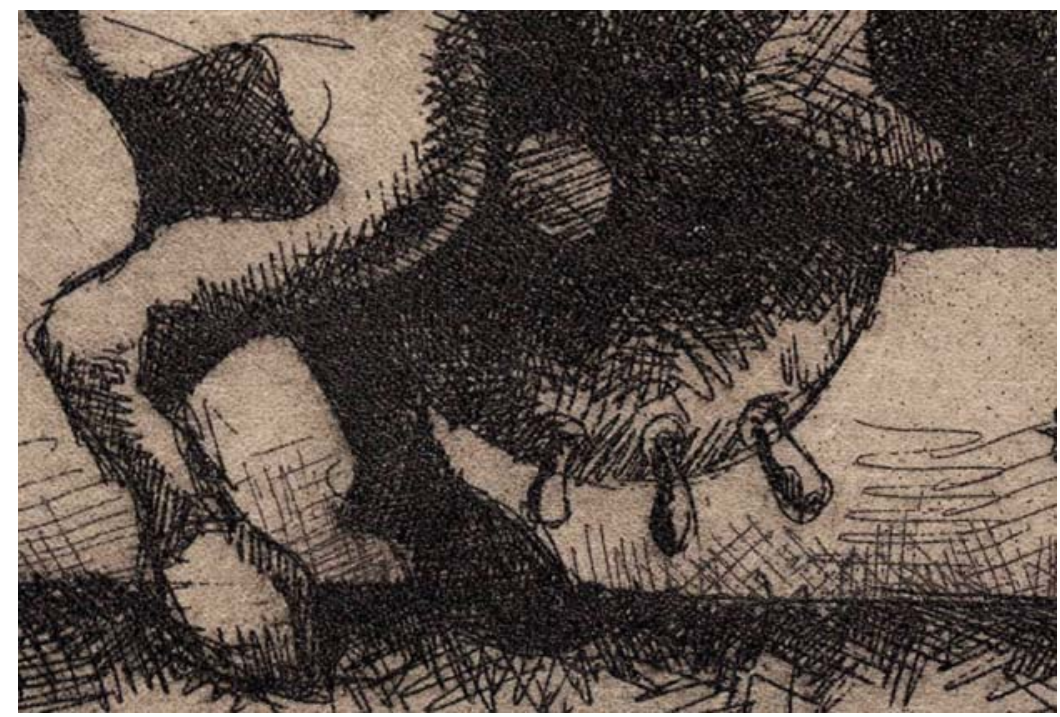

Fig. 83: Detalle de los grafismos de la estampa VA-025.

todas y cada una de las líneas presentes en la plancha, así como en el CE-025, el CO-027 y el VA-025 (fig. 83) entre otros, todos los cuales ofrecen resultados excepcionales en lo que al registro de hasta el más mínimo de los seños del aguafuerte se refiere, e incluso las líneas más sutiles se encuentran reflejadas sin ningún tipo de problema 0 inconveniente. Tan sólo indicar el hecho de que sobre superficies excesivamente satinadas, como las que a veces podemos encontrar en ciertos cueros de cabra y vaca, las líneas pueden tender a ciertas deformaciones producidas por un deficiente asentamiento de la tinta 
sobre un soporte de tales características. Sin embargo, siempre que evitemos dichas pieles, los resultados serán lo suficientemente satisfactorios como para que los cueros sean susceptibles de actuar como soportes para el aguafuerte.

En lo que respecta al lado carne de las pieles las consideraciones pertinentes cambian por el conocido afelpado presente en las mismas. Dicha textura no afecta a los grafismos lineales del aguafuerte tanto como acabamos de ver con respecto a la mancha de aguatinta, debido a su mayor potencia de cubrición, por lo que los resultados son también de gran calidad si exceptuamos los

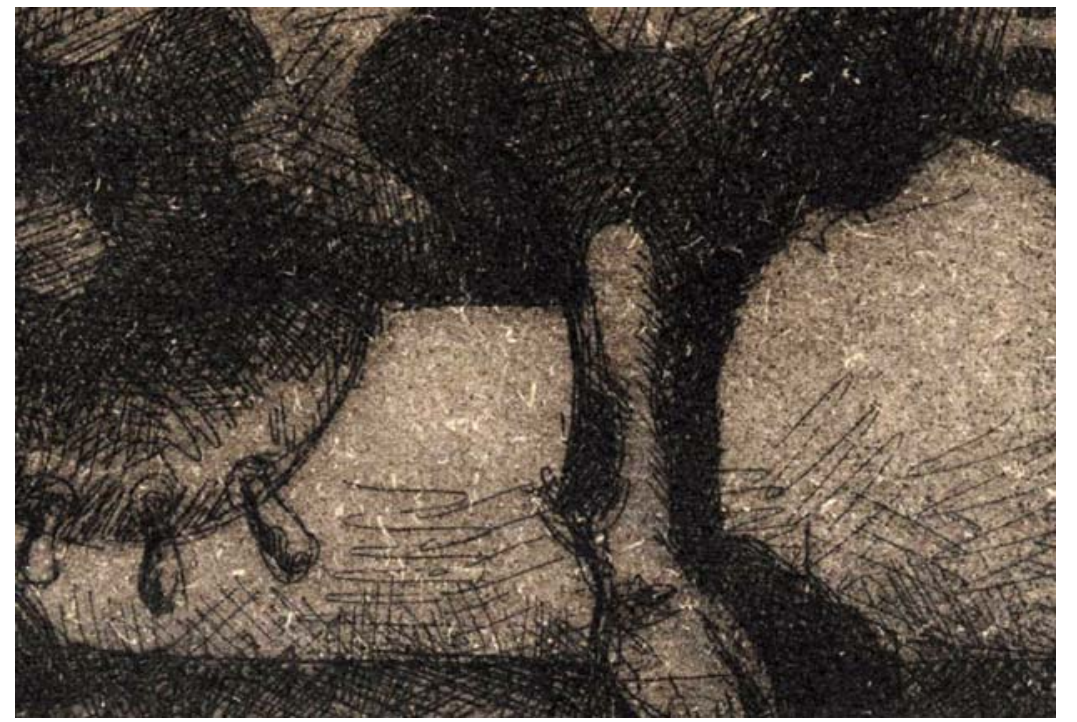

Fig. 84: Detalle de la imagen VA-026 en la que se aprecia el efecto del afelpado del lado flor sobre los grafismos. 
casos en los que el afelpado del cuero es excesivamente acusado. En éstos, las líneas quedan desvirtuadas por efecto de la textura del soporte. Así ocurre en las estampas VA-026 (fig. 84) y VA-030, en las que el afelpado provoca deficiencias en la estampación y el registro de las líneas de la imagen.

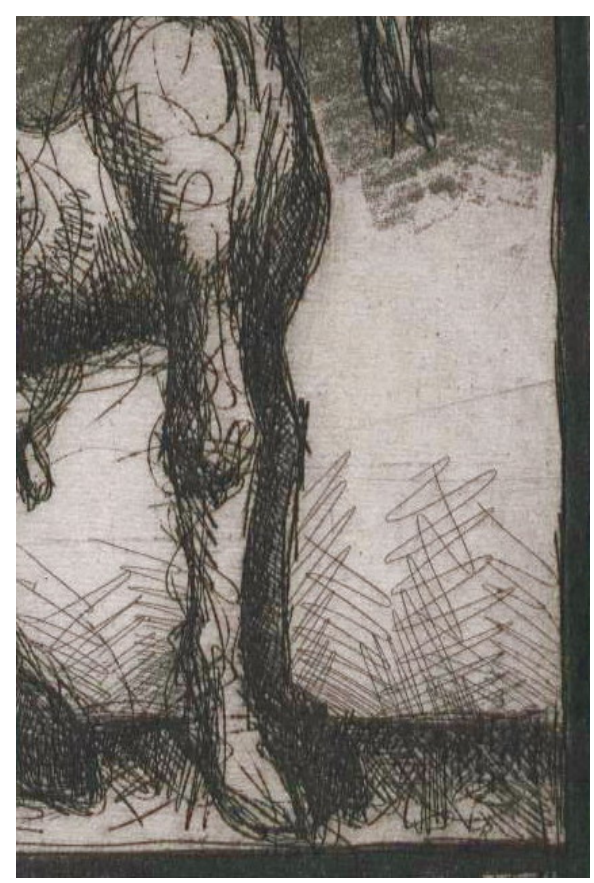

Fig. 85: Detalle de la imagen CA-026 donde se puede apreciar el excelente resultado de los grafismos.
Sin embargo, en los casos en los que las pieles ofrecen un afelpado de gran sutileza en su lado carne, los resultados son prácticamente idénticos a los observados sobre el lado flor, y así lo podemos apreciar en imágenes como la CE-026 y, sobre todo, la CA-026 (fig. 85), una de las mejores imágenes obtenidas sobre pieles junto a su pareja sobre el lado flor, CA-025. 


\section{- Contraste y brillo}

El contraste en estas estampas calcográficas depende casi con totalidad de la relación tonal entre el soporte y la tinta negra empleada, aunque intervienen otros factores cuya incidencia debemos comentar. El primer factor viene determinado por el oscurecimiento del aguatinta al contacto con la superficie afelpada del lado carne de los cueros, que puede afectar a la apariencia general de la imagen y por tanto a su contraste. Relacionado con el afelpado de la piel aparece el segundo de los factores; nos referimos al hecho de que las pieles, sobre todo en su lado carne, presentan una enorme capacidad de absorción de la tinta presente en la plancha calcográfica, fenómeno que, de no haber realizado un entintado correcto, puede provocar que obtengamos una estampa demasiado oscura y carente de contrastes. Si durante la limpieza de la plancha previa a la estampación dejamos demasiada tinta en la matriz, como haríamos en un velo o en un entrapado, 153 el cuero recoge toda la tinta y obtenemos una imagen oscura, con ausencia de zonas limpias y sin contraste ni fuerza plástica. Por tanto es necesaria una limpieza ortodoxamente perfecta de la superficie de la plancha matriz si queremos conseguir una imagen nítida y que refleje de manera fiel las líneas grabadas.

\footnotetext{
${ }^{153}$ El velo o sfumato se realiza dejando una fina película de tinta sobre la superficie de la plancha con objeto de lograr un aspecto más etéreo y menos contrastado de la estampa. Por su lado, el entrapado o retroussage es el proceso por el cual, una vez entintada la plancha, se intenta hacer salir suavemente la tinta presente en las entalladuras para conseguir líneas más cálidas.
} 
Por último el brillo, también aparece como un campo de fácil estudio al venir determinado por la escasa cantidad de tinta que se deposita en la superficie de las pieles. Al contrario que en la xilografía, cuya capa de tinta es muy gruesa, en las estampas calcográficas la tinta aparece con menos intensidad, lo que repercurte en la fuerza de los brillos. Tan sólo en cueros con superficies muy satinadas y brillantes en su lado flor tenemos brillos sobre la piel, los cuales nunca llegan a alcanzar la intensidad observada en las estampas xilográficas. En lo que respecta al lado carne y como ya es de suponer, el brillo es casi nulo e inexistente en la práctica totalidad de las estampas y tan sólo en imágenes sobre cueros con un afelpado mínimo, aparecen ligerísimos brillos en los puntos de mayor acumulación de tinta.

\section{IV.1.2.b. Tinta blanca}

Las estampaciones calcográfícas hechas con tinta blanca sobre soportes de cuero conforman un capítulo especial dentro del corpus general del análisis que venimos realizando; un capítulo destacado, no por su calidad sino por todo lo contrario: por su ínfimo nivel y sus resultados absolutamente negativos. Si ya durante el estudio de las estampas xilográficas realizadas con la misma tinta blanca pudimos comprobar el gran número de inconvenientes que 
aparecían sin cesar, en este caso los problemas se multiplican sin pausa hasta convertir al blanco en una tinta casi inútil para estampar grabados calcográficos sobre pieles animales. Sin embargo, dentro de la mínima calidad que ofrecen estas imágenes podemos hacer una distinción: si están realizadas sobre el lado flor de los cueros no pasan de ser, en el mejor de los casos, mediocres; por su lado, aquellas estampadas sobre el afelpado del lado carne presentan una calidad absolutamente pésima.

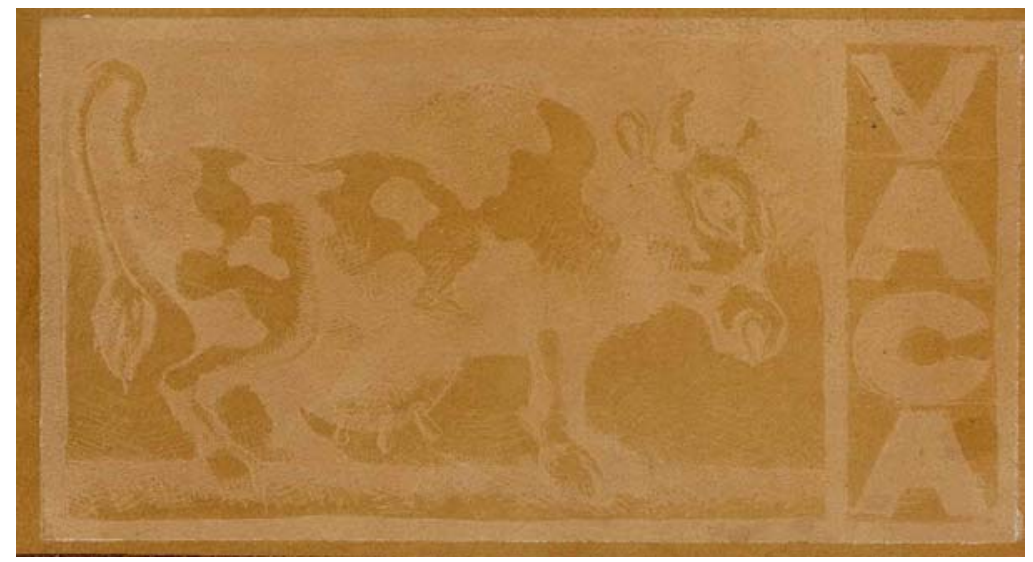

Fig. 86: Estampa con tinta blanca sobre lado carne vacuno.

Este hecho viene provocado por efecto del afelpado de la superficie, que recoge casi la totalidad de la tinta presente en la plancha y también la absorbe y oculta impidiendo una correcta percepción de la imagen. Si observamos la figura (fig. 86), realizada sobre piel de vacuno de tono medio, y tenemos en cuenta que se trata 
de la mejor de las estampas obtenidas sobre el lado carne de los cueros se entenderá que hayamos decidido obviar el análisis pormenorizado de este tipo de impresiones dada su patente inutilidad. Como consecuencia, en el anexo documental tampoco se encontrarán fichas referentes a ellas, aunque los resultados si se tendrán en cuenta a la hora de realizar las estadísticas relativas a la calidad de los procedimientos, pieles y tintas cuyos resultados se expondrán en las consideraciones parciales de los capítulos correspondientes. Por tanto todas las reflexiones aportadas en los siguientes apartados estarán siempre referidas a las estampas obtenidas a partir del empleo de los lados flor de las distintas pieles que conforman este estudio.

\section{- Aguatinta}

Pasando a analizar más concretamente los resultados obtenidos mediante el aguatinta, apreciamos una vez más la poca calidad general de las imágenes. En las pieles claras, con ejemplos como los CA-031 (fig. 87), CE-031, CO-031 y VA-031, tan sólo es ligeramente perceptible en la zona de mayor intensidad, aunque sin $n$ alcanzar nunca un nivel aceptable, y por supuesto muy lejos de lo que podríamos esperar de la tinta blanco cubriente. 


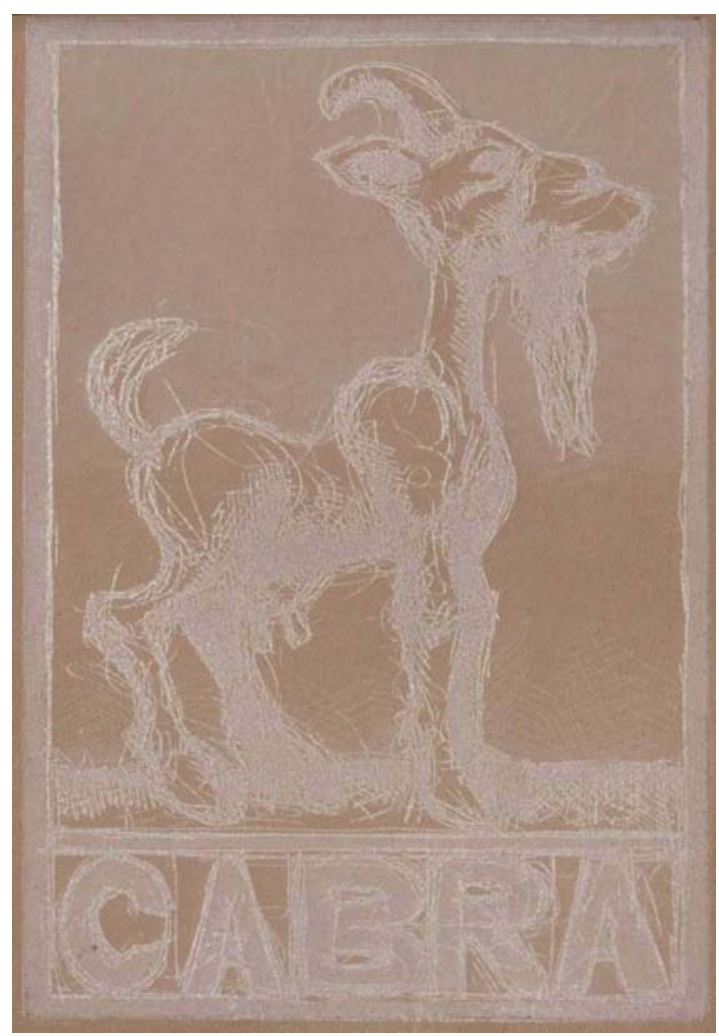

Fig. 87: Estampa CA-031.

Por el contrario en las áreas donde debería observarse las aguatintas algo más ligeras, el tono se mimetiza y confunde con el color del soporte hasta hacerse casi irreconocible. Algo muy similar se repite al analizar los resultados sobre los cueros de tono medio; véanse las imágenes CA-032, CE-032, CO-032 (fig. 88) y VA-032, en las que vuelve a ser muy difícil distinguir el tono del aguatinta más claro del color del cuero que actúa como soporte. Pese a encontrarnos ya con una piel cuyo tono debería permitir que las zonas más potentes 
de la imagen se destacaran de manera evidente, todavía no se hace patente, por lo que las estampas nunca alcanzan un nivel aceptable.

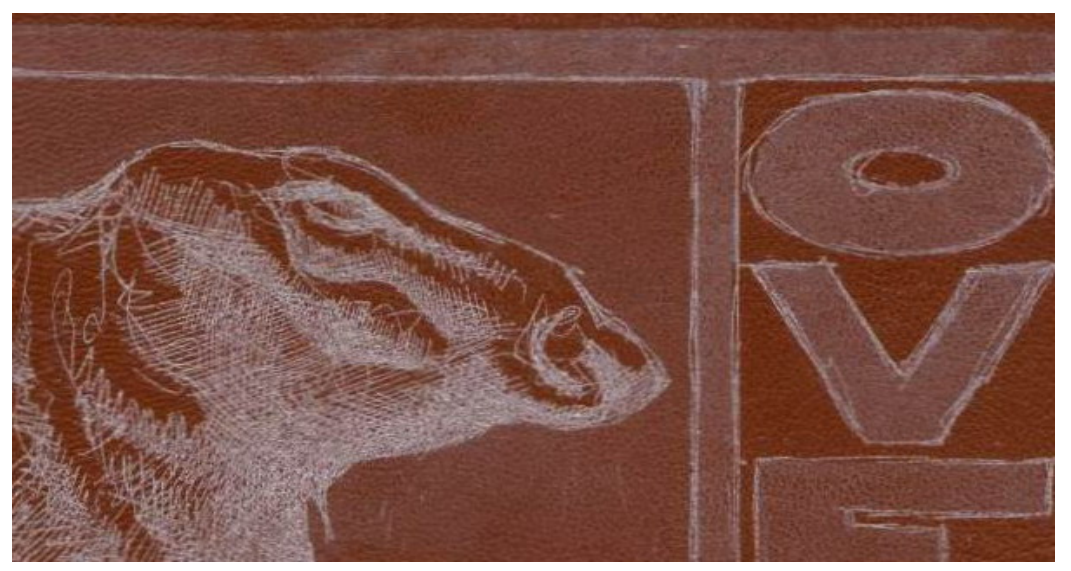

Fig. 88: Detalle de la figura CO-032 en el que aparecen las dos zonas de aguatinta.

Es tan sólo sobre pieles oscuras, donde podemos finalmente encontrar alguna estampa reseñable, imágenes en las que la intensidad del tono se asemeja y acerca algo más a lo que sería deseable. De tal modo, podemos citar y destacar el caso VA-033 y sobre todo el CA-033 (fig. 89), quizás el mejor de este apartado. En esta última impresión podemos distinguir con bastante nitidez algunos tonos de aguatinta, que se diferencian con claridad del color del soporte de piel sobre el que se encuentran estampadas. Sin embargo, esta estampa y los demás resultados obtenidos, no dejan de ser mediocres, y nos hacen mantener la consideración negativa del empleo de la tinta blanca para aguatinta sobre cuero. 


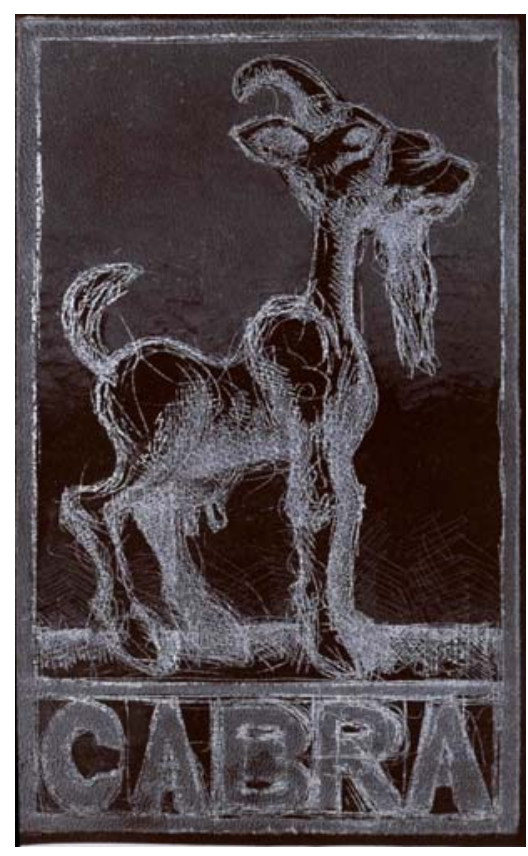

Fig. 89: Estampa CA-033.
El caso de las pieles

de cerdo ofrece alguna particularidad especial que lo diferencia del resto de los cueros escogidos, y requiere de un breve comentario aparte. Como es sabido, la superficie del forro porcino elegido para este estudio presenta una textura mucho más acusada que las restantes, tanto en su lado carne como en el lado flor. Al recibir la impresión del aguatinta, esta superficie rugosa se comporta de manera particular y en este caso, dificulta la correcta estampación de las imágenes. En casos como el CE-032 (fig. 90), podemos ver como la tinta no asienta de manera regular sobre el cuero, sino que presenta cambios de tonalidad asociados a la presencia de los folículos pilosos, que impiden una correcta estampación y producen un resultado deficiente. Es evidente que la extrema debilidad del aguatinta estampada en blanco se ve mucho más afectada por esta superficie heterogénea e irregular, mientras que en el resto de las pieles, con acabados mucho más homogéneos y satinados, desaparecerán estos problemas. 


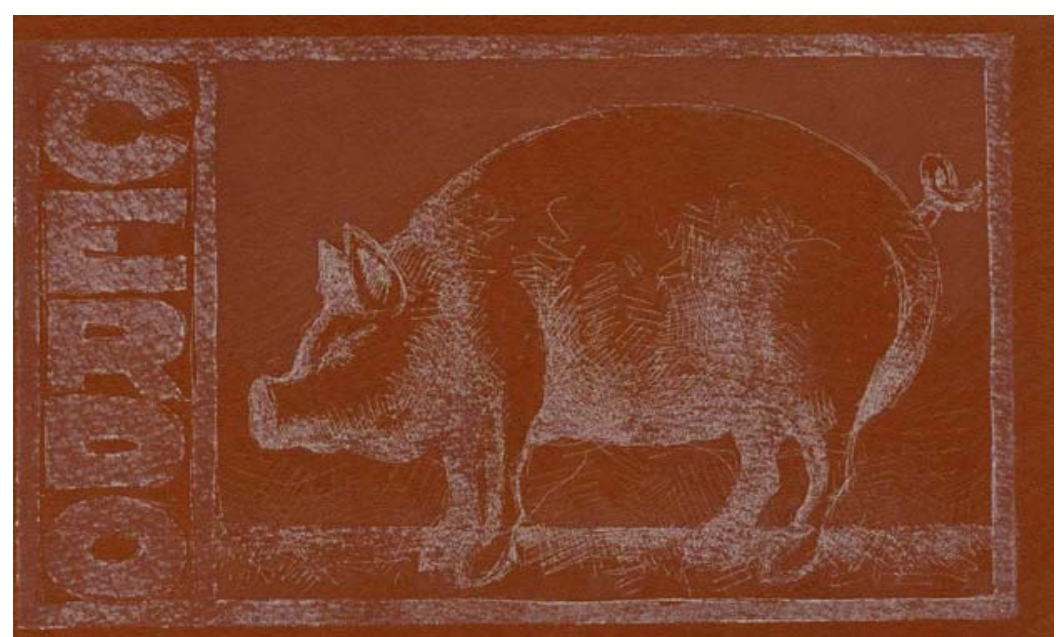

Fig. 90: Estampa CE-032 en la cual se percibe claramente las deficiencias de asentamiento de la tinta blanca.

\section{- Aguafuerte}

La naturaleza del aguafuerte condiciona los resultados obtenidos por la mayor cantidad de tinta depositada sobre el cuero, con los efectos de esta mayor potencia lineal apreciables ya desde los primeros ejemplos analizados sobre pieles claras. Pese a esta mejoría, los resultados del aguafuerte siguen siendo tan negativos como los observados son relación a la mancha de aguatinta, con la consecuente pérdida de nitidez en la mayor parte de los grafismos más potentes, y la casi nula visibilidad de las líneas más finas y sutiles. 
En los cueros de tono medio la situación mejora ostensiblemente como puede comprobarse en los ejemplos CA-032 y C0-032 (fig. 91), en los que las líneas más potentes se registran con relativa calidad siendo perfectamente visibles, lo que no ocurre con los grafismos más sutiles y ligeros, los cuales todavía no son apreciables con excesiva nitidez en casi ninguno de los casos analizados.

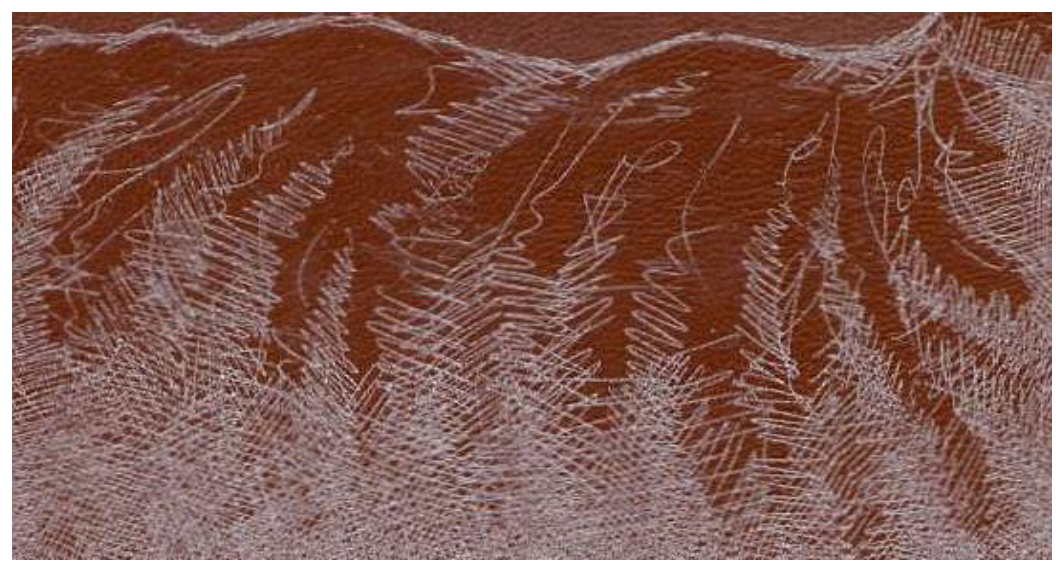

Fig. 91: Detalle de los grafismos de la estampa CO-032.

En las pieles oscuras es donde obtenemos los mejores resultados de toda la serie, en los que, a pesar de los inconvenientes ya conocidos por la poca intensidad del tono de blanco alcanzado, podemos ya encontrar registrados casi la totalidad de las líneas y los grafismos. Así ocurre sobre todo en la estampa CA-033 (fig.89), sin duda la mejor de las conseguidas con tinta blanca, al aparecer nítidamente los grafismos más ligeros del aguafuerte, mientras que el 
resto de las líneas más potentes alcanzan un nivel de intensidad bastante correcto.

Si durante el análisis del aguatinta nos hemos visto obligados a distinguir las estampas obtenidas sobre cueros porcinos por su deficiente calidad, en este caso nos vemos en la misma situación. En efecto, la textura de las pieles también afecta a las líneas del aguafuerte, tal y como podemos ver en las imágenes CE-032 (fig. 92) y

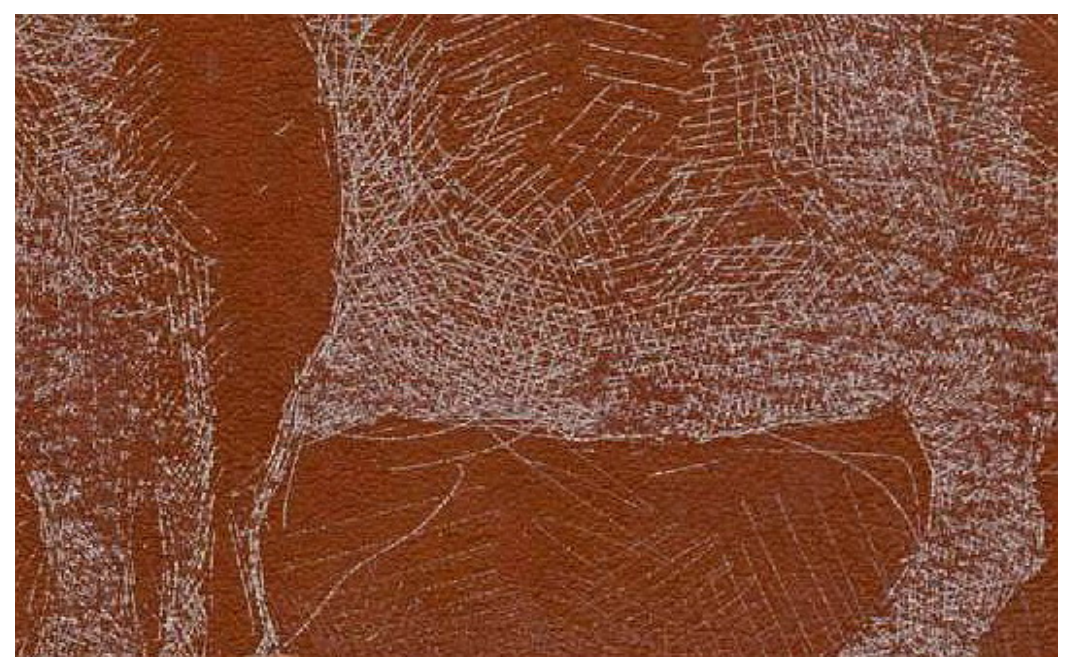

Fig. 92: Detalle de los grafismos deficientemente estampados de la imagen CE-032, con innumerables complicaciones y problemas.

CE-033. En ellas el registro de los grafismos se ve interrumpido y modificado en numerosas ocasiones por efecto de los folículos pilosos presentes en la superficie de la piel, impidiendo una imagen nítida y correcta. Mientras que otras tintas, como la negra 0 , como veremos 
más adelante, la azul opaca, son capaces de superar estos inconvenientes, la tinta blanca no lo hace, por lo que la calidad de las estampas es a todas luces deficiente.

\section{- Contraste y brillo}

El campo del contraste en estas estampas viene determinado, en todos los casos, por la intensidad alcanzada por la tinta blanca al ser recogida por los cueros, y mientras la tinta negra apenas cambiaba de intensidad ni tono al ser estampada sobre las pieles, no ocurre lo mismo con la tinta blanca. Ya hemos analizado los fenómenos que sufre el nivel de intensidad de la tinta blanca en los diferentes tipos de cueros y de ellos depende el contraste de las distintas estampas. Así, en los casos en que la tinta blanca no alcanza un tono elevado y cercano al blanco cubriente que sería ideal, el contraste se resiente de manera evidente, lo que ocurre en la inmensa mayoría de las veces. Tan sólo en los casos en los que se unen en una misma estampa un nivel aceptable de intensidad de la tinta junto con un tono lo suficientemente oscuro del soporte, aparece un nivel de contraste que permite obtener una imagen potente y plásticamente atractiva, cosa que ocurre en ejemplos como el CA-033 o el CO-033 (fig. 93). 
Por lo que respecta al brillo, en ninguno de los casos aparece ningún tipo de brillo o reflejo sobre la superficie de la tinta. Es más, debido a la naturaleza absolutamente mate de la tinta blanca, en los casos en que el soporte piel presenta algún tipo de acabado satinado acompañado de brillos, la propia tinta oculta dichos reflejos aportando a la imagen una apariencia eminentemente mate.

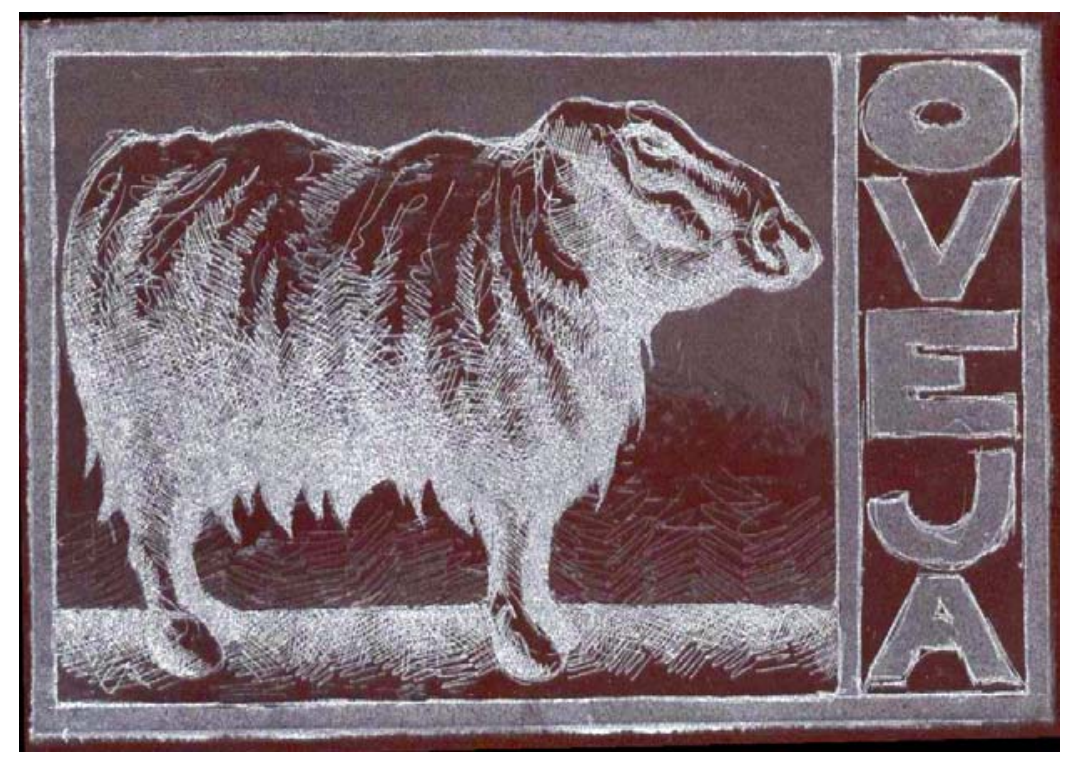

Fig. 93: Estampa CO-033, una de las mejores con tinta blanca. 


\section{IV.1.2.c. Tinta azul traslúcido}

Como ya ocurriera al analizar las imágenes xilográficas obtenidas mediante el empleo de esta tinta, en este caso aparecen llamativos fenómenos, algunos de los cuales se encuentran entre los más interesantes de todo el estudio. El alto porcentaje de preparación traslúcida presente en la mezcla usada provoca la aparición de estampas de gran luminosidad, nitidez y limpieza, con algunos de los mejores ejemplos de imágenes calcográficas de todo el grupo de casos estudiado.

\section{- Aguatinta}

En la práctica totalidad de los ejemplos analizados, los resultados obtenidos son de un nivel altísimo, tanto en el lado carne como en el lado flor de las pieles. La nitidez y la limpieza del registro de los tonos del aguatinta es muy elevada, consiguiéndose de tal modo áreas homogéneas y regulares en la mayoría de los casos. Tan sólo en estampas realizadas sobre superficies excesivamente afelpadas se pueden apreciar inconvenientes derivados del efecto de la textura característica del lado carne, como ocurre en las imágenes CO-035 y VA-035 (fig. 94), en las que el nivel de registro continúa siendo sin embargo muy aceptable y satisfactorio. 
Al igual que en el caso de las estampas xilográficas, el uso de esta tinta provoca la acentuación de todos los fenómenos comentados, ya sea la mezcla por transparencia como el oscurecimiento del tono de la tinta al contacto con una superficie afelpada. El primero aparece en todas las imágenes de este apartado, ya esté estampada sobre el lado

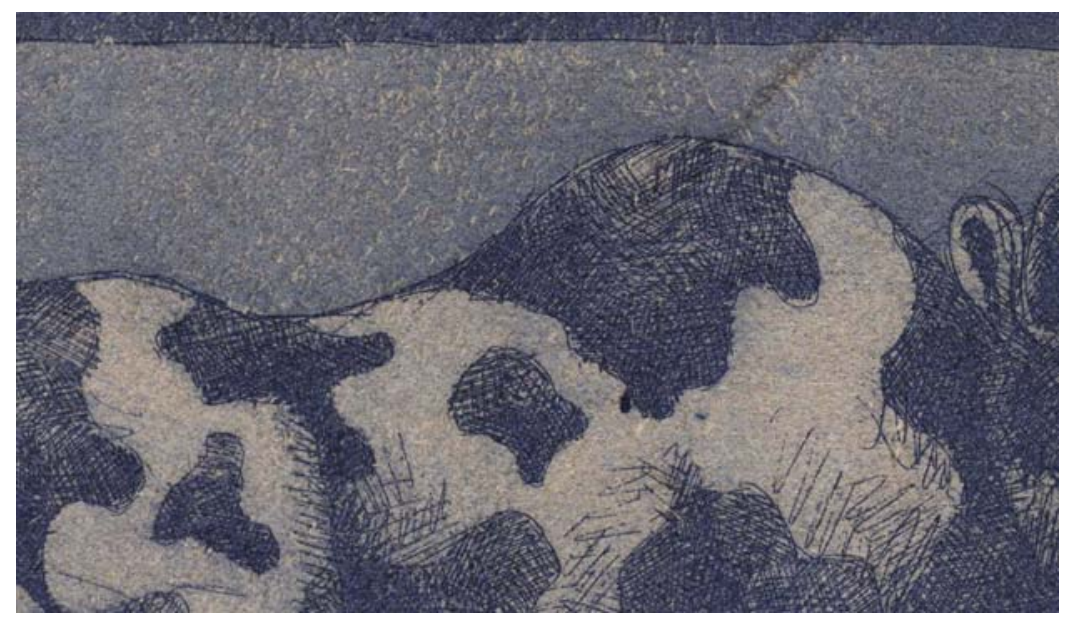

Fig. 94: Detalle de la estampa VA-035, donde se aprecia el afelpado del lado carne del cuero.

flor como sobre el lado carne. Sin embargo, este efecto de cambio cromático no es tan visible y apreciable como lo era en los ejemplos xilográficos, presentándose de manera más atenuada, tal y como puede comprobarse en la fig. 95, en la cual aparecen, tanto las estampas realizadas mediante xilografía como las calcográficas que estamos analizando en estos momentos. 


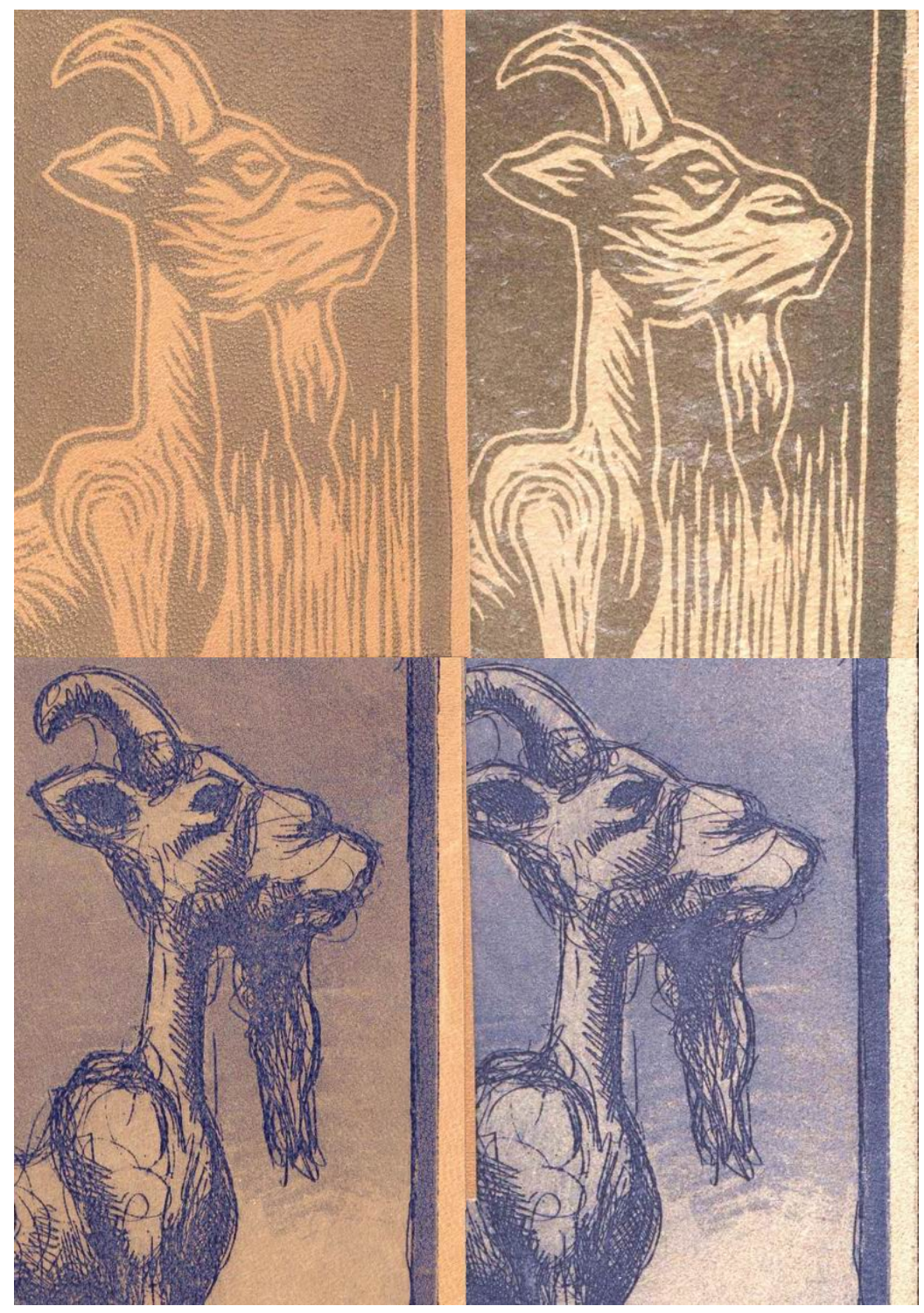

Fig. 95: Varias estampas realizadas con azul traslúcido. De izquierda a derecha y de arriba abajo: xilografía flor, xilografía carne, calcografía flor y calcografía carne. 
El oscurecimiento de la tinta al contacto con la textura afelpada continúa repitiéndose en todas las estampas del lado carne, aunque su efecto no es tan patente como en las imágenes xilográficas, las cuales se muestran mucho más sensibles a estos cambios provocados por la naturaleza del soporte de piel. De nuevo podemos comprobarlo en la fig. 95, en la que es visible el distinto grado de influencia de los fenómenos según la técnica con la que trabajemos las estampas.

\section{- Aguafuerte}

Los trazos lineales del aguafuerte presentan también efectos similares a los de las zonas de aguatinta, aunque con características específicas como corresponde a la naturaleza de cada técnica concreta. La mezcla por transparencia continúa apareciendo en la totalidad de los ejemplos aunque disminuida por la mayor cantidad de tinta depositada en los grafismos del aguafuerte, la cual dificulta dicho efecto. También el oscurecimiento de la tinta al contacto con el afelpado del lado carne es patente en todos los casos, pero sin alcanzar las diferencias que se observaban al comparar dos imágenes xilográficas, tal y como vemos en la fig. 95.

El inconveniente principal derivado del empleo de estas tintas viene dado al estampar sobre superficies excesivamente satinadas y brillantes. En situaciones como las de las imágenes CA-034 (fig. 96), 


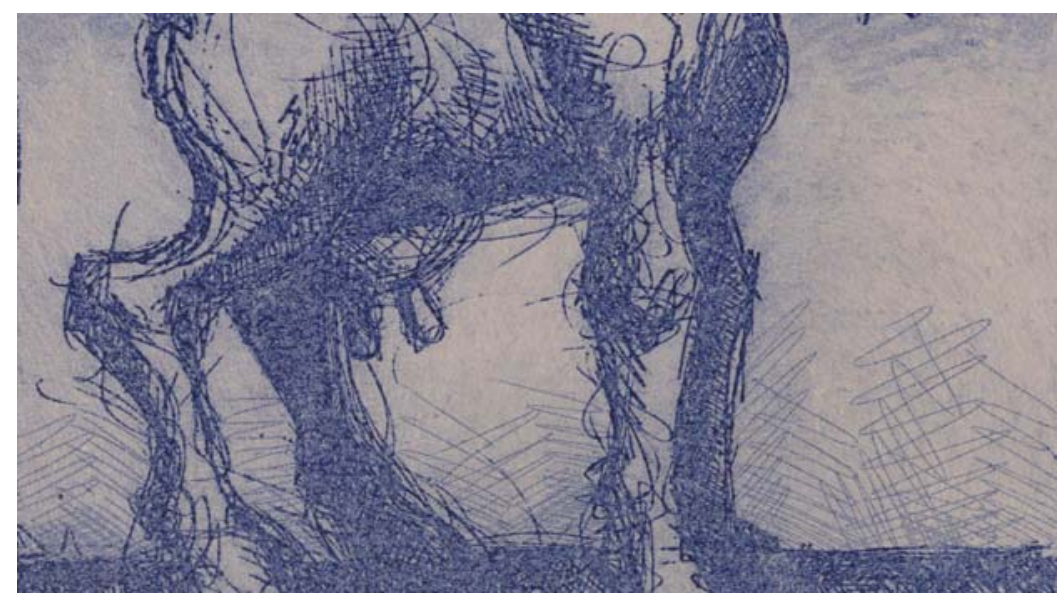

Fig. 96: Estampa CA-034 en la que se pueden apreciar los incómodos grumos producidos por el deficiente asentamiento de la tinta.

en las que los cueros utilizados ofrecen un acabado pulido y sin apenas textura, la tinta azul traslúcido presenta deficiencias derivadas de un incorrecto asentamiento sobre superficie del cuero. Provocado por este hecho aparece la textura grumosa, centrada y localizada en las zonas de mayor densidad de grafismo por la consiguiente acumulación de tinta. En dichas áreas el soporte de cuero satinado se ve incapaz de absorber satisfactoriamente la carga de tinta, lo cual provoca que se desvirtúe el registro lineal, con efectos muy desagradables en algunas ocasiones.

Pese a las deficiencias y problemas, el nivel alcanzado con estas tintas es muy alto y, en casi todos los casos analizados, los resultados son muy satisfactorios, ya sea en los grafismos más gruesos y potentes como en aquellos más sutiles. Unos y otros se 
registran casi a la perfección, y sólo en casos en los que el soporte escogido ofrece un afelpado excesivamente acusado, véase el ejemplo VA-039, pueden llegar a apreciarse mínimas deficiencias de registro.

\section{- Contraste y brillo}

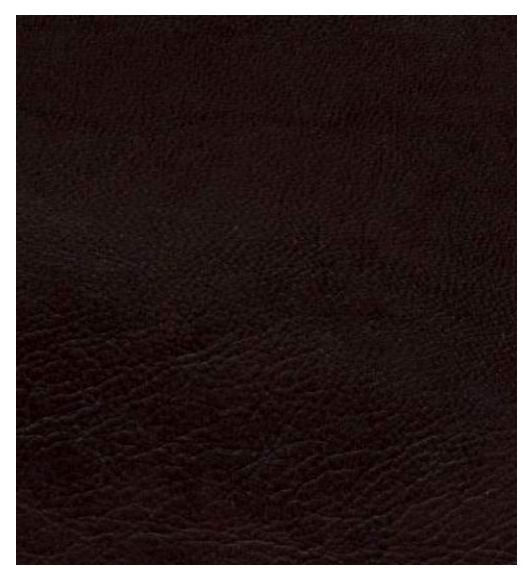

Fig. 97: Detalle de la estampa CO.038 en la que se aprecia el inexistente contraste.
Pese a lo que podría suponerse al emplear una tinta con tal carga de preparación traslúcida en su composición, en la mayoría de las estampas conseguidas se alcanzan unos niveles de contraste lo suficientemente elevados como para dar lugar a una correcta visión de las imágenes. Esto es debido fundamentalmente a la mezcla por transparencia y al oscurecimiento de la tinta, los cuales provocan cambios en la intensidad original de la tinta hasta conseguir que ésta contraste con los soportes de piel. Es obvio que también el tono de la superficie del cuero es un factor fundamental para lograr intensidad en lo que al contraste se refiere, pero tan sólo en ejemplos muy puntuales, como el CO-038 (fig. 97) entre otros, el tono del cuero provocará que el 
contraste sea tan mínimo que impida apreciar correctamente la imagen estampada.

El análisis del brillo viene determinado por la superficie elegida para ser utilizada como soporte. Como era de esperar, sobre el lado carne de los cueros los reflejos son totalmente inexistentes por efecto del afelpado, mientras que en lo referente al lado flor podremos encontrar una cierta gama de brillos. Así, en impresiones realizadas sobre cueros porcinos, los reflejos son casi inapreciables y no dificultan una correcta visión de la imagen, algo parecido a lo que ocurre en algunos cueros vacunos y ovinos. ${ }^{154}$ En el otro extremo tenemos estampas realizadas sobre cueros oscuros muy satinados y ya de por sí brillantes, los cuales presentan excesivos reflejos que llegan a resultar molestos a la hora de apreciar la estampa. A medio camino entre estos extremos podemos encontrar todo un abanico de brillos asociados a la naturaleza particular de cada tipo de cuero concreto, pudiendo cambiar éstos según el acabado particular que cada pellejo posea.

\section{IV.1.2.d. Tinta azul opaco}

Ya vimos dentro del apartado xilográfico como las imágenes obtenidas mediante el empleo de estas tintas eran totalmente

\footnotetext{
${ }^{154}$ Como las estampas VA-034 y CO-034.
} 
diferentes a las de las tintas blancas o traslúcidas, y muy similares a las alcanzadas utilizando tintas negras. Los ejemplos que analizamos a continuación están en la misma línea que las conclusiones parciales que pueden extraerse de aquel análisis, aunque aportan nuevas características que completan el estudio de las estampas calcográficas.

\section{- Aguatinta}

En general, los resultados obtenidos en casi todas las estampas son muy correctos y de gran calidad, ya que la ausencia de preparación traslúcida hace que la tinta posea una potencia visual que le permite crear zonas homogéneas y regulares sobre las distintas superficies de los cueros. Los dos tonos del aguatinta son perfectamente distinguibles en todos los casos, y tan sólo en los ejemplos realizados sobre soportes excesivamente afelpados sus intensidades se acercan, aunque sin llegar nunca a confundirse. De nuevo debemos referirnos a los factores de mezcla por transparencia y de oscurecimiento de la tinta. La primera es obviamente mucho menor estas estampas que en las conseguidas empleando tinta traslúcida, la cual es mucho más sensible al tono del soporte. Sin embargo, y pese a la mayor fuerza plástica y cromática de las tintas opacas, su efecto no desaparece por completo, pese a que es más difícil de apreciar dado que los tonos obtenidos son mucho más oscuros que los de las tintas 
traslúcidas. Observando el ejemplo CE-042 (fig. 98) podemos darnos cuenta perfectamente de lo comentado ya que el tono azul de la tinta se ha convertido en un color violáceo oscuro de gran intensidad. Algo similar ocurre en otras estampas sobre cueros de cordero o vacuno, consiguiéndose tonalidades cromáticas de gran riqueza y muy difíciles de reproducir fuera del contexto concreto en el que han visto la luz.

El oscurecimiento del tono de la tinta es también más que evidente en muchos casos de estampaciones sobre el lado carne de los cueros, aunque al igual que comentábamos al referirnos a las aguatintas, la diferencia con el tono obtenido sobre el lado flor de la misma piel nunca alcanza las cotas apreciadas al trabajar con tintas traslúcidas.

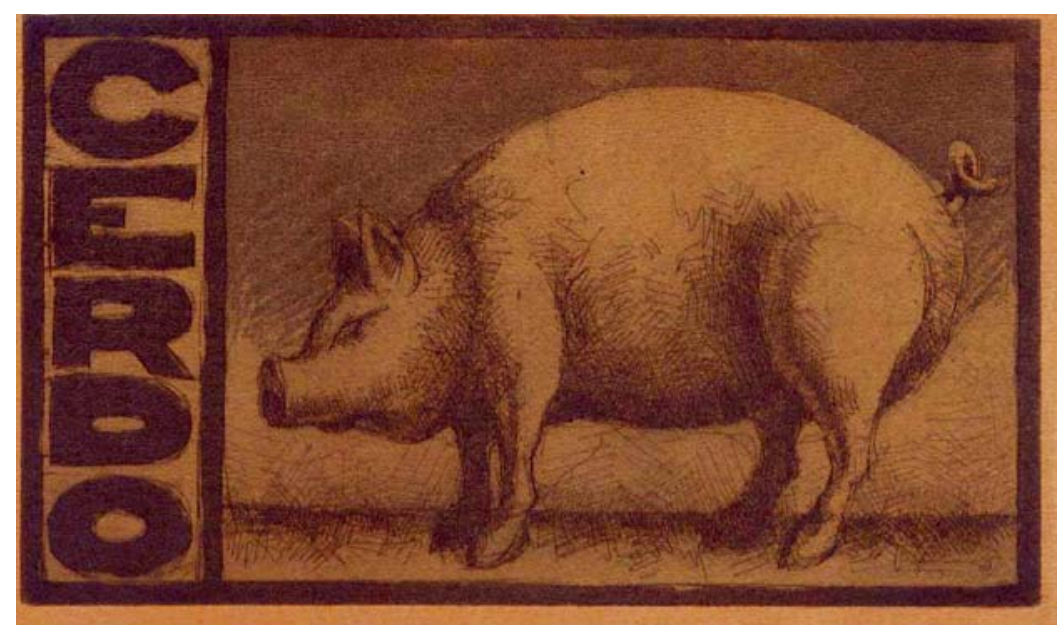

Fig. 98: Estampa CE-042. 


\section{- Aguafuerte}

Antes de pasar a comentar las posibles particularidades de cada uno de los ejemplos particulares, indicar que los resultados alcanzados en lo que al registro lineal se refiere son excelentes. La tinta azul opaco se comporta de manera similar a la negra en lo que a potencia y definición se refiere, logrando una nitidez de grafismos absolutamente excepcional. No hay más que analizar imágenes como las CA-041, CE-043, CO-040 (fig. 99) o VA-042 para darnos cuenta que tanto sobre superficies lisas como sobre soportes que presentan acabados afelpados y rugosos, el comportamiento de la tinta es

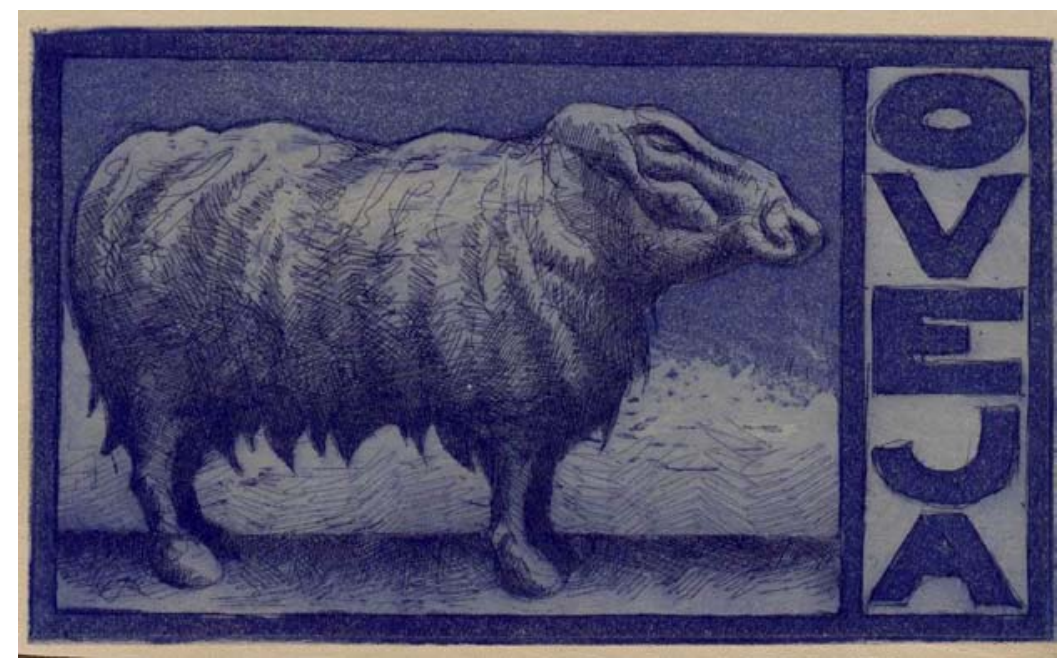

Fig. 99: Imagen CO-040, una de las mejores de las realizadas con la tinta azul opaco. 
excelente. Tanto los grafismos más potentes como los más sutiles se encuentran perfectamente reflejados sobre el cuero con una nitidez extraordinaria, a la par que configuran imágenes de gran potencia visual.

En lo que respecta a los fenómenos de mezcla y oscurecimiento tonal, los grafismos estampados con esta tinta no pueden ser ajenos a sus efectos, aunque sea de manera mucho más leve que en otros casos como los del aguatinta o el de la tinta azul traslúcido. De tal modo, se produce un cierto oscurecimiento al contacto con el afelpado del lado carne de una piel, aunque en muchas ocasiones es casi imperceptible si lo comparamos con el estampado sobre el lado flor de la misma piel. Tan sólo hay que comparar cualquier pareja de estampas para darnos cuenta de que el fenómeno es prácticamente inapreciable. La mezcla por transparencia sigue por el contrario las mismas normas que las establecidas al referirnos a las aguatintas del apartado anterior, y consigue también interesantes tonalidades de marcada diferencia con el color original de la tinta empleada.

Si al estudiar los aguafuertes de las imágenes estampadas con tinta traslúcida hemos visto cómo en las zonas de mayor densidad de tinta se producía el desagradable efecto de granulado, éste desaparece ahora. En ninguno de los cueros sobre los que se había observado dicho inconveniente vemos que se repita al utilizar tintas opacas, por lo que se deduce que el problema podría estar suscitado 
por la preparación traslúcida presente en la composición de la tinta, ausente en este caso, lo que hace que desaparezca el problema.

\section{- Contraste y brillo}

Dado que el oscurecimiento de la tinta no es tan acusado como en otras ocasiones, el nivel de contraste que posean las imágenes viene determinado casi en exclusividad por la relación tonal entre la tinta y el soporte, pudiendo encontrar toda una gama de intensidades. Tan sólo en impresiones sobre cueros muy oscuros el contraste es tan escaso como para casi impedir la apreciación de la imagen, tal y como ocurre en los casos CE-044 (fig. 100) y CO-044.

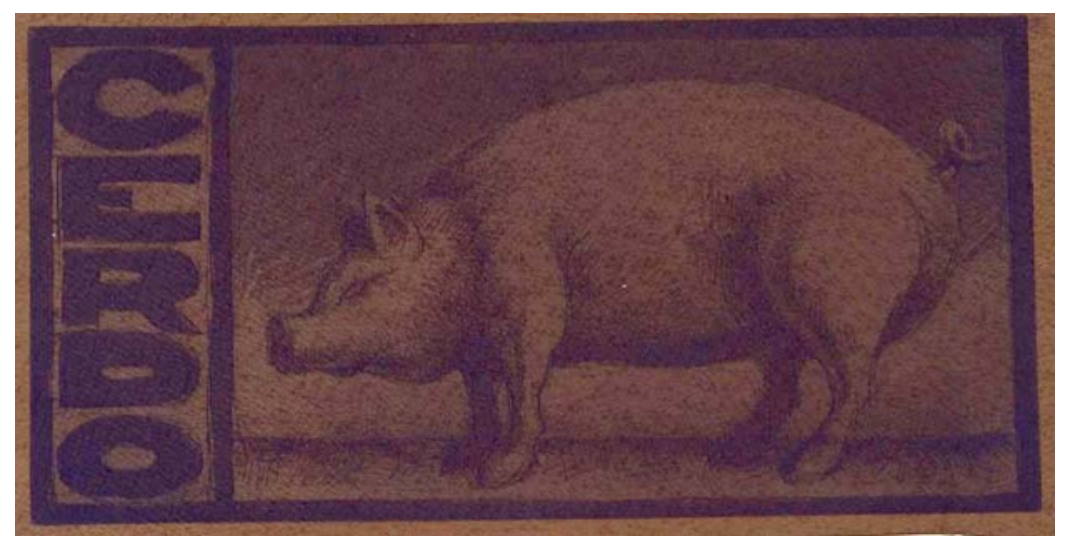

Fig. 100: Imagen CE-044, en la que el tono tan oscuro del soporte provoca que el contraste no sea excesivamente intenso. 
IV. Análisis y catalogación

En cuanto al brillo, la tinta azul opaca se comporta de manera casi idéntica a la negra, por lo que se puede aplicar en este caso las conclusiones alcanzadas en el apartado V.2.1.C. 


\section{IV.1.3. Reflexiones parciales}

Analizadas las diferentes respuestas de los cueros ante las impresiones de grabado, podemos ofrecer algunas consideraciones y reflexiones extraídas de dicho estudio parcial. Para tal fin nos apoyamos en los resultados estadísticos configurados mediante el recuento de las calificaciones cualitativas otorgadas a las estampas. ${ }^{155}$ Esas calificaciones han sido valoradas con respecto a los criterios convencionales establecidos al inicio de la experimentación y reseñadas en el cap. IV.1. Así, esta fase está orientada a dilucidar qué tipos concretos de cueros se muestran como adecuados para continuar trabajando en las actuaciones prácticas de la investigación, en las cuales se seleccionarán únicamente aquellos soportes que mejores resultados ofrezcan para una correcta estampación. Antes de pasar a comentar en profundidad las estadísticas, consideramos necesario ofrecer algunas anotaciones de carácter general, y aportar las recomendaciones de trabajo que hemos observado y consideramos fundamentales para una impresión satisfactoria. Nos referimos a la presión que se debe ejercer para la estampación, y a la tinta que se debe aplicar a la plancha matriz.

155 Toda la información estadística se encuentra recogida en al Apéndice Documental, capítulo II, p. 397 y siguientes. 
- Presión

La primera de estas indicaciones, la presión del tórculo durante la estampación, es un factor al que nos hemos referido de manera esporádica en los apartados anteriores, la cual debe ajustarse para evitar un exceso que produzca inconvenientes de difícil solución sobre la estampa. En lo que respecta a la xilografía, esta atención a los niveles de presión es todavía más importante debido a que cualquier exceso de presión provoca deformaciones del trazo y de los contornos de la imagen, como puede apreciarse en la fig. 101. Sin embargo, no quedan aquí los problemas que pueden aparecer al estampar planchas xilográficas, sino que incluso pueden provocarse deformaciones de la propia piel y, dependiendo de su elasticidad o rigidez, dichos

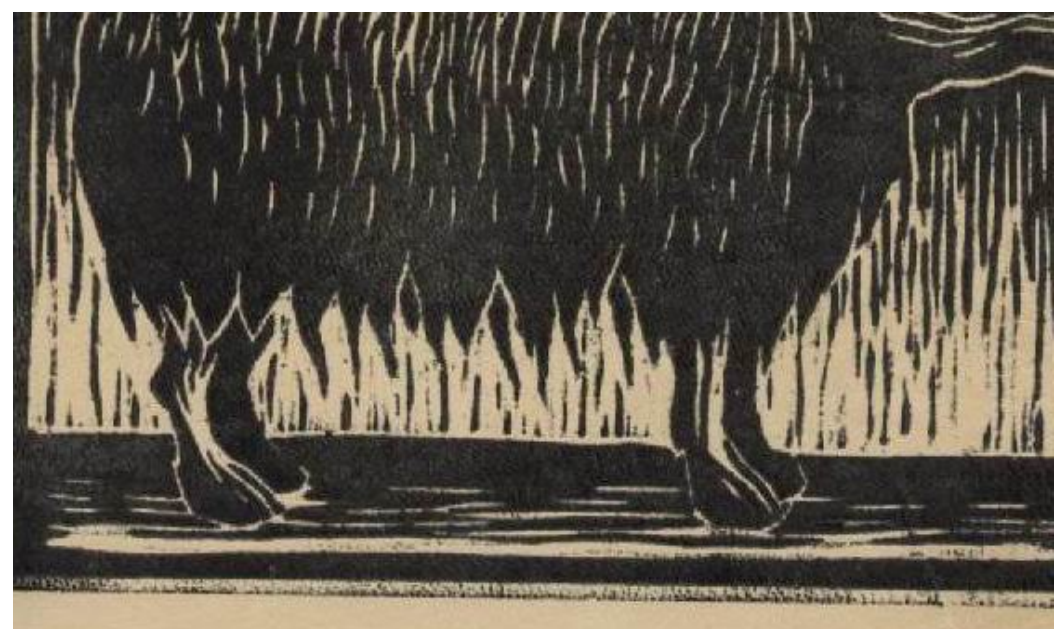

Fig. 101: Detalle de una estampación con exceso de presión, la cual se manifiesta en las deformaciones de los bordes de la imagen. 
problemas serán más o menos acuciantes. ${ }^{156}$

\section{- Cantidad de tinta}

El otro factor a tener en cuenta con vistas a evitar inconvenientes indeseables durante la estampación, es la cantidad de tinta presente en la matriz, y como norma general, debe aplicarse la mínima necesaria para una impresión satisfactoria. Los problemas derivados de un exceso son diferentes dependiendo de la técnica empleada; así, en las estampas xilográficas puede provocar deformaciones en los contornos de las zonas de tinta, sobre todo al

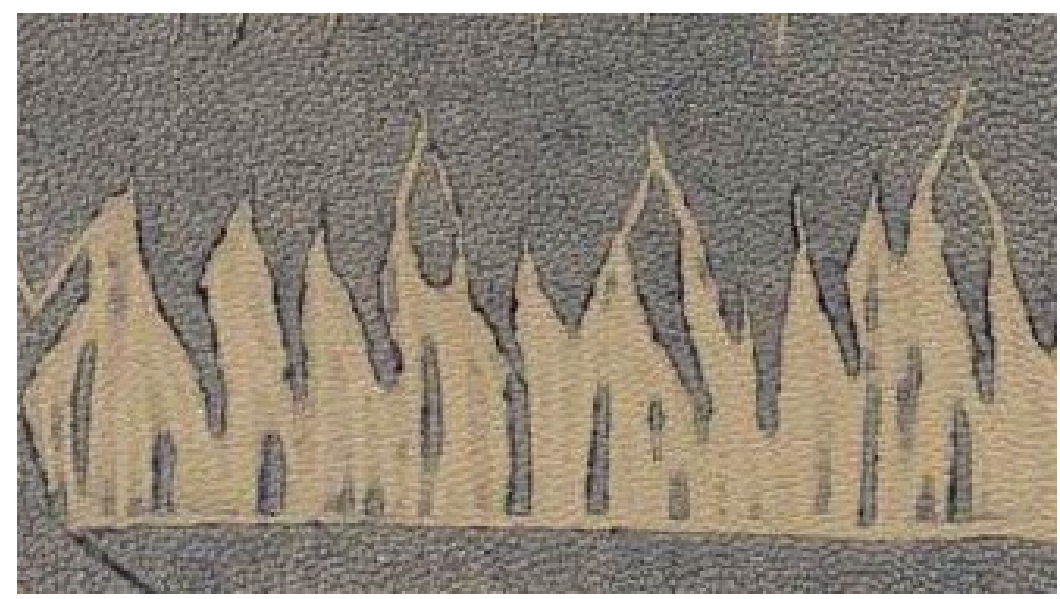

Fig. 102: Detalle de una estampa xilográfica que presenta un exceso de tinta.

156 Son especialmente graves en cueros como los de cordero, de gran 
trabajar sobre superficies muy satinadas, en particular sobre los lados flor como puede verse en la fig. 102. Este fenómeno de deformación de los contornos es muy similar en apariencia al apreciado al estampar con unos niveles de presión excesiva, pese a que están motivados por factores totalmente diferentes.

Por su parte las imágenes calcográficas impresas con una cantidad excesiva de tinta aparecen oscuras, sucias y carentes de contraste por efecto del extraordinario poder absorbente de los cueros, de tal modo que se hace necesaria una limpieza ortodoxa de la plancha para evitar la aparición de estos inconvenientes.

Aclarados brevemente estos dos factores comunes a toda estampación de grabado, podemos pasar a comentar de manera pormenorizada los resultados globales del proceso de estampación, para lo cual dividimos los siguientes apartados en relación a la técnica empleada para la realización de las imágenes.

elasticidad. Véase apartado III.1.3., p. 163. 


\section{IV.1.3.a. Estampas xilográficas}

Del total de las 96 imágenes xilográficas incluidas en la experimentación, el 61,5\% presenta un resultado positivo ${ }^{157}$ (32,3\% de estampas muy buenas y $29,2 \%$ buenas) frente a tan sólo un $14,6 \%$ del

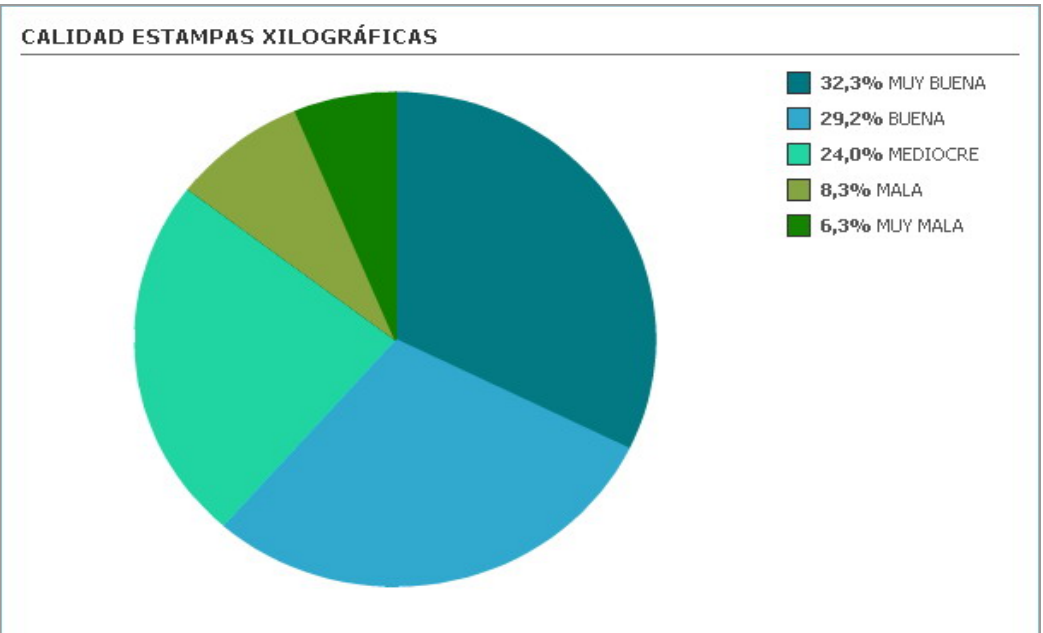

Fig. 103:

global con calificación negativa. Podemos por tanto comprobar, por los datos estadísticos, que los soportes de cuero presentan una superficie muy válida a la hora de realizar estampaciones xilográficas (fig. 103).

${ }^{157}$ A partir de ahora entenderemos positivo como aquel que engloba las calificaciones de buena y muy buena, y negativo el que hace lo propio con mala y muy mala. 
Sin embargo, los resultados de la experimentación nos proporcionan una gran cantidad de datos alternativos que permiten ofrecer una serie de conclusiones de interés. De tal modo, podemos distinguir entre las estampas realizadas sobre el lado flor y el lado carne de los cueros, distinción que indica el mejor resultado de las imágenes realizadas sobre la cara interna de los cueros, sobre el lado carne. El 64,6\% de dichas impresiones presenta una calificación positiva, con un $39,6 \%$ de casos de muy buena calidad, frente al $58,3 \%$ de las obtenidas sobre el lado flor de los mismos cueros.

Esta comparación permite afirmar que los cueros ofrecen una mejor respuesta a la impresión xilográfica cuando se usa el lado carne como superficie receptora de la tinta, aun cuando los resultados del lado flor son también muy positivos. ¿A qué puede ser debida esta diferencia? Sin duda al hecho de que la tinta asienta mejor sobre un soporte ligeramente rugoso, como el afelpado propio del lado interno de los cueros, que sobre una superficie, en ocasiones demasiado satinada, como la que se puede encontrar en los lados flor de muchas pieles.

Pasando a comentar los resultados en relación a las distintas pieles, aparecen estadísticas muy llamativas que conviene analizar en profundidad. De los cuatro cueros empleados en la experimentación hay tres que ofrecen una respuesta sustancialmente mejor que el restante, y así, las pieles de cabra, cerdo y cordero se muestran como soportes de altas prestaciones, quedando algo rezagado el cuero 
proveniente de ganado vacuno. Este último tan sólo ofrece un 45,9\% de estampas con calificación positiva, frente al $66,6 \%$ de los cueros de cabra y cerdo, y el 70,9\% de las pieles ovinas. Estos cueros de cordero destacan sobre el resto con un $45,9 \%$ de impresiones de muy buena calidad, porcentaje que casi llega a doblar al de otros soportes como los de ganado caprino o vacuno (fig. 104).

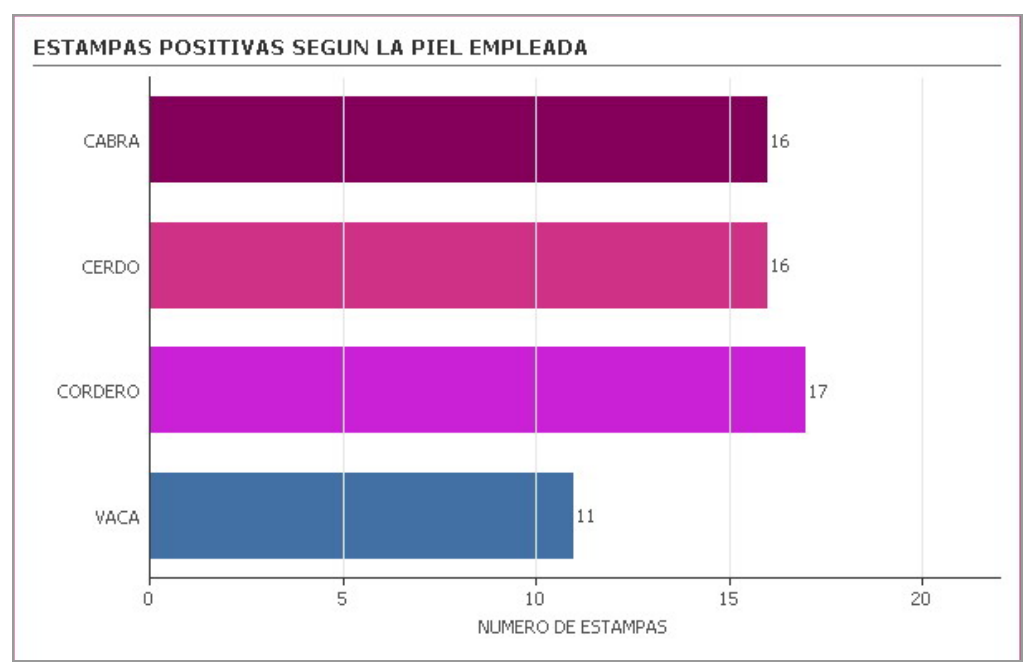

Fig. 104.

Pese a estos datos tan positivos de los cueros ovinos, hay que destacar el hecho excepcional de que al utilizar las pieles de cerdo, ninguna de las estampas obtenidas ha sido calificada de manera negativa (fig. 105). 


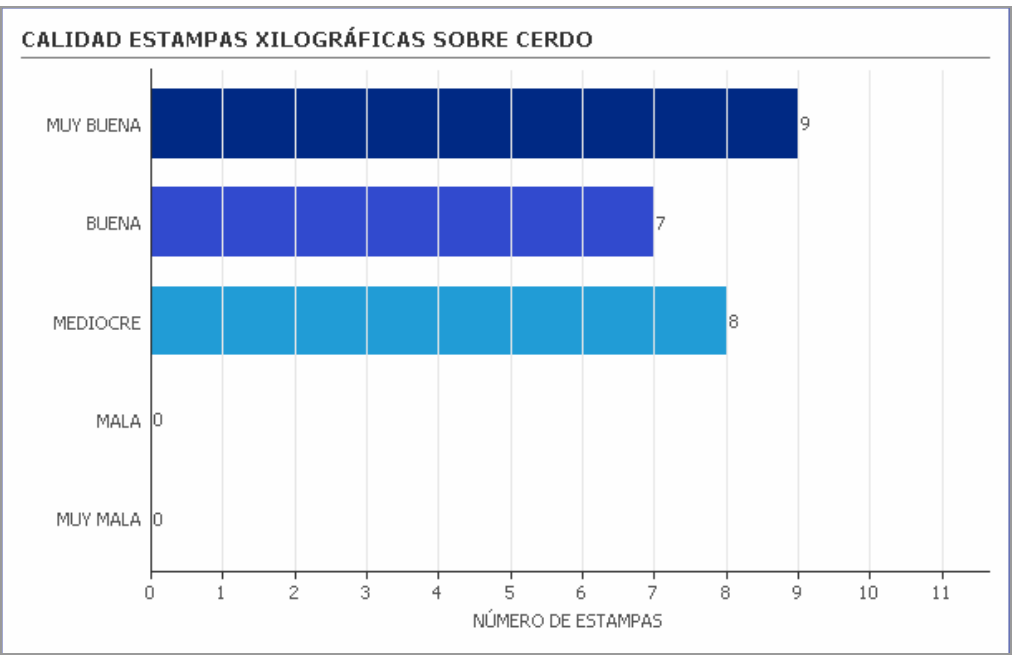

Fig. 105.

Al $66,6 \%$ de impresiones positivas (37,5\% muy buenas y $29,1 \%$ buenas), se suma un $33,3 \%$ de estampas mediocres, por lo que ninguna de las xilografías sobre piel de cerdo puede calificarse como mala o muy mala. Sin duda se trata de un dato extraordinario que no vuelve a repetirse en toda la experimentación, y que viene a señalar como óptima la respuesta de estos cueros a las impresiones xilográficas con cualquier tipo de tinta. La naturaleza propia del forro de cerdo empleado en este trabajo ha ayudado, sin la menor duda, a conseguir estos excelentes resultados, ya que ambas caras de la piel presentan una superficie carente de satinados excesivos, lo que permite al forro de cerdo erigirse en el mejor soporte de cuero de los analizados. 
También las estadísticas relacionadas con la tinta utilizada en la estampación nos ofrecen interesantes reflexiones. De las cuatro tintas empleadas tan sólo el blanco (fig. 106) presenta serios problemas de utilización, mientras que las tres restantes se muestran válidas para estampaciones xilográficas (fig. 107). Esta tinta blanca consigue obtener impresiones de buena calidad solamente en el 37,5\%

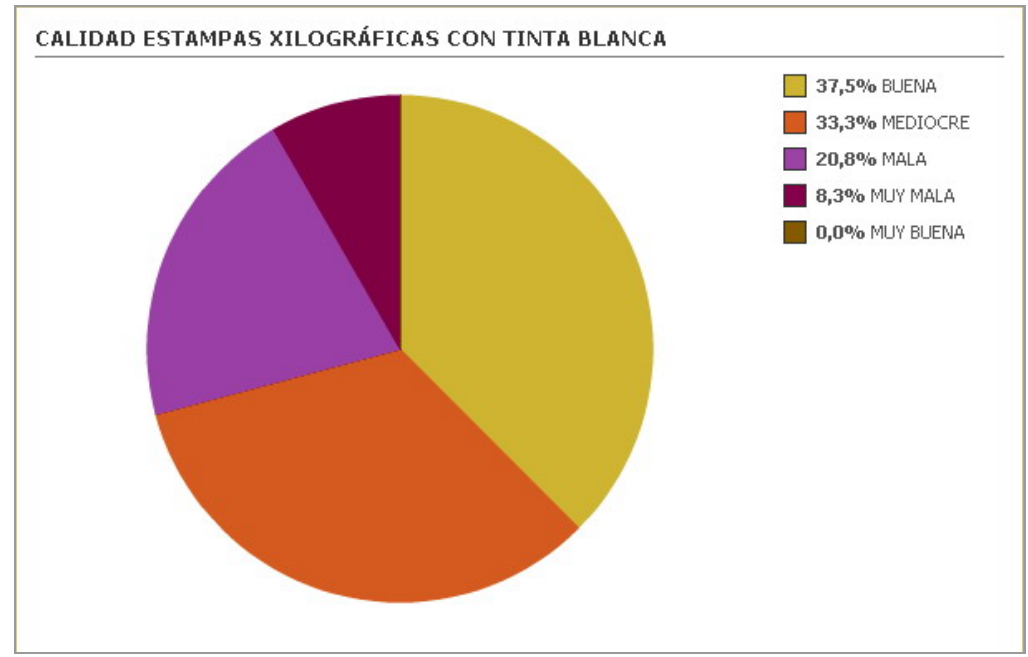

Fig. 106.

de los casos, con un llamativo 0\% de estampas de muy buena calidad. A su vez, los casos de calidad negativa ascienden hasta un $29,2 \%$ del total, con un $20,9 \%$ de imágenes de mala calidad y un $8,3 \%$ de muy mala, lo que la convierte en la peor de las cuatro tintas para estampar xilografías sobre piel. 


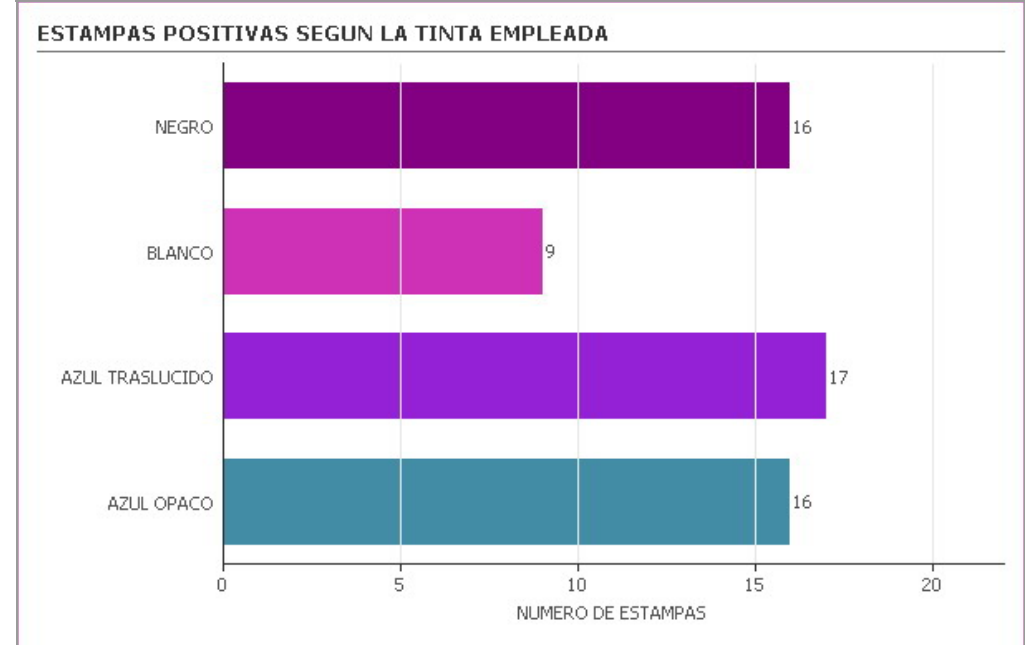

Fig. 107.

Las restantes tres tintas se comportan de manera similar, con muy bajos porcentajes de estampas de calidad negativa: 8,3\% para el negro y el azul traslúcido, y 12,5\% para el azul opaco, aunque la mayoría de estas impresiones son las realizadas sobre cueros de tonos muy oscuros, los cuales condicionan sobremanera la percepción de los resultados. Pese a ésto, del total de estampas impresas con cada una de las tintas, sólo 4 de ellas ofrecen calidad muy negativa (una en cada uno de los azules y dos con la tinta negra), lo que indica una respuesta excelente en esta fase concreta de la experimentación (fig. 107). Destacar a su vez el 71,3\% de estampas buenas o muy buenas de las realizadas con el azul traslúcido (41,6\% y $29,7 \%$ respectivamente) y en especial el $50 \%$ de imágenes de muy buena calidad obtenidas con la tinta azul opaco. Este último porcentaje de 
casos de muy buena calificación es el más alto de toda la experimentación, lo que nos induce a considerar que la tinta azul opaco es la mejor para trabajar con planchas xilográficas sobre cuero, incluso por encima de la tinta negra.

Repasados brevemente los resultados estadísticos recogidos, creemos estar en situación de poder ofrecer unas líneas generales que definan la que puede ser calificada como piel ideal para una estampa xilográfica:

- $\quad$ El cuero elegido debe ser de estructura sólida y sin presentar deformaciones de grosor o flexibilidad, con objeto de que la estampación sea homogénea a lo largo y ancho del soporte. 158

- El tono debe ser relativamente claro para conseguir un nivel de contraste suficientemente intenso para que la imagen estampada pueda ser perfectamente visible, lo que permite emplear la práctica totalidad de los cueros presentes en la investigación, salvo los lados flor de las pieles oscuras.

- Por lo que se refiere a la elección del lado de la piel, nos encontramos ante dos posibilidades igualmente válidas:

158 . Estas características son reunidas por los cueros provenientes de la zona del espinazo del animal, y nunca por aquellos que provengan de los extremos. 
- Un lado carne poco afelpado con objeto de que la textura no sea excesivamente rugosa y pueda afectar al registro xilográfico.

- Un lado flor con poco satinado para que la tinta pueda asentar perfectamente sobre la superficie del cuero y no ofrezca inconvenientes de registro.

La elección de uno y otro soporte queda determinada por los intereses personales del estampador, pudiendo decantarse por cualquiera de las dos opciones, dado que los riesgos de que la calidad de la estampa resultante se viera afectada serían mínimos en ambos casos.

Las estampas realizadas sobre soportes que respeten las indicaciones reseñadas como resultado del análisis realizado, ofrecerán un resultado óptimo desde todos los puntos de vista. Algunas de sus ventajas quedan reseñadas en la siguiente lista:

- Su definición de registro será perfecta, sin deformaciones ni modificaciones.

- No aparecerán brillos excesivos que puedan deformar la visión de la imagen.

- El secado de la tinta será rápido. 
IV. Análisis y catalogación

- El asentamiento de la impresión será correcto y sin inconvenientes.

- Poseeremos un mayor margen para el error ante un hipotético exceso de presión durante el proceso de estampación. 


\section{IV.1.3.b. Estampas calcográficas}

Los resultados globales no son tan positivos como los de las imágenes xilográficas, con un 46,8\% de las 96 impresiones de calificación positiva (con un 26,0\% de estampas muy buenas y un $20,8 \%$ de buenas) frente al $61,8 \%$ de la xilografía, y un $33,4 \%$ negativas, por un $14,6 \%$ de las xilográficas (fig. 108). Estas estadísticas generales demuestran la mejor respuesta de las

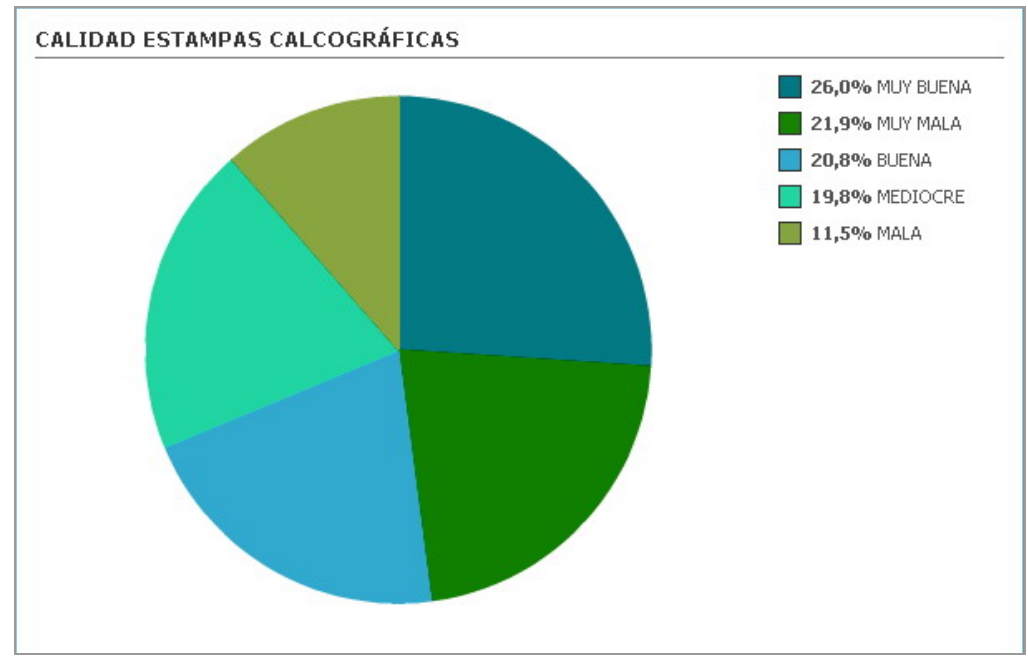

Fig. 108.

impresiones xilográficas en comparación con las calcográficas, mejoría que está íntimamente relacionada con la naturaleza propia de cada una de las técnicas. Así, la mayor carga de tinta depositada por las planchas xilográficas se muestra como de enorme importancia para 
cubrir satisfactoriamente la superficie del soporte. El tipo de huella gráfica de la calcografía, mucho más sutil que la xilográfica, hace que sea más sensible a posibles cambios en las características del soporte, de cuero. Pese a estas consideraciones, los resultados de las impresiones calcográficas deben ser calificados como buenos en general, sobre todo en lo que respecta al lado flor de las pieles.

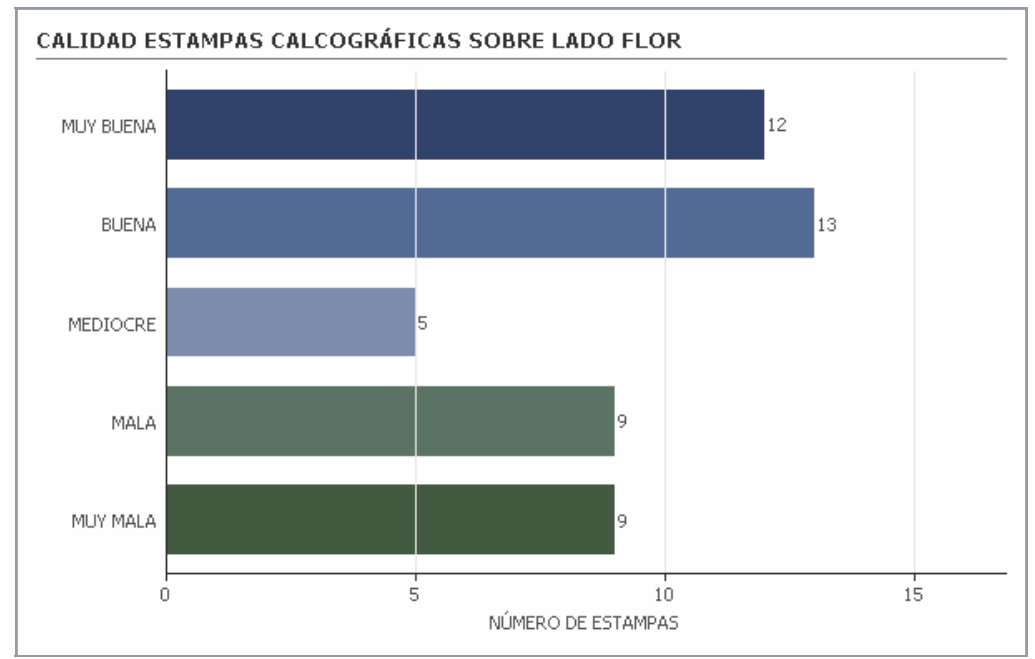

Fig. 109.

En efecto, al comparar las calificaciones relativas a los dos lados de la piel, las estadísticas muestran una clara ventaja de las impresas sobre la cara externa de los cueros (fig. 109). Así, en el lado flor, el $52 \%$ de las imágenes son positivas (25,0\% muy buenas y $27,0 \%$ buenas ) mientras que sobre el lado carne tan solo el 41,6\% merece esa calificación (27,0\% muy buenas y $14,6 \%$ buenas ). Queda de 
manifiesto que, en líneas generales, las imágenes calcográficas se registran mejor sobre superficies ligeramente satinadas y no tanto sobre soportes que puedan presentar un afelpado que llegue a desvirtuar tanto las líneas, como el graneado del aguatinta. ${ }^{159}$ Estas conclusiones globales no indican sin embargo que no puedan existir estampas de excelente calidad sobre el lado carne de ciertos cueros aunque siempre con condicionantes que analizamos más abajo.

Sin duda llama la atención el elevado número de imágenes calcográficas calificadas como muy malas, 21 de un total de 96 (un $21,9 \%$, frente al $6,3 \%$, en el caso de la xilografía) hecho que está estrechamente relacionado con los numerosos problemas comentados al analizar las impresiones con tinta blanca. De esas 21 impresiones de muy mala calidad, 17 corresponden a ejemplos realizados con dicha tinta, factor que debe aclarase convenientemente para valorar justamente el resto de resultados de las otras tres tintas.

Para comentar las estadísticas relativas a las pieles, podemos proponer una ordenación de las mismas de mejor a peor respuesta frente a la impresión calcográfica, tal y como queda reflejado en la fig. 110. En base a los porcentajes de estampas positivas obtenidas podemos afirmar que el cuero que mejor responde para ser usado como soporte es el de cordero (62,5\% de impresiones positivas) seguido por el de cerdo y cabra (54,2\% y $41,7 \%$ respectivamente),

${ }^{159}$ Como vemos los resultados son bastante opuestos a los alcanzados con las imágenes xilográficas, donde las mejores estadísticas se daban sobre el lado flor de los cueros. Véase apartado IV.1.1., p. 187. 
para finalizar con el de vaca (con un $33,3 \%$ de estampas buenas 0 muy buenas). Destaca muy positivamente el $41,6 \%$ de estampas sobre cueros ovinos con una calificación muy buena, porcentaje tan sólo superado por el 45,9\% de imágenes xilográficas sobre la misma piel de cordero. A la vista de estos datos es evidente que la piel de cordero se ofrece como un soporte de muy buena respuesta para impresiones tanto calcográficas como xilográficas, superando estadísticamente a los tres cueros analizados.

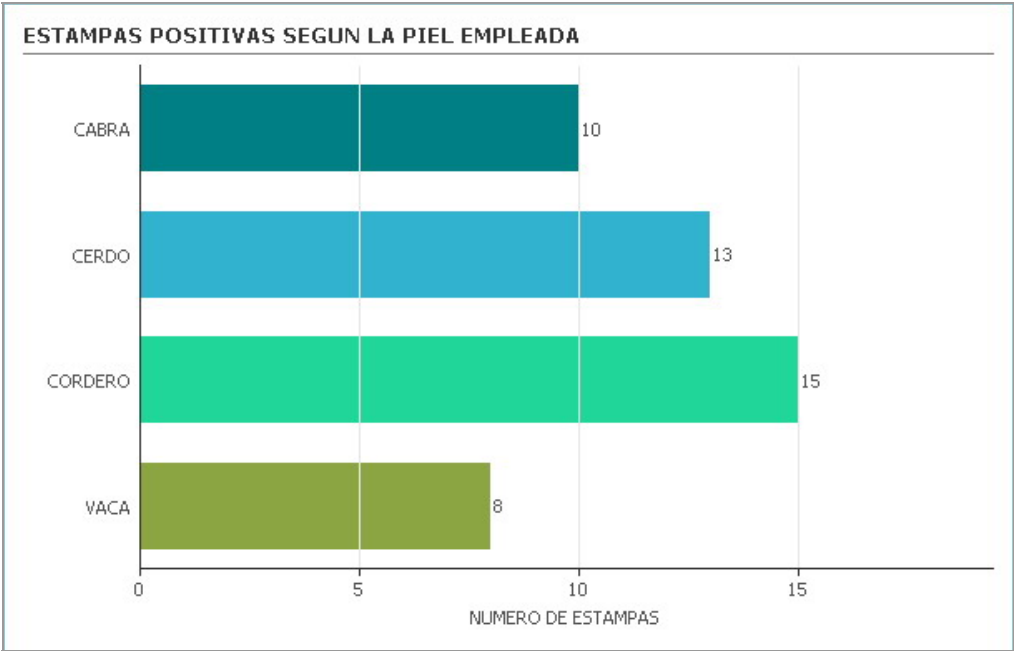

Fig. 110.

De éstos, los de cerdo y cabra se mantienen en unos niveles aceptables, destacando el $29,2 \%$ de impresiones muy buenas sobre cueros caprinos, y el 33,3\% de estampas buenas sobre el forro de cerdo. Sin embargo, llama la atención las bajas calificaciones de los 
cueros vacunos (fig. 111), con tan sólo una de cada tres imágenes considerada como buena o muy buena, debido a las características

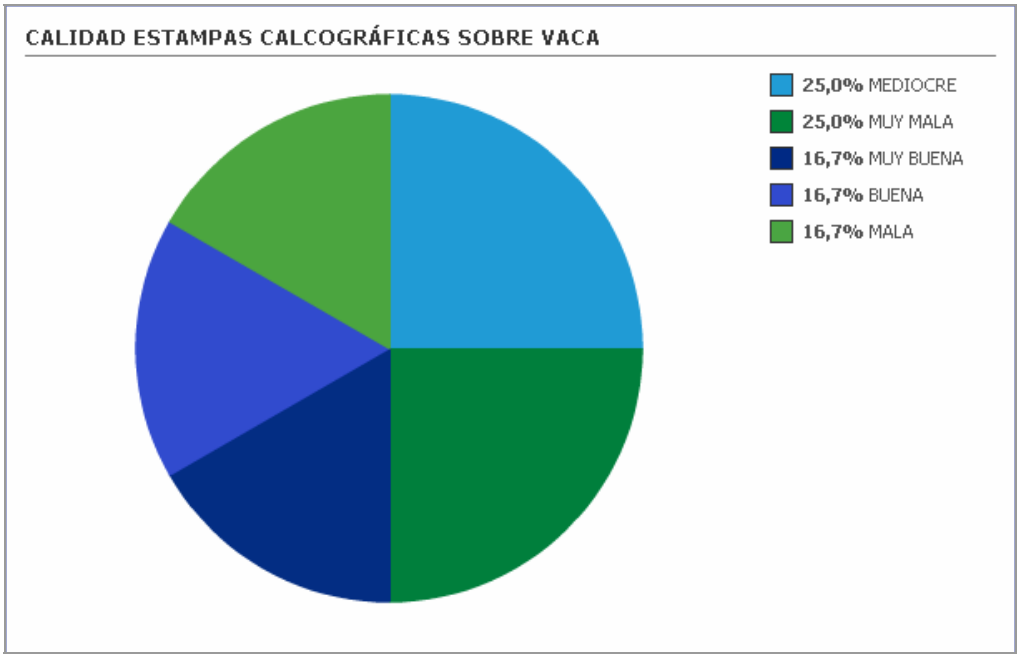

Fig. 111.

especiales de estas pieles; sus lados flor excesivamente satinados y unas caras internas de la piel con un afelpado muy evidente, la convierten en una superficie que no ofrece fácilmente resultados positivos, con un $41,6 \%$ de las impresiones con calificación negativa (16,6\% malas y $25,0 \%$ muy malas). Sobre los lados flor la tinta presenta problemas de asentamiento y secado por efecto del acabado satinado y la baja absorción del soporte, mientras que el afelpado interno provoca en muchas ocasiones deficiencias en el registro y en la nitidez de la imagen estampada. 
Los datos referentes a las tintas empleadas en la estampación ofrecen también interesantes reflexiones, destacando en ellas un caso particular que merece una atención especial: la tinta blanca. Al igual que en las estampas xilográficas el empleo de blanco provoca una notoria caída de los niveles de calidad de las estampas, situándose a mucha distancia de las otras tres tintas (fig. 112). De éstas, los mejores resultados los obtienen las dos tintas azules, seguidas muy de cerca

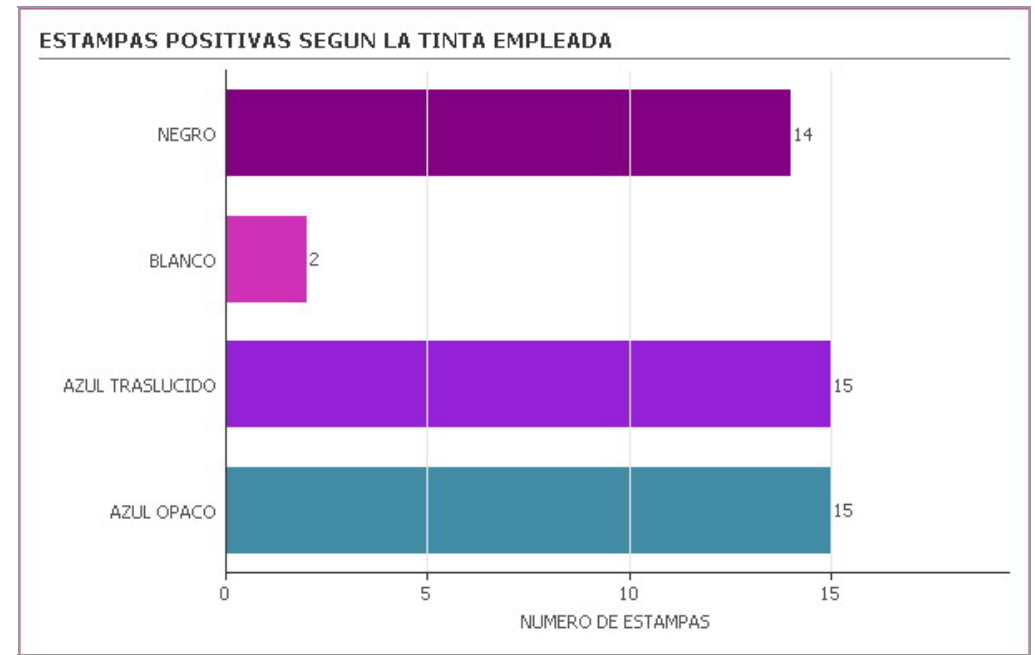

Fig. 112.

por la negra. El azul traslúcido ofrece un 63,3\% de impresiones positivas, e igual porcentaje obtienen las estampas realizadas con azul opaco: ambas tintas azules presentan 8 estampas de muy buena calidad, el 33,3\%, y 7 de buena calificación, el 29,7\% del total de 24 imágenes. Muy cerca se encuentra la tinta negra, con un $58,2 \%$ de 
ejemplos positivos, entre los que destacan hasta 10 casos de muy buena calidad (el $41,6 \%$ del total), que superan incluso en este apartado a las tintas azules. En definitiva, y pese a no llegar a los porcentajes alcanzados en las estampas xilográficas, las tres tintas son muy válidas para trabajar con a planchas calcográficas y soportes de cuero, lográndose interesantes resultados sobre todas y cada una de las pieles seleccionadas para esta primera etapa del proceso de análisis y catalogación. 160

Mención aparte merece el caso de la tinta blanca, cuyas especiales características y peculiaridades hacen que su empleo sea de extrema dificultad. Si ya lo es al usarla sobre papel, estos inconvenientes se multiplican con los soportes de cuero, como queda reflejado en las estadísticas obtenidas. De tal modo, el 78,55\% de las estampas son de mala o muy mala calidad, con un llamativo $61,95 \%$ de estas últimas: casi dos de cada tres ofrecen unos resultados ínfimos y paupérrimos (fig. 113). Únicamente 2 imágenes (el 8,3\% del total), merecen la calificación de buenas y ninguna de muy buena, en concreto las CO-032 y CO-033, ambas sobre cueros de cordero en su lado flor. 161

\footnotetext{
${ }^{160} \mathrm{El}$ porcentaje de impresiones positivas del negro desciende desde el 66,8\% de la xilografía hasta el actual 58,2\%. Por su parte el azul traslúcido sufre una caída similar, del 71,3\% al 63,0\%, al igual que el azul opaco, que lo hace desde un $66,6 \%$ a un $62,5 \%$ del total de las estampas.

${ }^{161}$ Tan sólo se han analizado estampas impresas sobre el lado flor de los cueros debido a la absoluta imposibilidad de estampar sobre una superficie afelpada con resultados aceptables. Sin embargo, sí se han incluido en el recuento estadístico, otorgándoles una calificación de muy mala a la hora de realizar las consideraciones pertinentes.
} 


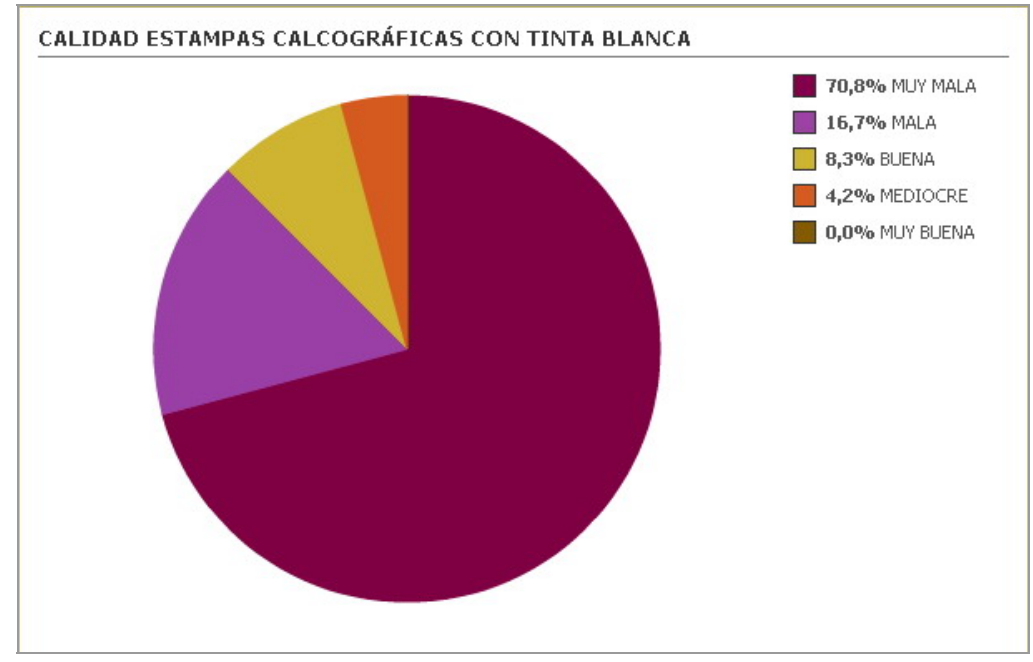

Fig. 113.

Si comparamos los datos obtenidos en las impresiones xilográficas podemos apreciar cambios sustanciales que merecen ser comentados, ya que, si bien en lo que respecta a la xilografía la tinta blanca era también la que peores resultados obtenía, en este caso concreto la diferencia con las tres tintas restantes se ha multiplicado ostensiblemente, y la calidad de las impresiones ha descendido enormemente. En las imágenes xilográficas, tan sólo el 8,3\% obtenía la calificación de muy malas, porcentaje que aumenta hasta el 61,95\% de las estampas calcográficas. Este brusco descenso de la calidad de las impresiones con blanco viene a incidir en la práctica inutilidad del empleo de esa tinta en las estampaciones calcográficas ya que, si al estampar xilografías ya ofrecía serios inconvenientes, ahora las ventajas son inexistentes, y es casi imposible un uso satisfactorio de dicha tinta. 
Al igual que con las estampas xilográficas, una vez finalizado este breve repaso por los datos estadísticos más relevantes, procedemos a proponer un modelo-tipo de soporte de cuero ideal con vistas a conseguir una impresión calcográfica altamente satisfactoria, Sin olvidar los criterios convencionales que rigen esta elección:

- El cuero escogido deberá presentar una superficie lo más homogénea y regular posible, siempre que se desee lograr una impresión de la misma homogeneidad. Las diferencias de grosor provocan cambios de presión que dificultan una estampación correcta, ya sea por defecto de dicha presión como por exceso de la misma, con los inconvenientes conocidos. ${ }^{162}$ Las pieles excesivamente flexibles también pueden ofrecer problemas durante la impresión, por lo que es recomendable evitar tales cueros y decantarse por soportes más estables.

- $\quad$ La elección del tono del soporte es quizá la más subjetiva, ya que será la intensidad del contraste deseado la que condicionará el decantarse por uno u otro color del cuero, aunque recomendamos una gama ligeramente clara. Por lo general los cueros más claros suelen presentar una mejor absorción y un acabado menos satinado o brillante que los que están demasiado tintados. El ejemplo más claro lo tenemos con los tres tonos de forro de cerdo escogidos para la

\footnotetext{
${ }^{162}$ Véase apartado IV.1.2., p. 221.
} 
experimentación. Sin embargo, la enorme variedad de posibilidades que la industria del cuero ofrece actualmente hace necesario no generalizar en lo que a estas cuestiones se refiere.

- La elección del lado del cuero sobre el que se va a estampar, por su naturaleza es, al igual que en el caso de la xilografía, la más delicada e importante. Por lo general la mejor zona corresponde a un lado flor muy poco satinado, superficie que ofrecerá una serie de ventajas muy interesantes.

- Registro de alta calidad y gran nitidez de la imagen, más difícil de conseguir de tratarse de una superficie afelpada.

- Asentamiento perfecto de la tinta sobre el cuero, que podría presentar problemas si se estampara sobre una piel excesivamente satinada.

- Mayor limpieza y claridad de la imagen, provocada por la menor absorción del lado flor de los cueros en comparación con el lado carne afelpado.

- Ausencia de brillos demasiado intensos y mejor integración de la imagen estampada con el. 
IV. Análisis y catalogación

- Mayor margen de error ante un eventual exceso de presión en el tórculo, el cual sería fatal con una superficie pulida como soporte. 
IV. Análisis y catalogación 


\section{IV.2. SEGUNDA FASE}

En este nuevo apartado ampliamos el campo de experimentación al incorporar tres nuevos procedimientos que se unen a la calcografía y la xilografía para formar el fundamento práctico sobre la que nos basaremos para elaborar la propuesta personal.

Este apartado práctico parte del análisis de tres procedimientos muy diferentes entre sí, aunque todos ellos relacionados, en mayor o menor grado, con el mundo del grabado: punta seca, estezado o gofrado en húmedo y transferencia.

La primera de estas técnicas, la punta seca, es una técnica tradicional del grabado calcográfico cuyo análisis permitirá completar 
un amplio estudio de las posibilidades de las pieles como superficies receptoras de estampas calcográficas. Sus similitudes con el aguafuerte en lo que a carga de tinta se refiere, permitirán que nos centremos solamente en algunos aspectos concretos, pues se pueden aplicar a las estampas de punta seca gran parte de las reflexiones del análisis de los ejemplos calcográficos de la primera etapa de la experimentación. ${ }^{163}$

Si la punta seca está estrechamente relacionada con la historia del grabado, el estezado es, por su parte, uno de los procedimientos más empleados a lo largo de la historia de los cueros artísticos, sobre todo dentro del campo de la encuadernación. ${ }^{164}$ La inclusión de esta técnica dentro de nuestra experimentación está relacionada con el interés expuesto en la introducción de realizar no sólo Arte sobre piel, sino también en piel, e incluso fusionar ambos conceptos. El trabajo del estezado, como también los de gofrado, repujado o grabado, cambian las características intrínsecas del cuero, el cual deja de ser un mero soporte para convertirse en parte constituyente de la imagen, estableciendo un todo plástico de naturaleza diferente (fig. 114). De ahí el enorme interés que el estudio de las posibilidades plásticas de un procedimiento como éste puede tener para la experimentación y realización de la propuesta de trabajo artístico personal. Sin embargo,

\footnotetext{
${ }^{163}$ Estas anotaciones comunes están centradas sobre todo en lo referente a los brillos y a los niveles de contraste de las estampas. El resultado tan similar en ambos campos está relacionado con la carga de tinta depositada por la plancha sobre el soporte de cuero, muy parecida en ambas técnicas. Véase apartado IV.1.3.b., p. 268.

${ }^{164}$ Véase apartado II.2.1., p. 117.
} 
el enfoque otorgado al estezado pretende alejarse de sus posibilidades industriales y de los procedimientos mecánicos asociados a la técnica. Nuestro interés es, por el contrario, abordar las posibilidades que ofrece a un grabador para la realización de sus estampas cuando lo integra en su práctica con las herramientas y maquinaria habitual en un taller de grabado. 165 Es por ello que las reflexiones que alcancemos están siempre referidas a ese ámbito de trabajo, el del taller de un grabador, y nunca al campo de la decoración industrial de cueros y pieles, el cual no corresponde a esta investigación.

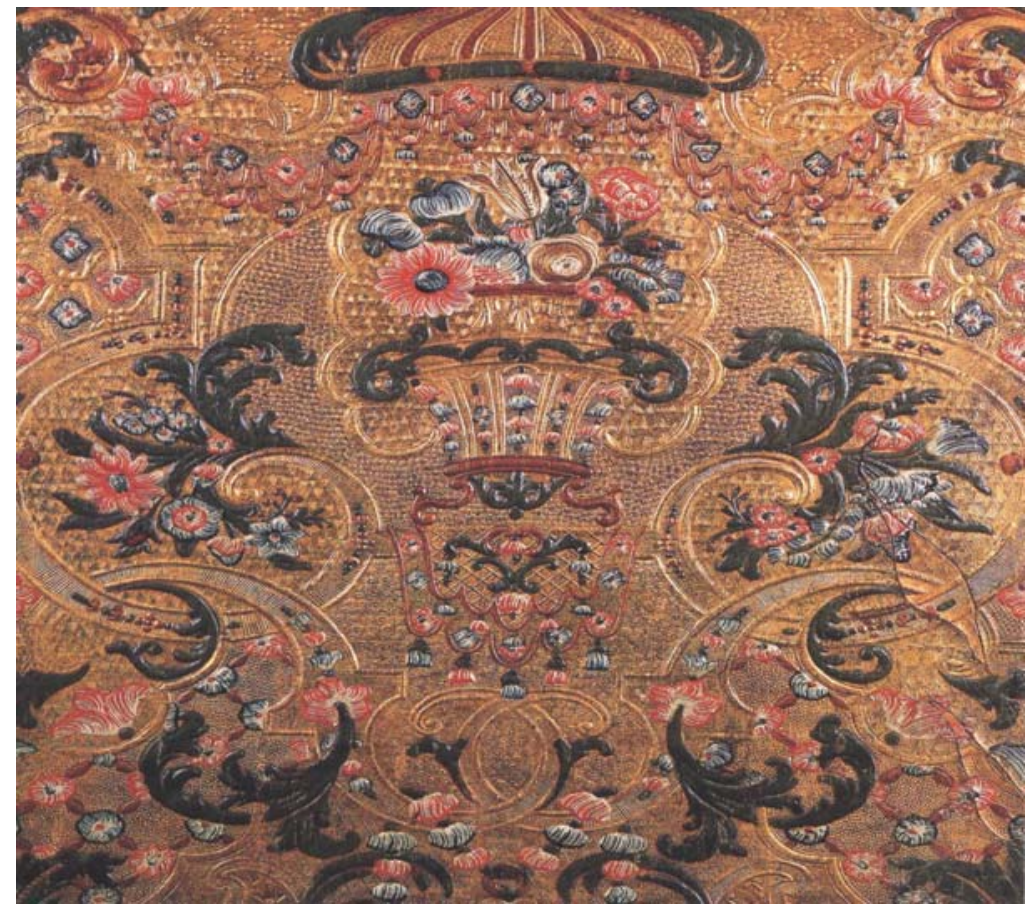

Fig. 114: Fragmento de guadamacil gofrado, policromado y dorado.

165 Como se verá más adelante, nos estamos refiriendo a una prensa de presión vertical. 
Por último, la transferencia se nos presenta como una alternativa totalmente diferente a las dos anteriores dada su modernidad y el contraste que se establece con los procedimientos mucho más tradicionales, cada uno en su campo especifico, de la punta seca y el estezado. Es evidente que la inclusión de esta solución plástica está estrechamente ligada a los objetivos, intereses e inquietudes personales relacionadas con la creación de una serie de obras plásticas propias. La posibilidad de incluir la imagen fotográfica dentro de la propuesta plástica ha sido fundamental para escoger esta técnica como la última a analizar dentro del proceso de experimentación. Tampoco hay que olvidar que el procedimiento que emplearemos posee puntos de conexión evidentes con todos los estudiados hasta el momento,166 y así, desde la xilografía y la calcografía, hasta la punta seca, el estezado y, por fin, la transferencia, todas las técnicas incluidas en la experimentación tienen en el uso de prensas y tórculos un elemento común que las relaciona.

Vistos brevemente algunos de los factores que han condicionado la experimentación, se hace necesaria una alusión a los soportes que emplearemos en esta fase práctica. A diferencia de lo ocurrido al estampar las imágenes xilográficas y calcográficas, en las que empleamos un total de 12 tipos de cueros diferentes, en esta nueva fase del trabajo reducimos el número con vistas a optimizar los resultados. Así, tras analizar los resultados obtenidos y relacionarlas

${ }^{166}$ Es una transferencia química mediante la aplicación de disolventes y presión. 
con la naturaleza de los procedimientos técnicos a emplear en esta etapa, vemos conveniente seleccionar los soportes de tonalidad más clara, independientemente del animal del que procedan. Excluimos los cueros de tonos medios y sobre todo los oscuros, con objeto de evitar problemas e inconvenientes relacionados con los niveles de percepción del contraste, reduciendo por tanto la cantidad de soportes diferentes a un total de cuatro. 


\section{IV.2.1. Punta seca}

El análisis de este procedimiento nos permite ampliar el estudio de la respuesta de los cueros como soportes para imágenes calcográficas. A estas alturas de la investigación vemos posible la reducción del número de tintas empleadas, sin que por ello mengüe la calidad y validez de las consideraciones a las que podremos llegar en este apartado. Así, tras considerar los resultados obtenidos por las distintas tintas en las estampaciones calcográficas, limitamos el estudio al empleo de la tinta azul opaco.

Los factores que han influido en esta elección están relacionados con la naturaleza de dicha tinta y sus cualidades específicas. Es evidente que el blanco queda descartado por los múltiples problemas que presenta su uso, mientras que las otras tres tintas ofrecian unos resultados muy parejos, ${ }^{167}$ por lo que la elección de una u otra de estas tres tintas no podía fiarse tan sólo a cuestiones meramente estadísticas, sino que debía tener en cuenta otra serie de factores. En este punto concreto, la tinta azul ofrece un abanico de ventajas que acabaron por inclinar la balanza de su lado: su intensidad es muy similar a la del negro, mientras que su naturaleza facilita el análisis de posibles cambios tonales y mezclas por transparencia, al

${ }^{167}$ En efecto, el 58,2\% de las imágenes estampadas con negro eran buenas o muy buenas, mientras que ambas tintas azules presentaban un porcentaje del 63\% de estampas positivas. 
igual que el azul traslúcido, posicionándose como la tinta más adecuada para esta nueva tanda de estampaciones calcográficas.

El material escogido como matriz ha sido el mismo que en el caso de las estampas del primer bloque, el zinc, ya que el escaso número de estampaciones planeadas dentro de este proceso concreto permite valorar la posibilidad de alcanzar resultados óptimos sin tener que recurrir al empleo del cobre.

En lo que respecta a la imagen que se ha de estampar sobre los cueros, el menor número de pieles diferentes no hace tan necesaria la distinción de las estampas a partir de representaciones zoomórficas como las del apartado relativo a la xilografía y la calcografía, optándose en su lugar por crear una sin ningún motivo figurativo, tan sólo dos zonas perfectamente diferenciadas (fig. 115):

- Zona superior con una potente línea horizontal.

- Zona inferior poblada por una trama lineal que conforma una gradación tonal formada por grafismos de menor intensidad que el anterior, aunque en número mucho mayor. 


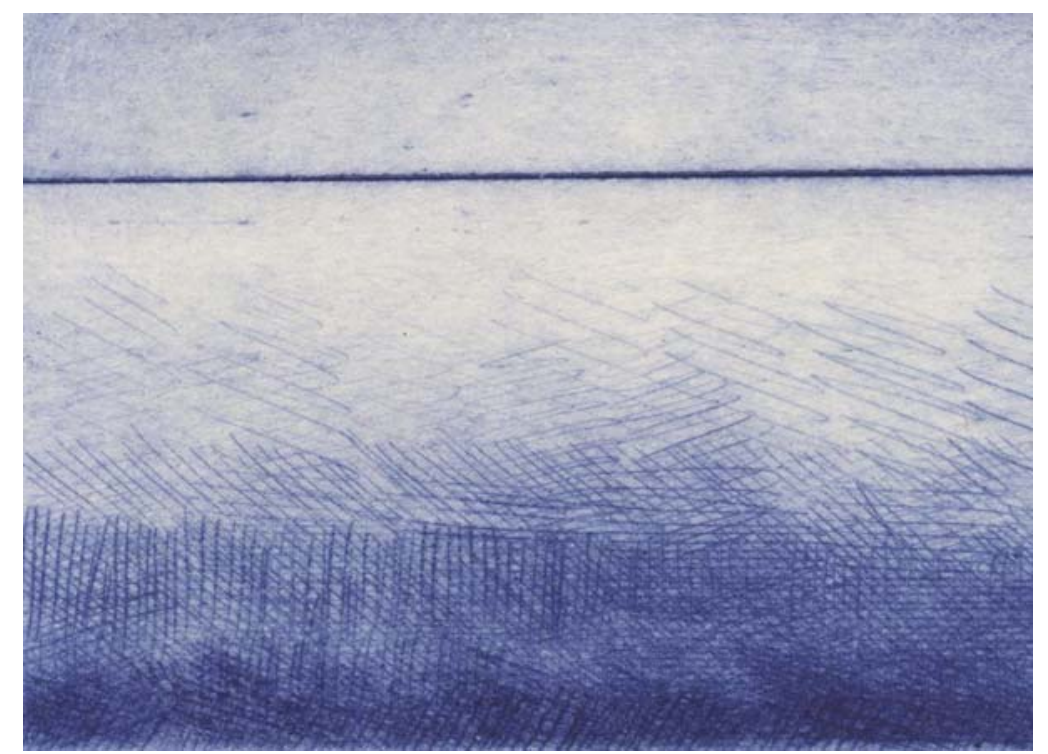

Fig. 115: Estampación sobre papel de la imagen elegida para la experimentación con punta seca.

A partir de estos grafismos se analizan los resultados de los cueros como soportes para la punta seca, haciendo especial hincapié en el estudio de uno de los rasgos distintivos de esta técnica al compararla con el aguafuerte: la tinta recogida por las rebabas de las incisiones de la plancha matriz. Esta impresión de las rebabas es analizada tanto en las líneas más sutiles que forman la trama, como en la potente línea aislada de la parte superior de la estampa, donde obviamente es mucho más evidente y patente. 


\section{IV.2.1.a. Análisis de los resultados}

En lo que respecta a las estampas sobre piel de cabra (fig. 116), ambas poseen un nivel de calidad bastante elevado, destacando la PS-002168 sobre el lado carne. En los dos ejemplos el registro es de una nitidez extraordinaria, con todas las líneas, incluso las más sutiles, perfectamente impresas sobre el cuero. Sin embargo, en lo referente a la tinta de las rebabas, ésta no se encuentra registrada de manera totalmente satisfactoria sobre el lado flor, mientras que sobre el sutil afelpado del lado carne se estampa perfectamente. Tanto el contraste como el brillo siguen las pautas ya analizadas al tratar las imágenes calcográficas con esta misma tinta azul opaco ${ }^{169}$, y siempre que la limpieza de la plancha sea ortodoxa, el resultado será de extraordinaria calidad, especialmente sobre el lado carne.

\footnotetext{
${ }^{168} \mathrm{Al}$ igual que en las estampas xilográficas y calcográficas, en este segundo bloque usamos una codificación de las imágenes. Si en aquellos casos el código hacía referencia al tipo de piel (CA para cabra, CE para cerdo, y así sucesivamente), en este apartado los códigos comienzan por unas letras relacionadas con la técnica empleada. Así, tendremos PS para punta seca, ES para estezado y TRA para la transferencia.

${ }^{169}$ Véase cap. IV.1.2.d., p. 250. En todas las alusiones a las imágenes calcográficas de este capítulo, nos referiremos al mismo apartado.
} 


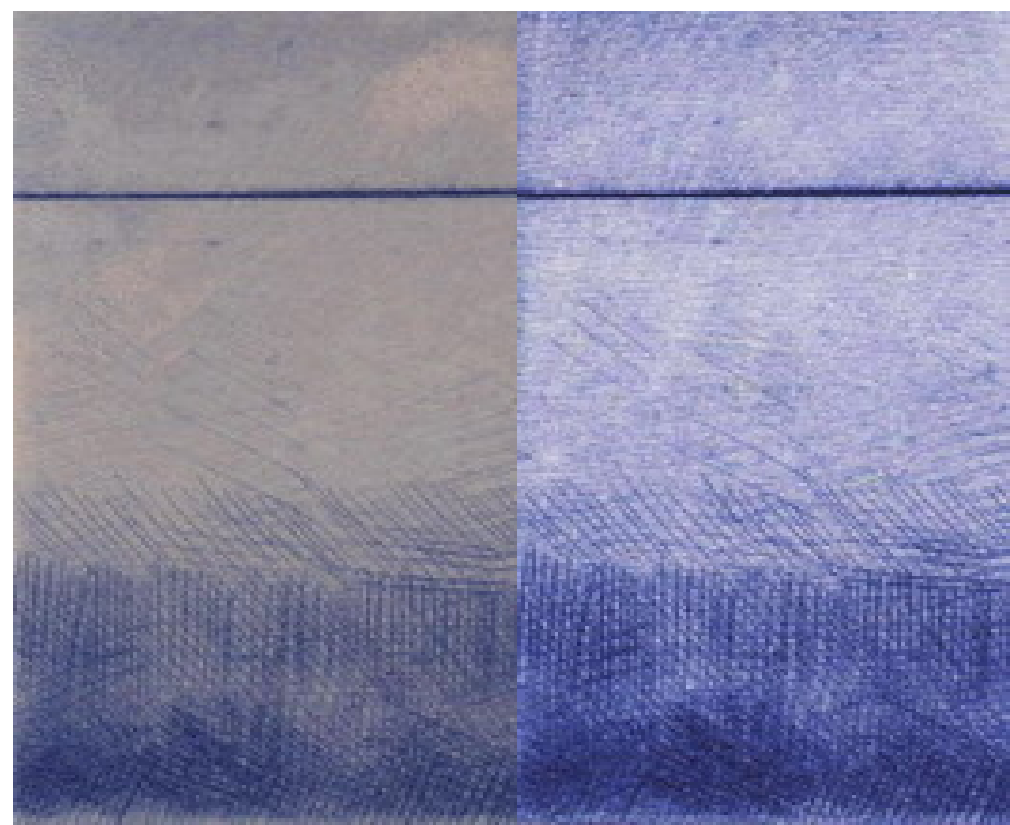

Fig. 116: Estampación sobre cuero de cabra: lado flor PS-001 (izquierda) y lado carne PS-002 (derecha)

Los cueros de cerdo (fig. 117) no ofrecen un nivel de calidad tan alto como los caprinos debido a los efectos de la textura superficial de dichas pieles; en efecto, presentan la conocida rugosidad y los orificios de los folículos pilosos, elementos que afectan a la nitidez del registro de los grafismos de punta seca. En el lado flor, en la estampa PS-003, la textura provoca que las líneas más finas se vean desvirtuadas y lleguen a desaparecer en muchas zonas de la imagen, a la vez que el soporte se muestra incapaz de recoger de manera totalmente satisfactoria la carga de tinta presente en las rebabas de la plancha. Por lo que se refiere al lado carne, si bien desaparece la 
textura agrietada y los orificios, el afelpado algo rugoso de la superficie hace que, al igual que en la anterior, en esta imagen tampoco se alcance una calidad suficiente en el registro de las líneas.

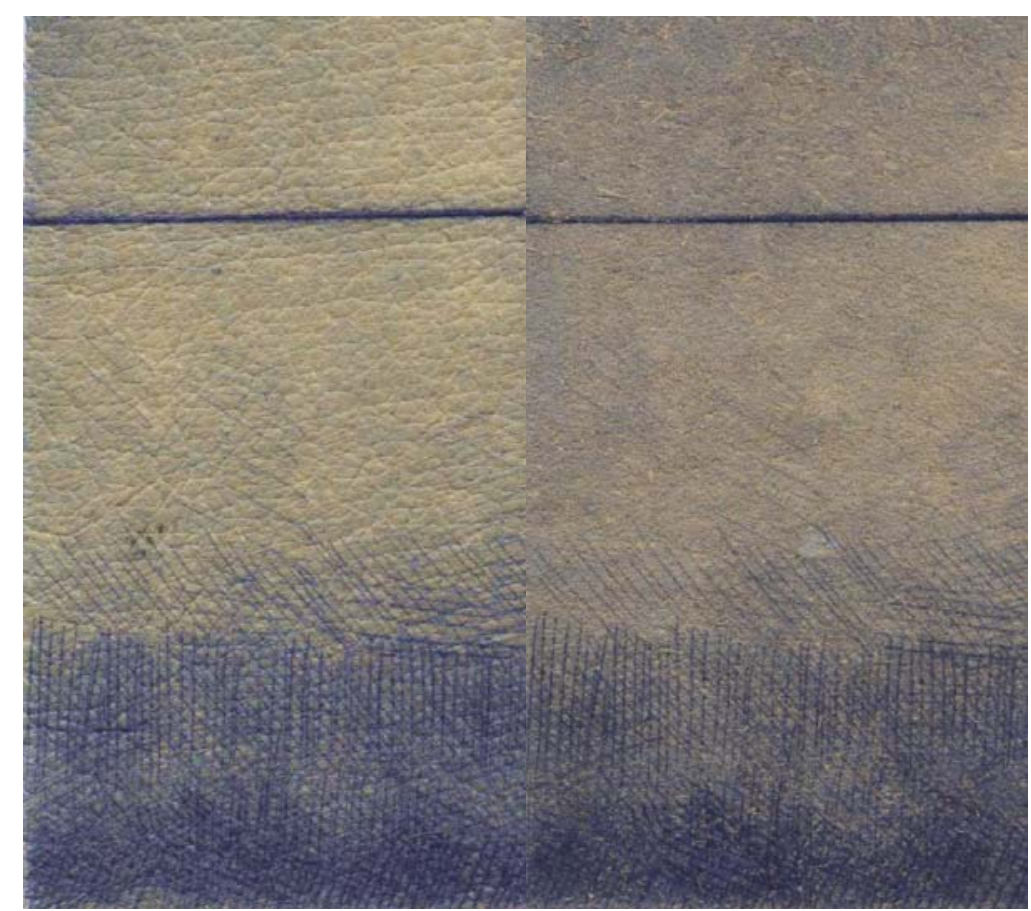

Fig. 117: Estampación sobre cuero de cerdo: lado flor PS-003 (izquierda) y lado carne PS-004 (derecha)

Tampoco las rebabas son registradas de manera correcta, perdiéndose la apariencia típica de la punta seca, y además, a diferencia de otros cueros, la piel de cerdo presenta inconvenientes a la hora de recoger la tinta sobrante depositada sobre la plancha. Ésta no se imprime de manera uniforme y homogénea, sino que lo hace de 
modo irregular, incidiendo negativamente en la calidad final de la estampa.

La piel de cordero (fig. 118) ofrece de nuevo una respuesta extraordinaria como soporte para la punta seca, con características muy similares a las del cuero caprino. En este caso, la mayor calidad se observa sobre el lado flor de la piel, mientras que en el lado interno, la PS-006, a pesar de ser de buena calidad no alcanza los mismos niveles. En la imagen PS-005, todos los aspectos de análisis, ya sea el registro de los grafismos como la capacidad de recepción de la tinta de las rebabas, muestran unos resultados extraordinarios. Todas las líneas de la plancha, por débiles y sutiles que puedan ser, se encuentran estampadas con extrema nitidez, y en las zonas de mayor densidad de grafismos éstos se registran con absoluta limpieza y sin inconvenientes de ningún tipo. La tinta de las rebabas también se puede apreciar sobre el cuero de un modo casi perfecto, consiguiéndose el acabado y la apariencia propias de una imagen realizada con punta seca.

El análisis de la imagen sobre el lado carne es algo diferente al anterior, aunque el nivel de calidad general sea también positivo y satisfactorio. Por efecto del afelpado de la superficie interna de la piel, el registro de los grafismos más finos se ve algo condicionado, y no logra una nitidez tan grande como en el ejemplo PS-005 sobre el lado flor. La limpieza del registro tampoco es tan elevada, aunque no llega a suponer un inconveniente excesivo que haga descender la calidad 


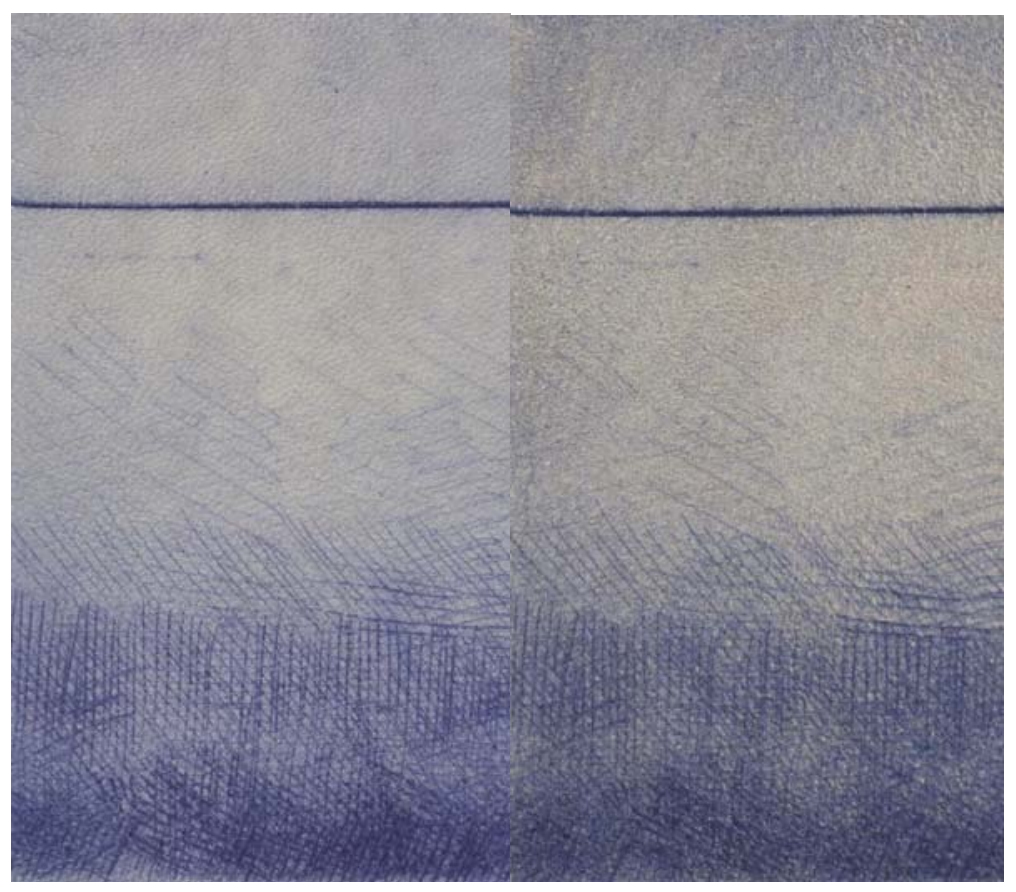

Fig. 118: Estampación sobre cuero de cordero: lado flor PS-005 (izquierda) y lado carne PS-006 (derecha)

global de la imagen. Las rebabas se encuentran estampadas de forma bastante correcta, sobre todo las de la gruesa línea superior, aunque sin alcanzar los niveles de perfección de la estampa sobre el lado externo del cuero. Pese a todo esta imagen PS-006 puede ser considerada de manera muy positiva, y los resultados sobre este tipo de cueros ovinos son satisfactorios siempre que el afelpado de la piel sea sutil y tenue, ya que de lo contrario los inconvenientes de registro se multiplican. En lo que respecta al brillo y al contraste, ambas estampas se comportan de manera casi idéntica a las de aguafuerte y aguatinta. 
Por último, los cueros de vaca (fig. 119) son los que mayores diferencias de calidad presentan entre sus dos lados, con una calificación de buena para el lado flor y mala para el lado carne. Esta diferencia viene provocada por las características propias de esta piel, con un acusado afelpado en su cara interna que condiciona los resultados sobre dicha superficie. El ejemplo sobre el lado flor PS-007, muestra un nivel de registro de los grafismos casi perfecto, a lo que ayuda el acabado tan satinado del cuero, con todas las líneas estampadas de manera muy correcta. Sin embargo, este mismo satinado de la superficie del soporte provoca que la tinta de las rebabas no sea recogida de manera igualmente satisfactoria, lo que hace que se pierda la apariencia propia de las estampas a la punta seca. El propio acabado del cuero hace que la intensidad de la tinta en la zona de mayor densidad de grafismos no sea lo elevada que cabría esperar, ya que la piel no es capaz de recoger toda la carga de tinta presente en ellos. ${ }^{170}$

${ }^{170}$ Este hecho influye en el nivel de contraste de la imagen, el cual no es todo lo intenso que cabría esperar. 


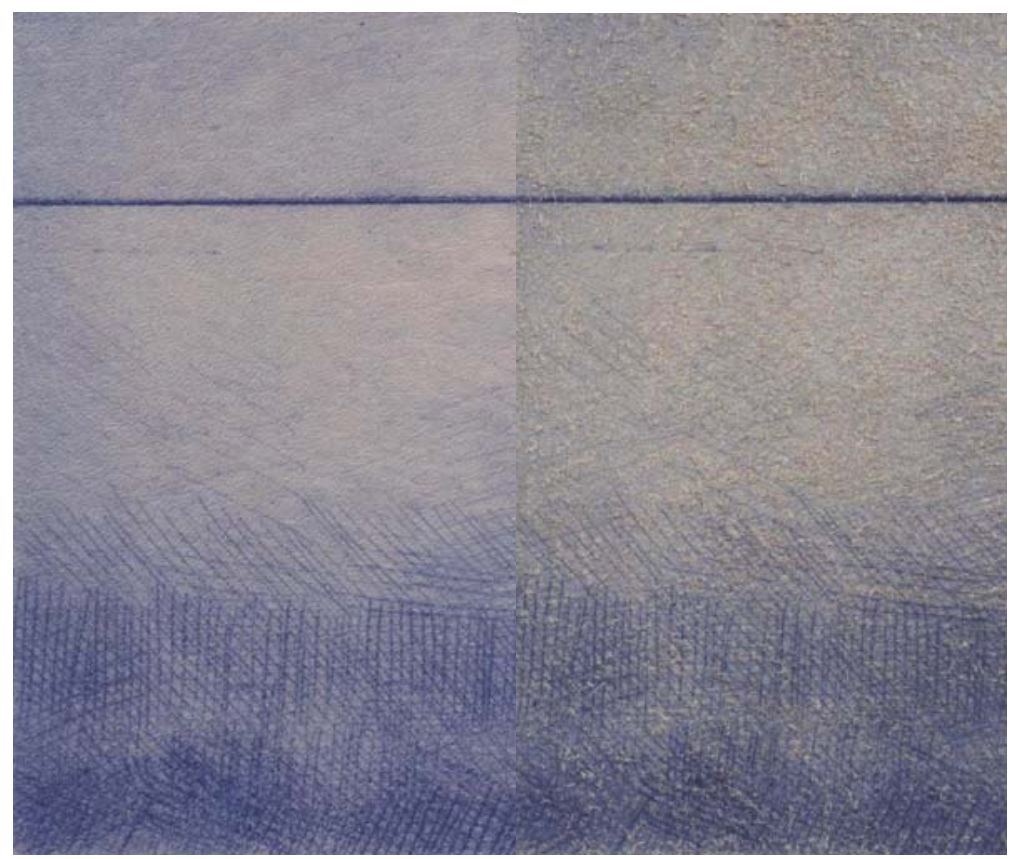

Fig. 119: Estampación sobre cuero de vaca: lado flor PS-007 (izquierda) y lado carne PS-008 (derecha)

La imagen PS-008 es sin embargo muy diferente y de peor calidad. El excesivo afelpado de la superficie condiciona el registro de las líneas hasta provocar que algunas de ellas no se encuentren estampadas correctamente y que incluso lleguen a desaparecer. A su vez, esa misma textura es la culpable de que las rebabas de la plancha no se puedan registrar de manera homogénea y regular, provocando un evidente descenso de la calidad de la estampa, lo que le impide competir con su pareja sobre el lado flor. El contraste y el brillo vuelven a ser similares a los ya analizados en el grabado calcográfico, con el lógico oscurecimiento general de la imagen estampada sobre el lado carne del cuero. 


\section{IV.2.1.b. Reflexiones parciales}

Una vez analizados todos los casos expuestos podemos redactar unas breves consideraciones acerca de este procedimiento de grabado y de la respuesta de los cueros a la estampación con dicha técnica. En líneas generales los resultados pueden considerarse positivos, ya que tan sólo uno de los casos ha sido calificado como muy malo, mientras que muchos de ellos han recibido una valoración positiva. Pese a ello, en este apartado se produce un hecho estadístico reseñable: el porcentaje de imágenes de aguafuerte y aguatinta que han obtenido una calificación de buena o muy buena es el mismo que para la punta seca, concretamente el $62 \% 5 \%$, por lo que puede concluirse que los resultados obtenidos al emplear la punta seca son muy similares a los ya analizados al respecto de las estampas realizadas en el apartado IV.1..

Analizando casos más concretos vemos que los mejores ejemplos son los PS-002 y PS-005, sobre lado carne de cabra y lado flor de cordero respectivamente. ${ }^{171}$ Estos dos soportes parecen los idóneos a la hora de ser empleados como receptores de imágenes de punta seca, aunque cada uno ofrezca unas características propias

\footnotetext{
${ }^{171}$ Estos mismos cueros ya habían demostrado su validez con el grabado analizado en el apartado IV.1.2.d. Así, el cuero de cabra claro en su lado carne conseguía una calificación buena al ser estampada una imagen calcográfica con azul opaco (CA-041), mientras que el cuero de cordero en su lado flor (CO-040) obtenía una calificación de muy buena.
} 
diferentes; mientras en uno obtenemos una estampa sobre una superficie afelpada, el otro nos proporciona un acabado satinado y mucho más pulido. De tal modo, según sean los intereses particulares y la naturaleza de la obra a realizar podremos decantarnos por una u otra superficie, sabiendo que los resultados obtenidos serán en ambos casos muy satisfactorios.

No puede decirse lo mismo de las pieles de cerdo y vaca en su lado carne, que no han alcanzado unos niveles de calidad mínimos. En todos los casos este descenso viene provocado por lo rugoso de las superficies de esos cueros, ya sean la agrietada y horadada del cuero porcino en su lado externo, como las afelpadas de los dos lados carne restantes.

Podemos concluir que las características de un soporte de cuero ideal para estampar imágenes con punta seca pueden resumirse en las siguientes:

- Superficie homogénea y sin excesivas irregularidades que puedan afectar de manera notoria al registro de la plancha.

- Acabado del cuero con dos posibilidades, ambas válidas y susceptibles de ser empleadas indistintamente:

- Lado flor poco satinado y sin excesivo brillo.

- Lado carne con un afelpado extremadamente sutil y sin una textura excesiva. 
IV. Análisis y catalogación

Si el cuero que empleamos como soporte cumple estas condiciones, los resultados serán óptimos y podremos decidirnos por la punta seca como procedimiento técnico a emplear. 


\section{IV.2.2. Estezado}

El segundo procedimiento de este bloque está centrado en la consecución de relieves sobre la superficie de los cueros, superando así la estricta bidimensionalidad del resto de experimentaciones para adentrarnos en un campo diferente. Para lograr estos efectos sobre la superficie del soporte recurriremos a una de las numerosas técnicas empleadas a lo largo de la historia, el estezado en húmedo. ${ }^{172}$ Como ya vimos, ${ }^{173}$ existen diversos procedimientos para conseguir relieves sobre el cuero, destacando el gofrado, el repujado, el grabado y el estezado. Sin embargo, nos hemos decantado por este último en base a una serie de factores relacionados con su mayor facilidad de realización para un grabador.

El estezado, a diferencia de las anteriores técnicas, permite un trabajo más directo y sencillo a partir de planchas matrices de diversos materiales como pueden ser la madera, el pvc, el DM174 o cualquier tipo de metal. Unido a ésto destaca el hecho de que las herramientas y

\footnotetext{
${ }^{172}$ El estezado es la decoración de la piel con hierros en seco, ya sea por golpe o por presión. Se diferencia por tanto del gofrado, el cual es una estampación por medio de calor, aunque en ambos procedimientos se proceda a mojar la piel antes de lograr los relieves. Véase BERMEJO MARTÍN, J. B. coor., (1998) p. 120.

${ }^{173}$ Véase capítulo II.2., p. 115 y siguientes.

${ }^{174}$ También conocido como medio denso, será el material escogido para la matriz en este apartado de la investigación. Su composición esta formada por unas fibras muy pequeñas de material lígneo unidas con resina sintética, ofreciendo así una estructura uniforme y una textura fina.
} 
maquinaria que usamos durante este apartado son las propias del mundo del grabado, ya sea la prensa vertical típica de los trabajos xilográficos 0 el tórculo de presión horizontal. De este modo, el procedimiento del estezado queda estrechamente relacionado con el ámbito de la estampa al emplear para su realización dos de los elementos fundamentales de este último: una plancha matriz y una prensa. ${ }^{175}$

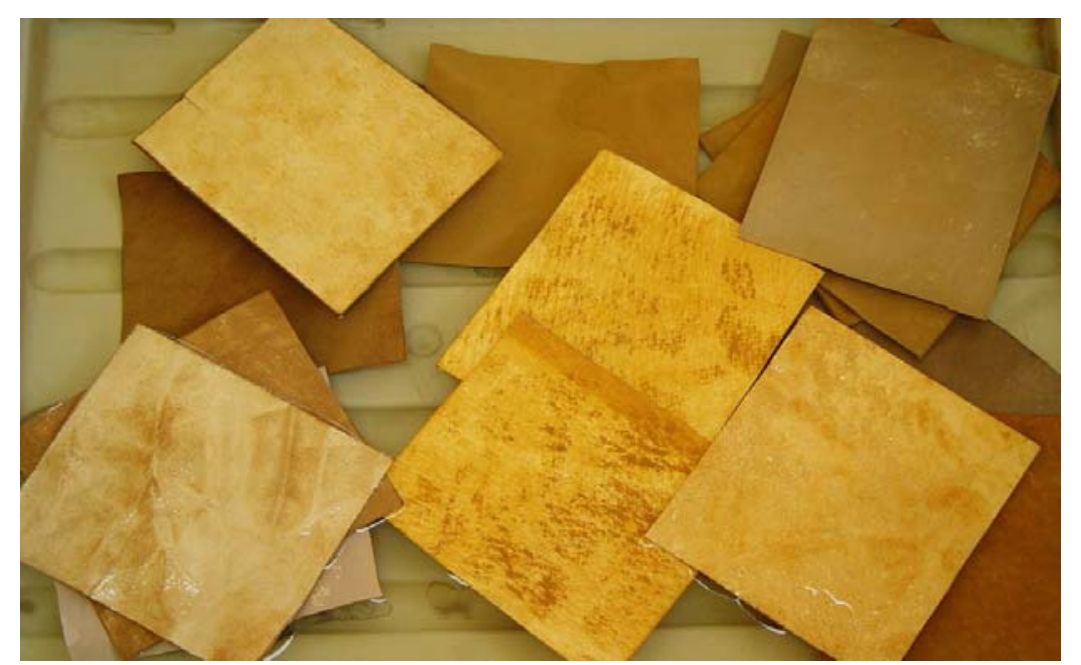

Fig. 120: Diversos trozos de cuero inmersos en agua.

La técnica del estezado está basado fundamentalmente en el mojado y humedecido de los cueros previamente a su impresión en relieve (fig. 120). Si en el gofrado de la piel es el calor intenso el agente físico que permite que la forma presente en el hierro candente

${ }^{175}$ En casi todos los textos consultados, al referirse a la acción de gofrar o estezar una piel, se emplea indistintamente el verbo estampar. 
se grabe sobre el cuero, en este caso será mediante el mojado completo de la piel como conseguiremos esa impresión en relieve. Al preparar la experimentación se nos planteó una cuestión relacionada con este proceso de humectación de la piel: ¿respondería de igual forma un cuero sumergido en agua una hora, qué aquel que lo está durante cuatro, cinco o incluso más tiempo?

Es evidente que el mojado de la piel está destinado a conseguir una mayor flexibilidad del material con objeto de que las formas en relieve presentes en la plancha puedan ser transportadas mediante la presión a la superficie del cuero. Sin embargo, la información bibliográfica no despejaba la duda acerca de la capacidad de absorción de agua por parte de la piel, ni tampoco si la cantidad de líquido retenido pudiera ser diferente dependiendo del tiempo que ésta estuviera en el agua. Para comprobar si las pieles absorbían más y más a medida que pasaban tiempo dentro del agua, y por tanto se volvían más flexibles, ${ }^{176}$ realizamos una prueba de pesado de los cueros anotando el tiempo pasado bajo el agua, cuyos resultados quedan reflejados en la fig. 121.

\footnotetext{
${ }^{176}$ No hay que olvidar que en este proceso de estezado, cuanto más flexible y dúctil se vuelva un cuero, mayor facilidad encontraremos a la hora de estampar el relieve de la plancha.
} 


\begin{tabular}{|l|c|c|c|c|}
\hline & Peso neto & $\begin{array}{c}\text { Peso tras } \\
\mathbf{1} \text { hora }\end{array}$ & $\begin{array}{c}\text { Peso tras } \\
\mathbf{3} \text { horas }\end{array}$ & $\begin{array}{c}\text { Peso tras } \\
\mathbf{6} \text { horas }\end{array}$ \\
\hline CABRA & $6 \mathrm{~g}$ & $14 \mathrm{~g}$ & $15 \mathrm{~g}$ & $16 \mathrm{~g}$ \\
\hline CERDO & $5 \mathrm{~g}$ & $11 \mathrm{~g}$ & $11 \mathrm{~g}$ & $11 \mathrm{~g}$ \\
\hline CORDERO & $9,5 \mathrm{~g}$ & $22 \mathrm{~g}$ & $22 \mathrm{~g}$ & $22 \mathrm{~g}$ \\
\hline VACA & $7 \mathrm{~g}$ & $16 \mathrm{~g}$ & $16 \mathrm{~g}$ & $17 \mathrm{~g}$ \\
\hline
\end{tabular}

Fig. 121. Tabla de pesaje de las pieles.

Se escogieron cuatro trozos de cada una de las pieles, con medidas regulares de $10 \times 10 \mathrm{~cm}$ para todos ellos, procediendo a su pesado en las diferentes condiciones anotadas en la tabla: peso neto en seco, peso tras una hora de inmersión en agua, tras tres y tras seis horas de mojado. Los resultados de este proceso muestran que los cueros, tras un periodo de una hora en el cual absorben una gran cantidad de agua, mantienen un peso estable a lo largo de las horas siguientes, no absorbiendo más liquido. Como media, las pieles aumentan su peso en un $110 \%$, pasando a pesar algo más del doble de su peso inicial. ${ }^{177}$ En vista de estos datos se determina que el nivel de absorción de agua al cabo de una hora, y por tanto el grado de flexibilidad alcanzado por los cueros, es muy próximo al máximo posible, lo que hacia inútil conservar más tiempo las pieles dentro del líquido.

\footnotetext{
${ }^{177}$ En el caso de los soportes ovinos este porcentaje aumenta hasta casi el 150 $\%$, lo que influye de manera determinante en su respuesta a la impresión en relieve.
} 
Decidido el tiempo que los cueros permanecerían mojados antes de ser estampados en relieve, falta por concretar la naturaleza de la matriz que sirva para el estezado. Se emplea una plancha de DM de 4 milímetros de grosor en la que se han realizado, mediante gubias xilográficas, una serie de incisiones de unos 2 milímetros de profundidad aproximadamente. Los motivos de esta decisión son nuevamente funcionales y basados en la facilidad de crear los relieves en la matriz a partir del uso de las gubias. Sin embargo, la posibilidad de emplear cualquier otro tipo de material queda abierta a futuros estudios aunque los resultados definitivos, esto es, el relieve sobre la superficie del cuero, no diferirán excesivamente de los alcanzados en esta experimentación.

Falta por determinar el factor fundamental dentro de este apartado práctico del estezado: el tiempo de presión. En un primer momento de la experimentación sólo se contempla dar una pasada por el tórculo, aplicando un alto grado de presión a la plancha y al cuero depositado sobre ella. Sin embargo, tras unas primeras pruebas infructuosas en las que apenas se logra una mínima impresión en relieve, decidimos sustituir el empleo del tórculo por la prensa vertical, con objeto de poder conservar las planchas y los cueros bajo el efecto de la presión durante un periodo de tiempo más largo.

Las primeras pruebas hacen evidente la enorme mejoría de los resultados bajo estos condicionantes, mucha presión durante mucho 
tiempo, por lo que se decide establecer unos tiempos fijos para todas las pieles. De este modo quedan establecidos cuatro periodos de tiempo para analizar la respuesta de los cueros mojados:

- Impresión rápida178

-15 minutos

-1 hora

-24 horas

Cada tipo de cuero se mantiene durante estos periodos bajo el efecto de la presión de la prensa vertical, obteniéndose de tal modo 16 respuestas diferentes de estampación en relieve.

Por lo que respecta a las pieles empleadas en este apartado, se hace necesaria una puntualización acerca del lado de los cueros sobre el cual realizamos la impresión en relieve. Comprobamos que la huella sólo es visible en las estampaciones sobre el lado flor, y nunca sobre el afelpado del lado carne, el cual desvirtua los contornos de los relieves.

\footnotetext{
${ }^{178}$ Entendemos aquí por impresión rápida aquella en la que se realiza la estampación con la aplicación de presión en el menor tiempo posible para poner en contacto la piel con la matriz grabadora.
} 


\section{IV.2.2.a. Análisis de los resultados}

Comenzando por los cueros de cabra podemos ya establecer una serie de notas generales que se repiten en las demás pieles empleadas en la experimentación con la técnica del estezado. En los dos primeros casos, hasta 15 minutos dentro de la prensa vertical con la máxima presión, apenas si se percibe un mínimo cambio en la superficie de la piel, con un grado de relieve absolutamente insignificante. Pasada 1 hora ya podemos apreciar como la presión ha comenzado a hacer efecto sobre el cuero mojado, pudiendo verse

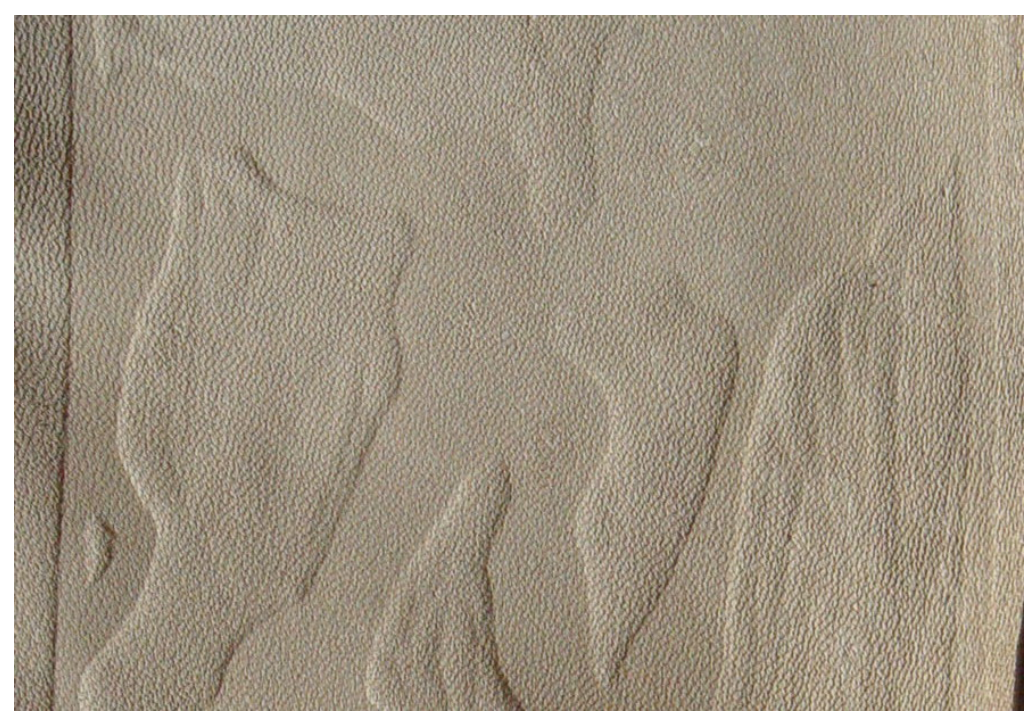

Fig. 122: Detalle del relieve alcanzado en un cuero de cabra tras 1 hora bajo presión 
claramente los contornos de la figura y distinguirse unas zonas más hundidas que las otras que quedan en relieve (fig. 122). Sin embargo, es al mantener el cuero durante 24 horas bajo los efectos de la presión cuando podemos ya comprobar el acusado relieve que pretendíamos conseguir; en este punto la piel se muestra capaz de recoger en su superficie todas las variaciones de relieve presentes en la plancha de madera, llegando incluso a reflejar los trazos producidos por la gubia al eliminar material de la matriz.

Los soportes de cerdo se comportan de manera muy similar, aunque con características particulares derivadas de la especial naturaleza de la superficie de las pieles porcinas. La conocida textura del cuero de cerdo hace algo más difícil la apreciación de los relieves impresos en los primeros ejemplos de la serie, los correspondientes a los tiempos cortos de presión. En efecto, durante la primera hora bajo presión, incluyendo los casos de la impresión rápida, 15 minutos y 1 hora, apenas si podemos intuir los contornos de las zonas en relieve, contornos que quedan casi difuminados por efecto del agrietado de la piel en su lado flor. Tan sólo tras mantener el cuero dentro de la prensa vertical durante 24 horas podemos conseguir una intensidad del relieve de calidad, muy similar a la alcanzada con los cueros de cabra. Sin embargo, a diferencia de estos últimos, las pieles de cerdo no se muestran tan adecuadas para captar los relieves más sutiles presentes en la plancha de madera, los cuales quedan a menudo desvirtuados (fig. 123). Por otro lado, en las zonas de la piel donde ésta ha estado en contacto directo con las partes más elevadas de la plancha y por 
tanto donde la presión ha sido más fuerte, la textura característica del cuero porcino desaparece por completo. Se produce así un interesante contraste entre estas áreas totalmente lisas y pulidas por efecto del estezado y el resto del cuero que todavía presenta el agrietado propio de este tipo de piel.

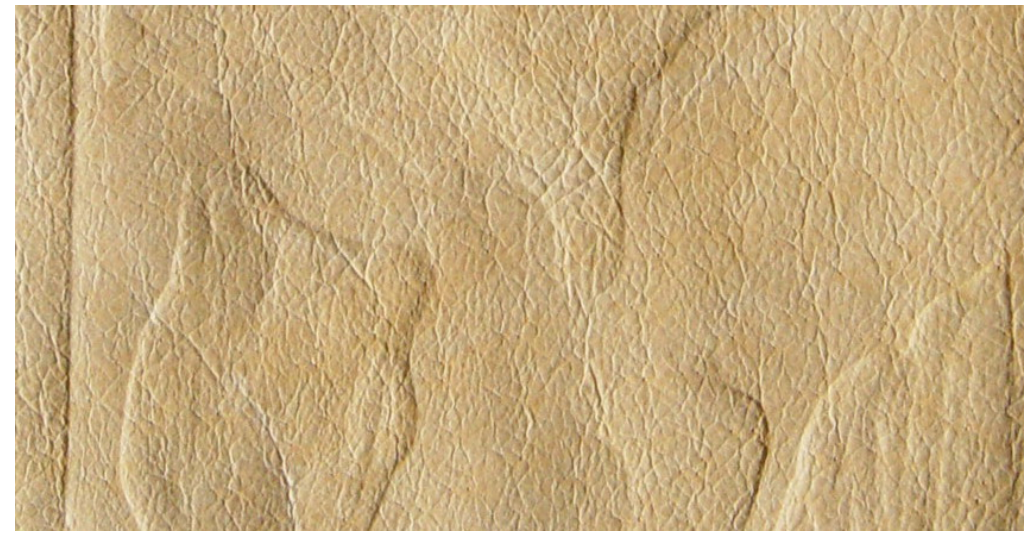

Fig. 123: Detalle del cuero de cerdo tras un tiempo de presión de una hora. Nótese como la textura típica del cuero porcino no desaparece.

Los cueros de cordero son, sin la menor duda, los que mejores resultados ofrecen, con una respuesta extraordinaria gracias a su gran flexibilidad. Podemos apreciar las notables diferencias con el resto de las pieles incluso en los tiempos cortos de presión, y ya en el primer caso, el de impresión rápida, se aprecian, aunque de manera leve, los contornos de los relieves, cosa que no había ocurrido con ningún otro tipo de piel. Al pasar 15 minutos en la prensa la piel ovina ya recoge de manera nítida la forma de la plancha aunque el relieve no 
sea todavía excesivamente potente, como queda patente en la fig. 124 , y sin embargo, en este punto los resultados de este cuero son mucho mejores que en los anteriores, ya que en ellos es prácticamente imperceptible.

Tras permanecer una hora en la prensa la piel ovina ofrece un

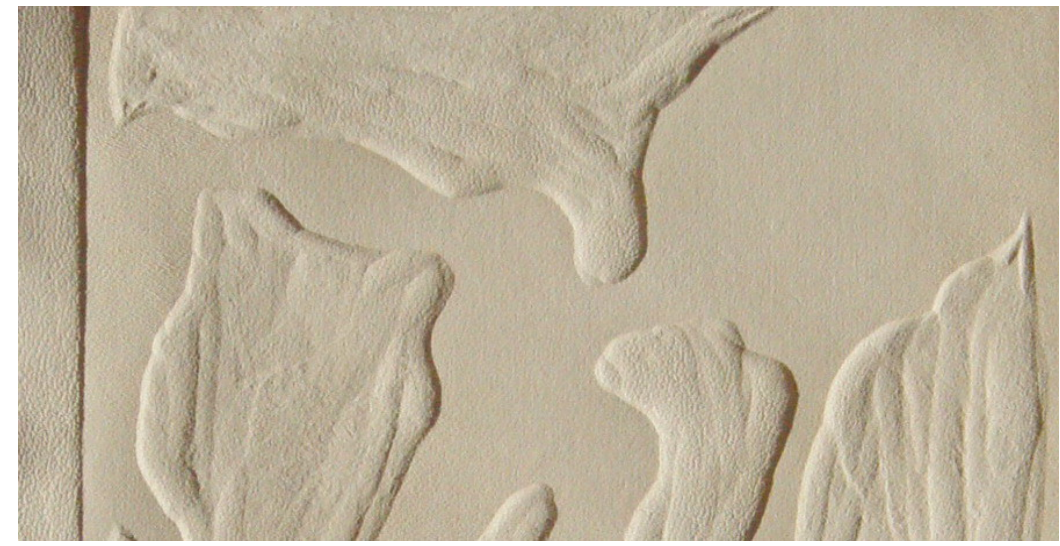

Fig. 124: Relieve sobre piel de cordero tras 15 minutos de presión.

resultado extraordinario, comparable al del resto de cueros al pasar 24 horas, $y$ todos los relieves de la plancha se encuentran perfectamente registrados, ya que la suave textura de la superficie del soporte no interfiere en absoluto en la impresión. Dado que al pasar una hora bajo presión los resultados son ya tan positivos, la diferencia entre este ejemplo y el obtenido tras 24 horas dentro de la prensa no es tan evidente como en el resto de las pieles. En este último ejemplo, tras 24 horas en la prensa, el nivel de intensidad del relieve es extraordinario, adaptándose de manera perfecta a las diferencias de altura presentes en la matriz estampadora. 
Al analizar los cueros de vaca volvemos a encontrar un soporte de características similares a los de cabra y cerdo, por lo que en los dos ejemplos iniciales de la serie, tras la impresión rápida y 15 minutos en la prensa, apenas podamos apreciar cambios significativos en la superficie de la piel. No es hasta que el cuero permanece durante 1 hora dentro de la prensa vertical cuando podemos ya ver de manera clara y patente los contornos de las formas en relieve. Pese a ello, su intensidad todavía no es todo lo potente que cabría desear, de manera similar a lo que ocurría con las pieles caprinas y porcinas. Finalmente, tras permanecer 24 horas bajo los efectos de la presión, el cuero vacuno sí recoge y refleja sobre su superficie todas y cada una de las variaciones de profundidad presentes en la plancha con un resultado óptimo (fig. 125). La ligera textura de esta piel en su lado flor queda eliminada por la presión, aunque sin llegar a producir los efectos de contraste que veíamos al analizar el cuero de cerdo.

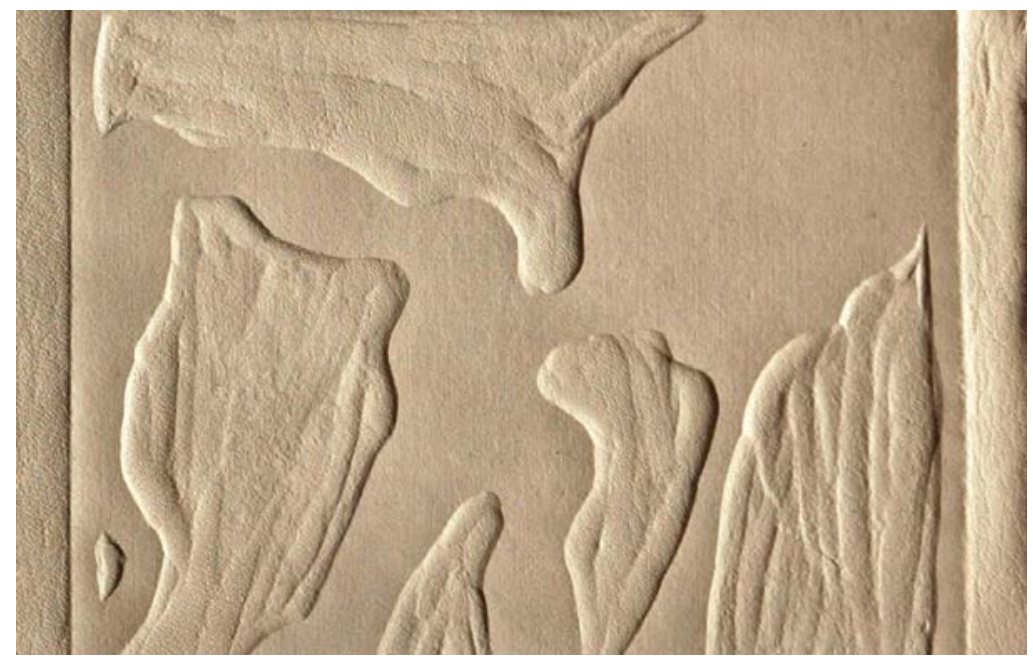

Fig. 125: Relieve sobre piel de vaca tras 24 horas de presión. 


\section{IV.2.2.b Reflexiones parciales}

Desde un punto vista general debemos decir que los resultados obtenidos son de calidad más que aceptable, teniendo en cuenta que el mecanismo empleado para la consecución del relieve se adapta a los condicionantes y las posibilidades de un taller de grabado común. A la hora de exponer estas breves anotaciones hablaremos en relación a los factores más importantes que actúan dentro del proceso: tiempo de presión y tipo de cuero.

\section{- Tiempo de presión}

Sin duda nos encontramos ante un factor fundamental dentro de esta fase de la experimentación, pues las diferencias entre las impresiones que han permanecido hasta 15 minutos bajo presión, y las que han estado hasta 24 horas dentro de la prensa son tremendas. Independientemente de la piel empleada, es sólo tras 24 horas cuando podemos obtener los relieves de la intensidad deseada. Sin embargo, ¿dónde reside realmente la diferencia entre una piel que ha permanecido 1 hora bajo la prensa y otra que lo ha hecho 24 horas? ¿No es suficiente tiempo 1 hora para conseguir que la piel adopte las formas de la superficie de la plancha? 
La respuesta está relacionada íntimamente con el tiempo de permanencia en la prensa, pero además con un factor determinante: el secado del cuero.

La diferencia entre una piel que ha estado 1 hora dentro de la prensa y aquella que lo ha hecho todo un día es realmente que esta última ha perdido toda la humedad bajo los efectos de la presión, mientras que aquella ha secado fuera de la prensa vertical. Al mojar la piel antes de someterla a la presión lo que se pretende es aumentar su grado de flexibilidad con objeto de que recoja mejor los relieves de la plancha, pero si ésta pierde esa humedad sin estar sometida a la presión, el cuero tiende a recuperar su estado previo, mitigándose los efectos de la impresión en relieve. Si, por el contrario, permitimos que la piel seque en contacto con la plancha mientras todavía está sometida a la presión, al sacarla de la prensa totalmente carente de humedad su bajo grado de flexibilidad le impide recuperar su estado primitivo, por lo que las formas en relieve permanecen sin sufrir modificaciones posteriores.

Así, para conseguir los efectos de relieve deseados lo verdaderamente importante es que la piel permanezca en contacto con la plancha y bajo presión el tiempo necesario hasta que seque totalmente. Este tiempo será por lo tanto relativo y relacionado con múltiples factores tales como: 
- Tipo de piel.

- Grosor.

- Cantidad de agua absorbida por el cuero.

- Humedad relativa del ambiente.

- Temperatura ambiental.

- Posibilidad de utilizar material absorbente durante la impresión: papel absorbente, telas, fieltros...

- Intensidad de la presión ejercida con la prensa.

Todas estas coordenadas condicionan el tiempo necesario para lograr el secado de la piel dentro de la plancha y por consiguiente para alcanzar una intensidad de relieve lo más satisfactoria posible. Dependiendo de la temperatura ambiental o de la humedad relativa obtenemos unos tiempos de secado que pueden variar de manera considerable, y lo mismo podemos afirmar si nos referimos al grosor de la piel 0 al aumento de peso por efecto de la absorción de agua. Una vez alcanzado el secado total bajo los efectos de la presión, todo el tiempo restante que la piel se encuentre dentro de la prensa resulta innecesario, dado que habremos logrado la máxima intensidad de relieve que admite la piel.

\section{- Tipo de cuero.}

Pese a que el factor tiempo es sin duda el más importante para conseguir las impresiones en relieve, la elección de un cuero u otro 
también es determinante y condiciona en buena medida el trabajo con este tipo de procesos. El cuero de cordero es, sin el menor margen de duda, el más indicado para realizar este tipo de trabajos de estezado; su gran flexibilidad lo hace ideal para recoger los cambios de nivel de la plancha y reflejarlos en su superficie, registrando hasta el más mínimo accidente presente en la matriz. Esta enorme flexibilidad le confiere interesantes ventajas con respecto al resto de las pieles, ventajas que pueden incidir en una disminución del tiempo de trabajo y en una mayor facilidad de intervención sobre el cuero.

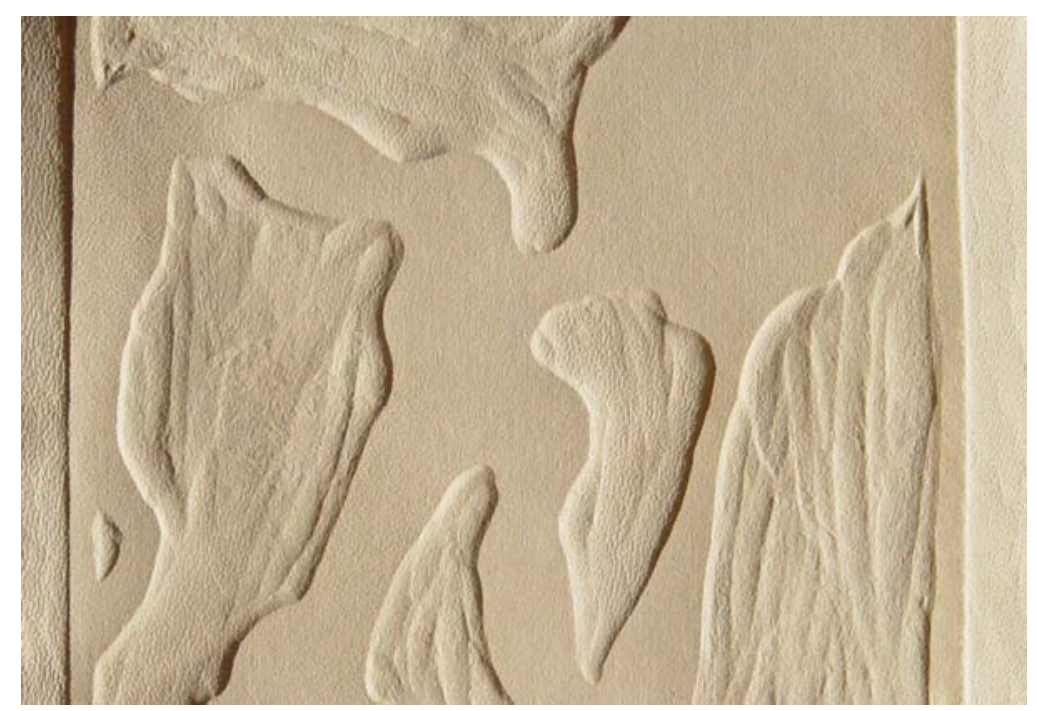

Fig. 126: Relieve sobre el cuero ovino tras 1 hora bajo los efectos de la presión vertical.

De tal modo, es el cuero ovino el que más rápidamente responde a los efectos de la presión, con un resultado casi óptimo tras 
1 hora dentro de la prensa vertical tal y como puede apreciarse en la fig. 126. Esto indica que, al contrario de lo que ocurre con el resto de las pieles, no es absolutamente necesario esperar a que el soporte de cuero ovino seque bajo los efectos de la presión para lograr un relieve más que aceptable. Si bien no cabe la más mínima duda de que los resultados serán mejores en el caso de que el proceso de secado se produzca de manera íntegra dentro de la prensa, el hecho de poder alcanzar resultados muy satisfactorios en mucho menos tiempo que con las otras pieles analizadas, hace que la piel de cordero sea la mejor opción para acortar los periodos de trabajo y facilitar la impresión.

Pese a lo comentado, si se decide utilizar cualquier otro cuero, recordemos que los resultados finales obtenidos tras el secado bajo presión son en todos los casos positivos y de gran calidad, presentando cada tipo de piel diferente una serie de características propias asociadas a su textura superficial. 


\section{IV.2.3. Transferencia}

El último de los procedimientos alternativos que completa esta segunda fase de experimentación práctica previa a la propuesta de investigación personal es el de la transferencia de imágenes. Como ya se ha indicado brevemente en líneas precedentes, el incluir la transferencia dentro de este punto de la investigación está claramente ligado a los objetivos de la propuesta plástica personal. Es evidente que su relación con el mundo del grabado y la estampación es menos estrecha que en el caso del estezado, pero finalmente nos hemos decidido a incluirla dados los puntos de contacto existentes. ${ }^{179}$

El primero de éstos es el procedimiento seguido para lograr la transferencia, dado que el empleo del tórculo lo relaciona con los procesos de grabado y estampación más tradicionales. ${ }^{180}$ El segundo punto de contacto se establece si consideramos las fotocopias a partir de las cuales trabajamos como planchas matrices para cada una de las transferencias. ${ }^{181} \mathrm{Al}$ igual que la preparación de la plancha para el

\footnotetext{
${ }^{179}$ Actualmente el procedimiento de la transferencia se encuentra totalmente integrado dentro del campo de la estampación, trabajándose con frecuencia e interrelacionándose con las técnicas propias de dicho ámbito.

${ }^{180}$ Todas las pruebas realizadas es este apartado práctico están logradas a partir de la utilización de la presión horizontal aplicada con el tórculo como elemento fundamental para la consecución de una correcta transferencia de la imagen.

${ }^{181}$ Es evidente que el concepto de matriz en su sentido más ortodoxo queda algo alejado, dado que una fotocopia queda casi totalmente destruida e inservible una vez se ha procedido a la transferencia.
} 
monotipo queda inutilizada tras su estampación, así le ocurre a la fotocopia, y si bien es cierto que ambos procedimientos imposibilitan casi totalmente el tiraje y la numeración, ello no es óbice para que se incluyan en el ámbito de la estampa de edición.

Antes de pasar a analizar los resultados obtenidos, es necesario comentar algunos condicionantes técnicos que han definido el proceso de transferencia de imágenes. Al realizar una transferencia electrográfica existen tres factores fundamentales: la fotocopia, el modo de transferirla y el soporte escogido. Dado que este último nos viene determinado por la naturaleza de nuestro trabajo específico, nos referiremos a los dos primeros ítems, especificando sus características concretas. ${ }^{182}$

En lo que respecta a las fotocopias empleadas, se opta por utilizar fotocopias a color, ${ }^{183}$ dejando de lado las fotocopias en blanco y negro; seguimos un criterio totalmente personal y condicionado por los intereses plásticos y estéticos a desarrollar en la fase posterior. Con objeto de poder comparar de manera satisfactoria los resultados obtenidos sobre las diferentes pieles seleccionadas, utilizamos 8 fragmentos de la misma fotocopia (fig. 127), y no 8 fotocopias distintas, de modo que se evitan en lo posible las eventuales diferencias, ya sea

\footnotetext{
${ }^{182}$ En esta fase volvemos a utilizar ambas caras de las pieles seleccionadas, lo que hace que el número total de superficies sea de ocho.

183 Todas las fotocopias, tanto de esta fase de experimentación práctica como de la posterior propuesta plástica personal, están realizadas con la misma fotocopiadora, una Canon-3300.
} 
en la intensidad del tóner o en su fijación sobre el papel de soporte, que pudieran aparecer dentro del grupo de fotocopias elegidas. Estas variaciones entre diferentes fotocopias podrían llegar a dificultar el análisis correcto de los resultados, por lo que se intentan evitar a toda costa en el proceso de experimentación práctica.

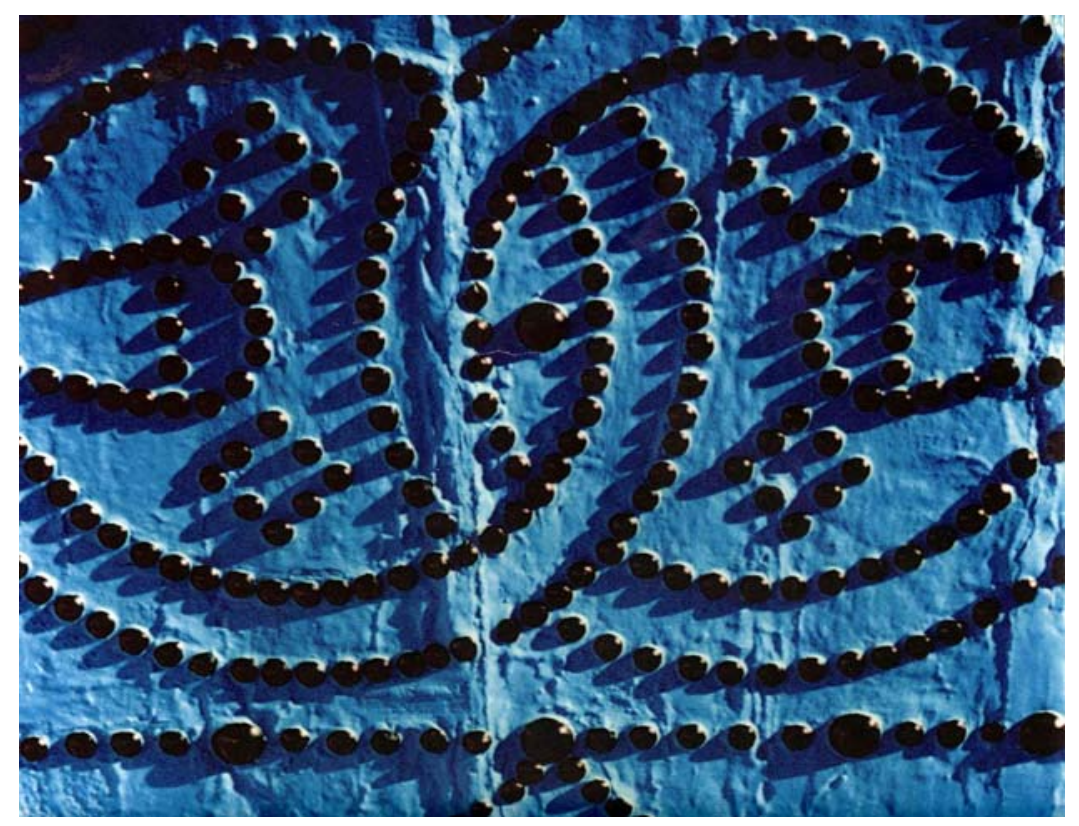

Fig. 127: Fragmento de la fotocopia utilizada como base para las transferencias de este apartado.

El procedimiento escogido para la transmisión de la imagen electrográfica al soporte de piel es la transferencia mediante la acción de disolventes químicos y presión, ${ }^{184}$ dejando de lado otras opciones

${ }^{184}$ El disolvente empleado en todas las transferencias ha sido el disolvente universal de la marca SPB compuesto por metanol y etano. 


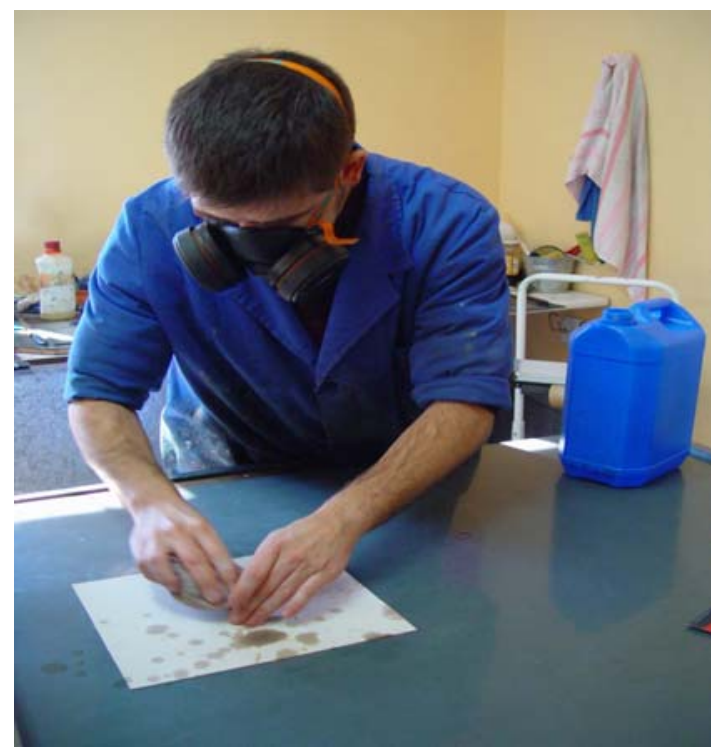

Fig. 128: Aplicación del disolvente sobre la superficie del cuero.

como el proceso térmico. De las múltiples posibilidades existentes en lo que a la aplicación del disolvente se refiere, 185 nos decantamos, tras numerosas pruebas, por depositar el líquido sobre el soporte con un trapo de algodón. (fig. 128) Con ello se consigue una acción directa del producto sobre la película de pigmento presente en la fotocopia, que unida a la presión ejercida por el tórculo, da como resultado unas imágenes muy satisfactorias.

${ }^{185}$ Sobre el dorso de la fotocopia, mediante vaporizadores, empleando brochas, utilizando tan sólo los vapores emanados del mismo... 
Tanto la cantidad de disolvente como la intensidad de la presión han sido ajustadas al mínimo necesario, dado que un exceso en alguna de ellas imposibilita una transferencia correcta, desvirtuándose la imagen fotográfica tanto en sus contornos como en su gama cromática.

\section{IV.2.3.a. Análisis de los resultados}

Los cueros de cabra son, sin la menor duda, los que mejores condiciones presentan para ser utilizados como soportes para transferencias electrográficas. Sobre el lado flor ligeramente satinado (fig. 129) la respuesta de la imagen es de gran calidad, ofreciendo tan

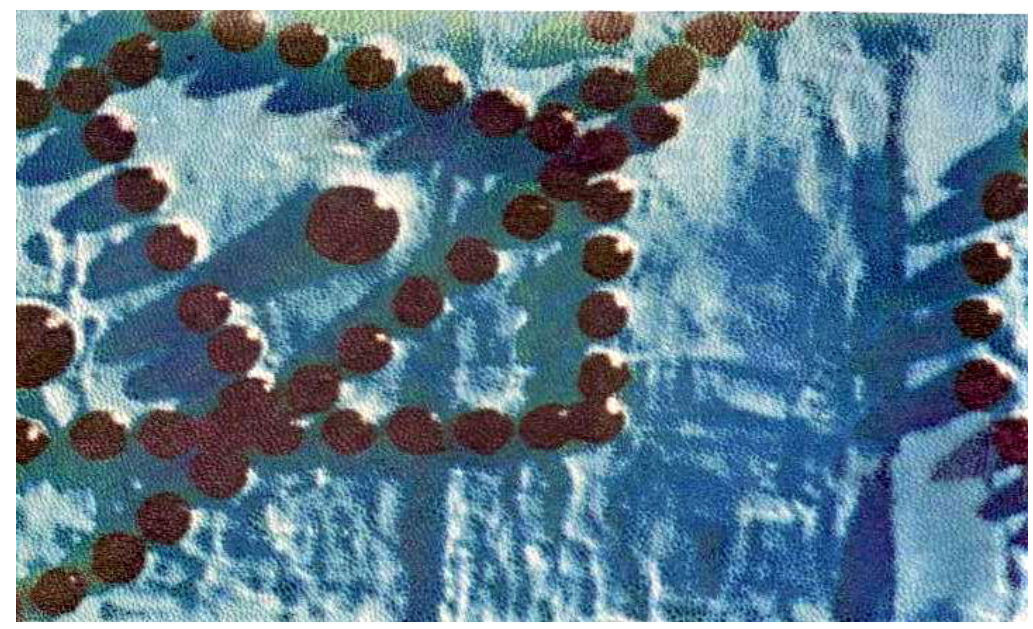

Fig. 129: Transferencia sobre piel de cabra en su lado flor: TRA-01. 
sólo algunos inconvenientes aislados. Por un lado, los negros no alcanzan una intensidad totalmente satisfactoria pese a que su tono es bastante elevado, mientras que la superficie algo brillante del cuero no se muestra capaz de registrar de manera perfecta los medios tonos, lo que da lugar a una imagen ligeramente más contrastada que la existente en la fotocopia.

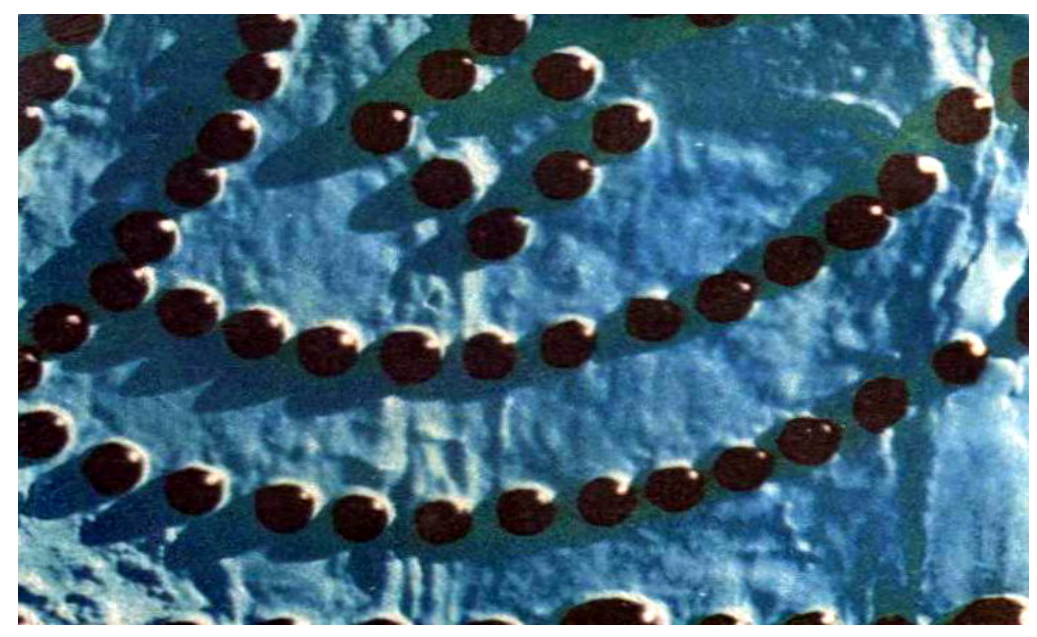

Fig. 130: Transferencia sobre piel de cabra en su lado carne: TRA-02.

Si el lado flor ofrece un resultado más que positivo, es en el lado carne de este cuero caprino en el que nos encontramos con el mejor soporte para ser empleado como receptor de transferencias. (fig. 130) La respuesta es prácticamente perfecta, con un registro excelente de la intensidad de los negros así como de los tonos medios, lo que permite una reproducción de la imagen presente en la fotocopia de enorme fidelidad. Al igual que ocurre con cualquier tipo de tinta usada 
en las estampaciones precedentes, el afelpado del lado carne del cuero oscurece ligeramente el tono general de la imagen. Sin embargo, su incidencia en el ejemplo es mínima, por lo que no logra interferir en el excelente resultado obtenido con esta piel caprina.

Los soportes de cerdo no se comportan de la misma manera que los anteriores, y ofrecen numerosos inconvenientes. En su lado flor (fig. 131) el resultado de la transferencia no puede ser definido de otra manera que no sea incidiendo en su mala calidad global. Su acabado satinado, así como la característica textura agrietada del cuero porcino, provocan que la película de pigmento no asiente de manera correcta, con lagunas y pérdida de la casi totalidad de tonos medios de la imagen. Tampoco el negro alcanza una intensidad aceptable, a la vez que, en las zonas donde se ha depositado el pigmento proveniente de la fotocopia, surgen unos molestos e irregulares brillos y reflejos que entorpecen la visión de la imagen.

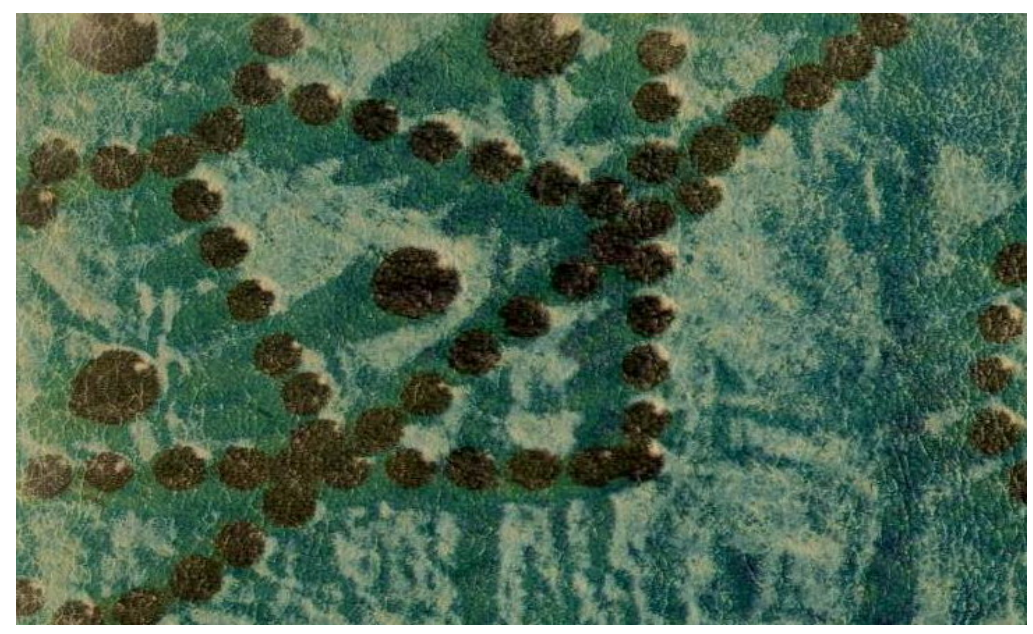

Fig. 131: Transferencia sobre piel de cerdo en su lado flor: TRA-03. 
En el lado carne (fig. 132) la situación sufre una leve mejoría, aunque ésta no le permita alcanzar unos niveles de calidad suficientes. Si bien llegan a desaparecer los brillos, consecuencia lógica del afelpado del soporte, este mismo acabado rugoso provoca un oscurecimiento patente de la imagen, fenómeno que dificulta la apreciación de los tonos medios. También el cromatismo de la transferencia se ve afectado, dado que el intenso azul que caracteriza la fotografía original se ve transformado en un gris azulado algo pardo, perdiendo toda su viveza e intensidad cromática.

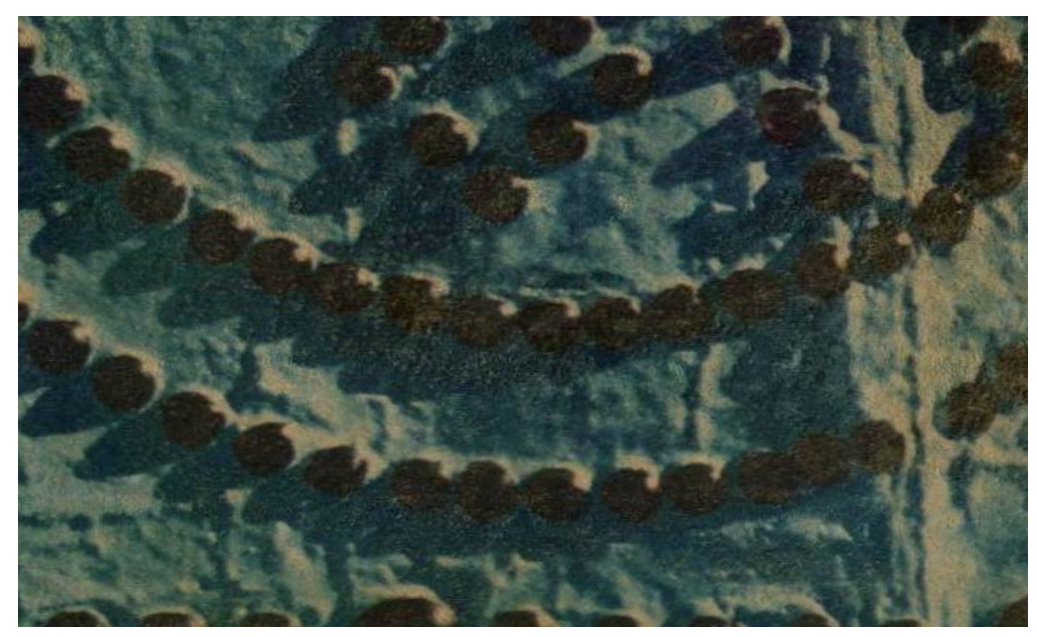

Fig. 132: Transferencia sobre piel de cerdo en su lado carne: TRA-04. 


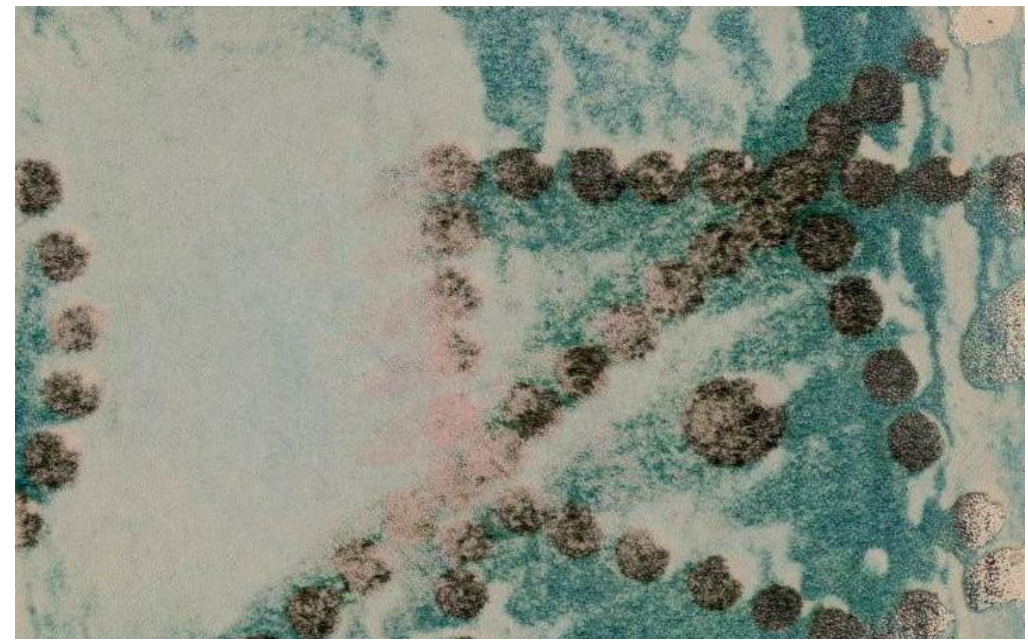

Fig. 133: Transferencia sobre piel de cordero en su lado flor: TRA-05.

El cuero de cordero es el que mayores diferencias muestra entre uno y otro lado de la piel, con un ejemplo de muy mala calidad, el TRA-05 (fig. 133) sobre la flor del cuero, y otro de buen nivel, el TRA06 en el lado carne. El primero acusa el acabado excesivamente satinado de la piel ovina, lo que impide que el tóner asiente de manera mínimamente aceptable. Aparecen enormes lagunas en las cuales apenas ha sido depositada una ínfima cantidad de pigmento, mientras que en las áreas donde puede llegar a apreciarse la imagen, ésta carece de la intensidad y nitidez necesaria como para convertirse en un ejemplo válido. Llama la atención la muy deficiente recepción del tono negro por este soporte concreto, dado que tan sólo en ciertas zonas merece ser llamado con tal nombre, mientras que en el resto tan sólo podemos referirnos a él con el adjetivo de gris.

Si el resultado anterior era pésimo, no se puede decir lo mismo de la transferencia en el lado carne, la cual, pese al afelpado lógico de 
dicha superficie, ofrece unas características totalmente diferentes. (fig. 134) Si exceptuamos un oscurecimiento general de la imagen algo más intenso que el apreciado en el ejemplo TRA-02 sobre piel de cabra ${ }^{186}$ y mínimas irregularidades de asentamiento en ciertas zonas, el resultado es muy positivo. Los tonos medios se encuentran correctamente registrados, así como las áreas de un negro más intenso, lo que la convierte en uno de los mejores ejemplos de los alcanzados.

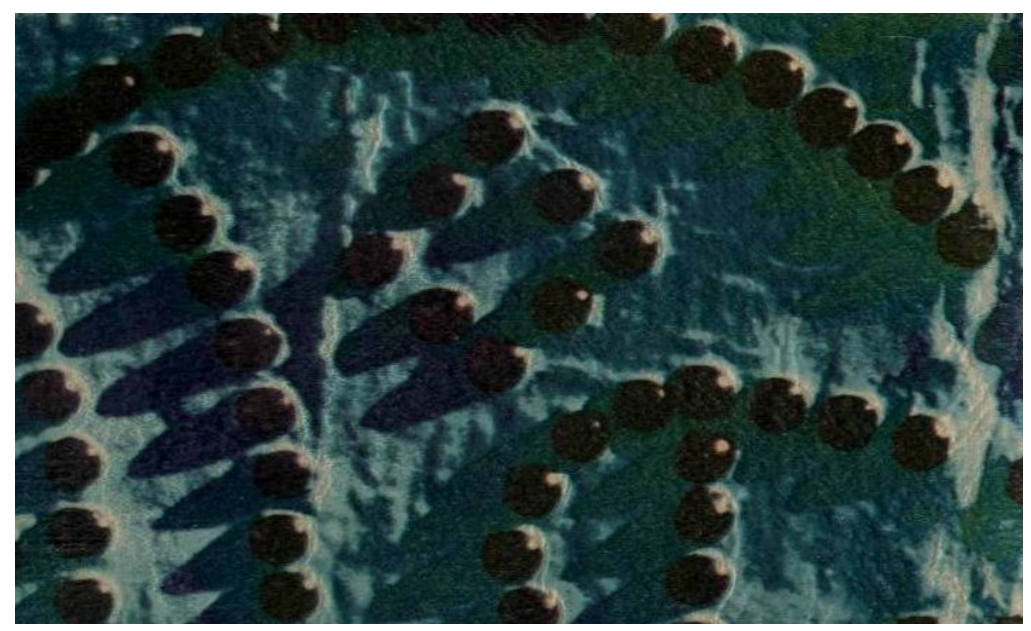

Fig. 134: Transferencia sobre piel de cordero en su lado carne: TRA-06.

Por último, los cueros de vaca ofrecen patentes diferencias entre los resultados alcanzados sobre cada uno de los lados de la piel, aunque en este caso se invierten los papeles con respecto al cuero de

${ }^{186}$ Este oscurecimiento más acusado viene provocado por un afelpado mucho más acentuado en este cuero ovino. 
cordero: la transferencia sobre la flor de la piel, TRA-07, es de buen nivel, y es el ejemplo en el lado carne, TRA-08, el que presenta los mayores inconvenientes. Por lo que respecta al lado flor, y como ya hemos adelantado, su nivel es bastante positivo, con un registro más que correcto de los tonos más intensos si exceptuamos mínimas zonas que no interfieren en la apreciación global de la imagen. (fig. 135) Aparece sin embargo un fenómeno que no se repite en el resto de los cueros seleccionados y es que, por efecto del satinado de la flor del cuero, el tono general de la fotografía no es reflejado con fidelidad por la transferencia. Así, en lugar de alcanzar una imagen con la misma intensidad tonal, lo que obtenemos es un resultado mucho más claro sin lograr el azul intenso que domina la fotografía original. Pese a ello,

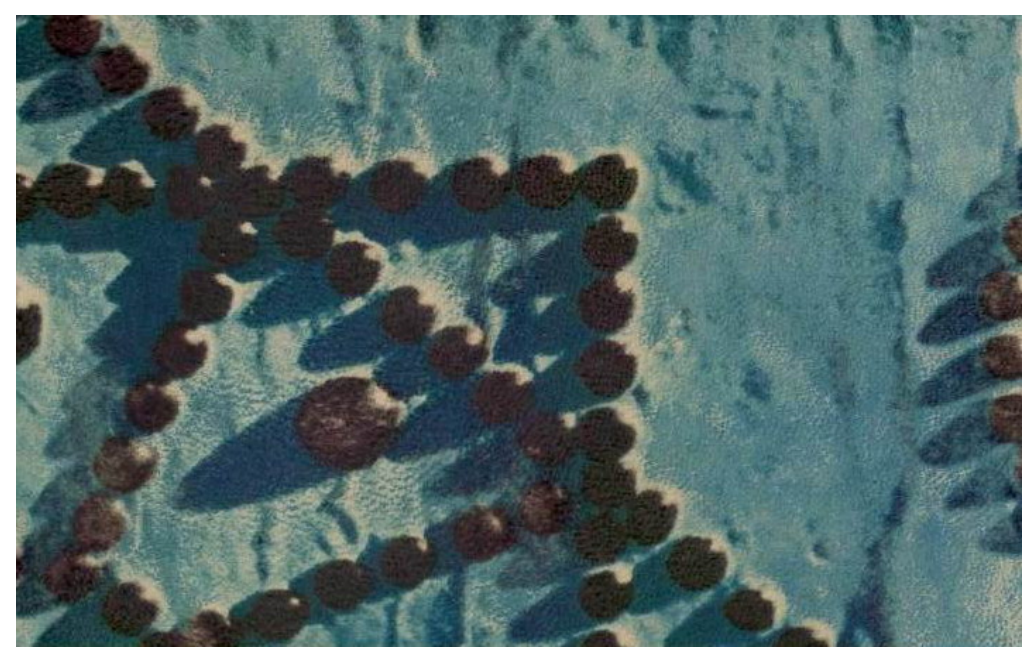

Fig. 135: Transferencia sobre piel de vaca en su lado flor: TRA-07. 
no aparecen lagunas ni zonas vacías de tóner, lo que permite que el nivel de calidad sea más que aceptable.

Todo lo contrario ocurre en el último de los ejemplos reflejado en la fig. 136. Por efecto del acusado afelpado que presenta la superficie del lado carne de estos cuero vacunos, la imagen transferida sufre un más que evidente oscurecimiento que desvirtúa su apariencia. El afelpado es tan acusado en algunas zonas que llega a dificultar un correcto asentamiento del pigmento sobre la piel, provocando en ciertas áreas una ausencia de nitidez que devalúan el nivel de calidad de la estampa.

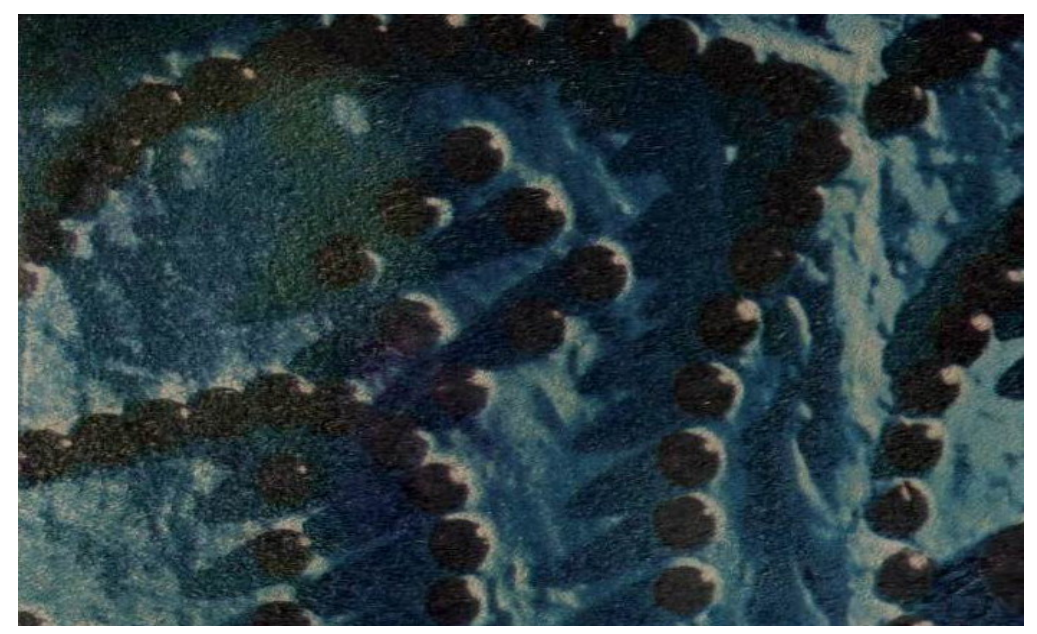

Fig. 136 Transferencia sobre piel de vaca en su lado carne: TRA-08. 


\section{IV.2.3.b Reflexiones parciales}

Vistos los resultados obtenidos en todas las pieles seleccionadas, podemos realizar unas breves reflexiones en torno a este bloque experimentador. La calidad de las transferencias permite observar que el $50 \%$ de ellas puede ser calificado como bueno o muy bueno, mientras el restante porcentaje no lograba alcanzar un aceptable nivel. Destacaremos que tan sólo una de las imágenes, la TRA-02 correspondiente al lado carne del cuero caprino, ofrece unas características óptimas para conseguir una transferencia lo más fiel posible a la imagen original, por lo que servirá de referencia con la que comparar el resto de los ejemplos.

Las superficies que peores resultados han ofrecido han sido tanto las de flor muy satinada, como los lados carne de acusada textura. En el primer caso la película de tóner no logra asentar de manera correcta sobre el cuero, y produce intensos brillos en las zonas de mayor densidad de pigmento depositado. Por su lado, si la piel presenta un excesivo afelpado éste provoca dos fenómenos de negativa incidencia sobre la transferencia: un deficiente asentamiento del pigmento sobre una superficie en exceso irregular; y un intenso oscurecimiento general de la imagen que puede llegar a desvirtuarla al anular sus contrastes. 
Los soportes que han ofrecido aceptables condiciones, sin importar el tipo de animal del que proviniera, son las pieles cuyos lados flor poseen un acabado no demasiado satinado, tal y como apreciamos en los ejemplos TRA-01 y TRA-07. ${ }^{187}$ Sobre estas superficies la película de tóner es capaz de asentar de manera satisfactoria, logrando una nitidez de registro y una fidelidad al original más que correctas. Sin embargo, el cuero que se ha comportado de forma extraordinaria ha sido el caprino en su lado carne, lado carne de un muy sutil afelpado que permite que no aparezcan los inconvenientes citados, y evita por tanto el deficiente asentamiento del tóner y, sobre todo, el excesivo oscurecimiento de la imagen transferida. ${ }^{188}$

Podemos afirmar que los soportes ideales para ser empleados como receptores de transferencias son aquellos que poseen una naturaleza similar al empleado en el ejemplo TRA-02, pudiendo encontrarse tales condiciones en cualquier tipo de cuero, ya sea caprino, porcino, ovino o vacuno. Estas características pueden ser resumidas en unos pocos rasgos definitorios:

- Lado carne con un afelpado lo más sutil posible.

- Tonalidad clara.

- Superficie regular, homogénea y sin imperfecciones.

\footnotetext{
${ }^{187}$ Correspondientes al cuero de cabra y al vacuno.

${ }^{188}$ En muchas ocasiones el oscurecimiento es tan ligero que tan sólo comparando directamente el original con la imagen transferida es posible apercibirse del mismo.
} 


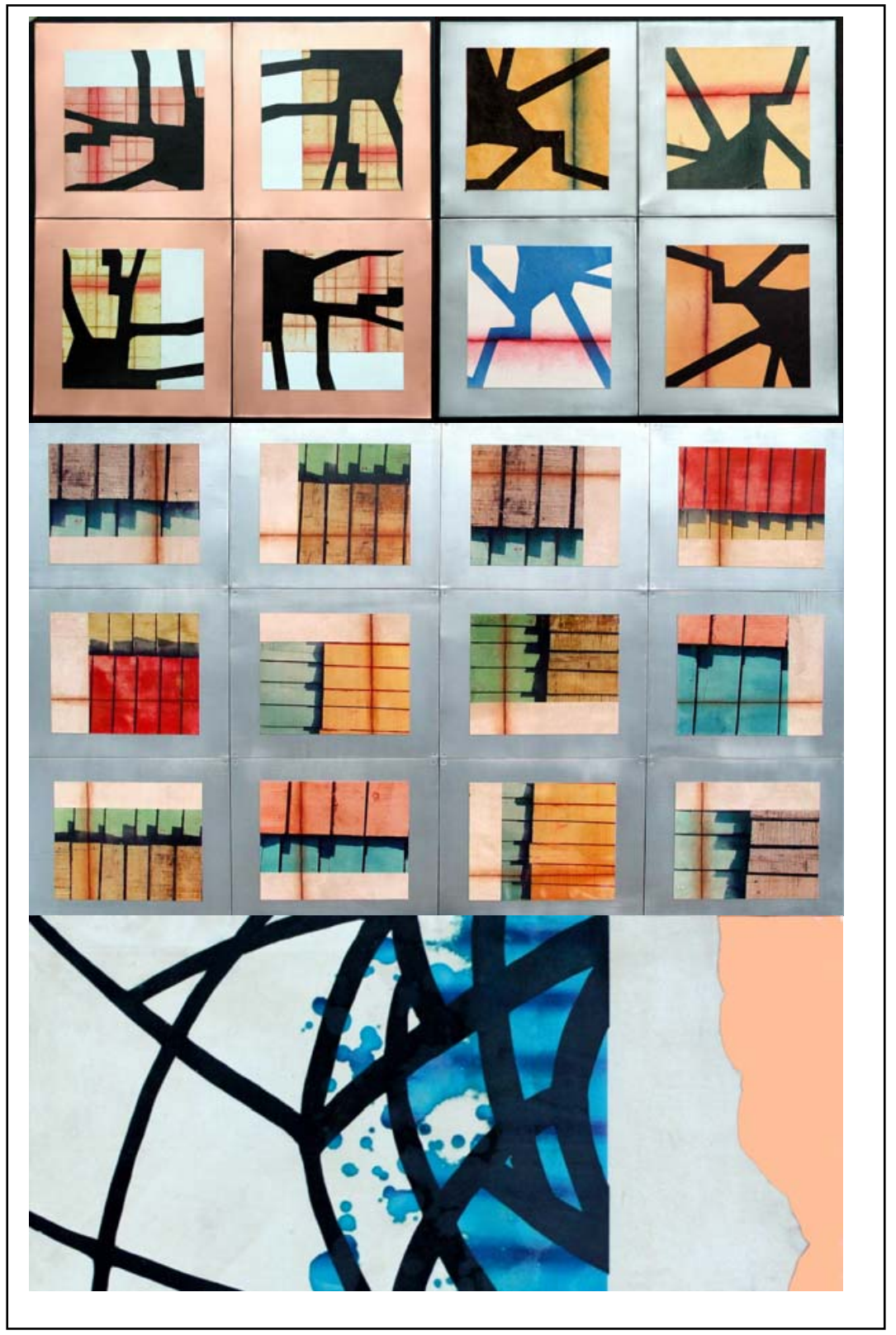





\section{V.PROPUESTA PLÁSTICA PERSONAL}

\section{V.1. ANOTACIONES PREVIAS}

Como se ha indicado en la introducción, los primeros antecedentes de utilización de la piel como soporte para obra personal datan del curso académico 2000-2001, en el citado curso "Grabado en relieve y libro artístico", del programa de doctorado "Grabado y estampación" del Departamento de Dibujo de la Facultad de Bellas Artes de San Carlos de Valencia. La edición de tres ejemplares de libro de artista en los cuales el cuero tenía un papel fundamental como soporte de las imágenes, estampadas en aquel caso concreto a partir de planchas metálicas en relieve y matrices de técnicas aditivas (fig. 137), fue el pistoletazo de salida para el trayecto que ahora culminamos. 


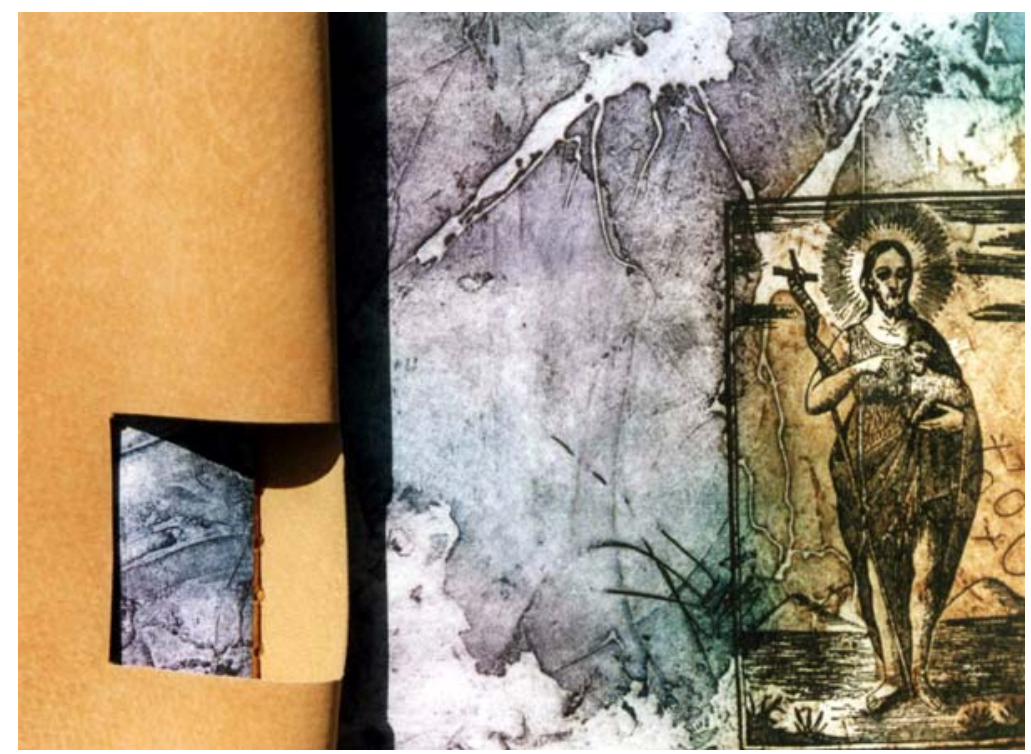

Fig. 137 Detalle del libro de artista Un villancico de verano (2001)

Técnicas aditivas y estampación en relieve sobre papel y piel de cerdo.

En la mencionada edición de libros de artista el cuero utilizado fue el de forro de cerdo, con una tonalidad media que permitió una serie de estampaciones en relieve a partir de una plancha metálica con una iconografía de origen religioso, con resultados de gran nitidez en las imágenes y una apreciable calidad de matices y texturas.

Este primer empleo del cuero no pasó de responder a una inquietud puntual por acercarnos a soportes alternativos, sin que supusiera en ningún caso una experimentación sistemática u organizada de las posibilidades plásticas del soporte. De hecho, sobre la piel animal las únicas intervenciones gráficas que realizadas fueron, 
además de las comentadas estampaciones en relieve, la escritura de unas frases con pluma y tinta china, y en ambos casos la única tinta empleada fue la negra, sin entrar a valorar la posibilidad de introducir tintas de colores, ya fuera al estampar como al escribir con la pluma. Pese a la evidente simplicidad de los procedimientos gráficos empleados en estos trabajos iniciales sobre cuero, éstos supusieron, sin el menor género de duda, el pistoletazo de salida para toda la actuación posterior, tanto en lo que se refiere a la experimentación sistemática de impresión sobre piel, como a la investigación plástica con el cuero como soporte. Fue durante el planteamiento y resolución de los libros de artista cuando el cuero se reveló como un material susceptible de poder ser empleado como parte constituyente de una obra plástica con entidad propia, ofreciendo, incluso desde este primer episodio, un amplio abanico de posibilidades que ahora estamos teniendo oportunidad de corroborar.

Poco a poco el resto de los procedimientos fue entrando dentro del abanico de opciones que la piel animal ofrece. Aquellas relacionadas con el grabado calcográfico, léase punta seca, aguafuerte y aguatinta, llegaron de manera natural y lógica como consecuencia de trabajar los cueros con técnicas propias del mundo de la estampa. Sin embargo, otras soluciones plásticas tuvieron una aparición mucho más casual y fueron guiadas por la intuición o por el más caprichoso de los azares. Así, la posibilidad de trabajar mediante la transferencia de imágenes electrográficas, que en un principio quedaba fuera de un estudio en profundidad, surge de manera casi inesperada, causando 
una profunda y positiva impresión por el enorme mundo de posibilidades estéticas que abre a la hora de crear una obra personal con la piel como soporte, después de todos los estudios y análisis efectuados. ${ }^{189}$

Desde el primer momento, el poder introducir imágenes fotográficas en las obras se presenta como una fuente de enormes ventajas para la configuración de nuestra poética personal, y da lugar a una serie de piezas bajo un profundo deseo experimentador, combinando en muchas de ellas la transferencia con otras técnicas ortodoxas propias del mundo de la estampa, sobre todo la punta seca debido a su inmediatez de trabajo y su frescura gestual. Como es lógico, las primeras obras producidas eran de pequeño formato, tratando de familiarizarnos lo antes posible con los posibles inconvenientes que todo procedimiento novedoso conlleva al aplicarlo de manera práctica. Obras como las reflejadas en la fig. 138 demuestran, pese a su modestia, este empeño por lograr unos resultados aceptables.

${ }^{189}$ Pese a lo azaroso del proceso comentado, es obvio que fue el entorno de trabajo con la piel el que provocó la aparición de estas nuevas posibilidades. 

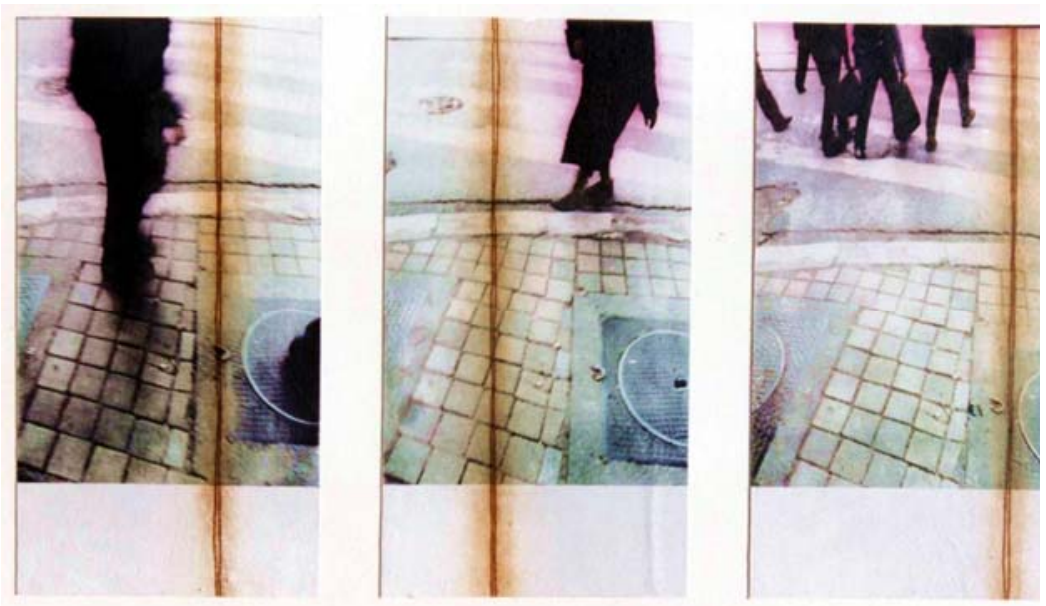

Fig. 138: Paseantes (2002) Transferencia y punta seca sobre piel de cabra y papel, 35 x $20 \mathrm{~cm}$ (cada uno)

Como puede verse aquí, en un momento inicial de experimentación plástica totalmente libre, el cuero fue combinado con el papel, ya fuera como soporte y sostén para las flexibles porciones de piel o como parte constituyente de las obras realizadas. Sin embargo, y debido a cuestiones meramente estéticas centradas sobre todo en el escaso contraste existente entre el tono de piel empleado en la mayoría de los trabajos y el papel, se inició una búsqueda de un material alternativo que pudiera dialogar plásticamente de manera más eficiente con el cuero. 
De este proceso de prueba y descarte de diferentes superficies, surge la idea de combinar el cuero con metales tales como el zinc y el cobre. Dialogan de tal modo la calidez de la piel con la frialdad del metal; la textura rugosa y orgánica del cuero con el acabado pulido y acerado del zinc y el cobre; los contornos muchas veces orgánicos de los pellejos con los bordes cortantes y agresivos de las planchas; el mate de las superficies orgánicas con el brillo intenso de los soportes metálicos.

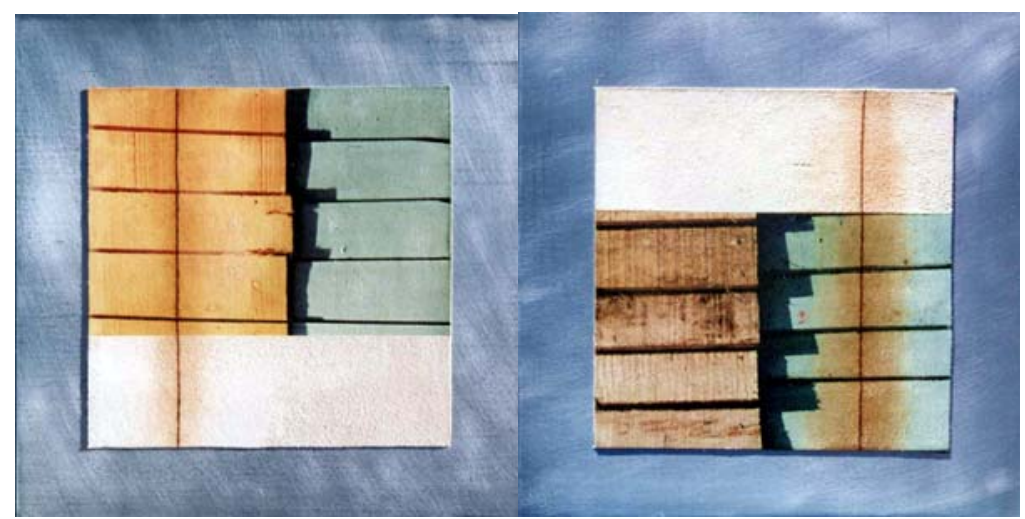

Fig. 139: Estambul I (2003) Transferencia y punta seca sobre piel de cabra y zinc, 25 x $50 \mathrm{~cm}$. 


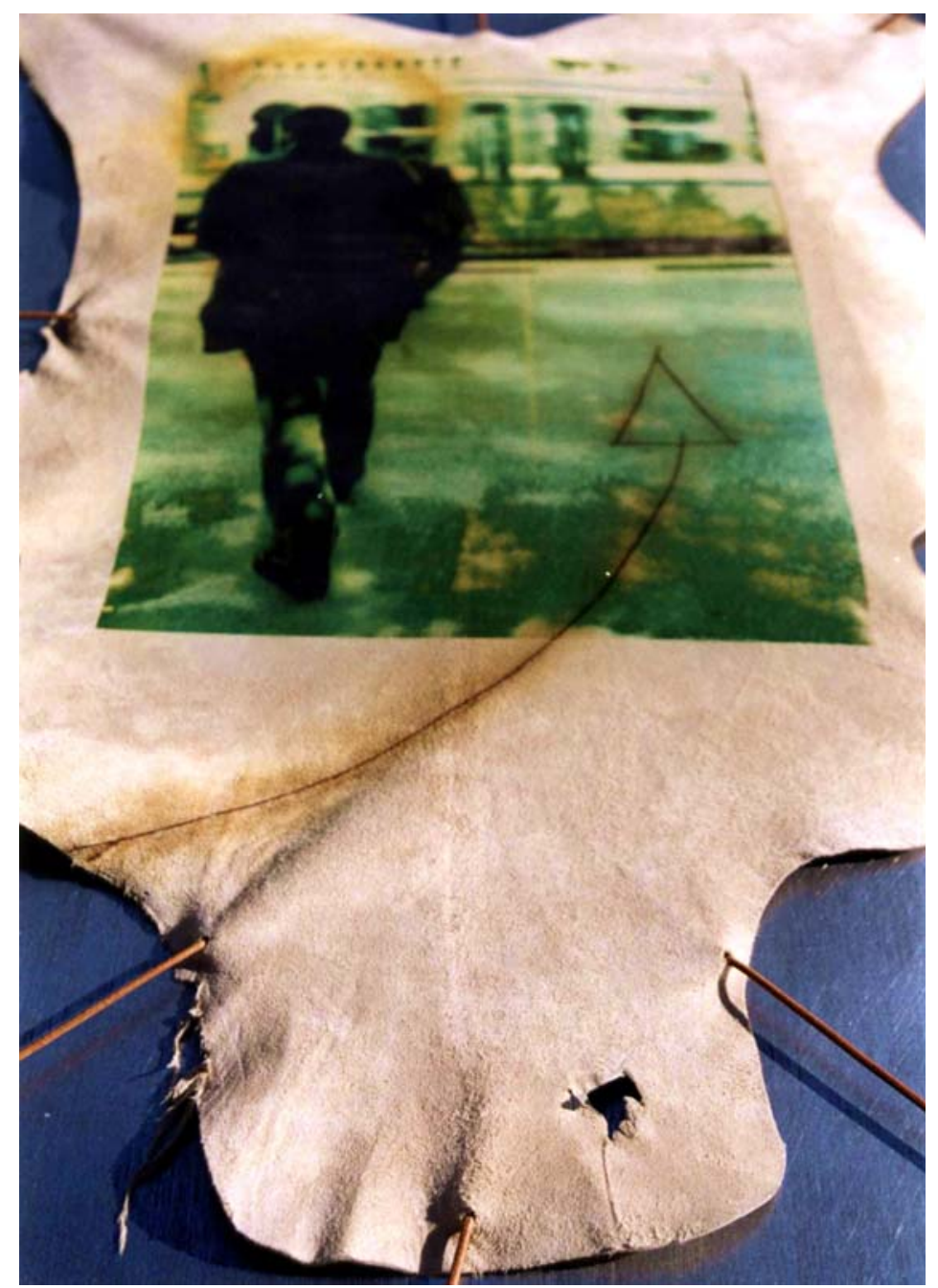

Fig. 140: Túnez II (detalle) (2003) Transferencia y punta seca sobre piel de cabra y zinc, 50 x $40 \mathrm{~cm}$.

Esta confrontación de materiales ofrece un innegable interés desde el primer momento y se configura como uno de los ejes alrededor del cual se vertebra una obra plástica personal con el cuero 
como protagonista, y obras como las de las figs. 139 y 140 demuestran este incipiente interés por combinar ambos materiales.

Es obvio que las experiencias de este periodo de creación plástica no se restringen tan sólo a la transferencia o la punta seca, sino que se compaginan con toda una serie de pruebas de estampación calcográfica y xilográfica que tienen el cuero como soporte, con experiencias destinadas a acumular la mayor cantidad posible de datos en lo que se refiere al trabajo con dichas técnicas. Muestra de estas pruebas puede ser el grabado de la fig. 141, en el cual se han incluido porciones de piel de cordero estampadas a varias tintas sobre una estampación precedente realizada sobre papel y a una tinta. 190

En este caso la estampación se realiza sobre el lado flor del cuero ovino, consiguiéndose un registro muy correcto de los grafismos presentes en la plancha matriz, lo que permite su fusión con la estampa sobre papel que acoge los trozos de piel animal. Pese a no tratarse de obras ideadas desde su germen para ser trabajadas con el cuero como soporte, este tipo de actuaciones han sido de gran utilidad para poder comprender, en unos primeros momentos, la naturaleza de las pieles y sus posibles ventajas e inconvenientes como soporte para grabado.

\footnotetext{
${ }^{190}$ De ahora en adelante, cuando hagamos referencia al papel, éste será siempre Superalfa de la marca Guarro, a no ser que se especifique lo contrario.
} 


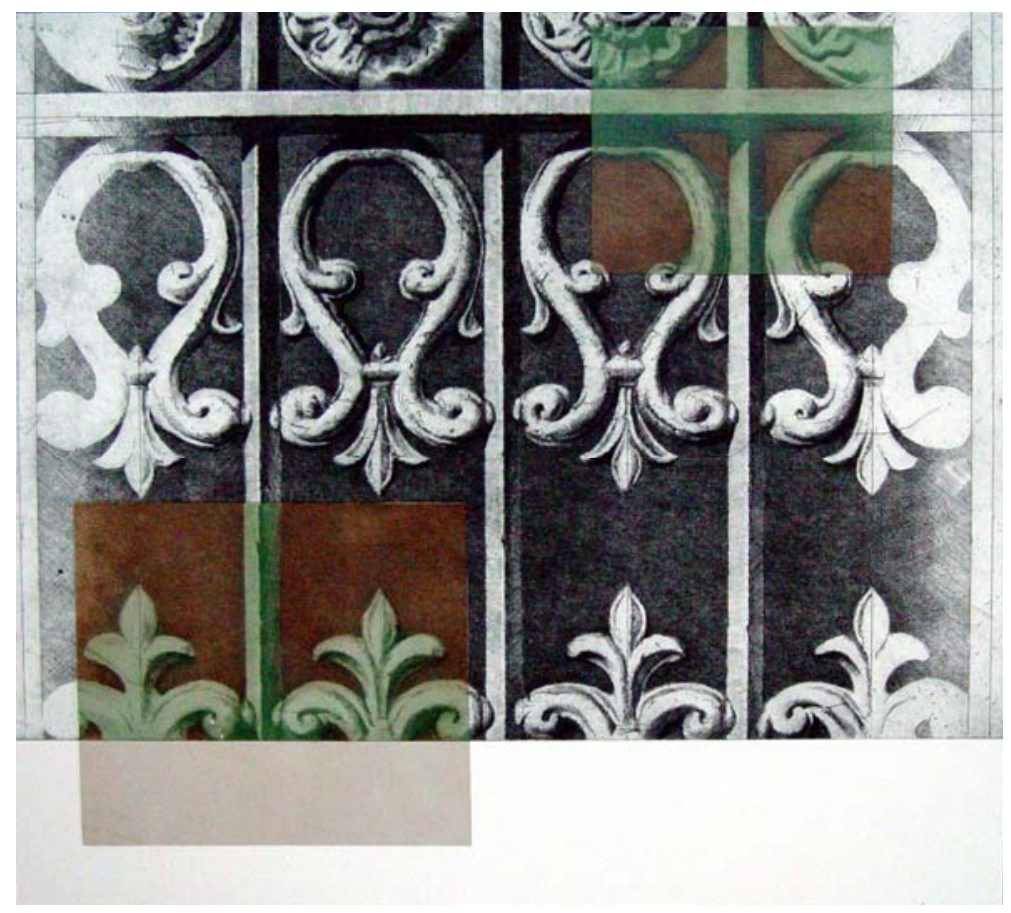

Fig. 141: Intervalos I (2004) Aguafuerte sobre papel y piel de cordero, 55 x $55 \mathrm{~cm}$.

Otras anotaciones que hemos de hacer tienen que ver con el plano conceptual en el que se moverá la obra, y que también tiene su origen en la etapa de formación doctoral. El año 2001 fue clave para la maduración y desarrollo de este proceder plástico, con dos momentos, uno teórico y el otro práctico, de gran importancia para nuestra investigación actual. 
El primero de ellos fue el trabajo historiográfico realizado para el curso de doctorado impartido por el profesor Dr. Fernando Evangelio dentro del programa Grabado y estampación del Departamento de Dibujo de la Universidad Politécnica de Valencia. Pese a que el programa de dicho curso estaba centrado en la evolución de los métodos de reproducción mecánica de imágenes asociados al mundo del grabado, nuestra investigación giró en torno a la figura del artista noruego Edvard Munch (1863-1944), y más particularmente a su labor como grabador. Auténtico revolucionario de la estampa, el artista nórdico no sólo anticipó con su pintura rasgos que años más tarde recogerían los expresionistas, sino que con algunas de sus creaciones gráficas adelantó soluciones y procedimientos de enorme importancia posterior. En muchos de sus grabados no se conformaba con obtener una sola estampa válida, sino que su afán experimentador le llevaba a combinar distintas tintas y planchas en estampaciones sucesivas, logrando numerosas versiones diferentes y dotando de una inusitada riqueza a su mundo artístico en lo que a la gráfica se refiere. (fig. 142)

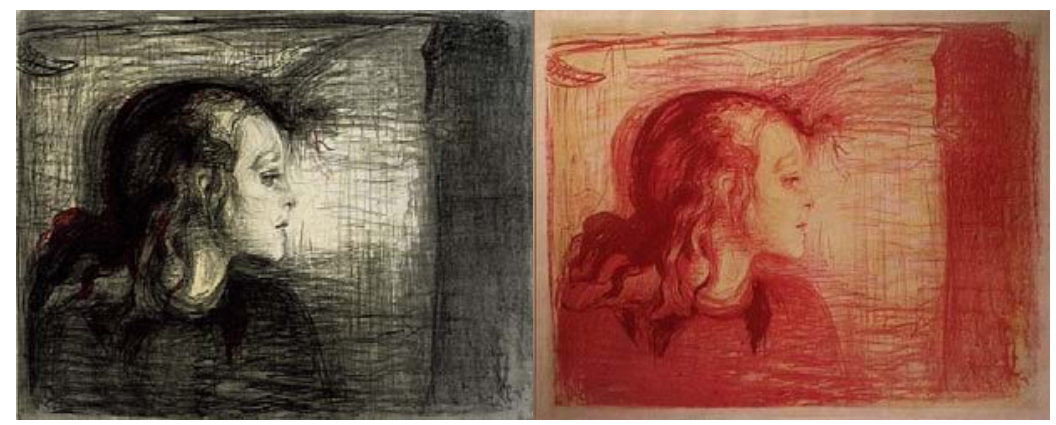

Fig. 142: Dos versiones diferentes de la litografía La niña enferma, estampadas ambas en el año 1896 pero cambiando las tintas de impresión. 
Contemporáneamente a esta investigación historiográfica se desarrolló el trabajo para otro curso de doctorado del mismo programa y universidad, en este caso el denominado como Obra gráfica y proceso impartido por el profesor Dr. José Manuel Guillén. Como propuesta personal de trabajo para el curso, en este caso eminentemente práctico, se optó por profundizar en las posibilidades creativas que por entonces veníamos estudiando en relación al trabajo teórico acerca de Munch: la obtención de una serie de estampas diferentes entre sí pero provenientes todas ellas de la misma plancha matriz.

Pese a que, en nuestra opinión actual, el resultado no fue excesivamente satisfactorio desde un punto de vista estético, en esas obras (fig. 143) puede ya rastrearse el germen del cual nacen muchos de los planteamientos y postulados que pueblan la presente propuesta plástica. Podemos ya ver el gusto por la repetición formal matizada por pequeñas modificaciones entre los módulos que forman la serie completa, la combinación de diferentes soluciones técnicas a partir del empleo de estampas provenientes de una misma plancha matriz, así como un intento de sacar al grabado de su tradicional marco con cristal protector al pegarlo sobre tablas de madera y barnizarlo. 


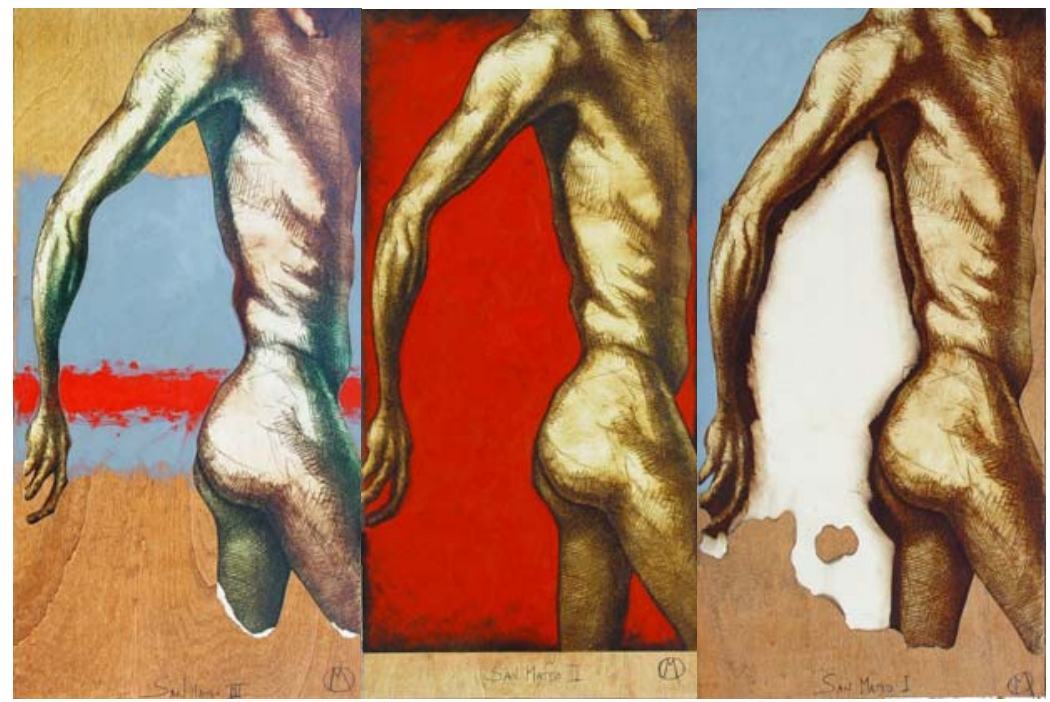

Fig. 143: Tetramorfos: San Marcos (2001) Aguafuerte sobre papel pegado a tabla, pintado, recortado y quemado, 100 x $150 \mathrm{~cm}$.

Estos dos impulsos coetáneos se combinaron unos meses más tarde con el tremendo impacto recibido por la visita a una exposición del artista irlandés Sean Scully (nacido en 1945) en el Instituto Valenciano de Arte Moderno (IVAM) a comienzos del año 2002. ${ }^{191}$ La visión de su obra, de manera silenciosa y muchas veces con enorme sutilidad, fue apareciendo como un factor de gran influencia en la conformación de toda una serie de propuestas propias. Puede verse en la fig. 144 como las formas modulares que configuran

${ }^{191}$ Sean Scully. Óleos. Pasteles. Acuarelas. Fotografías. Del 31 de enero al 7 de abril de 2002. Comisarios: Armin Zweite y María Muller. 
las pinturas, pasteles y acuarelas de Scully, se posicionan siguiendo parámetros seriales y secuencias formales hasta adquirir, sobre todo en las pinturas de mayor tamaño, una extraordinaria monumentalidad.

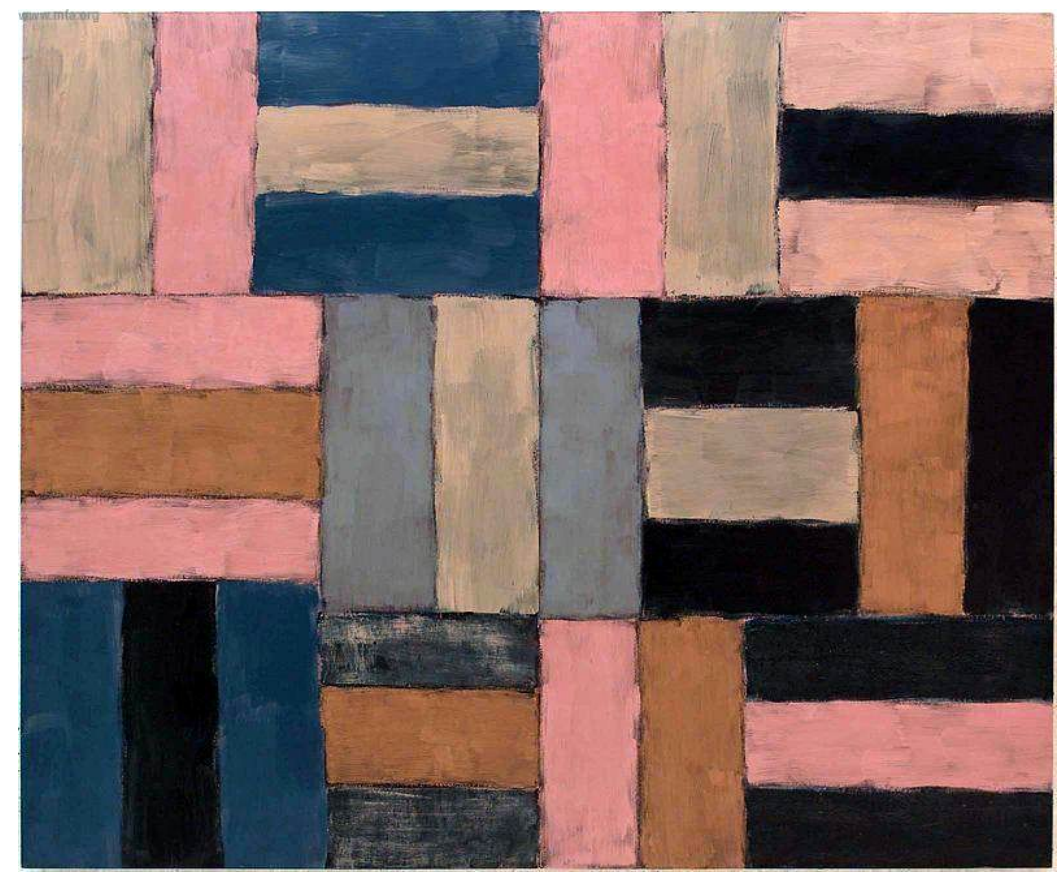

Fig. 144: Wall of light pink (1998) Óleo sobre lienzo, 274x304, Museum of Fine Arts, Boston. 
Esta poética particular del artista irlandés, cuyas formas parecen derivar en ocasiones de sus experiencias con la fotografía de fachadas y edificios (fig. 145), nos causó una honda impresión a partir de la cual intentamos hacer evolucionar una propuesta plástica personal que fuera capaz de combinar todos los factores percibidos de manera tan contundente.

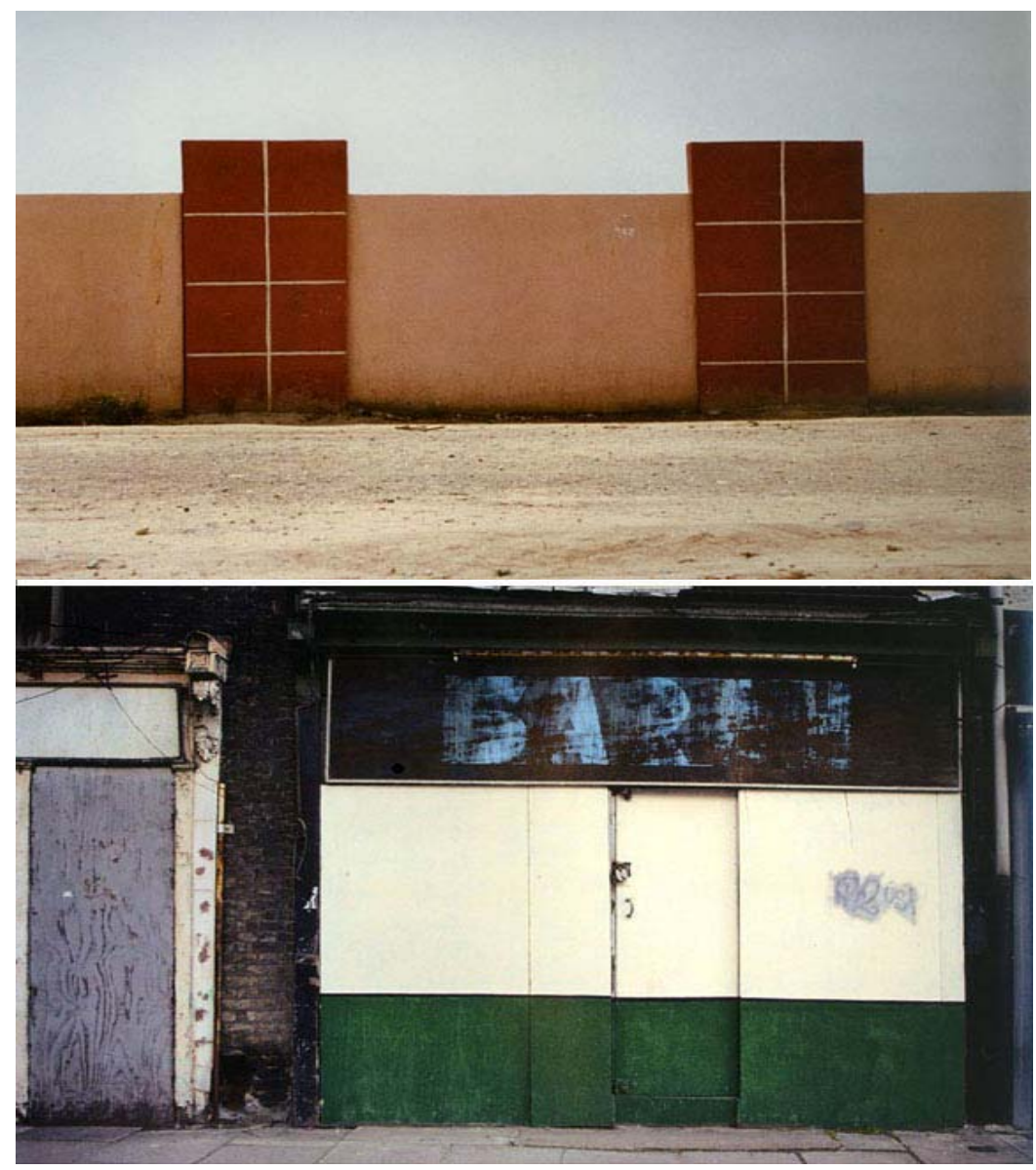

Fig. 145: De arriba abajo: Morocco (1995), fotografía sobre plexiglas, 93x122 cm. Sareh London door (2000), fotografía sobre plexiglas, 93×122 


\section{V.2. DEFINICIÓN Y OBJETIVOS ESPECÍFICOS}

Todo el bagaje acumulado tras meses de experiencias de taller, unido a las reflexiones teóricas y prácticas extraídas de la realización de los apartados precedentes que conforman esta tesis, nos permite afrontar, en este preciso momento, la creación de una serie de obras plásticas que resuman visualmente los descubrimientos logrados gracias al análisis pormenorizado llevado a cabo en esta investigación. Éstas intentarán fusionar diferentes técnicas para configurar un lenguaje plástico lo más rico posible, una sintaxis estética que combine las distintas soluciones que la piel animal ofrece, no sólo como soporte que acoja las creaciones, sino también como parte constituyente de la obra. Continuando los hallazgos alcanzados en las piezas anteriormente comentadas, se unirán las cualidades inherentes de los cueros con la naturaleza de metales tales como el zinc y el cobre, tratando de profundizar en la poética de contraste entre ambos materiales que se ha introducido en páginas previas. 
Para que la obra personal que vamos a realizar como pueda responder a los intereses que han dirigido esta tesis doctoral, se hace preciso establecer una serie de objetivos a alcanzar en esta última fase, objetivos que podemos establecer en dos grandes grupos. Por un lado los estrechamente relacionados con los resultados obtenidos en apartados precedentes de la investigación, es decir, aquellos que están relacionados directamente con la metodología investigadora planteada; por otro, los referentes al empleo del cuero como vehículo para la expresión creativa dentro del corpus de obra plástica a realizar, es decir, aquellos con un carácter formal y estilístico.

\section{- Objetivos metodológicos:}

- Demostrar la viabilidad de aplicación de las experiencias prácticas realizadas en vistas a la producción de una obra plástica personal.

- Estudiar las posibilidades creativas del cuero en combinación con otros materiales como el papel, la madera o los metales. 
- Combinar las diferentes técnicas estudiadas en las etapas previas con el fin de conformar un lenguaje estético que tenga al cuero como elemento integrado e integrador.

\section{- Objetivos formales y estilísticos:}

- Desarrollar, de manera libre y creativa, las posibilidades estéticas de los procedimientos experimentados en relación con la piel.

- Crear un corpus de obra plástica que emplee un lenguaje expresivo basado en la utilización de la piel, sin que ello coarte su definición estética. 


\section{V.3. METODOLOGÍA Y PROCESO}

Para dar forma a nuestra creación plástica concebimos una estructura de tres grandes etapas, correspondientes cada una de ellas, a la concepción de la obra, su planificación técnica y su resolución definitiva. Las obras que más adelante se analizan de manera más detallada, comparten hasta un cierto punto todas y cada una de las guías de actuación planteadas, pero evolucionan de manera independiente dependiendo de las diferentes combinaciones de técnicas y procedimientos seleccionados para su materialización definitiva.

En la fase de concepción distinguimos por una parte la reflexión acerca de los referentes externos así como los precedentes personales $y$, por otra, las primeras definiciones de la obra, plasmadas en bocetos y apuntes varios. La planificación técnica aborda la elección de procedimientos gráficos que aplicamos y, en base a ellos, 
decidimos la piel adecuada y definimos el formato final de los trabajos. Una vez finalizado estos pasos podemos pasar a la fase de resolución, en la cual debemos prestar una especial atención a la organización del proceso de impresión, finalizando con la manipulación e inclusión de soportes metálicos combinados con los cueros en las zonas que nuestros intereses plásticos lo requieran.

De tal modo, el proceso queda establecido en las siguientes etapas:

- Concepción de la obra

o Precedentes personales y referentes previos

o Primeras ideas

- Planificación técnica

- Elección de procedimientos gráficos

o Elección del soporte y definición del formato

- Resolución

o Organización del proceso de impresión

o Inclusión de soportes metálicos 


\section{V.3.1. Concepción de la obra}

Desde nuestro punto de vista una producción creativa no puede desvincularse de la creación realizada anteriormente por quién lleva a cabo dicha obra, no sólo de las últimas creaciones, sino incluso de todo el conjunto de propuestas estéticas producido a lo largo del tiempo. Cada obra se configura de tal modo como el resultado de la asimilación de infinidad de factores estéticos, plásticos y visuales, pero también, a qué negarlo, de cualquier otro tipo de información sensorial y conceptual que el creador haya recibido previamente. Es por ello que las obras que mostramos como aplicación de la anterior etapa de investigación están íntimamente relacionadas con multitud de factores diferentes, algunos de los cuales podemos analizar para tratar de rastrear el germen de muchas de las soluciones estéticas alcanzadas.

Es evidente que el trabajo de experimentación rigurosa y pormenorizada que hemos desarrollado en la fase anterior de la tesis es un pilar fundamental sobre el que se apoyan las obras a realizar. La elección de una u otra técnica conduce a la utilización del cuero idóneo mientras que, si decidimos que el factor determinante para algunas de nuestras obras sea un tipo de piel en concreto, ello provocará condicionantes especiales a la hora de elegir la técnica a emplear. La experimentación y catalogación pormenorizada afecta y actúa como 
referencia técnica, pero durante el largo proceso de actuación van a surgir ideas, conceptos e intuiciones que tendrán su plasmación creativa en la realización definitiva de la obra.

Una propuesta plástica propia no puede tampoco abstraerse del lenguaje personal que ha conformado la producción del autor durante los últimos años. Es lógico que los conceptos e hilos que han urdido toda la obra precedente afecten de manera permanente a cualquier nueva propuesta que se decida afrontar en un momento dado de una trayectoria creativa. En nuestro caso, el hilo conductor que guía de manera patente y constante todas y cada una de las obras expuestas es el concepto de repetición formal, con objeto de configurar series de imágenes con entidad propia. El recurso de la seriación es bien conocido dentro de la historia del Arte, y ya fue empleado por maestros del Impresionismo como Claude Monet (1840-1926) ${ }^{192}$, suponiendo un referente plástico de indudable importancia para generaciones posteriores de artistas. Sin embargo, en nuestro caso el acercamiento a este recurso es resultado de las experiencias dentro del ámbito específico del grabado y la estampación, y las posibilidades de reiteración formal que el trabajo a partir de planchas matrices permite.

192 Recuérdense algunas de sus series como las dedicadas a las Vistas de la catedral de Rouan (1892-1894) o los Almiares (1900-1909). 
A lo largo de los últimos meses se ha ido configurando, de manera paulatina, una estética propia que surge como resultado de la fusión de innumerables aspectos y factores, algunos de los cuales acabamos de analizar brevemente. Durante todo este proceso de formación y evolución han surgido obras que pueden servir como paradigma de los diferentes pasos y estadios alcanzados hasta llegar al momento actual en el que proponemos la obra que culmina esta tesis.

Un primer paso hacia el tipo de composiciones que abundan en la obra a realizar sobre cuero, son los trabajos englobados bajo el título genérico de Prisioneros-Libres, realizados a partir de la combinación de varias matrices calcográficas y xilográficas de pequeño formato hasta dar forma a construcciones de marcada ortogonalidad, la cual se intenta combinar con cierta variación cromática y dinamismo interno (fig. 146). En este tipo de composiciones observamos un claro avance hacia soluciones donde la sucesión de formas se convierte en el hilo conductor de las obras, seriación que abandona una estricta axialidad horizontal para configurarse dentro de retículas que se desarrollan en dos direcciones y que están ordenadas conforme a una composición inscrita en una trama rectangular. Este tipo de composición alcanzada es de gran trascendencia para la producción posterior, en la cual debemos incluir las obras realizadas como conclusión a este trabajo investigador. 


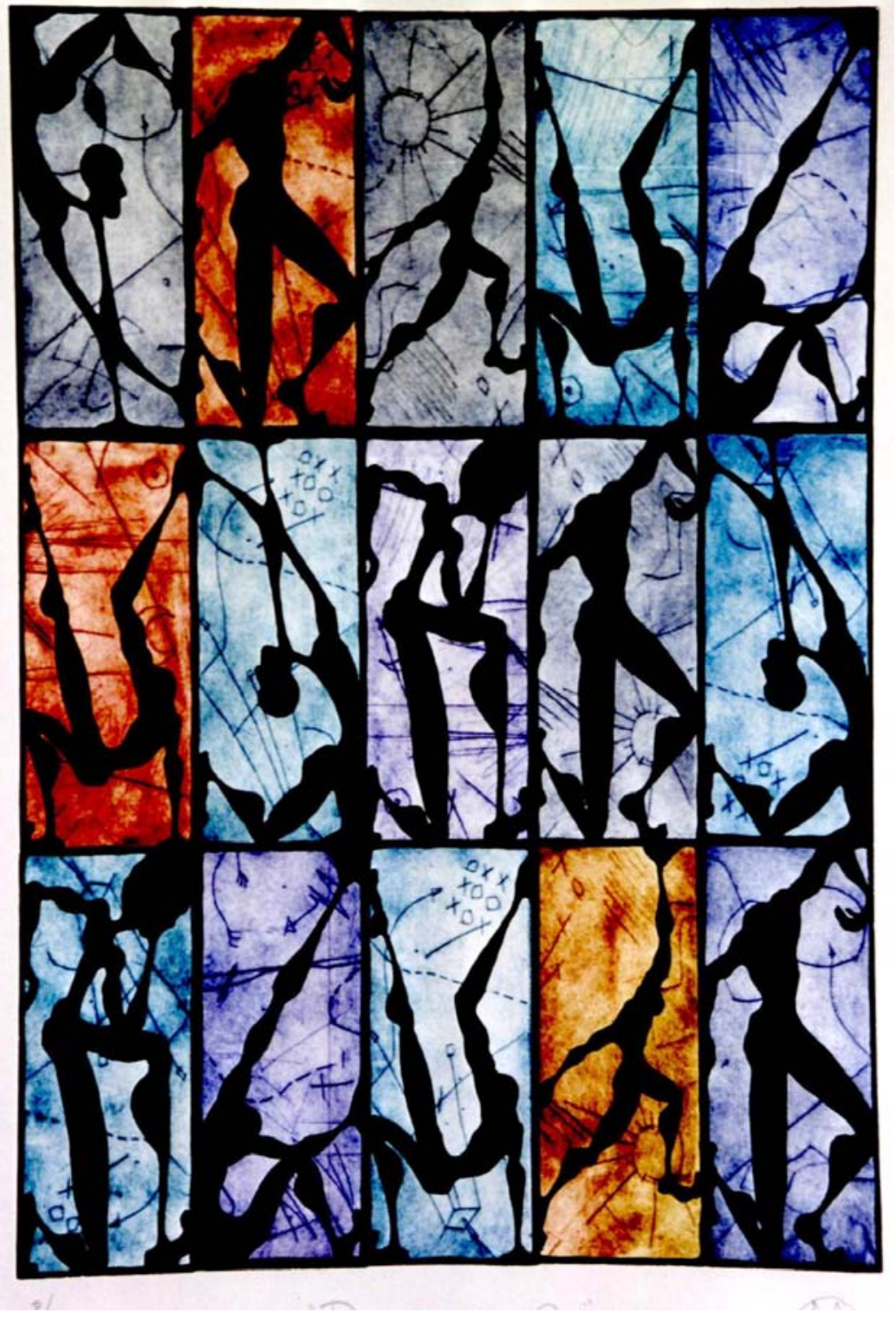

Fig. 146: Prisioneros-Libres (2002). Punta seca y xilografía sobre papel (6 planchas de punta seca y 6 de xilografía), 60 x $50 \mathrm{~cm}$. 
Algo similar ocurre con la serie titulada Palermo (fig. 147), en la cual, a partir de una plancha calcográfica se configura la pieza al modificar el color de la tinta de estampación en cuatro impresiones diferentes de una matriz de 50×50 $\mathrm{cm}$. Se trata en cada caso, de cuatro papeles distintos cada uno estampado con un color y pegados sobre una superficie de madera para crear la sensación visual de reiteración y repetición formal, a la vez que variación cromática. Sin duda es un recurso muy conocido y empleado hasta la saciedad por movimientos como el Pop-Art, con célebres ejemplos en obras de Andy Warhol (1928-1987) o Jasper Johns (1930) entre muchos otros, y en este caso se ha de entender como un episodio transitorio en la búsqueda de un lenguaje propio que aglutine ciertas influencias entre las que obviamente se encuentran los artistas citados

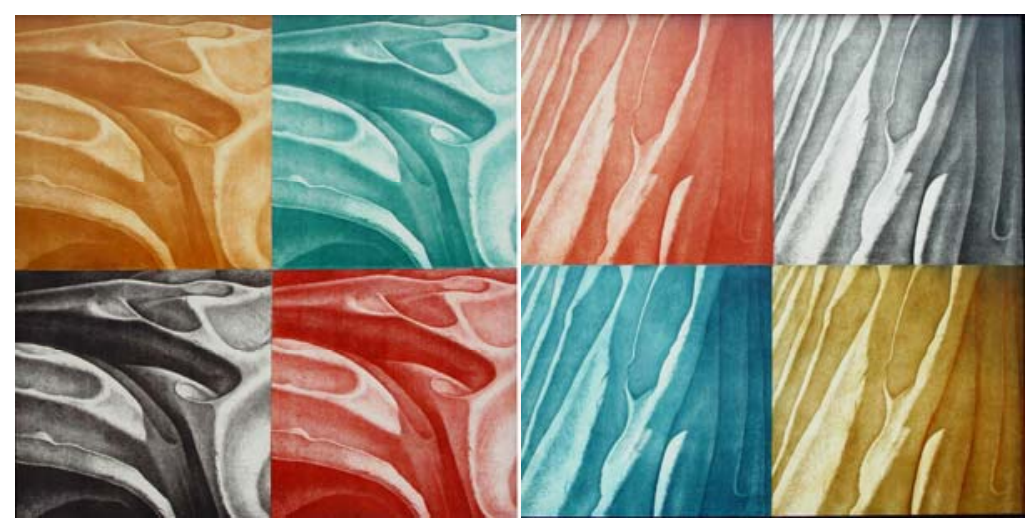

Fig. 147: Palermo I y Palermo II (2002) Aguafuerte sobre papel y tabla, 100x100 cm (cada uno) 
En este punto toman protagonismo los bocetos, apuntes, esbozos e ideas varias materializadas de forma gráfica sobre cualquier superficie. Si bien en numerosas ocasiones la realización de bocetos es absolutamente imprescindible, en nuestro caso su papel es el de afianzar inicialmente la idea generadora y no el de condicionar el resultado a conseguir. En el trabajo que nos ocupa, los esbozos de las obras expuestas sirven como visualización previa de una idea ya madurada con anterioridad en la mente o sugerida por trabajos precedentes, y no tanto como elemento en cuya gestación se forjen y tomen cuerpo nuevos conceptos plásticos. El resultado ha de ser entendido más como la consecuencia de la evolución de trabajos previos, y no tanto como el fruto de un intenso trabajo de planificación mediante bocetos o esbozos exhaustivos.

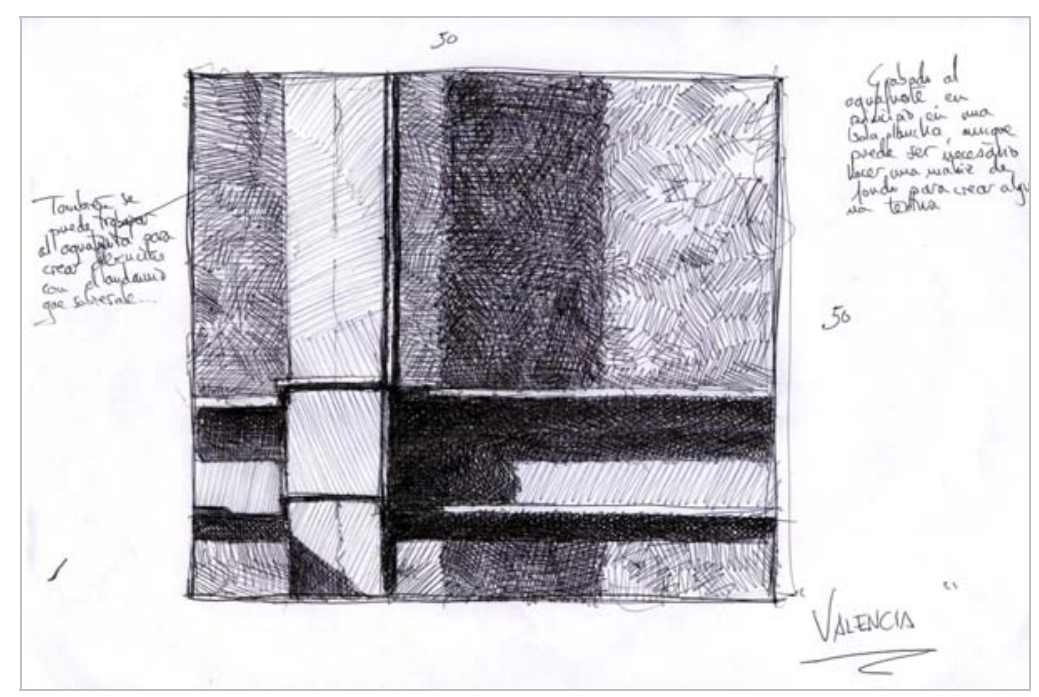

Fig. 148: Boceto para un aguafuerte. 


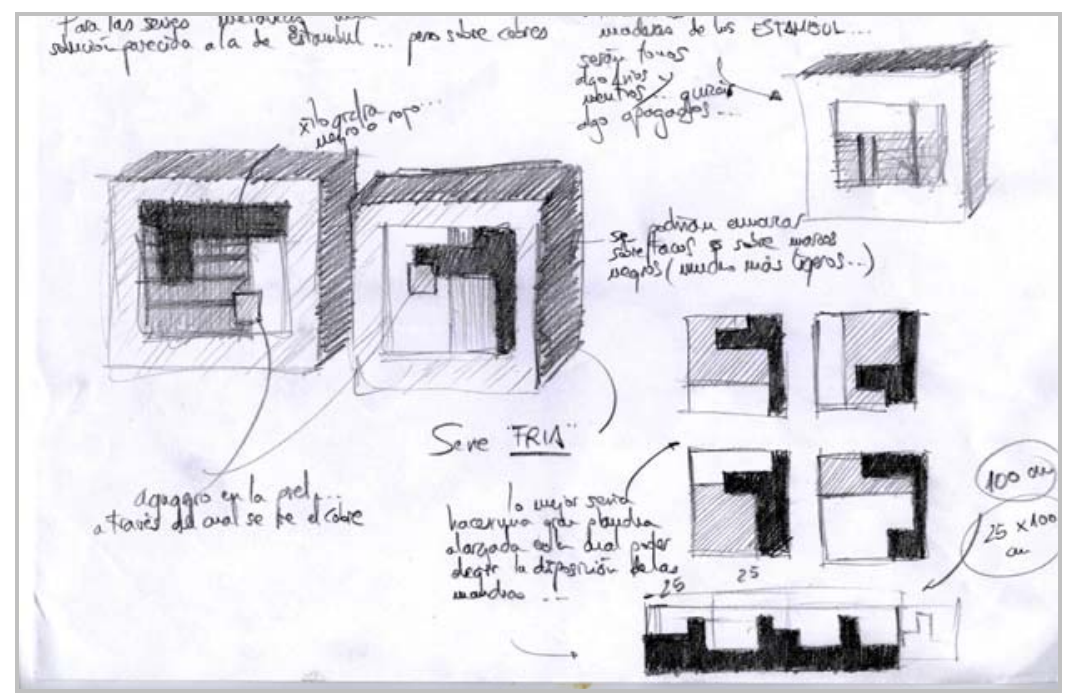

Fig. 149: Apunte para una obra realizada mediante transferencia y xilografía sobre cuero

Su papel es mucho más trascendente en trabajos en los cuales dominan técnicas gráficas tales como las correspondientes a la xilografía o la calcografía, como puede verse en la fig.148. Por su lado, en el caso de las obras donde es la fotografía la fuente principal de estímulos visuales, en aquellas resueltas con la transferencia o en las que ésta posee un papel protagonista, los bocetos poseen un rol diferente aunque no por ello menos importante en la formación de los trabajos, como queda reflejado en la fig. 149. En todos ellos, sea cual sea la técnica a emplear, no sólo se trata de ofrecer una primera imagen esbozada de la obra y sus características gráficas y estéticas, sino que tienen un papel fundamental las anotaciones de todo tipo que pueblan los apuntes. En ellas se reflexiona acerca de cuestiones 
prácticas relacionadas con aspectos como las dimensiones, los materiales a utilizar, las técnicas escogidas o los contrastes de texturas y colores que presentará la obra final, primordiales para la realización definitiva de las propuestas.

En este punto se hace necesario introducir un factor que tiene suma importancia en la conformación de los trabajos expuestos: el empleo de herramientas informáticas durante la planificación de las obras. Aparte de las posibilidades que ofrecen las técnicas gráficas tradicionales a la hora de realizar bocetos 0 apuntes, en nuestro caso el uso del ordenador ha sido de una importancia capital dentro del proceso de planificación de la propuesta personal. Tanto en las obras resueltas mediante técnicas tradicionales del mundo del grabado, como en las que interviene la transferencia de imágenes fotográficas, las posibilidades que ofrecen las herramientas informáticas han sido empleadas de diferentes modos. Así, muchas de las imágenes y las soluciones plásticas del trabajo personal tienen como germen fotografías modificadas digitalmente con arreglo a intereses estéticos concretos, siendo por tanto un factor a tener en cuenta dentro de este proceso creativo. 


\section{V.3.2. Planificación técnica}

Pese a los puntos de contacto que establecemos entre todas las propuestas plásticas, intentamos a su vez que cada una de ellas posea una autonomía propia gracias a las características específicas que los diferentes procedimientos gráficos empleados les otorgan, configurando de tal modo un conjunto de trabajos homogéneos y variados al mismo tiempo; un grupo de obras relacionadas internamente pese a su heterogeneidad. Serán tres los elementos que nos permiten alcanzar estos objetivos: la poética de la serie, el empleo del cuero como soporte, y la combinación de éste con los metales.

Toda la información definida ya en los bocetos sirve para introducir un factor de esencial importancia con vistas a alcanzar un resultado satisfactorio: las continuas decisiones que salpican el proceso y condicionan de manera muy marcada las obras dada, su relación con factores tales como la técnica, el cuero escogido como soporte, las dimensiones de la pieza y los materiales alternativos que completan los trabajos. Estos factores toman una importancia inusitada por las especiales características del material que empleamos como soporte, el cuero, y por las técnicas escogidas para trabajar. Es por ello que un paso fundamental para que el resultado de nuestras propuestas sea satisfactorio, es el de conocer los condicionantes que 
la combinación de todos estos elementos marca, con el fin de poder escoger la opción que mejor se adapte a los criterios plásticos y estéticos que pretendemos reflejar en las obras.

De tal modo, una vez que la idea generadora ha sido convenientemente fijada mediante bocetos y apuntes, es momento de elegir las técnicas con las que llevaremos a buen término la ejecución de nuestro trabajo. El procedimiento escogido es absolutamente determinante dado que condiciona, en ocasiones de manera radical, el tipo de cuero que debemos emplear. En cada caso específico el cuero debe adaptarse a los requerimientos particulares del procedimiento empleado, y así, no siempre la piel que responde de manera perfecta a una estampación calcográfica hace lo propio al ser sometida a una transferencia. Si tenemos en cuenta que todas las obras que exponemos a continuación han sido llevadas a cabo combinando varias técnicas diferentes, vemos cómo esta decisión inicial es de suma importancia para el buen fin del trabajo. La elección de uno u otro tipo de cuero en relación a la técnica escogida será comentada en profundidad en la ficha de cada caso concreto. Con la selección de los procedimientos de las obras expuestas se trata de ofrecer un amplio abanico de respuestas de índole práctica, con lo que un grabador, analizando las decisiones tomadas en cada una de esas obras, podrá llegar a formarse un criterio que le sirva para resolver situaciones similares. 
El tipo de tinta y su número son otros factores que intervienen en la configuración y planteamiento de la obra, ofreciendo condicionantes en ocasiones de enorme importancia. Pese a que será un tema que trataremos de manera pormenorizada en cada uno de los ejemplos que presentamos a continuación, indicar que tenemos en cuenta todo lo aprehendido en la etapa de experimentación para conocer la respuesta de las pieles. ${ }^{193}$

Otra de las decisiones a adoptar en este punto de la planificación del trabajo es la referente a las dimensiones totales que adoptarán las obras en función tanto de la técnica como del tipo de cuero, factores ambos que influyen en su configuración definitiva. Así, el primer condicionante con el que nos enfrentamos al abordar una obra sobre cuero es el tamaño de la misma piel que nos sirve como soporte; es imposible encontrar cueros de todas las dimensiones que deseemos, existiendo la limitación propia del tamaño del animal del cual provienen. Al contrario de lo que sucede con el papel o el lienzo, es prácticamente imposible encontrar pieles excesivamente grandes, a lo que debemos añadir el hecho de que, en muchas ocasiones, una gran parte del cuero no es de utilidad para nuestro trabajo de estampación, 194 por lo que no podemos abordar grabados de grandes

\footnotetext{
${ }^{193}$ Véase apartado IV.1.3., p. 256.

${ }^{194} \mathrm{Si}$ deseamos trabajar sobre formatos regulares, ya sean rectangulares o poligonales, debemos eliminar los bordes sobrantes de la piel correspondientes a las faldas, la cabeza y las garras, áreas que, por otro lado, presentan irregularidades superficiales e internas muy evidentes.
} 
formatos o debemos hacerlo a partir de varios fragmentos de cuero unidos hasta formar la obra definitiva.

Sin embargo, las limitaciones de tamaño no finalizan con este comentario de índole general acerca de los cueros, sino que cada tipo de piel posee unas medidas estándar que obligan a plantear consideraciones prácticas y específicas antes de comenzar la realización de las estampas; no tiene el mismo tamaño un cuero ovino que uno vacuno o una piel caprina, y debemos prestar mucha atención a estos factores a la hora de escoger la combinación de técnica y soporte que estructure nuestra propuesta. De manera general puede establecerse un orden ascendente en lo que al tamaño de los cueros se refiere, salvando las excepciones que puedan aparecer al obtener una piel concreta, y puede afirmarse que los cueros de cabra son generalmente los más pequeños, seguidos por los de cordero y los de cerdo, de tamaños similares aunque algo más grande el segundo. Por último, los cueros de vaca tienen mayores dimensiones totales y de ellos podemos extraer porciones de gran tamaño para estampaciones de envergadura especial. Así, a la hora de seleccionar el tipo de cuero debemos tener siempre presente las dimensiones de la obra que queremos realizar, tratando de armonizar las características propias de la piel escogida con los fines perseguidos desde el punto de vista plástico y las técnicas que pretendemos utilizar. 
Por lo que respecta a las técnicas tradicionales de la estampa, la calcografía y la xilografía, las limitaciones de tamaño son las mismas a las que se enfrenta cualquier grabador al trabajar sobre papel: dimensión y características del tórculo, medidas de las planchas, etc. En definitiva, serán las condiciones propias de cada taller las que delimiten las posibilidades de actuación de cada grabador, sin que intervengan factores relacionados con el soporte de cuero empleado.

La transferencia ofrece condicionantes diferentes, dado que en ella los factores de limitación de tamaño provienen de las fotocopias que sirven como base para las imágenes. Si empleamos fotocopias en blanco y negro los tamaños que podremos obtener en el mercado son mucho mayores que al utilizar fotocopias en color. ${ }^{195}$ Estos factores condicionan de manera evidente las características de la obra, por lo que debemos tenerlos siempre presentes para no encontrarnos con problemas insalvables dentro del proceso de materialización definitiva.

\footnotetext{
${ }^{195}$ Es posible conseguir fotocopias en blanco y negro hasta un tamaño estándar de DIN A0 (841x1189 mm.), mientras que si nos decantamos por el color, el límite será, en la mayoría de las ocasiones, de unas dimensiones estándar de DIN A3 (297x420 mm.).
} 


\section{V.3.3. Resolución}

El factor más importante que determina el proceso de materialización de todos los elementos teóricos, conceptuales y técnicos que hemos analizado con anterioridad es la secuencia de los pasos a realizar sobre el cuero que actúa como soporte. 196 Este ordenamiento afecta a los trabajos que combinan distintos procedimientos técnicos para su resolución, desapareciendo en caso de que el objetivo a alcanzar sea una estampación calcográfica 0 xilográfica, o una mera transferencia sobre la piel animal, sin fusionar diferentes técnicas en una misma obra. Sin embargo, para combinar varios procedimientos de los analizados es preciso prestar especial atención al orden en el cual se procede sobre el cuero, ya que de ello depende en muchas ocasiones un resultado satisfactorio. De manera general pueden establecerse una serie de normas y preceptos genéricos que sirvan como guía para organizar una secuencia correcta dentro del proceso de realización y materialización de los trabajos.

Cuando deseemos combinar calcografía y xilografía sobre el cuero, el orden de estampación está regido, no tanto por cuestiones

\footnotetext{
${ }^{196}$ No nos referimos en este punto al proceso estricto de estampación de las matrices calcográficas o xilográficas, el cual sigue el procedimiento tradicional, sino a la combinación de diferentes soluciones plásticas sobre las pieles y al orden concreto de esa sucesión de procedimientos.
} 
prácticas relacionadas con la naturaleza del soporte, como por condicionantes muy similares a los que podemos encontrar al trabajar sobre papel. Así, si escogemos estampar inicialmente los seños calcográficos y finalizar imprimiendo la mancha xilográfica, ésta cubre absolutamente los grafismos precedentes, ocultándolos totalmente en caso de tratarse de una tinta opaca, o estableciendo transparencias y veladuras si hemos optado por una tinta traslúcida. Lo contrario ocurre en caso de proceder de manera inversa, sin que la naturaleza intrínseca del cuero escogido influya de manera significativa sobre el resultado definitivo de la estampación.

Al introducir la transferencia de imágenes electrográficas dentro de la ecuación, las especiales características de su proceso hacen que sea conveniente colocarla al inicio de la secuencia de realización. El hecho de que para conseguir una transferencia idónea hayamos optado por el procedimiento de aplicar el disolvente universal sobre la superficie del cuero, ${ }^{197}$ hace que, para evitar dañar y estropear una estampación calcográfica o xilográfica que pudiera haber sobre la piel, sea necesario proceder a esta aplicación en un momento inicial del proceso. De tal modo, una vez la imagen se encuentra transferida sobre el cuero y el disolvente se ha evaporado en su totalidad, podemos estampar sobre el soporte sin riesgo alguno para la integridad de la película de tinta. Tan sólo en el caso de que la imagen a transferir ocupe una porción de soporte sobre el que no vayamos a

${ }^{197}$ Véase apartado IV.2.3., p. 315. 
estampar o una zona libre de tinta dentro de una imagen, podremos decidir realizar la transferencia en otro momento, aunque siempre teniendo un cuidado extremo en evitar que el disolvente entre en contacto con la tinta presente en la superficie del cuero.

El caso del estezado es radicalmente distinto al de la transferencia, y si en la anterior es recomendable aplicarla al principio de la secuencia de trabajo, en esta ocasión será mucho más conveniente hacerlo al final de todo el proceso, pues no hay inconveniente alguno en mojar el cuero una vez estampado $\mathrm{Si}$ actuamos de tal modo, el relieve conseguido en la superficie del cuero presenta toda su intensidad en la obra definitiva. Sí pueden surgir problemas en el caso de realizar un acusado relieve sobre una zona de la piel que ofrezca una gruesa capa de pigmento de toner transferido, dado que éste convierte la piel en una superficie más rígida, pudiendo aparecer grietas y escamados en las zonas donde se encuentra la película de pigmento. La opción de realizar el gofrado al final del proceso está guiada por el interés en obtener un relieve intenso y perfectamente visible, pero puede darse que un grabador desee un relieve de gran sutilidad, en cuyo caso la posibilidad de aplanar el gofrado obtenido inicialmente mediante sucesivas pasadas de tórculo puede resultar de enorme interés. ${ }^{198}$

\footnotetext{
${ }^{198}$ Cosa que ocurre si tras secar la piel gofrada la hacemos pasar bajo la presión del tórculo una o varias veces, dado que pierde el efecto de relieve.
} 
Por último, un factor a considerar durante la realización, en este caso relacionado con la poética personal de nuestra propuesta, es el de la combinación de la piel con otros materiales como los metales. Como se indicó anteriormente, son el cobre y el zinc los escogidos para dialogar visualmente con el cuero y las imágenes estampadas sobre él, y es precisamente ese diálogo y su plasticidad el único condicionante que se nos presenta al escoger entre uno $u$ otro material. No existen en este caso impedimentos o inconvenientes de índole práctica, sino que nuestra elección está tan sólo determinada por cuestiones meramente estéticas. Son los colores de las tintas o las imágenes transferidas, las formas creadas o las composiciones propuestas sobre las pieles, las que hacen que nos decantemos por uno u otro metal. La mayor frialdad del zinc con su brillo ligeramente acerado combina mejor en ocasiones con tonos gélidos de los grabados y estampas, mientras que el cobre, mucho más cálido, puede contrastar con su tono anaranjado con verdes o azules que dominen algunas de las fotografías transferidas sobre el cuero. Las posibilidades de combinación están regidas en esta ocasión por criterios visuales, cromáticos, tonales y relacionados con la estética que deseemos para nuestras obras.

Una vez decidida la secuencia de los procedimientos y técnicas, podemos pasar a analizar de manera individualizada las obras seleccionadas, con las cuales se ha tratado de ofrecer un amplio abanico de soluciones no sólo estéticas y relacionadas con la poética 
personal, sino también como muestra de carácter eminentemente práctico, con el fin de que sirva de ayuda a cualquier grabador interesado en la realización de obras que combinen los factores previamente expuestos, y para cuantos deseen continuar con la búsqueda iniciada con nuestra propuesta de investigación. 


\section{V.4. SELECCIÓN DE OBRAS}

En la realización de todas las propuestas expuestas a continuación, el hilo conductor ha sido la dialéctica de la seriación de imágenes y el contraste de materiales, tratando de dotar a todas ellas de coherencia estructural pese a las diferentes técnicas y procedimientos que toman parte en su configuración. El orden de presentación de los trabajos intenta ceñirse a la exposición de los resultados de apartados anteriores de la experimentación práctica, comenzando por la combinación de técnicas tradicionales de grabado y estampación para, a continuación, introducir en la ecuación los procedimientos analizados en la segunda fase. Se analiza un ejemplo de cada combinación de técnicas de manera individualizada, ofreciendo, al finalizar este comentario, una selección de imágenes de obras de características semejantes, completando con ello el panorama de cada uno de los grupos establecidos. 


\section{V.4.1. Xilografía y calcografía}




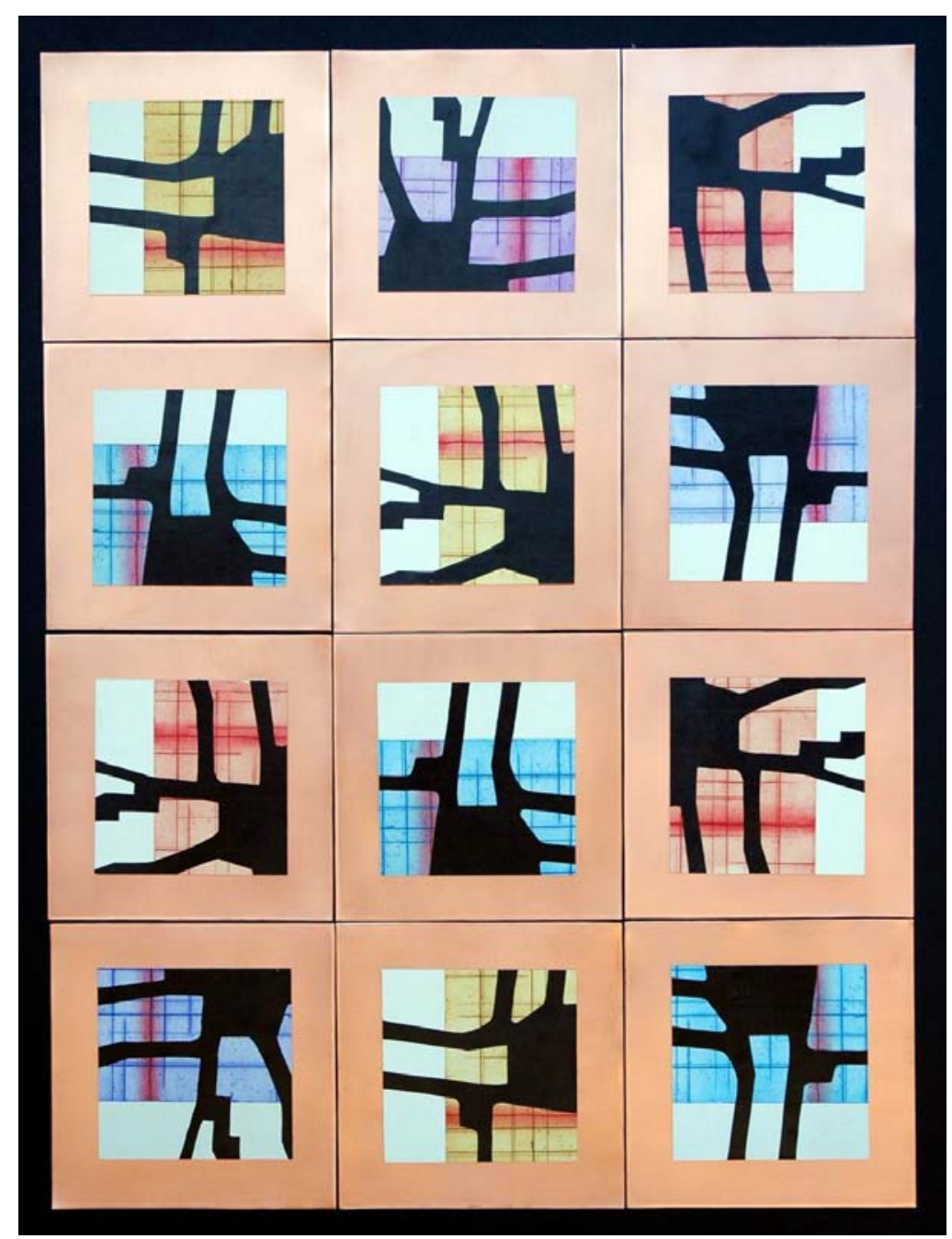

Fig. 150

TíTULO: Callejero V

AÑO DE REALIZACIÓN: 2005

MEDIDAS: $110 \times 85 \mathrm{~cm}$. 
PROCEDIMIENTOS TÉCNICOS: Aguafuerte, xilografía y punta seca NÚMERO DE ELEMENTOS: 12

MATRIZ

NÚMERO DE PLANCHAS: 4

MATERIAL: Zinc (2) y DM (2)

DIMENSIONES: 18 × $18 \mathrm{~cm}$.

ENTINTADO

NÚMERO DE TINTAS: 16

PROCEDIMIENTO: Entrapado y rodillo

SOPORTE

PIEL: Cabra

DIMENSIONES DE CADA PIEZA: $17 \times 17 \mathrm{~cm}$. LADO: Carne

METAL: Cobre

DIMENSIONES DE CADA PIEZA: $25 \times 25 \mathrm{~cm}$.

SECUENCIA: Aguafuerte/punta seca/xilografía

OBSERVACIONES: En esta pieza se utilizan tres planchas, dos de ellas calcográficas y una xilográfica, no incluyendo las transferencias de imágenes fotográficas. Emplea como soporte metálico el cobre, por lo que la riqueza cromática se consigue al utilizar dos gamas cromáticas opuestas en la estampación de la plancha de aguafuerte que actúa como fondo. Por su parte, la plancha de la punta seca se estampa en todos los elementos con una tinta rojiza, mientras que la imagen xilográfica está estampada usando tinta negra. 


\section{ANÁLISIS:}

La pieza seleccionada para comentar las posibilidades de la combinación de las técnicas xilográficas y calcográficas corresponde a la serie titulada Callejero, a la cual pertenecen a su vez el resto de los trabajos analizados dentro de este apartado concreto. Este grupo de obras tiene como origen la abstracción formal de partes concretas del plano del callejero del centro histórico de la ciudad de Valencia, entendiendo las formas y contornos creados por la intersección de calles, plazas y callejones, como imágenes y estructuras susceptibles de ser empleadas como base para la realización de una propuesta plástica personal. Mediante una selección de ciertas zonas y una modificación de las formas escogidas, se llegó a obtener una serie de imágenes geométricas abstractas como las que pueden verse en la fig. 151, a las cuales tan sólo les quedaba ser invertidas tonalmente para conseguir el germen de las planchas xilográficas que conforman esta serie de obras, tal y como se aprecia en el boceto reproducido en la fig. 152.

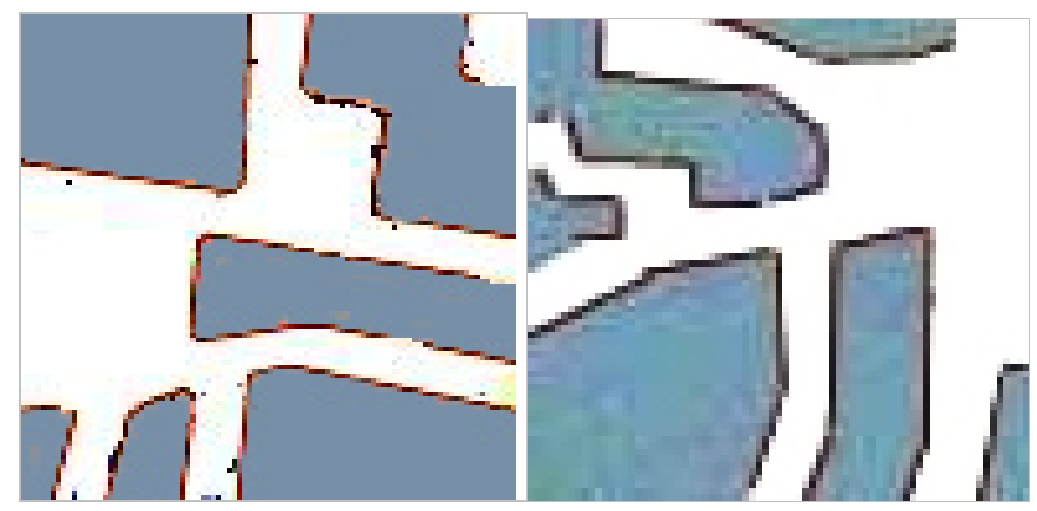

Fig. 151: Porciones del plano de Valencia empleadas como motivo. 


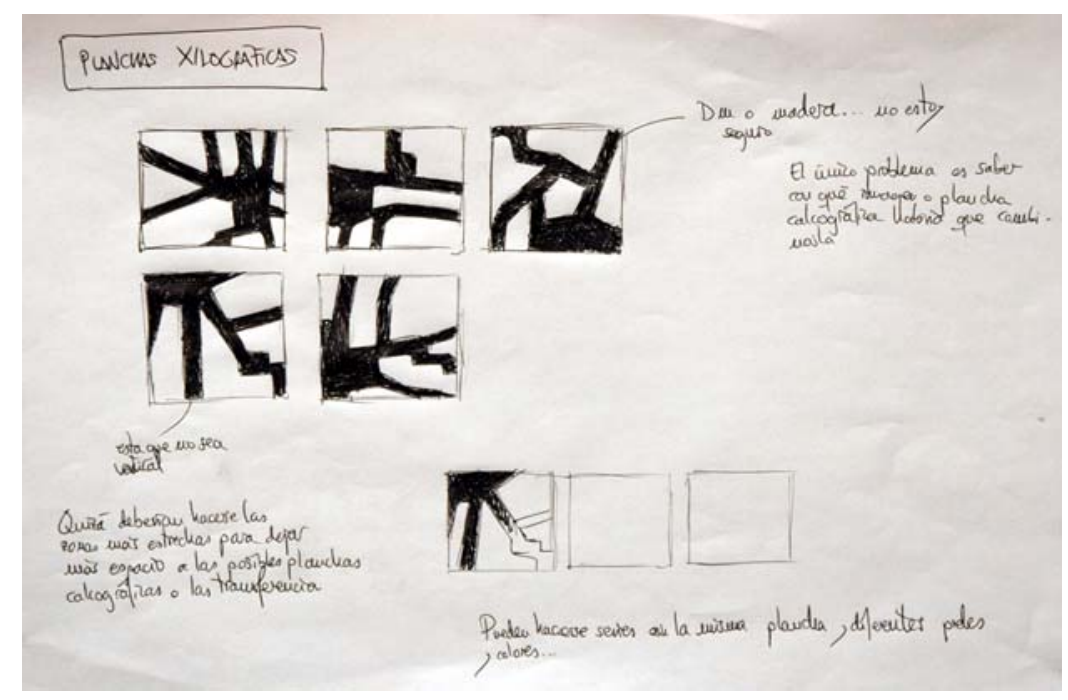

Fig. 152: Boceto extraído a partir de las imágenes modificadas en el ordenador

Una vez elegidas las imágenes que configurarían las dos matrices xilográficas a partir de las cuales está resuelta la pieza, se combinan con una plancha grabada a la punta seca con una serie de líneas verticales y horizontales, creándose de tal modo una irregular cuadrícula ortogonal que sirve de fondo a las formas xilográficas. Es a partir de la combinación de estas dos matrices, así como de la inclusión de una tercera plancha con una potente línea de punta seca, tal y como se resuelven cada uno de los elementos que conforman la composición final de la obra.

Siguiendo las pautas establecidas en apartados precedentes, el eje alrededor del cual gira la propuesta plástica de la serie es la creación de contrastes y confrontaciones entre los distintos agentes 
formales de las piezas. En el ejemplo que nos ocupa, estas disparidades pueden rastrearse en todos los niveles, comenzando por la configuración de cada uno de los elementos independientes que configuran la obra, elementos cuyo número asciende a 12 en este caso concreto. Así, en cada porción de cuero vemos como dialogan la masa compacta de las zonas estampadas mediante la xilografía, con los grafismos de las áreas resueltas calcográficamente, estando a su vez enfrentadas la ortogonalidad de estas últimas líneas con las formas mucho más libres de las matrices xilográficas.

A este contraste formal se une el contraste cromático que se establece entre los distintos elementos de la obra, dado que los tonos escogidos para los fondos calcográficos de cada uno de los cueros pueden dividirse entre los pertenecientes a una gama fría y los que lo hacen por su parte a una gama cálida. Los rojos, ocres y anaranjados se oponen a los azules, turquesas y violetas, disponiéndose en la superficie de las porciones de cobre con la intención de alcanzar un cierto equilibrio cromático por contraste. Por último, podemos referirnos al diálogo entre materiales que se repite a lo largo de todas las piezas seleccionadas y analizadas en lo sucesivo, con la frialdad del metal acogiendo la superficie cálida de los cueros, sean éstos del tipo que sean.

Desde un punto de vista compositivo, la obra recupera esquemas de organización en base a cuadrículas ortogonales en las cuales se disponen elementos similares dentro de su diversidad, 
pudiendo a su vez establecerse paralelismos entre esta obra concreta y la reproducida en la fig. 146 perteneciente a la serie PrisionerosLibres. En los dos casos es una cuadrícula geométrica la que condiciona la apariencia de las piezas, y en ambas obras, éstas están resueltas mediante la combinación de punta seca en los fondos coloreados con siluetas negras logradas a partir de la estampación xilográfica con tinta negra. De tal modo, podríamos concluir que la presente obra se nos ofrece como una lógica evolución desde unos conceptos formales existentes dentro de la trayectoria de los últimos años; una evolución desde unas formas todavía claramente figurativas pese a su síntesis estructural, hasta unos resultados de patente abstracción. Esta transformación, unida al cambio de soporte y todo lo que éste conlleva, permiten la aparición de una serie de piezas que tratan de avanzar hacia nuevas soluciones sin olvidar los precedentes que han permitido su concepción y realización definitivas. 


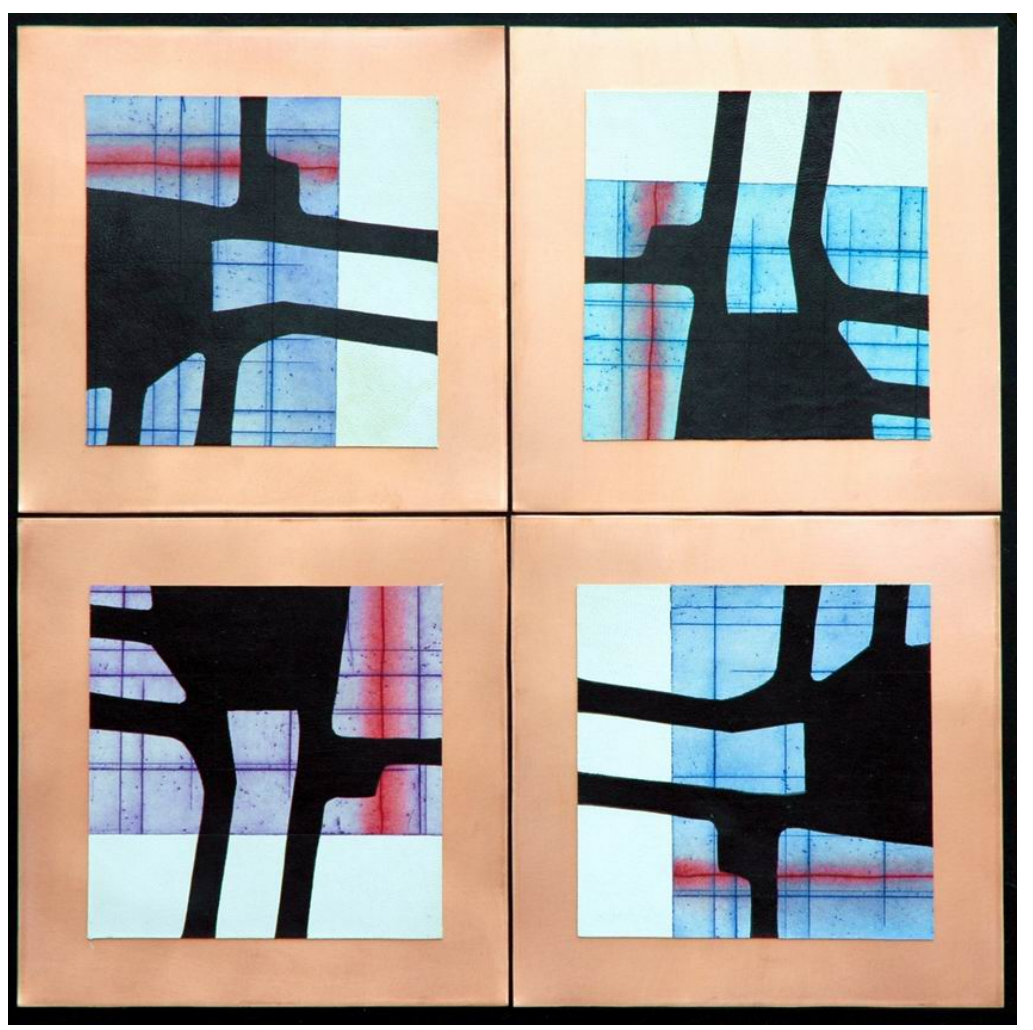

Fig. 153

TÍTULO: Callejero II

AÑO DE REALIZACIÓN: 2005

MEDIDAS: $50 \times 50 \mathrm{~cm}$. 
PROCEDIMIENTOS TÉCNICOS: Xilografía, aguafuerte y punta seca NÚMERO DE ELEMENTOS: 4

MATRIZ

NÚMERO DE PLANCHAS: 3

MATERIAL: Zinc (2) y DM (1)

DIMENSIONES: 18 × $18 \mathrm{~cm}$. (cada una)

ENTINTADO

NÚMERO DE TINTAS: 5

PROCEDIMIENTO: Entrapado y rodillo

SOPORTE

PIEL: Cordero

DIMENSIONES DE CADA PIEZA: $17 \times 17 \mathrm{~cm}$.

LADO: Flor

METAL: Cobre

DIMENSIONES DE CADA PIEZA: $25 \times 25 \mathrm{~cm}$.

SECUENCIA: Aguafuerte/punta seca/xilografía

OBSERVACIONES: A diferencia de la anterior, en este caso los tonos de fondo conseguidos mediante la estampación del aguafuerte son azulados y violáceos, con un carácter mucho más frío que intenta contrastar cromáticamente con el tono del soporte de cobre. La composición se resuelve, al igual que en la fig. 155, a partir de una estampa casi idéntica (tan sólo varía el tono del fondo) que se gira hasta lograr cuatro posiciones diferentes. 


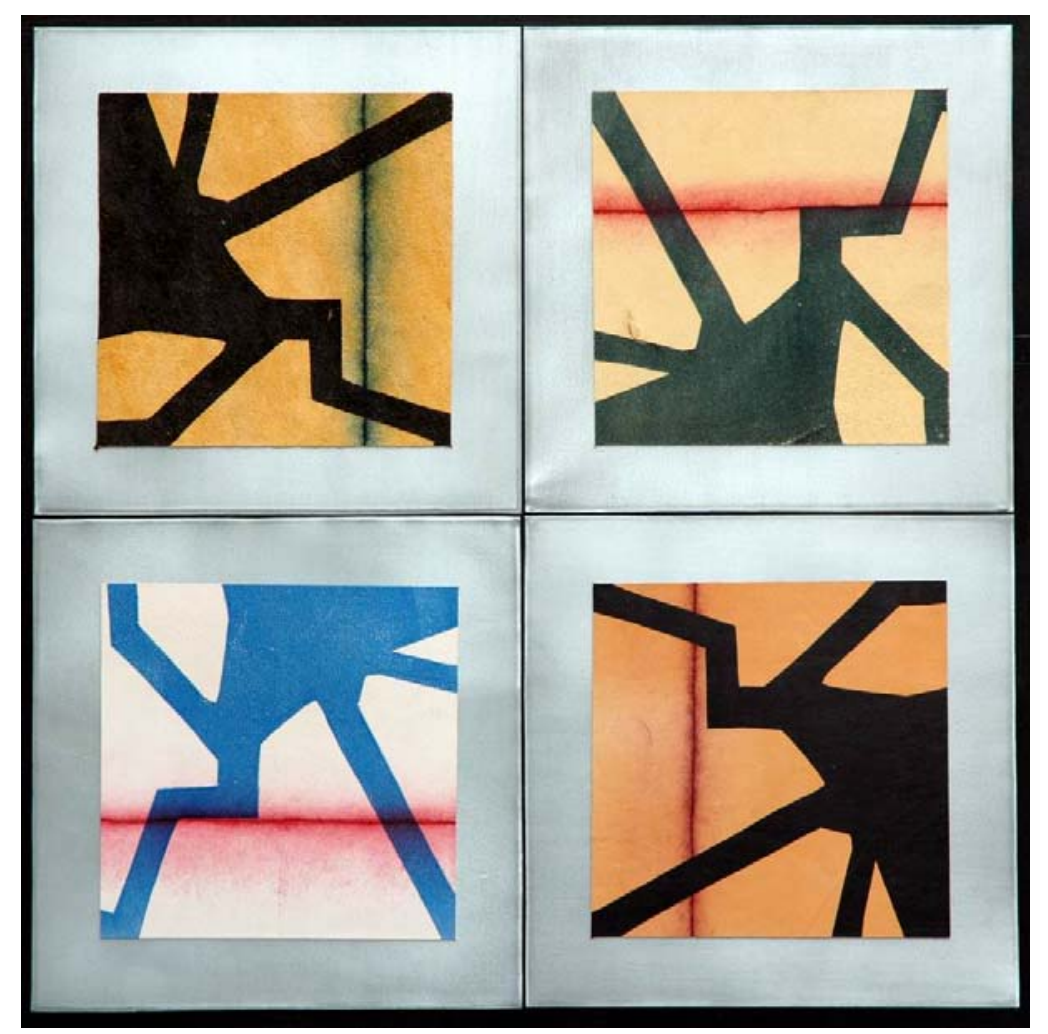

Fig. 154

TÍTULO: Callejero III

AÑO DE REALIZACIÓN: 2005

MEDIDAS: $50 \times 50 \mathrm{~cm}$. 
PROCEDIMIENTOS TÉCNICOS: Xilografía y punta seca

NÚMERO DE ELEMENTOS: 4

MATRIZ

NÚMERO DE PLANCHAS: 2

MATERIAL: Zinc (1) y DM (1)

DIMENSIONES: 18 × $18 \mathrm{~cm}$. (cada una)

ENTINTADO

NÚMERO DE TINTAS: 6 (4 calcográficas y 2 xilográficas)

PROCEDIMIENTO: Entrapado y rodillo

SOPORTE

PIEL: Cabra, cordero y vacuno

DIMENSIONES DE CADA PIEZA: $17 \times 17 \mathrm{~cm}$.

LADO: Carne y flor

METAL: Zinc

DIMENSIONES DE CADA PIEZA: $25 \times 25 \mathrm{~cm}$.

SECUENCIA: Punta seca/xilografía

OBSERVACIONES: En esta pieza se elimina el fondo de aguafuerte y en su lugar se muestra la variedad cromática del fondo gracias a la utilización de 4 pieles de tonos y características diferentes, a la vez que aparece una estampación xilográfica con dos tintas: un negro y un azul traslúcido. Esta última tinta contrasta con la piel de manera particular (véase al respecto el apartado IV.1.1.c., p. 206-215) provocando la aparición de tonos de especial interés que dotan de riqueza cromática a la obra. La combinación de ambos lados de la piel como soporte aporta la variedad de texturas presentes en el trabajo. 


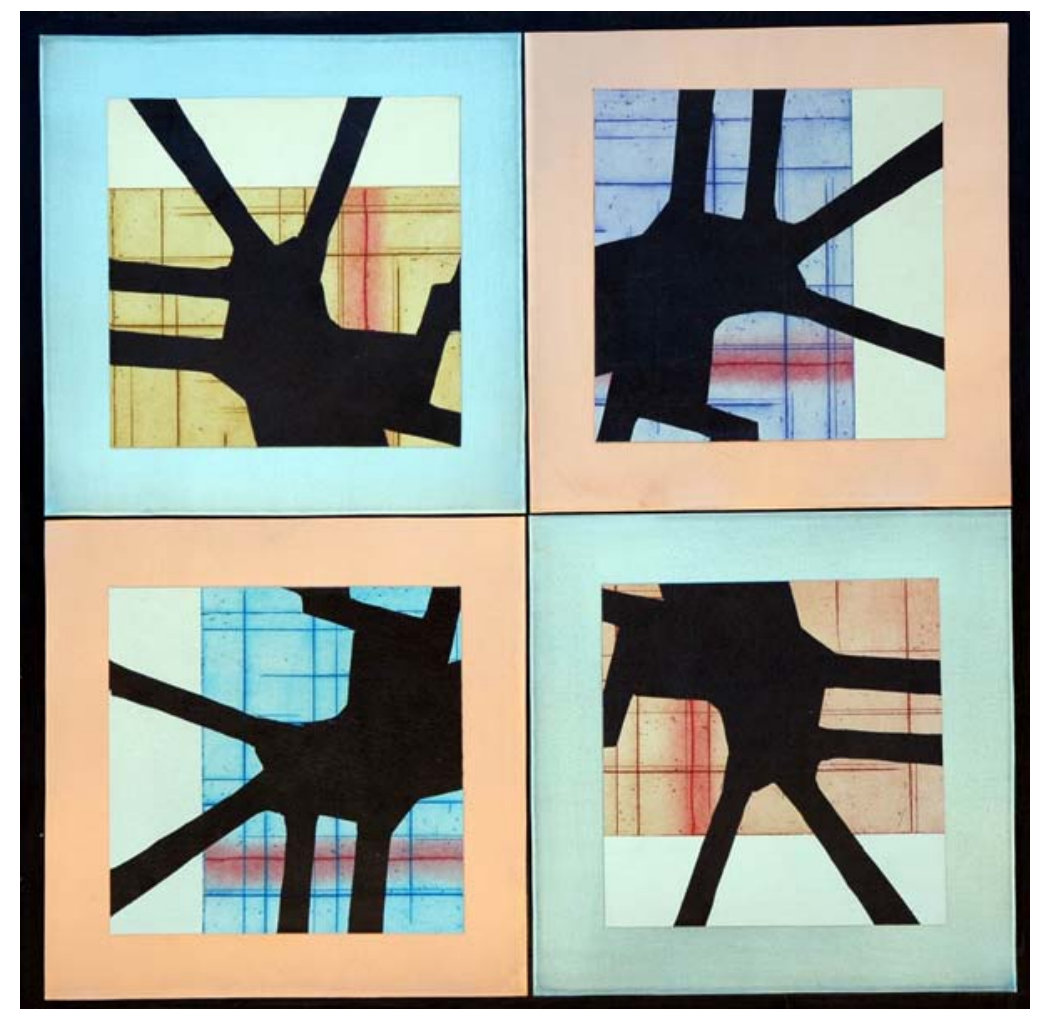

Fig. 155

TÍTULO: Callejero IV

AÑO DE REALIZACIÓN: 2006

MEDIDAS: $50 \times 50 \mathrm{~cm}$. 
PROCEDIMIENTOS TÉCNICOS: Xilografía, aguafuerte y punta seca NÚMERO DE ELEMENTOS: 4

MATRIZ

NÚMERO DE PLANCHAS: 3

MATERIAL: Zinc (2) y DM (1)

DIMENSIONES: 18 × $18 \mathrm{~cm}$. (cada una)

ENTINTADO

NÚMERO DE TINTAS: 6 (5 calcográficas y 1 xilográfica)

PROCEDIMIENTO: Entrapado y rodillo

SOPORTE

PIEL: Cabra

DIMENSIONES DE CADA PIEZA: $17 \times 17 \mathrm{~cm}$.

LADO: Flor

METAL: Cobre y zinc

DIMENSIONES DE CADA PIEZA: $25 \times 25 \mathrm{~cm}$.

SECUENCIA: Aguafuerte/punta seca/xilografía

OBSERVACIONES: En esta ocasión se combinan en la misma pieza tanto los dos metales que habitualmente se emplean, el zinc y el cobre, como las gamas cromáticas fría y cálida. Con ello se logra una obra de una mayor riqueza visual gracias a la combinación de dichos elementos en el mismo trabajo. 


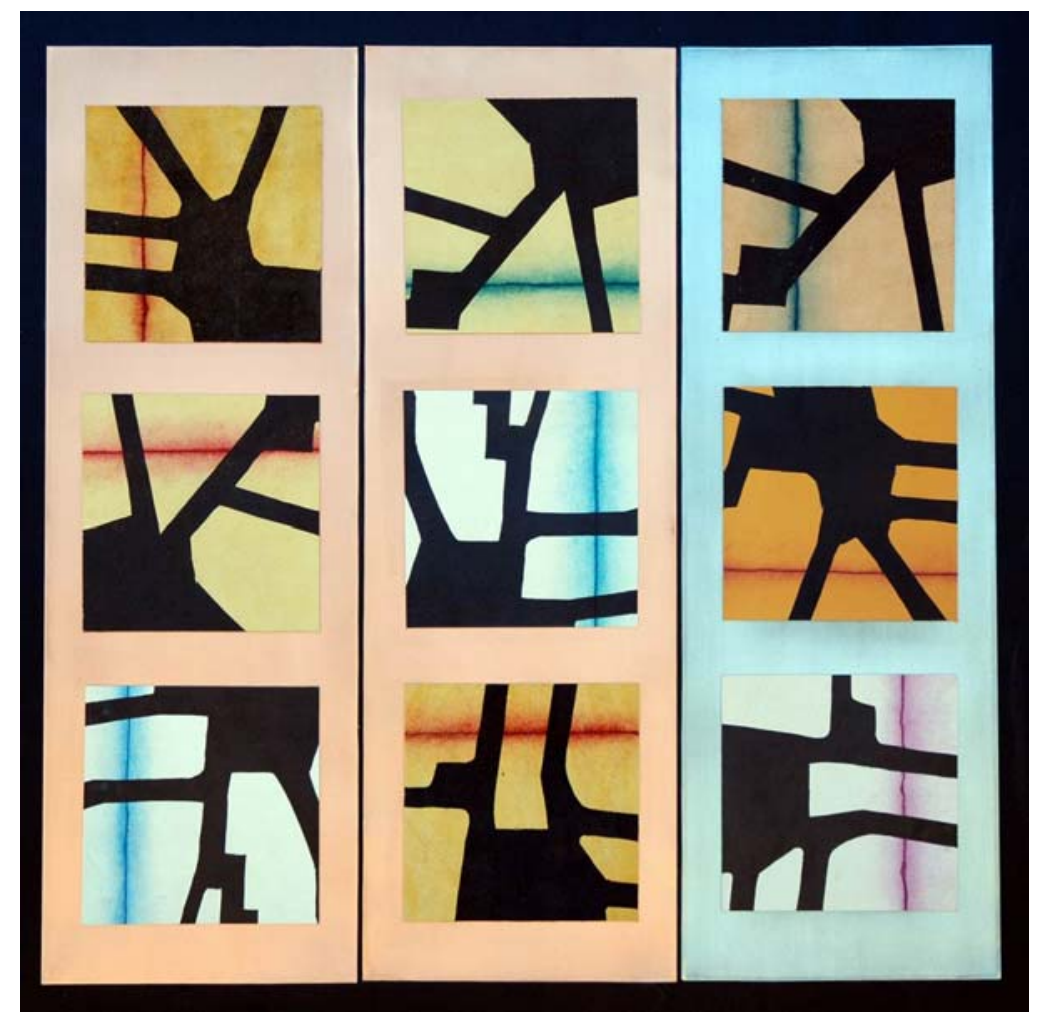

Fig. 156

TÍTULO: Callejero VI

AÑO DE REALIZACIÓN: 2006

MEDIDAS: $70 \times 70 \mathrm{~cm}$. 
PROCEDIMIENTOS TÉCNICOS: Xilografía y punta seca

NÚMERO DE ELEMENTOS: 3

MATRIZ

NÚMERO DE PLANCHAS: 5

MATERIAL: Zinc (1) y DM (4)

DIMENSIONES: 18 × $18 \mathrm{~cm}$. (cada una)

ENTINTADO

NÚMERO DE TINTAS: 10 (9 calcográficas y 1 xilográfica)

PROCEDIMIENTO: Entrapado y rodillo

SOPORTE

PIEL: Cabra, cordero y vacuno

DIMENSIONES DE CADA PIEZA: $15 \times 15 \mathrm{~cm}$.

LADO: Flor y carne

METAL: Cobre y zinc

DIMENSIONES DE CADA PIEZA: $60 \times 20 \mathrm{~cm}$.

SECUENCIA: Punta seca/xilografía

OBSERVACIONES: Ha desaparecido la plancha de aguafuerte que servía de fondo para emplear tan sólo los procedimientos de la punta seca y la xilografía. La línea de punta seca posee en cada ocasión un tono distinto, lo que unido a la diversidad de pieles empleadas logra dotar a la pieza de variaciones cromáticas. Se suma a esto el uso de diversos cueros cada uno de ellos con unas características diferentes, a la vez que una estampación por ambos lados de la piel. La combinación de ambos soportes metálicos tiene el mismo fin comentado de aportar riqueza visual al la obra. 


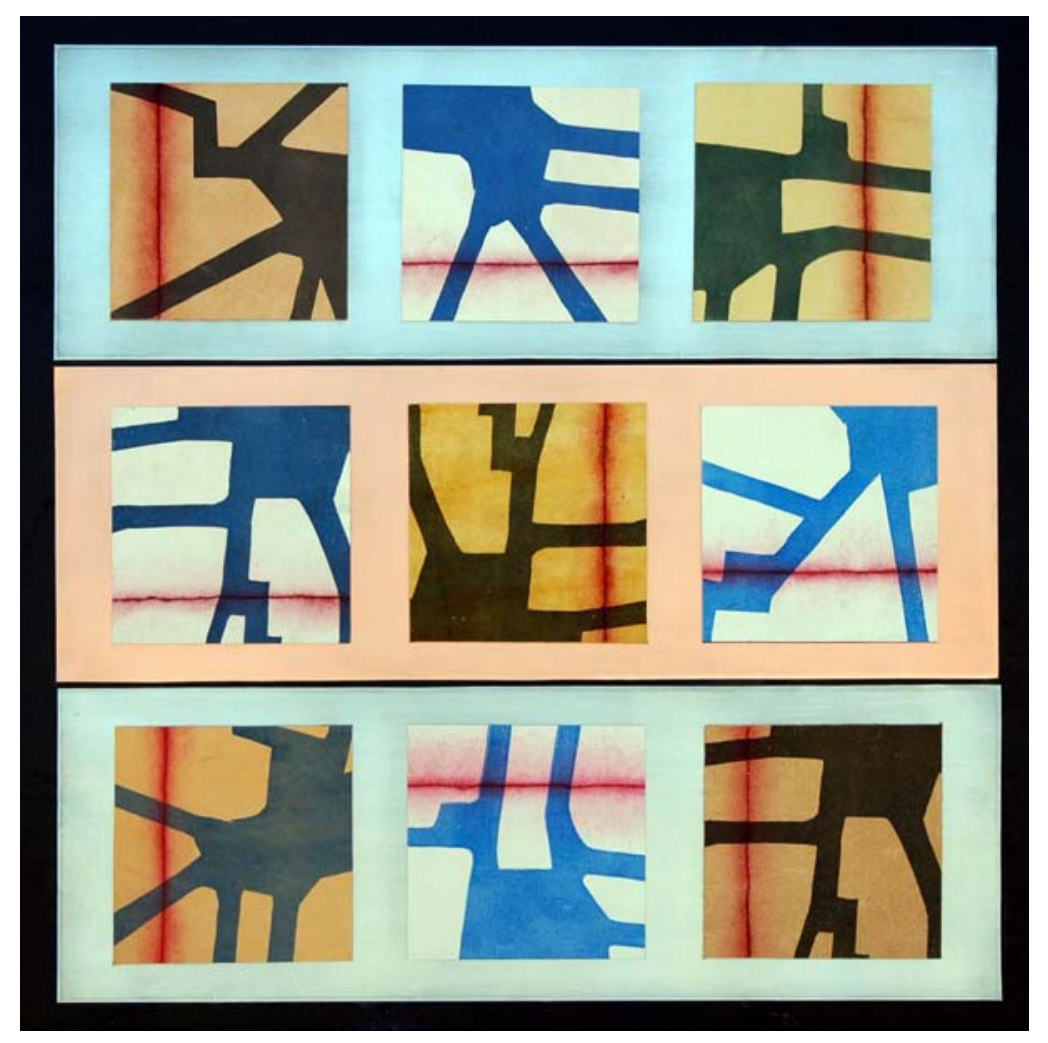

Fig. 157

TíTULO: Callejero VII

AÑO DE REALIZACIÓN: 2006

MEDIDAS: $70 \times 70 \mathrm{~cm}$. 
PROCEDIMIENTOS TÉCNICOS: Xilografía y punta seca

NÚMERO DE ELEMENTOS: 3

MATRIZ

NÚMERO DE PLANCHAS: 5

MATERIAL: Zinc (1) y DM (4)

DIMENSIONES: 18 × $18 \mathrm{~cm}$. (cada una)

ENTINTADO

NÚMERO DE TINTAS: 3 (2 calcográficas y 1 xilográfica)

PROCEDIMIENTO: Entrapado y rodillo

SOPORTE

PIEL: Cabra, cordero, cerdo y vacuno

DIMENSIONES DE CADA PIEZA: $15 \times 15 \mathrm{~cm}$.

LADO: Flor y Carne

METAL: Cobre y zinc

DIMENSIONES DE CADA PIEZA: $20 \times 60 \mathrm{~cm}$.

SECUENCIA: Punta seca/xilografía

OBSERVACIONES: La particularidad más relevante de esta pieza es la utilización de tinta azul traslúcida para la estampación de las planchas xilográficas en lugar del negro. Ello condiciona la apariencia del trabajo dado que dicha tinta modifica su color al contacto con las superficies de las distintas pieles empleadas. Por su parte, la matriz de punta seca tiene dos tonos muy similares: un rojo intenso y un magenta, los cuales aportan una nota de color y grafía muy diferenciadas. 
V. Propuesta plástica personal

386 


\section{V.4.4. Xilografía y transferencia}




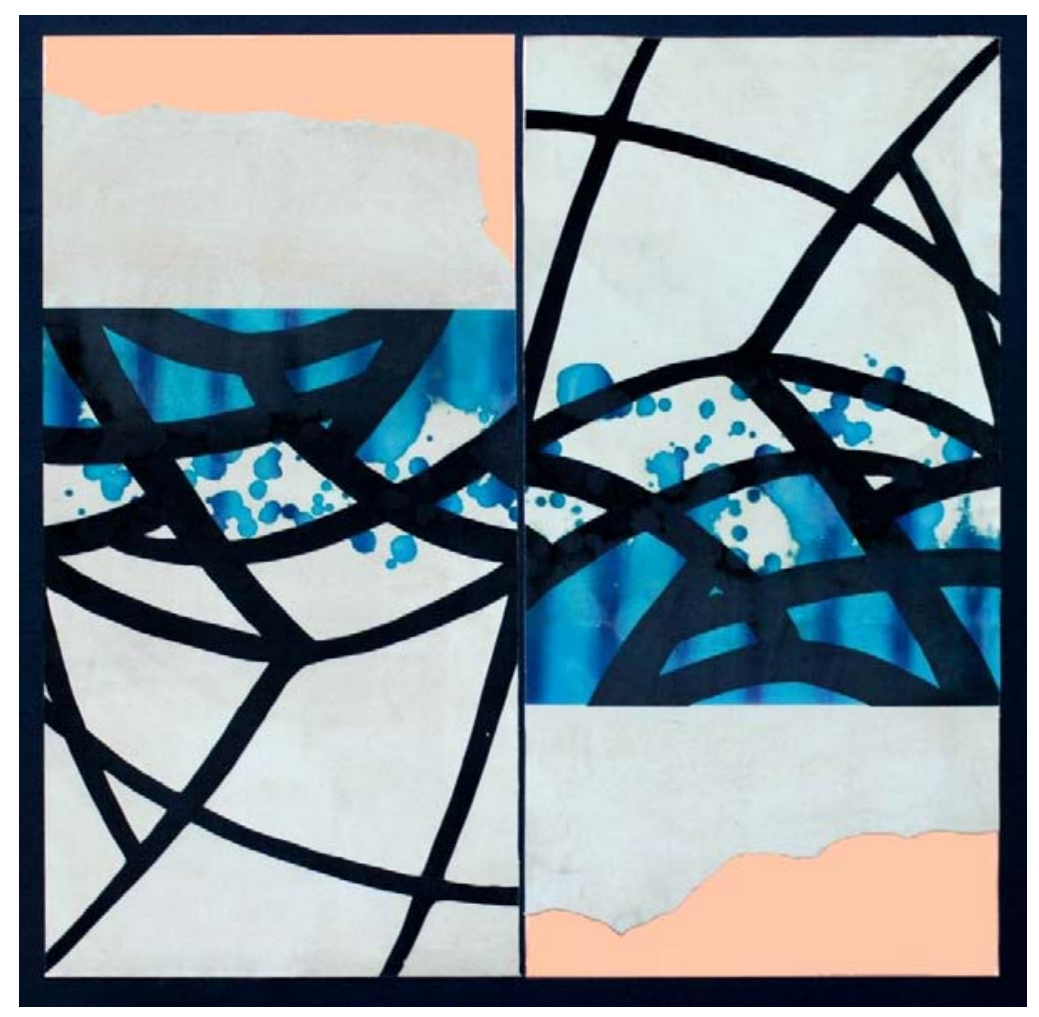

Fig. 158

TÍTULO: Arquitectura I

AÑO DE REALIZACIÓN: 2006

MEDIDAS: $80 \times 80 \mathrm{~cm}$. 
PROCEDIMIENTOS TÉCNICOS: Xilografía y transferencia

NÚMERO DE ELEMENTOS: 2

MATRIZ

NÚMERO DE PLANCHAS: 1

MATERIAL: DM

DIMENSIONES: 50 × $35 \mathrm{~cm}$.

ENTINTADO

NÚMERO DE TINTAS: 1

PROCEDIMIENTO: Rodillo

SOPORTE

PIEL: Cabra

DIMENSIONES DE CADA PIEZA: 65 × $35 \mathrm{~cm}$.

LADO: Carne

METAL: Cobre

DIMENSIONES DE CADA PIEZA: 70 × $35 \mathrm{~cm}$.

SECUENCIA: Transferencia/xilografía

OBSERVACIONES: El modo de aplicación del disolvente para conseguir la transferencia electrográfica crea un goteado sobre la superficie del cuero que consigue el efecto de irregularidad orgánica presente en el resultado final, efecto que dialoga con el también desigual borde de la piel escogida, la cual ha conservado el acabado original. 


\section{ANÁLISIS:}

En el caso de las obras resueltas mediante la combinación de estampación xilográfica más transferencia, éstas pueden englobarse dentro de una serie común a la que hemos denominado Arquitecturas, de la cual hemos a su vez seleccionado la pieza que nos ocupa. En esta serie, tanto la imagen transferida como el grabado xilográfico poseen un origen relacionado con la fotografía, origen que es mucho más evidente en relación con la técnica electrográfica, pero que como veremos a continuación también condiciona la apariencia de la estampa. La composición de la pieza está basada en la repetición de un mismo elemento de forma casi idéntica y el girado de uno de ellos 180 grados hasta confrontar ambas partes. Pese a esta reiteración formal, se trata de evitar la apariencia exactamente idéntica en ambas secciones de la obra mediante la elección de dos procedimientos: la conservación del borde heterogéneo de los cueros en uno de los lados de dichos soportes; y la utilización del recurso del goteado de disolvente con objeto de transferir las imágenes electrográficas de manera desigual. Con estos mecanismos se elude un aspecto absolutamente especular que podría conllevar cierta pobreza visual, objetivo que puede rastrearse en la práctica totalidad de las obras seleccionadas en este apartado final.

Por lo que se refiere a la imagen xilográfica, la cual se convierte en dominante dada su preeminencia visual asociada al empleo de potentes grafismos de tinta negra, pese a su naturaleza 
plenamente abstracta está extraída de una imagen fotográfica concreta. La fotografía digital que sirve de base al diseño de la plancha xilográfica recoge las bóvedas góticas del antiguo Palacio Real del Castillo de Praga, cuyos arcos se entrelazan de modo extraordinariamente variado y original hasta crear una retícula de formas orgánicas totalmente diferentes a la imagen habitual que una cubierta gótica pueda ofrecer. A partir de esta fotografía, y empleando herramientas informáticas de tratamiento de imágenes, las líneas y ritmos generales de la estructura tridimensional dan lugar a una composición bidimensional reducida a dos tonos (fig. 159), susceptible de ser transportada a la plancha xilográfica. ${ }^{199}$

Al igual que en el resto de las obras seleccionadas, en ésta los contrastes adoptan un rol determinante a la hora de configurar plásticamente la pieza. La misma superposición entre la imagen transferida y la estampa ofrece tanto un contraste cromático (azules/negro) como formal (irregularidad/regularidad) pese a que las líneas ligeramente curvas que dominan la imagen xilográfica traten de dialogar y relacionarse con los contornos de las gotas de color que pueblan el cuero. Los bordes orgánicos de las pieles se encuentran a su vez enmarcados dentro de una estructura compositiva en la que predominan las líneas verticales y horizontales, ya sean las de los

\footnotetext{
${ }^{199}$ Este proceso de abstracción de formas sintéticas a partir de imágenes fotográficas digitales es común a todas las obras de la serie Arquitecturas resueltas mediante la combinación de xilografía y transferencia.
} 


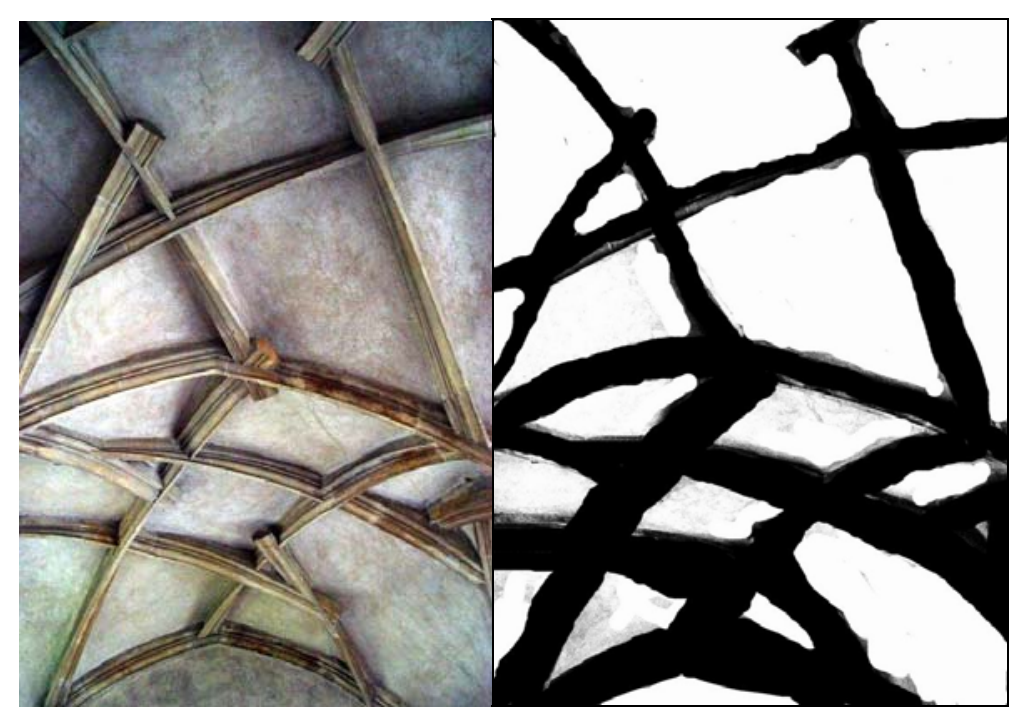

Fig. 159: A la izquierda, fotografía original; a la derecha boceto bidimensional extraído de la primera.

propios límites de la obra, como la divisoria entre los dos elementos 0 las horizontales que delimitan el final de la zona transferida y estampada. Si en otras ocasiones la composición era estrictamente ortogonal y geométrica, como puede verse en la fig. 150, en este caso la inclusión de estos bordes heterogéneos remite de manera instantánea a la cualidad orgánica del soporte de cuero. A su vez, estos bordes irregulares permiten que el constante contraste existente entre el metal que sirve como base, en este caso cobre, y la piel sea todavía más evidente y de mayor potencia visual. También en los ejemplos en los que el cuero está cortado de manera totalmente regular existe este contraste de materiales gracias al diálogo de texturas que se establece, pero en esta pieza el borde desigual hace que esta oposición sea si cabe más patente. 
De tal manera, esta pieza, y toda la serie a la que pertenece, comparten las dos constante plásticas que dominan la práctica totalidad de las obras seleccionadas: por un lado los contrastes y por otro la descontextualización de elementos formales hasta conseguir composiciones de distinta naturaleza. Se intenta con ello que este grupo de obras se encuentre directamente relacionado estéticamente con el resto de las propuestas personales, pero que a la vez posea una cierta personalidad diferente lograda mediante la específica combinación de procedimientos que han permitido su materialización. 


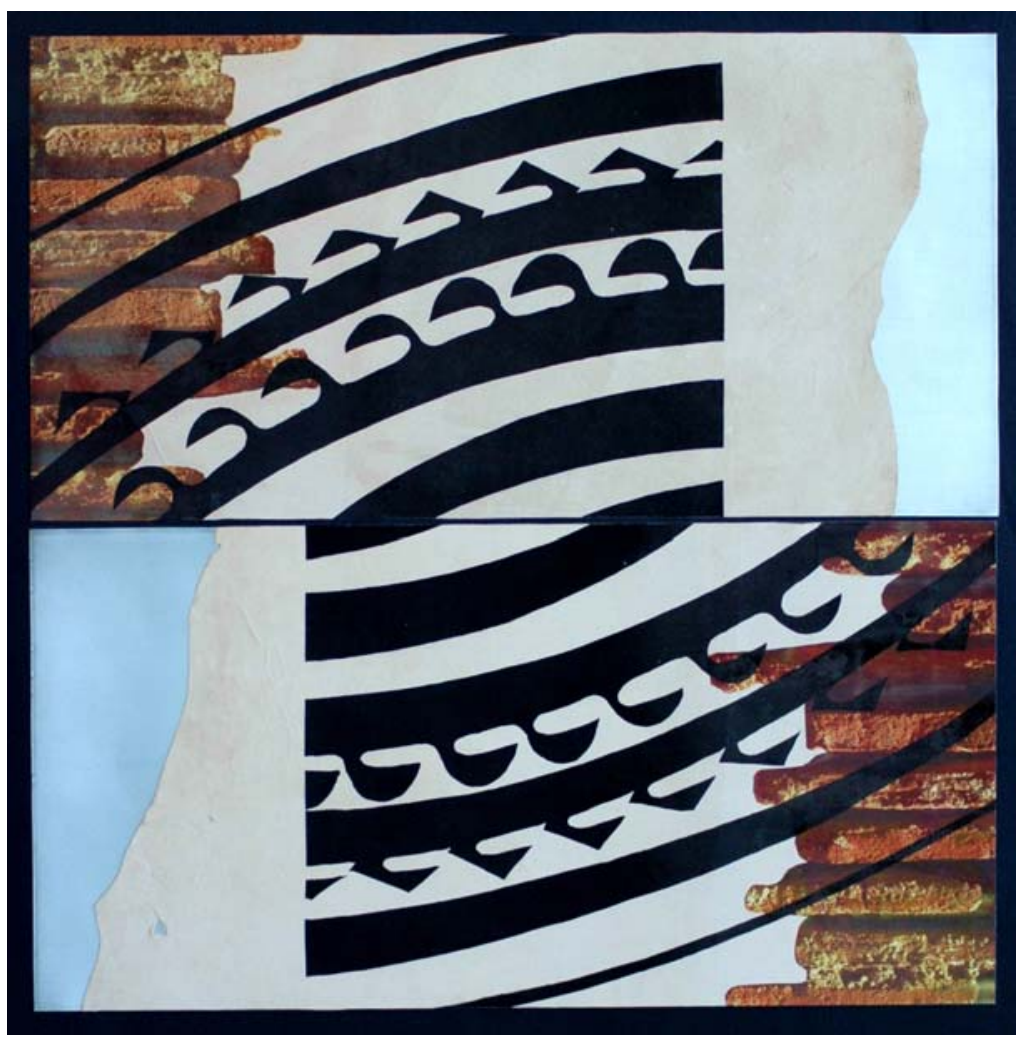

Fig. 160

TÍTULO: Arquitectura II

AÑO DE REALIZACIÓN: 2006

MEDIDAS: 80 × $80 \mathrm{~cm}$. 
PROCEDIMIENTOS TÉCNICOS: Xilografía y transferencia

NÚMERO DE ELEMENTOS: 2

MATRIZ

NÚMERO DE PLANCHAS: 1

MATERIAL: DM

DIMENSIONES: 50 × $35 \mathrm{~cm}$.

\section{ENTINTADO}

NÚMERO DE TINTAS: 1

PROCEDIMIENTO: Rodillo

SOPORTE

PIEL: Cabra

DIMENSIONES DE CADA PIEZA: $65 \times 35 \mathrm{~cm}$.

$$
\text { LADO: Carne }
$$

METAL: Zinc

DIMENSIONES DE CADA PIEZA: 70 x $35 \mathrm{~cm}$.

\section{SECUENCIA: Transferencia/xilografía}

OBSERVACIONES: En este caso, en lugar del goteado es el recorte de la imagen fotocopiada siguiendo el contorno de una hilera de ladrillos el que insiste en el concepto arquitectónico de la serie. En la misma línea se puede situar la imagen xilográfica escogida, dado que se trata de una abstracción de las arquivoltas de la portada románica del Palau de la Catedral de Valencia. 


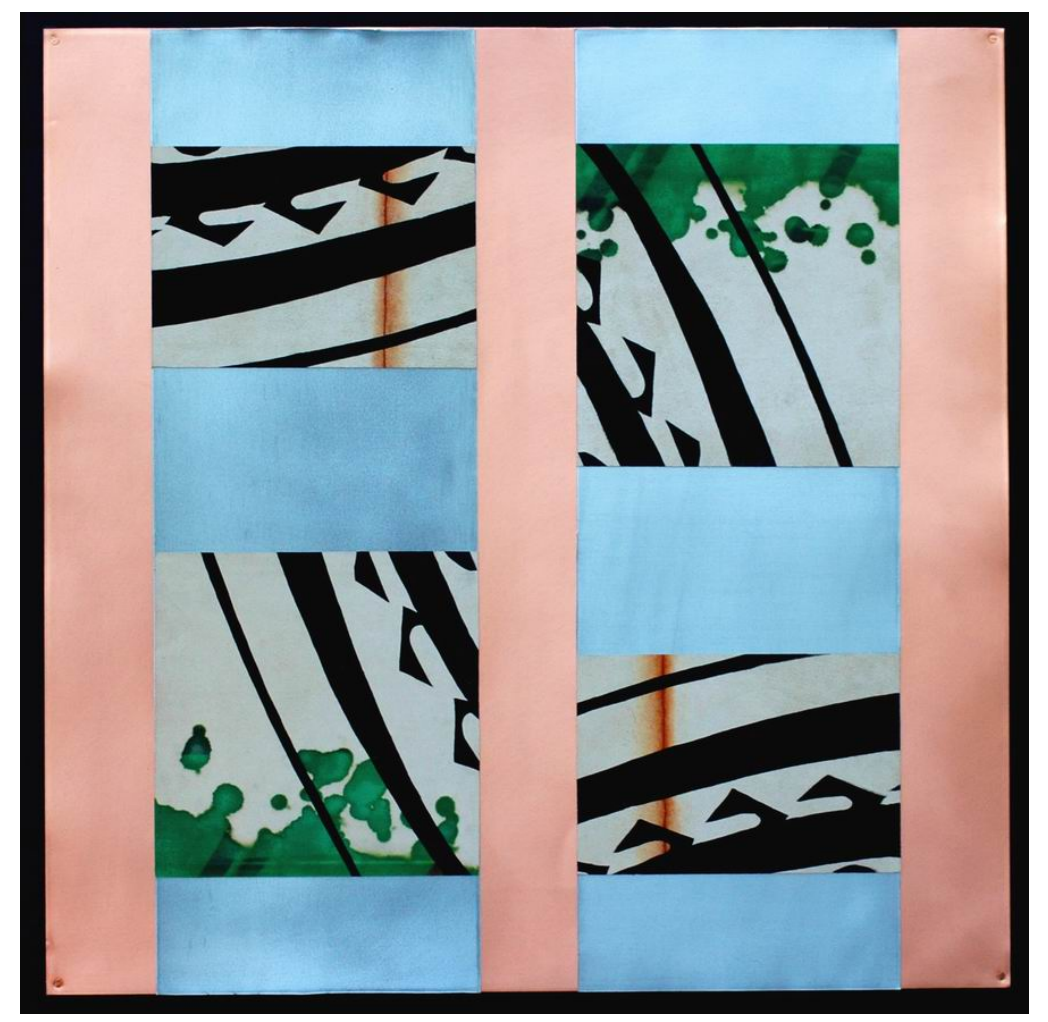

Fig. 161

TÍTULO: Arquitectura III

AÑO DE REALIZACIÓN: 2006

MEDIDAS: $70 \times 70 \mathrm{~cm}$. 
PROCEDIMIENTOS TÉCNICOS: Xilografía, transferencia y punta seca NÚMERO DE ELEMENTOS: 4

MATRIZ

NÚMERO DE PLANCHAS: 2

MATERIAL: DM (1) y zinc (1)

DIMENSIONES: 50 × $35 \mathrm{~cm}$.

ENTINTADO

NÚMERO DE TINTAS: 2

PROCEDIMIENTO: Rodillo y entrapado

SOPORTE

PIEL: Cabra

DIMENSIONES DE CADA PIEZA: $24 \times 24 \mathrm{~cm}$. (2) y $18 \times 24 \mathrm{~cm} .(2)$ LADO: Carne

METAL: Cobre (1) y zinc (2)

DIMENSIONES DE CADA PIEZA: Cobre: 70 x $70 \mathrm{~cm}$.

Zinc: $70 \times 24 \mathrm{~cm}$.

SECUENCIA: Transferencia/punta seca/xilografía

OBSERVACIONES: Obra realizada a partir de la plancha empleada en la fig. 160, de la cual se han escogido dos fragmentos para, mediante su duplicación y girado, conformar esta pieza. Aparte del recurso del goteado de disolvente, en este caso se incluyen dos seños de punta seca sobre las porciones de cuero trabajadas sin transferencia electrográfica, completando un ejemplo en el cual se combinan las tres técnicas que se han analizado en este estudio. A su vez, se han combinado los dos metales en el fondo de mayor cromatismo 


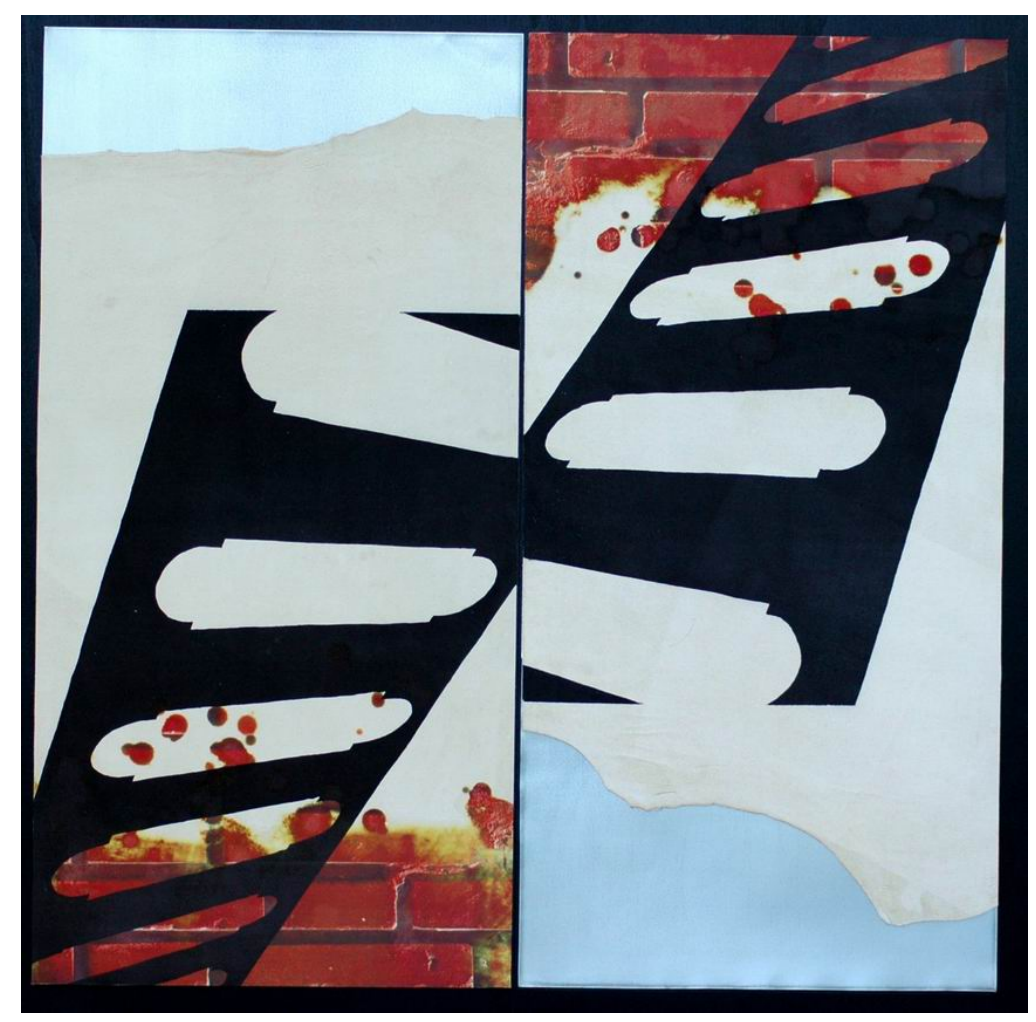

Fig. 162

TÍTULO: Arquitectura IV

AÑO DE REALIZACIÓN: 2006

MEDIDAS: 80 x $80 \mathrm{~cm}$. 
PROCEDIMIENTOS TÉCNICOS: Xilografía y transferencia

NÚMERO DE ELEMENTOS: 2

MATRIZ

NÚMERO DE PLANCHAS: 1

MATERIAL: DM

DIMENSIONES: 50 × $35 \mathrm{~cm}$.

ENTINTADO

NÚMERO DE TINTAS: 1

PROCEDIMIENTO: Rodillo

SOPORTE

PIEL: Cabra

DIMENSIONES DE CADA PIEZA: 65 × $35 \mathrm{~cm}$.

LADO: Carne

METAL: Zinc

DIMENSIONES DE CADA PIEZA: 70 × $35 \mathrm{~cm}$.

SECUENCIA: Transferencia/xilografía

OBSERVACIONES: Se vuelve a utilizar el recurso del goteado como mecanismo de transferencia de las imágenes electrográficas, aunque la composición queda dominada por el diálogo establecido entre las dos imágenes xilográficas (realmente la misma girada 180 grados al igual que otros ejemplos de esta serie). Mediante la elección del zinc como soporte se establece un contraste cromático entre la calidez de la gama de la imagen fotográfica y la frialdad del tono del metal. 

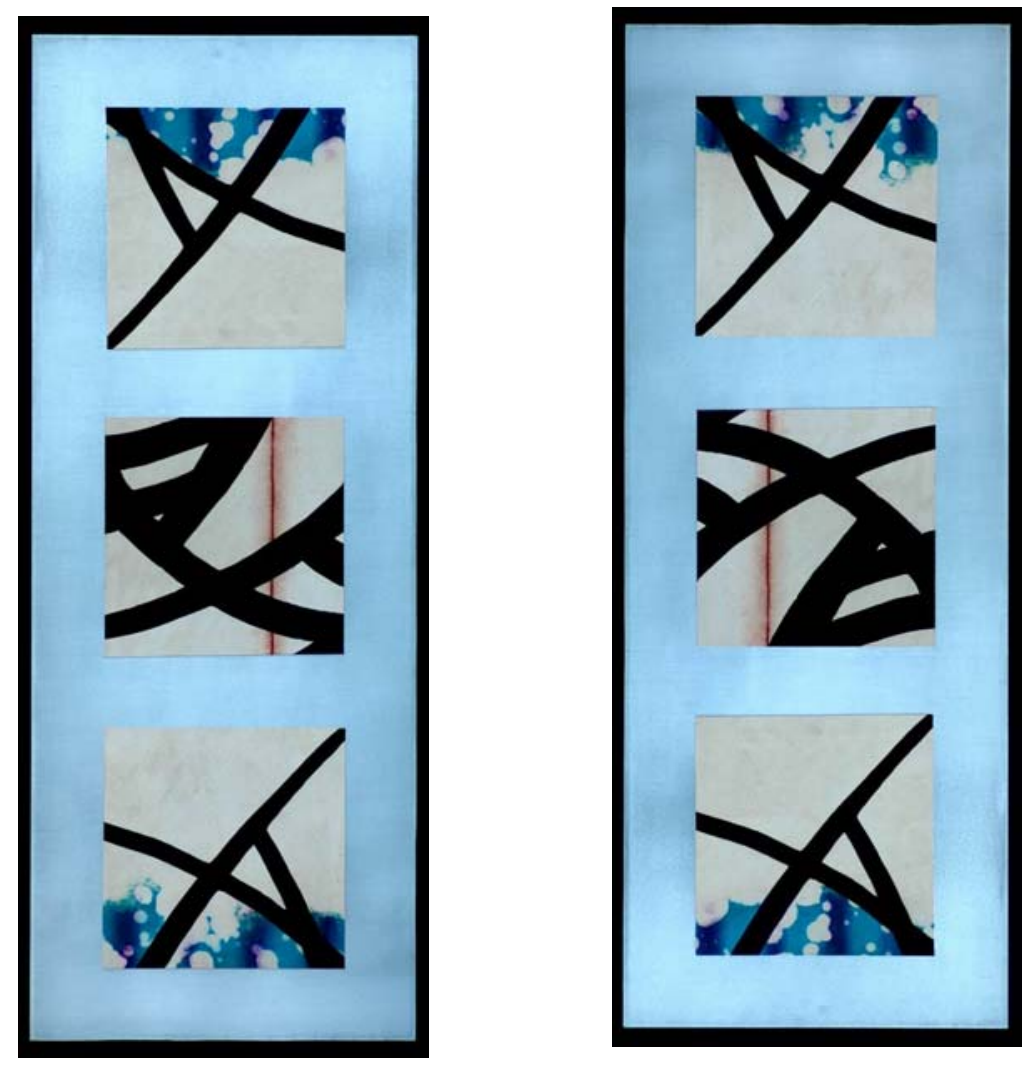

Fig. 163

TÍTULO: Arquitectura V

AÑO DE REALIZACIÓN: 2006

MEDIDAS: $75 \times 50 \mathrm{~cm}$. 
PROCEDIMIENTOS TÉCNICOS: Xilografía, transferencia y punta seca NÚMERO DE ELEMENTOS: 6

MATRIZ

NÚMERO DE PLANCHAS: 2

MATERIAL: DM (1) y zinc (1)

DIMENSIONES: 50 × $35 \mathrm{~cm}$. (DM) y $25 \times 25 \mathrm{~cm}$. (zinc)

ENTINTADO

NÚMERO DE TINTAS: 2

PROCEDIMIENTO: Rodillo y entrapado

SOPORTE

PIEL: Cabra

DIMENSIONES DE CADA PIEZA: $20 \times 20 \mathrm{~cm}$.

LADO: Carne

METAL: Cobre

DIMENSIONES DE CADA PIEZA: $70 \times 25 \mathrm{~cm}$.

SECUENCIA: Transferencia/punta seca/xilografía

OBSERVACIONES: En este caso se trata de nuevo de una obra creada a partir de fragmentos seleccionados de la plancha empleada para la creación de la pieza reflejada en la fig. 158. El recurso del goteado está aquí utilizado de manera inversa al resto de los ejemplos: aquí las gotas quedan en blanco y el resto de la imagen se transfiere. Esto es posible al emplear en esta obra la fotocopia previamente utilizada en la realización de la imagen de la fig. 158, fotocopia en la cual el tóner de las zonas de las gotas ha desaparecido, quedando tan sólo el de las áreas que en aquel caso no se transfirieron. 


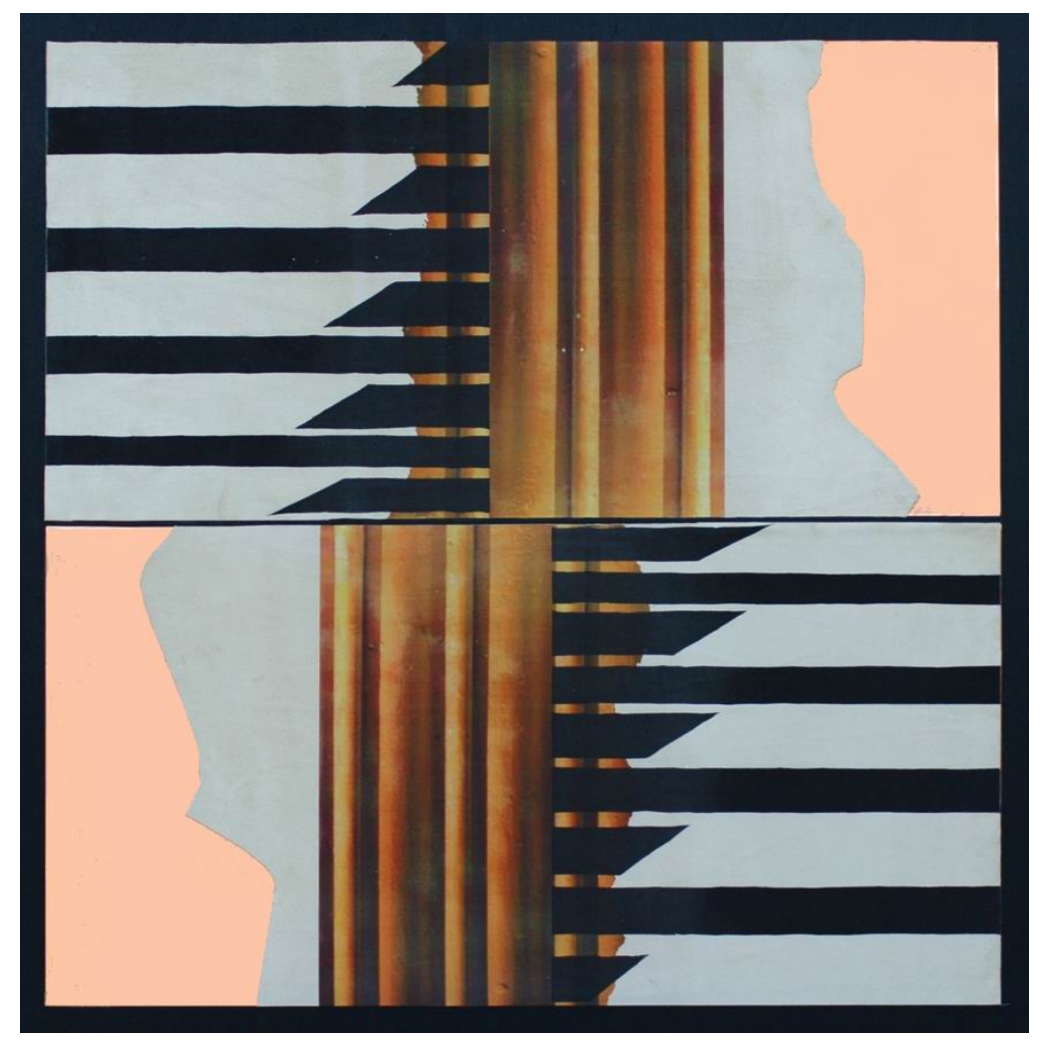

Fig. 164

TÍTULO: ArquitecturaV I

AÑO DE REALIZACIÓN: 2006

MEDIDAS: 80 x $80 \mathrm{~cm}$. 
PROCEDIMIENTOS TÉCNICOS: Xilografía y transferencia

NÚMERO DE ELEMENTOS: 2

MATRIZ

NÚMERO DE PLANCHAS: 1

MATERIAL: DM

DIMENSIONES: 50 × $35 \mathrm{~cm}$.

ENTINTADO

NÚMERO DE TINTAS: 1

PROCEDIMIENTO: Rodillo

SOPORTE

PIEL: Cabra

DIMENSIONES DE CADA PIEZA: $65 \times 35 \mathrm{~cm}$.

LADO: Carne

METAL: Cobre

DIMENSIONES DE CADA PIEZA: $70 \times 35 \mathrm{~cm}$.

SECUENCIA: Transferencia/xilografía

OBSERVACIONES: Formalmente esta pieza intenta insistir en el contraste entre la ortogonalidad de las formas transferidas y estampadas xilográficamente, y la irregularidad del borde del cuero empleado. A diferencia de otros casos, en este ejemplo la xilografía y la transferencia tan sólo se unen en una pequeña zona de las pieles, dominando el resto del cuero cada una de manera independiente. 
V. Propuesta plástica personal

404 


\section{V.4.3. Calcografía y transferencia}




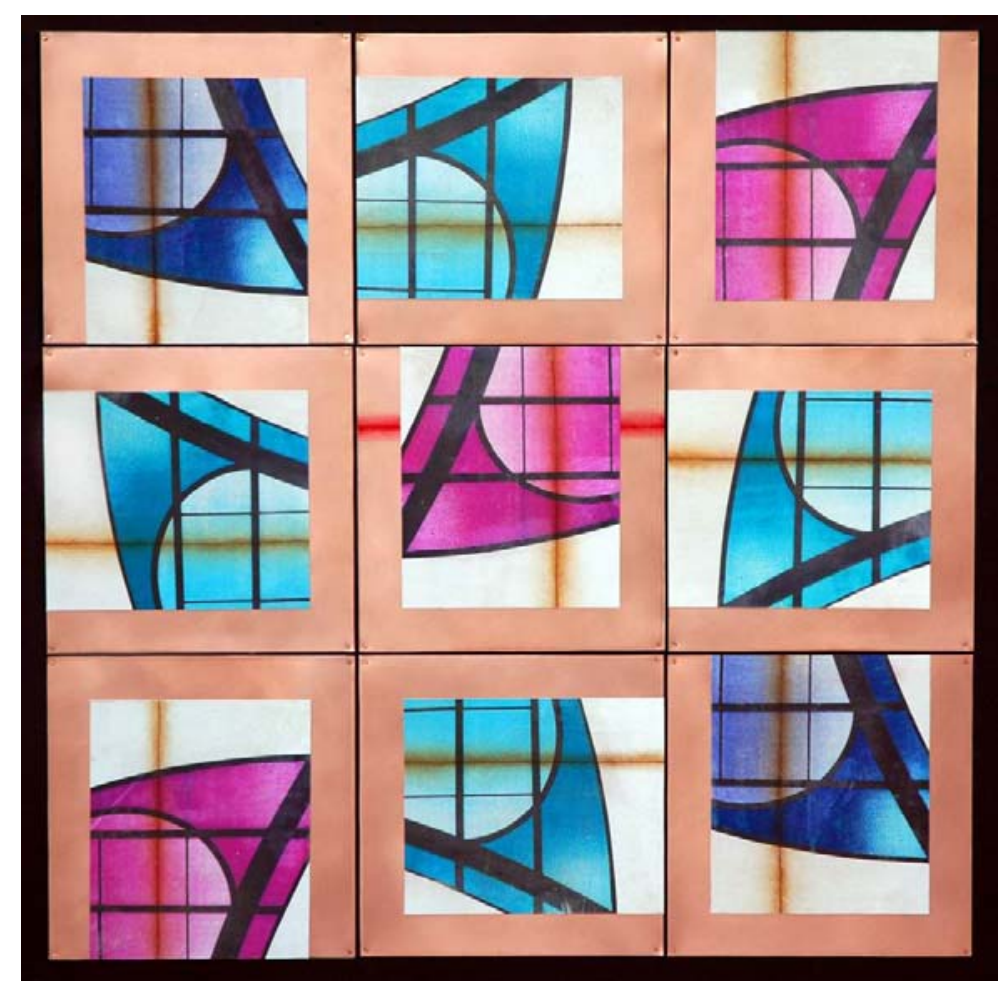

Fig. 165

TÍTULO: Valencia

AÑO DE REALIZACIÓN: 2005

MEDIDAS: 120 x $120 \mathrm{~cm}$. 
PROCEDIMIENTOS TÉCNICOS: Transferencia y punta seca NÚMERO DE ELEMENTOS: 9

MATRIZ

NÚMERO DE PLANCHAS: 1

MATERIAL: Zinc

DIMENSIONES: $35 \times 35 \mathrm{~cm}$.

ENTINTADO

NÚMERO DE TINTAS: 3

PROCEDIMIENTO: Entrapado

SOPORTE

PIEL: Cabra

DIMENSIONES DE CADA PIEZA: $25 \times 30 \mathrm{~cm}$. LADO: Carne

METAL: Cobre

DIMENSIONES DE CADA PIEZA: $35 \times 35 \mathrm{~cm}$.

SECUENCIA: Transferencia/punta seca/grabado del soporte

OBSERVACIONES: En la porción central de cobre aparece una línea creada mediante la acción de una punta, entintando a continuación la superficie del metal con tinta calcográfica. Por último, y antes de proceder al pegado de las pieles en la superficie del cobre, se ha aplicado barniz mate para cuadros, de manera exactamente igual a lo realizado en el resto de los soportes metálicos de la propuesta personal que venimos analizando. 


\section{ANÁLISIS:}

En la obra seleccionada, perteneciente a la serie titulada Valencia y cuyo germen formal se encuentra precisamente en dicha ciudad, vemos como es la transferencia electrográfica la que domina la composición. A diferencia de otros trabajos en los cuales la imagen fotográfica transferida poseía un papel secundario al recaer el mayor peso visual en otros procedimientos, en esta obra son las formas transferidas a la piel las que condicionan y conforman la apariencia de la pieza. La imagen fotográfica que sirve como punto de partida (fig. 166) es un detalle de una vidriera del recientemente restaurado Mercado de Colón de Valencia, con bandas curvas combinadas con perpendiculares que crean una trama lineal que sirve como cobijo a zonas de colores azulados. Mediante la manipulación por ordenador del archivo fotográfico digital los colores de la toma viran hacia azules

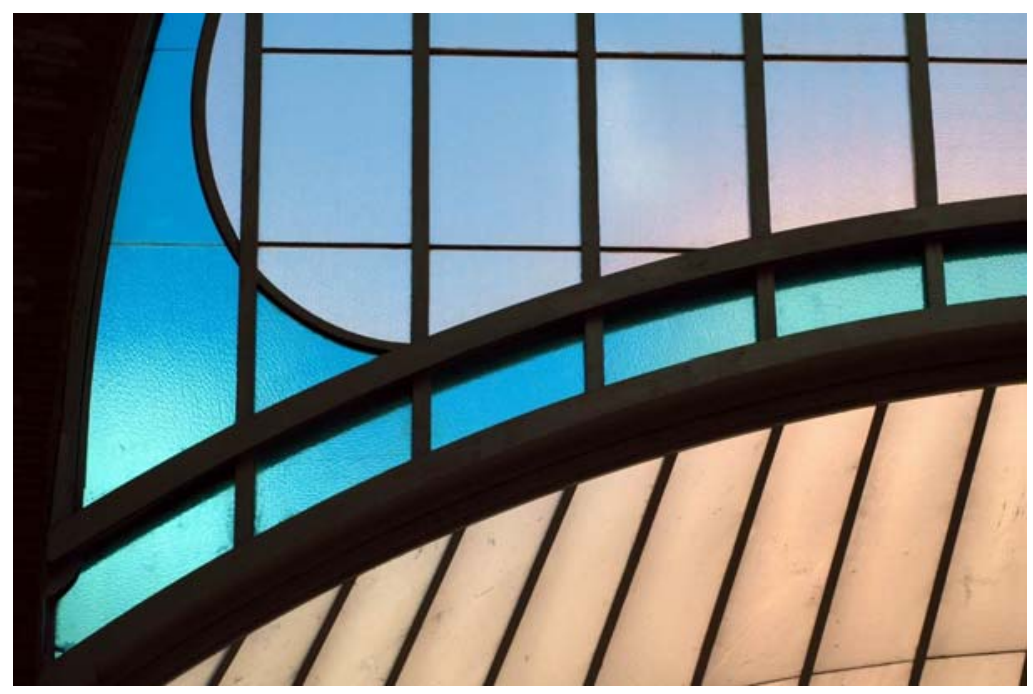

Fig. 166: Fotografía digital 
más intensos y violetas, permaneciendo siempre dentro de una gama cromática que dota de homogeneidad a la obra. Dado que el cromatismo de la propuesta concreta queda en gran parte determinado por el pigmento transferido y su contraste con el tono del cobre que le sirve como fondo y soporte, se crea una contraposición entre la calidez del metal y los matices de una gama azulada y fría, contraste que se une a otros para configurar la concepción plástica de la obra elegida.

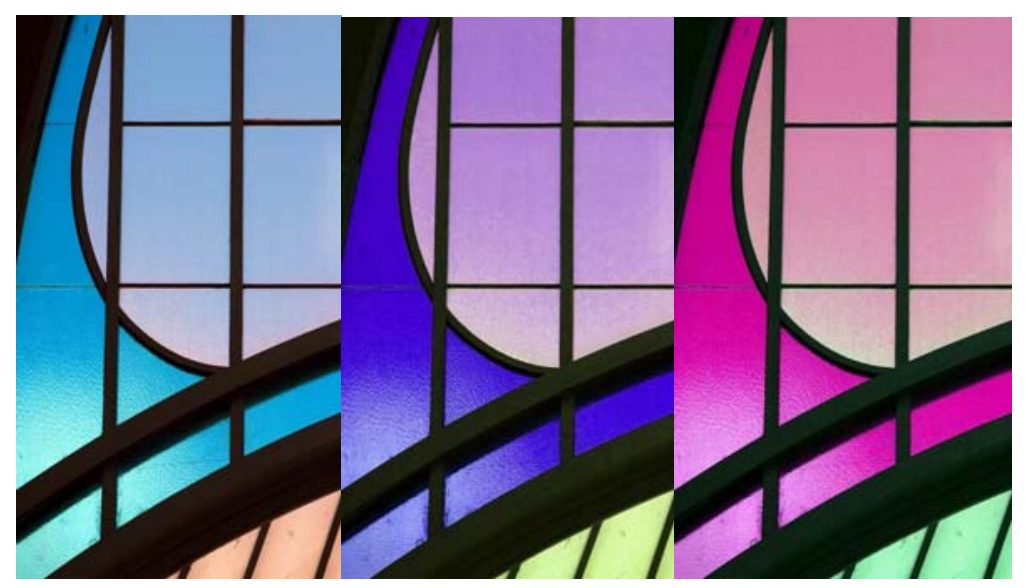

Fig. 167

Las formas ligeramente modernistas de la vidriera fotografiada sugieren la posibilidad de cortar la fotocopia siguiendo algunos de los contornos curvilíneos de la imagen, rompiendo así la estricta apariencia rectilínea que domina otras piezas de la misma serie (ver fig. 169 y fig. 172). De tal modo, las zonas de cuero libres de pigmento no responden a áreas rectangulares como en la gran mayoría de los trabajos realizados, sino que aparecen como porciones triangulares y 
trapezoidales con alguno de sus lados curvos. Estos contornos de la imagen transferida, así como la curva que domina el interior de la vidriera, proponen un nuevo contraste formal y lineal entre las porciones de piel perfectamente rectangulares, las líneas perpendiculares que se cruzan dentro de la zona transferida y la cuadricula ortogonal formada por el cobre por un lado, y estas líneas curvas que conforman las zonas cromáticas por otro. A diferencia de otras posibles soluciones (fig. 172), en este caso se ofrece un contraste gráfico que trata de romper la rígida estructura formal creada por el cruce de numerosas líneas paralelas y perpendiculares, organización ortogonal a la que se suma el trazo de punta seca que culmina la pieza.

En efecto, en esta obra el papel dejado a las técnicas tradicionales del mundo del grabado y la estampación es algo tangencial y accesorio, tratándose de una línea resuelta con punta seca y colocada sobre las imágenes transferidas. Estampada en un color cálido que la relaciona cromáticamente con el tono del cobre, contrasta, como el metal, con los azules y violetas de la composición cromática, incidiendo en la contraposición tonal ya comentada. Como se ha avanzado, se coloca y dispone de forma paralela el borde de la piel, integrándose por tanto en la retícula ortogonal que configura la pieza en su conjunto y dialogando con el límite curvo de la imagen transferida. 
Al estar estampado después de realizada la transferencia, la tinta calcográfica se deposita sobre la película de pigmento, lo que provoca la aparición de dos planos de profundidad sobre la superficie de la piel. El trazo calcográfico aparece superpuesto, haciendo que la formación geométrica retroceda de manera muy sutil hasta un segundo plano desde el que continúa proyectando su fuerza cromática. Esta leve superposición es la única concesión a lo que podríamos llamar tridimensionalidad, dado que la pieza está dominada por un profundo sentido de planitud y superficialidad decorativa, con todas las connotaciones positivas que posee este término dentro del campo de las artes plásticas. Al igual que en otras composiciones de la misma serie, se produce un acercamiento a la abstracción formal a partir de la descontextualización de elementos extraídos de la realidad, de la propia ciudad. Mediante este proceso las formas se vuelven planas, pierden su significado para revelar la fuerza de su significante, desaparecen las identificaciones para convertirse tan sólo en formas, geometrías, composiciones de líneas y colores.

De tal modo, la obra puede organizarse en torno a dos conceptos principales que funcionan a modo de ejes alrededor de los que giran el resto de los elementos que componen la propuesta plástica. Por un lado tenemos los diferentes contrastes que hemos venido citando a lo largo de las últimas líneas, contrastes intensos que huyen conscientemente de la sutilidad para contraponer factores de manera muy evidente. Incluimos aquí el diálogo que se establece entre la cálida piel y el metal, pero también el contraste entre los tonos 
cálidos del cobre y el cromatismo más frío de las formas transferidas, cuyos contornos curvos se combinan a su vez con la retícula ortogonal. A estas relaciones visuales se une, como el otro vértice de conformación de la obra, esa descontextualización previamente referida y la superficialidad ornamental que tratan de alcanzar las propuestas escogidas. 
V. Propuesta plástica personal

413 


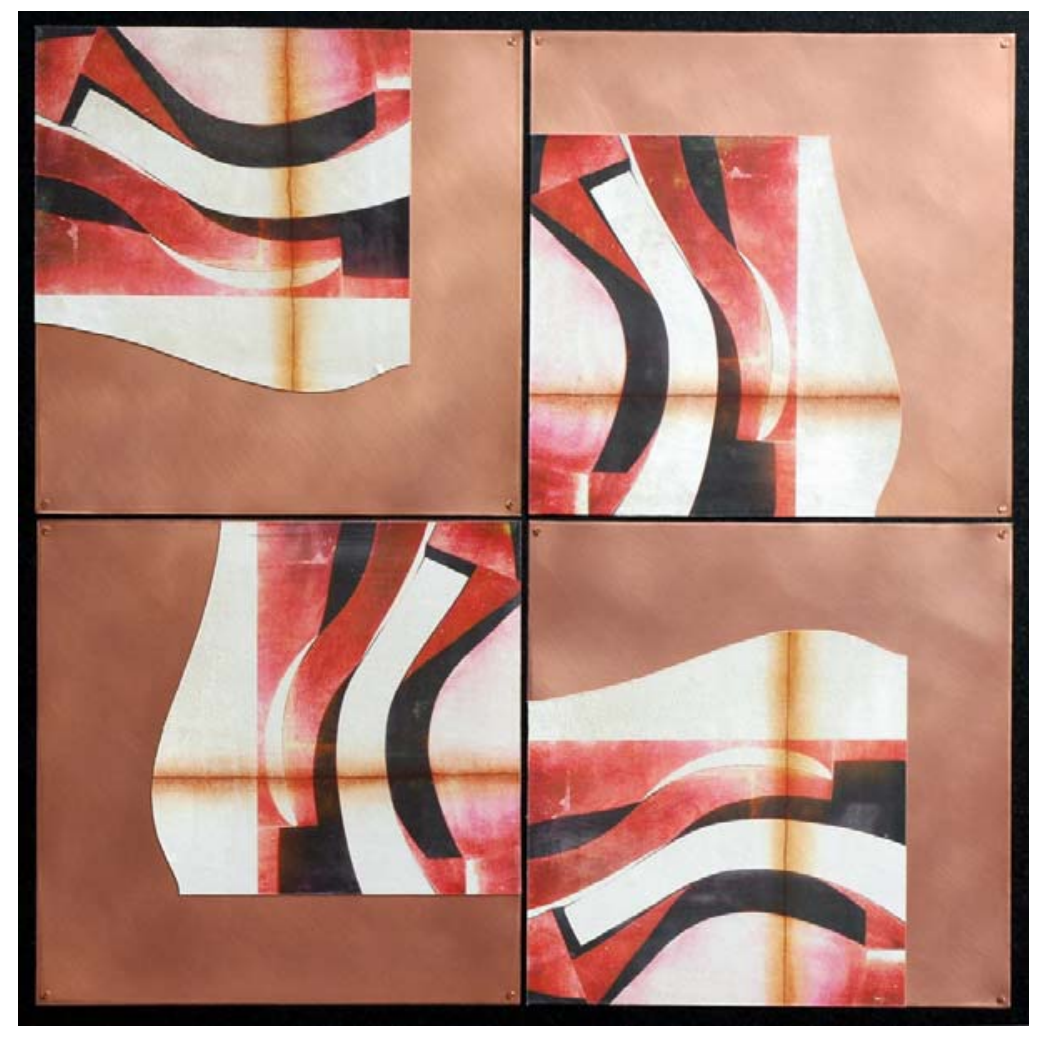

Fig. 168

TíTULO: Almansa I

AÑO DE REALIZACIÓN: 2005

MEDIDAS: $80 \times 80 \mathrm{~cm}$ 
PROCEDIMIENTOS TÉCNICOS: Transferencia y punta seca NÚMERO DE ELEMENTOS: 4

MATRIZ

NÚMERO DE PLANCHAS: 1

MATERIAL: Zinc

DIMENSIONES: 35 × $35 \mathrm{~cm}$.

ENTINTADO

NÚMERO DE TINTAS: 1

PROCEDIMIENTO: Entrapado

SOPORTE

PIEL: Cabra

DIMENSIONES DE CADA PIEZA: $25 \times 25 \mathrm{~cm}$.

LADO: Carne

METAL: Cobre

DIMENSIONES DE CADA PIEZA: $35 \times 35 \mathrm{~cm}$.

SECUENCIA: Transferencia/punta seca

OBSERVACIONES: En esta obra se corta de manera curvilínea, no la fotocopia sino la misma piel, con unas curvas que dialogan con las formas presentes en la imagen transferida. La superficie del cobre no presenta ningún tipo de incisión, dejándolo intacto y protegiéndolo tan sólo con barniz. A su vez, se ha eliminado una porción de fotocopia para permitir la apreciación de la textura del soporte en la zona libre de pigmento, dotando de una mayor riqueza visual a cada uno de los elementos configuradotes de la pieza. 


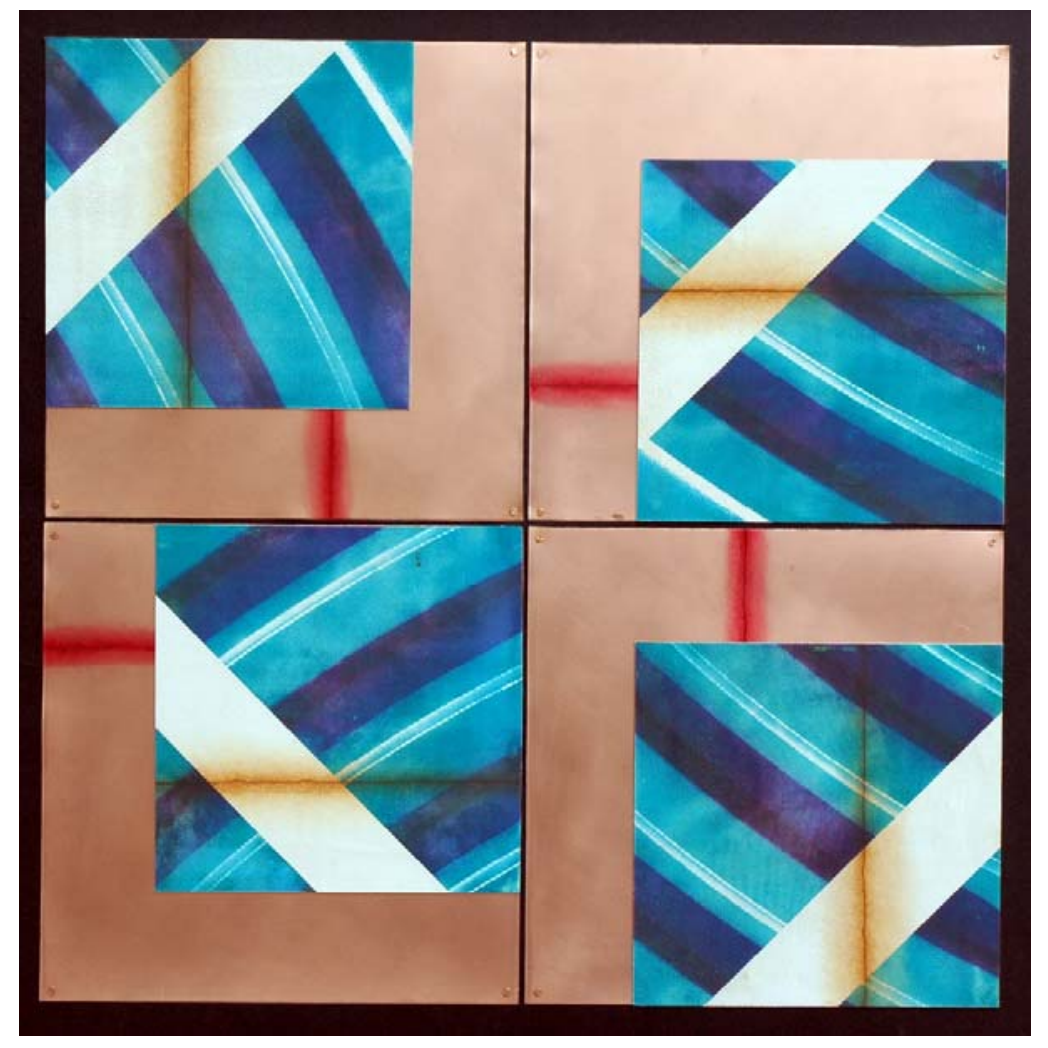

Fig. 169

TÍTULO: Roma II

AÑO DE REALIZACIÓN: 2005

MEDIDAS: $80 \times 80 \mathrm{~cm}$ 
PROCEDIMIENTOS TÉCNICOS: Transferencia y punta seca NÚMERO DE ELEMENTOS: 4

MATRIZ

NÚMERO DE PLANCHAS: 1

MATERIAL: Zinc

DIMENSIONES: 35 × $35 \mathrm{~cm}$.

ENTINTADO

NÚMERO DE TINTAS: 1

PROCEDIMIENTO: Entrapado

SOPORTE

PIEL: Cabra

DIMENSIONES DE CADA PIEZA: $25 \times 25 \mathrm{~cm}$.

LADO: Carne

METAL: Cobre

DIMENSIONES DE CADA PIEZA: $35 \times 35 \mathrm{~cm}$.

SECUENCIA: Transferencia/punta seca/grabado del soporte OBSERVACIONES: En este trabajo la ortogonalidad se rompe con las bandas diagonales de piel intacta que se cruzan con los diseños de las zonas transferidas. Se incluyen incisiones sobre la superficie del cobre, entintadas en un tono rojo intenso que dialoga con el trazo anaranjado de la punta seca y con el tono del soporte de cobre, contrastando todo ello con la frialdad del azul de la imagen fotografiada. 

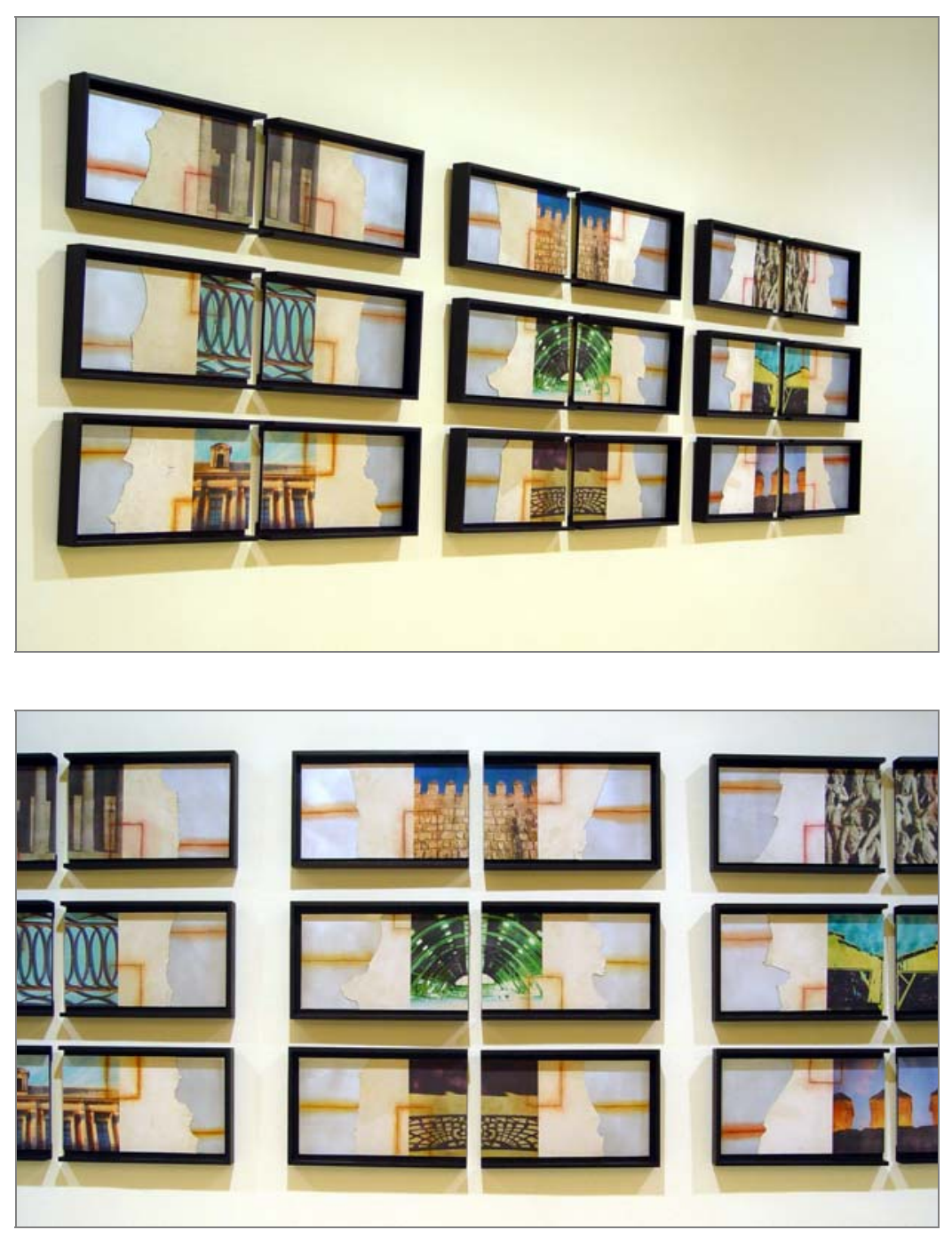

Fig. 170

TÍTULO: Reflejos II

AÑO DE REALIZACIÓN: 2004

MEDIDAS: $100 \times 250 \mathrm{~cm}$ 
PROCEDIMIENTOS TÉCNICOS: Transferencia y punta seca NÚMERO DE ELEMENTOS: 18

MATRIZ

NÚMERO DE PLANCHAS: 1 x 18

MATERIAL: Zinc

DIMENSIONES: 40 × $30 \mathrm{~cm}$.

\section{ENTINTADO}

NÚMERO DE TINTAS: 9

PROCEDIMIENTO: Entrapado

SOPORTE

PIEL: Cabra

DIMENSIONES DE CADA PIEZA: Variables LADO: Carne

METAL: Zinc

DIMENSIONES DE CADA PIEZA: $23 \times 42 \mathrm{~cm}$.

SECUENCIA: Transferencia/punta seca/grabado del soporte OBSERVACIONES: Esta pieza se configura como la suma de varias unidades de menor tamaño para formar una composición regular. Cada una de estas unidades (9) se ha dividido a su vez en dos partes, con lo que el conjunto lo forman 18 fragmentos agrupados dos a dos. Los motivos urbanos se combinan con los lados irregulares de la piel, la punta seca y las líneas incisas sobre el metal, logrando mayor riqueza cromática que en otras obras. 

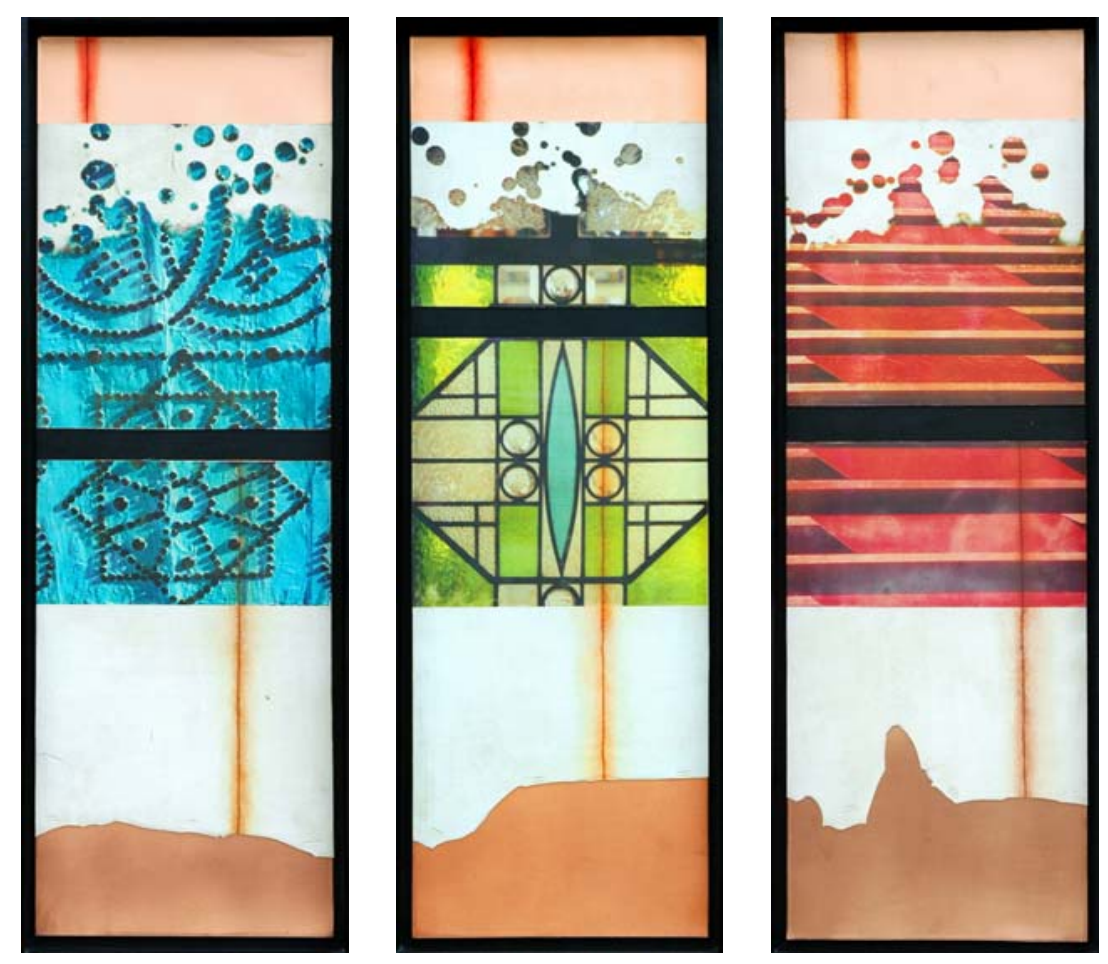

Fig. 171

TÍTULO: Ciudades

AÑO DE REALIZACIÓN: 2005

MEDIDAS: 80 × $30 \mathrm{~cm}$ (cada uno) 
PROCEDIMIENTOS TÉCNICOS: Transferencia y punta seca NÚMERO DE ELEMENTOS: 2 (cada uno)

MATRIZ

NÚMERO DE PLANCHAS: 1 (cada uno)

MATERIAL: Zinc

DIMENSIONES: 40 × $30 \mathrm{~cm}$.

ENTINTADO

NÚMERO DE TINTAS: 1

PROCEDIMIENTO: Entrapado

SOPORTE

PIEL: Cabra

DIMENSIONES DE CADA PIEZA: Variables LADO: Carne

METAL: Cobre

DIMENSIONES DE CADA PIEZA: Variables

SECUENCIA: Transferencia/punta seca/grabado del soporte OBSERVACIONES: Esta serie de trabajos compuesta por 20 piezas, de las que aquí mostramos tan sólo 3 ejemplos, se aleja de los presupuestos visuales de otros ejemplos propuestos, con una organización que nada tiene que ver con retículas ortogonales. Se han incluido varios recursos: por un lado la conservación del borde irregular de las pieles en la zona inferior, y por otro el empleo del procedimiento del goteado de disolvente en la zona superior. Con ello se otorga una apariencia de mayor diversidad visual a la obra. 


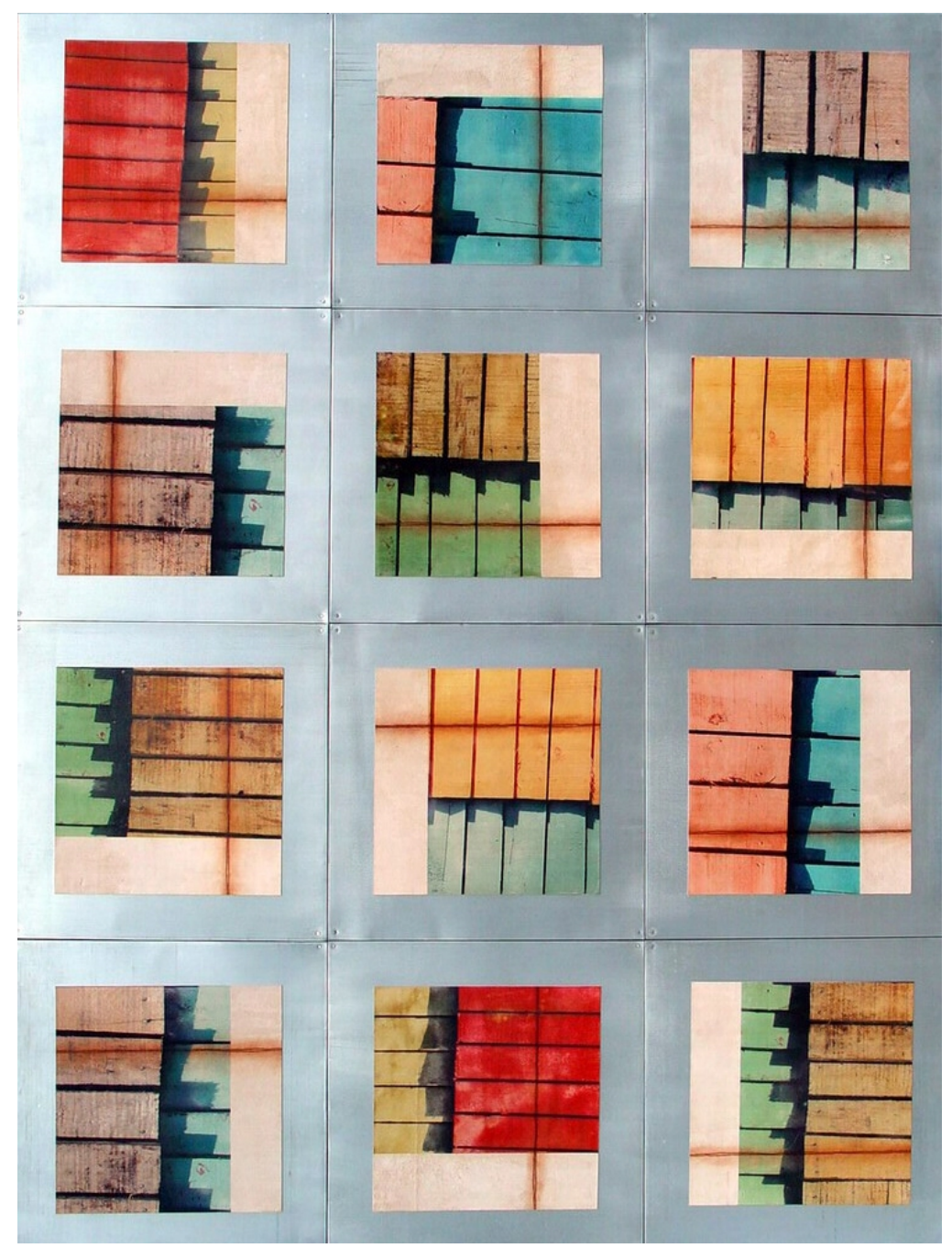

Fig. 172

TÍTULO: Estambul II

AÑO DE REALIZACIÓN: 2004

MEDIDAS: 140 x $105 \mathrm{~cm}$. 
PROCEDIMIENTOS TÉCNICOS: Transferencia y punta seca NÚMERO DE ELEMENTOS: 12

MATRIZ

NÚMERO DE PLANCHAS: 1 x 12

MATERIAL: Zinc

DIMENSIONES: 40 × $40 \mathrm{~cm}$.

\section{ENTINTADO}

NÚMERO DE TINTAS: 1

PROCEDIMIENTO: Entrapado

SOPORTE

PIEL: Cabra

DIMENSIONES DE CADA PIEZA: $25 \times 25 \mathrm{~cm}$. LADO: Carne

METAL: Zinc

DIMENSIONES DE CADA PIEZA: $35 \times 35 \mathrm{~cm}$.

SECUENCIA: Transferencia/punta seca

OBSERVACIONES: En este caso en lugar de proceder a la resolución de la pieza a partir de una única fotografía modificada digitalmente, se incluyen transferencias provenientes de diversas imágenes, logrando una mayor variedad cromática al ofrecer zonas de colores muy diversos sobre el zinc. No presenta ningún tipo de intervención sobre el metal, con la excepción de los clavos que sirven como soporte. 
V. Propuesta plástica personal 
V. Propuesta plástica personal

\section{V.4.4. Estezado}



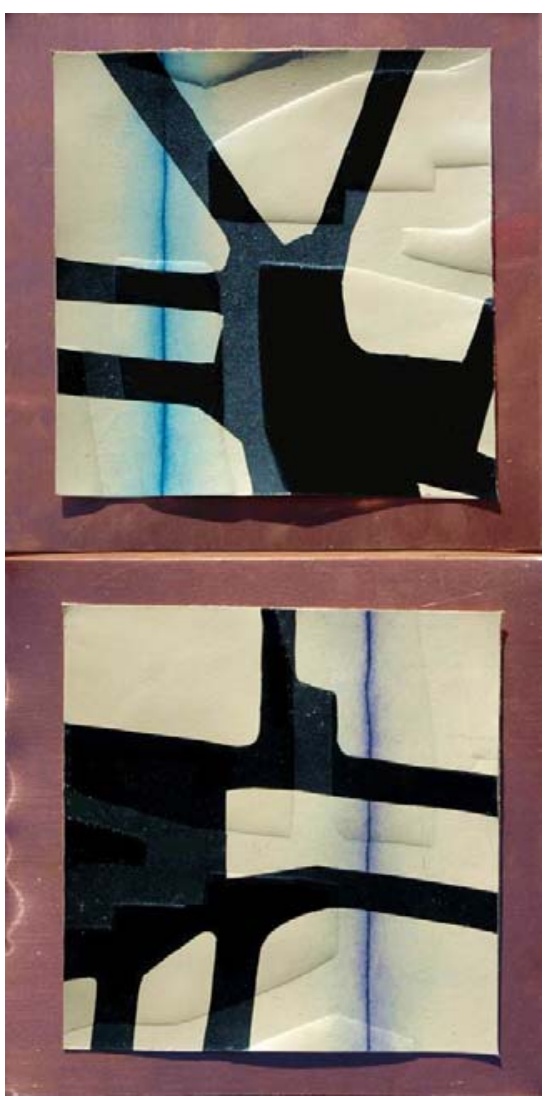

Fig. 173

TÍTULO: Callejero X

AÑO DE REALIZACIÓN: 2006

MEDIDAS: $50 \times 25 \mathrm{~cm}$ 
PROCEDIMIENTOS TÉCNICOS: Xilografía, punta seca y gofrado NÚMERO DE ELEMENTOS: 2

MATRIZ

NÚMERO DE PLANCHAS: 4

MATERIAL: Zinc (1) y DM (3)

DIMENSIONES: 20 × $20 \mathrm{~cm}$. (zinc) y 20 × $20 \mathrm{~cm}$. (DM)

ENTINTADO

NÚMERO DE TINTAS: 3

PROCEDIMIENTO: Entrapado y rodillo

SOPORTE

PIEL: Cabra

DIMENSIONES DE CADA PIEZA: 20 × $20 \mathrm{~cm}$. LADO: Flor

METAL: Cobre

DIMENSIONES DE CADA PIEZA: 25 × $25 \mathrm{~cm}$.

SECUENCIA: Punta seca/xilografía/estezado

OBSERVACIONES: Sobre dos cueros estampados con diferentes planchas xilográficas se ha realizado un estezado mediante la misma matriz en relieve. El cuero de cabra, pese a no poseer la flexibilidad del ovino, refleja perfectamente las diferencias de relieve producidas por el estezado, apareciendo una ausencia de brillo en las zonas cubiertas de tinta xilográfica que han estado en contacto directo con la presión vertical. 


\section{ANÁLISIS:}

Al emplear el procedimiento del estezado dentro de una propuesta plástica personal, se combina con otras técnicas utilizadas a lo largo de esta experimentación práctica, en concreto aquellas que configuran la serie denominada Callejero, esto es, la xilografía y la calcografía. En el caso analizado, la pieza se compone de dos elementos, cada uno de ellos resuelto gracias a la unión de la punta seca y la estampación en relieve, esta última con tinta negra, a los cuales se les ha incorporado un estezado con una tercera matriz en relieve. Esta plancha del estezado trata de servir como vínculo visual entre dos elementos formalmente dispares si exceptuamos la línea vertical de punta seca que se repite en ambas pieles. Así, el estezado se repite en los dos elementos, aunque girando $180^{\circ}$ su orientación para evitar una apariencia excesivamente uniforme y homogénea que empobreciera la pieza.

Sin embargo, el papel del estezado no se reduce a este propósito de unificación visual de las dos partes en las que se divide la pieza, sino que funciona en una dirección totalmente opuesta y dota de una riqueza plástica inusitada a la obra; en las zonas de cuero estampadas xilográficamente y que a su vez han recibido la acción de la presión, el intenso brillo de la película de tinta negra desaparece por completo. 200 Se crean de tal modo unas zonas de negro mate que contrastan de manera extraordinaria con las áreas de negro

\footnotetext{
${ }^{200}$ Motivado por el satinado de la piel de cabra en su lado flor.
} 
acharolado en las cuales no se ha ejercido la presión directa de la plancha en relieve, tal y como puede apreciarse en la fig. 174 .

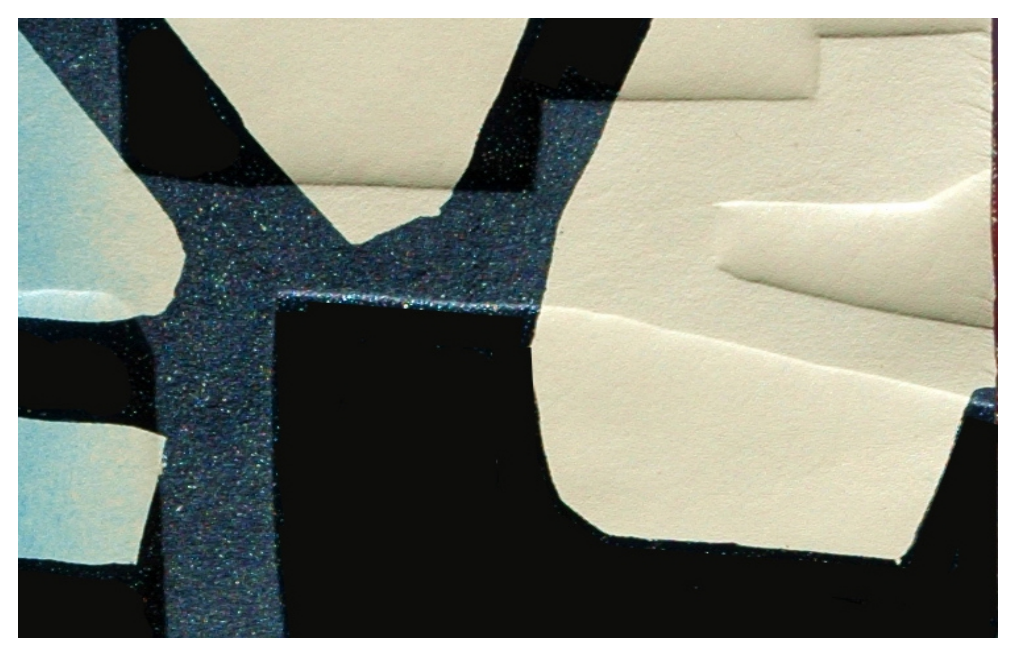

Fig.174: Detalle de la fig. 173 dónde se aprecia la diferencia de brillo.

Así, el estezado cumple dos papeles de gran importancia en la configuración plástica de la pieza, dado que no sólo unifica ambas partes de la misma, sino que provoca la aparición de un tipo de contraste que no se había manifestado en ninguno de los otros ejemplos propuestos dentro de este apartado, haciendo que la obra gane en riqueza visual de una manera más que visible. 


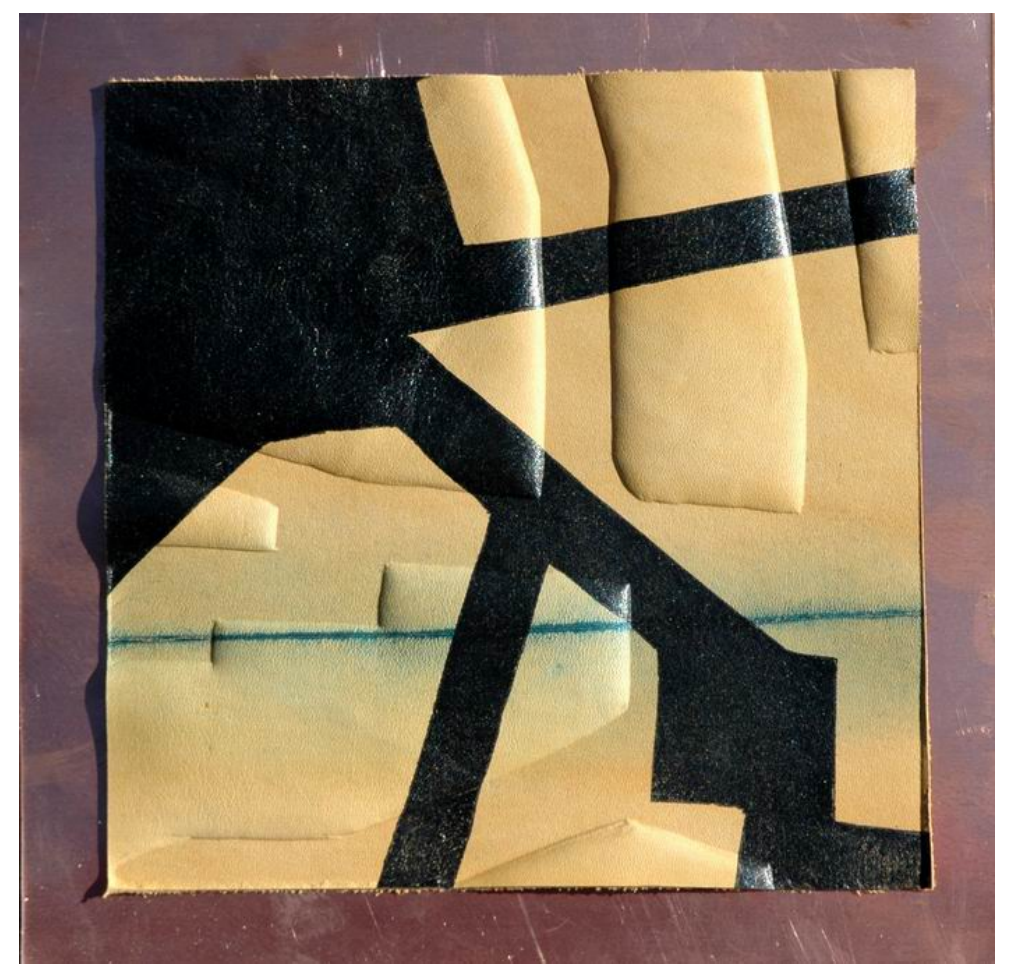

Fig. 175

TÍTULO: Callejero XI

AÑO DE REALIZACIÓN: 2006

MEDIDAS: $25 \times 25 \mathrm{~cm}$ 
PROCEDIMIENTOS TÉCNICOS: Xilografía, punta seca y gofrado NÚMERO DE ELEMENTOS: 1

MATRIZ

NÚMERO DE PLANCHAS: 3

MATERIAL: Zinc (1) y DM (2)

DIMENSIONES: $20 \times 20 \mathrm{~cm}$. (zinc) y $20 \times 20 \mathrm{~cm}$. (DM) ENTINTADO

NÚMERO DE TINTAS: 2

PROCEDIMIENTO: Entrapado y rodillo

SOPORTE

PIEL: Cordero

DIMENSIONES DE CADA PIEZA: $20 \times 20 \mathrm{~cm}$. LADO: Flor

METAL: Cobre

DIMENSIONES DE CADA PIEZA: $25 \times 25 \mathrm{~cm}$.

SECUENCIA: Punta seca/xilografía/estezado

OBSERVACIONES: La piel de cordero se muestra perfecta para lograr un marcado relieve en todas las zonas del cuero, tanto aquellas donde se deposita la tinta, como en las libres de esta última. La ausencia de brillo en las áreas que han recibido la presión no es tan acusada como en otros ejemplos, por lo que la pieza ofrece un resultado más homogéneo y regular. 


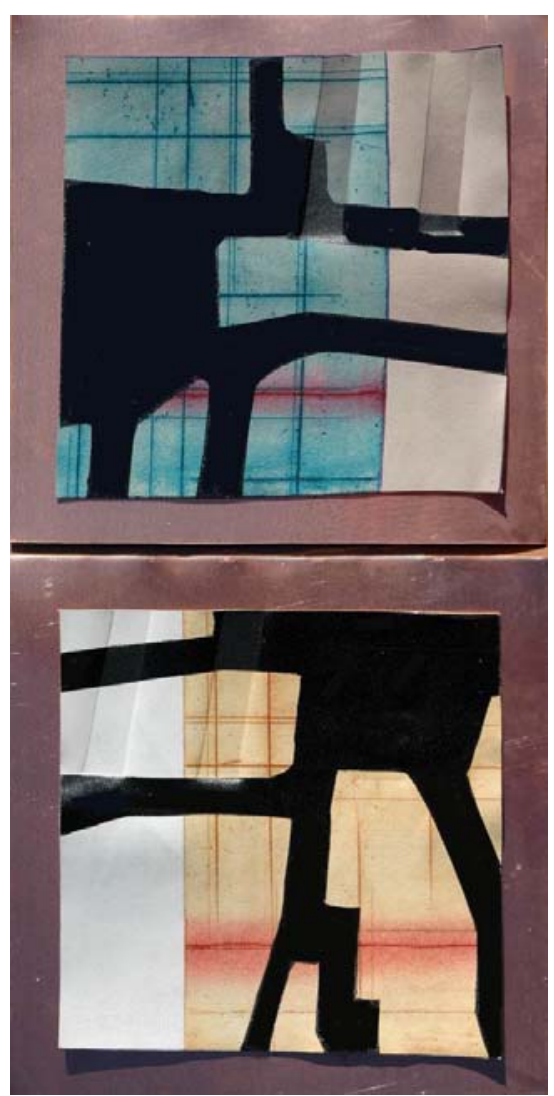

Fig. 176

TÍTULO: Callejero XII

AÑO DE REALIZACIÓN: 2006

MEDIDAS: $50 \times 25 \mathrm{~cm}$ 
PROCEDIMIENTOS TÉCNICOS: Xilografía, punta seca, calcografía y gofrado

NÚMERO DE ELEMENTOS: 2

MATRIZ

NÚMERO DE PLANCHAS: 5

MATERIAL: Zinc (2) y DM (3)

DIMENSIONES: 20 × $20 \mathrm{~cm}$. (zinc) y $20 \times 20 \mathrm{~cm}$. (DM)

ENTINTADO

NÚMERO DE TINTAS: 5

PROCEDIMIENTO: Entrapado y rodillo

SOPORTE

PIEL: Cabra

DIMENSIONES DE CADA PIEZA: $20 \times 20 \mathrm{~cm}$. LADO: Flor

METAL: Cobre

DIMENSIONES DE CADA PIEZA: $25 \times 25 \mathrm{~cm}$.

SECUENCIA: Calcografía/punta seca/xilografía/estezado

OBSERVACIONES: En este caso, en lugar de emplear una plancha de estezado del mismo tamaño que la porción de piel, el relieve se concentra tan sólo en una pequeña zona de la obra, por lo que su papel, desde un punto de vista plástico, es menos preponderante que en ejemplos anteriores. La presión ha eliminado algo de brillo en las áreas sobre las que ha actuado, creándose diferentes acabados en la superficie de la tinta xilográfica que dotan de variedad visual a la pieza. 
V. Propuesta plástica personal

434 


\section{CONCLUSIONES}

La presente tesis ha satisfecho los objetivos propuestos en la introducción, pero no debe ser entendida como el final de un camino 0 un callejón sin salida, sino como el inicio de un trayecto susceptible de ser continuado por sucesivos investigadores. Se trata por tanto, de una tesis abierta que plantea una serie de campos de estudio para futuras búsquedas, ya sea desde un punto de vista científico como artístico. Es evidente la existencia de estudios que adoptan un enfoque meramente técnico en lo que al cuero se refiere, analizando en profundidad los procesos de curtido o las diferentes alternativas fisicoquímicas que el tratamiento de las pieles ofrece, pero queda todavía mucho por explorar en lo que se refiere a la interacción de esas mismas pieles y los productos intrínsecamente relacionados con el campo de la creación plástica. 
Las posibilidades de profundización no se restringen a este ámbito concreto, sino que dentro del propio campo de la investigación artística, todavía son muchas las puertas por franquear, tanto en lo que respecta al mundo de la estampa como al de otros procedimientos pictóricos, dibujísticos o escultóricos. La litografía, la serigrafía y otros procesos relacionados con el grabado y la estampación no han sido abordados en esta investigación, lo que deja numerosas opciones abiertas para ampliar el conocimiento del soporte que nos ocupa y su vinculación con dichas técnicas. Por su lado, las posibilidades que el cuero ofrece en relación con el resto de procedimientos artísticos son prácticamente innumerables, convirtiéndose en una más que interesante opción para próximos investigadores.

Pese a lo comentado, nuestra tesis ha ofrecido una serie de conclusiones que colman los objetivos indicados al comienzo de la misma, dado que hemos demostrado sobradamente la validez del cuero como soporte para la práctica artística gracias al conocimiento exhaustivo de sus cualidades y su naturaleza, validez que ha sido puesta de manifiesto tanto durante la experimentación metódica como en su aplicación creativa en la obra personal.

El bloque teórico que abre la tesis ha servido para conocer, en un grado suficiente, la naturaleza específica del material, ofreciendo unas pautas de actuación sin las cuales el trabajo práctico sobre el cuero hubiera sido mucho más dificultoso, cuando no imposible. Dentro 
de este mismo bloque, hemos de destacar la importancia del estudio de las diferentes manifestaciones artísticas que han utilizado la piel animal como soporte a lo largo de la historia del Arte. La distinción entre Arte en piel y sobre piel ha permitido enfocar nuestra definitiva propuesta plástica personal a la consecución de unas obras que combinaran ambos factores diferenciadores; unas obras que tuvieran los cueros como soportes, pero en las que, al mismo tiempo, estos cueros adoptaran un rol protagonista en la configuración de las piezas. Pese a que ninguna de las muestras seleccionadas coincidía exactamente con los presupuestos de la que sería nuestra propuesta plástica, su análisis y estudio se ha presentado como fundamental para comprender la amplitud de procedimientos que el cuero es capaz de aceptar, mostrándonos la flexibilidad del material y permitiéndonos abordar la segunda fase práctica con un mayor bagaje teórico.

Los objetivos prácticos relacionados con la respuesta del cuero a las distintas técnicas propuestas han quedado sobradamente satisfechos. En todos y cada uno de los procedimientos analizados, el trabajo de taller ha permitido la consecución de un acervo de datos y conclusiones que permiten afrontar la estampación sobre piel animal con muchas garantías de éxito. Tanto en lo que se refiere a la xilografía y la calcografía, de indudable peso específico dentro de la investigación como corresponde a su importancia en lo que al mundo de la estampa se refiere, como en lo relacionado con las técnicas alternativas seleccionadas, creemos haber alcanzado un grado de conocimiento suficiente. En cada procedimiento concreto se ha 
propuesto un modelo de piel ideal para la consecución de un resultado satisfactorio, por lo que, ajustándose a dicho patrón, las posibilidades de conseguir una estampación positiva son muy altas. Por lo que se refiere al trabajo xilográfico y calcográfico con las distintas tintas seleccionadas, los resultados han satisfecho nuestras expectativas si exceptuamos las estampas realizadas con la tinta blanca, la cual ha presentado, como ya hemos reseñado en los apartados correspondientes, numerosos inconvenientes. Sin embargo, creemos que la raíz última de estos problemas no se encuentra tanto en la naturaleza del soporte como en las especiales características de dicha tinta, dado que los inconvenientes también pueden surgir al estampar sobre papel. Las conclusiones aportadas en los capítulos y apartados correspondientes pueden ser, por tanto, de gran utilidad para un hipotético grabador interesado en emplear los cueros como soporte para su trabajo artístico, confiando en que pueda encontrar en ellas respuesta a las dudas que pudieran surgir durante el proceso de estampación. Para disipar dichas dudas creemos que puede ser a su vez de gran provecho la consulta del material aportado en el apéndice documental que completa la presente tesis, material que se encuentra dividido y organizado de manera tal que pueda satisfacer la necesidad de conocer la respuesta de un cuero determinado a un procedimiento concreto. Con ambas herramientas, las reflexiones parciales a cada técnica y las fichas de trabajo de todas ellas, estimamos haber sido capaces de satisfacer las necesidades básicas de un posible grabador que desee adentrarse en la estampación sobre cuero utilizando las técnicas seleccionadas, teniendo siempre presentes las numerosas 
posibilidades de ampliación y profundización que nuestra tesis deja abiertas a futuros investigadores.

Por último hemos de referirnos al empleo de los cueros en la configuración de una propuesta plástica personal, en cuyo caso las conclusiones no pueden ser más que muy positivas. En todas las combinaciones procedimentales analizadas, el cuero se ha comportado como un actor relevante dentro de la conformación de las distintas series de piezas, alcanzando un protagonismo plástico y visual determinante en la percepción de los trabajos. Desde el punto de vista técnico no ha ofrecido ningún inconveniente y ha permitido realizar las piezas de manera fluida y natural, pero es desde un enfoque puramente plástico cuando el cuero se ha presentado como una opción más que interesante como sustituto del tradicional papel. La calidez de su textura y las posibilidades de contraste visual con los metales que dicha cualidad ofrece; su carácter orgánico, el cual le confiere toda una serie de significados asociados; la opción de presentarlo sin protección superficial gracias a su mayor durabilidad y resistencia; los interesantes cambios cromáticos provocados en la naturaleza de las tintas estampadas sobre él; sus bordes irregulares, susceptibles de ser introducidos en las obras como un factor estético más; o la posibilidad de combinar en la misma pieza diferentes porciones de cuero con el fin de que sus características propias dialoguen y se complemente, son factores a nuestro juicio más que suficientes para mostrarnos satisfechos con el resultado del empleo de la piel animal en la configuración de nuestra propuesta plástica. 
Durante el devenir histórico, los cueros han gozado de periodos de esplendor como materiales empleados en los más diversos campos, esplendor que ha sido siempre sustituido por el ostracismo y olvido en el que actualmente se encuentran en muchos de esos ámbitos, siendo reemplazados por otros materiales más modernos o económicos. Sin embargo, dentro del mundo del grabado y la estampación, los cueros nunca han disfrutado de un papel preponderante como soportes pese a los resultados más que positivos que hemos reflejado en nuestra investigación. ¿A qué ha sido debida esta omisión, esta indiferencia ante sus posibilidades plásticas, este desuso evidente, este desprecio por sus cualidades expresivas? ¿Tan sólo a factores económicos o de facilidad de aprovisionamiento y suministro del material, obviamente más difícil de conseguir que el tradicional papel? No nos corresponde en este momento analizar las causas de este fenómeno, pero nos vemos en la obligación de intentar una modesta reivindicación de las posibilidades técnicas, plásticas, artísticas y expresivas de los cueros como soportes para la estampa.

Tanto con la catalogación exhaustiva realizada, como con la propuesta personal presentada, creemos haber demostrado la viabilidad del empleo de este tipo de soportes en combinación con diversas técnicas y procedimientos, pero a nuestro juicio, su atractivo no reside tan sólo en estas cuestiones, sino que se imbrica directamente con todo un rosario de significados conceptuales que indefectiblemente asociamos al cuero. 
Elemento orgánico por su origen, atávico en ocasiones, considerado arcaico en un tiempo donde dominan los materiales industriales, opuesto con su calidez intrínseca a la frialdad de muchos de los objetos que nos rodean, el uso del cuero dentro de una producción plástica aporta toda una serie de consideraciones que escapan a la mera materia, a la simple forma. Es justamente en la posibilidad de provocar un diálogo visual y conceptual entre la naturaleza orgánica del soporte y la idiosincrasia de los nuevos procedimientos técnicos, donde entendemos que reside una vía de aprovechamiento de las pieles animales como parte constituyente de una obra plástica personal coherente. Es precisamente en el contraste entre esas connotaciones asociadas al cuero y las nuevas tecnologías contemporáneas aplicadas al mundo de la estampa, dónde creemos que se encuentran las mayores potencialidades expresivas de este material. Material para el cual reivindicamos un lugar de igualdad junto a otros soportes tradicionales del grabado, sin olvidar sus limitaciones e inconvenientes, pero haciendo hincapié en sus múltiples ventajas técnicas, sus interesantes virtudes plásticas y las posibilidades conceptuales y estéticas que puede aportar a quién desee zambullirse en el apasionante mundo del empleo del cuero como soporte para sus estampas. 


\section{REFERENCIAS BIBLIOGRÁFICAS}

AGUILÓ ALONSO, M. P. (1987), Cordobanes y guadamecíes. En: A. Bonet Correa, coor., Historia de las artes aplicadas en España, Ediciones Cátedra, p. 325-336.

AGUILÓ ALONSO, M. P. (1993), Colección Colomer Munmany. Cordobanes y guadamecíes artísticos, Antiquaria, 44-28.

AGUILÓ ALONSO, M. P. (1998), Cordobanes y guadamecíes. En: A. Colomer Munmany et al., El Arte en la piel. Catálogo de la exposición celebrada en Madrid, Fundación Central Hispano, 8 octubre - 30 noviembre 1998, Madrid, Museo de l'Art de la Pell - Fundación Central Hispano, p. 17-31. 
AINSWORTH, M. W. (1994), Petrus Christus. Renaissance master of Bruges, New York, Metropolitan Museum.

ALBI, J. (1979a), La huella de los Hernandos en el arte de Vicente Macip y de Joan de Joanes, Archivo de Arte Valenciano, 50, 17-32.

ALBI, J. (1979b), Juan de Juanes y su círculo artístico, Valencia.

ALCALÁ MELLADO, J.R. (1989), El procedimiento electrográfico digital: una alternativa a los procedimientos mecánicos y tradicionales de generación, reproducción y estampación de imágenes con fines artísticos, Valencia, Universidad Politécnica de Valencia.

ALEXANDER, J. C. (1992), Medieval illuminators and their methods of work, Yale, Yale University Press.

ALVARO ZAMORA, M. I. (2003), Las artes decorativas mudéjares. En: Valencia/2003, Els vestits del saber. Enquadernacions mudéjars a la Universitat de València, Valencia, La Nau, Universitar de València, marzo-junio 2003, Vicerrectorado de Cultura-Universitat de València, p. 174-184.

ARTE (1969), Arte flamenco y holandés, Milán, Grolier. 
ASUNCIÓN PASTOR, J. (2001), El papel, Barcelona, Parramón ediciones.

BARCELONA/1992, L'Art en la Pell: Cordovans i guadamassils de la colecció Colomer Munmany, Barcelona, Generalitat de Catalunya.

BARRUCAND, M.; BEDNORZ, A. (1992), Arquitectura islámica en Andalucía, Colonia, Editorial Taschen.

BENESCH, O. (1966), La pintura alemana, de Durero a Holbein, Barcelona, Editorial Skyra.

BERMEJO MARTÍN, J. B. coord. (1998), Enciclopedia de la encuadernación, Madrid, Ollero y Ramos Ediciones.

BERMÚDEZ LÓPEZ, J. (2001), La Alhambra. En: M. Hattstein; P. Delius ed., El Islam. Arte y arquitectura, Colonia, Konemann.

BERTI, L. (1967), Andrea del Castagno, Barcelona, Toray.

BLUNT, A. (1983), Arte y arquitectura en Francia: 1500-1700, Madrid, Ediciones Cátedra.

BOLOGNA, G. (1994), Manuscritos y miniaturas. El libro antes de Gutemberg, Madrid, Editorial Anaya. 
BONET CORREA, A. coord. (1987), Historia de las artes aplicadas e industriales en España, Madrid, Ediciones Cátedra.

CANO PÉREZ, V. (1987), Estructura y microestructura en la obra gráfica de Rembrandt y Piranesi. Análisis del grafismo como elemento individualizador de la expresión gráfica, Valencia, Universidad Politécnica de Valencia.

CARBONELL; CASANELLI ed. (2003), El mediterráneo y el arte: del Gótico al inicio del Renacimiento, Barcelona, Lunwerg.

CHATELET, A.; THUILLIER, J. (1994), La pintura francesa, de Fouquet a Poussin, Barcelona, Skyra.

CHECA CREMADES, F. (1983), Pintura y escultura del Renacimiento en España: 1450-1600, Madrid, Ediciones Cátedra.

DAHL, S. (1985), Historia del libro, Madrid, Alianza Editorial.

DE HAMEL, C. (1999), Copistas e iluminadores, Madrid, Akal.

DICCIONARIO (2000), Diccionario de uso del español Maria Moliner, Madrid, Editorial Gredos.

DOMÍNGUEZ BORDONA, J. (1962), "Miniatura", Ars Hispaniae, vol. XVIII, Madrid, Plus Ultra. 
ESTEVE BOTEY, F. (1993), Historia del grabado, Madrid, Editorial Labor.

FERRANDIS TORRES, J. (1955), Cordobanes y guadamecíes, Madrid, Sociedad española de amigos del arte.

FRANCASTEL, P. (1970), Historia de la pintura francesa, Madrid, Alianza Editorial.

GANZ, P. (1950), The paintings of Hans Holbein, London, The Phaidon Press.

GARCÍA DE CORTAZAR, J. A.; SESMA MUÑOZ, J. A. (2001), Historia de la Edad Media. Una síntesis interpretativa, Madrid, Alianza Editorial.

GIDEON, S. (1988), El presente eterno: Los comienzos de la arquitectura, Madrid, Alianza Editorial.

GOMEZ RAGGIO, F. (1996), El libro de la encuadernación, Madrid, Alianza Editorial.

GONZALO MAESO, D. (1979), La piel en el judaísmo, Vic, Colomer Munmany. 
GRABAR, O. (1988), La Alambra: iconografía, formas y valores, Madrid, Alianza Editorial.

GRACIA, C. (1998), Arte valenciano, Madrid, Ediciones Cátedra.

GUÍA (1980), Guía de minerales y rocas, Barcelona, Grijalbo.

HAAK, B. (1980), Rembrandt: dibujos, Barcelona, Gustavo Gili.

HAUSER, A. (2004), Historia social de la literatura y el arte, Barcelona, Mondadori.

HATTSTEIN; DELIUS ed. (2001), El Islam: arte y arquitectura, Colonia, Konemann.

HIDALGO OGAYAR, J. (1994), Catálogo de las miniaturas conservadas en el Museo Nacional de Artes Decorativas de Madrid, Alcalá de Henares, Universidad de Alcalá.

IMPELLUSO, L. (2002), Héroes y dioses de la Antigüedad, Barcelona, Electa.

KRAMER, C. (2000), Mil años de arte miniado, Madrid, Ars Milleni.

LACERCA, A. M. (1976), Curtición de cueros y pieles, Buenos Aires, Albatros. 
LAMBERT, S. (2001), Prints: art and techniques, London, V\&A

Publications.

LOGAN, A-M. (1988), Dutch and flemish drawings and watercolours.

The collection of the Detroit Institute of Arts, New York, Hudson Hills

Press.

LÓPEZ SERRANO, M. (1972), La encuadernación español, Madrid, ANABA.

LUNA, J. J. (1990), Pintura británica (1500-1820), Summa Artis, vol. XXXIII, Madrid, Espasa Calpe.

MADRID/1998, El Arte en la piel, Madrid, Fundación Central Hispano, 8 octubre-30 noviembre 1998, Madrid, Museo de l'Art de la PellFundación Central Hispano.

MADRID/2004, Maestros de la invención de la colección E. De

Rothschild del Museo del Louvre, enero-mayo 2004, Madrid, Fundación Juan March.

MADRID/2005, Durero. Obras maestras de la Albertina, 8 marzo-29 mayo 2005, Madrid, Museo Nacional del Prado. 
MADURELL MARIMÓN, J. M. (1973), El antiguo arte del guadameci, Vic, Colomer Munmany.

MANDIGORRA LLAVATA, M. L. (2003), ¿Juzgar un libro por sus cubiertas? Encuadernaciones del siglo XV. En: Valencia/2003, Els vestits del saber. Enquadernacions mudéjars a la Universitat de València, Valencia, La Nau, Universitar de València, marzo-junio 2003, Vicerrectorado de Cultura-Universitat de València, p. 185-192.

MENTRE, M. (1996), Iluminated manuscripts of medieval Spain, London, Thames and Hudson.

MIDDLETON, B. C. (2001), Restauración de encuadernaciones en piel, Madrid, Clan editorial.

MIGUELEZ, C. (1805), Arte de curtir o instrucción general de curtidos, Madrid, Imprenta Real.

MORRIS, C. (1999), Willem de Kooning, New York, The Wonderland Press.

NIETO ALCAIDE, V. (1987), Encuadernación. En: A. Bonet Correa coor., Historia de las artes aplicadas e industriales en España, Madrid, Ediciones Cátedra.

PACHT, O. (1987), La miniatura medieval, Madrid, Alianza Editorial. 
PANOFSKY, E. (1982), Vida y arte de Alberto Durero, Madrid, Alianza Editorial.

PANOFSKY, E. (1985), Renacimiento y renacimientos en el arte occidental, Madrid, Alianza Editorial.

PÉREZ-DOLZ, F.; GUTIÉRREZ MARÍN, M. (1943), Los estudios de plantas y animales de Alberto Durero, Barcelona, Editorial Orbis.

PIELES (1994), Pieles de ovino y caprino, Madrid, Ministerio de Agricultura, Pesca y Alimentación.

PIGNATTI, T. (1981), El dibujo: de Altamira a Picasso, Madrid, Ediciones Cátedra.

PIJOAN, J. (1977), El arte del Renacimiento en el Norte y Centro de Europa, Summa Artis, vol. XV, Madrid, Espasa Calpe.

QUÍMICA (1985), Química técnica de tenería, Barcelona, Igualada.

REMBRANDT (2000), Rembrandt the printmaker, London, British Museum Press.

REYNOLDS, G. (1988), Watercolours, a concise history, London, Thames and Hudson. 
RODRÍGUEZ LEÓN, A. (2003), La importancia de la imagen xilográfica y su fundamento visual en el libro de artista contemporáneo. Una aportación personal, Valencia, Universidad Politécnica de Valencia.

ROSENBERG, J. (1987), Rembrandt vida y obra, Madrid, Alianza Editorial.

SÁNCHEZ MARIANA, M. (1995), Introducción al libro manuscrito, Madrid, Arco Libros.

STRAUSS, W. L. ed. (1982), The ilustrated Barstch, vol. 3, New York, Abaris books.

TOMAN, R. ed., (1996), El románico, Colonia, Konemann.

TOMAN, R. ed., (1998), El gótico, Colonia, Konemann.

TOMAS, F. (1998), Escrito, pintado. (Dialéctica entre escritura e imágenes en la conformación del pensamiento europeo), Madrid, Visor.

TOUSSANT-SAMAT, M. (1994), Historia técnica y moral del vestido: las pieles, Madrid, Alianza Editorial. 
VALENCIA/1998, De lo divino a lo humano. Rembrandt en la Biblioteca Nacional, 4 agosto-27 septiembre 1998, Valencia, Museo de Bellas Artes de Valencia, Generalitat Valenciana.

VAN LUTTERVELT, R. (1967), Tesoros de la pintura en los museos de Holanda, Barcelona, Daimon.

VIVES, R. (1994), Del cobre al papel: la imagen multiplicada, Barcelona, Icaria Editorial.

VIVES CISCAR, J. (1881), Los guadamaciles valencianos, Valencia, Imprenta de Doménech.

VIVES PIQUE, R. (2003), Guía para la identificación de grabados, Madrid, Arco Libros.

V.V.A.A. Willem de Kooning: tracing the figure. Los Angeles: The Museum of Contemporary Art, 2002.

WATERHOUSE, E. (1993), Pintura en Gran Bretaña: 1530-1790, Madrid, Ediciones Cátedra.

WEINSTEIN, K. (1998), El arte de los manuscritos medievales, Barcelona, Tres Torres.

WEITZMANN, K. (1990), El rollo y el códice, Madrid, Editorial Nerea. 
WERNER GROHN, H. (1964), Hans Holbein, Buenos Aires, Codex.

WILLIAMS, J. (1987), La miniatura española en la Alta Edad Media, Madrid, Casariego.

YARZA, J. (1985), Arte y arquitectura en España: 500-1250, Madrid, Ediciones Cátedra.

ZANOLI, A. (1964), Andrea del Castagno, Buenos Aires, Codees. 




\section{"EL USO DE LA PIEL ANIMAL COMO SOPORTE PARA OBRA GRÁFICA ORIGINAL"}

(TOMO SEGUNDO)

Autor: Óscar Juan Martínez García Directora: Dra. Blanca Rosa Pastor Cubillo 



\section{FICHAS}

I.1. FICHAS XILOGRAFÍA

Cabra 6

Tinta negra 6

Tinta blanca 18

Tinta azul traslúcido $\quad 30$

Tinta azul opaco 42

Cerdo $\quad 54$

Tinta negra 54

Tinta blanca $\quad 66$

Tinta azul traslúcido $\quad 78$

Tinta azul opaco 90

Cordero 102

Tinta negra 102

Tinta blanca 114

Tinta azul traslúcido $\quad 126$

Tinta azul opaco 138

Vaca 150

Tinta negra 150

Tinta blanca 162

Tinta azul traslúcido $\quad 174$

Tinta azul opaco 186

I.2. FICHAS CALCOGRAFÍA 199

Cabra 200

Tinta negra 200

Tinta blanca 212

Tinta azul traslúcido 218

Tinta azul opaco 230

Cerdo 242

Tinta negra 242

Tinta blanca 254

Tinta azul traslúcido $\quad 260$

Tinta azul opaco 272

Cordero 284

Tinta negra 284

Tinta blanca 296 


$\begin{array}{lll} & \text { Tinta azul traslúcido } & 302 \\ \text { Vaca } & \text { Tinta azul opaco } & 314 \\ & & 326 \\ & \text { Tinta negra } & 326 \\ & \text { Tinta blanca } & 338 \\ & \text { Tinta azul traslúcido } & 344 \\ & \text { Tinta azul opaco } & 356\end{array}$

I.3. FICHAS PUNTA SECA 369

Cabra $\quad 370$

Cerdo 372

Cordero 374

Vaca 376

I.4. FICHAS ESTEZADO 379

Cabra $\quad 380$

Cerdo 381

Cordero $\quad 382$

Vaca 383

I.5. FICHAS TRANSFERENCIA 385

Cabra 386

Cerdo 388

Cordero 390

Vaca 392

\section{TABLAS ESTADÍSTICAS}

II.1. Estadísticas generales 397

II.2. Estadísticas intervención xilográfica 411

II.2. Estadísticas intervención calcográfica 425 


\section{FICHAS}



Apéndice documental. Fichas xilografía

\section{I.1. FICHAS XILOGRAFÍA}



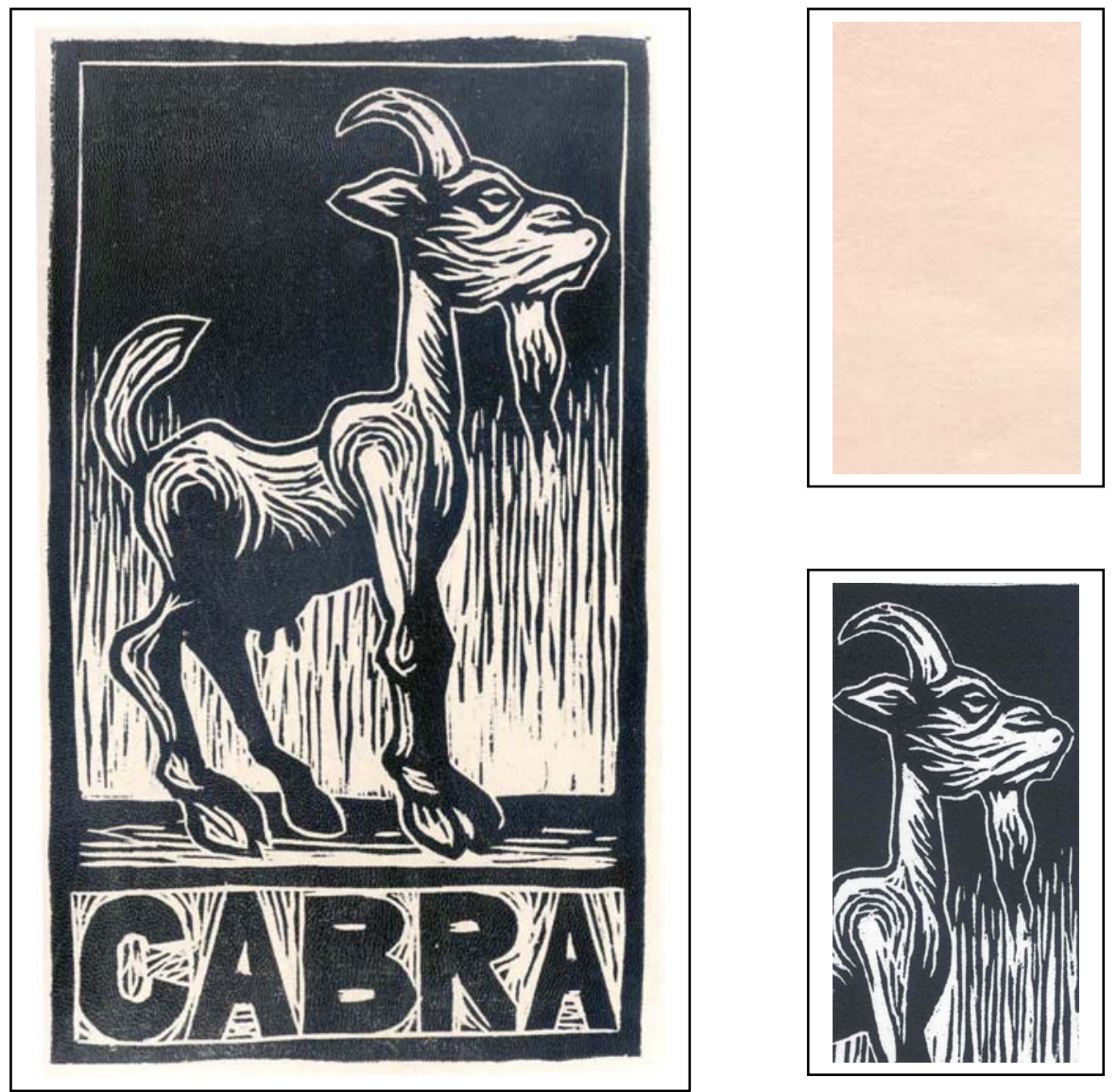

CÓDIGO: CA-001

TIPO DE PIEL: Cabra

TINTA: Negra
TÉCNICA: Xilografía

TONO DE PIEL: Claro

SUPERFICIE: Lado flor 


\section{CALIDAD: Muy buena}

Estampación en el lado flor con muy buena calidad del registro. Se debe estampar con la mínima presión posible ya que de lo contrario se producirán defectos notables. Al ser una piel con un acabado muy fino y bastante satinada, un pequeño exceso de presión hará que la tinta no asiente bien en la superficie de la piel y produzca manchas, estropeando la estampa.

MANCHA: Resultado perfecto ya que la textura propia de la piel es tan sutil que no afecta a la superficie entintada. A pesar de ello, en las zonas entintadas, la textura de la piel se pone de manifiesto haciéndose más visible, aunque sin llegar a perjudicar la correcta visión de la imagen.

GRAFISMO: Muy buena calidad siempre que estampemos con la presión justa. A más presión se producirán defectos muy visibles, sobre todo en los grafismos más delicados, los cuales pueden emborronarse e incluso perderse.

CONTRASTE: El negro resulta perfecto para este tono de piel, sin sufrir ningún cambio en su apariencia y cubriendo perfectamente las superficies escogidas. Por tanto el contraste es muy intenso y crea una imagen con gran potencia plástica.

BRILLO: El resultado es ligeramente satinado aunque no llega a molestar a la vista. El acabado tan satinado de la piel provoca la aparición de dicho brillo. 

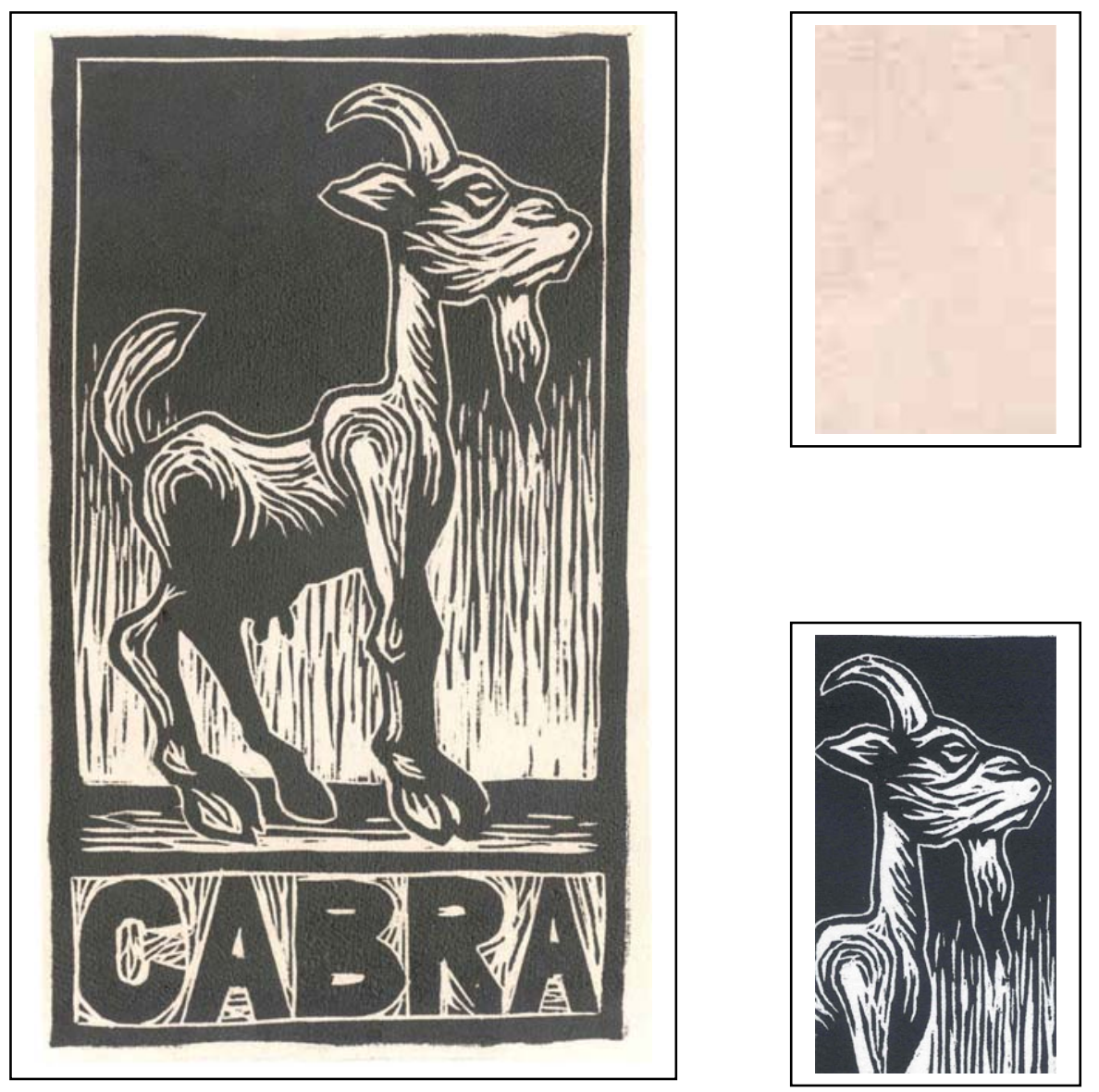

CÓDIGO: CA-002

TIPO DE PIEL: Cabra

TINTA: Negra
TÉCNICA: Xilografía

TONO DE PIEL: Claro

SUPERFICIE: Lado carne 


\section{CALIDAD: Muy buena}

Muy buen resultado de la estampa. Es posible estampar con un poco más de presión ya que en el lado carne las pieles nunca presentan un acabado tan satinado como en el lado flor. Debido a esto la piel admite una ligera presión extra sin que se produzcan los defectos observado en la otra cara.

MANCHA: El resultado es casi perfecto si se estampa con la presión justa. Si lo hacemos con menos presión aparecerán texturas provocadas por el afelpado de la piel.

GRAFISMO: También presenta un resultado muy satisfactorio sin los problemas advertidos por el lado flor. Todos los grafismos se registran de una manera excelente y sin apenas complicaciones.

CONTRASTE: Debido a que los tonos de ambas caras son casi idénticos la intensidad de contraste es prácticamente la misma que en el lado flor. Por tanto se obtiene una imagen perfectamente válida desde un punto de vista plástico y visual.

BRILLO: El acabado es totalmente mate debido a que el afelpado presente en la piel elimina cualquier atisbo de posibles brillos en la superficie, creándose una imagen de gran calidad. 

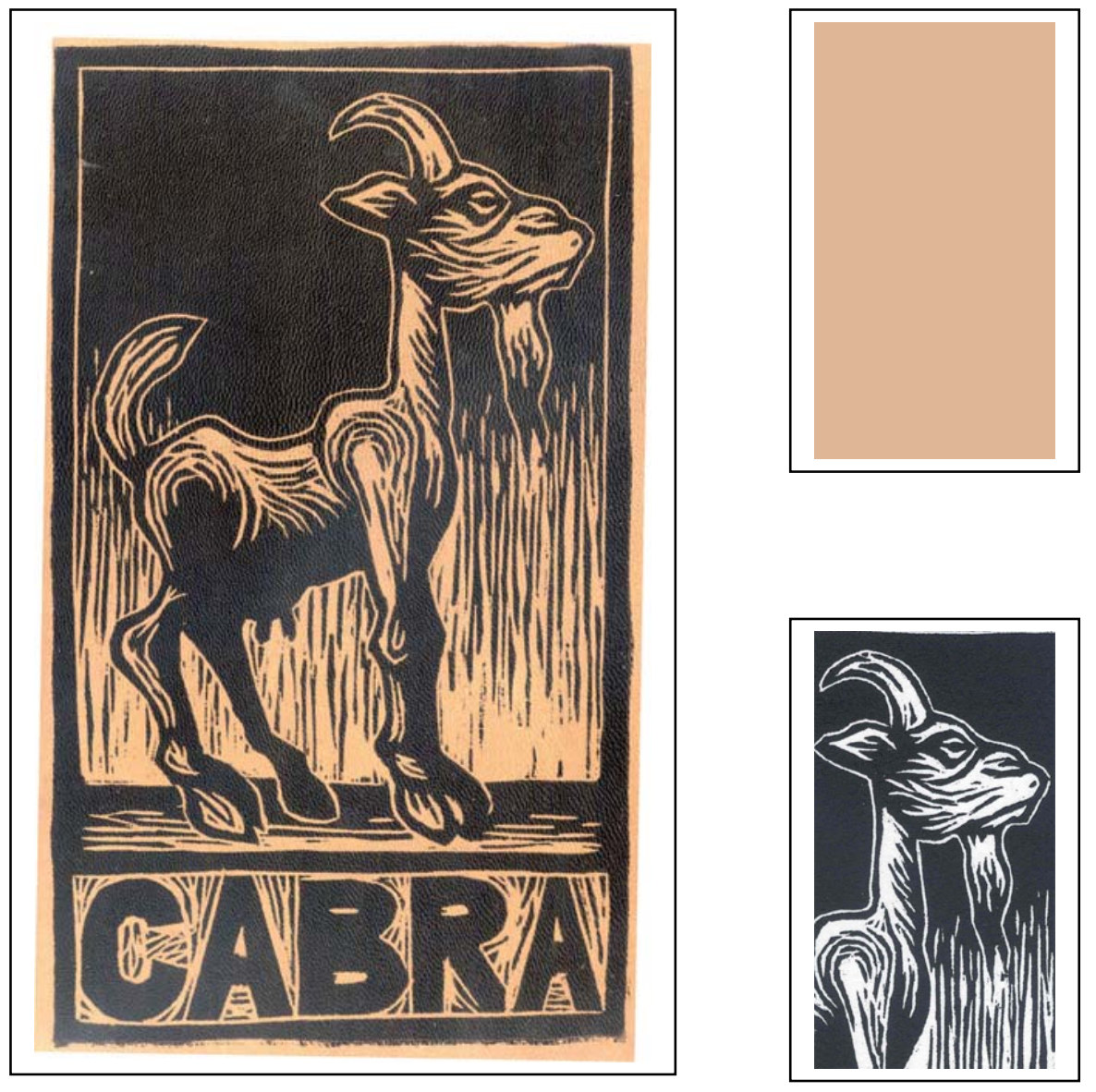

CÓDIGO: CA-003

TIPO DE PIEL: Cabra

TINTA: Negra
TÉCNICA: Xilografía

TONO DE PIEL: Medio

SUPERFICIE: Lado flor 


\section{CALIDAD: Buena}

Ejemplo de muy buen resultado, casi idéntico al obtenido sobre la piel clara (CA-001). La piel de cabra, con su textura tan delicada y sutil, registra perfectamente las imágenes xilográficas consiguiéndose estampas de gran calidad.

MANCHA: Perfecta. No existe ningún tipo de problema, obteniéndose una zona entintada densa y potente. La textura de la piel se hace más visible en las zonas donde se deposita la tinta.

GRAFISMO: Siempre que estampemos con la mínima presión necesaria los seños de los grafismos se registrarán sin ninguna dificultad ni problema. Si se produce un exceso de presión los contornos de los grafismos serán irregulares, estropeando la estampa.

CONTRASTE: Al usar un tono de piel algo más oscuro el nivel de contraste se ha reducido un tanto. A pesar de ello el contraste sigue siendo lo suficientemente intenso como para crear una imagen totalmente válida.

BRILLO: La estampa presenta un ligero acabado satinado en las zonas entintadas, el cual está provocado por la gran cantidad de tinte presente en la superficie de la piel. Esto hace que dicho cuero presente un acabado muy pulido y que la tinta, al extenderse sobre ella, cobre un cierto brillo. 

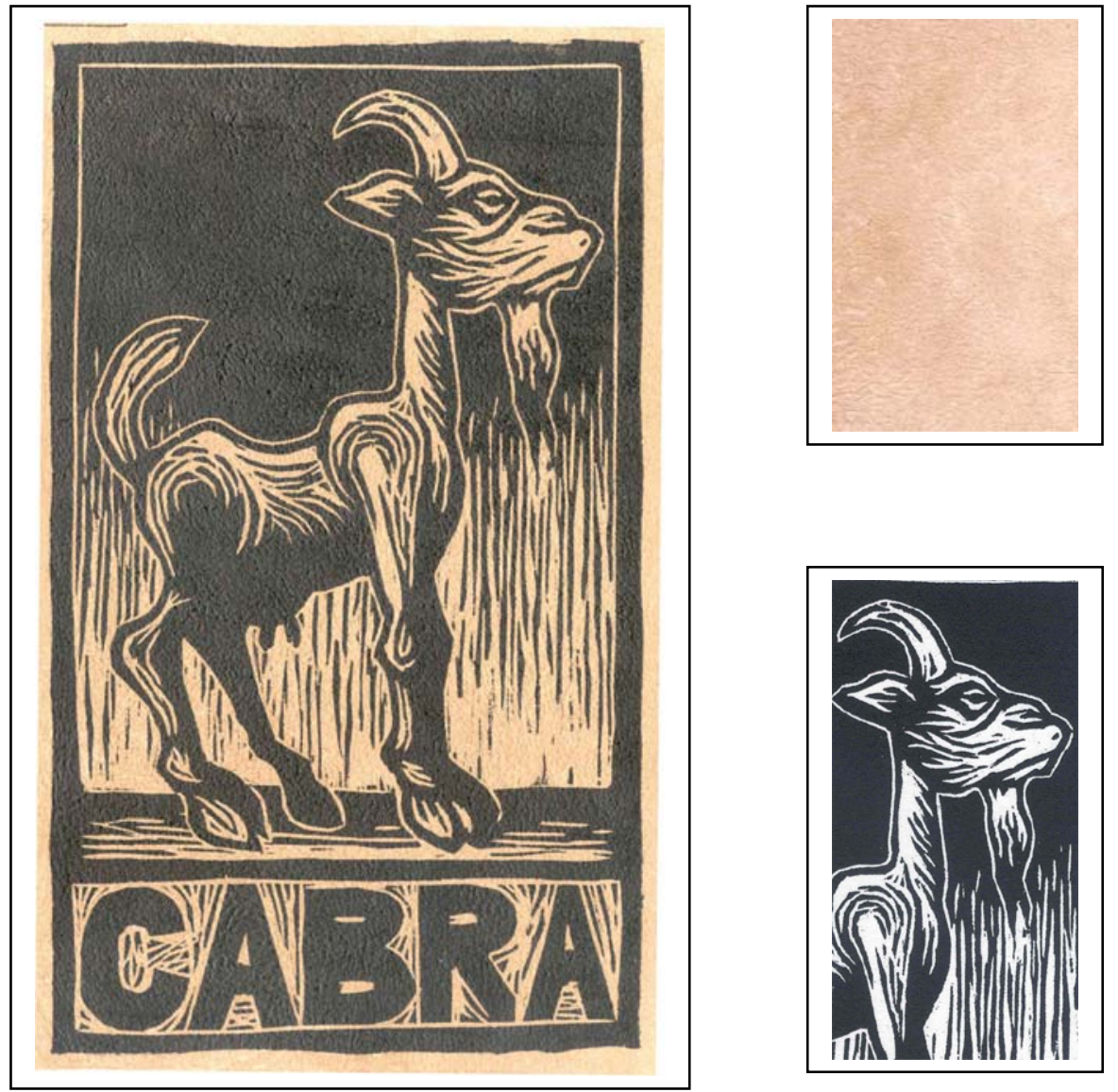

CÓDIGO: CA-004

TIPO DE PIEL: Cabra

TINTA: Negra
TÉCNICA: Xilografía

TONO DE PIEL: Medio

SUPERFICIE: Lado carne 


\section{CALIDAD: Muy buena}

Como ya hemos comentado el negro se muestra como una tinta ideal para casi todo tipo de estampas sobre piel, presentando mínimos inconvenientes y variaciones de un ejemplo a otro. Ofrece un acabado muy parecido al de su compañera sobre la piel clara. Igualmente podemos aplicar un pequeño exceso de presión sin que ello repercuta en el resultado final de la estampa.

MANCHA: De gran calidad, no presenta apenas inconvenientes importantes, extendiéndose la tinta por la superficie de la piel sin problemas aparentes.

GRAFISMO: Registro casi perfecto, sin apenas problemas. Los trazos mantienen sus contornos sin ser afectados por el ligero afelpado presente en la superficie de la piel en su lado carne.

CONTRASTE: El tono del lado carne es ligeramente más claro que el del lado flor, por lo que la intensidad del contraste será aún mayor.

BRILLO: No existe. En la cara envés el resultado es totalmente mate, sin rastro de brillos de ningún tipo, algo que se repetirá en casi todos los ejemplos realizados sobre estas superficies afelpadas. 

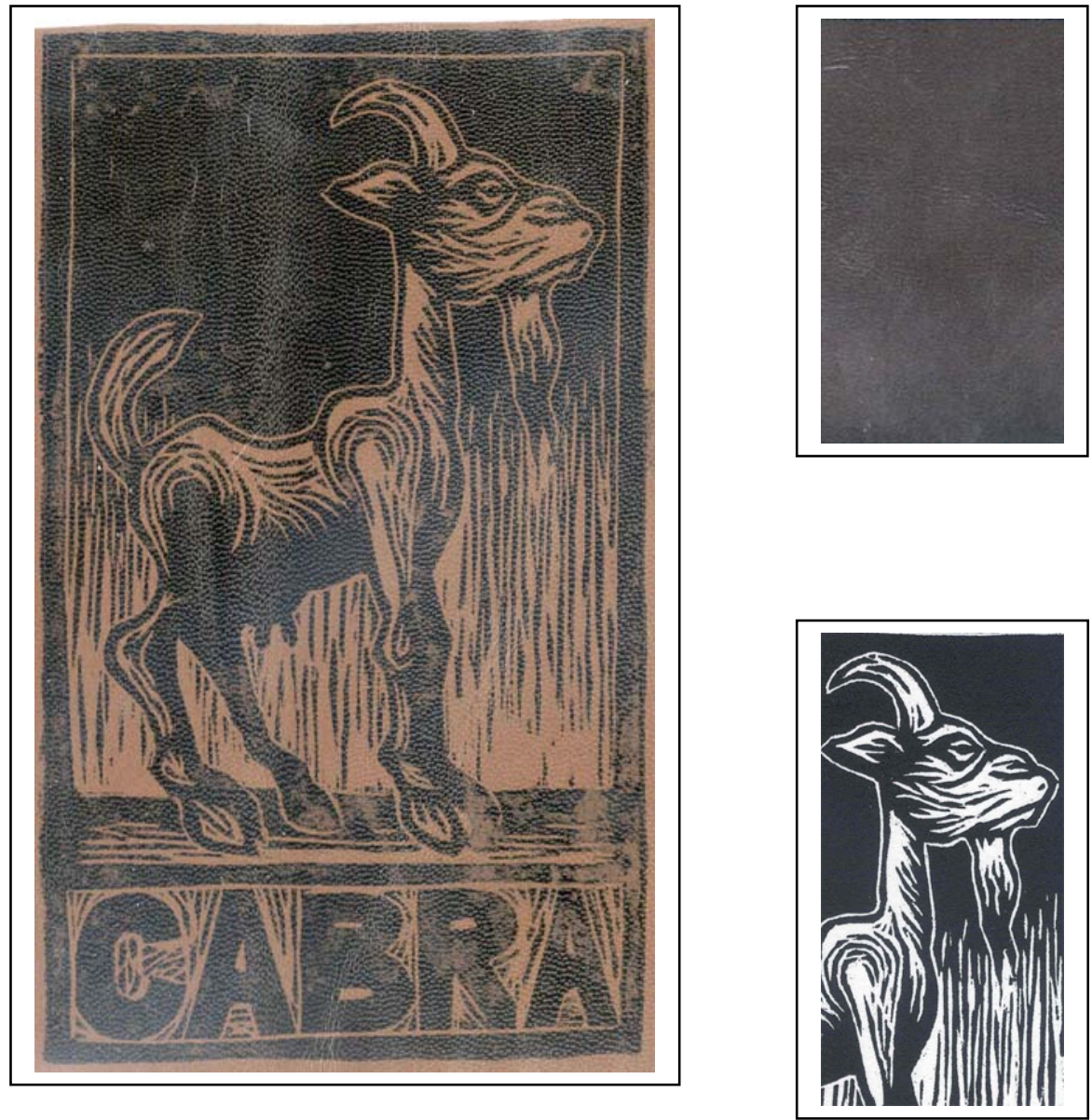

CÓDIGO: CA-005

TIPO DE PIEL: Cabra

TINTA: Negra
TÉCNICA: Xilografía

TONO DE PIEL: Oscuro

SUPERFICIE: Lado flor 


\section{CALIDAD: Mala}

Presenta serios inconvenientes ya que por efecto del excesivamente satinado acabado de la piel, la tinta no es capaz de asentar correctamente en algunas zonas, lo que provoca defectos muy visibles. A la hora del secado también ofrece problemas ya que debido a la pátina satinada presente en la piel la tinta tarda mucho tiempo en secar definitivamente.

MANCHA: Muy deficiente. La tinta negra pone en evidencia la textura de la piel en aquellas zonas en las cuales es capaz de asentar sobre el cuero, con los minúsculos agujeros agrupados en grupos de tres. Sin embargo en otras zonas presenta un aspecto muy irregular y deficiente.

GRAFISMO: Siempre que la presión sea la adecuada los trazos del grafismo se registrarán con normalidad, a no ser que la tinta no logre asentar sobre el cuero. Recordar que dicha presión debe ser la mínima posible ya que de lo contrario el trazo reventará y dificultará la obtención de una buena estampa.

CONTRASTE: La tinta negra adquiere una gran intensidad al contacto con la superficie satinada de la piel, lo que hace que el contraste sea bastante pronunciado, a pesar de lo oscuro del soporte.

BRILLO: La tinta no opera ningún cambio en la intensidad del brillo de la piel, el cual es ya lo suficientemente fuerte pudiendo llegar a ser incluso molesto. 

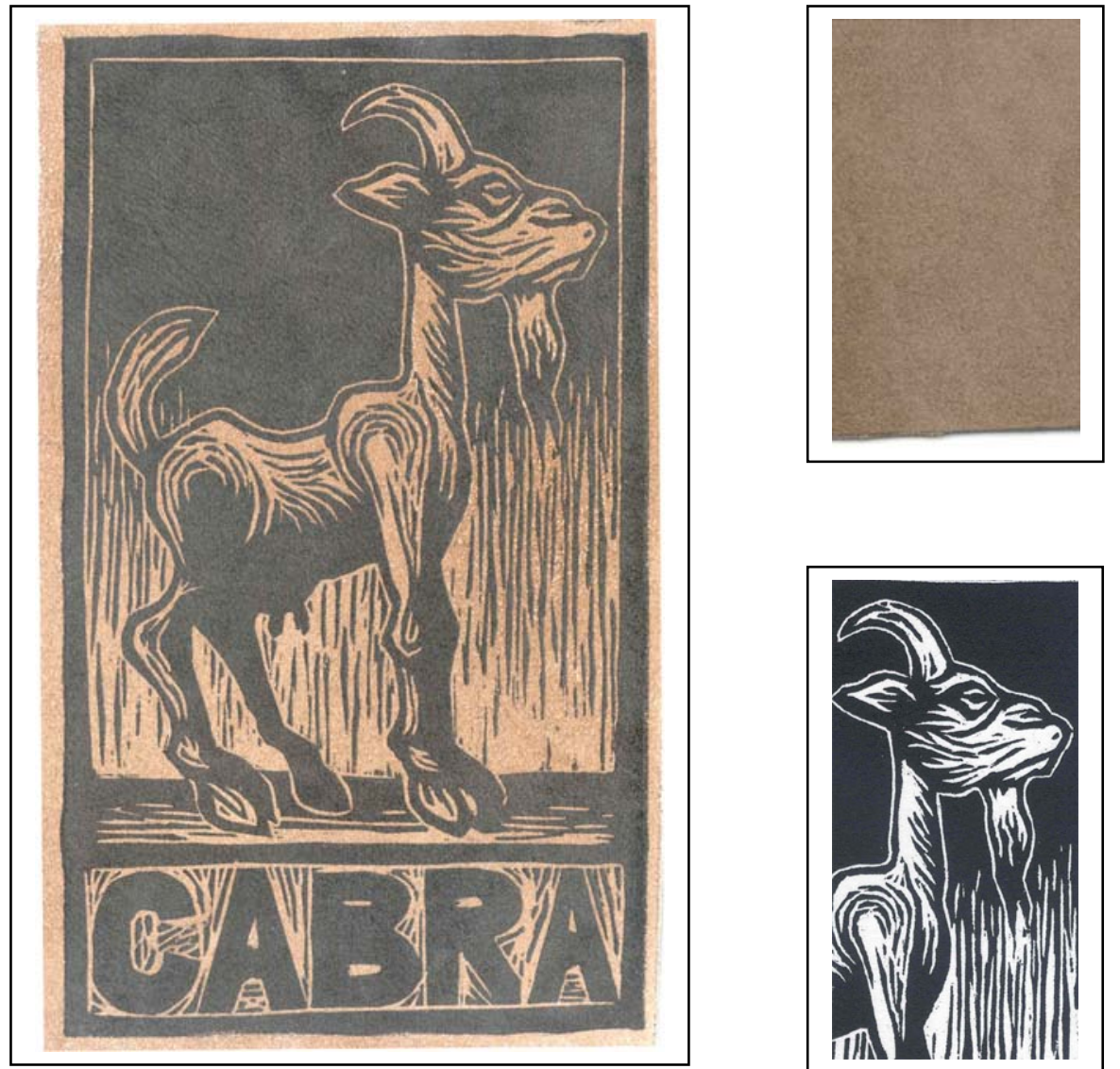

CÓDIGO: CA-006

TIPO DE PIEL: Cabra

TINTA: Negra
TÉCNICA: Xilografía

TONO DE PIEL: Oscuro

SUPERFICIE: Lado carne 


\section{CALIDAD: Buena}

Como ya hemos comentado el negro se muestra como una tinta ideal para casi todo tipo de estampas sobre piel, presentando mínimos inconvenientes y variaciones de un ejemplo a otro.

MANCHA: Homogénea y regular. Debido a la gran cantidad de tinta que recoge la piel y a la presión ejercida, en las zonas entintadas desaparece casi por completo el afelpado propio del lado carne.

GRAFISMO: Sin ningún tipo de problemas. Notar que en las estampas sobre el lado carne no es necesario cuidar tanto la presión del tórculo, ya que la piel admite algo más de intensidad de presión antes de llegar a deformar los trazos.

CONTRASTE: Adecuado y suficiente para conseguir una imagen reconocible y válida, ya que el tono de este lado es algo más claro que el del lado flor.

BRILLO: La tinta pierde todo tipo de brillos al contacto con el acabado afelpado de lado carne. Por tanto la imagen carece de los mismos, pero por otro lado la tinta también pierde parte de su intensidad y se obtienen una imagen un tanto apagada y anodina, sin la fuerza plástica de otros ejemplos. 

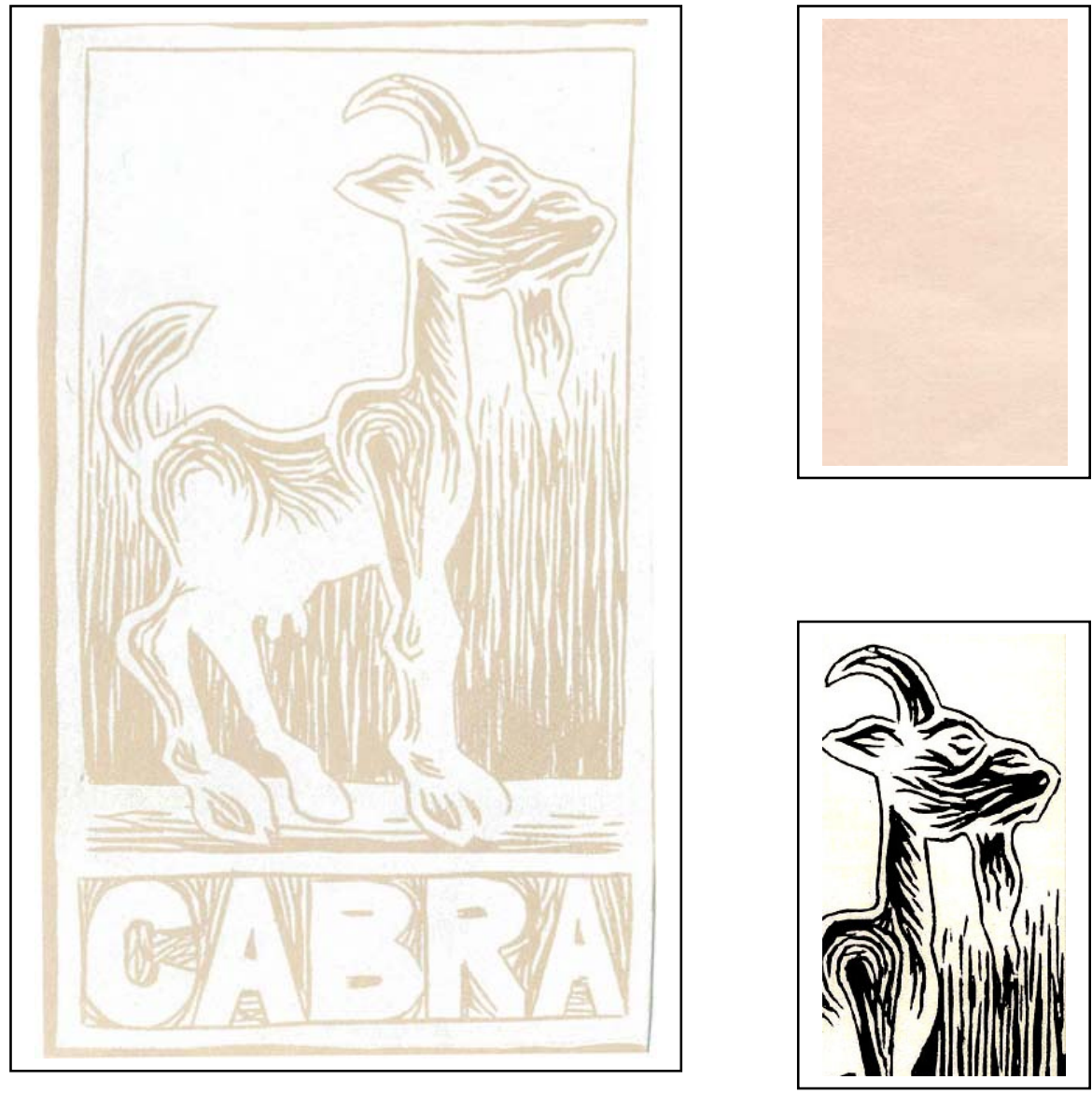

CÓDIGO: CA-007

TÉCNICA: Xilografía

TIPO DE PIEL: Cabra

TONO DE PIEL: Claro

TINTA: Blanca

SUPERFICIE: Lado flor 


\section{CALIDAD: Mediocre}

Las estampaciones en blanco presentan variantes importantes con respecto a las realizadas en negro. A pesar de usar un blanco cubriente, la tinta no llega a tapar ni a cubrir por completo las imperfecciones o la propia textura de la piel.

MANCHA: Resultado bastante aceptable, aunque nunca con la calidad del estampado con tinta negra en ejemplos anteriores como los de las estampas CA-001 o CA-003. Resulta muy complicado conseguir un blanco verdadero que cubra por completo la piel.

GRAFISMO: La calidad de los trazos es muy buena. Se disimulan los defectos que pudieran aparecer en la zona de la mancha, ya que debido a la menor extensión de piel entintada estos problemas son más difíciles de apreciar.

CONTRASTE: El contraste es muy escaso debido al tono tan claro de la piel, así como a que no se consigue un blanco potente. Aún así el resultado es fácilmente legible.

BRILLO: La tinta blanca apenas produce brillos, tan sólo un ligero acabado satinado en las zonas de piel entintadas. 

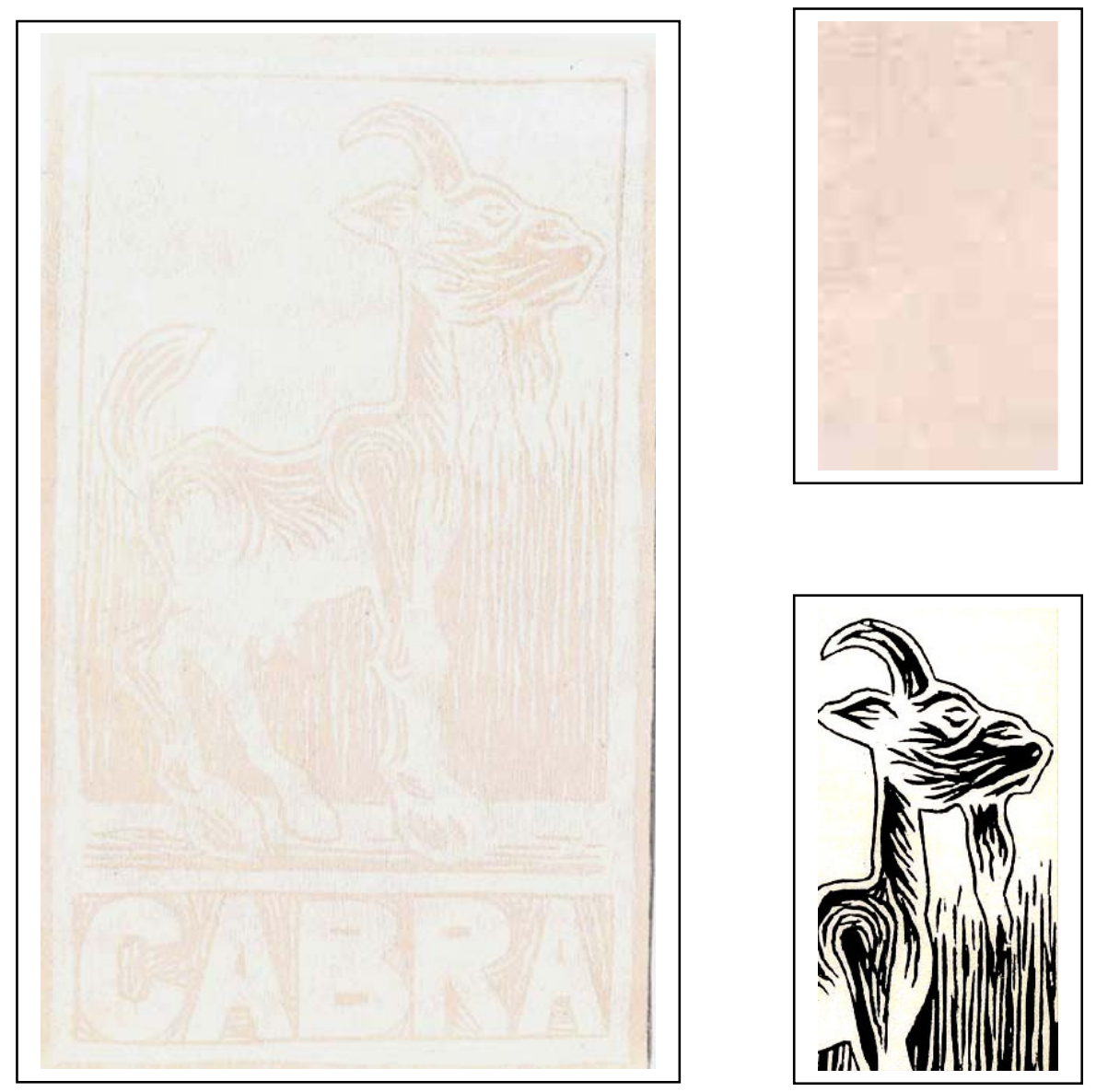

CÓDIGO: CA-008

TÉCNICA: Xilografía

TIPO DE PIEL: Cabra

TONO DE PIEL: Claro

TINTA: Blanca

SUPERFICIE: Lado carne 


\section{CALIDAD: Mala}

En las estampaciones con tinta blanca sobre el lado carne es donde más cambios se producen. Es resultado suele ser de escasa calidad, agravado en este caso por el escaso contraste entre la tinta y el fondo.

MANCHA: De muy mala calidad general. La tinta no cubre las imperfecciones de la piel y se crea un tono grisáceo que dota a las zonas estampadas de una superficie heterogénea y débil.

GRAFISMO: Al hacerse los contornos muy débiles los grafismos se difuminan hasta desaparecer en algunas zonas concretas de la imagen.

CONTRASTE: Casi inapreciable debido al estrecho margen tonal que separa a la tinta del color del fondo. La imagen se hace así difícilmente reconocible y legible, creándose una estampa falta de fuerza y potencia plástica.

BRILLO: Se produce un extraño efecto por el cual las superficies entintadas cobran una apariencia totalmente mate, dando la sensación de que es la zona de piel libre de tinta la que posee un cierto brillo satinado muy tenue. 

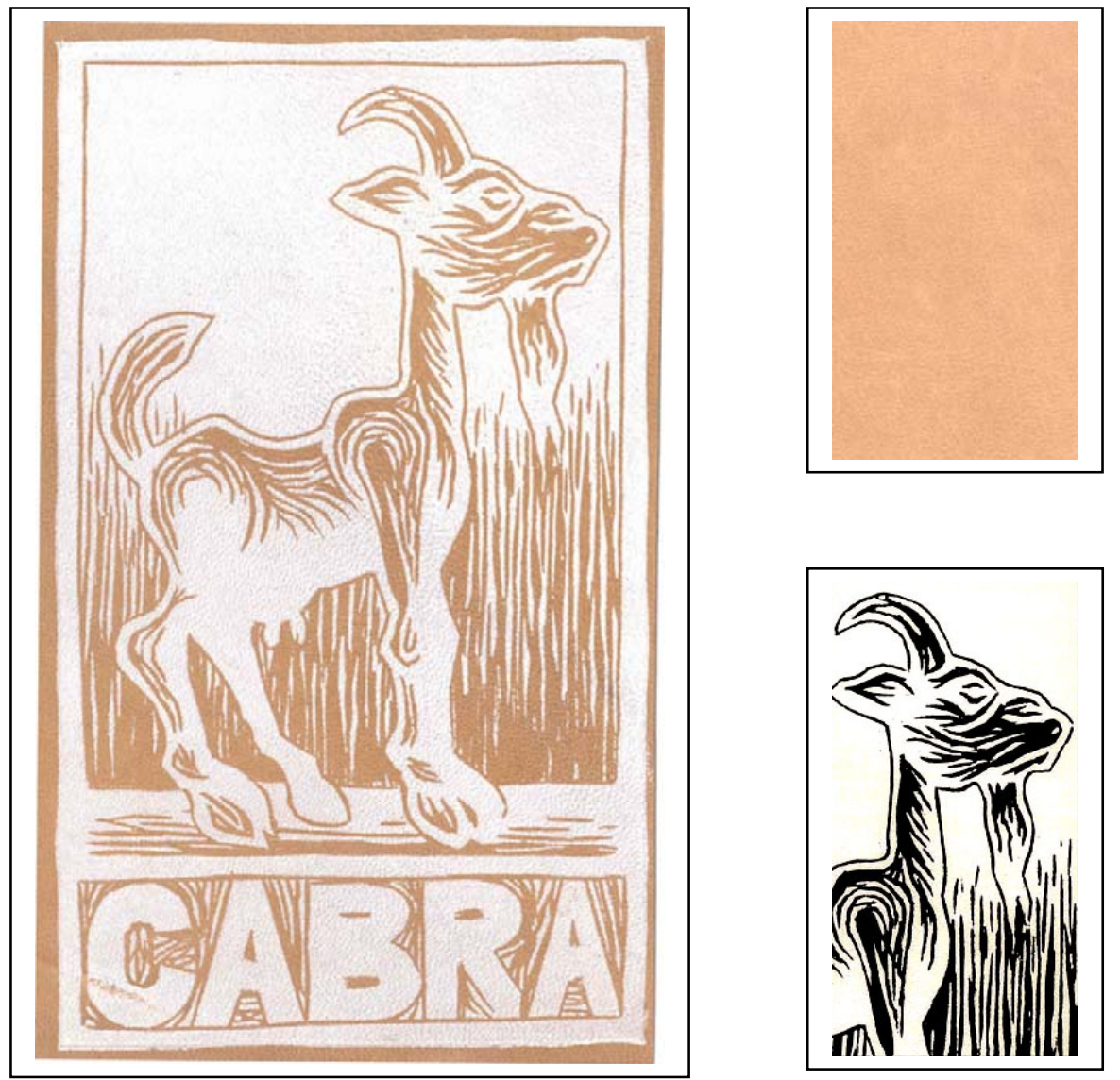

CÓDIGO: CA-009

TÉCNICA: Xilografía

TIPO DE PIEL: Cabra

TONO DE PIEL: Medio

TINTA: Blanca

SUPERFICIE: Lado flor 


\section{CALIDAD: Buena}

Las características ya comentadas en la estampación sobre la piel clara se nos muestran de nuevo aquí, aunque matizadas. Se demuestra que el blanco no es el color más idóneo para realizar una estampa sobre soporte piel, aunque en esta ocasión ofrezca un resultado satisfactorio.

MANCHA: De bastante buen resultado. Si la superficie de la piel es uniforme y no presenta defectos la estampa se estampará correctamente. En las zonas entintadas se hace más patente la textura propia de la piel, con sus orificios característicos.

GRAFISMO: Si la presión es la correcta el registro de los seños del grafismo será satisfactorio. Los contornos no presentan dificultades de estampación y las texturas creadas en la plancha se transfieren fielmente a la piel.

CONTRASTE: Mucho más intenso que con la piel clara, algo obvio al tener un tono de soporte mucho más oscuro. A pesar de no alcanzar el blanco verdadero el resultado es muy correcto.

BRILLO: Ligero brillo satinado que no entorpece la visión de la imagen. Dichos reflejos aparecen por efecto de la gran cantidad de tinte que posee la piel en su superficie, lo que provoca la aparición de dicho acabado brillante. 

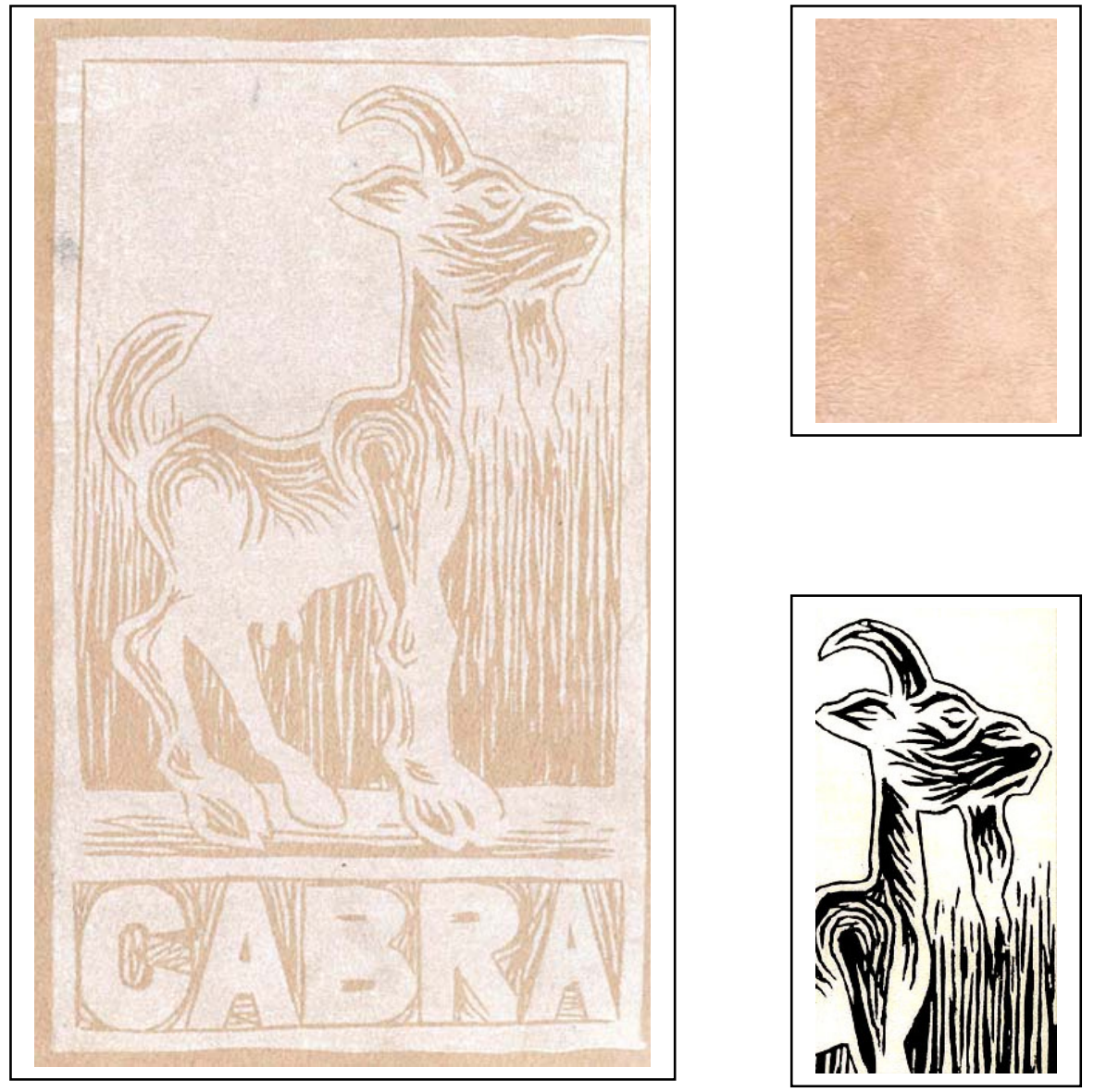

CÓDIGO: CA-010

TÉCNICA: Xilografía

TIPO DE PIEL: Cabra

TONO DE PIEL: Medio

TINTA: Blanca

SUPERFICIE: Lado carne 


\section{CALIDAD: Mediocre}

Presenta los mismos inconvenientes que sobre la piel clara, aunque en esta ocasión matizados levemente por un mayor contraste.

MANCHA: Como ya hemos comentado la tinta no es capaz de cubrir la superficie de la piel, por lo que la mancha no llega a ser uniforme. El acabado afelpado e irregular de la piel se aumenta al contacto con la tinta, obteniéndose una textura áspera y algo desagradable. Todo esto ocurre a pesar de que la piel recoge gran cantidad de tinta de la plancha pero pese a todo el resultado es dudoso.

GRAFISMO: El efecto es mejor que en la mancha debido a que la superficie a cubrir es mucho menor, pero aún así no es del todo satisfactorio.

CONTRASTE: Algo más potente, lo que permite crear una imagen perfectamente reconocible aunque carente de fuerza.

BRILLO: Se produce exactamente el mismo efecto que con la piel clara: la superficie entintada es mate, mientras que es la piel la que parece poseer un ligero brillo satinado muy suave. 

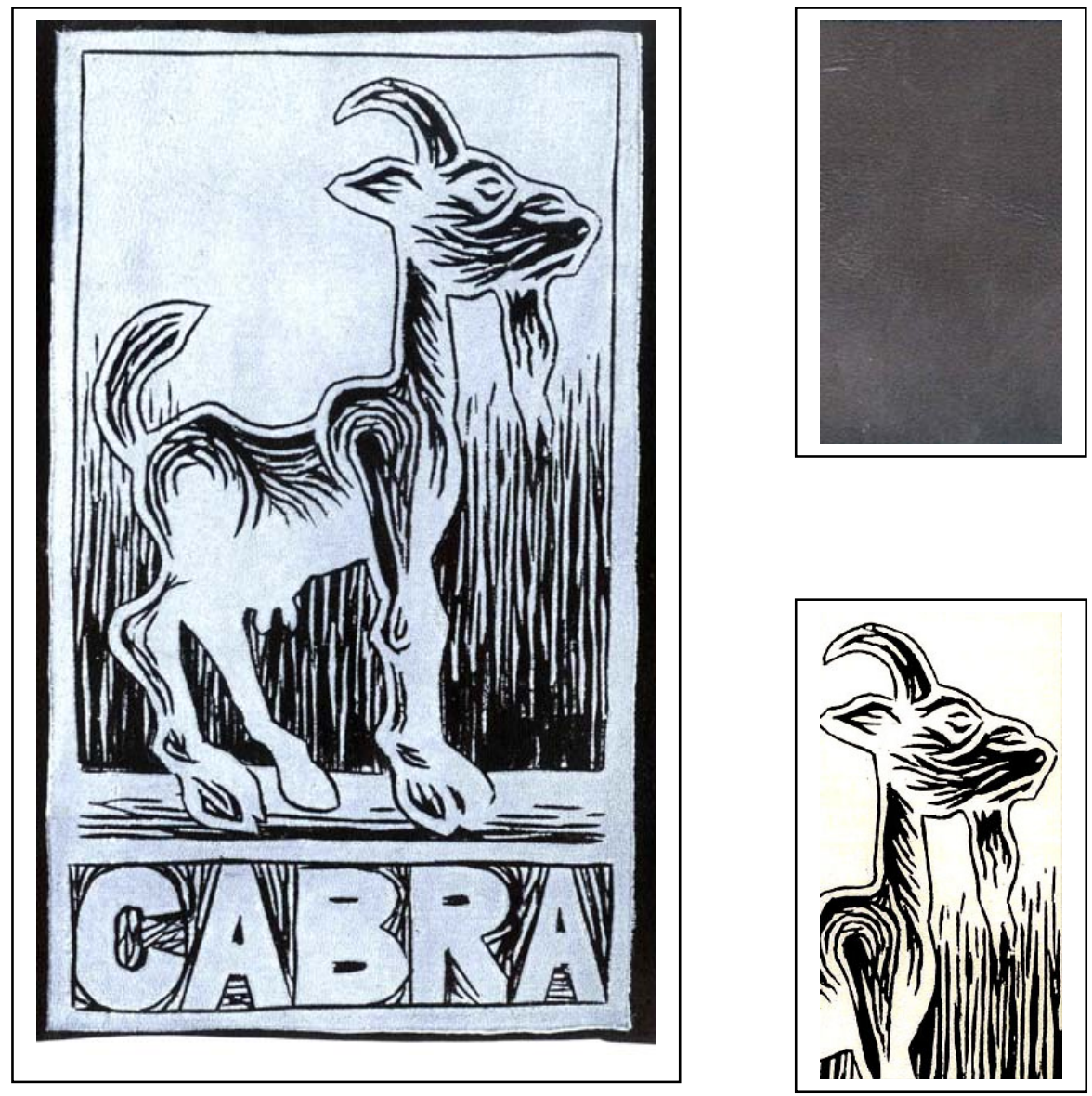

CÓDIGO: CA-011

TIPO DE PIEL: Cabra

TINTA: Blanca
TÉCNICA: Xilografía

TONO DE PIEL: Oscuro

SUPERFICIE: Lado flor 


\section{CALIDAD: Mediocre}

Estampa en la que las ventajas e inconvenientes del uso de tintas blancas se ponen más de manifiesto. Pese a ser de buena calidad general, se debe estudiar con detenimiento para sacar conclusiones válidas.

MANCHA: A pesar de ser un "blanco cubriente", la realidad de la tinta dista mucho de su denominación comercial. En efecto el blanco jamás llega a alcanzar la intensidad deseada, lo que provoca que la mancha deje ver ciertas irregularidades y surja la típica grumosidad que siempre aparece en las zonas donde se concentra mayor cantidad de tinta blanca.

GRAFISMO: Los defectos apreciados se disimulan en gran medida.

CONTRASTE: Pese a lo comentado con respecto a la intensidad de la tinta, el contraste es bastante potente y se crea una imagen muy válida. A esto ayuda obviamente el tono tan oscuro de la piel que sirve como soporte.

BRILLO: La tinta blanca, totalmente mate, matiza en gran medida el acusado brillo que posee la superficie tan satinada de la piel de cabra. Aún así la estampa tiene un brillo bastante fuerte que, sin embargo, no llega a ser perjudicial para la imagen. 

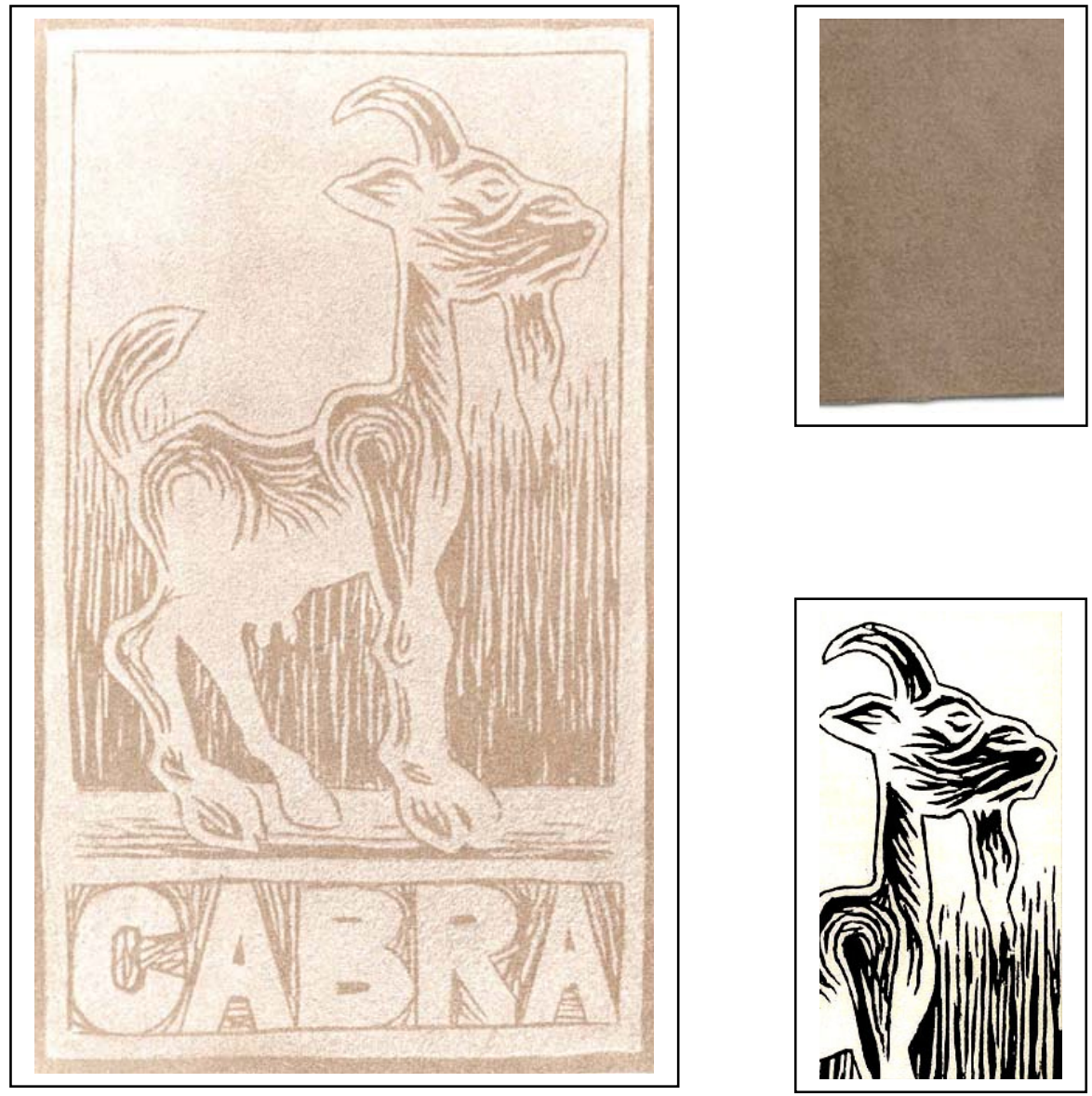

CÓDIGO: CA-012

TÉCNICA: Xilografía

TIPO DE PIEL: Cabra

TONO DE PIEL: Oscuro

TINTA: Blanca

SUPERFICIE: Lado carne 


\section{CALIDAD: Mala}

Los problemas encontrados en las dos pieles más claras con respecto al uso del blanco sobre superficies afelpadas (CA-008 y CA-010) se verifican en esta estampa. Dichos inconvenientes se ven mínimamente aliviados por el tono oscuro de la piel aunque no desaparecen.

MANCHA: A pesar de que, al estampar, la piel recoge casi la totalidad de la tinta presente en la plancha esto no se ve reflejado en el resultado de la estampa. En efecto, tenemos un tono grisáceo sin apenas intensidad y alejadísimo del blanco verdadero que hubiera sido deseable.

GRAFISMO: Los defectos aparecidos sobre la mancha se repiten en este caso. Sin embargo los contornos de los seños están bastante bien registrados y, a pesar del afelpado de la piel, no se producen irregularidades en sus características básicas.

CONTRASTE: Pese a todos los problemas comentados se aprecia un pequeño contraste que permite la lectura de la imagen, pero que no impide ni evita el encontrarnos con una estampa carente de fuerza e intensidad.

BRILLO: Si unimos la superficie afelpada de la piel con el carácter totalmente mate de la tinta blanca, obtenemos una imagen sin ningún tipo de brillo ni acabados satinados. 

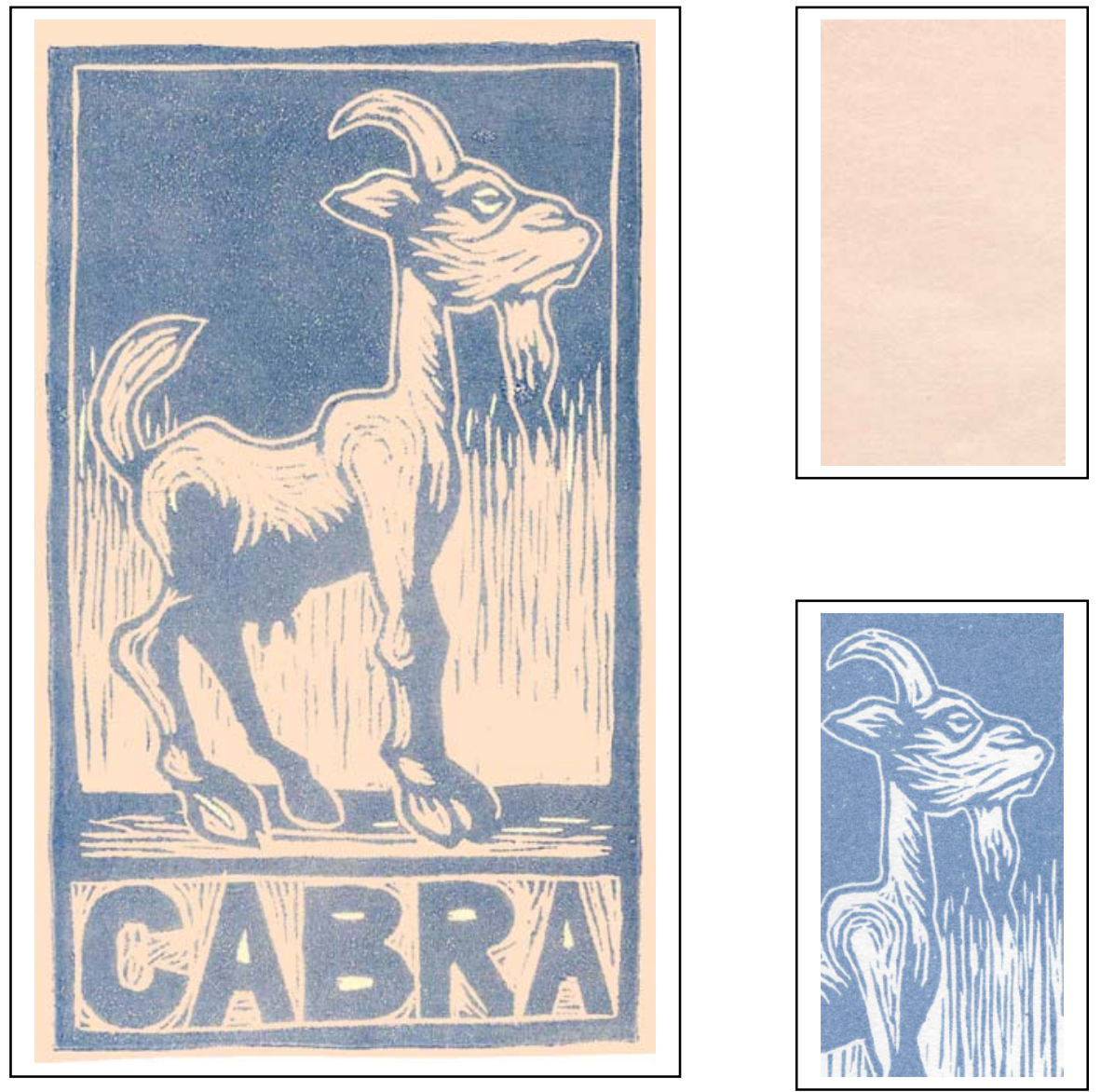

CÓDIGO: CA-013

TIPO DE PIEL: Cabra

TINTA: Azul traslúcido
TÉCNICA: Xilografía

TONO DE PIEL: Claro

SUPERFICIE: Lado flor 


\section{CALIDAD: Buena}

Las tintas transparentes actúan de manera muy curiosa sobre las pieles. El resultado es bastante satisfactorio teniendo en cuenta que se trata de una tinta con casi un $90 \%$ de preparación traslúcida en su composición. En estas estampas las características de la piel son fundamentales para el resultado final de la imagen.

MANCHA: Es bastante uniforme, aunque el hecho de ser tan transparente hace que cualquier imperfección o cambio en la superficie de la piel sea perfectamente visible. Al ser una piel tan satinada la tinta no asienta de manera perfecta, creándose una textura granulada algo molesta.

GRAFISMO: Se presenta un tanto quebrado e irregular debido a la gran cantidad de preparación traslúcida que provoca que la tinta no se adhiera con uniformidad a la piel.

CONTRASTE: El contraste es correcto y produce una imagen perfectamente legible. El color de la tinta cambia por transparencia hasta convertirse en un azul un tanto más oscuro y quebrado que el de la tinta original.

BRILLO: El exceso de base transparente hace que la tinta adquiera un brillo más acusado, aunque sin llegar a perjudicar la visión de la estampa. 

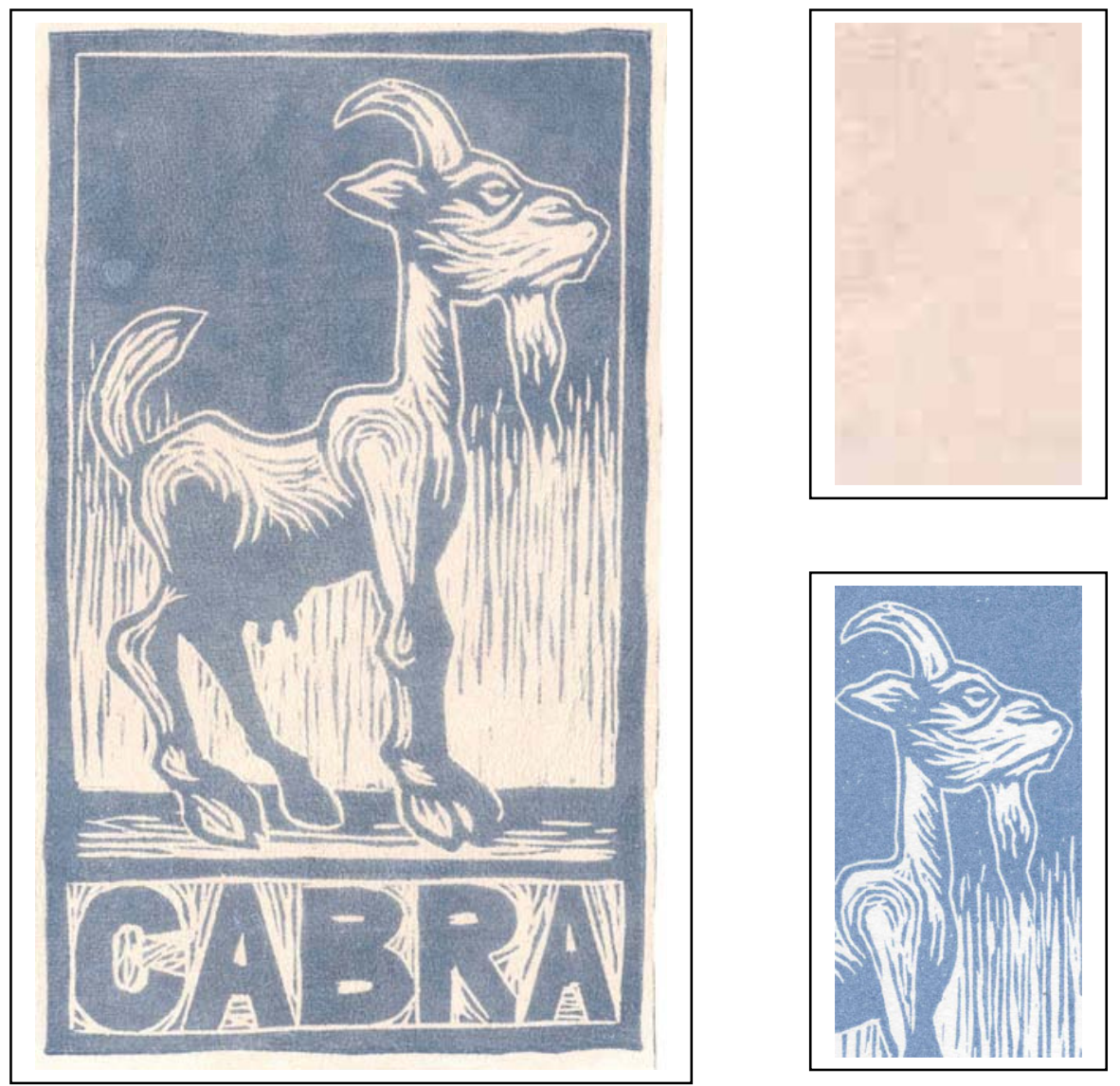

CÓDIGO: CA-014

TIPO DE PIEL: Cabra

TINTA: Azul traslúcido
TÉCNICA: Xilografía

TONO DE PIEL: Claro

SUPERFICIE: Lado carne 


\section{CALIDAD: Buena}

Con las tintas transparentes ocurre un fenómeno muy curioso al estampar sobre el lado carne: la tinta se oscurece de manera muy visible, lo que unido a la mezcla por transparencia del fondo hace que sus características cambien notablemente.

MANCHA: Debido a la gran transparencia de la tinta la mancha no cubre totalmente la superficie de la piel dejando ver cualquier irregularidad de la misma, ya sea de textura o de color. Por tanto la mancha será difícilmente uniforme aunque no por ello de menor calidad si el soporte posee las cualidades necesarias.

GRAFISMO: En algunas zonas pierde fuerza y consistencia, todo ello debido a la naturaleza tan traslúcida de la tinta empleada en la estampación.

CONTRASTE: El contraste es más acusado que en el lado flor. Esto es debido a dos factores: el tono más claro del lado carne y, por otro lado y mucho más importante, el hecho de que la tinta oscurezca al contacto de la superficie afelpada.

BRILLO: Es apenas apreciable, creándose una superficie casi mate a pesar de la gran cantidad de preparación traslúcida de la tinta, lo que haría suponer que obtendríamos una tinta algo más brillante y satinada. 

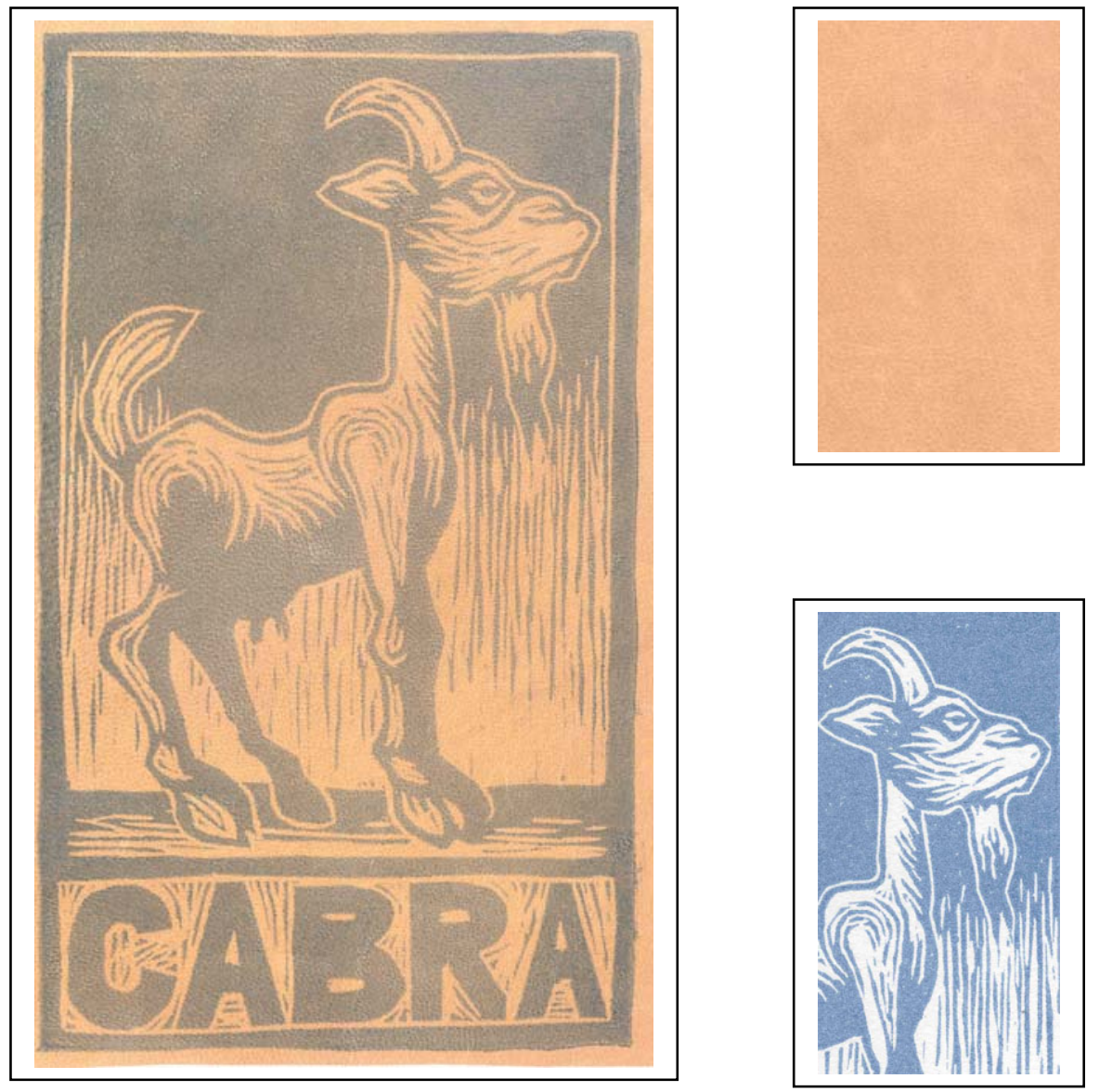

CÓDIGO: CA-015

TÉCNICA: Xilografía

TIPO DE PIEL: Cabra

TONO DE PIEL: Medio

TINTA: Azul traslúcido

SUPERFICIE: Lado flor 


\section{CALIDAD: Muy buena}

Todas las observaciones realizadas para con la piel clara (CA-013) se pueden repetir en este caso. Tan sólo se apreciarán cambios evidentes en el contraste y en el hecho de que la tinta hace mucho más patente la textura propia de la piel.

MANCHA: Muy uniforme y de buena calidad. Si la piel no presenta irregularidades evidentes en su superficie la mancha será casi perfecta y sin problemas visibles. El color varía de una manera muy evidente debido a la mezcla por transparencia, apareciendo un gris tenue y ligeramente azulado.

GRAFISMO: Debido a la naturaleza tan transparente de la tinta pierde vigor en ciertas zonas. Aún así el registro es muy satisfactorio, con unos contornos muy fieles al original. Ante un exceso de presión las líneas reventarían con suma facilidad estropeando la estampa.

CONTRASTE: El contraste es, obviamente, mucho menor que en las estampas sobre piel clara pero aún lo suficientemente fuerte como para hacer claramente legible la imagen.

BRILLO: La estampa resultante es bastante brillante, situándose en el límite de lo perjudicial y nocivo para la correcta visión de la imagen. 

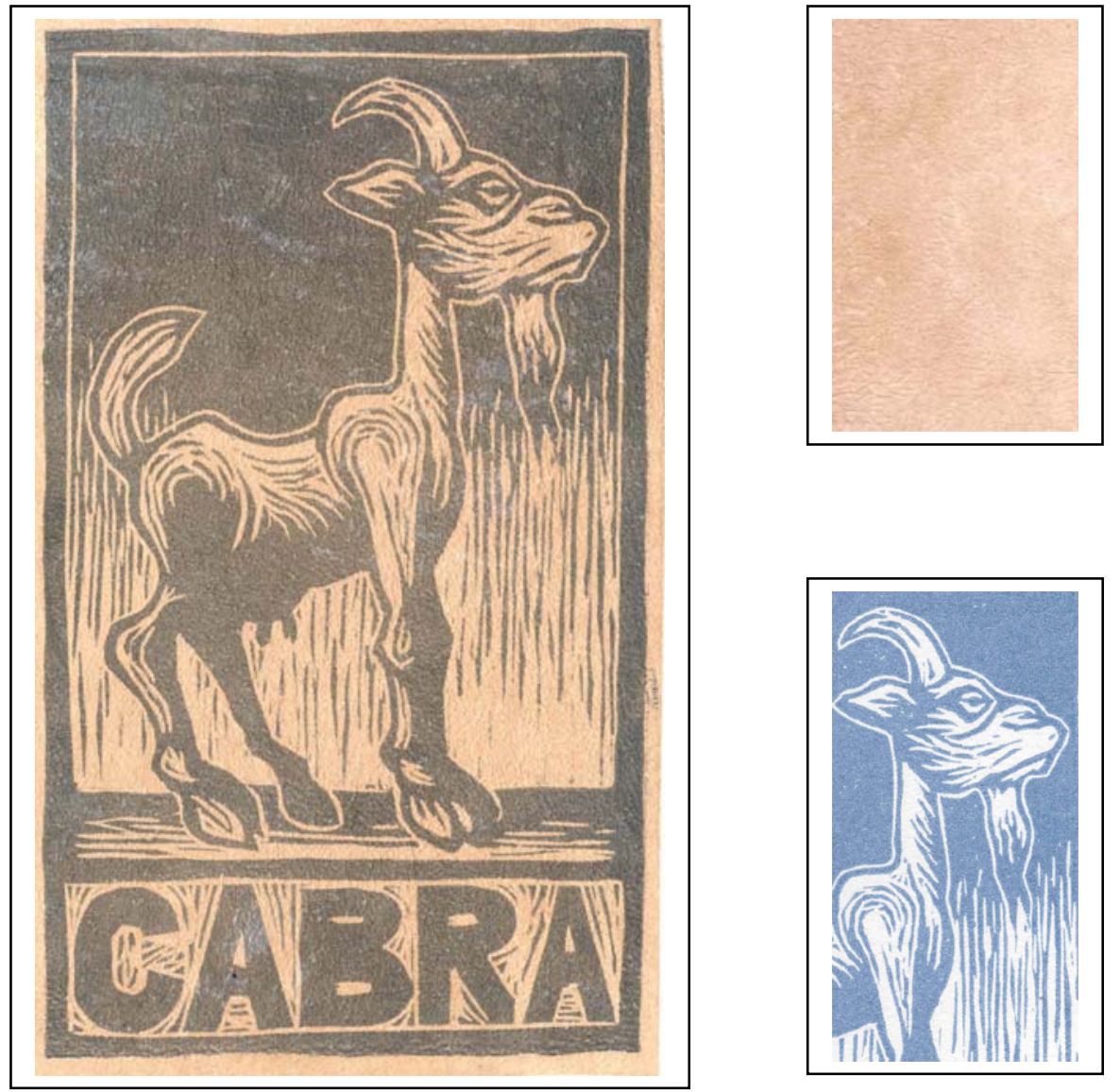

CÓDIGO: CA-016

TIPO DE PIEL: Cabra

TINTA: Azul traslúcido
TÉCNICA: Xilografía

TONO DE PIEL: Medio

SUPERFICIE: Lado carne 


\section{CALIDAD: Buena}

En este ejemplo ciertas irregularidades de la piel han influido decisivamente en el resultado final de la estampa.

MANCHA: Si la piel es uniforme la mancha también lo será. En este ejemplo la piel era en apariencia bastante homogénea pero al estampar salieron a la luz ciertas zonas con características algo distintas. Estas variaciones cambiaron las cualidades de la tinta, provocando la aparición de una mancha heterogénea e irregular. El color ha sufrido un cambio radical, obteniéndose un gris oscuro en el que han desaparecido por completo los matices azulados de la tinta original.

GRAFISMO: De muy buena definición, mucho mejor que en el lado flor del mismo tipo de cuero.

CONTRASTE: Es más acusado que el lado flor, debido al oscurecimiento de la tinta, creando una imagen con buen fuerza expresiva y fácilmente legible.

BRILLO: Teóricamente deberíamos conseguir una estampa totalmente mate. Sin embargo en esta imagen aparecen zonas donde la tinta adquiere unos brillos de contornos irregulares provocados por cambios en la naturaleza de la piel. Si la superficie presenta un acabado afelpado regular y uniforme el brillo desaparecerá por completo. 

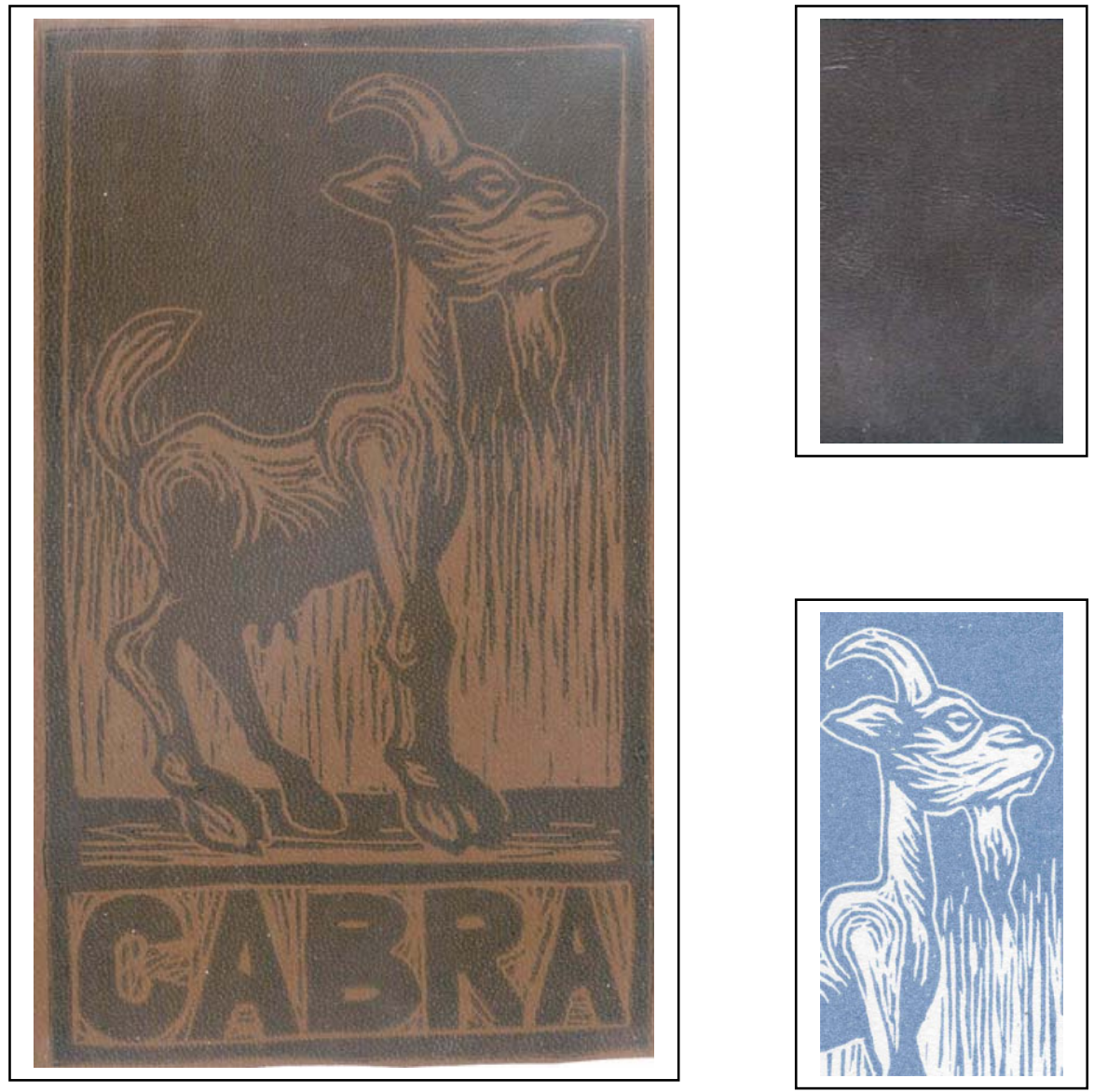

CÓDIGO: CA-017

TIPO DE PIEL: Cabra

TINTA: Azul traslúcido
TÉCNICA: Xilografía

TONO DE PIEL: Oscuro

SUPERFICIE: Lado flor 


\section{CALIDAD: Mediocre}

Como en casi todas las estampas sobre piel de cabra en ésta también encontramos una gran exactitud en los registros de la imagen. Sin embargo el mínimo contraste existente en la estampa hace que la imagen sea difícilmente apreciable, lo que condiciona el resto de los factores.

MANCHA: Es de gran calidad y se muestra como una mancha perfectamente homogénea y regular, sin anomalías y ni inconvenientes. El color es irreconocible, habiéndose transformado en un gris muy oscuro que tan sólo se intuye sobre la superficie de la piel.

GRAFISMO: Bastante correcto. Sin embargo su apreciación se hace muy dificultosa debido al escasísimo contraste existente en la estampa.

CONTRASTE: Escaso e insuficiente para crear una imagen potente y adecuada. El tono del soporte es demasiado oscuro como para que la tinta tan transparente pueda ser percibida sin dificultad.

BRILLO: Sobre una piel tan satinada como ésta el uso de una tinta con tanta carga de preparación traslúcida no altera el ya de por sí potente brillo presente en la superficie de la piel, el cual es excesivo para una estampa xilográfica. 

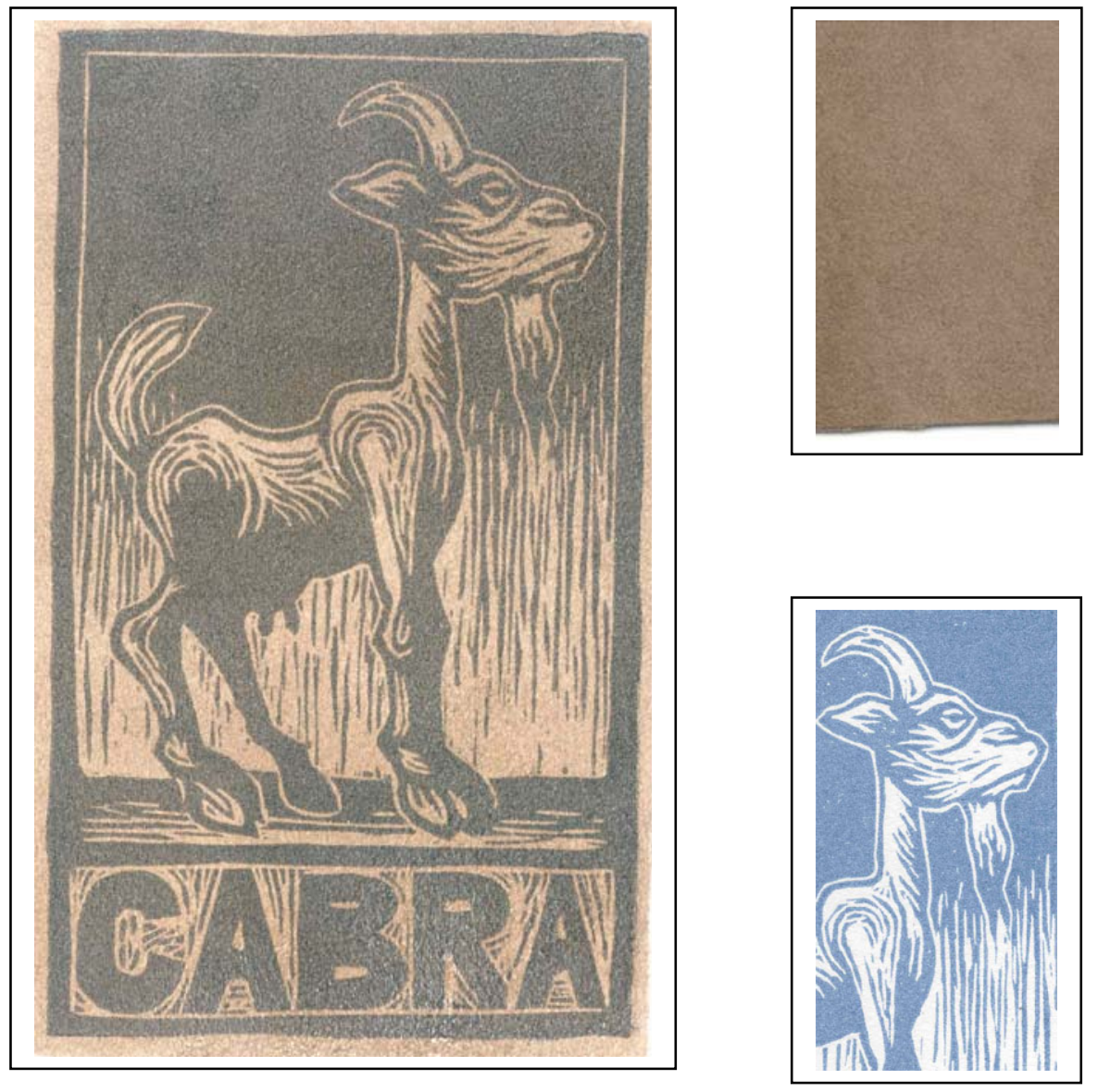

CÓDIGO: CA-018

TIPO DE PIEL: Cabra

TINTA: Azul traslúcido
TÉCNICA: Xilografía

TONO DE PIEL: Oscuro

SUPERFICIE: Lado carne 


\section{CALIDAD: Buena}

Ejemplo de mucha mejor calidad que su gemela del lado flor (CA017). Esto es debido al tono ligeramente más claro de la piel en este lado carne.

\section{MANCHA:}

Bastante uniforme y homogénea. La tinta transparente si bien no llega a cubrir totalmente la superficie de la piel, si que la oscurece lo suficiente como para crear una mancha muy válida y adecuada. El color se ha transformado en un gris oscuro con ligeros matices violáceos, alejadísimo del tono original de la tinta azul.

GRAFISMO: Al igual que la mancha los grafismos son registrados perfectamente por la superficie afelpada del lado carne.

CONTRASTE: Como ya se ha comentado la tinta transparente se comporta de un modo especial al contacto con una superficie rugosa como la del lado carne. Al oscurecerse sobremanera se crea un contraste bastante pronunciado, lo suficiente como para producir una imagen legible y válida.

BRILLO: Es casi inexistente, reduciéndose a minúsculos puntos brillantes diseminados por la superficie entintada de la piel. De todas formas no llega en ningún momento a ser perjudicial ni molesto para la correcta visión de la imagen. 

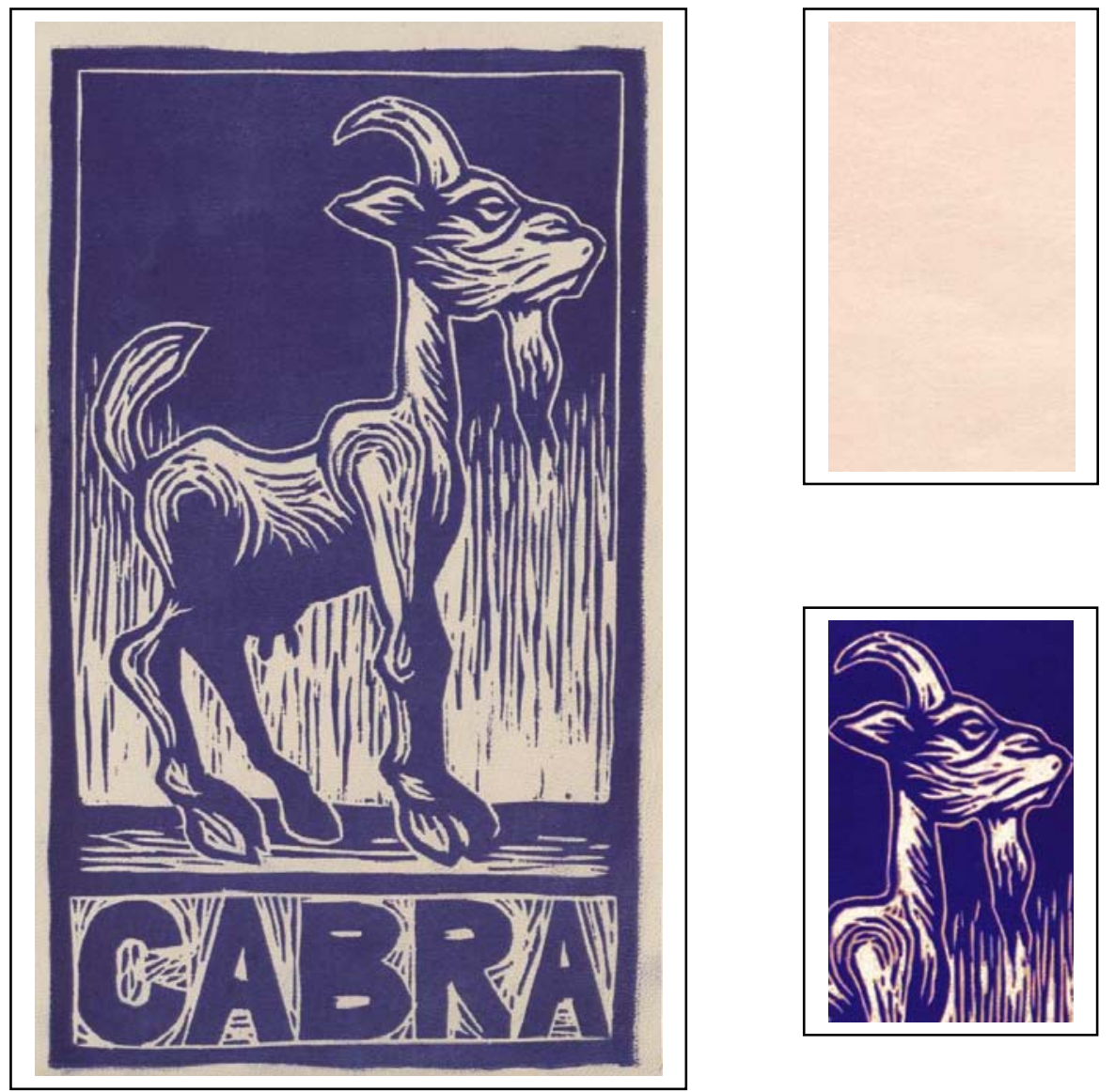

CÓDIGO: CA-019

TIPO DE PIEL: Cabra

TINTA: Azul opaco
TÉCNICA: Xilografía

TONO DE PIEL: Claro

SUPERFICIE: Lado flor 
CALIDAD: Buena.

La calidad de la estampa es elevada, con el color depositándose con corrección sobre la superficie de la piel logrando una imagen muy correcta y legible sin apenas inconvenientes. Sobre la piel clara, una tinta tan potente como ésta ofrece resultados muy satisfactorios.

MANCHA: Casi perfecta y muy uniforme, tan sólo se aprecian ciertos inconvenientes en la zona superior derecha, debidos probablemente a cambios sutiles de la superficie de la piel en este lado flor.

GRAFISMO: Muy correcto. Si no queremos que aparezcan defectos y deformaciones deberemos estampar con la mínima presión necesaria, al igual que ocurre en la práctica totalidad de los ejemplos analizados.

CONTRASTE: Bastante elevado e intenso como es lógico al unir una superficie clara como la del cuero que nos ocupa, y un tono de tinta tan oscuro y potente como el azul opaco empleado.

BRILLO: Aparece un levísimo y ligero brillo en las zonas donde se deposita la tinta, brillo que por otro lado no dificulta para nada la apreciación de la estampa. Dichos reflejos no son uniformes, sino que en algunas zonas son algo más intensos. 

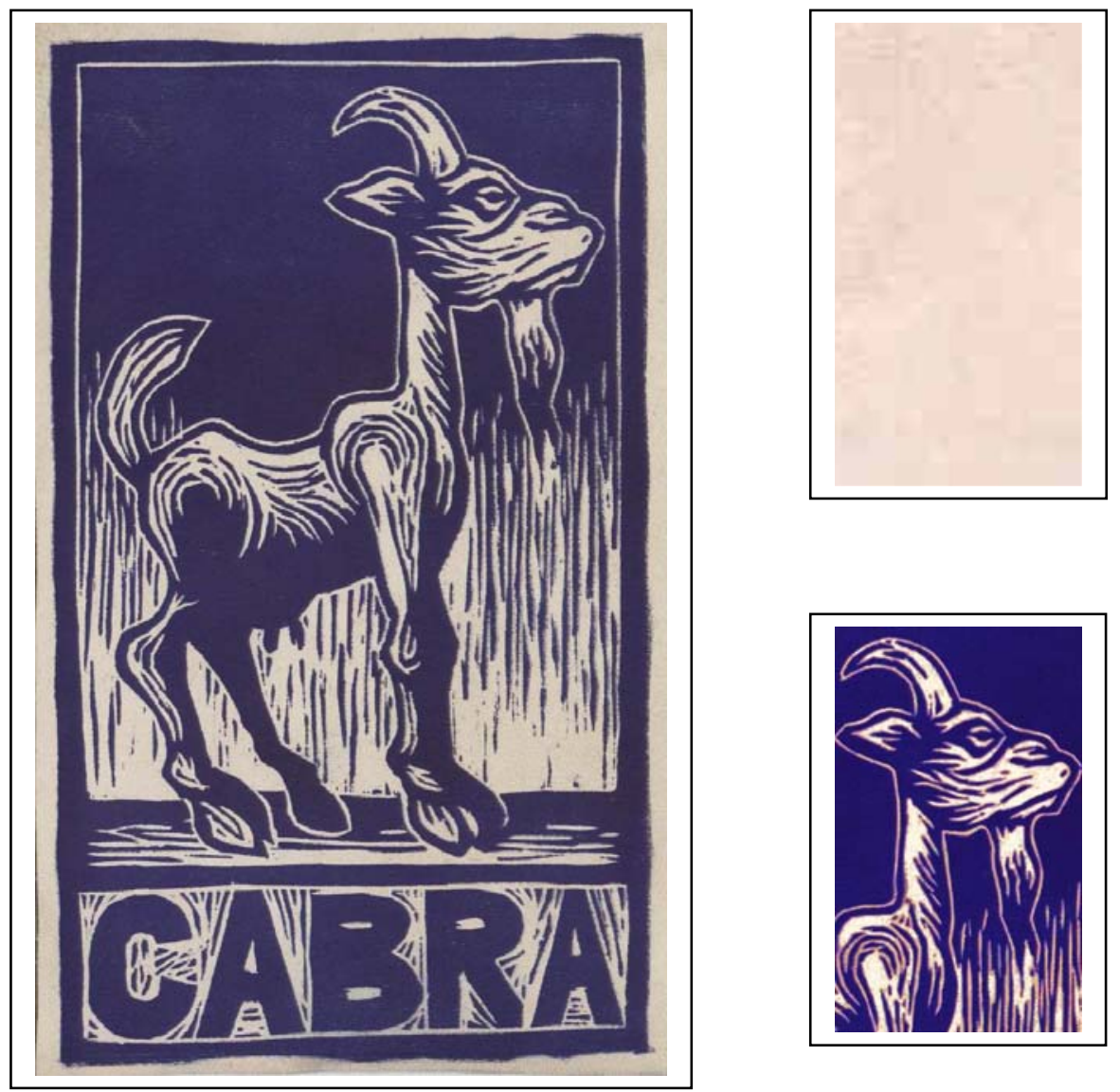

CÓDIGO: CA-020

TIPO DE PIEL: Cabra

TINTA: Azul opaco
TÉCNICA: Xilografía

TONO DE PIEL: Claro

SUPERFICIE: Lado carne 
CALIDAD: Muy buena.

El resultado es prácticamente perfecto sobre esta superficie, el cual es una de los mejores de todo el estudio. Pese a ello aparecen ciertos inconvenientes de secado de la tinta sobre el cuero, necesitando de un periodo de tiempo extraordinariamente largo para un asentamiento definitivo de la misma sobre la piel. Una vez superado este intervalo de tiempo, la imagen permanece estable en el soporte empleado.

MANCHA: Perfecta desde todos los puntos de vista. Siempre que la superficie del cuero no ofrezca irregularidades excesivas, el resultado de la estampación será muy satisfactorio, consiguiéndose una mancha intensa y homogénea.

GRAFISMO: También perfecto siempre que realicemos nuestra estampación con la mínima presión necesaria con objeto de evitar deformaciones de los seños xilográficos.

CONTRASTE: Muy intenso debido al ligero oscurecimiento que sufre la tinta al contacto con el afelpado del lado carne de la piel. Se logra de tal modo un azul profundo que contrasta perfectamente con el tono tan claro del soporte piel.

BRILLO: Nulo como corresponde a una superficie afelpada como ésta, a pesar de que el afelpado de este forro caprino sea apenas perceptible al tacto. 

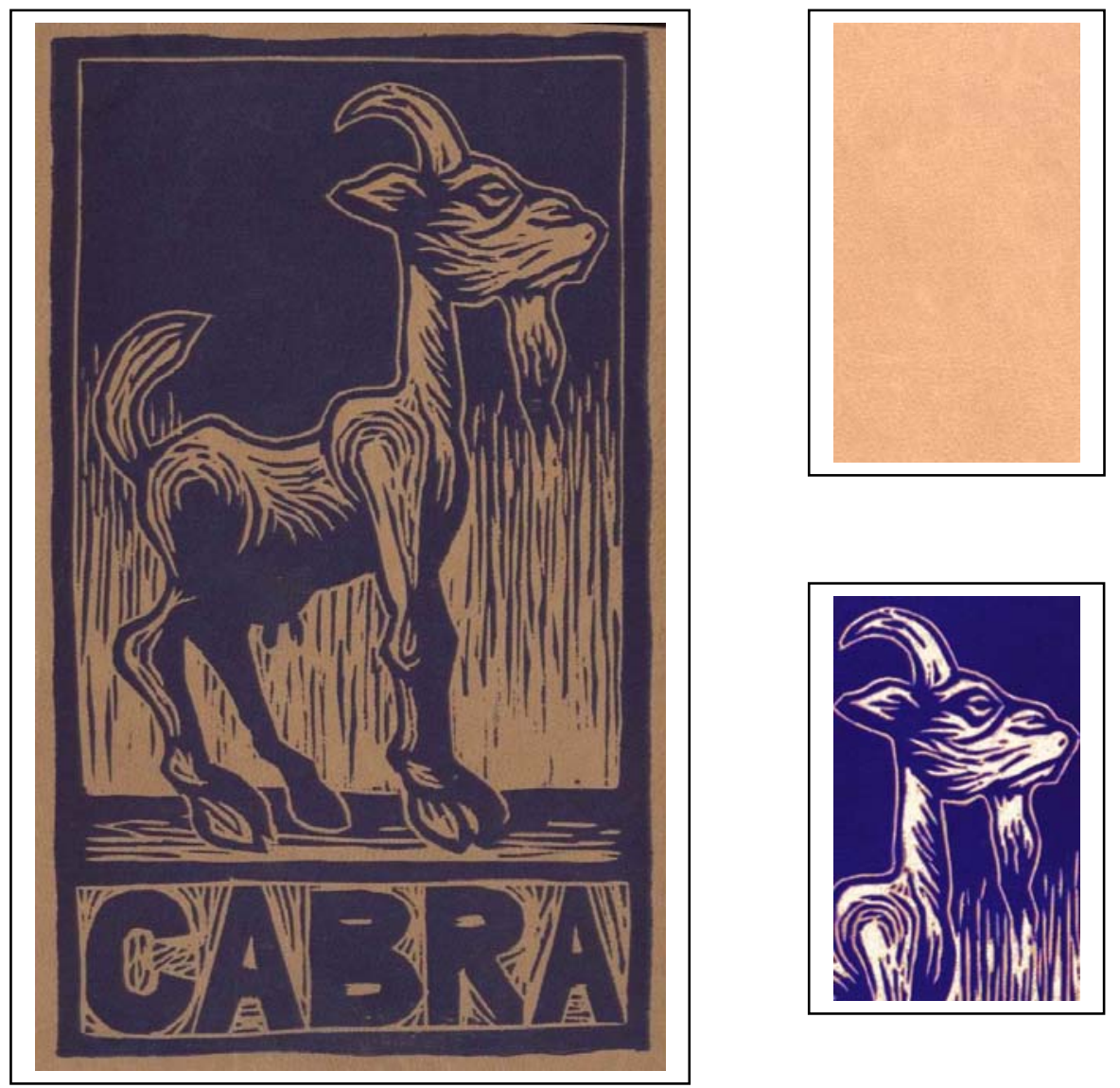

CÓDIGO: CA-021

TIPO DE PIEL: Cabra

TINTA: Azul opaco
TÉCNICA: Xilografía

TONO DE PIEL: Medio

SUPERFICIE: Lado flor 
CALIDAD: Buena.

A pesar del ligero acabado brillante y satinado de la piel, la tinta logra asentar adecuadamente sobre su superficie, lográndose una estampa de un buen resultado general. Indicar que, al igual que ocurría en ejemplos anteriores, el periodo de secado total de la tinta es extremadamente largo (incluso varios meses) hasta conseguir una película resistente y correcta.

MANCHA: Homogénea y uniforme, siempre que se estampe con la presión correcta y adecuada. Si realizamos nuestra estampación con un grado de presión excesiva, la piel puede llegar a repeler la tinta, provocando la aparición de un ejemplo de ínfimo nivel.

GRAFISMO: Correcto y válido en líneas generales. Sirve el mismo comentario que el realizado acerca de la mancha en relación con una presión excesiva, indicando que en este caso, además de un asentamiento deficiente de la tinta sobre el cuero, se obtendrían seños xilográficos irregulares y desvirtuados.

CONTRASTE: Todavía muy intenso a pesar del tono algo más oscuro del cuero. La tinta se oscurece mínimamente hasta alcanzar una saturación suficiente como para lograr un adecuado contraste con el soporte piel.

BRILLO: La tinta mantiene el mismo brillo que de por sí poseía el cuero, por lo que los reflejos son homogéneos y no demasiado molestos para una correcta visión de la estampa. 

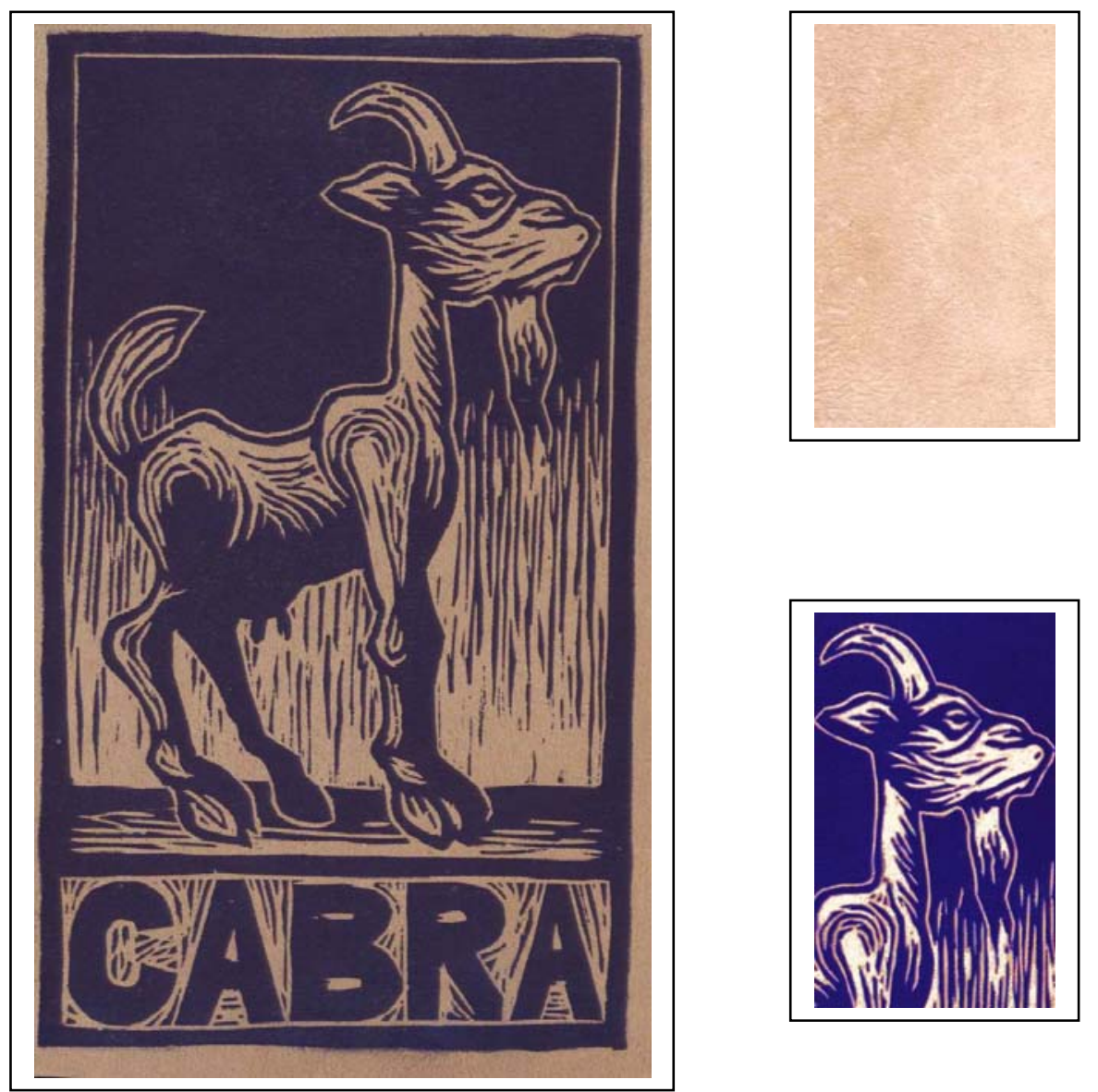

CÓDIGO: CA-022

TIPO DE PIEL: Cabra

TINTA: Azul opaco
TÉCNICA: Xilografía

TONO DE PIEL: Medio

SUPERFICIE: Lado carne 
CALIDAD: Muy buena.

Estampa de apariencia perfecta, sin apenas defectos superficiales y con un excelente nivel de mancha y grafismo. Este tipo de tinta continúa necesitando de un tiempo de secado muy largo hasta alcanzar un acabado estable al tacto.

MANCHA: Perfecta si la piel ofrece una superficie homogénea y sin demasiadas irregularidades. En este caso concreto así ocurre, por lo que la tinta crea unas zonas entintadas de gran potencia visual. El tono inicial y original de azul sufre un patente oscurecimiento al contacto con el afelpado del cuero, lo que provoca un cambio en sus características hasta convertirse en un tono azul oscuro mucho más intenso que el de la tinta.

GRAFISMO: Perfecto, con las líneas y los contornos xilográficos presentando una gran nitidez y definición. Si se controla un posible exceso de presión, el resultado será sin duda excelente.

CONTRASTE: Intenso debido al ligero oscurecimiento de la tinta anteriormente comentado, el cual provoca que el contraste sea lo suficientemente potente como para permitir apreciar la imagen de manera perfecta.

BRILLO: Nulo al estampar sobre una superficie afelpada. 

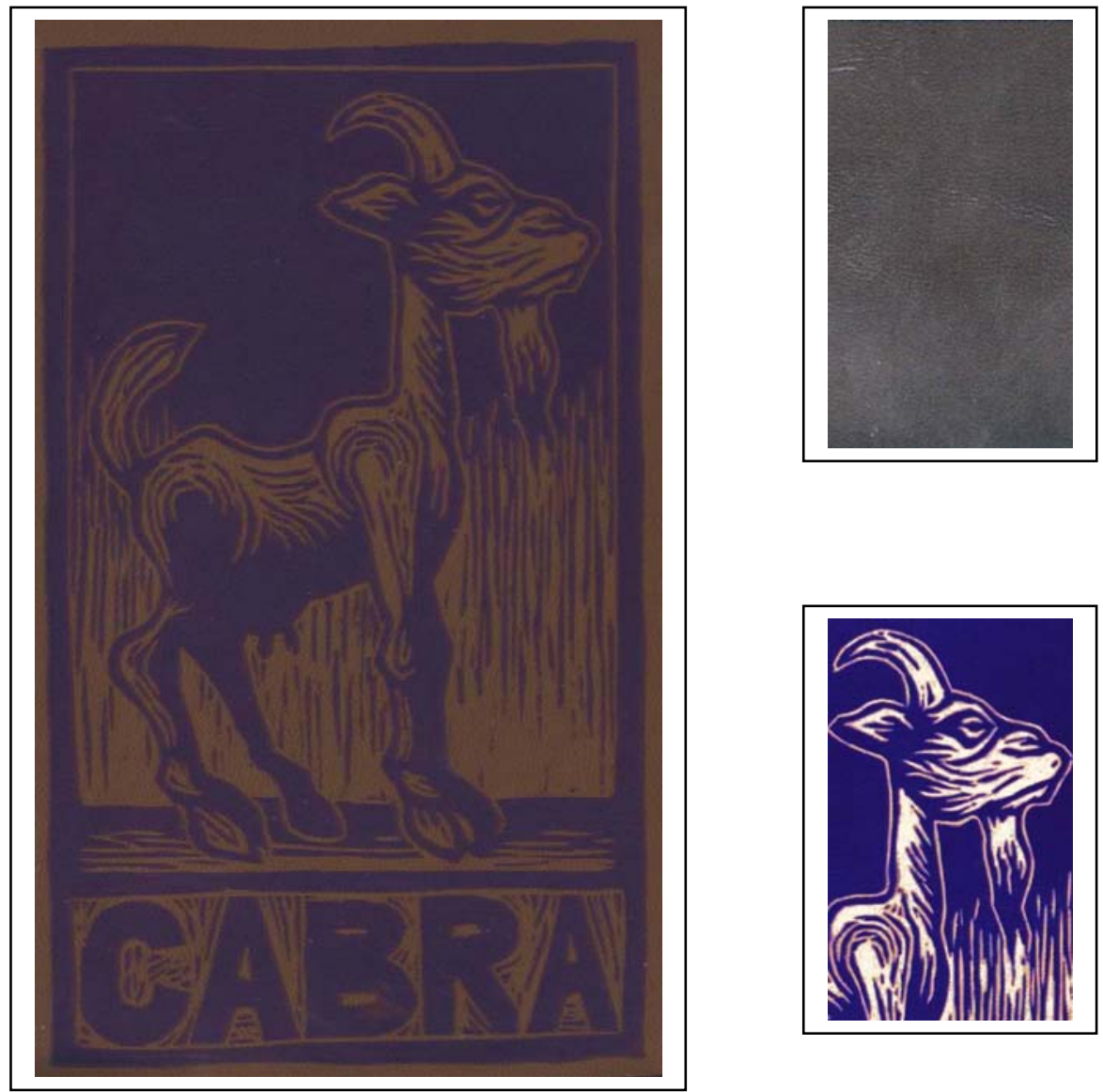

CÓDIGO: CA-023

TIPO DE PIEL: Cabra

TINTA: Azul opaco
TÉCNICA: Xilografía

TONO DE PIEL: Oscuro

SUPERFICIE: Lado flor 
CALIDAD: Mediocre.

A pesar de que la tinta todavía hace posible la apreciación de la imagen, los problemas de contraste y brillo provocan que el nivel de la estampa no sea excesivamente elevado. Se repite a su vez el fenómeno ya comentado del largo periodo de secado necesario hasta un asentamiento correcto de la tinta sobre la piel.

MANCHA: Bastante homogénea y regular si tenemos en cuenta lo satinado del cuero en su lado flor. Si nos excedemos con la presión probablemente aparecerán problemas de asentamiento de la tinta, estropeando la estampa irremediablemente.

GRAFISMO: Correcto siempre que la presión ejercida durante el proceso de estampación sea la correcta en relación al grosor de la piel empleada.

CONTRASTE: El tono algo oscuro de la piel provoca que el contraste sea algo menos intenso en ejemplos anteriores. La tinta sufre el conocido proceso de oscurecimiento, pero sin llegar a alcanzar un tono lo suficientemente oscuro como para provocar la aparición de un contraste demasiado intenso.

BRILLO: El potente brillo del soporte condiciona la estampa y provoca que la tinta también ofrezca unos intensos reflejos que interfieren en la correcta visión de la imagen. 

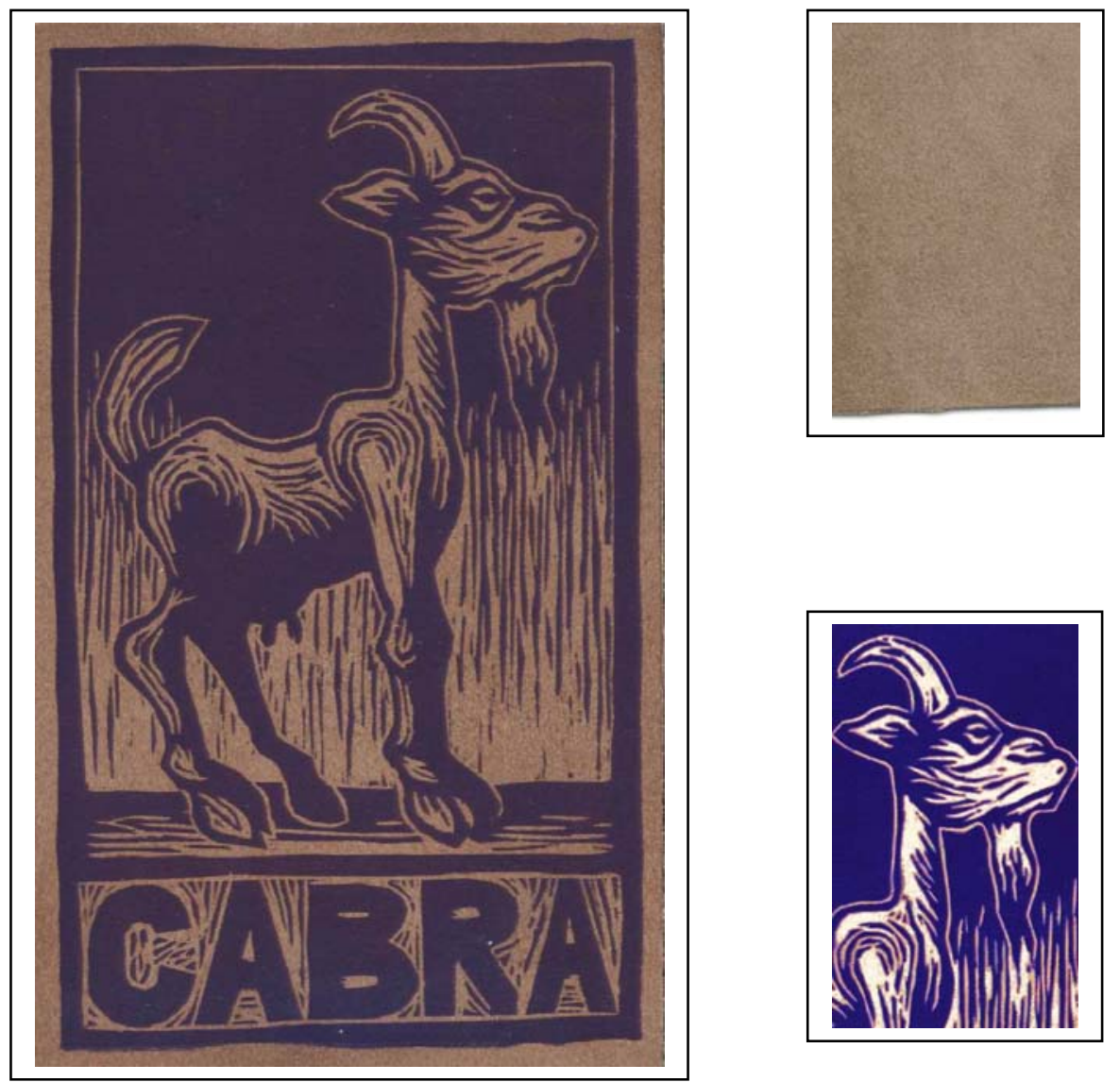

CÓDIGO: CA-024

TIPO DE PIEL: Cabra

TINTA: Azul opaco
TÉCNICA: Xilografía

TONO DE PIEL: Oscuro

SUPERFICIE: Lado carne 
CALIDAD: Buena.

El nivel de la estampa es muy elevado, de gran calidad general e interesantes resultados. Pese a estar realizada sobre una superficie afelpada los problemas de secado continúan existiendo, con un tiempo necesario de algunos meses hasta que la tinta presenta un acabado estable sobre el cuero.

MANCHA: Homogénea y regular, casi perfecta y obteniéndose una superficie intensa que no se ve afectada en demasía por el afelpado de esta superficie. El tono de azul sufre el citado proceso de oscurecimiento hasta transformarse en un azul muy oscuro e intenso.

GRAFISMO: Perfecto siempre que, como ya hemos comentado en numerosas ocasiones, se controle la presión ejercida durante la estampación.

CONTRASTE: Lo suficientemente intenso como para crear una estampa atractiva e interesante, ayudado por el oscurecimiento de la tinta antes comentado.

BRILLO: Prácticamente nulo como corresponde a una estampación sobre una superficie afelpada como la que nos ocupa. 


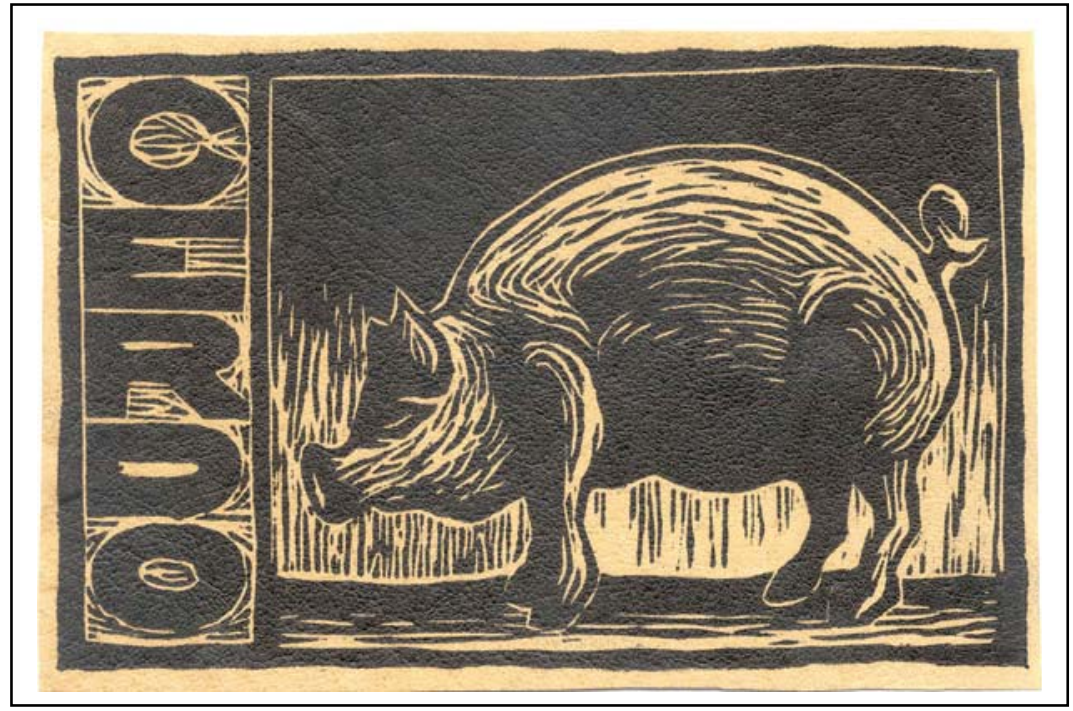

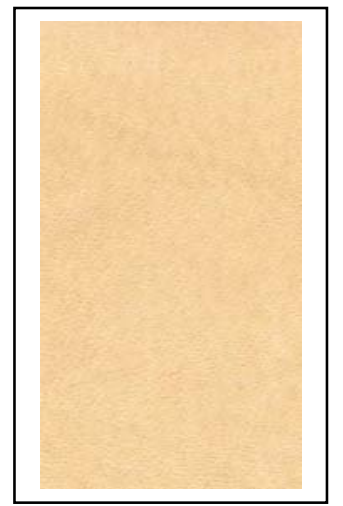

CÓDIGO: CE-001

TIPO DE PIEL: Cerdo

TINTA: Negro

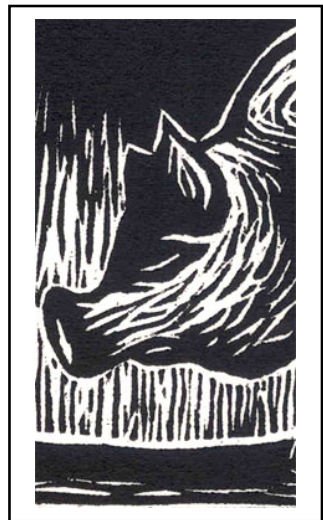

TÉCNICA: Xilografía

TONO DE PIEL: Claro

SUPERFICIE: Lado flor 


\section{CALIDAD: Muy buena}

Ejemplo de gran calidad, siendo uno de los mejores de todos los realizados. El negro cubre perfectamente la superficie de la piel, evitando la aparición de problemas que si aparecen al usar otro tipo de tintas como la blanca o la azul transparente.

MANCHA: De gran densidad y totalmente homogénea. La textura de la piel es visible pero podemos hacerla aún más patente si estampamos con menos presión. Si hacemos esto la tinta no penetrará hasta el fondo de los orificios capilares, dejándonos una atractiva textura. Sin embargo esta solución es de difícil control debido a los ya conocidos cambios de grosor de las pieles animales.

GRAFISMO: Sin ningún tipo de problema, el registro es adecuado.

CONTRASTE: El contraste es muy acusado y potente. La tinta negra contrasta de manera excepcional con el tono marrón claro de la piel de cerdo.

BRILLO: Debido al acabado casi mate de la piel utilizada, la de "forro" de cerdo, la estampa presenta un ligero brillo que no llega a perjudicar la correcta visión de la imagen. Si la superficie de la piel es uniforme, el brillo resultante también lo será. 


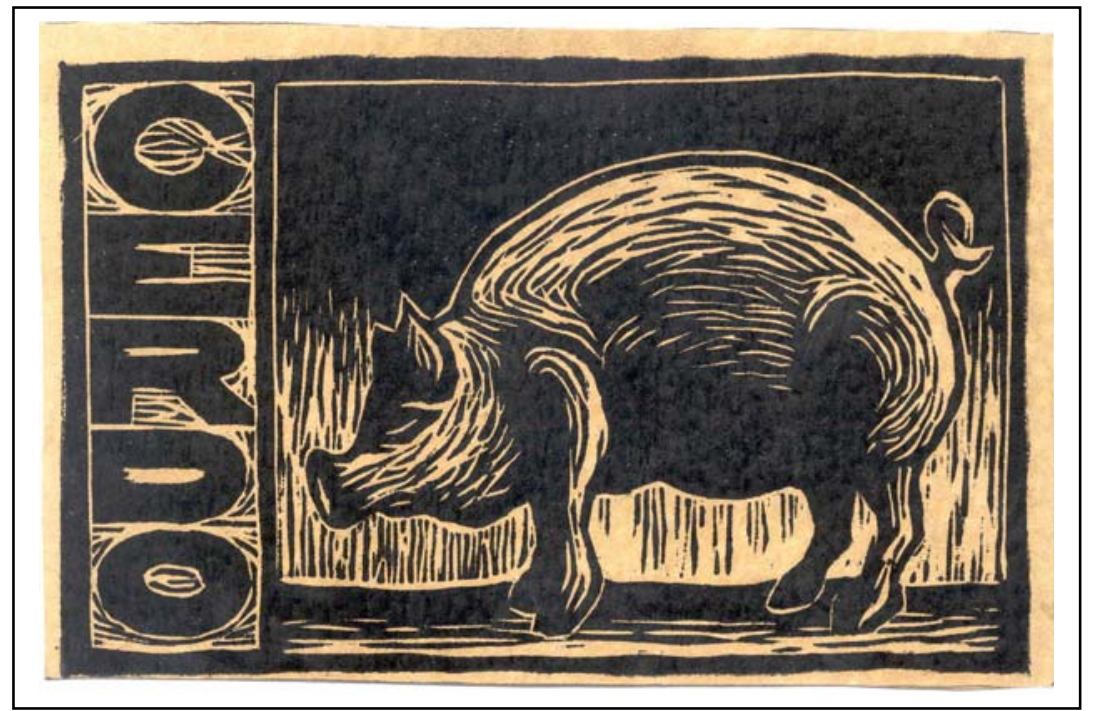

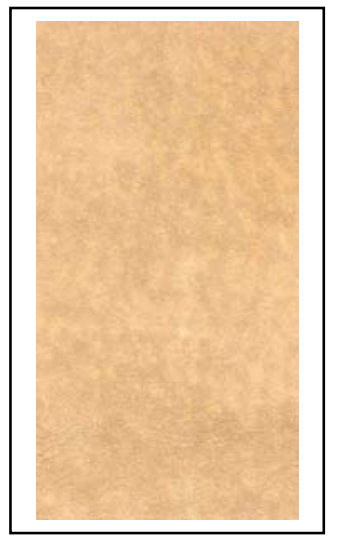

CÓDIGO: CE-002

TIPO DE PIEL: Cerdo

TINTA: Negro

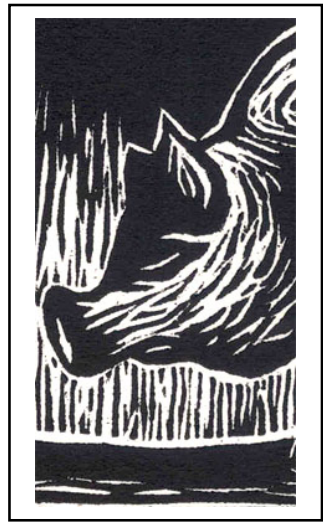

TÉCNICA: Xilografía

TONO DE PIEL: Claro

SUPERFICIE: Lado carne 


\section{CALIDAD: Muy buena}

Estampa de muy buena calidad al igual que la anterior. No presenta ningún problema específico aunque se debe comentar que al estampar sobre el lado carne podemos estampar con un ligero aumento de presión. Al no poseer ningún tipo de acabado satinado, la piel admite un pequeño exceso de presión si fuera necesario.

MANCHA: Regular y homogénea. En algunas pieles la textura propia del cerdo es visible incluso por el lado carne, por lo que se puede obtener dicha textura estampando con menor presión. Sin embargo la calidad y definición de ésta nunca será comparable a la lograda por el lado flor.

GRAFISMO: Literalmente perfecto, como si fuera sobre papel y no piel.

CONTRASTE: Prácticamente igual que en el lado flor, debido a que el forro de cerdo apenas presenta variaciones de tono entre ambas caras, flor y carne, que en otras pieles si que se producen. Obtenemos por tanto una imagen muy válida desde un punto de vista plástico.

BRILLO: Sobre este lado se consigue un fantástico acabado totalmente mate debido al afelpado de la superficie. Esto, unido a la homogeneidad de la mancha, hace de esta estampa una de las mejores de todo el estudio. 


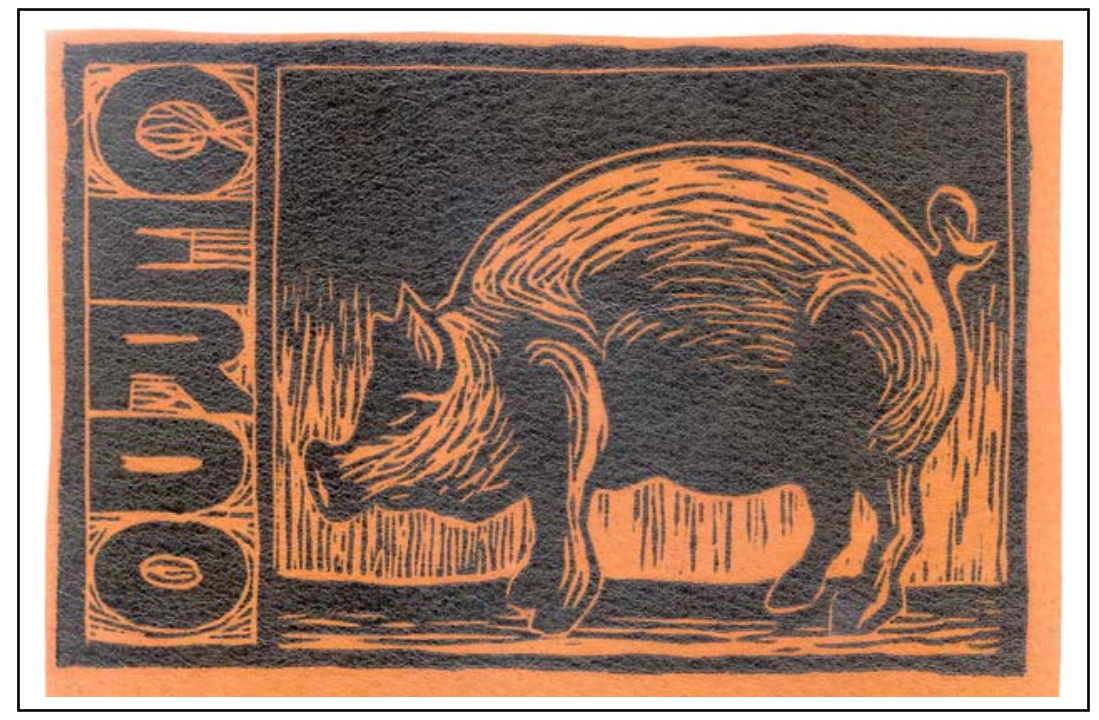

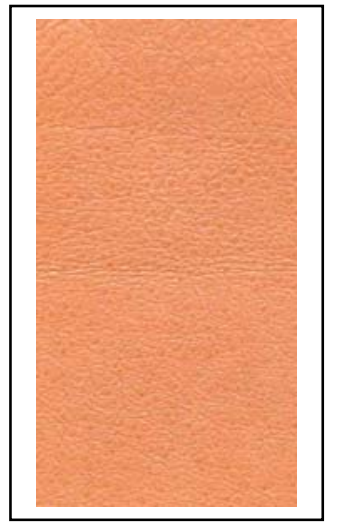

CÓDIGO: CE-003

TIPO DE PIEL: Cerdo

TINTA: Negro

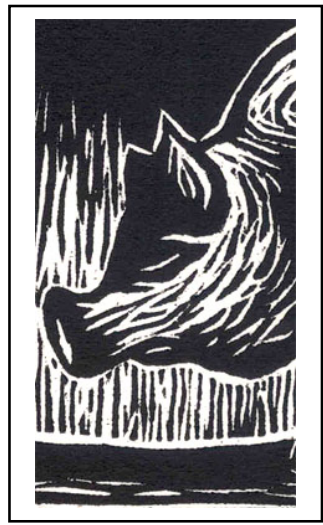

TÉCNICA: Xilografía

TONO DE PIEL: Medio

SUPERFICIE: Lado flor 


\section{CALIDAD: Muy buena}

Ejemplo de parecidas características a la realizada sobre la piel clara (CE-001), aunque con las lógicas diferencias de contraste y brillo provocadas por los cambios en la superficie de la piel.

MANCHA: Homogénea y sin ningún tipo de inconveniente. El mismo efecto de textura comentado para el ejemplo sobre la piel clara se puede conseguir en este caso concreto. Indicar que no todas las pieles de cerdo poseen la misma intensidad de textura, apreciándose importantes cambios entre unas y otras.

GRAFISMO: Al igual que en las estampas anteriores en este caso en concreto no aparecen inconvenientes. Los seños del grafismo se registran perfectamente, sin alteraciones de contornos ni irregularidades.

CONTRASTE: Al elevar el tono del fondo es obvio que la intensidad del contraste con la tinta será algo menor. Aún así la imagen resultante se aprecia sin problemas, siendo totalmente válida.

BRILLO: Presenta las mayores diferencias y problemas. Al ser una piel tintada en su superficie sin llegar a ser satinada, aparece un acabado ligeramente más brillante. Esto hace que la tinta negra adquiera un brillo algo molesto a la hora de apreciar la imagen. 


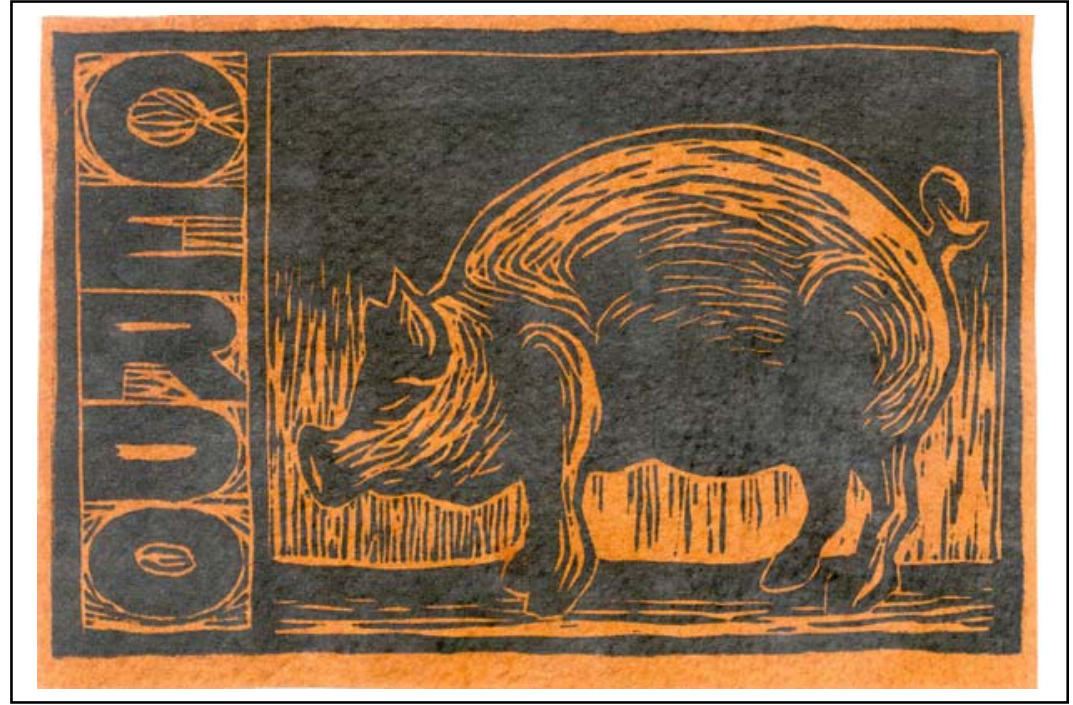

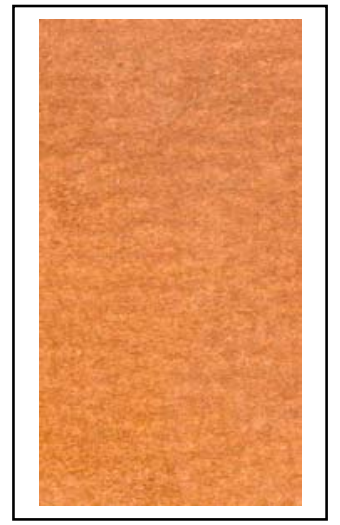

CÓDIGO: CE-004

TIPO DE PIEL: Cerdo

TINTA: Negro

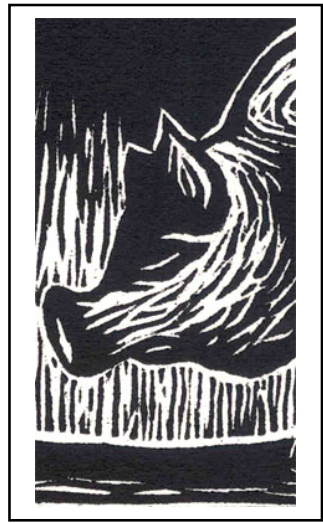

TÉCNICA: Xilografía

TONO DE PIEL: Medio

SUPERFICIE: Lado carne 


\section{CALIDAD: Muy buena}

Estampa muy parecida a su homóloga sobre el lado flor (CE-003), aunque con particularidades referentes a la homogeneidad de la mancha y el brillo.

MANCHA: A pesar de cubrir totalmente y de forma correcta la superficie de la piel, la mancha presenta un acabado heterogéneo e irregular. No es uniforme, observándose texturas que perturban la visión, las cuales tienen su origen en cambios en la naturaleza de la piel que no son visibles a simple vista.

GRAFISMO: Debido a la zona tan pequeña por donde se extiende la tinta no se llegan a observar tan claramente los defectos comentados con respecto a la mancha.

CONTRASTE: Las particularidades analizadas no influyen en la intensidad del contraste entre la tinta y el fondo. Al ser el color de éste último casi igual que el del lado flor, dicha intensidad de contraste será prácticamente la misma que la ya comentada.

BRILLO: Son precisamente irregularidades referentes al brillo las que hacen de esta estampa un ejemplo poco válido. Si en el lado flor el brillo era homogéneo y regular por toda la mancha de tinta, en esta ocasión los reflejos aparece en ciertas zonas concretas, mientras que en otras la tinta continúa mate. Puedes ser que ciertas irregularidades del tinte aplicado sobre la piel expliquen este comportamiento tan extraño. 


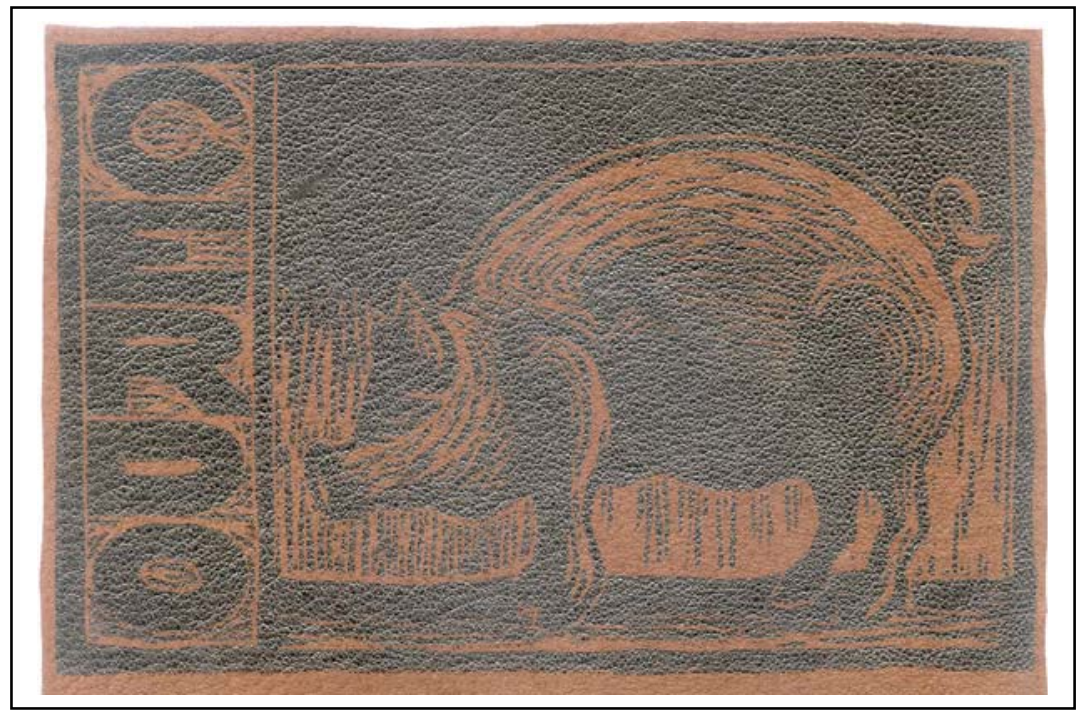

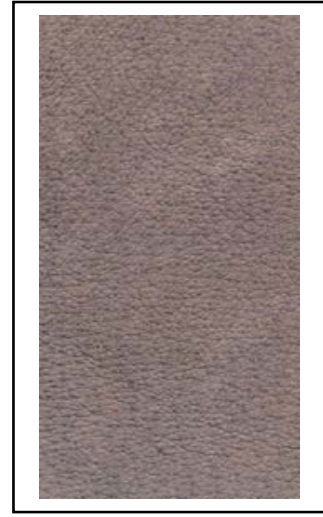

CÓDIGO: CE-005

TIPO DE PIEL: Cerdo

TINTA: Negro

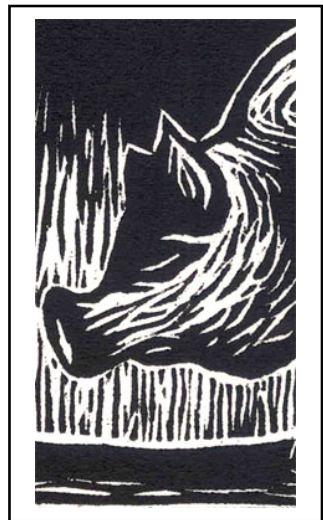

TÉCNICA: Xilografía

TONO DE PIEL: Oscuro

SUPERFICIE: Lado flor 


\section{CALIDAD: Mediocre}

Dentro de los ejemplos en negro sobre piel de cerdo ésta es la menos satisfactoria, no por problemas propios de la estampación, sino por distorsiones del brillo y del contraste. Estas irregularidades son provocadas por las características de la superficie de la piel.

MANCHA: De gran calidad y densidad. No presenta problemas ni defectos visibles. Como en todos los ejemplos sobre piel porcina con tinta negra la mancha xilográfica no presenta mayores dificultades y su estampación es totalmente correcta.

GRAFISMO: Debido a que la piel es algo más satinada, a igual presión que sobre otros tipos de pieles porcinas, los grafismos pueden presentar deformaciones en sus contornos, provocadas por una mala adhesión de la tinta a la superficie del soporte.

CONTRASTE: La imagen es difícilmente reconocible por efecto del escaso contraste. El tono tan elevado del tinte aplicado sobre la piel provoca que el contraste no sea tan intenso como en otras ocasiones, creándose una imagen oscura y poco clara.

BRILLO: La tinta negra adquiere un molesto brillo bastante intenso. La mayor presencia de colorante sobre la superficie de la piel provoca la aparición de dichos reflejos, los cuales impiden la correcta apreciación de la imagen. 


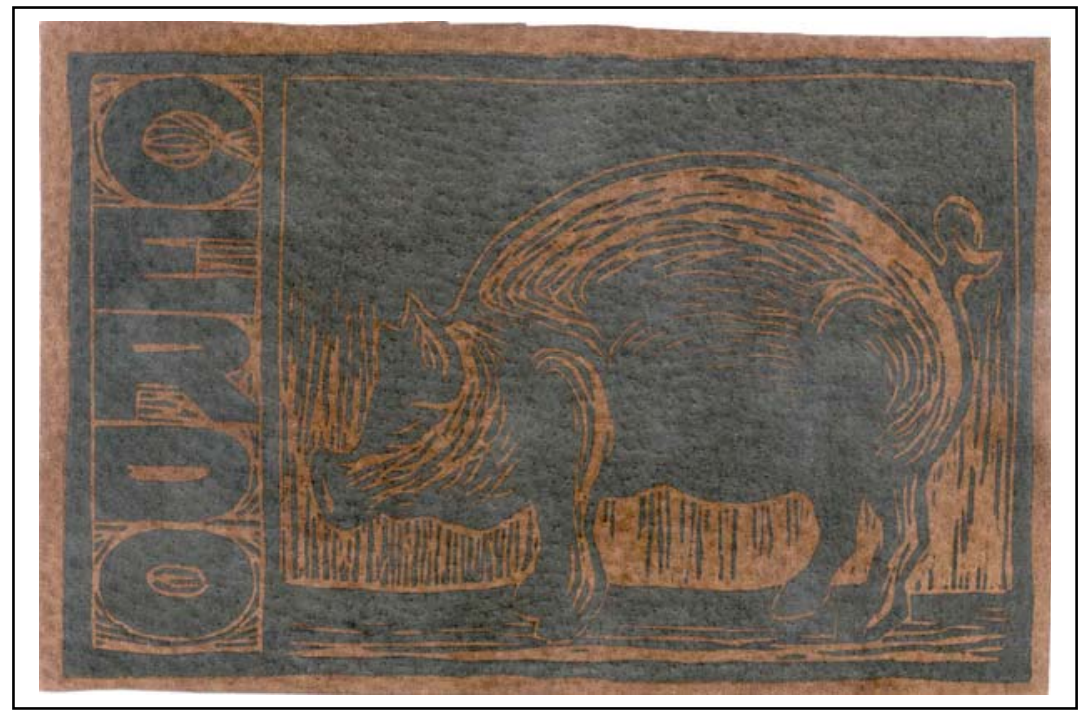

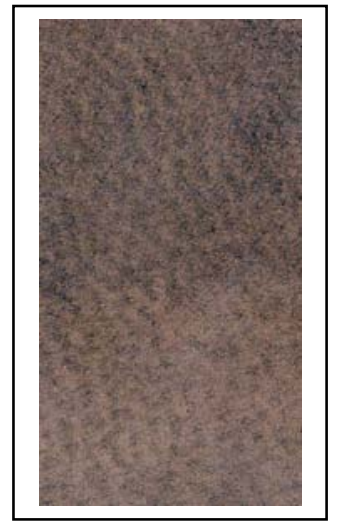

CÓDIGO: CE-006

TIPO DE PIEL: Cerdo

TINTA: Negro

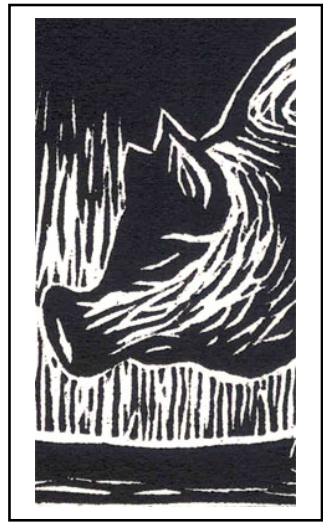

TÉCNICA: Xilografía

TONO DE PIEL: Oscuro

SUPERFICIE: Lado carne 


\section{CALIDAD: Mediocre}

Estampación de mediocre calidad dentro del grupo de imágenes sobre piel porcina. Presenta deficiencias en casi todos los factores y campos estudiados, siendo tan sólo los grafismos los únicos que resisten un análisis positivo.

MANCHA: Irregular y con alteraciones de saturación de tinta.

GRAFISMO: Mediocre, aunque no tan deficiente como la mancha. Seguramente la escasa amplitud de los trazos hace que las imperfecciones sean de más difícil apreciación que en las amplias zonas entintadas de la mancha.

CONTRASTE: Al igual que en lado flor el contraste es muy escaso, privando a la imagen de la necesaria fuerza expresiva para permitir una correcta visión.

BRILLO: No aparece el acusado brillo del lado flor (CE-005), pero encontramos unas incómodas variaciones del satinado que resultan muy molestas. Se observa un acabado levemente satinado y ceroso con zonas de mayor intensidad de brillo, creando una imagen molesta. Sería preferible un brillo homogéneo como el del lado flor a un acabado irregular e incontrolable como el que aparece en este ejemplo. 

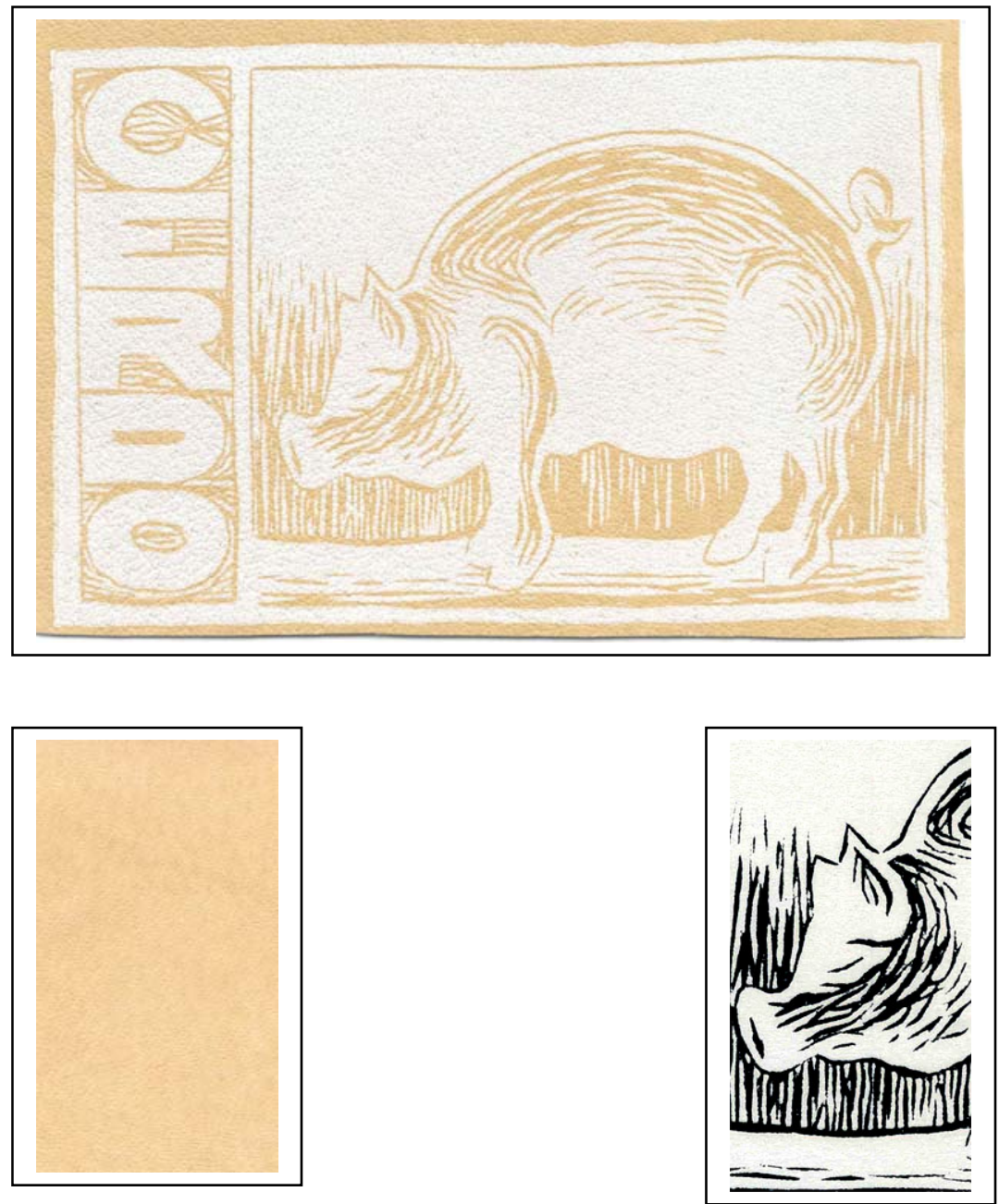

CÓDIGO: CE-007

TÉCNICA: Xilografía

TIPO DE PIEL: Cerdo

TONO DE PIEL: Claro

TINTA: Blanca

SUPERFICIE: Lado flor 


\section{CALIDAD: Buena}

Las estampaciones con blanco sobre la piel de cerdo son las que se comportan de manera más satisfactoria de las realizadas en este estudio. El tipo de piel "cerdo flor", aquella usada para los forros de los zapatos y también llamada "forro", se muestra idónea para casi todo tipo de trabajos.

MANCHA: Muy uniforme y de buena calidad, el blanco de la tinta remarca y refuerza la textura característica de la piel porcina, ya de por sí bastante evidente. La piel de cerdo presenta profundos agujeros a los que, en muchas ocasiones, no llega la tinta, quedando intactos y dotando a la mancha de una interesante textura.

GRAFISMO: Perfectamente estampado. Remarcar que, debido a que la piel de cerdo es muy flexible, si estampamos con una presión excesiva ésta nos provocará manchas en los contornos. Dichas irregularidades serán especialmente visibles y perjudiciales en los grafismos.

CONTRASTE: A pesar de lo claro de la piel y de que no se llega a conseguir un blanco verdadero, el contraste es lo suficientemente intenso como para hacer visible la imagen.

BRILLO: La piel de "cerdo flor" no presenta nunca acabados demasiado brillantes ni satinados. Esto hace que, unida a la tinta blanca totalmente mate, se cree una superficie sin ningún tipo de reflejo. 

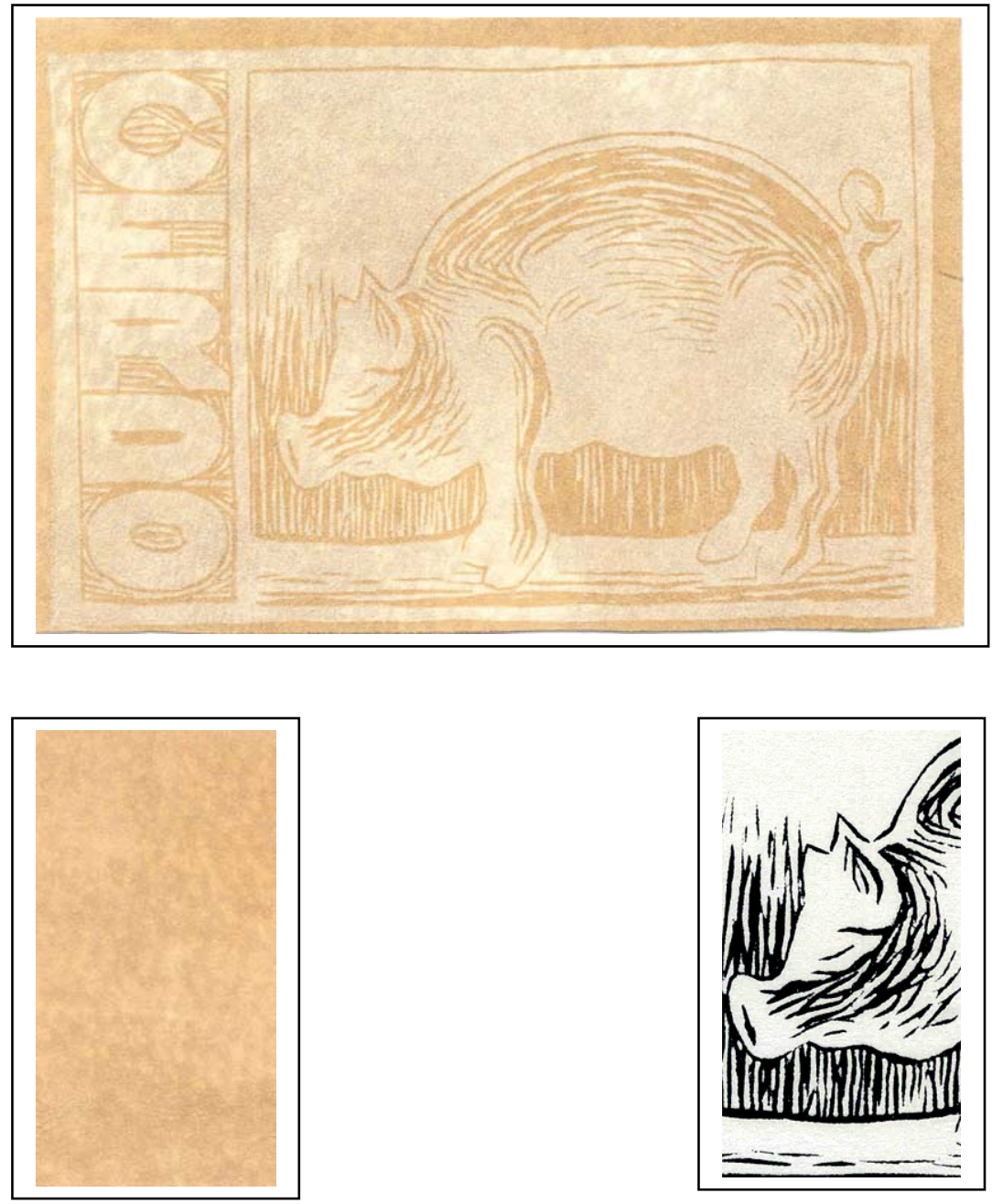

CÓDIGO: CE-008

TÉCNICA: Xilografía

TIPO DE PIEL: Cerdo

TONO DE PIEL: Claro

TINTA: Blanca

SUPERFICIE: Lado carne 


\section{CALIDAD: Mediocre}

La piel de "cerdo flor" es una de las pocas en las que el lado carne es igual o más oscuro que el lado flor, lo que provocará cambios en algunas de las consideraciones apreciadas. Este tipo de piel posee un marcado afelpado en su lado carne el cual condicionará las estampas a realizar, sobre todo aquellas con tinta blanca.

MANCHA: No muy uniforme ni homogénea. Ésto es debido al afelpado de la piel y a la imposibilidad de la tinta para cubrir dicha superficie con normalidad. Presenta ciertas irregularidades que son debidas a las diferencias de texturas en el afelpado del lado carne. Tras tener en cuenta estas consideraciones el resultado es bastante satisfactorio.

GRAFISMO: El afelpado de la piel hace que los grafismos pierdan nitidez y definición, presentando un aspecto mediocre.

CONTRASTE: A pesar de que el fondo es algo más oscuro que el lado flor el contraste es mucho menor por motivo del efecto ya comentado de la tinta blanca sobre superficies con textura rugosa. En efecto, el blanco se convierte en un gris claro que no es capaz de crear un contraste apropiado con el tono del soporte.

BRILLO: Inexistente. Al unir una tinta blanca y una superficie afelpada el brillo desaparece por completo en todas las ocasiones. 

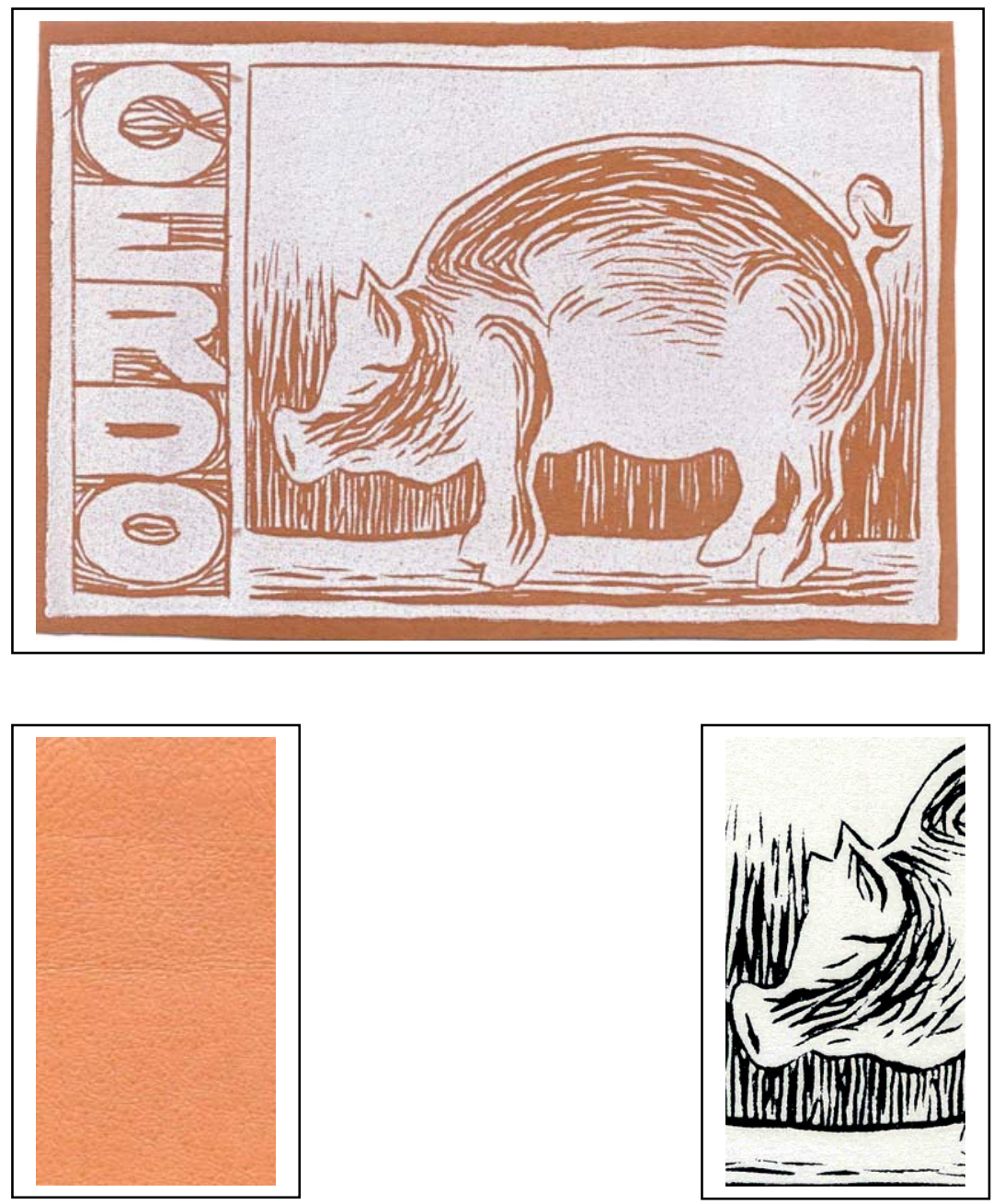

CÓDIGO: CE-009

TÉCNICA: Xilografía

TIPO DE PIEL: Cerdo

TONO DE PIEL: Medio

TINTA: Blanca

SUPERFICIE: Lado flor 


\section{CALIDAD: Muy buena}

Esta estampa es una de las mejores de todas las realizadas en el estudio de imágenes xilográficas. Las características de la piel de "forro" de cerdo son ideales para este tipo de estampas.

MANCHA: De bastante buena calidad, muy uniforme y sin variaciones ni imperfecciones. Tan sólo hacer notar el acabado ligeramente "granulado" de la tinta blanca, aunque señalando que no es un fenómeno exclusivo de las estampaciones sobre piel sino que se observa también en imágenes realizadas sobre papel.

GRAFISMO: Muy buen resultado y definición.

CONTRASTE: Muy correcto y lo suficientemente intenso como para ser capaz de crear una imagen atractiva y perfectamente reconocible. La tinta blanca nunca alcanza el tono de saturación que sería deseable pero en este caso el contraste con el fondo es válido y satisfactorio.

BRILLO: Prácticamente inexistente. Podría decirse que la tinta blanca elimina el tenue brillo que posee la propia piel, obteniéndose una superficie totalmente mate en las zonas entintadas de blanco. Este es un resultado totalmente opuesto al que se observa al usar tintas negras 0 transparentes. 

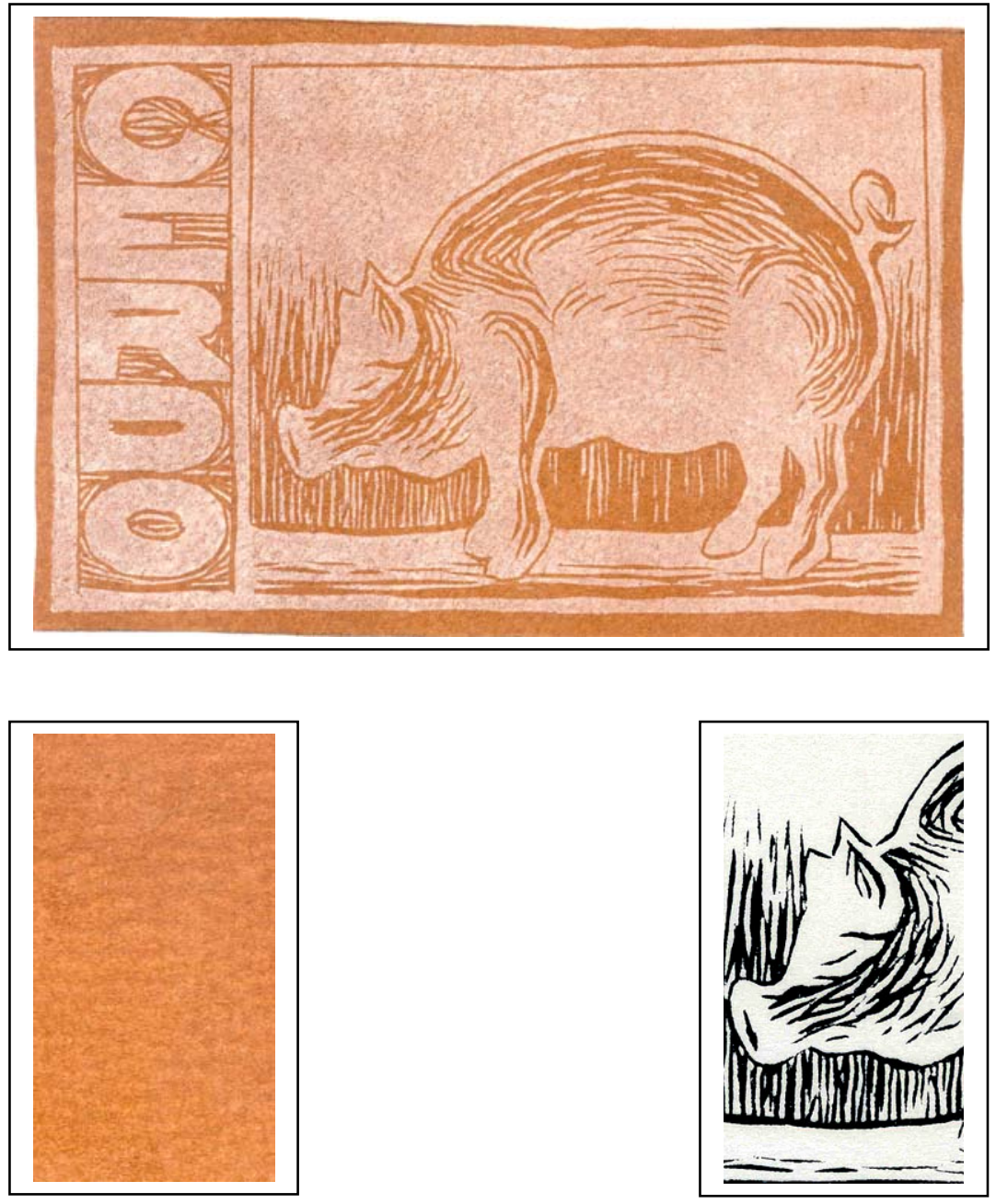

CÓDIGO: CE-010

TÉCNICA: Xilografía

TIPO DE PIEL: Cerdo

TONO DE PIEL: Medio

TINTA: Blanca

SUPERFICIE: Lado carne 


\section{CALIDAD: Mediocre}

En esta estampa vemos un ejemplo claro de cómo la misma tinta produce efectos totalmente distintos aplicada en uno u otro lado de la misma piel. En este caso se muestra como una solución de mucha menos calidad o, en todo caso, de resultados radicalmente distintos a los obtenidos por el lado flor de la misma piel.

MANCHA: Algo irregular en su homogeneidad y saturación, presentando zonas de menor cantidad de tinta provocadas por imperfecciones del acabado afelpado del lado carne. Aún así podría resultar interesante según los efectos deseados en la estampación.

GRAFISMO: Perfecto en sus contornos y su definición, no así en su saturación de tinta, la cual al igual que la de la mancha ha sufrido cambios radicales.

CONTRASTE: Como se ha comentado la tinta blanca, al contactar con la superficie afelpada del lado carne, se convierte en un gris muy alejado del blanco verdadera que sería deseable. Por consiguiente el contraste será de mucha menor intensidad que en el lado flor, aunque sin llegar a hacer difícil la comprensión y correcta visión de la imagen.

BRILLO: Nulo, lógico al unir tinta blanca y superficie afelpada. 


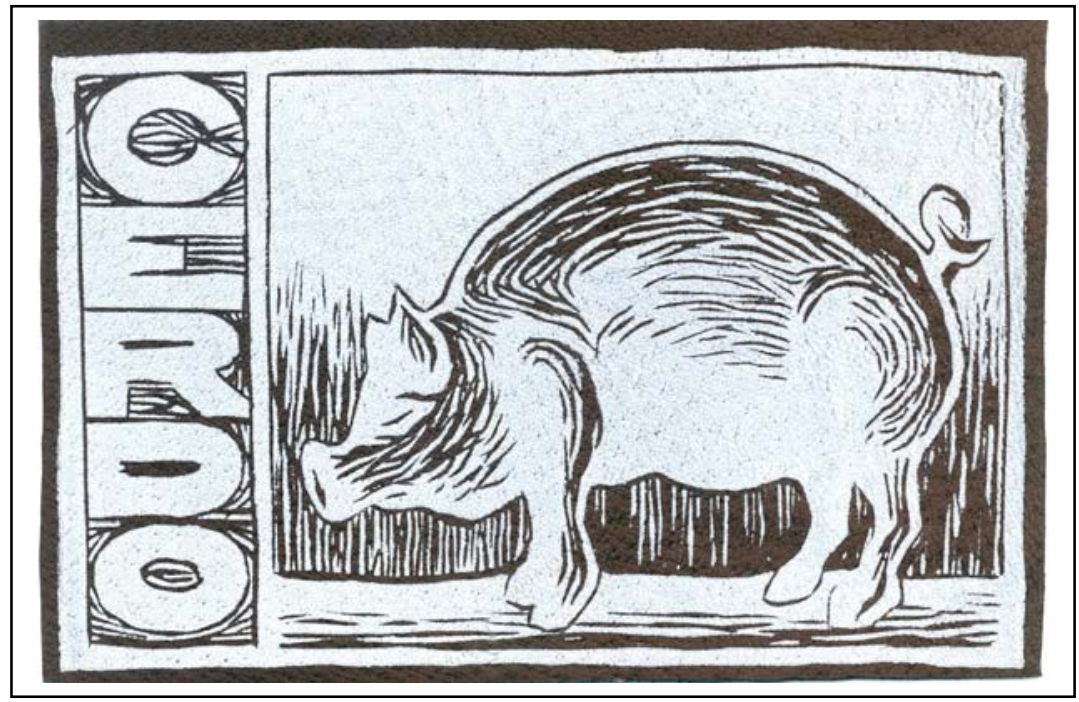

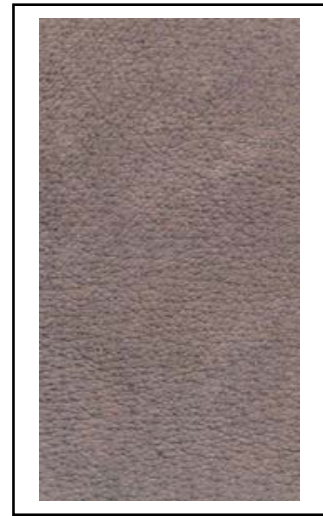

CÓDIGO: CE-011

TIPO DE PIEL: Cerdo

TINTA: Blanca

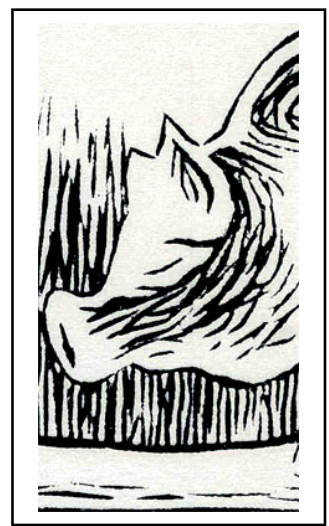

TÉCNICA: Xilografía

TONO DE PIEL: Oscuro

SUPERFICIE: Lado flor 


\section{CALIDAD: Buena}

Estampa de gran calidad debido a las características de la piel porcina y a las óptimas relaciones de contraste entre el fondo y la tinta con la que se ha estampado la imagen.

MANCHA: De muy buen resultado y sin defectos visibles. Se pueden apreciar los orificios propios de los folículos capilares tan característicos de la piel de cerdo. Como ya se ha comentado este efecto puede favorecerse mediante una estampación con la mínima presión posible, en cuyo caso estos orificios serán perfectamente visibles dotando a la imagen de una textura particular. Sin embargo nunca llega a alcanzar el grado de intensidad de blanco que sería deseable.

GRAFISMO: Sin problemas ni defectos. Apenas presentas dificultades y los grafismos se registran con total fidelidad y limpieza.

CONTRASTE: Optimo. El elevado tono marrón oscuro de la piel hace destacar perfectamente la imagen estampada en blanco. Además la tinta blanca alcanza una muy buena intensidad lo que provoca el comentado contraste.

BRILLO: Nulo. Como ya se ha comentado la tinta blanca llega a eliminar el leve brillo encerado que pudiera presentar la piel. En este caso no ocurre como con la tinta negra la cual, sobre esta misma superficie, crea un incomodísimo brillo. 


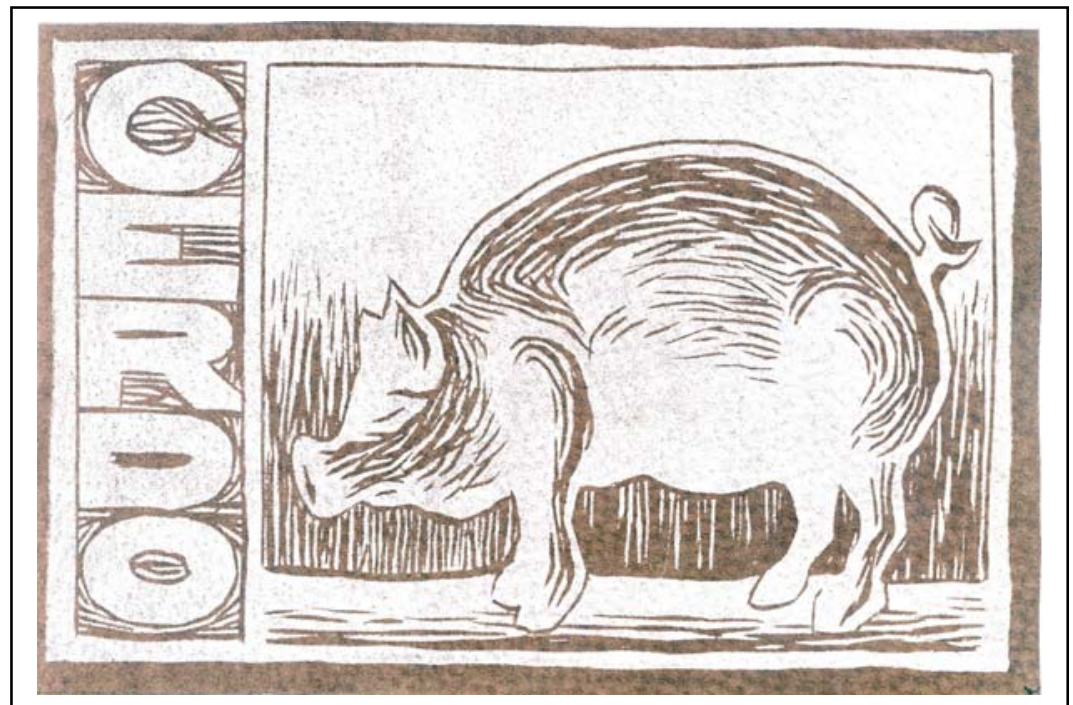

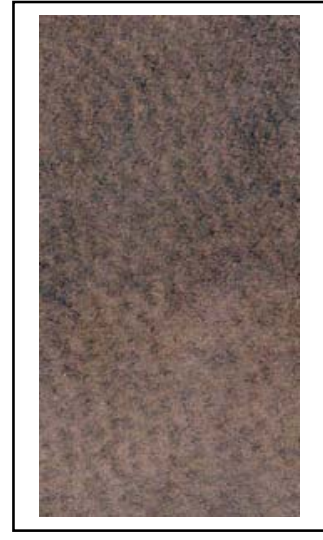

CÓDIGO: CE-012

TIPO DE PIEL: Cerdo

TINTA: Blanca

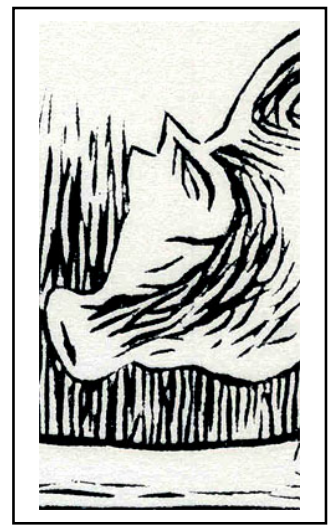

TÉCNICA: Xilografía

TONO DE PIEL: Oscuro

SUPERFICIE: Lado carne 


\section{CALIDAD: Buena}

Imagen muy curiosa y bastante peculiar debido a las características que adopta la tinta blanca al ser estampada sobre este lado carne de la propia piel oscura. Bien controlada y asumiendo mínimas imperfecciones proporciona resultados curiosos e interesantes.

MANCHA: Bastante uniforme por lo general, aunque denota ligeros cambios de tono y saturación provocados por cambios en la superficie de la piel. Estas variaciones son incontrolables pero dotan al resultado final de cierta riqueza plástica. Son apreciables los orificios de los pelos pero en este caso, al contrario de lo que ocurría en el lado flor (CE-011), se presentan no como minúsculos puntos oscuros, sino como zonas con mayor saturación de tinta y por lo tanto más blancas.

GRAFISMO: Perfecto y sin mayores problemas.

CONTRASTE: A pesar de ocurrir algo parecido a lo ya comentado con la piel media en su lado carne (CE-010), un descenso del tono de saturación de blanco hasta llegar a un gris pálido, el contraste es bastante acentuado. Se crea por tanto una imagen de gran calidad y plasticidad.

BRILLO: Nulo. La unión de la superficie afelpada del lado carne y la tinta blanca impide la aparición de cualquier tipo de brillo que pudiera interferir en la imagen y su correcta lectura y visión. 


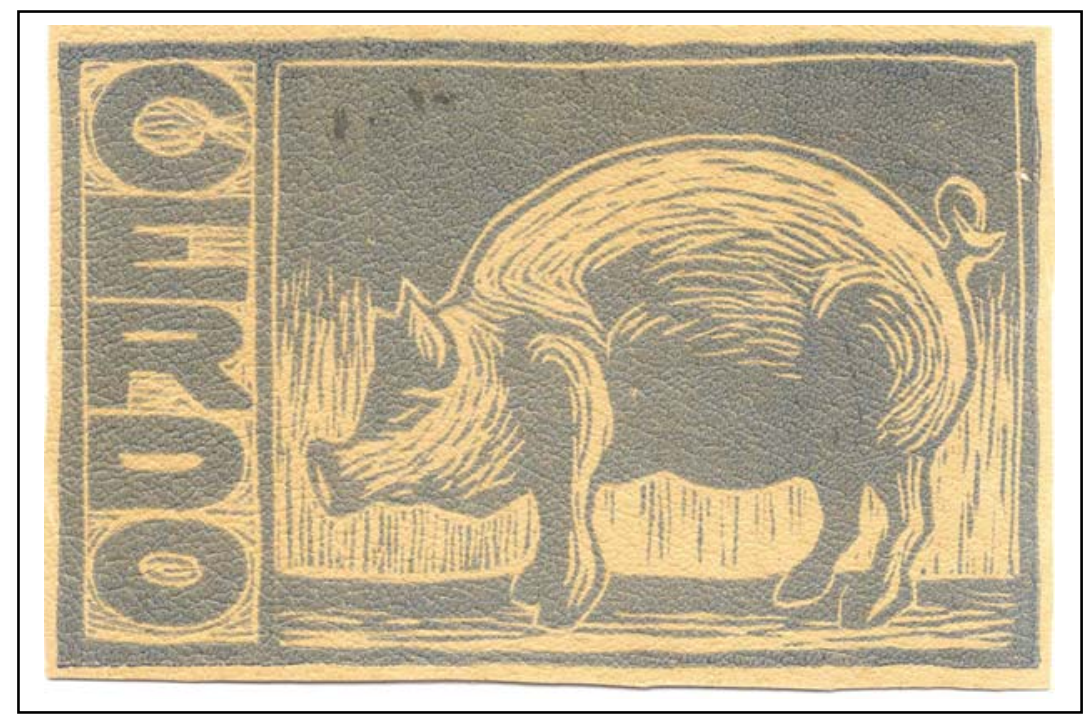

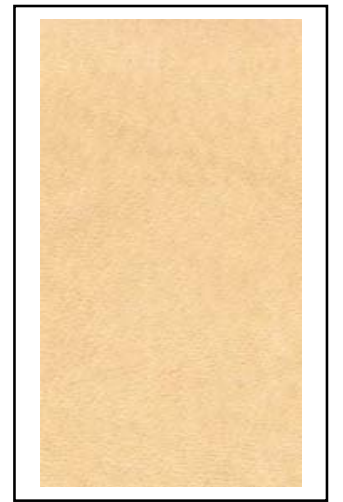

CÓDIGO: CE-013

TIPO DE PIEL: Cerdo

TINTA: Azul traslúcido

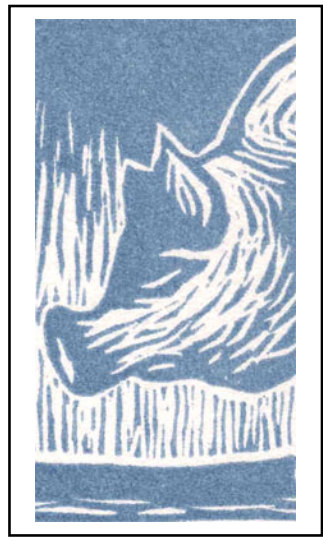

TÉCNICA: Xilografía

TONO DE PIEL: Claro

SUPERFICIE: Lado flor 


\section{CALIDAD: Muy buena}

Comienza con esta estampa la serie de imágenes con el azul transparente. Debido al color ocre de la piel y a la transparencia de la propia tinta el color resultante cambia totalmente hasta convertirse en un azul verdoso casi gris. De todas formas es una estampa de bastante nivel y buen resultado.

MANCHA: Muy homogénea y de gran calidad. Aparecen ciertas anomalías en la zona superior izquierda pero son debidas a imperfecciones de la superficie de la piel. También se observa que la tinta se introduce en las hendiduras existentes entre los orificios de los folículos capilares, dando lugar a una acentuación de la textura de la piel.

GRAFISMO: Bastante buen resultado, si bien dada la gran transparencia de la tinta hay ciertos grafismos de pequeño grosor que se hacen casi imperceptibles.

CONTRASTE: A pesar de la tinta tan leve y débil el contraste aún sigue siendo fuerte como para crear una imagen atractiva y plásticamente válida.

BRILLO: Aparece un ligero brillo provocado por la gran cantidad de base transparente que contiene la tinta. A pesar de ello los reflejos nunca llegan a resultar molestos y no interfieren en la correcta lectura de la estampa. 


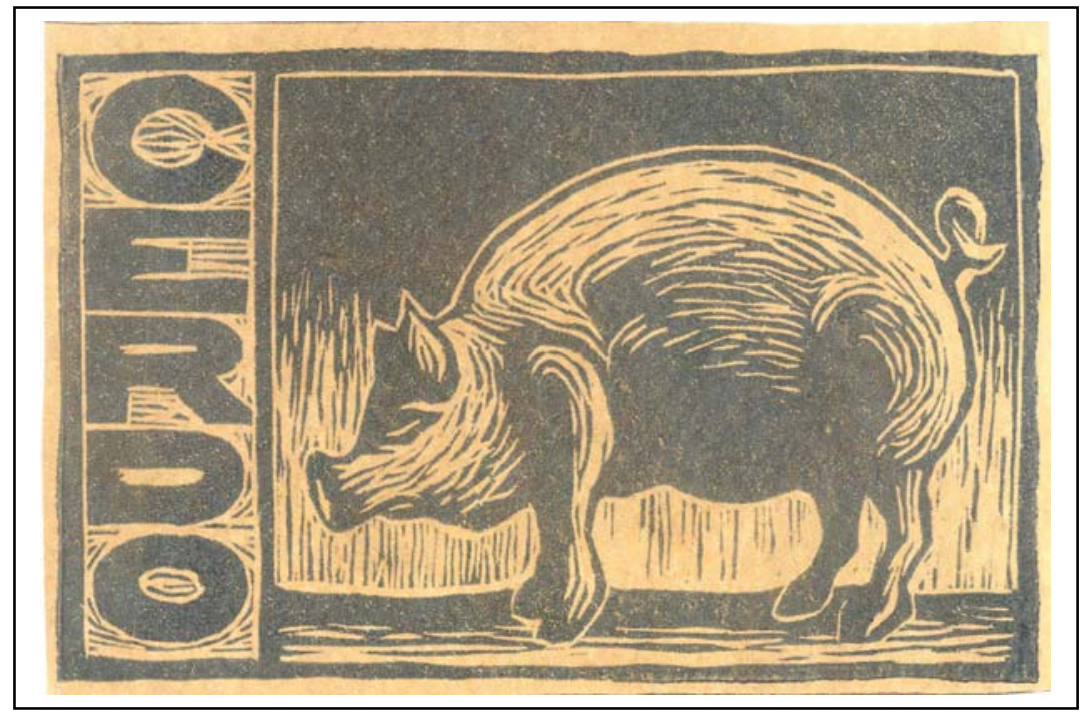

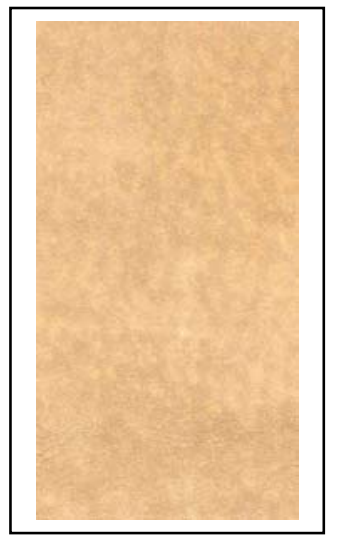

CÓDIGO: CE-014

TIPO DE PIEL: Cerdo

TINTA: Azul traslúcido

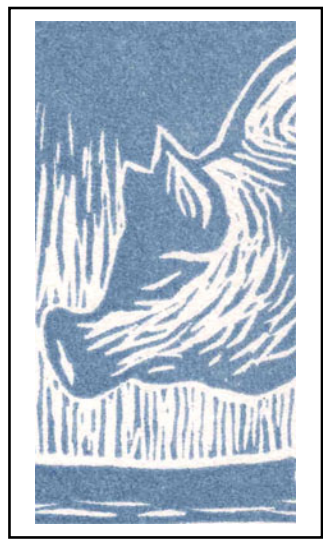

TÉCNICA: Xilografía

TONO DE PIEL: Claro

SUPERFICIE: Lado carne 


\section{CALIDAD: Buena}

Esta estampa presenta bastantes diferencias con su compañera en el lado flor (CE-013). Estas variaciones se deben ante todo al acabado afelpado del lado interno de la piel, el cual cambia las características del tono de tinta resultante.

MANCHA: La mancha no es totalmente uniforme por efecto de las irregularidades presentes en la superficie de la piel, las cuales no son ocultadas en absoluto por la tinta transparente. También se hacen patentes los orificios de los pelos en este caso como minúsculas zonas sin tinta azul. A pesar de todo la mancha es suficientemente válida como para crear una imagen atractiva.

GRAFISMO: Mucho mejor que en el lado flor; ésto es provocado porque el tono azul se ha oscurecido, lo que permite que todos los seños y líneas del grafismo queden perfectamente reflejados en la imagen.

CONTRASTE: Mejor que en el lado flor como consecuencia de lo ya comentado. La tinta azul transparente, al contacto con la superficie afelpada del lado carne, produce un tono bastante más oscuro que sobre el lado flor. Esto provoca que el contraste sea más pronunciado y por tanto obtengamos una imagen más potente.

BRILLO: Apenas perceptible, casi nulo, a pesar de la gran cantidad de base transparente que contiene la tinta utilizada (alrededor del 90\%). 

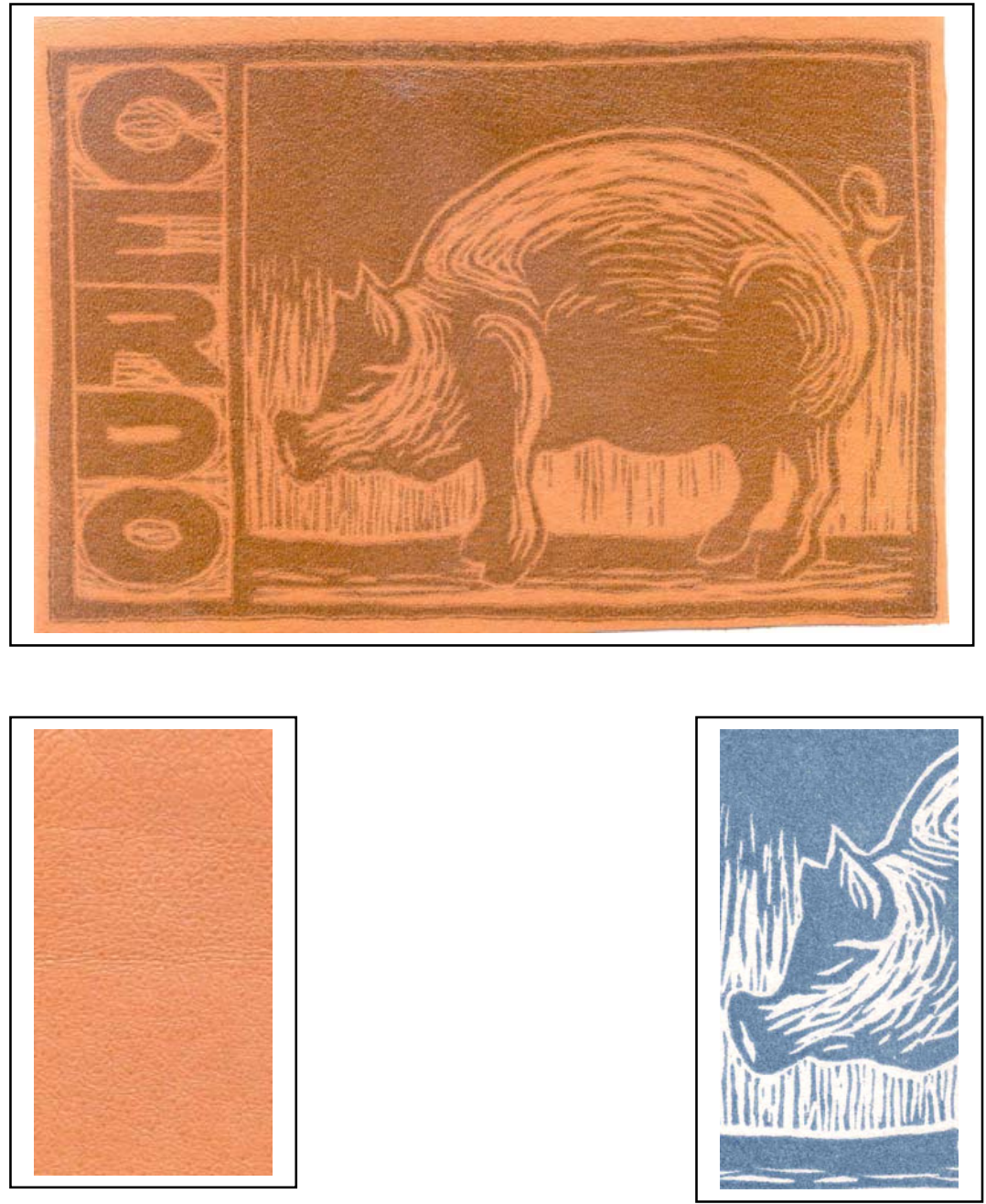

CÓDIGO: CE-015

TÉCNICA: Xilografía

TIPO DE PIEL: Cerdo

TONO DE PIEL: Medio

TINTA: Azul traslúcido

SUPERFICIE: Lado flor 


\section{CALIDAD: Buena}

Ejemplo muy curioso y que arroja interesantes datos acerca de las tintas transparentes y su utilización sobre un soporte piel.

MANCHA: Muy homogénea y estable. El uso de la tinta transparente evidencia y acentúa la textura natural de la piel, en este caso oscureciendo los orificios de los pelos y las texturas entre ellos. Debido a la extrema transparencia de la tinta el color azul de la misma se ha transformado totalmente. Se ha producido una mezcla visual entre el tono marrón rojizo de la piel y el azul de la tinta, obteniéndose un marrón un tanto más oscuro que el original del fondo y con un ligerísimo toque verdoso.

GRAFISMO: Por efecto de la transparencia de la tinta en los grafismos observamos irregularidades que si bien son apreciables en un estudio minucioso, no interfieren en la lectura general de la imagen.

CONTRASTE: El contraste se ha visto reducido en gran medida aunque todavía es reconocible la imagen estampada. Sin embargo carece de la fuerza necesaria para ser la única tinta que defina la estampa.

BRILLO: Por efecto del colorante de la piel y de su acabado ligeramente más satinado que en la piel clara, aparece un brillo en las zonas cubiertas de tinta. Si bien es bastante evidente dicho brillo no resulta demasiado molesto. 


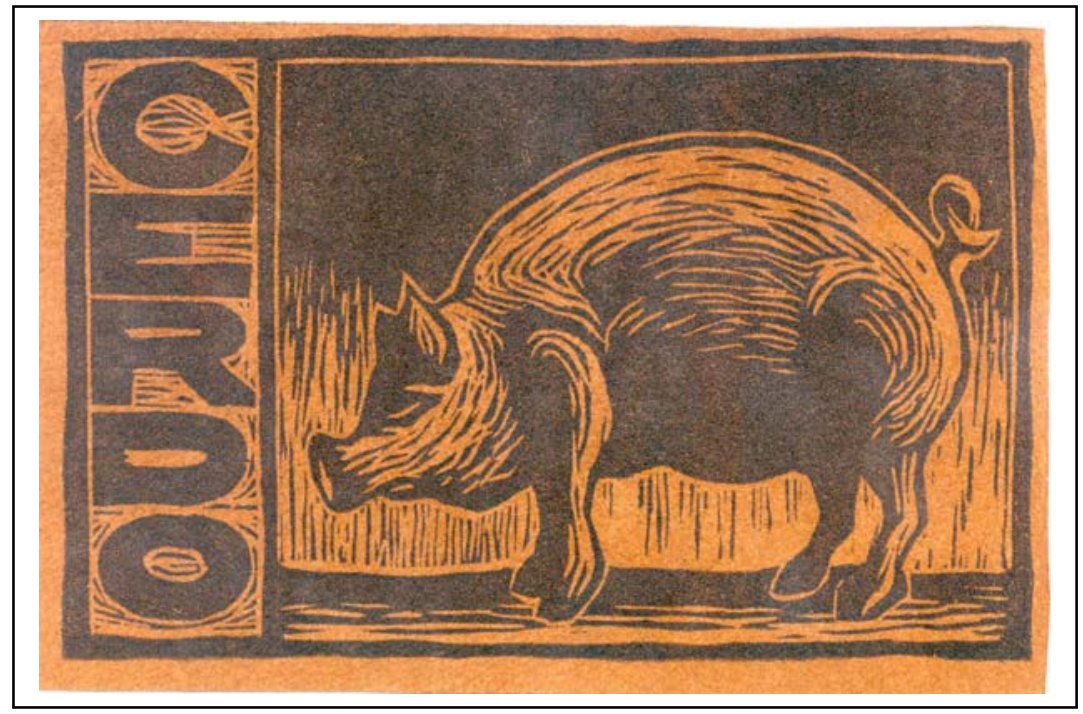

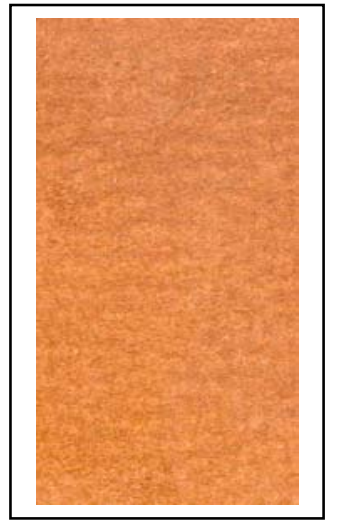

CÓDIGO: CE-016

TIPO DE PIEL: Cerdo

TINTA: Azul traslúcido

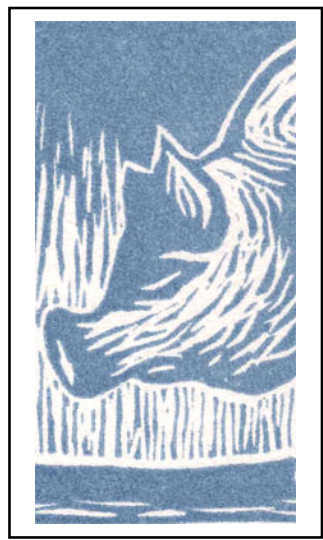

TÉCNICA: Xilografía

TONO DE PIEL: Medio

SUPERFICIE: Lado carne 


\section{CALIDAD: Muy buena}

Excelente calidad de estampación y registro, y muy interesante a la hora de comprobar el comportamiento de las tintas transparentes sobre el lado carne de las pieles.

MANCHA: De gran nivel y homogeneidad a pesar de la gran cantidad de preparación traslúcida presente en la mezcla. Si el trozo de piel no presenta irregularidades manifiestas, la tinta se extenderá sobre la superficie de manera inmaculada. El color azul de la tinta se ha transformado radicalmente hasta convertirse en un marrón violáceo oscuro o un granate oscuro. Este cambio es mucho más evidente que en el lado flor ya que, como hemos comentado anteriormente, las tintas transparentes se oscurecen sobremanera al contacto con la superficie afelpada del lado carne. De todas formas el color obtenido es de un gran interés e imposible de obtener por otros medios que no sean los de usar una tinta de este tipo.

GRAFISMO: Perfecto, sin los problemas observados en el lado flor (CE-015).

CONTRASTE: Al oscurecerse toda la tinta el contraste es muy satisfactorio, mucho más que en su homóloga del lado flor. Se crea una imagen perfectamente legible y de gran fuerza plástica.

BRILLO: Debido al afelpado de la piel el brillo desaparece casi por completo, limitándose a minúsculos puntos diseminados por la superficie entintada. 


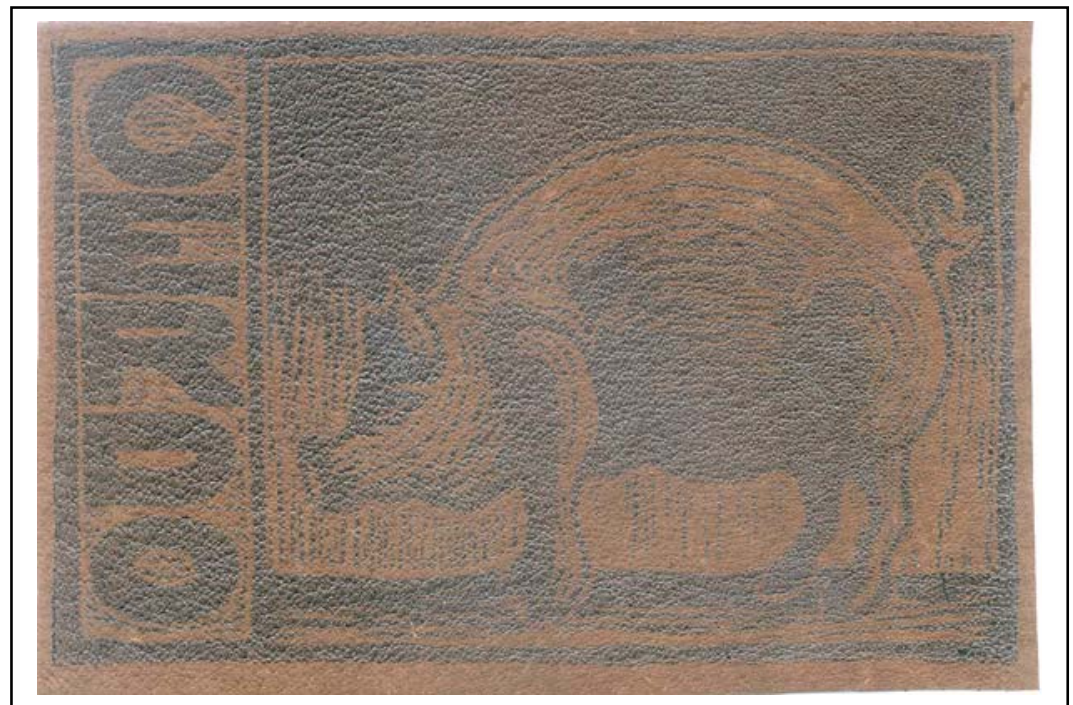

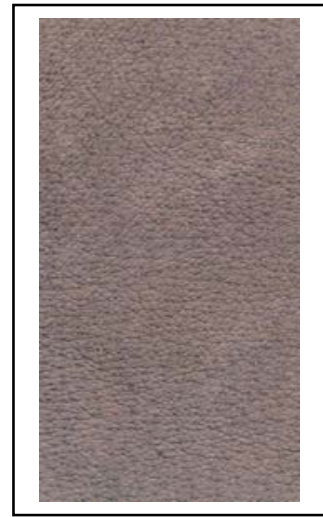

CÓDIGO: CE-017

TIPO DE PIEL: Cerdo

TINTA: Azul traslúcido

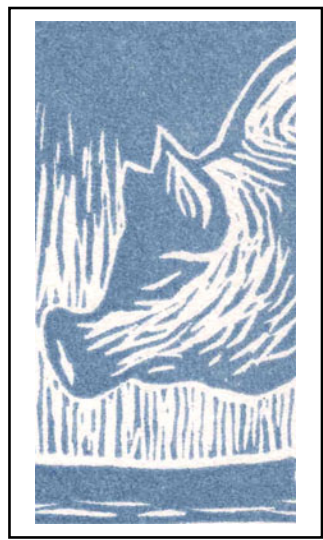

TÉCNICA: Xilografía

TONO DE PIEL: Oscuro

SUPERFICIE: Lado flor 


\section{CALIDAD: Mediocre}

Debido al tono tan oscuro de esta piel la tinta transparente pierde casi toda su razón de ser en estampas sobre este tipo de piel porcina. De hecho los problemas vendrán dados casi exclusivamente por inconvenientes de contraste y brillo.

MANCHA: Perfecta a pesar de lo difícil de su apreciación. La mancha es homogénea y regular sin presentar mayores dificultades de estampación y registro.

GRAFISMO: Se pierde un tanto por efecto de lo oscuro del soporte piel y por problemas ya aparecidos sobre la piel de tono medio. Estos últimos son pequeñas irregularidades en ciertos trazos muy finos, aunque no dificultan demasiado la lectura general de la imagen.

CONTRASTE: Mínimo. Se trata sin lugar a dudas del gran problema de esta estampa y condiciona a todos los demás factores de la misma. Dificulta sobremanera la lectura de la imagen hasta hacerla casi imperceptible.

BRILLO: Al unirse la gran cantidad de tinta junto con la preparación traslúcida, aparece un brillo excesivo que dificulta e incomoda la visión de la estampa. Unido al mínimo contraste hace de este ejemplo uno de los menos positivos de todo el estudio. 


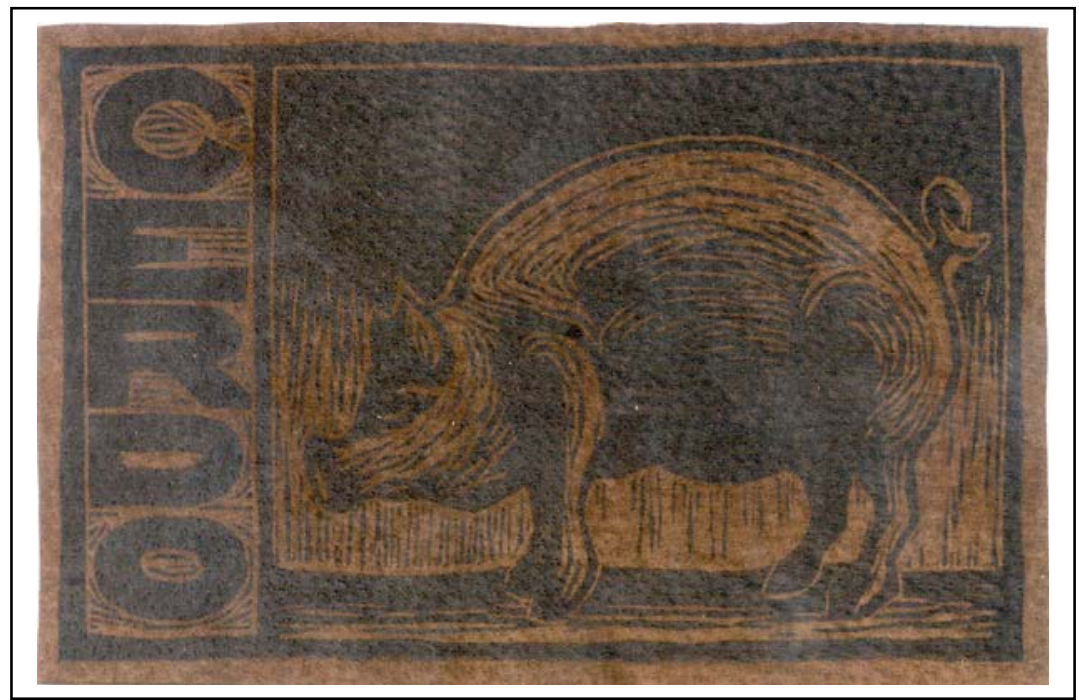

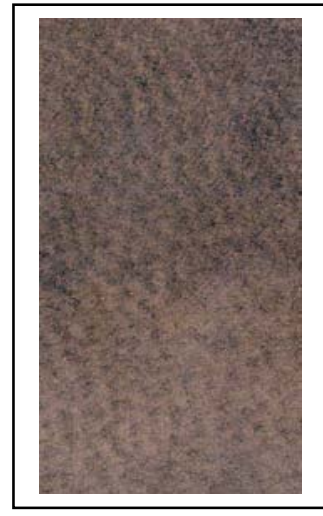

CÓDIGO: CE-018

TIPO DE PIEL: Cerdo

TINTA: Azul traslúcido

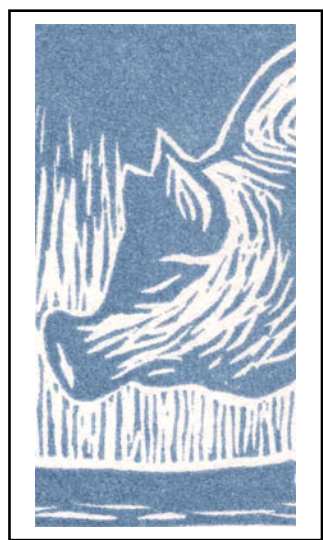

TÉCNICA: Xilografía

TONO DE PIEL: Oscuro

SUPERFICIE: Lado carne 


\section{CALIDAD: Mediocre}

Ejemplo de mediocre nivel debido a lo inapropiado del uso de la tinta transparente sobre una superficie tan oscura. Sin embargo se muestra algo mejor que la estampa sobre el lado flor (CE-017).

MANCHA: Bastante uniforme aunque la tinta pone de manifiesto la textura de la piel porcina en su lado carne, ésto es, minúsculos agujeros y orificios pertenecientes a los pelos del animal.

GRAFISMO: Correcto y sin grandes problemas ni inconvenientes.

CONTRASTE: Muy escaso aunque algo mejor que en su homóloga del lado flor. Sin embargo sigue sin ser lo suficientemente pronunciado como para hacer la imagen legible sin dificultad.

BRILLO: Aparece un ligero brillo irregular sobre las superficies entintadas. Esto se debe a la masiva presencia de tintes y ceras sobre la superficie del soporte, lo que unido a la tinta transparente provoca la aparición de dichos brillos. 


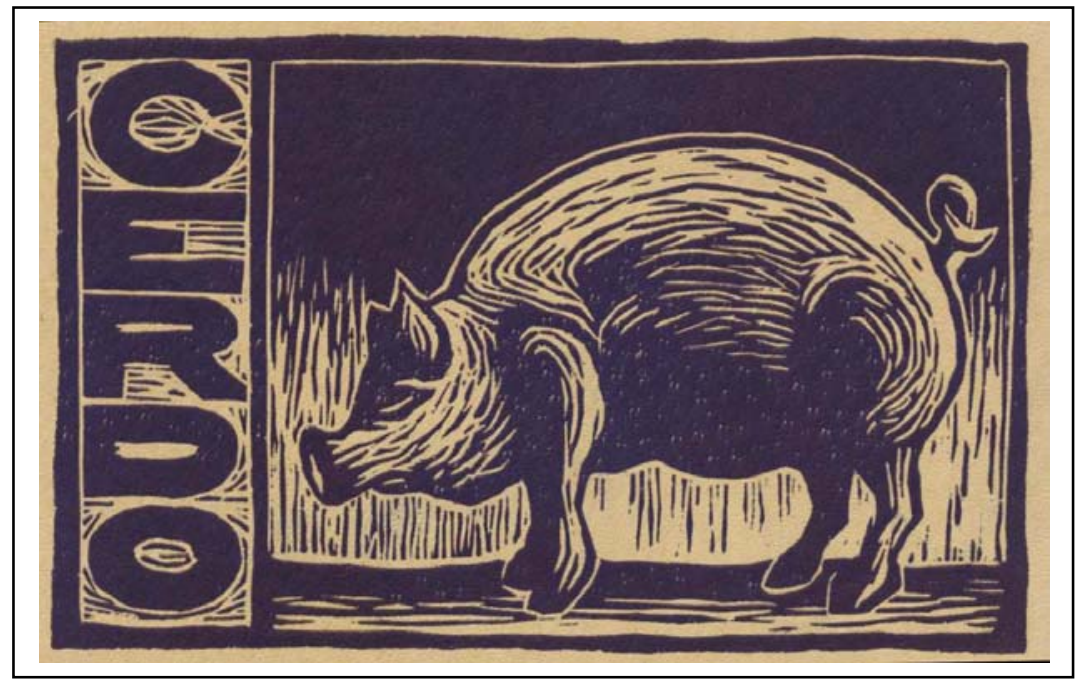

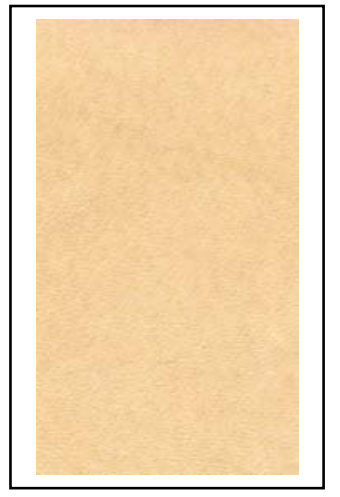

CÓDIGO: CE-019

TIPO DE PIEL: Cerdo

TINTA: Azul opaco

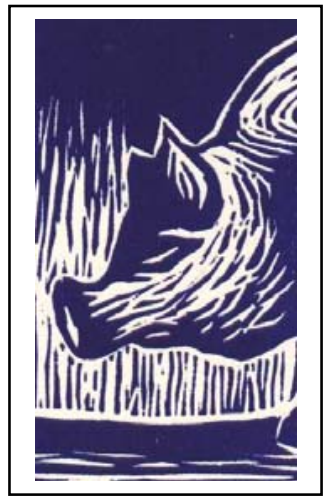

TÉCNICA: Xilografía

TONO DE PIEL: Claro

SUPERFICIE: Lado flor 
CALIDAD: Muy buena.

Estampa de gran nivel general, con un registro perfecto y muy buen resultado global, configurándose como una de las mejores de todo el estudio que venimos realizando. Los resultados tan positivos inciden en las buenas condiciones presentadas por este tipo de pieles porcinas en otros ejemplos.

MANCHA: Perfecta, homogénea y regular en todas las zonas de la imagen. Al usar una presión mínima aparece la conocida y típica textura de los folículos pilosos del cuero porcino, textura que puede ser utilizada para enriquecer la imagen. Si se desean eliminar, tan sólo debe aplicarse una presión algo más intensa, lo que provocará su desaparición.

GRAFISMO: Perfecto al igual que la mancha. Tan sólo se debe prestar atención a un posible exceso de presión.

CONTRASTE: Intenso y muy correcto, creándose una imagen de gran potencia visual y muy atractiva plásticamente. La tinta apenas sufre un mínimo oscurecimiento que no desvirtúa sus características iniciales.

BRILLO: Aparece un leve brillo ceroso que no interfiere en la correcta visión de la imagen. 


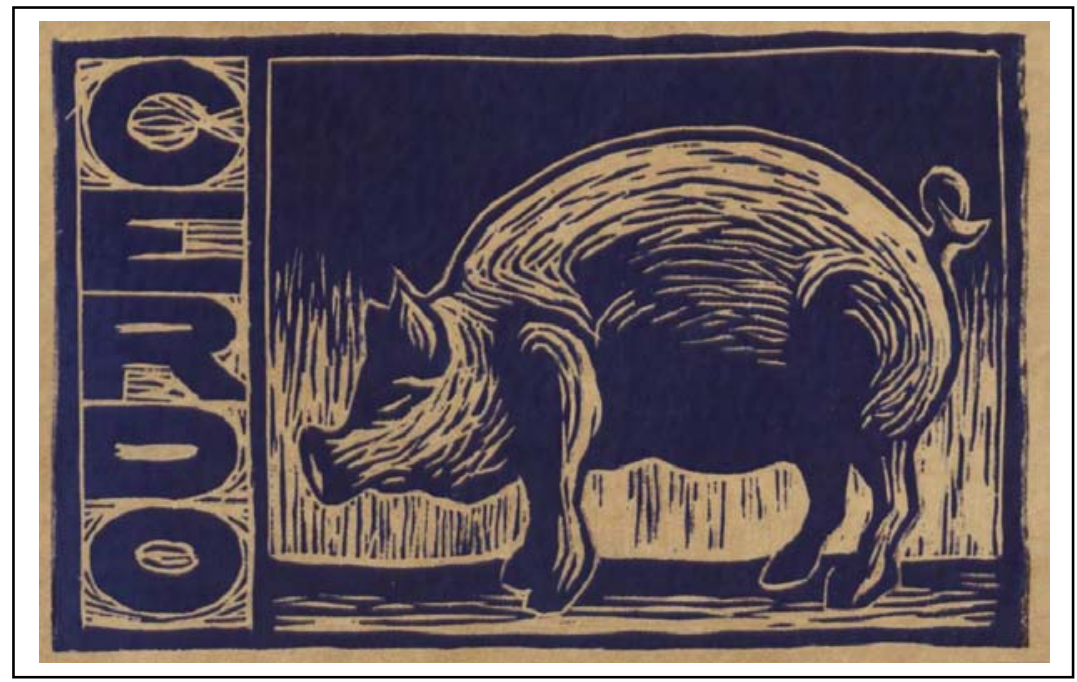

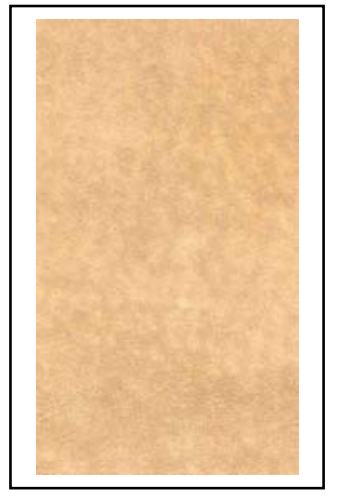

CÓDIGO: CE-020

TIPO DE PIEL: Cerdo

TINTA: Azul opaco

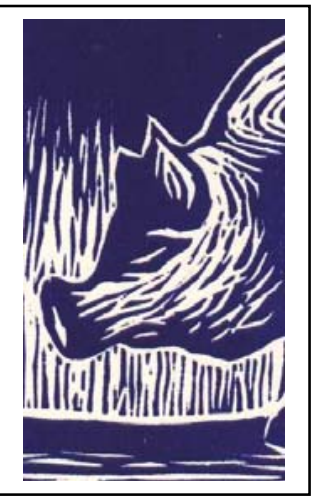

TÉCNICA: Xilografía

TONO DE PIEL: Claro

SUPERFICIE: Lado carne 
CALIDAD: Muy buena.

Al igual que su compañera sobre el lado flor, esta imagen es de extraordinario nivel general en todos los apartado estudiados. Tanto la mancha como el grafismo, el contraste o el brillo ofrecen un resultado excepcional y muy satisfactorio.

MANCHA: Perfecta, regular y de gran homogeneidad. En este lado carne es más difícil que aparezcan los orificios de los folículos pilosos antes comentados, aunque todavía se puede apreciar la textura propia de los cueros porcinos.

GRAFISMO: Al igual que la mancha, ofrece unos resultados perfectos siempre que la presión ejercida al estampar sea la correcta. Indicar que en el lado carne el margen de error en lo que a un posible exceso de presión se refiere, es algo mayor que sobre el algo más afelpado lado flor.

CONTRASTE: Correcto y bastante intenso, permite la creación de una imagen atractiva y potente.

BRILLO: Lógicamente nulo al tratarse de una superficie rugosa y afelpada como la que presentan casi todos los lados carne de los cueros estudiados. 


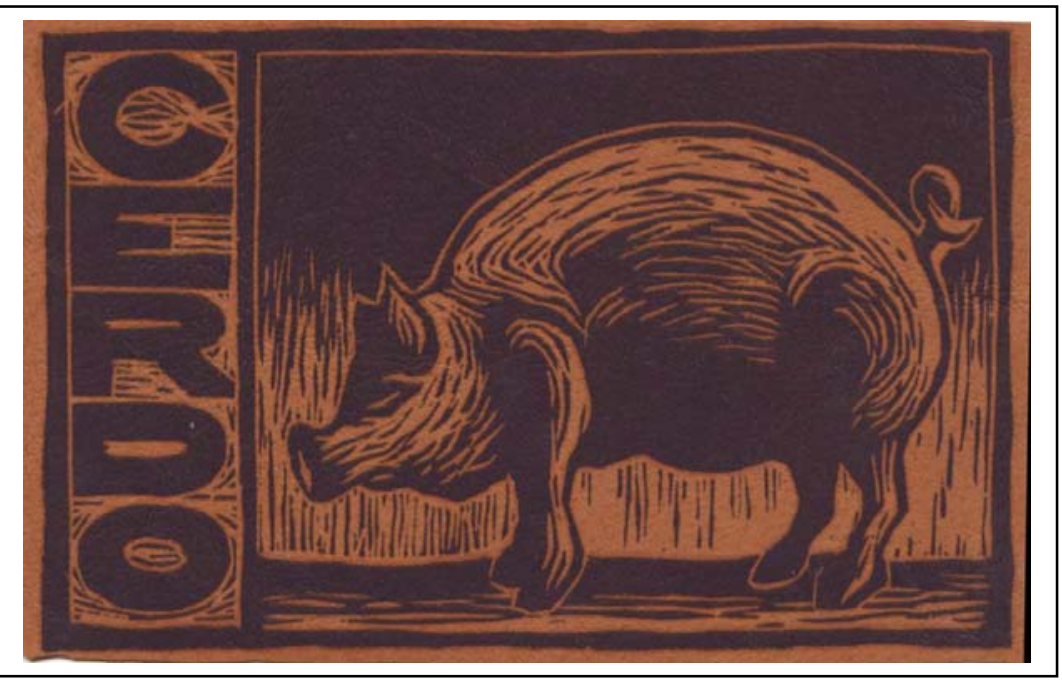

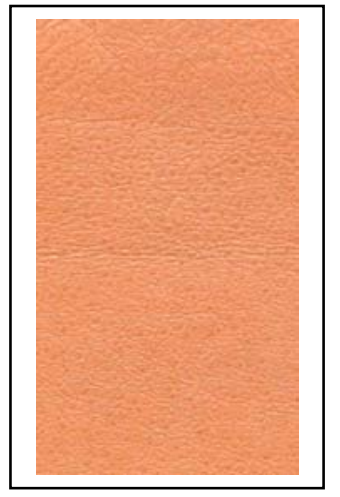

CÓDIGO: CE-021

TIPO DE PIEL: Cerdo

TINTA: Azul opaco

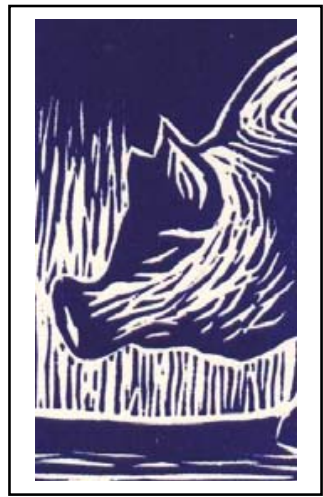

TÉCNICA: Xilografía

TONO DE PIEL: Medio

SUPERFICIE: Lado flor 
CALIDAD: Buena.

Ejemplo de buen nivel aunque con algunas peculiaridades que le impiden alcanzar una categoría superior. Presenta un ligero problema de absorción del aceite de la tinta, el cual se expande alrededor de las zonas entintadas manchado la piel. Este fenómeno puede aliviarse incluyendo algún tipo de secativo o modificante en la composición de la tinta, como puede ser el carbonato de magnesio.

MANCHA: Casi perfecta, sin irregularidades ni problemas evidentes. La textura propia de la piel porcina puede aparecer dependiendo de la intensidad de la presión ejercida durante la estampación.

GRAFISMO: También de muy buen resultado, aunque siempre dependiendo del grado de presión utilizada en la impresióm.

CONTRASTE: Lo bastante intenso y correcto como para permitir una visión satisfactoria de la imagen. La tinta sufre un ligero oscurecimiento que ayuda a que el nivel de contraste sea algo más elevado y potente.

BRILLO: Debido a lo satinado de la superficie del cuero, la tinta adquiere una apariencia brillante que sin embargo no resulta perjudicial para un visionado correcto de la estampa. 


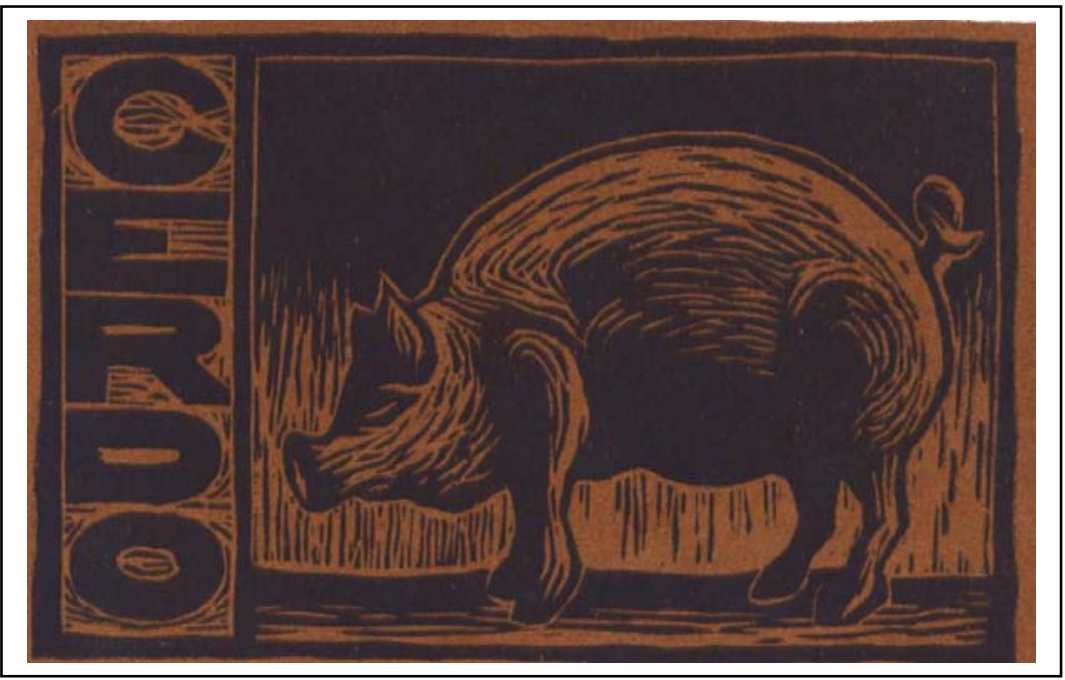

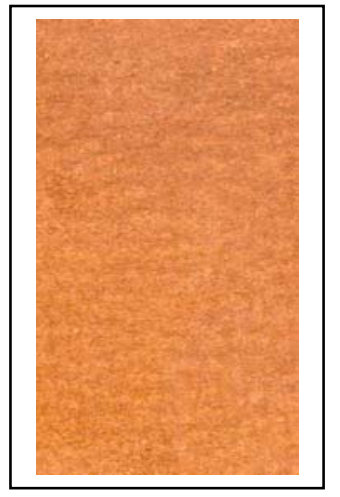

CÓDIGO: CE-022

TIPO DE PIEL: Cerdo

TINTA: Azul opaco

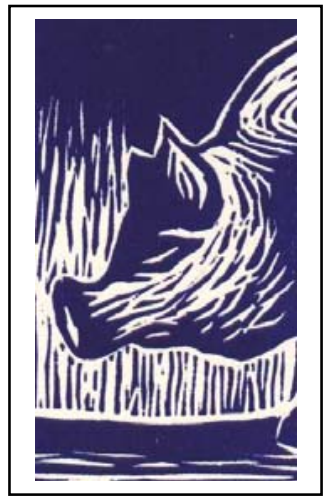

TÉCNICA: Xilografía

TONO DE PIEL: Medio

SUPERFICIE: Lado carne 
CALIDAD: Muy buena.

Ejemplo excelente en el que los problemas apreciados en la anterior estampa sobre el lado flor desaparecen por completo. Por tanto la deficiente absorción del aceite de la tinta y los brillos comentados dejen de tener incidencia en esta estampa.

MANCHA: Perfecta, muy regular y sin defectos en toda la superficie entintada. En este caso la textura de los folículos pilosos no se aprecia a simpe vista por efecto del ligero afelpado de la piel.

GRAFISMO: Al igual que la mancha perfecto. El ligero afelpado del cuero no afecta a la definición de los contornos de los seños xilográficos y permite una estampación con algo más de presión sin que por ello aparezcan defectos o deformaciones de los grafismos.

CONTRASTE: Intenso y correcto, a lo que ayuda el patente oscurecimiento del tono original de la tinta azul, la cual se convierte casi en un negro azulado de gran profundidad que contraste de manera evidente con el tono marrón rojizo del cuero.

BRILLO: Nulo, como es lógico en una superficie afelpada. 

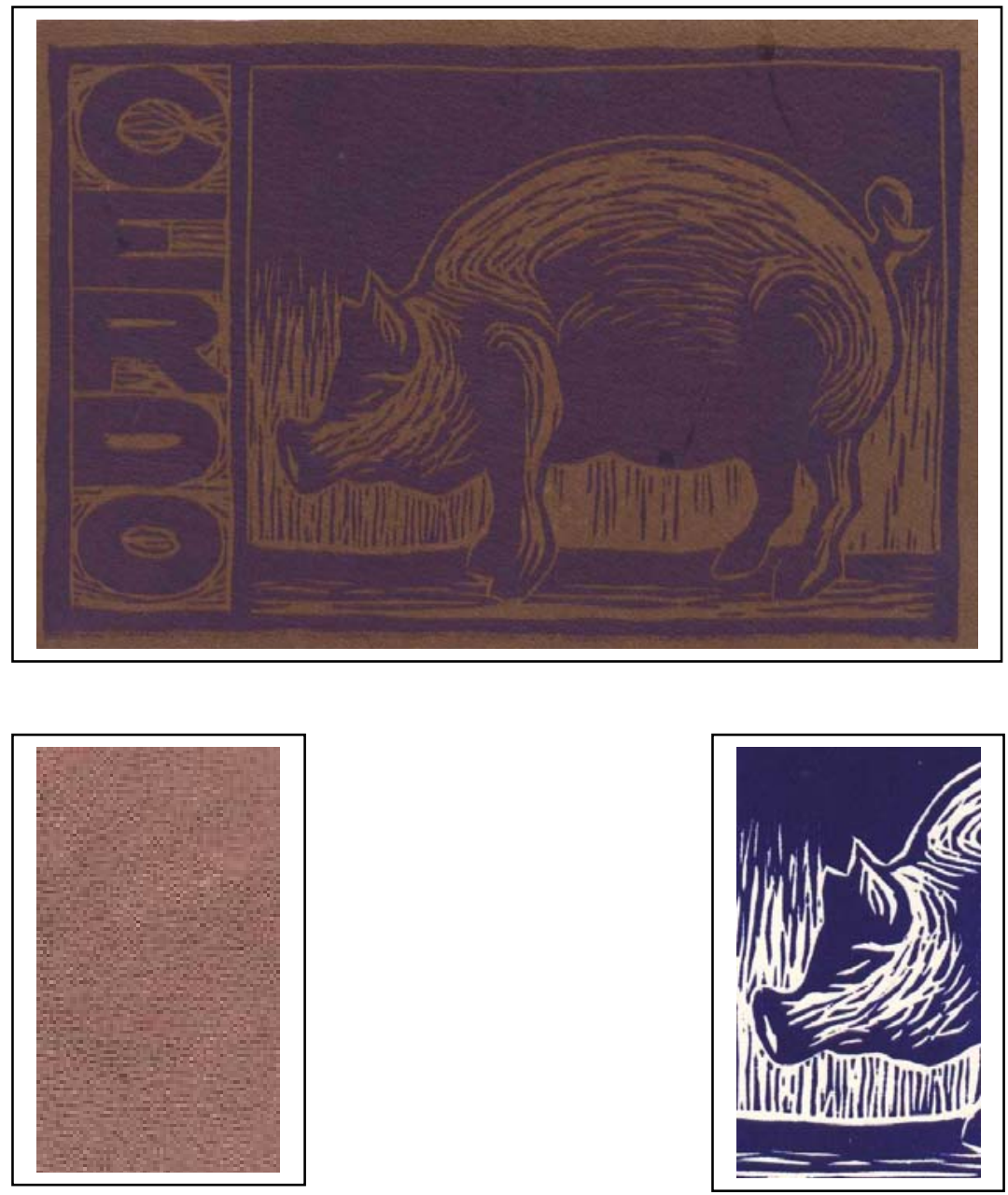

CÓDIGO: CE-023

TÉCNICA: Xilografía

TIPO DE PIEL: Cerdo

TONO DE PIEL: Oscuro

TINTA: Azul opaco

SUPERFICIE: Lado flor 
CALIDAD: Mediocre.

El tono excesivamente oscuro del cuero provoca que este ejemplo no sea totalmente satisfactorio como otros anteriores sobre pieles más claras. A su vez aparecen problemas de secado provocados por lo satinado de la superficie de la piel, la cual no es capaz de absorber todo el pigmento de la tinta.

MANCHA: Homogénea y regular, aunque con los problemas de secado ya comentados anteriormente. La tinta cubre perfectamente la superficie del cuero acentuando si cabe la ya de por sí evidente textura propia de las pieles porcinas.

GRAFISMO: Correcto y bien definido, con los contornos registrados de manera positiva siempre que la presión sea la correcta. Indicar que en cueros muy satinados como este, la posibilidad de aparición de deformaciones por un exceso de tinta es más elevada que en pieles de acabado más mate.

CONTRASTE: Débil por efecto del tono del soporte. Aún así la imagen es perceptible sin excesiva dificultad, aunque careciendo de la potencia visual necesaria.

BRILLO: Algo intenso y molesto debido al acabado tan satinado de la superficie de la piel utilizada como soporte. 


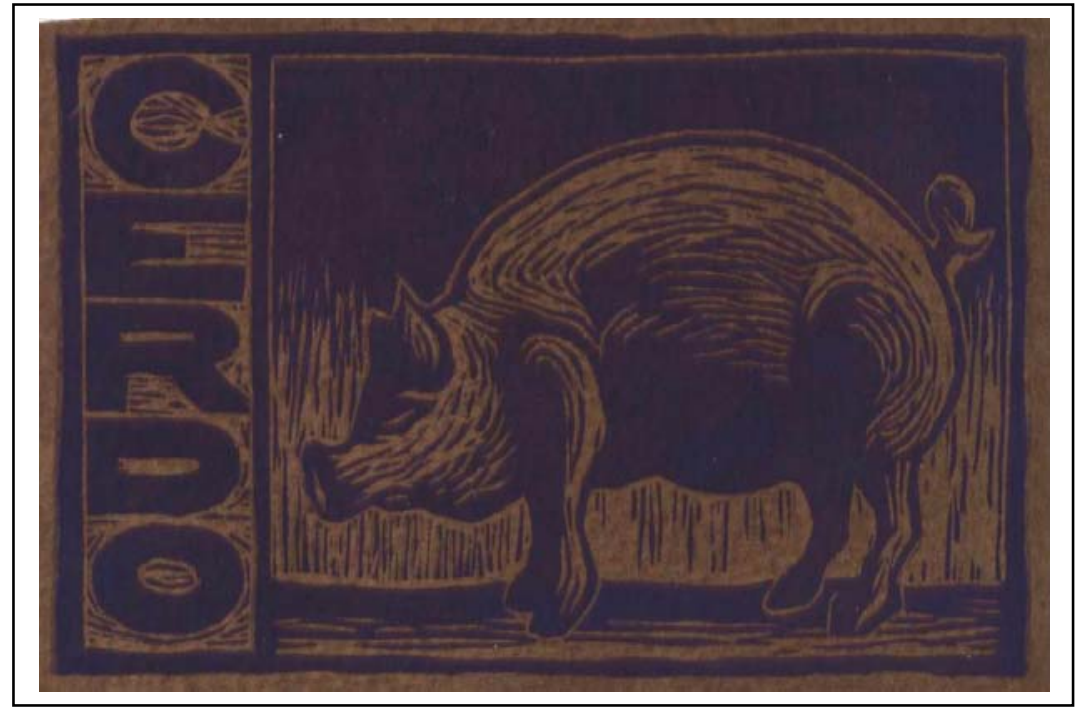

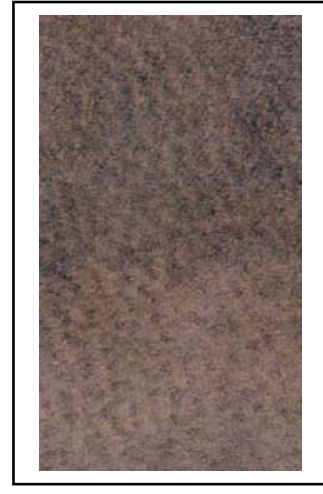

CÓDIGO: CE-024

TIPO DE PIEL: Cerdo

TINTA: Azul opaco

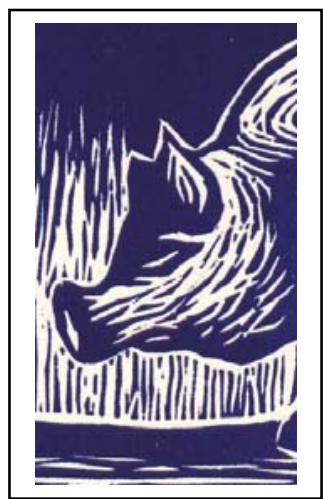

TÉCNICA: Xilografía

TONO DE PIEL: Oscuro

SUPERFICIE: Lado carne 
CALIDAD: Mediocre.

El brillo de la estampa anterior desaparece pero el contraste sigue sin ser lo suficientemente intenso como para crear una imagen totalmente satisfactoria. A su vez continúan apareciendo ciertos problemas de secado y asentamiento de la tinta sobre la superficie del soporte piel.

MANCHA: Homogénea y regular, llegando a cubrir las posibles irregularidades de la superficie del cuero. El tono de la tinta se oscurece hasta acercarse a un gris azulado muy oscuro.

GRAFISMO: Correcto, aunque si el soporte piel ofrece un excesivo afelpado pueden llegar a desvirtuarse los contornos de los seños xilográficos presentes en la imagen.

CONTRASTE: A pesar del patente oscurecimiento de la tinta ya comentado, ésta no permita alcanzar un nivel de contraste demasiado elevado. Aún así la imagen se percibe con total facilidad, no como en otros ejemplos analizados en este estudio.

BRILLO: Inexistente como era de esperar en un ejemplo realizado sobre una superficie afelpada como esta. 

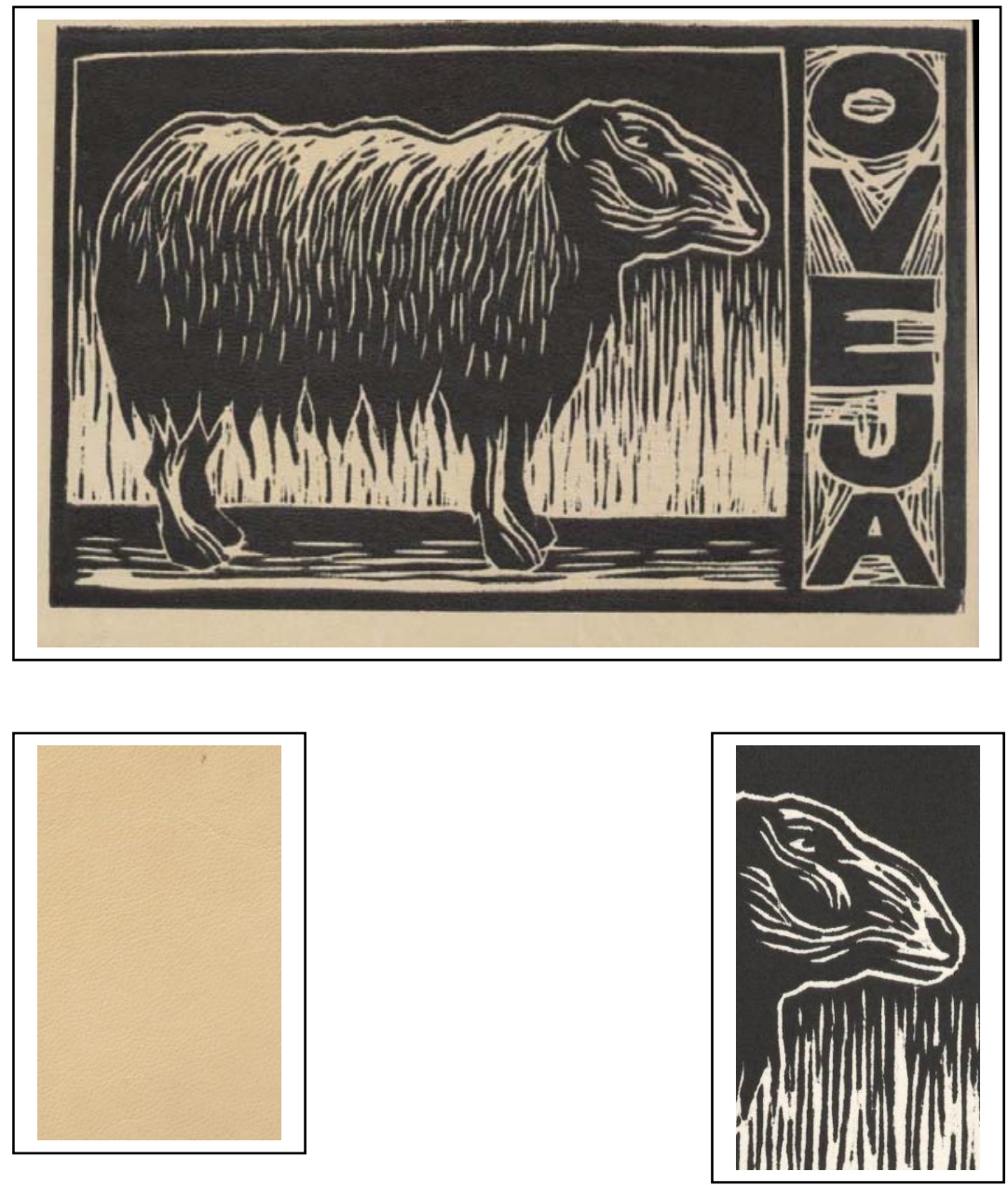

CÓDIGO: C0-001

TÉCNICA: Xilografía

TIPO DE PIEL: Cordero

TONO DE PIEL: Claro

TINTA: Negro

SUPERFICIE: Lado flor 
CALIDAD: Muy buena.

Estampa de excelente nivel general, sin apenas inconvenientes y de un resultado muy satisfactorio. No presenta problemas de secado 0 asentamiento de la tinta. En estampas realizadas con excesos de presión se ha comprobado una transferencia deficiente de la tinta, muchos problemas en los contornos y una apariencia muy desagradable.

MANCHA: Perfecta. La tinta negra cubre perfectamente la superficie del cuero. La delicada textura de la piel se pone más de manifiesto en las zonas entintadas, lográndose un efecto muy interesante y plástico.

GRAFISMO: Perfecto también, siempre que la presión sea la mínima, ya que si no se desvirtuarán casi todos los contornos de los grafismos.

CONTRASTE: Lógicamente muy intenso y apropiado para lograr una imagen potente y perfectamente reconocible.

BRILLO: La tinta provoca la aparición de un ligero brillo que, sin embargo, no logra resultar molesto para la correcta visión de la estampa. 


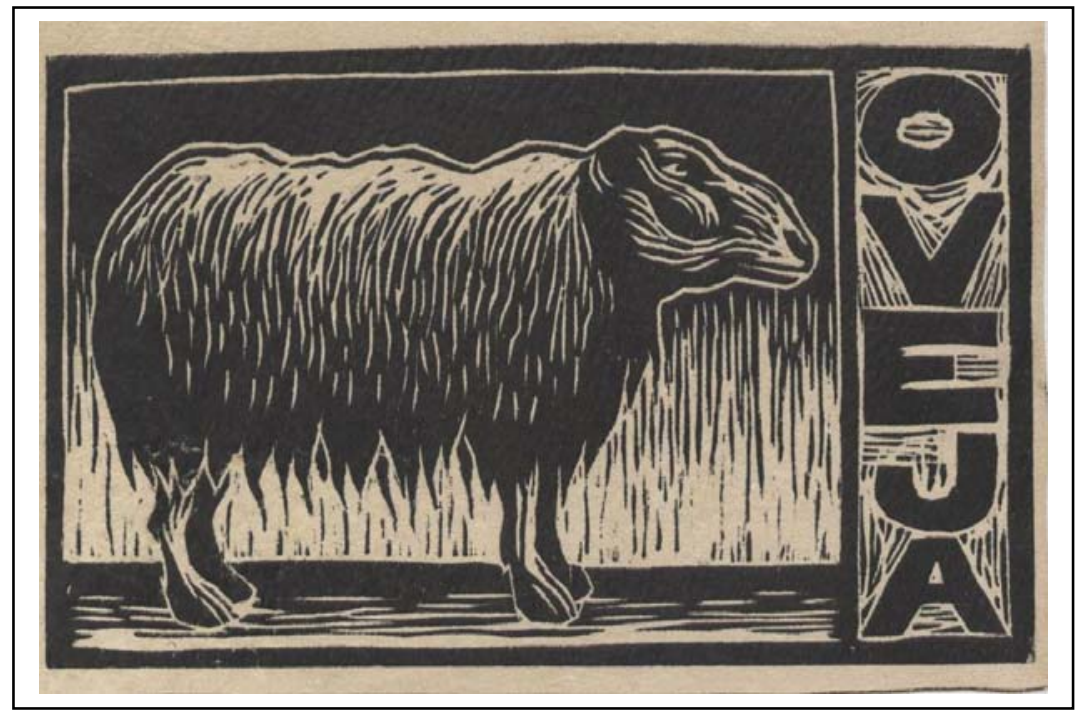

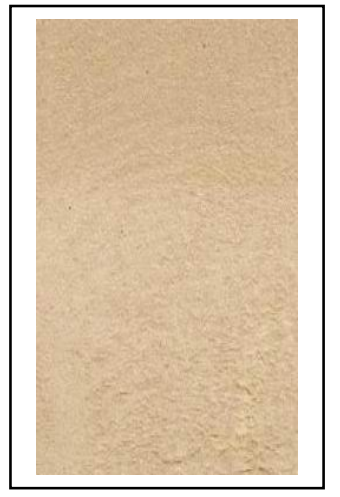

CÓDIGO: CO-002

TIPO DE PIEL: Cordero

TINTA: Negro

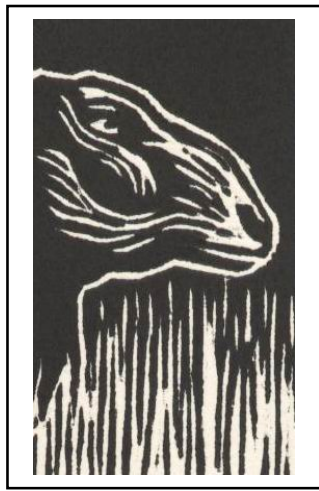

TÉCNICA: Xilografía

TONO DE PIEL: Claro

SUPERFICIE: Lado carne 
CALIDAD: Buena.

El ejemplo es de alta calidad pero la textura algo rugosa del lado carne del cuero hace que en ciertas zonas se produzcan irregularidades. No ofrece problemas de secado y la presión a emplear puede ser algo mayor que sobre el lado flor, aunque siempre intentando que sea la mínima posible.

MANCHA: Buena en términos generales, con los problemas ya comentados en el apartado anterior. En las zonas con un acabado uniforme del cuero la mancha es perfecta y homogénea.

GRAFISMO: Muy bueno ya que la textura de la piel no llega a desvirtuar los contornos de los seños xilográficos.

CONTRASTE: Al igual que en su gemela del lado flor es un contraste de gran intensidad y apropiado para lograr una imagen atractiva desde un punto de vista plástico.

BRILLO: Nulo como corresponde a una estampa realizada sobre una superficie afelpada como la que corresponde al lado carne de este tipo de cueros. 

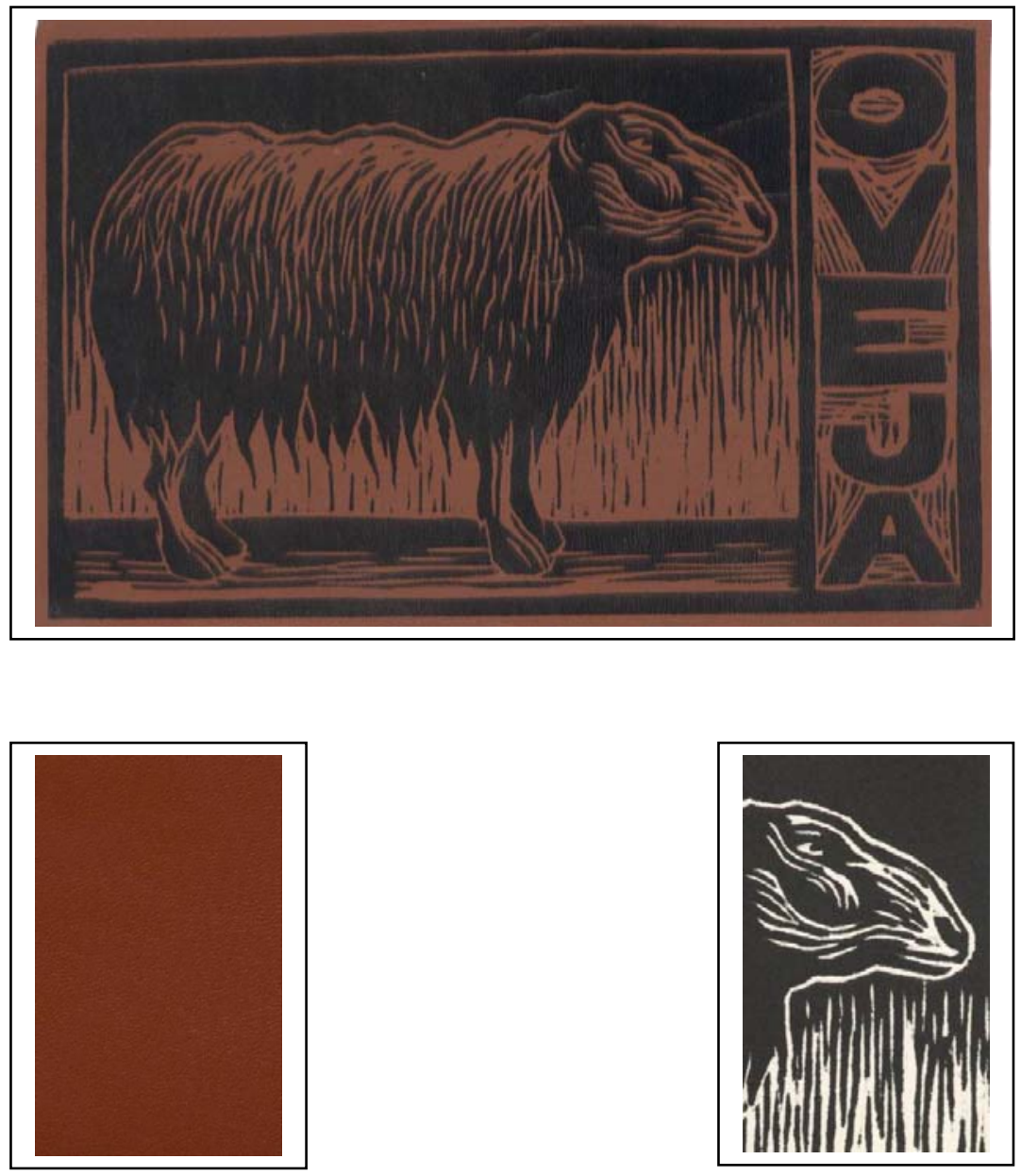

CÓDIGO: CO-003

TÉCNICA: Xilografía

TIPO DE PIEL: Cordero

TONO DE PIEL: Medio

TINTA: Negro

SUPERFICIE: Lado flor 
CALIDAD: Buena.

Estampa de muy alto nivel, tan sólo presenta algún ligero inconveniente relacionado con un brillo algo excesivo en algunas ocasiones. No ofrece problemas de secado y estampará correctamente siempre que empleemos la mínima presión posible y necesaria para una correcta impresión.

MANCHA: Perfecta, homogénea y regular, sin alteraciones de ningún tipo y cubriendo perfectamente las zonas entintadas. Al igual que sobre el cuero más claro del tono la tinta aumenta y acrecienta la textura propia de la piel de cordero.

GRAFISMO: Perfecto siempre que se estampe con la presión correcta y conveniente.

CONTRASTE: Algo menos intenso que sobre el cuero claro pero todavía lo suficientemente fuerte como para conseguir crear una imagen plásticamente interesante.

BRILLO: Debido al acabado algo más satinado de esta piel se aprecia un brillo en las zonas entintadas que puede llegar a ser molesto dependiendo de la iluminación de la estampa. Pese a todo la imagen es perfectamente válida. 

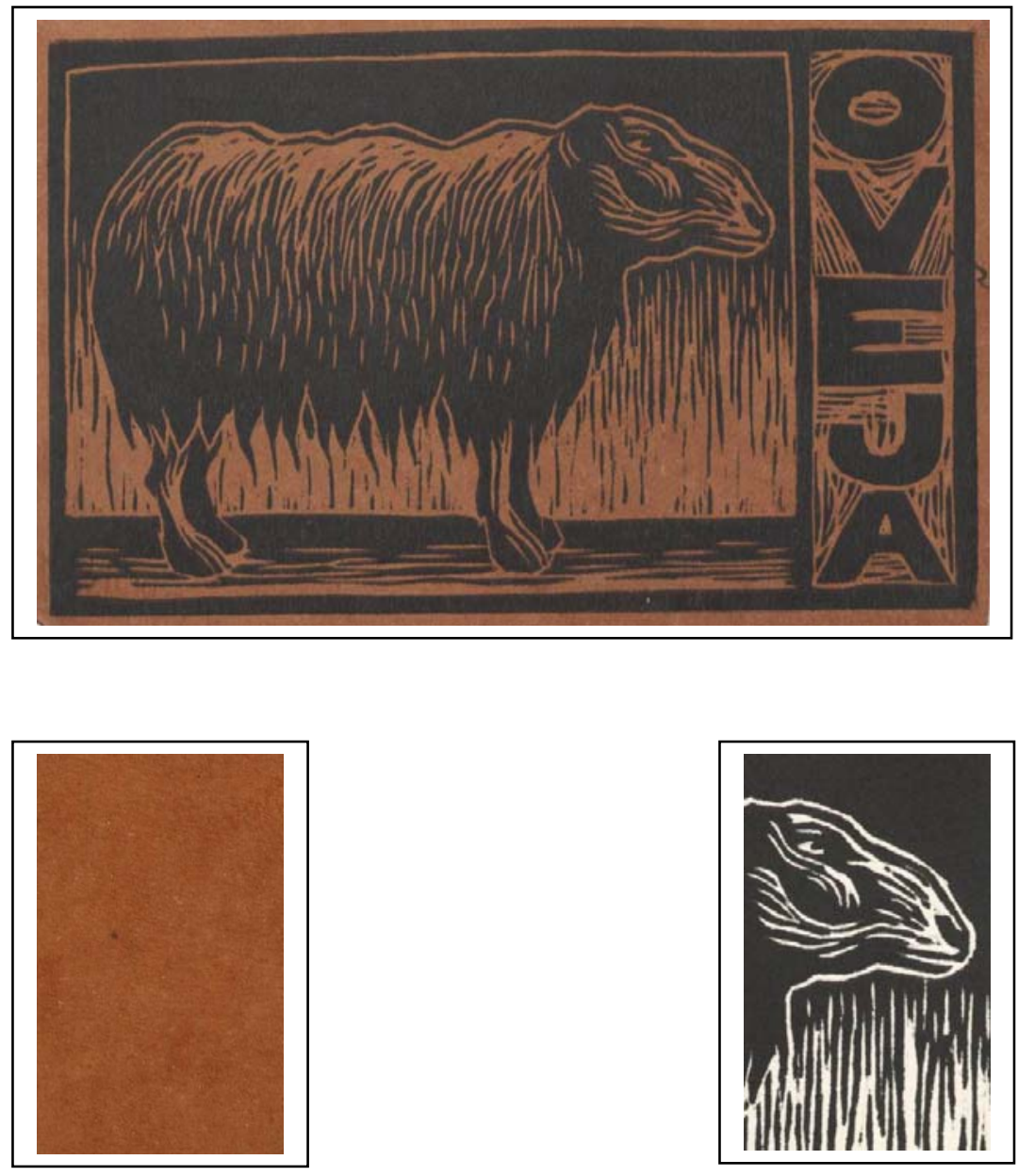

CÓDIGO: CO-004

TÉCNICA: Xilografía

TIPO DE PIEL: Cordero TONO DE PIEL: Medio

TINTA: Negro

SUPERFICIE: Lado carne 
CALIDAD: Muy buena

Ejemplo de altísima calidad, mejor incluso que su pareja en el lado flor. El hecho de que el afelpado de esta superficie tenga un tono más claro que la anterior y un afelpado muy suave, favorecen la gran calidad de esta estampa. No hay problemas de secado o asentamiento de la tinta.

MANCHA: Perfecta, de resultado excepcional, homogénea y regular. La tinta cubre sin inconvenientes la superficie de la piel logrando una mancha ideal.

GRAFISMO: Perfecto al igual que la mancha, con un registro inmejorable de todos los contornos de la imagen. Todas las líneas del ejemplo se estampan de manera excepcional en cada una de las zonas de la superficie del cuero.

CONTRASTE: Muy intenso, más que sobre la misma piel en su lado flor, lográndose una imagen muy potente desde un punto de vista plástico.

BRILLO: Aparece un ligerísimo brillo en las zonas estampadas de la imagen, aunque no llega a ser perjudicial para una correcta visión de la estampa. 

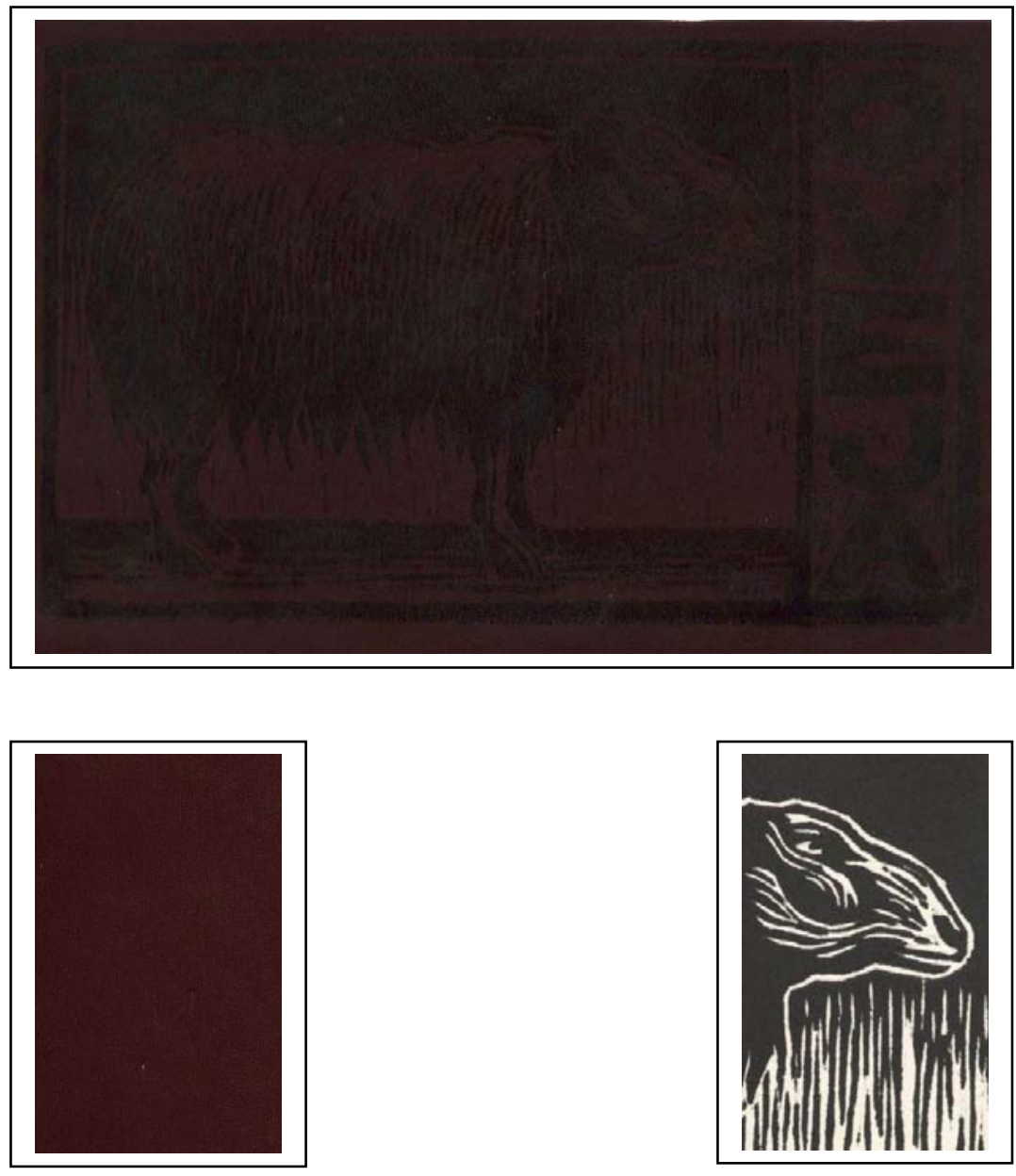

CÓDIGO: C0-005

TÉCNICA: Xilografía

TIPO DE PIEL: Cordero

TONO DE PIEL: Oscuro

TINTA: Negro

SUPERFICIE: Lado flor 
CALIDAD: Muy mala.

El excesivo tono de la piel hace que la calidad de la estampa sea pésima. La imagen apenas se percibe debido al mínimo contraste y al excesivo brillo de la estampa. Por otro lado no aparecen inconvenientes de secado 0 asentamiento de la tinta sobre el cuero.

MANCHA: La tinta cubre correctamente la superficie del soporte piel, creando una película homogénea y regular, aunque el contraste hace que todo quede supeditado a este factor.

GRAFISMO: Ocurre exactamente lo mismo que lo referido anteriormente con respecto a la mancha.

CONTRASTE: Se trata obviamente del mayor problema de la estampa. El tono excesivamente oscuro del cuero hace casi imposible la apreciación de la imagen provocando que el ejemplo sea nulo plásticamente.

BRILLO: Aparece un molesto brillo que dificulta la visión del ejemplo, lo que unido al contraste tan escaso provoca una estampa de ínfima calidad 

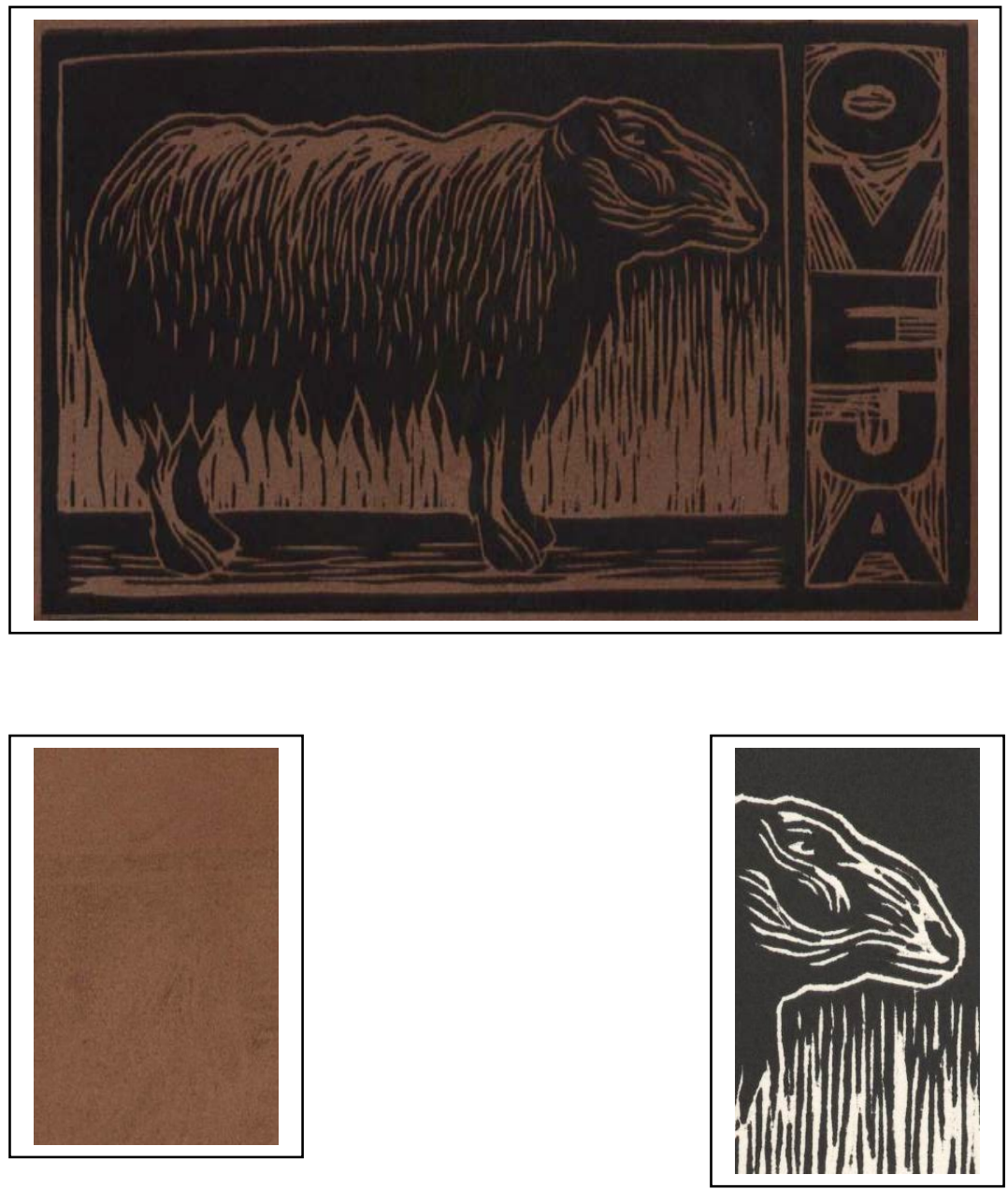

CÓDIGO: C0-006

TÉCNICA: Xilografía

TIPO DE PIEL: Cordero

TONO DE PIEL: Oscuro

TINTA: Negro

SUPERFICIE: Lado carne 
CALIDAD: Muy buena

Todo lo contrario que su pareja de tan mala calidad en el lado flor. A pesar del tono algo oscuro del soporte cuero la estampa es de altísima calidad plástica y técnica.

MANCHA: Perfecta a todos los efectos. Totalmente homogénea y regular, cubriendo perfectamente la superficie de la piel y consiguiendo un negro de gran calidez e intensidad. En definitiva una mancha de altísimo nivel.

GRAFISMO: Al igual que la mancha roza la perfección. Ninguno de los contornos se ve distorsionado, siempre que no se someta a la estampa a una presión excesiva durante el proceso de obtención del ejemplo.

CONTRASTE: A pesar del tono algo elevado del soporte piel se consigue un contraste muy interesante que permite alcanzar una intensidad muy correcta. La imagen obtenida es por tanto de gran calidad estética y visual.

BRILLO: Prácticamente nulo como corresponde a una estampa realizada sobre una superficie afelpada como esta. 

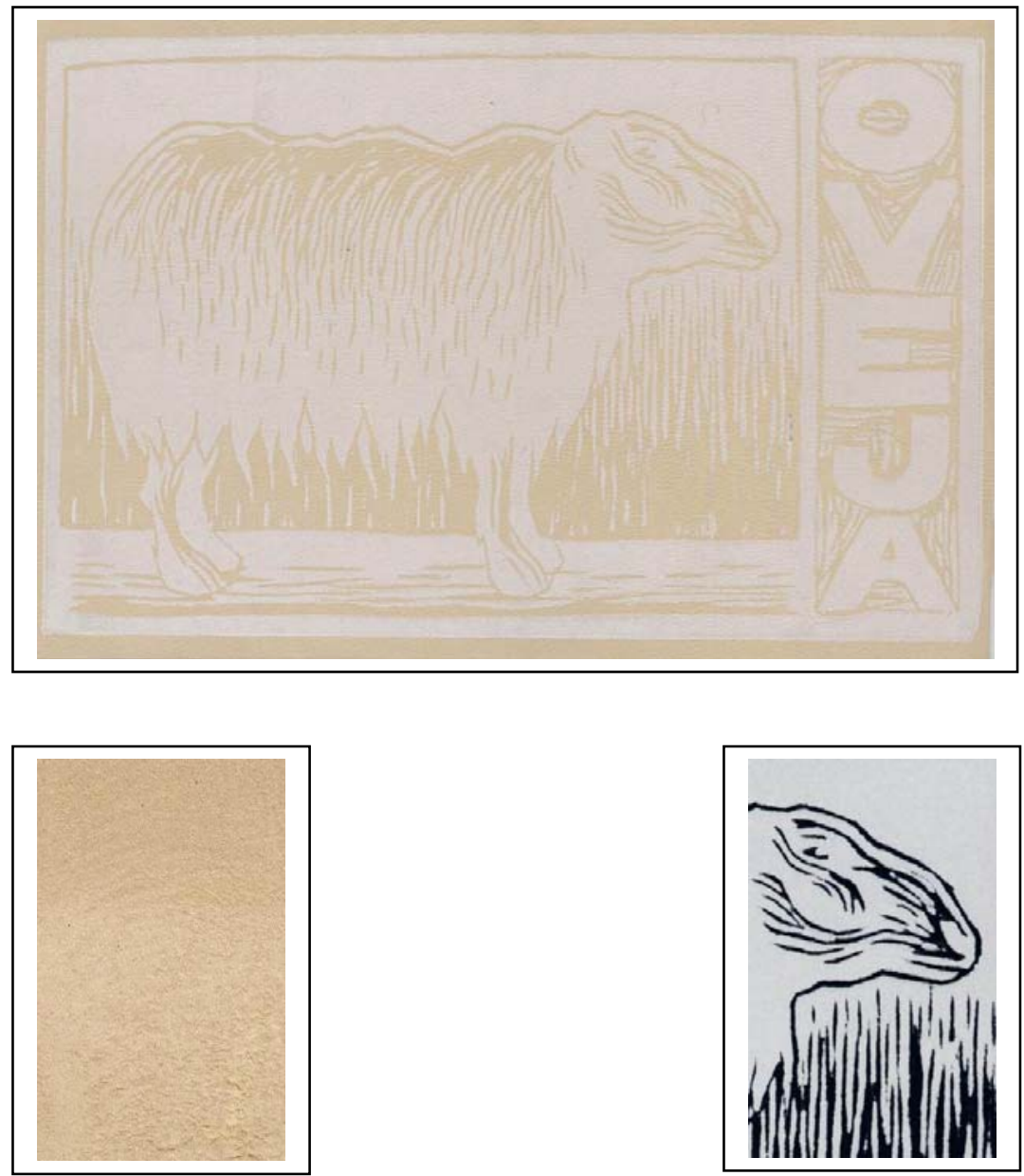

CÓDIGO: C0-007

TÉCNICA: Xilografía

TIPO DE PIEL: Cordero

TONO DE PIEL: Claro

TINTA: Blanco

SUPERFICIE: Lado flor 
CALIDAD: Mediocre

El blanco no se muestra como una tinta idónea para realizar estampas sobre piel. Pese a todo el resultado no es excesivamente malo, consiguiéndose una estampa de aceptable calidad. No aparecen por otro lado problemas de secado o asentamiento de la tinta sobre el soporte piel.

MANCHA: Muy correcta, alcanzándose una mancha bastante homgénea y regular pese a las características de la tinta blanca ya comentadas en otras ocasiones durante este trabajo.

GRAFISMO: De resultados parecidos a los de la mancha antes analizada.

CONTRASTE: Escaso, aunque se consigue apreciar la imagen sin excesivas dificultades. El hecho de que la tinta blanca no alcanze un grado de intensidad deseado hace que el contraste con esta piel tan clara no sea demasiado intenso. Se trata seguramente del inconveniente que provoca que la estampa no alcance un nivel mucho mayor.

BRILLO: Como es lógico con una tinta blanca opaca, el brillo es prácticamente nulo e inexistente sobre la superficie del cuero. 

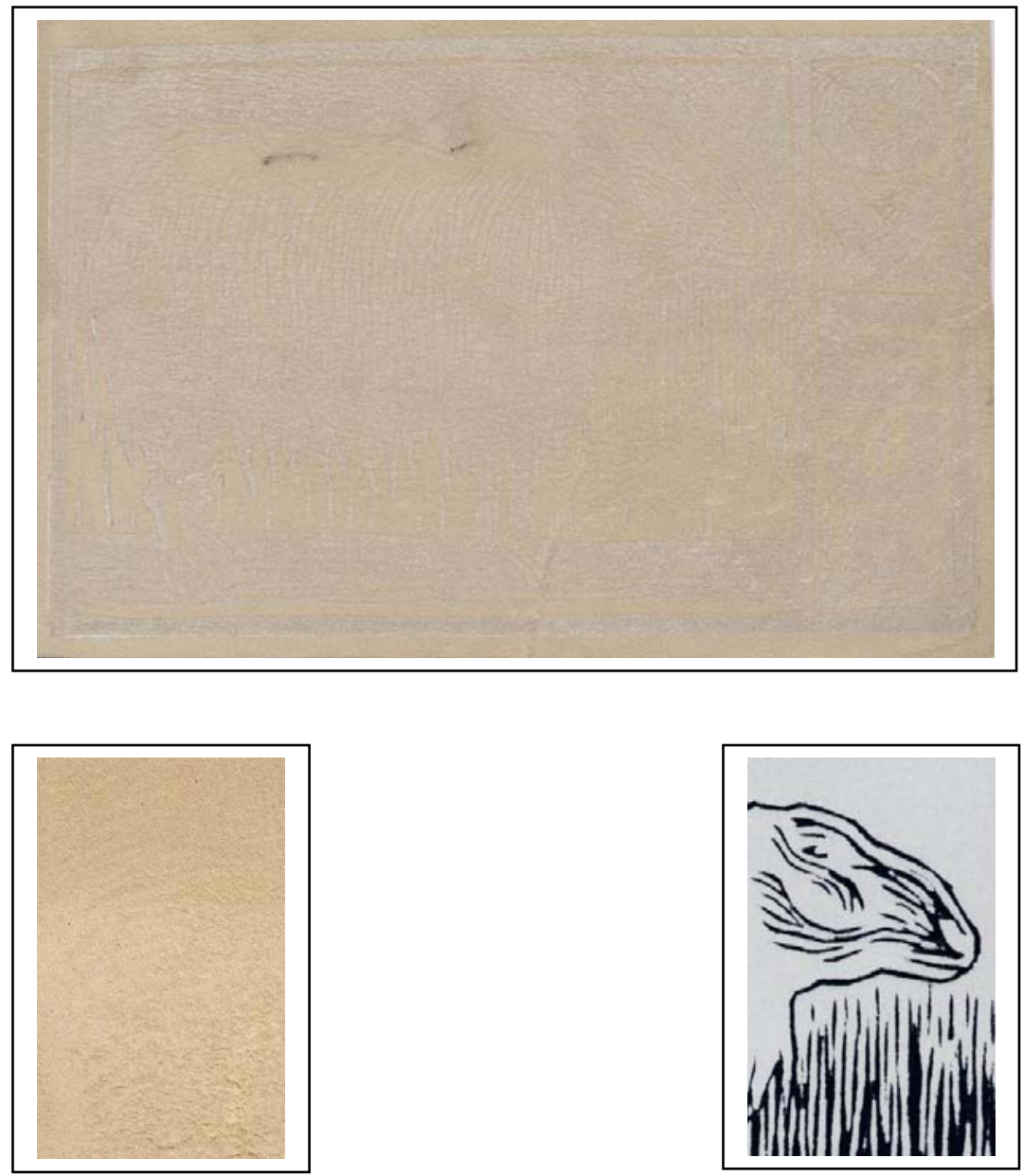

CÓDIGO: C0-008

TÉCNICA: Xilografía

TIPO DE PIEL: Cordero

TONO DE PIEL: Claro

TINTA: Blanco

SUPERFICIE: Lado carne 
CALIDAD: Muy mala

Ejemplo de pésima calidad, totalmente nulo e inútil. Ninguno de los apartados estudiados alcanza un mínimo nivel de resultados. Lo único positivo es que no presenta problemas de secado y asentamiento de la tinta sobre la superficie del cuero.

MANCHA: Pésima, la tinta blanca no es capaz de cubir la superficie del soporte piel, lográndose una textura muy desagradable. Es prácticamente imposible distinguir las zonas entintadas de las que no lo están, debido a que el aflepado del lado carne del cuero ha absorvido casi la totalidad de la tinta presente en la plancha.

GRAFISMO: Al igual que la mancha, pésimo. Se pierden casi todos los contornos de la imagen, dificultando muchísimo la correcta apreciación de las formas de la imagen.

CONTRASTE: Casi nulo por efecto de lo comentado anteriormente. Es realmente dificil apreciar la imagen y sus contornos, ya que la tinta blanca no logra contrastar con el tono de la piel.

BRILLO: Totalmente inexistente como es lógico al unir una tinta blanca opaca y una superficie tan aflepada como la que nos ocupa. 

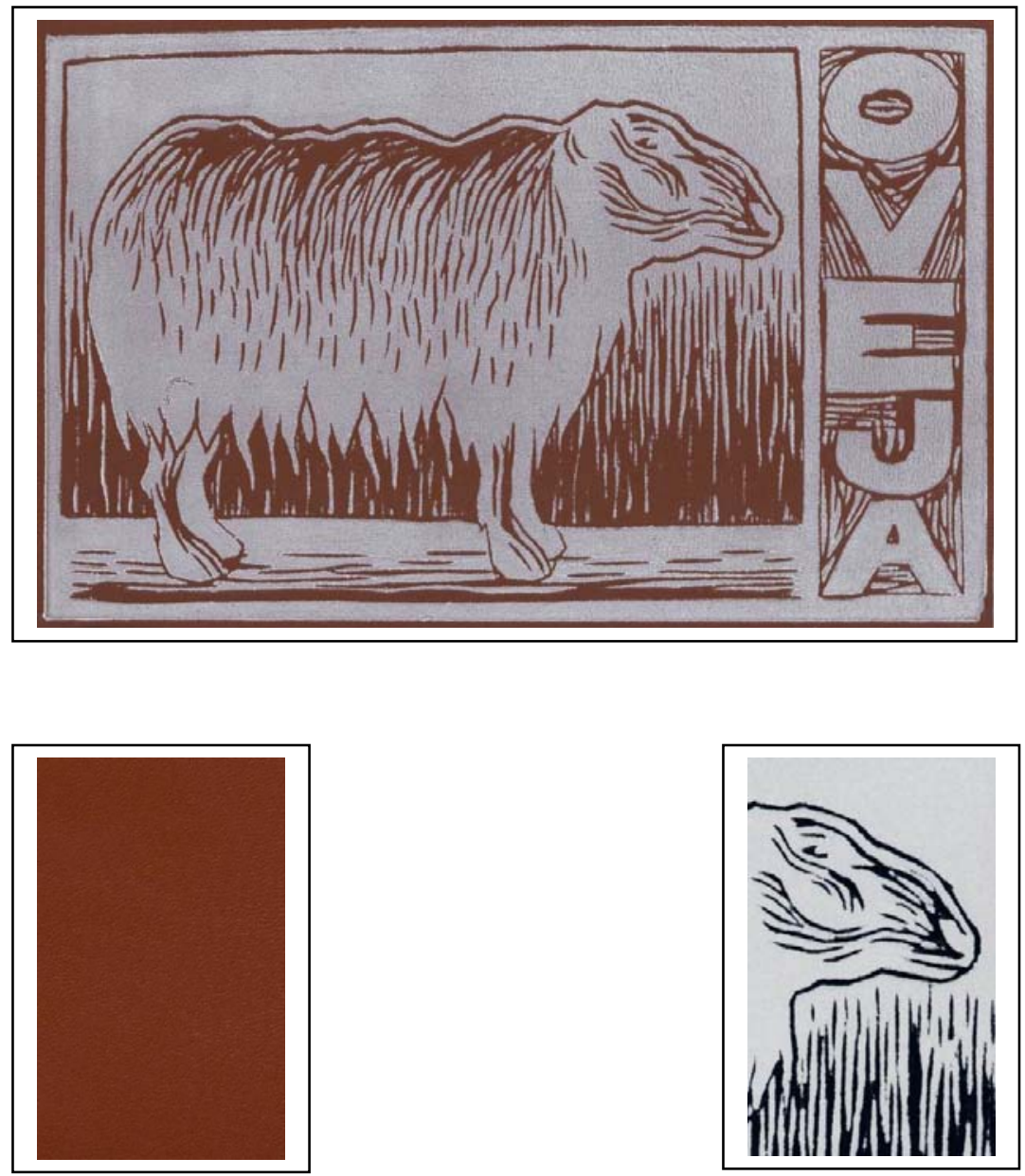

CÓDIGO: C0-009

TÉCNICA: Xilografía

TIPO DE PIEL: Cordero

TONO DE PIEL: Medio

TINTA: Blanco

SUPERFICIE: Lado flor 
CALIDAD: Buena.

El tono mucho más oscuro de este tipo de piel hace que la tinta blanca logre una intensidad mucho mayor y que el nivel de calidad de la estampa sea mejor que las anteriores sobre la piel de tono más claro. Por otro lado no apareccen problemas de secado o asentamiento de la tinta.

MANCHA: Bastante homogénea y regular, logrando cubrir de manera aceptable la superficie del cuero para crear una película de tinta de alto nivel.

GRAFISMO: El acabado satinado de la piel provoca una ligera deformación de los contornos de los grafismos incluso al actuar con un grado de presión muy ajustado. De todos modos no afecta de manera excesiva al conjunto general de la estampa.

CONTRASTE: Intenso y bastante correcto a pesar de que la tinta blanca nunca logre alcanzar su grado de intensidad ideal. Pese a esto se llega a crear una imagen muy atractiva desde un punto de vista plástico.

BRILLO: La tinta blanca no modifica el ligero brillo ya de por sí existente sobre la superficie de la piel. 

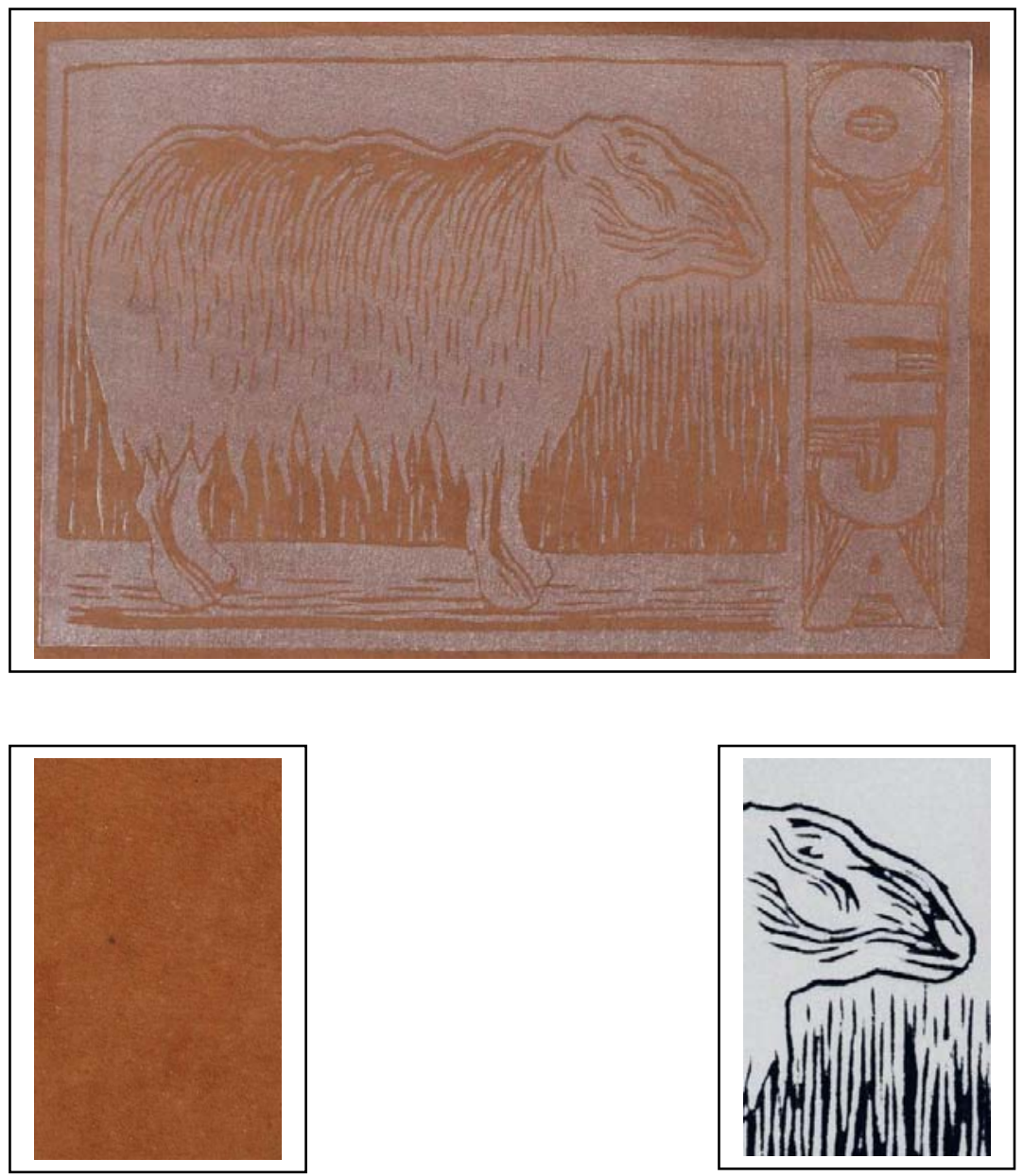

CÓDIGO: C0-010

TÉCNICA: Xilografía

TIPO DE PIEL: Cordero

TONO DE PIEL: Medio

TINTA: Blanco

SUPERFICIE: Lado carne 
CALIDAD: Mala.

La tinta blanca no se muestra capaz de cubrir correctamente la superficie de la piel y no logra una estampa de mínima calidad. Los problemas se repiten en el grafismo y en el contraste, aunque por otro lado no se aprecien inconvenientes en lo que respecta al secado 0 al asentamiento de la tinta sobre el soporte.

MANCHA: Irregular y heterogénea, de aspecto grumoso y sucio. El afelpado del cuero no es cubierto por la capa de tinta, lo que impide la consecución de una mancha correcta y satisfactoria. En lugar de un blanco intenso lo que se logra es un tono grisáceo muy poco atractivo y mortecino.

GRAFISMO: Al igual que la mancha también irregular; los contornos de ciertas zonas se han registrado de manera mediocre, produciendo una estampa de escasa calidad.

CONTRASTE: Algo escaso a pesar del tono ligeramente oscuro del cuero, ya que la tinta blanca reacciona de manera pésima al contacto con la superficie afelpada, la cual la absorve e impide que forme una película correcta sobre la piel.

BRILLO: Totalmente nulo como corresponde al emplear tintas blancas y soportes afelpados como los de todos los lados carne de los cueros empleados. 

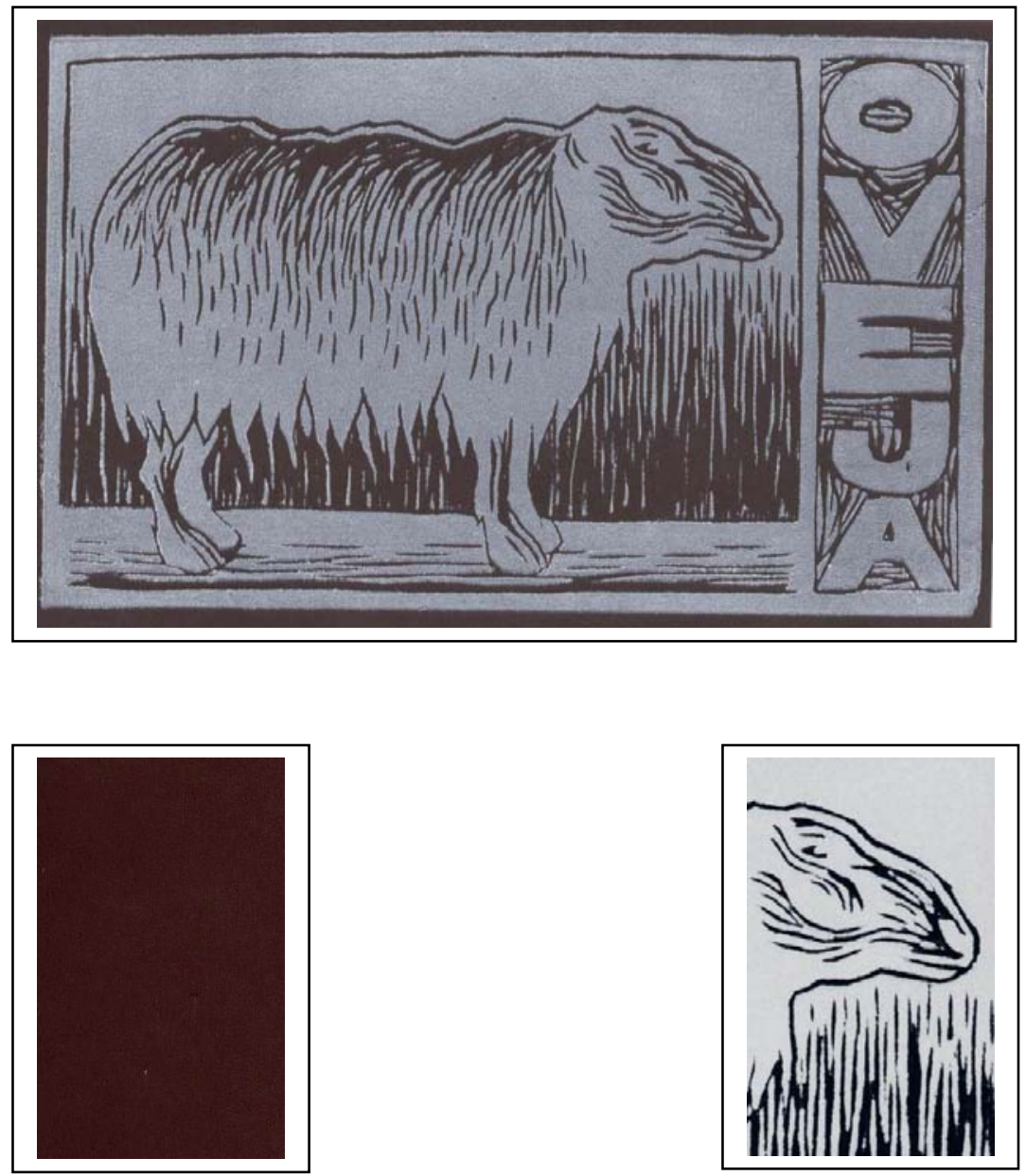

CÓDIGO: C0-011

TÉCNICA: Xilografía

TIPO DE PIEL: Cordero

TONO DE PIEL: Oscuro

TINTA: Blanco

SUPERFICIE: Lado flor 
CALIDAD: Buena.

Bastante satisfactoria como estampa de tinta blanca, aunque con lligeros inconvenientes en los contornos de los grafismos. El secado y asentamiento de la tinta en por otro lado perfecto y sin ningún tipo de inconvenientes.

MANCHA: Bastante buena para ser el resultado de una estampacíon con tinta blanca. El aspecto de la mancha es aceptablemente correcto aunque algo grumoso en ciertas zonas de gran densidad de tinta.

GRAFISMO: Algo más irregular quizá por efecto de una ligera presión excesiva unida a las propiedades y naturaleza propias de la tinta blanca. Pese a ello el resultado es infinitamente mejor que en otros ejemplos ya comentados empleando tinta blanca.

CONTRASTE: A pesar de que el blanco no alcanza la intensidad cubriente deseada, el contraste es bastante elevado y logra crear una imagen de gran interés plástico.

BRILLO: Por efecto del acabado satinado del cuero, en las zonas entintadas aparece un ligerísimo brillo ceroso que no interfiere en absoluto en la correcta visión de la imagen. 

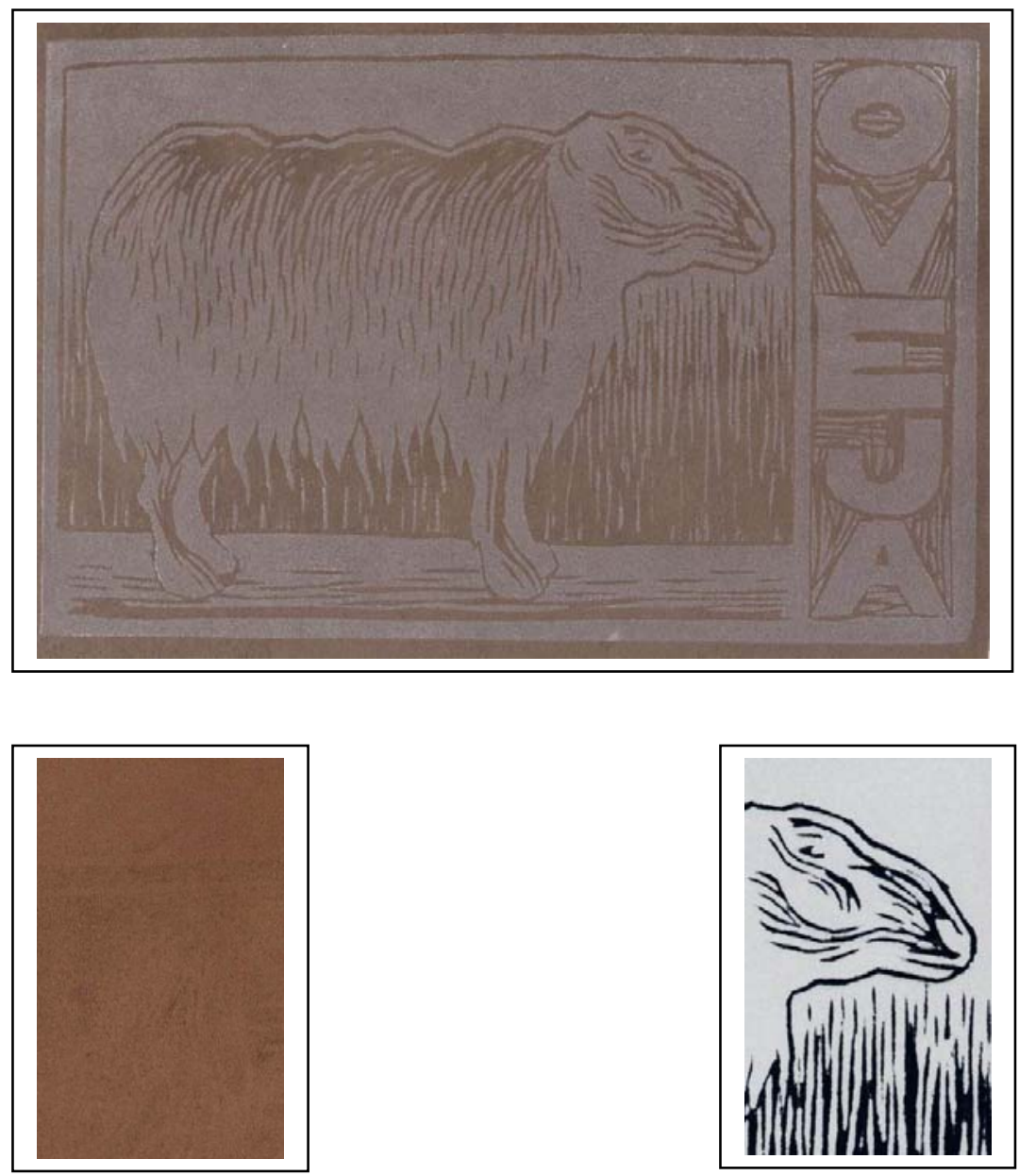

CÓDIGO: C0-012

TÉCNICA: Xilografía

TIPO DE PIEL: Cordero

TONO DE PIEL: Oscuro

TINTA: Blanco

SUPERFICIE: Lado carne 
CALIDAD: Mala.

A pesar del tono algo más oscuro de este tipo de piel con respecto a los otros dos estampados sobre lado carne, la tinta blanca continúa sin ser capaz de contrastar con el tono del soporte, no alcanzando la calidad deseada. El secado y asentamiento de la tinta son sin embargo perfectos y sin inconvenientes.

MANCHA: Débil, irregular y poco homogénea. La tinta no se muestra capaz de cubrir la auperficie afelpada del cuero en este lado carne, convirtiéndose en un gris oscuro sucio que no contrasta con el soportepiel.

GRAFISMO: Se repiten los mismos problemas comentados con la mancha. Ciertos contornos pierden nitidez por efecto de los problemas antes citados.

CONTRASTE: Poco intenso y algo débil ya que el soporte afelpado impide que el blanco alcance una intensidad mínima como para contrastar con el tono de la piel.

BRILLO: Totalmente nulo e inexistente como era de esperar en un caso como este. 

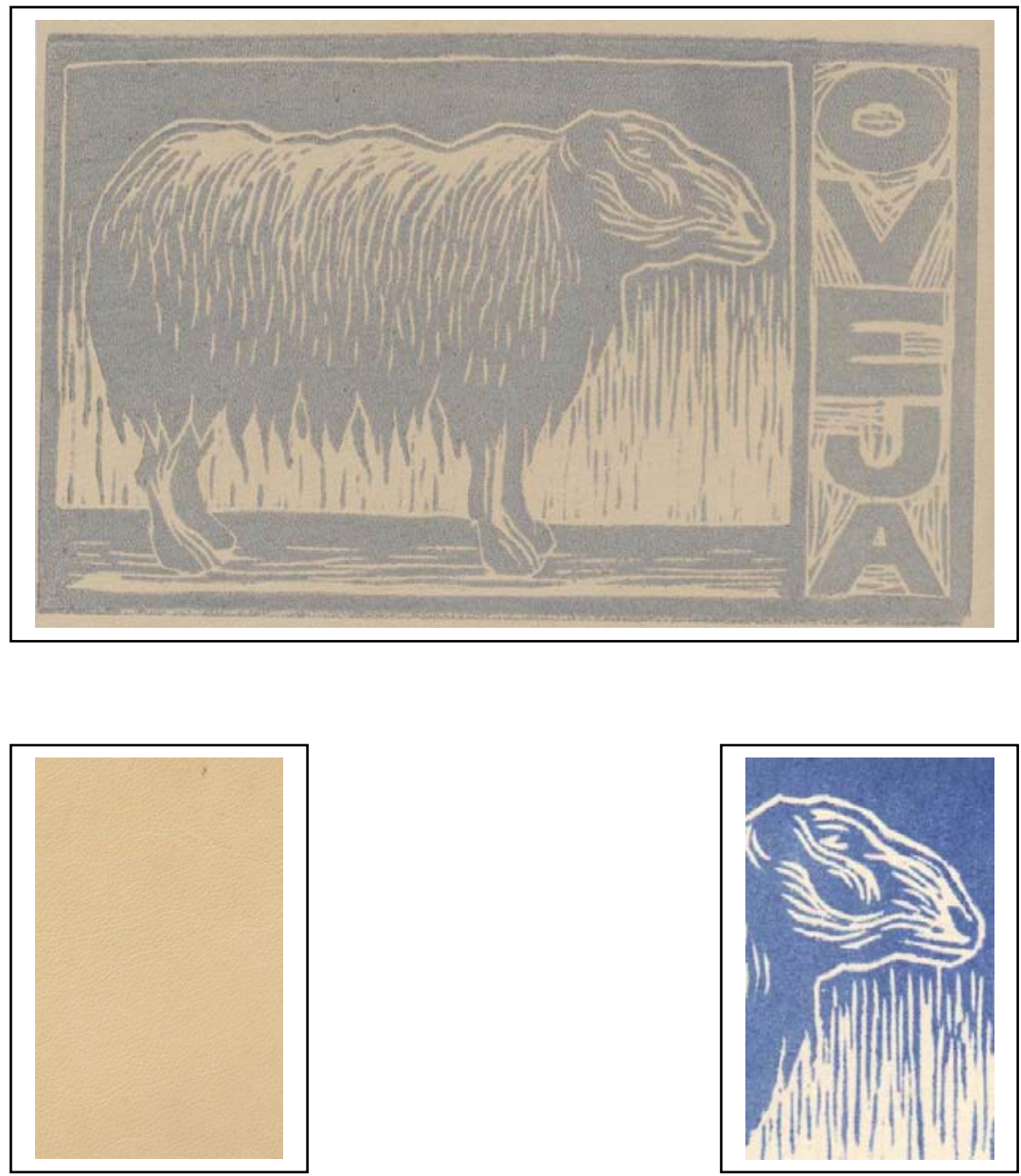

CÓDIGO: C0-013

TÉCNICA: Xilografía

TIPO DE PIEL: Cordero

TONO DE PIEL: Claro

TINTA: Azul traslúcido

SUPERFICIE: Lado flor 
CALIDAD: Buena.

Ejemplo de buen nivel pese a la gran cantidad de preparación traslúcida de la tinta. No ofrece problemas de secado ni asentamiento como es lógico en una mezcla con tal cantidad de base traslúcida, la cual acelera el secado de la estampa. Aparece en grado muy elevado la mezcla por transparencia, cambiando el tono de la tinta al contacto con la superficie de la piel.

MANCHA: Bastante regular y homogénea, sin embargo el hecho de ser una tinta tan transparente provoca que la misma no cubra totalmente las posibles irregularidades del cuero. A su vez se produce una acentuación visual de la ligera textura del soporte piel.

GRAFISMO: Repite las características comentadas en el apartado anterior referente a la mancha.

CONTRASTE: No muy elevado por el tono tan claro del azul utilizado en el proceso de estampación. Aun así la imagen es perfectamente visible y reconocible.

BRILLO: Aparece un ligero brillo que no resulta perjudicial para la correcta visión de la estampa. 

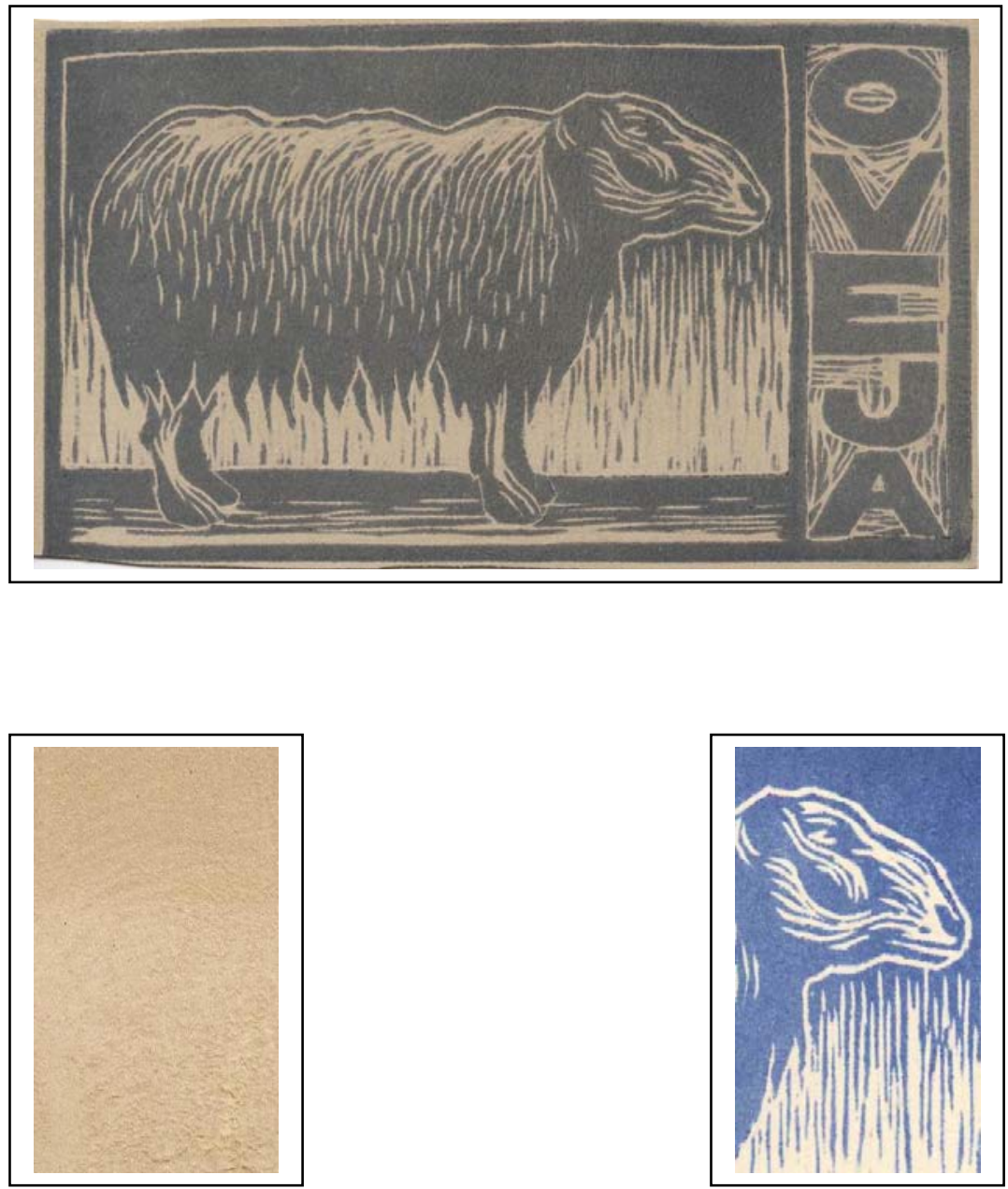

CÓDIGO: C0-014

TÉCNICA: Xilografía

TIPO DE PIEL: Cordero

TONO DE PIEL: Claro

TINTA: Azul traslúcido

SUPERFICIE: Lado carne 
CALIDAD: Buena.

Estampa diferente a la anterior sobre el lado flor pero también de buena calidad y más que correctos resultados. Como era lógico no aparecen inconvenientes relacionados con el secado o asentamiento de la tinta sobre la piel. De nuevo vemos como cambia el tono de la tinta.

MANCHA: Bastante homogénea y regular, y mucho más oscura que la anterior ya que la tinta sufre el conocido proceso de oscurecimiento al contacto con el afelpado del cuero en su lado carne. El tono azul traslúcido se transforma en un color mucho más intenso y grisáceo por efecto a su vez de la mezcla por transparencia.

GRAFISMO: Se reproducen las mismas características que las de la mancha, con algunos contornos distorsionados por efecto del afelpado en ocasiones excesivamente acusacdo del cuero.

CONTRASTE: Mucho más intenso que en el caso anterior como consecuencia de los dos procesos antes comentados. Se crea de tal modo una imagen interesante desde un punto de vista plástico.

BRILLO: Totalmente nulo al estar realizada sobre la superficie afelpada del lado carne. 

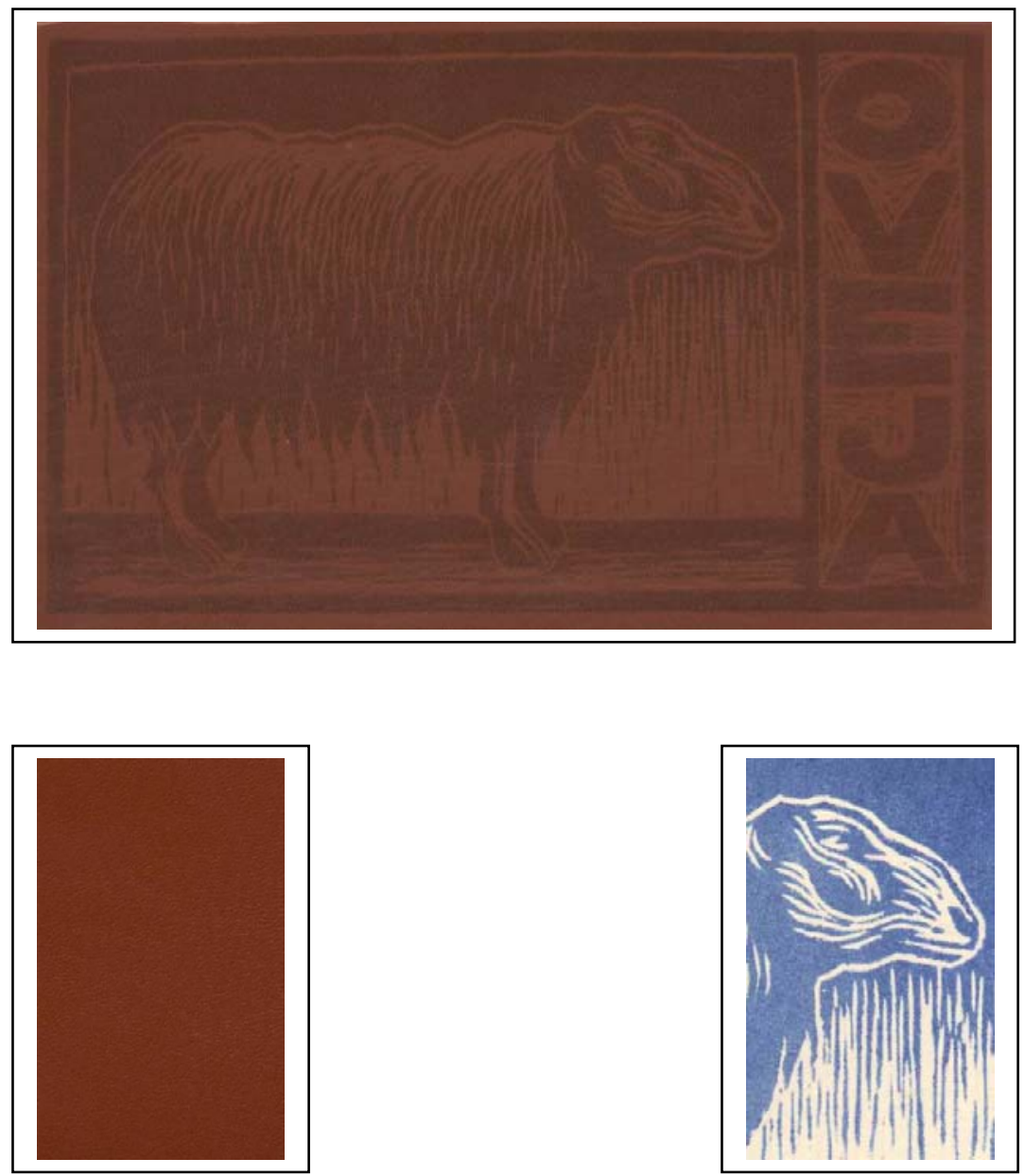

CÓDIGO: C0-015

TÉCNICA: Xilografía

TIPO DE PIEL: Cordero

TONO DE PIEL: Medio

TINTA: Azul traslúcido

SUPERFICIE: Lado flor 
CALIDAD: Mediocre.

El registro de la mancha y el grafismo son perfectos, pero el contraste y el brillo perjudican seriamente la calidad y el resultado de la estampa. Por otro lado no aparecen problemas de secado de la tinta traslúcida.

MANCHA: Perfecta en su registro y en la cubrición del soporte piel. Se crea una película homogénea y regular pero con evidentes problemas de contraste que comentaremos a continuación. Indicar que la mezcla por transparencia actua de manera evidente haciendo que el inicial tono azul de la tinta se convierta en un marrón cálido totalmente diferente.

GRAFISMO: También bastante bueno aunque debido a la falta de nitidez algunos contornos pierden vigencia y se hacen difíciles de apreciar con facilidad.

CONTRASTE: Evidentemente se trata del inconveniente fundamental de este ejemplo. A pesar del cambio de tono de la tinta, ésta no logra contrastar con la superficie del cuero debido a su gran transparencia.

BRILLO: Aparece un brillo algo excesivo que puede llegar a perjudicar una correcta visión del ejemplo, interfiriendo en su calidad general como ya hemos comentado con anterioridad. 

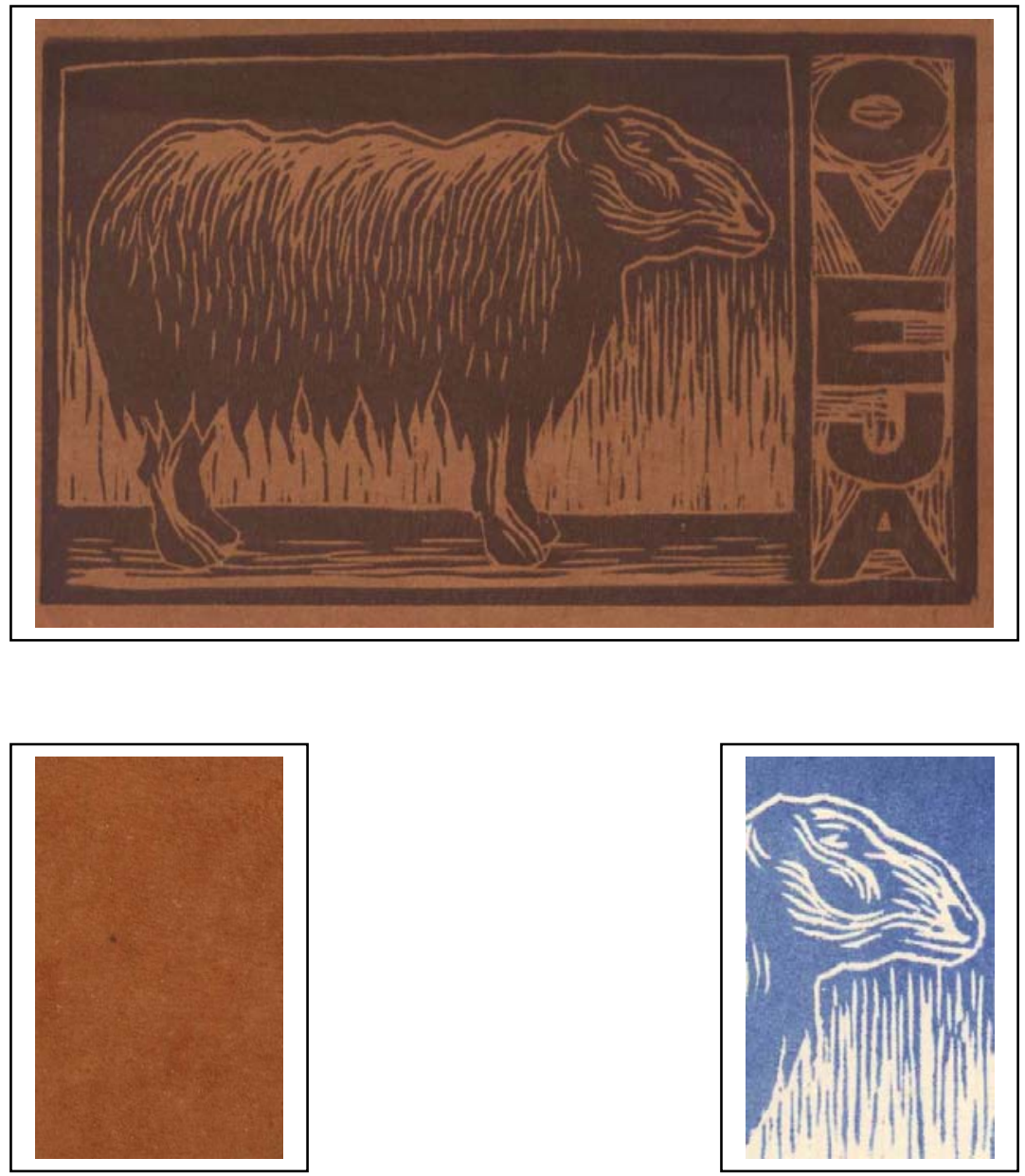

CÓDIGO: C0-016

TÉCNICA: Xilografía

TIPO DE PIEL: Cordero

TONO DE PIEL: Medio

TINTA: Azul traslúcido

SUPERFICIE: Lado carne 
CALIDAD: Muy buena.

Ejemplo de extraordinario nivel técnico y plástico, con una respuesta perfecta en todos y cada uno de los apartados estudiados, así como en las cuestiones referentes al secado y asentamiento de la tinta sobre el cuero. Se trata sin duda de una de las mejores estampas de todo el bloque.

MANCHA: Perfecta, homogénea y regular, cubriendo la totalidad de la superficie del cuero sin presentar inconveniente alguno y consiguiendo un acabado de la mancha muy satisfactorio y correcto. La mezcla por transparencia provoca la aparición de un tono marrón en lugar del original azul de la tinta, color de cualidades más que interesantes que hace de esta estampa un ejemplo muy util de las posibilidades de dicho proceso de mezcla de colores.

GRAFISMO: Perfecto al igual que la mancha, con un registro ideal de los contornos de todos los seños xilográficos. Ambos elementos ofrecen un resultado excepcional y totalmente satisfactorio.

CONTRASTE: Más intenso y correcto que en el ejemplo anterior. El oscurecimiento de la tinta es muy patente, pasando de un azul transparente a un tono marrón rojizo con tintes violáceos, el cual contrasta de manera intensa con el soprte, creando una imagen muy interesante desde este punto de vista.

BRILLO: Totalmente nulo por efecto del afelpado de la piel. 

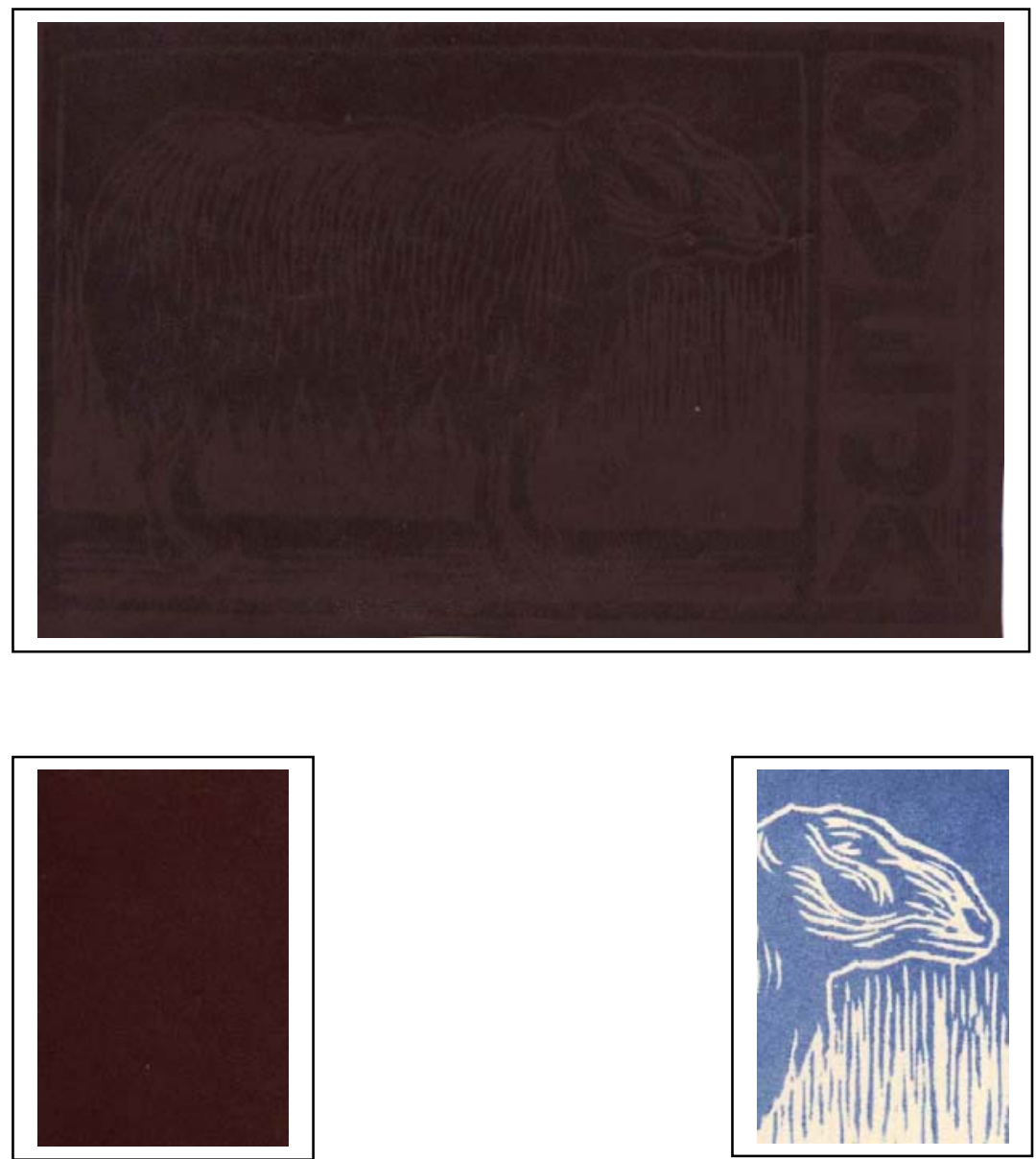

CÓDIGO: C0-017

TIPO DE PIEL: Cordero

TINTA: Azul traslúcido
TÉCNICA: Xilografía

TONO DE PIEL: Oscuro

SUPERFICIE: Lado flor 
CALIDAD: Muy mala.

El tono tan extremadamente oscuro del soporte piel hace que todo quede supeditado al mínimo contraste existente en la estampa. No aparecen de todas formas problemas de secado de la tinta a pesar del acabado tan satinado del cuero.

MANCHA: Apenas perceptible si no es gracias al brillo presente sobre la superficie de la piel. Pese a todo la tinta se encuentra estampada de manera bastante regular sobre el cuero, aunque el tono de éste no nos permita apreciarla.

GRAFISMO: Al igual que la mancha es muy dificil de apreciar, aunque parece que el registro de los contornos xilográficos es correcto.

CONTRASTE: Totalmente nulo por la unión del tono tan oscuro del soporte cuero y la gran cantidad de preparación traslúcida presente en la mezcla de la tinta. Se trata obviamente del problema principal de la estampa, aspecto que condiciona a todos los demás.

BRILLO: Al mínimo contraste se une un brillo a todas luces excesivo provocado por el acabado tan satinado del cuero y por las características de la tinta empleada. Dicho brillo hace muy dificil visionar la imagen estampada sobre la piel. 

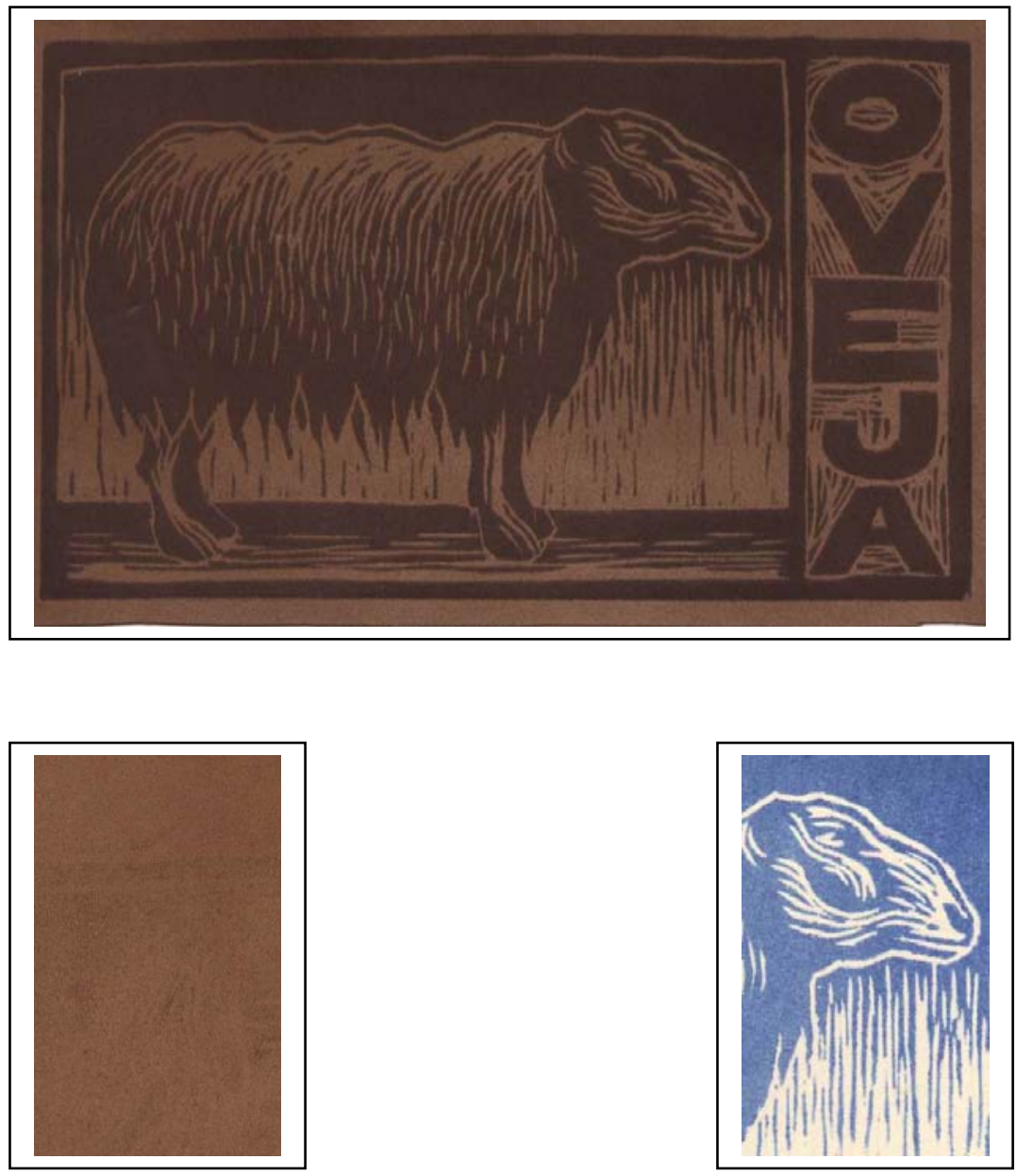

CÓDIGO: C0-018

TÉCNICA: Xilografía

TIPO DE PIEL: Cordero

TONO DE PIEL: Oscuro

TINTA: Azul traslúcido

SUPERFICIE: Lado carne 
CALIDAD: Muy buena.

A pesar de que el contraste es algo menor que en el ejemplo CO016, la calidad de la estampa es igualmente notable, con algunos aspectos excepcionales por su respuesta a la estampación sobre piel. Tampoco presenta problemas de secado 0 asentamiento de la tinta sobre el afelpado del cuero.

MANCHA: Perfecta, totalmente homogénea, regular y de un tono intenso que consigue un resultado muy satisfactorio en las zonas enintadas. Indicar que tanto el oscurecimiento al contacto con el afelpado, como la mezcla por transparencia, hacen acto de presencia con una intensidad más que evidente.

GRAFISMO: Perfecto también y de uns gran calidad general. El afelpado tan sutil de este tipo de cuero no influye en el registro de los contornos xilográficos, consiguiéndose un nivel muy alto de nitidez.

CONTRASTE: La tinta azul sufre un proceso de oscurecimiento y cambio cromático espectacular: pasa del azul original a un gris oscuro algo rojizo que contrasta de manera correcta con el tono marrón del soporte.

BRILLO: Totalmente nulo por efecto de la superficie afelpada de este tipo de piel en su lado carne. 

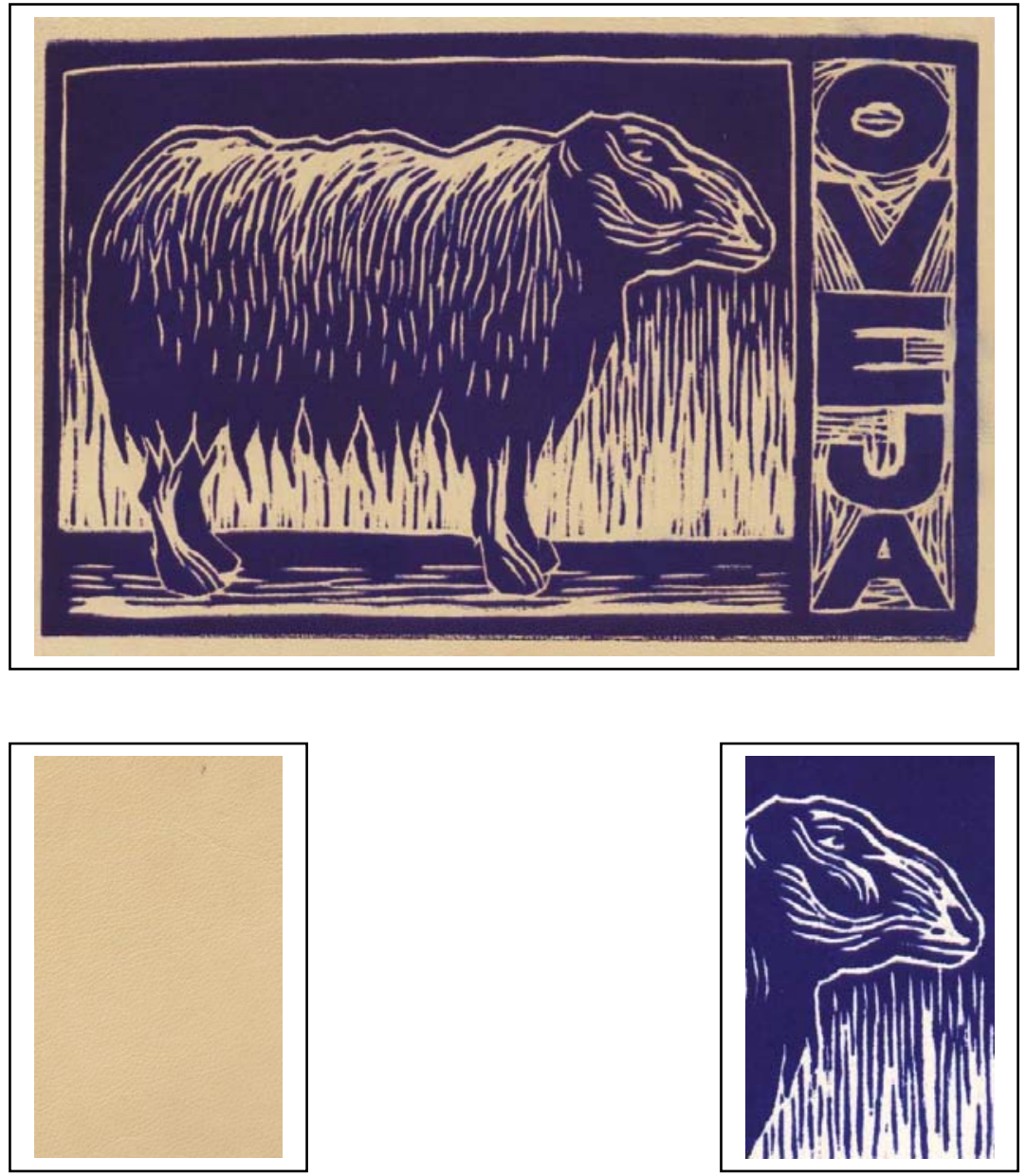

CÓDIGO: C0-019

TÉCNICA: Xilografía

TIPO DE PIEL: Cordero

TONO DE PIEL: Claro

TINTA: Azul opaco

SUPERFICIE: Lado flor 
CALIDAD: Muy buena.

Desde el punto de vista visual y estético es totalmente perfecta, aunque presenta problemas de secado y asentamiento de este tipo de tinta azul. Los inconvenientes vienen derivados de un periodo de tiempo de secado excesivamente largo que puede hacer incómoda su manipulación.

MANCHA: Perfecta, totalmente homogénea y regular, con ka tinta cubriendo perfectamente la superficie de la piel. El tono azul se mantiene casi intacto sobre el cuero, sin apenas mezcla por transparencia, algo lógico en esta tinta mucho más opaca y cubriente.

GRAFISMO: Perfecto a su vez, manteniendo las características de la mancha y con un registro más que correcto de los contornos siempre que procedamos a estampar con el grado mínimo de presión que sea posible. De no hacerlo así será muy probable que obtengamos alteraciones de los seños xilográficos debido a la gran flexibilidad de la piel de cordero y a fácil deformación.

CONTRASTE: Muy intenso, perfecto para lograr una imagen muy interesante y potente plásticamente hablando.

BRILLO: Aparece un ligerísimo brillo que apenas es perceptible y que no dificulta en absoluto la visión de la imagen estampada sobre el cuero. 

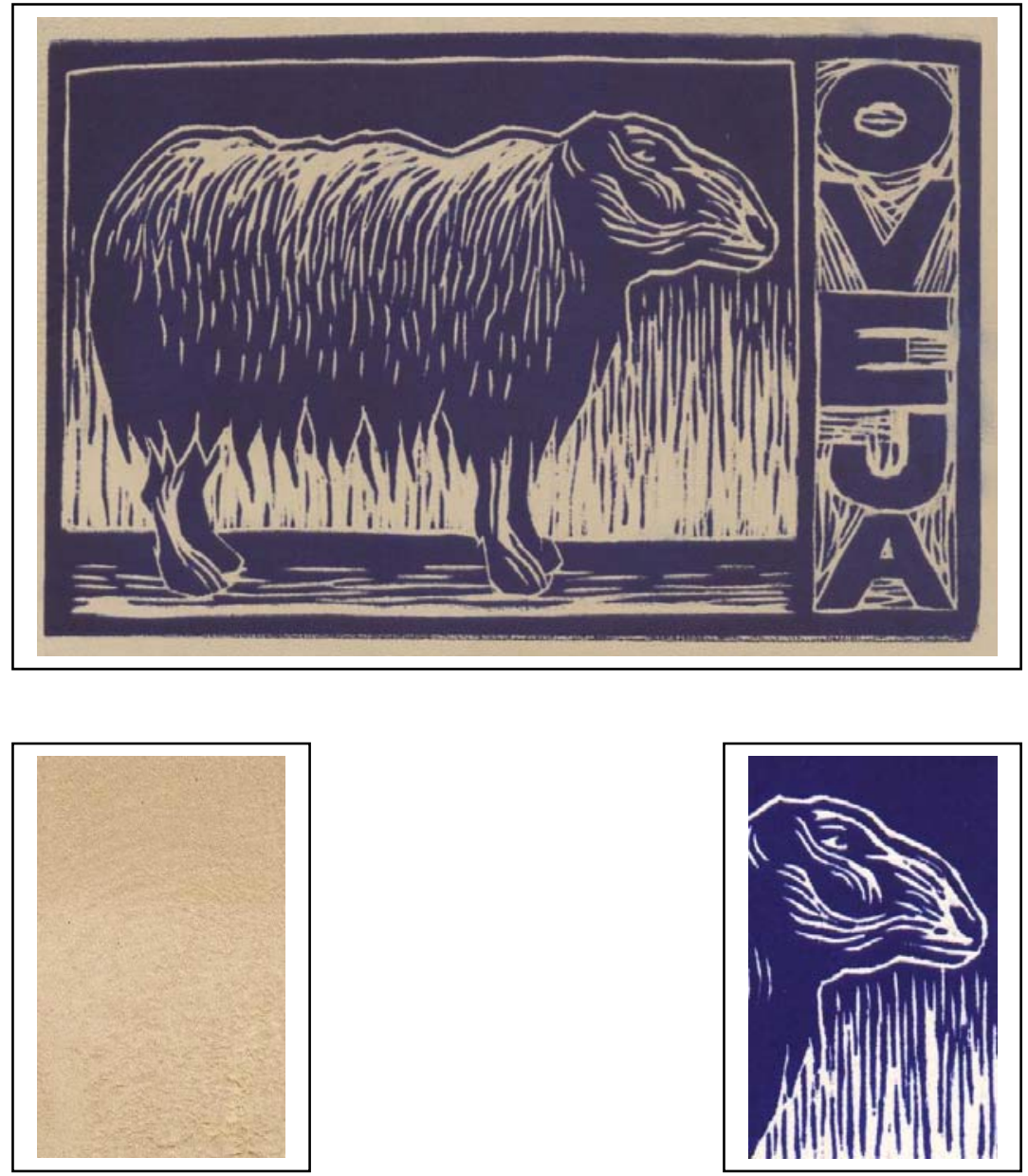

CÓDIGO: CO-020

TÉCNICA: Xilografía

TIPO DE PIEL: Cordero

TONO DE PIEL: Claro

TINTA: Azul opaco

SUPERFICIE: Lado carne 
CALIDAD: Muy buena.

Al igual que su gemela sobre el lado flor es técnicamente perfecta, aunque todavía ofrece inconvenientes relacionados al apartado del asentamiento de la tinta. Sin embargo los problemas son menos acuciantes que sobre la superficie satinada de la anterior imagen ya que el afelpado absorve la tinta de manera evidente.

MANCHA: Perfecta, con la tinta cubriendo de manera ideal la superficie del cuero y logrando un acabado muy satisfactorio. El tono azul se oscurece ligeramente al contacto con el afelpado del lado carne, pero mantiene casi todas las características del color inicial empleado en la estampación.

GRAFISMO: Pefecto también, con un registro extraordinario de los seños xilográficos. En este caso la posibilidad de deformaciones de la imagen disminuyen algo, aunque todavía se debe prestar suma atención a los excesos de presión.

CONTRASTE: Muy intenso y parecido al de la estampa anterior sobre el lado flor ya que los tonos del soporte son muy similares y el grado de oscurecimiento de la tinta mínimo.

BRILLO: Totalmente nulo al estampar sobre superficies afelpadas como esta. 

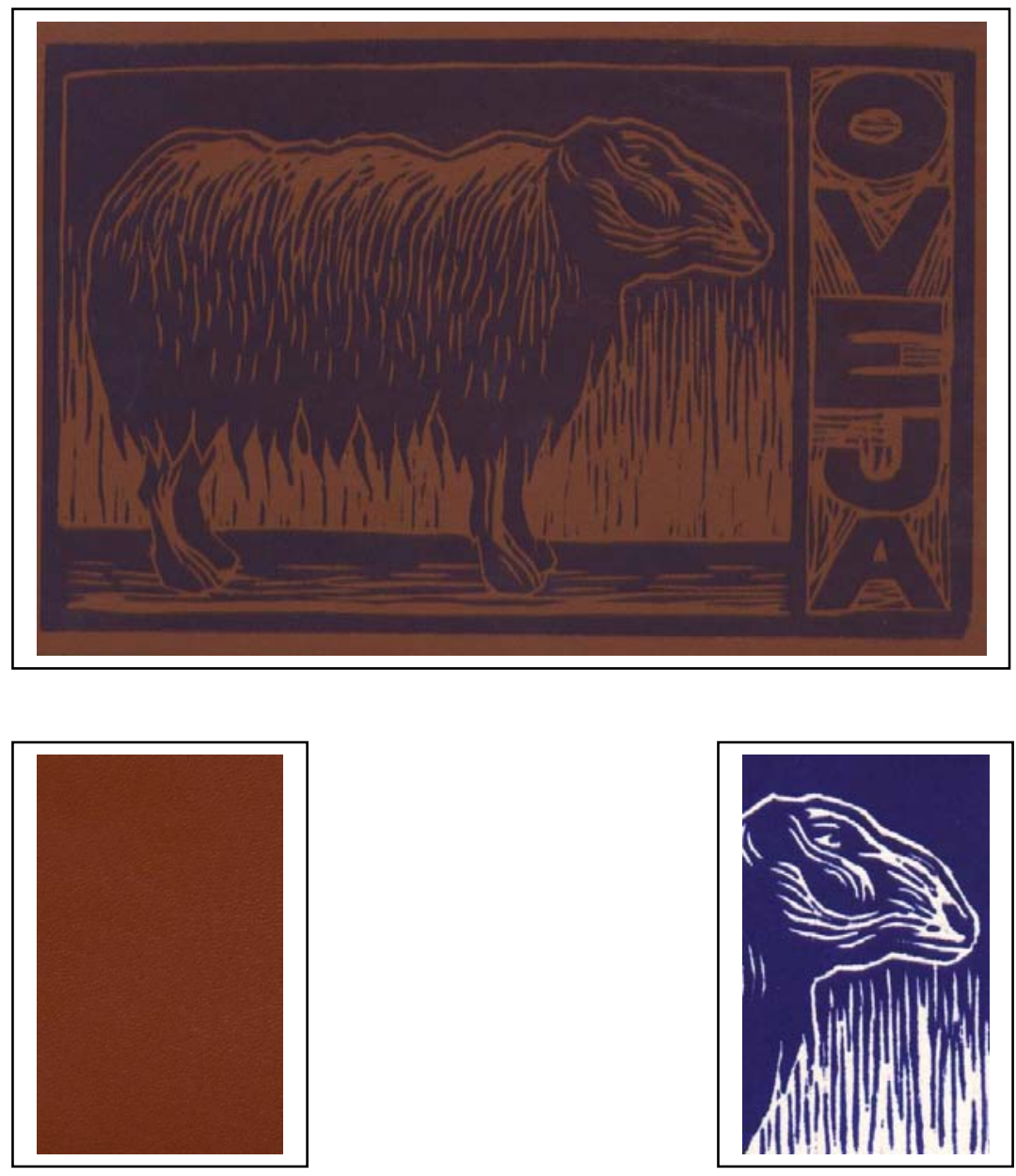

CÓDIGO: C0-021

TÉCNICA: Xilografía

TIPO DE PIEL: Cordero

TONO DE PIEL: Medio

TINTA: Azul opaco

SUPERFICIE: Lado flor 
CALIDAD: Muy buena.

En este caso los problemas de secado desaparecen y no ofrecen ningún tipo de inconveniente serio. Visualmente, y pese al no excesivamente intenso contraste de la imagen, la estampa presenta una calidad excelente en todos los apartados estudiados.

MANCHA: Homogénea, perfecta y regular, sin ningún tipo de problema aparente. La película de tinta formada sobre la superficie de la piel cubre ésta perfectamente y no ofrece inconvniente alguno. Se produce un ligero cambio aparente del tono de azul empleado por efecto del color del soporte, aunque sin llegar a los extremos de la mezcla por transparencia apreciada en las estampas realizadas con azul traslúcido.

GRAFISMO: Al igual que la mancha, perfecto. Si controlamos la presión exacta no aparecerán problemas de deformaciones del cuero y por consiguiente de los seños.

CONTRASTE: Debido al tono algo más oscuro de la piel, la intensidad del contraste no es excesiva, aunque continúa presentando un resultado correcto que permite la obtención de una estampa interesante.

BRILLO: La tinta no modifica la apariencia ligeramente satinada del cuero, no provocando brillos excesivos ni molestos para la correcta visión del ejemplo. 

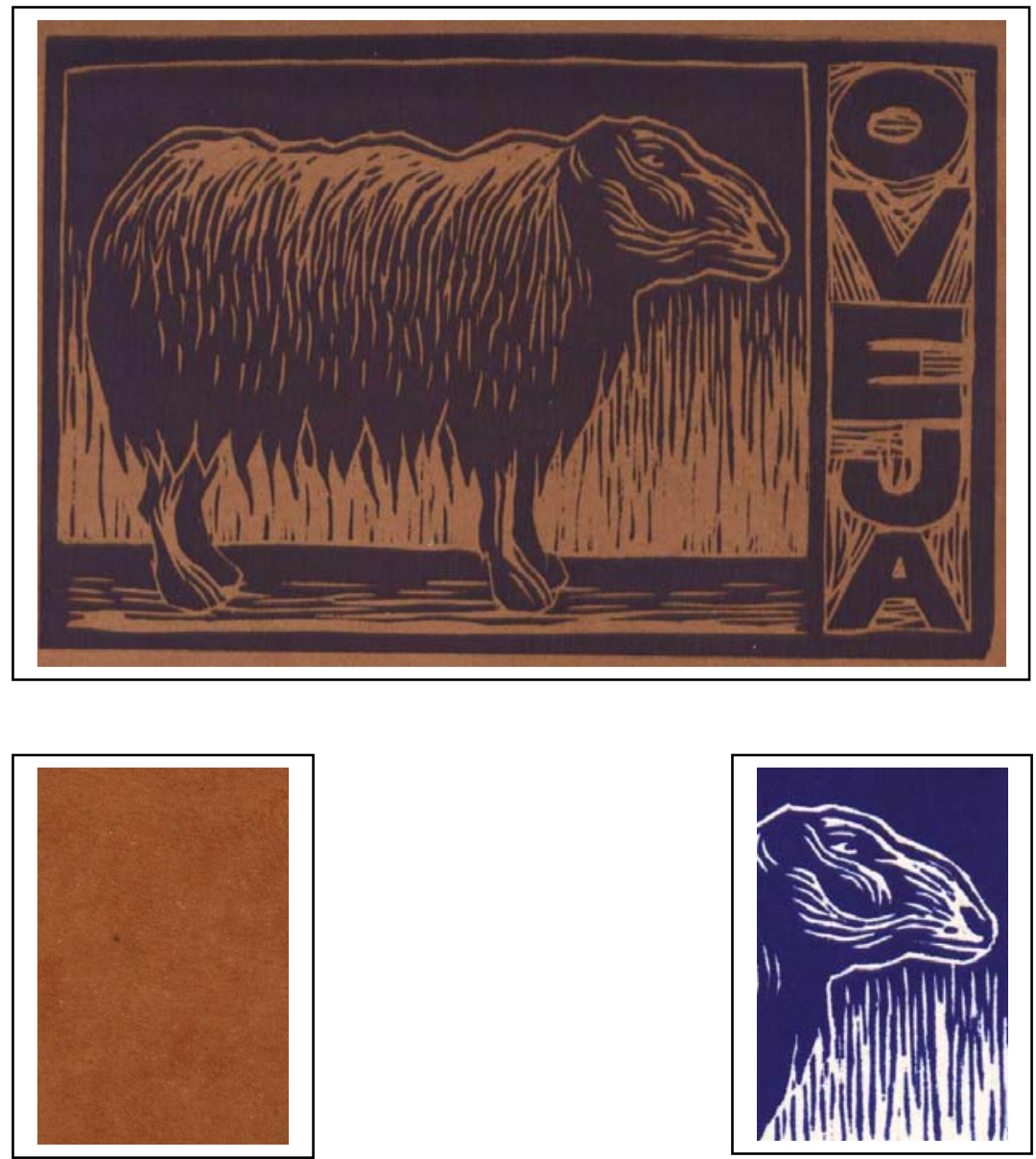

CÓDIGO: CO-022

TÉCNICA: Xilografía

TIPO DE PIEL: Cordero

TONO DE PIEL: Medio

TINTA: Azul opaco

SUPERFICIE: Lado carne 
CALIDAD: Muy buena.

De igual o mejor calidad que la anterior sobre el lado flor gracias al mayor contraste conseguido en esta estampa, contraste que viene determinado por los factores que analizaremos a continuación. Por otro lado no presenta problemas de asentamiento o secado de la tinta.

MANCHA: Perfecta, sin inconvenientes ni problemas, la tinta se muestra capaz de cubrir de manera correcta la superficie ligeramente afelpada del cuero. Dicha tinta sufre un oscurecimiento al contacto con la textura propia del lado carne, proceso que provoca un cambio en su apariencia hasta convertirse en un azul muy oscuro con ligeros toques violáceos.

GRAFISMO: Sin deformaciones ni imperfecciones aparentes, con gran calidad y nitidez en el registro y un excelente nivel general.

CONTRASTE: Intenso gracias al tono algo más claro del cuero en este lado carne, y sobre todo al ya comentado proceso de oscurecimiento del tono azul hasta alcanzar ese color casi negro antes citado. Así, obtenemos un contraste muy adecuado para una correcta apreciación de la estampa realizada.

BRILLO: Nulo como era de esperar al estampar sobre superficies afelpadas como ésta. 

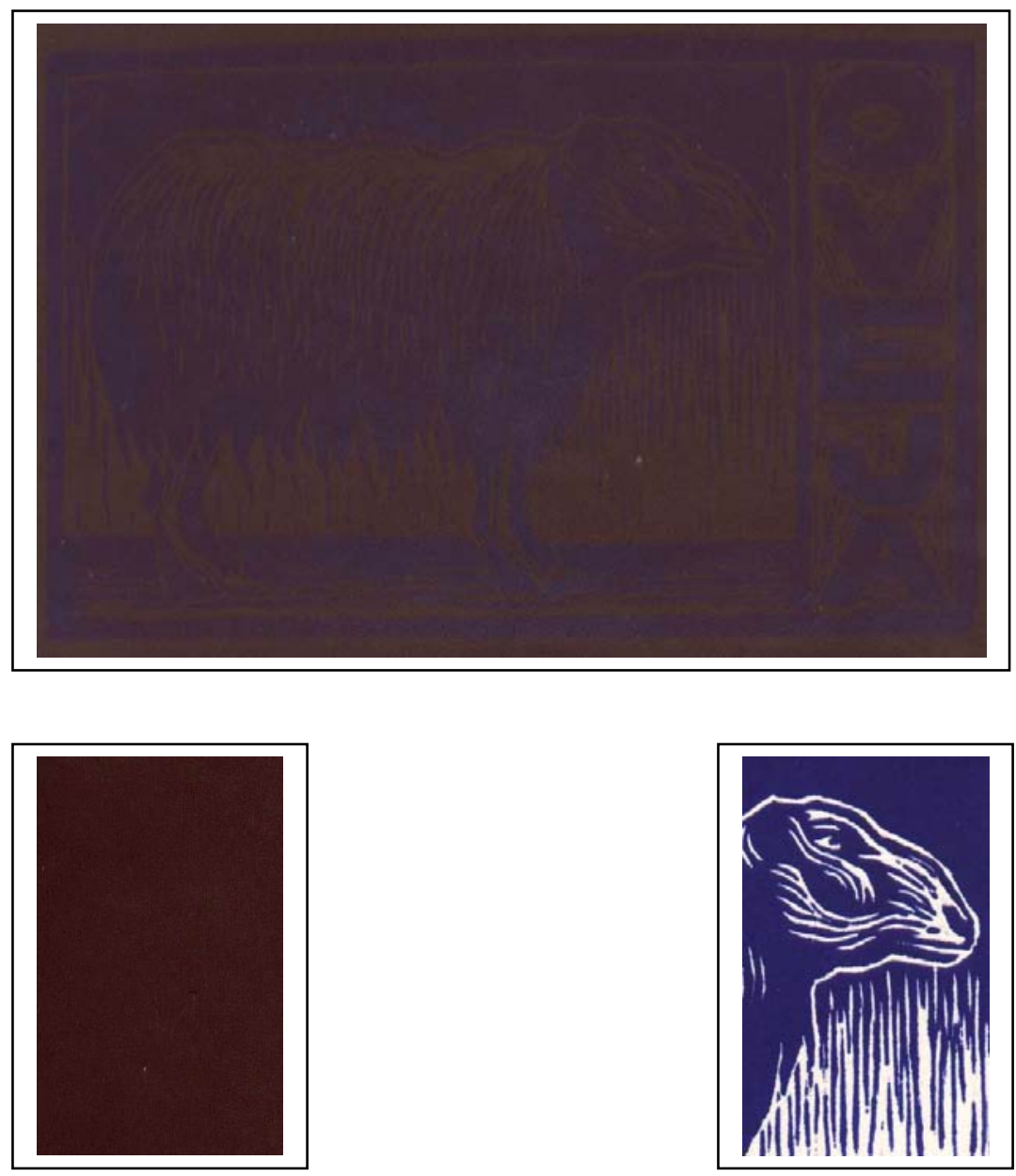

CÓDIGO: CO-023

TÉCNICA: Xilografía

TIPO DE PIEL: Cordero

TONO DE PIEL: Oscuro

TINTA: Azul opaco

SUPERFICIE: Lado flor 
CALIDAD: Muy mala.

El tono tan oscuro, casi negro, del soporte piel hace que la imagen estampada sea casi irreconocible, provocando un ínfimo nivel de calidad general del ejemplo. Por otro lado no aparecen problemas relativos al secado de la tinta 0 al asentamiento de la misma.

MANCHA: Casi inapreciable, perdiéndose las formas y haciendo muy dificil la identificación de las formas.

GRAFISMO: Al igual que la mancha, su nivel de resultado es muy bajo, con los contornos casi perdidos sobre el fondo tan excesivamente oscuro del cuero.

CONTRASTE: Evidentemente se trata del problema fundamental del ejemplo, con una intensidad casi nula que hace imposible distinguir a primera vista las formas y las imágenes estampadas sobre la piel. La tinta se muestra incapaz de contrastar mínimamente con el tono del soporte, por lo que el ejemplo es nulo desde un punto de vista plástico.

BRILLO: La tinta apenas modifica el ya de por sí elevado nivel de brillo presente sobre la satinada superficie del cuero. 

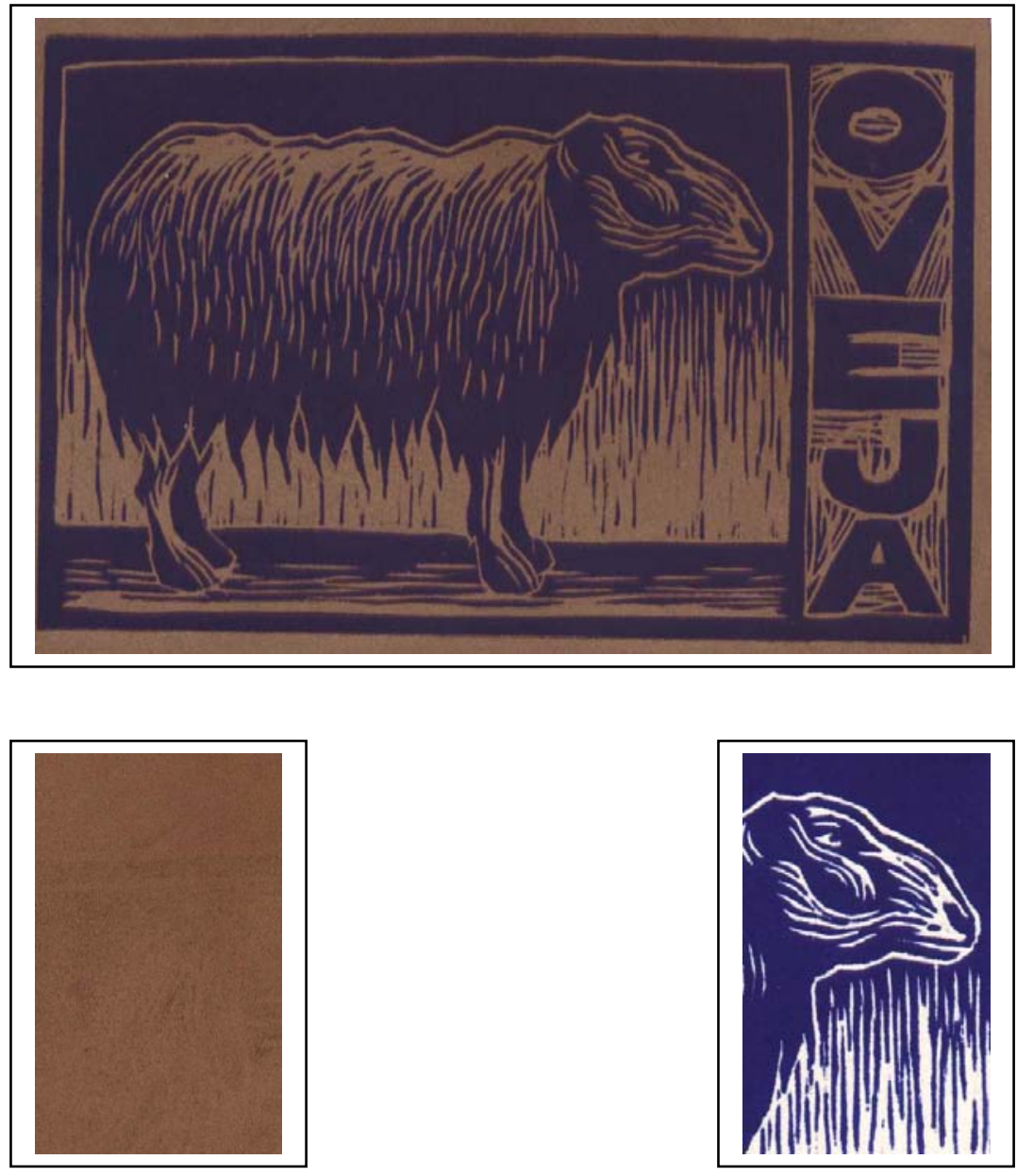

CÓDIGO: CO-024

TÉCNICA: Xilografía

TIPO DE PIEL: Cordero

TONO DE PIEL: Oscuro

TINTA: Azul opaco

SUPERFICIE: Lado carne 
CALIDAD: Muy buena.

Todo lo contrario que sobre el lado flor de esta misma piel de cordero oscura, en este caso el soporte ofrece un tono mucho más ligero que permite una estampación casi perfecta en todos los aspectos. Tampoco presenta excesivos inconvenientes de asentamiento de tinta o secado de la misma.

MANCHA: Excelente, la tinta logra cubrir perfectamente la superficie afelpada de la piel, logrando unas zonas entintadas de gran homogeneidad y regularidad.

GRAFISMO: También casi perfecto, sin deformaciones de registro y con una gran nitidez de estampación.

CONTRASTE: Muy correcto y lo suficientemente intenso como para crear una imagen plástica y estéticamente muy válida e interesante. La tinta azul se oscurece ligeramente al contacto con el afelpado del lado carne, lo que ayuda a la aparición de un contraste incluso más elevado que en estampas anteriores.

BRILLO: Totalmente inexistente e insignificante como es lógico al estampar sobre una superficie texturada como en el ejemplo que nos ocupa. 


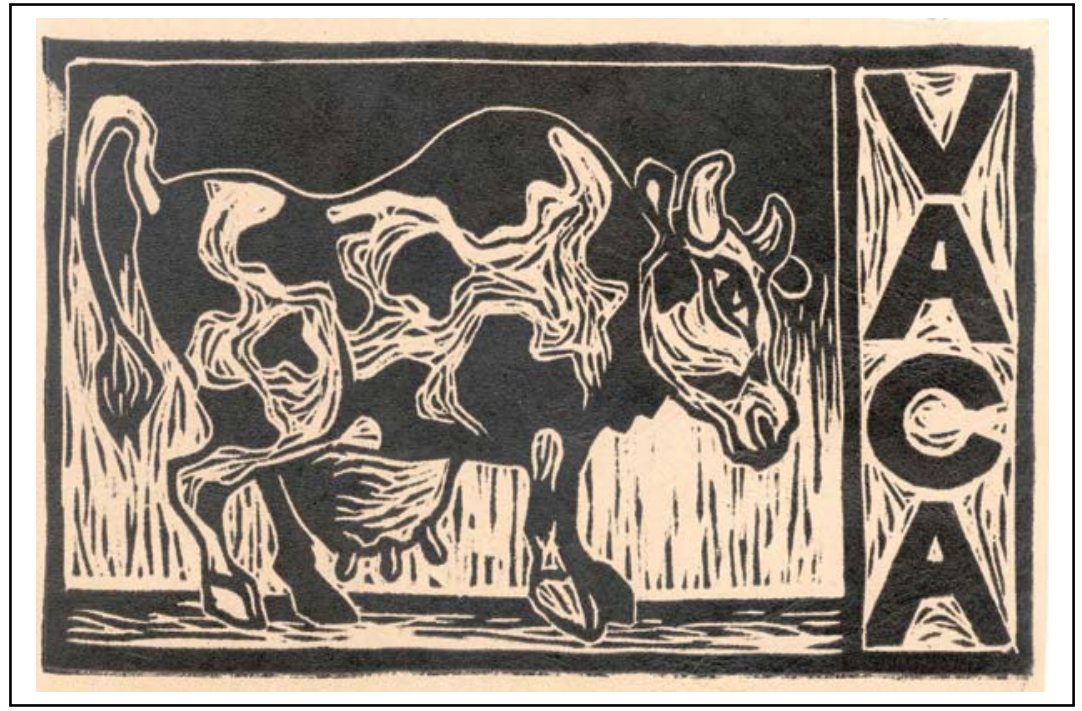

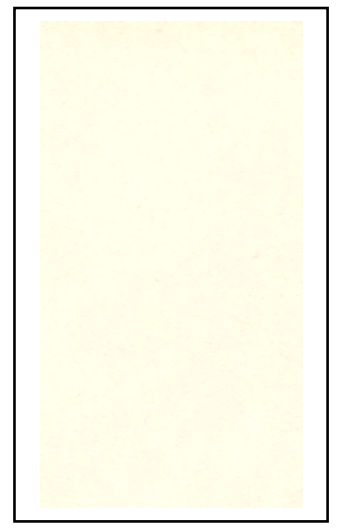

CÓDIGO: VA-001

TIPO DE PIEL: Vaca

TINTA: Negro

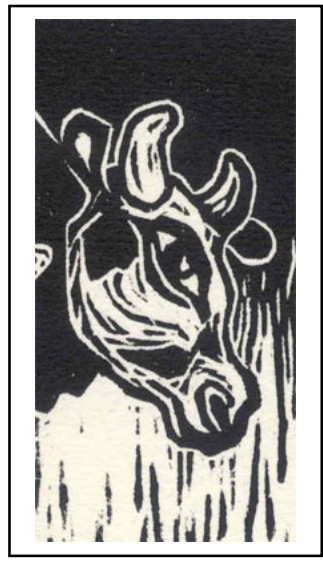

TÉCNICA: Xilografía

TONO DE PIEL: Claro

SUPERFICIE: Lado flor 


\section{CALIDAD: Muy buena}

Al igual que en el resto de ejemplos de utilización de tinta negra sobre un soporte claro (CA-001 o CE-001), los resultados son muy satisfactorios y positivos. La imagen es de una gran calidad y nitidez, sin aparentes defectos que pudieran afearla o estropearla.

MANCHA: Perfecta y sin ningún tipo de inconveniente. La piel recoge perfectamente la tinta necesaria para crear una mancha de una gran densidad de negro. La ligera textura de la piel se hace algo más visible en las zonas entintadas debido al brillo que imprime la tinta negra.

GRAFISMO: Sin mayores problemas. Al no presentar una superficie demasiado satinada no existen problemas de deformación de ligeros y estrechos trazos. Tampoco presenta inconvenientes referentes a la adhesión de la tinta sobre la piel, problemas que suelen aparecer si la misma es demasiado satinada y brillante.

CONTRASTE: Muy acusado debido al tono tan ligero de la superficie de la piel, creándose una imagen perfectamente válida.

BRILLO: Como ya se ha comentado la tinta presenta un ligero brillo que no llega nunca a ser molesto ni perjudicial para la visión de la estampa. 


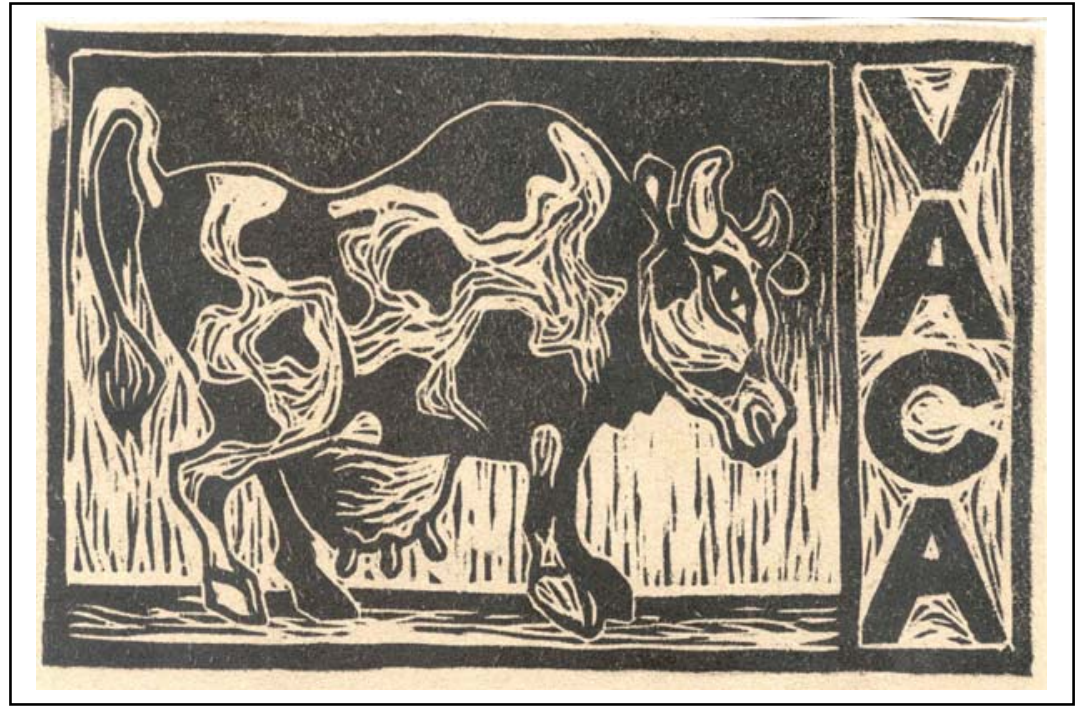

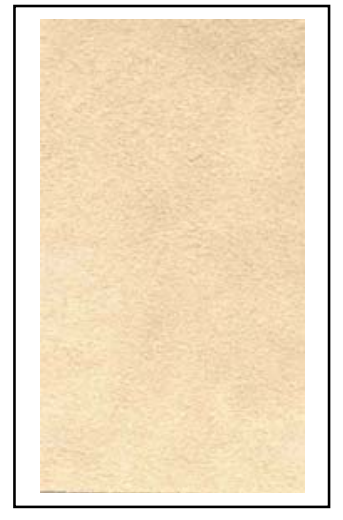

CÓDIGO: VA-002

TIPO DE PIEL: Vaca

TINTA: Negro

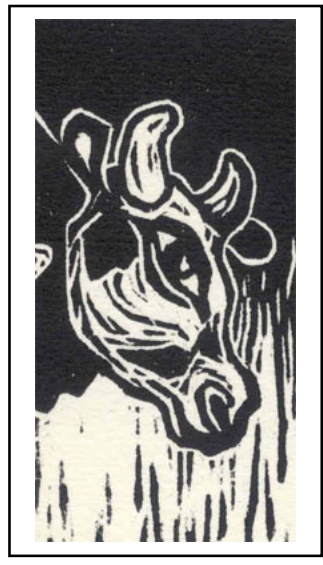

TÉCNICA: Xilografía

TONO DE PIEL: Claro

SUPERFICIE: Lado carne 


\section{CALIDAD: Mediocre}

Esta piel presenta un marcado afelpado en su lado carne, hecho que condicionará las estampas realizadas sobre esta superficie. Por lo demás el comportamiento del soporte es bastante correcto y no ofrece mayores dificultades de estampación.

MANCHA: El ya comentado afelpado de la piel afecta sobremanera a la calidad de la mancha. Este es un claro ejemplo de estampa sobre una superficie rugosa en la cual la tinta no es capaz de cubrir por completo todos los pelillos que cubren la piel. Por lo tanto el negro absoluto no se consigue y numerosas zonas presentan un aspecto incorrecto y con irregularidades.

GRAFISMO: Los defectos ya comentados siguen presentes como es obvio en las zonas de grafismos. Sin embargo en estas áreas son mucho más difíciles de apreciar y pasan casi inadvertidos en muchas ocasiones.

CONTRASTE: A pesar de los defectos puntuales que pueda presentar la zona entintada, el contraste con el fondo es muy correcto e intenso, y lo suficientemente acentuado como para crear una imagen válida y potente.

BRILLO: Inexistente debido al excesivo afelpado de la piel el cual "absorbe" todo el brillo que pudiera presentar la tinta. 


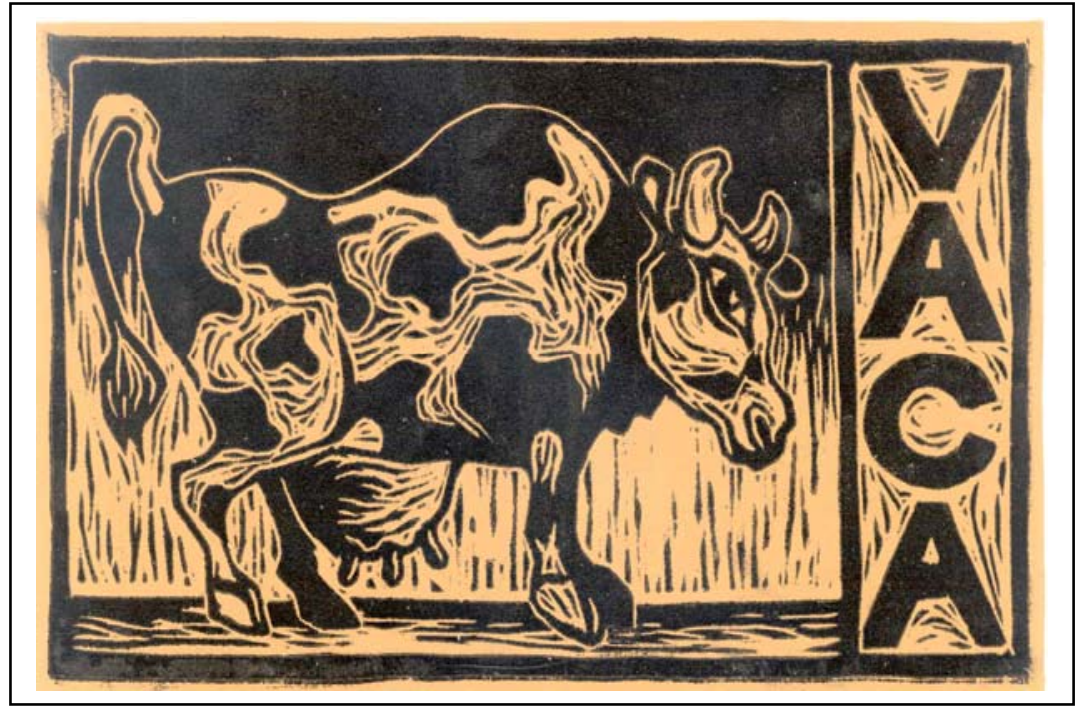

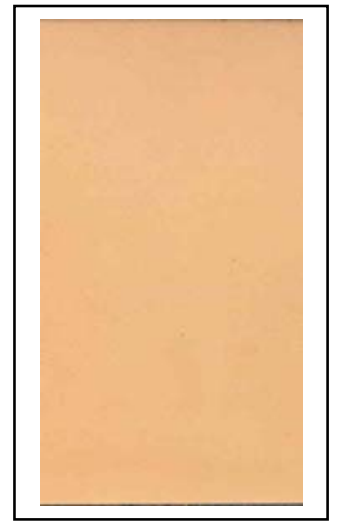

CÓDIGO: VA-003

TIPO DE PIEL: Vaca

TINTA: Negro

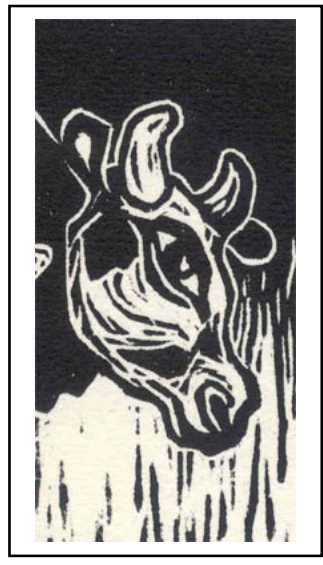

TÉCNICA: Xilografía

TONO DE PIEL: Medio

SUPERFICIE: Lado flor 


\section{CALIDAD: Buena}

Estampa de gran nivel aunque con mínimos inconvenientes. Uno de ellos es el excesivo tiempo de secado que requiere la tinta debido a la superficie tan satinada de la piel. Utilizando una pequeña porción de preparación traslúcida en la mezcla de la tinta podremos reducir este tiempo de secado que, de otra forma, puede llegar a ser incluso de semanas.

MANCHA: Perfecta y sin ningún tipo de problema.

GRAFISMO: La superficie tan pulida de la piel hace que en ciertas zonas, y si la presión es mínimamente excesiva, la tinta no asiente bien sobre la superficie del soporte. Esto se hace evidente a lo largo de los contornos por lo que es mucho más patente en las zonas de gran densidad de grafismos. Sin embargo no afecta en demasía a la percepción de la estampa.

CONTRASTE: Muy adecuado e intenso debido a la extraordinaria intensidad que logra alcanzar la tinta negra sobre la superficie de la piel. Se consigue una imagen totalmente válida y potente.

BRILLO: La tinta adquiere un marcado brillo provocado por la gran saturación de tintes sobre la piel, pudiendo llegar a ser incluso molesto en algunas ocasiones. 


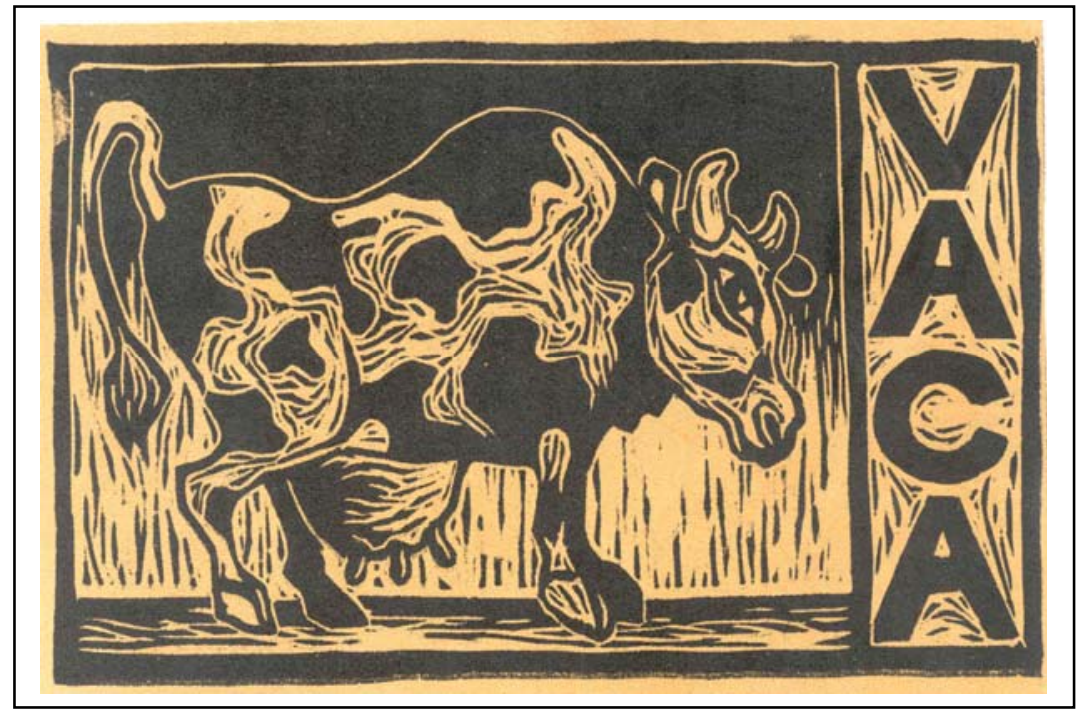

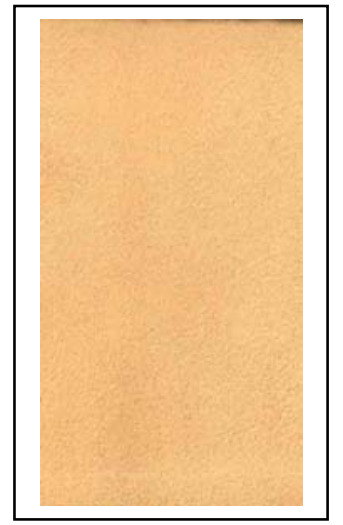

CÓDIGO: VA-004

TIPO DE PIEL: Vaca

TINTA: Negro

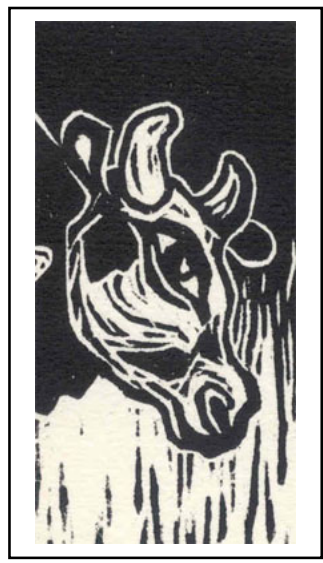

TÉCNICA: Xilografía

TONO DE PIEL: Medio

SUPERFICIE: Lado carne 


\section{CALIDAD: Muy buena}

En este caso tenemos una superficie totalmente distinta a las típicas de los lados carne de otros tipos de pieles. En lugar del afelpado que sería lógico encontrar observamos un acabado extraordinariamente suave y sutil, muy alejado de la rugosidad de otros acabados. Este hecho influirá de manera decisiva en los resultados obtenidos.

MANCHA: Prácticamente perfecta y sin ningún inconveniente. El acabado tan suave de la piel hace que la tinta se comporte de una manera excepcional, extendiéndose con una gran regularidad y calidad.

GRAFISMO: Al igual que en la mancha, no se observan defectos visibles en lo que a las zonas de grafismo se refiere. Se registran todos y cada uno de los seños presentes en la matriz con gran nitidez.

CONTRASTE: Muy correcto. Sin llegar a ser un tono tan denso e intenso como en el lado flor, el negro obtenido es de una gran fuerza, lo que supone que se consiga un contraste suficientemente acentuado como para crear una imagen válida y potente.

BRILLO: Casi inexistente. El acabado afelpado de la superficie de la piel evita la aparición de cualquier tipo de brillos o satinaciones. 


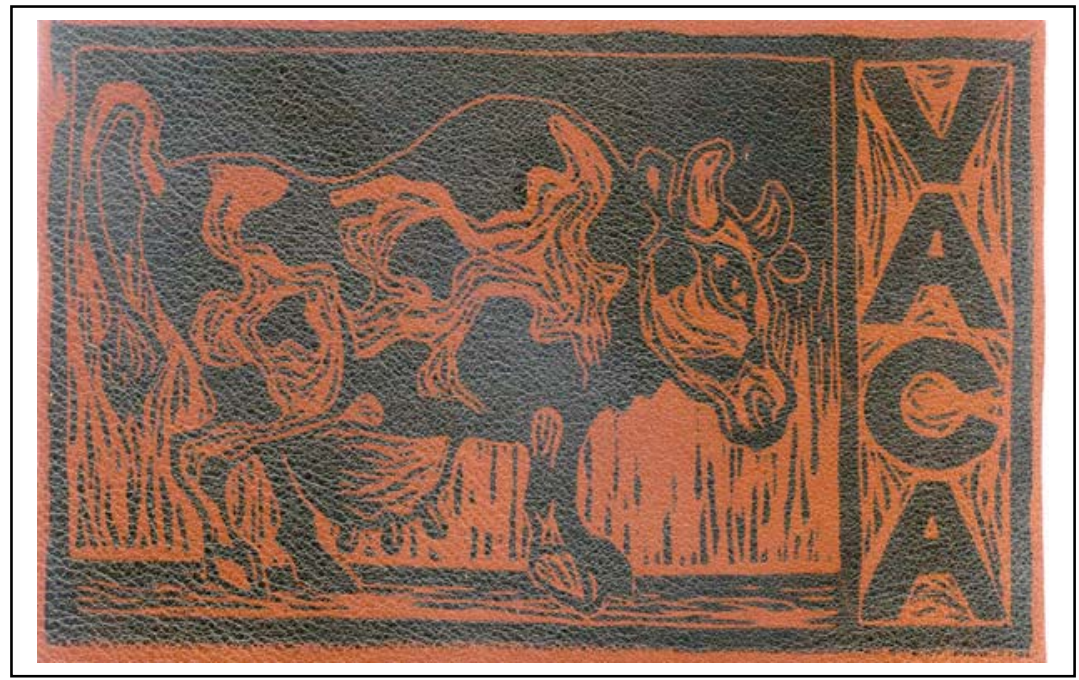

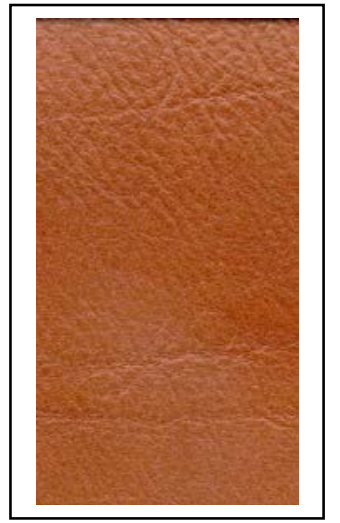

CÓDIGO: VA-005

TIPO DE PIEL: Vaca

TINTA: Negro

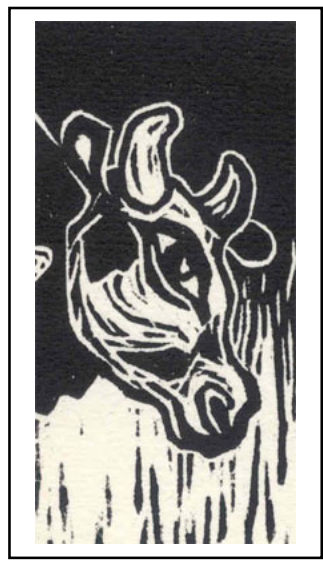

TÉCNICA: Xilografía

TONO DE PIEL: Oscuro

SUPERFICIE: Lado flor 


\section{CALIDAD: Mediocre}

En este caso hemos escogido una piel con una textura muy marcada en su lado flor. Sin embargo en el ejemplo que nos ocupa, el de una estampación en negro, su incidencia en el resultado final será mínima.

MANCHA: De gran densidad y homogeneidad, no presenta ningún tipo de inconvenientes. La textura de la piel no influye a la hora de conseguir una mancha de gran calidad.

GRAFISMO: Sin problemas aparentes, registra a la perfección todos y cada uno de los seños y líneas de la matriz. No presenta inconvenientes relacionados con los contornos como si aparecían en otros ejemplos anteriores.

CONTRASTE: El elevado tono de la piel provoca que el contraste se reduzca drásticamente. Aun así es lo suficientemente fuerte como para hacer perceptible la imagen sin demasiados problemas.

BRILLO: La tinta negra aumenta aún más el brillo ya de por sí presente en la superficie de la piel, llegando a resultar incluso molesto y a dificultar la visión de la estampa. 


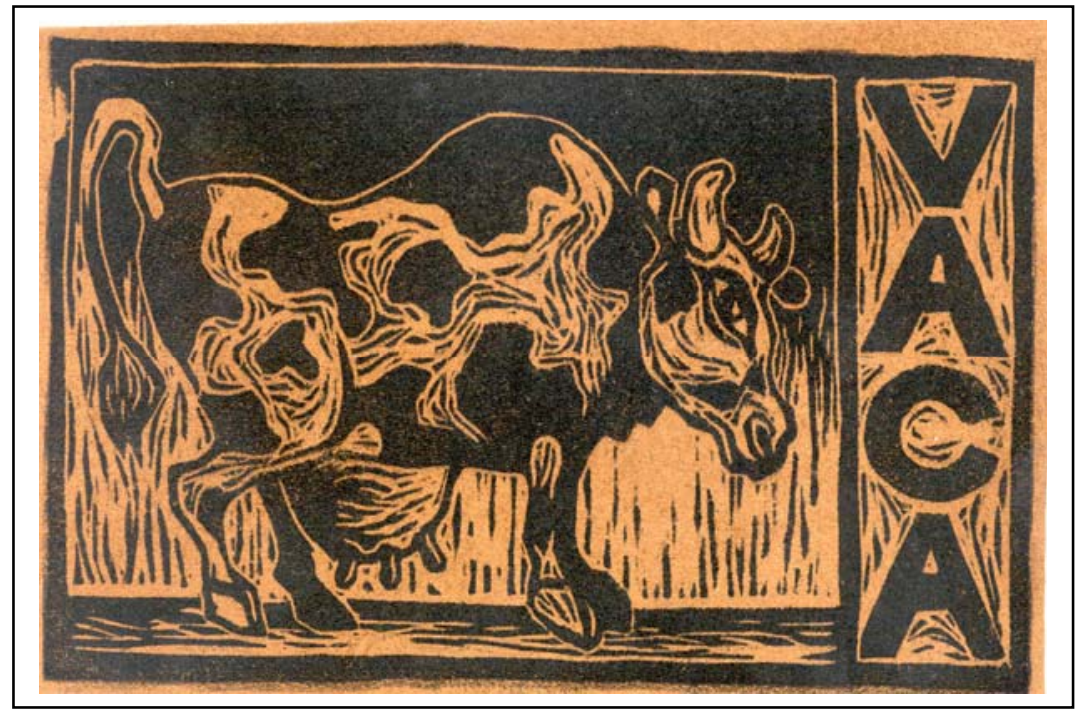

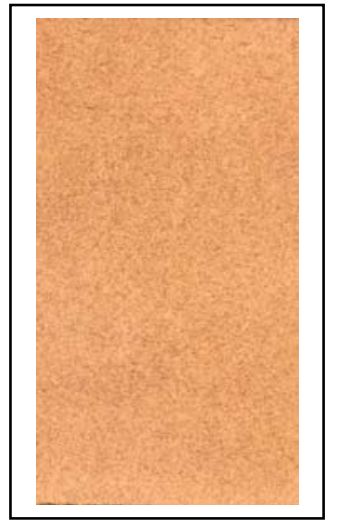

CÓDIGO: VA-006

TIPO DE PIEL: Vaca

TINTA: Negro

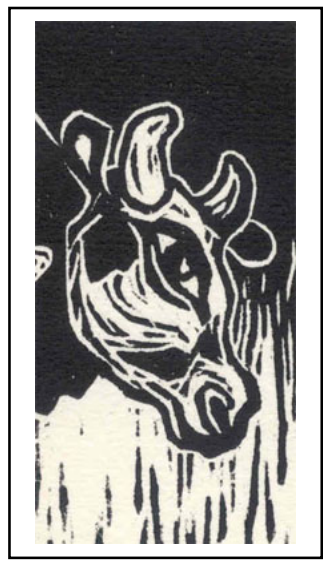

TÉCNICA: Xilografía

TONO DE PIEL: Oscuro

SUPERFICIE: Lado carne 


\section{CALIDAD: Buena}

Volvemos a encontrar un lado carne con una superficie bastante afelpada, texturada y rugosa, aunque sin llegar a los extremos de la piel vacuna clara (VA-002). A pesar de ello la estampa es de gran calidad, debido en parte al tono algo más claro de esta superficie, el cual favorece la aparición de un mayor contraste.

MANCHA: No presenta ningún defecto visible, consiguiéndose un negro de una gran intensidad y regularidad.

GRAFISMO: Debido al afelpado de la superficie del soporte algunos contornos se ven afectados ligeramente, aunque sin influir de manera importante en el resultado final de la estampa ni en la correcta estampación de los grafismos.

CONTRASTE: El hecho de que el lado carne sea algo más claro que el lado flor (VA-005) al menos en este caso, provoca que el contraste sea más intenso y elevado. Así obtenemos una imagen mucho más correcta y potente.

BRILLO: Nulo. No se aprecia ningún resquicio de brillo a pesar del uso de una gran cantidad de tinta negra para la estampación de este imagen. 

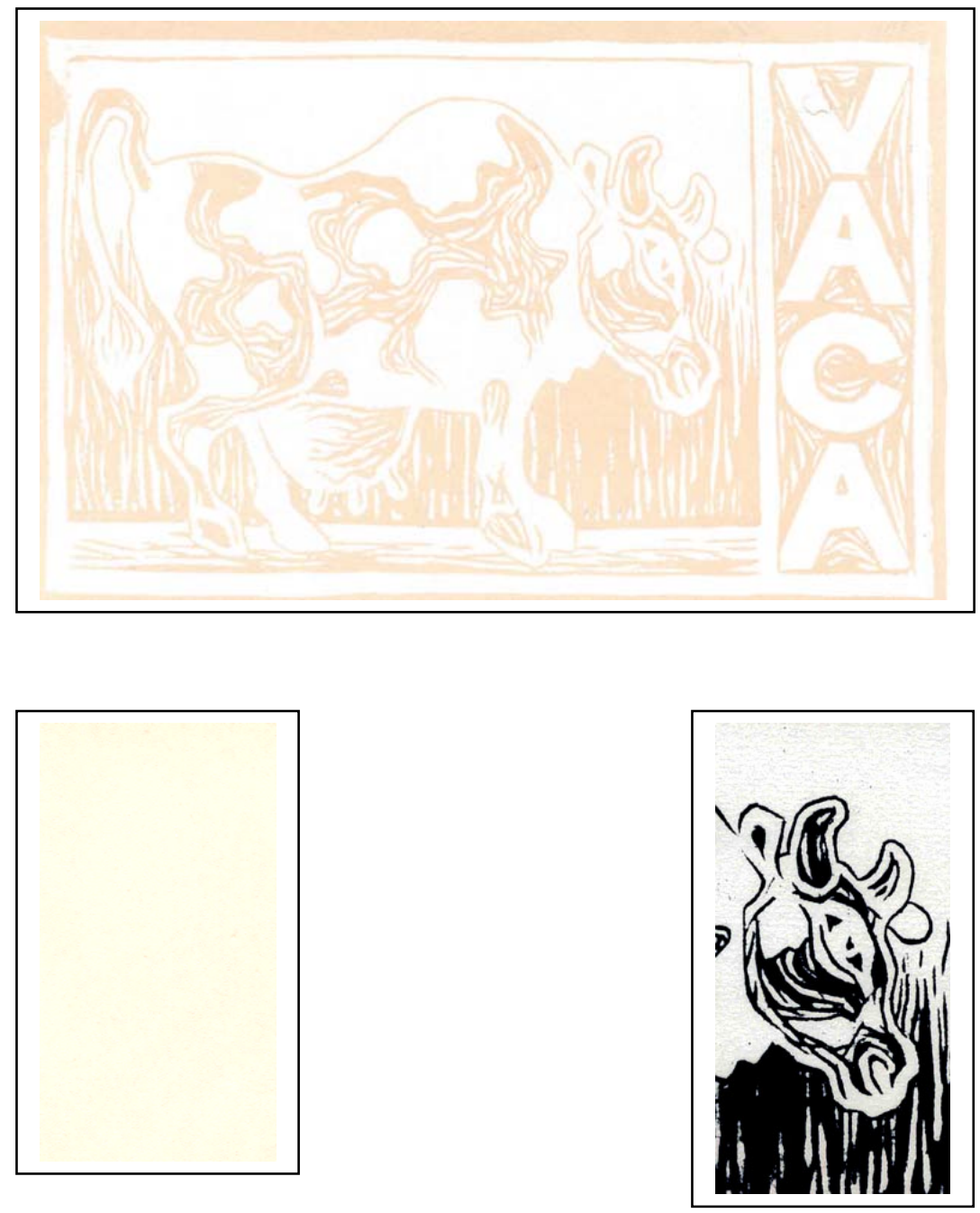

CÓDIGO: VA-007

TÉCNICA: Xilografía

TIPO DE PIEL: Vaca

TONO DE PIEL: Claro

TINTA: Blanca

SUPERFICIE: Lado flor 


\section{CALIDAD: Buena}

Imagen de bastante buen resultado a pesar de realizarse con tinta blanca sobre un soporte tan claro. Se trata por tanto de una de las mejores estampas entintadas en blanco y sobre este tono de piel.

MANCHA: Homogénea y regular. Extrañamente no aparece, o no se aprecia, el típico acabado a grumos de la tinta blanca. En su lugar dicha tinta se extiende manera uniforme sobre la superficie del soporte, consiguiéndose una mancha de muy buena calidad.

GRAFISMO: Bastante buen resultado aunque los contornos aparecen algo difusos y poco nítidos. En general los trazos han sido registrados con normalidad y sin demasiados problemas.

CONTRASTE: Escaso debido al tono del soporte. Aun así la imagen es correcta y fácilmente legible, aunque adoleciendo de cierta falta de fuerza e intensidad.

BRILLO: Aparece un ligerísimo brillo en las zonas entintadas, pero en ningún momento resulta dañino ni perjudicial para la correcta visión de la imagen. Este brillo es muy extraño ya que, como se ha comentado en numerosas ocasiones, la tinta blanca posee una naturaleza claramente mate y casi nunca produce ningún tipo de reflejos. 

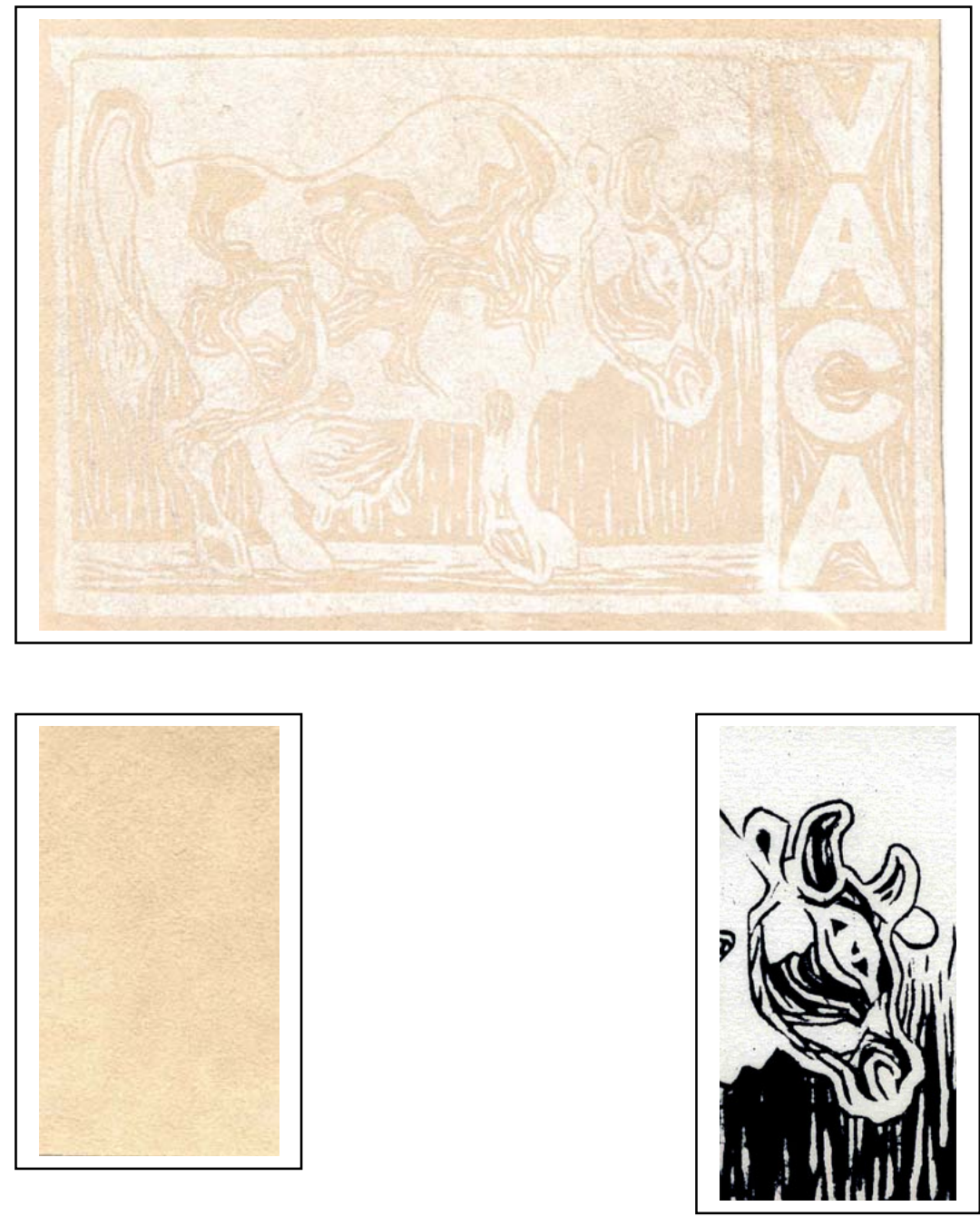

CÓDIGO: VA-008

TÉCNICA: Xilografía

TIPO DE PIEL: Vaca

TONO DE PIEL: Claro

TINTA: Blanca

SUPERFICIE: Lado carne 


\section{CALIDAD: Muy mala}

Estampa de pésima calidad que pone de manifiesto la imposibilidad de trabajar con tintas blancas sobre superficies muy afelpadas y de tonalidades claras.

MANCHA: Irregular y llena de defectos. La tinta blanca, a pesar de la gran cantidad presente en la superficie del soporte, es incapaz de cubrir la textura de la piel. Por tanto deja al descubierto todas y cada una de las imperfecciones de su superficie. La piel recoge una gran cantidad de tinta de la plancha matriz, pero después esta carga no se ve reflejada en la imagen.

GRAFISMO: Muy mediocre. Las líneas llegan a perderse en algunas zonas por efecto de la excesiva textura de la piel, creándose una imagen confusa y de mala calidad.

CONTRASTE: Mínimo y a todas luces insuficiente para una correcta visión de la estampa. Hay zonas donde es difícil percibir los contornos de la figura y de los diferentes trazos y líneas que la componen.

BRILLO: Nulo. La unión de afelpado y tinta blanca da, casi con total seguridad, un acabado completamente mate y sin ningún tipo de reflejos. 

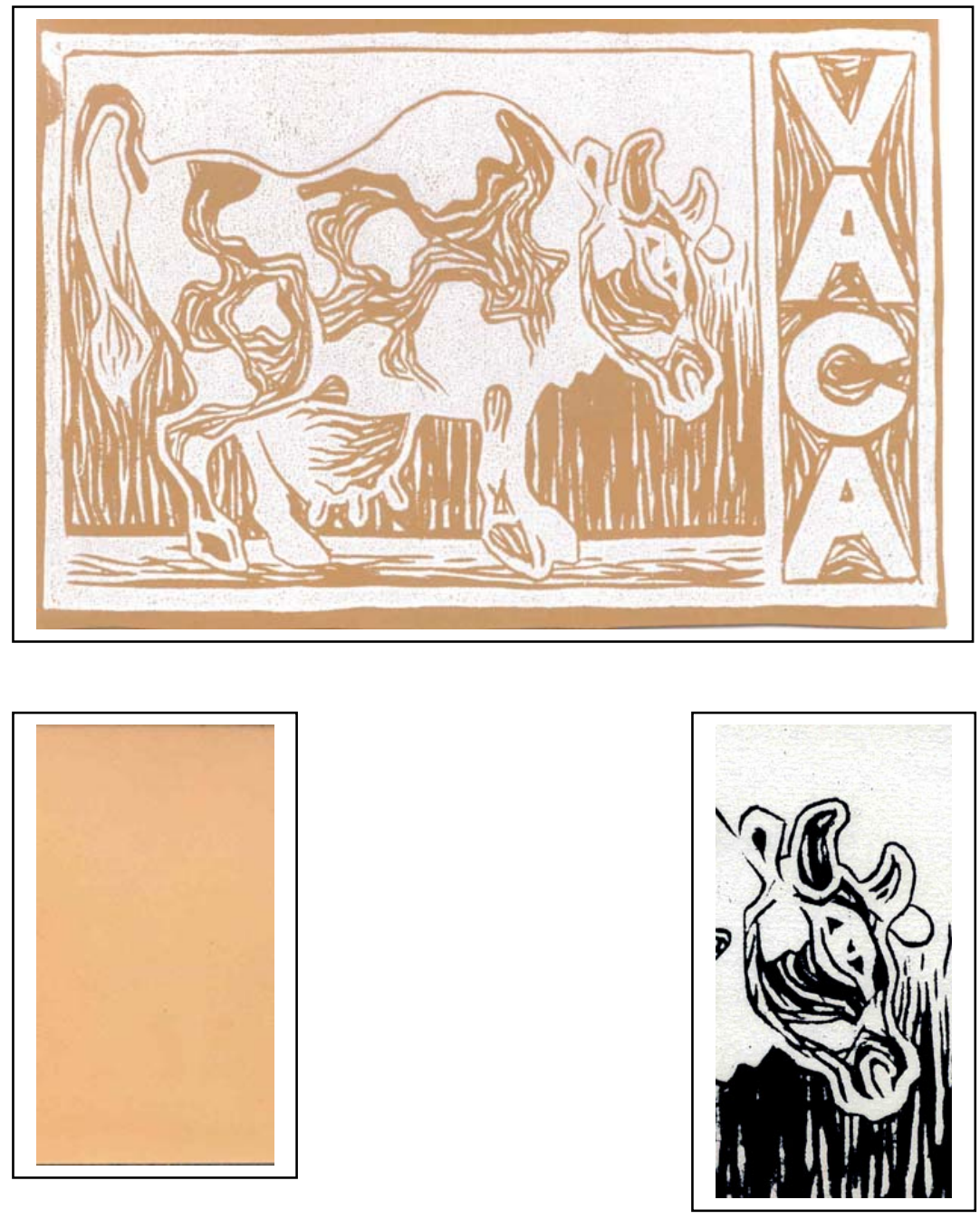

CÓDIGO: VA-009

TÉCNICA: Xilografía

TIPO DE PIEL: Vaca

TONO DE PIEL: Medio

TINTA: Blanca

SUPERFICIE: Lado flor 


\section{CALIDAD: Mediocre}

Ejemplo con aspectos muy positivos y otros claramente negativos que debemos estudias e intentar solucionar.

MANCHA: Presenta un acuciante problema asociado al uso de grandes cantidades de tinta blanca: los grumos que invaden la mancha. La tinta blanca no se extiende de manera uniforme por la piel, creando una textura algo desagradable. El problema puede ser subsanado y paliado en cierta medida mediante la incorporación de preparación traslúcida a la tinta blanca. Ésta hará algo más fluida la tinta y tenderán a desaparecer estas texturas. Sin embargo, por el contrario, la tinta perderá algo de su intensidad y de su poder cubriente por lo que también disminuirá el contraste.

GRAFISMO: Debido a la menor superficie los problemas antes comentados se reducen y son más difíciles de apreciar. Sin embargo los trazos continúan teniendo los contornos algo difusos e irregulares.

CONTRASTE: El contraste es lo suficientemente acentuado e intenso como para hacer de la estampa una imagen legible y correcta. Los inconvenientes ya comentados no afectan en este caso al contraste entre fondo y figura.

BRILLO: Aparece un ligero brillo a pesar de la naturaleza mate de la tinta blanca. Éste no interfiere en la visión de la imagen ni resulta molesto. 

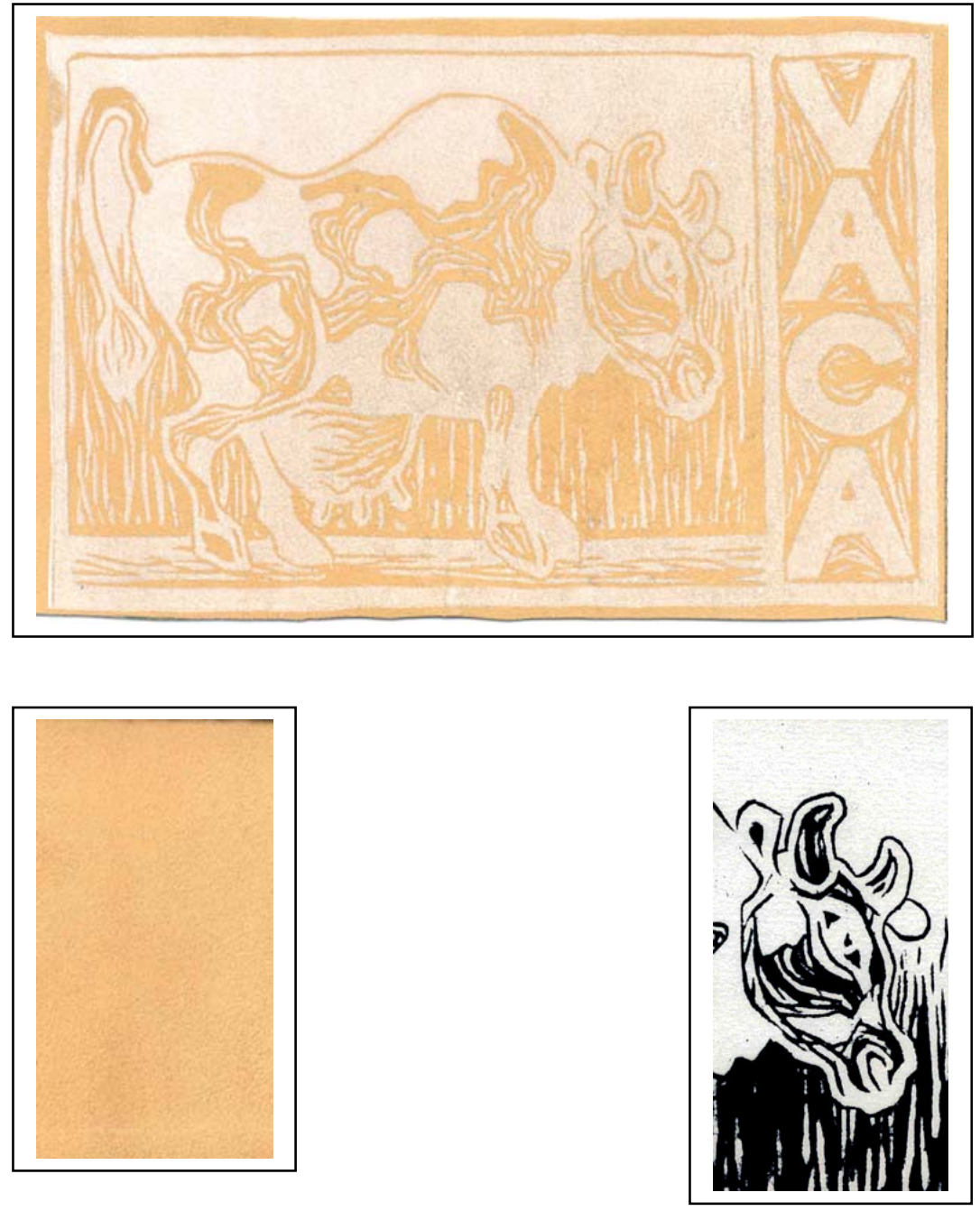

CÓDIGO: VA-010

TÉCNICA: Xilografía

TIPO DE PIEL: Vaca

TONO DE PIEL: Medio

TINTA: Blanca

SUPERFICIE: Lado carne 


\section{CALIDAD: Mala}

Ejemplo de resultados algo mejor que el anterior sobre el lado carne de la piel clara (VA-008). Ésto está provocado porque el afelpado en esta piel es muy sutil, lo que disminuye el efecto perjudicial de dicha textura para con las tintas blancas. A pesar de todo la imagen no es satisfactoria ni colma las necesidades mínimas de una correcta estampación.

MANCHA: Relativamente uniforme aunque varía con relación a la superficie de la piel. Así la mancha es más nítida, homogénea e intensa en las zonas de afelpado más sutil, mientras que donde la textura es más rugosa la mancha es mucho más grisácea, irregular y de menor calidad.

GRAFISMO: Ocurre exactamente lo mismo que lo comentado con la mancha, aunque siempre siendo más difícil de ser apreciado.

CONTRASTE: Escaso, aunque permite identificar las formas y los contornos sin excesivas dificultades. El blanco de la tinta, al contacto con la superficie afelpada del lado carne, se ha convertido en un gris lo que disminuye la intensidad del contraste y ofrece una imagen carente de fuerza.

BRILLO: Como ocurre casi siempre que se unen la textura afelpada y la tinta blanca en este ejemplo no aparece ningún tipo de brillos. 


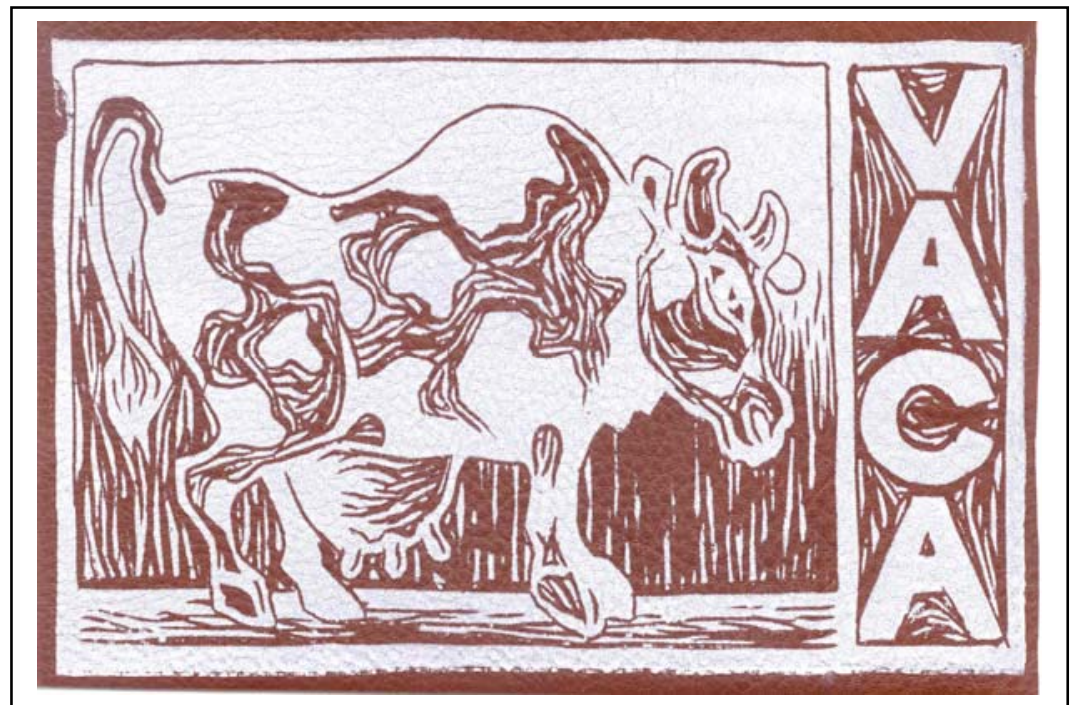

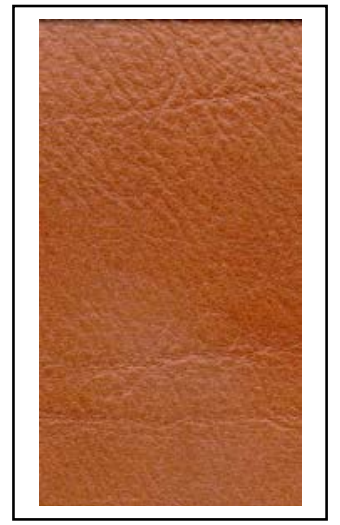

CÓDIGO: VA-011

TIPO DE PIEL: Vaca

TINTA: Blanca

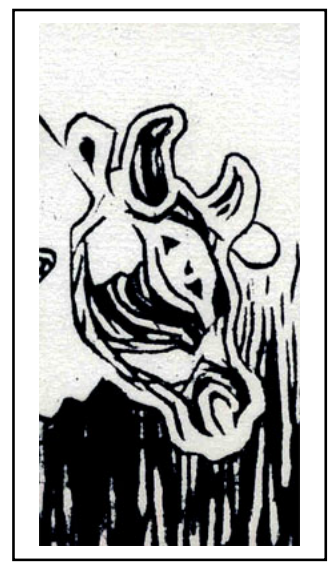

TÉCNICA: Xilografía

TONO DE PIEL: Oscura

SUPERFICIE: Lado flor 


\section{CALIDAD: Buena}

Ejemplo de muy buen nivel ya que los problemas e inconvenientes de anteriores estampas se ven disminuidos y aliviados. Aún así dichas irregularidades no desaparecen por completo y continúan presentes en la estampa.

MANCHA: Muy uniforme, regular y de bastante intensidad a pesar de no alcanzar el blanco verdadero. El acabado grumoso se ha visto atenuado hasta hacerse casi inapreciable y, por otro lado, la textura propia de la piel se ve acentuada en las zonas entintadas con blanco.

GRAFISMO: Buen resultado y acabado, notándose tan sólo una ligera irregularidad en sus contornos.

CONTRASTE: Muy intenso y potente. Se crea una imagen muy válida y atractiva. El tono tan oscuro de la superficie de la piel influye de manera decisiva en esta intensidad del contraste.

BRILLO: La tinta blanca elimina algo del brillo que posee la piel, provocando la aparición de una superficie mate en las zonas entintadas. 

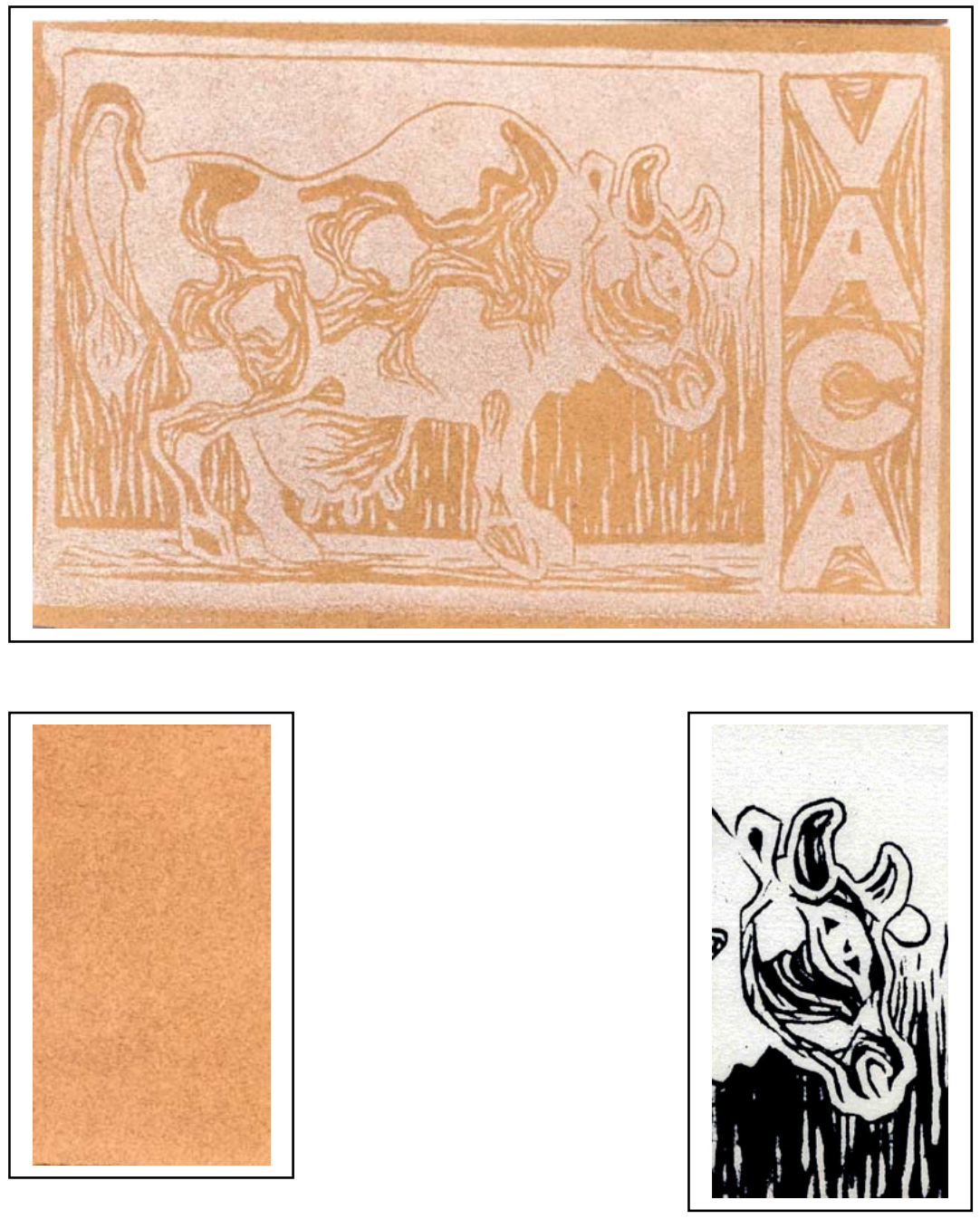

CÓDIGO: VA-012

TÉCNICA: Xilografía

TIPO DE PIEL: Vaca

TONO DE PIEL: Oscuro

TINTA: Blanca

SUPERFICIE: Lado carne 


\section{CALIDAD: Mediocre}

Como ya se ha comentado el lado carne de este tipo de piel es muy rugoso y afelpado, así como de un marrón mucho más claro que el tono del lado flor. Estos factores influirán decisivamente en los resultados obtenidos.

MANCHA: A pesar de lo rugoso de la piel la mancha posee una aceptable calidad. Sin embargo se debe tener mucho cuidado en su manipulación ya que el pelo es tan sutil que podría llegar a estropearse la estampa.

GRAFISMO: Aceptable, aunque los contornos se encuentran muy difuminados.

CONTRASTE: No muy intenso ni potente por efecto del tono medio de la piel y, sobre todo del gris en el que se ha convertido la tinta blanca usada en la estampación. Se trata de un gris que no contrasta en demasía con el tono marrón de la superficie de la piel.

BRILLO: Prácticamente nulo e inapreciable, lógico si tenemos en cuenta la gran cantidad de pelo presente en la piel. 


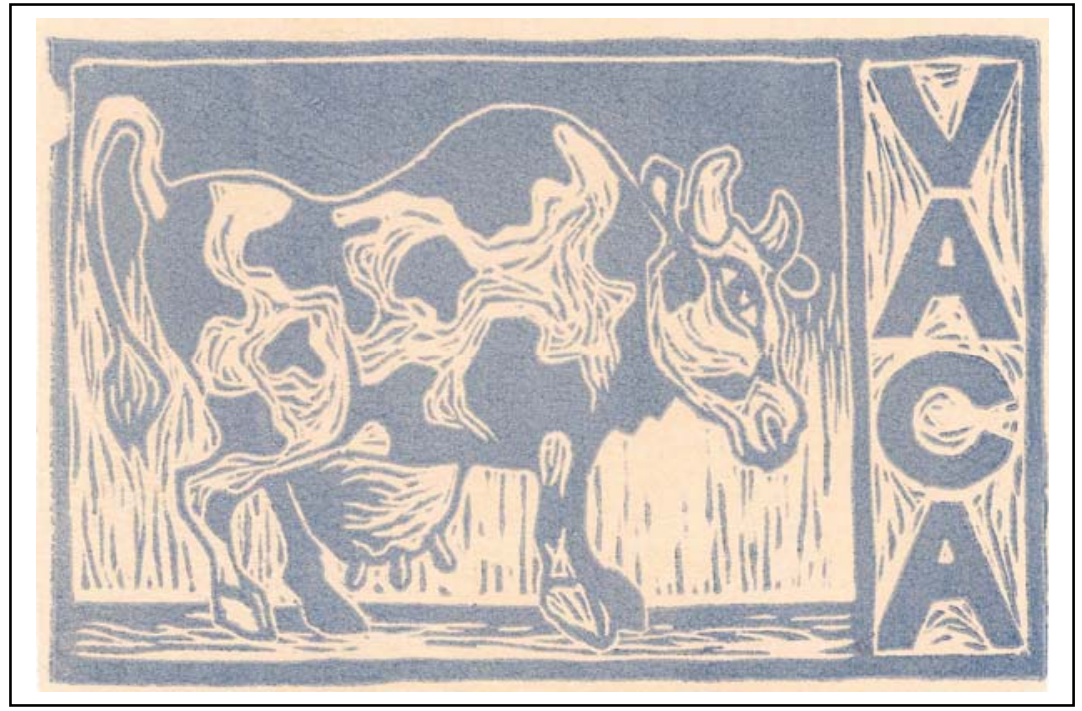

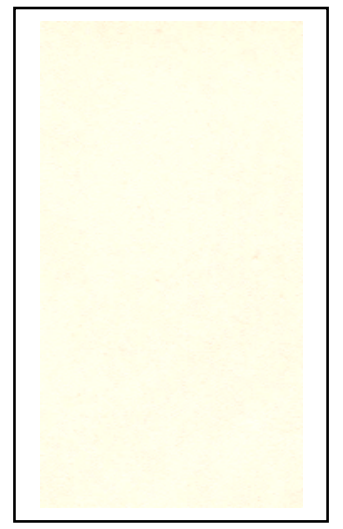

CÓDIGO: VA-013

TIPO DE PIEL: Vaca

TINTA: Azul traslúcido

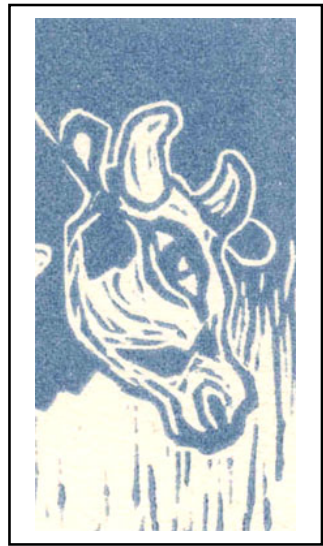

TÉCNICA: Xilografía

TONO DE PIEL: Claro

SUPERFICIE: Lado flor 


\section{CALIDAD: Muy buena}

Estampa de muy buen nivel aunque con las características propias de las imágenes estampadas con tintas muy transparentes. Los colores resultantes de estas estampaciones cambian sustancialmente con respecto al tono original de azul, obteniéndose tonalidades muy especiales e interesantes.

MANCHA: Muy homogénea y de gran regularidad si la superficie de la piel no presenta defectos ni irregularidades. Se extiende sobre ésta de manera casi perfecta para crear una mancha de buen nivel. El tono de la tinta cambia ligeramente, oscureciéndose y pasando a obtenerse un azul quebrado de gran calidad cromática.

GRAFISMO: Debido a la gran transparencia de la tinta pueden aparecer irregularidades en ciertos contornos, las cuales se relacionarían con un mínimo exceso de presión.

CONTRASTE: Muy correcto ya que al sufrir el ya comentado proceso de oscurecimiento, la tinta se convierte en un azul medio que contrasta perfectamente con el tono amarfilado de la superficie del soporte.

BRILLO: Aparece un leve brillo por efecto de la gran cantidad de preparación transparente presente en la tinta. Sin embargo no llega a ser perjudicial para la correcta visión de la imagen. 

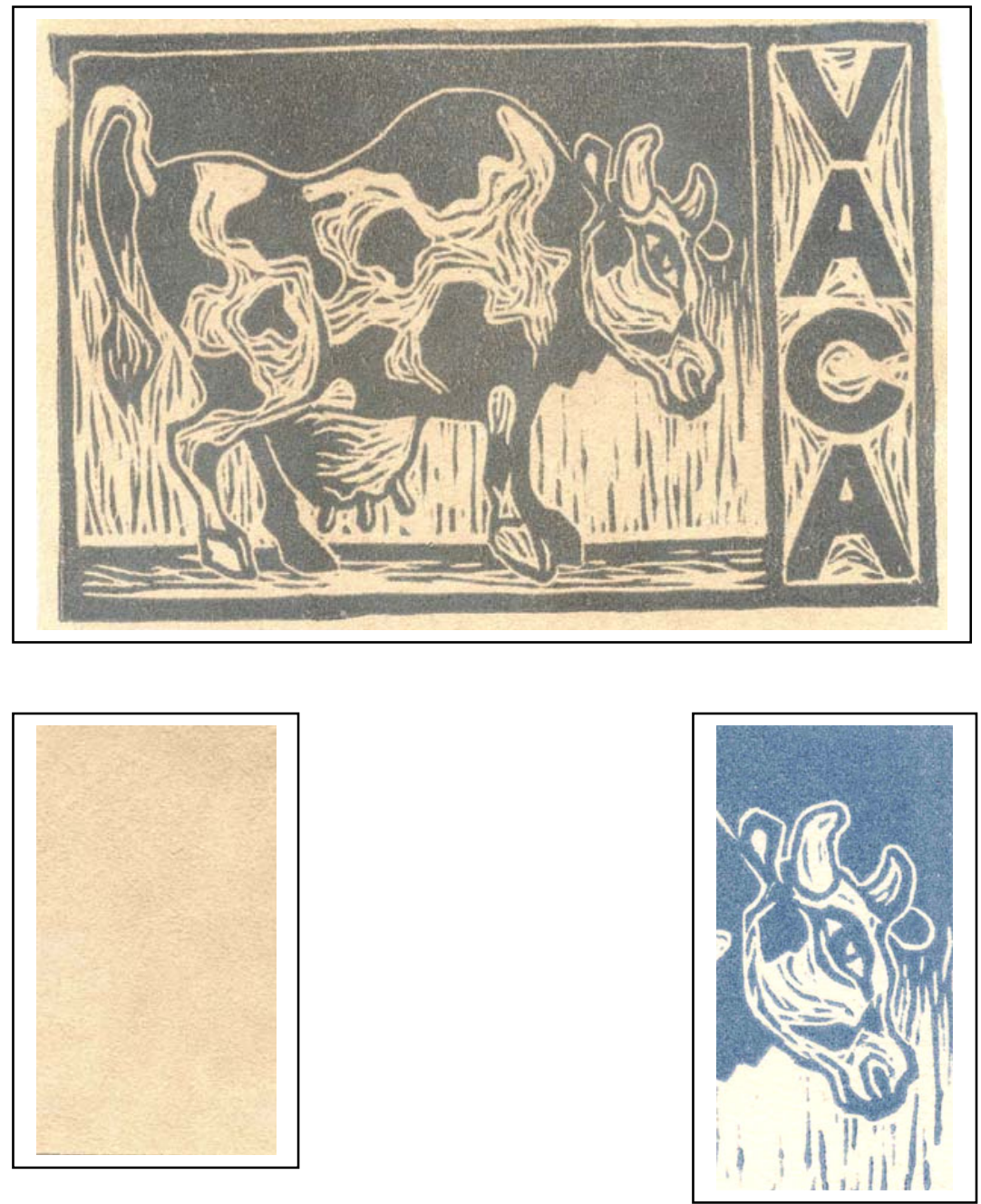

CÓDIGO: VA-014

TÉCNICA: Xilografía

TIPO DE PIEL: Vaca

TONO DE PIEL: Claro

TINTA: Azul traslúcido

SUPERFICIE: Lado carne 


\section{CALIDAD: Buena}

En este ejemplo se repiten los interesantes efectos ya aparecidos con anterioridad al usar tintas muy transparentes sobre las superficies afelpadas típicas del lado carne de casi todas las pieles (CA-014, CA-014, CE-014, CE-016...).

MANCHA: A pesar del afelpado de la piel la tinta cubre bastante bien la superficie de la misma, haciéndolo además de forma homogénea. El pelo no desaparece bajo la tinta y la presión pero queda muy disimulado y su presencia nunca es dañina para la estampa.

GRAFISMO: Prácticamente perfecto, sin los problemas de otras ocasiones.

CONTRASTE: El proceso de oscurecimiento de las tintas transparentes al contacto con una superficie afelpada es patente en esta estampa. El tono azul de la tinta original se ha transformado en un azul verdoso quebrado mucho más oscuro que el original. Ésto hace que el contraste sea muy correcto e intenso, creándose una imagen muy atractiva.

BRILLO: Inexistente a pesar de la gran cantidad de tinta transparente presente en la mezcla. El "pelo" de la piel absorbe todos los posibles brillos que pudieran aparecer. 

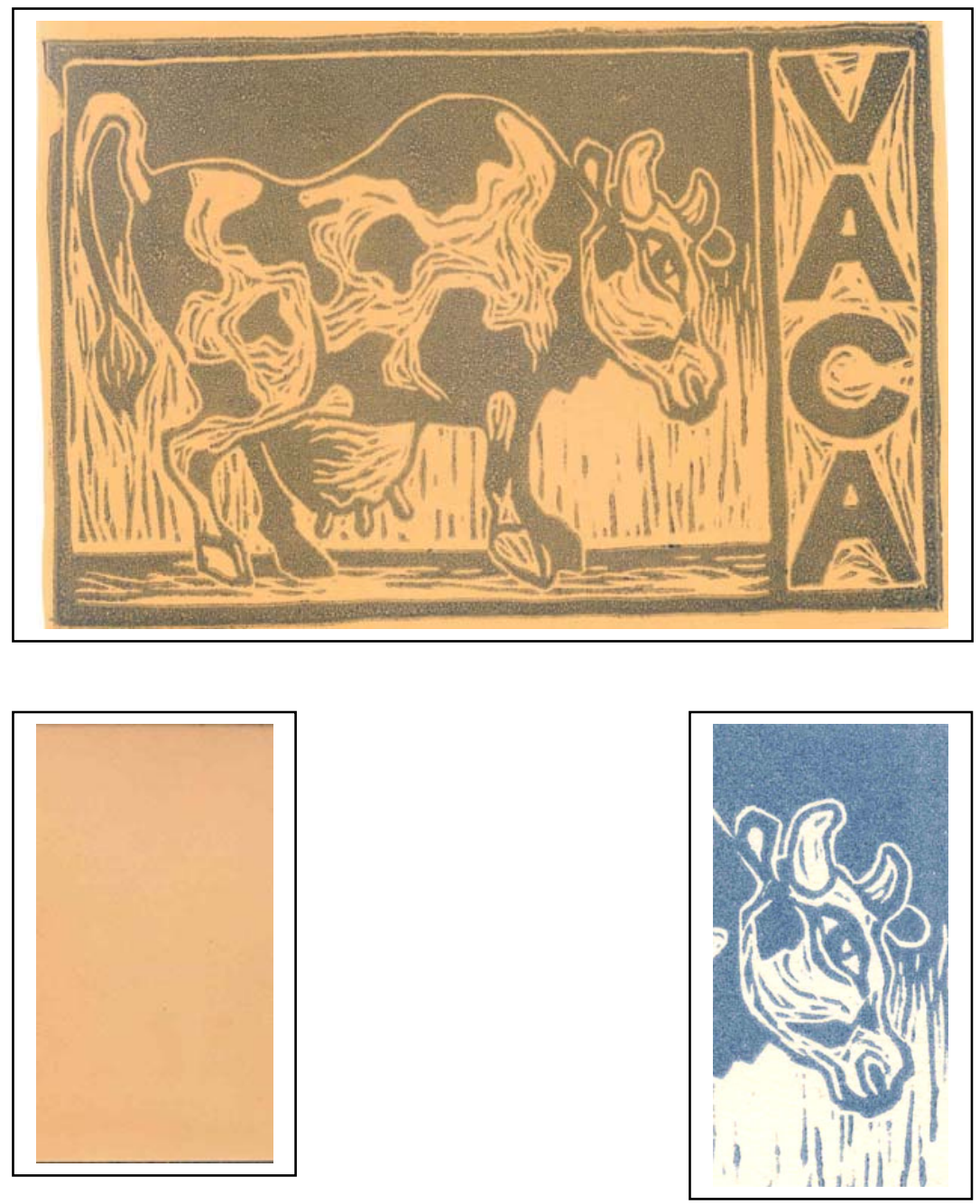

CÓDIGO: VA-015

TÉCNICA: Xilografía

TIPO DE PIEL: Vaca

TONO DE PIEL: Medio

TINTA: Azul traslúcido

SUPERFICIE: Lado flor 


\section{CALIDAD: Mediocre}

Ejemplo en el que aparecen problemas relativos al contacto entre una superficie satinada y una tinta con alto contenido en preparación traslúcida o transparente.

MANCHA: La tinta transparente no asienta de manera correcta sobre una superficie tan pulida, creándose una textura parecida a la observada al usar tintas blancas. En efecto, la tinta no se extiende de manera uniforme y regular por sobre la superficie. En su lugar se agrupa en pequeños grumos que crean una textura extraña y algo desagradable.

GRAFISMO: Se repiten los efectos comentados en la mancha, aunque en los contornos aparece otro defecto de estampación mucho más evidente. Este nuevo defecto podría estar relacionado con lo anteriormente comentado y con un exceso de presión a la hora de estampar.

CONTRASTE: La tinta continúa oscureciéndose por mezcla por transparencia, apareciendo un gris azulado que contrasta de manera bastante correcta con el tono de la piel. Se crea así un contraste de intensidad adecuada y una imagen perfectamente legible.

BRILLO: Aparece un fuerte brillo consecuencia tanto de la gran cantidad de preparación traslúcida como de lo satinado de la piel. 


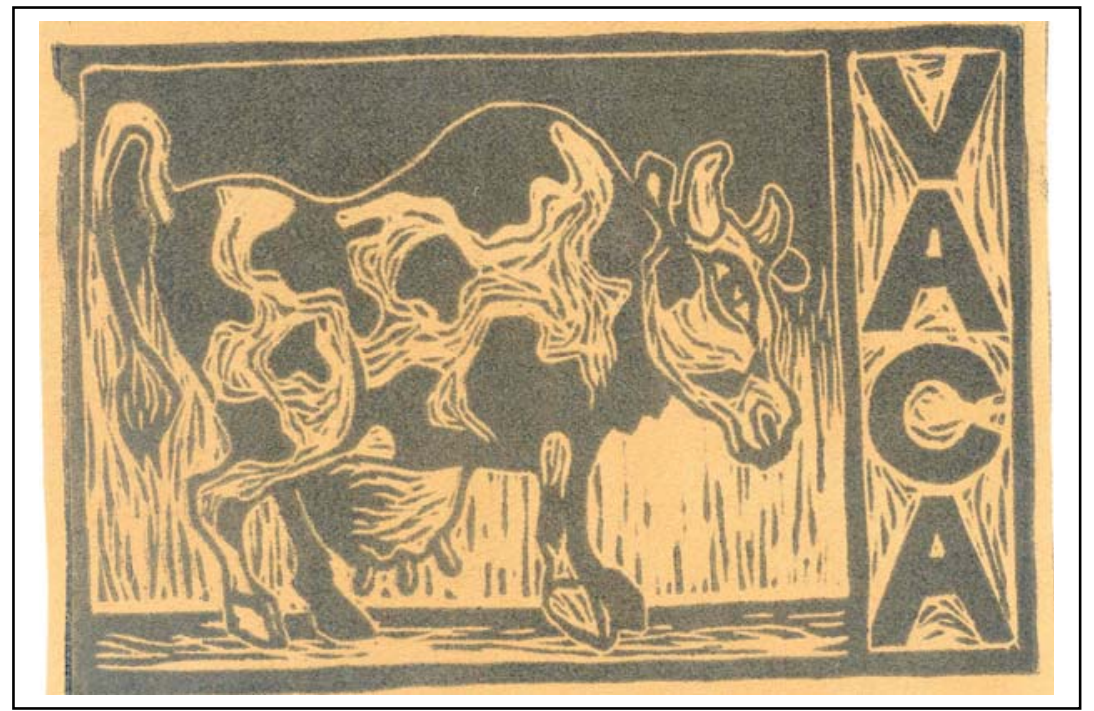

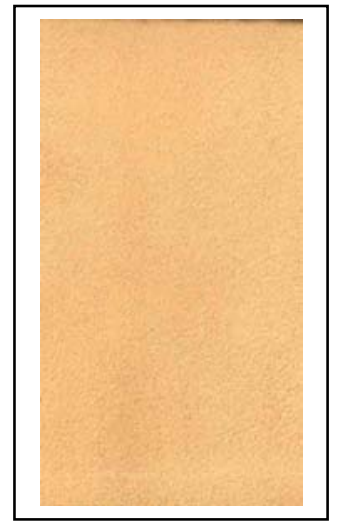

CÓDIGO: VA-016

TIPO DE PIEL: Vaca

TINTA: Azul traslúcido

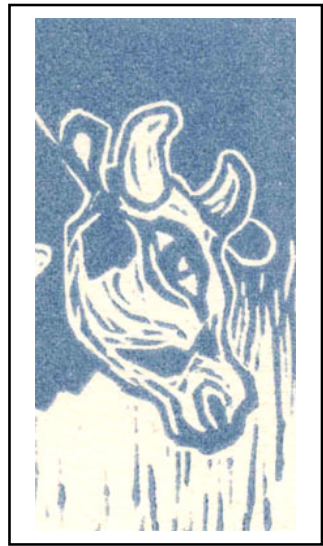

TÉCNICA: Xilografía

TONO DE PIEL: Medio

SUPERFICIE: Lado carne 


\section{CALIDAD: Muy buena}

En esta piel desaparecen todos los problemas comentados anteriormente en el ejemplo sobre el lado flor (VA-015). Esto se debe a que el afelpado de esta superficie es tremendamente sutil y no afecta a los resultados obtenidos al estampar.

MANCHA: Perfecta. Muy homogénea y regular, la tinta cubre sin mayores problemas la superficie de la piel sin apreciarse ningún tipo de irregularidad.

GRAFISMO: Casi perfecto. Tan sólo se aprecian los contornos ligeramente irregulares en algunas zonas de la imagen. Por lo demás la respuesta a la impresión es muy satisfactoria.

CONTRASTE: Muy correcto e intenso. La piel ha oscurecido la tinta hasta convertirla en un gris verdoso muy oscuro que contrasta perfectamente con el tono marrón claro de la superficie del soporte.

BRILLO: Debido a que el afelpado es tan sutil aparece un ligerísimo brillo sobre las zonas entintadas, aunque sin llegar nunca a ser molesto para la correcta visión de la imagen estampada. 

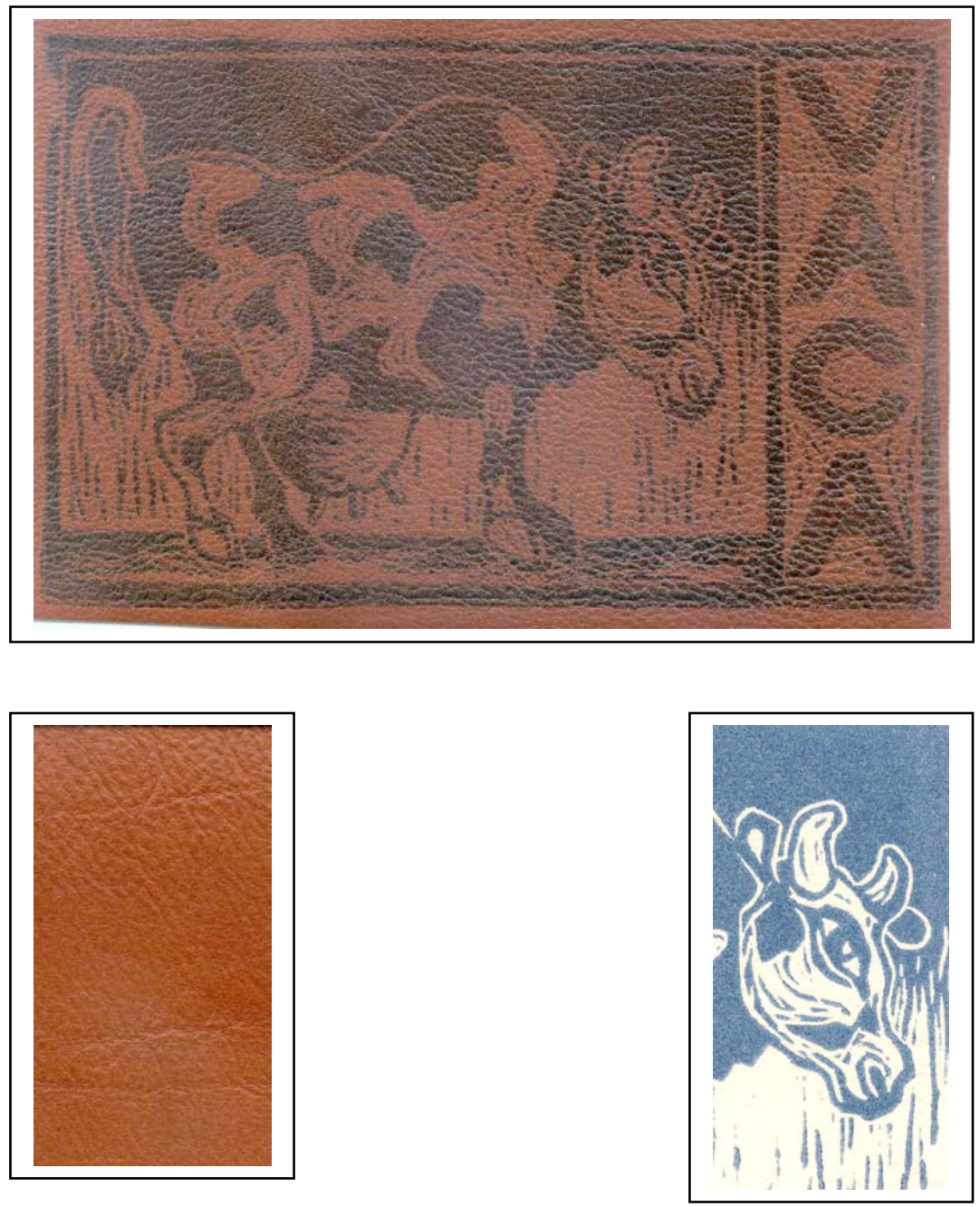

CÓDIGO: VA-017

TÉCNICA: Xilografía

TIPO DE PIEL: Vaca

TONO DE PIEL: Oscuro

TINTA: Azul traslúcido

SUPERFICIE: Lado flor 


\section{CALIDAD: Muy mala}

Estampa casi inútil desde un punto de vista estético. Lo oscuro del soporte imposibilita que la tinta transparente se perciba con normalidad, careciendo casi por completo del contraste necesario para una correcta visión. Los demás factores, a pesar de lo difícil de su apreciación, parecen comportarse de manera satisfactoria.

MANCHA: Bastante uniforme y regular cubre perfectamente la superficie texturada de la piel. En este caso, debido a lo débil de la tinta, no se aprecia un aumento de la textura propia de la piel vacuna.

GRAFISMO: Correcto, aunque debido al mínimo contraste algunos trazos son difíciles de apreciar.

CONTRASTE: Sin ninguna duda el gran problema de esta estampa. Es mínimo por efecto de lo transparente de la tinta y lo oscuro de la superficie del soporte. Impide la correcta visión de la estampa y crea una imagen etérea y vaga.

BRILLO: Aparece un intenso brillo sobre las zonas entintadas, el cual puede llegar a ser muy molesto y a dificultar la apreciación de la imagen. 


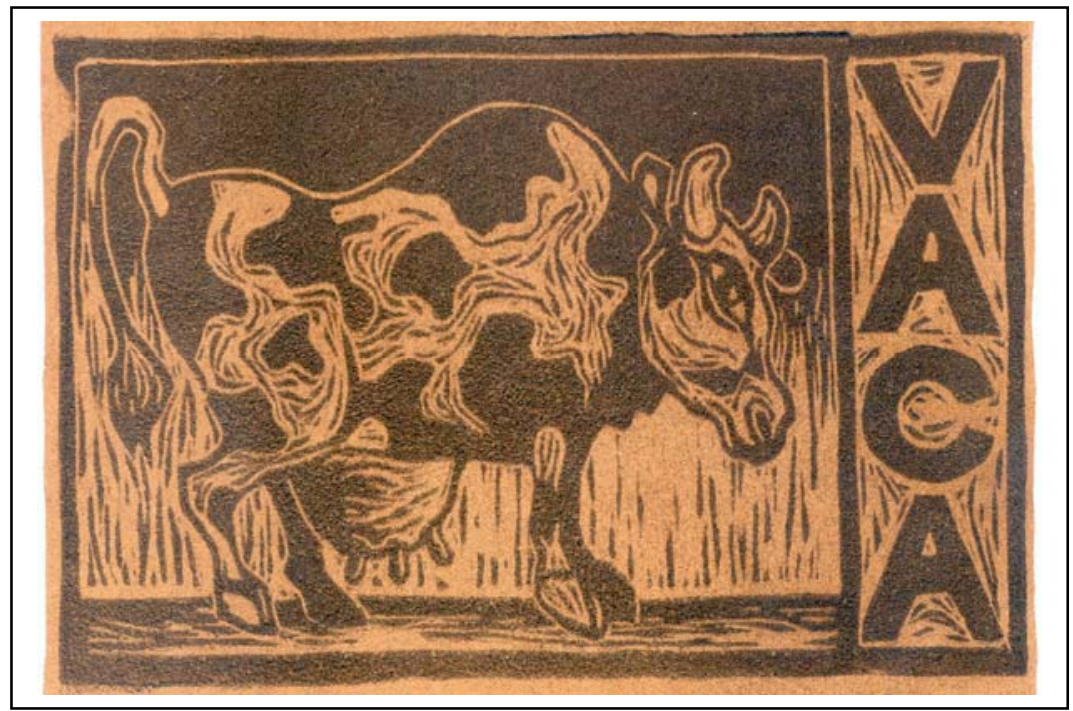

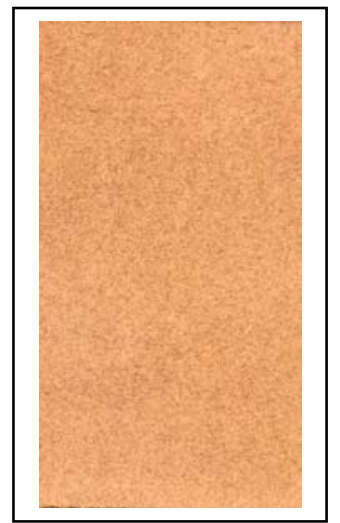

CÓDIGO: VA-018

TIPO DE PIEL: Vaca

TINTA: Azul traslúcido

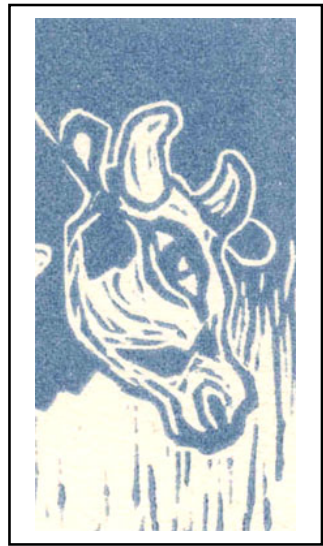

TÉCNICA: Xilografía

TONO DE PIEL: Oscuro

SUPERFICIE: Lado carne 


\section{CALIDAD: Buena}

Ejemplo muy interesante del comportamiento de la tinta transparente sobre un acabado afelpado. Se trata de una de las estampas de mayor calidad de todo el estudio, con características cromáticas de gran valor.

MANCHA: Casi perfecta, homogénea y muy uniforme a no ser que se encuentre sobre una zona de excesivo afelpado. La tinta cubre perfectamente la superficie del soporte, creándose una mancha muy interesante.

GRAFISMO: Bastante correcto y de buena calidad, aunque en las zonas con excesivo "pelo" puedan llegar a difuminarse sus contornos.

CONTRASTE: Muy correcto e intenso. La tinta azul transparente ha sufrido un cambio radical y tremendo: al contacto con la piel se ha transformado en un marrón violáceo de gran calidez y calidad. Este tono contrasta maravillosamente bien con el tono marrón del soporte. Indicar que este tipo de tonos son imposibles de conseguir si no se trabaja mediante el uso de tintas muy transparentes sobre una superficie afelpada.

BRILLO: Prácticamente nulo e inexistente. Aparecen reflejos tenues sobre la tinta pero nunca llegan a dificultar ni perjudicar a la visión de la imagen. 

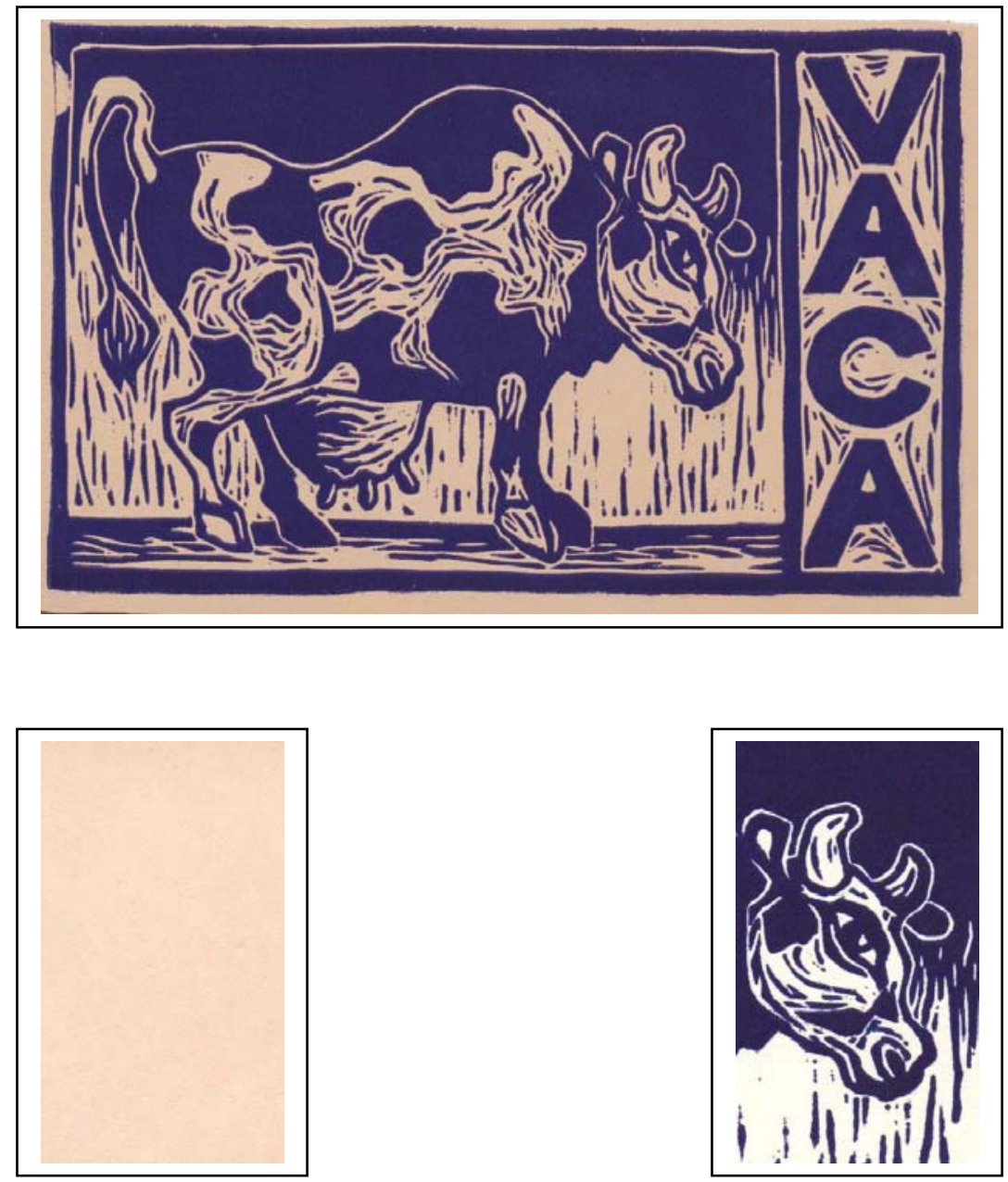

CÓDIGO: VA-019

TIPO DE PIEL: Vaca

TINTA: Azul opaco
TÉCNICA: Xilografía

TONO DE PIEL: Claro

SUPERFICIE: Lado flor 
CALIDAD: Muy buena.

Visualmente perfecta como estampa, el único inconveniente es que aparecen todavía ligeros problemas de secado y asentamiento de la tinta sobre la superficie del soporte piel. Si exceptuamos estas consideraciones, el resto de apartados analizados presentan un nivel excelente.

MANCHA: Perfecta, sin problemas y regular, cubre de manera ideal la cara flor del cuero sin que puedan enunciarse inconvenientes de relevancia.

GRAFISMO: Al igual que el apartado anterior, el resultado es casi perfecto siempre que, como hemos repetido hasta la saciedad, se estampe con la mínima presión posible. De tal modo evitaremos los posibles defectos de definición de los contornos de los seños xilográficos.

CONTRASTE: Muy intenso y adecuado para la obtención de una estampa perfectamente válida desde un punto de vista plástico. La tinta apenas sufre ningún tipo de oscurecimiento al contacto con la piel.

BRILLO: Aparece un ligero brillo en las zonas entintadas, que sin embargo no provoca dificultades a la hora de una correcta apreciación del ejemplo. 

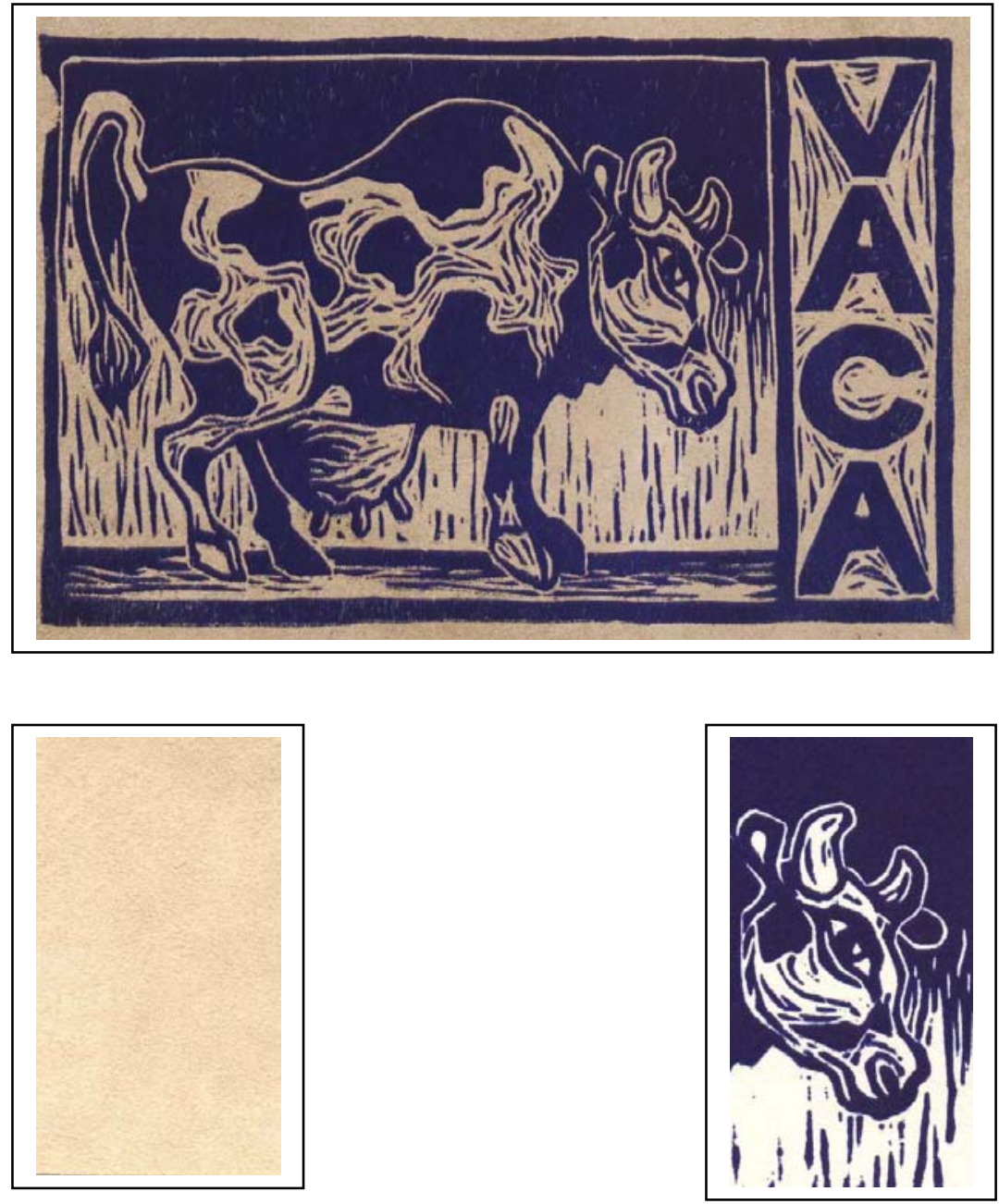

CÓDIGO: VA-020

TIPO DE PIEL: Vaca

TINTA: Azul opaco
TÉCNICA: Xilografía

TONO DE PIEL: Claro

SUPERFICIE: Lado carne 
CALIDAD: Mediocre.

Aparentemente se trata de un ejemplo satisfactorio pero existen dos factores que perjudican su nivel de calidad. Por un lado tenemos irregularidades de la mancha y por otro la aparición de problemas referentes al secado, como casi todas las estampas realizadas con este tipo de tinta concreta.

MANCHA: Algo irregular debido a que la tinta no es capaz de cubri perfectamente todo el afelpado del soporte piel en este lado carne. Por ello aparecen pequeños hilos 0 jirones de piel entre las zonas entintadas, fenómeno que se acentúa si frotamos las zonas comentadas.

GRAFISMO: Mucho mejor que la mancha, aunque tan sólo sea porque al ser de menor extensión, en las zonas estudiadas se hace más difícil apreciar las irregularidades anteriormente comentadas.

CONTRASTE: Intenso y muy correcto para crear una imagen fácilmente legible. Como es lógico en superficies afelpadas como ésta, la tinta azul sufre un ligero oscurecimiento, aunque nunca comparable al observado en estampas realizadas con azul traslúcido.

BRILLO: Nulo como corresponde a un ejemplo sobre soporte afelpado, el cual absorbe los posibles reflejos que pudieran aparecer. 

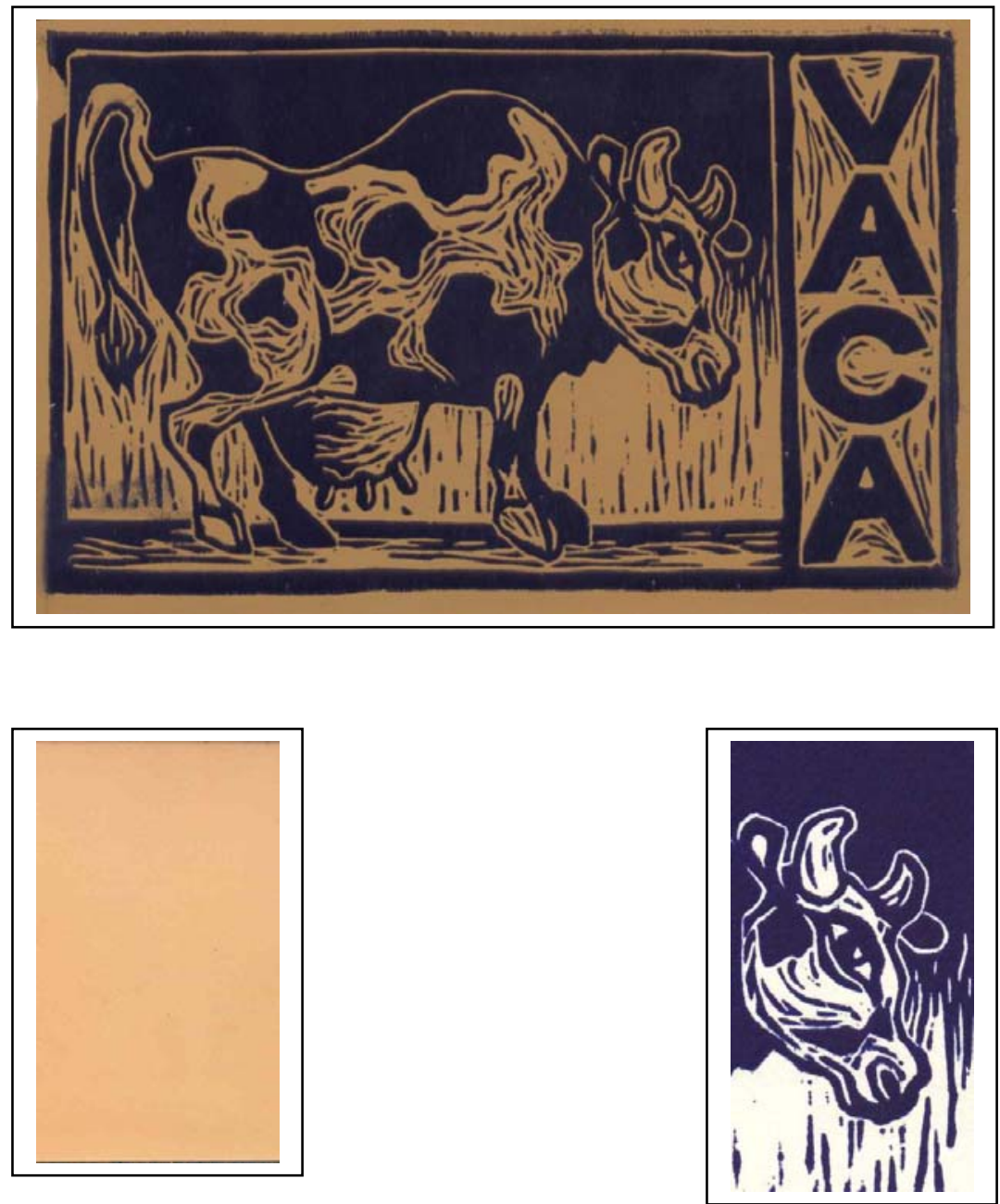

CÓDIGO: VA-021

TIPO DE PIEL: Vaca

TINTA: Azul opaco
TÉCNICA: Xilografía

TONO DE PIEL: Medio

SUPERFICIE: Lado flor 
CALIDAD: Mediocre.

Aunque visualmente sea una estampa casi perfecta, en este tipo de pieles y con esta tinta concreta aparecen graves problemas de secado que dificultan mucho su manejo y manipulación en un posible trabajo definitivo. La tinta no seca superficialmente hasta 2 meses y medio después de la estampación, y todavía tras ese tiempo continúa manchando al tacto.

MANCHA: Perfecta visualmente hablando, ya que la tinta logra cubrir sin problemas la superficie del cuero que le sirve como soporte.

GRAFISMO: Bueno, aunque se deben extremar las precauciones el estampar sobre una piel tan satinada como esta y con una superficie tan impermeable que no acepta demasiado bien la tinta. Si cometemos un mínimo exceso de presión el resultado será desastroso al deformarse los contornos.

CONTRASTE: Correcto a pesar del ligero tono marrón del cuero. La tinta sufre un leve oscurecimiento que ayuda a la aparición de un contraste elevado y suficiente.

BRILLO: Por efecto de lo impermeable del cuero, la tinta adquiere un brillo intenso que puede llegar a resultar molesto en determinadas ocasiones. 

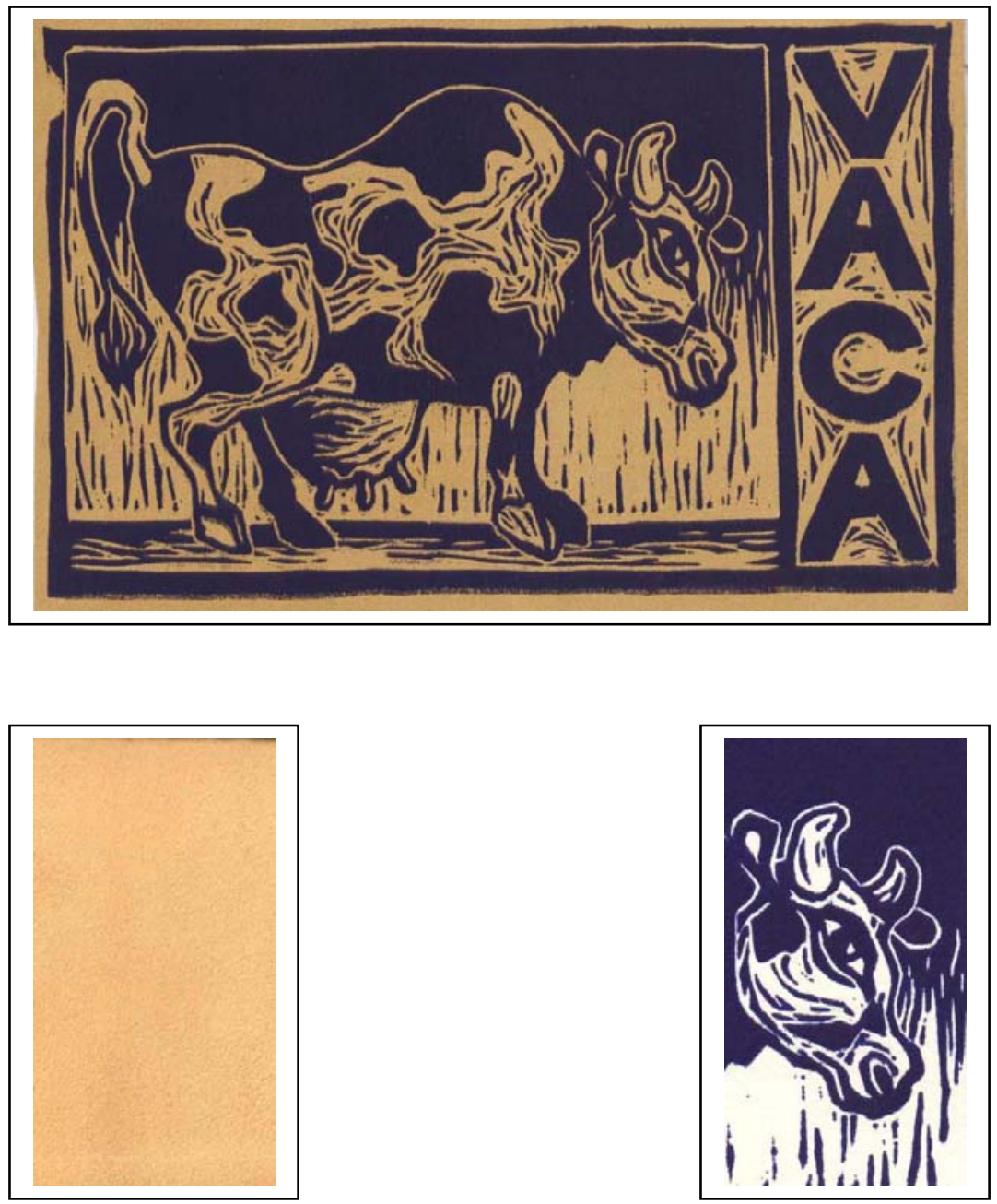

CÓDIGO: VA-022

TÉCNICA: Xilografía

TIPO DE PIEL: Vaca

TONO DE PIEL: Medio

TINTA: Azul opaco

SUPERFICIE: Lado carne 
CALIDAD: Muy buena.

La estampa es visualmente perfecta en todos los aspectos analizados. Los problemas de secado y asentamiento antes comentados sobre el lado flor se reducen al mínimo por acción del afelpado de la piel, el cual absorbe gran cantidad de tinta favoreciendo su secado.

MANCHA: Perfecta, homogénea y regular, cubriendo sin problemas el afelpado, en este caso ligero, del soporte piel y consiguiendo áreas entintadas de gran calidad general.

GRAFISMO: Siempre que estampemos con la presión correcta, el resultado será perfecto y con un registro más que correcto. Si nos excedemos en la presión los inconvenientes se sucederán sin pausa.

CONTRASTE: Intenso gracias al oscurecimiento al que se ve sometida la tinta y al tono no excesivamente oscuro del cuero, creando y configurando una imagen muy satisfactoria.

BRILLO: Como era de esperar en una superficie afelpada como esta, es totalmente inexistente, provocando que la imagen estampada y el soporte se integren de manera perfecta. 

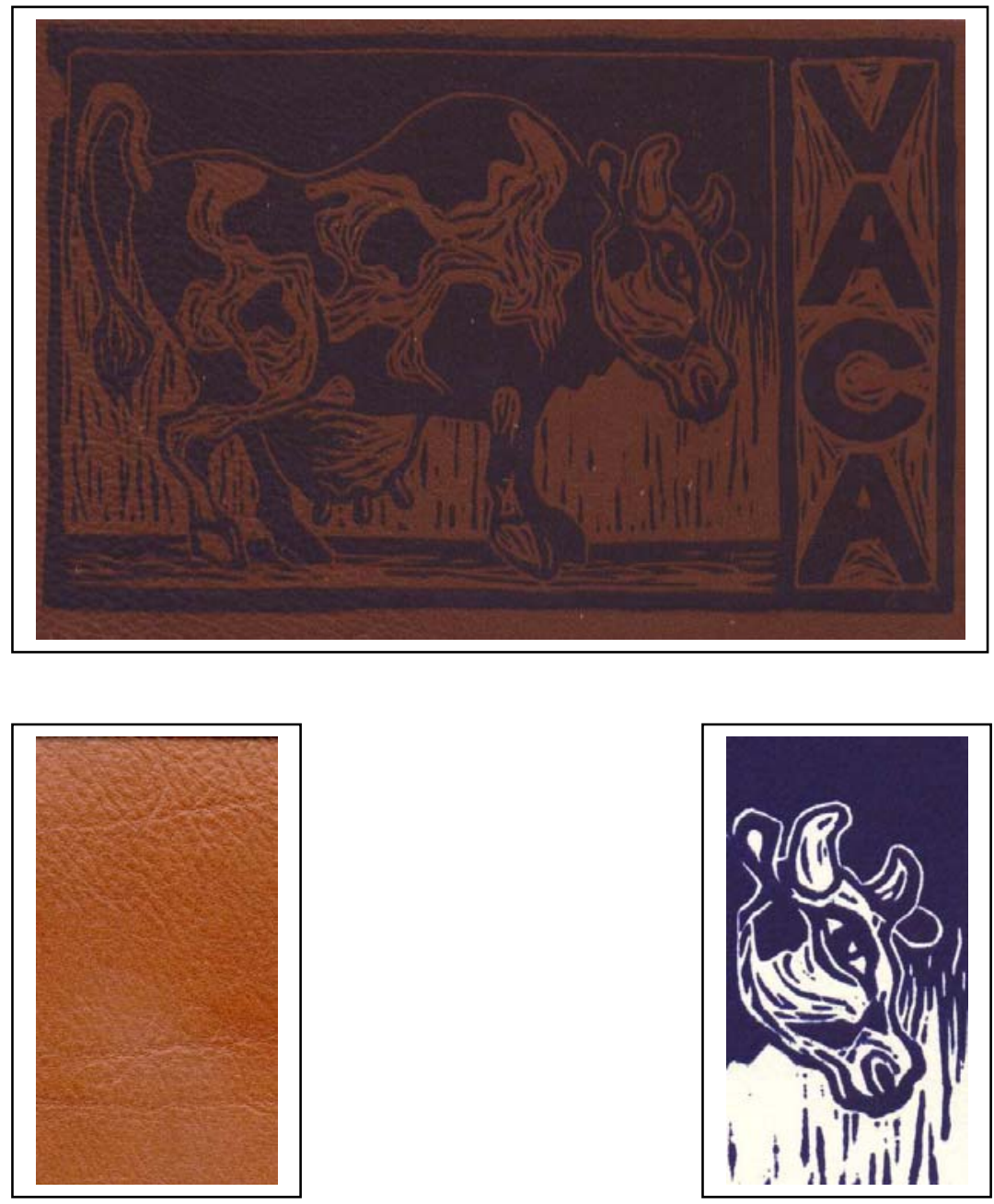

CÓDIGO: VA-023

TÉCNICA: Xilografía

TIPO DE PIEL: Vaca

TONO DE PIEL: Oscuro

TINTA: Azul opaco

SUPERFICIE: Lado flor 
CALIDAD: Mala.

A pesar de que plásticamente podría ser una estampa aceptable, vuelven a aparecer los consabidos inconvenientes de asentamiento y secado de la tinta (incluso 3 meses después de su estampación). Estos problemas provocan que no sea un ejemplo totalmente válido como impresión sobre cuero.

MANCHA: Buena, con la tinta cubriendo la superficie de la piel sin apenas problemas de registro, lográndose unas áreas entintadas de gran homogeneidad.

GRAFISMO: Bueno siempre que el nivel de presión sea el correcto en el momento de la estampación.

CONTRASTE: Algo débil pese al oscurecimiento que padece la tinta azul. El tono marrón rojizo del soporte piel hace que la imagen carezca de la fuerza necesaria que la convertiría en un ejemplo más potente desde un punto de vista visual.

BRILLO: La piel ya presenta un claro brillo que la tinta no hace más que continuar, provocando que la estampa pueda llegar a ser algo difícil de apreciar dependiendo de la iluminación y del ángulo de incidencia de la luz sobre el cuero. 

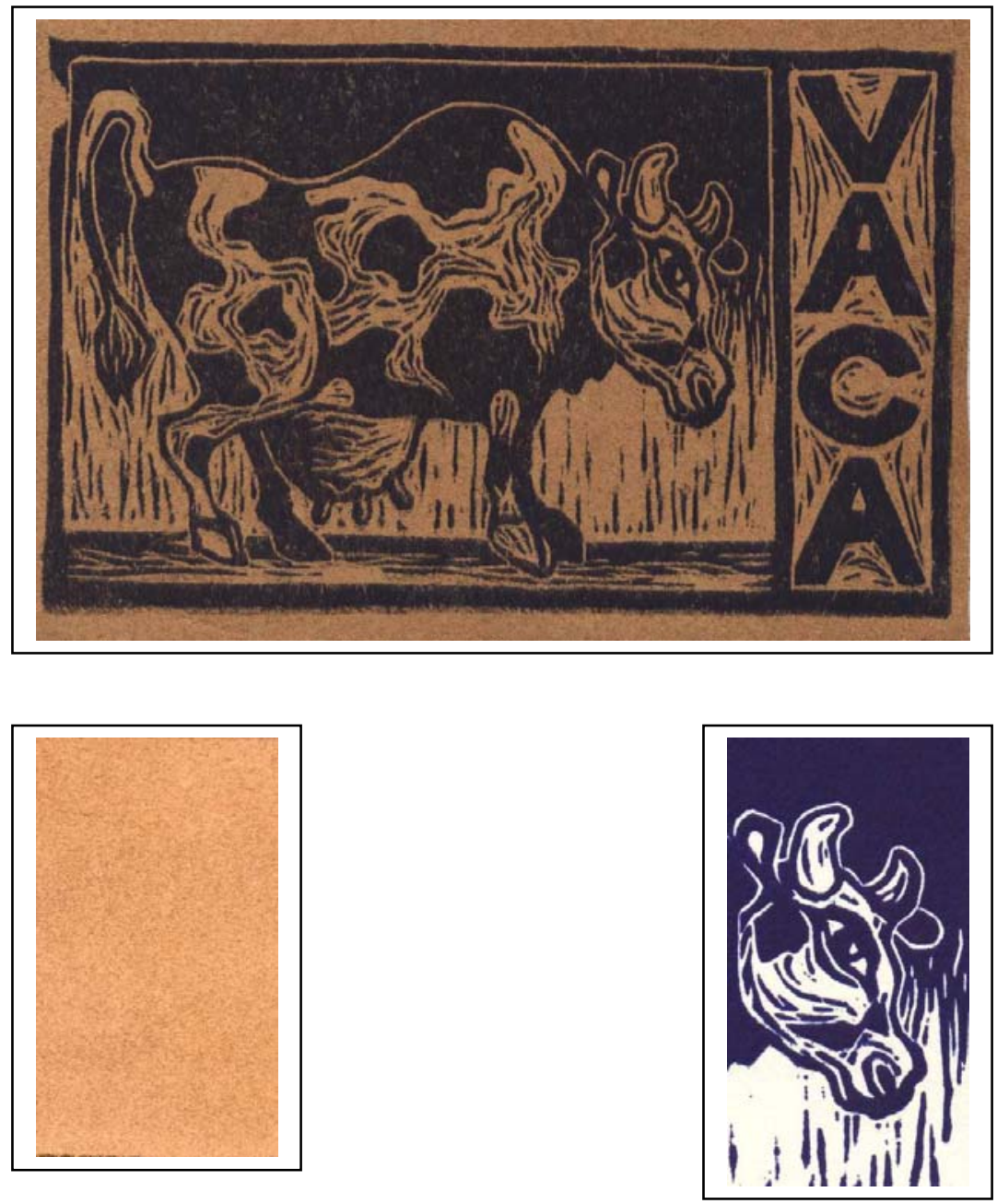

CÓDIGO: VA-024

TIPO DE PIEL: Vaca

TINTA: Azul opaco
TÉCNICA: Xilografía

TONO DE PIEL: Oscuro

SUPERFICIE: Lado carne 
CALIDAD: Mediocre.

Diversos factores hacen de este ejemplo una estampa de poco nivel. El problema del secado continúa apareciendo a pesar del afelpado tan acusado del lado carne de este cuero concreto, y es precisamente dicha textura rugosa la causante del segundo inconveniente de la imagen.

MANCHA: Mediocre debido a que la tinta no se muestra capaz de cubrir totalmente el intenso afelpado de la superficie del cuero. Las zonas entintadas ofrecen una apariencia irregular y sucia, muy alejada de otros resultados obtenidos en el presente estudio.

GRAFISMO: Presenta los mismo inconvenientes que la mancha antes comentada.

CONTRASTE: Gracias al patente oscurecimiento del tono de la tinta se logra un contraste bastante intenso que permite identificar la imagen a pesar de los problemas comentados en los dos apartados anteriores.

BRILLO: Absolutamente nulo por efecto del excesivo afelpado del lado carne de este cuero vacuno. 
Apéndice documental. Fichas xilografía

198 
I.2. Fichas calcografía

\section{I.2. FICHAS CALCOGRAFÍA}



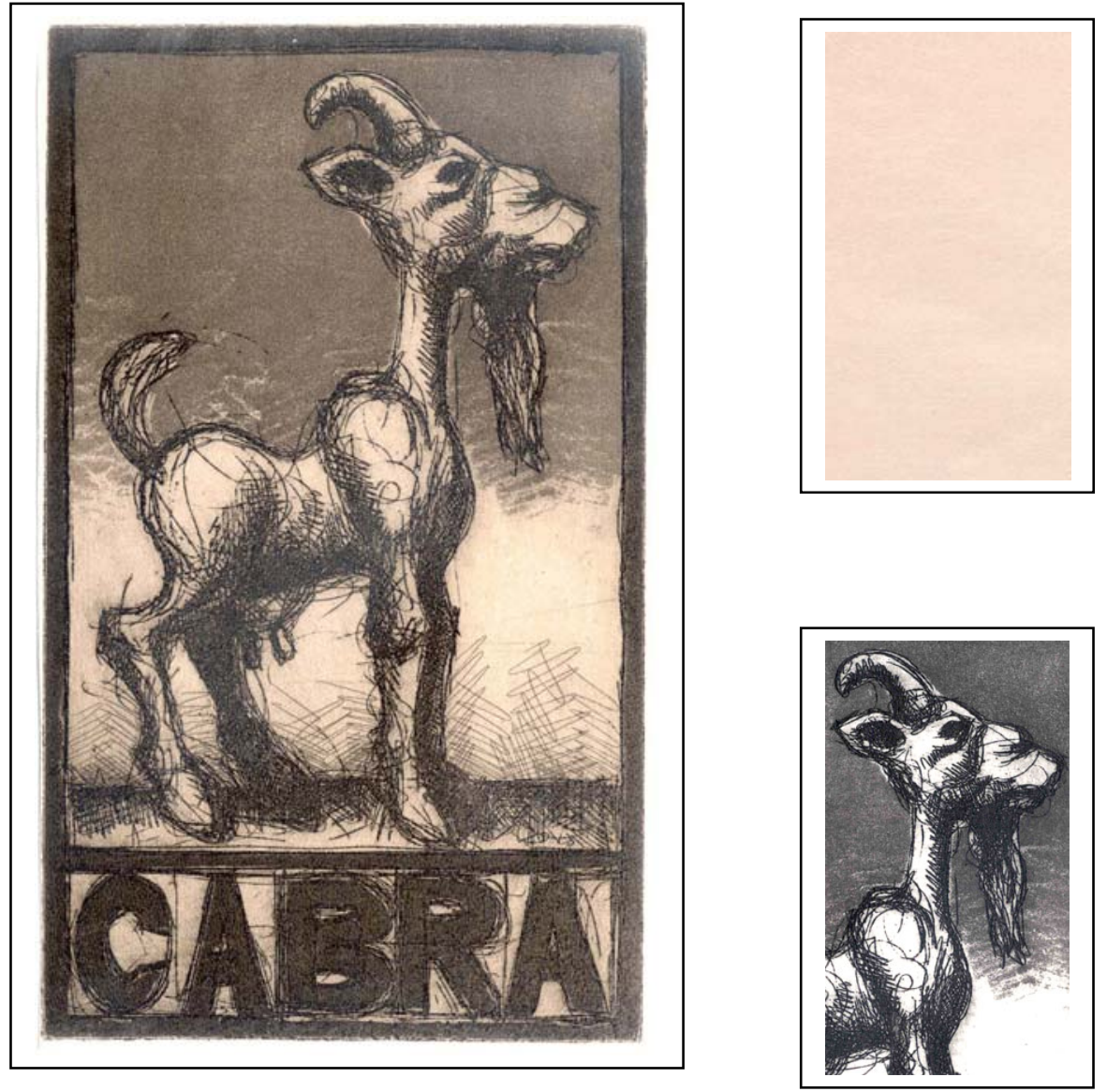

CÓDIGO: CA-025

TIPO DE PIEL: Cabra

TINTA: Negro
TÉCNICA: Calcografía

TONO DE PIEL: Claro

SUPERFICIE: Lado flor 


\section{CALIDAD: Muy buena}

Es esta una de las mejores estampas calcográficas sobre piel, debido a la sutileza del acabado de la propia piel de cabra. Notar que para una estampación más correcta se debería añadir una cantidad de preparación traslúcida en una proporción 1:1. Con ello la tinta es más fluida y la piel la recoge mejor.

AGUATINTA: En los grises el resultado es perfecto, registrando con normalidad y sin problemas. En los negros el acabado es bastante satisfactorio aunque sin alcanzar la perfección de los tonos grises.

AGUAFUERTE: Los trazos más débiles han sido estampados con absoluta perfección, como lo haría el mejor papel disponible. Todos los seños están registrados sin cortes ni irregularidades. En cuanto a los trazos potentes también se consigue un resultado muy positivo registrando con fidelidad todo cuanto hay en la plancha.

CONTRASTE: Bastante correcto. Notar que, debido a que la piel recoge absolutamente toda la tinta de la superficie de la plancha, en las zonas teóricamente blancas aparece una pátina ligeramente oscura que puede entorpecer el contraste. Para evitarla se deben limpiar estas zonas algo más, con tarlatana o papel, hasta aclararlas.

BRILLO: Aparece un claro brillo que se acentúa en las zonas donde se deposita mayor cantidad de tinta. 

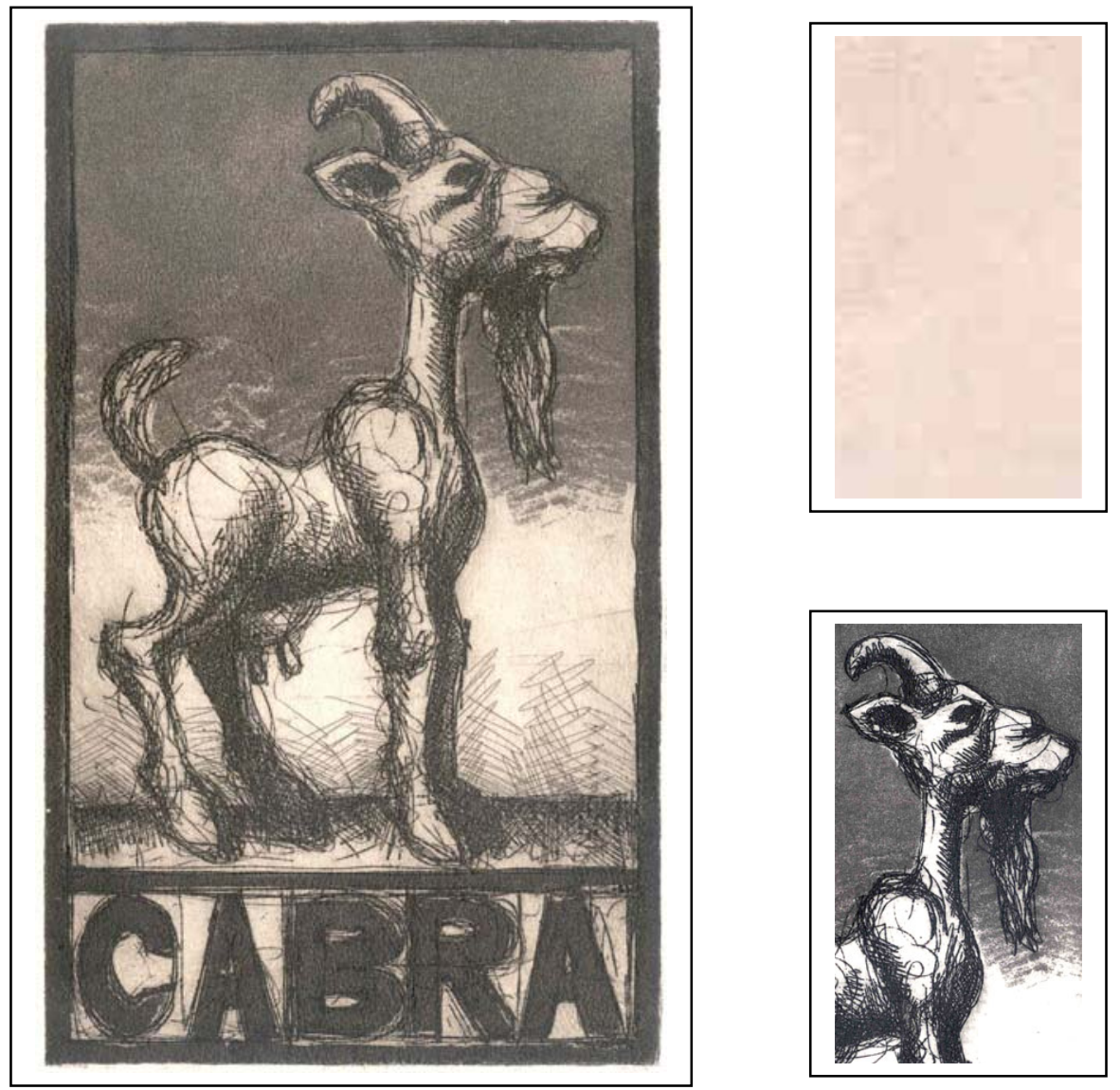

CÓDIGO: CA-026

TIPO DE PIEL: Cabra

TINTA: Negro
TÉCNICA: Calcografía

TONO DE PIEL: Claro

SUPERFICIE: Lado carne 


\section{CALIDAD: Muy buena}

Estampa de menor calidad, aunque todavía muy válida, debido a la gran cantidad de tinta es capaz de absorber la piel, lo que oscurece toda la superficie y dificulta la obtención de zonas blancas o carentes de tinta.

AGUATINTA: Muy correcta tanto en los grises como en los negros. El gris sube un tanto de tono hasta convertirse en un gris bastante oscuro, mientras que el negro también se satura mucho más. En definitiva se oscurecen ambos tonos debido al afelpado de la piel, el cual, como ya se ha comentado, oscurece toda tinta que entra en contacto con él.

AGUAFUERTE: El resultado es tan perfecto como en lado flor. Tanto los trazos sutiles como los más gruesos se registran sin ningún tipo de problema.

CONTRASTE: Correctísimo. Se debe indicar que, para conseguir un contraste apropiado y eliminar la pátina grisácea que ensuciaría la imagen, se incorporará preparación traslúcida en proporción 1:1 con la tinta negra. Así obtendremos un negro que no pierde intensidad pero que ganará en transparencia.

BRILLO: Casi inexistente, tan sólo se aprecian mínimos brillos en las zonas de grafismo más potente y, por consiguiente, de mayor cantidad de tinta acumulada. 

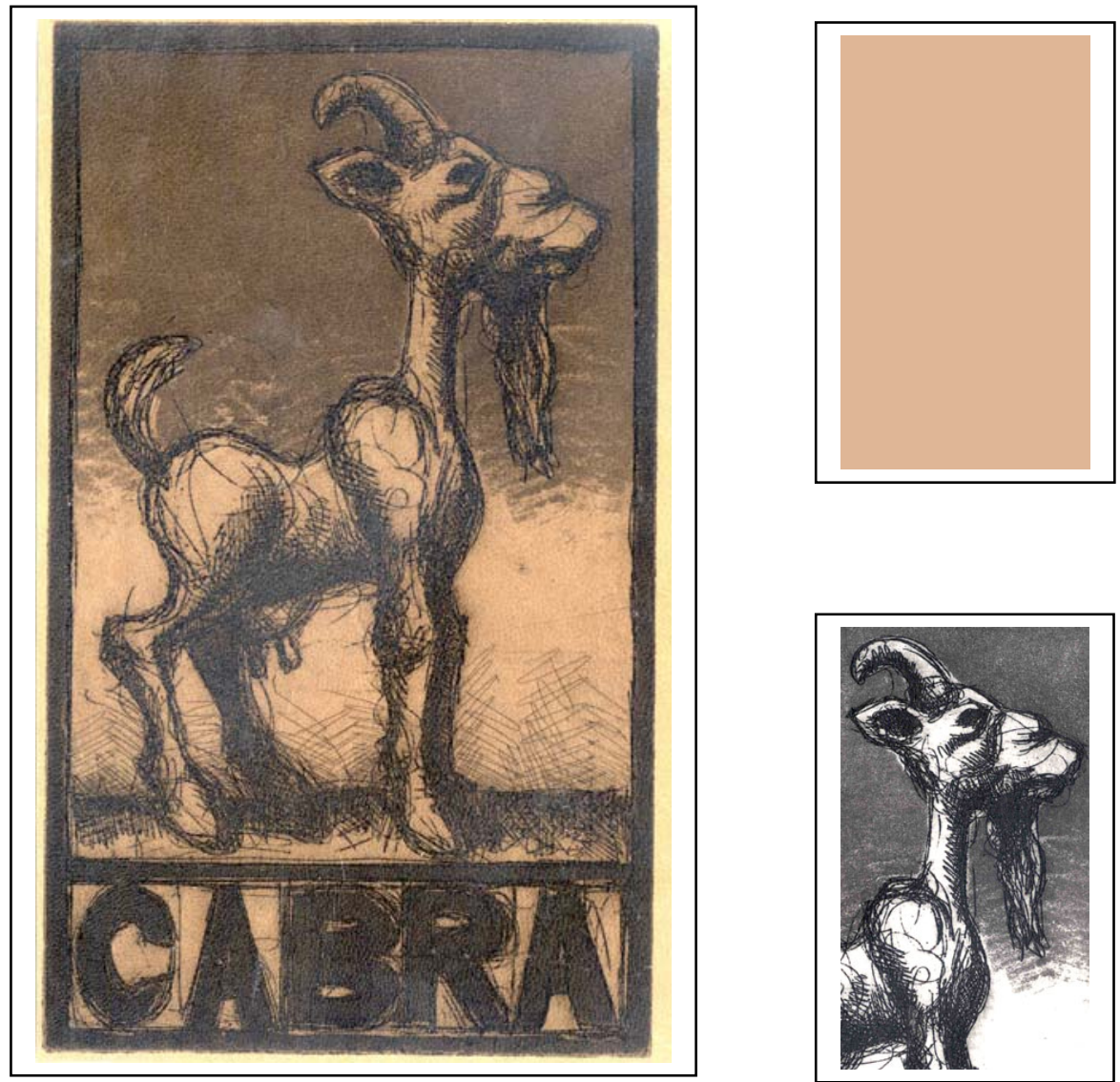

CÓDIGO: CA-027

TIPO DE PIEL: Cabra

TINTA: Negro
TÉCNICA: Calcografía

TONO DE PIEL: Medio

SUPERFICIE: Lado flor 


\section{CALIDAD: Buena}

Estampa de muy correcta calidad en la que prácticamente todos los elementos presentes en la plancha se han estampado perfectamente. Para ello repetir que se ha usado la mezcla de preparación traslúcida y tinta ya comentada con anterioridad.

AGUATINTA: Tanto las manchas grises como aquellas casi negras han sido registradas correctamente. No se produce ningún embotamiento de la tinta ni ningún defecto visible, consiguiéndose tonalidades muy precisas y similares al original en papel.

AGUAFUERTE: Sin apenas problemas, ya sean los trazos sutiles como aquellos más gruesos y potentes. Ambos tipos de seños estampan de manera satisfactoria.

CONTRASTE: No tan fuerte y marcado como en la piel clara pero todavía suficientemente intenso como para conseguir una imagen correcta. Importantísimo el hecho de utilizar la preparación traslúcida en la mezcla, así como el limpiar lo más posible las zonas claras de la imagen. De no hacerlo una pátina grisácea cubriría estas áreas de la estampa condicionando el contraste.

BRILLO: Debido al acabado satinado de la piel aparece un brillo algo intenso aunque sin llegar a ser demasiado perjudicial para la correcta visión de la imagen. 

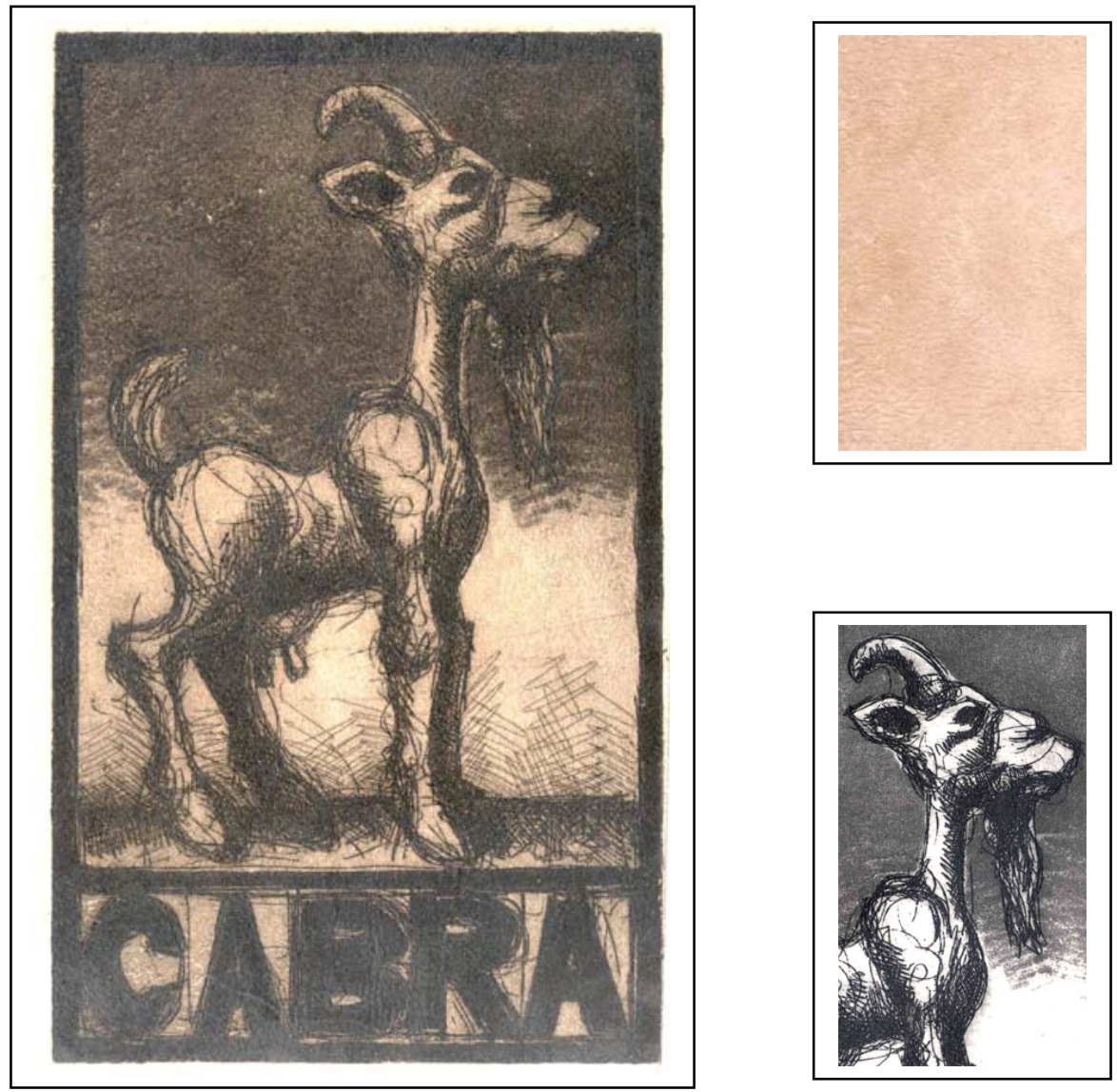

CÓDIGO: CA-028

TIPO DE PIEL: Cabra

TINTA: Negro
TÉCNICA: Calcografía

TONO DE PIEL: Medio

SUPERFICIE: Lado carne 


\section{CALIDAD: Mediocre}

Ejemplo que, al compararlo con su "gemelo" en el lado flor (CA-021), nos revela las notables diferencias que existen al estampar sobre uno $u$ otro lado del mismo tipo de piel.

AGUATINTA: La superficie afelpada recoge mayor cantidad de tinta que la satinada y se oscurece sobremanera. Así la diferencia entre el gris y el negro se estrecha hasta hacerse mínima en algunas zonas. En definitiva tenemos un patente oscurecimiento de los tonos del aguatinta, llegando a ser ambos de casi igual intensidad y muy cercanos al negro.

AGUAFUERTE: Se observa un fenómeno parecido al comentado para el aguatinta: un oscurecimiento generalizado. En este caso se revela como un mayor grosor en todas y cada una de las líneas de la imagen, tanto en las más finas como, sobretodo, en las más gruesas.

CONTRASTE: Todavía es suficiente como para crear una imagen plásticamente atractiva, aunque debido al oscurecimiento generalizado se radicaliza para acabar perdiendo gamas medias y tono grises.

BRILLO: Prácticamente nulo a pesar de la gran cantidad de tinta negra presente en la superficie de la piel. Sin embargo el afelpado del lado carne provoca ese acabado totalmente mate. 

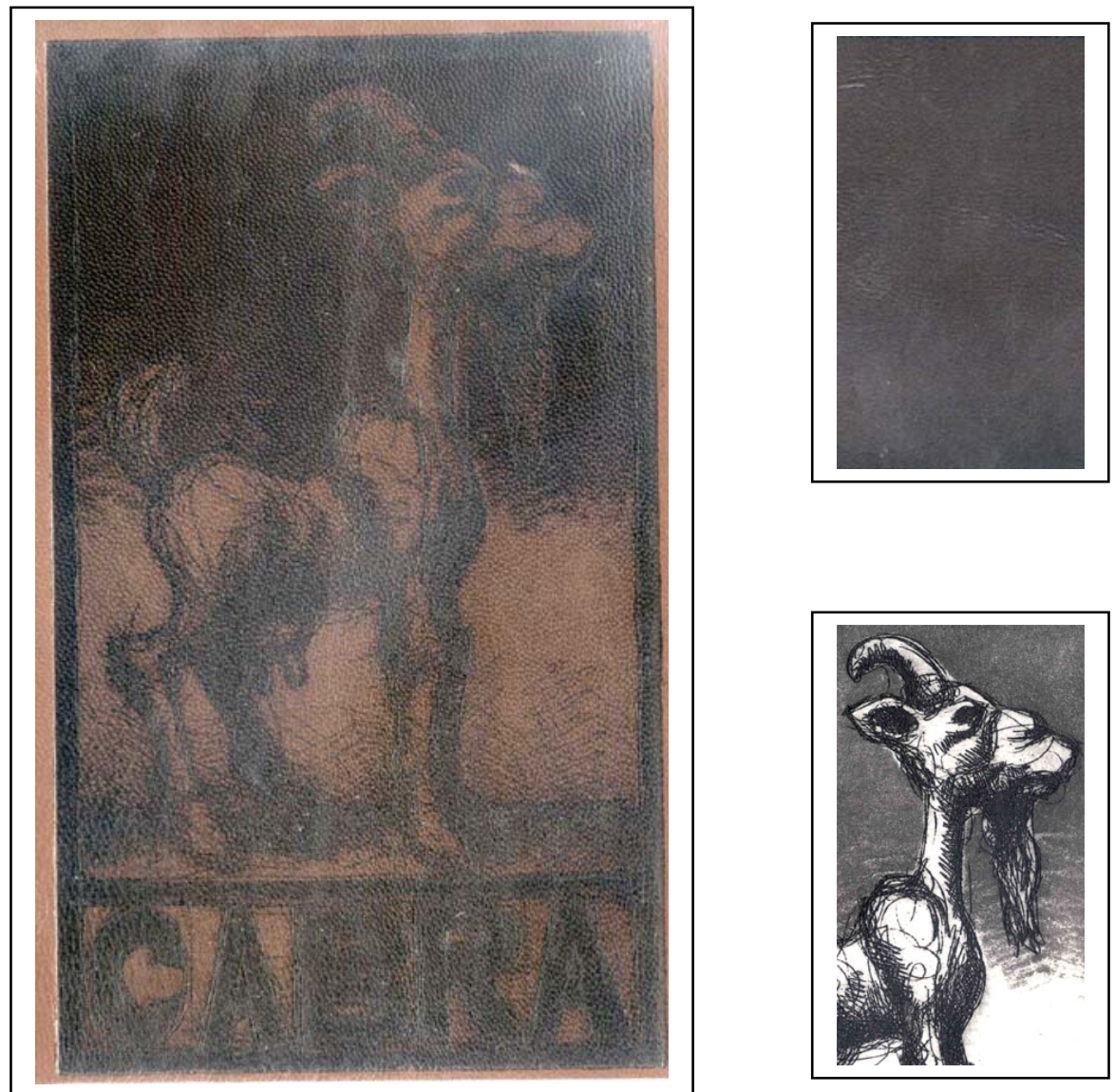

CÓDIGO: CA-029

TIPO DE PIEL: Cabra

TINTA: Negro
TÉCNICA: Calcografía

TONO DE PIEL: Oscuro

SUPERFICIE: Lado flor 


\section{CALIDAD: Mala}

Estampa poco válida debido sobre todo al excesivamente oscuro tono del soporte, el cual hace casi imposible apreciar la imagen estampada sobre él.

AGUATINTA: A pesar de las dificultades de visión parece que la piel ha registrado correctamente tanto la aguatinta más sutil correspondiente a los grises, como la más potente que vendría a ser el negro.

AGUAFUERTE: Buen resultado aunque difícil de apreciar por lo escaso del contraste y el elevado brillo presente en la estampa.

CONTRASTE: Muy escaso. Es sin duda el gran problema de este ejemplo. A pesar de la intensidad del negro éste no es capaz de imponerse sobre el tomo tan oscuro del fondo, impidiendo la aparición del mínimo contraste necesario para una correcta visión de la imagen impresa.

BRILLO: Excesivo, viéndose incrementado el brillo original de la piel tan satinada con la aportación de la tinta negra y la carga adicional de preparación traslúcida presente en la mezcla. Dificulta sobremanera la apreciación de la imagen. 

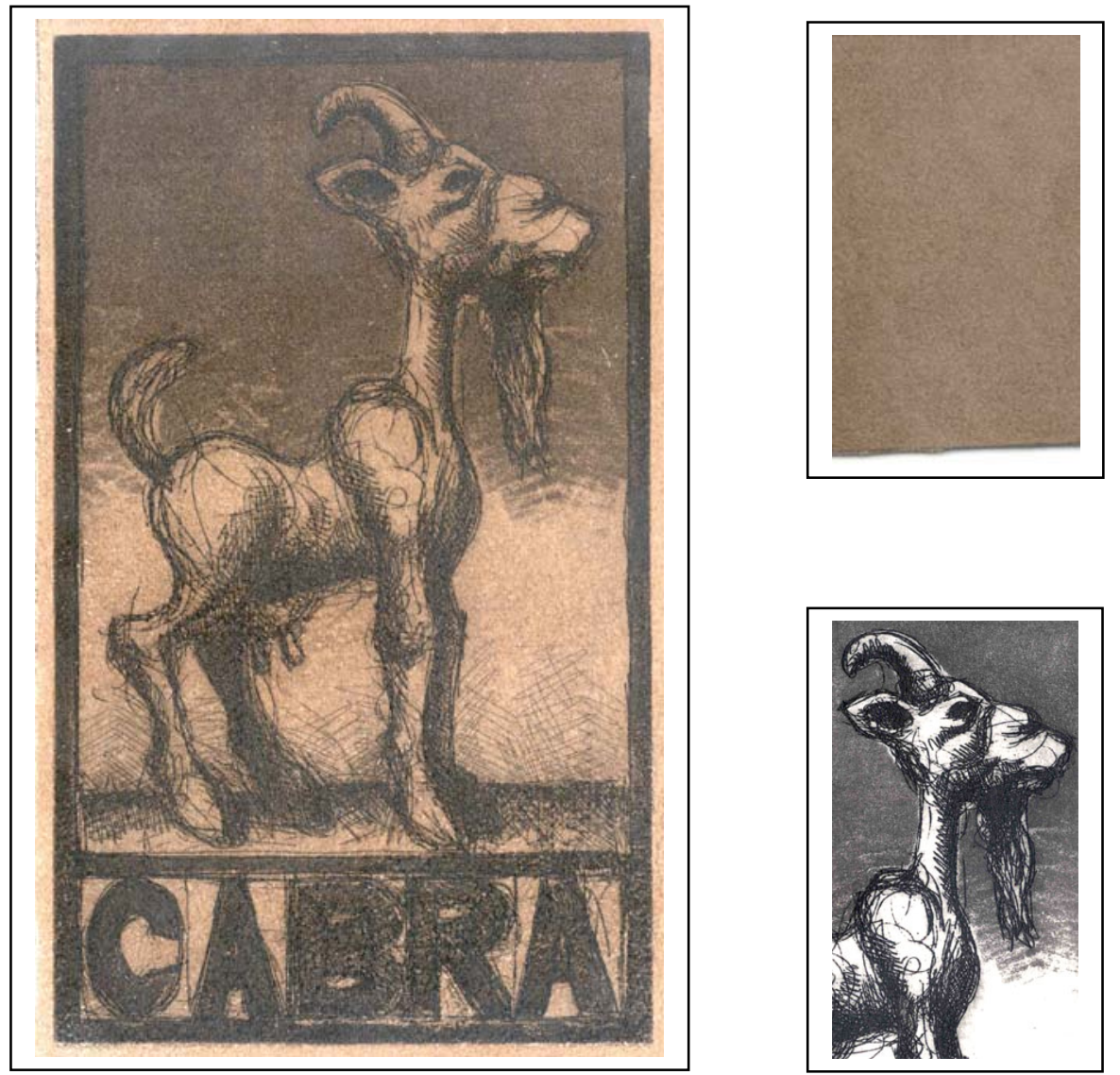

CÓDIGO: CA-030

TIPO DE PIEL: Cabra

TINTA: Negro
TÉCNICA: Calcografía

TONO DE PIEL: Oscuro

SUPERFICIE: Lado carne 


\section{CALIDAD: Mediocre}

Estampa algo mejor que su homóloga en el lado flor (CA-023), debido al tono más claro de la piel en esta superficie. Sin embargo aparecen problemas relacionados con el acabado excesivamente afelpado del lado carne en este tipo de pieles.

AGUATINTA: Como ya hemos observado en numerosos ejemplos anteriores tales como las estampas CA-020 y CA-022, la tinta de las aguatintas más sutiles oscurece sobremanera la superficie afelpada de la piel, subiendo el tono hasta alcanzar un gris muy oscuro casi negro. Por su parte los tonos negros recogen una gran cantidad de tinta, consiguiendo una gran intensidad.

AGUAFUERTE: A pesar de lo afelpado y rugoso de la piel ésta es capaz de registrar medianamente bien algunos trazos de aguafuerte, incluso aquellos más sutiles y delicados. Sin embargo el afelpado de esta piel no la hace adecuada ni apropiada para una estampa al aguafuerte plenamente satisfactoria.

CONTRASTE: Algo más intenso que en el ejemplo anterior aunque sin llegar a ser lo suficientemente potente como para obtener una imagen satisfactoria.

BRILLO: Casi inexistente como consecuencia de la gran cantidad de "pelo" presente en la superficie de la piel por su lado carne. Este afelpado consigue absorber totalmente los brillos que pudieran aparecer, lográndose una estampa mate y sin satinado. 

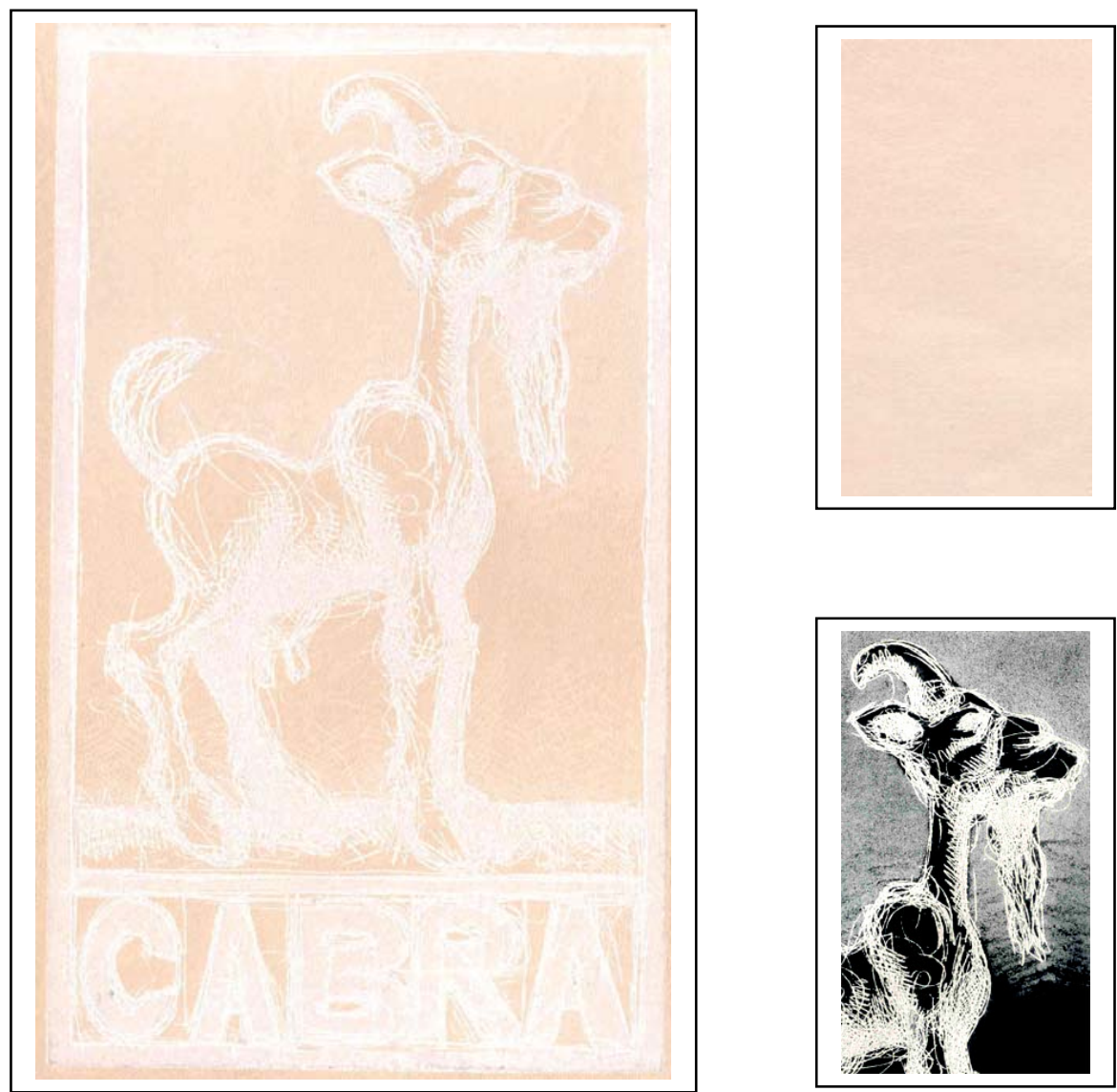

CÓDIGO: CA-031

TÉCNICA: Calcografía

TIPO DE PIEL: Cabra

TONO DE PIEL: Claro

TINTA: Blanco

SUPERFICIE: Lado flor 


\section{CALIDAD: Mala}

En esta estampa se aprecian claramente las dificultades para realizar imágenes con técnicas relativas al grabado calcográfico y tintas blancas. Debido a los pésimos resultados obtenidos, no se realizarán estudios detallados de estampaciones con tinta blanca sobre el lado carne. Los resultados de dichas pruebas son siempre inútiles y de una ínfima calidad.

AGUATINTA: De mínima calidad. Los grises son casi imperceptibles y las aguatintas más potentes se convierten en un gris pálido alejadísimo del teórico blanco que deberíamos obtener.

AGUAFUERTE: Mediocres resultados. Los trazos sutiles se pierden y es casi imposible reconocerlos. Mientras, los trazos gruesos tienen una mejor respuesta aunque todavía muy limitada. Así, son las líneas aisladas las que se registran con mayor nitidez mientras que en las zonas de acumulación de grafismos la tinta crea una amalgama informe que impide reconocer los trazos, apareciendo la ya conocida textura grumosa tan común al utilizar tinta blanca.

CONTRASTE: Muy escaso, se puede reconocer la imagen no sin problemas pero la estampa carece de toda fuerza y expresividad.

BRILLO: La tinta blanca convierte en mates las zonas donde se asienta, eliminando el ligero brillo ceroso de la superficie de la piel. 

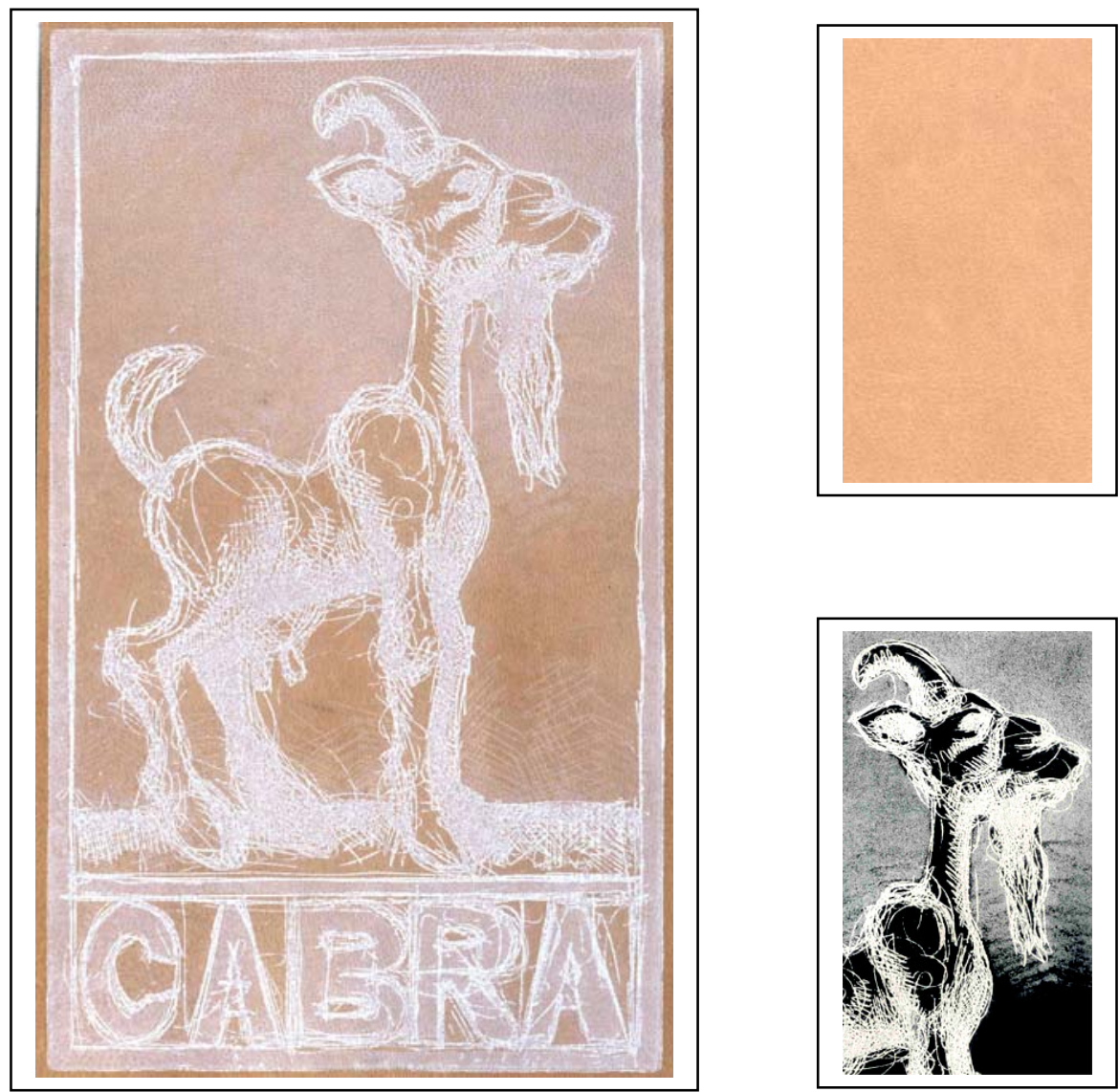

CÓDIGO: CA-032

TIPO DE PIEL: Cabra

TINTA: Blanco
TÉCNICA: Calcografía

TONO DE PIEL: Medio

SUPERFICIE: Lado flor 


\section{CALIDAD: Mediocre}

Ejemplo de mejor calidad que el de la piel clara (CA-025), aunque continúa presentando marcados problemas de muy difícil solución.

AGUATINTA: Comienza a intuirse la presencia de los tonos más ligeros, alcanzando intensidades todavía demasiado bajas, mientras que las aguatintas potentes se estampan correctamente aunque siempre sin llegar a los niveles de saturación deseados.

AGUAFUERTE: Las líneas más sutiles se aprecian con dificultad, mientras que las más gruesas se estampan de manera más correcta. Como en el caso sobre piel clara las líneas aisladas son las que mejor aparecen, mientras que son las zonas con mayor profusión de trazos las que presentan problemas. Aparece de nuevo la textura con grumos y para intentar paliar sus efectos se puede aplicar un poco de preparación traslúcida a la tinta. Con esto lograremos evitar un tanto este problema pero, por otro lado, perderemos intensidad de blanco ya que la tinta se vuelve menos cubriente.

CONTRASTE: Bastante mejor que sobre la piel clara, permite una visión satisfactoria de la imagen pero sin conseguir alcanzar el blanco verdadero.

BRILLO: La tinta blanca elimina el brillo de la superficie de la piel creando marcados contrastes de brillo en la estampa. 

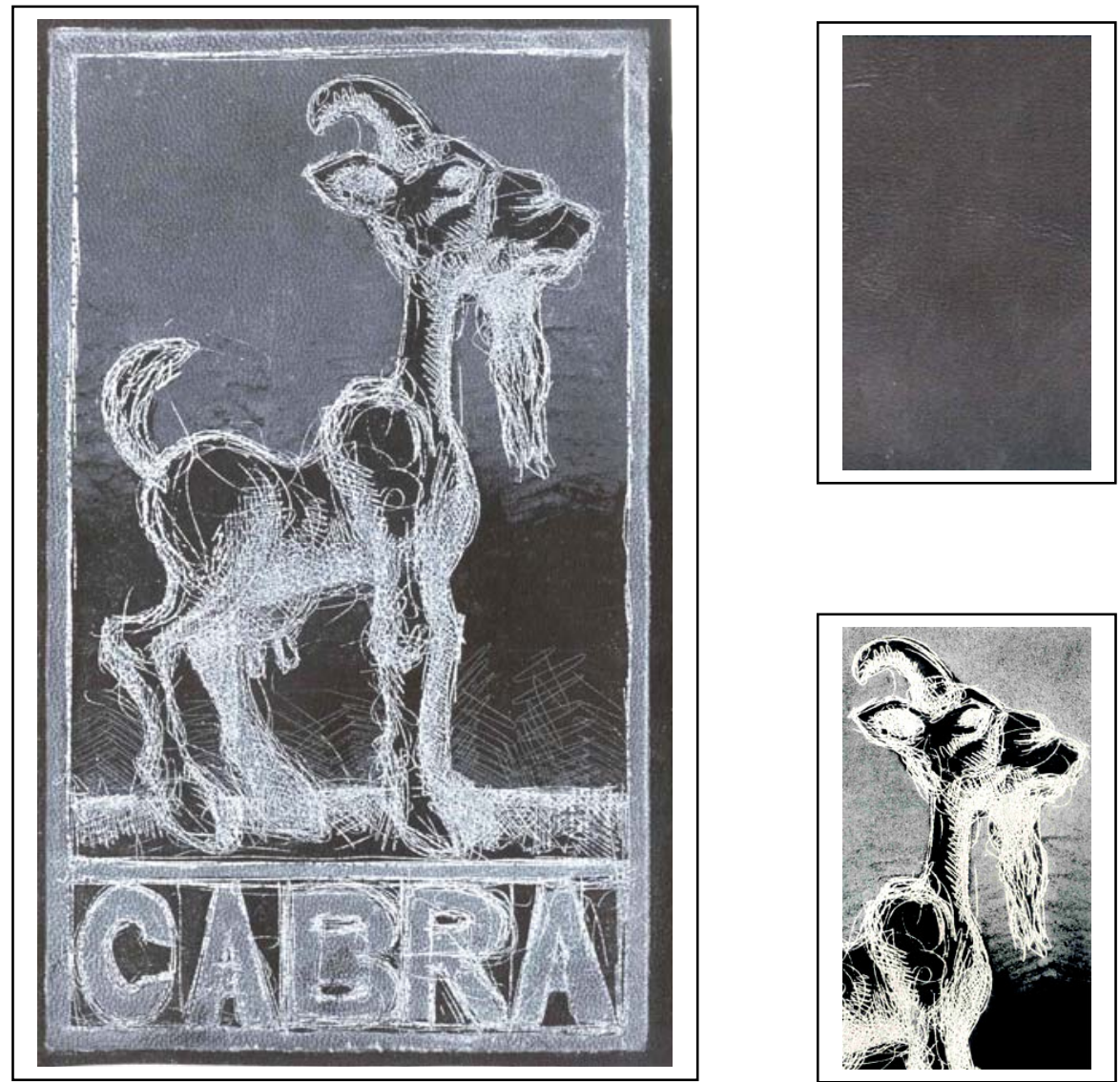

CÓDIGO: CA-033

TIPO DE PIEL: Cabra

TINTA: Blanco
TÉCNICA: Calcografía

TONO DE PIEL: Oscuro

SUPERFICIE: Lado flor 


\section{CALIDAD: Muy mala}

A medida que se eleva el tono del soporte los resultados con la piel y la tinta son más satisfactorios y mejores. Esto no es sólo debido a un lógico contraste sino a que normalmente las pieles más oscuras presentan una superficie más satinada, lo que favorece la estampación con tintas blancas.

AGUATINTA: Mucho más correcta que las anteriores, ambos tonos registran con mejor calidad aunque sin alcanzar intensidades muy elevadas. Notar que en las zonas entintadas la textura de la piel se pone de manifiesto con mucha mayor fuerza que en las libre de tinta.

AGUAFUERTE: Se continúa con el proceso que venimos apreciando: las líneas más sutiles se hacen mucho más patentes (aunque con un trazo quebrado) y los trazos gruesos aislados alcanzan una buena calidad de impresión. Lógicamente el desagradable efecto granulado de las zonas más densas se intensifica.

CONTRASTE: Muy correcto debido a la suficiente intensidad de la tinta blanca y al tono oscuro del soporte el cual facilita la aparición de un adecuado contraste.

BRILLO: Como en los casos anteriores la tinta blanca, mate por naturaleza, acaba con el brillo presente en la superficie tan satinada y trabajada de la piel. 

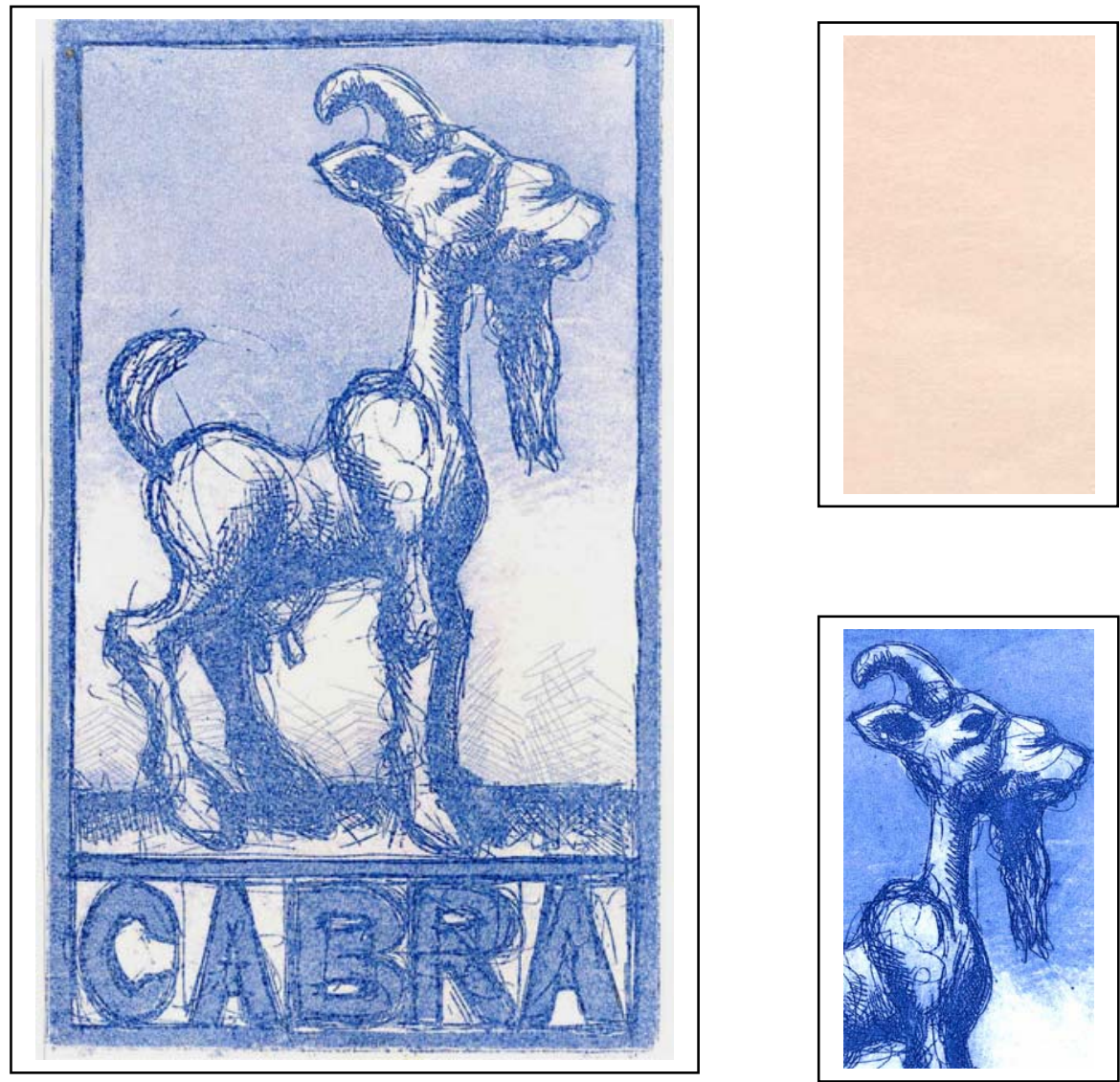

CÓDIGO: CA-034

TIPO DE PIEL: Cabra

TINTA: Azul traslúcido
TÉCNICA: Calcografía

TONO DE PIEL: Claro

SUPERFICIE: Lado flor 


\section{CALIDAD: Mediocre}

Estampa de bastante buena calidad en una primera visión, pero que presenta defectos dignos de tener en cuenta tras un examen más minucioso.

AGUATINTA: Observamos una clara diferencia entre los tonos más sutiles y aquellos más potentes. En los primeros la calidad de la estampación es casi perfecta, mientras que en los segundos encontramos algunos problemas. En efecto, donde se aprecia una acumulación de tinta, con la consiguiente preparación traslúcida, vemos una textura parecida a la observada al usar tinta blanca: una grumosidad y una deficiente extensión de la tinta por la superficie.

AGUAFUERTE: Ocurre exactamente lo mismo que con el aguatinta. Los trazos finos y sutiles están estampados perfectamente, mientras que en las zonas donde se concentran gran cantidad de líneas y por consiguiente de tinta, encontramos la conocida textura irregular a base de grumos.

CONTRASTE: Correcto ya que la tinta transparente es capaz de cubrir y contrastar con el tono tan claro de la piel, creándose una imagen perfectamente reconocible y de suficiente fuerza plástica.

BRILLO: Al ya de por sí existente en la superficie de la piel la tinta añade otra cantidad de brillo suplementario. Éste se concentra en los grafismos más gruesos y potentes y en las zonas de acumulación de tinta. 

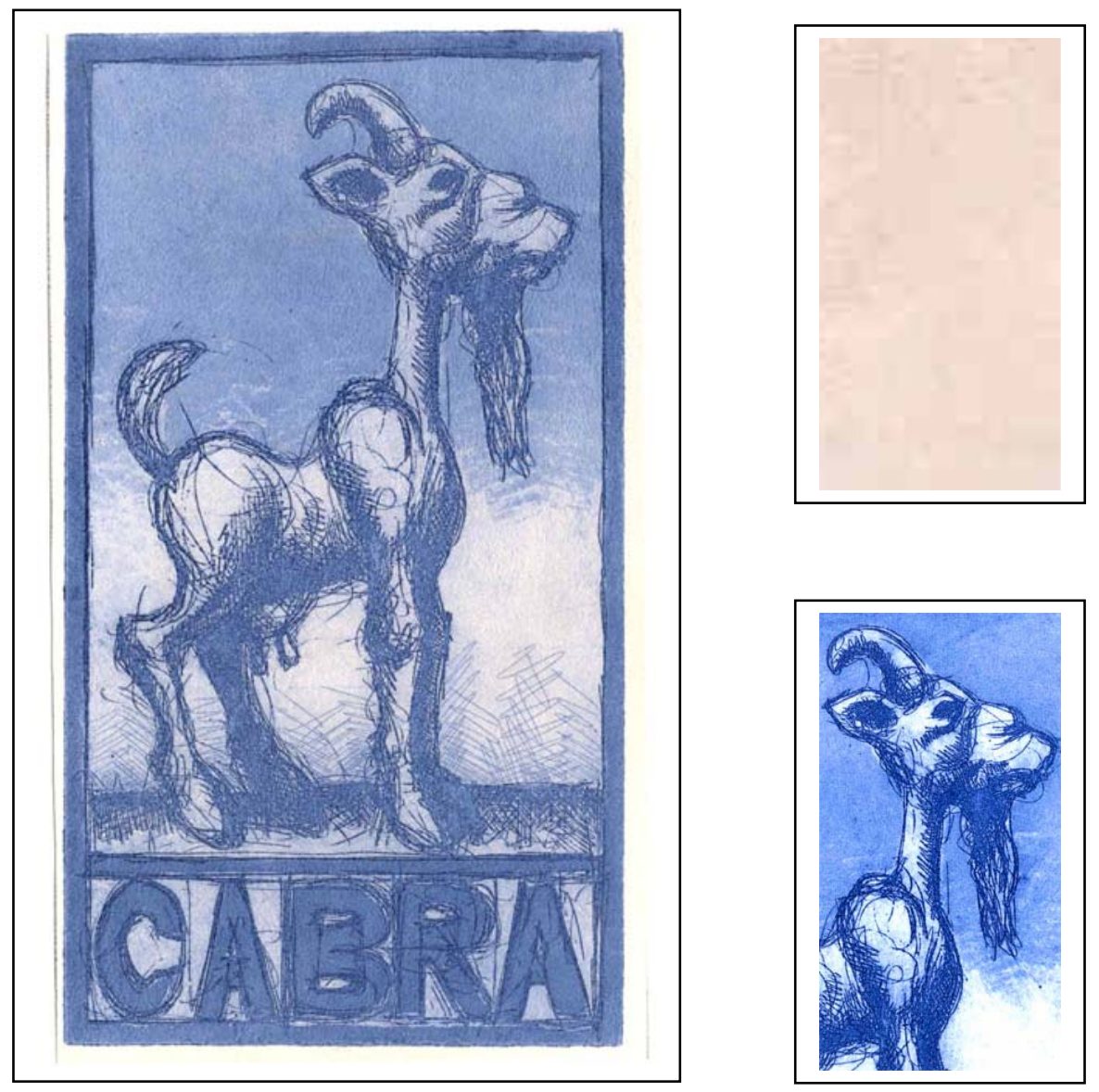

CÓDIGO: CA-035

TIPO DE PIEL: Cabra

TINTA: Azul traslúcido
TÉCNICA: Calcografía

TONO DE PIEL: Claro

SUPERFICIE: Lado carne 


\section{CALIDAD: Muy buena}

Fantástica estampa, una de las mejores de todos los ejemplos propuestos. Indicar que se trata de una imagen sobre el lado carne, pero que dicha superficie carece casi por completo de afelpado, teniendo un acabado sedoso y muy fino.

AGUATINTA: Perfecta. Los tonos más claros registran con total fidelidad el original, mientras que los tonos más oscuros también estampan perfectamente bien. Los problemas aparecidos en el lado flor desaparecen por completo debido a que, al no ser una superficie tan satinada, la tinta no forma grumos que puedan enturbiar la visión.

AGUAFUERTE: También perfecto; ambos tipos de líneas, las sutiles y las potentes, registran con total nitidez y claridad sin el menor fallo ni problema. Tampoco aparecen las texturas comentadas para otros ejemplos en las zonas de acumulación de tinta.

CONTRASTE: Muy correcto ya que, como ya se ha comentado anteriormente, la tinta transparente al contacto con una superficie afelpada se oscurece muy ostensiblemente. Al sufrir este oscurecimiento el contraste aparecido con el tono del fondo es correcto y suficiente para crear una imagen válida.

BRILLO: Prácticamente nulo; tan sólo aparecen minúsculos puntos brillantes en zonas con gran acumulación de tinta, pero nunca interfiriendo en la correcta visión. 

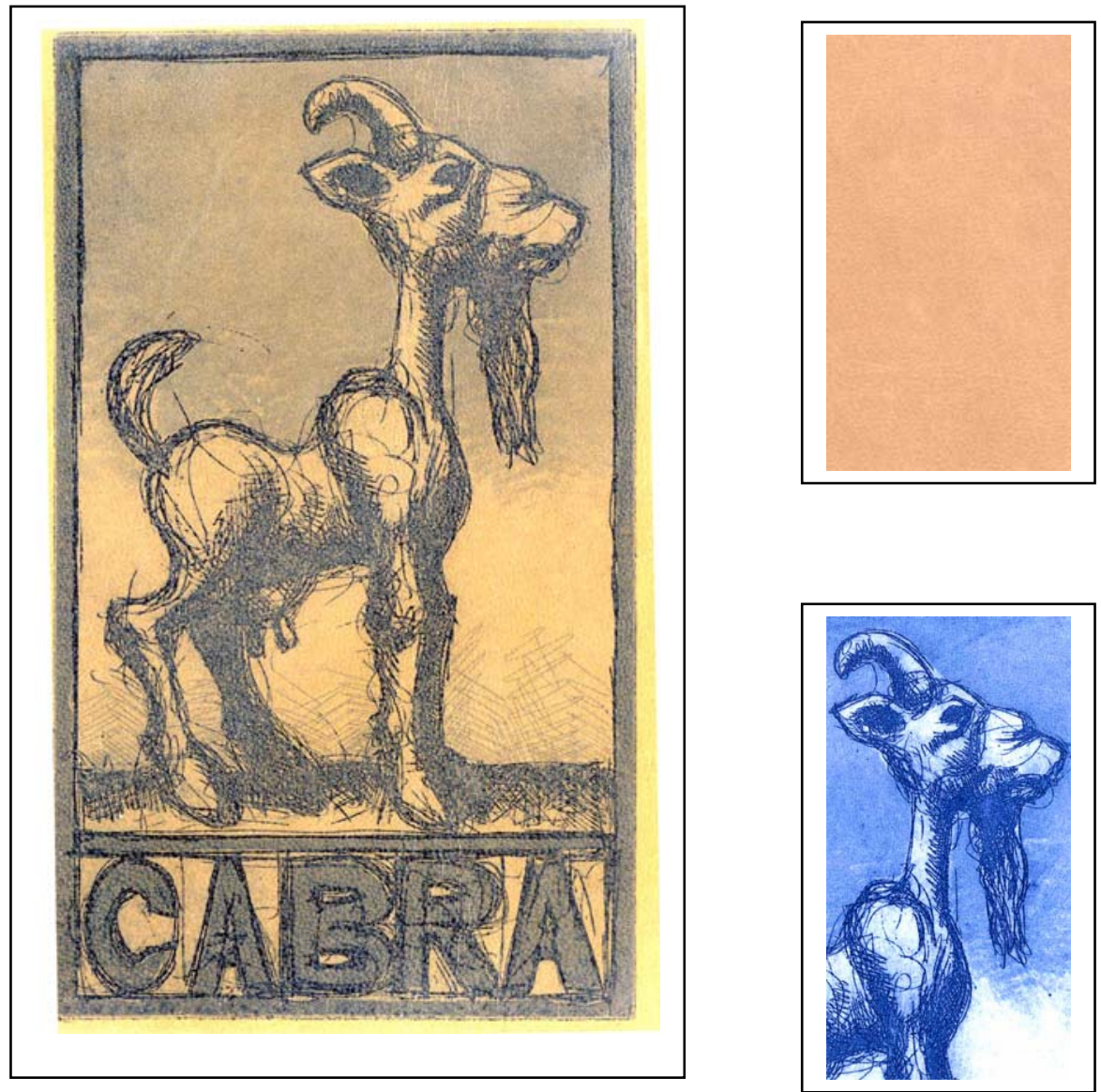

CÓDIGO: CA-036

TIPO DE PIEL: Cabra

TINTA: Azul traslúcido
TÉCNICA: Calcografía

TONO DE PIEL: Medio

SUPERFICIE: Lado flor 


\section{CALIDAD: Buena}

Ejemplo de buena calidad general aunque se repiten los inconvenientes observados en la estampa sobre piel clara y lado flor (CA034). Esto es, problemas de grumos en las zonas con mayor acumulación de tinta ya sea en el aguatinta como en el aguafuerte.

AGUATINTA: El tono gris claro está estampado con gran fidelidad y sin ningún tipo de problemas. Por el contrario en las zonas oscuras vemos el ya conocido problema de la textura "a grumos", lo que resta un poco de calidad a estas áreas de la imagen.

AGUAFUERTE: Sucede algo parecido a lo observado en el aguatinta. Las líneas finas se estampan sin inconvenientes pero las gruesas presentan inconvenientes. Por un lado las líneas potentes aisladas poseen una calidad notable, pero por el contrario en las zonas con gran densidad de grafismos vuelve a repetirse el problema ya comentado.

CONTRASTE: A pesar de tener un tono de fondo algo más oscuro el contraste sigue siendo lo suficientemente intenso como para crear una imagen correcta y plásticamente válida.

BRILLO: Al brillo ya de por sí evidente de la piel viene a sumarse el que incorpora la tinta. Sin embargo no llega a resultar excesivamente molesto para la visión de la imagen. 

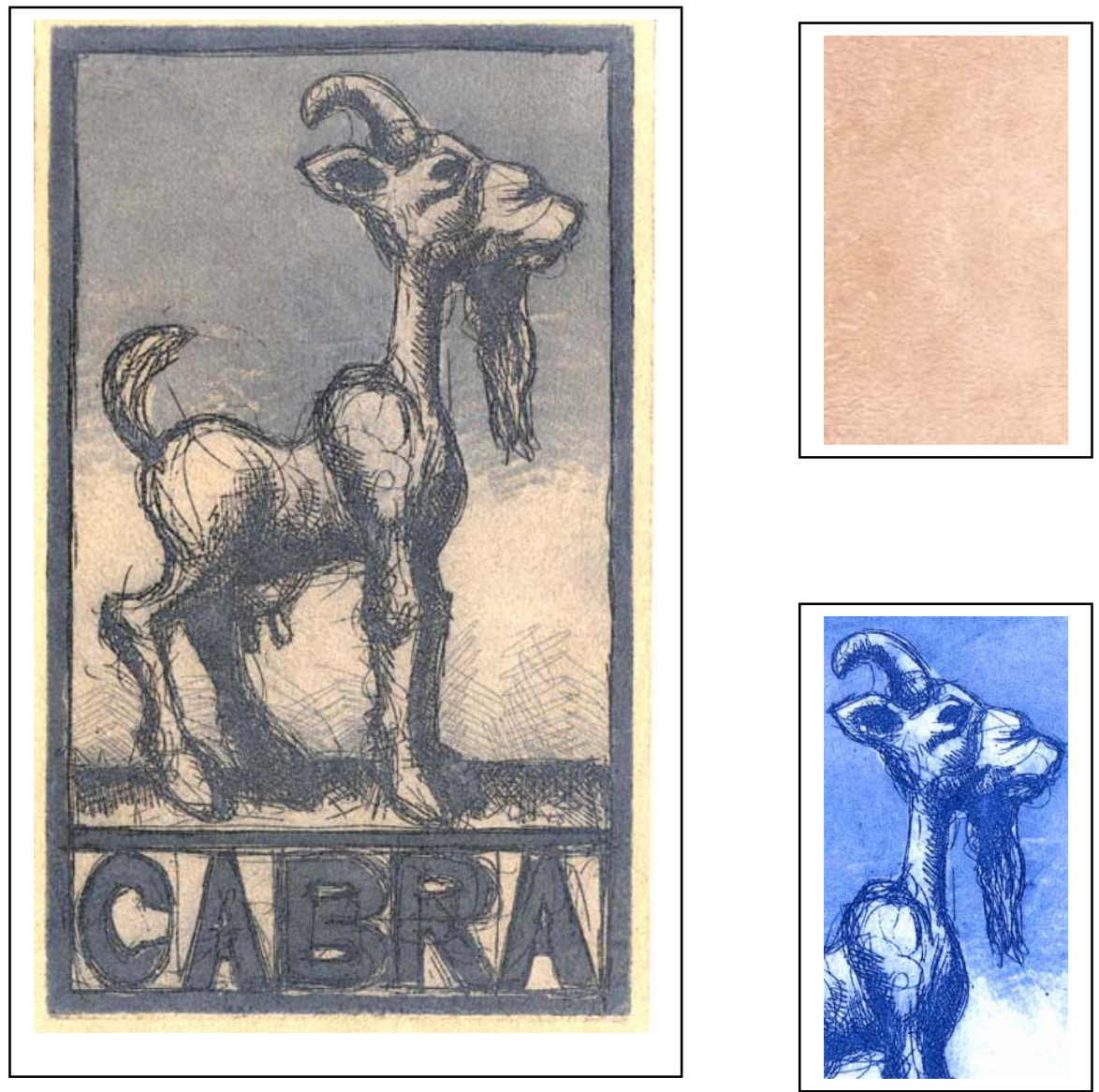

CÓDIGO: CA-037

TIPO DE PIEL: Cabra

TINTA: Azul traslúcido
TÉCNICA: Calcografía

TONO DE PIEL: Medio

SUPERFICIE: Lado carne 


\section{CALIDAD: Muy buena}

Estampa de parecidas características a la del lado carne en la piel clara de este mismo estudio (CA-029), con mínimas diferencias en lo referente al contraste y a la intensidad del mismo.

AGUATINTA: Prácticamente perfectos, tanto el tono más claro como el oscuro e intenso. Ambos registran con gran nitidez los tonos originales de la plancha, con la única particularidad de padecer una ligera subida de tono, oscureciéndose el conjunto de la estampa.

AGUAFUERTE: Sin ningún tipo de problema visible, tanto las líneas finas como las gruesas registran perfectamente logrando una gran nitidez de grafismo.

CONTRASTE: Al existir un acabado algo más afelpado en este tipo de piel, el tono general de la tinta azul transparente se ha oscurecido notoriamente. Como también ha subido el tono del soporte el contraste se mantiene casi igual que sobre la piel clara.

BRILLO: Nulo e inexistente como era de esperar al estampar sobre una superficie afelpada y rugosa, con los efectos ya conocidos y sobradamente explicados. 

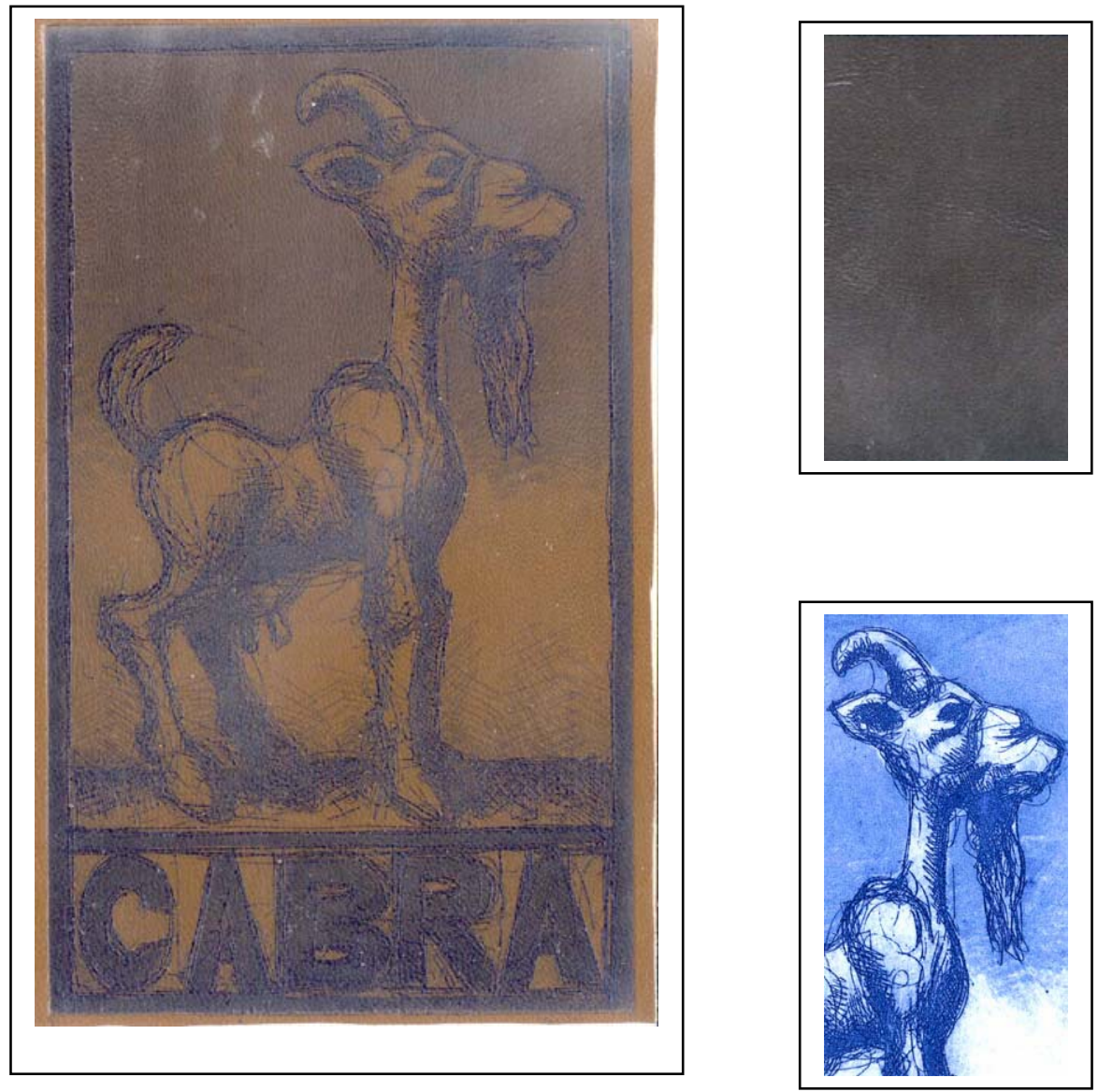

CÓDIGO: CA-038

TIPO DE PIEL: Cabra

TINTA: Azul traslúcido
TÉCNICA: Calcografía

TONO DE PIEL: Oscuro

SUPERFICIE: Lado flor 


\section{CALIDAD: Mala}

Ejemplo de poco interés plástico debido al tono tan oscuro del soporte, el cual provoca que el contraste sea escaso y que la imagen sea difícil de apreciar correctamente.

AGUATINTA: Siguiendo con lo observado en ejemplos anteriores el tono más sutil no presenta ningún problema, mientras que aquellos más oscuros y densos vuelven a evidenciar esa textura con grumos e irregularidades tan típica de las zonas donde se produce una acumulación de tinta.

AGUAFUERTE: Características parecidas a las estampas sobre piel de tonos claros y medios (CA-028 y CA-030). Las líneas finas no presentan problemas, las gruesas aisladas tampoco, pero en las zonas de grafismo denso vemos aparecer de nuevo la textura "a grumos".

CONTRASTE: Muy escaso por efecto del tono tan saturado y oscuro de la piel. Esto dificulta sobremanera la visión general de la imagen, apareciendo ésta como demasiado oscura y sin contraste.

BRILLO: Bastante elevado e incluso molesto debido a su excesiva intensidad. La superficie de la piel está muy saturada de tintes y ceras, poseyendo un marcado brillo que no aconseja su uso como soporte para estampas calcográficas. 

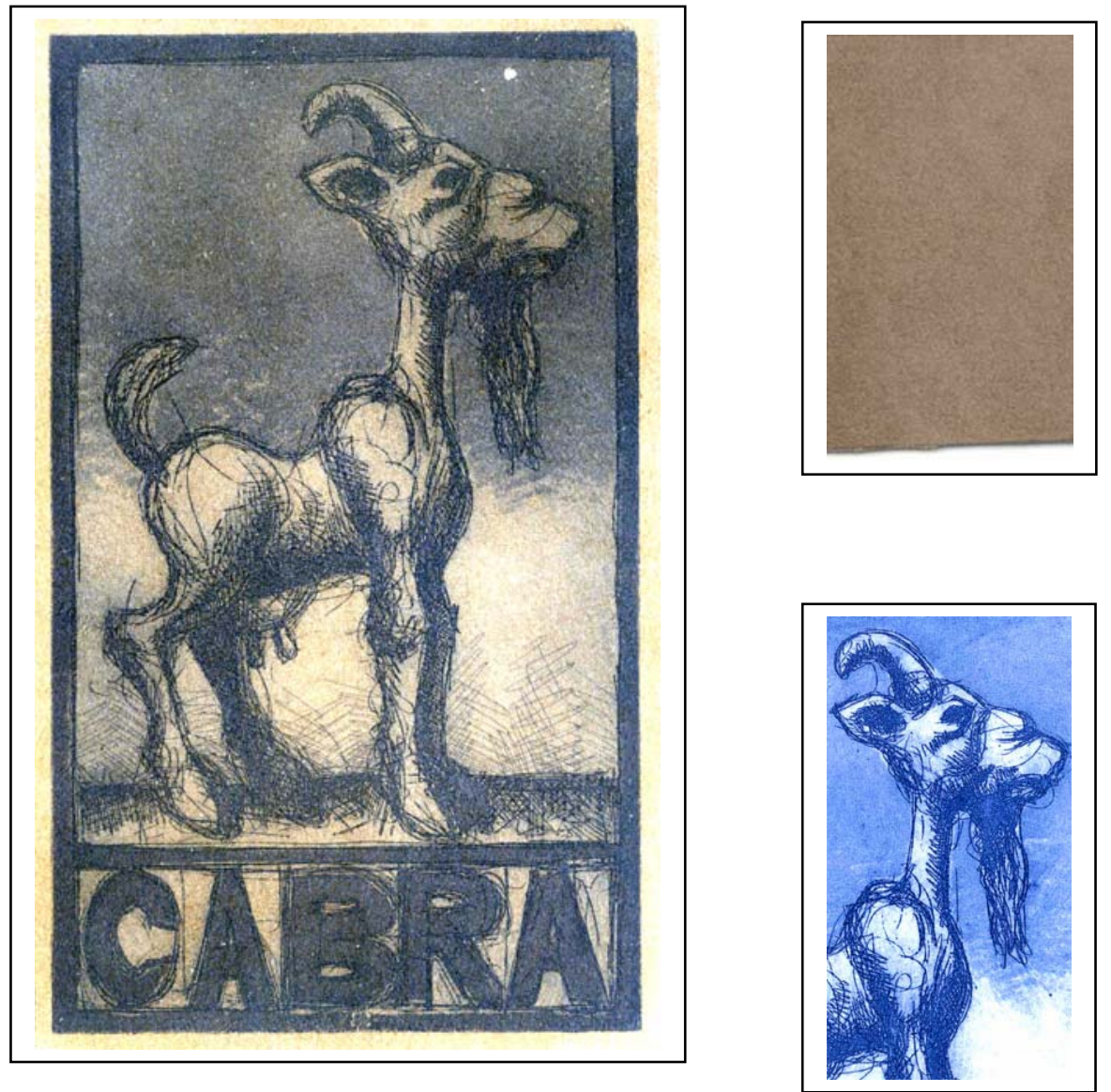

CÓDIGO: CA-039

TIPO DE PIEL: Cabra

TINTA: Azul traslúcido
TÉCNICA: Calcografía

TONO DE PIEL: Oscuro

SUPERFICIE: Lado carne 


\section{CALIDAD: Mediocre}

Estampa con factores muy interesantes y positivos pero con otros problemáticos que condicionan la estampa e imposibilitan un resultado plenamente satisfactorio. A pesar de esto es de mejor calidad que su pareja en el lado flor (CA-032), debido al acabado afelpado de la piel.

AGUATINTA: Bastante correcta, tanto la sutil como la más densa. Ambas se oscurecen sobremanera al contacto con la superficie afelpada pero conservan sus características.

AGUAFUERTE: Muy válido, tanto las líneas finas como las potentes. No aparecen los problemas relativos a la textura tan desagradable ya conocida. Esto se debe al acabado tan afelpado de la piel, el cual impide la formación de este tipo de texturas. Por tanto, en las zonas con un grafismo más denso tenemos un tono oscuro de gran atractivo y calidez.

CONTRASTE: Medio y sin gran contundencia a pesar del proceso de oscurecimiento ya comentado. El tono del fondo condiciona el contraste, el cual, a pesar de no ser excesivo, permite todavía una correcta visión de la imagen.

BRILLO: Casi inexistente como es lógico en una estampa realizada sobre un lado carne tan rugoso, texturado y afelpado. 

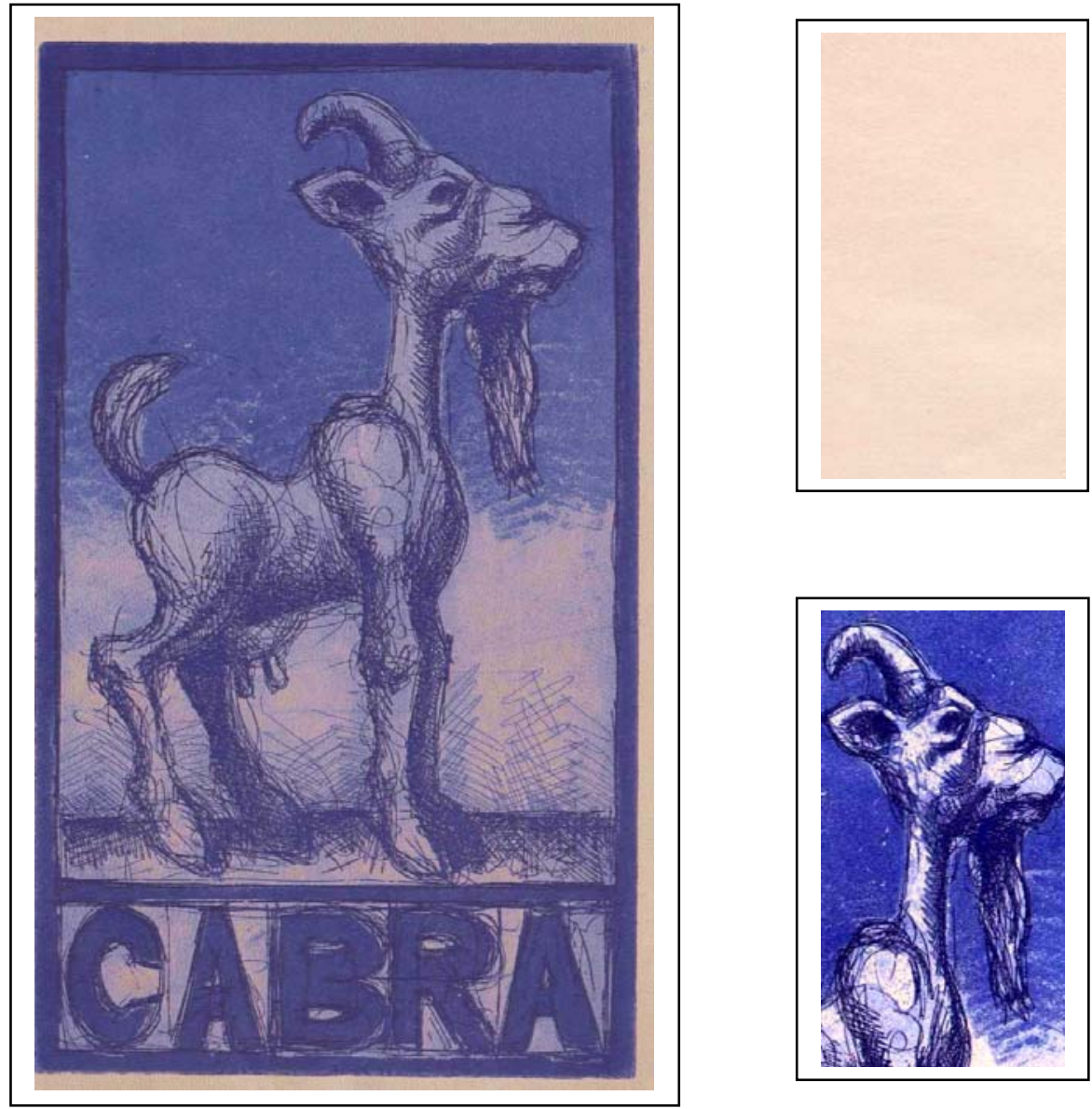

CÓDIGO: CA-040

TIPO DE PIEL: Cabra

TINTA: Azul opaco
TÉCNICA: Calcografía

TONO DE PIEL: Claro

SUPERFICIE: Lado flor 


\section{CALIDAD: Muy buena}

Ejemplo entre los mejores de todo el estudio, sin ningún tipo de problemas de contraste, definición u homogeneidad. Sin duda se trata de una superficie ideal para este tipo de estampación. Es necesario un tiempo de secado bastante largo para conseguir un asentamiento total de la tinta sobre el cuero.

AGUATINTA: Perfecta, ambos tonos de azul se registran de manera correcta, manteniendo sus diferencias entre sí y con gran regularidad en toda la superficie. Todos y cada uno de los distintos efectos presentes en la plancha matriz se transfieren perfectamente al soporte piel.

AGUAFUERTE: También perfecto al igual que el aguatinta, con un registro muy correcto de los dos tipos de líneas de la plancha. Tanto los grafismos más sutiles como los más potentes se estampan sin ningún tipo de problema, con gran nitidez y alto nivel de calidad.

CONTRASTE: Intenso y adecuado como para crear una imagen fácilmente reconocible y de buena apariencia plástica. La tinta azul sufre un ligero oscurecimiento que ayuda a que el citado contraste sea el adecuado.

BRILLO: Aparece un ligero brillo que no resulta molesto ni interfiere en la correcta visión de la estampa. 

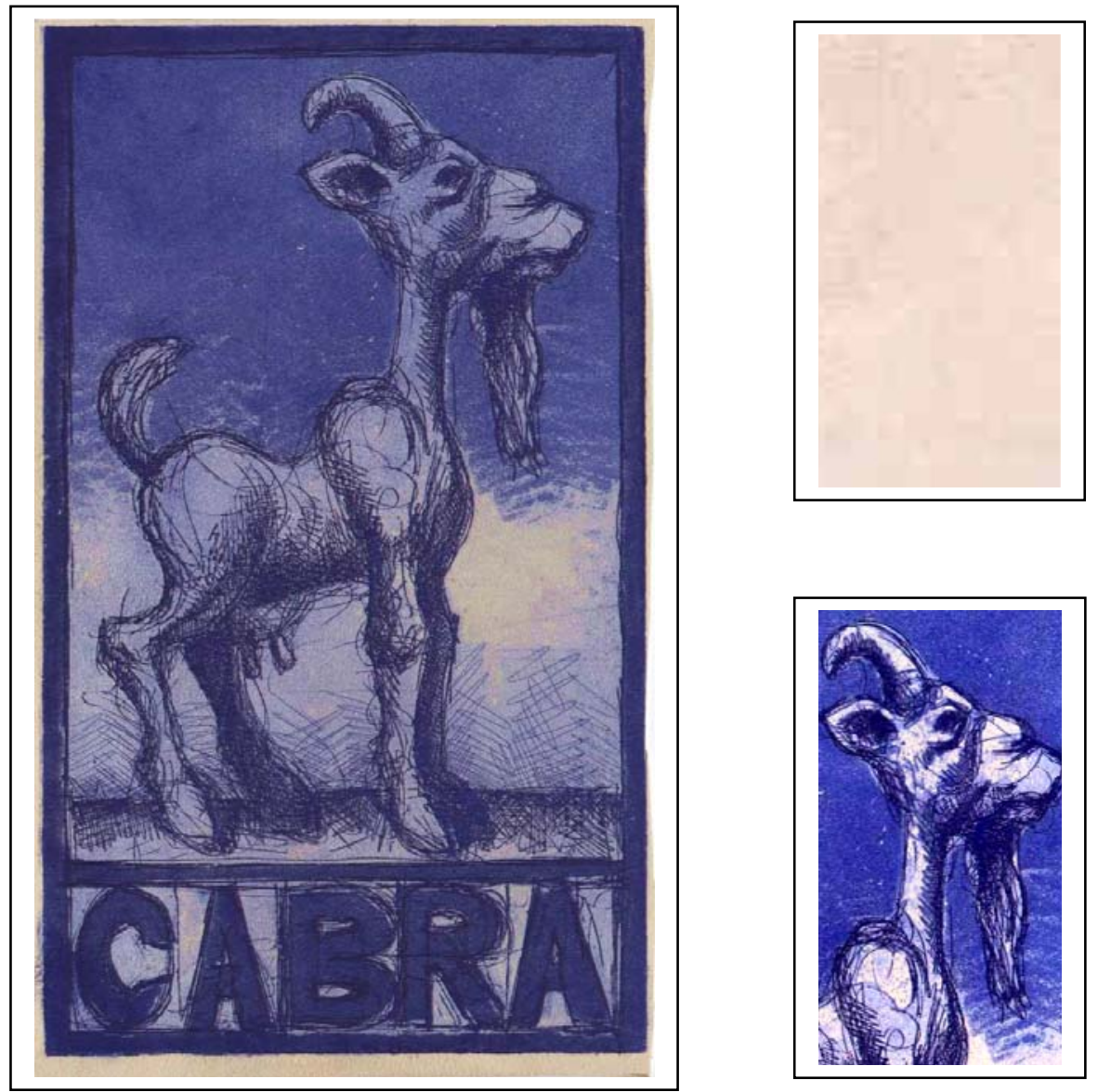

CÓDIGO: CA-041

TIPO DE PIEL: Cabra

TINTA: Azul opaco
TÉCNICA: Calcografía

TONO DE PIEL: Claro

SUPERFICIE: Lado carne 


\section{CALIDAD: Buena}

Las pequeñas irregularidades del afelpado del lado carne de la piel afectan de manera más evidente al resultado de estampas calcográficas que en el caso de las xilográficas por efecto de la menor cantidad de tinta depositada en las primeras. Desaparecen casi por completo los problemas de secado y asentamiento antes comentados.

AGUATINTA: Algo mediocre ya que aparecen numerosas irregularidades tonales, provocadas por posibles diferencias de la superficie del cuero. A pesar de todo los dos tonos mantienen sus diferencias de intensidad y el resultado general no es excesivamente defectuoso.

AGUAFUERTE: Muy bueno; los defectos antes comentados al respecto del aguatinta no inciden del mismo modo sobre los grafismos lineales, estando ambos tipos de líneas registrados de manera muy satisfactoria.

CONTRASTE: Bastante intenso, lo que permite la creación de una imagen legible sin apenas problemas. Lógicamente la tinta sufre un ligero oscurecimiento al contacto con la superficie afelpada del cuero, pero siempre en menor grado que en el caso del azul traslúcido.

BRILLO: Nulo como es lógico al estampar sobre un soporte afelpado como en este caso concreto. 

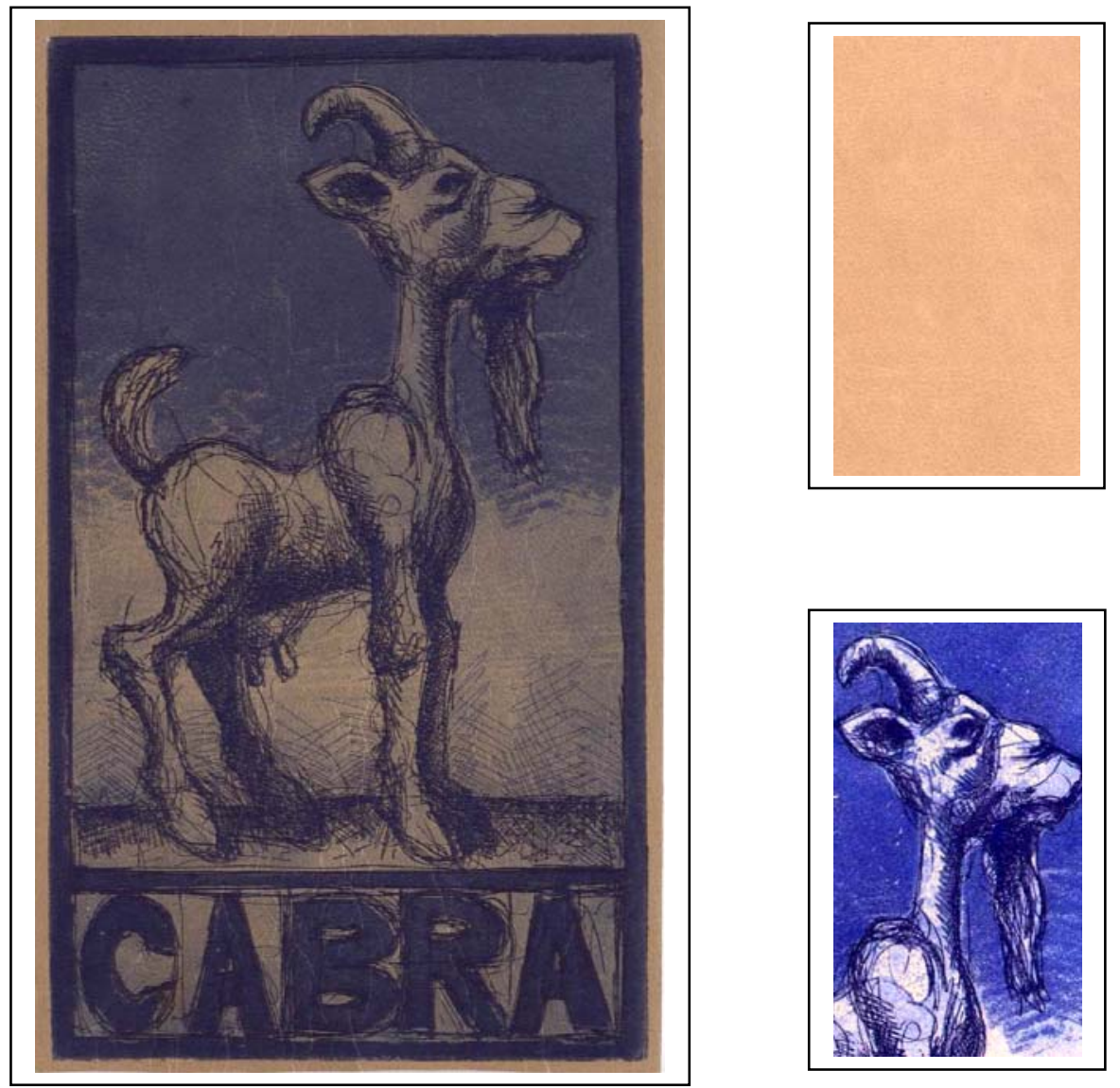

CÓDIGO: CA-042

TIPO DE PIEL: Cabra

TINTA: Azul opaco
TÉCNICA: Calcografía

TONO DE PIEL: Medio

SUPERFICIE: Lado flor 


\section{CALIDAD: Muy buena}

La estampa no presenta ningún problema reseñable dentro de los campos estudiados en este proyecto. Todas las variables responden correctamente al análisis. En lo que respecta al secado y al asentamiento de la tinta, los problemas todavía aparecen pero en grado mucho menos intenso que en los casos xilográficos.

AGUATINTA: Casi perfecta. A pesar del lógico oscurecimiento de la piel tenemos ambos tonos de azul perfectamente estampados y sin apenas irregularidades superficiales.

AGUAFUERTE: Perfecto, tanto las líneas sutiles como las más gruesas se registran manteniendo su naturaleza intacta. La superficie se muestra idónea para este tipo de grafismos lineales.

CONTRASTE: Muy correcto, lógicamente no tan intenso como en los ejemplos sobre pieles más claras, pero todavía muy evidente, lo que permite la obtención de una imagen correcta y legible.

BRILLO: La tinta repite y reproduce el brillo algo ceroso que ya poseía el propio cuero, sin modificar apenas dicho acabado. Pese a esto no llega a ser un reflejo perjudicial para la visión de la estampa. 

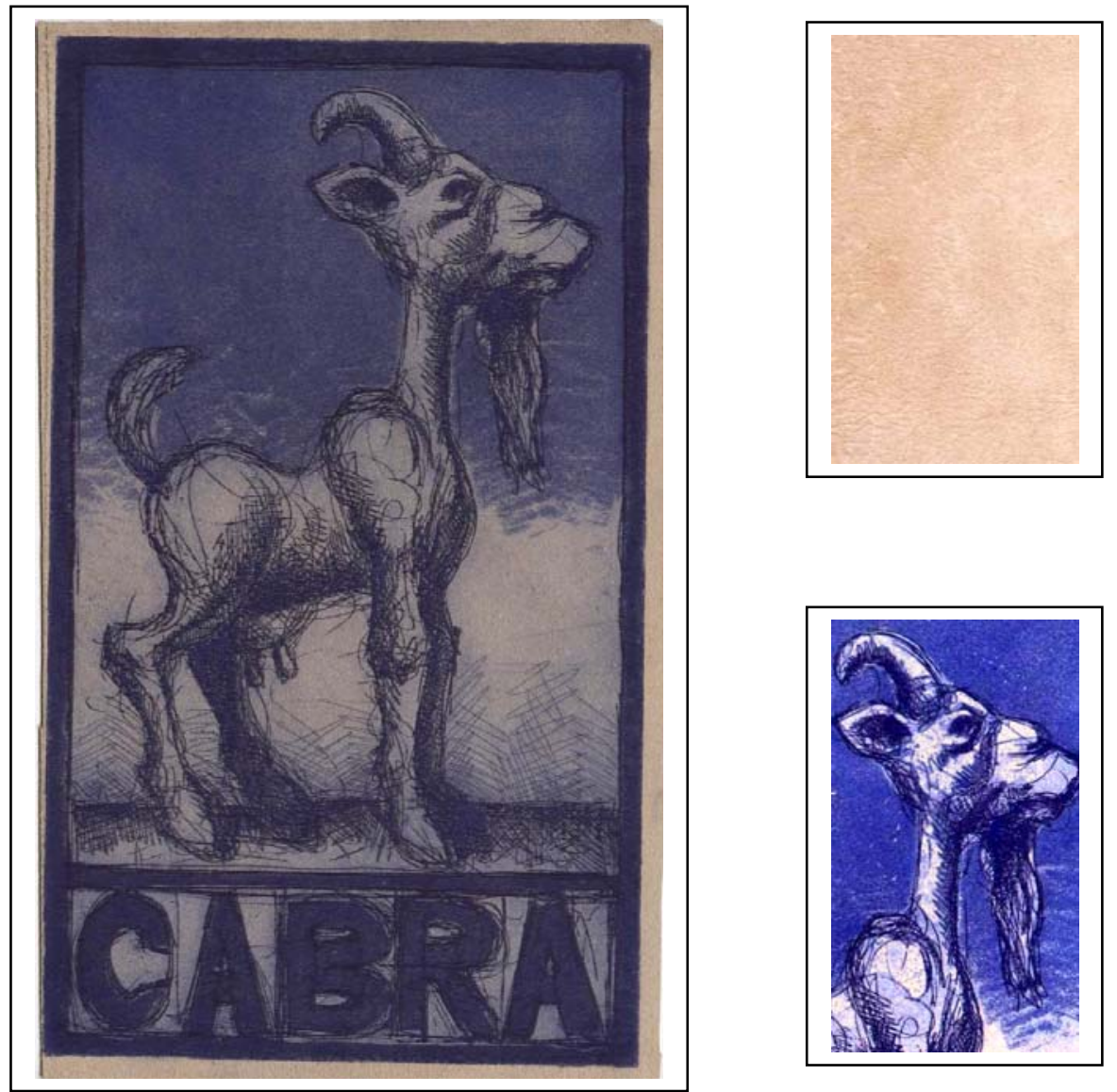

CÓDIGO: CA-043

TIPO DE PIEL: Cabra

TINTA: Azul opaco
TÉCNICA: Calcografía

TONO DE PIEL: Medio

SUPERFICIE: Lado carne 


\section{CALIDAD: Muy buena}

La estampa se presenta como una de los mejores ejemplos de grabado calcográfico de todo el estudio. El hecho de conseguir una superficie homogénea es fundamental para el buen fin de la impresión. Los problemas de secado y asentamiento de la tinta aparecen en grado mínimo y apenas reseñable.

AGUATINTA: Perfecta. A pesar del patente y claro oscurecimiento al que se ve obligada la tinta, ambos tonos de azul conservan sus gradaciones internas de intensidad. Así mismo no se observan deficiencias de homogeneidad en ninguna de las zonas de la imagen.

AGUAFUERTE: A su vez perfecto como el aguatinta. Los grafismos se registran de manera totalmente satisfactoria, siendo particularmente evidente el caso de las líneas más sutiles, las cuales, a pesar del afelpado de la superficie del cuero, están estampadas perfectamente.

CONTRASTE: Algo menos intenso que en otros ejemplos pero todavía suficientemente fuerte gracias al comentado oscurecimiento de la tinta azul al contacto con el afelpado del soporte piel.

BRILLO: Nulo como corresponde al lado carne del forro de cabra empleado como soporte para la estampa. 

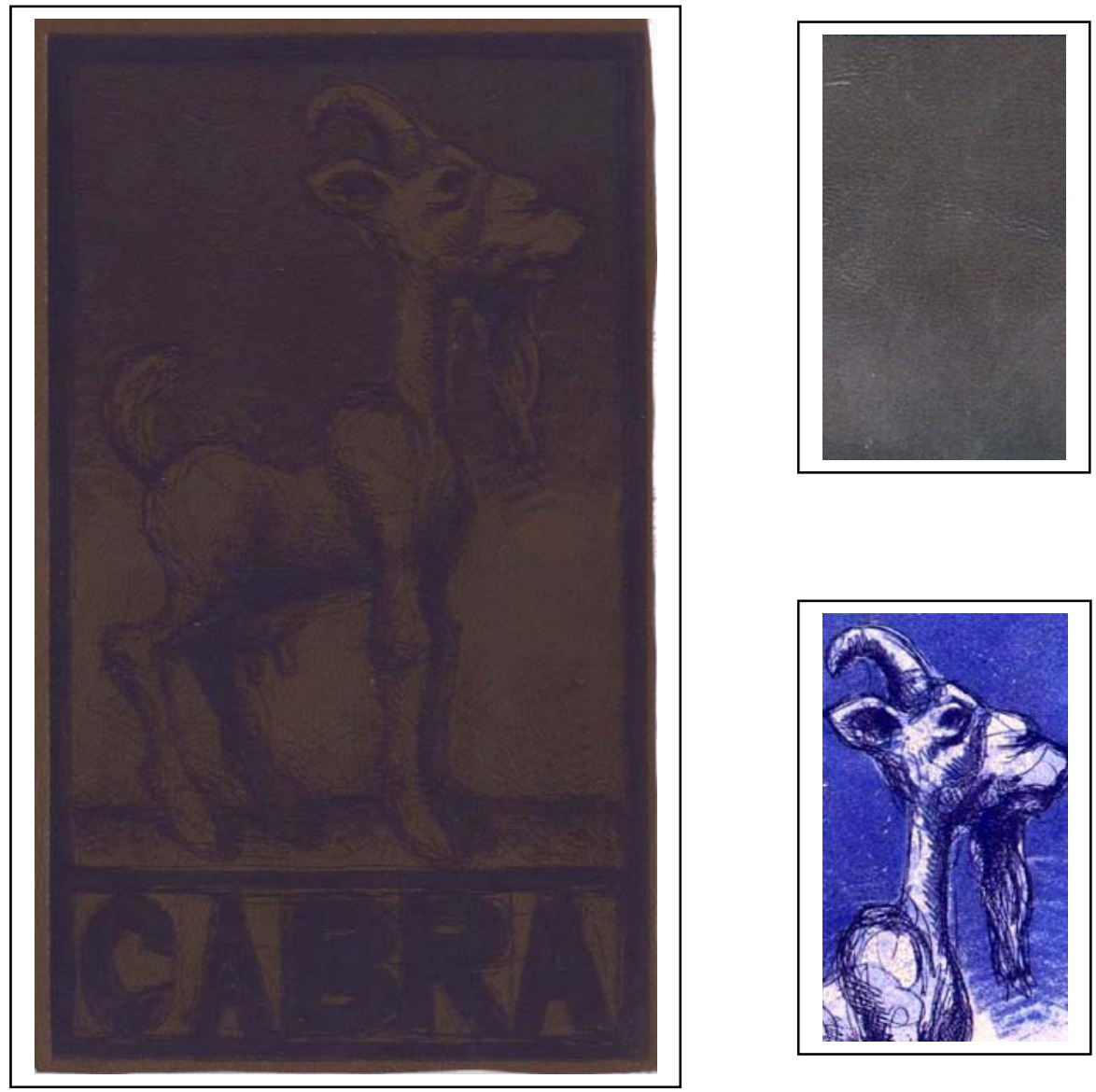

CÓDIGO: CA-044

TIPO DE PIEL: Cabra

TINTA: Azul opaco
TÉCNICA: Calcografía

TONO DE PIEL: Oscuro

SUPERFICIE: Lado flor 


\section{CALIDAD: Mediocre}

En este ejemplo inciden de manera evidente los grados de contraste y brillo, ambos muy elevados, lo que provoca que la apariencia de la estampa no sea la deseable. El inconveniente del secado y asentamiento todavía aparece hasta que no ha pasado un largo periodo de tiempo y la tinta seca totalmente.

AGUATINTA: Muy correcta a pesar de lo oscuro del soporte. Ambos tonos todavía mantienen sus características propias y estampan de manera bastante satisfactoria sobre una superficie muy satinada y pulida.

AGUAFUERTE: También casi perfecto, con un registro muy correcto de todos los grafismos realizados en la superficie de la plancha matriz.

CONTRASTE: Obviamente algo escaso y de poca intensidad debido al tono tan oscuro del cuero. Aún así la imagen es fácilmente reconocible aunque careciendo de la necesaria fuerza plástica y visual que sería deseable.

BRILLO: Excesivamente intenso provocado por el acabado tan satinado del cuero. Este hecho es determinante para calificar esta estampa de mediocre, ya que el resto de campos analizados se comportan de manera bastante correcta. 

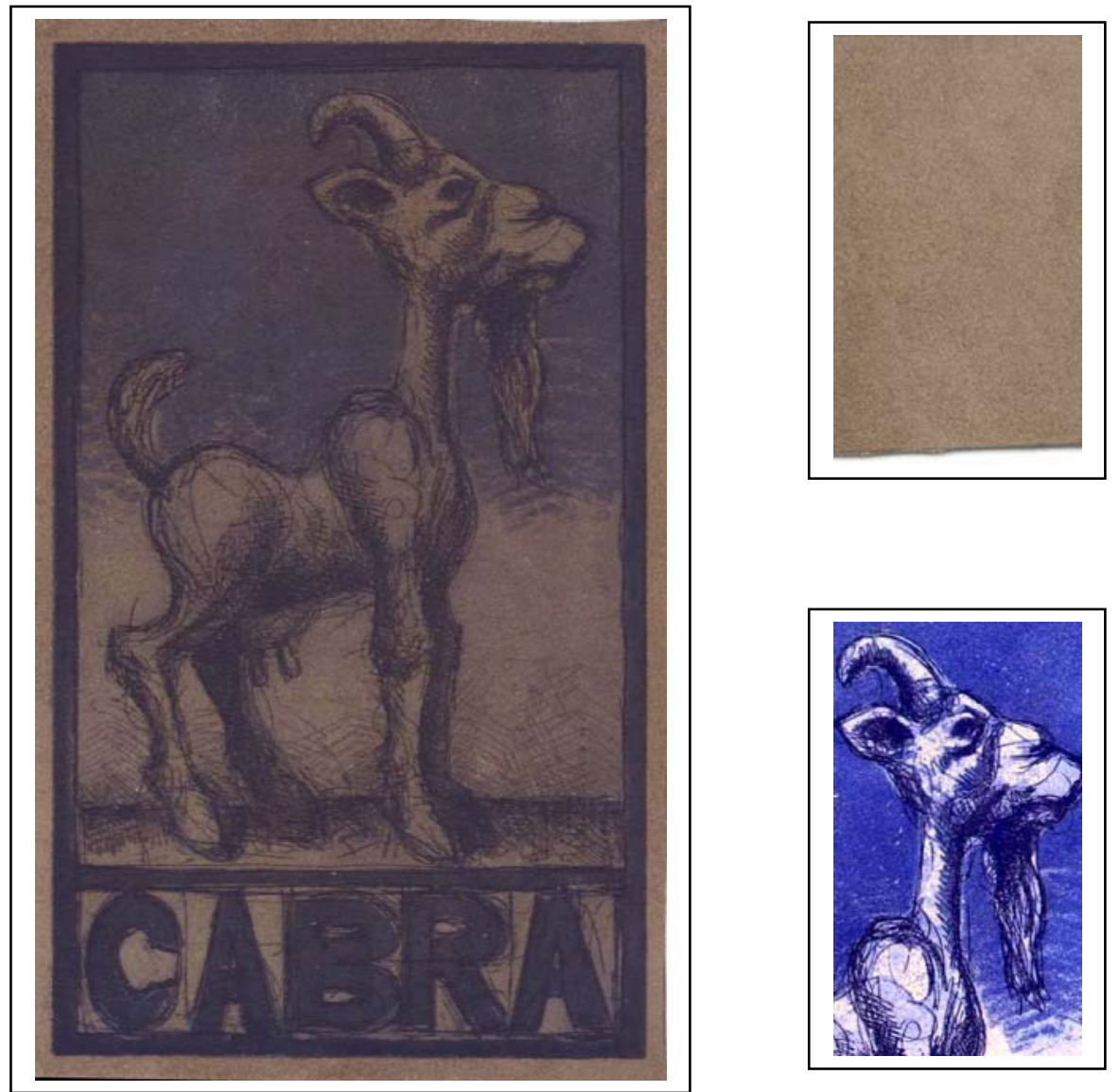

CÓDIGO: CA-045

TIPO DE PIEL: Cabra

TINTA: Azul opaco
TÉCNICA: Calcografía

TONO DE PIEL: Oscuro

SUPERFICIE: Lado carne 


\section{CALIDAD: Mala}

La superficie algo irregular de la piel condiciona a esta estampa calcográfica. Sobre todo las zonas de aguatinta no ofrecen un acabado satisfactorio, aunque los demás apartados se muestran con un nivel algo más alto. En lo que respecta al secado de la tinta, ésta necesita de un tiempo muy largo para un total asentamiento de la misma sobre la superficie de la piel.

AGUATINTA: Como ya se ha indicado, aparecen numerosas irregularidades que provocan, sobre todo en las zonas más claras, que la estampa no pueda considerarse como totalmente correcta. En las zonas con mayor cantidad de tinta las deficiencias son mucho menos evidentes.

AGUAFUERTE: Correcto aunque los grafismos más sutiles no se aprecien de manera totalmente satisfactoria.

CONTRASTE: El patente oscurecimiento de la tinta provoca que el grado de intensidad del contraste sea todavía lo suficientemente elevado como para hacer de la imagen una estampa visible.

BRILLO: Nulo como era de esperar en un ejemplo realizado sobre una superficie tan afelpada como esta. 

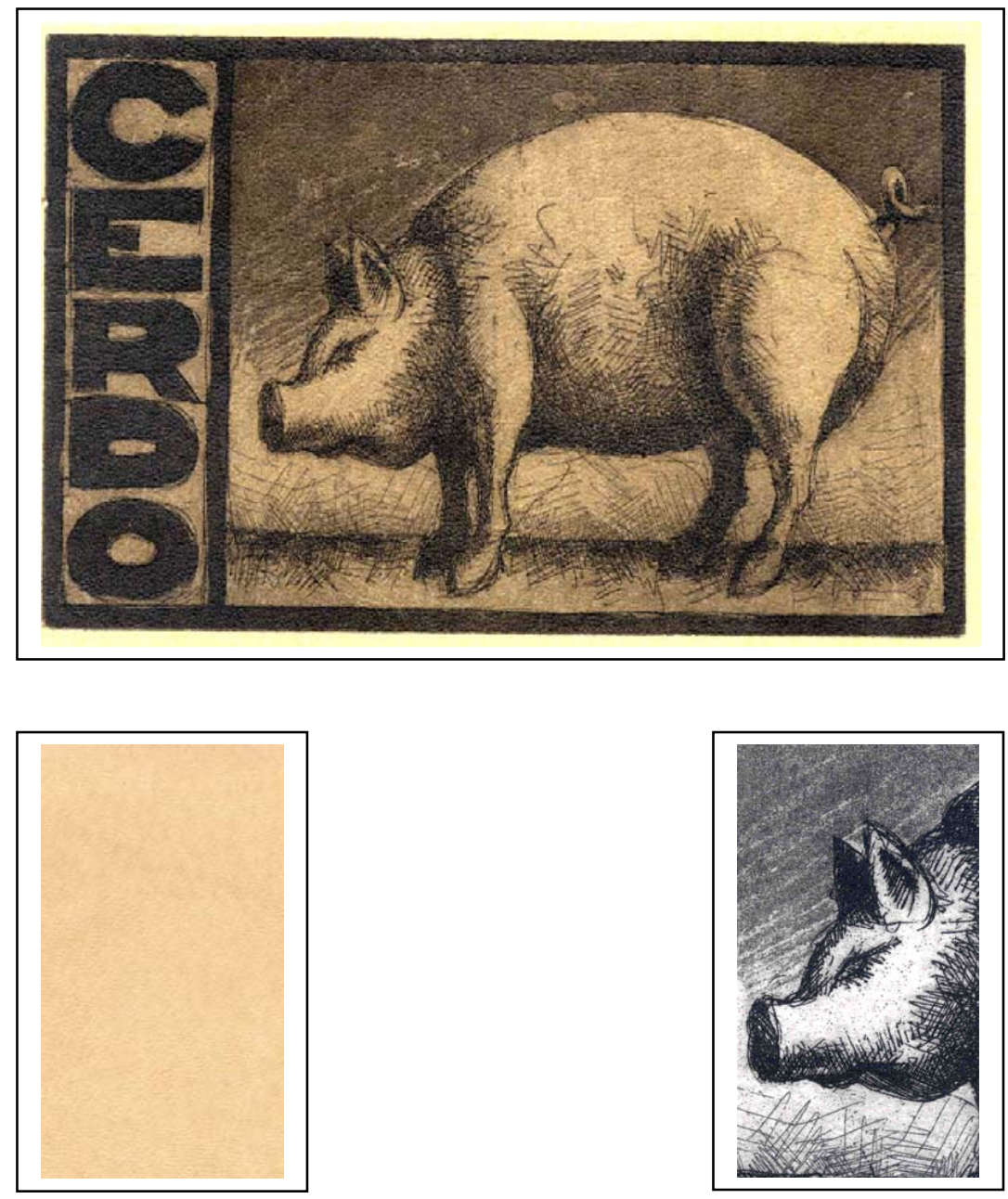

CÓDIGO: CE-025

TÉCNICA: Calcografía

TIPO DE PIEL: Cerdo

TONO DE PIEL: Claro

TINTA: Negro

SUPERFICIE: Lado flor 


\section{CALIDAD: Muy buena}

Ejemplo de apreciable nivel debido a las características propias de la piel porcina y en concreto del "forro" de cerdo, tipo de piel usado para estos ejemplos. Indicar que se ha añadido un 50\% de preparación traslúcida a la tinta negra para hacerla más fluida y evitar la pátina oscura que aparecería sin su utilización. Así mismo esta preparación traslúcida dota de cierta intensidad y brillo a la tinta, haciendo las estampas más atractivas y potentes.

AGUATINTA: Casi perfecta. Tanto los grises pálidos como los oscuros están registrados con total nitidez y sin mayores inconvenientes.

AGUAFUERTE: Exactamente igual que el aguatinta. Todas las líneas de la imagen han sido estampadas y registradas perfectamente, sin influir la textura propia de la piel porcina.

CONTRASTE: Bastante correcto e intenso. Válido como para crear una imagen perfectamente aceptable desde un punto de vista plástico.

BRILLO: Debido a la incorporación de preparación traslúcida a la tinta empleada aparece un ligero brillo ceroso que sin embargo nunca resulta molesto para la visión y apreciación de la imagen. 


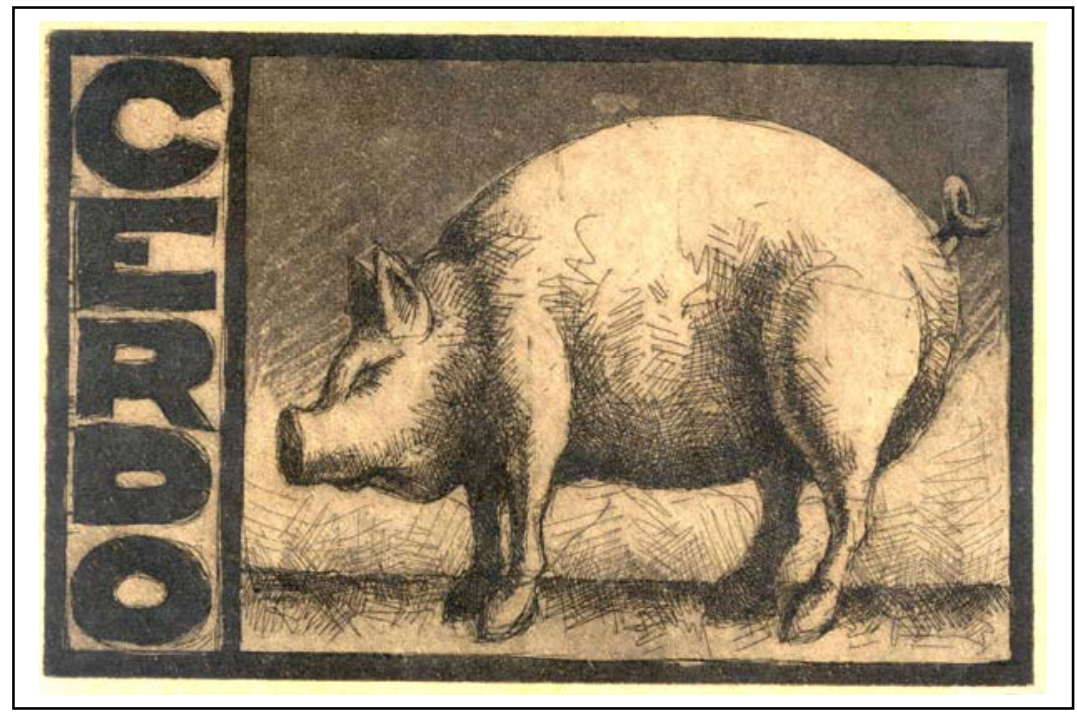

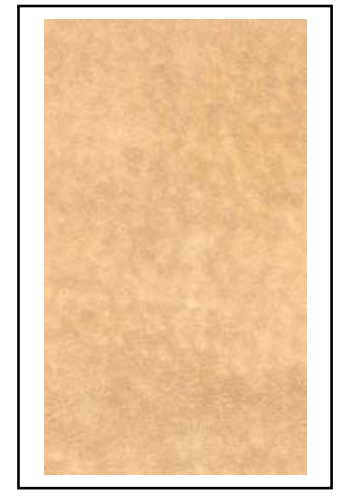

CÓDIGO: CE-026

TIPO DE PIEL: Cerdo

TINTA: Negro

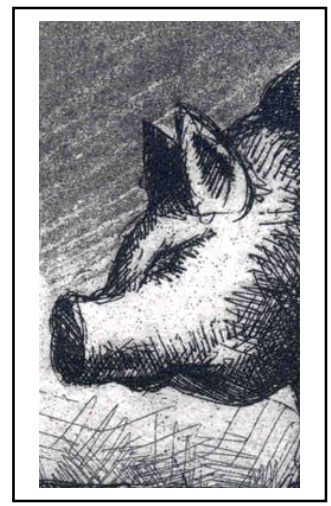

TÉCNICA: Calcografía

TONO DE PIEL: Claro

SUPERFICIE: Lado carne 


\section{CALIDAD: Muy buena}

Ejemplo de buenísima calidad que pone de manifiesto las grandes condiciones de la piel porcina como receptora y soporte de imágenes impresas mediante técnicas propias del grabado calcográfico.

AGUATINTA: Perfecta. Tan sólo hacer notar que el tono general de los grises ha subido ligeramente, oscureciéndose un tanto. Esto está provocado por el acabado ligeramente afelpado de la superficie de la piel.

AGUAFUERTE: También de muy buen nivel. El afelpado de la piel no afecta para nada a la hora de registrar nítidamente todos y cada uno de los trazos y las líneas presentes en la plancha de zinc.

CONTRASTE: Muy correcto e intenso. Permite observar una imagen totalmente válida y sin ningún tipo de problema.

BRILLO: Inexistente ya que la superficie rugosa y afelpada del lado carne impide la formación de dichos brillos. Esta superficie "absorbe" una gran cantidad de tinta y evita la aparición de acabados satinados y brillantes. 


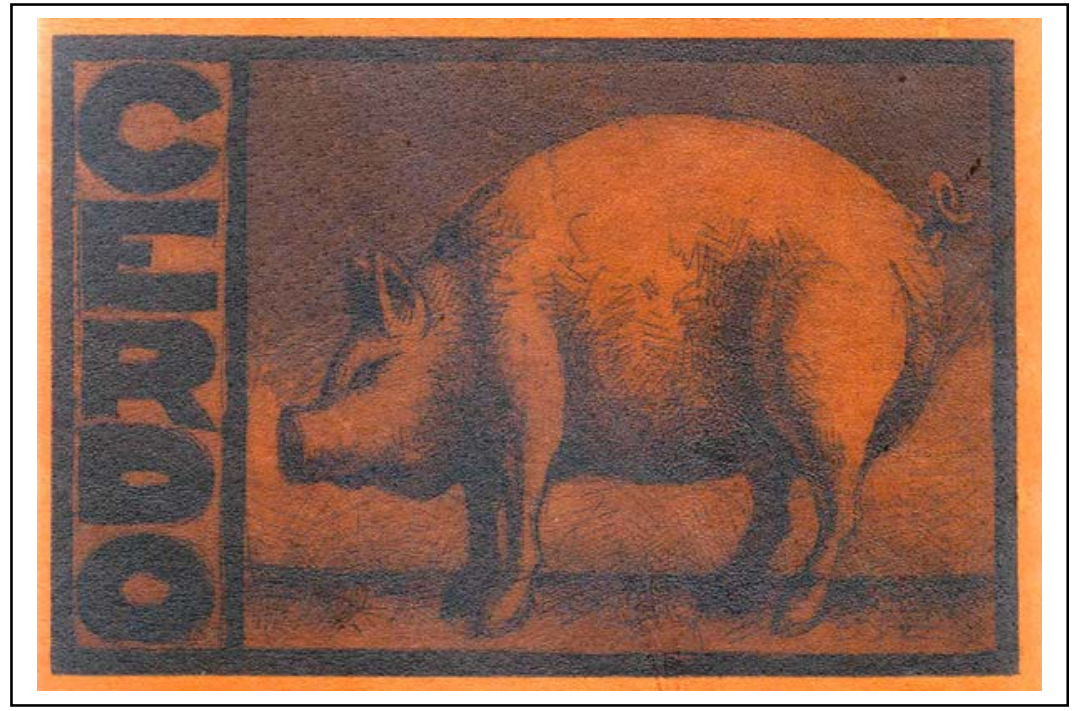

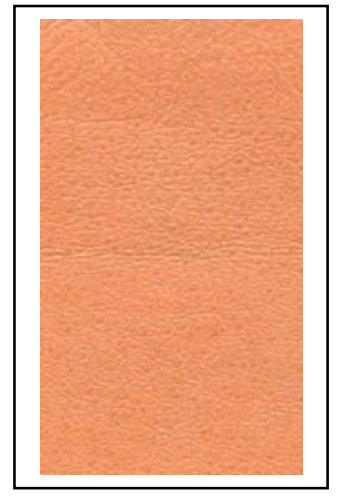

CÓDIGO: CE-027

TIPO DE PIEL: Cerdo

TINTA: Negro

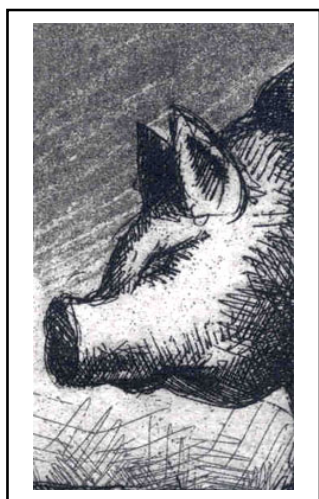

TÉCNICA: Calcografía

TONO DE PIEL: Medio

SUPERFICIE: Lado flor 


\section{CALIDAD: Buena}

Estampa de buen nivel general aunque un poco escasa de contraste y subida de brillo, lo que la convierte en algo difícil de apreciar. El tono del soporte es demasiado oscuro como para conseguir una imagen totalmente satisfactoria.

AGUATINTA: Muy buen resultado tanto los grises como los tonos casi negros. El tono general de ambos se ha oscurecido levemente por efecto del color algo subido del soporte.

AGUAFUERTE: Buena respuesta de ambos tipos de líneas. Las más sutiles registran con normalidad, aunque son algo difíciles de apreciar debido al tono algo oscuro del soporte. Los trazos más gruesos y potentes están estampados perfectamente bien, creando unas zonas oscuras de gran calidez en las partes con gran densidad de grafismos.

CONTRASTE: No muy acentuado debido al tono tan subido y oscuro del fondo. Aun así la imagen general es apreciables sin grandes condicionantes aunque sin llegar a poseer un contraste totalmente válido.

BRILLO: El hecho de emplear preparación traslúcida en la mezcla, así como la gran cantidad de tinte presente en la superficie de la piel, hace que aparezca un ligero brillo que, sin embargo, no llega a resultar excesivamente perjudicial para la correcta visión de la imagen. 

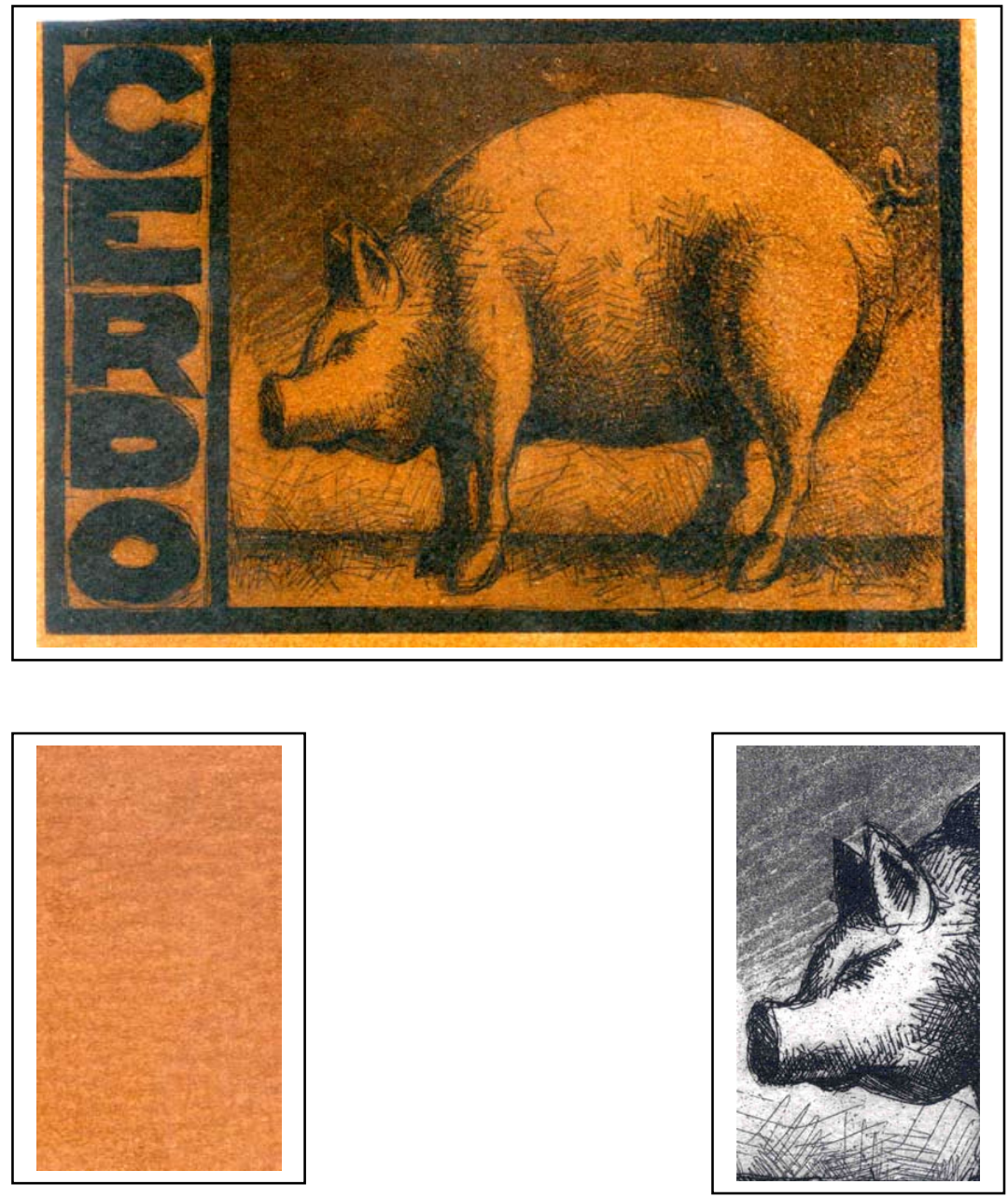

CÓDIGO: CE-028

TÉCNICA: Calcografía

TIPO DE PIEL: Cerdo

TONO DE PIEL: Medio

TINTA: Negro

SUPERFICIE: Lado carne 


\section{CALIDAD: Buena}

Estampa de muy parecidas características a su homóloga del lado flor. Esto es debido a las similares condiciones de la piel de forro porcino en sus dos caras, el lado flor y el lado carne.

AGUATINTA: Debido al mínimo afelpado existente en la piel las características de los tonos cambian levemente. Pierden algo de nitidez y ganan en densidad tonal, sobre todo las más oscuras. Aún así el resultado es bastante satisfactorio.

AGUAFUERTE: El resultado es casi idéntico al observado en el lado flor de esta misma piel (CE-021), con la única variación de que, en zonas con mayor afelpado, las líneas se desvirtúan un tanto y pierden nitidez en sus contornos.

CONTRASTE: Mínimamente mejor que en lado flor debido al ligero oscurecimiento general de la imagen, lo que produce un mejor contraste.

BRILLO: Nulo como es de esperar al estampar sobre una superficie ligeramente afelpada como es la de este lado carne. 

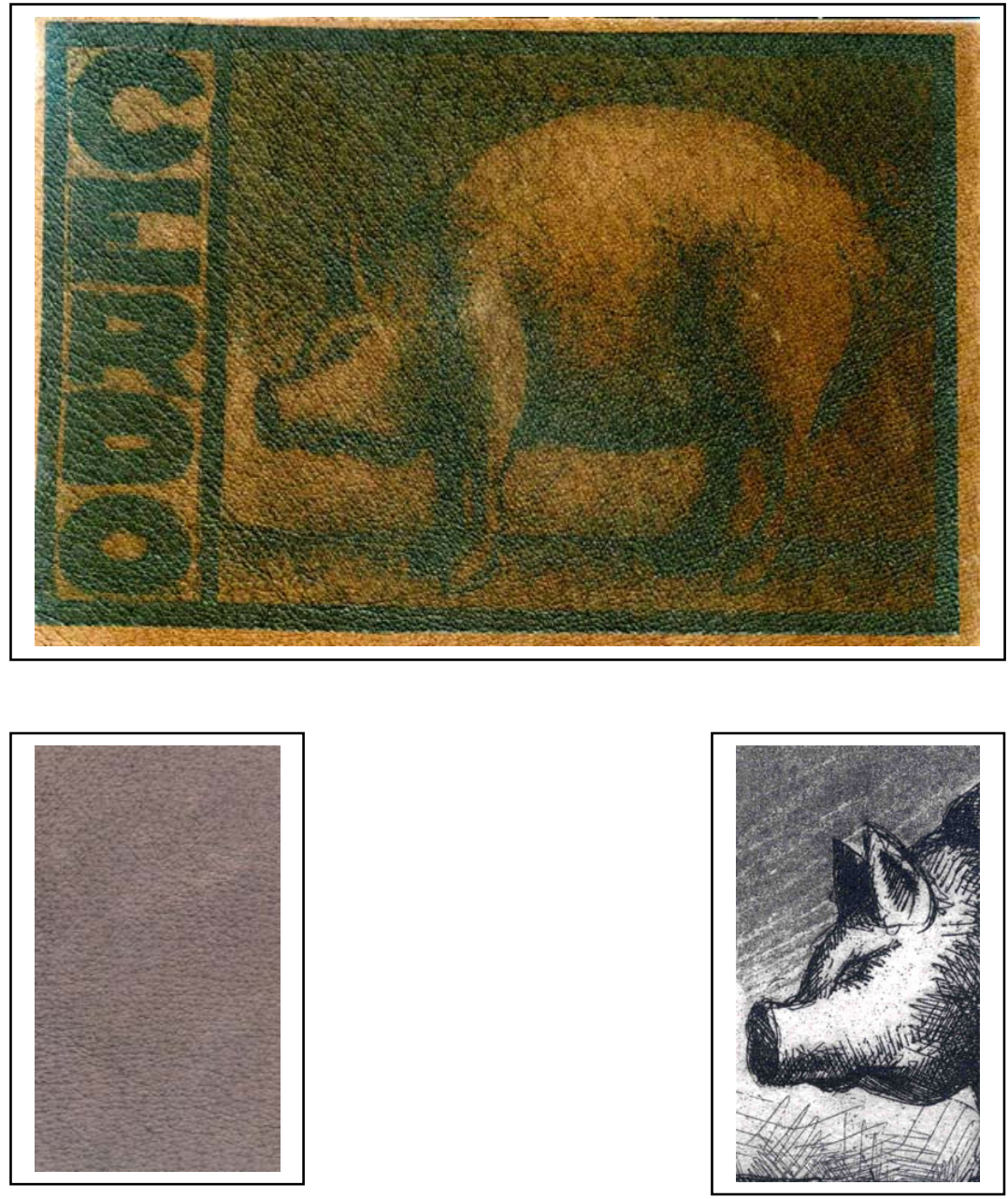

CÓDIGO: CE-029

TÉCNICA: Calcografía

TIPO DE PIEL: Cerdo

TONO DE PIEL: Oscuro

TINTA: Negro

SUPERFICIE: Lado flor 


\section{CALIDAD: Mediocre}

Como suele ocurrir con estampas realizadas sobre soportes muy oscuros la imagen crece casi por completo de contraste, lo que dificulta sobremanera su correcta visión.

AGUATINTA: Difícil de apreciar, parece que ambos tipos de tono registran con bastante nitidez. Sin embargo toda la imagen sufre un patente oscurecimiento en todas las zonas de la misma.

AGUAFUERTE: Muy complicado de apreciar por efecto de la ausencia casi total de contraste. Las líneas débiles se pierden, así como las gruesas aisladas. Tan sólo son reconocibles las manchas y zonas oscuras producidas por la acumulación de grafismos.

CONTRASTE: El gran problema de este ejemplo. Es casi inexistente y condiciona por tanto al resto de los valores de la imagen. A pesar de lo intenso de la tinta negra, el tono tan oscuro de la superficie de la piel impide la aparición del conveniente contraste.

BRILLO: Aparece un ligero brillo debido a la gran cantidad de tinte presente en la piel, lo que la hace más satinada y provoca la aparición de dichos reflejos. 


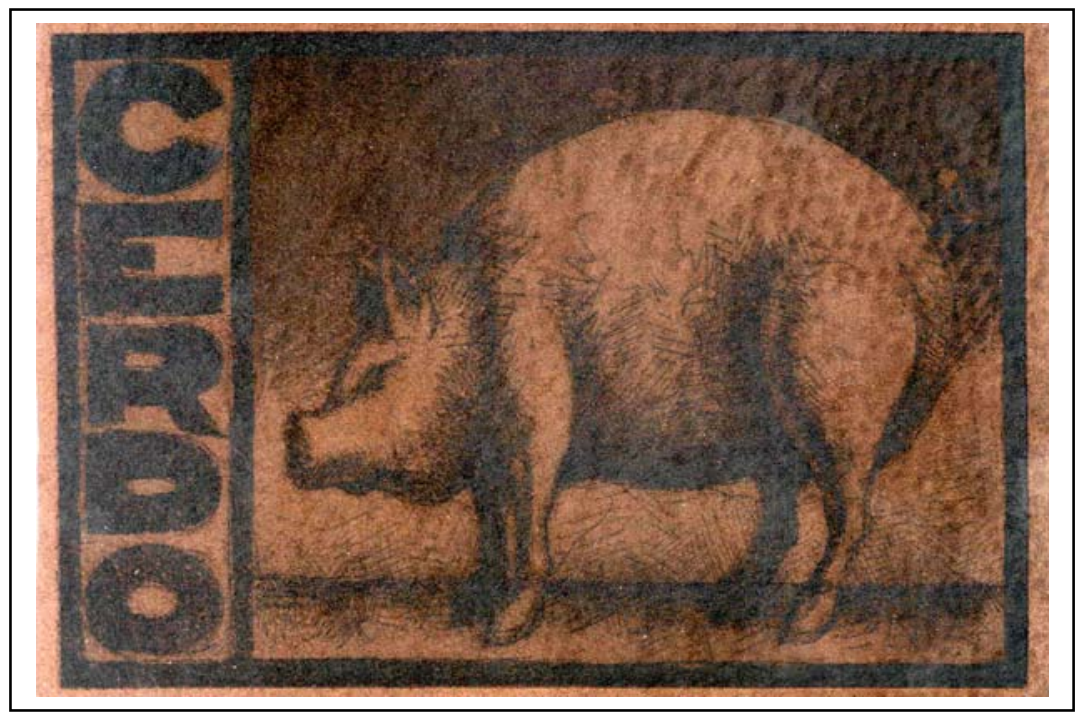

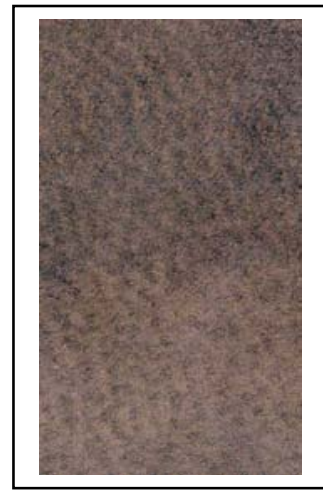

CÓDIGO: CE-030

TIPO DE PIEL: Cerdo

TINTA: Negro

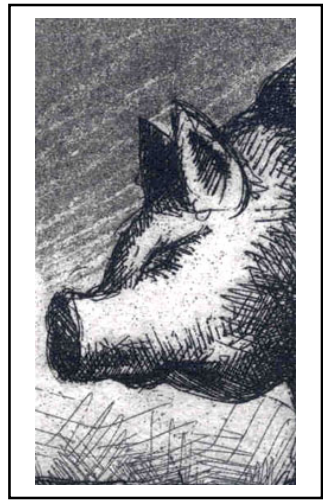

TÉCNICA: Calcografía

TONO DE PIEL: Oscuro

SUPERFICIE: Lado carne 


\section{CALIDAD: Mediocre}

Estampa de muy mediocre resultado, con problemas evidentes en casi todos los apartados estudiados.

AGUATINTA: Mediocre. Muy densa y excesivamente cargada sobre todo en las zonas de un gris claro. Éstas se convierten, al contacto con la superficie afelpada, en zonas de un tono mucho más intenso y prácticamente negras.

AGUAFUERTE: Debido al excesivo afelpado de esta piel y su tono oscuro, las líneas aisladas se pierden y difuminan en el fondo. Tan sólo las zonas más oscuras creadas por densidad de grafismos son apreciables, aunque poseyendo una escasa calidad.

CONTRASTE: Muy deficiente. Impide una cómoda visión de la imagen, a pesar de que toda la estampa ha sufrido un patente oscurecimiento general, tanto en las manchas como en las líneas.

BRILLO: Aparecen brillos irregulares e incontrolables por distintas zonas de la estampa. Éstos son muy molestos y dificultan sobremanera la apreciación de la imagen. 

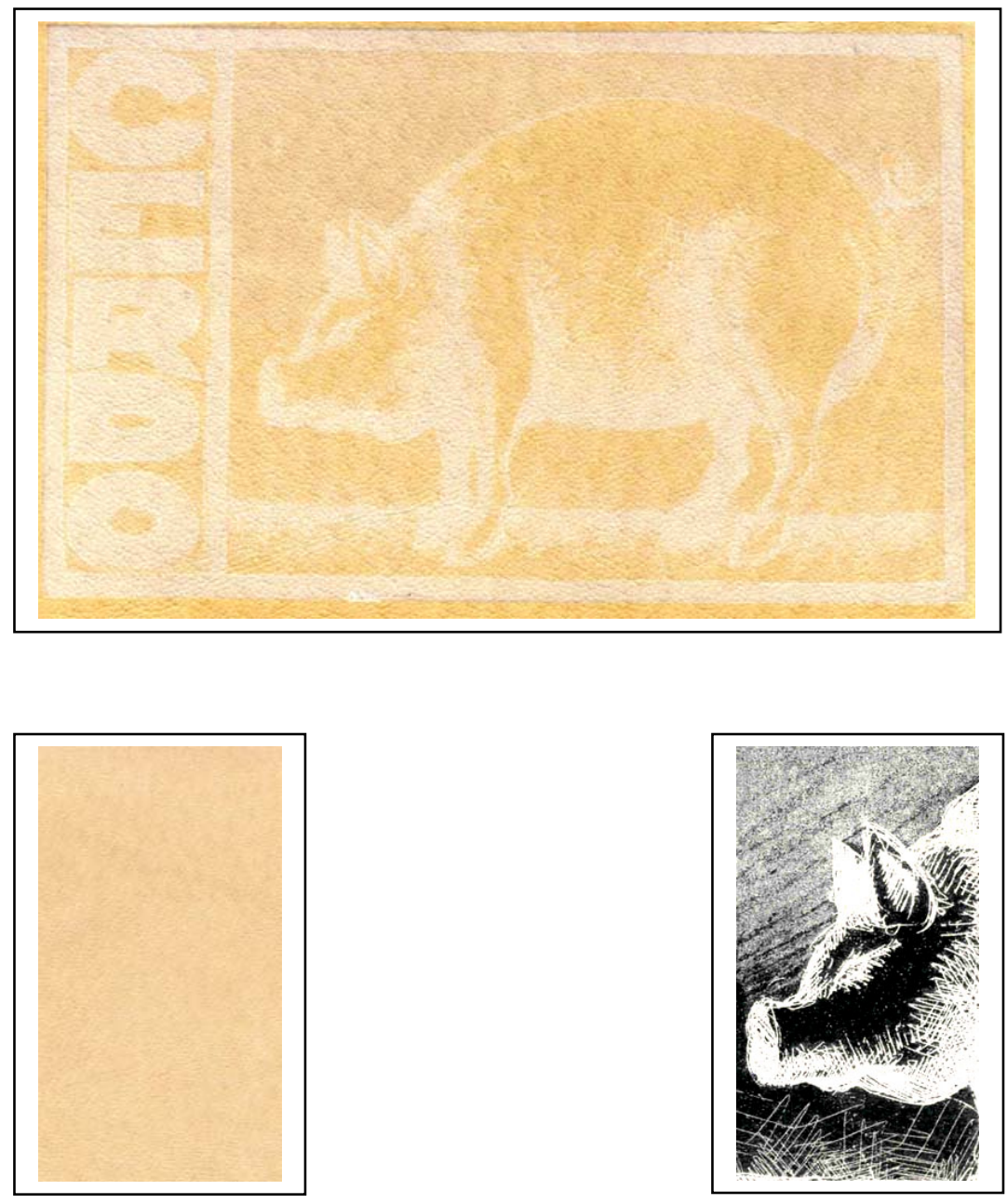

CÓDIGO: CE-031

TÉCNICA: Calcografía

TIPO DE PIEL: Cerdo

TONO DE PIEL: Claro

TINTA: Blanca

SUPERFICIE: Lado flor 


\section{CALIDAD: Muy mala}

Estampa absolutamente inútil desde un punto de vista plástico y estético. Denota claramente la dificultad de usar el blanco para grabados calcográficos sobre piel. Ni uno sólo de los apartados estudiados posee un mínimo de calidad.

AGUATINTA: Desastrosa. Se crea un gris "sucio" en todas las zonas entintadas que resulta horroroso y alejado por completo del blanco verdadero que sería deseable conseguir.

AGUAFUERTE: Inapreciables todas las líneas y grafismos aislados. En las zonas de gran densidad y acumulación de grafismos se aprecia una mancha de gris "sucio" de ínfima calidad plástica.

CONTRASTE: Absolutamente nulo. Impide casi por completo la apreciación de la imagen ya que el tono obtenido se difumina y pierde sobre la superficie de la piel.

BRILLO: Inexistente debido al uso de tinta blanca, de naturaleza mate. 

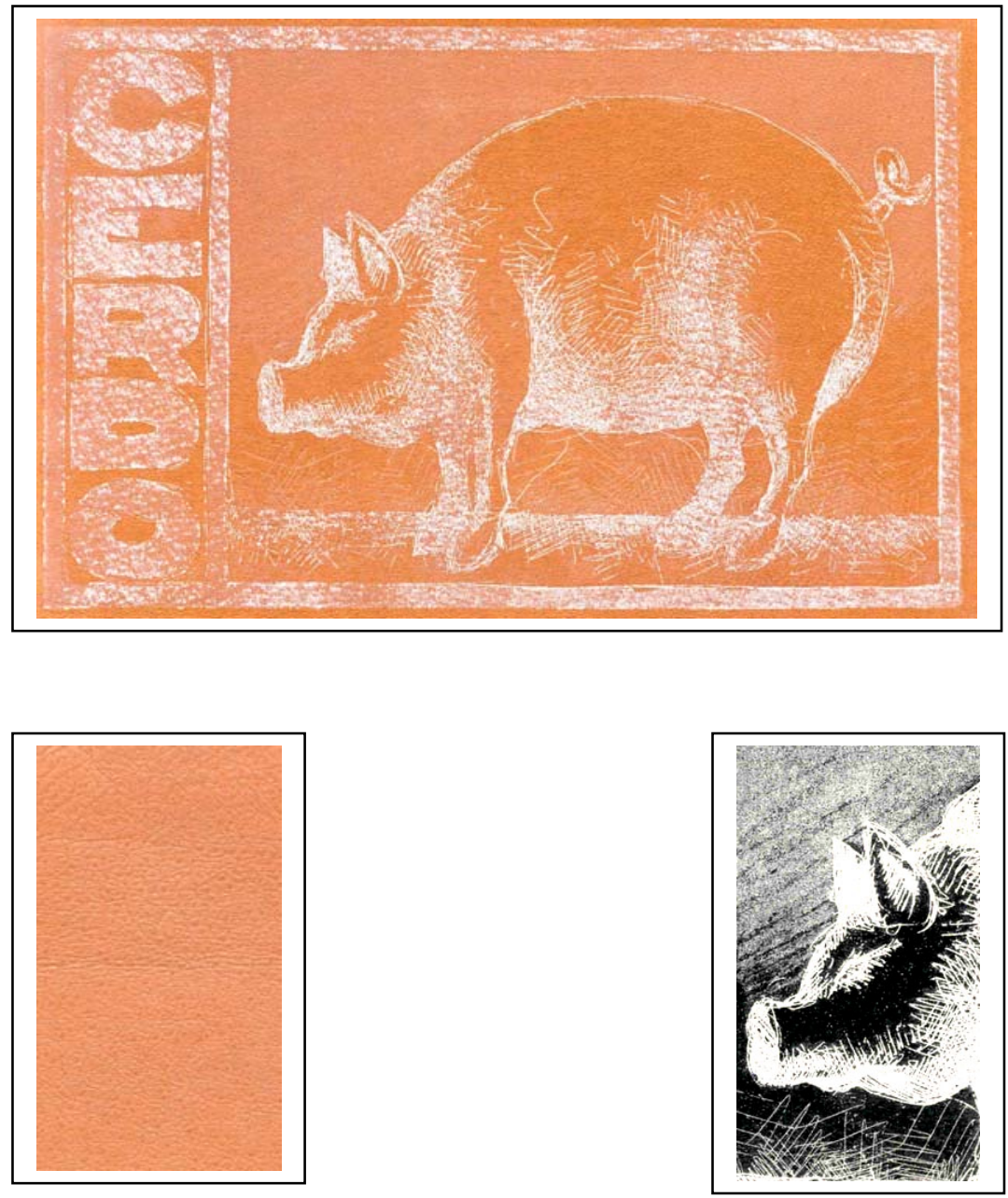

CÓDIGO: CE-032

TÉCNICA: Calcografía

TIPO DE PIEL: Cerdo

TONO DE PIEL: Medio

TINTA: Blanca

SUPERFICIE: Lado flor 


\section{CALIDAD: Mala}

Resultado mucho mejor que sobre la piel clara (CE-024), pero todavía muy inapropiado e insatisfactorio como estampa válida.

AGUATINTA: Muy irregular. En las zonas más claras ha desaparecido por completo, mientras que en las más intensas registra de manera extraña. En efecto, hay zonas donde la piel recoge una aceptable cantidad de tinta, pero en otras la misma desaparece de la estampa. En definitiva posee una calidad mediocre.

AGUAFUERTE: Resultado algo mejor aunque todavía inapropiado; las líneas sutiles son muy difíciles de apreciar, mientras que los grafismos aislados más potentes son los que mejor resultado dan. En las zonas de gran densidad lineal, y por tanto de tinta, aparece de nuevo el conocido problema de "grumosidad" de la tinta blanca, creándose una textura muy desagradable.

CONTRASTE: Algo más potente y mejor. La imagen es ya reconocible a pesar de los vacíos y las ausencias de tinta en algunas zonas concretas.

BRILLO: La tinta blanca elimina el mínimo brillo que pudiera existir sobre la superficie de la piel. 

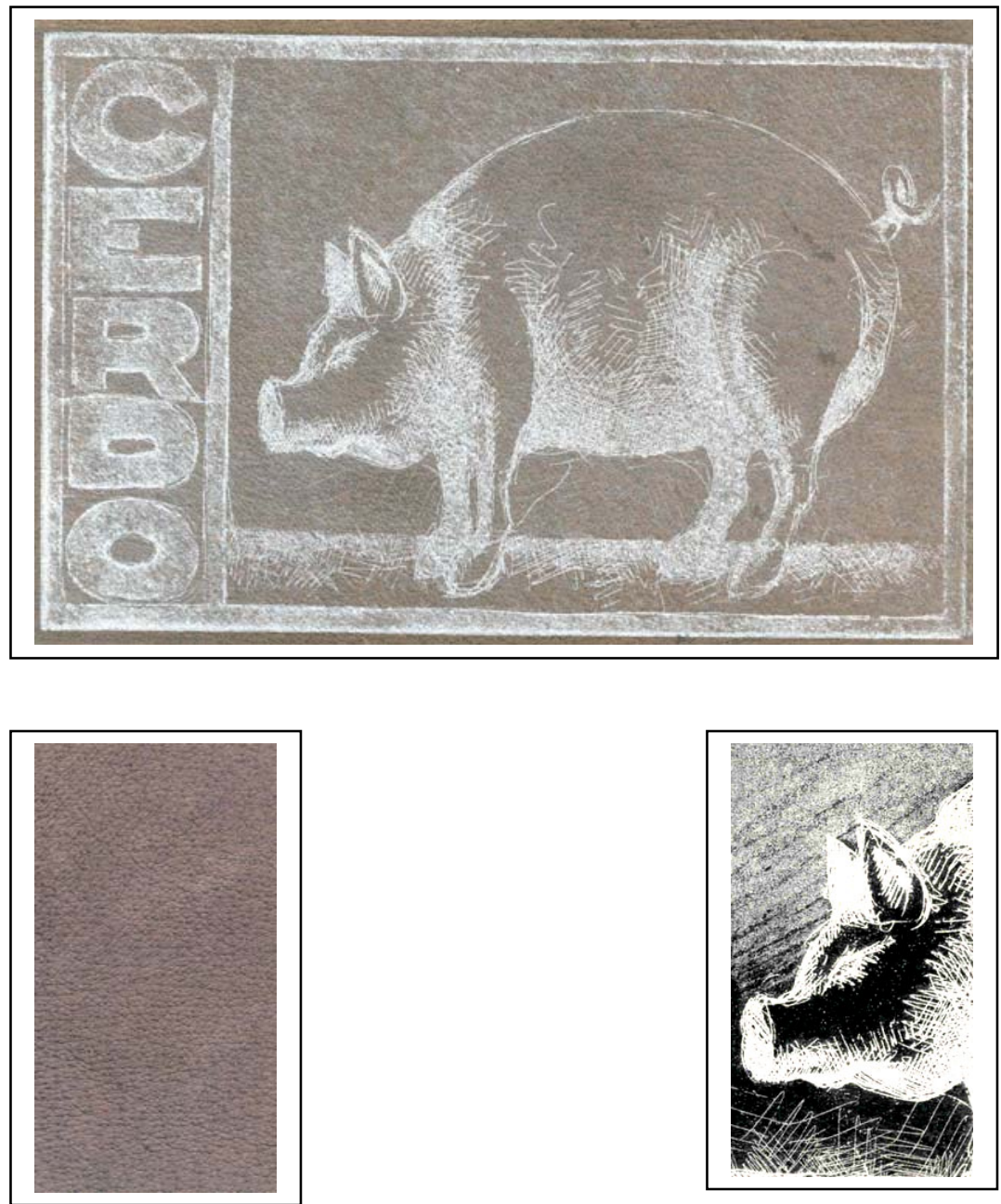

CÓDIGO: CE-033

TÉCNICA: Calcografía

TIPO DE PIEL: Cerdo

TONO DE PIEL: Oscuro

TINTA: Blanca

SUPERFICIE: Lado flor 


\section{CALIDAD: Mala}

Indicar que para esta imagen se ha aplicado una cantidad de preparación transparente a la tinta empleada, en una proporción 1:1. Esto hace que la tinta sea más fluida y estampe mejor, pero por otro lado debilita la intensidad del blanco. Por tanto sólo es aconsejable su uso sobre soportes muy oscuros como este.

AGUATINTA: Las zonas más débiles continúan sin recoger tinta, mientras que en las más densas vuelve a aparecer el problema de la piel media, aunque atenuado por el empleo de preparación traslúcida.

AGUAFUERTE: En las zonas de líneas sutiles todavía no se registra con normalidad, pero en los grafismos más potentes el resultado es casi perfecto. En efecto, las líneas aisladas registran casi con normalidad y en las zonas de gran densidad de grafismo el efecto "a grumos" se ha reducido visiblemente.

CONTRASTE: Mucho más intenso y correcto que en ejemplos anteriores. A pesar del empleo de preparación traslúcida en la tinta el blanco resultante consigue contrastar de manera aceptable con el tono oscuro del soporte piel.

BRILLO: A pesar de la presencia de base transparente en la mezcla, el brillo es totalmente inexistente por efecto de la tinta blanca de naturaleza mate. 

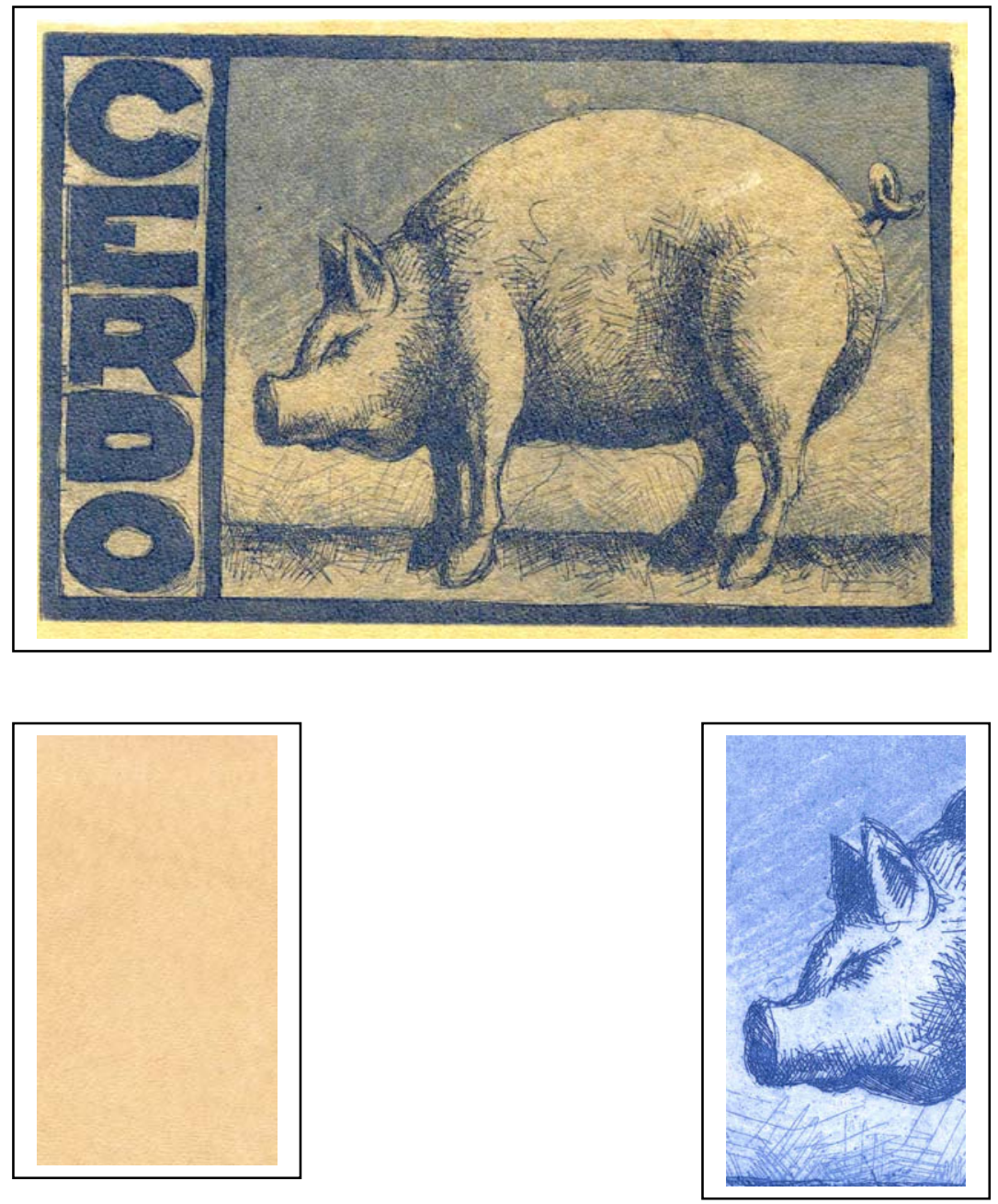

CÓDIGO: CE-034

TÉCNICA: Calcografía

TIPO DE PIEL: Cerdo

TONO DE PIEL: Claro

TINTA: Azul traslúcido

SUPERFICIE: Lado flor 


\section{CALIDAD: Muy buena}

Ejemplo de gran calidad y muy buenos resultados generales. El "forro" de cerdo se muestra de nuevo como una superficie ideal para casi todo tipo de estampas y en particular para aquellas realizadas con tintas de gran transparencia.

AGUATINTA: De gran calidad. Ambos tonos registran con gran fidelidad las intensidades de la matriz sin sufrir apenas variaciones en sus características. Los tonos más claros están estampados de una manera perfecta, como no lo habían hecho en ningún otro ejemplo anterior.

AGUAFUERTE: Perfecto. Todas y cada una de las líneas están registradas con absoluta nitidez, tanto las sutiles como las potentes. En las zonas de gran acumulación de grafismos no aparece ningún tipo de irregularidad, estampándose todo con gran precisión.

CONTRASTE: Como ya se ha comentado en numerosas ocasiones la tinta azul transparente sufre un proceso de oscurecimiento muy patente, lo que provoca un cambio en sus características. Así se convierte en un azul más intenso que contrata sin mayores problemas con el tono del fondo.

BRILLO: Podemos apreciar un ligerísimo brillo ceroso en las áreas entintadas, por efecto de la gran cantidad de preparación traslúcida en la mezcla (alrededor de un 95\%). Sin embargo no resulta perjudicial para la visión de la imagen. 


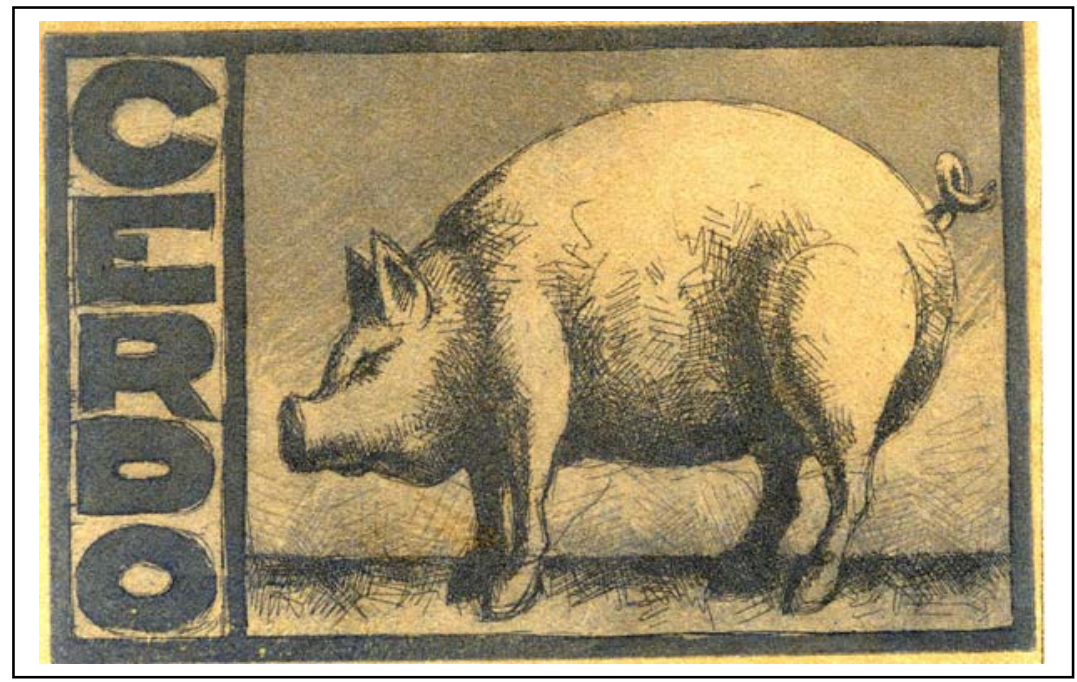

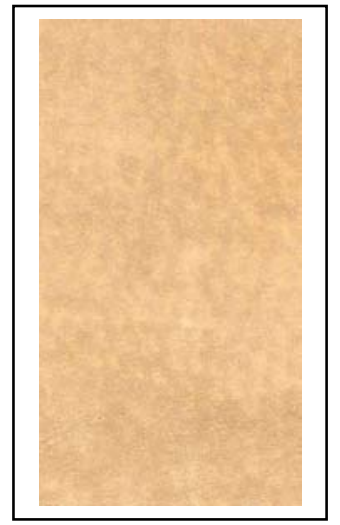

CÓDIGO: CE-035

TIPO DE PIEL: Cerdo

TINTA: Azul traslúcido

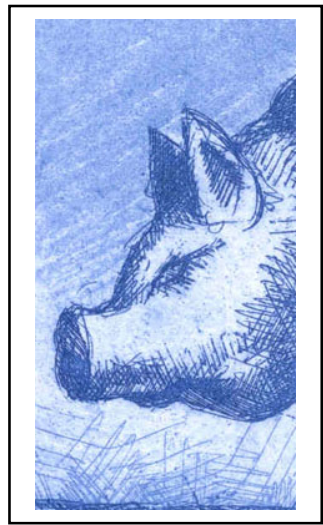

TÉCNICA: Calcografía

TONO DE PIEL: Claro

SUPERFICIE: Lado carne 


\section{CALIDAD: Muy buena}

Imagen de muy buen resultado y parecidas características a su homóloga en lado flor, sufriendo mínimas variaciones que pasaremos a comentar a continuación.

AGUATINTA: Casi perfecta y muy fiel a los tonos originales de la imagen. Notar un ligero oscurecimiento por efecto del afelpado del soporte en este lado carne. Sin embargo este oscurecimiento no afecta demasiado a las relaciones tonales entre los azules más sutiles y aquellos más densos y oscuros.

AGUAFUERTE: También rozando la perfección. El resultado es muy similar al del lado flor (CE-028), con la única salvedad de que, si el afelpado es muy rugoso y patente, los trazos pudieran desvirtuarse ligeramente aunque sin perder gran nitidez.

CONTRASTE: Intenso y apropiado para crear una imagen válida. El oscurecimiento de la tinta al contacto con el lado carne y su típico afelpado ayuda a la aparición de dicho contraste.

BRILLO: Inexistente y nulo debido a que el afelpado del soporte "absorbe" todos los posibles brillos que pudieran crearse en la superficie entintada. 

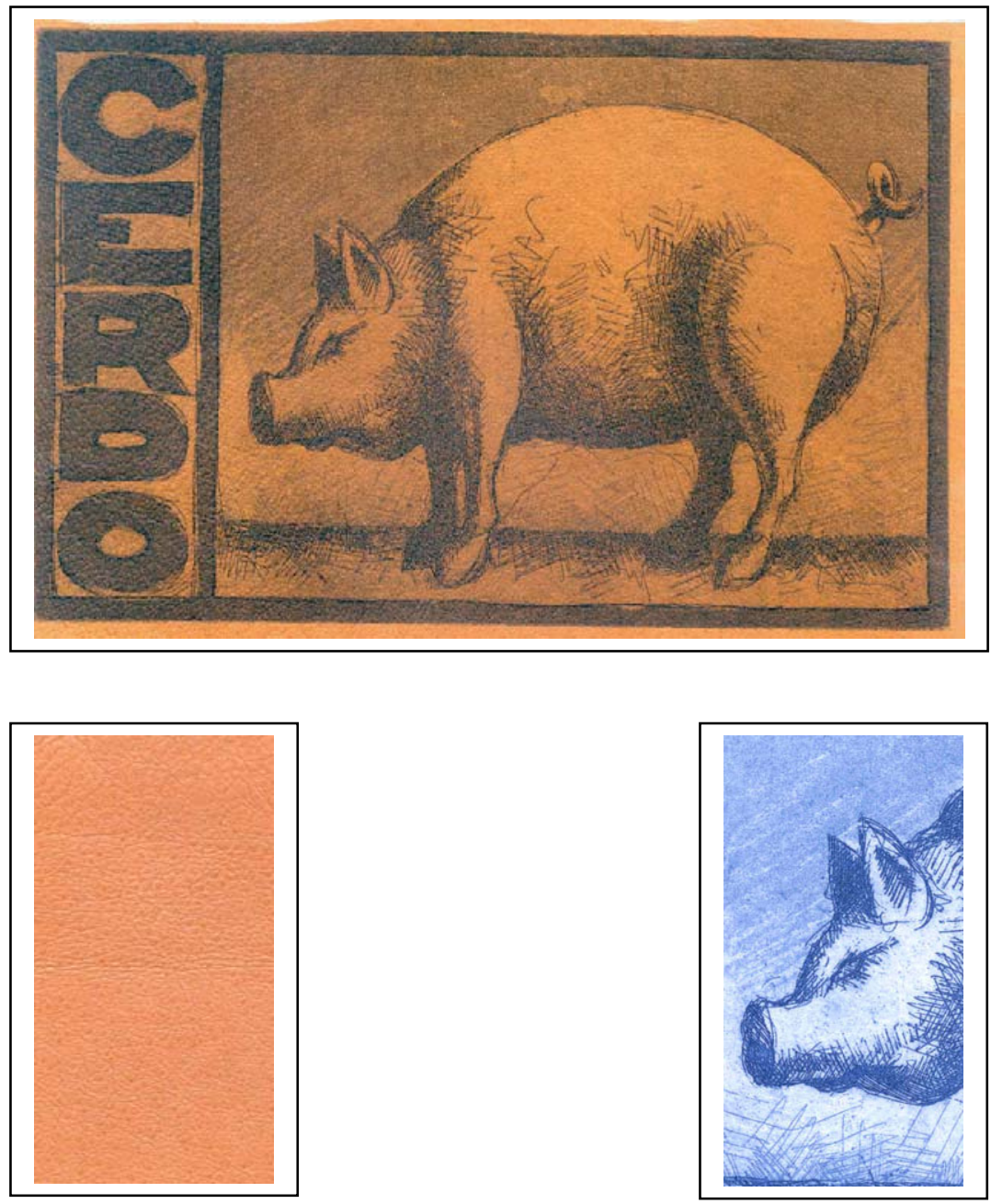

CÓDIGO: CE-036

TÉCNICA: Calcografía

TIPO DE PIEL: Cerdo

TONO DE PIEL: Medio

TINTA: Azul traslúcido

SUPERFICIE: Lado flor 


\section{CALIDAD: Buena}

Ejemplo de buena calidad a pesar de que la naturaleza de la tinta provoca sustanciales cambios en sus características cromáticas y tonales. Pese a todo es perfectamente válida como imagen impresa.

AGUATINTA: Ambos tonos registran con bastante nitidez $\mathrm{e}$ intensidad, sobre todo el más oscuro de los dos. El tono más débil pierde algo de fuerza y se hace más difícil de apreciar, aunque sin llegar a perder demasiada calidad.

AGUAFUERTE: Perfecto. Todas las líneas están registradas sin mayores problemas ni inconvenientes, con una perfecta nitidez y una correcta intensidad. No aparecen problemas ni en los trazos aislados ni en aquellas zonas de acumulación de grafismos.

CONTRASTE: Correcto. La tinta azul transparente se ha transformado totalmente en un marrón violáceo muy interesante. Es obvio que el tono tan rojizo del soporte ha influido para este cambio tan radical, provocando así la aparición de un contraste bastante intenso y válido.

BRILLO: En las zonas entintadas aparece un leve brillo provocado por la unión de dos factores: el gran porcentaje de preparación traslúcida de la mezcla y la gran cantidad de tinte presente en la superficie de la piel. Sin embargo no llega a ser perjudicial para la correcta apreciación de la imagen. 


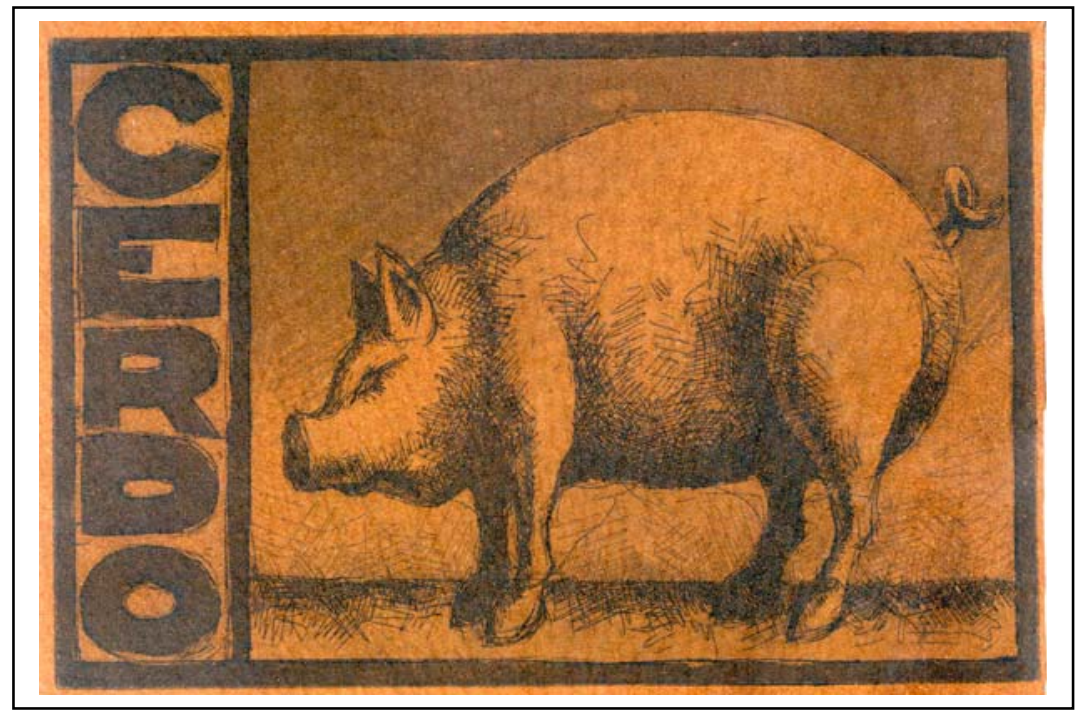

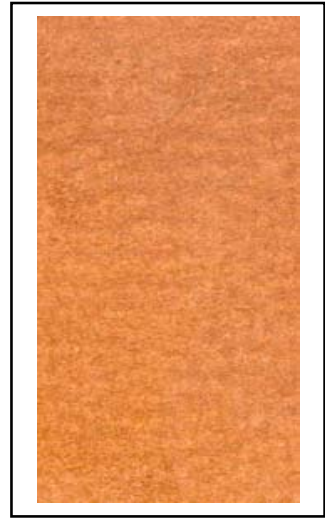

CÓDIGO: CE-037

TIPO DE PIEL: Cerdo

TINTA: Azul traslúcido

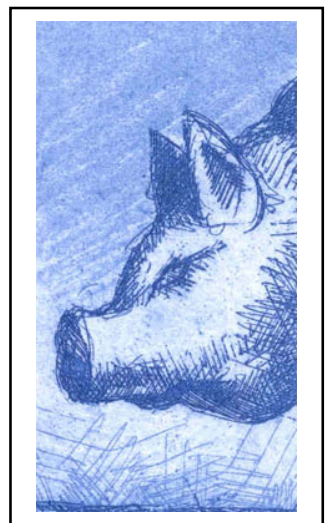

TÉCNICA: Calcografía

TONO DE PIEL: Medio

SUPERFICIE: Lado carne 


\section{CALIDAD: Buena}

De muy parecidas características a la estampa sobre el lado flor (CE-030) aunque en este caso puede que incluso de mejor calidad que aquella. La ausencia de brillo y un contraste más intenso provocan esta mejoría con respecto al ejemplo anterior.

AGUATINTA: Muy correctos ambos tonos. El área más oscura alcanza una intensidad y saturación muy satisfactorias, mientras que las zonas débiles mantienen un aceptable nivel de calidad.

AGUAFUERTE: Perfecto, tanto las líneas débiles como las potentes se registran de manera muy correcta.

CONTRASTE: El oscurecimiento de la tinta azul es todavía más patente en este caso, por lo que el contraste con el soporte será todavía más intenso. Se crea por tanto una imagen muy válida, correcta y perfectamente legible.

BRILLO: Nulo e inexistente. Como es obvio al estampar sobre una superficie afelpada como la que nos ocupa los brillos no existen, ni siquiera al usar una tinta con gran cantidad de preparación traslúcida como la empleada en este caso concreto. 


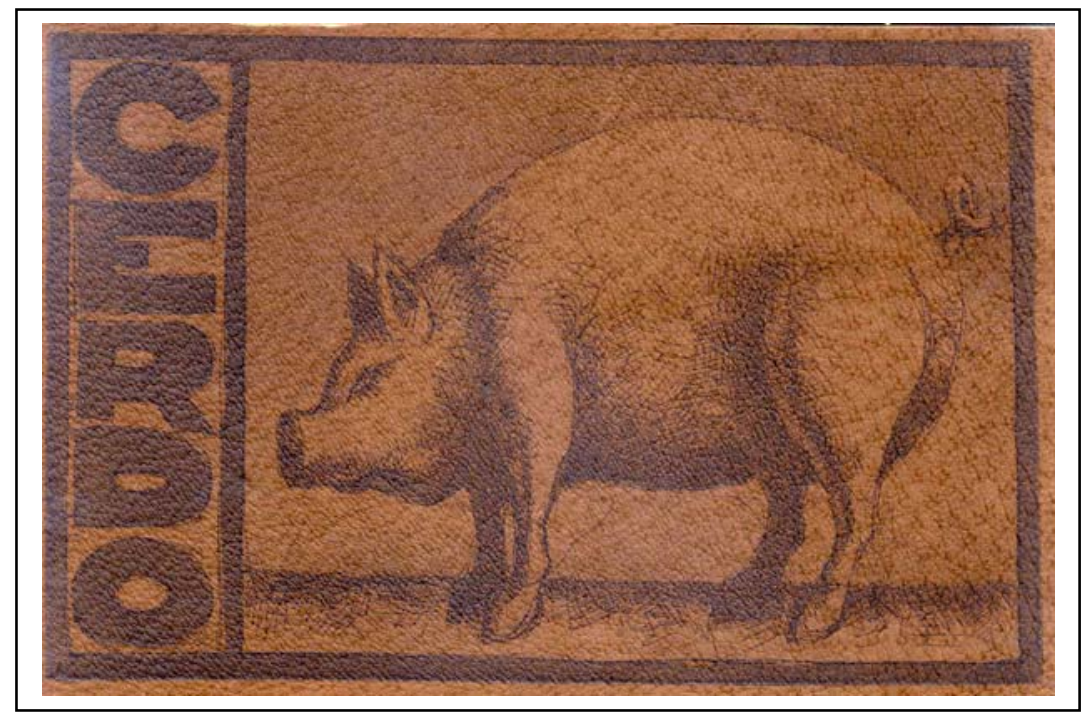

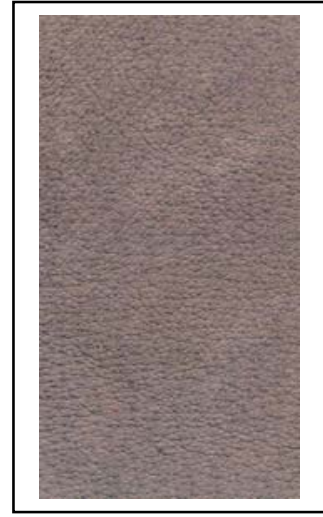

CÓDIGO: CE-038

TIPO DE PIEL: Cerdo

TINTA: Azul traslúcido

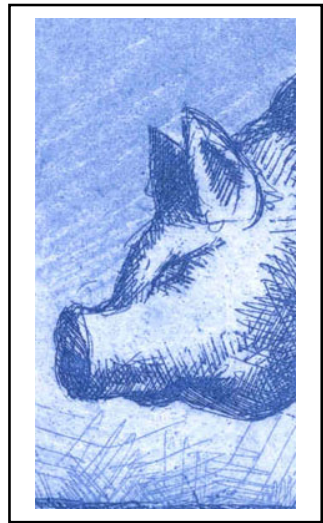

TÉCNICA: Calcografía

TONO DE PIEL: Oscuro

SUPERFICIE: Lado flor 


\section{CALIDAD: Buena}

Si no fuera por el escaso contraste estaríamos frente a una estampa de altísima calidad. Sin embargo lo oscuro del soporte condiciona la visión de la imagen e impide una correcta apreciación de la estampa.

AGUATINTA: El tono más débil y sutil se pierde totalmente debido a lo oscuro de la superficie de la piel. Sin embargo el más oscuro es todavía perfectamente visible y posee una aceptable intensidad.

AGUAFUERTE: Ocurre algo parecido a lo observado en el aguatinta. Los trazos sutiles se pierden casi por completo mientras que aquellos más potentes son visibles sin ningún tipo de problema. Las zonas más densas en cuanto a grafismos se refiere conservan un buen nivel de registro y visibilidad.

CONTRASTE: Muy escaso aunque todavía permite la apreciación y diferenciación de las formas básicas de la imagen. Gracias a que la tinta se ha oscurecido de una manera muy ostensible se hace posible la aparición de ese escaso contraste.

BRILLO: Un ligero brillo es visible en las zonas entintadas de la estampa aunque no llega nunca a disturbar la visión de la imagen. 


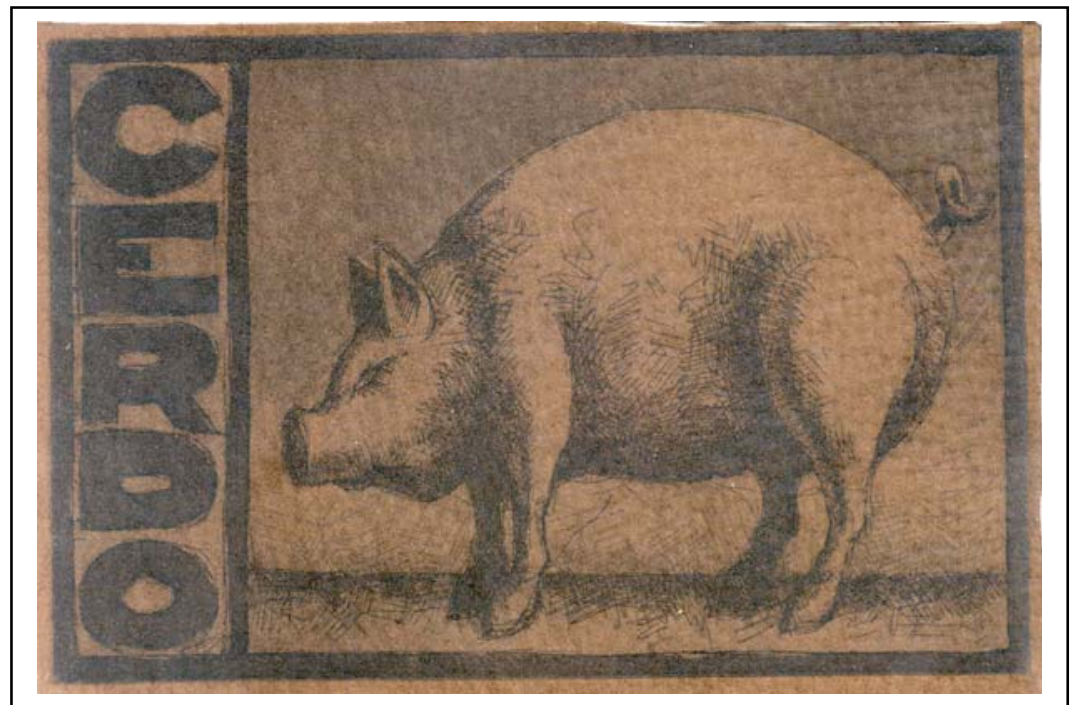

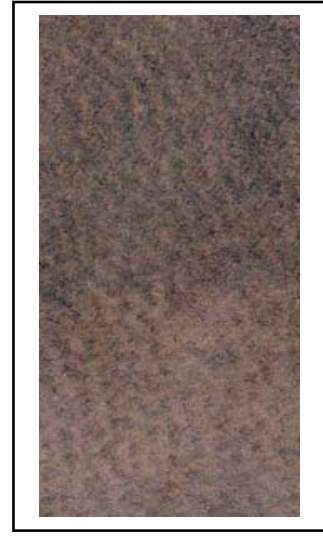

CÓDIGO: CE-039

TIPO DE PIEL: Cerdo

TINTA: Azul traslúcido

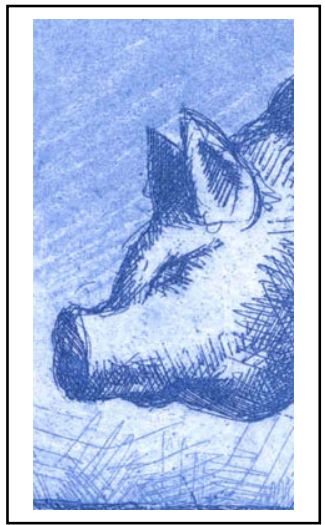

TÉCNICA: Calcografía

TONO DE PIEL: Oscuro

SUPERFICIE: Lado carne 


\section{CALIDAD: Mediocre}

Ejemplo muy parecido al anterior sobre el lado flor (CE-032) aunque, como ocurriera con la piel de tono medio, éste se muestra como de mejor calidad que el anterior.

AGUATINTA: De buenos resultados generales. Las zonas más claras y sutiles se hacen difíciles de percibir por lo oscuro del fondo, aunque son ligeramente más patentes que sobre el lado flor. Por el contrario las áreas más intensas están registradas sin ningún tipo de problemas ni inconvenientes.

AGUAFUERTE: Al igual que en el aguatinta los trazos más potentes y gruesos son más fáciles de identificar que aquellos más débiles y sutiles. A pesar de ello el resultado general es más que aceptable y de buen nivel.

CONTRASTE: Todavía escaso, se muestra como el principal problemas de esta estampa. Es sin embargo algo mejor que el registrado sobre el lado flor, ya que el oscurecimiento de la tinta azul transparente es mucho más acusado en esta superficie afelpada. Por tanto el contraste con el soporte piel es algo más intenso.

BRILLO: Prácticamente nulo e inexistente debido al afelpado de la piel. 


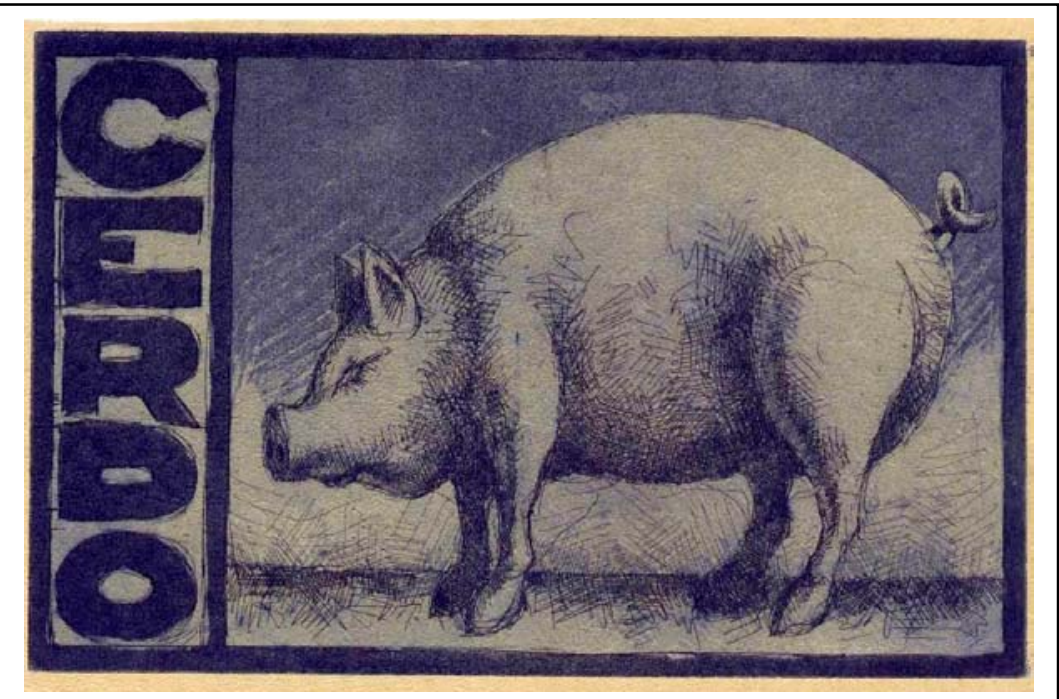

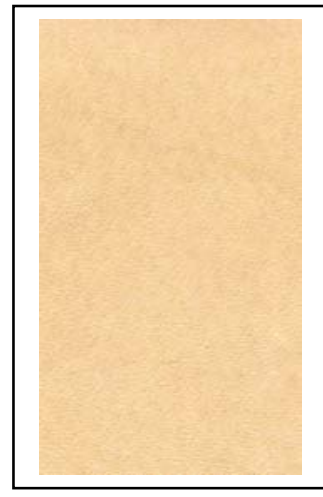

CÓDIGO: CE-040

TIPO DE PIEL: Cerdo

TINTA: Azul opaco

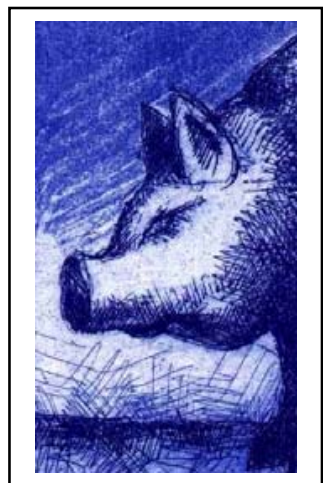

TÉCNICA: Calcografía

TONO DE PIEL: Claro

SUPERFICIE: Lado flor 


\section{CALIDAD: Buena}

Ejemplo de apreciable calidad, aunque debemos indicar que para conseguir una estampación nítida se recomienda limpiar la plancha de manera que el entrapado sea lo más mínimo posible. Este entrapado, que en el papel puede ser satisfactorio, en la piel provocará la aparición de una imagen excesivamente sucia y oscura. Los problemas de secado continúan aunque de manera más reducida.

AGUATINTA: Perfecta, regular y homogénea. Las diferencias tonales entre los dos azules se perciben perfectamente, consiguiendo unas zonas de aguatinta de gran calidad.

AGUAFUERTE: Buena calidad en el registro de los grafismos, tanto los más sutiles como los más potentes, estando ambos tipos de seños estampados con gran nitidez.

CONTRASTE: Correcto, permitiendo una imagen legible. Sin embargo si se desea un mayor contraste se deben limpiar a conciencia las zonas libres de grafismos de la plancha matriz. Si no lo hacemos así, toda la superficie quedará ensuciada por una pátina de tinta que disminuirá el contraste.

BRILLO: Ligero brillo ceroso en las zonas de mayor acumulación de tinta, el cual no interfiere en la correcta visión de la estampa. 


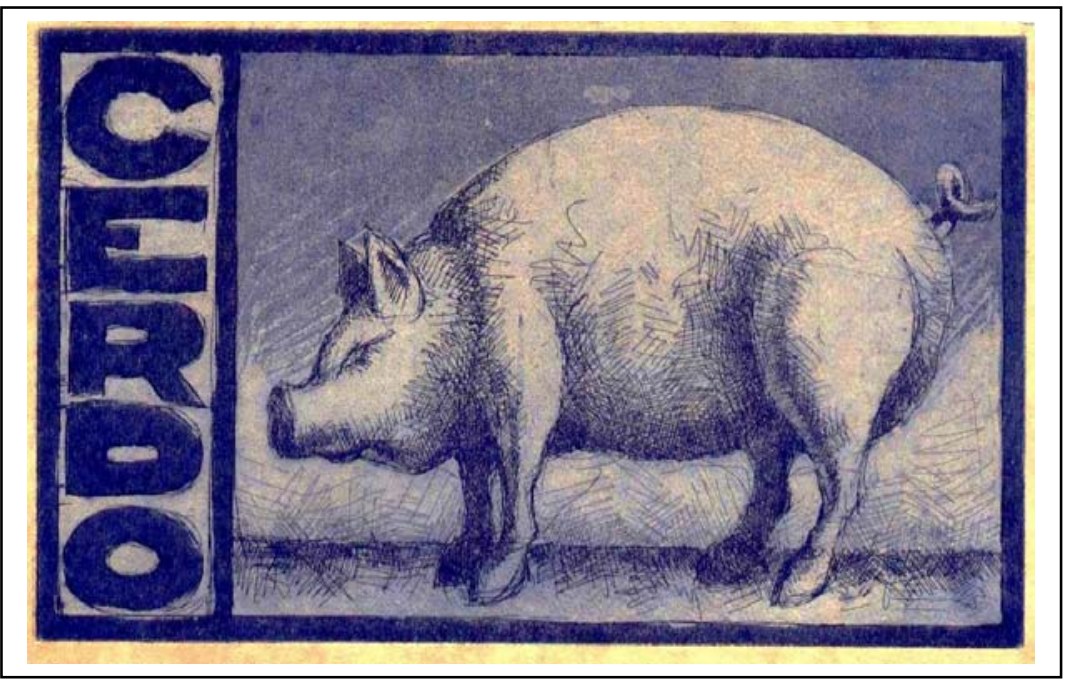

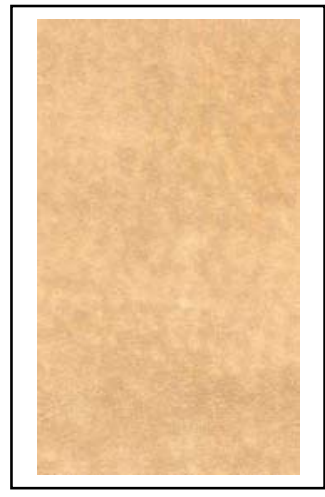

CÓDIGO: CE-041

TIPO DE PIEL: Cerdo

TINTA: Azul opaco

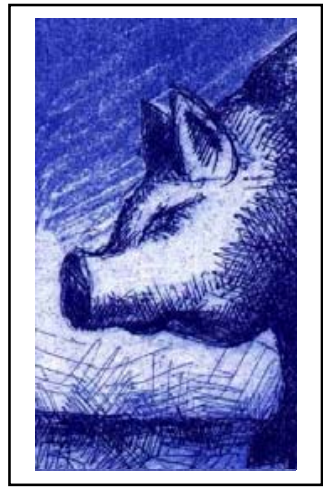

TÉCNICA: Calcografía

TONO DE PIEL: Claro

SUPERFICIE: Lado carne 


\section{CALIDAD: Muy buena}

Estampa de excelente nivel desde donde todos los problemas de secado desaparecen por completo, así como los ligeros brillos que pueden aparecer sobre el lado flor de los cueros porcinos. Todos los campos analizados presentan un resultado de gran nivel.

AGUATINTA: Perfecta al igual que en el lado flor. Si la superficie del soporte piel no presenta irregularidades de afelpado, los tonos del aguatinta se estampan muy satisfactoriamente, conservando las diferencias tonales que presenta el seño de la plancha matriz.

AGUAFUERTE: Al igual que el aguatinta, el aguafuerte ofrece un resultado perfecto, con un registro ideal de ambos tipos de grafismos. ligero afelpado del lado carne de los cueros porcinos no afecta de manera evidente al registro de las líneas del aguafuerte.

CONTRASTE: Intenso y correcto, a lo que ayuda el ligero oscurecimiento que sufre la tinta azul, lo que permite la aparición de dicho grado de contraste. Para intensificar este nivel de contraste se hace necesaria, como ya se ha comentado anteriormente, una limpieza exhaustiva de la superficie de la plancha.

BRILLO: Absolutamente nulo el estampar sobre un soporte afelpado como éste del lado carne del cuero porcino. 

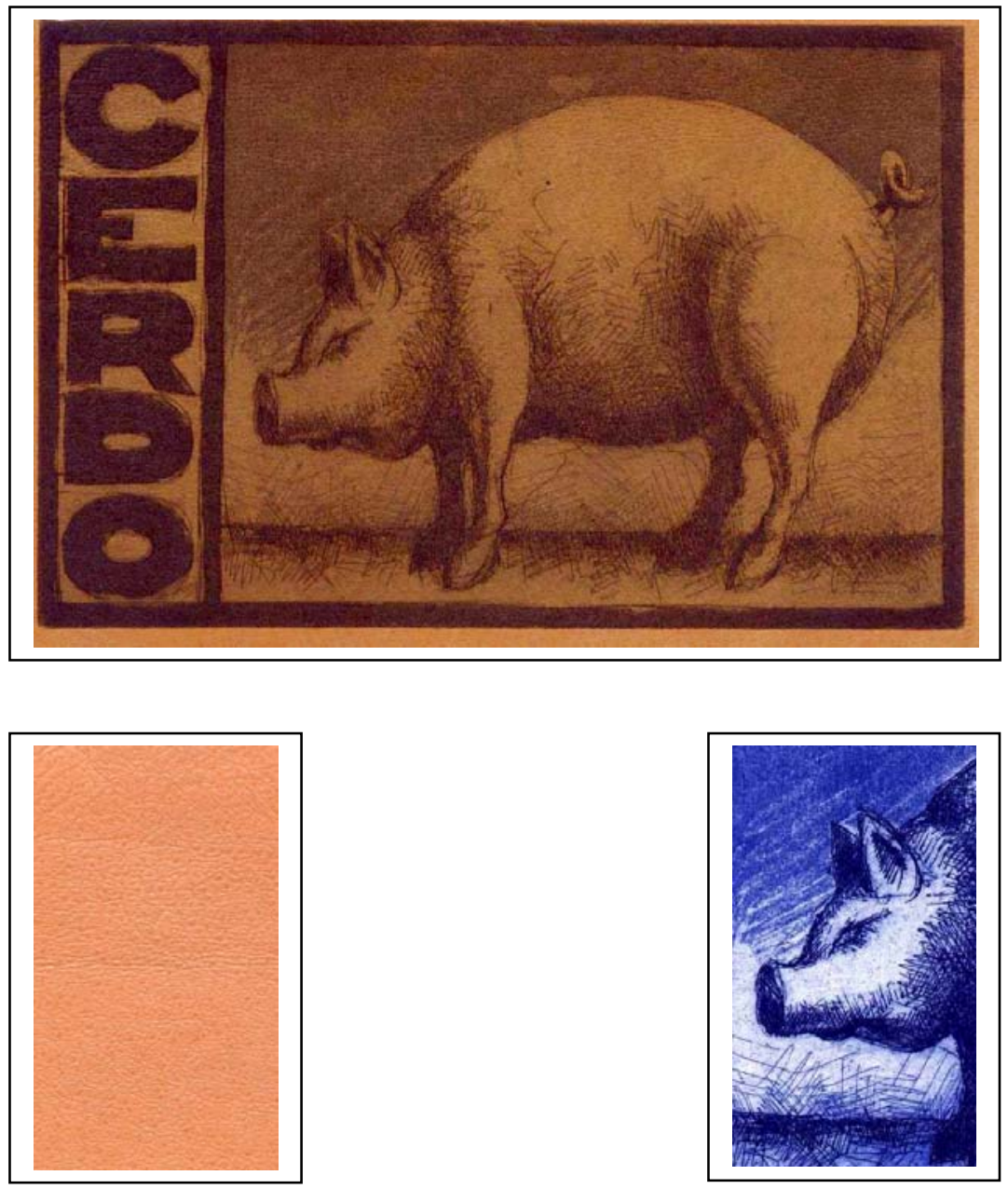

CÓDIGO: CE-042

TÉCNICA: Calcografía

TIPO DE PIEL: Cerdo

TONO DE PIEL: Medio

TINTA: Azul opaco

SUPERFICIE: Lado flor 


\section{CALIDAD: Buena}

Ejemplo de muy aceptable nivel, con gran respuesta a la impresión y buen contraste, creándose una imagen de resultados satisfactorios. Los problemas de secado y asentamiento de la tinta aparecen, pero en un grado tan mínimo que no afecta a la apariencia de la estampa.

AGUATINTA: De muy buen resultado, con un registro casi perfecto de ambos tonos de azul, los cuales mantienen sus diferencias y no desvirtúan su naturaleza.

AGUAFUERTE: Perfecto. Ambos tipos de línea (las sutiles y las más potentes) conservan su nitidez y se registran sin ningún tipo de inconvenientes o problemas.

CONTRASTE: Aceptable, aunque lógicamente no tan intenso y potente como en otros ejemplos sobre cueros más claros. La tinta azul sufre un oscurecimiento patente, así como un cambio de tonalidad, convirtiéndose, mediante una mezcla por transparencia, en un color violáceo oscuro de características muy interesantes.

BRILLO: Aparece un ligero brillo ceroso que no llega a resultar excesivamente molesto para la correcta apreciación de la estampa. 


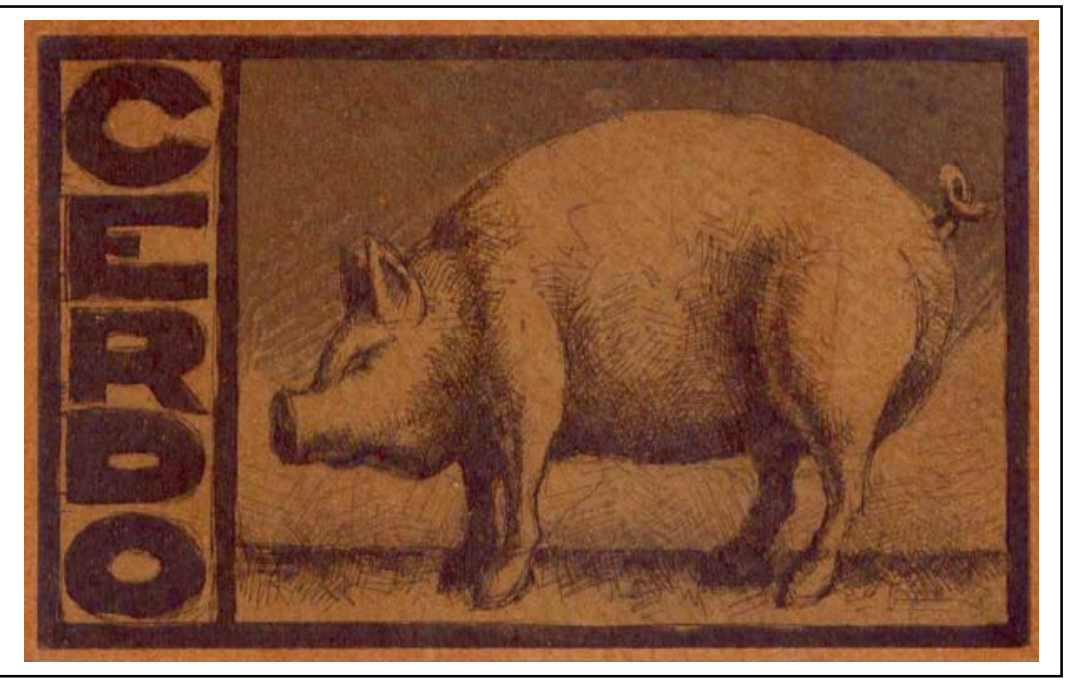

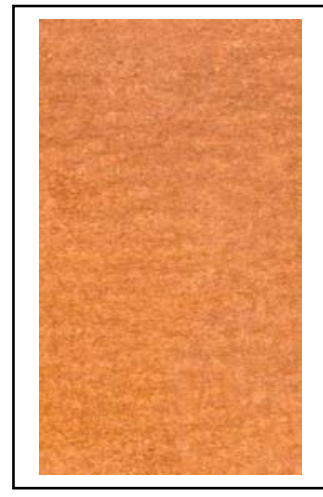

CÓDIGO: CE-043

TIPO DE PIEL: Cerdo

TINTA: Azul opaco

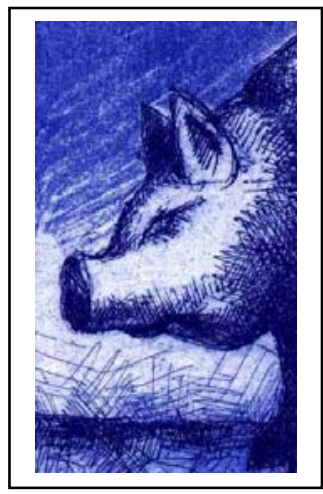

TÉCNICA: Calcografía

TONO DE PIEL: Medio

SUPERFICIE: Lado carne 


\section{CALIDAD: Buena}

Vemos aceptables resultados en esta estampa, obteniéndose un ejemplo interesante desde numerosos puntos de vista, aunque con mínimos inconvenientes relacionados con el acabado afelpado del soporte piel. Los problemas de secado son inapreciables y no afectan en absoluto al resultado de la estampa.

AGUATINTA: Muy correcta, manteniéndose la diferencia tonal entre ambos tipos de azul. Sin embargo en zonas con un afelpado algo más rugoso la tinta no es capaz de cubrir el pelo del cuero, por lo que aparecen ligeras irregularidades, las cuales no afectan sin embargo al nivel general de la estampa.

AGUAFUERTE: Perfecto, no afectando en absoluto el afelpado del lado carne para un correcto registro de los dos tipos de líneas presentes en la imagen.

CONTRASTE: Lo suficientemente intenso como para crear una imagen atractiva e interesante, a lo que ayuda el oscurecimiento de la tinta hasta alcanzar un tono azul violáceo oscuro. Siempre que la limpieza de la plancha sea correcta, el contraste será de aceptable nivel.

BRILLO: Nulo como era lógico en una estampa sobre un lado carne de afelpado superficial. 

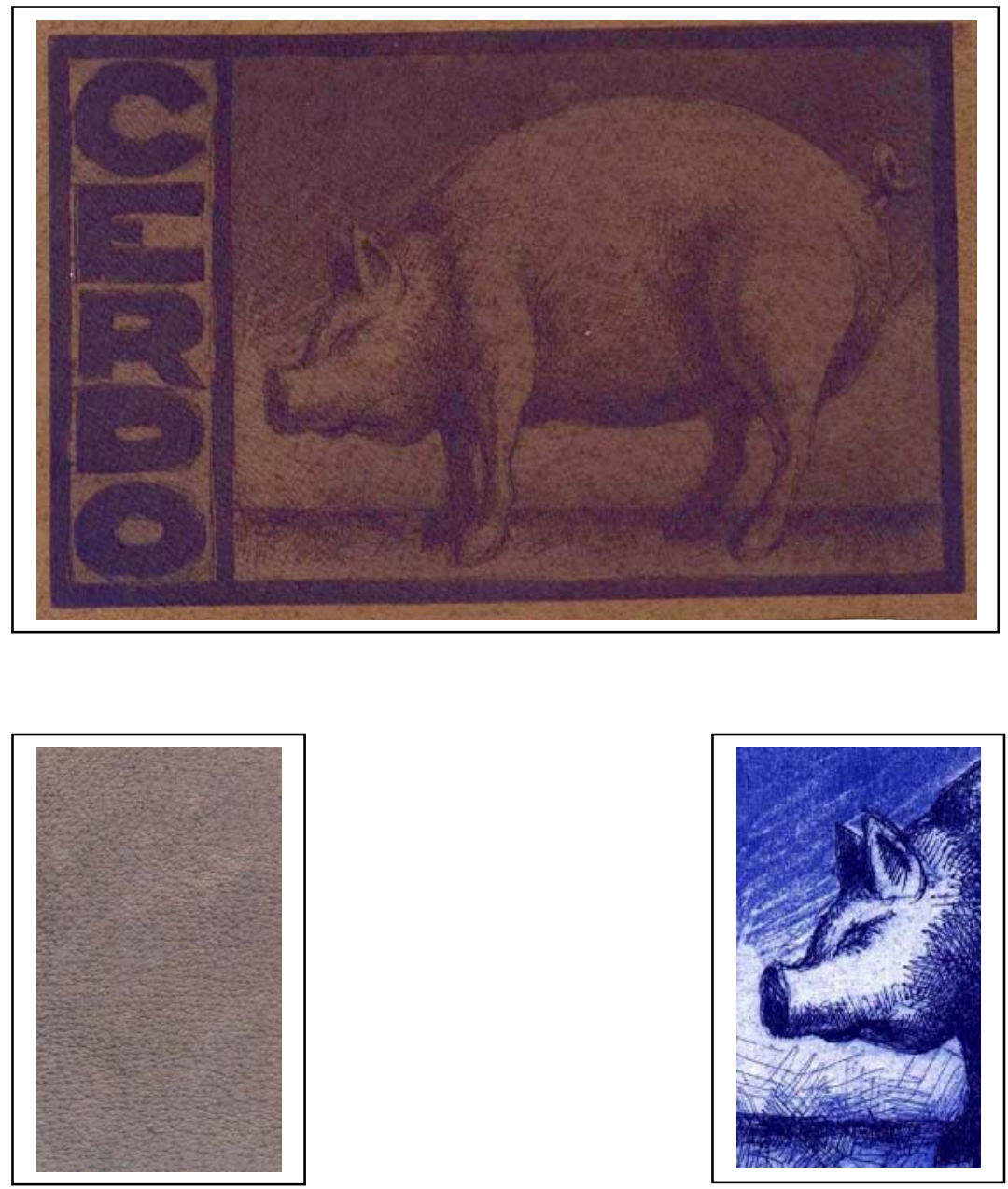

CÓDIGO: CE-044

TÉCNICA: Calcografía

TIPO DE PIEL: Cerdo

TONO DE PIEL: Oscuro

TINTA: Azul opaco

SUPERFICIE: Lado flor 


\section{CALIDAD: Mala}

La excesiva oscuridad del soporte, así como los incómodos brillos que se crean en la superficie de la estampa, hacen que este ejemplo no sea tan satisfactorio como otros ya comentados. Otros factores se comportan de manera correcta, pero quedan eclipsados por los inconvenientes citados.

AGUATINTA: Correcta, aunque de muy difícil apreciación. Parece cubrir correctamente la superficie del soporte piel, manteniendo las diferencias entre los dos tonos de azul, aunque el más claro de ellos es bastante difícil de apreciar.

AGUAFUERTE: Mediocre. Las líneas aisladas, tanto las sutiles como las de mayor grosor, apenas se perciben. Tan sólo en las zonas de mayor densidad lineal se pueden apreciar sin demasiados problemas los seños del aguafuerte.

CONTRASTE: Obviamente se trata del gran problema de este ejemplo. Es un contraste casi nulo por efecto de la superficie tan oscura del cuero. El oscurecimiento de la tinta no logra compensar dicho tono tan intenso.

BRILLO: Aparece un uniforme brillo algo molesto y que, unido a la falta de contraste, provoca que la imagen sea muy difícil de apreciar. 


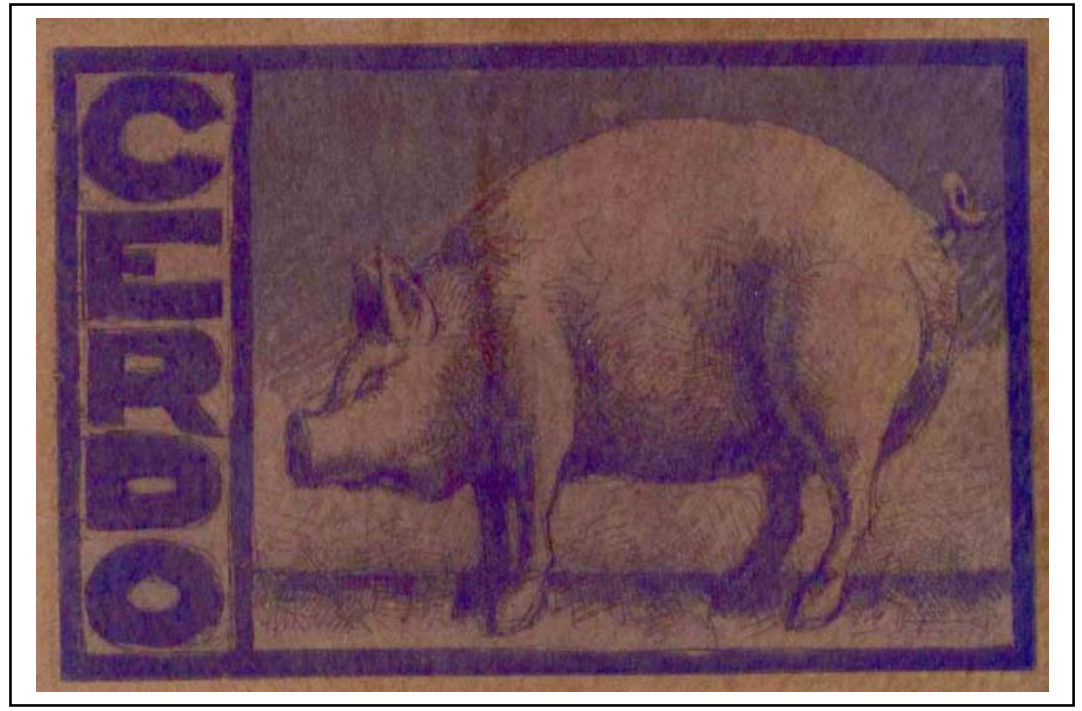

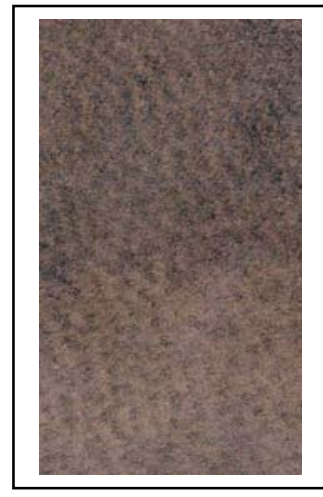

CÓDIGO: CE-045

TIPO DE PIEL: Cerdo

TINTA: Azul opaco

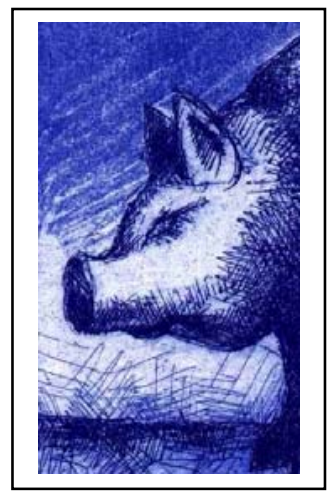

TÉCNICA: Calcografía

TONO DE PIEL: Oscuro

SUPERFICIE: Lado carne 


\section{CALIDAD: Mediocre}

El tono algo más claro de la piel en este lado carne y la falta de brillos hace que esta estampa sea algo mejor que su gemela sobre el lado flor, aunque nunca alcanzando un mínimo nivel de calidad. El secado es perfecto y no presenta problemas de asentamiento reseñables.

AGUATINTA: Mediocre. Se perciben ambos tonos de azul aunque la tinta no es capaz de cubrir totalmente el afelpado del cuero, lo que provoca la aparición de irregularidades en casi todas las zonas de la estampa.

AGUAFUERTE: Algo mejor que sobre el lado flor aunque todavía de baja calidad general. Las líneas más finas y aisladas son difíciles de apreciar, pero no así las zonas de mayor densidad lineal y acumulación de grafismos.

CONTRASTE: Más intenso que en la anterior pero todavía escaso como para crear una imagen satisfactoria. La tinta se oscurece patentemente, lo que permite que la estampa sea reconocible aunque sin alcanzar la intensidad necesaria.

BRILLO: Como es lógico en lo que se refiere a una estampa realizada sobre el lado carne afelpado de un cuero, el brillo es absolutamente nulo. 

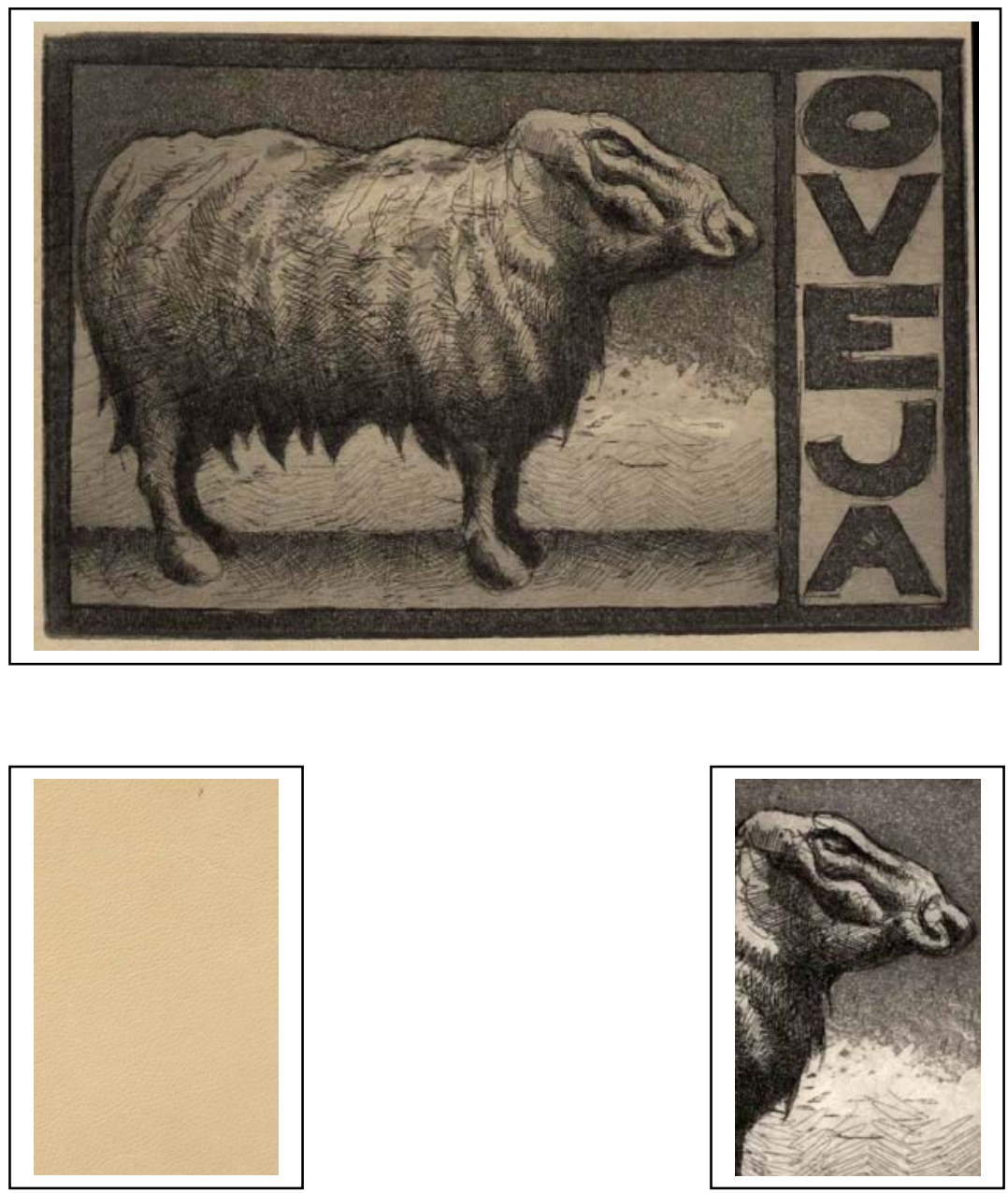

CÓDIGO: C0-025

TÉCNICA: Calcografía

TIPO DE PIEL: Cordero

TONO DE PIEL: Claro

TINTA: Negro

SUPERFICIE: Lado flor 
CALIDAD: Muy buena

Ejemplo de gran calidad y en el cual todos los campos analizados presentan resultado más que satisfactorios. Tanto el registro del aguatinta como los seños lineales se encuentran reflejados de manera casi perfecta sobre la superficie de la piel de cordero.

AGUATINTA: Muy satisfactoria, con ambos tonos perfectamente diferenciados y registrados sin inconvenientes aparentes. Se consiguen áreas de gran homogeneidad y regularidad sobre el soporte piel.

AGUAFUERTE: Perfecto. Tanto en las zonas de gran densidad de líneas, como en aquellos grafismos aislados y de gran sutileza, todos los seños lineales están registrados de manera muy correcta. Incluso los grafismos más finos y sutiles son perfectamente reconocibles y se encuentran estampados con gran nitidez.

CONTRASTE: Muy intenso como era lógico al unir una tinta tan potente como la negra y un soporte de tono tan claro como el de esta piel de cordero.

BRILLO: Prácticamente inexistente a pesar de que estampemos en una superficie sin afelpado alguno como en este caso que nos ocupa. 


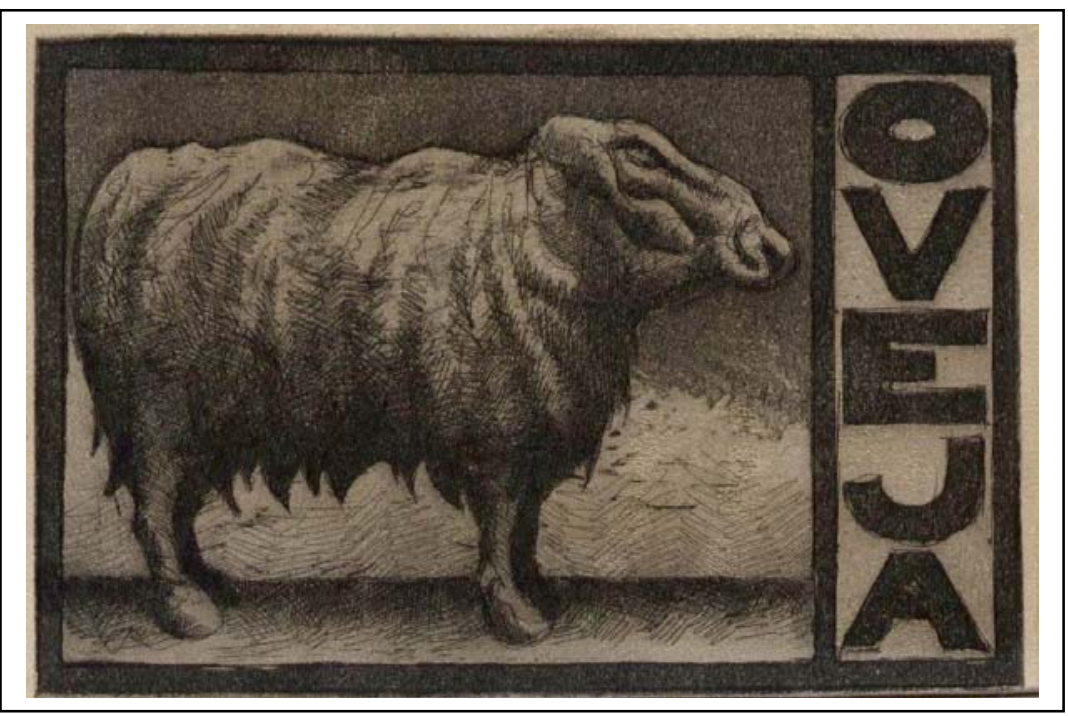

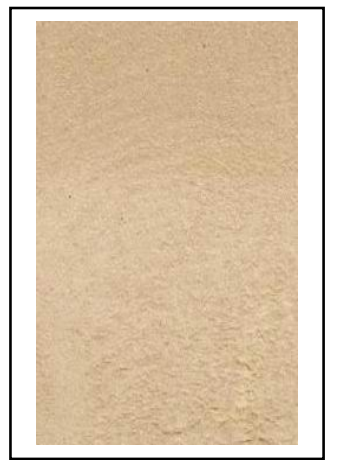

CÓDIGO: C0-026

TIPO DE PIEL: Cordero

TINTA: Negro

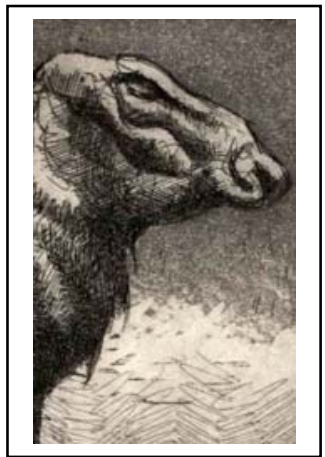

TÉCNICA: Calcografía

TONO DE PIEL: Claro

SUPERFICIE: Lado carne 


\section{CALIDAD: Muy buena}

De características muy similares a su gemela sobre el lado flor ya que el afelpado de la piel de cordero es de gran sutileza y no afecta por tanto en demasía a la naturaleza de la imagen estampada sobre él.

AGUATINTA: Muy homogénea y regular tanto en las zonas más oscuras como en aquellas más claras, quedando perfectamente evidente la diferencia entre ambas intensidades tonales pese al ligero oscurecimiento a que se ve sometida la tinta negra.

AGUAFUERTE: Perfecto. Ya sean las líneas más gruesas como aquellas más finas y aisladas, todas ellas se encuentran registradas de manera muy satisfactoria y sin ningún género de inconveniente reseñable. El afelpado del cuero no logra provocar deformaciones y desvirtuaciones del grafismo del aguafuerte ni siquiera en las comentadas líneas más ligeras y sutiles.

CONTRASTE: Muy correcto e intenso ayudado por el mínimo oscurecimiento del tono negro de la tinta empleada en la estampación. La imagen posee por tanto una gran fuerza plástica e intensidad.

BRILLO: Como es lógico en una superficie afelpada como ésta, los brillos son totalmente inexistentes. 

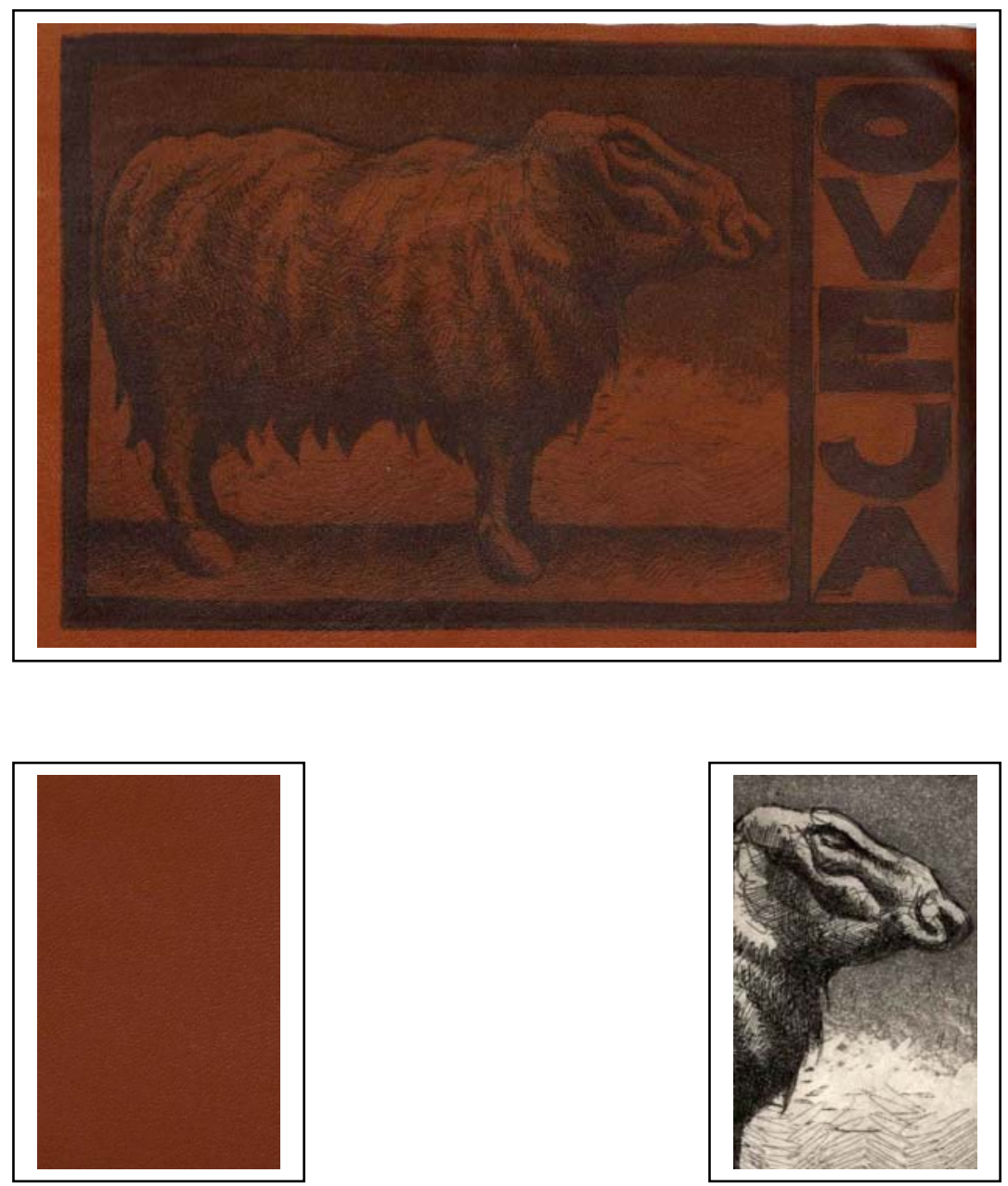

CÓDIGO: C0-027

TÉCNICA: Calcografía

TIPO DE PIEL: Cordero

TONO DE PIEL: Medio

TINTA: Negro

SUPERFICIE: Lado flor 


\section{CALIDAD: Mediocre}

A pesar de que el nivel del aguatinta y del aguafuerte sea óptimo, el escaso contraste existente en la imagen provoca que el nivel de calidad de la misma se vea disminuido de manera notable. También el ligero brillo que aparece en la superficie entintada puede resultar algo molesto.

AGUATINTA: Prácticamente perfecta al igual que en los casos anteriores (CO-025 y CO-026). A pesar del escaso contraste y del oscurecimiento general de la imagen todavía pueden distinguirse de manera evidente las dos intensidades del aguatinta presente en la plancha matriz.

AGUAFUERTE: Óptimo, con un registro totalmente satisfactorio de todos los tipos de seños y grafismos de la imagen, ya sean las zonas de mayor densidad lineal como los seños más aislados y sutiles.

CONTRASTE: Evidentemente el gran inconveniente de este ejemplo concreto dada su escasa intensidad. Pese a que la imagen es reconocible sin demasiados inconvenientes, el ejemplo carece de la fuerza plástica necesaria para lograr un alto nivel de calidad.

BRILLO: Como ya hemos indicado al inicio aparece un brillo que puede llegar a resultar incluso molesto en algunas ocasiones, lo que vuelve a incidir en la calidad global del ejemplo. 


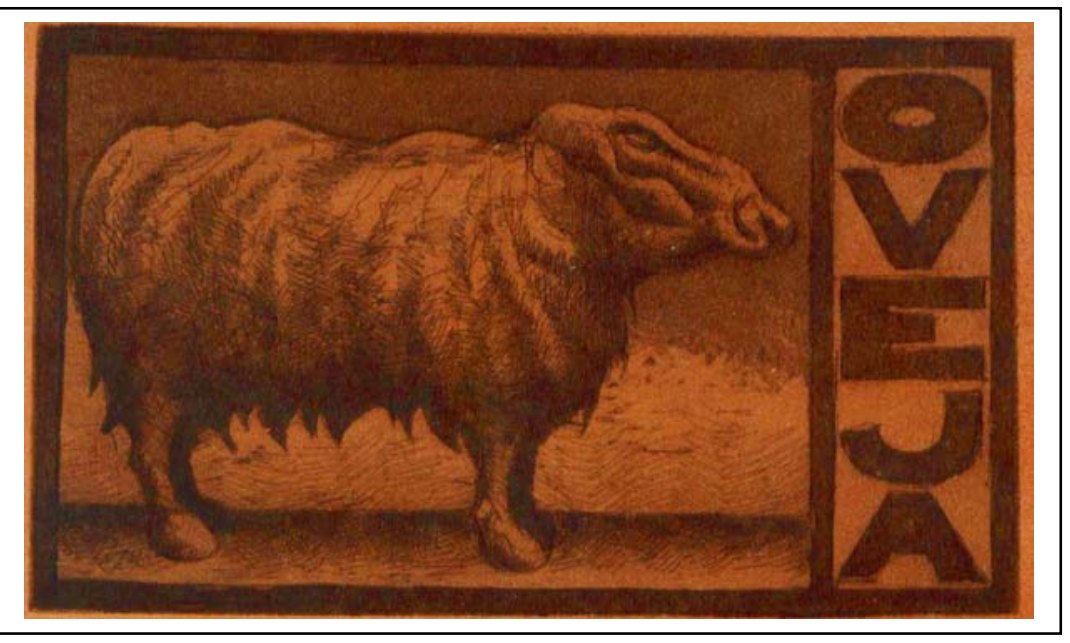

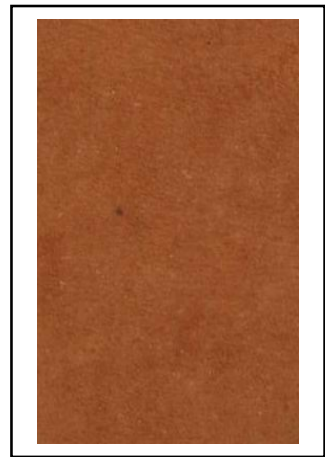

CÓDIGO: C0-028

TIPO DE PIEL: Cordero

TINTA: Negro

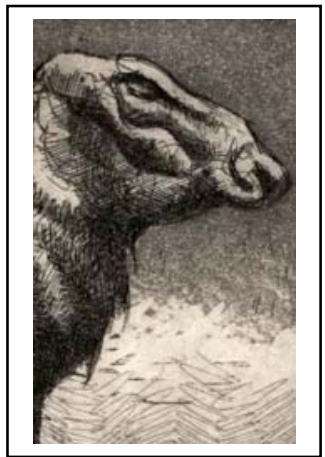

TÉCNICA: Calcografía

TONO DE PIEL: Medio

SUPERFICIE: Lado carne 


\section{CALIDAD: Muy buena}

A diferencia del ejemplo anterior sobre el lado flor, esta imagen ofrece unos niveles de calidad muy superiores, basados sobre todo en el grado de contraste conseguido por la tinta sobre el cuero. El afelpado tan sutil que presentan las pieles de cordero permite que las estampas no ofrezcan demasiados inconvenientes por efecto de ese acabado rugoso que tanto afecta a otras estampas analizadas.

AGUATINTA: Perfecta a todos los efectos, con ambas intensidades registradas de manera óptima. Las áreas entintadas ofrecen un acabado homogéneo y regular sin inconvenientes.

AGUAFUERTE: Al igual que el aguatinta, los seños del aguafuerte se encuentran registrados de manera muy satisfactoria. El ligero afelpado no afecta a las líneas más sutiles, mientras que, como era lógico, en las zonas de mayor densidad de grafismos no se aprecian problemas de ningún tipo.

CONTRASTE: Mucho más intenso que en el ejemplo anterior, lo que permite que el nivel de calidad de la imagen sea mucho mayor. El tono del cuero de cordero en su lado carne es algo más claro que sobre el lado flor, y a ésto se une el hecho de que la estampa sufre un oscurecimiento general que le permite lograr un nivel de intensidad de contraste mucho más elevado.

BRILLO: Nulo como era de esperar con el afelpado del cuero. 


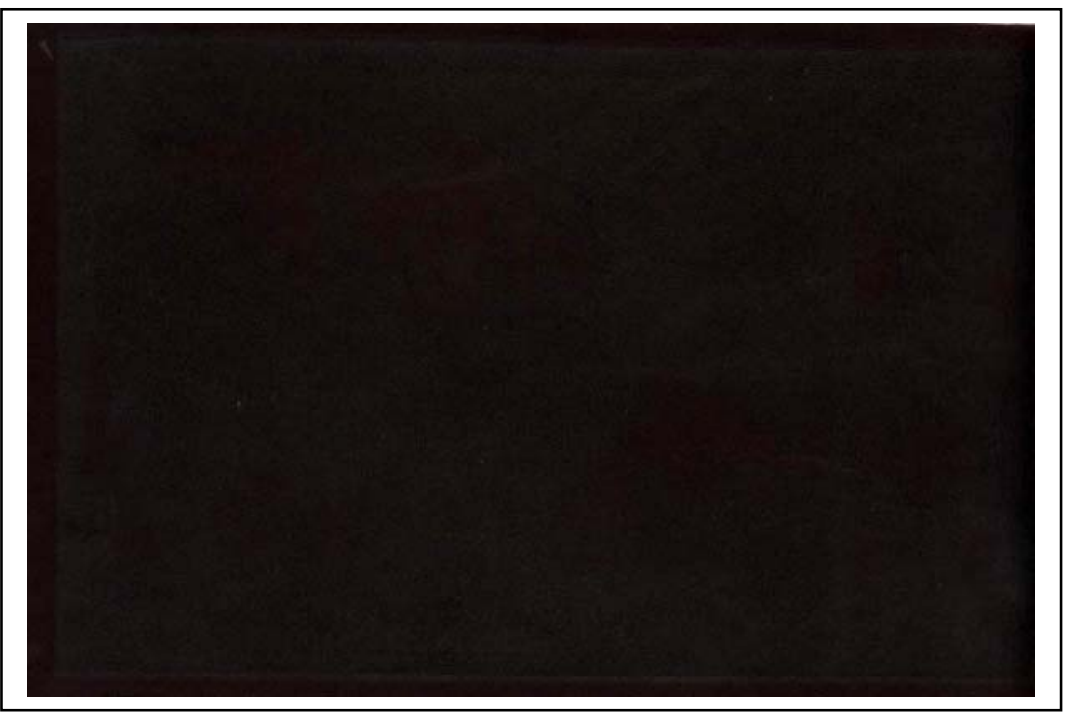

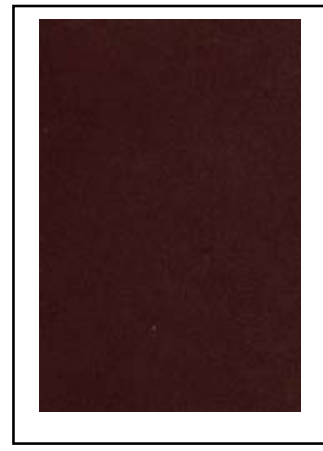

CÓDIGO: C0-029

TIPO DE PIEL: Cordero

TINTA: Negro

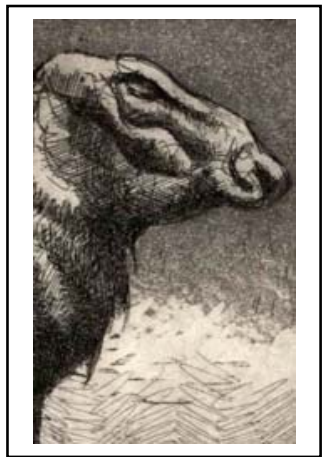

TÉCNICA: Calcografía

TONO DE PIEL: Oscuro

SUPERFICIE: Lado flor 


\section{CALIDAD: Muy mala}

En este ejemplo se lleva al extremo el problema del contraste, algo que ya había aparecido en la estampa CO-027. En efecto la imagen es absolutamente imposible de apreciar debido al tono tan oscuro, casi negro, del soporte piel sobre el que se encuentra estampada la imagen.

AGUATINTA: Imposible de apreciar por efecto del nulo contraste existente en la estampa. La tinta depositada sobre la superficie del cuero apenas puede distinguirse del soporte por el diferente grado de brillo que presentan dichas zonas.

AGUAFUERTE: Al igual que el aguatinta, no es posible decir si los grafismos están bien o mal registrados debido a la imposibilidad de distinguirlos del tono del soporte.

CONTRASTE: Obviamente se trata del gran problema de este ejemplo, problema de tal intensidad que llega a hacer totalmente inútil la estampa. En ningún otro ejemplo de todo el estudio el grado de contraste había sido tan bajo, aunque estas características se repetirán en las estampas CO-038 y CO-045.

BRILLO: Como ya hemos comentado aparecen potentes brillos en las zonas entintadas del cuero, incluso más intensos que el propio del soporte piel, ya de por sí bastante elevado. Es gracias a estos reflejos que podemos distinguir las zonas donde se ha depositado la tinta de aquellas en las que el cuero no se encuentra entintado. 


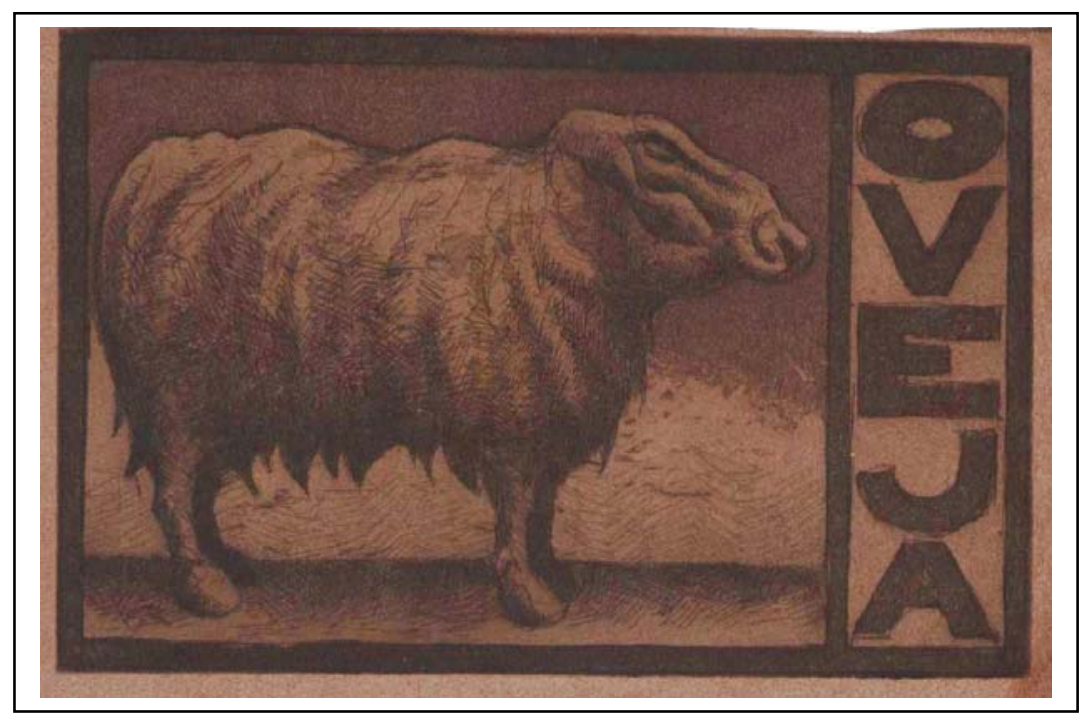

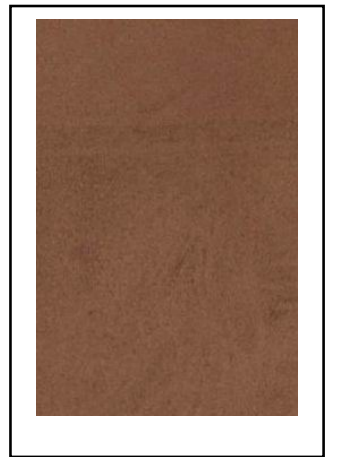

CÓDIGO: C0-030

TIPO DE PIEL: Cordero

TINTA: Negro

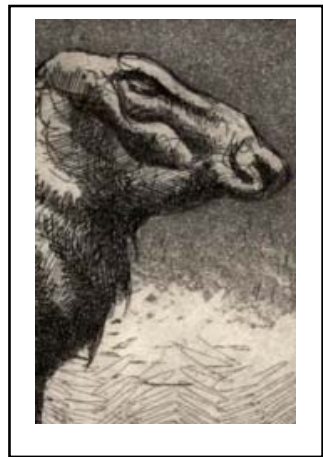

TÉCNICA: Calcografía

TONO DE PIEL: Oscuro

SUPERFICIE: Lado carne 


\section{CALIDAD: Buena}

El tono del cuero de cordero oscuro en este lado carne es sustancialmente más claro que en el lado flor, lo que provoca que el nivel de calidad de la estampa sea mucho mayor ya que se logra alcanzar un contraste lo suficientemente elevado como para permitir una correcta apreciación de la imagen.

AGUATINTA: Óptima en sus resultados, con ambos tonos registrados de manera muy satisfactoria y sin problemas de homogeneidad 0 regularidad. El afelpado tan sutil del cuero de cordero se presenta como un soporte ideal para este tipo de seño calcográfico.

AGUAFUERTE: Al igual que el aguatinta, el aguafuerte se encuentra estampado de manera más que correcta. Tanto las zonas de gran densidad lineal como los grafismos más sutiles ofrecen un resultado más que aceptable para una superficie afelpada como la que nos ocupa.

CONTRASTE: Como ya hemos indicado el tono algo más claro del cuero en este lado carne permite un nivel de contraste mucho más intenso que logra crear una imagen mucho más potente e indudablemente más interesante desde un punto de vista plástico.

BRILLO: Como era de esperar, totalmente inexistente al estampar sobre una superficie afelpada como la de este cuero. 

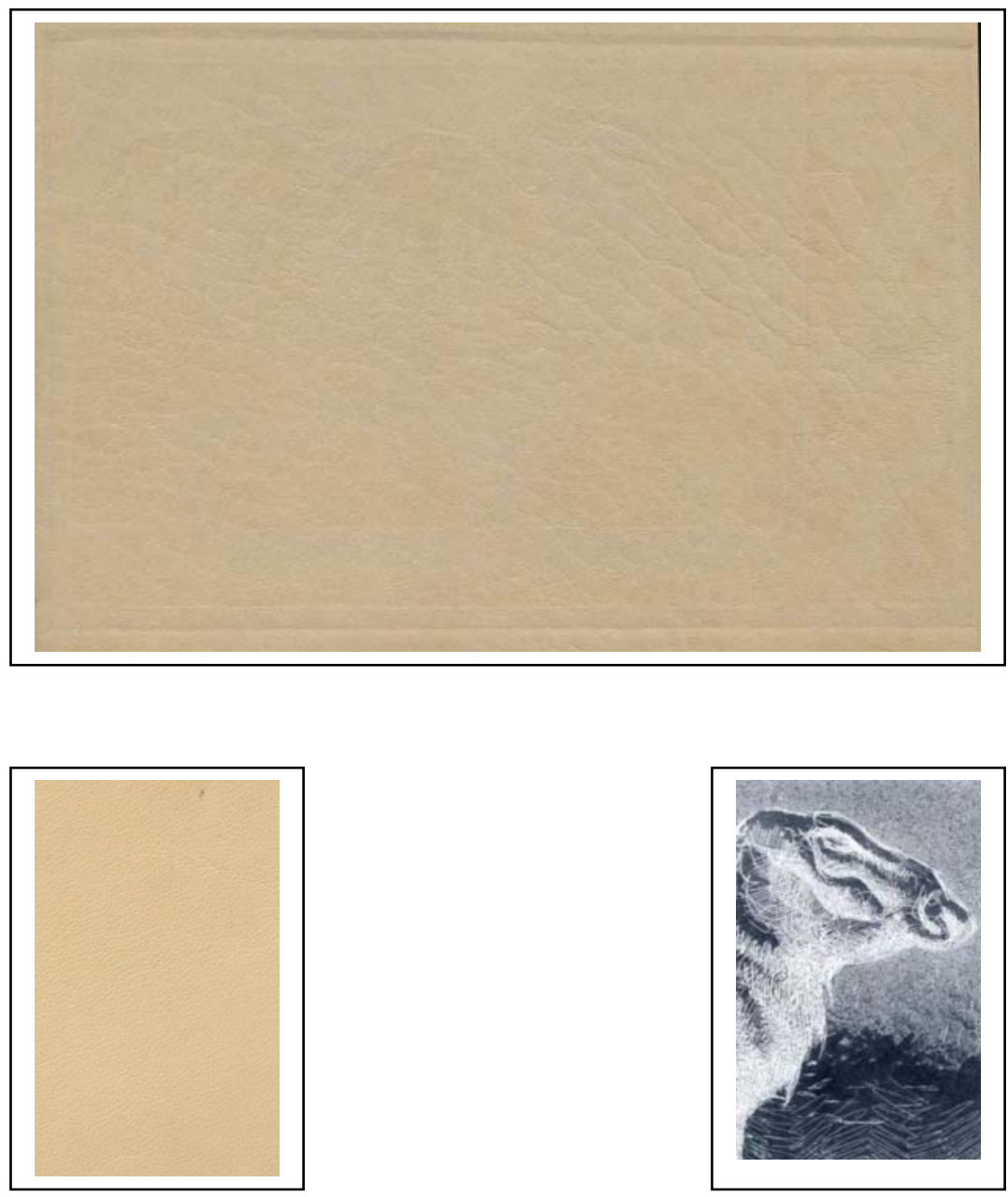

CÓDIGO: C0-031

TÉCNICA: Calcografía

TIPO DE PIEL: Cordero

TONO DE PIEL: Claro

TINTA: Blanco

SUPERFICIE: Lado flor 


\section{CALIDAD: Muy mala}

Ejemplo de parecidas características al CO-029 aunque aquel estuviera realizado con tinta negra y este con tinta blanca. En efecto, al igual que en el caso citado, en esta estampa nos es prácticamente imposible determinar que zonas del cuero están entintadas y cuales no, ya que el tono de la tinta se mimetiza de manera absoluta con la piel.

AGUATINTA: Imposible de determinar y conocer el resultado por los problemas de contraste antes comentados.

AGUAFUERTE: Tan solo las líneas que conforman el marco exterior de la imagen pueden distinguirse con suma dificultad del tono del soporte piel, por lo que su análisis es totalmente imposible.

CONTRASTE: Es indudablemente el gran inconveniente de esta estampa, algo que era de esperar si tenemos en cuenta los resultados que suelen obtenerse con el empleo de tintas blancas. El grado de contraste es tan mínimo que tan sólo es comparable con los ejemplos realizados sobre la piel de cordero oscura sobre su lado flor, los cuales muestran un nivel de contraste igual de mínimo.

BRILLO: Pese a estar estampada sobre una superficie que carece de afelpado, la tinta blanca impide, debido a su naturaleza eminentemente mate, la aparición de cualquier tipo de reflejo o brillo sobre el cuero. 


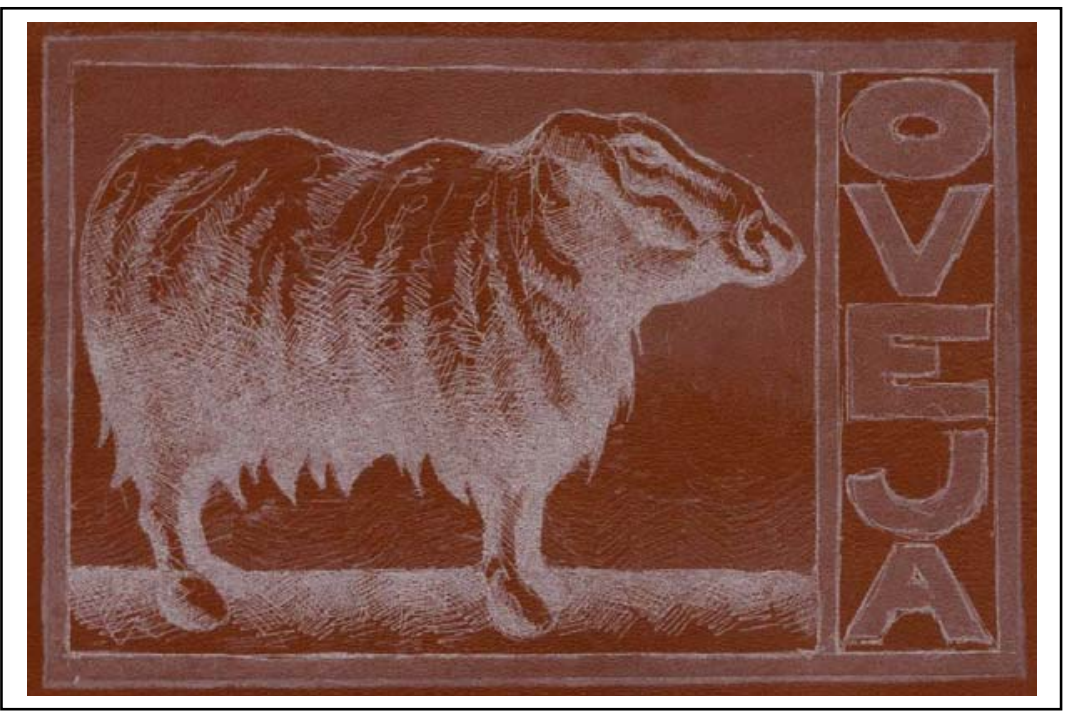

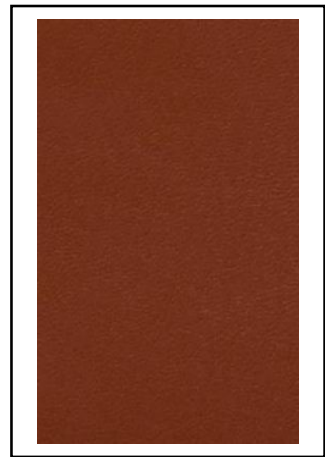

CÓDIGO: C0-032

TIPO DE PIEL: Cordero

TINTA: Blanco

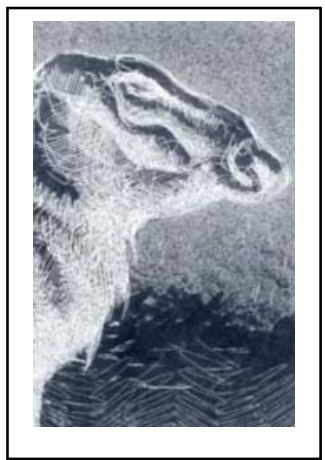

TÉCNICA: Calcografía

TONO DE PIEL: Medio

SUPERFICIE: Lado flor 


\section{CALIDAD: Buena}

Sin duda alguna nos encontramos quizá ante una de las mejores estampas realizadas con tinta blanca, tan sólo equiparable a la siguiente sobre la piel oscura de cordero (CO-033). En efecto, tanto las aguatintas como los seños lineales ofrecen un resultado que ninguna otra imagen había podido ni siquiera soñar con alcanzar. Pese a todo, la estampa presenta un ligero problema de asentamiento de la tinta blanca sobre la superficie del cuero, aunque es subsanable añadiendo un poco de preparación traslúcida a la mezcla.

AGUATINTA: Muy correcta para los resultados que se vienen obteniendo al emplear tintas blancas. A pesar de no alcanzar un grado de intensidad demasiado elevado, el nivel es muy satisfactorio.

AGUAFUERTE: Casi perfecto, ya que tan sólo las líneas más sutiles y aisladas presentan ligeros problemas de registro. El resto de los grafismos están registrados de manera óptima, con gran intensidad del blanco en las zonas de mayor densidad de líneas.

CONTRASTE: Muy correcto y lo suficientemente intenso como para provocar la aparición de una imagen muy potente desde un punto de vista plástico, totalmente diferente a la gran mayoría de las conseguidas a partir del empleo de tinta blanca.

BRILLO: Totalmente nulo en las zonas entintadas de la estampa, eliminando la tinta el posible brillo existente en la superficie del cuero. 

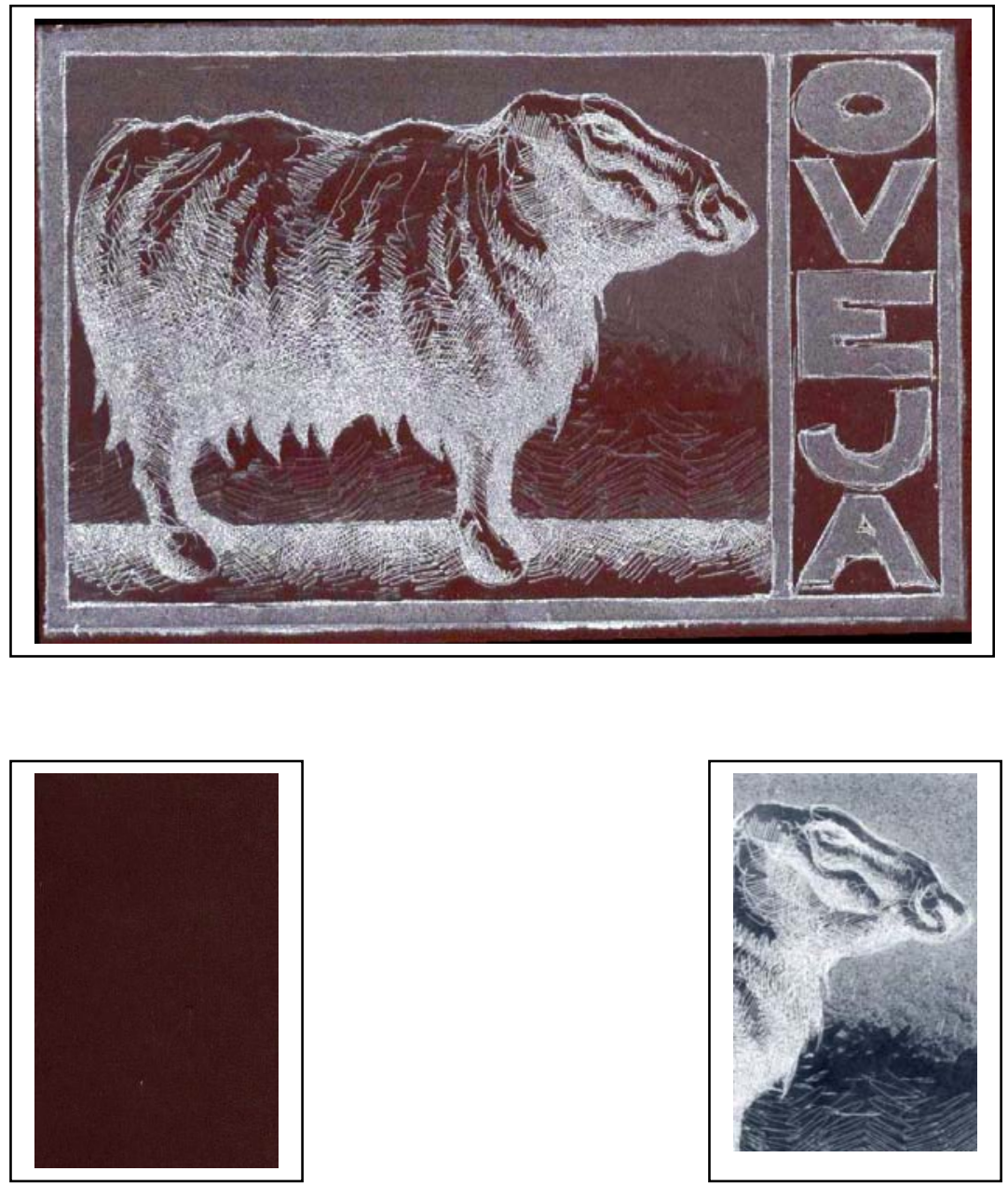

CÓDIGO: C0-033

TÉCNICA: Calcografía

TIPO DE PIEL: Cordero

TONO DE PIEL: Oscuro

TINTA: Blanco

SUPERFICIE: Lado flor 


\section{CALIDAD: Buena}

Quizá incluso mejor que el ejemplo anterior (CO-032) debido al mayor contraste alcanzado entre la tinta blanca y el tono tan oscuro del soporte piel. Tan sólo podemos citar como ligero inconveniente la aparición de ciertos grumos y un acabado irregular en las zonas de mayor densidad lineal, sin que llegue a convertirse en un problema demasiado importante.

AGUATINTA: De resultado mejor que la anterior y sin duda la mejor de todo el estudio. Los tonos están perfectamente diferenciados y alcanzando un nivel de intensidad muy elevado y totalmente diferente al logrado por otros ejemplos ya comentados.

AGUAFUERTE: Casi perfecto, con las líneas más sutiles estampadas de manera muy correcta y sin apenas deformaciones. Tan sólo en las zonas de mayor densidad de grafismos aparecen problemas de grumos y acabados irregulares, aunque sin llegar a ser demasiado importantes de cara a una apreciación general de la estampa.

CONTRASTE: Muy intenso y correcto y el más potente de todos los ejemplos realizados con tinta blanca. Permite que la imagen ofrezca un aspecto muy interesante desde un punto de vista estético, algo muy difícil de conseguir empleando tintas blancas.

BRILLO: La tinta blanca oculta el brillo existente en la superficie del cuero de cordero, dotando a la estampa de un acabado mate. 

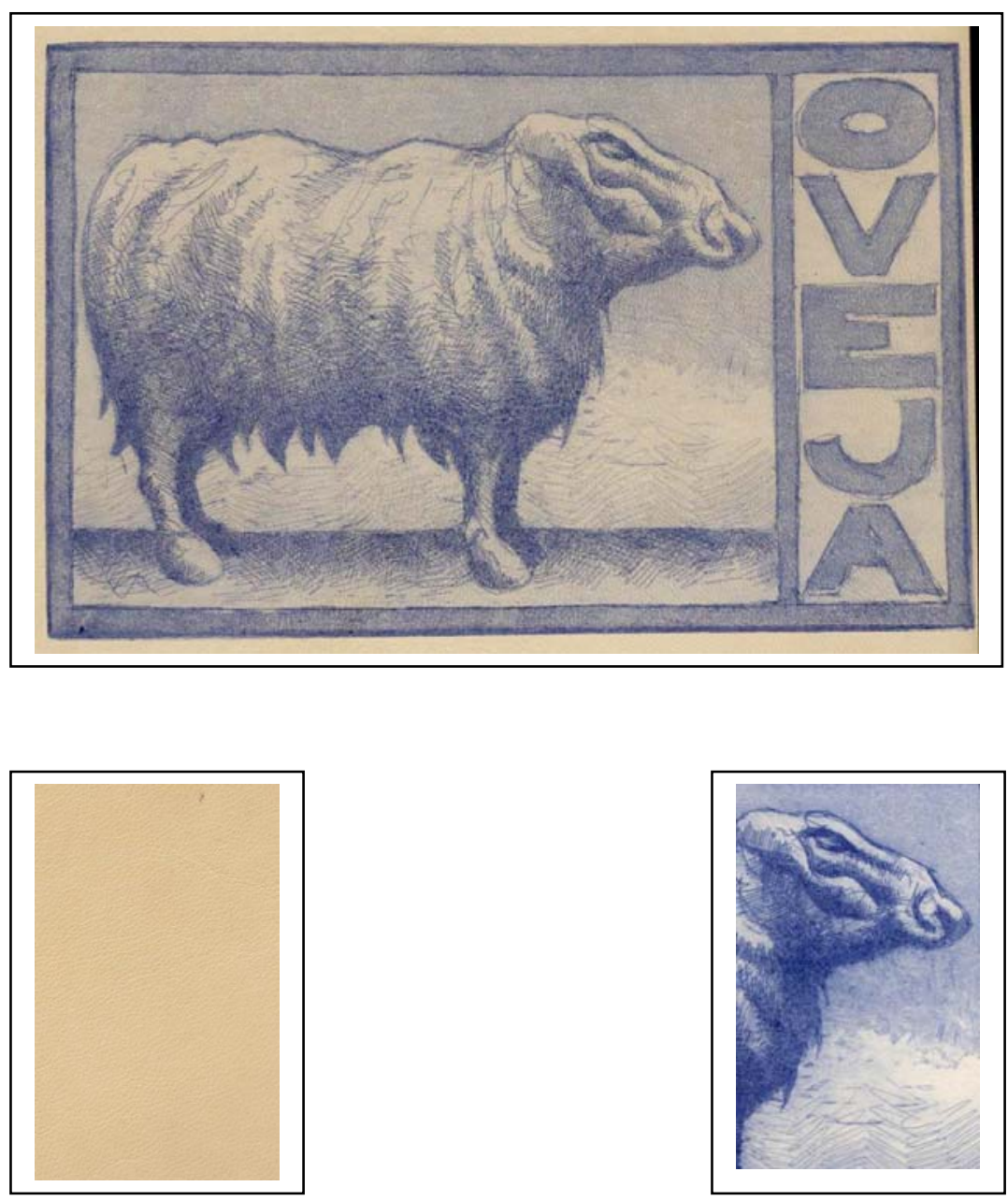

CÓDIGO: C0-034

TÉCNICA: Calcografía

TIPO DE PIEL: Cordero

TONO DE PIEL: Claro

TINTA: Azul traslúcido

SUPERFICIE: Lado flor 


\section{CALIDAD: Buena}

Ejemplo de aceptable nivel pese a no alcanzar los niveles de otras estampas realizadas con la tinta azul translúcido. El tono tan claro de la tinta no llega a contrastar demasiado con el tono del soporte, lo que impide que la imagen posea la intensidad de su gemela en el lado carne, la CO-035. La gran cantidad de carga traslúcida de la tinta hace que en las zonas de aguatinta la homogeneidad no sea todo lo correcta que sería deseable.

AGUATINTA: Como hemos comentado anteriormente, aparecen ciertas irregularidades en las áreas del aguatinta, sobre todo en el tono más intenso (aquel que constituye los bordes de la imagen). Pese a todo el nivel es correcto, con una buena estampación de las zonas más sutiles.

AGUAFUERTE: De bastante buen nivel general, con las líneas aisladas y más finas perfectamente visibles. También en las zonas de mayor densidad de grafismos podemos encontrar un registro correcto, sin llegar a aparecer el acabado grumoso que podemos encontrar en otros ejemplos con esta misma tinta.

CONTRASTE: No demasiado intenso ya que el tono de la tinta no sufre apenas oscurecimiento al contacto con la superficie del cuero. A pesar de ello la imagen es visible sin complicaciones.

BRILLO: Nulo pese a que se ha empleado una tinta con gran carga de preparación traslúcida sobre una superficie satinada. 

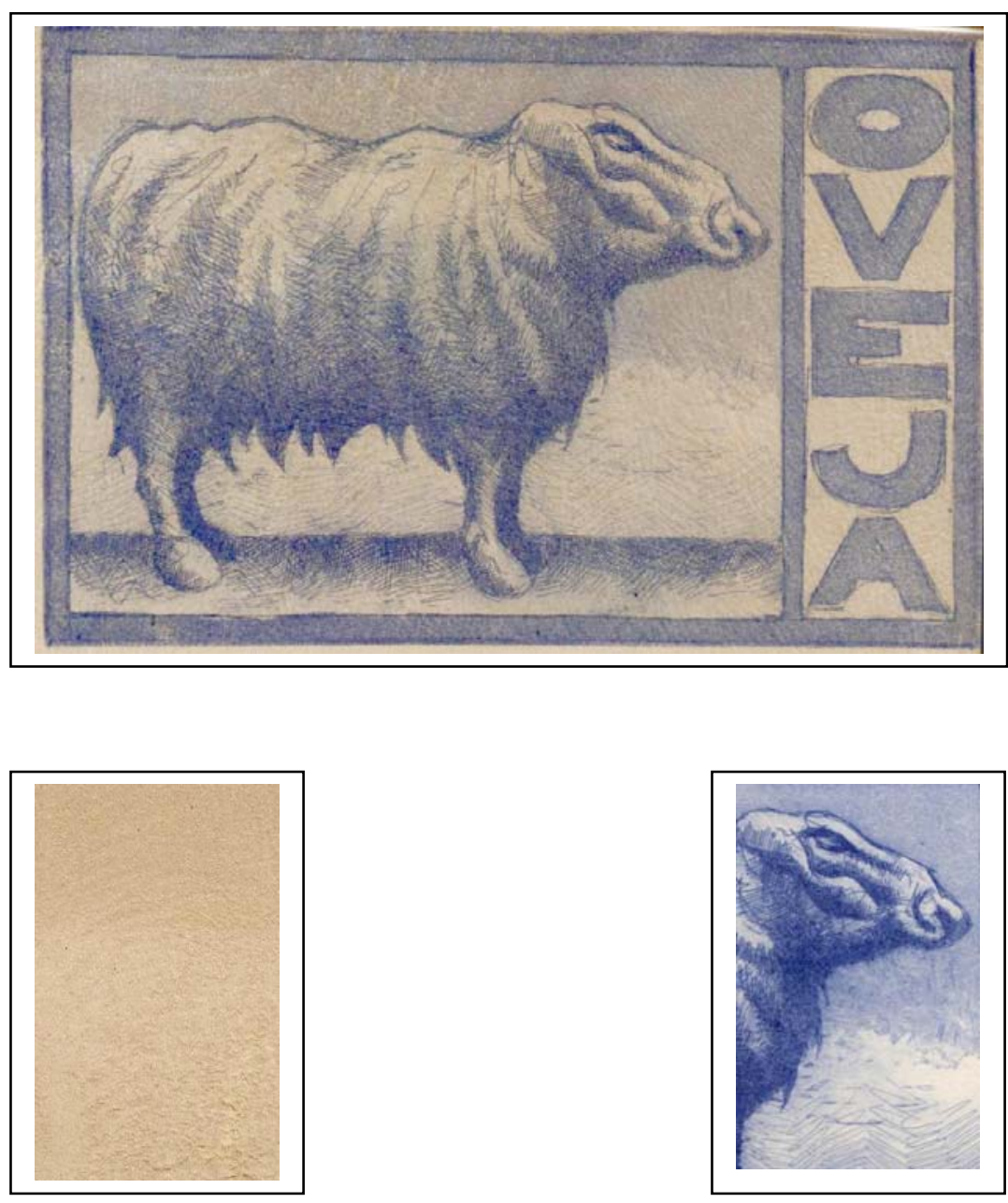

CÓDIGO: C0-035

TÉCNICA: Calcografía

TIPO DE PIEL: Cordero

TONO DE PIEL: Claro

TINTA: Azul traslúcido

SUPERFICIE: Lado carne 


\section{CALIDAD: Muy buena}

Gracias a que el contraste es algo mayor que en el ejemplo anterior, esta imagen alcanza un muy alto nivel de calidad, con mejores resultados en el registro del aguatinta y una mejor apariencia general gracias al oscurecimiento al que se ve sometida la tinta al contacto con la superficie afelpada del lado carne del cuero empleado como soporte.

AGUATINTA: Muy buen resultado, mejor que en la imagen CA-034 ya que no aparecen inconvenientes ni irregularidades en las zonas más oscuras de la imagen. También las áreas más sutiles ofrecen un acabado óptimo.

AGUAFUERTE: Perfecto y sin apenas problemas reseñables. El ligero afelpado de la superficie del cuero no impide un correcto registro tanto de los grafismos más potentes como de los más sutiles. Ambos tipos de línea están reflejados óptimamente sobre el lado carne del cuero de cordero.

CONTRASTE: Algo más intenso gracias al marcado oscurecimiento que sufre la tinta azul traslúcido al contacto con el leve afelpado del cuero. Gracias a dicha intensidad la imagen ofrece un acabado mucho mejor que su gemela la CO-034

BRILLO: Imperceptible como era de esperar al estampar sobre el lado carne de un cuero. 


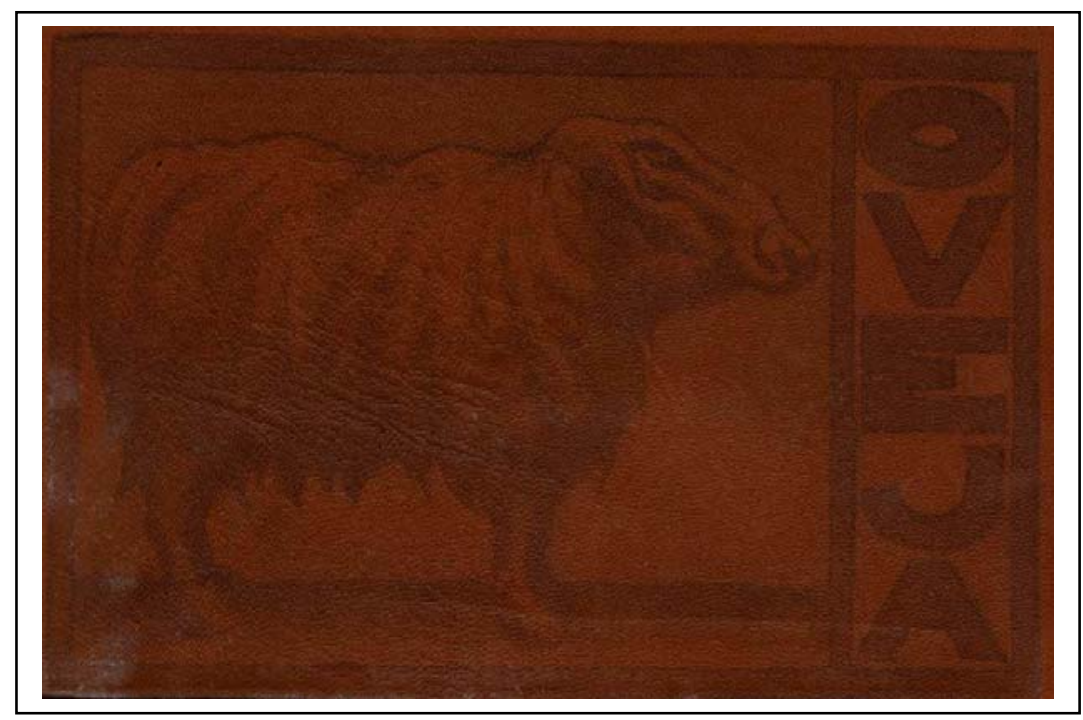

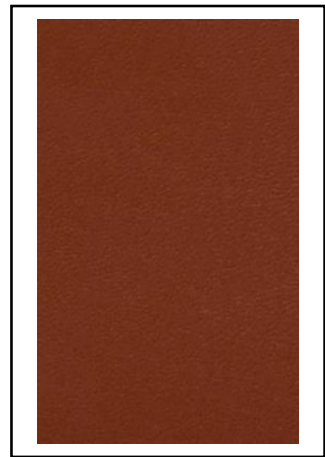

CÓDIGO: C0-036

TIPO DE PIEL: Cordero

TINTA: Azul traslúcido

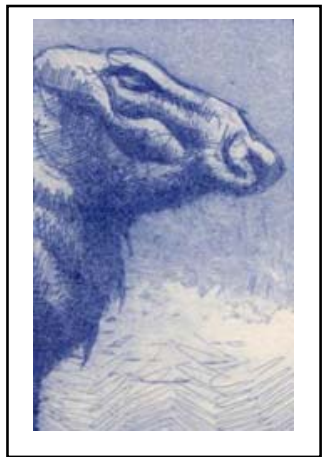

TÉCNICA: Calcografía

TONO DE PIEL: Medio

SUPERFICIE: Lado flor 


\section{CALIDAD: Mediocre}

Sobre esta superficie algo más oscura el contraste es demasiado escaso como para crear una imagen lo suficientemente potente y atractiva. El tono de la tinta no consigue sobreponerse al del cuero, por lo que se pierde y no permite apreciar de manera correcta la imagen.

AGUATINTA: Pese a lo difícil de su apreciación parece estar correctamente registrada sobre la piel. Ambas intensidades se pueden diferenciar perfectamente y no parecen aparecer irregularidades ni defectos de homogeneidad.

AGUAFUERTE: Por efecto del escaso contraste las líneas más sutiles desaparecen confundidas con el tono del soporte piel. Tan sólo las zonas donde se concentran mayor cantidad de líneas se pueden apreciar aunque perdiéndose los contornos de las formas.

CONTRASTE: Evidentemente se trata del principal problema de la estampa, ya que la tinta no oscurece al contacto con la piel y no logra contrastar con esta última. La baja intensidad del contraste condiciona todos los campos restantes de la estampa.

BRILLO: El cuero posee de por sí un marcado brillo, el cual no es afectado por la tinta. Ésta no produce ningún tipo de cambio en la superficie de la piel, la cual conserva sus reflejos comentados. 


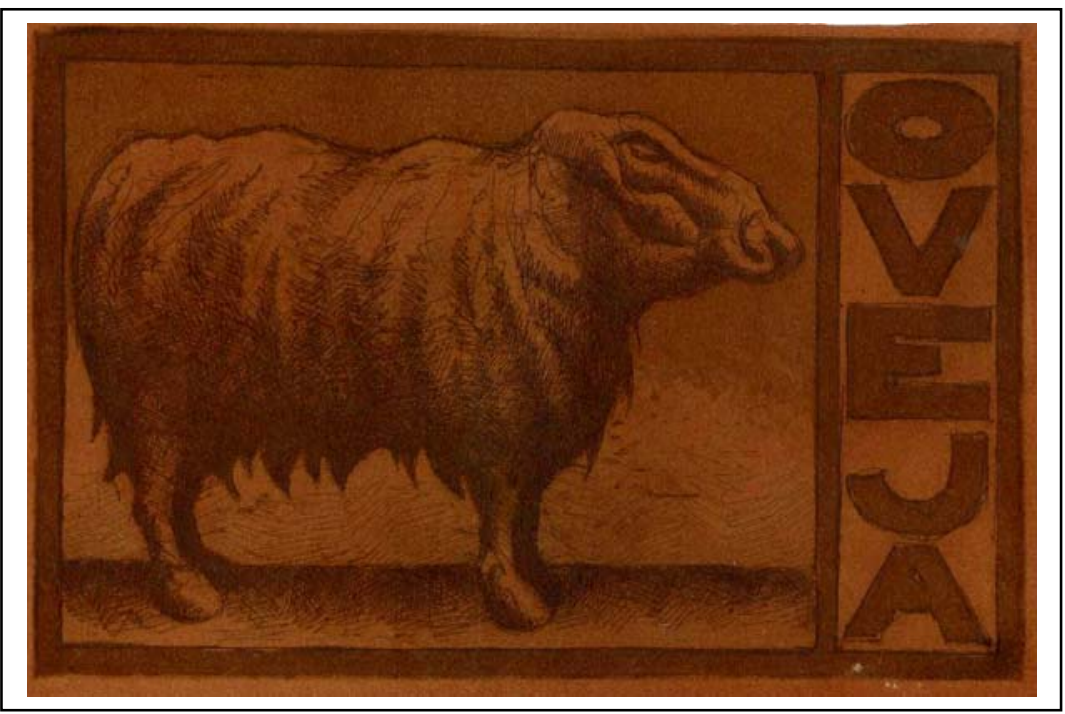

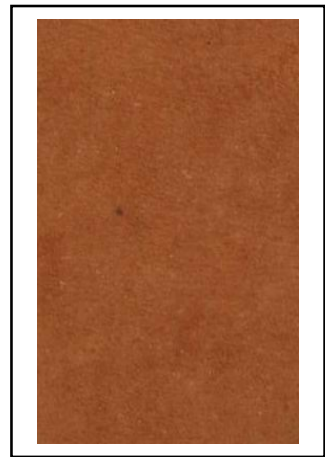

CÓDIGO: C0-037

TIPO DE PIEL: Cordero

TINTA: Azul traslúcido

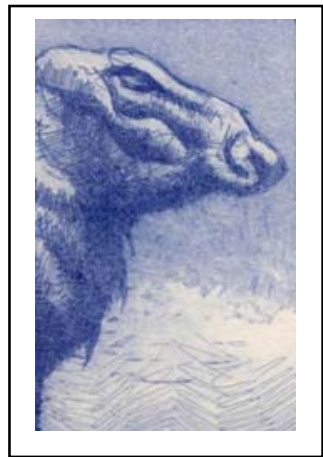

TÉCNICA: Calcografía

TONO DE PIEL: Medio

SUPERFICIE: Lado carne 


\section{CALIDAD: Muy buena}

Al contrario que su gemela sobre el lado flor (CO-036) esta estampa alcanza muy altos niveles de calidad sobre un soporte de prácticamente el mismo tono. La diferencia entre ambas imágenes viene provocada por el oscurecimiento que sufre la tinta azul traslúcida al contacto con el afelpado del cuero en su lado carne.

AGUATINTA: Perfecta, sin irregularidades ni defectos aparentes. Ambos tonos están óptimamente estampados sobre el cuero, con un marcado oscurecimiento y una mezcla por transparencia de la tinta original, convirtiéndose en un tono grisáceo azulado totalmente diferente al de la tinta.

AGUAFUERTE: Sin problemas reseñables, todos los seños presentes en la plancha matriz están reflejados de manera totalmente correcta sobre el cuero. El ligero afelpado no afecta a la nitidez del seño del aguafuerte, el cual es perfectamente visible.

CONTRASTE: Mucho más intenso que en su gemela sobre el lado flor (CO-036) gracias al comentado oscurecimiento de la tinta. La intensidad es lo suficientemente alta como para crear una imagen muy atractiva desde el punto de vista plástico.

BRILLO: Inexistente como corresponde a una estampación sobre una superficie afelpada como la que nos ocupa. 


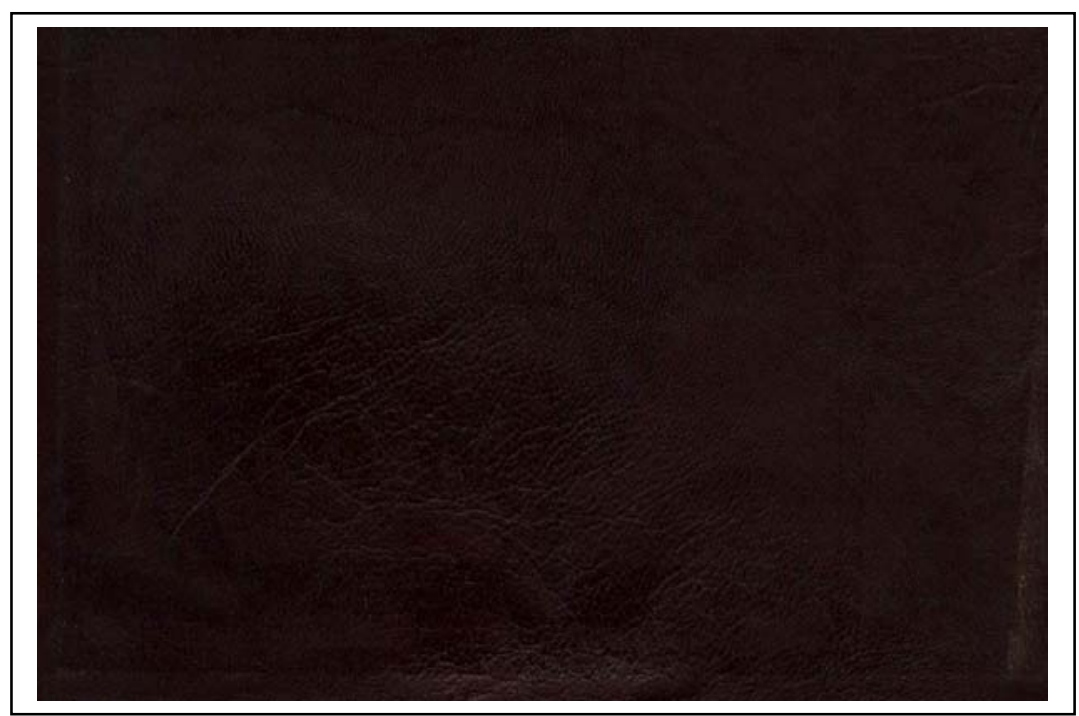

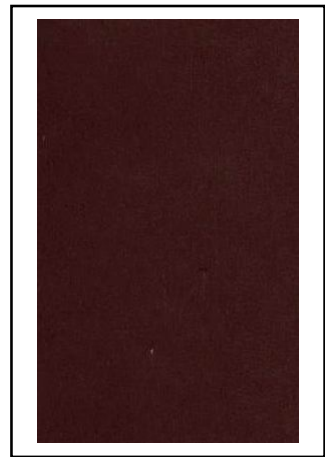

CÓDIGO: C0-038

TIPO DE PIEL: Cordero

TINTA: Azul traslúcido

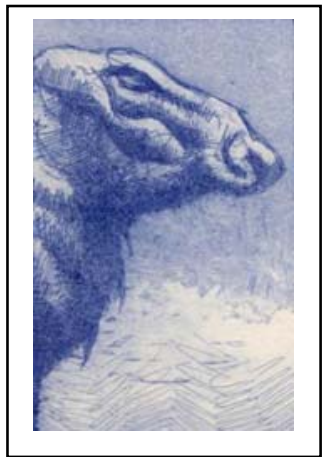

TÉCNICA: Calcografía

TONO DE PIEL: Oscuro

SUPERFICIE: Lado flor 


\section{CALIDAD: Muy mala}

Al igual que la imagen CO-029, este ejemplo se muestra como absolutamente inútil ya que el contraste entre la imagen estampada y el soporte es totalmente nulo. Es prácticamente imposible distinguir lo estampado del cuero que le sirve como soporte, y tan sólo gracias a un leve brillo que aparece en las zonas entintadas podemos intuir donde acaba la imagen y empieza el soporte.

AGUATINTA: Absolutamente imposible de dilucidar, es inútil tratar de lograr cualquier conclusión a partir de este ejemplo concreto, ya que no es posible apreciar los tonos del aguatinta.

AGUAFUERTE: Prácticamente igual que el aguatinta: imposible de dilucidar donde se encuentran las líneas de la imagen.

CONTRASTE: Evidentemente el nivel de intensidad del contraste es el gran problema al que se enfrenta esta estampa. Al ser absolutamente nulo la imagen desaparece y no puede apreciarse.

BRILLO: Gracias al acusado brillo que aparece en las zonas entintadas del cuero podemos ser capaces de distinguir de manera algo precaria los límites de la imagen estampada. La tinta azul traslúcido llega a provocar unos reflejos todavía más intensos que los que ya de por sí ofrecía el soporte piel. 


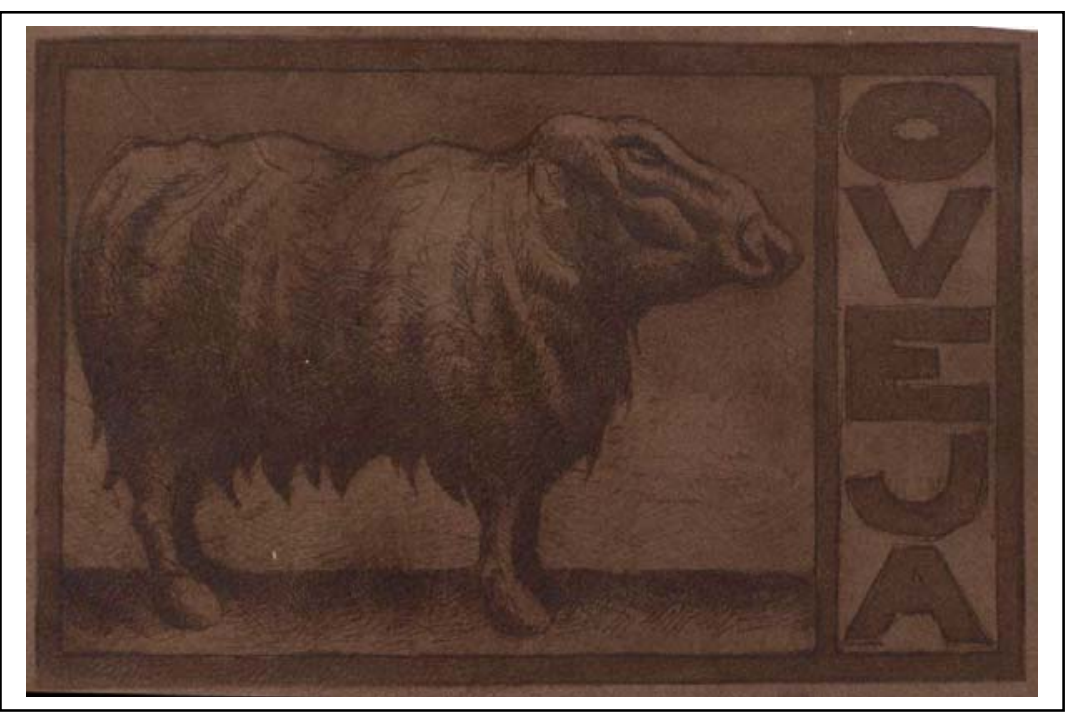

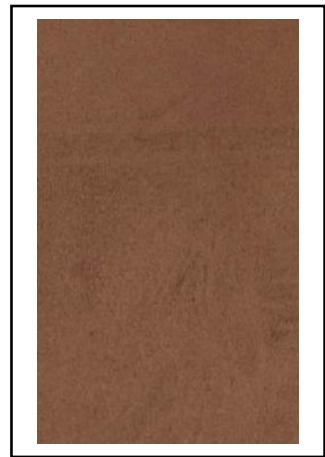

CÓDIGO: C0-039

TIPO DE PIEL: Cordero

TINTA: Azul traslúcido

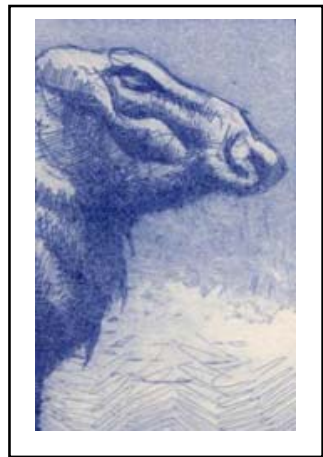

TÉCNICA: Calcografía

TONO DE PIEL: Oscuro

SUPERFICIE: Lado carne 


\section{CALIDAD: Mediocre}

De mucha mejor calidad que el ejemplo estampado sobre el lado flor, a pesar de esta mejoría la imagen no logra alcanzar unos niveles aceptables. Los resultados mejoran gracias al tono mucho más claro del lado carne del cuero y al oscurecimiento al que se ve sometida la tinta al contacto con dicha superficie afelpada.

AGUATINTA: Con evidentes deficiencias tanto en las zonas más oscuras (las cuales presentan irregularidades patentes) como en las claras y sutiles (que llegan a desaparecer casi por completo y son muy difíciles de percibir).

AGUAFUERTE: Correcto. Los seños gruesos y potentes se encuentran registrados con normalidad, pero las más aisladas y sutiles son difíciles de apreciar dado el afelpado del cuero y el escaso nivel de intensidad de las propias líneas.

CONTRASTE: Mucho más fuerte que en el ejemplo anterior (CA038), aunque sin llegar a alcanzar niveles de gran intensidad. La tinta sufre un marcado proceso de oscurecimiento y cambio de tonalidad hasta convertirse en un gris parduzco muy diferente de la tinta empleada.

BRILLO: Absolutamente nulo ya que el afelpado del cuero en su lado carne absorbe cualquier tipo de reflejo que pudiera aparecer en la superficie de la piel. 


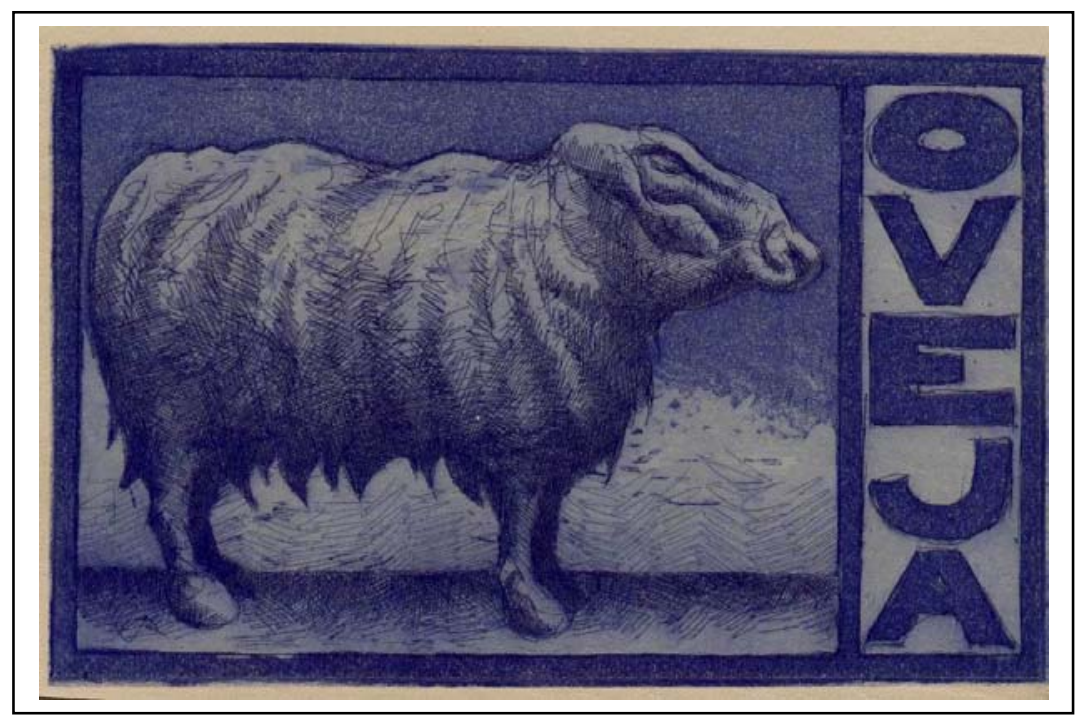

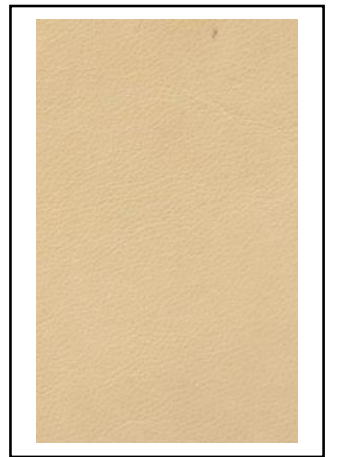

CÓDIGO: C0-040

TIPO DE PIEL: Cordero

TINTA: Azul opaco

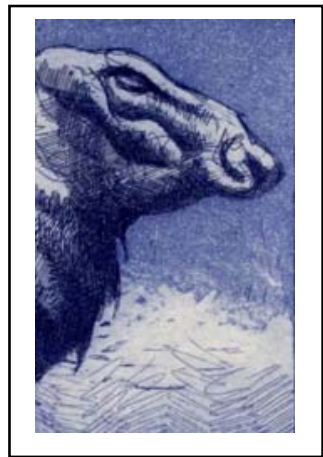

TÉCNICA: Calcografía

TONO DE PIEL: Claro

SUPERFICIE: Lado flor 


\section{CALIDAD: Muy buena}

Ejemplo de extraordinaria calidad general, muy superior a la realizada empleando tinta traslúcida ya que en este caso la imagen logra alcanzar una intensidad en su contraste con el soporte que permite la aparición de una estampa muy interesante. No existen excesivos problemas de secado y asentamiento de la tinta azul opaco, siempre que el tiempo de secado sea lo suficientemente largo.

AGUATINTA: De excelentes resultados en ambos tonos presentes en la plancha. El tono más claro (el cual es en muchas ocasiones el que mayores inconvenientes ofrece) está estampado con gran nitidez y claridad, sin problemas reseñables.

AGUAFUERTE: Perfecto, con todas y cada una de las líneas registradas de manera muy satisfactoria sobre el soporte piel sin que aparezcan problemas de nitidez en los grafismos.

CONTRASTE: Lo suficientemente intenso como para permitir la creación de una imagen potente desde un punto de vista plástico y estético. La tinta sufre un ligero oscurecimiento que sin embargo no llega a desvirtuar las características propias de la misma.

BRILLO: Aparece un mínimo brillo ceroso en las zonas cubiertas de tinta, reflejos que no dificultan en absoluto la correcta apreciación de la imagen. 


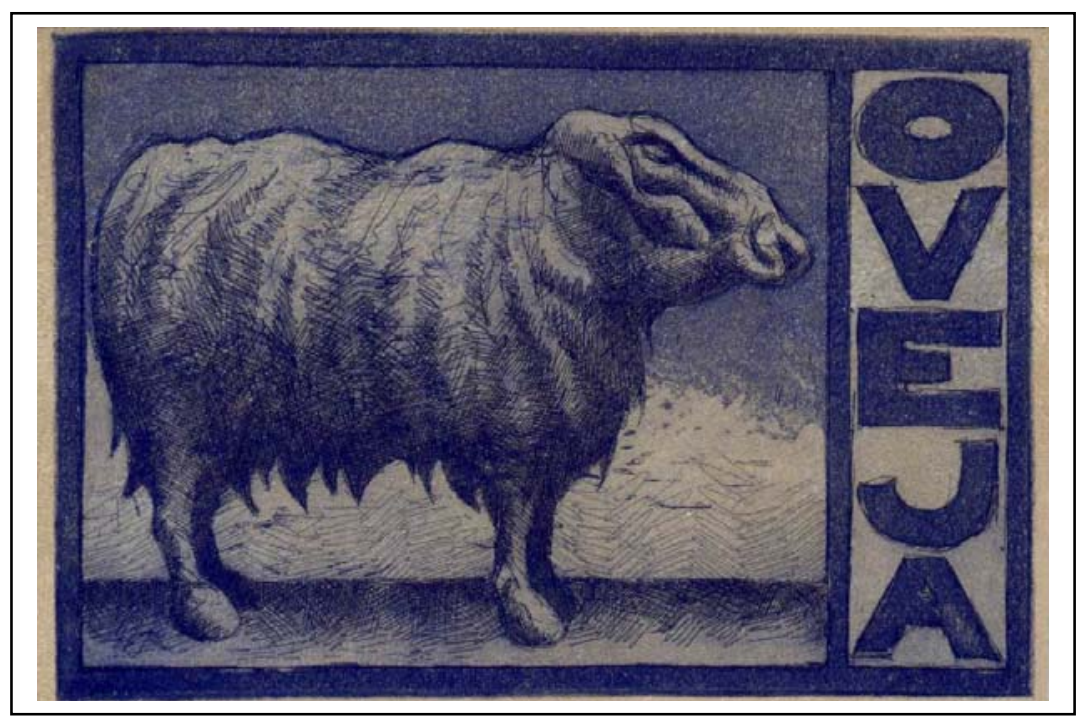

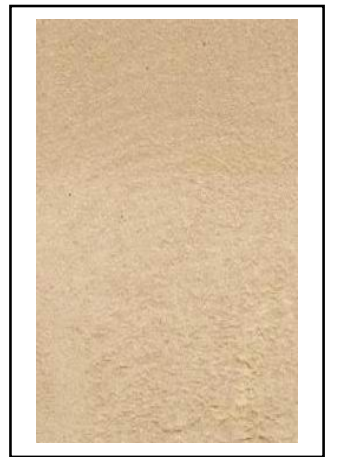

CÓDIGO: C0-041

TIPO DE PIEL: Cordero

TINTA: Azul opaco

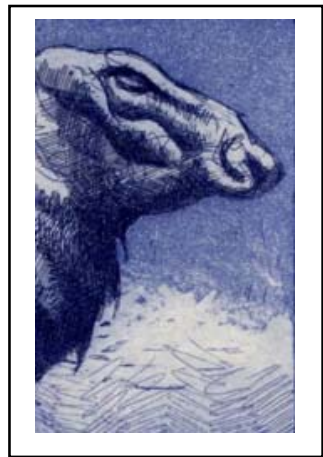

TÉCNICA: Calcografía

TONO DE PIEL: Claro

SUPERFICIE: Lado carne 


\section{CALIDAD: Muy buena}

De parecidas características a la estampa anterior sobre el lado flor, también este ejemplo alcanza unos muy altos niveles de calidad global. El ligero oscurecimiento al que se ve sometida la tinta permite la aparición de una imagen de gran potencia plástica. Indicar por otro lado que los inconvenientes relativos al secado disminuyen en gran medida debido a que el afelpado del lado carne absorbe mucho mejor la carga de tinta depositada por la plancha matriz.

AGUATINTA: Perfecta y sin inconvenientes de ningún tipo. Ambos tonos están reflejados con fidelidad y conservan la relación tonal entre ellos a pesar del citado oscurecimiento de la tinta al contacto con el afelpado del lado carne.

AGUAFUERTE: También óptimo al igual que el aguatinta, todas las líneas se registran sin problemas aparentes, con un alto grado de nitidez y sin deformaciones.

CONTRASTE: Debido al comentado oscurecimiento del tono de la tinta el nivel de contraste es algo más intenso que en su gemela sobre el lado flor (CO-040), creando una estampa muy interesante. El azul ha sufrido un ligero cambio de tonalidad haciéndose, no sólo más oscuro, sino también más grisáceo.

BRILLO: Absolutamente nulo como era de esperar sobre esta superficie afelpada del lado carne. 

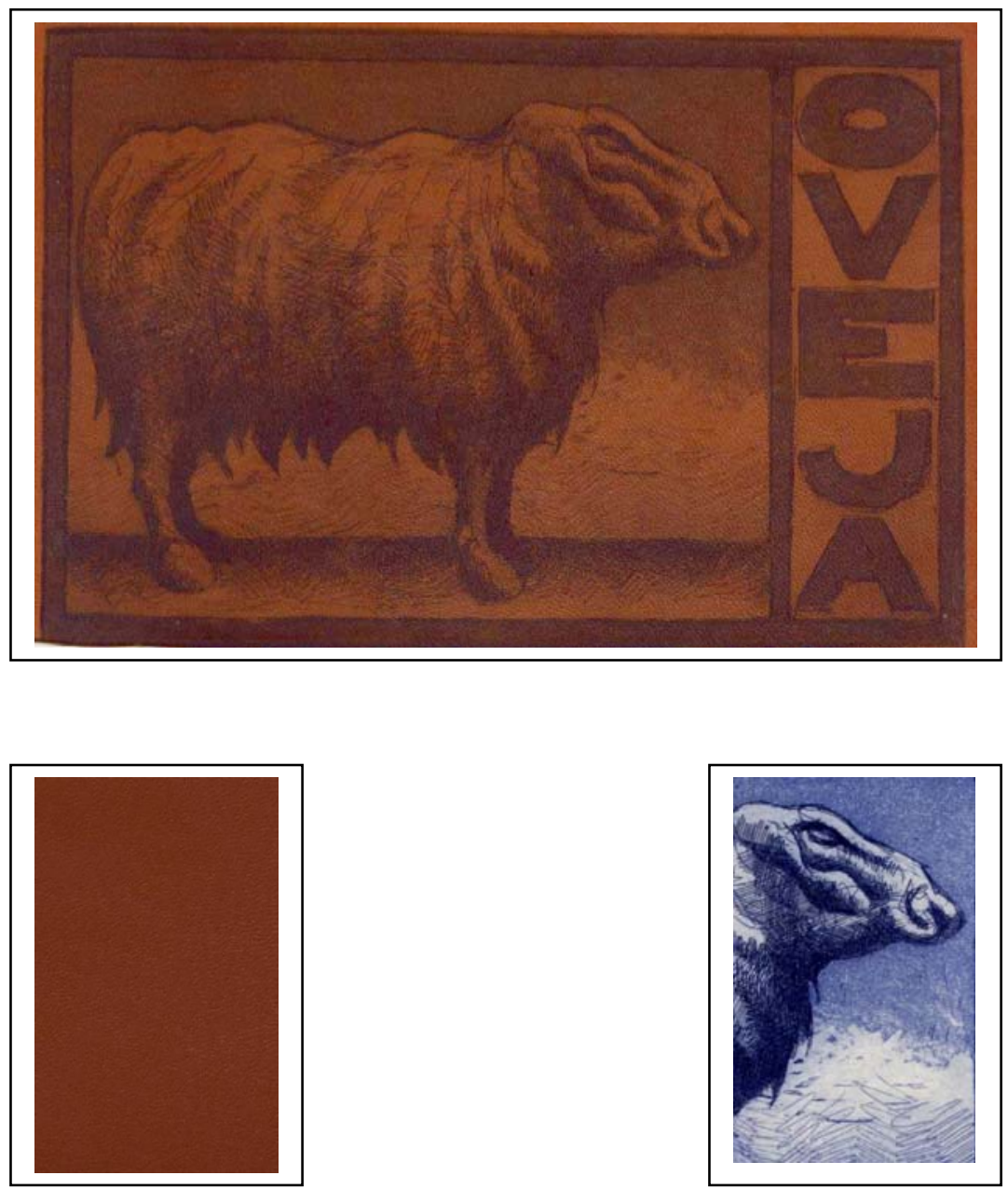

CÓDIGO: C0-042

TÉCNICA: Calcografía

TIPO DE PIEL: Cordero

TONO DE PIEL: Medio

TINTA: Azul opaco

SUPERFICIE: Lado flor 


\section{CALIDAD: Muy buena}

De nuevo estamos ante un ejemplo de altísimo nivel de calidad, con todos los campos analizados ofreciendo unos resultados muy satisfactorios y sin apenas problemas dignos de ser reseñados. Los inconvenientes relativos al secado y asentamiento de la tinta se encuentran muy disminuidos con respecto al ejemplo sobre piel de tono claro (CO-040), por lo que son casi insignificantes.

AGUATINTA: De buen resultado en ambos tonos presentes en la imagen. Pese al oscurecimiento de la tinta y a la mezcla por transparencia que aparece en la estampa, las características de las zonas de aguatinta se mantienen estables y sin irregularidades visibles.

AGUAFUERTE: Perfecto, sin problemas de registro ni nitidez de los grafismos. El único inconveniente, aunque menor, es que debido al brillo existente sobre la superficie de la piel, las líneas más finas y aisladas son visibles con algo de dificultad, aunque se encuentran estampadas de manera totalmente correcta.

CONTRASTE: Obviamente mucho menor que en los ejemplos realizados sobre tonos de soporte más claros. Pese a todo todavía es lo suficientemente intenso como para que la imagen posea un indudable interés plástico.

BRILLO: Como hemos indicado, la superficie del cuero presenta un brillo evidente, el cual no es modificado sustancialmente por la película de tinta depositada sobre ella. 

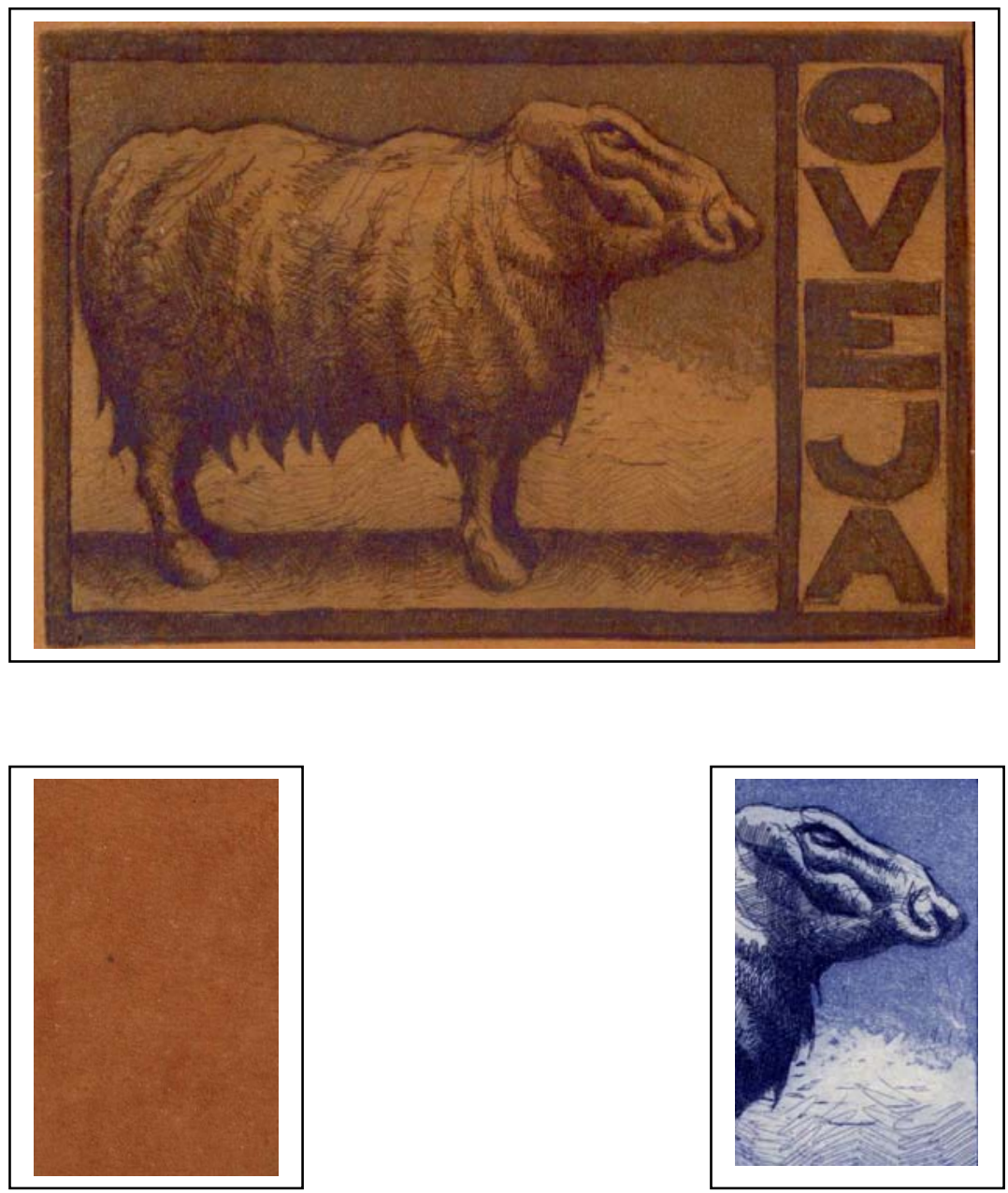

CÓDIGO: C0-043

TÉCNICA: Calcografía

TIPO DE PIEL: Cordero

TONO DE PIEL: Medio

TINTA: Azul opaco

SUPERFICIE: Lado carne 
CALIDAD: Muy buena

De parecidas características a la anterior (CO-042) aunque con un mayor contraste provocado por el marcado oscurecimiento de la tinta azul al contacto con la superficie afelpada del lado carne del cuero. Además de este proceso de oscurecimiento se puede apreciar una evidente mezcla por transparencia, convirtiéndose el azul original en un marrón violáceo de gran intensidad.

AGUATINTA: Perfecta, con un registro homogéneo y regular de todas las áreas entintadas de la superficie del soporte piel. El tono más claro ofrece un resultado óptimo pese al afelpado del acabado del cuero en su lado interno. El oscurecimiento no afecta a la relación tonal entre ambas intensidades del seño del aguatinta.

AGUAFUERTE: También óptimo en sus resultados, con absolutamente todas las líneas perfectamente registradas sin ningún problema de nitidez en lo que al registro del seño se refiere. El ligero afelpado del cuero no logra interferir en la calidad del grafismo, incluso de aquellos más finos y sutiles.

CONTRASTE: Mucho más intenso que en su gemela sobre el lado flor de esta misma piel. El oscurecimiento del tono de la tinta es fundamental para alcanzar este nivel de intensidad del contraste que venimos comentando.

BRILLO: Totalmente nulo al estar estampado sobre una superficie afelpada que absorbe los reflejos que pudieran producirse. 


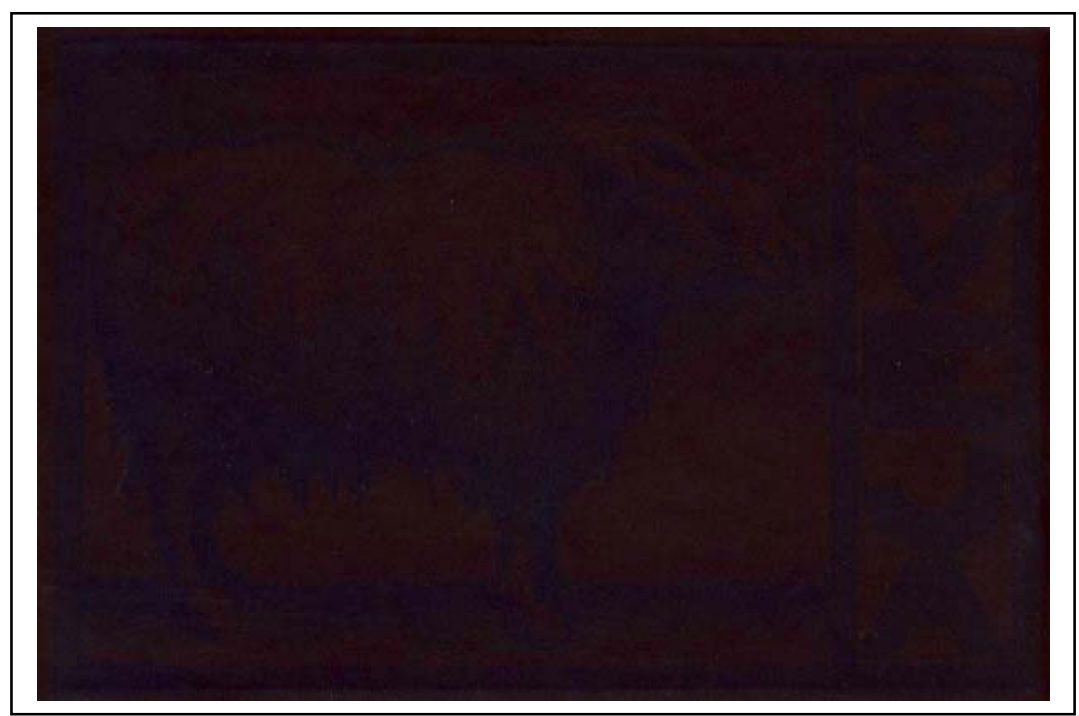

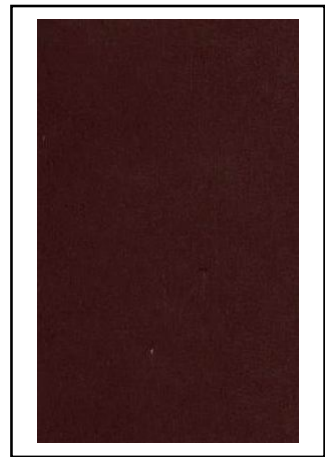

CÓDIGO: C0-044

TIPO DE PIEL: Cordero

TINTA: Azul opaco

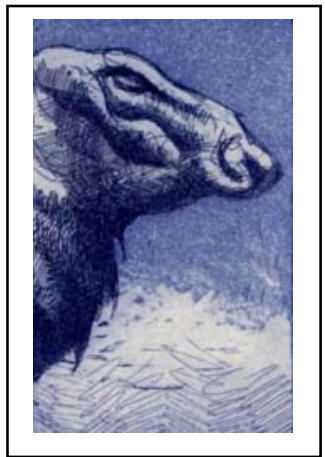

TÉCNICA: Calcografía

TONO DE PIEL: Oscuro

SUPERFICIE: Lado flor 


\section{CALIDAD: Muy mala}

Al igual que en otros ejemplos ya comentados con anterioridad sobre el mismo tipo de piel (CO-029 y CO-038), esta imagen se presenta como absolutamente inútil desde un punto de vista estético y plástico. El nulo contraste hace casi imposible distinguir los contornos de la figura estampada sobre el cuero, dificultando al máximo el estudio de esta estampa. Por otro lado, y como único dato positivo a destacar, indicar que los problemas de secado y asentamiento de la tinta desaparecen casi por completo.

AGUATINTA: Casi imposible de analizar ya que tan sólo, y bajo una iluminación muy especial, se pueden distinguir las zonas más oscuras del aguatinta, aquellas referentes a los bordes de la imagen estampada sobre el cuero. Por lo demás nos es imposible analizar más en profundidad este elemento.

AGUAFUERTE: Todavía peor que el aguatinta ya que apenas se pueden diferenciar las zonas de mayor agrupamiento de líneas y grafismos, desapareciendo por completo las líneas aisladas, ya sean las de carácter más sutil como aquellas más potentes y gruesas.

CONTRASTE: Absolutamente nulo debido al tono tan oscuro del soporte piel. Ni siquiera una tinta tan potente como el azul opaco empleado en esta estampa logra contrastar con el cueto.

BRILLO: La tinta no modifica el ya de por sí bastante intenso brillo presente en la superficie de la piel. 


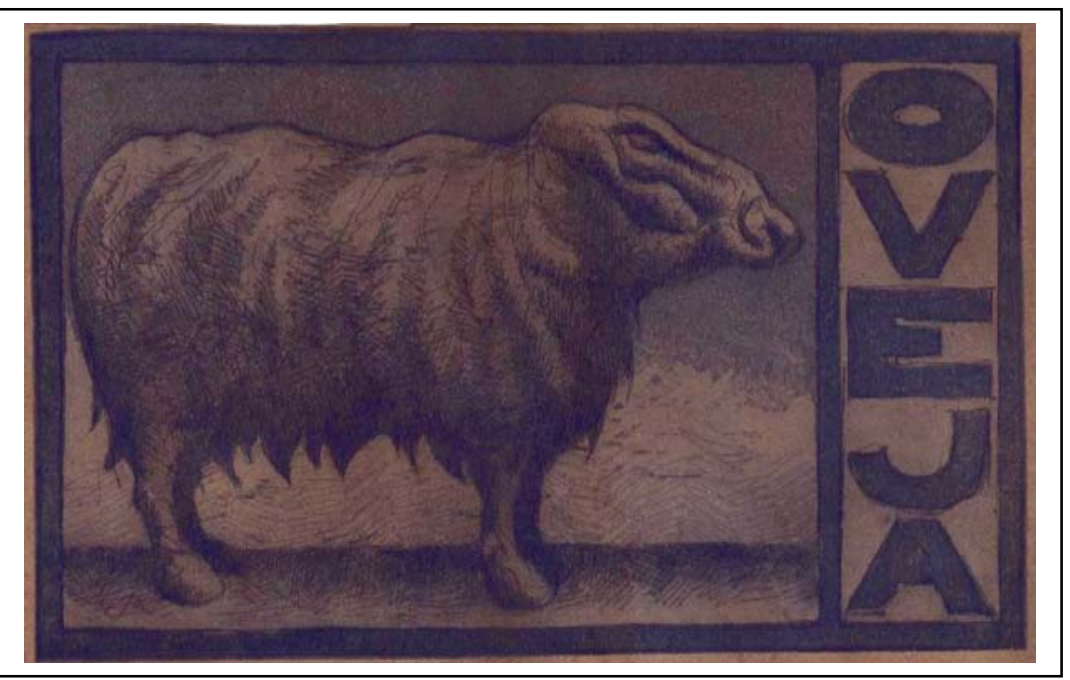

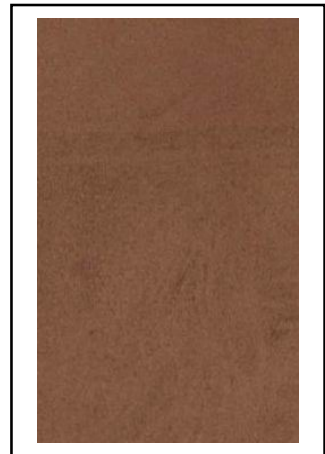

CÓDIGO: C0-045

TIPO DE PIEL: Cordero

TINTA: Azul opaco

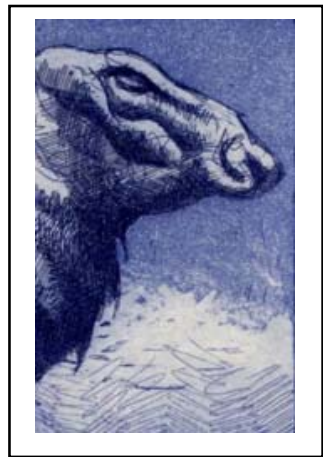

TÉCNICA: Calcografía

TONO DE PIEL: Oscuro

SUPERFICIE: Lado carne 


\section{CALIDAD: Buena}

A diferencia de la anterior (CO-044) esta estampa ofrece una apariencia mucho más atractiva y válida para nuestro estudio, determinada por el mayor grado de contraste alcanzado entre el tono de la tinta y el del soporte. El oscurecimiento de la tinta, unido a ese soporte más claro, permite la aparición de una imagen de cierto nivel, muy alejada de los pésimos resultados de su gemela sobre el lado flor.

AGUATINTA: Muy correcta en ambas intensidades. Tanto las zonas más oscuras como aquellas más claras están reflejadas sin ningún tipo de problema de importancia. El oscurecimiento es patente, así como la mezcla por transparencia, la cual provoca que el azul inicial se transforme en un tono mucho más oscuro y cercano al gris azulado intenso.

AGUAFUERTE: Perfecto en su definición y registro. Las líneas más sutiles y finas se encuentran perfectamente estampadas a pesar del afelpado que recubre la superficie del cuero en su lado carne.

CONTRASTE: Sin llegar a ser todo lo intenso que sería deseable, si alcanza unos niveles suficientes como para permitir apreciar la imagen sin el menor tipo de problemas. Sin duda es la gran ventaja con respecto a su compañera sobre el lado flor, mucho más oscuro.

BRILLO: Inexistente como era de esperar sobre una superficie afelpada como la de este cuero en su lado carne. 

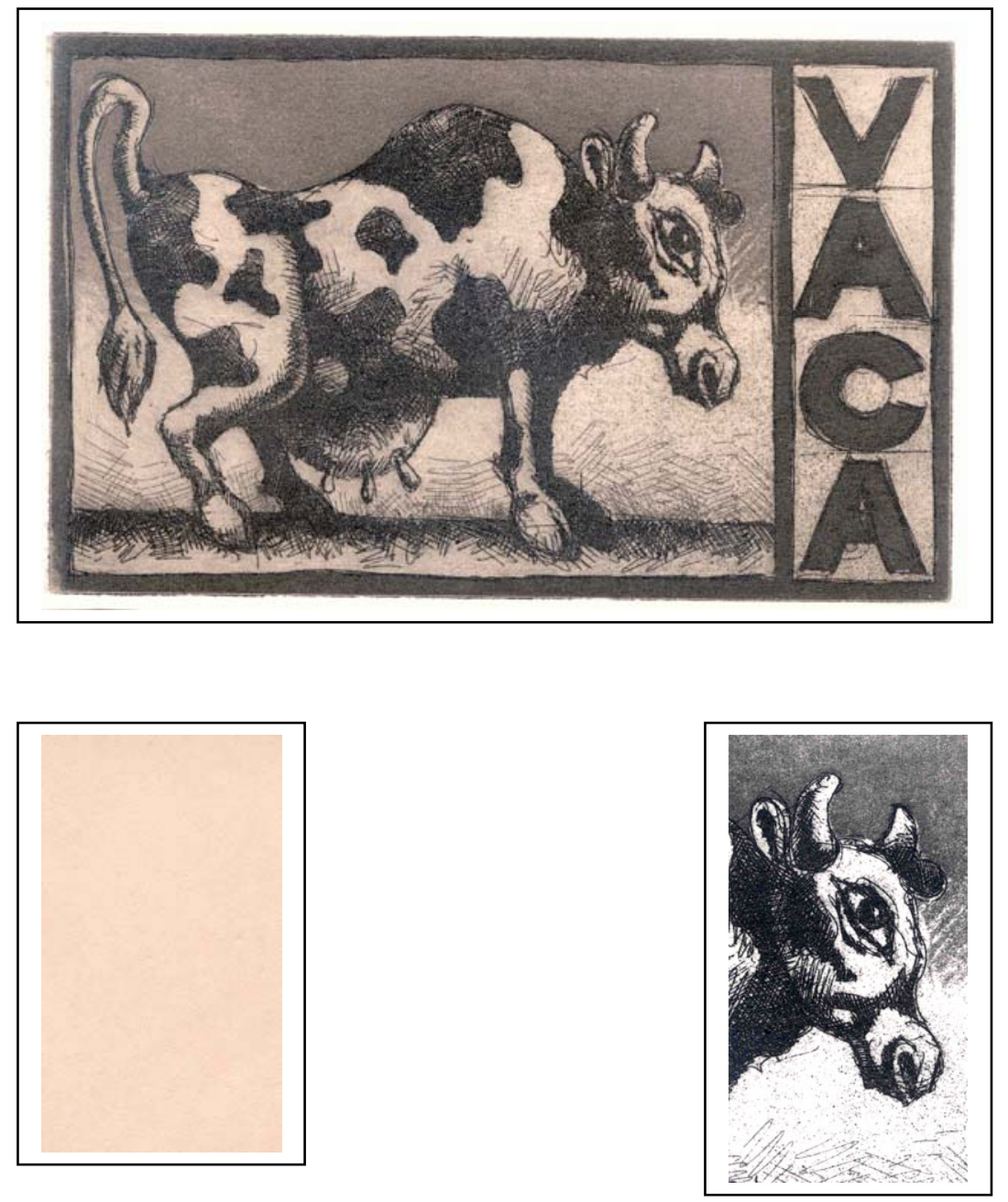

CÓDIGO: VA-025

TÉCNICA: Calcografía

TIPO DE PIEL: Vaca

TONO DE PIEL: Claro

TINTA: Negro

SUPERFICIE: Lado flor 


\section{CALIDAD: Muy buena}

Estampa de excepcional resultado y calidad, sin ninguna duda una de las mejores de todo el conjunto del estudio. No posee problemas ni inconvenientes y todo son ventajas al usar esta piel en concreto.

AGUATINTA: Perfecta. Ambos tonos están registrados y estampados con absoluta fidelidad y perfección, incluso con mejores resultados que en determinados tipos de papel.

AGUAFUERTE: Perfecto. Todos los seños presentes en la matriz, por minúsculos que fueran, están registrados con tremenda nitidez en la superficie de la piel. No se observan irregularidades ni problemas en ningún tipo de grafismo.

CONTRASTE: Muy intenso y adecuado. La tinta negra asienta perfectamente bien sobre el soporte creando un negro intenso que contrasta sin problemas con el tono de la piel. Se crea una imagen potente y válida desde todos los puntos de vista.

BRILLO: Aparece un ligero brillo que, al contrario de lo que pudiera parecer, favorece a la imagen ya que la dota de intensidad y vivacidad, ayudando a la creación de una estampa perfecta en todos los sentidos. 

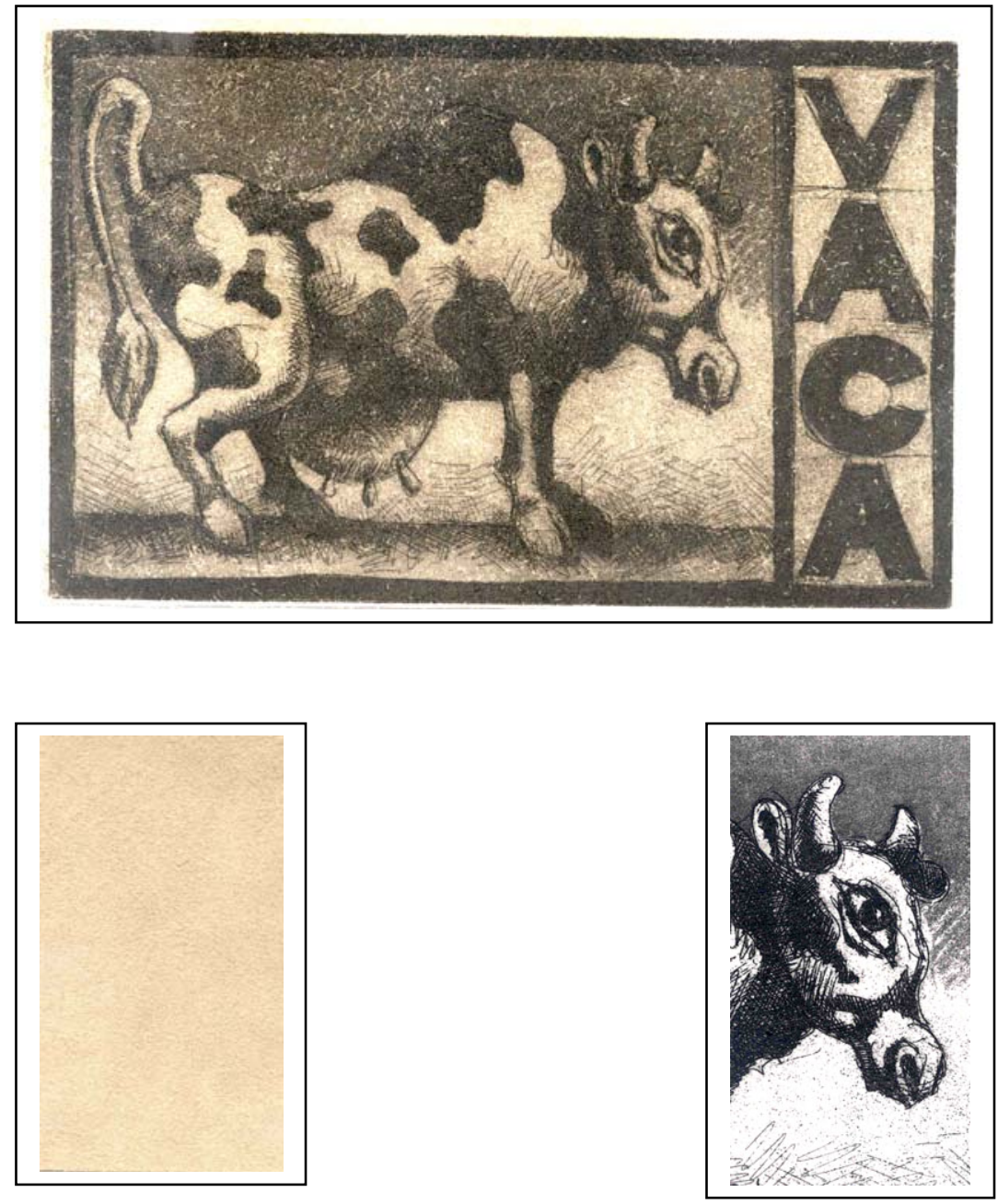

CÓDIGO: VA-026

TÉCNICA: Calcografía

TIPO DE PIEL: Vaca

TONO DE PIEL: Claro

TINTA: Negro

SUPERFICIE: Lado carne 


\section{CALIDAD: Mediocre}

Ejemplo de mediocre calidad que contrasta sobremanera con el excepcional resultado del lado flor (VA-019). Este descenso de calidad es debido a la excesiva rugosidad de esta superficie, con un afelpado demasiado acuciado el cual perjudica a algunos factores de la imagen.

AGUATINTA: Mediocre debido a que la tinta no se muestra capaz de cubrir todos los "pelos" presentes en la superficie de la piel, apareciendo una textura irregular que dificulta la correcta visión de la estampa.

AGUAFUERTE: Sufre las mismas dificultades que el aguatinta, aunque en este caso son menos patentes. Los registros son correctos pero las líneas se desvirtúan por efecto del excesivo afelpado de la superficie de la piel.

CONTRASTE: Intenso y correcto en líneas generales, aunque la textura del pelo dificulta la visión de la imagen. También indicar que se observa un acuciante oscurecimiento de toda la estampa por efecto del afelpado del lado carne.

BRILLO: Absolutamente nulo debido al exceso de afelpado presente en la superficie del soporte. 

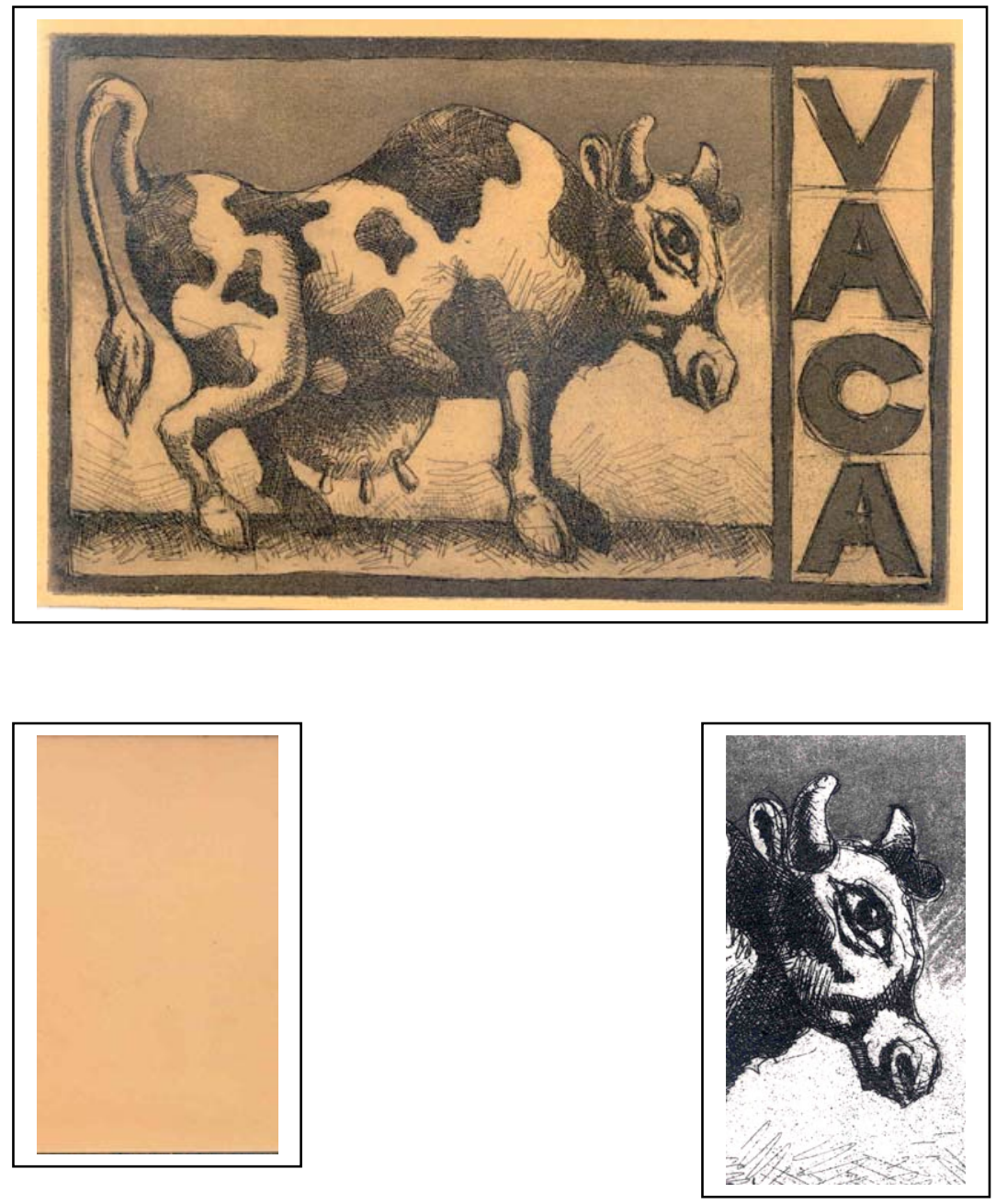

CÓDIGO: VA-027

TÉCNICA: Calcografía

TIPO DE PIEL: Vaca

TONO DE PIEL: Medio

TINTA: Negro

SUPERFICIE: Lado flor 


\section{CALIDAD: Muy buena}

Imagen de muy buenos resultados, casi tanto como el ejemplo sobre la piel clara (VA-025). Este tipo de piel se nos muestra como una superficie excelente e idónea para realizar grabados calcográficos sobre ella.

AGUATINTA: Perfecta. Ambos tonos se estampan con absoluta nitidez. La superficie tan lisa de la piel permite un registro exacto de todos y cada uno de los distintos tonos de grises presentes en la matriz.

AGUAFUERTE: Al igual que el aguatinta también perfecto. Todas las líneas están registradas con absoluta claridad. Tanto los trazos más sutiles como los gruesos y potentes están estampados perfectamente y sin irregularidades.

CONTRASTE: Correcto a pesar de que el tono del soporte-piel ha subido un tanto. Ahora tenemos un marrón medio algo más oscuro que en los ejemplos anteriores, pero esto no impide que se cree un adecuado e intenso contraste y por tanto una imagen totalmente válida.

BRILLO: Podemos encontrar un marcado brillo provocado por la superficie tan satinada de la piel y la gran cantidad de tinta presente en algunas zonas de la imagen. Sin embargo la imagen no se ve perjudicada en demasía por estos reflejos. 

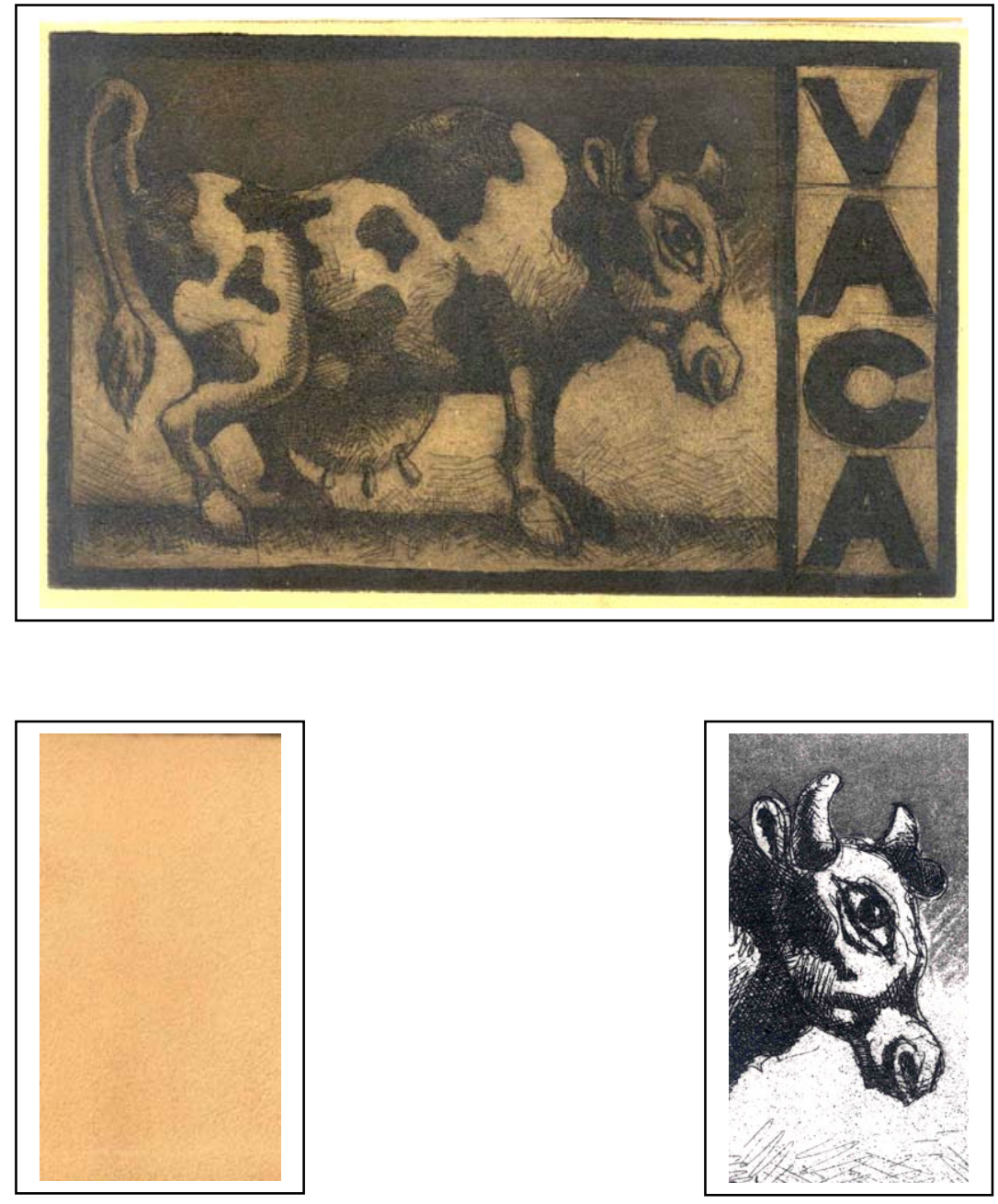

CÓDIGO: VA-028

TÉCNICA: Calcografía

TIPO DE PIEL: Vaca

TONO DE PIEL: Medio

TINTA: Negro

SUPERFICIE: Lado carne 


\section{CALIDAD: Mediocre}

Estampa de aceptable calidad pero que muestra algunos defectos relacionados con la presencia de un acabado afelpado en este lado carne de la piel.

AGUATINTA: Se produce un claro oscurecimiento general de los tonos del aguatinta provocado por el afelpado, lo que conlleva que ambos grises se igualen hasta confundirse en algunas zonas.

AGUAFUERTE: Muy correcto y de buen resultado general en ambos seños.

CONTRASTE: Por efecto del afelpado presente en la superficie de la piel podemos observar un marcado proceso de oscurecimiento de toda la estampa, lo que provoca modificaciones en la intensidad del contraste. En efecto, éste se ve disminuido en su potencia e intensidad, obteniéndose una estampa demasiado oscura y sin la vivacidad que sería deseable.

BRILLO: A pesar del afelpado de la superficie de la piel podemos apreciar la aparición de ciertos brillos en las zonas entintadas. Esto es debido a que dicho acabado "a felpa" no es excesivamente rugoso y a la gran cantidad de tinta recogida por la piel. 


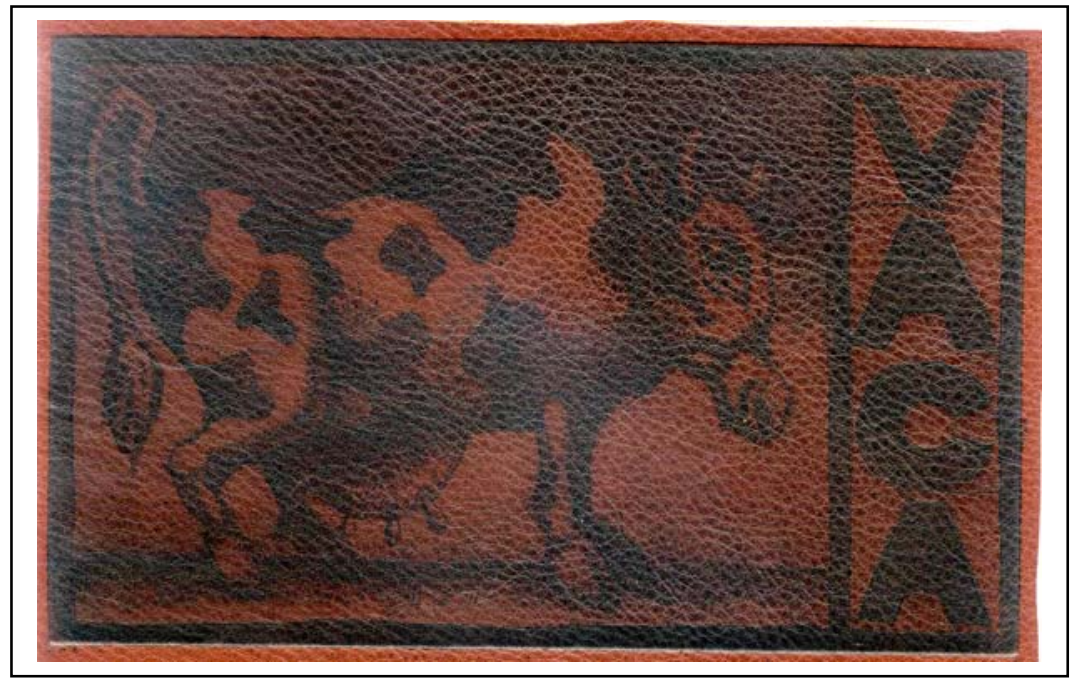

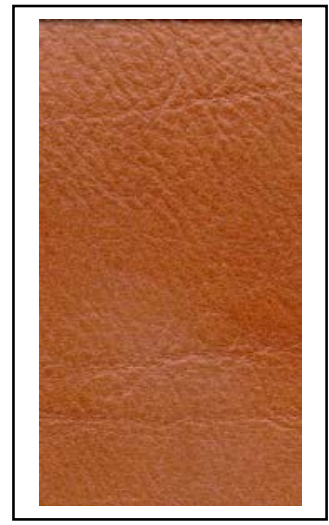

CÓDIGO: VA-029

TIPO DE PIEL: Vaca

TINTA: Negro

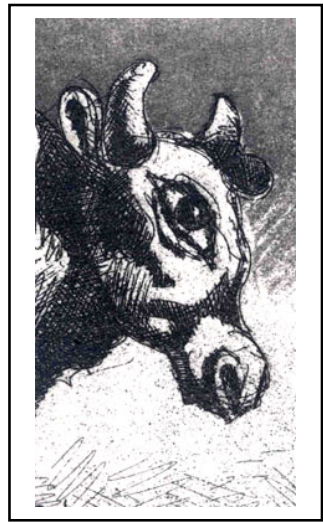

TÉCNICA: Calcografía

TONO DE PIEL: Oscuro

SUPERFICIE: Lado flor 


\section{CALIDAD: Muy mala}

Estampa de mediocres resultados por efecto de dos factores determinantes: por un lado el tono tan oscuro del soporte piel y por otro el acusado brillo que aparece sobre la superficie de la estampa.

AGUATINTA: Los dos tonos se igualan casi totalmente formando una mancha uniforme y muy oscura que, a pesar de ello, es de difícil apreciación por lo oscuro de la superficie de la piel.

AGUAFUERTE: Las líneas se han perdido casi totalmente y son muy difíciles de percibir y apreciar. Tan sólo en aquellas zonas donde se produce una acumulación de grafismos podemos observar un área más oscura aunque sin llegar a distinguir dichas líneas.

CONTRASTE: Mínimo. Se trata del gran problema de esta estampa ya que la tinta negra no es capaz de contrastar lo suficiente con el tono tan oscuro del soporte, por lo que la imagen se nos presenta como excesivamente oscura.

BRILLO: La piel ya poseía de por sí un marcado brillo por lo que, tras la estampación, en las zonas entintadas aparecen una serie de reflejos que resultan muy molestos. 


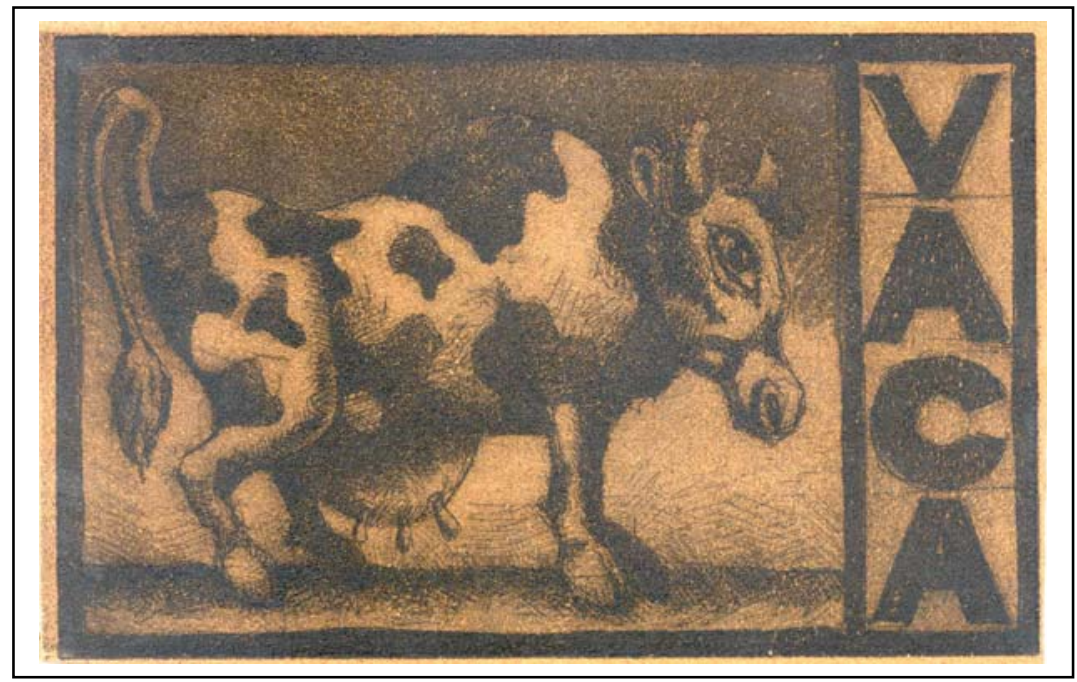

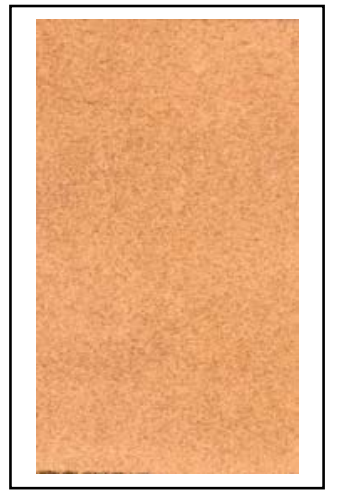

CÓDIGO: VA-030

TIPO DE PIEL: Vaca

TINTA: Negro

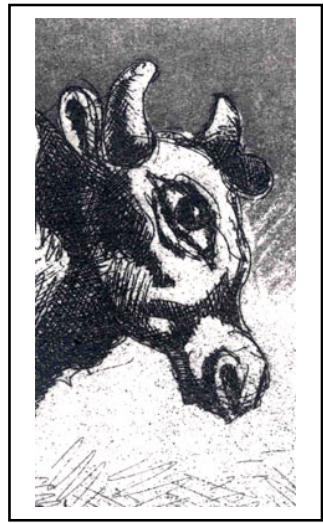

TÉCNICA: Calcografía

TONO DE PIEL: Oscuro

SUPERFICIE: Lado carne 


\section{CALIDAD: Mala}

Ejemplo de mediocre calidad por efecto, de nuevo, del excesivo afelpado de la superficie de la piel. Esta textura tan rugosa impide que los seños se registren con normalidad a la vez que provoca un oscurecimiento tremendo de la imagen.

AGUATINTA: Demasiado oscuros ambos tonos, sobre todo aquel más claro. En efecto los grises se oscurecen en demasía hasta convertirse en tonos casi negros y llegar a fundirse con las zonas más oscuras de la estampa.

AGUAFUERTE: Por efecto del afelpado muchos seños y líneas se pierden casi totalmente y tan sólo se perciben como zonas oscuras aunque sin apenas nitidez.

CONTRASTE: Escaso debido a dos factores: por un lado el tono algo elevado del soporte piel y por otro el patente oscurecimiento que sufre la práctica totalidad de la estampa. Estos dos elementos provocan que el contraste, a pesar de ser algo más intenso que sobre el lado flor (VA-023), no consiga crear una imagen potente y válida.

BRILLO: Prácticamente nulo debido a que el afelpado de la superficie de la piel absorbe los posibles reflejos que pudieran crearse en ella. 


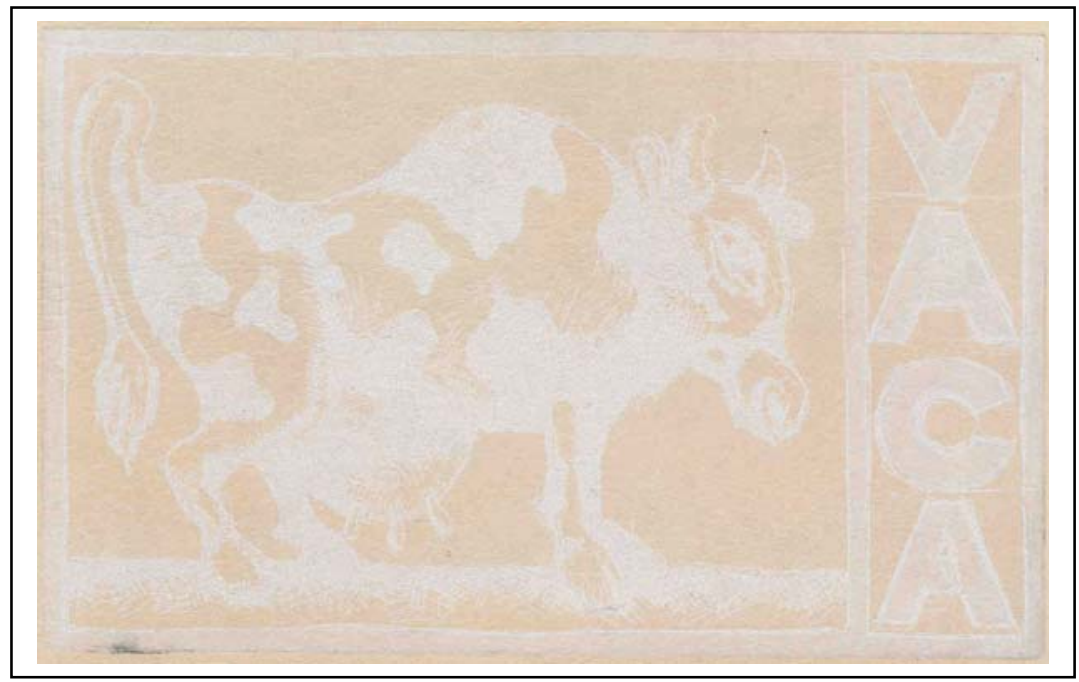

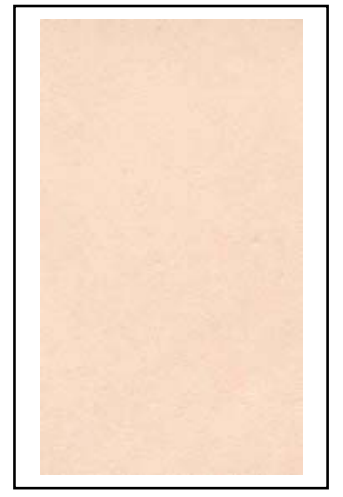

CÓDIGO: VA-031

TIPO DE PIEL: Vaca

TINTA: Blanca

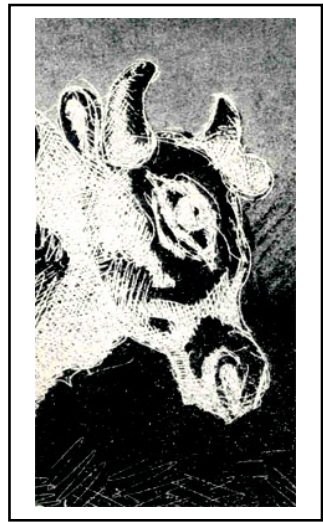

TÉCNICA: Calcografía

TONO DE PIEL: Claro

SUPERFICIE: Lado flor 


\section{CALIDAD: Muy mala}

Como ya hemos visto en muchos ejemplos anteriores el uso de tintas blancas en estampas calcográficas no es muy conveniente. Esta imagen nos vuelve a demostrar lo que ya sabíamos ya que presenta una serie de inconvenientes de muy difícil solución.

AGUATINTA: Pésima. El tono más claro desaparece totalmente y es imposible distinguirlo del fondo. Por su lado el tono más intenso nunca alcanza el grado de saturación necesario para hacerse visible sin problemas, convirtiéndose en un gris "sucio" muy pálido que se pierde en el conjunto de la estampa.

AGUAFUERTE: Muy mediocre. Las líneas aisladas son casi imposibles de distinguir y tan sólo en aquellas zonas de acumulación de grafismos podemos observar unas manchas de un gris "sucio". En definitiva de horrorosos resultados generales.

CONTRASTE: Escasísimo. La tinta blanca no alcanza un grado de saturación adecuado por lo que, unido al tono tan claro del soporte piel, el contraste es mínimo. Por tanto la imagen obtenida es vaga y carente de toda fuerza plástica y expresiva.

BRILLO: Apenas aparece un ligerísimo brillo sobre las zonas entintadas pero sin llegar a ser molesto en ningún caso. 


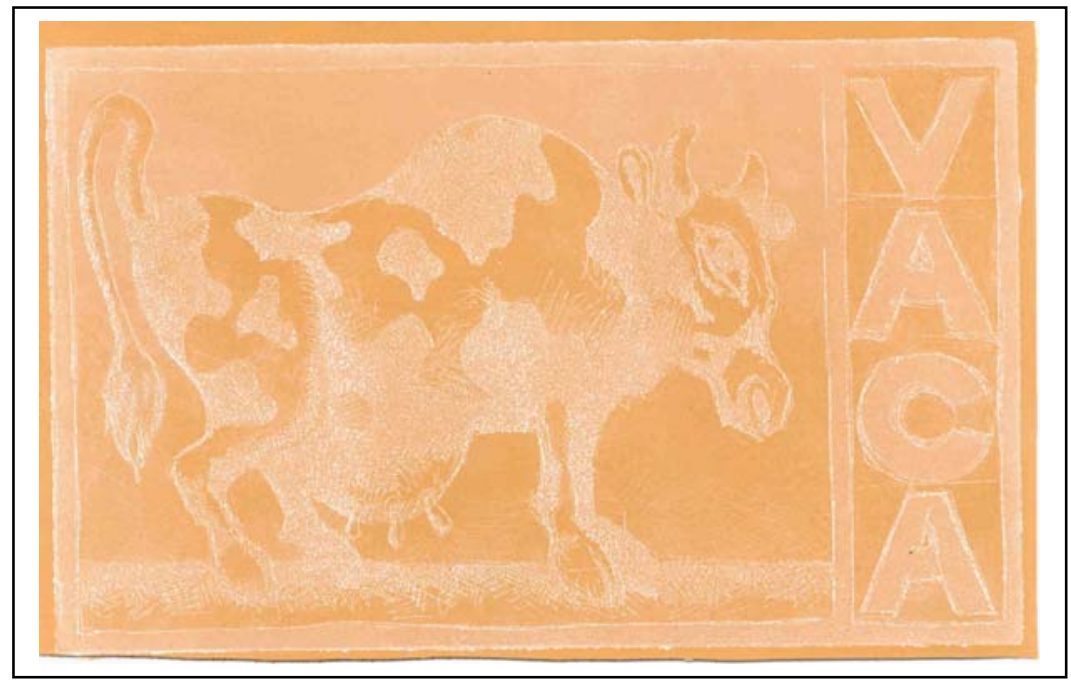

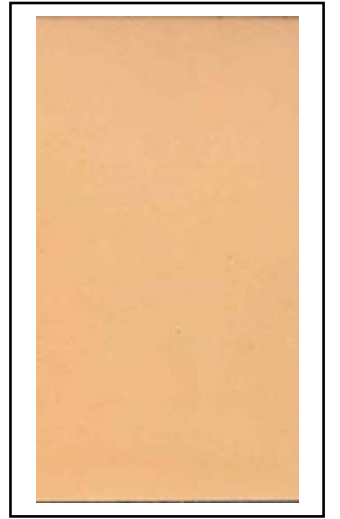

CÓDIGO: VA-032

TIPO DE PIEL: Vaca

TINTA: Blanca

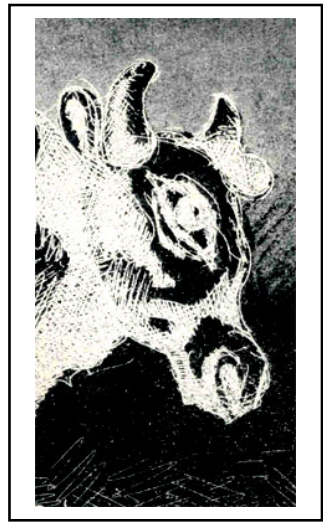

TÉCNICA: Calcografía

TONO DE PIEL: Medio

SUPERFICIE: Lado flor 


\section{CALIDAD: Muy mala}

Ejemplo algo mejor que el realizado sobre la piel de tono claro (VA024) por efecto de un mayor contraste entre la tinta "blanca" y el soporte piel. Aún así no alcanza un nivel mínimo de calidad como para poder afirmar que se trata de un estampa válida.

AGUATINTA: El tono más sutil comienza a hacerse visible pero se funde totalmente con el oscuro. Así, tenemos una gran mancha de la misma intensidad tonal sin poder distinguirse apenas las diferencias entre una y otra zona. El resultado es en definitiva mediocre.

AGUAFUERTE: Las líneas aisladas más potentes y gruesas son las únicas que se perciben, aunque no sin dificultades e irregularidades. Por su parte las líneas más finas desaparecen casi por completo y tan sólo en las zonas de mayor densidad de grafismos podemos percibir claramente la existencia de las mismas. Indicar que en estas zonas se produce un efecto ya comentado con anterioridad en algunas estampas xilográficas: la aparición de una textura "a grumos" en las zonas de mayor cantidad de tinta.

CONTRASTE: Algo mejor y más intenso pero todavía insuficiente para crear una imagen potente y válida desde un punto de vista plástico.

BRILLO: La tinta blanca elimina el ligero brillo presente en la superficie. 


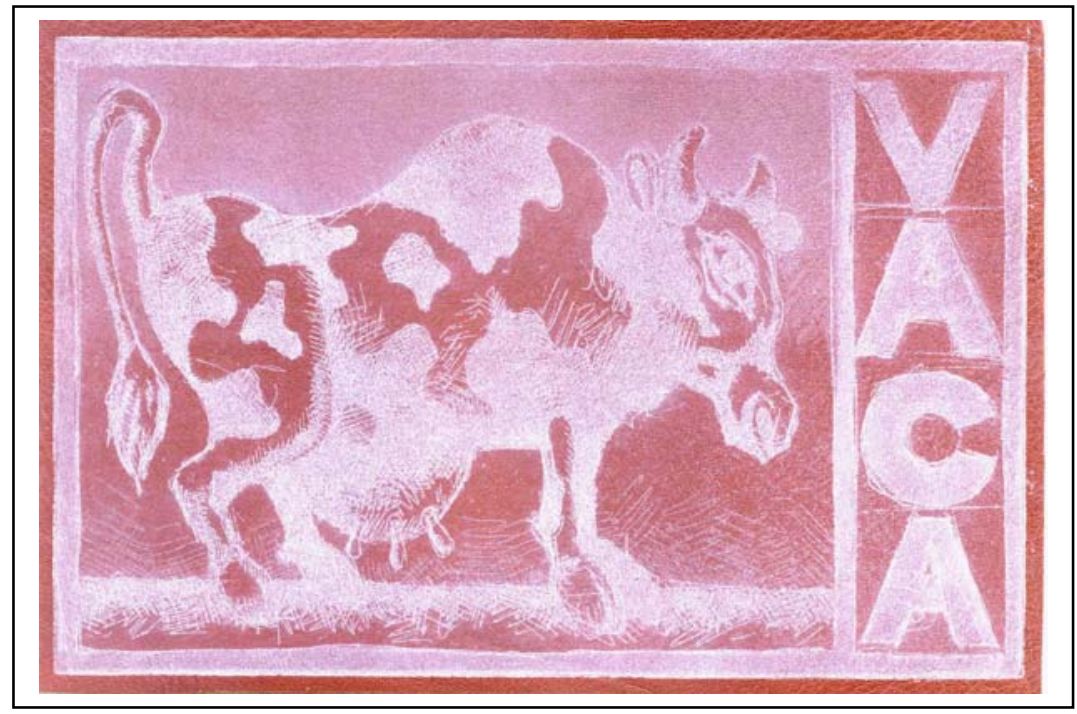

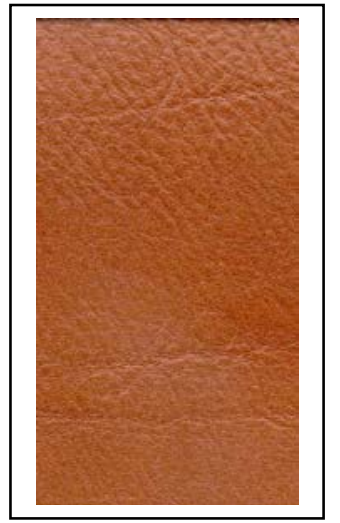

CÓDIGO: VA-033

TIPO DE PIEL: Vaca

TINTA: Blanca

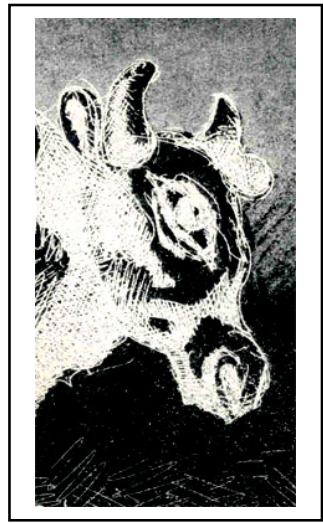

TÉCNICA: Calcografía

TONO DE PIEL: Oscuro

SUPERFICIE: Lado flor 


\section{CALIDAD: Mala}

Debido al tono tan oscuro del soporte este ejemplo parece ser algo mejor que otros anteriores, pero todavía presenta inconvenientes casi insalvables que lo convierten en una estampa de mediocre calidad.

AGUATINTA: Se hace patente la diferencia tonal entre ambas intensidades de blanco pero los resultados siguen siendo de muy baja calidad. En efecto, nunca se consigue un "blanco verdadero" por lo que la mancha es irregular y poco homogénea.

AGUAFUERTE: Todas las líneas son ya visibles aunque presentan irregularidades evidentes en su trazado. Están registradas con escasa nitidez y potencia pero el resultado es mucho mejor que en anteriores estampas.

CONTRASTE: A pesar de lo intenso del tono de la superficie de la piel el contraste no llega a ser lo intenso que cabría esperar. Esto es debido a la imposibilidad patente de la tinta blanca por conseguir una saturación correcta, por lo que el contraste permite apreciar sin problemas las formas de la imagen pero no logra crear una imagen potente.

BRILLO: Al igual que en el ejemplo sobre la piel media, la tinta blanca elimina el leve brillo que poseía la superficie del cuero por efecto de su naturaleza mate y opaca. 


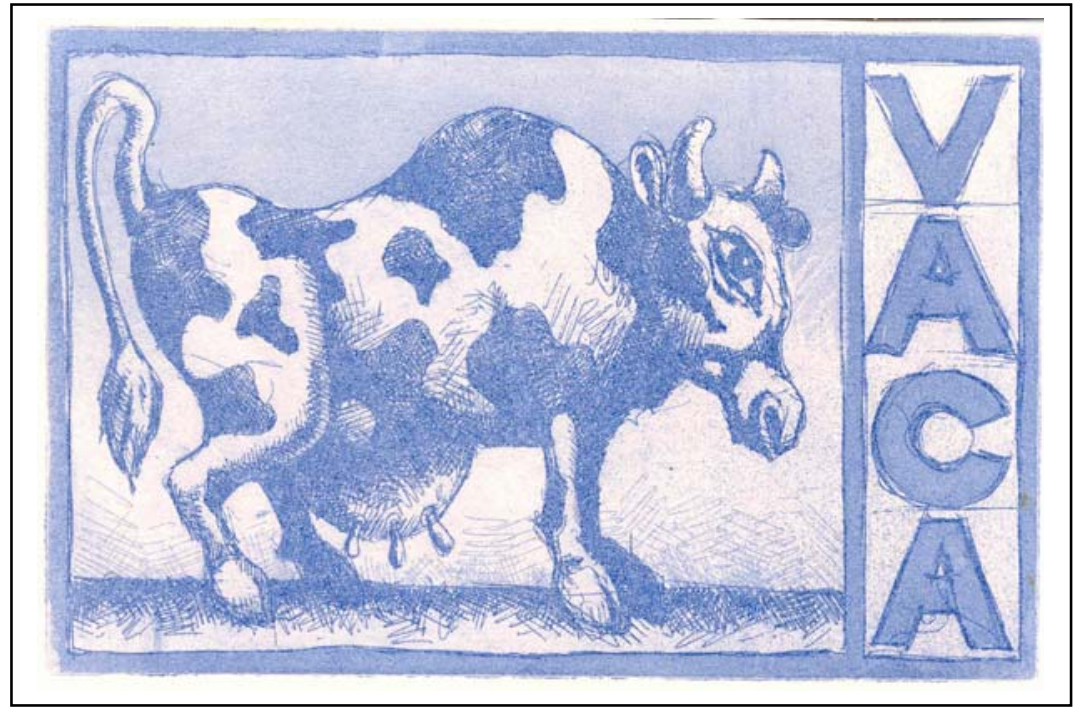

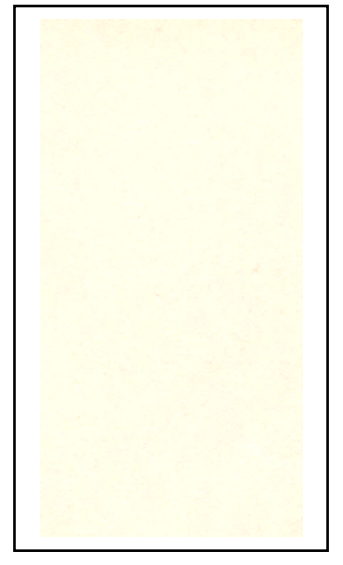

CÓDIGO: VA-034

TIPO DE PIEL: Vaca

TINTA: Azul traslúcido

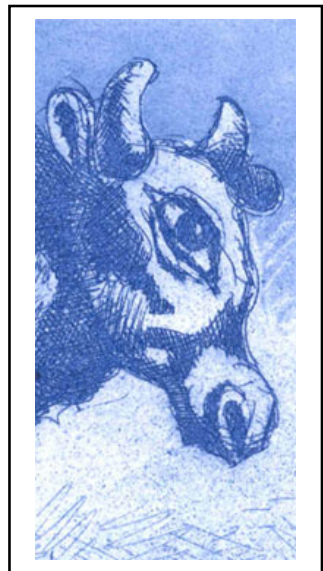

TÉCNICA: Calcografía

TONO DE PIEL: Claro

SUPERFICIE: Lado flor 
CALIDAD: Muy buena

Ejemplo de altísima calidad que demuestra que este tipo de piel vacuna es una superficie ideal para casi todo tipo de estampas calcográficas. De características muy parecidas al ejemplo con tinta negra sobre esta misma piel (VA-019).

AGUATINTA: Perfecta. No se aprecian inconvenientes de ningún tipo y ambos tonos de azul están estampados de una manera muy correcta y con una relación entre ellos perfecta.

AGUAFUERTE: De nivel muy alto. Las líneas están registradas perfectamente y tan sólo se observan mínimas irregularidades en las zonas de mayor densidad de grafismos. En estas áreas se aprecia un textura algo irregular provocada por la gran cantidad de tinta presente en la superficie, cantidad que, debido a lo satinado de la piel, ésta no es capaz de absorber con normalidad.

CONTRASTE: Perfecto. Se crea un contraste lo suficientemente intenso como para obtener una imagen perfectamente válida. A esto ayuda el ligero oscurecimiento que sufre la tinta azul transparente al contacto con una superficie algo más oscura.

BRILLO: Por efecto de lo satinado de la piel y de la gran cantidad de preparación traslúcida presente en la tinta se crean unos ligeros brillos que nunca llegan a ser molestos. 


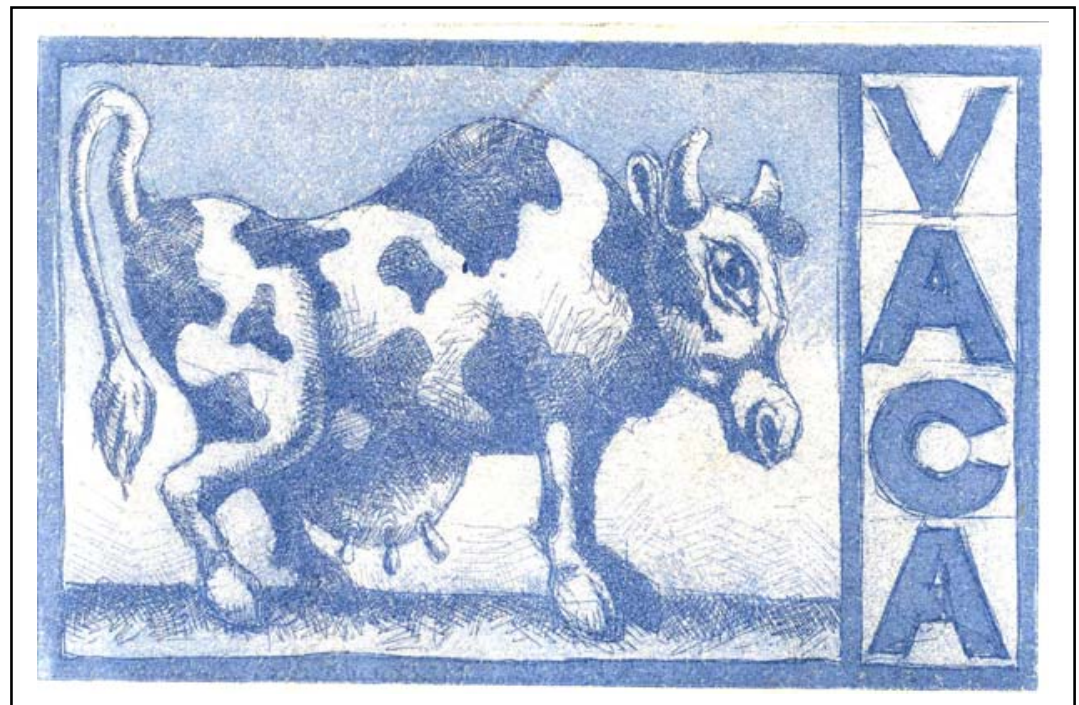

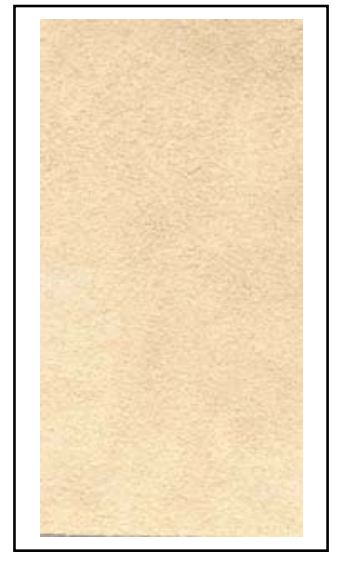

CÓDIGO: VA-035

TIPO DE PIEL: Vaca

TINTA: Azul traslúcido

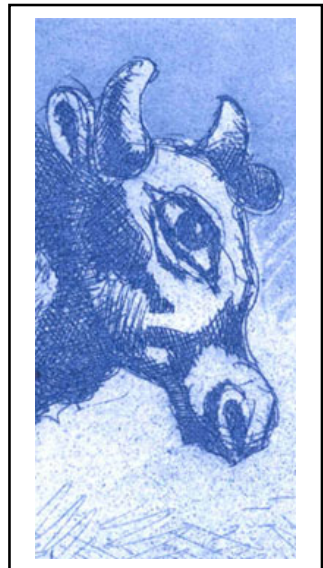

TÉCNICA: Calcografía

TONO DE PIEL: Claro

SUPERFICIE: Lado carne 


\section{CALIDAD: Buena}

Al igual que en el ejemplo con tinta negra sobre esta misma piel (VA020), aparecen inconvenientes por lo texturado de la superficie del lado carne. El excesivo afelpado provoca ciertas irregularidades que no impiden sin embargo que la estampa tenga un alto nivel de calidad.

AGUATINTA: Muy correctos ambos tonos si exceptuamos el hecho de que aparezcan mínimas irregularidades por efecto del "pelo" de la superficie, el cual no logra cubrir totalmente la tinta.

AGUAFUERTE: Casi perfecto ya que los inconvenientes relativos al afelpado no le afectan tanto como a otros factores. En las zonas de gran acumulación de grafismos no aparece la textura "a grumos", ya que esta superficie si que es capaz de absorber toda la cantidad de tinta de la estampa.

CONTRASTE: Mínimamente menos intenso que en el ejemplo anterior sobre el lado flor (VA-019), sin embargo todavía es lo suficientemente fuerte como para crear una imagen muy válida.

BRILLO: Nulo e inexistente por efecto del afelpado de la piel que sirve como soporte para la estampa. 


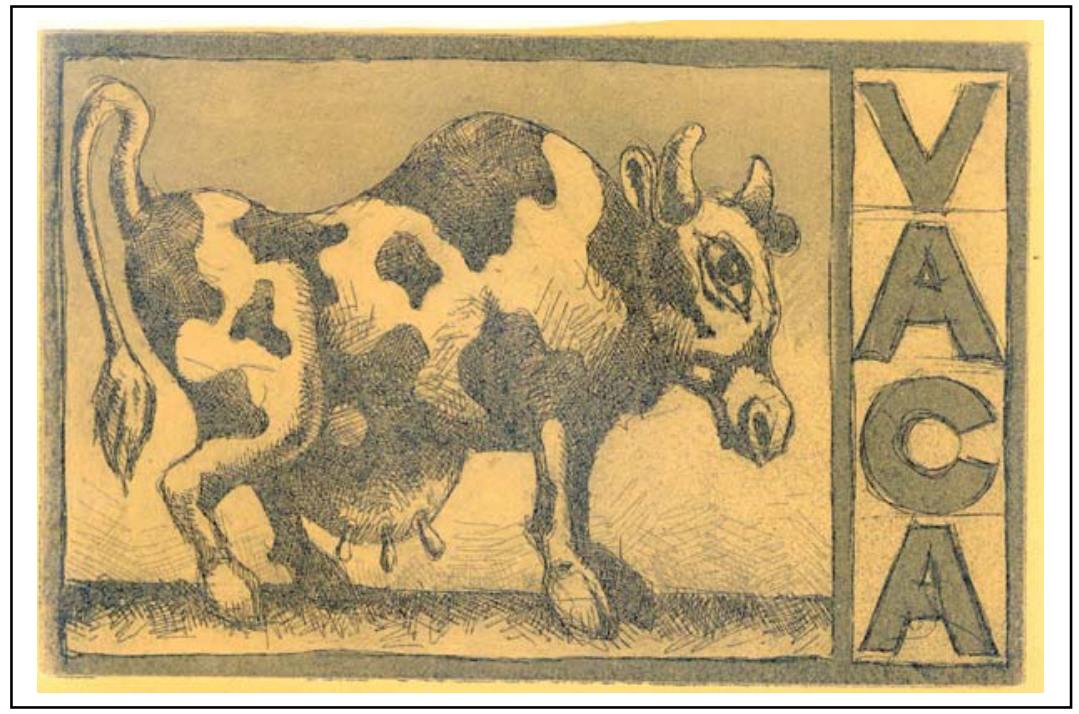

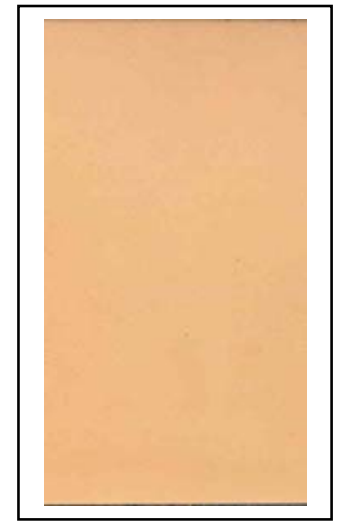

CÓDIGO: VA-036

TIPO DE PIEL: Vaca

TINTA: Azul traslúcido

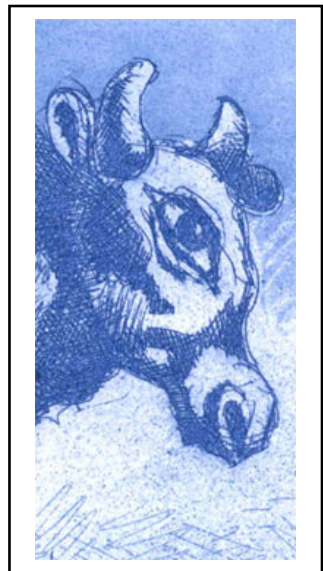

TÉCNICA: Calcografía

TONO DE PIEL: Medio

SUPERFICIE: Lado flor 


\section{CALIDAD: Buena}

Debido a lo satinado de la superficie del soporte piel, en esta estampa aparecen ciertos inconvenientes en las zonas de mayor acumulación de tinta. Sin embargo la apariencia general de la imagen es muy correcta y estas irregularidades sólo se aprecian en un examen más detallado y minucioso.

AGUATINTA: Perfecta en los tonos más claros, por el contrario en las zonas más oscuras presenta inconvenientes. En efecto, en estas áreas de mayor acumulación de tinta tenemos de nuevo la conocida textura "a grumos" por efecto de la imposibilidad de la piel para absorber toda esta cantidad de tinta de su superficie.

AGUAFUERTE: Ocurre algo similar a lo observado con el aguatinta. En las líneas aisladas no aparece ningún tipo de problema pero en las zonas de gran densidad de grafismos y seños tenemos de nuevo la textura ya comentada con anterioridad.

CONTRASTE: Algo menos intenso que en ciertos ejemplos anteriores como los VA-028 y VA-029 pero todavía suficiente como para obtener una imagen válida y correcta desde un punto de vista plástico.

BRILLO: En las zonas entintadas tenemos un patente brillo provocado por la gran cantidad de preparación traslúcida presente en la mezcla empleada para la estampación. 


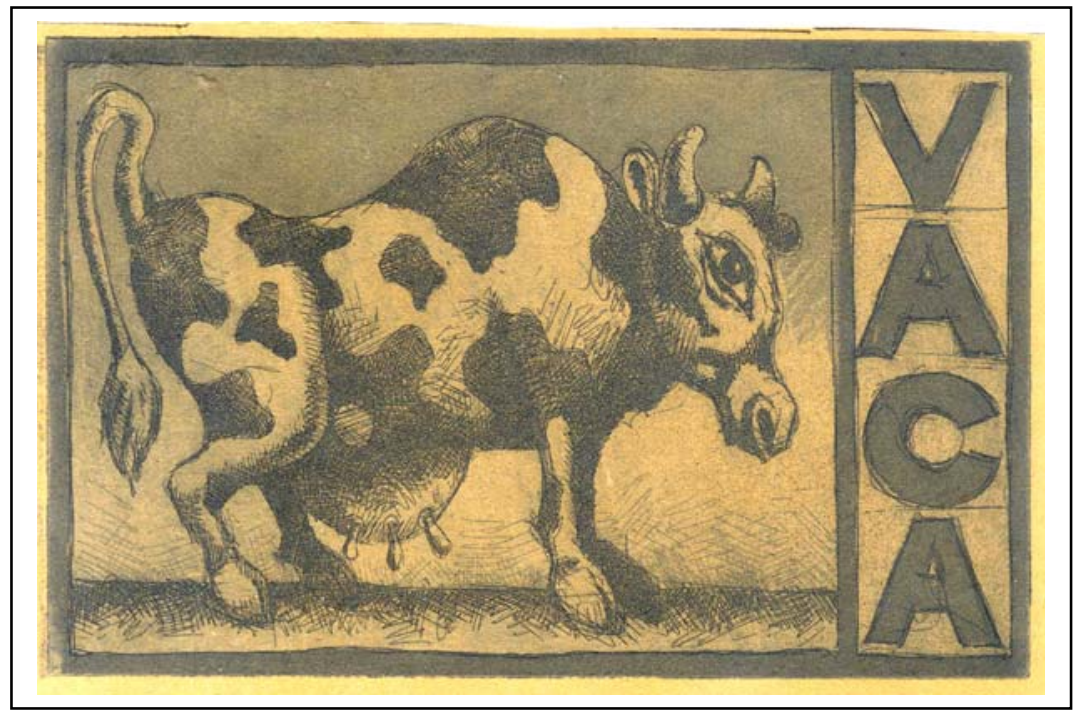

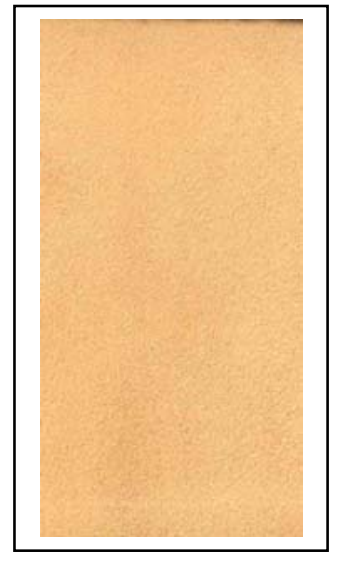

CÓDIGO: VA-037

TIPO DE PIEL: Vaca

TINTA: Azul traslúcido

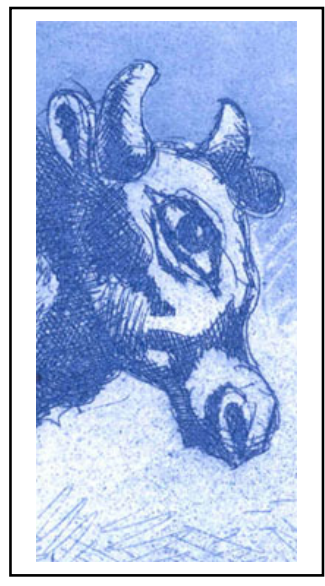

TÉCNICA: Calcografía

TONO DE PIEL: Medio

SUPERFICIE: Lado carne 


\section{CALIDAD: Muy buena}

Estampa de mejor calidad que la anterior (VA-030) debido a que el afelpado tan sutil de esta superficie evita la aparición de la textura "a grumos" tan desagradable, a la vez que no impide la obtención de una imagen de gran nitidez y claridad.

AGUATINTA: Muy correcta. Ambos tonos están registrados con gran nitidez siendo perfectamente visible y patente la diferencia entre ambos. El afelpado tan sutil de este tipo de cuero permite un registro perfecto de hasta los mínimos seños presentes en la plancha de zinc.

AGUAFUERTE: Perfecto. Sin problemas en las líneas ni en las zonas de gran acumulación de grafismos, donde ya no aparece la textura "a grumos" ya comentada con anterioridad.

CONTRASTE: La tinta azul transparente ha sufrido un patente proceso de oscurecimiento que la ha convertido en un azul grisáceo más oscuro. Este cambio en la naturaleza de la tinta permite que, a pesar de que el tono del soporte piel es también algo más intenso, se cree un contraste suficiente como para obtener una imagen válida y correcta.

BRILLO: Casi inexistente y nulo. Apenas un ligero reflejo en las zonas entintadas que no ofrece ningún inconveniente para la correcta visión de la imagen. 


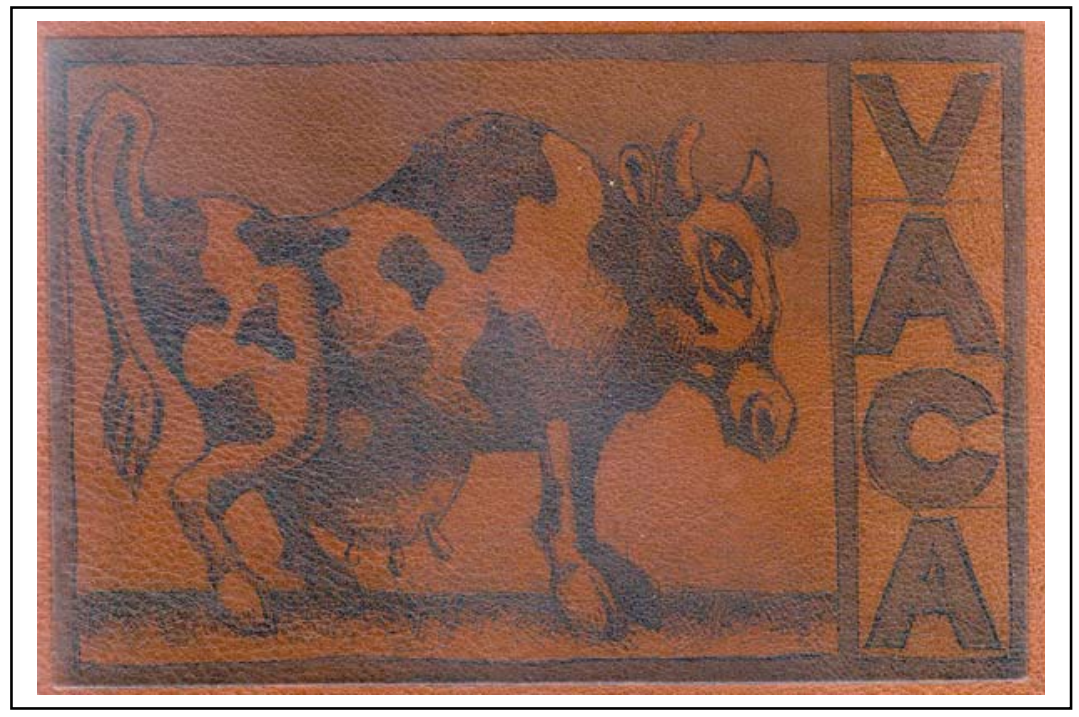

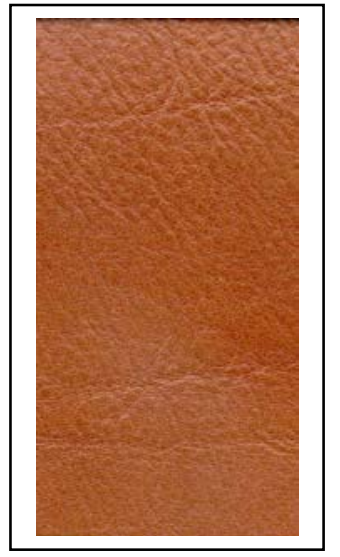

CÓDIGO: VA-038

TIPO DE PIEL: Vaca

TINTA: Azul traslúcido

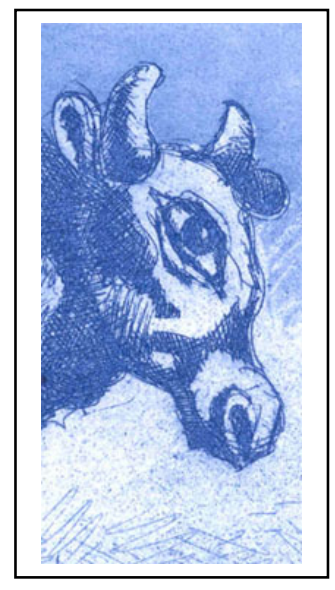

TÉCNICA: Calcografía

TONO DE PIEL: Oscuro

SUPERFICIE: Lado flor 


\section{CALIDAD: Mala}

Lo oscuro e intenso de la superficie del soporte hace que esta estampa esté condicionada por la ausencia casi total de contraste. Por lo demás parece que los restantes apartados estudiados son de una calidad aceptable a pesar de lo difícil de su apreciación.

AGUATINTA: Difícil de observar aunque parece que de una correcta estampación. El tono más claro se pierde casi totalmente por efecto de lo oscuro del fondo, pero las zonas más oscuras si son claramente reconocibles.

AGUAFUERTE: Las líneas aisladas son muy difíciles de apreciar pero no así las zonas oscuras obtenidas mediante acumulación de grafismos. En éstas últimas no se aprecia ningún rastro de la textura "a grumos", quizá debido a que esta piel en concreto presenta una superficie muy brillante pero con cierta rugosidad.

CONTRASTE: El gran inconveniente de esta estampa. A pesar de que la imagen es visible ésta carece de fuerza plástica y expresiva, lo que condiciona al resto de la estampa.

BRILLO: La superficie de la piel ya poseía de por sí un potente brillo y la tinta no es capaz de modificarlo en ninguno de los sentidos posibles. 


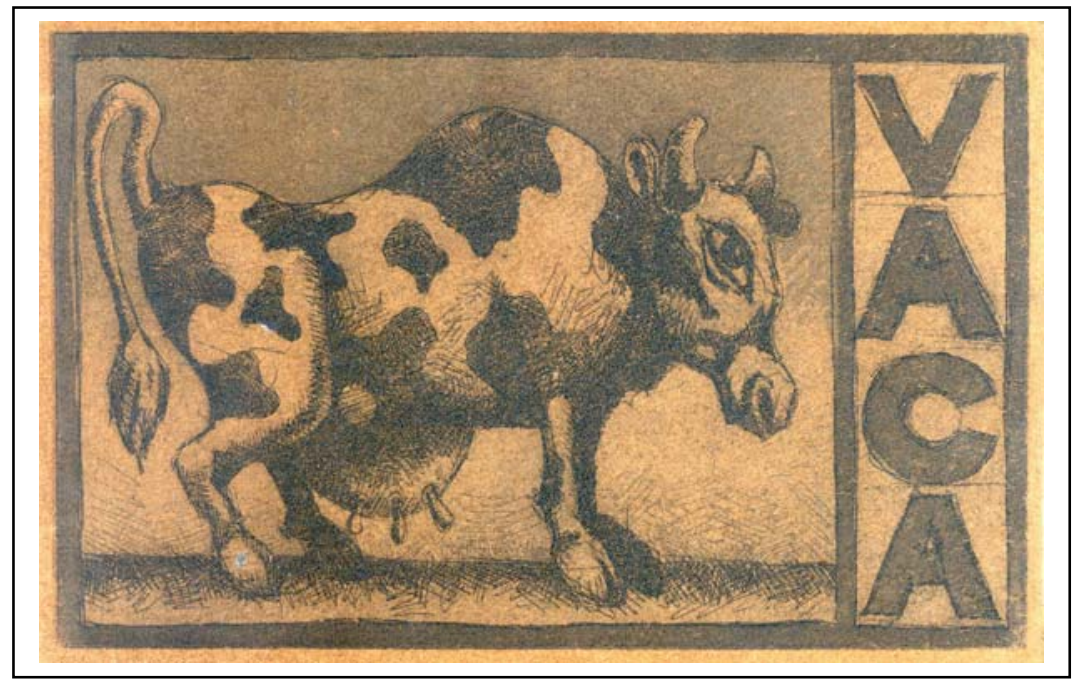

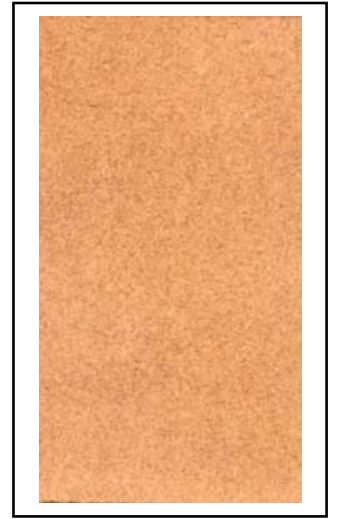

CÓDIGO: VA-039

TIPO DE PIEL: Vaca

TINTA: Azul traslúcido

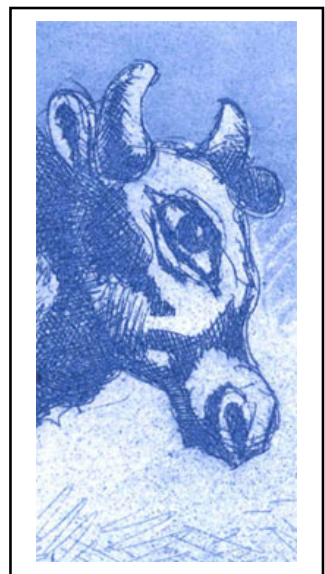

TÉCNICA: Calcografía

TONO DE PIEL: Oscuro

SUPERFICIE: Lado carne 


\section{CALIDAD: Mediocre}

El hecho de que en esta piel el lado carne sea mucho más claro que el lado flor permite que esta estampa tenga mucha mejor calidad que la anterior (VA032). Así ya no tenemos el gran inconveniente del contraste tan escaso del ejemplo sobre el lado flor y la percepción de la imagen es mucho más correcta.

AGUATINTA: De muy buen resultado general. Ambos tonos se han registrado con gran claridad manteniendo la diferencia de intensidad entre ellos. Obviamente no aparece ningún tipo de textura parecida a la observada en ejemplos sobre el lado flor como las de las estampas VA-028 y VA-030.

AGUAFUERTE: Perfecto. A pesar de ser una estampa por el lado carne y presentar la superficie un marcado afelpado, las líneas están registradas con gran nitidez, ya sean las más fuertes y gruesas como las sutiles.

CONTRASTE: Como ya se ha indicado el tono de este lado carne es de menor intensidad que la flor, por lo que el contraste debería ser mayor. A esto se une el tremendo oscurecimiento que ha sufrido al tinta azul hasta convertirse en un gris oscuro muy cercano al negro.

BRILLO: Nulo e inexistente como corresponde a una estampa sobre afelpado. 


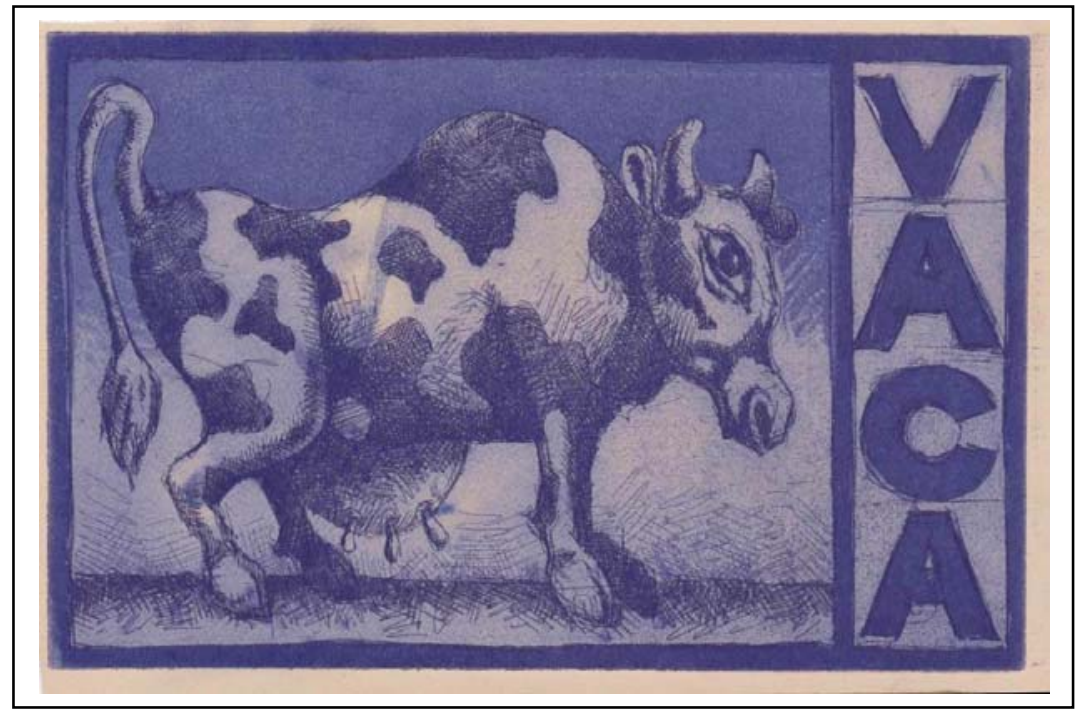

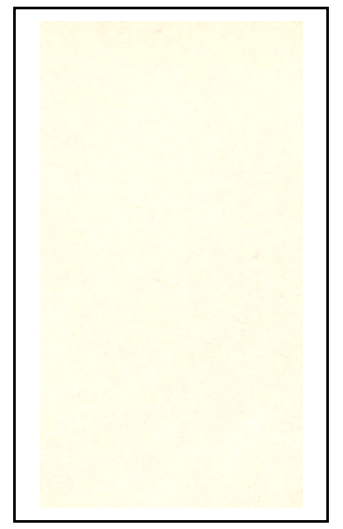

CÓDIGO: VA-040

TIPO DE PIEL: Vaca

TINTA: Azul opaco

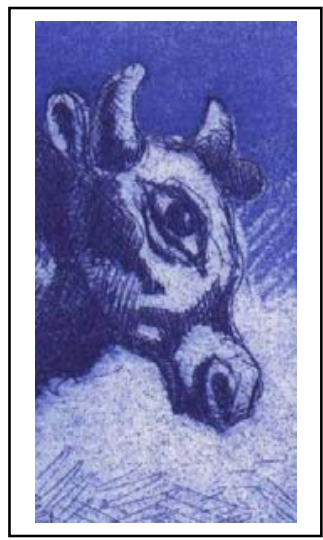

TÉCNICA: Calcografía

TONO DE PIEL: Claro

SUPERFICIE: Lado flor 


\section{CALIDAD: Buena}

Visualmente perfecta en todos los aspectos, esta estampa todavía presenta problemas de secado a pesar de que los ejemplos de grabado calcográfico ofrecen menores inconvenientes que las estampas xilográficas debido a la menor cantidad de tinta sobre la superficie de la piel.

AGUATINTA: Perfecta desde un punto de vista visual, con ambos tonos diferenciados nítidamente y estampados con absoluta fidelidad al seño de la plancha matriz.

AGUAFUERTE: También perfecto, registrándose ambos tipos de línea con una claridad extraordinaria. Tanto las zonas de densidad de grafismo como aquellas líneas más aisladas reproducen fielmente los trazos presentes en la plancha de zinc.

CONTRASTE: Suficientemente intenso como para crear una imagen satisfactoria a pesar de que la tinta apenas se oscurece al contacto con el cuero que sirve como soporte.

BRILLO: Aparece un ligerísimo brillo casi inapreciable y que, obviamente, no dificulta en absoluto la apreciación de la imagen. 

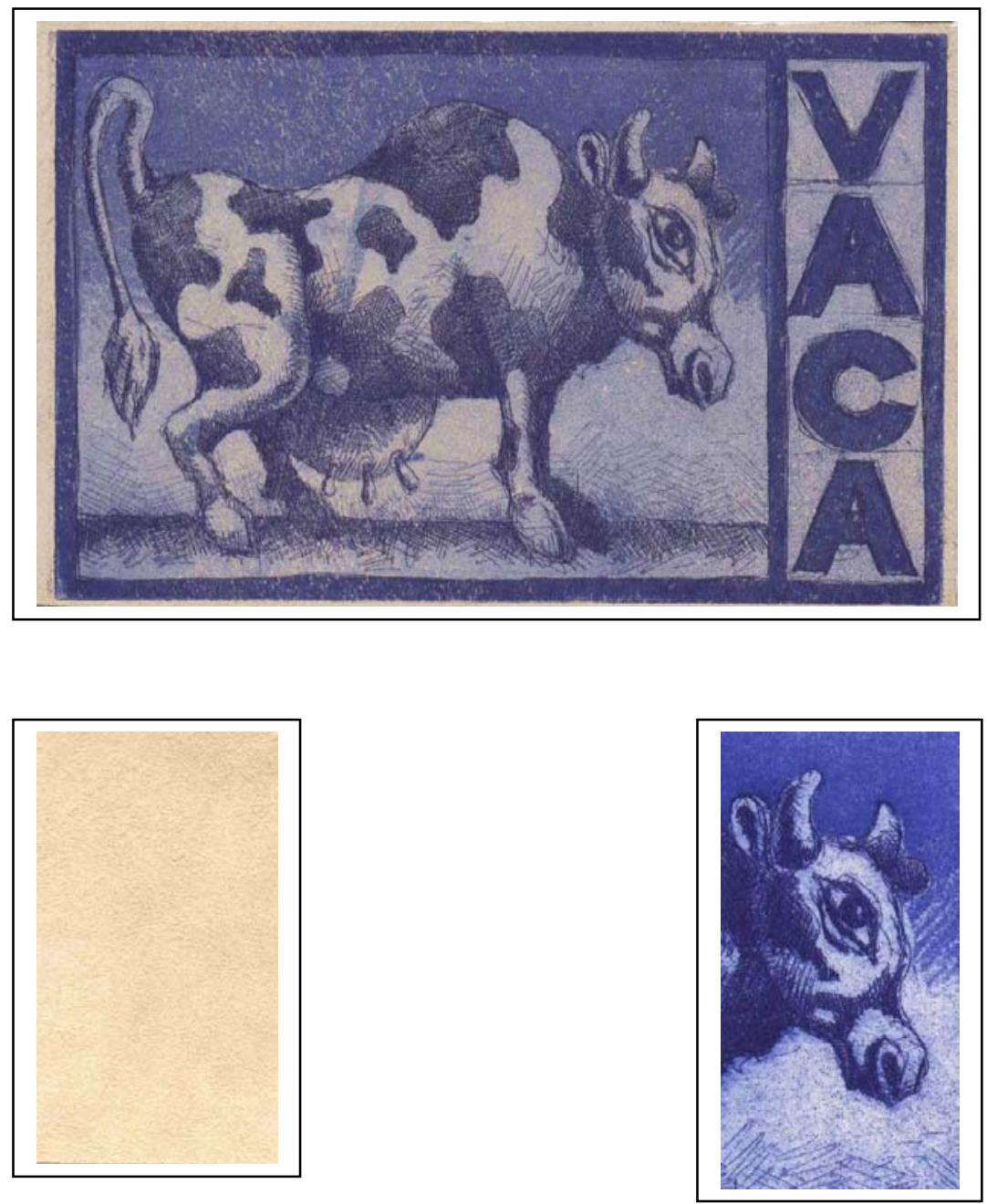

CÓDIGO: VA-041

TÉCNICA: Calcografía

TIPO DE PIEL: Vaca

TONO DE PIEL: Claro

TINTA: Azul opaco

SUPERFICIE: Lado carne 


\section{CALIDAD: Mediocre}

En este caso, y gracias al afelpado tan acusado de la superficie del cuero y a la escasa tinta en la estampa, los problemas de secado y asentamiento desaparecen casi por completo del ejemplo. Sin embargo aparecen nuevos inconvenientes referentes al aguatinta y en menor medida a los grafismos.

AGUATINTA: De escasa calidad por efecto del excesivo afelpado de este tipo de piel vacuna en su lado carne. La tinta depositada sobre el soporte no es suficiente como para evitar la aparición de una textura muy desagradable en las zonas entintadas. Aun así siguen apreciándose los diferentes tonos de azul que conforman la imagen.

AGUAFUERTE: Algo mejor que la aguatinta ya que dicha textura rugosa no afecta con la misma intensidad a los grafismos lineales, los cuales son capaces de mantener su naturaleza casi intacta. A pesar de todo en las zonas de afelpado más intenso incluso las líneas más potentes se ven afectadas.

CONTRASTE: Correcto gracias al ligero oscurecimiento de la tinta y al tono de la piel.

BRILLO: Como es lógico absolutamente inexistente. 


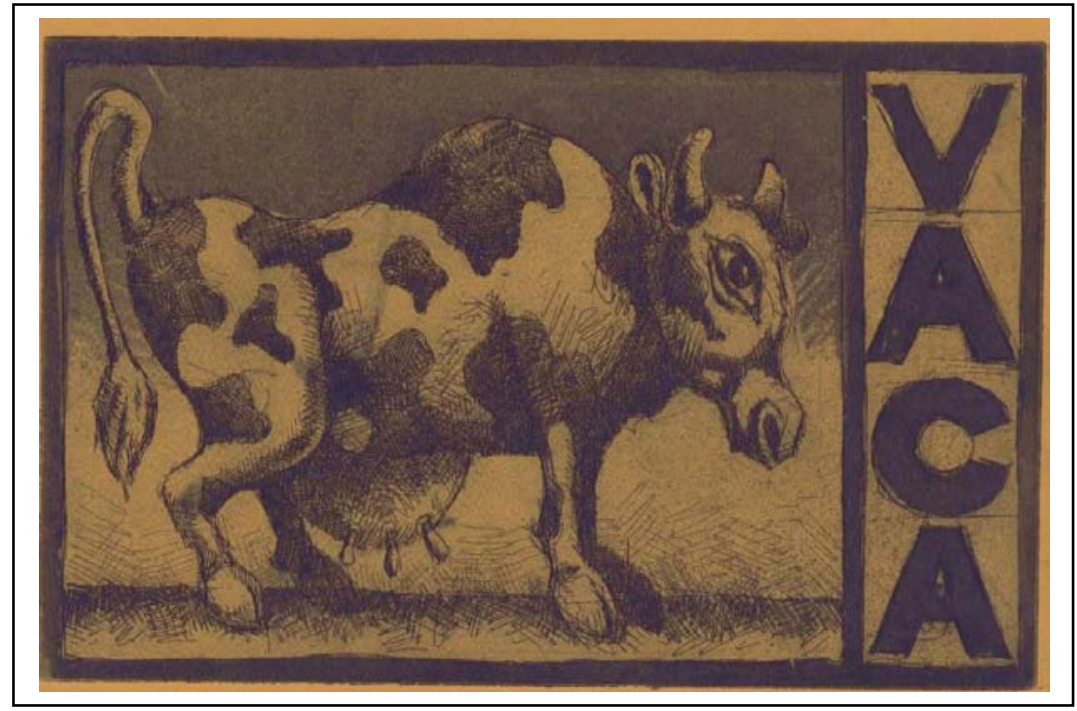

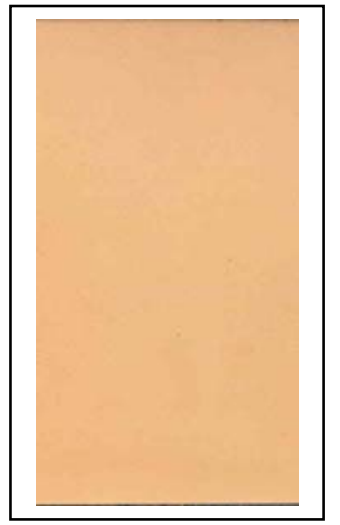

CÓDIGO: VA-042

TIPO DE PIEL: Vaca

TINTA: Azul opaco

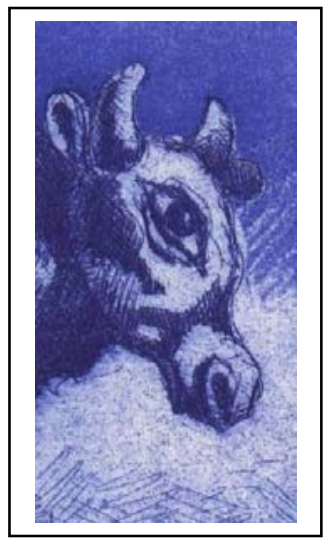

TÉCNICA: Calcografía

TONO DE PIEL: Medio

SUPERFICIE: Lado flor 


\section{CALIDAD: Buena}

A pesar de que los inconvenientes de secado continúan existiendo incluso en estas estampas calcográficas, visualmente la imagen es casi perfecta, sin problemas evidentes y con un buen resultado en todos los campos analizados.

AGUATINTA: De óptimo resultado tanto en las zonas más claras como en aquellas oscuras, manteniéndose las diferencias entre ambos tonos y lográndose áreas homogéneas y de una gran regularidad.

AGUAFUERTE: Perfecto, con todas y cada una de las líneas de la plancha matriz registradas de manera totalmente satisfactoria y con extraordinaria fidelidad a los seños presentes en la plancha de zinc.

CONTRASTE: A pesar del tono beige de la piel el ligero oscurecimiento al que se ve sometida la tinta hace que la intensidad del contraste sea suficiente como para crear una imagen visualmente satisfactoria.

BRILLO: Se puede percibir un mínimo brillo ceroso que no interfiere en la visión de la estampa, brillo por otro lado lógico si tenemos en cuenta las características del soporte piel en el cual hemos estampado. 


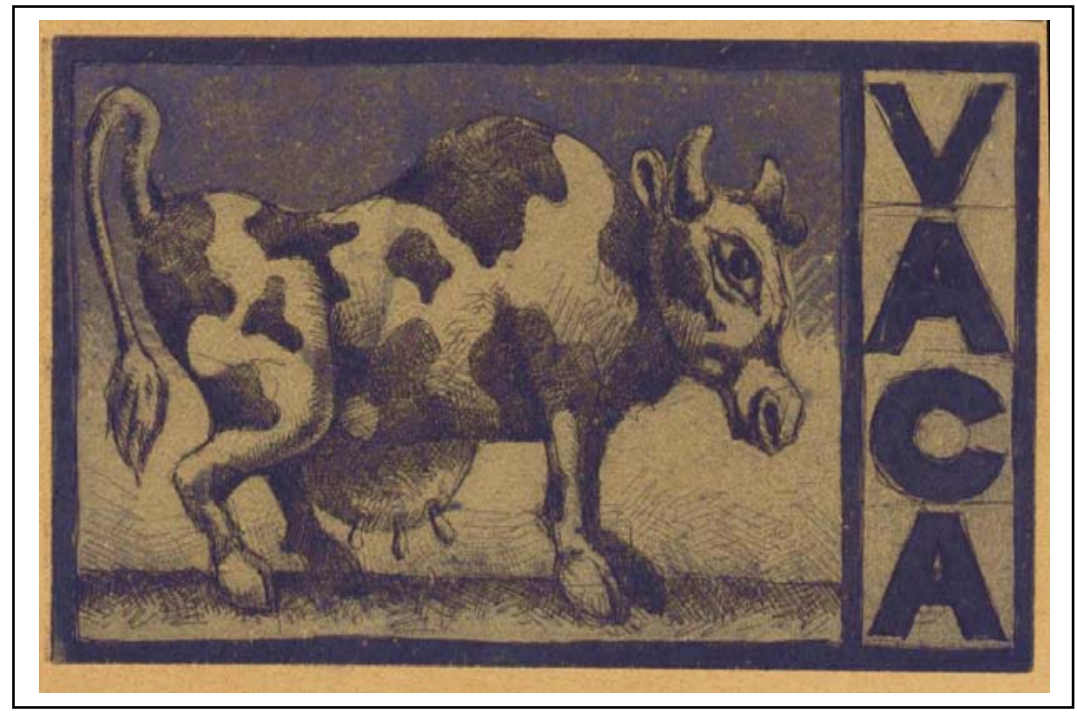

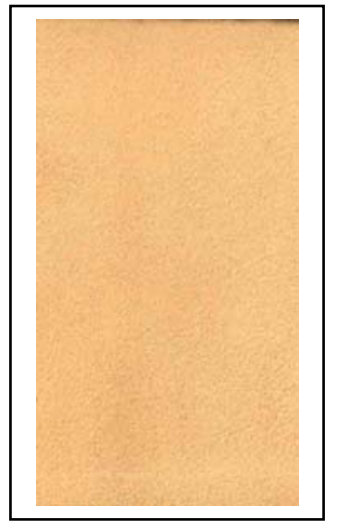

CÓDIGO: VA-043

TIPO DE PIEL: Vaca

TINTA: Azul opaco

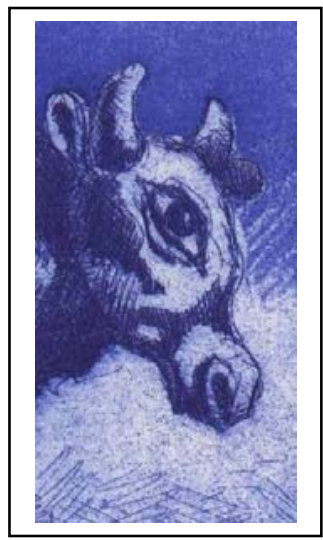

TÉCNICA: Calcografía

TONO DE PIEL: Medio

SUPERFICIE: Lado carne 


\section{CALIDAD: Mediocre}

A los consabidos problemas de secado se une la textura afelpada de la piel, la cual impide una estampación totalmente regular y homogénea de la imagen. El citado afelpado provocará el conocido oscurecimiento de la tinta al contacto con el soporte cuero, como analizaremos a continuación.

AGUATINTA: El excesivo acabado afelpado del lado carne de esta piel vacuna hace que los tonos se oscurezcan de manera evidente y que aparezca una textura sucia e irregular en las zonas entintadas. La tinta no es capaz de cubrir este acabado rugoso del cuero, provocando la aparición de dicho inconveniente.

AGUAFUERTE: Mejor que el aguatinta aunque las líneas también se ven afectadas en las zonas de más afelpado del soporte.

CONTRASTE: La tinta, al oscurecerse de manera patente, favorece la aparición de un contraste lo suficientemente intenso como para crear una imagen satisfactoria y perfectamente reconocible.

BRILLO: Totalmente nulo como es lógico al estampar sobre un soporte con un acabado de afelpado tan acusado como éste. 


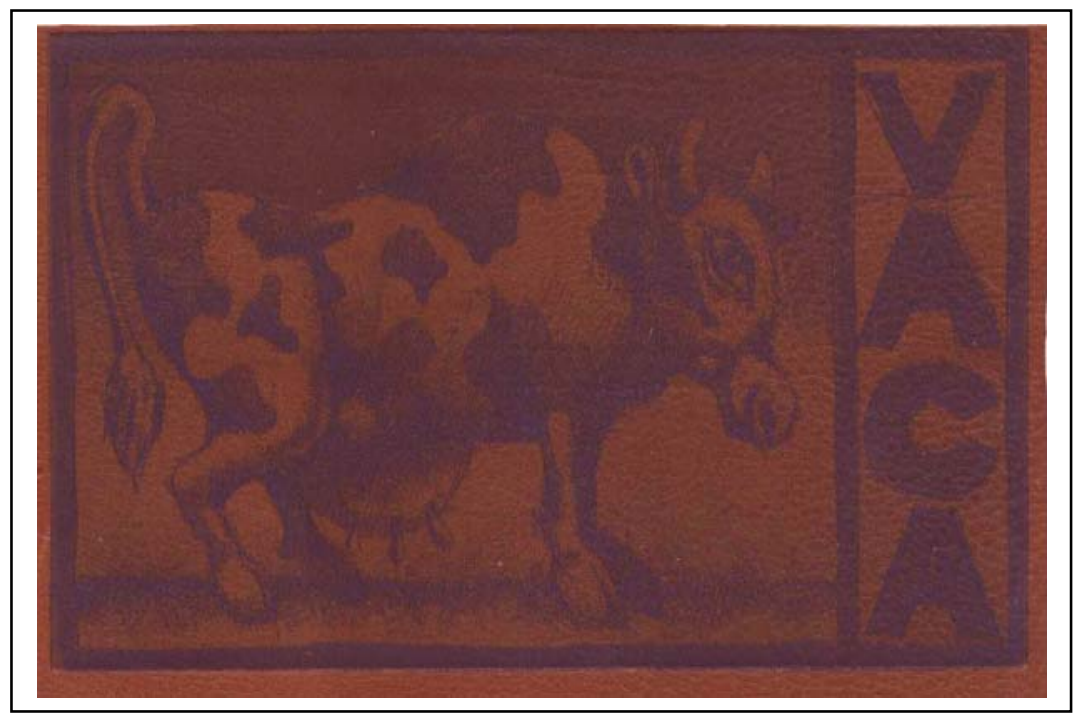

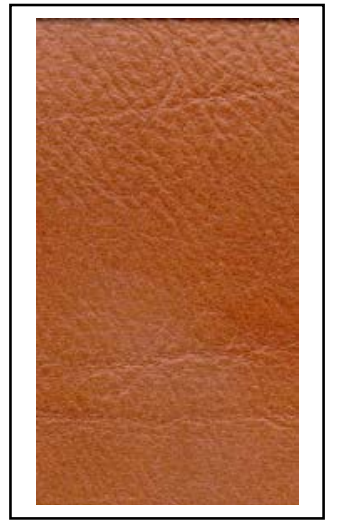

CÓDIGO: VA-044

TIPO DE PIEL: Vaca

TINTA: Azul opaco

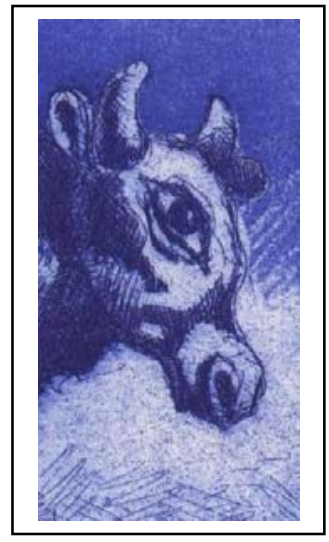

TÉCNICA: Calcografía

TONO DE PIEL: Oscuro

SUPERFICIE: Lado flor 


\section{CALIDAD: Mala}

En la mala calidad del ejemplo inciden sobre todo el escaso contraste logrado en la imagen y el hecho, tantas veces repetido en estas estampas realizadas con azul opaco, de que continúen existiendo problemas de secado y asentamiento de la tinta incluso mucho tiempo después de haber procedido a la estampación.

AGUATINTA: Correcta a pesar de lo difícil de su apreciación. Todavía mantiene las diferencias entre ambos tonos de azul y parece lograr cierta homogeneidad en las zonas entintadas.

AGUAFUERTE: También de buen resultado aunque las líneas aisladas son a veces difíciles de percibir sobre la superficie del cuero. Son aquellos grafismos más sutiles los que ofrecen mayor dificultad a la hora de ser apreciados con total nitidez.

CONTRASTE: Sin duda alguna el gran inconveniente de este ejemplo. El tono tan oscuro del soporte piel impide que la tinta contraste lo suficiente a pesar del marcado oscurecimiento al que se ve sometida esta última al contacto con el cuero.

BRILLO: La tinta repite el brillo ya de por sí presente en la superficie del cuero, sin añadir reflejos extras al acabado brillante del soporte. 

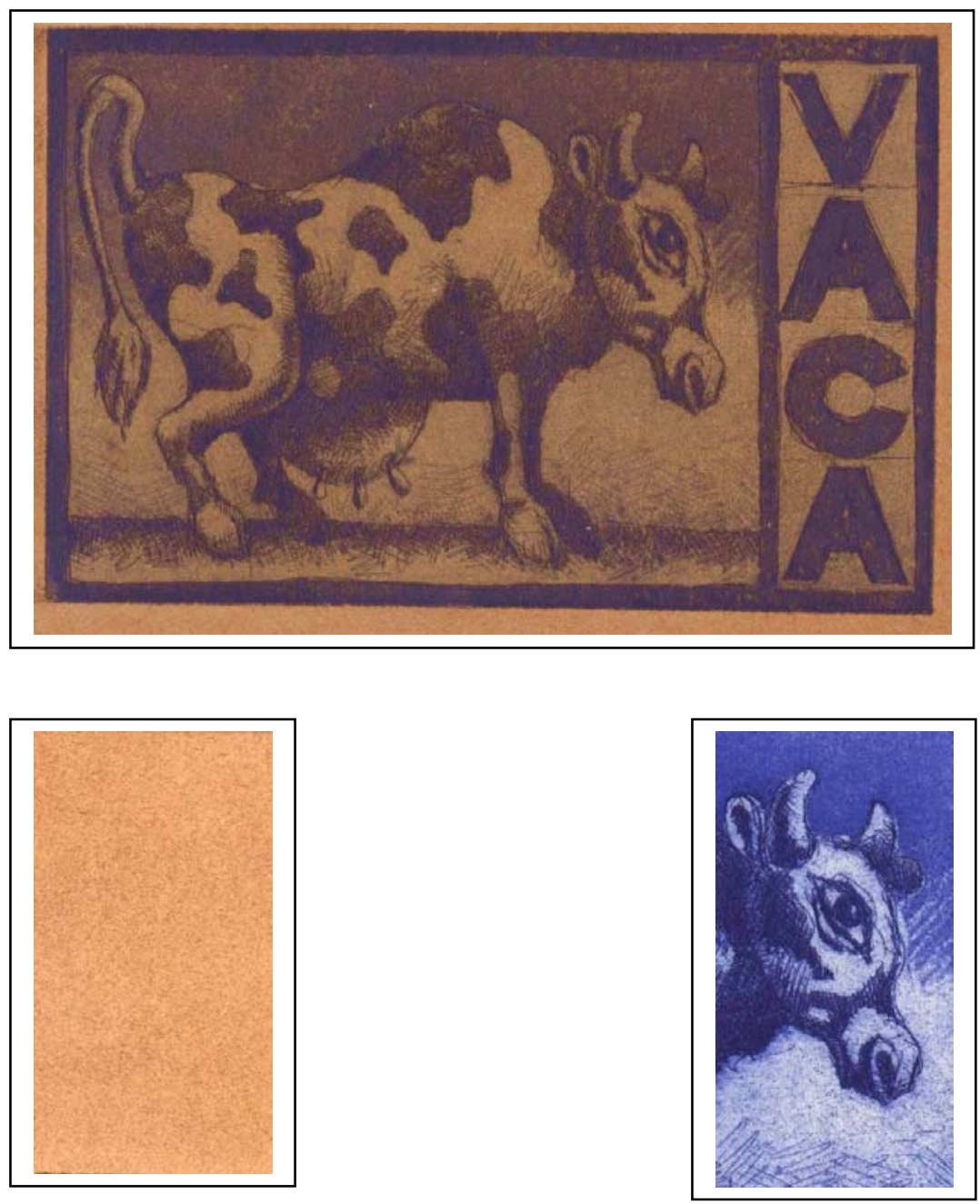

CÓDIGO: VA-045

TÉCNICA: Calcografía

TIPO DE PIEL: Vaca

TONO DE PIEL: Oscuro

TINTA: Azul opaco

SUPERFICIE: Lado carne 


\section{CALIDAD: Mediocre}

Este ejemplo se asemeja en gran medida al de la piel de tono medio en su lado carne (VA-043), manteniendo casi las mismas conclusiones ya vertidas sobre dicha estampa.

AGUATINTA: De nuevo el acabado tan rugoso de la superficie del soporte piel provoca que la tinta no cobre una apariencia homogénea en las zonas entintadas. Aun así se sigue percibiendo sin ningún problema la diferenciación de tonos entre las distintas áreas de la imagen.

AGUAFUERTE: Algo irregular, sobre todo las líneas aisladas, las cuales se ven desvirtuadas por efecto del afelpado perdiendo nitidez y claridad de registro. Los seños más sutiles no pueden superponerse al acabado rugoso del soporte.

CONTRASTE: No muy intenso pero todavía lo suficientemente potente como para que la imagen sea reconocible sin demasiados problemas. El oscurecimiento al que se ve sometida la tinta azul provoca que el grado de contraste sea correcto.

BRILLO: Totalmente nulo como corresponde a una estampa sobre superficie afelpada como las que nos ocupa. 

I.3. Fichas punta seca

\section{I.3. FICHAS PUNTA SECA}



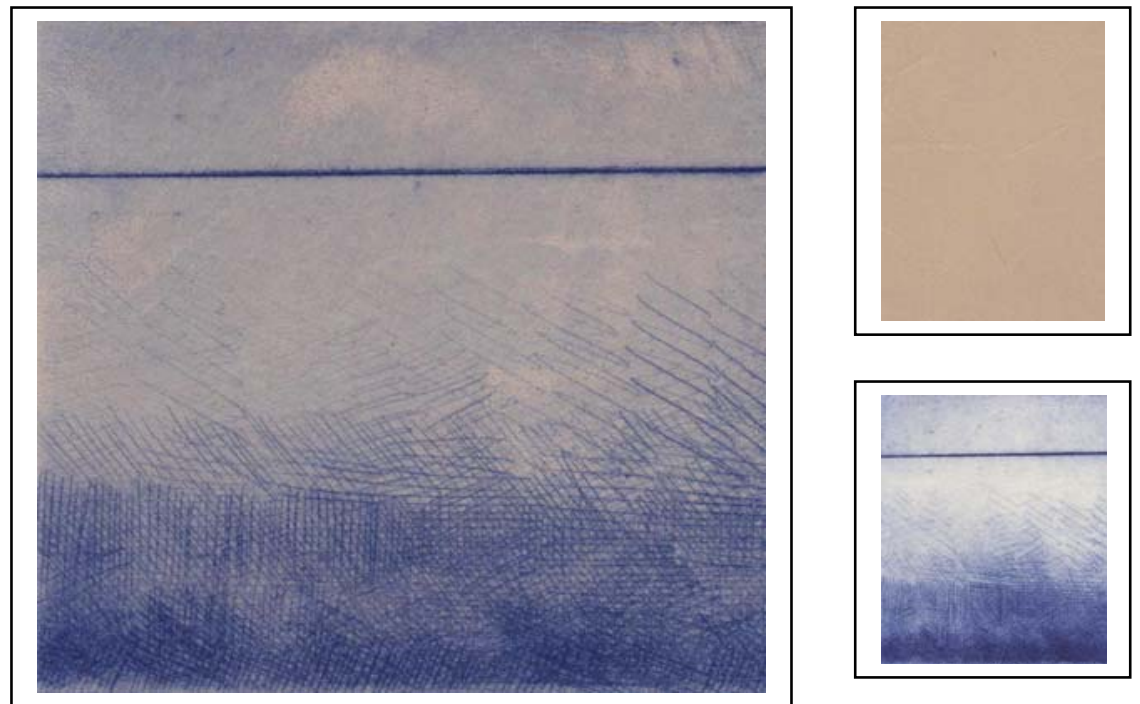

CÓDIGO: PS-001

PIEL: Cabra
SUPERFICIE: Lado flor

CALIDAD: Buena

Excelente nivel de registro de los grafismos de la plancha, aunque no tanto de la tinta depositada en las rebabas de las líneas grabadas. La superficie tan pulida de la piel permite esa nitidez de registro, pero impide que la piel recoja de manera correcta el resto de la tinta, por lo que el aspecto de la imagen es más parecido a una aguafuerte muy sutil que a una estampa de punta seca. Pese a todo, los resultados son bastante satisfactorios siempre que se tengan en cuenta los factores comentados. 

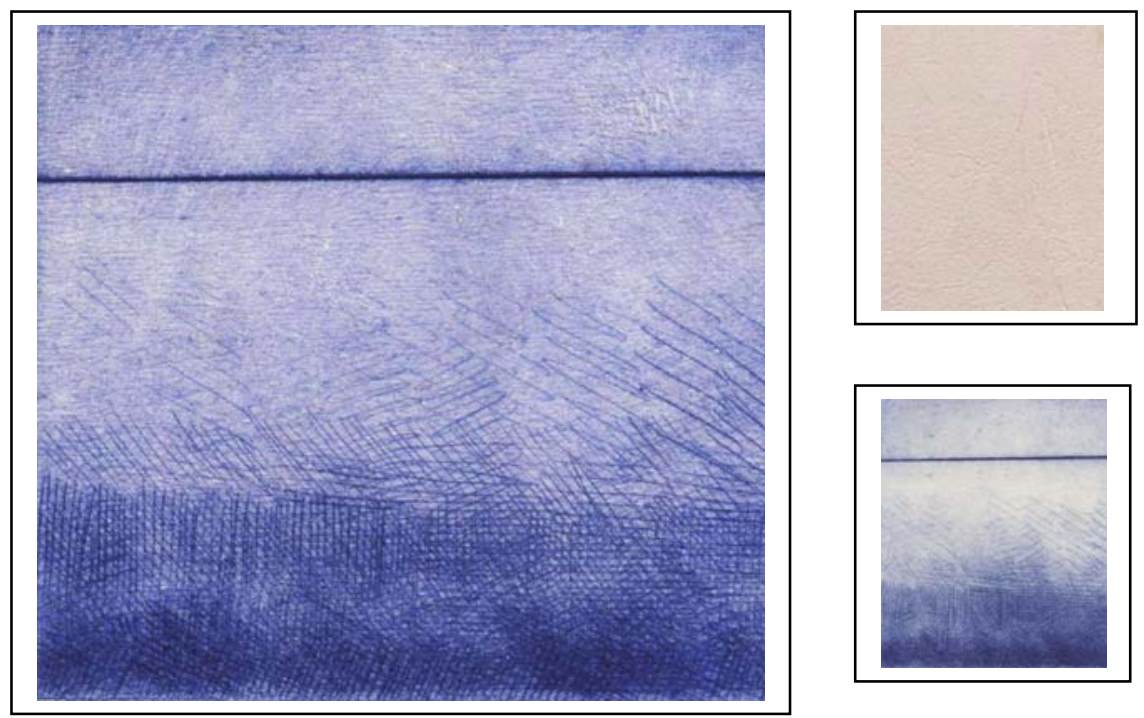

CÓDIGO: PS-002

SUPERFICIE: Lado carne

PIEL: Cabra

CALIDAD: Muy buena

Perfecta en todos los aspectos. La nitidez del registro es muy alta a pesar de estar estampada sobre una superficie ligeramente afelpada, con todas las líneas impresas de manera muy correcta. La tinta de las rebabas se encuentra registrada sin ningún tipo de problema, lo que hace de ella una superficie ideal para ser usada como soporte para estampas de punta seca. Se aprecia un ligero oscurecimiento provocado por el afelpado del cuero, fenómeno controlable a partir de una limpieza ortodoxa de la matriz. Se trata de uno de los mejores soportes para estampas con punta seca, siempre que el afelpado sea muy sutil y apenas perceptible, ya que de lo contrario la naturaleza de la impresión cambiará. 

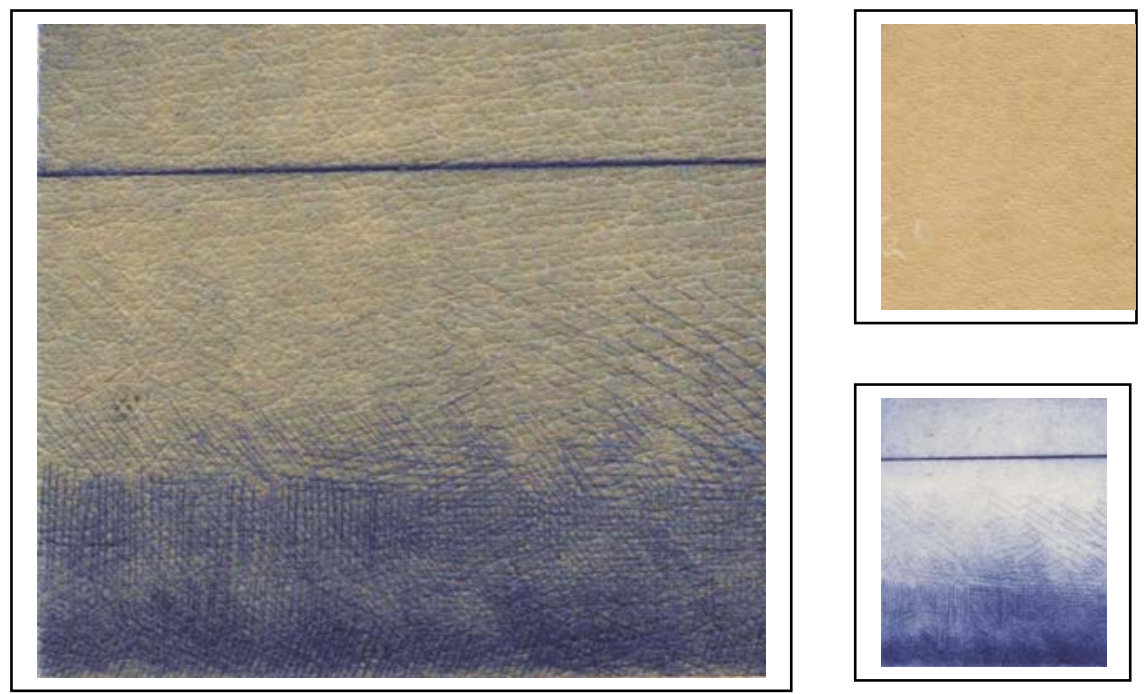

CÓDIGO: PS-003

SUPERFICIE: Lado flor

PIEL: Cerdo

CALIDAD: Mediocre

La textura tan acusada de la piel porcina provoca que el registro de los sutiles grafismos de la punta seca se vea condicionado, con el resultado de una estampa sin demasiada nitidez y en la cual se pierden las líneas más débiles. Éstas son casi imperceptibles en muchas zonas del cuero, y tan sólo en las áreas de mayor densidad de grafismos son visibles sin problemas. En lo que respecta a la tinta presente en las rebabas, la piel no es capaz de recogerla de manera totalmente satisfactoria, lo que hace que la estampa no posea el acabado propio de la punta seca, no siendo por tanto una superficie idónea para ser usada como soporte para este tipo de impresiones. 

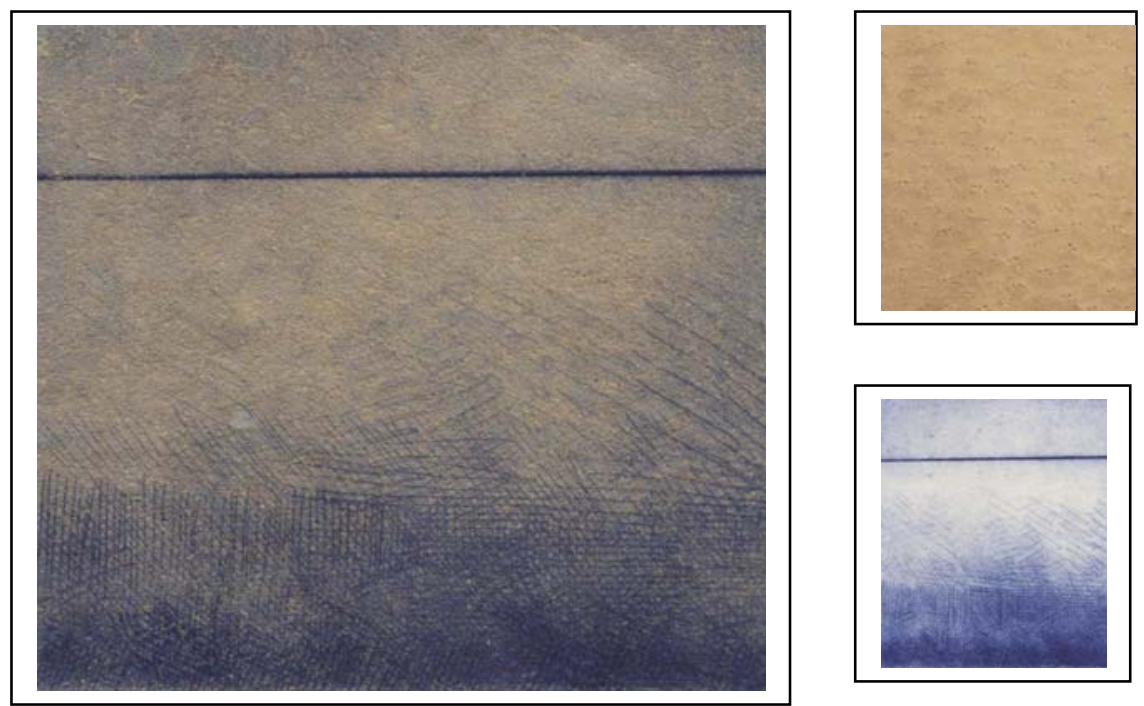

CÓDIGO: PS-004

SUPERFICIE: Lado carne

PIEL: Cerdo

CALIDAD: Mediocre

Pese a estar estampada sobre el lado carne del cuero, la textura es lo bastante uniforme y suave como para permitir que casi la totalidad de los grafismos de la imagen sean visibles sin interferencias excesivas. Sin embargo las líneas más sutiles se pierden por efecto del ligero afelpado de la piel, lo que condiciona el resultado de la impresión. El soporte tampoco se muestra demasiado efectivo a la hora de recoger la tinta de las rebabas, lo que impide conseguir el acabado propio de las imágenes realizadas mediante la punta seca. Uniendo todos estos factores obtenemos una impresión con un bajo nivel de calidad general. 

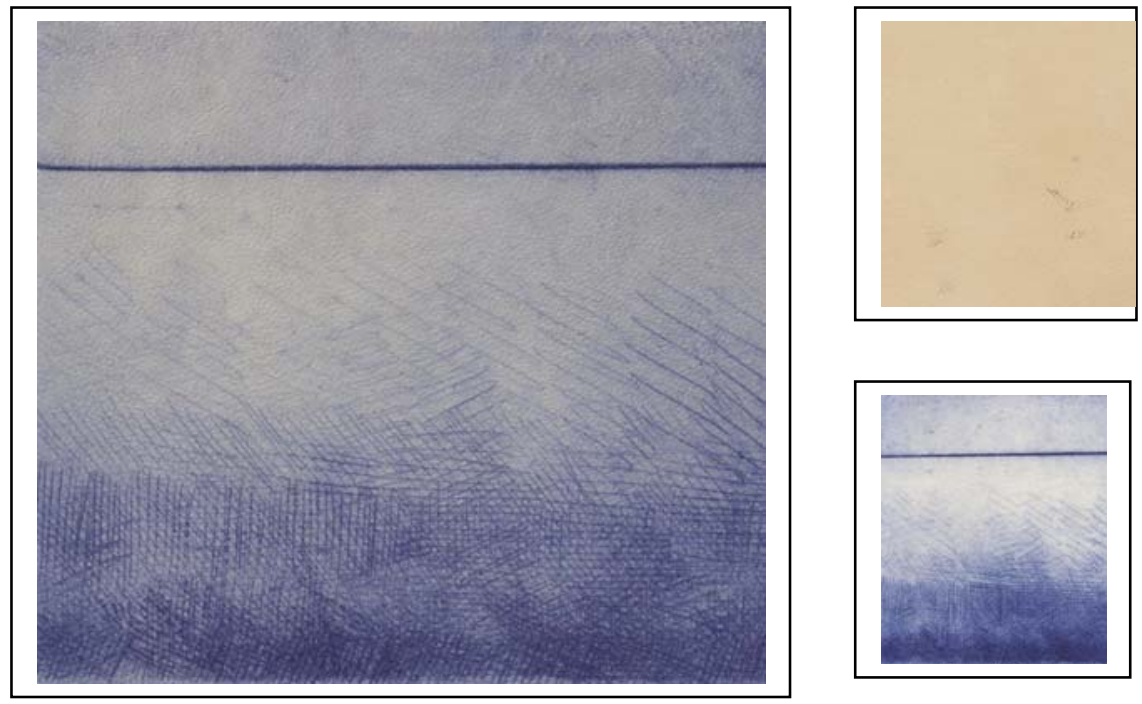

CÓDIGO: PS-005

SUPERFICIE: Lado flor

PIEL: Cordero

CALIDAD: Muy buena

Perfecta en lo que se refiere al registro de todas las líneas de la imagen, con una gran nitidez incluso en los grafismos más ligeros y sutiles. La textura tan suave de la superficie del cuero hace que la punta seca se impresione de manera muy satisfactoria y correcta, sin interferencias de ningún tipo. También se muestra como un soporte muy válido a la hora de recoger la tinta de las rebabas de la plancha, consiguiendo un acabado de enorme calidad. Sin duda una de las mejores impresiones sobre piel a partir del uso de la punta seca, comparable a las de mayor calidad de la experimentación. 

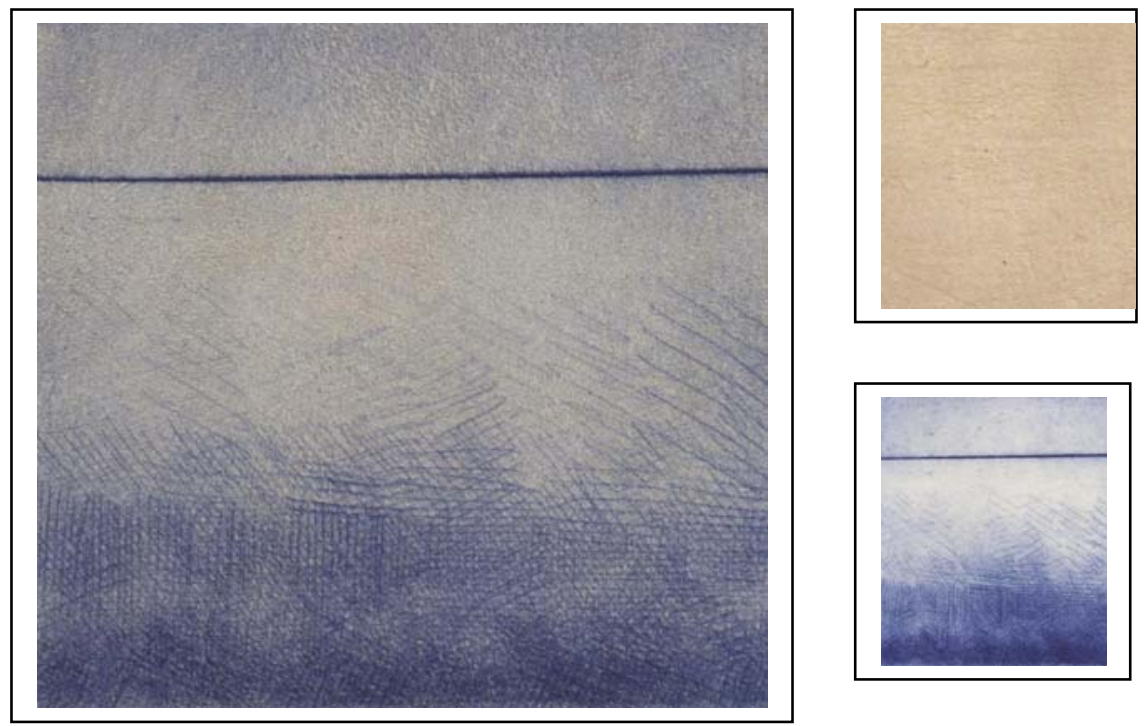

CÓDIGO: PS-006

SUPERFICIE: Lado carne

PIEL: Cordero

CALIDAD: Buena

El hecho de que la estampación sea sobre el lado carne no impide que esta imagen alcance un más que aceptable nivel de calidad general. Casi todas las líneas de la plancha se encuentran reflejadas de manera satisfactoria sobre el cuero, a excepción de las más finas que se pierden por efecto del sutil afelpado. En lo que se refiere al registro de la tinta de las rebabas, el resultado es correcto, aunque sin llegar a ser todo lo positivo que era de esperar. Siempre que el afelpado no sea excesivamente acusado, los resultados sobre estos cueros serán satisfactorios, cosa que cambiará de hacerlo sobre superficies demasiado texturadas que afectarán a las características de la imagen. 

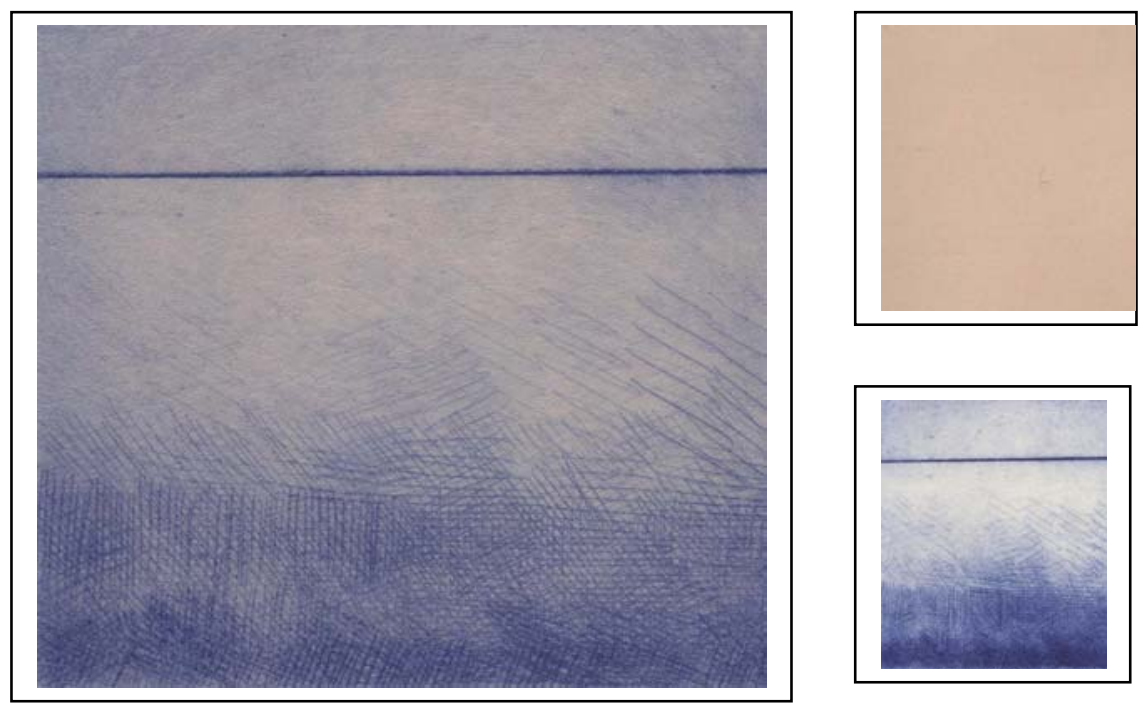

CÓDIGO: PS-007

PIEL: Vaca
SUPERFICIE: Lado flor

El acabado tan satinado de esta piel provoca que el registro de las líneas sea casi perfecto, con una gran nitidez en la impresión de todas las líneas de la imagen, incluso aquellas más sutiles. Sin embargo, ese mismo acabado satinado hace que el soporte no sea capaz de recoger de manera satisfactoria la tinta presente en las rebabas de los grafismos de la punta seca. Esto provoca que la impresión general no sea totalmente positiva, dado que no se consigue alcanzar el nivel de intensidad de la tinta que sería deseable. Pese a todo no se deben despreciar las posibilidades que este tipo de superficies ofrecen a la hora de servir como soportes para la punta seca. 

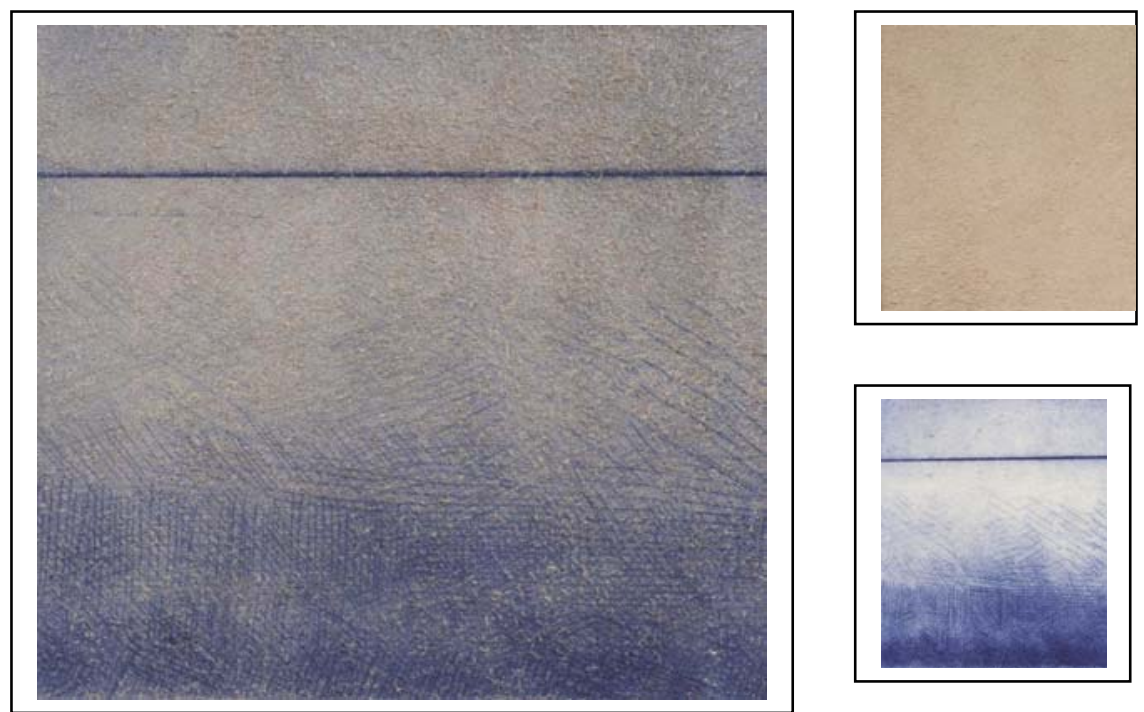

CÓDIGO: PS-008

SUPERFICIE: Lado carne

PIEL: Vaca

CALIDAD: Mala

Esta estampa está condicionada por el excesivo afelpado que presenta el lado carne, el cual interfiere en una correcta impresión de la imagen. Las líneas se encuentran desvirtuadas por efecto de la textura del cuero, perdiéndose las más finas y careciendo de la nitidez necesaria las más potentes y visibles. Como era de esperar en este tipo de cueros, la tinta de las rebabas no está registrada con limpieza, lo que impide que la calidad de la estampa sea positiva. El afelpado de la superficie de la piel provoca, como era lógico, el oscurecimiento de la imagen, fenómeno que se une a los comentados con anterioridad. 
I.3. Fichas punta seca 


\section{I.4. FICHAS ESTEZADO}



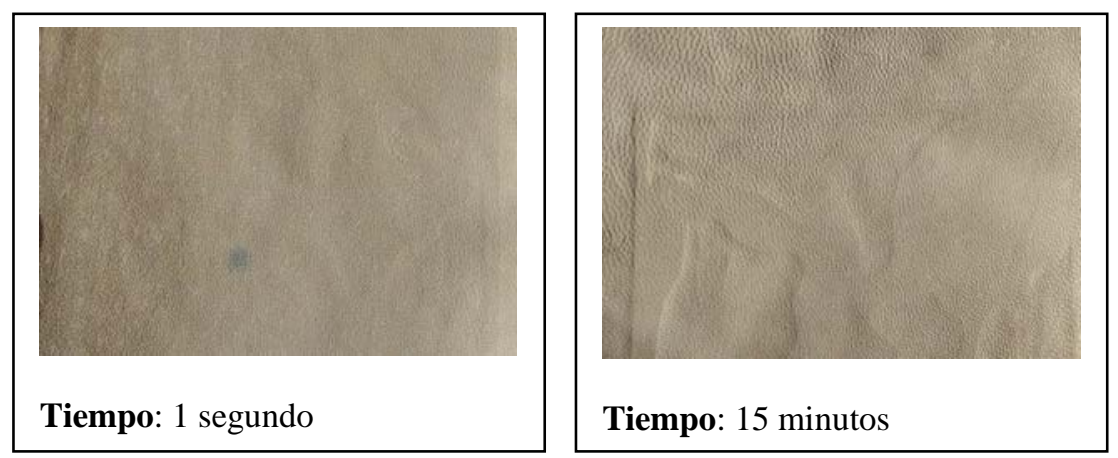

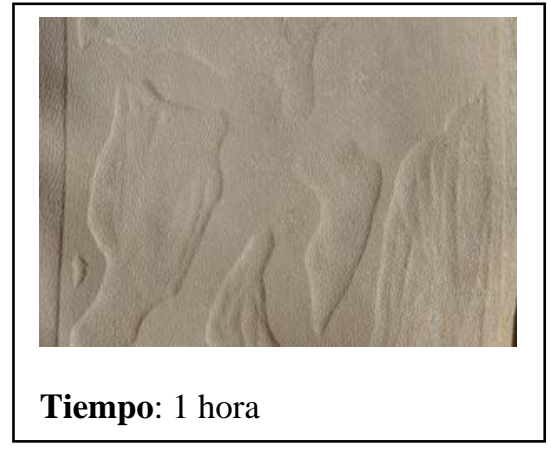

TIPO DE PIEL: Cabra

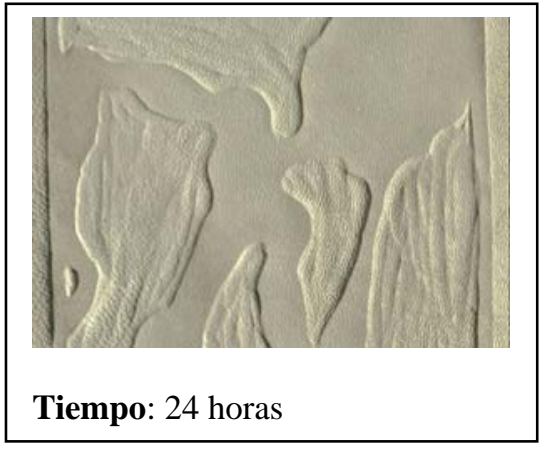

LADO: Flor

Durante los primeros 15 minutos la presión apenas logra hacer efecto sobre la superficie de la piel, con un relieve absolutamente inexistente en la muestra lograda tras un segundo bajo la prensa vertical. No ocurre lo mismo a partir de la primera hora bajo presión, cuando ya podemos apreciar de manera bastante correcta los contornos del relieve. Sin embargo, éste no será lo suficientemente intenso hasta que la piel no seque dentro de la prensa, cosa que ocurre de manera casi segura una vez que ha permanecido durante 24 horas bajo presión. En esta última muestra, la intensidad del relieve alcanza los niveles suficientes como para no desaparecer al poco tiempo. 

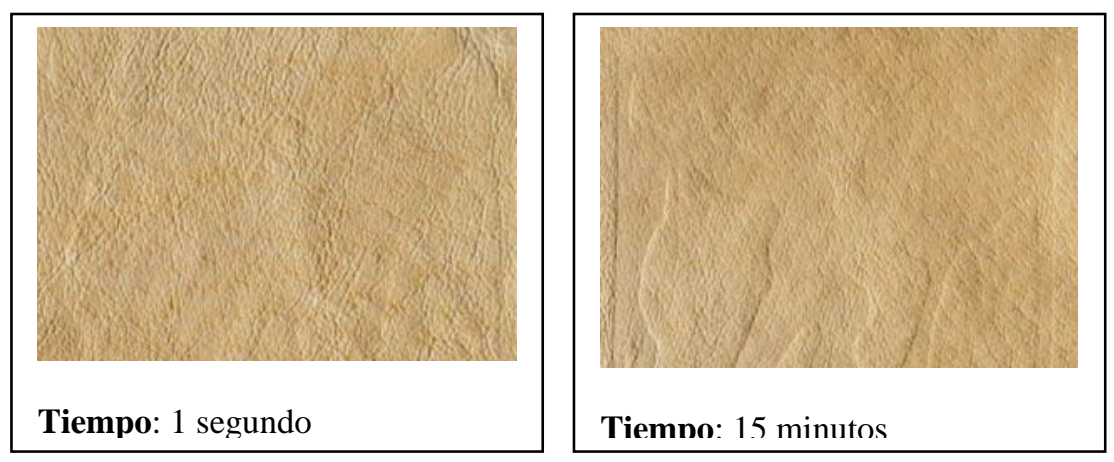

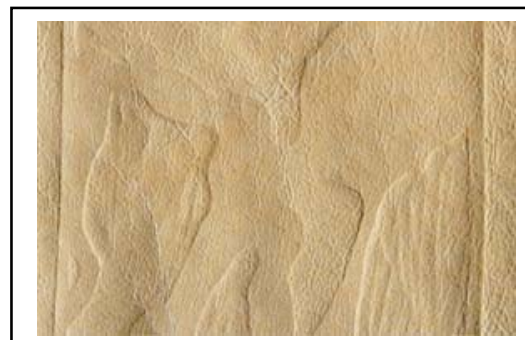

Tiempo: 1 hora

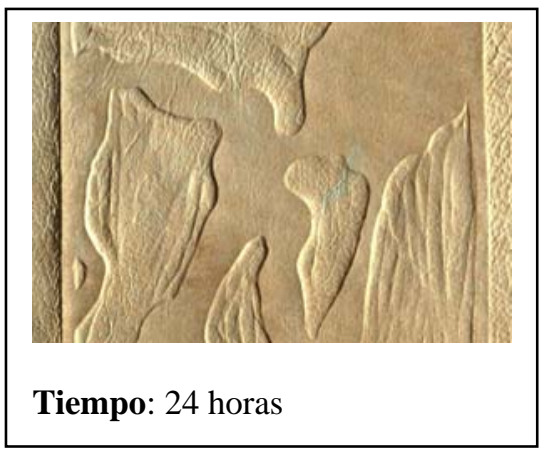

LADO: Flor

TIPO DE PIEL: Cerdo

La piel de cerdo no se muestra demasiado receptiva a los relieves durante las tres primeras muestras del proceso. En las dos primeras, tras un segundo y 15 minutos, apenas si podemos llegar a percibir, de manera muy sutil, los contornos de los relieves, pero sin llegar nunca a ofrecer un resultado satisfactorio. Incluso tras una hora bajo presión, la intensidad del relieve es muy escasa, pudiendo apreciar sin problema las formas de la plancha, pero sin que la piel haya recogido el relieve como sería deseable. Es tan sólo tras permanecer 24 horas dentro de la prensa, cuando podemos lograr una intensidad lo suficientemente elevada como para que podamos dar por positivo el proceso de impresión en relieve. 

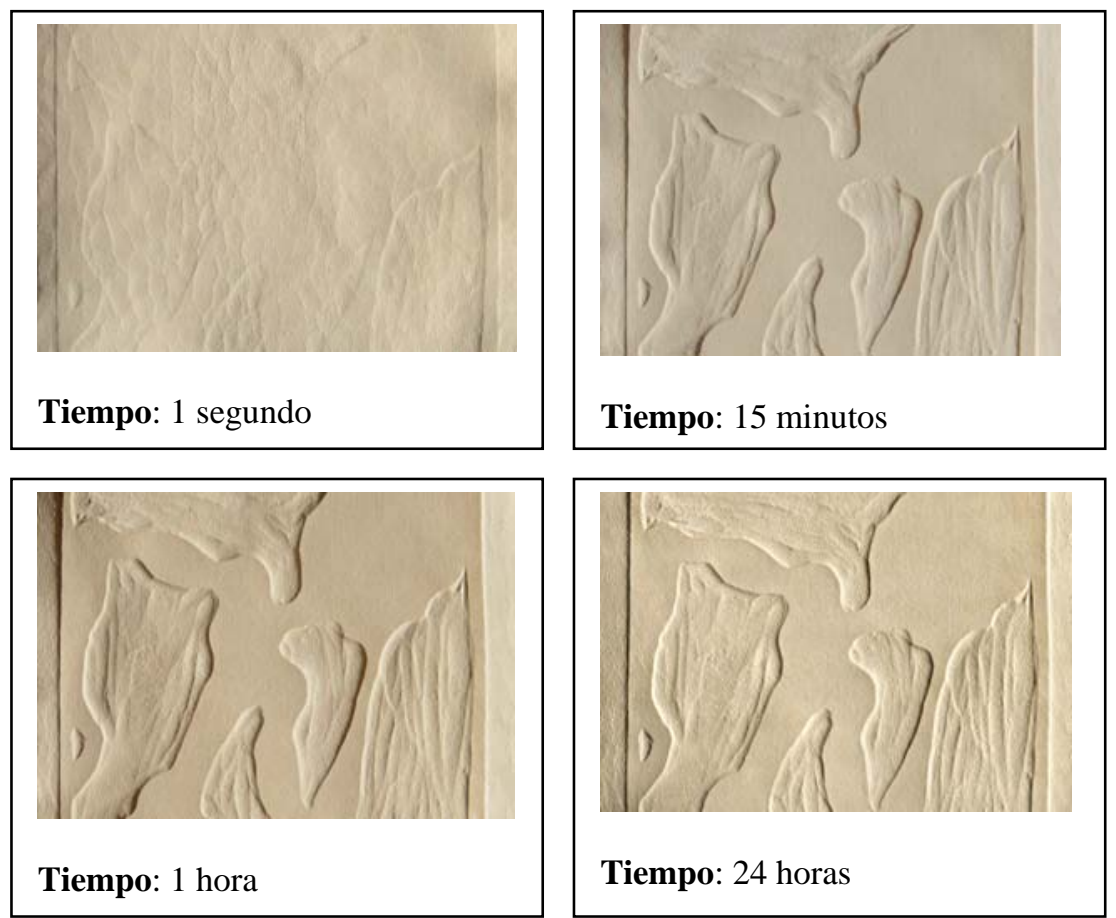

Tiempo: 1 hora

\section{LADO: Flor}

TIPO DE PIEL: Cordero

La piel de cordero es, sin duda, la que mejor acepta los relieves de la plancha. Tras el primer segundo bajo presión es posible incluso llegar a distinguir, aunque de manera muy leve, los contornos de la imagen. Sin embargo, el cambio sufrido por la piel tras permanecer tan sólo 15 minutos dentro de la prensa, es absolutamente excepcional: los relieves se encuentran recogidos de manera prácticamente perfecta. De tal modo, en las dos últimas muestras la intensidad del relieve es máxima, no necesitando ni siquiera que la piel seque dentro de la prensa para poder lograr un resultado altamente satisfactorio. Como hemos dicho, el cuero de cordero es el ideal para este tipo de manipulaciones y procesos gracias a su flexibilidad. 

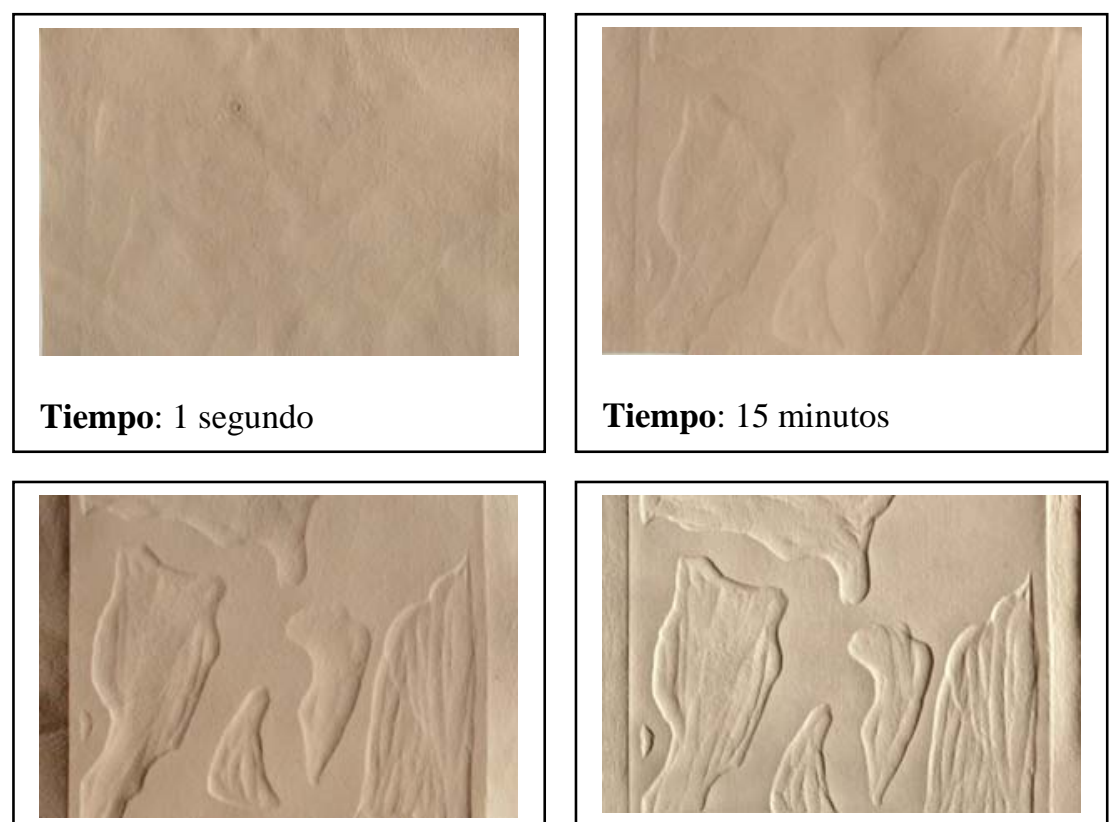

Tiempo: 1 hora

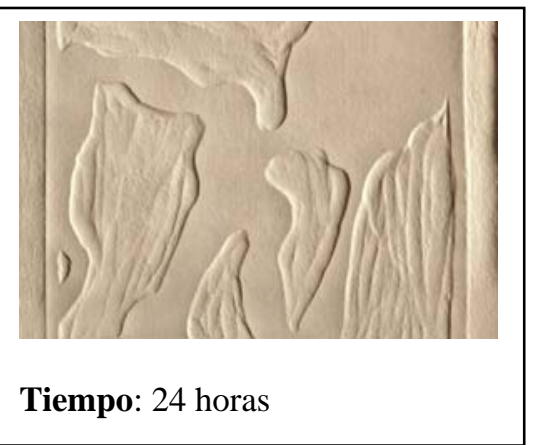

TIPO DE PIEL: Vaca

LADO: Flor

La piel de vacuno, de gran dureza superficial, no recoge los relieves de manera satisfactoria durante los primeros 15 minutos bajo presión (lo que equivale a las dos primeras muestras del proceso). Debemos esperar a que la piel permanezca hasta 1 hora dentro de la prensa para que los contornos de la imagen aparezcan con total claridad, pero no será hasta el último de los ejemplos, tras 24 horas, cuando la intensidad del relieve sea la deseable. Por lo tanto, será necesario que el cuero alcance un secado completo, para que las formas de la plancha queden reflejadas en su superficie y se logre un relieve satisfactorio que no desaparezca a las pocas horas. 
I.4. Fichas estezado

384 


\section{I.5. FICHAS TRANSFERENCIA}



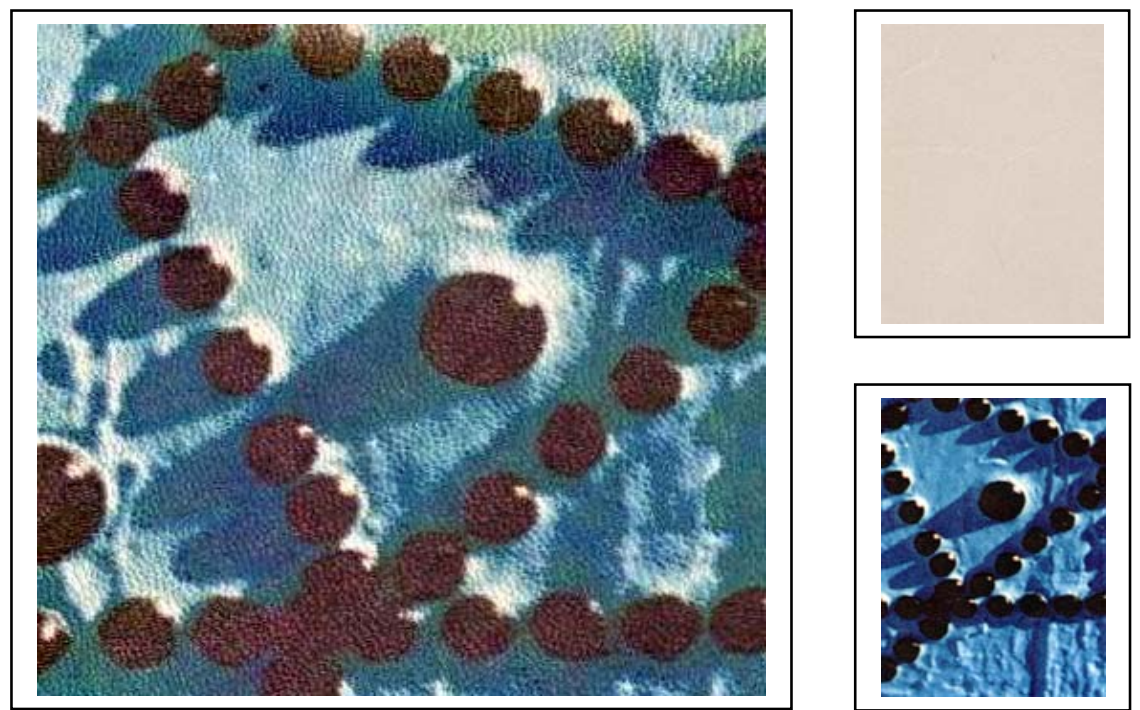

CÓDIGO: TR-001

PIEL: Cabra
SUPERFICIE: Lado flor

CALIDAD: Buena

La piel de cabra se muestra como una de las mejores como soporte para transferencias químicas incluso por su lado flor. La respuesta es muy satisfactoria, tan sólo con pequeños problemas a la hora de transferir el negro, el cual no logra alcanzar un nivel de intensidad tan elevado como en otros ejemplos que veremos. También se observan dificultades en reflejar los medios tonos, lográndose una imagen muy contrastada a diferencia de lo que ocurrirá con su gemela sobre el lado carne (TRA-02). Pese a estos pequeños inconvenientes el resultado es muy correcto si lo comparamos con el resto de transferencias sobre el lado flor (TRA-03, TRA-05 y TRA-07) 

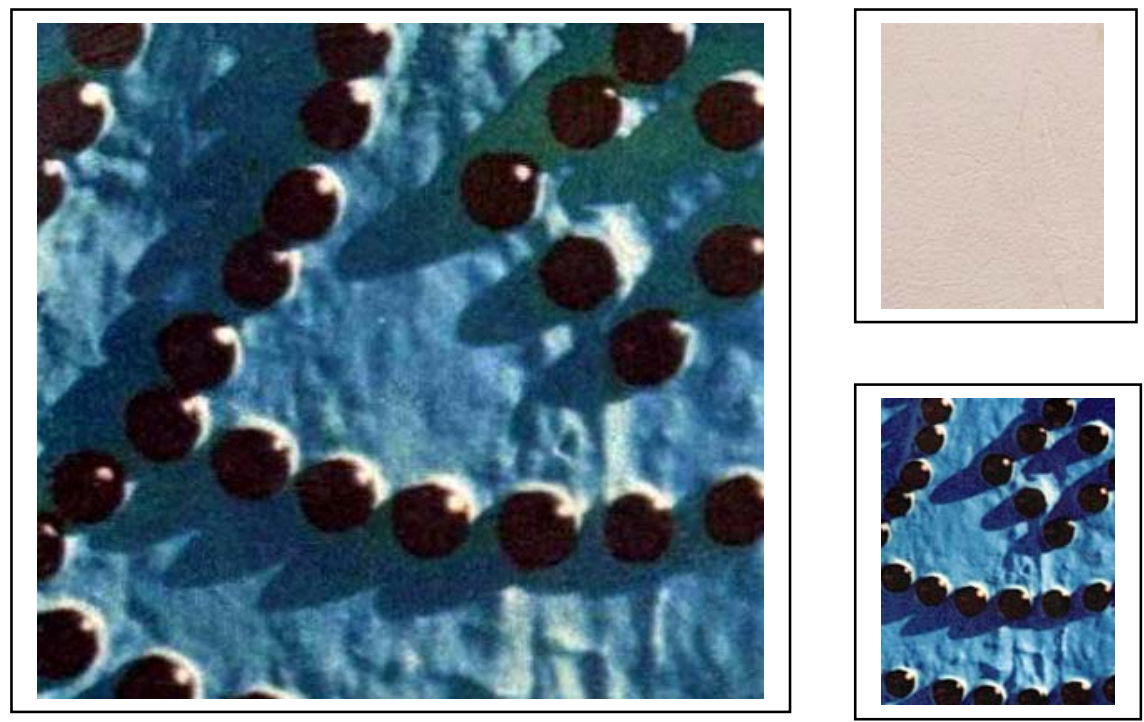

CÓDIGO: TR-002

SUPERFICIE: Lado carne

PIEL: Cabra

CALIDAD: Muy buena

La piel de cabra se muestra como una de las mejores como soporte para transferencias químicas incluso por su lado flor. La respuesta es muy satisfactoria, tan sólo con pequeños problemas a la hora de transferir el negro, el cual no logra alcanzar un nivel de intensidad tan elevado como en otros ejemplos que veremos. También se observan dificultades en reflejar los medios tonos, lográndose una imagen muy contrastada a diferencia de lo que ocurrirá con su gemela sobre el lado carne (TRA-02). Pese a estos pequeños inconvenientes el resultado es muy correcto si lo comparamos con el resto de transferencias sobre el lado flor (TRA-03, TRA-05 y TRA-07) 


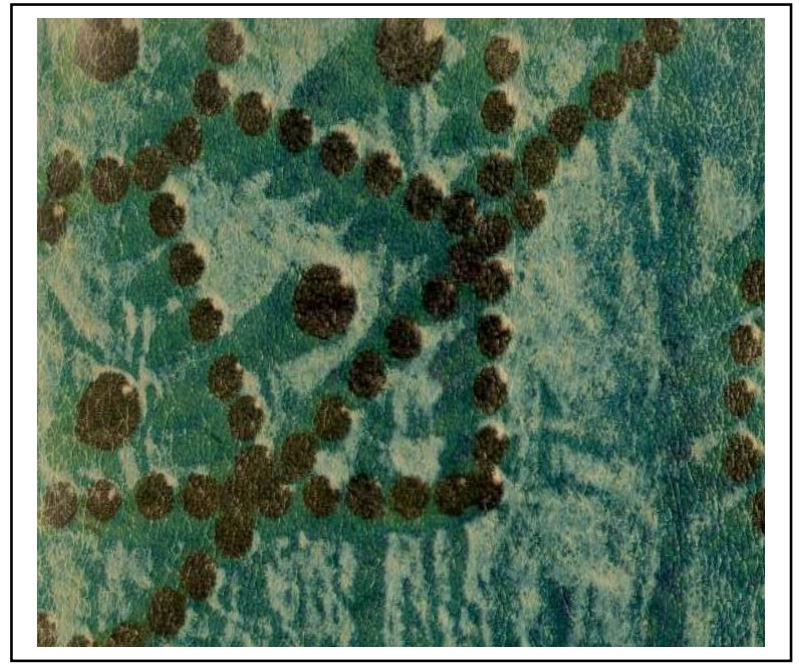

CODIGO: TRA-03
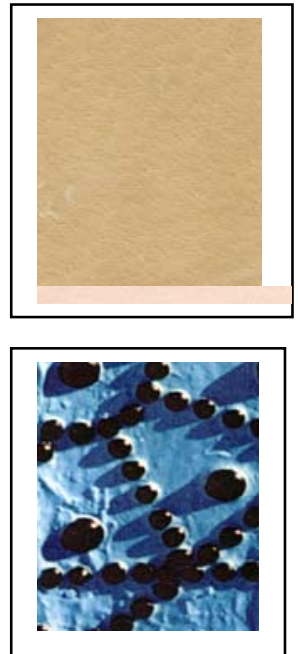

PIEL: Cerdo

LADO PIEL: Flor

CALIDAD: Mala

A diferencia del ejemplo TRA-01 sobre piel de cabra, este cuero porcino ofrece numerosos inconvenientes a la hora de ser empleado como soporte para transferencias químicas. Todos ellos vienen condicionados por el acabado de la piel de cerdo, un acabado que provoca que el pigmento de la fotocopiadora no se asiente de manera correcta sobre la superficie. Así, tenemos zonas de deficiente transferencia, ausencia de intensidad en el negro y un excesivo brillo en las áreas donde el toner se ha depositado con mayor densidad. En definitiva, este tipo de forros porcinos no se presentan como un soporte ideal en su lado flor, consideración que cambiará en el siguiente ejemplo sobre lado carne (TRA-04). 


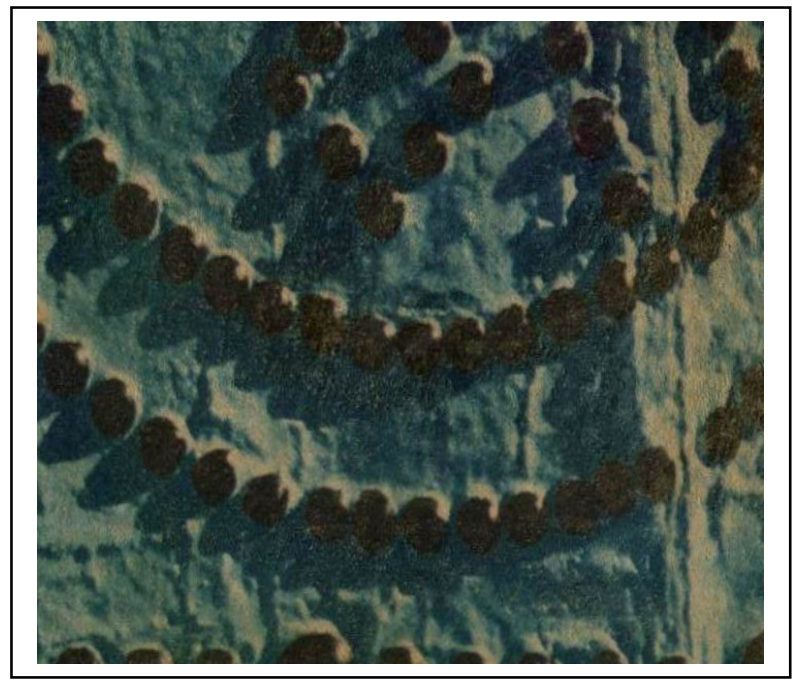

CODIGO: TRA-04
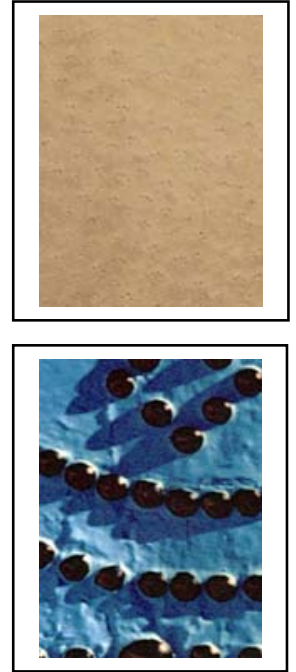

PIEL: Cerdo

LADO PIEL: Carne

CALIDAD: Mediocre

Las diferencias con respecto al ejemplo anterior son evidentes, centrándose en dos aspectos fundamentales. El primero es el oscurecimiento patente de la imagen al contacto con el afelpado del lado carne del cuero, mientras que el segundo está relacionado con la ausencia total de brillos en la superficie cubierta por el pigmento. Este último factor está íntimamente relacionado con la naturaleza del soporte y su afelpado (el cual elimina cualquier brillo que pudiera aparecer), y dota a la imagen de una apariencia de mayor calidad que la anterior. Pese a esta mejoría el afelpado desvirtúa la nitidez de la imagen original y provoca que el resultado no sea tan bueno como en otros ejemplos sobre los lados carne de las pieles. 

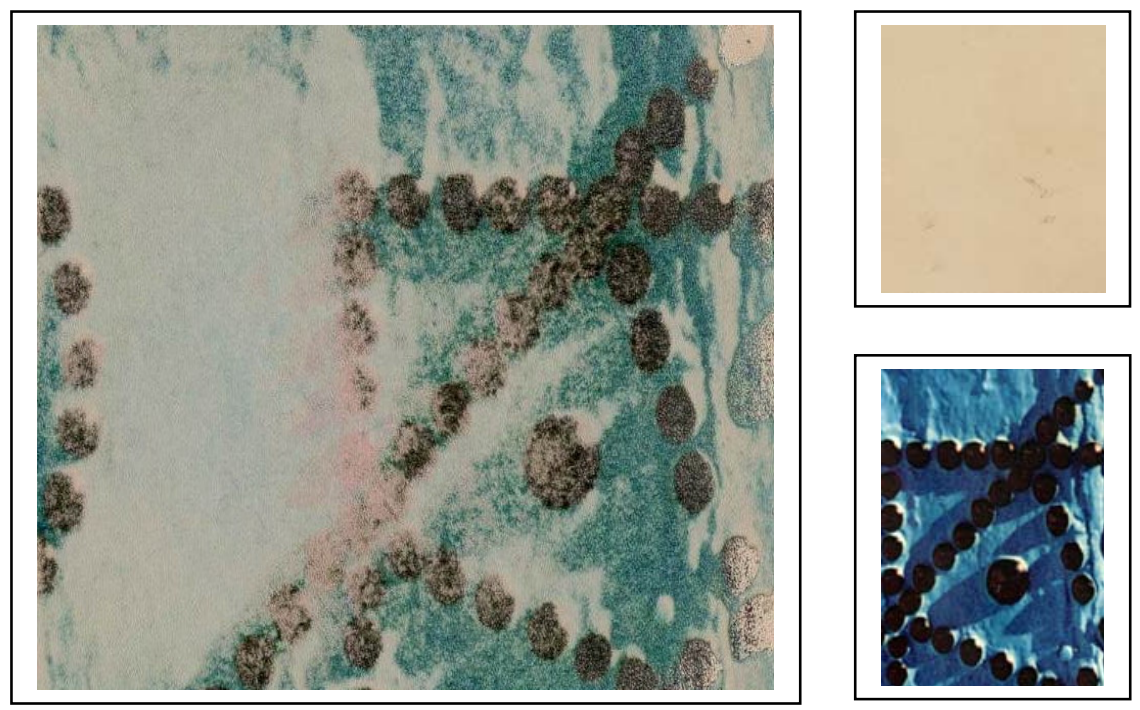

CODIGO: TRA-05

PIEL: Cordero

LADO PIEL: Flor

CALIDAD: Muy mala

Una de las peores transferencias de todo el grupo es esta realizada sobre la piel ovina, cuyo acabado algo satinado y brillante provoca que el pigmento no asiente de manera correcta sobre el cuero. Apenas ciertas zonas de la imagen se han transferido de manera satisfactoria, con numerosas lagunas y una muy deficiente transferencia del tono negro de la fotocopia. Aparecen de nuevo potentes brillos en las zonas cubiertas por el pigmento, al igual que ocurría en el ejemplo TRA-03 sobre el lado flor de la piel de cerdo. El resultado es pésimo en todos los sentidos, constituyéndose como uno de los peores soportes para este tipo de técnica. 


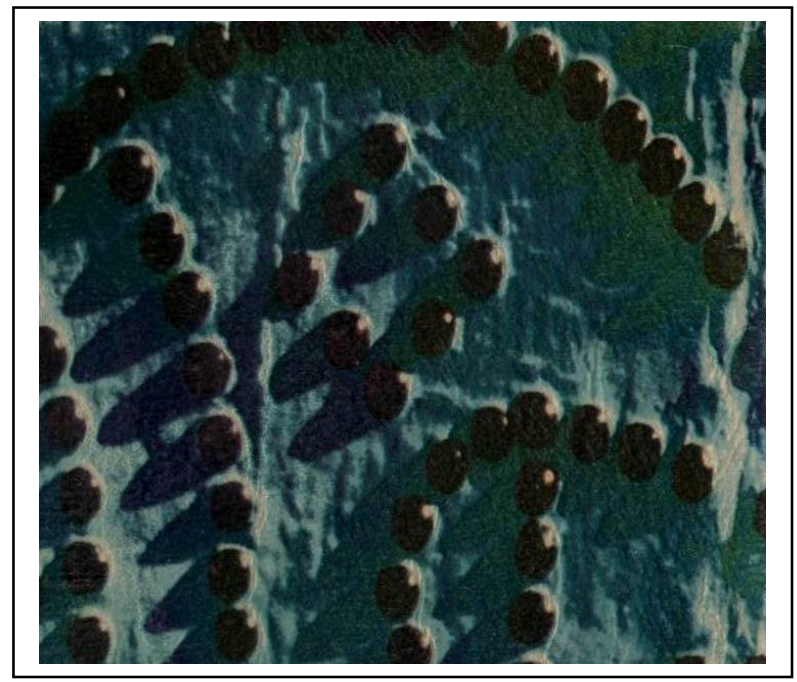

CODIGO: TRA-06
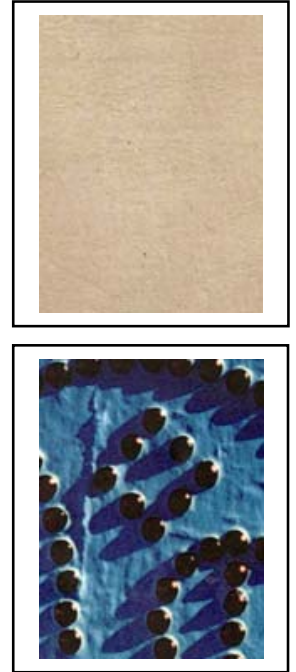

PIEL: Cordero

LADO PIEL: Carne

CALIDAD: Buena

En este ejemplo ocurre todo lo contrario que en el anterior (TRA-05), con unos resultados de aceptable nivel a pesar de aparecer ciertas irregularidades en algunas zonas de la imagen. Éstas se concentran en las áreas de sombra, en las cuales el pigmento negro no ha logrado una transferencia y un asentamiento óptimo. Indicar que a pesar de tratarse de una imagen realizada sobre el lado carne de un cuero, en las zonas de mayor densidad de pigmentación aparecen ligeros brillos, los cuales sin embargo no llegan a ser demasiado molestos como para poder tener una correcta visión del ejemplo. 


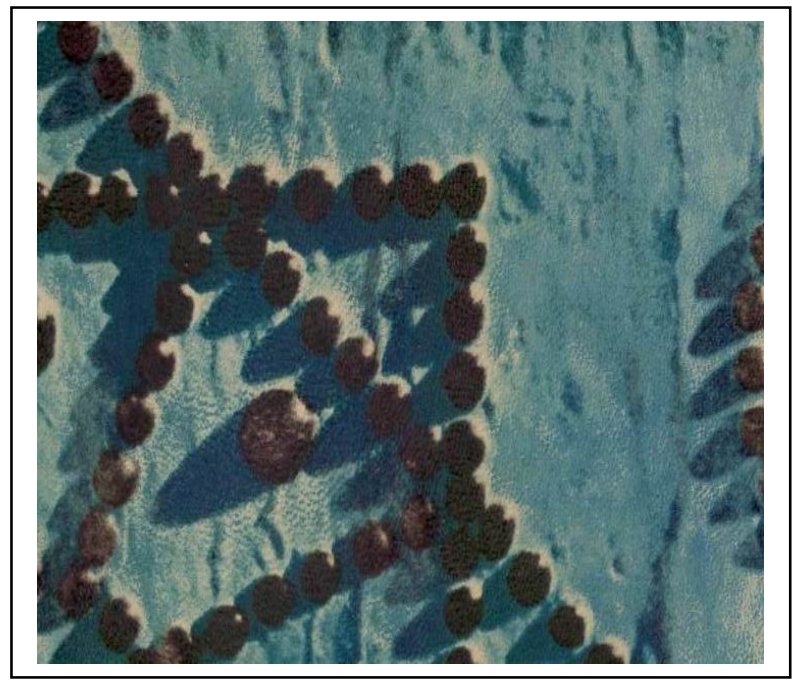

CODIGO: TRA-07
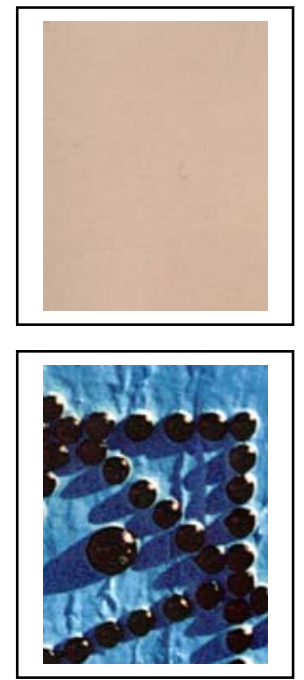

PIEL: Vaca

LADO PIEL: Flor

CALIDAD: Buena

Pese a presentar ciertos problemas de asentamiento del pigmento, esta superficie se muestra como muy apropiada para ser utilizada como soporte para transferencias químicas. Siempre que los niveles de presión y cantidad de disolvente sean los precisos, las imágenes se transferirán de manera muy satisfactoria. Se debe estar muy atento a dichos niveles ya que cualquier mínima variación de los mismos llevará unida una deficiente transferencia de los tonos negros de la imagen original, los cuales se verán disminuidos en su intensidad. A diferencia de lo que sería de esperar, y pese a estar trabajando sobre una superficie satinada de un cuero en su lado flor, no aparecen apenas brillos excesivos sobre la piel, lo que permite que la imagen transferida se integre de manera casi perfecta en el soporte. 

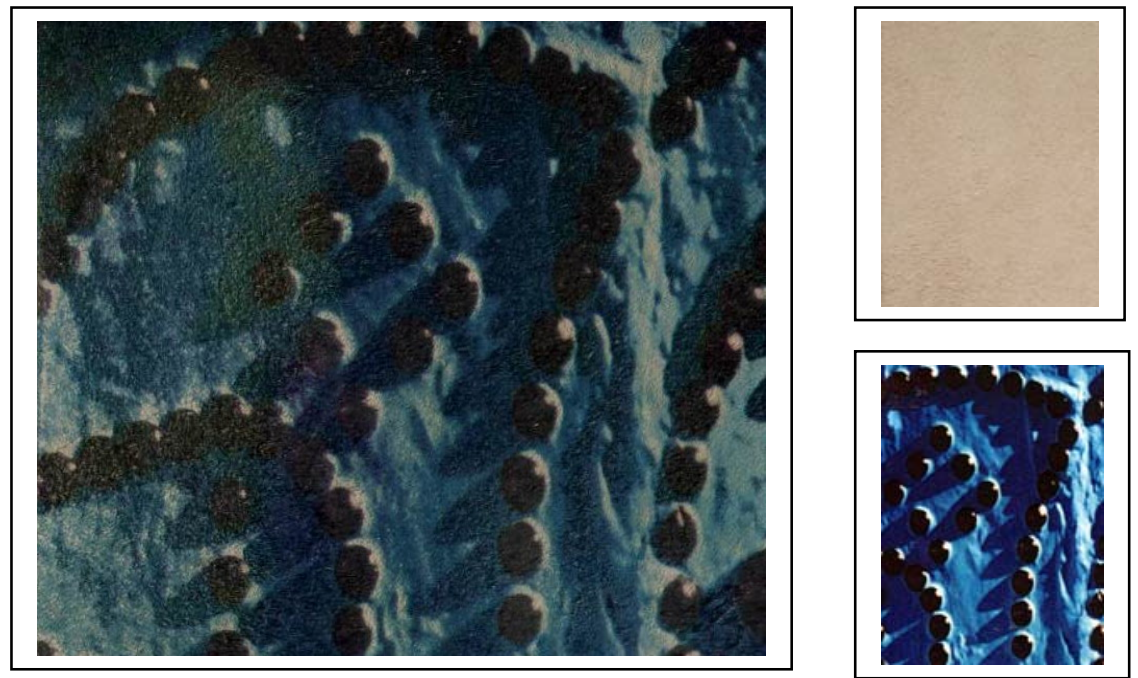

CODIGO: TRA-08

PIEL: Vaca

LADO PIEL: Carne

CALIDAD: Mediocre

El principal problema de este ejemplo concreto es el excesivo afelpado de ciertas zonas de la piel, afelpado que provoca deficiencias de transferencia de la imagen original. De nuevo vemos como la imagen sufre un proceso de oscurecimiento evidente al contacto con la superficie del cuero en su lado carne (efecto común no sólo a todos los ejemplos de transferencias, sino también a las estampas xilográficas y calcográficas), oscurecimiento que no llega a desvirtuar la apariencia de la imagen. Indicar a su vez que no aparece ningún tipo de brillo en la superficie del cuero, a diferencia de lo que hemos visto que ocurría en la imagen TRA-06. 
I.5. Fichas transferencia

394 


\section{TABLAS ESTADÍSTICAS}


II. Tablas estadísticas 
II. Tablas estadísticas

\section{II.1. Estadísticas generales}


II. Tablas estadísticas 


\section{ESTAMPAS TOTALES}
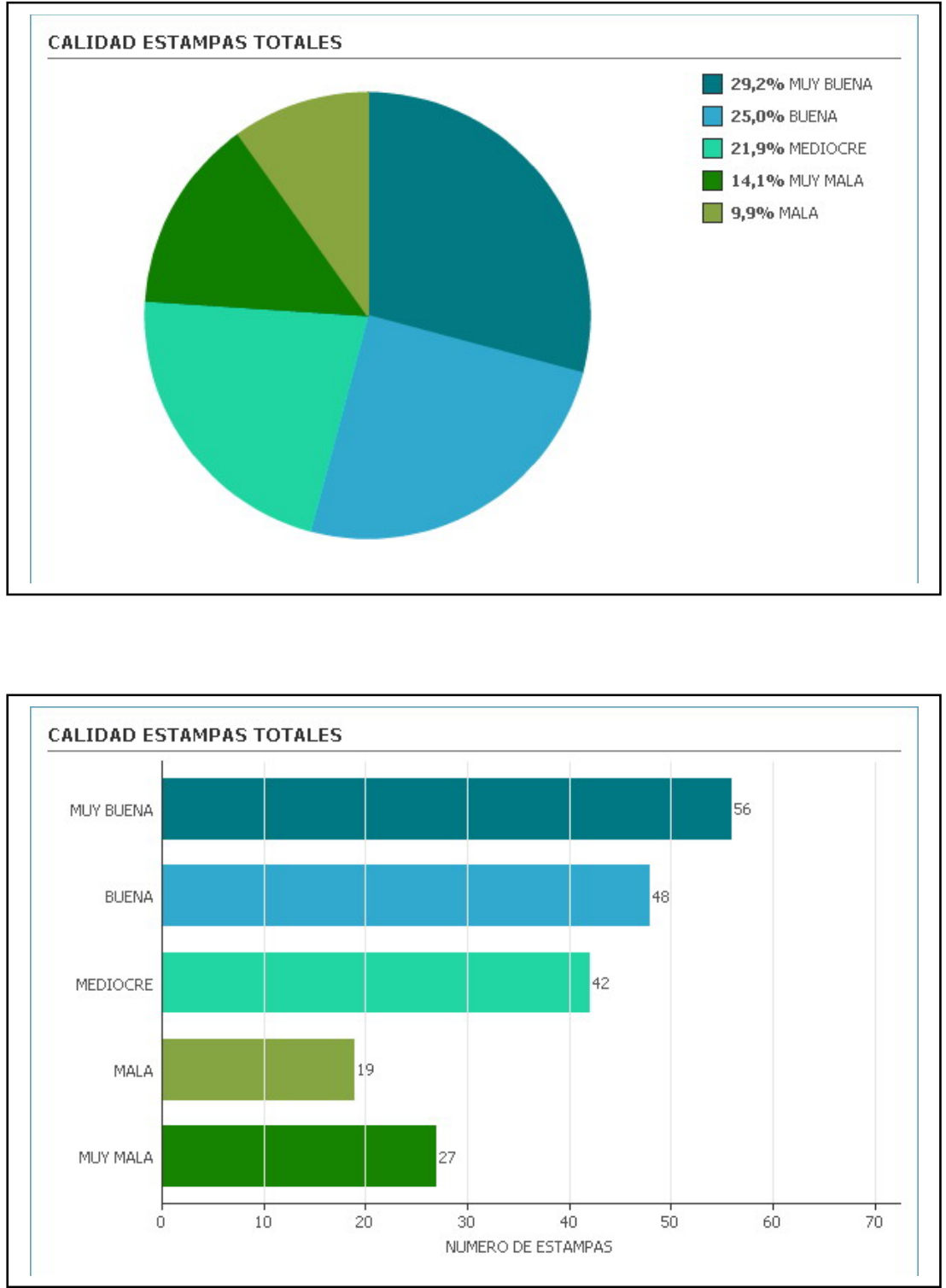
ESTAMPAS LADO FLOR
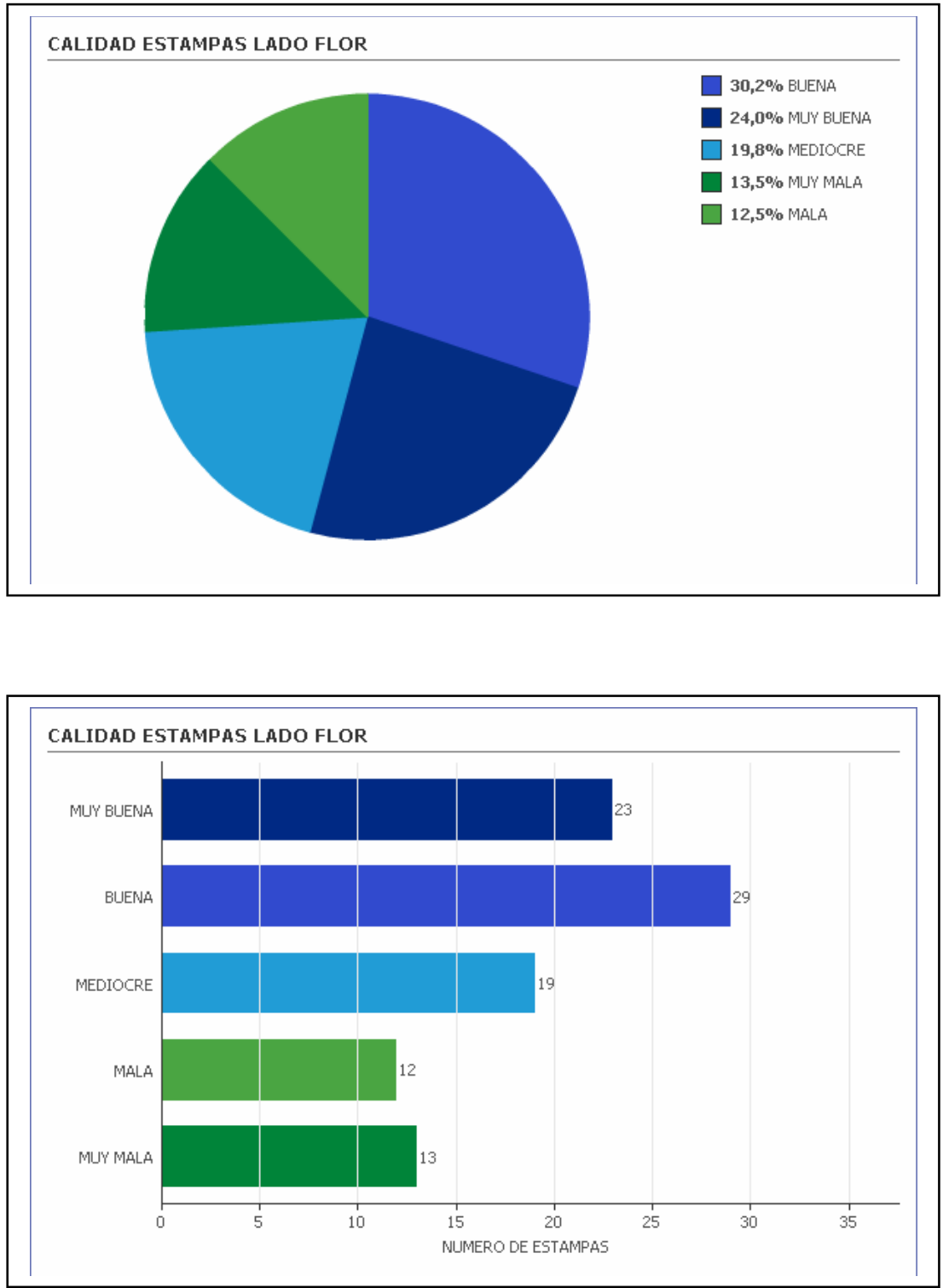
ESTAMPAS LADO CARNE
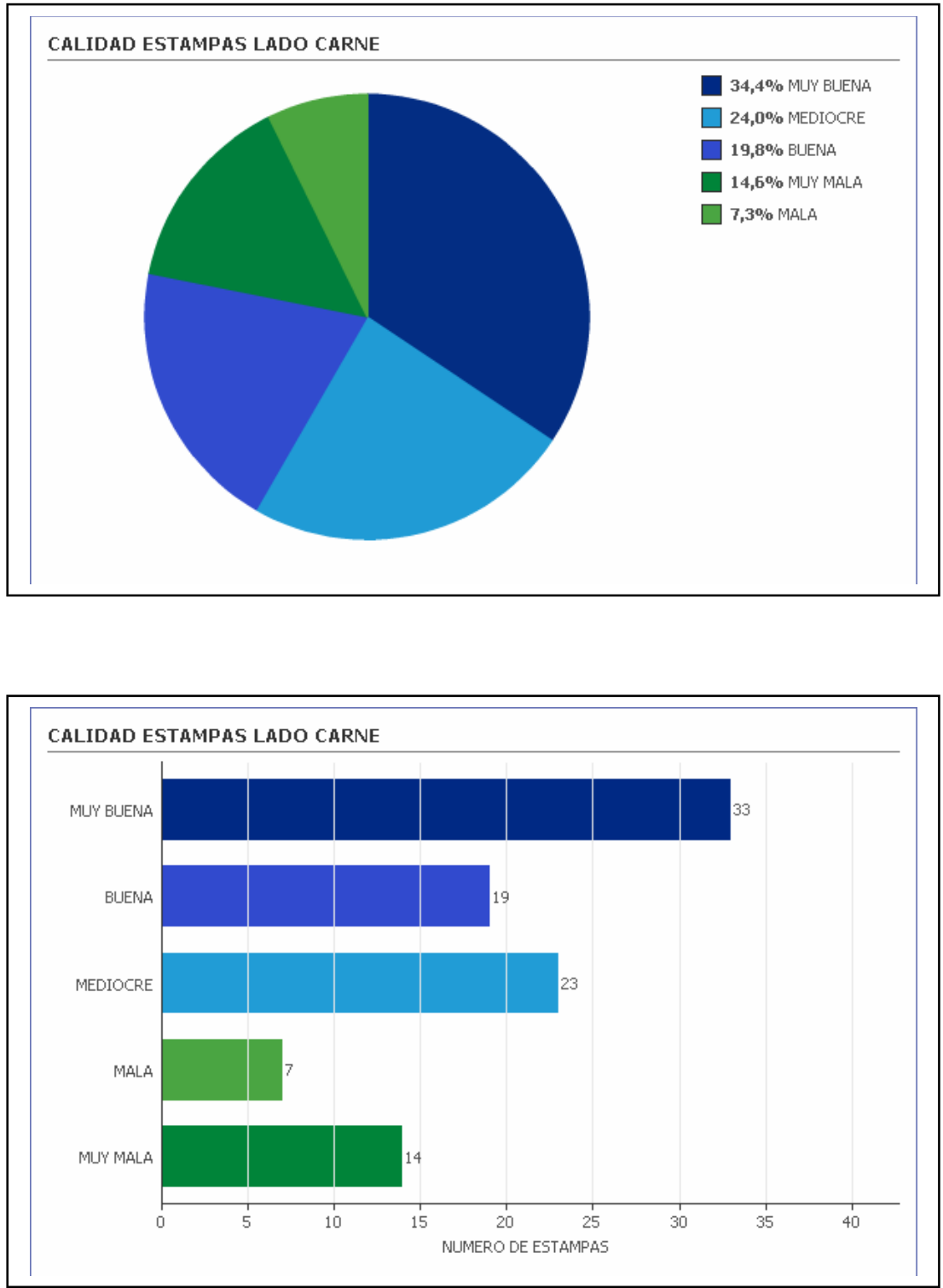
II. Tablas estadísticas

ESTAMPAS PIEL DE CABRA:
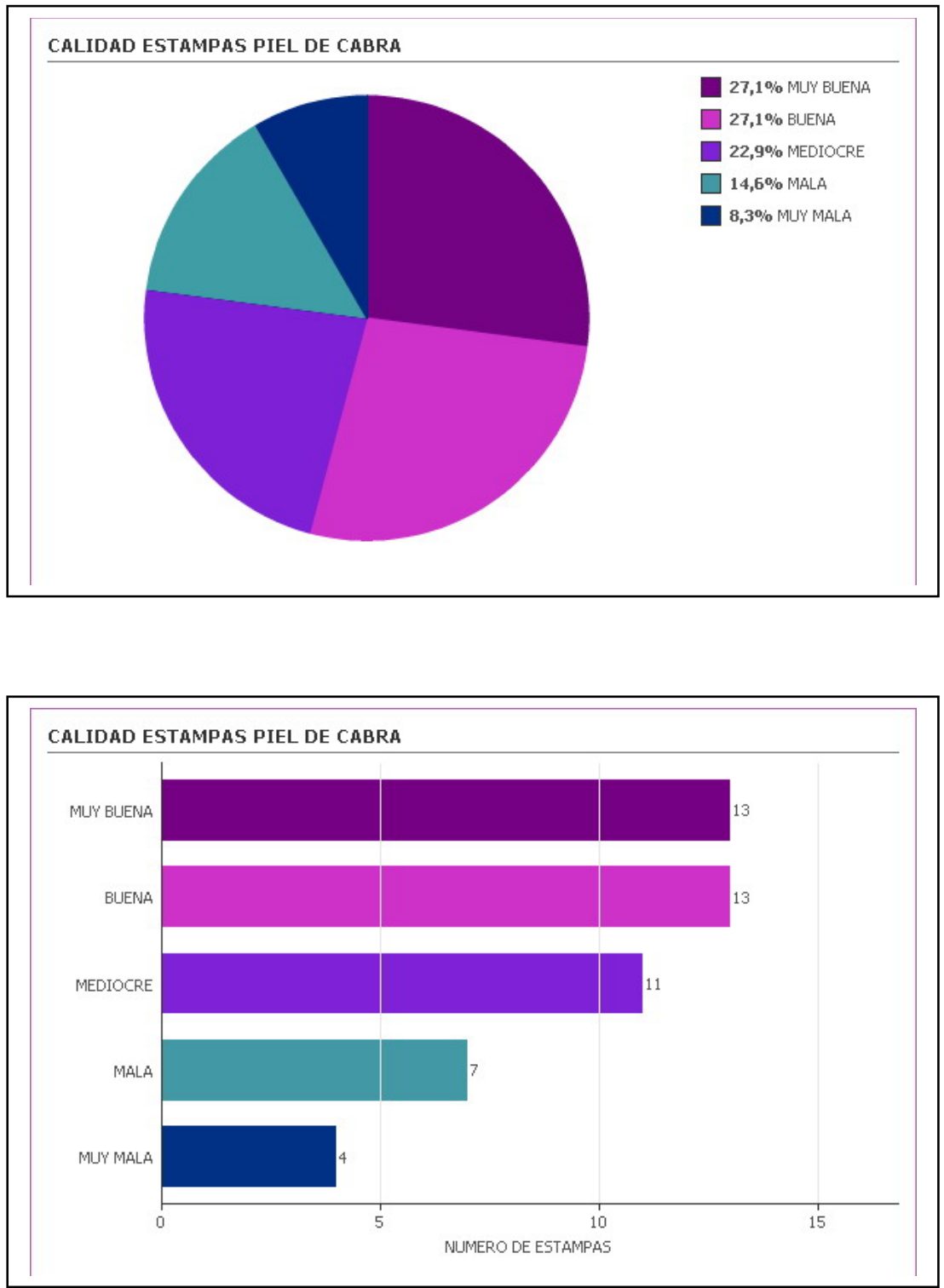
II. Tablas estadísticas

ESTAMPAS PIEL DE CERDO:
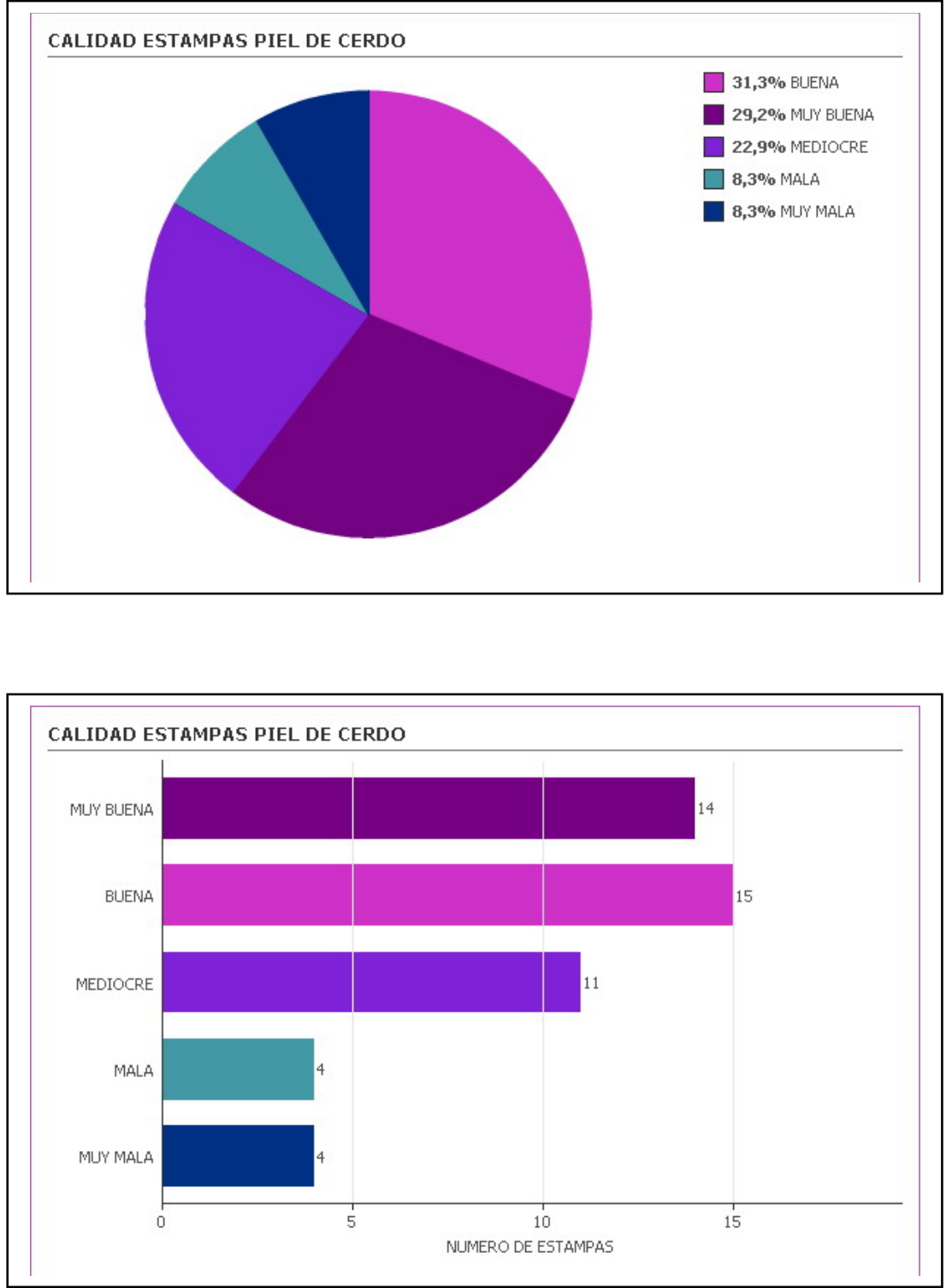
ESTAMPAS PIEL DE CORDERO:
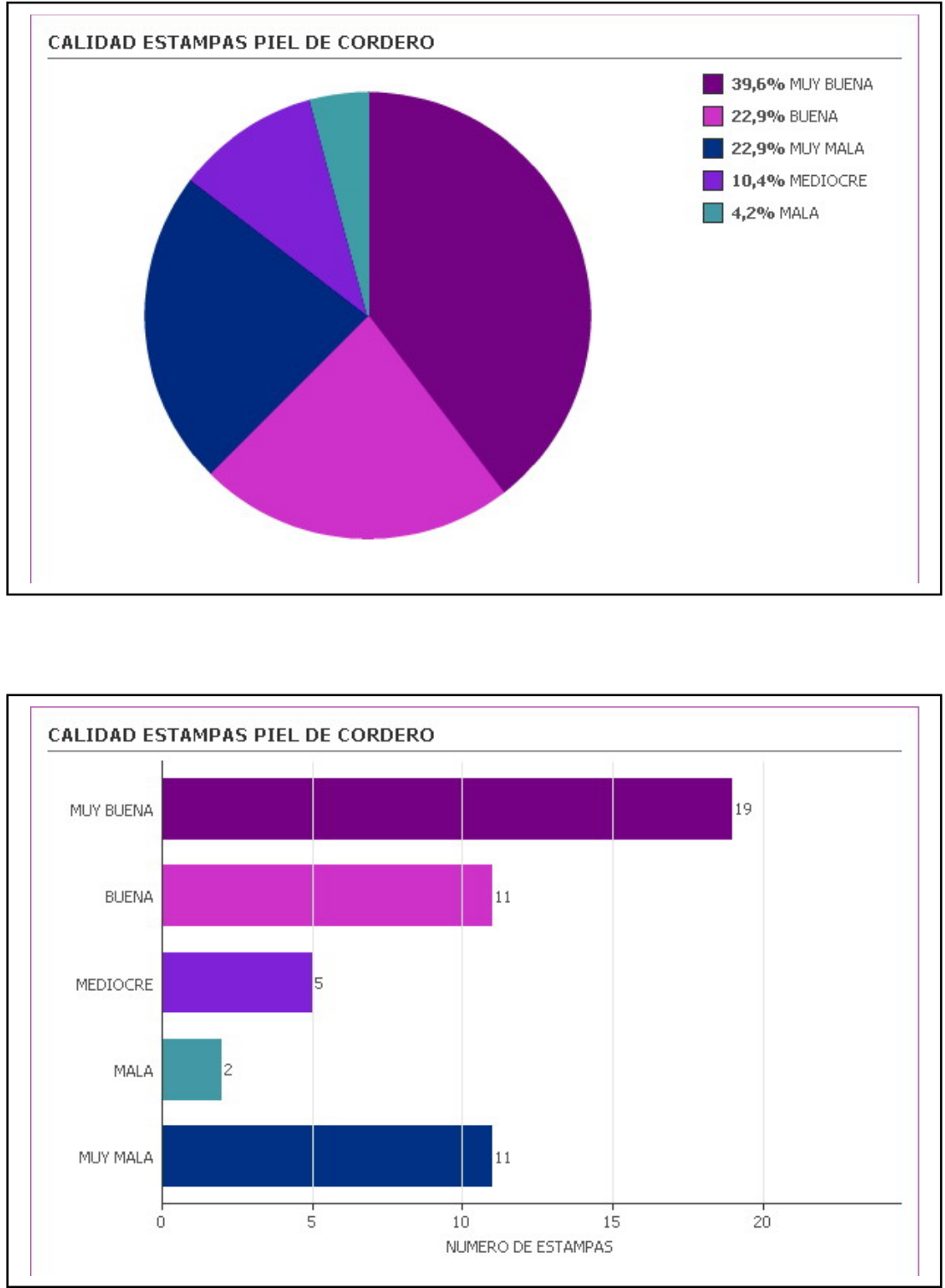
II. Tablas estadísticas

ESTAMPAS PIEL DE VACA:
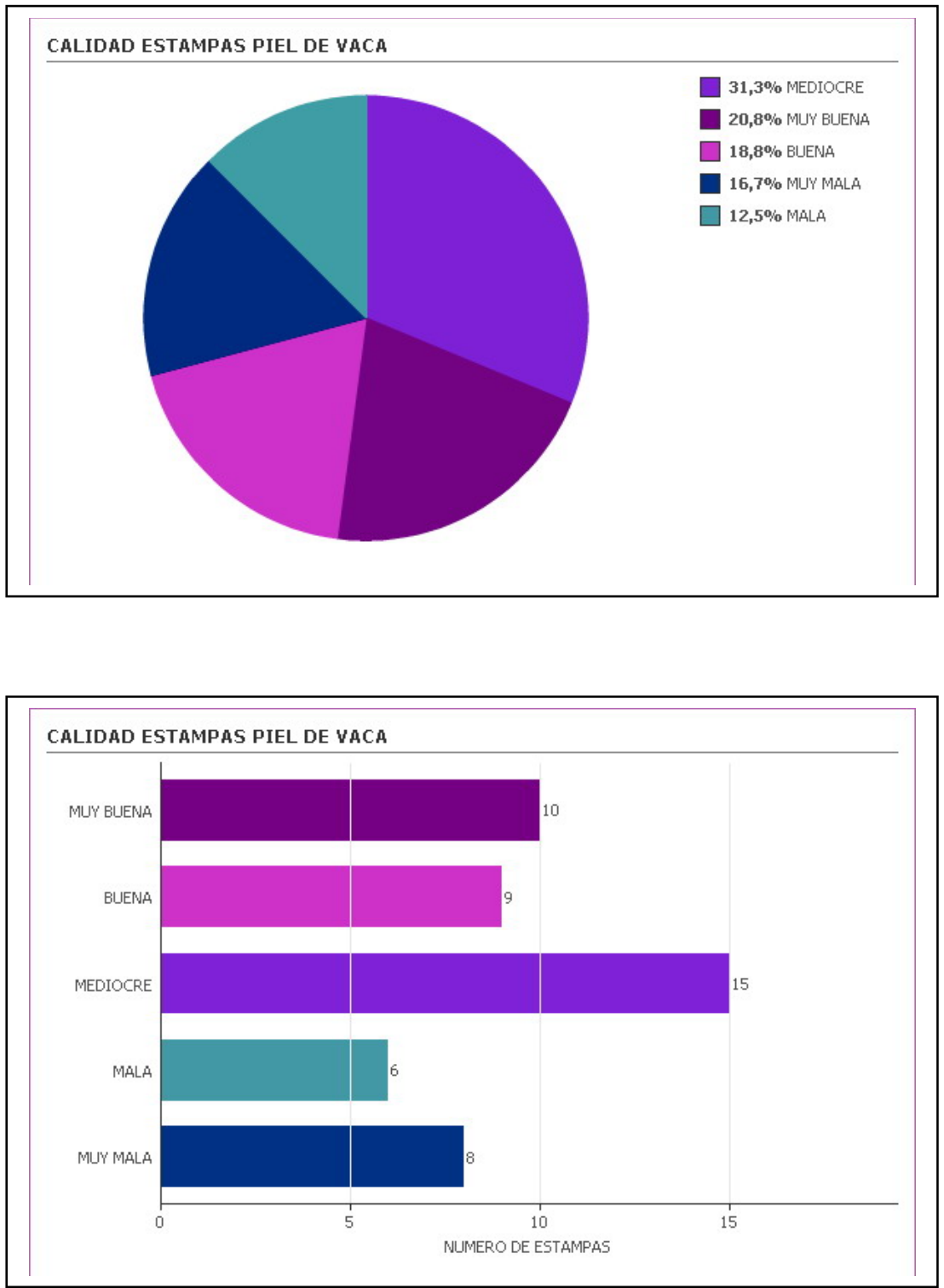
II. Tablas estadísticas

ESTAMPAS TINTA NEGRA:
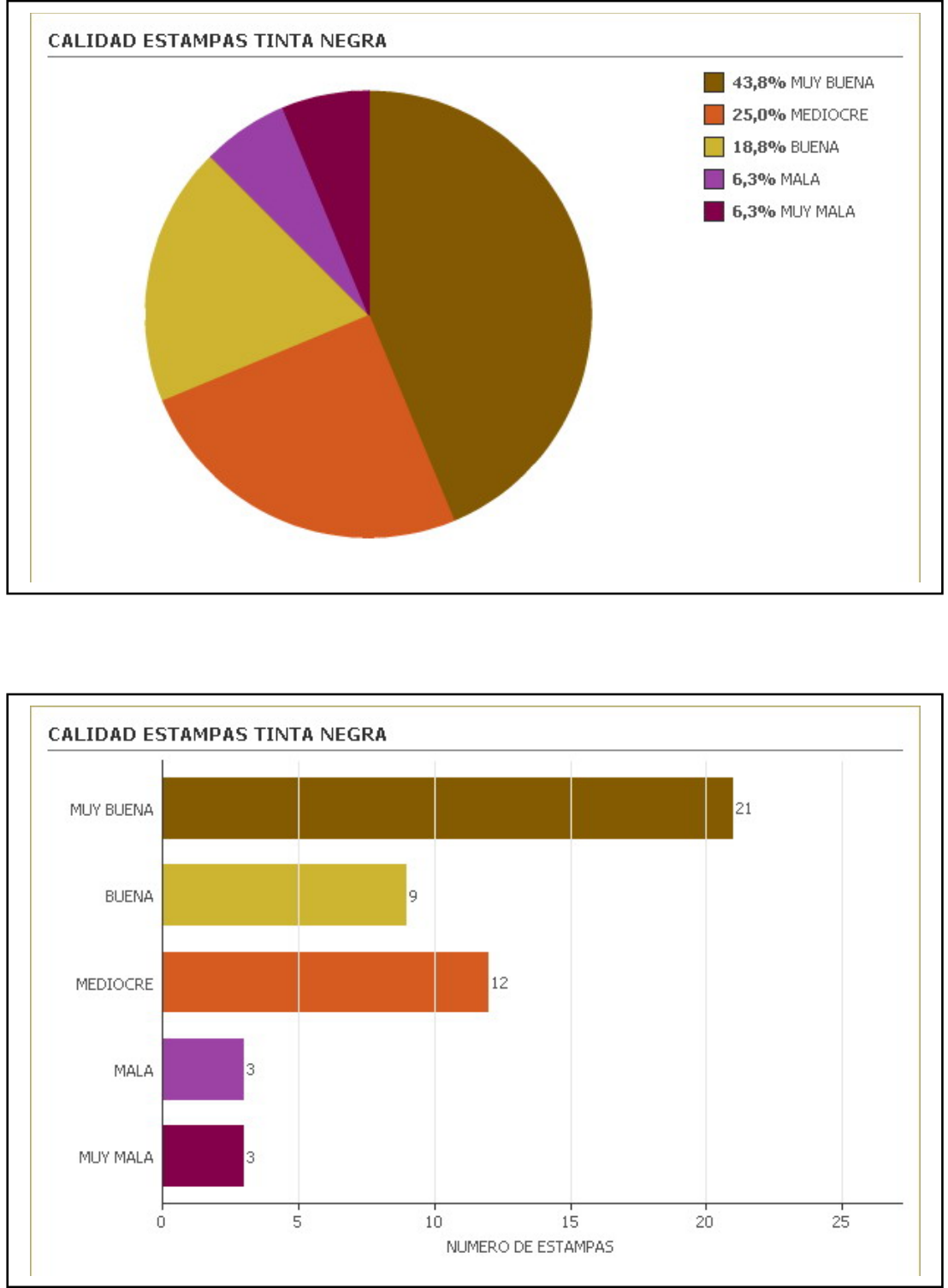
II. Tablas estadísticas

ESTAMPAS TINTA BLANCA:
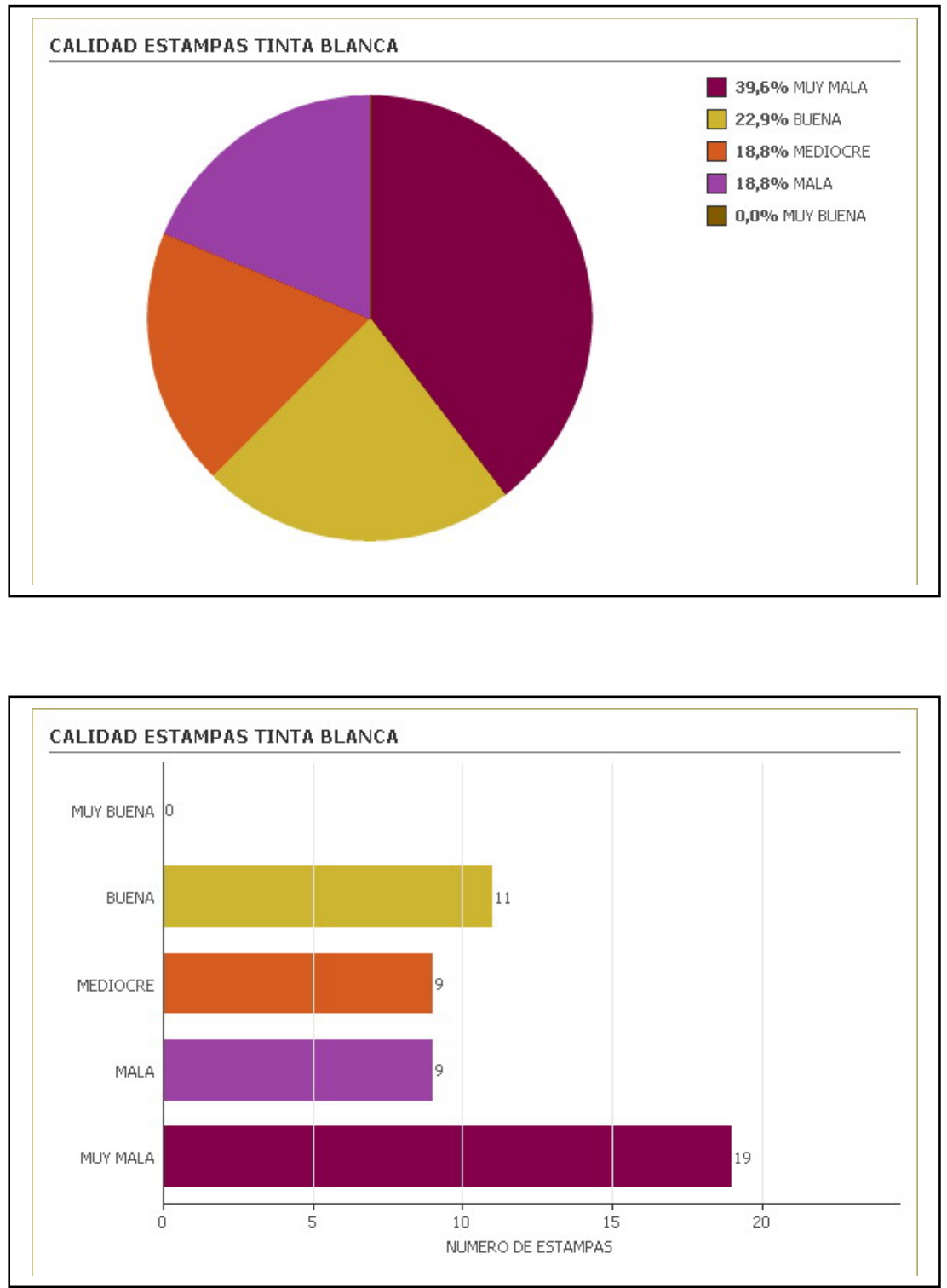
ESTAMPAS TINTA AZUL TRASLÚCIDO:
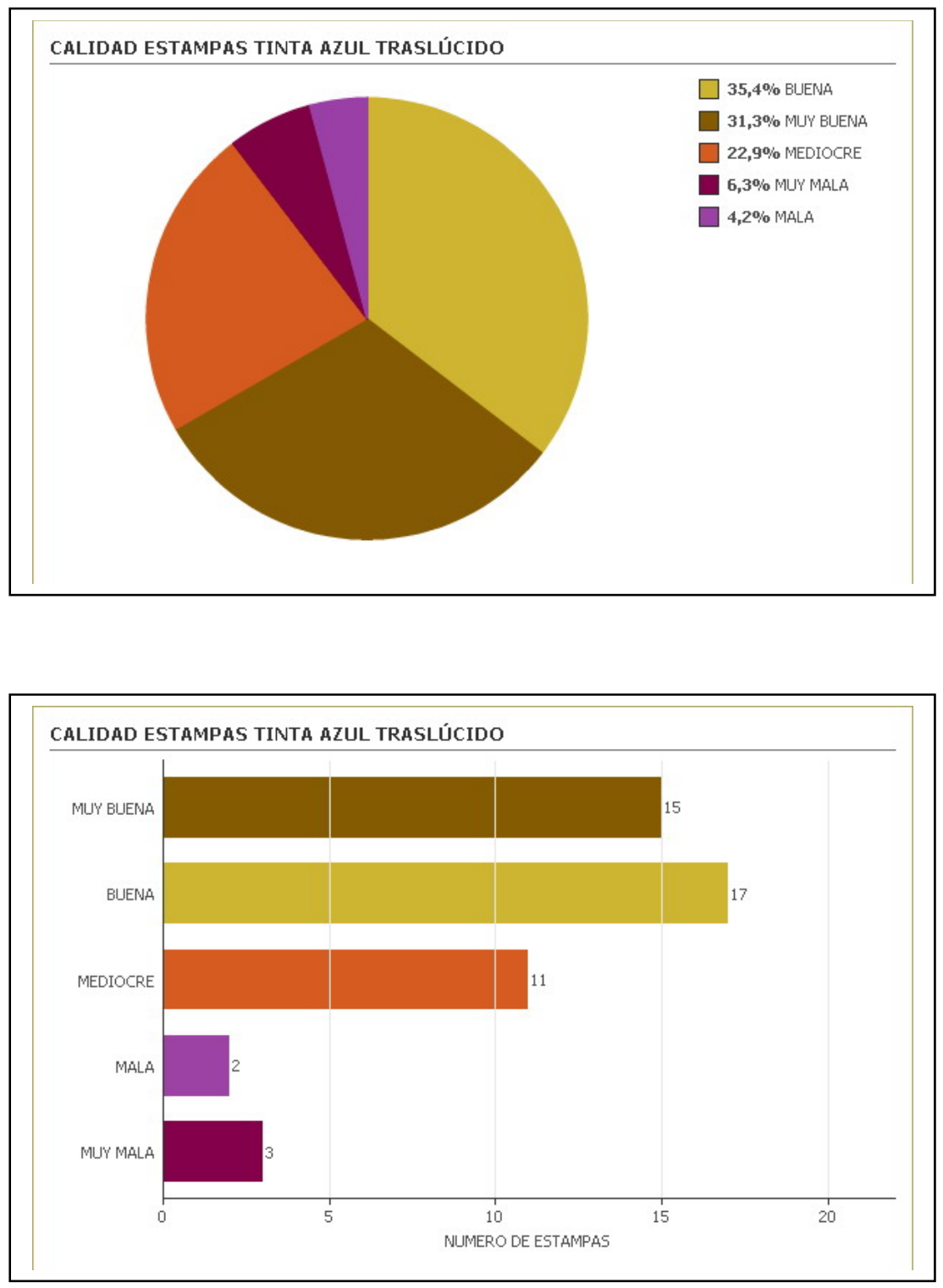
II. Tablas estadísticas

ESTAMPAS TINTA AZUL OPACO:
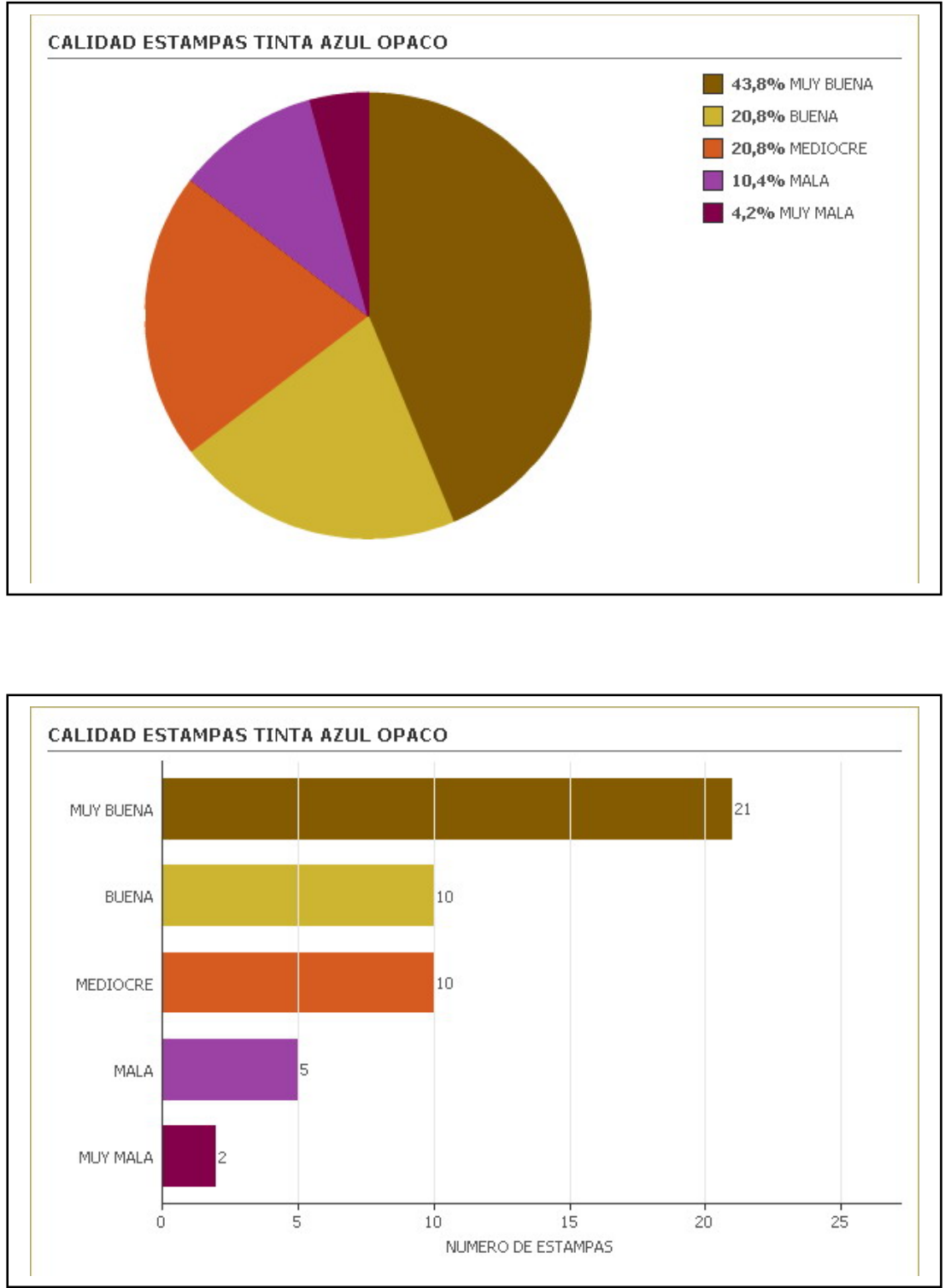
II. Tablas estadísticas 


\section{II.2. Estadísticas intervención xilográfica}


II. Tablas estadísticas 
ESTAMPAS XILOGRÁFICAS
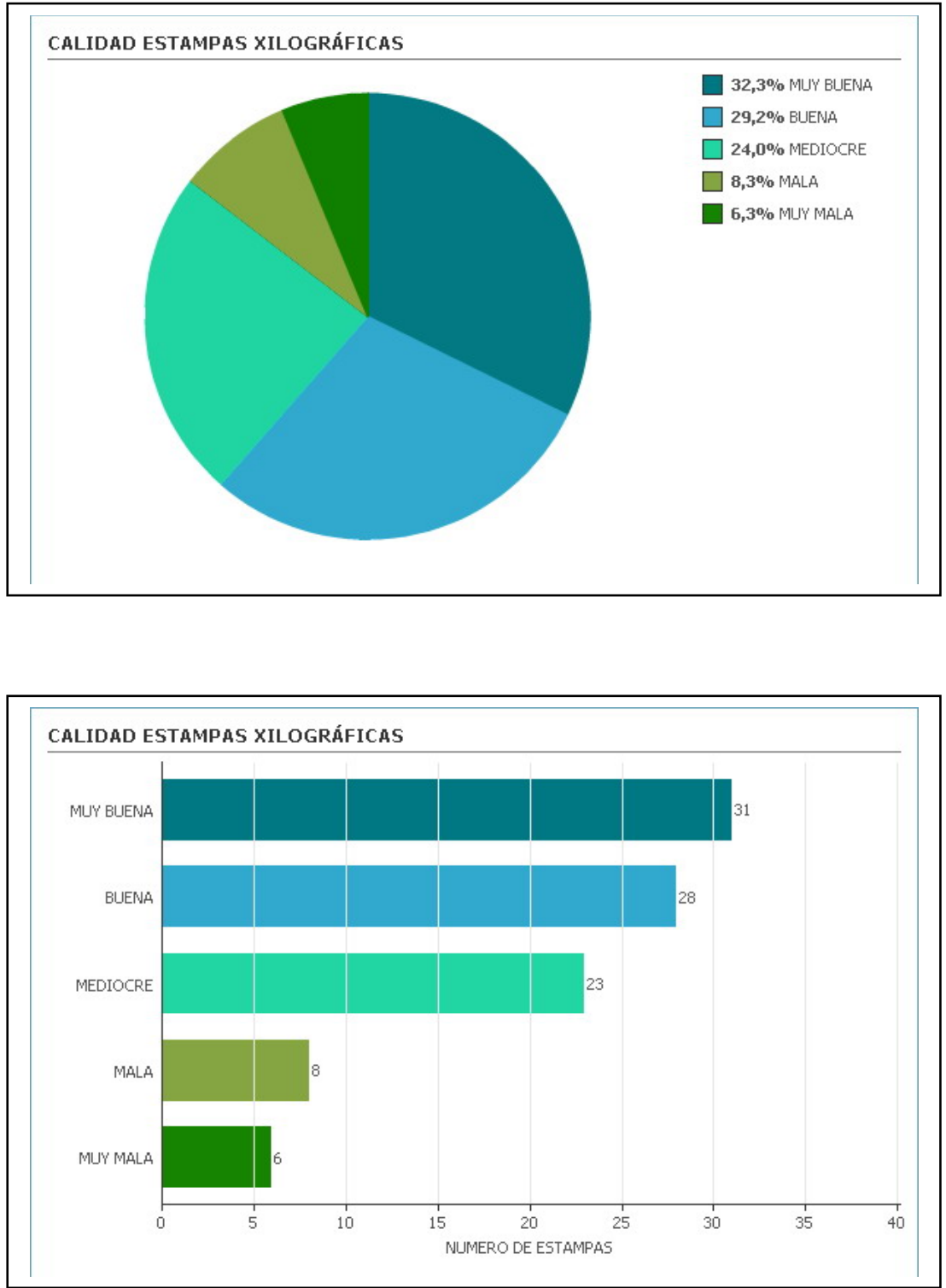
ESTAMPAS XILOGRÁFICAS SOBRE LADO FLOR
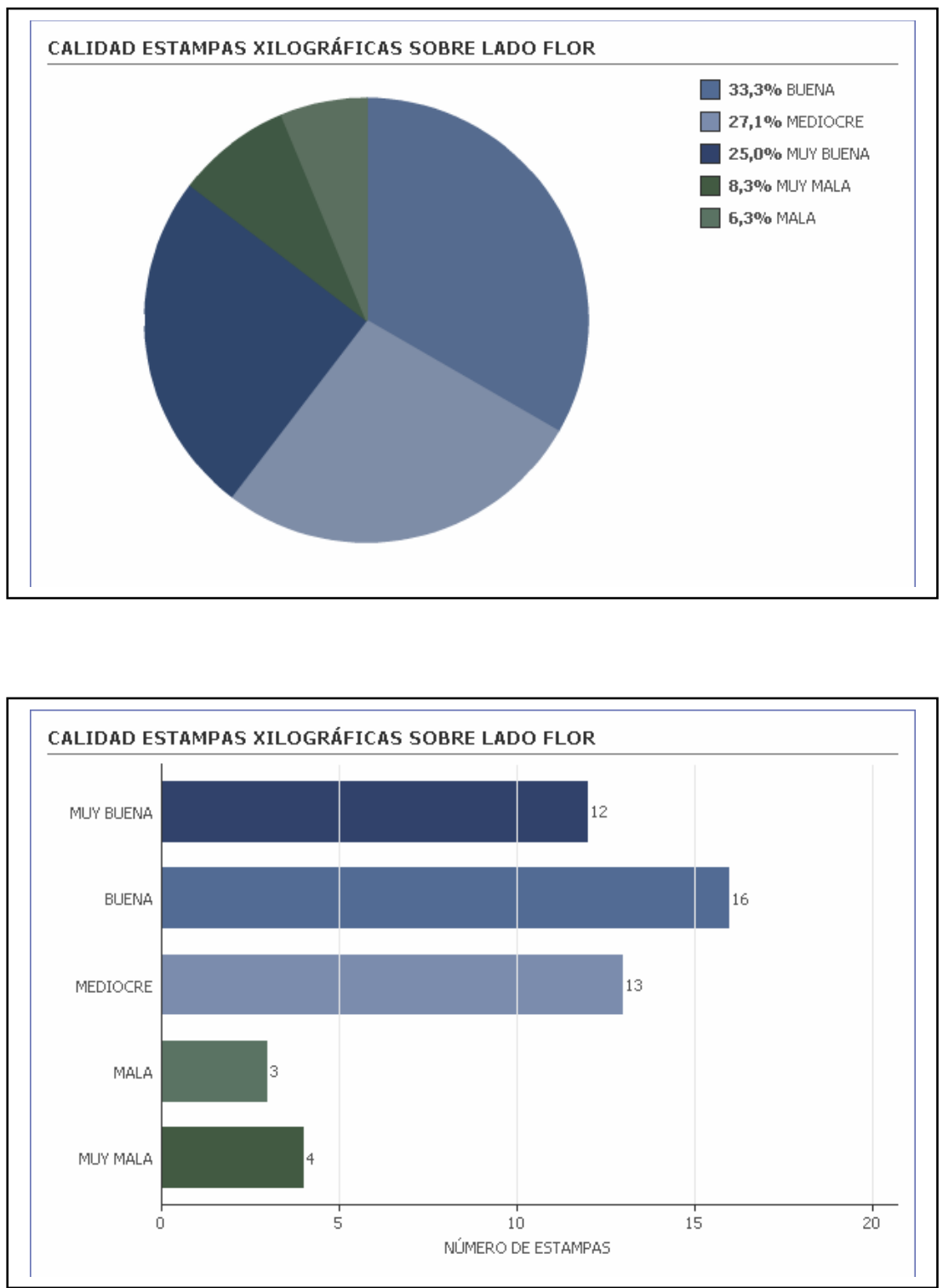


\section{ESTAMPAS XILOGRÁFICAS SOBRE LADO CARNE}
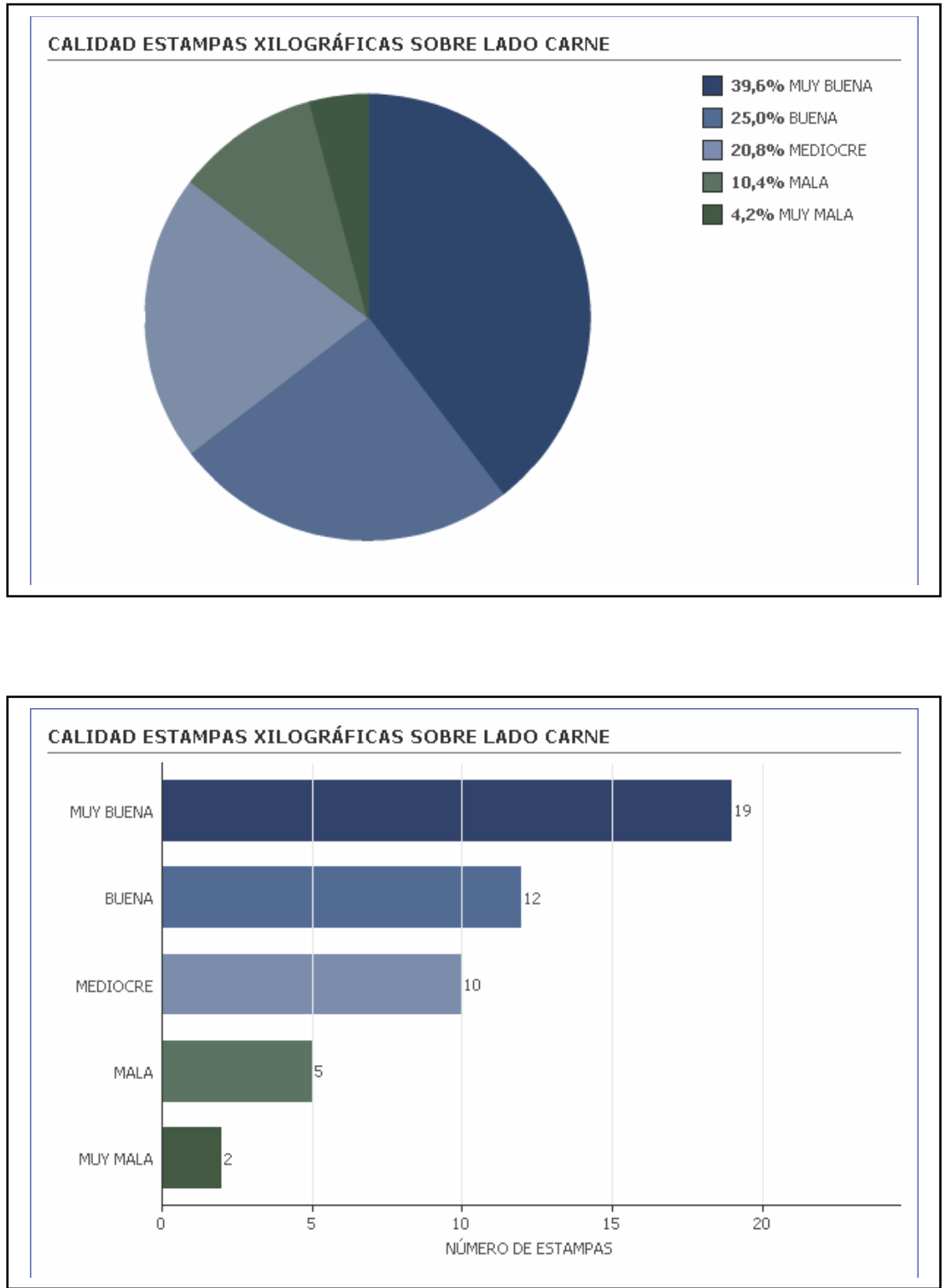


\section{ESTAMPAS XILOGRÁFICAS SOBRE CABRA}

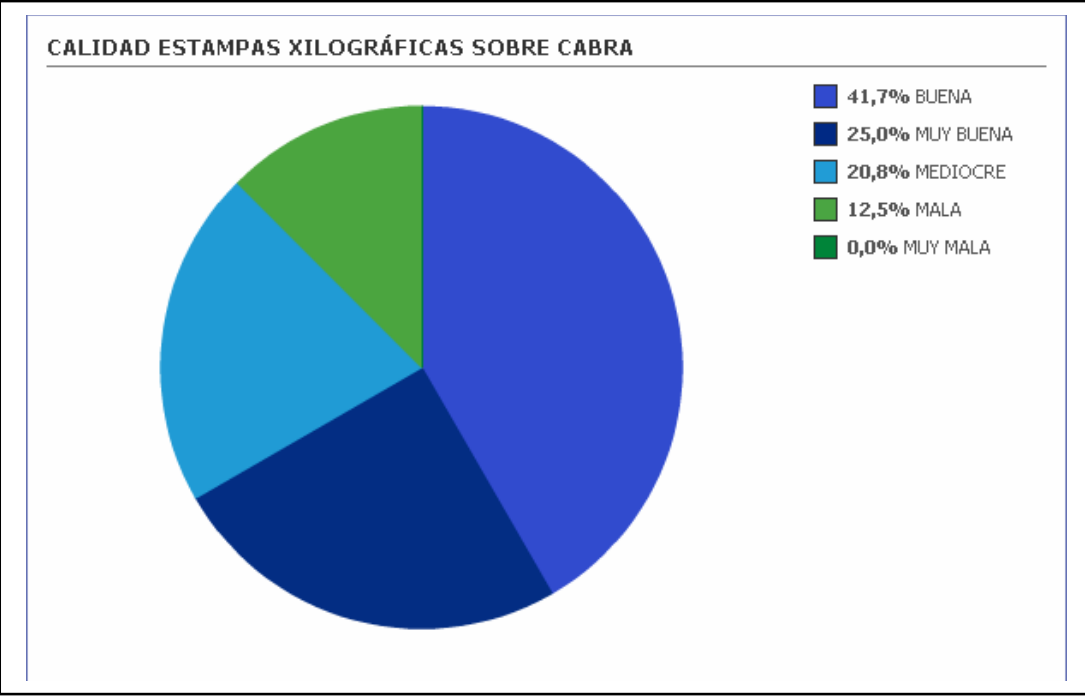

CALIDAD ESTAMPAS XILOGRÁFICAS SOBRE CABRA

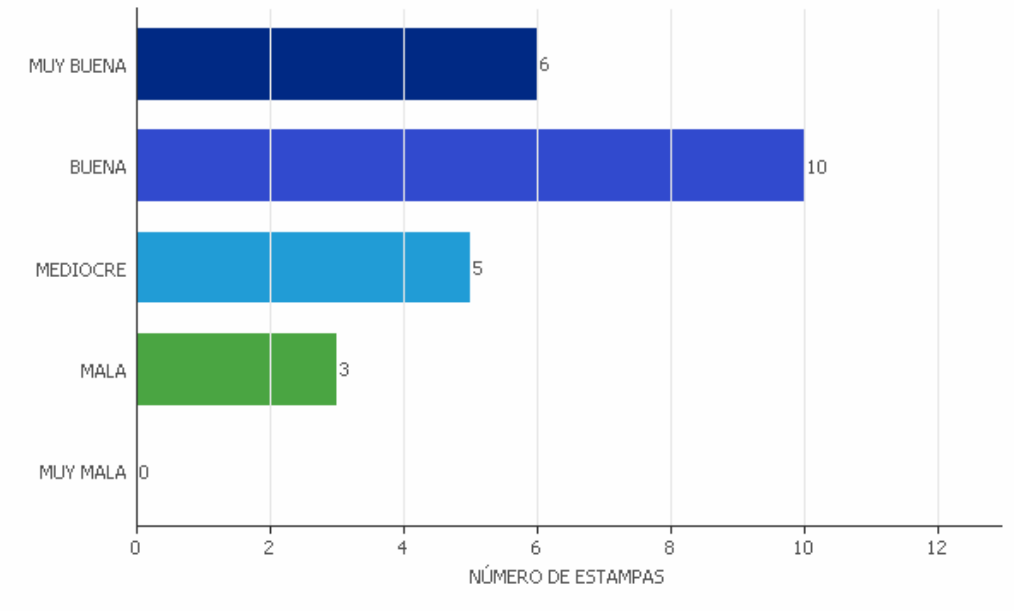




\section{ESTAMPAS XILOGRÁFICAS SOBRE CERDO}
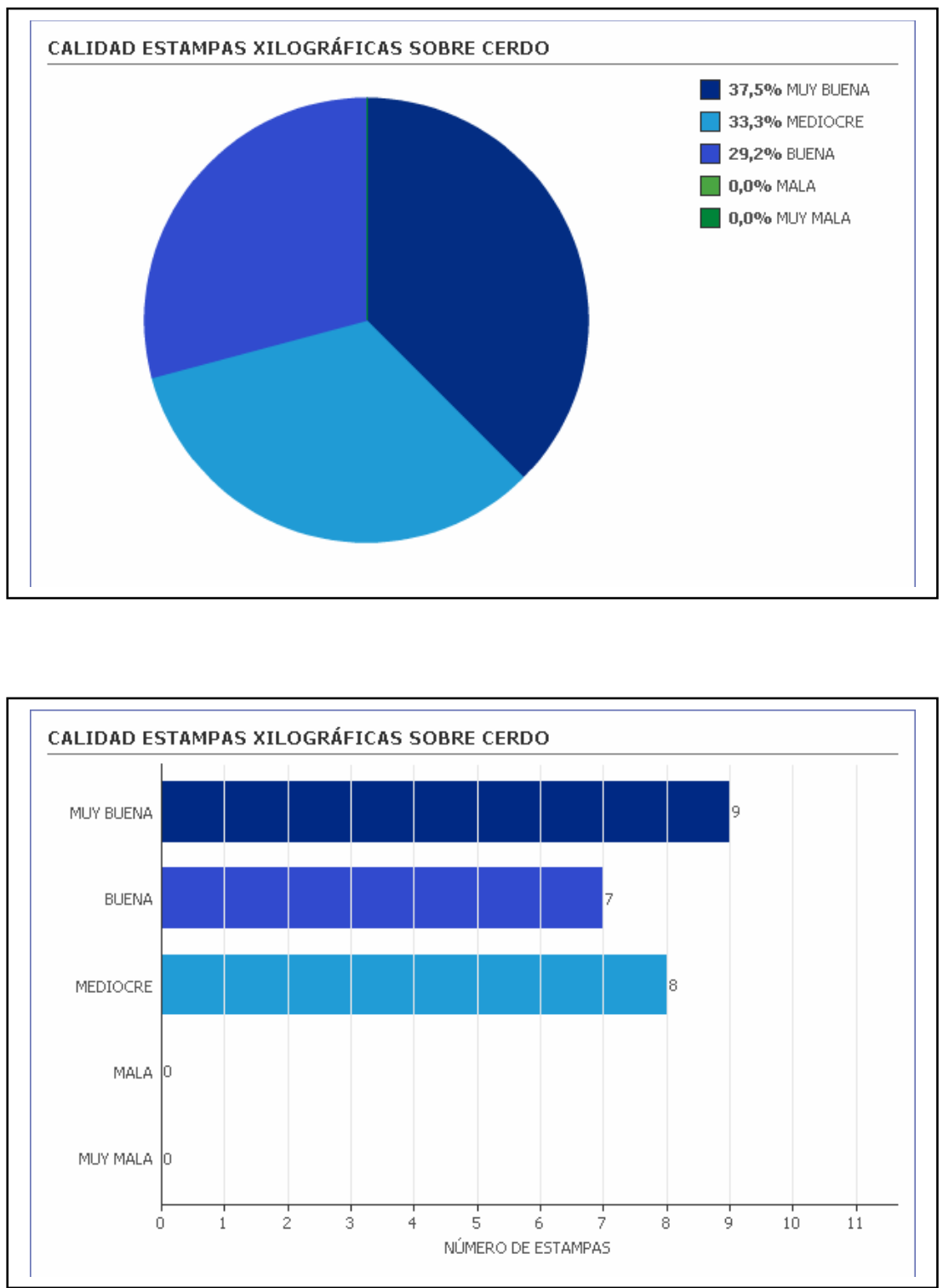


\section{ESTAMPAS XILOGRÁFICAS SOBRE CORDERO}
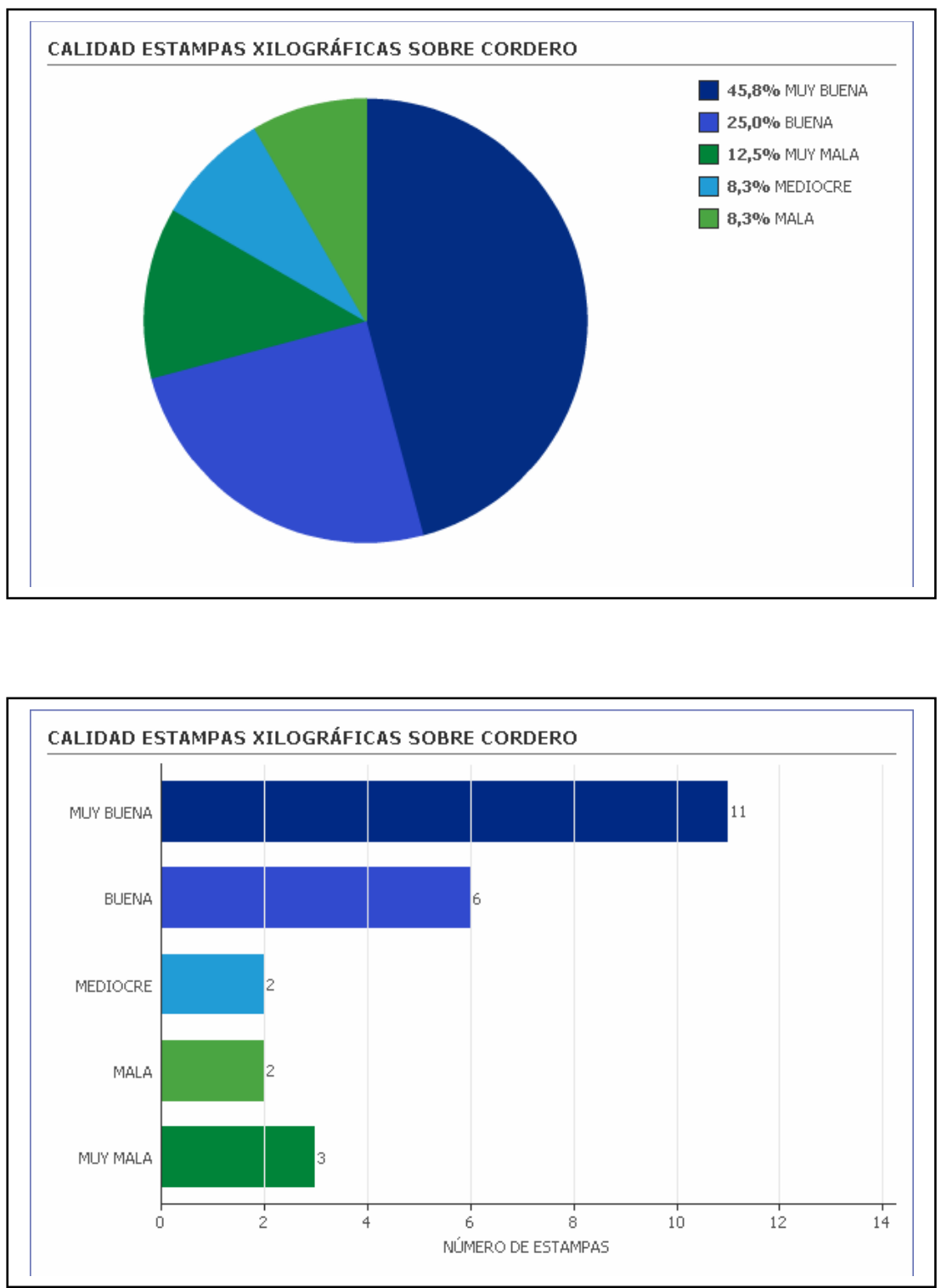
ESTAMPAS XILOGRÁFICAS SOBRE VACA
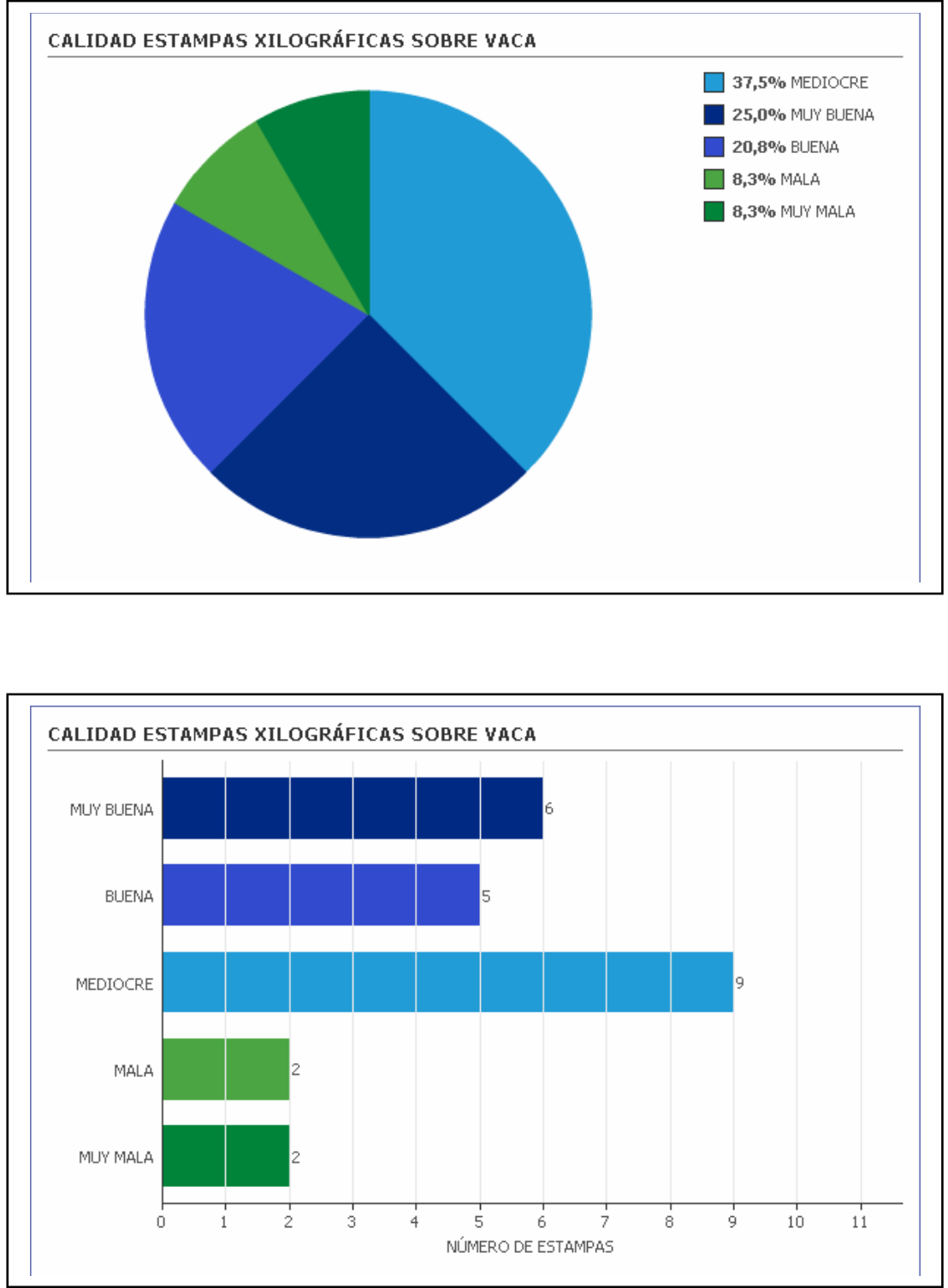


\section{ESTAMPAS XILOGRÁFICAS CON NEGRO}
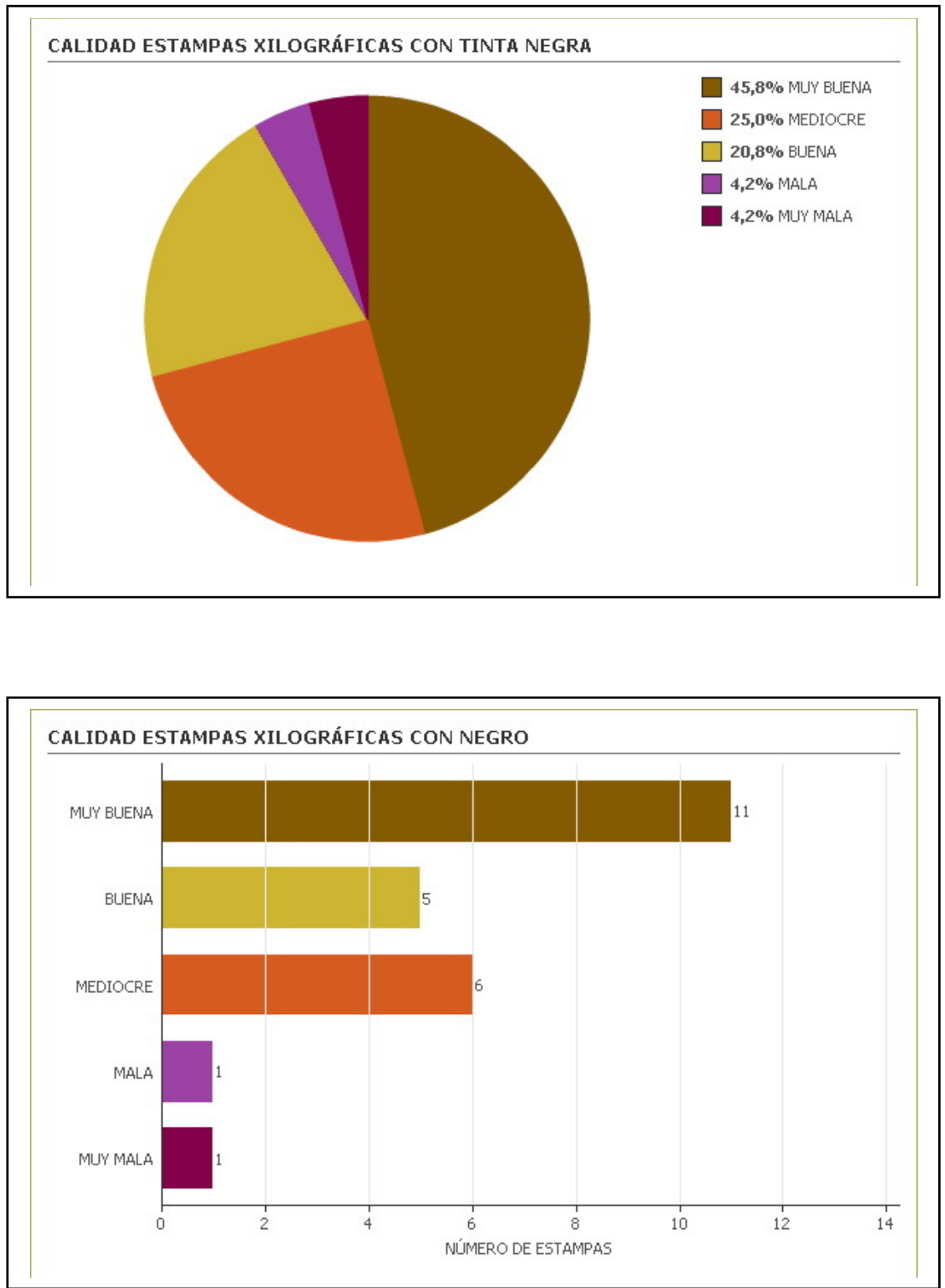
ESTAMPAS XILOGRÁFICAS CON BLANCO
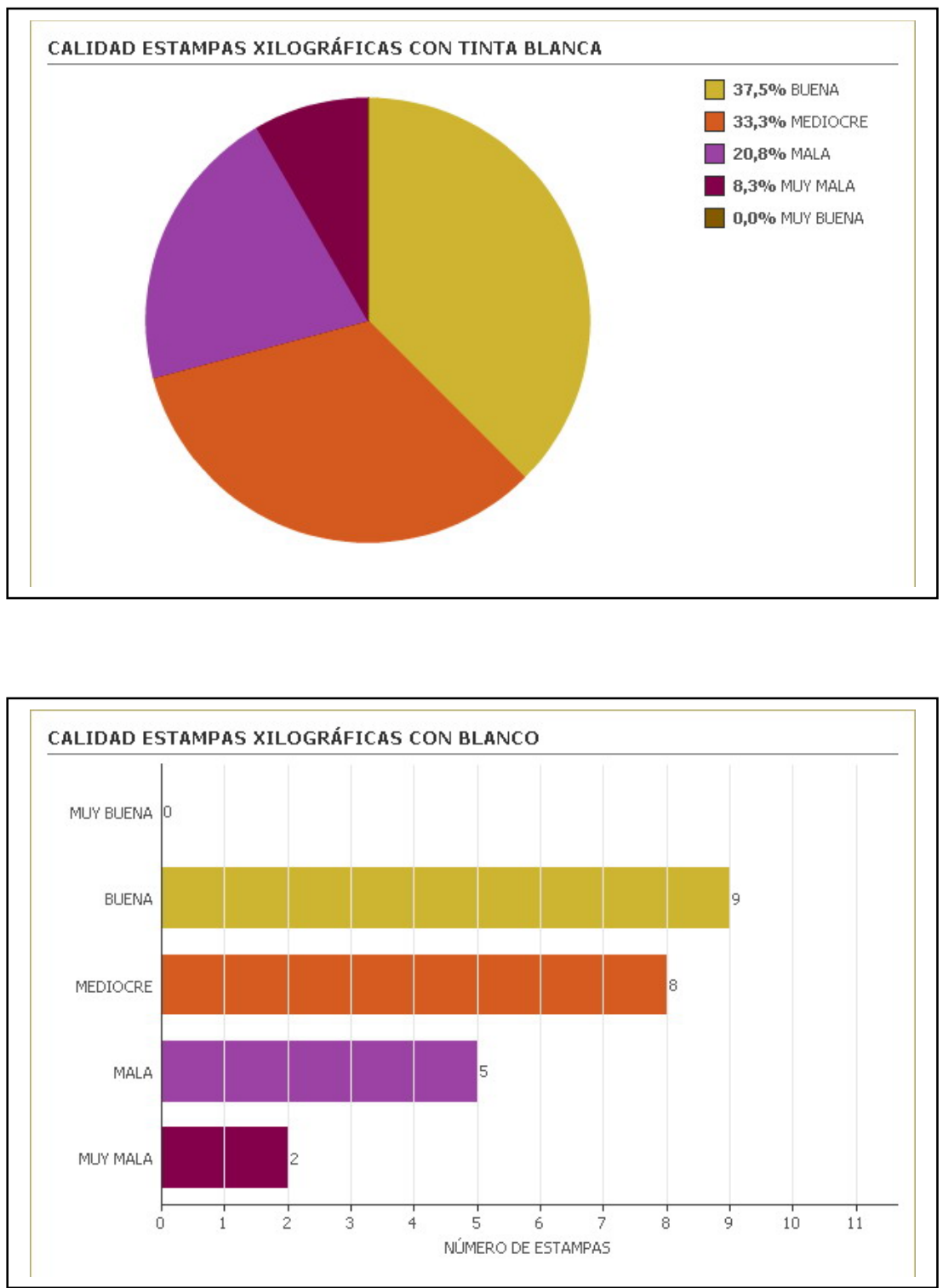
ESTAMPAS XILOGRÁFICAS CON AZUL TRASLÚCIDO
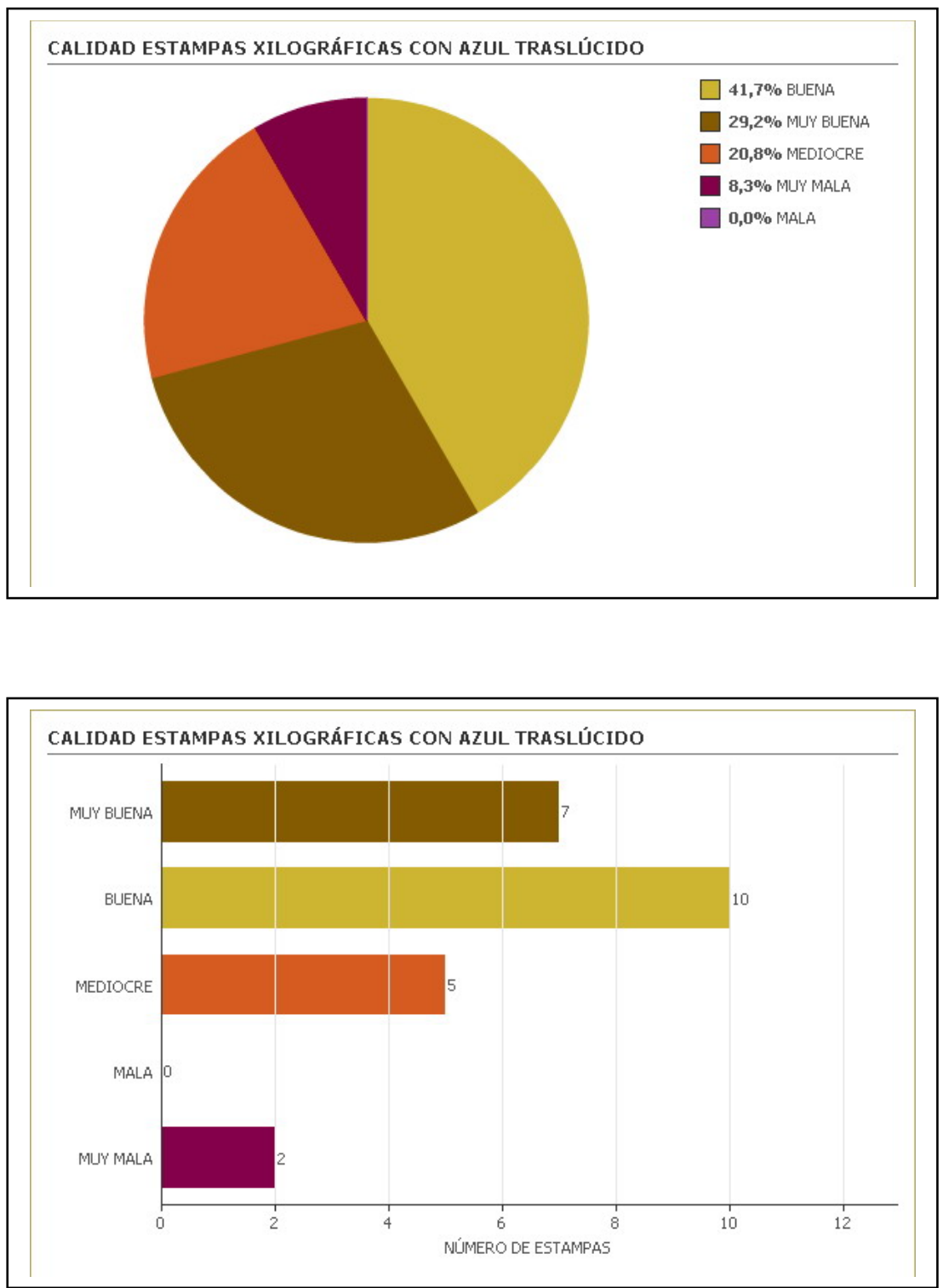
ESTAMPAS XILOGRÁFICAS CON AZUL OPACO
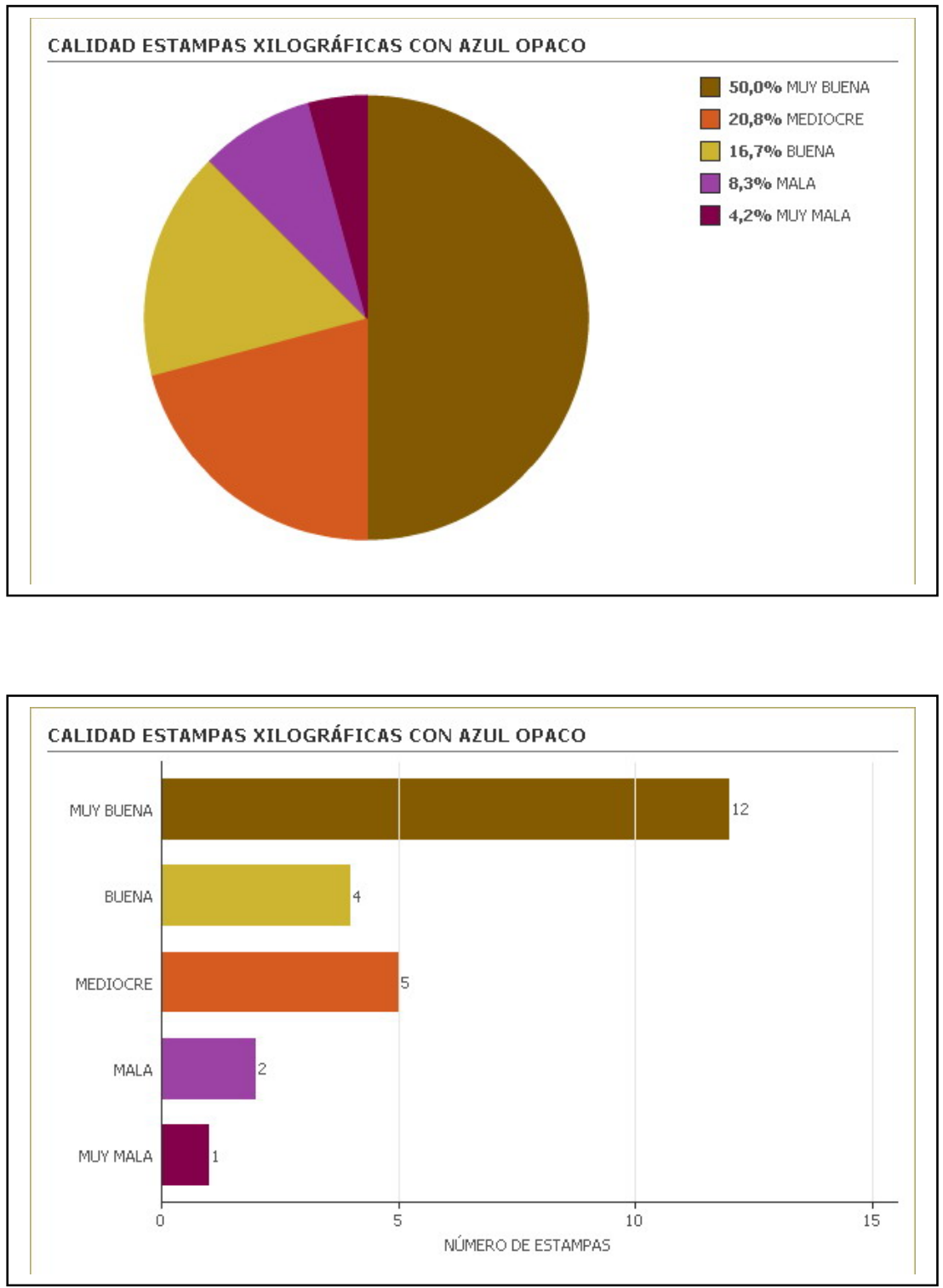
II. Tablas estadísticas 


\section{II.3. Estadísticas intervención calcográfica}


II. Tablas estadísticas 


\section{ESTAMPAS CALCOGRÁFICAS}
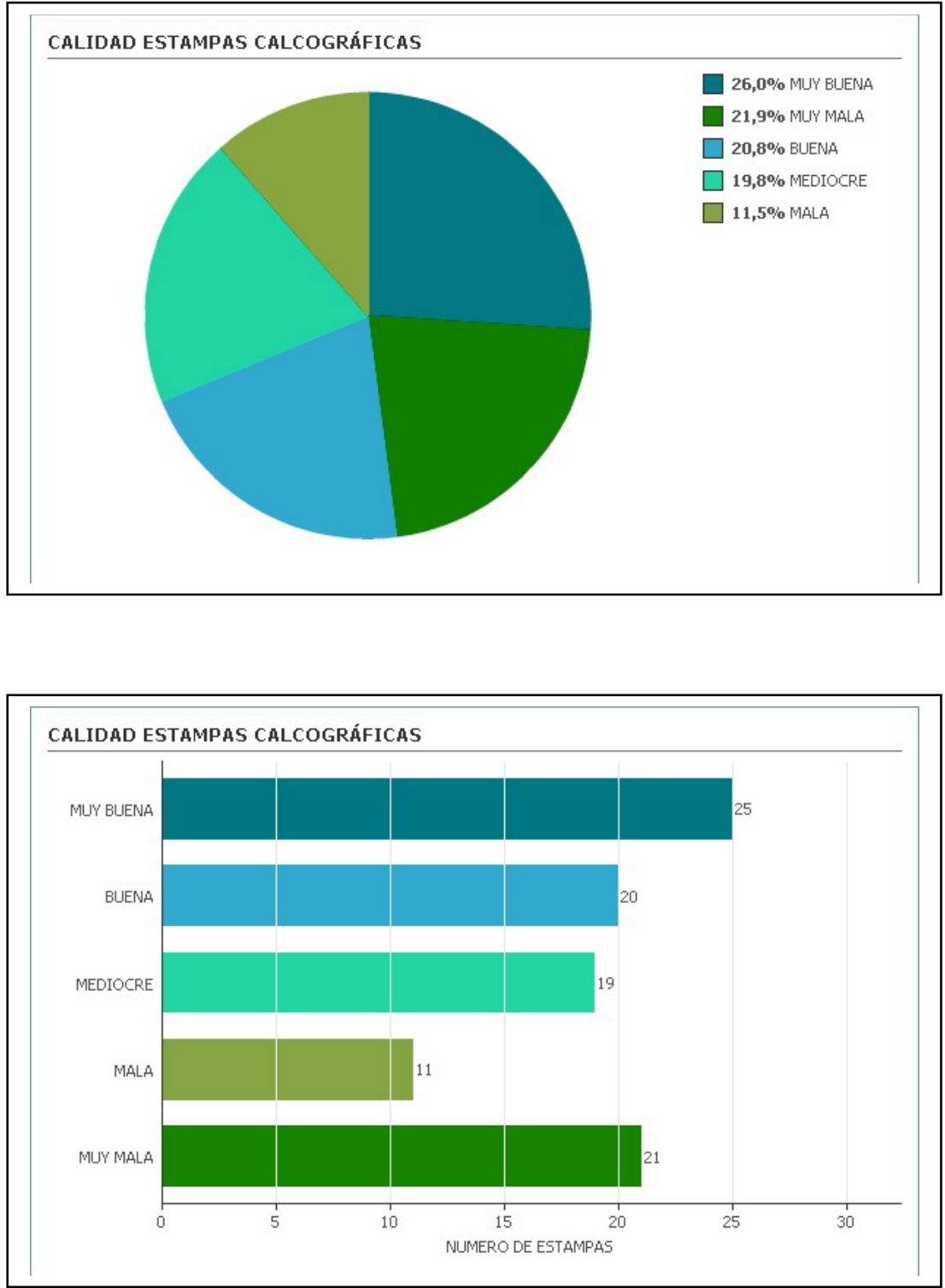
ESTAMPAS CALCOGRÁFICAS SOBRE LADO FLOR
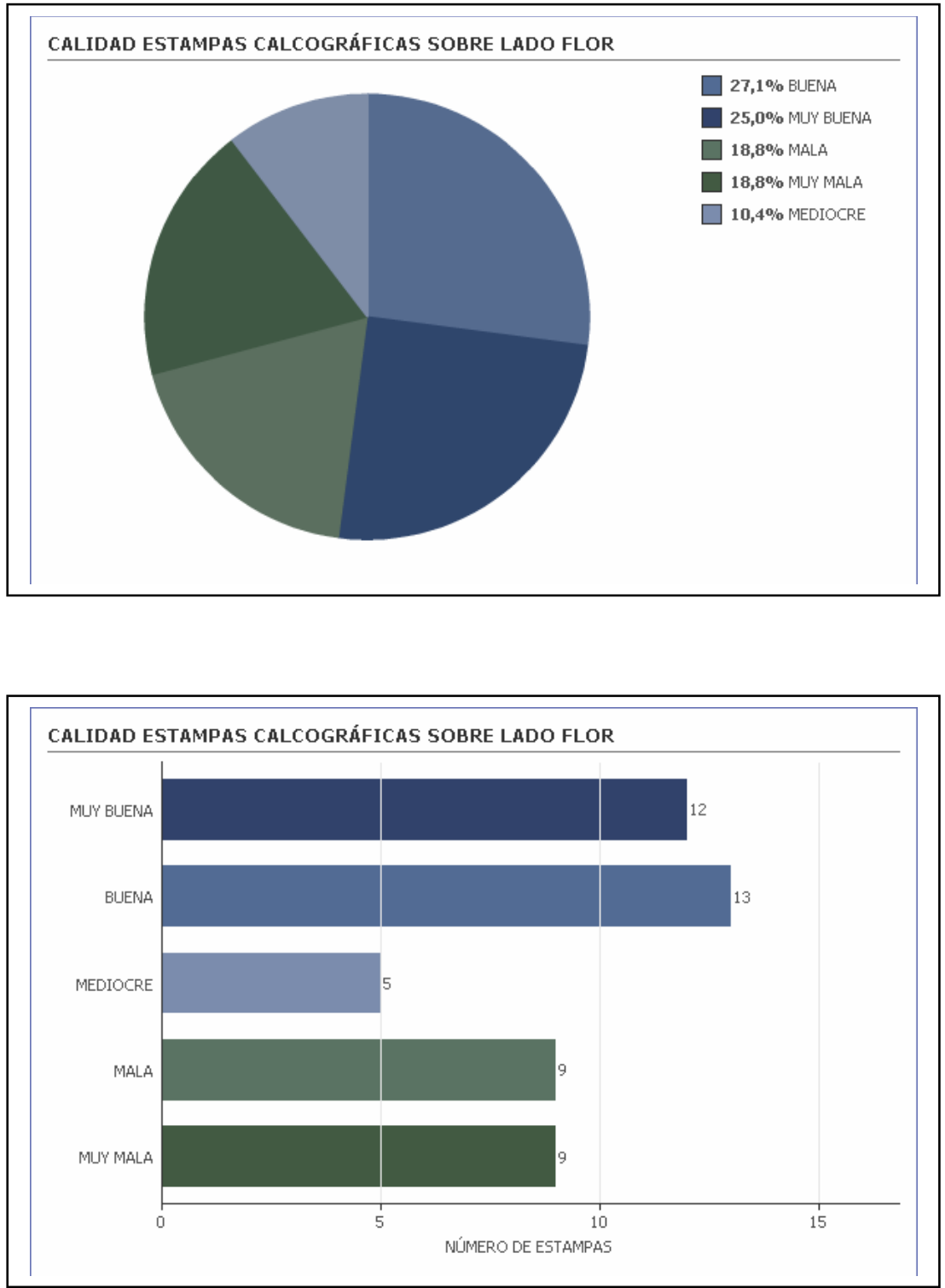
ESTAMPAS CALCOGRÁFICAS SOBRE LADO CARNE
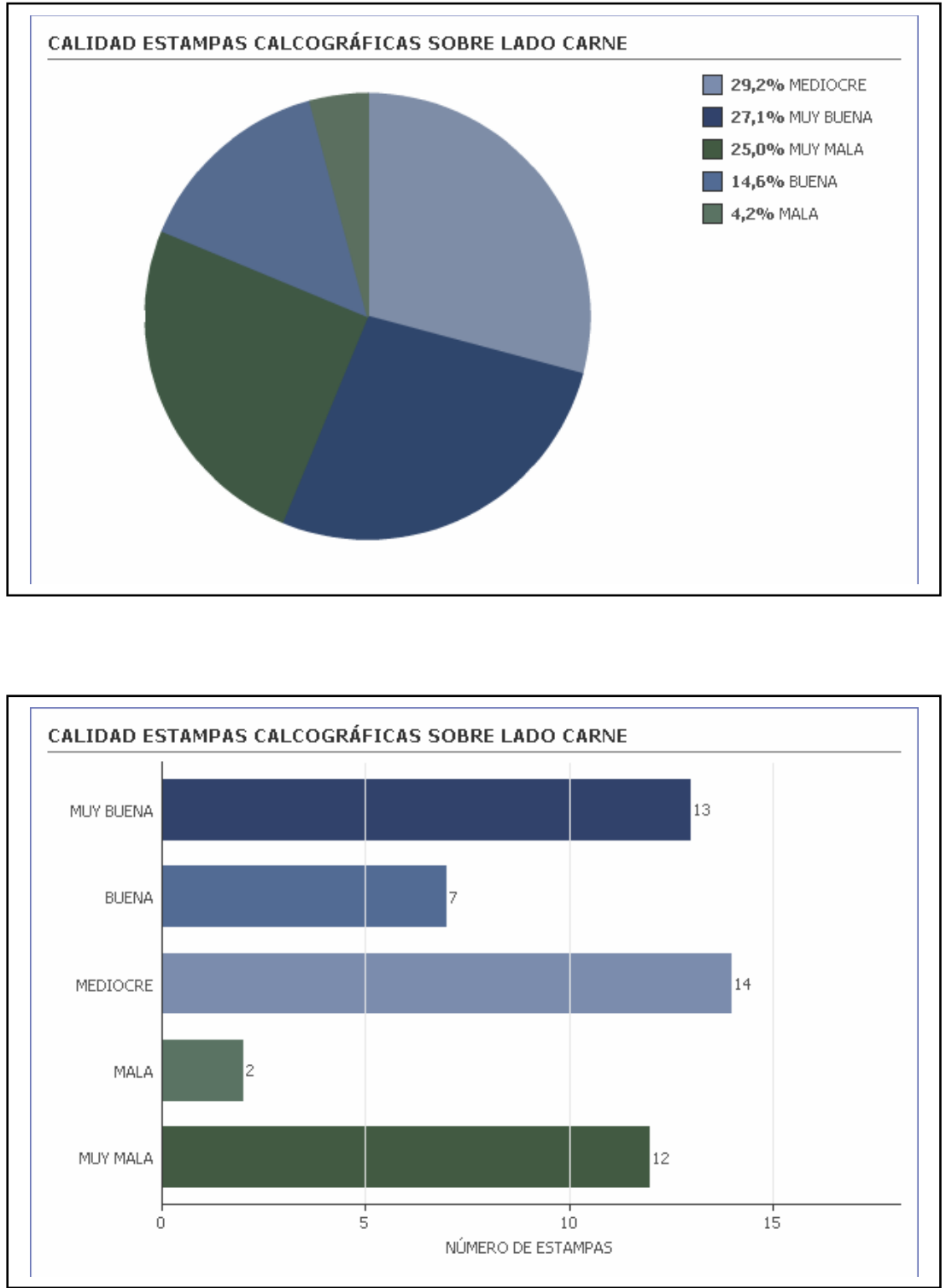
ESTAMPAS CALCOGRÁFICAS SOBRE CABRA
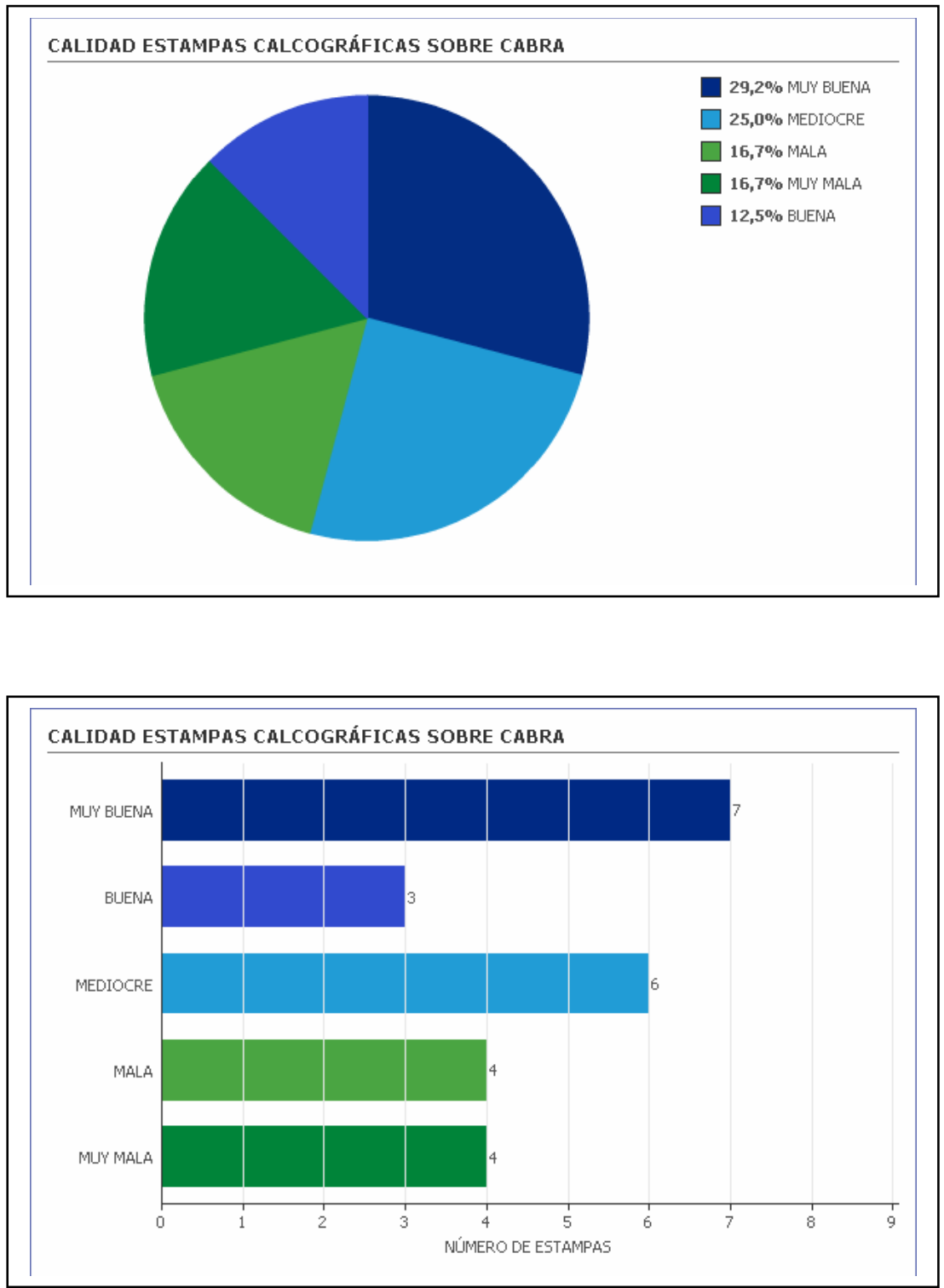
ESTAMPAS CALCOGRÁFICAS SOBRE CERDO
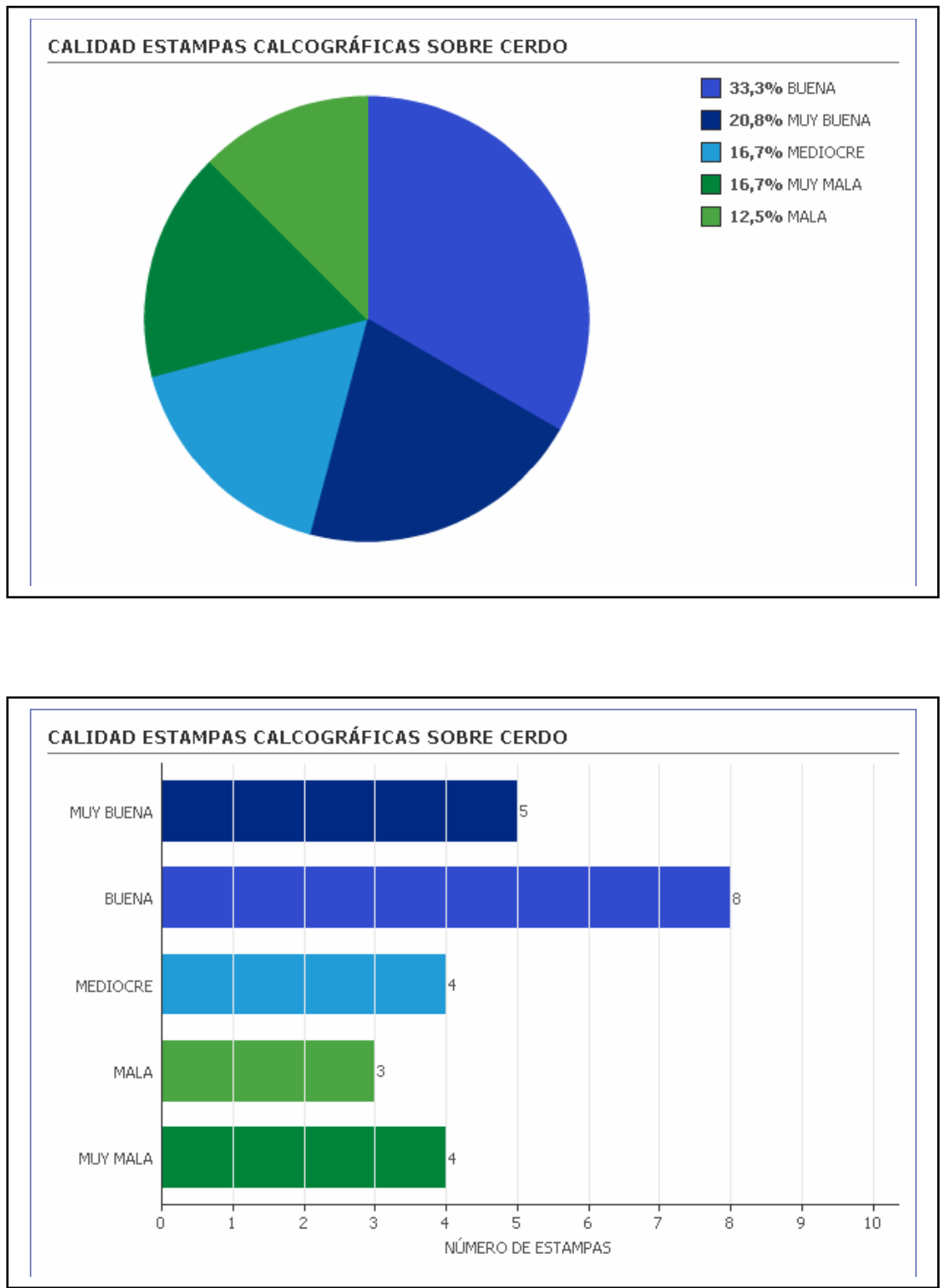
ESTAMPAS CALCOGRÁFICAS SOBRE CORDERO

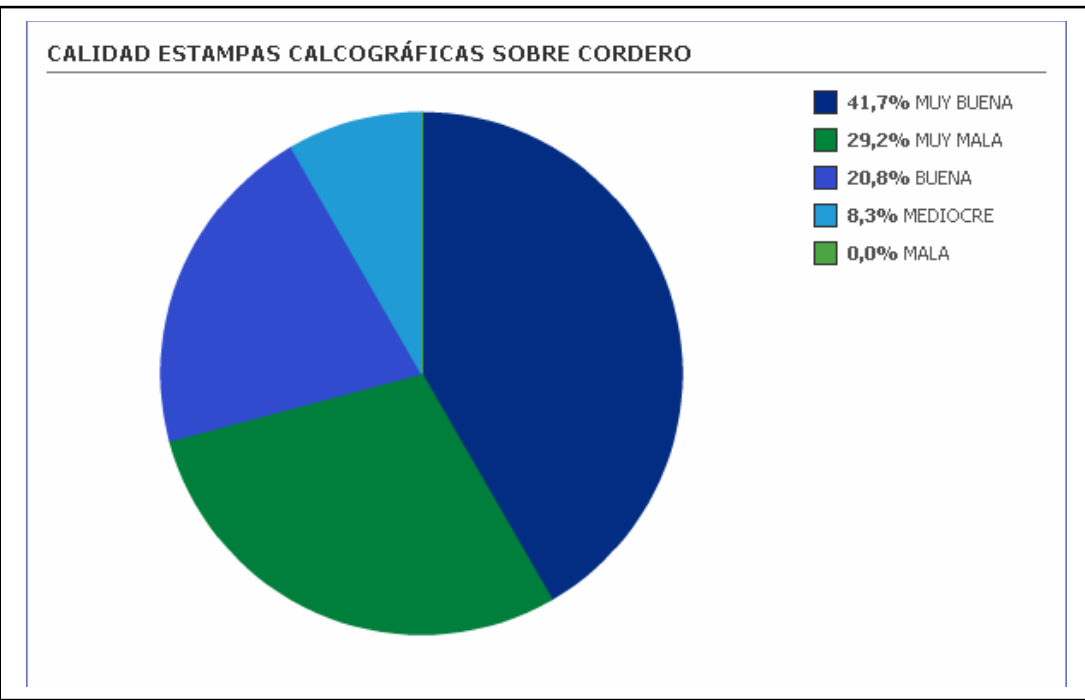

CALIDAD ESTAMPAS CALCOGRÁFICAS SOBRE CORDERO

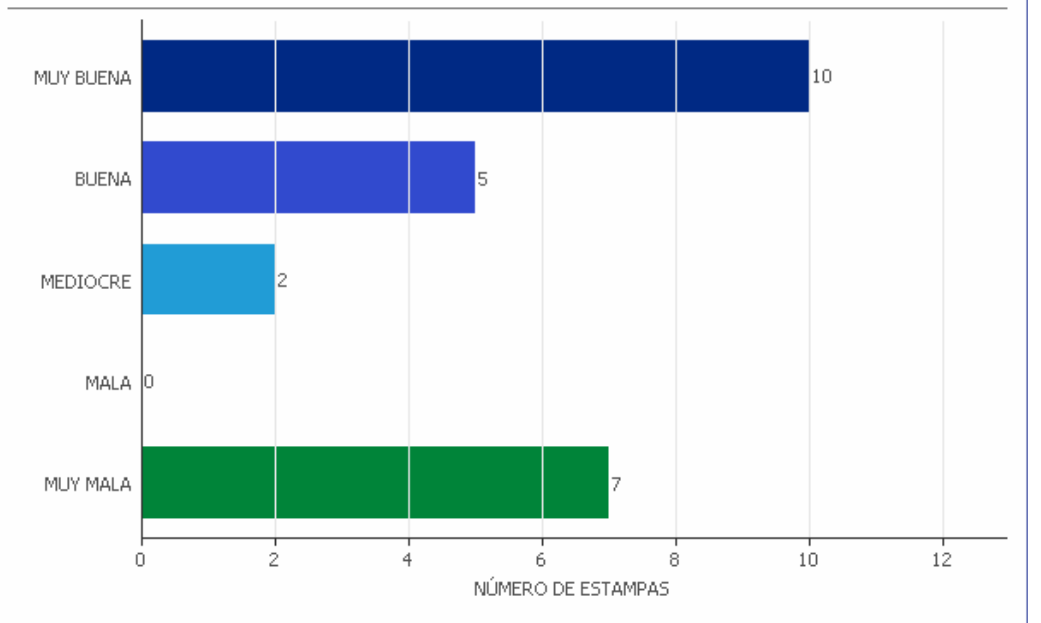


ESTAMPAS CALCOGRÁFICAS SOBRE VACA
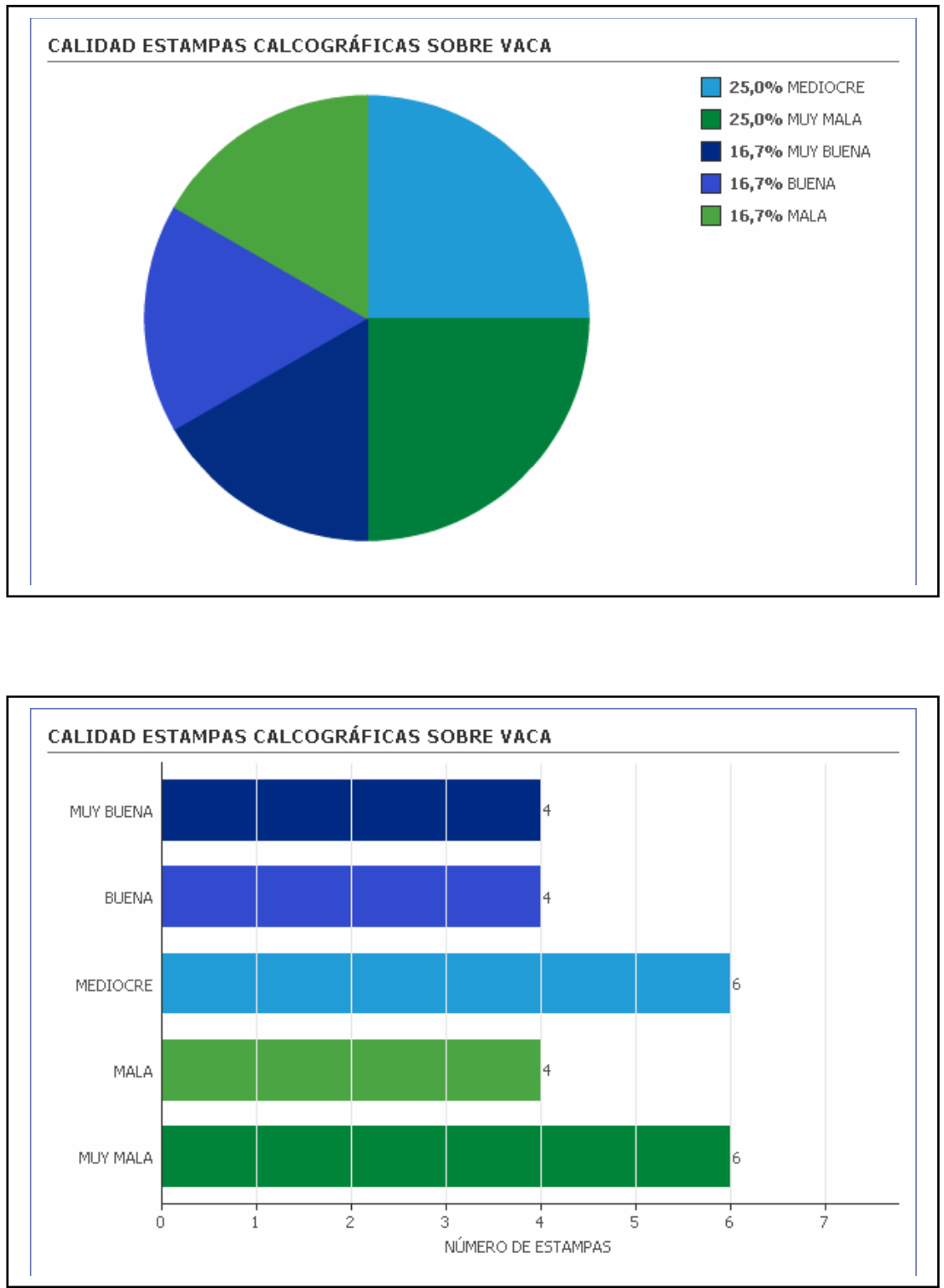
ESTAMPAS CALCOGRÁFICAS CON NEGRO
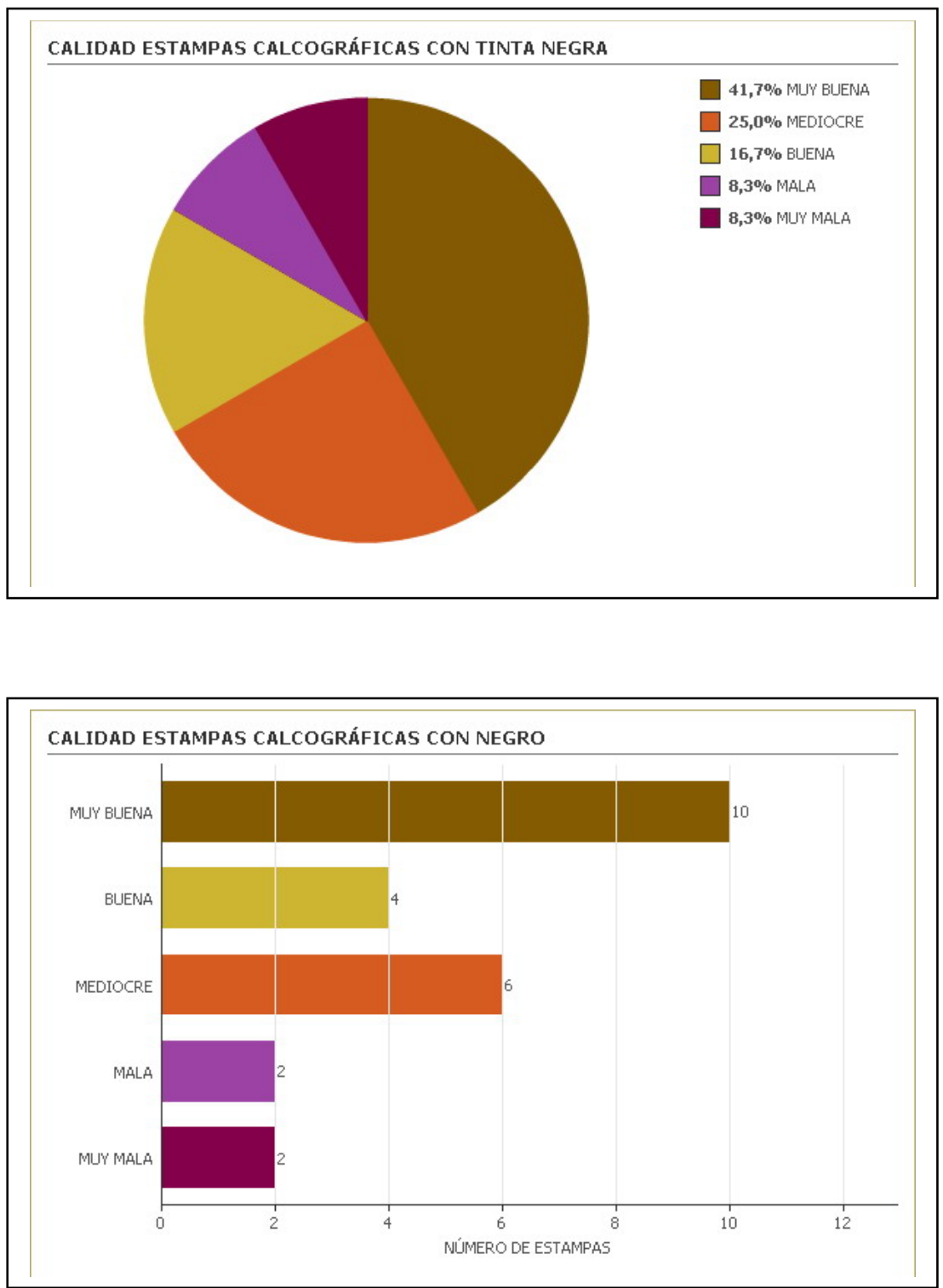


\section{ESTAMPAS CALCOGRÁFICAS CON BLANCO}
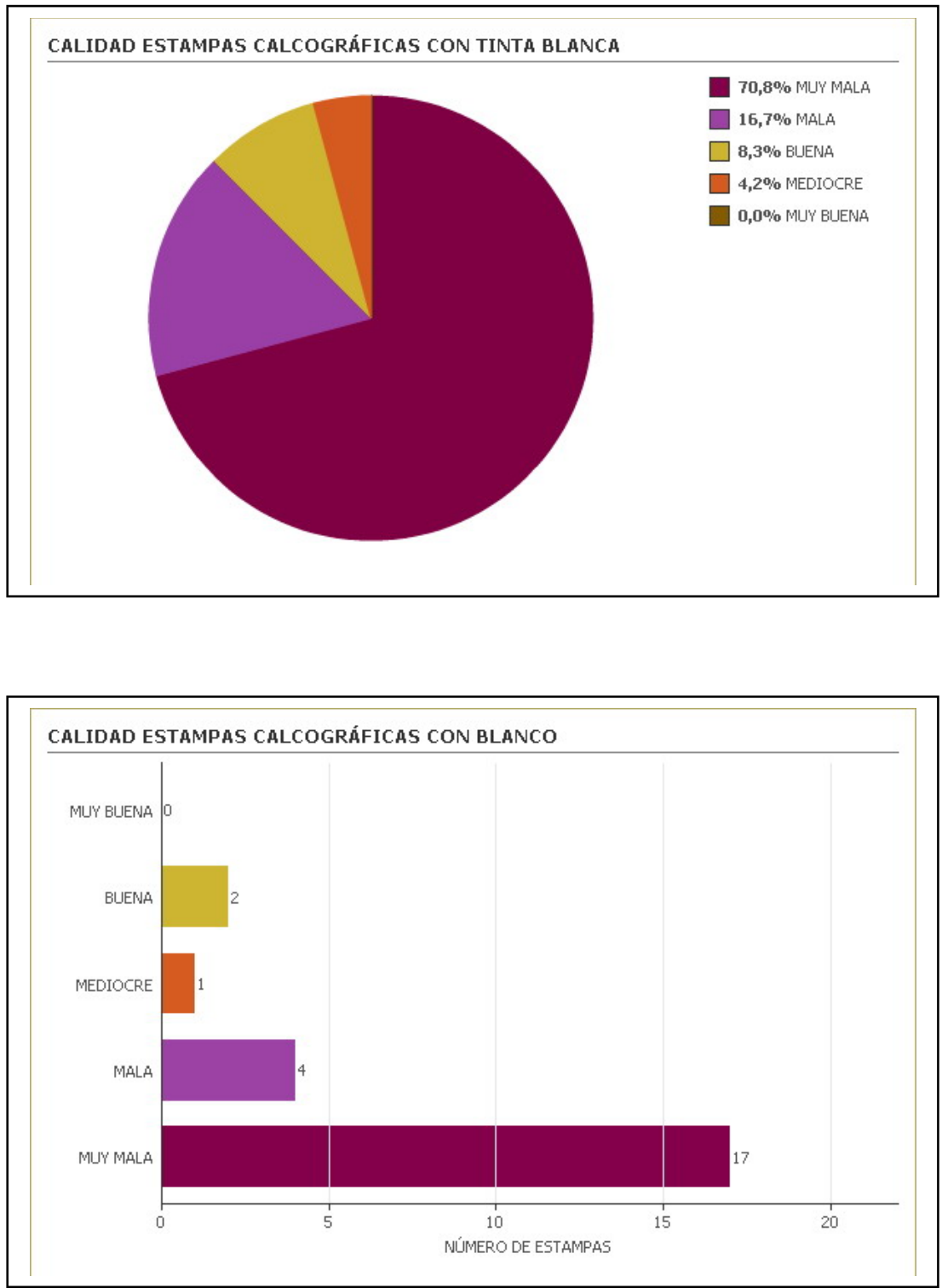
ESTAMPAS CALCOGRÁFICAS CON A. TRASLÚCIDO

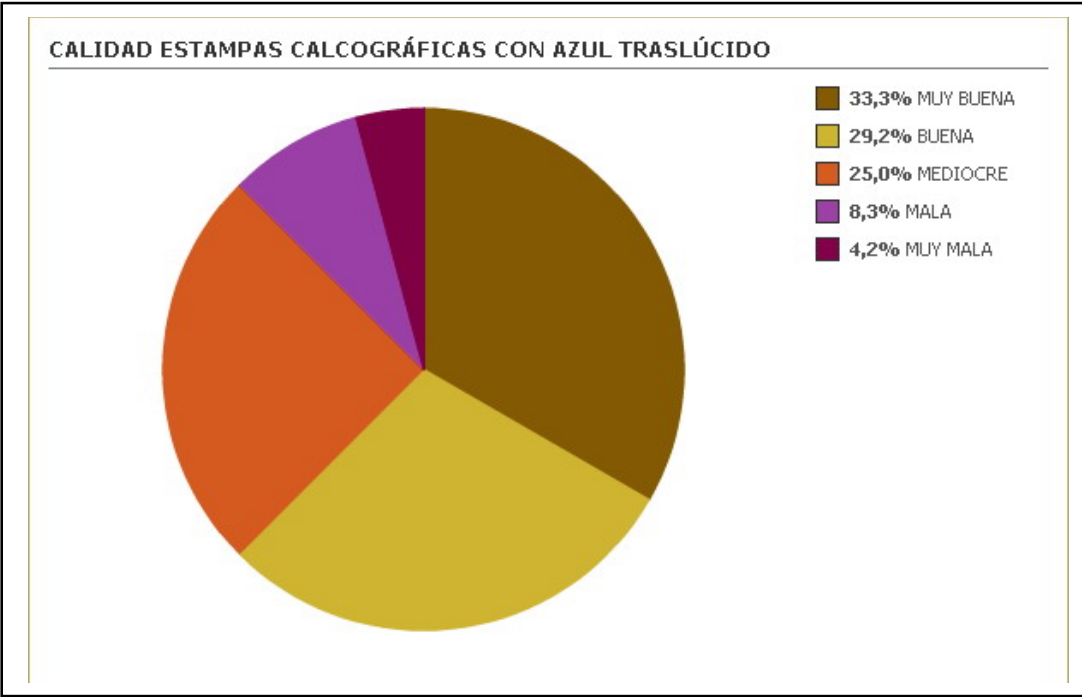

CALIDAD ESTAMPAS CALCOGRÁFICAS CON AZUL TRASLÚCIDO

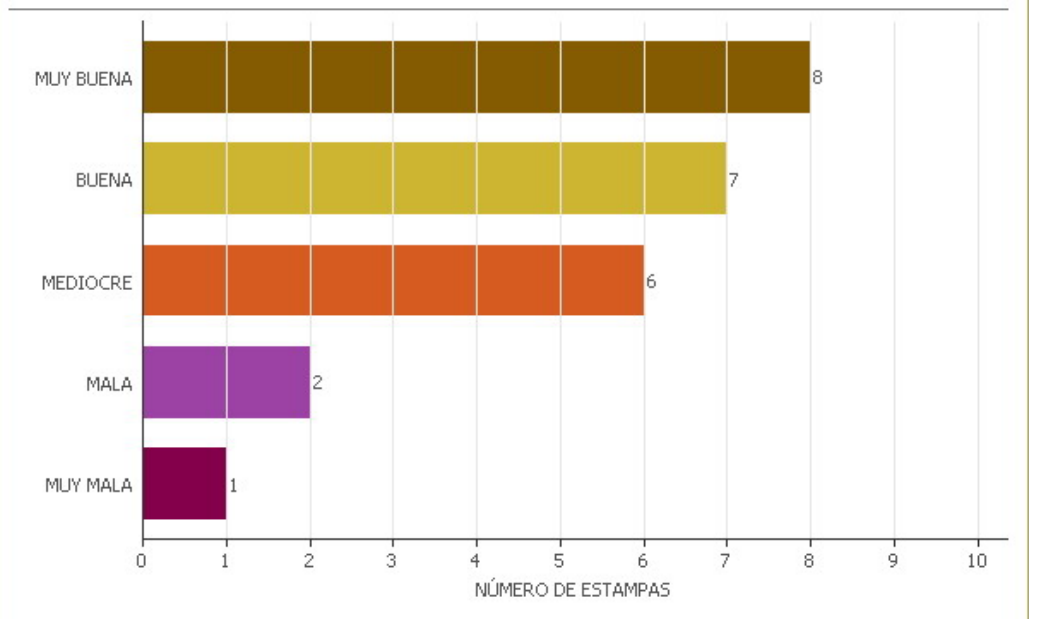


ESTAMPAS CALCOGRÁFICAS CON AZUL OPACO

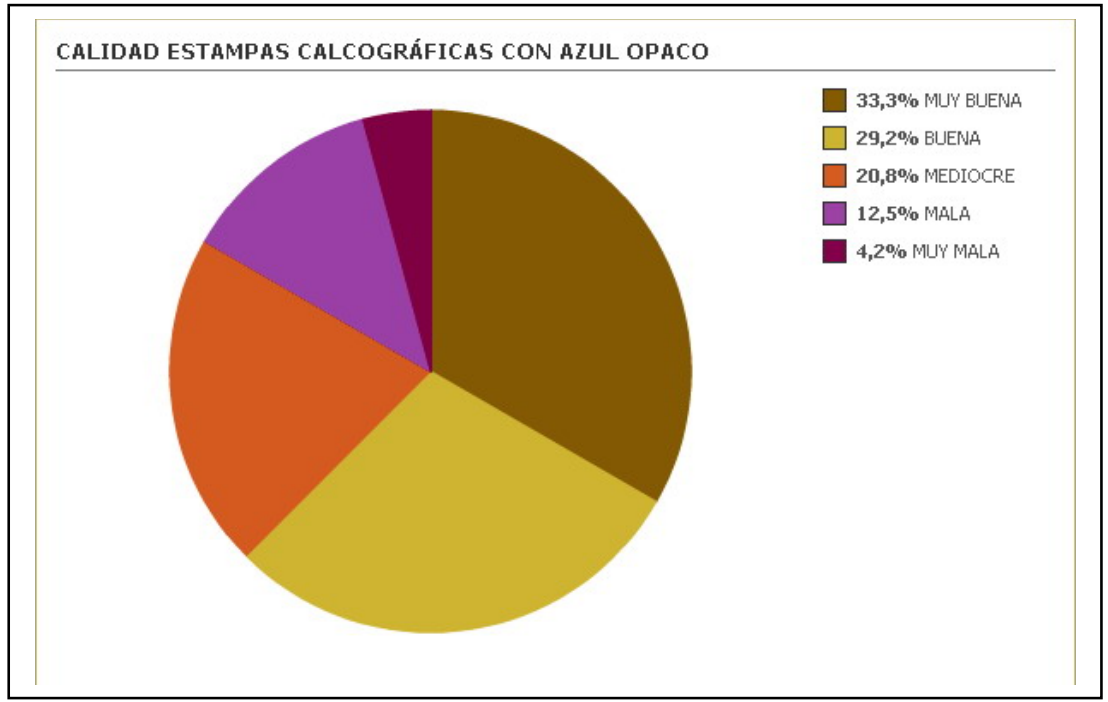

CALIDAD ESTAMPAS CALCOGRÁFICAS CON AZUL OPACO

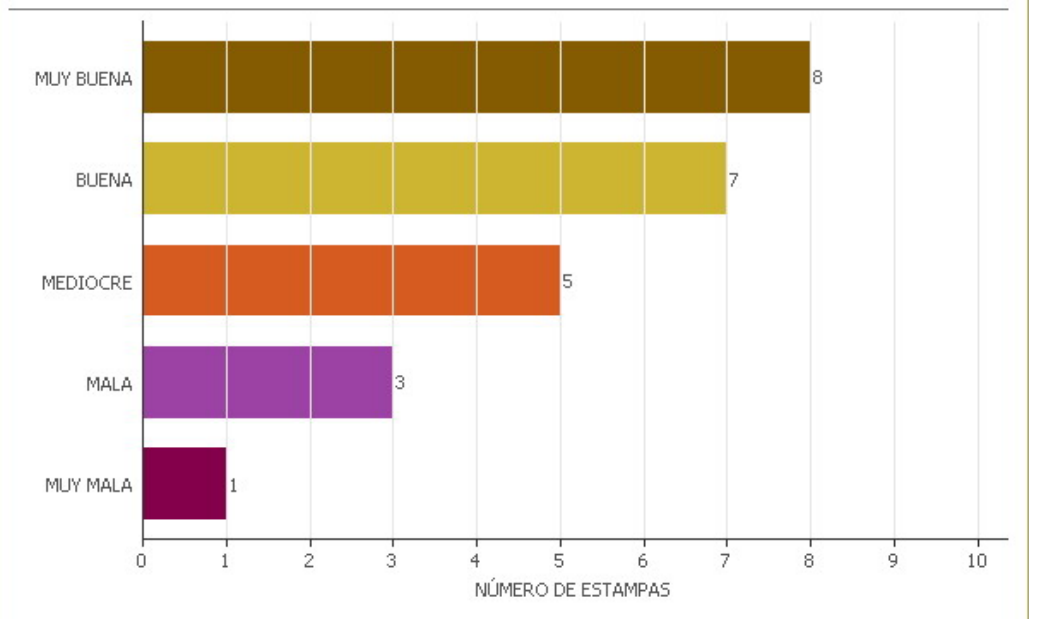




